\title{
Nadeelcompensatie en tegemoetkoming in planschade
}

\author{
Citation for published version (APA):
}

Huijts, J. H. M. (2020). Nadeelcompensatie en tegemoetkoming in planschade: Titel 4.5 Awb en afdeling 15.1 Omgevingswet: tussen eenheid en verscheidenheid. [, Maastricht University]. https://doi.org/10.26481/dis.20200326jh

Document status and date:

Published: 01/01/2020

DOI:

10.26481/dis.20200326jh

Document Version:

Publisher's PDF, also known as Version of record

\section{Please check the document version of this publication:}

- A submitted manuscript is the version of the article upon submission and before peer-review. There can be important differences between the submitted version and the official published version of record.

People interested in the research are advised to contact the author for the final version of the publication, or visit the DOI to the publisher's website.

- The final author version and the galley proof are versions of the publication after peer review.

- The final published version features the final layout of the paper including the volume, issue and page numbers.

Link to publication

\footnotetext{
General rights rights.

- You may freely distribute the URL identifying the publication in the public portal. please follow below link for the End User Agreement:

www.umlib.nl/taverne-license

Take down policy

If you believe that this document breaches copyright please contact us at:

repository@maastrichtuniversity.nl

providing details and we will investigate your claim.
}

Copyright and moral rights for the publications made accessible in the public portal are retained by the authors and/or other copyright owners and it is a condition of accessing publications that users recognise and abide by the legal requirements associated with these

- Users may download and print one copy of any publication from the public portal for the purpose of private study or research.

- You may not further distribute the material or use it for any profit-making activity or commercial gain

If the publication is distributed under the terms of Article $25 \mathrm{fa}$ of the Dutch Copyright Act, indicated by the "Taverne" license above, 


\section{BOUWRECHT MONOGRAFIEËN}

Nadeelcompensatie en tegemoetkoming in planschade

Titel 4.5 Awb en afdeling 15.1 Omgevingswet: tussen eenheid en verscheidenheid

Mr. J.H.M. Huijts 

Nadeelcompensatie en tegemoetkoming in planschade 
ISBN 978-94-6315-052-1

NUR 823

\section{(C) 2020, J.H.M. Huijts}

Alle rechten voorbehouden. Niets uit deze uitgave mag worden verveelvoudigd, opgeslagen in een geautomatiseerd gegevensbestand, of openbaar gemaakt, in enige vorm of op enige wijze, hetzij elektronisch, mechanisch, door fotokopieën, opnamen of enige andere manier, zonder voorafgaande schriftelijke toestemming van de uitgeverij. Voor zover het maken van kopieën uit deze uitgave is toegestaan op grond van art. 16h tot en met 16m Auteurswet 1912 jo. het Besluit van 27 november 2002, Stb. 2002, 575, dient men de daarvoor wettelijk verschuldigde vergoedingen te voldoen aan de Stichting Reprorecht (Postbus 3060, $2130 \mathrm{~KB}$ Hoofddorp). Voor het overnemen van gedeelte(n) uit deze uitgave in bloemlezingen, readers en andere compilatiewerken dient men zich tot de Stichting Instituut voor Bouwrecht te wenden.

No part of this book may be reproduced in any form, by print, photo print, microfilm or any other means without written permission from the publisher. 


\title{
Nadeelcompensatie en tegemoetkoming in planschade
}

\author{
Titel 4.5 Awb en afdeling 15.1 Omgevingswet: \\ tussen eenheid en verscheidenheid
}

\section{Proefschrift}

ter verkrijging van de graad van doctor aan de Universiteit Maastricht, op gezag van de Rector Magnificus, prof. dr. Rianne M. Letschert volgens het besluit van het College van Decanen,

in het openbaar te verdedigen

op woensdag 20 mei 2020 om 16.00 uur

door

Jonathan Hubertus Maria Huijts 


\section{Promotores}

Prof. dr. Ch.W. Backes (Universiteit Utrecht)

Prof. dr. B.P.M. van Ravels (Radboud Universiteit)

\section{Beoordelingscommissie}

Prof. dr. G.E. van Maanen (Voorzitter)

Prof. dr. J.E. van den Brink (Universiteit van Amsterdam)

Dr. G.M. van den Broek (Universiteit Utrecht)

Dr. M.K.G. Tjepkema (Universiteit Leiden) 


\section{Woord vooraf}

Gedurende mijn academische loopbaan ben ik nooit aangesteld geweest in de functie van promovendus. Dat u nu dit voorwoord leest, betekent dat er inmiddels toch een afgerond proefschrift ligt. Daarvoor ben ik in de eerste plaats dank verschuldigd aan mijn promotoren. Chris Backes zorgde altijd ervoor dat de grote lijnen van het onderzoek niet uit het oog werden verloren. Ook op persoonlijk vlak heb ik veel van hem geleerd. Bruno van Ravels gaf altijd scherpzinnig en gedetailleerd commentaar, waarin hij refereerde aan bronnen die alleen in de krochten van het nadeelcompensatierecht kunnen worden gevonden. Beiden waren van grote waarde voor de totstandkoming van dit proefschrift. Graag spreek ik ook mijn dank uit aan de leden van de beoordelingscommissie: Gerrit van Maanen, Berthy van den Broek, Jacobine van den Brink en Michiel Tjepkema. Hun commentaar was erg waardevol bij de afronding van dit boek.

Ook ben ik dank verschuldigd aan Ellen Hardy en Sascha Hardt. Samen met Chris Backes durfden zij het aan om een jonge, nog niet afgestudeerde masterstudent privaatrecht aan te stellen als docent staats- en bestuursrecht aan de gelijknamige afdeling van de Universiteit Maastricht. Het vertrouwen dat zij uitspraken door middel van deze - niet per se gebruikelijke - beslissing heeft mij altijd gemotiveerd om hard te werken aan dit proefschrift. Formeel gezien, had ik slechts éen dag om aan dit onderzoek te besteden en moesten de drie resterende dagen van mijn aanstelling worden besteed aan het geven van onderwijs. Praktisch bleek echter regelmatig meer onderzoekstijd beschikbaar, omdat mijn Maastrichtse collega's bereid waren om bepaalde onderwijstaken van mij over te nemen. Ik ben hun erg dankbaar daarvoor, evenals voor hun collegialiteit, steun en vriendschap.

Na drie mooie jaren aan de Maastrichtse rechtenfaculteit begon ik aan een nieuw avontuur als docent aan de afdeling staats- en bestuursrecht van de Universiteit Leiden. Ook daar heb ik mij vanaf dag één als een vis in het water gevoeld, niet in het minst door mijn Leidse collega's. Zij maken dat ik iedere dag met veel plezier en vol goede moed naar mijn werk ga. Ook hen bedank ik graag voor hun collegialiteit, steun en vriendschap. Een bijzonder woord van dank wil ik bovendien richten aan het dagelijks bestuur van onze afdeling, dat wordt voorgezeten door Ymre Schuurmans. Samen met de overige bestuursleden gaf zij mij veel tijd en ruimte om aan dit proefschrift te werken, blijk van vertrouwen en waardering, en kansen om mijzelf te ontplooien.

Ook een aantal andere personen wil ik graag bij naam bedanken. Dat geldt in de eerste plaats voor mijn (voormalig) kamergenoten: Eveline van der Linden, Sofie Polleunis, Alke Metselaar en Fatma Çapkurt. Ik heb altijd veel steun ontleend aan hun luisterende oren en motiverende woorden. Door de gezelligheid op onze kamers was het zeker geen straf om tot in de late uurtjes aan dit proefschrift te 
werken. Vervolgens mag Fokke Fernhout zeker niet onvermeld blijven. Toen ik nog studeerde, introduceerde hij mij in de wereld van het wetenschappelijk onderzoek. Als beschermheer van het Infopunt Schade A2 Maastricht liet hij mij bovendien kennismaken met het nadeelcompensatierecht en was hij belangrijk voor de ontwikkeling van mijn schrijfvaardigheid. Ook bedank ik graag Rob Timmermans - die ik leerde kennen tijdens mijn werkzaamheden aan dit Infopunt - omdat hij mij regelmatig inzicht verschafte in de bestuurlijke nadeelcompensatiepraktijk van Rijkswaterstaat. Voorts ben ik dank verschuldigd aan Wendy Roger voor haar waardevolle taalkundige suggesties ten aanzien van de Engelstalige samenvatting van dit proefschrift. Ook bedank ik graag al mijn studenten: ik heb veel met jullie gelachen en van jullie geleerd, hopelijk was dat wederzijds!

Ten slotte wil ik mijn familie en vrienden bedanken. Daarbij noem ik bewust geen namen, zodat ik zeker weet dat ik niemand vergeet. De afgelopen jaren heb ik veel feestjes, verjaardagen en andere bijeenkomsten moeten laten schieten om dit proefschrift te kunnen schrijven. Hun begrip daarvoor en de onvoorwaardelijke steun die ik van hen heb gekregen, waren van onschatbare waarde. Meer in het bijzonder schieten woorden tekort om mijn moeder, broertje en zusjes te bedanken. Ik hoop dat zij desondanks weten hoe belangrijk zij voor mij zijn geweest gedurende het hele schrijfproces. Dit boek draag ik dan ook graag op aan hen. Die 'eer' zullen zij moeten delen met Pieter van Nunen - mijn veel te vroeg overleden oom, die in geuren en kleuren kon vertellen over zijn werk als muziekdocent aan het Munnikenheide college te Etten-Leur en de vele overige avonturen die hij beleefde. Hij was in vele opzichten als een vader voor mij. Het kwam geregeld voor dat hij op één dag meermaals vroeg hoe het met mijn boek ging, en welke titel ik nou precies zou krijgen als ik het eenmaal succesvol zou weten te verdedigen. Helaas zal hij dit boek nooit kunnen lezen, maar in gedachten reik ik het eerste exemplaar graag aan hem uit!

Het bronnenonderzoek voor dit proefschrift is afgerond op 7 maart 2019 - de dag waarop de Tweede Kamer het voorstel voor de Invoeringswet Omgevingswet aannam. Met latere publicaties, jurisprudentie en overige ontwikkelingen is in principe geen rekening gehouden.

Leiden, januari 2020

Jonathan Huijts 


\section{Inhoudsopgave}

Woord vooraf

Lijst van afkortingen

xvii

\section{Inleiding}

1.1 Aanleiding tot het onderzoek

1.2 Het doel van het onderzoek en de te beantwoorden onderzoeksvragen

1.3 De plaats van het égalitébeginsel binnen het onderzoek 8

$1.4 \quad$ Methode en verdere afbakening van het onderzoek 10

$\begin{array}{lll}1.5 & \text { Opbouw van het onderzoek } & 14\end{array}$

2. Het huidige en toekomstige nadeelcompensatierecht in vogelvlucht

$2.1 \quad$ Inleiding

2.2 Hoe de totstandkoming van een recht op nadeelcompensatie in de Nederlandse rechtsorde leidde tot een nadeelcompensatiedoolhof 19

$\begin{array}{lll}2.3 & \text { Selectie van hedendaagse nadeelcompensatieregelingen } & 34\end{array}$

2.3.1 Afdeling 6.1 Wet ruimtelijke ordening 36

2.3.2 Beleidsregel nadeelcompensatie Infrastructuur \& Waterstaat 201938

2.3.3 Twee Amsterdamse nadeelcompensatieregelingen 41

2.3.4 De Gemeenschappelijke regeling Schadeschap Luchthaven $\begin{array}{ll}\text { Schiphol } & 45\end{array}$

$\begin{array}{lll}\text { 2.3.5 Conclusie } & 47\end{array}$

$2.4 \quad$ Het toekomstige nadeelcompensatierecht 48

2.4.1 Selectie van regelingen 48

2.4.2 Doelstellingen en uitgangspunten die aan de Wns ten grondslag liggen 49

2.4.2.1 De aan de Wns ten grondslag liggende doelstellingen 50

2.4.2.2 Uitganspunten van de Wns 53

2.4.2.3 Een eerste, algemene reflectie op de doelstellingen en

2.4.2.4 Tussenconclusie: beantwoording van de eerste deelvraag 58

$\begin{array}{ll}2.4 .3 & \text { De Omgevingswet }\end{array}$

2.5 Staatsrechtelijke grenzen aan (formeel)wettelijke nadeel-

2.5.1 Verhouding van de formele wet tot art. 1 EP EVRM 64

2.5.2 Verhouding van de formele wet tot het ongeschreven
égalitébeginsel

2.5.3 De algemene verhouding van titel 4.5 Awb tot overige regelgeving 67

2.5.4 De regelgevende bevoegdheid van de regering en ministers 68 
2.5.5 De regelgevende bevoegdheid van gemeenten, provincies en waterschappen

2.5.6 Grenzen aan de opstelling van beleidsregels 74

2.6 Totstandkoming van zuiverere schadebesluiten en de toetsing daarvan door de bestuursrechter

3. De reikwijdte en exclusiviteit van nadeelcompensatieregelingen

3.1 Inleiding

3.2 Deelvraag 2: verschillen tussen de geselecteerde, thans geldende regelingen en verklaringen daarvoor

3.2.1 Verschillende methoden om de reikwijdte af te bakenen 86

3.2.2 Het uitputtende karakter van de afbakeningen van reikwijdte 90

3.2.3 Schaduwschade en het exclusieve karakter van de opsommingen uit de WRO en Wro

3.2.4 Op het planschaderecht toegespitste verklaringen 97

$\begin{array}{ll}3.3 & 101\end{array}$

$\begin{array}{lll}\text { 3.3.1 De reikwijdte van titel 4.5 Awb } & 101\end{array}$

$\begin{array}{ll}\text { 3.3.2 De reikwijdte van afd. 15.1 Ow } & 105\end{array}$

3.3.2.1 Behoud van een limitatieve, exclusieve opsomming 105

3.3.2.2 Argumenten van het kabinet voor behoud van een limitatieve, exclusieve opsomming 107

$\begin{array}{ll}\text { 3.3.2.3 Vergroting van de schaduwschadeproblematiek } & 108\end{array}$

$\begin{array}{lll}\text { 3.3.3 Schematisch overzicht } & 111\end{array}$

3.4 Hoofdvraag: spiegeling aan de doelstellingen en uitgangspunten die ten grondslag liggen aan de Wns $\quad 112$

$\begin{array}{lll}3.4 .1 & \text { Titel } 4.5 \mathrm{Awb} & 112\end{array}$

$\begin{array}{lll}3.4 .2 & \text { Afd. } 15.1 \mathrm{Ow} & 114\end{array}$

3.4.2.1 Het exclusieve karakter van art. 15.1 lid 1 Ow 114

3.4.2.2 Argumenten van het kabinet om geen regeling voor de

$\begin{array}{ll}\text { 3.4.2.3 Verschuiven van het schademoment } & 119\end{array}$

$\begin{array}{ll}\text { 3.4.2.4 Een oplossing voor de schaduwschadeproblematiek } & 121\end{array}$

$\begin{array}{lll}3.5 & \text { Conclusie } & 128\end{array}$

4. Causaal verband

4.1 Inleiding

4.2 Deelvraag 2: verschillen tussen de geselecteerde, thans geldende regelingen en verklaringen daarvoor

4.2.1 De tekst van de regelingen en de daarbij behorende toelichtingen 131

$\begin{array}{ll}\text { 4.2.2 De causaliteitsleer van art. 6:98 BW } & 134\end{array}$

4.2.3 Condicio sine qua non in het planschade- en nadeelcompensatierecht

4.2.3.1 De planvergelijking 
4.2.3.2 Schade door wijziging van juridische regimes in het nadeelcompensatierecht

4.2.3.3 Schade door feitelijk overheidshandelen in het nadeelcompensatierecht

4.2.4 Toerekening naar redelijkheid in het planschade- en nadeelcompensatierecht

$\begin{array}{ll}4.3 & 146\end{array}$

$\begin{array}{lll}\text { 4.3.1 Titel 4.5 Awb } & 146\end{array}$

$\begin{array}{lll}\text { 4.3.2 Afd. } 15.1 \mathrm{Ow} & 147\end{array}$

4.4 Hoofdvraag: spiegeling aan de doelstellingen en uitgangspunten die ten grondslag liggen aan de Wns 153

4.4.1 De motivering van het rechterlijk causaliteitsoordeel 154

$\begin{array}{ll}\text { 4.4.2 Meervoudige causaliteit } & 157\end{array}$

4.4.3 Enkele losse opmerkingen omtrent afd. 15.1 Ow 163

$\begin{array}{lll}4.5 & \text { Conclusie en concrete voorstellen } & 165\end{array}$

5. Schade

$\begin{array}{lll}5.1 & \text { Inleiding } & 169\end{array}$

5.2 Voor compensatie in aanmerking komende schadesoorten $\quad 170$

5.2.1 Deelvraag 2: verschillen tussen de geselecteerde, thans geldende $\begin{array}{ll}\text { regelingen en verklaringen daarvoor } & 170\end{array}$

$\begin{array}{ll}\text { 5.2.2 Deelvraag 3: het toekomstige recht } & 173\end{array}$

$\begin{array}{lll}\text { 5.2.3 Hoofdvraag: spiegeling aan de doelstellingen en } & \\ & \text { uitgangspunten die ten grondslag liggen aan de Wns } & 174\end{array}$

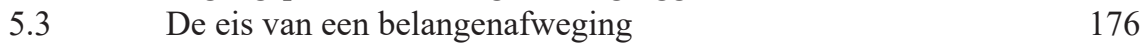

5.3.1 Deelvraag 2: verschillen tussen de geselecteerde, thans

$\begin{array}{ll}\text { 5.3.2 Deelvraag 3: het toekomstige recht } & 179\end{array}$

5.3.3 Hoofdvraag: spiegeling aan de doelstellingen en uitgangspunten die ten grondslag liggen aan de Wns 184

$\begin{array}{lll}5.4 & \text { Vergoeding van kosten van schadebeperkende maatregelen } & 190\end{array}$

5.4.1 Deelvraag 2: verschillen tussen de geselecteerde, thans geldende regelingen en verklaringen daarvoor $\quad 190$

5.4.1.1 Gaan de geselecteerde, thans geldende regelingen in op de mogelijkheid tot vergoeding?

$\begin{array}{ll}\text { 5.4.1.2 Een dubbele redelijkheidstoets } & 192\end{array}$

5.4.1.3 Zijn de kosten van de schadebeperkende maatregel onderdeel van de schade?

5.4.1.4 Is voorafgaande goedkeuring vereist voor het treffen van de maatregel?

5.4.2 Deelvraag 3: het toekomstige recht 196

5.4.3 Hoofdvraag: spiegeling aan de doelstellingen en uitgangspunten die ten grondslag liggen aan de Wns 196

5.5 Vergoeding van kosten van deskundigenbijstand 201

5.5.1 Deelvraag 2: verschillen tussen de geselecteerde, thans geldende regelingen en verklaringen daarvoor 
5.5.1.1 Gaan de geselecteerde, thans geldende regelingen in op de mogelijkheid tot vergoeding?

5.5.1.2 Rechtsbijstand en andere deskundigenbijstand 203

$\begin{array}{ll}\text { 5.5.1.3 De dubbele redelijkheidstoets } & 203\end{array}$

5.5.1.4 Zijn de kosten onderdeel van de schade? 205

$\begin{array}{lll}\text { 5.5.1.5 Forfaitaire stelsels } & 206\end{array}$

5.5.1.6 De redelijkheid van deskundigenkosten die de aanvrager heeft gemaakt met betrekking tot de indiening van zijn aanvraag om nadeelcompensatie

5.5.2 Deelvraag 3: het toekomstige recht

5.5.3 Hoofdvraag: spiegeling aan de doelstellingen en uitgangspunten die ten grondslag liggen aan de Wns 211

$5.6 \quad$ Vergoeding van wettelijke rente 216

5.6.1 Deelvraag 2: verschillen tussen de geselecteerde, thans geldende regelingen en verklaringen daarvoor

5.6.2 Deelvraag 3: het toekomstige recht

5.6.3 Hoofdvraag: spiegeling aan de doelstellingen en uitgangspunten die ten grondslag liggen aan de Wns

5.7.1 Deelvraag 2: verschillen tussen de geselecteerde, thans geldende regelingen en verklaringen daarvoor

5.7.1.1 Permanente waardedaling van onroerende zaken 223

$\begin{array}{ll}\text { 5.7.1.2 Inkomensderving } & 231\end{array}$

$\begin{array}{lll}\text { 5.7.1.3 Tijdelijke derving van woongenot } 236 & 231\end{array}$

$\begin{array}{lll}\text { 5.7.1.4 Conclusie } & 238\end{array}$

$\begin{array}{ll}\text { 5.7.2 Deelvraag 3: het toekomstige recht } & 239\end{array}$

$\begin{array}{lll}\text { 5.7.2.1 Titel 4.5 Awb } & 239\end{array}$

$\begin{array}{lll}\text { 5.7.2.2 Afd. } 15.1 \mathrm{Ow} & 240\end{array}$

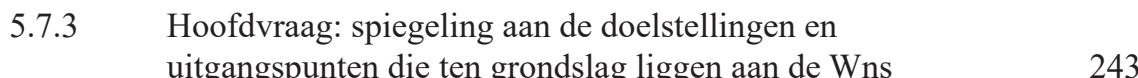

$\begin{array}{lll}\text { 5.7.3.1 Titel 4.5 Awb } & 243\end{array}$

$\begin{array}{lll}\text { 5.7.3.2 Afd. } 15.1 \mathrm{Ow} & 245\end{array}$

$\begin{array}{lll}\text { 5.7.3.3 Overige aanbevelingen } & 249\end{array}$

$\begin{array}{lll}\text { 5.7.3.4 Conclusie } & 250\end{array}$

$\begin{array}{lll}5.8 & \text { Conclusies en concrete voorstellen } & 251\end{array}$

6. Abnormale last

$\begin{array}{lll}6.1 & \text { Inleiding } 255\end{array}$

6.2 Permanente waardevermindering van onroerende zaken 260

6.2.1 Deelvraag 2: verschillen tussen de geselecteerde, thans
geldende regelingen en verklaringen daarvoor

6.2.1.1 Specifieke normering ten aanzien van permanente

6.2.1.2 De minimumdrempel uit de Wro 261

6.2.1.3 Toepassing van de Heiloo-factoren op indirecte schade 264 
6.2.1.4 Toepassing van de Heiloo-factoren op directe schade

6.2.1.5 De Heiloo-factoren zijn ook van toepassing buiten het

$\begin{array}{lll}\text { 6.2.1.6 } & \text { Conclusie } & 274 \\ \text { 6.2.2 } & \text { Deelvraag 3: het toekomstige recht } & 275\end{array}$

$\begin{array}{lll}\text { 6.2.2.1 Titel 4.5 Awb } & 275 \\ 6.2 .2 .2 & \text { Afd. } 15.1 \text { Ow }- \text { de invoering van een geflxeerd forfait van } 4 \% & 276\end{array}$

6.2.2.2 Afd. 15.1 Ow - de invoering van een gefixeerd forfait van 4\% 276

6.2.2.3 Afd. 15.1 Ow - anticumulatiebepalingen 281

6.2.2.4 Afd. 15.1 Ow - algemene maatregelen van bestuur 282

6.2.3 Hoofdvraag: spiegeling aan de doelstellingen en uitgangspunten die ten grondslag liggen aan de Wns 282

6.2.3.1 Het gefixeerde forfait van art. 15.7 lid $1 \mathrm{Ow} 283$

$\begin{array}{ll}\text { 6.2.3.2 Anticumulatiebepalingen } & 290\end{array}$

6.2.3.3 Art. 15.7 lid 4 Ow 292

$\begin{array}{lll}\text { 6.2.3.4 Conclusie } & 292\end{array}$

6.3 Inkomensderving 293

6.3.1 Deelvraag 2: verschillen tussen de geselecteerde, thans geldende regelingen en verklaringen daarvoor 293

6.3.2 Deelvraag 3: het toekomstige recht 306

6.3.3 Hoofdvraag: spiegeling aan de doelstellingen en
uitgangspunten die ten grondslag liggen aan de Wns

$\begin{array}{ll}6.4 & \text { Tijdelijke derving van woongenot } 310\end{array}$

6.4.1 Deelvraag 2: verschillen tussen de geselecteerde, thans
geldende regelingen en verklaringen daarvoor

6.4.1.1 Geen inhoudelijke normering door de regelingen 310

$\begin{array}{ll}\text { 6.4.1.2 De algemene jurisprudentielijnen } & 311\end{array}$

$\begin{array}{lll}\text { 6.4.1.3 Derving van woongenot door uitvoeringswerkzaamheden } & 312\end{array}$

6.4.1.4 Geen evidente verschillen tussen de regelingen 316

$\begin{array}{ll}\text { 6.4.2 Deelvraag 3: het toekomstige recht } & 316\end{array}$

6.4.3 Hoofdvraag: spiegeling aan de doelstellingen en

$\begin{array}{ll}\text { 6.5 Conclusies en concrete voorstellen } & 320\end{array}$

\section{De speciale last}

$\begin{array}{lll}7.1 & \text { Inleiding } & 327\end{array}$

7.2 Deelvraag 2: verschillen tussen de geselecteerde, thans
geldende regelingen en verklaringen daarvoor

7.2.1 De rol en codificatie van het criterium van de speciale last 331

$\begin{array}{ll}\text { 7.2.2 De afbakening van de referentiegroep } & 336\end{array}$

$\begin{array}{lll}7.2 .3 & \text { Conclusie } & 343\end{array}$

7.3 Deelvraag 3: het toekomstige recht 344

7.4 Hoofdvraag: spiegeling aan de doelstellingen en uitgangspunten die ten grondslag liggen aan de Wns $\quad 350$

$\begin{array}{lll}7.5 & \text { Conclusie en concrete voorstellen } & 356\end{array}$ 


\section{Risicoaanvaarding, niet voldoen aan de schade- beperkingsplicht en resterende vormen van eigen schuld}

$8.1 \quad$ Inleiding 359

8.2 Risicoaanvaarding 363

8.2.1 Deelvraag 2: verschillen tussen de geselecteerde, thans geldende regelingen en verklaringen daarvoor 363

8.2.1.1 Algemene jurisprudentielijnen 363

8.2.1.2 Grondslag voor tegenwerping van risicoaanvaarding 371

8.2.1.3 Bronnen van voorzienbaarheid 376

8.2.1.4 De stappen van art. 6:101 BW 382

8.2.1.5 Conclusie 389

8.2.2 Deelvraag 3: het toekomstige recht 391

8.2.2.1 Een algemene bepaling in titel 4.5 Awb 391

8.2.2.2 Geen actieve risicoaanvaarding vanwege art. $15.5 \mathrm{Ow} \quad 392$

8.2.2.3 Passieve risicoaanvaarding op grond van art. $15.6 \mathrm{Ow} \quad 395$

8.2.2.4 Conclusie 400

8.2.3 Hoofdvraag: spiegeling aan de doelstellingen en

8.2.3.1 Art. 4:126 lid 2, aanhef en onder a Awb 401

8.2.3.2 Art. $15.5 \mathrm{Ow} \quad 403$

8.2.3.3 Art. $15.6 \mathrm{Ow} \quad 404$

8.2.3.4 Conclusie 407

8.3 De schadebeperkingsplicht 407

8.3.1 Deelvraag 2: verschillen tussen de geselecteerde, thans
geldende regelingen en verklaringen daarvoor

8.3.2 Deelvraag 3: het toekomstige recht 411

8.3.3 Hoofdvraag: spiegeling aan de doelstellingen en
uitgangspunten die ten grondslag liggen aan de Wns

8.3.3.1 De vier stappen van art. 6:101 BW 412

8.3.3.2 Een potentieel verwarrende overweging uit de jurisprudentie 414

8.3.3.3 Conclusie 415

8.4 Resterende vormen van eigen schuld 415

8.4.1 Deelvraag 2: verschillen tussen de geselecteerde, thans

8.4.2 Deelvraag 3: het toekomstige recht 418

8.4.3 Hoofdvraag: spiegeling aan de doelstellingen en

8.5 Conclusie en concrete voorstellen 423

9. Overige materiële criteria voor toekenning van nadeelcompensatie

$9.1 \quad$ Voordeelverrekening

9.1.1 Deelvraag 2: verschillen tussen de geselecteerde, thans geldende regelingen en verklaringen daarvoor $\quad 429$

9.1.2 Deelvraag 3: het toekomstige recht 435 
9.1.3 Hoofdvraag: spiegeling aan de doelstellingen en uitgangspunten die ten grondslag liggen aan de Wns

9.2 Voldoende anderszins verzekerde schadevergoeding

9.2.1 Deelvraag 2: verschillen tussen de geselecteerde, thans geldende regelingen en verklaringen daarvoor

9.2.2 Deelvraag 3: het toekomstige recht

9.2.3 Hoofdvraag: spiegeling aan de doelstellingen en uitgangspunten die ten grondslag liggen aan de Wns

9.3.1 Deelvraag 2: verschillen tussen de geselecteerde, thans geldende regelingen en verklaringen daarvoor

9.3.2 Deelvraag 3: het toekomstige recht

9.3.3 Hoofdvraag: spiegeling aan de doelstellingen en uitgangspunten die ten grondslag liggen aan de Wns

\section{Procedurele voorschriften}

$10.1 \quad$ Inleiding

10.2 Eisen die worden gesteld aan de aanvrager 460

10.2.1 Deelvraag 2: Huidig recht 460

10.2.2 Deelvraag 3: Toekomstig recht 461

10.2.3 Hoofdvraag: spiegeling aan de doelstellingen en uitgangspunten die ten grondslag liggen aan de Wns

10.3 Eisen die worden gesteld aan de aanvraag

10.3.1 Deelvraag 2: verschillen tussen de geselecteerde, thans geldende regelingen en verklaringen daarvoor

10.3.2 Deelvraag 3: Toekomstig recht

10.3.3 Hoofdvraag: spiegeling aan de doelstellingen en

10.4.1 Deelvraag 2: verschillen tussen de geselecteerde, thans geldende regelingen en verklaringen daarvoor

10.4.2 Deelvraag 3: Toekomstig recht

10.4.3 Hoofdvraag: spiegeling aan de doelstellingen en uitgangspunten die ten grondslag liggen aan de Wns

10.5.1 Deelvraag 2: verschillen tussen de geselecteerde, thans geldende regelingen en verklaringen daarvoor

10.5.3 Hoofdvraag: spiegeling aan de doelstellingen en uitgangspunten die ten grondslag liggen aan de Wns 
10.6.3 Hoofdvraag: spiegeling aan de doelstellingen en uitgangspunten die ten grondslag liggen aan de Wns

10.7 Samenstelling van de adviescommissie

10.7.1 Deelvraag 2: verschillen tussen de geselecteerde, thans geldende regelingen en verklaringen daarvoor

10.7.2 Deelvraag 3: Toekomstig recht

10.7.3 Hoofdvraag: spiegeling aan de doelstellingen en uitgangspunten die ten grondslag liggen aan de Wns

10.8.1 Deelvraag 2: verschillen tussen de geselecteerde, thans geldende regelingen en verklaringen daarvoor

10.8.2 Deelvraag 3: Toekomstig recht

10.8.3 Hoofdvraag: spiegeling aan de doelstellingen en uitgangspunten die ten grondslag liggen aan de Wns

10.9 Inwinning van informatie door de adviescommissie

10.9.1 Deelvraag 2: verschillen tussen de geselecteerde, thans geldende regelingen en verklaringen daarvoor

10.9.2 Deelvraag 3: Toekomstig recht

10.9.3 Hoofdvraag: spiegeling aan de doelstellingen en uitgangspunten die ten grondslag liggen aan de Wns

10.10 Mogelijkheden tot inspraak voor de aanvrager, het bestuur en/of derde-belanghebbenden

10.10.1 Deelvraag 2: verschillen tussen de geselecteerde, thans geldende regelingen en verklaringen daarvoor

10.10.2 Deelvraag 3: Toekomstig recht

10.10.3 Hoofdvraag: spiegeling aan de doelstellingen en uitgangspunten die ten grondslag liggen aan de Wns

10.11.1 Deelvraag 2: verschillen tussen de geselecteerde, thans geldende regelingen en verklaringen daarvoor

10.11.2 Deelvraag 3: Toekomstig recht

10.11.3 Hoofdvraag: spiegeling aan de doelstellingen en uitgangspunten die ten grondslag liggen aan de Wns

10.12 Rechtsmiddelen

10.12.1 Deelvraag 2: verschillen tussen de geselecteerde, thans geldende regelingen en verklaringen daarvoor

10.12.2 Deelvraag 3: Toekomstig recht

10.12.3 Hoofdvraag: spiegeling aan de doelstellingen en uitgangspunten die ten grondslag liggen aan de Wns

10.13 Een voorschot op nadeelcompensatie of tegemoetkoming in planschade

10.13.1 Deelvraag 2: verschillen tussen de geselecteerde, thans geldende regelingen en verklaringen daarvoor

10.13.2 Deelvraag 3: Toekomstig recht

10.13.3 Hoofdvraag: spiegeling aan de doelstellingen en uitgangspunten die ten grondslag liggen aan de Wns 
10.14 Conclusie en concrete voorstellen

10.14.1 Voorstellen tot (a) aanpassing van titel 4.5 Awb

10.14.2 Aanbevelingen om (c) anderszins te voorzien in een bijzondere invulling, aanvulling of afwijking van titel 4.5 Awb

\section{Slotbeschouwing}

$11.1 \quad$ Inleiding 563

11.2 Aanbevelingen tot (a) aanpassing van titel 4.5 Awb 566

11.2.1 De aanbevolen redactie van titel 4.5 Awb 567

11.2.2 Reflectie op de aanbevolen redactie 575

11.3 Aanbevelingen tot (b) aanpassing van afd. 15.1 Ow 579

11.3.1 De aanbevolen redactie van afd. $15.1 \mathrm{Ow} \quad 580$

11.3.2 Reflectie op de aanbevolen redactie 584

11.4 Aanbevelingen om (c) anderszins te voorzien in bijzondere invullingen, aanvullingen, of afwijkingen van titel 4.5 Awb 587

11.4.1 Inleiding en aanbevelingen tot wijziging van andere formele wetgeving dan titel 4.5 Awb of afd. 15.1 Ow 587

11.4.2 Aanbevelingen aan het kabinet of de regering 588

$\begin{array}{ll}\text { 11.4.3 Aanbevelingen aan de rechter } & 592\end{array}$

11.4.4 Aanbevelingen aan overige bestuursorganen 594

$\begin{array}{lll}11.5 & \text { Slotopmerking } & 598\end{array}$

12. Valorisatie-addendum

12.1 Doelgroep van het proefschrift 599

12.2 De algemene maatschappelijke waarde van het proefschrift 599

12.3 Toegevoegde waarde van het proefschrift voor actoren in de $\begin{array}{ll}\text { nadeelcompensatiepraktijk } & 600\end{array}$

12.4 Verhouding tot andere wetenschappelijke publicaties 601

\section{Summary}

$\begin{array}{lll}13.1 & \text { Reason for the study } & 605\end{array}$

13.2 Objective of the study and the research questions to be answered 608

$\begin{array}{lll}13.3 & \text { Structure } & 609\end{array}$

$\begin{array}{lll}13.4 & \text { Answering the research questions } & 610\end{array}$

$\begin{array}{lll}13.5 & \text { The first sub-question } & 611\end{array}$

$\begin{array}{lll}13.6 & \text { The second sub-question } & 611\end{array}$

$\begin{array}{lll}13.7 & \text { The third sub-question } & 612\end{array}$

$\begin{array}{lll}13.8 & \text { The main research question } & 613\end{array}$

$\begin{array}{lll}13.9 & \text { Final remark } & 618\end{array}$

$\begin{array}{ll}\text { Lijst van aangehaalde literatuur } & 619\end{array}$

$\begin{array}{ll}\text { Jurisprudentieregister } & 641\end{array}$

$\begin{array}{ll}\text { Trefwoordenregister } & 659\end{array}$

$\begin{array}{ll}\text { Curriculum vitae } & 663\end{array}$ 



\section{Lijst van afkortingen}

$\begin{array}{ll}\text { A-G } & \text { Advocaat-generaal } \\ \text { AA } & \text { Ars Aequi } \\ \text { AAL } & \text { Ars Aequi Libri } \\ \text { aant. } & \text { aantekening(en) } \\ \text { AARvS } & \text { Afdeling advisering van de Raad van State } \\ \text { AB } & \text { Administratiefrechtelijke Beslissingen } \\ \text { ABRvS } & \text { Afdeling bestuursrechtspraak van de Raad van State } \\ \text { afd. } & \text { afdeling } \\ \text { afl. } & \text { aflevering } \\ \text { AGRvS } & \text { Afdeling voor de geschillen van het bestuur van de Raad van } \\ \text { amvb } & \text { State } \\ \text { AOC } & \text { algemene maatregel van bestuur } \\ \text { Ar } & \text { Air Operator Certificate } \\ \text { ARRvS } & \text { Aanwijzingen voor de regelgeving } \\ \text { art. } & \text { Afdeling rechtspraak van de Raad van State } \\ \text { AVN } & \text { artikel(en) } \\ \text { AV\&S } & \text { Algemene Verordening Nadeelcompensatie van de gemeente } \\ \text { Awb } & \text { Amsterdam } \\ \text { Bb } & \text { Aansprakelijkheid, Verzekering en Schade } \\ \text { Bbl } & \text { Algemene wet bestuursrecht } \\ \text { BJu } & \text { Bedrijfsjuridische berichten } \\ \text { BnIW 2019 } & \text { Besluit bouwwerken leefomgeving } \\ \text { BR } & \text { Boom Juridische uitgevers } \\ \text { Bro } & \text { Beleidsregel nadeelcompensatie Infrastructuur \& Waterstaat } \\ \text { BW } & \text { 2019 } \\ \text { B\&W } & \text { Bouwrecht } \\ \text { CBb } & \text { Besluit ruimtelijke ordening } \\ \text { CRvB } & \text { Burgerlijk Wetboek } \\ \text { Csqn } & \text { Burgemeester en wethouders } \\ \text { d.d. } & \text { College van Beroep voor het bedrijfsleven } \\ & \text { Centrale Raad van Beroep } \\ \text { Condicio sine qua non } \\ \text { de dato } \\ \end{array}$




$\begin{array}{ll}\text { Diss. } & \text { Dissertatie } \\ \text { Dr. } & \text { Doctor } \\ \text { Drs. } & \text { Doctorandus } \\ \text { DSO } & \text { Digitaal Stelsel Omgevingsrecht } \\ \text { e.a. } & \text { en anderen } \\ \text { EHRM } & \text { Europees Hof voor de Rechten van de Mens } \\ \text { EP EVRM } & \text { Eerste Protocol bij het Verdrag tot bescherming van de rechten } \\ & \text { van de mens en de fundamentele vrijheden } \\ \text { EVRM } & \text { Verdrag tot bescherming van de rechten van de mens en de } \\ \text { Gemw } & \text { fundamentele vrijheden } \\ \text { GmbH } & \text { Gemeentewet } \\ \text { GrS } & \text { Gesellschaft mit beschränkter Haftung } \\ \text { GS } & \text { Gemeenschappelijke regeling Schadeschap Luchthaven Schip- } \\ \text { Gst. } & \text { hol } \\ \text { GW } & \text { Groene Serie } \\ \text { HR } & \text { De gemeentestem } \\ \text { IBR } & \text { Grondwet } \\ \text { IOw } & \text { Hoge Raad } \\ \text { JBplus } & \text { Instituut voor Bouwrecht } \\ \text { j.o. } & \text { Invoeringswet Omgevingswet } \\ \text { KB } & \text { Jurisprudentie Bestuursrecht plus } \\ \text { KUN } & \text { juncto } \\ \text { Losb. } & \text { Koninklijk Besluit } \\ \text { Lvw } & \text { Katholieke Universiteit Nijmegen } \\ \text { Monw } & \text { Losbladig } \\ \text { Mr. } & \text { Luchtvaartwet } \\ \text { MvA } & \text { Monumentenwet } \\ \text { MvT } & \text { Meester } \\ \text { Nimby } & \text { Memorie van Antwoord } \\ \text { NIVEA } & \text { Memorie van Toelichting } \\ \text { NJ } & \text { Not in my backyard } \\ \text { NJB } & \text { Niet in voor en achtertuin } \\ \text { nr. } & \text { Nederlandse Jurisprudentie } \\ \text { NTB } & \text { Nederlands Juristenblad } \\ \text { NV } & \text { nummer(s) } \\ & \text { Nederlands Tijdschrift voor Bestuursrecht } \\ & \text { Nota naar aanleiding van het verslag } \\ & \end{array}$




$\begin{array}{ll}\text { NVW } & \text { Nota van wijziging } \\ \text { O\&A } & \text { Overheid \& Aansprakelijkheid } \\ \text { OAA } & \text { Open Access Advocate } \\ \text { Ow } & \text { Omgevingswet } \\ \text { p. } & \text { pagina } \\ \text { PBL } & \text { Planbureau voor de Leefomgeving } \\ \text { PKB } & \text { Planologische kernbeslissing } \\ \text { Prof. } & \text { Professor } \\ \text { PW } & \text { Provinciewet } \\ \text { Rb. } & \text { Rechtbank } \\ \text { Red. } & \text { Redactie } \\ \text { RMThemis } & \text { Rechtsgeleerd Magazijn Themis } \\ \text { RnR 1991 } & \text { Regeling nadeelcompensatie Rijkswaterstaat } \\ \text { RnVW 1999 } & \text { Regeling nadeelcompensatie Verkeer \& Waterstaat } 1999 \\ \text { r.o. } & \text { rechtsoverweging } \\ \text { SAOZ } & \text { Stichting Adviesbureau Onroerende Zaken } \\ \text { SBR } & \text { Studiereeks Burgerlijk Recht } \\ \text { sic } & \text { sic erat scriptum }\end{array}$

StAB Stichting Advisering Bestuursrechtspraak voor Milieu en Ruimtelijke Ordening, of Jurisprudentietijdschrift voor omgevingsrecht

Stb. Staatsblad

Stcrt. Staatscourant

T\&C Tekst \& Commentaar

TBR Tijdschrift voor Bouwrecht

TO

Tijdschrift voor Omgevingsrecht

TvPP Tijdschrift voor de Procespraktijk

UL Universiteit Leiden

UM Universiteit Maastricht

UU Universiteit Utrecht

UvA Universiteit van Amsterdam

VAR Vereniging voor Bestuursrecht

VBR Vereniging voor Bouwrecht

VNNZ Verordening Nadeelcompensatie Noord/Zuidlijn

VROM Ministerie van Volkshuisvesting, Ruimtelijke Ordening en Milieubeheer

VS $1999 \quad$ Verordening schadeschap Luchthaven Schiphol 
VS 2012 Verordening Schadeschap Luchthaven Schiphol 2012

VUGA Vereniging van Uitgevers voor de Gemeente Administratie

VV Voorlopig verslag

Wabo

Wet algemene bepalingen omgevingsrecht

Wet Arob

Wet administratieve rechtspraak overheidsbeschikkingen

Wlv

Wet luchtvaart

Wns

Wet nadeelcompensatie en schadevergoeding bij onrechtmatige besluiten

Wob Wet openbaarheid van bestuur

WPNR Weekblad voor Privaatrecht, Notariaat en Registratie

WRO Wet op de Ruimtelijke Ordening

Wro Wet ruimtelijke ordening

WVW 1994 Wegenverkeerswet 1994

z.j. $\quad$ zonder jaartal 


\section{Hoofdstuk 1}

\section{Inleiding}

\subsection{AANLEIDING TOT HET ONDERZOEK}

Dit proefschrift gaat over nadeelcompensatie, oftewel: schadevergoeding wegens rechtmatige overheidsdaad. Reeds eind jaren negentig van de vorige eeuw zijn pogingen ondernomen om een algemene regeling over nadeelcompensatie in de Algemene wet bestuursrecht (hierna: Awb) op te nemen. Als redenen daarvoor werden onder andere het "toenemende maatschappelijke belang" van nadeelcompensatie en een groot aantal jurisprudentiële ontwikkelingen aangedragen. ${ }^{1}$ In 2004 ontstond een stroomversnelling toen het kabinet in de nota 'Naar een slagvaardig bestuursrecht' opmerkte dat het arrest Groningen/Raatgever ${ }^{2}$ aanleiding gaf "om na te denken over aanpassing van de wetgeving rondom schadevergoeding naar aanleiding van overheidshandelen." Op initiatief van de "Commissie wetgeving algemene regels van bestuursrecht' werd vervolgens op 29 maart 2004 een expertmeeting over dit onderwerp georganiseerd op het ministerie van Justitie. ${ }^{3}$ Daarbij waren deskundigen aanwezig uit de rechterlijke macht, advocatuur, ministeriële departementen en de wetenschap. Ten aanzien van het onderwerp nadeelcompensatie kwam met name onvrede naar voren over de ingewikkelde bevoegdheidsverdeling tussen de civiele rechter en de bestuursrechter, die ook vandaag de dag nog bestaat. ${ }^{4}$ De aanwezige deskundigen spraken zich daarom uit voor een op het égalitébeginsel gegronde, algemene wettelijke nadeelcompensatieregeling die zou aansluiten bij het in de nadeelcompensatiepraktijk goed functionerende besluitmodel. $^{5}$

Na deze expertmeeting stelde de minister van Justitie, mede namens de minister van Binnenlandse Zaken en Koninkrijksrelaties, een "breed samengestelde studiegroep" in. De studiegroep kreeg als taak oplossingen te zoeken voor knelpunten inzake schadevergoeding bij onrechtmatige overheidsdaad. Zij mocht daarbij "zo nodig" ook schadevergoeding wegens rechtmatige overheidsdaad betrekken. De studiegroep is hiermee begin 2005 aangevangen en heeft in mei 2007 een voorontwerp uitgebracht. ${ }^{6}$ Dit voorontwerp is uitgegroeid tot de op 15 februari 2013 in het Staatsblad gepubliceerde 'Wet nadeelcompensatie en schadevergoeding bij

$1 \quad$ Kamerstukken II 2010/11, 32 621, nr. 3, p. 3 (MvT, Wns).

2 HR 17 december 1999, ECLI:NL:HR:1999:ZC3059 (Groningen/Raatgever).

3 Kamerstukken II 2003/04, 29 729, nr. 16, p. 12.

4 Zie paragraaf 2.2 over deze ingewikkelde bevoegdheidsverdeling.

$5 \quad$ Kamerstukken II 2010/11, 32 621, nr. 3, p. 3-4 (MvT, Wns).

$6 \quad$ Kamerstukken II 2010/11, 32 621, nr. 3, p. 4 (MvT, Wns). 
onrechtmatige besluiten' (hierna: Wns). ${ }^{7}$ Het gedeelte van de Wns dat ziet op schadevergoeding wegens onrechtmatig overheidshandelen is reeds in werking getreden. ${ }^{8}$ Het gedeelte van de Wns dat ziet op schadevergoeding wegens rechtmatig overheidshandelen moet nog steeds in werking treden. Aangezien dit proefschrift gaat over nadeelcompensatie spreekt het voor zich dat ik (doorgaans) aan dit gedeelte van deze wet refereer als ik het heb over de Wns. Voor dit proefschrift is met name van belang dat dit deel van de wet een algemene, op het égalitébeginsel gebaseerde regeling omtrent de toekenning van nadeelcompensatie in titel 4.5 Awb zal verankeren. Ook voegt het een nieuw, tweede lid toe aan art. 8:6 Awb en introduceert het enkele bepalingen van overgangsrecht.

De wetgever heeft meermaals de wens uitgesproken om titel 4.5 Awb in de plaats te laten treden van een groot deel van de thans bestaande nadeelcompensatieregelingen. ${ }^{9}$ In deze titel zijn de twee criteria opgenomen die het meest typerend zijn voor het égalitébeginsel, namelijk de criteria van een abnormale en speciale last. ${ }^{10}$ Daarnaast zijn andere materiële criteria in deze titel opgenomen, zoals het causaliteitscriterium, het bestaan van schade, de afwezigheid van risicoaanvaarding, en een schadebeperkingsplicht. Verder kent deze titel een aantal procedurele voorschriften, bijvoorbeeld over beslistermijnen, de eisen die aan een aanvraag om nadeelcompensatie worden gesteld, en de heffing van een recht om die aanvraag in behandeling te nemen.

De inwerkingtreding van de Wns laat lang op zich wachten. Deze regeling wordt - al vanaf de ontwerpfase, en na haar publicatie in het Staatsblad nog steeds - omgeven door discussie. Het belang van een algemene nadeelcompensatieregeling wordt breed onderschreven, maar het heeft er veel van weg dat de met de regeling gemoeide vragen dermate lastig zijn te beantwoorden en de betrokken (financiële) belangen dermate groot zijn dat de inwerkingtreding van deze wet steeds verder wordt uitgesteld. Een belangrijk deel van de vragen waarmee de wetgever wordt geconfronteerd, ziet op de reikwijdte van titel 4.5 Awb en - in relatie daarmee - de mate waarin deze regeling ruimte laat of zou moeten laten voor, dan wel in de plaats kan treden van, (onderdelen van) het thans bestaande veelvoud van bijzondere wettelijke en buitenwettelijke nadeelcompensatieregelingen. ${ }^{11}$

$7 \quad$ Stb. 2013, nr. 50.

$8 \quad$ Stb. 2013, nr. 162.

$9 \quad$ Zie daarover meer in het bijzonder paragraaf 2.4.2.1.

10 De wetgever spreekt in Kamerstukken II 2010/11, 32 621, nr. 3, p. 13 (MvT, Wns) van 'kernvoorwaarden'. Die term suggereert dat andere criteria, zoals de aanwezigheid van schade of het causaal verband tussen het rechtmatige overheidshandelen en die schade, van minder doorslaggevend belang zouden zijn. Om die misvatting te vermijden, zal in deze dissertatie niet van 'kernvoorwaarden' worden gesproken, maar van 'meest typerende criteria'.

11 Van den Broek \& Tjepkema 2015. 
Afhankelijk van hoe deze vragen worden beantwoord, kan de Awb-titel sterk bijdragen aan de mate waarin de wetgever zijn doelstelling behaalt om het nadeelcompensatierecht te vereenvoudigen, uniformeren en harmoniseren. ${ }^{12}$ Deze harmoniserende werking is niet beperkt tot de materiële criteria en procedurele voorschriften voor toekenning van nadeelcompensatie. Ook op het gebied van rechtsbescherming werkt de Awb-regeling harmoniserend. Zij zal namelijk steeds - behoudens enkele uitzonderingen, zoals schade veroorzaakt door formele wetgeving of strafvorderlijk overheidsoptreden ${ }^{13}$ - als publiekrechtelijke grondslag dienen voor de beslissing op aanvragen om nadeelcompensatie. Daardoor kwalificeren dergelijke beslissingen als appellabel besluit in de zin van art. 1:3 lid 1 jo. lid 2 Awb. Desalniettemin zijn tevens argumenten naar voren gebracht ter onderbouwing van de stelling dat ook na inwerkingtreding van titel 4.5 Awb behoefte zal blijven bestaan aan bijzondere regelingen. ${ }^{14}$ Het is deze spanning tussen de doelstelling van vereenvoudiging, uniformering en harmonisering enerzijds en de behoefte aan op bijzondere situaties toegesneden nadeelcompensatieregimes anderzijds, die de directe aanleiding vormt tot dit proefschrift. Ik richt mij in dit boek in het bijzonder op twee 'wetgevingsrelaties': (1) de verhouding van titel 4.5 Awb tot bijzondere, formeelwettelijke nadeelcompensatieregelingen en (2) de verhouding van titel 4.5 Awb tot bijzondere, 'lagere' nadeelcompensatieregelingen. ${ }^{15}$ Beide zal ik hierna kort toelichten.

Ten aanzien van de verhouding van titel 4.5 Awb tot bijzondere, formeelwettelijke nadeelcompensatieregelingen heeft de discussie zich de laatste jaren vooral toegespitst op de vraag of voor het omgevingsrecht een ander nadeelcompensatieregime moet gelden dan voor het overige nadeelcompensatierecht, of dat de thans bestaande status aparte van het omgevingsrecht juist dient te worden opgeheven. In dit verband dienen onder andere keuzes te worden gemaakt omtrent de wettelijke normering van de abnormale last en het al dan niet handhaven van limitatieve opsommingen van schadeoorzaken. Deze discussie wordt tegenwoordig met name gevoerd in het kader van de Omgevingswet (hierna: Ow). Bij aanname en bekrachtiging van het thans bij de Eerste Kamer aanhangige wetsvoorstel voor de Invoeringswet Omgevingswet (hierna: IOw), wordt namelijk een bijzondere nadeelcompensatieregeling - in de vorm van afd. 15.1 Ow - toegevoegd aan de Ow voor schade die het gevolg is van op de Ow gebaseerd overheidshandelen. Uit de toelichtende stukken behorende bij de IOw volgt dat titel 4.5 Awb uiterlijk

Zie paragraaf 2.4.2.1.

13 Zie paragraaf 3.3.1 voor een meer precieze beschrijving van de reikwijdte van titel 4.5 Awb.

14 Zie bijvoorbeeld Van den Broek \& Tjepkema 2015. Zij stellen verschillende varianten voor en bespreken hun 'voorkeursvariant' op p. 101-102 en 111-112. Die variant wordt op het terrein van het normaal maatschappelijk risico nader uitgewerkt in Van den Broek \& Tjepkema 2017, p. 29-31.

15 Daarmee doel ik op hiërarchisch aan de formeelwettelijke, algemene nadeelcompensatieregeling van titel $4.5 \mathrm{Awb}$ ondergeschikte, en vaak ook decentraal vastgestelde nadeelcompensatieregelingen. 
gelijktijdig met afd. $15.1 \mathrm{Ow}$ in werking zal treden. ${ }^{16}$ Dat zal naar verwachting geschieden op 1 januari $2021 .{ }^{17}$

Afd. 15.1 Ow zal als aanvulling op titel 4.5 Awb functioneren en zal bovendien in de plaats treden van een veelvoud van naar huidig recht belangrijke, omgevingsrechtelijke nadeelcompensatieregelingen. Het bekendste voorbeeld daarvan is de regeling inzake tegemoetkoming in planschade van afd. 6.1 Wet ruimtelijke ordening. Andere voorbeelden zijn art. 22 Tracéwet, art. 7.14 Waterwet en art. 4.2 Wet algemene bepalingen omgevingsrecht. ${ }^{18}$ Dit heeft tot gevolg dat het grootste deel van de aanvragen om nadeelcompensatie naar toekomstig recht zal worden afgedaan onder titel 4.5 Awb, al dan niet nader ingevuld door afd. 15.1 Ow en/of lagere nadeelcompensatieregelingen. Als het aankomt op de verhouding tussen titel 4.5 Awb en bijzondere, formeelwettelijke nadeelcompensatieregelingen zal in dit proefschrift daarom vooral worden ingegaan op de verhouding van deze titel tot afd. 15.1 Ow. $^{19}$

Ook de verhouding tussen de formeelwettelijke, algemene nadeelcompensatieregeling van titel 4.5 Awb en 'lagere' bijzondere nadeelcompensatieregelingen dient te worden verhelderd alvorens titel 4.5 Awb in werking kan treden. ${ }^{20}$ Dergelijke regelingen worden hier als bijzonder nadeelcompensatierecht bestempeld, omdat de in titel 4.5 Awb neergelegde materiële en procedurele bepalingen in dit onderzoek als hoofdbron van algemeen nadeelcompensatierecht worden gezien, ten opzichte waarvan alle overige geschreven regelingen bijzonder van aard zijn. Dat neemt niet weg dat die bijzondere regelingen een meer of minder algemeen karakter kunnen hebben. Een voorbeeld van een nadeelcompensatieregeling met een meer algemeen karakter is de Beleidsregel nadeelcompensatie Infrastructuur \& Waterstaat 2019. Deze beleidsregel speelt met name een belangrijke rol voor de praktijk van de natte en droge waterstaat. Bovendien vervulde deze beleidsregel een voorbeeldfunctie bij de vaststelling van veel andere beleidsregels en verordeningen, en zelfs bij de vaststelling van titel $4.5 \mathrm{Awb} .{ }^{21}$ Een ander voorbeeld van bijzonder nadeelcompensatierecht met een algemeen karakter is de Algemene Verordening Nadeelcompensatie van de gemeente Amsterdam. $\mathrm{Zij}$ is in beginsel van toepassing op al het rechtmatige handelen van het Amsterdamse gemeentebestuur, maar wordt bijvoorbeeld niet toegepast op schade veroorzaakt door de aanleg van de Noord/Zuidlijn. Voor de compensatie van deze schade heeft de Amsterdamse gemeenteraad namelijk een afzonderlijke regeling vastgesteld in de vorm van de

16 Kamerstukken II 2017/18, 34 986, nr. 3, p. 19 (MvT, IOw).

17 Kamerstukken II 2018/19, 33 118, nr. AU (Kamerbrief omtrent inwerkingtreding Ow).

18 Kamerstukken II 2017/18, 34 986, nr. 3, p. 35-36 (MvT, IOw).

19 Waarbij onder andere inspiratie wordt ontleend aan de inzichten die tot op heden zijn opgedaan onder afd. $6.1 \mathrm{Wro}$, art. $49 \mathrm{WRO}$ en art. $8.31 \mathrm{Wlv}$. Zie daarover paragraaf 2.3.

20 Kamerstukken I 2012/13, 32 621, nr. C, p. 8 (MvA I, Wns).

21 Kamerstukken I 2012/13, 32 621, nr. C, p. 2 (MvA I, Wns). 
Verordening Nadeelcompensatie Noord/Zuidlijn. Een ander voorbeeld van een bijzondere nadeelcompensatieregeling die - net als de Verordening Nadeelcompensatie Noord/Zuidlijn - een minder algemeen karakter heeft, betreft de Gemeenschappelijke regeling Schadeschap Luchthaven Schiphol. Zij voorziet onder meer in de tegemoetkoming in schade door de uitbreiding van Schiphol met een vijfde start- en landingsbaan.

\subsection{HeT DOEL VAN HET ONDERZOEK EN DE TE BEANTWOORDEN ONDERZOEKSVRAGEN}

De in titel 4.5 Awb vervatte normen zullen na inwerkingtreding in beginsel van toepassing zijn op het merendeel van alle aanvragen om nadeelcompensatie. ${ }^{22} \mathrm{Het}$ is echter denkbaar dat door daartoe bevoegde regelgevers of bestuursorganen zal worden gebruikgemaakt van expliciet of impliciet door titel 4.5 Awb geboden mogelijkheden tot invulling, afwijking en/of aanvulling. De keuzes omtrent het al dan niet (in ongewijzigde vorm) in stand houden van thans bestaande nadeelcompensatieregelgeving ${ }^{23}$ kunnen alleen op zinvolle wijze worden gemaakt als voldoende inzicht bestaat in de verhouding van titel 4.5 Awb tot afd. 15.1 Ow en tot overige bijzondere nadeelcompensatieregelingen. Gebrek aan dit inzicht lijkt in belangrijke mate bij te dragen aan het steeds opnieuw uitstellen van de inwerkingtreding van titel 4.5 Awb. Met dit onderzoek beoog ik bij te dragen aan dit inzicht. Daartoe zal de volgende hoofdvraag worden beantwoord:

Geven de aan de Wns ten grondslag liggende doelstellingen en uitgangspunten, mede in het licht van verklaringen voor verschillen tussen thans geldende nadeelcompensatieregelingen, reden om (a) titel $4.5 \mathrm{Awb}$ aan te passen, (b) afd. $15.1 \mathrm{Ow}$ aan te passen, en/of (c) anderszins te voorzien in een bijzondere invulling, aanvulling of afwijking van titel $4.5 \mathrm{Awb}$ ?

Onderdeel a en b strekken ertoe inzichtelijk te maken op welke punten titel 4.5 Awb respectievelijk afd. $15.1 \mathrm{Ow}$ aanpassing behoeven teneinde beter aan te sluiten op de aan de Wns ten grondslag liggende doelstellingen en uitgangspunten. Onderdeel c ziet op overige maatregelen waartoe deze doelstellingen en uitgangspunten aanleiding kunnen geven. Dat kan onder andere gaan om de vaststelling of wijziging van een formele wet, niet zijnde titel 4.5 Awb of afd. 15.1 Ow. Soms zal echter niet de formele wetgever, maar een andere actor binnen het nadeelcompensatierecht in de beste positie verkeren om de aan de Wns ten grondslag liggende doelstellingen en uitgangspunten te behartigen. Dan kan beantwoording van dit vraagonderdeel ook leiden tot aanbeveling van andersoortige maatregelen. ${ }^{24}$ Daarbij kan worden gedacht aan de vaststelling van lagere regelgeving en/of beleid,

22 Zie paragraaf 3.3.1 omtrent de precieze reikwijdte van titel 4.5 Awb.

23 Zie daarover ook paragraaf 1.1 en Kamerstukken II 2010/11, 32 621, nr. 6, p. 15-16 (NV II, Wns).

24 Zie hierover ook de laatste alinea van paragraaf 1.4. 
bijvoorbeeld op gemeentelijk niveau. Ook de rechter of het bestuur zal soms kunnen bijdragen aan de behartiging van de doelstellingen en uitgangspunten, bijvoorbeeld door een rechterlijke uitspraak respectievelijk besluit op een bepaalde wijze te motiveren. Ten slotte kan bijvoorbeeld worden gedacht aan een aanbeveling tot vaststelling van een modelbrief of modelbesluit.

De hoofdvraag zal eerst in hoofdstuk $3 \mathrm{t} / \mathrm{m} 10$ worden beantwoord per materieel criterium of procedureel voorschrift dat bepalend is voor de toekenning van nadeelcompensatie (zoals de criteria van abnormale en speciale last, en procedurele voorschriften over de indiening en behandeling van de aanvraag om nadeelcompensatie). ${ }^{25}$ De inzichten die daarbij worden opgedaan, vormen vervolgens de basis voor een alles overziende beantwoording van de hoofdvraag in hoofdstuk 11 - het sluitstuk van dit proefschrift. De hoofdvraag valt uiteen in een drietal deelvragen. De eerste deelvraag is algemeen van aard en luidt:

\section{Welke doelstellingen en uitgangspunten liggen ten grondslag aan de Wns?}

Deze deelvraag wordt in paragraaf 2.4 .2 beantwoord en strekt ertoe het toetsingskader van dit proefschrift vast te stellen. Dat toetsingskader bestaat uit de aan de Wns ten grondslag liggende doelstellingen en uitgangspunten. Hiervoor is gekozen omdat deze doelstellingen en uitgangspunten de meest recente weerspiegeling vormen van de waarden die de formele wetgever van belang acht voor een algemene nadeelcompensatieregeling. ${ }^{26}$

Voor de beantwoording van de hoofdvraag in hoofdstuk $3 \mathrm{t} / \mathrm{m} 10$ zullen bovendien steeds een tweede en derde deelvraag moeten worden beantwoord die betrekking hebben op het te bestuderen materiële criterium of procedurele voorschrift. Zij luiden als volgt:

2. Zijn er verschillen in de wijze waarop de geselecteerde, thans geldende regelingen zijn vormgegeven, en zo ja, hoe kunnen deze verschillen worden verklaard?

3. Hoe zal het toekomstige nadeelcompensatierecht worden vormgegeven door titel $4.5 \mathrm{Awb}$ en afd. 15.1 Ow?

25 In paragraaf 1.3 wordt nader ingegaan op de criteria en voorschriften die zullen worden bestudeerd.

26 Zowel in de hoofdvraag als deze deelvraag wordt bewust gesproken van aan de $W n s$ ten grondslag liggende doelstellingen en uitgangspunten. De Wns introduceert immers niet slechts titel $4.5 \mathrm{Awb}$, maar zal bijvoorbeeld ook een nieuw tweede lid aan art. 8:6 Awb toevoegen. Ook eventuele waardes die kunnen worden afgeleid uit de daarbij behorende toelichting moeten onderdeel kunnen uitmaken van het toetsingskader van dit proefschrift. 
Beantwoording van de tweede deelvraag is in de eerste plaats nodig omdat de aan de Wns ten grondslag liggende doelstellingen en uitgangspunten niet absoluut van aard zijn. Zo kan codificatie van een bijzondere regeling inzake risicoaanvaarding in afd. 15.1 Ow goed aansluiten op de doelstelling de rechtszekerheid te vergroten, maar tegelijkertijd afbreuk doen aan de doelstelling het nadeelcompensatierecht (zoveel mogelijk) te uniformeren en harmoniseren. Door te analyseren welke verschillen tussen de thans geldende nadeelcompensatieregelingen bestaan en welke verklaringen daarvoor kunnen worden aangedragen, zal het onderzoek bijdragen aan het inzicht dat de wetgever nodig heeft om de keuzes te kunnen maken die nodig zijn voor inwerkingtreding van titel 4.5 Awb. Op basis hiervan kunnen immers uitspraken worden gedaan omtrent de wenselijkheid en/of noodzaak van de opname van een bepaald type bepaling in titel $4.5 \mathrm{Awb}$, afd. $15.1 \mathrm{Ow}$, of lagere regelgeving of beleid. Dat is echter niet de enige reden waarom het thans geldende recht zal worden onderzocht. Bestudering van dat recht is namelijk ook relevant omdat een van de doelstellingen van titel $4.5 \mathrm{Awb}$ is het huidige nadeelcompensatierecht te codificeren. ${ }^{27}$ De mate waarin titel 4.5 Awb en afd. 15.1 Ow geschikt zijn om deze doelstelling te bereiken, kan niet worden vastgesteld zonder te onderzoeken in hoeverre de daarin vervatte materiële criteria en procedurele voorschriften voor de toekenning van nadeelcompensatie overeenstemmen met de invulling van die criteria en voorschriften naar huidig recht.

De derde deelvraag ziet op de vormgeving van het toekomstige nadeelcompensatierecht door titel 4.5 Awb en afd. 15.1 Ow. De noodzaak van haar beantwoording spreekt voor zich. Kennis omtrent de inhoud van beide regelingen, en inzicht in de wijze waarop deze regelingen dienen te worden toegepast volgens de daarbij behorende toelichtende stukken, is immers noodzakelijk om te kunnen bepalen hoe deze regelingen zich verhouden tot de aan de Wns ten grondslag liggende doelstellingen en uitgangspunten. Samenvattend, resulteert het voorafgaande in de volgende vraagstelling:

\section{Hoofdvraag}

Geven de aan de Wns ten grondslag liggende doelstellingen en uitgangspunten, mede in het licht van verklaringen voor verschillen tussen thans geldende nadeelcompensatieregelingen, reden om (a) titel $4.5 \mathrm{Awb}$ aan te passen, (b) afd. $15.1 \mathrm{Ow}$ aan te passen, en/of (c) anderszins te voorzien in een bijzondere invulling, aanvulling of afwijking van titel $4.5 \mathrm{Awb}$ ? 


\section{Deelvragen}

1. Welke doelstellingen en uitgangspunten liggen ten grondslag aan de Wns?

2. Zijn er verschillen in de wijze waarop de geselecteerde, thans geldende regelingen zijn vormgegeven, en zo ja, hoe kunnen deze verschillen worden verklaard?

3. Hoe zal het toekomstige nadeelcompensatierecht worden vormgegeven door titel 4.5 Awb en afd. 15.1 Ow?

In paragraaf 1.5 zal nader worden toegelicht hoe deze vraagstelling zich vertaalt in de wijze waarop dit proefschrift in hoofdstukken is onderverdeeld.

\subsection{DE PLAATS VAN HET ÉGALITÉBEGINSEL BINNEN HET ONDERZOEK}

Naar huidig recht vormt het égalitébeginsel de belangrijkste rechtsgrondslag voor de toekenning van nadeelcompensatie. Dat is ook de reden dat de wetgever ervoor heeft gekozen het égalitébeginsel als enige grondslag voor nadeelcompensatie in titel 4.5 Awb op te nemen. ${ }^{28}$ Ook na inwerkingtreding van deze titel zal het overgrote deel van alle nadeelcompensatie dus worden toegekend vanwege het égalitébeginsel. De reeds in dit hoofdstuk genoemde (maar ook andere) bijzondere regelingen zijn op het égalitébeginsel gebaseerd; er bestaan geen voorbeelden van regelingen die expliciet op een andere grondslag zijn gebaseerd. Wel wordt in de literatuur betoogd dat ook andere grondslagen een recht op nadeelcompensatie kunnen geven. ${ }^{29}$ Daarbij moet in het bijzonder worden gedacht aan het vertrouwensbeginsel, het evenredigheidsbeginsel en art. 1 EP EVRM. Op de wijze waarop het égalitébeginsel zich tot deze beginselen verhoudt, ga ik in deze dissertatie niet uitgebreid in. Dat is ook niet nodig, omdat de focus van dit proefschrift ligt op de verhouding van titel 4.5 Awb tot bijzondere nadeelcompensatieregelingen. ${ }^{30}$

De focus op regelgeving die op het égalitébeginsel is gebaseerd, betekent praktisch vooral dat de twee criteria die het égalitébeginsel het meest typeren - zijnde de criteria van de speciale en abnormale last - een belangrijk deel van dit onderzoek zullen uitmaken. ${ }^{31}$ Een onderzoek naar de verhouding tussen titel 4.5 Awb, afd. $15.1 \mathrm{Ow}$, en thans bestaande nadeelcompensatieregelingen is echter niet goed mogelijk zonder ook andere materiële criteria voor het bestaan van een recht op nadeelcompensatie te bestuderen. Deze andere criteria zijn namelijk niet in minde-

28 Kamerstukken II 2010/11, 32 621, nr. 3, p. 13-14 (MvT, Wns).

29 Zie Kamerstukken II 2010/11, 32 621, nr. 3, p. 13-14 (MvT, Wns) onder verwijzing naar onder andere Tjepkema 2010, p. 904-907.

30 In Huijts \& Tjepkema 2019 wordt ingegaan op de rol die de genoemde grondslagen zullen hebben na inwerkingtreding van titel $4.5 \mathrm{Awb}$.

31 Zie Kamerstukken II 2010/11, 32 621, nr. 3, p. 13, 23 (MvT, Wns) en Tjepkema 2012, p. 388. 
re mate doorslaggevend voor de beantwoording van de vraag of, en zo ja hoeveel, nadeelcompensatie dient te worden toegekend. Te denken valt aan het criterium inzake risicoaanvaarding, dat vooral reliëf heeft gekregen in de jurisprudentie inzake (het op materiële rechtszekerheid gebaseerde) art. 49 Wet op de Ruimtelijke Ordening (hierna: WRO) - de voorloper van de Wet ruimtelijke ordening. ${ }^{32}$ Ook kan worden gedacht aan criteria die inherent zijn aan iedere vorm van schadevergoeding, zoals de aanwezigheid van schade en causaal verband tussen die schade en de beweerde schadeoorzaak. Bij de selectie van de te bestuderen criteria is titel 4.5 Awb leidend geweest. Een en ander betekent dat ik de tweede en derde deelvraag en de hoofdvraag zal beantwoorden ten aanzien van de volgende materiële criteria voor toekenning van nadeelcompensatie:

- De beweerde schadeoorzaak dient onder de reikwijdte van de ingeroepen nadeelcompensatieregeling te vallen.

- Er dient sprake te zijn van causaal verband tussen de gestelde schade en beweerde schadeoorzaak.

- De gestelde schade dient daadwerkelijk te zijn geleden en het desbetreffende type schade dient voor compensatie in aanmerking te komen. Daarbij zal worden ingegaan op vragen als:

- Welke schadesoorten komen voor nadeelcompensatie in aanmerking?

- Dient de schade het gevolg te zijn van een door het bestuur gemaakte belangenafweging?

- Dient wettelijke rente te worden betaald over het te vergoeden schadebedrag?

- Hoe wordt de schade begroot?

- De schade dient te kwalificeren als een abnormale en speciale last.

- De aanvrager mag het risico op het ontstaan van de schade niet actief of passief hebben aanvaard, of een andere vorm van eigen schuld kunnen krijgen tegengeworpen.

- Er dienen geen overige redenen te bestaan om schade voor rekening van de aanvrager te laten. Daarbij zal worden ingegaan op vragen als:

- Is de vergoeding van de schade niet reeds voldoende anderszins (in natura) verzekerd?

- Onder welke omstandigheden kan eventueel door de schadeoorzaak ondervonden voordeel met het daardoor geleden nadeel worden verrekend (voordeelverrekening)?

Naast materiële criteria betrek ik ook procedurele voorschriften in dit onderzoek. De procedurele inrichting van nadeelcompensatieregelingen is niet iets dat vanzelfsprekend uit een materieel rechtsbeginsel als het égalitébeginsel voortvloeit, maar is binnen het nadeelcompensatierecht als zodanig wel van wezenlijk belang. In een onderzoek naar de verhouding tussen titel 4.5 Awb en bijzondere nadeelcompensatieregelingen kan bestudering van de belangrijkste procedurele voor- 
schriften dan ook niet ontbreken. Ook voor de selectie van de procedurele voorschriften die in dit onderzoek worden betrokken, geldt dat titel 4.5 Awb primair leidend is geweest. Toch heb ik gemeend er goed aan te doen om ook procedurele voorschriften in dit onderzoek te betrekken die niet in deze titel zijn neergelegd. Soms bevatten bijzondere nadeelcompensatieregelingen namelijk voor de praktijk belangrijke procedurele voorschriften die niet in titel 4.5 Awb kunnen worden teruggevonden, zoals voorschriften inzake de raadpleging en samenstelling van een adviescommissie en de eisen die aan haar advies worden gesteld. De mate waarin titel 4.5 Awb geschikt is om de aan de Wns ten grondslag liggende doelstellingen en uitgangspunten te waarborgen, kan daarom slechts (volledig) worden vastgesteld indien ook deze voorschriften in het onderzoek worden betrokken. Op het procedurele vlak zal beantwoording van de tweede en derde deelvraag en de hoofdvraag daarom betrekking hebben op de onderstaande procedurele voorschriften:

- De eisen die worden gesteld aan de aanvrager van nadeelcompensatie.

- De eisen die worden gesteld aan de aanvraag om nadeelcompensatie.

- De heffing van een recht voor het in behandeling nemen van de aanvraag.

- De verjaring van het recht op nadeelcompensatie.

- De voorwaarden waaronder het bestuur een adviescommissie kan en/of moet raadplegen.

- De eisen die worden gesteld aan de samenstelling van een adviescommissie.

- De eisen die aan de inhoud van het advies worden gesteld dat de adviescommissie dient uit te brengen.

- De wegen waarlangs de adviescommissie informatie kan vergaren.

- De mogelijkheden tot inspraak voor de aanvrager, het bestuur ${ }^{33}$ en/of derdebelanghebbenden.

- De termijnen die in acht moeten worden genomen door de partijen die betrokken zijn bij de aanvraag om nadeelcompensatie.

- De rechtsmiddelen die tegen het besluit op de aanvraag om nadeelcompensatie kunnen worden aangewend.

- De voorwaarden waaronder het bestuur een voorschot dient te verlenen aan de benadeelde.

\subsection{METHODE EN VERDERE AFBAKENING VAN HET ONDERZOEK}

Dit proefschrift betreft een klassiek-juridisch onderzoek waarin regelgeving, jurisprudentie en literatuur omtrent nadeelcompensatie is bestudeerd teneinde de in paragraaf 1.2 opgeworpen onderzoeksvragen te beantwoorden. ${ }^{34}$ Hierna zal ik de in paragraaf 1.3 gemaakte keuze om (op) het égalitébeginsel (gebaseerde regel-

33 Hiermee doel ik op mogelijkheden van het bestuur om zijn standpunt kenbaar te maken bij de adviescommissie.

34 Ontwikkelingen na de aanname van het voorstel voor de IOw door de Tweede Kamer (zie paragraaf 2.4.3) zijn in principe niet meer meegenomen in dit onderzoek. 
geving) centraal te stellen, en de gevolgen die zij voor het onderzoek heeft van nadere toelichting voorzien. Daartoe plaats ik eerst een opmerking ten aanzien van de tweede deelvraag: aangezien er naar huidig recht tientallen formeelwettelijke nadeelcompensatieregelingen en honderden nadeelcompensatieregelingen van lagere rangorde bestaan, kan de tweede deelvraag slechts worden beantwoord door een selectie van thans geldende nadeelcompensatieregelingen te maken. Deze selectie kan slechts op zinvolle wijze worden gemaakt nadat in paragraaf 2.2 enig inzicht is verschaft in de wijze van integratie van het égalitébeginsel in de Nederlandse rechtsorde en de daaruit voortvloeiende motieven voor de vaststelling van nadeelcompensatieregelingen. Daarom zal pas in paragraaf 2.3 worden toegelicht waarom de keuze is gevallen op afdeling 6.1 van de Wet ruimtelijke ordening (hierna: Wro), de Gemeenschappelijke regeling Schadeschap Luchthaven Schiphol (hierna: GrS), de Beleidsregel nadeelcompensatie Infrastructuur \& Waterstaat 2019 (hierna: BnIW 2019), de Verordening Nadeelcompensatie Noord/ Zuidlijn (hierna: VNNZ) en de Algemene Verordening Nadeelcompensatie van de gemeente Amsterdam (hierna: AVN). In die paragraaf zal tevens worden ingegaan op de vraag of de conclusies die worden getrokken naar aanleiding van de bestudering van deze regelingen ook breder toepasbaar zijn. Voor nu, volsta ik met de opmerking dat is beoogd regelingen met een groot praktisch belang en waardevolle (ontstaans- en/of toepassings)geschiedenis te selecteren. Ook is gezocht naar een balans tussen formeelwettelijke regelgeving en regelingen van lagere rangorde, een balans tussen centrale en decentrale regelgeving, en een balans tussen regelingen met een algemeen en bijzonder karakter.

Mijn volgende opmerking heeft eveneens betrekking op de tweede deelvraag, en dan meer specifiek op de daarin genoemde verklaringen voor verschillen tussen de thans geldende nadeelcompensatieregelingen. Dergelijke verklaringen kunnen zijn gelegen in juridisch relevante argumenten die al dan niet voortvloeien uit de bijzonderheden van het te reguleren deelterrein. Zo wordt in het omgevingsrecht doorgaans gebruikgemaakt van getrapte besluitvorming: een omgevingsvergunning is gebaseerd op een bestemmingsplan, en aan dat bestemmingsplan is een structuurvisie voorafgegaan. Bovendien veroorzaken dergelijke bestemmingsplannen hoofdzakelijk schade in de vorm van permanente waardedaling van onroerende zaken. Dat staat bijvoorbeeld in contrast met een ad hoc genomen besluit tot tijdelijke afsluiting van een weg wegens regulier onderhoud, dat een permanente waardedaling van onroerende zaken in beginsel niet op rechtmatige wijze kan veroorzaken. Een ander voorbeeld van een juridische verklaring werd reeds gegeven in paragraaf 1.1, namelijk dat een bijzondere nadeelcompensatieregeling algemeen van aard kan zijn, of juist toegespitst op een bepaalde soort schade of schadeveroorzakende ontwikkeling. Zo is het denkbaar dat de VNNZ het recht op nadeelcompensatie op bepaalde punten specifieker kan normeren, omdat deze verordening - in tegenstelling tot de AVN - slechts ziet op één schadeveroorzakend ruimtelijk project, namelijk de aanleg van de Noord/Zuidlijn.

Het dient echter niet uit het oog te worden verloren dat sommige verschillen tussen de geselecteerde, thans geldende regelingen deels of zelfs uitsluitend zullen kun- 
nen worden verklaard door niet-juridische motieven, zoals motieven van politieke aard. Vanuit juridisch perspectief kan slechts worden aangegeven binnen welke grenzen ruimte bestaat voor dit soort motieven. Ook kan inzichtelijk worden gemaakt wat de voor- en nadelen zijn van het toekennen van waarde aan dergelijke motieven. Zo zullen ruimere vergoedingen doorgaans leiden tot minder weerstand bij omwonenden tegen op zichzelf wenselijke ruimtelijke ontwikkelingen (de zogenoemde smeermiddelfunctie ${ }^{35}$ van het nadeelcompensatierecht), maar niet in goede aarde vallen bij de projectontwikkelaar die zich jegens het bestuur heeft verbonden om die vergoedingen te betalen. Voor een jurist is het minder goed mogelijk de wenselijkheid van dergelijke onderliggende motieven te beoordelen. In zoverre zij zich voordoen, zullen echter ook dit soort verklaringen worden meegenomen bij beantwoording van de tweede deelvraag en de hoofdvraag.

Omdat de directe aanleiding voor dit onderzoek is gelegen in de door de formele wetgever ondervonden problematiek van afstemming van titel 4.5 Awb tot afd. 15.1 Ow en de thans geldende nadeelcompensatieregelgeving, plaats ik ten derde een opmerking over de rol die rechterlijke uitspraken in dit onderzoek zullen spelen. Bij de beantwoording van de in paragraaf 1.2 opgeworpen onderzoeksvragen kan namelijk niet slechts worden volstaan met bestudering van de tekst van de geselecteerde regelingen en de daarbij behorende toelichtingen. Zo kan de mate waarin door titel 4.5 Awb en afd. 15.1 Ow wordt voldaan aan de doelstelling van codificatie van het nadeelcompensatierecht (een onderdeel van de hoofdvraag) slechts worden beoordeeld door rechterlijke uitspraken inzake het desbetreffende criterium voor toekenning van nadeelcompensatie te bestuderen. Bovendien is het goed denkbaar dat verschillende formuleringen in regelingen tot uiteenlopende materieelrechtelijke toepassingen van hetzelfde criterium kunnen leiden, maar juist ook dat vergelijkbare formuleringen tot uiteenlopende materieelrechtelijke toepassingen van hetzelfde criterium leiden. Ook de tweede deelvraag, die ziet op de (verklaring van) verschillen tussen de thans geldende regelingen, kan daardoor slechts volledig worden beantwoord door op basis van de onder de regelingen gewezen jurisprudentie na te gaan of er (gesanctioneerde) verschillen bestaan in de toepassing van de materiële criteria en procedurele voorschriften voor toekenning van nadeelcompensatie. Het kan bovendien niet worden uitgesloten dat aan dergelijke jurisprudentie ook verklaringen voor verschillen tussen de regelingen kunnen worden ontleend.

Een volgende belangrijke kanttekening is dat de bespreking van de materiële criteria en procedurele voorschriften niet uitputtend beoogt te zijn, in die zin dat alle literatuur en jurisprudentie wordt besproken die over de betreffende regelingen is verschenen. Leidend zijn de in paragraaf 1.2 besproken onderzoeksvragen, zodat ook voor wat betreft de analyse en selectie van literatuur en jurisprudentie het accent ligt op de mogelijke verschillen en overeenkomsten tussen de regelingen

35 Zie daarover paragraaf 2.2 onder het kopje 'Het hedendaagse nadeelcompensatiedoolhof' en de aanhef van paragraaf 2.3. 
in kwestie. Bovendien kan het per materieel criterium of procedureel voorschrift verschillen hoeveel aandacht wordt geschonken aan de daaromtrent gewezen jurisprudentie. Zo hebben de formele wetgever en de overige regelgevers tot op heden nauwelijks inhoudelijke eisen aan het causaal verband gesteld, waardoor de invulling van dit criterium in belangrijke mate is bepaald door de rechtspraak. Ondanks het hiervoor beschreven accent op de geselecteerde regelingen, is ook jurisprudentie en literatuur geanalyseerd die geen betrekking heeft op deze regelingen, maar wel inzicht kan verschaffen in het functioneren van deze regelingen, of anderszins relevant kan zijn voor aanbevelingen ten aanzien van het toekomstige nadeelcompensatierecht. Uiteraard kon dat vanwege de omvang van dit onderzoek niet uitputtend gebeuren en is het tot op zekere hoogte arbitrair welke bronnen in dit verband als essentieel moeten worden beschouwd.

In algemene zin zal in ieder geval blijken dat in verhouding minder jurisprudentie van de civiele rechter wordt besproken. Deze rechter kan namelijk niet worden geadieerd wanneer een (formeel)wettelijke nadeelcompensatieregeling of nadeelcompensatiebeleidsregel op de door de benadeelde geleden schade van toepassing is. ${ }^{36}$ De civiele rechter heeft daarom geen uitspraken gewezen onder de voor dit onderzoek geselecteerde regelingen. Toch kan bespreking van enige civielrechtelijke jurisprudentie in dit proefschrift niet achterwege blijven. In geschillen omtrent de toepassing van art. 49 WRO kon in de nasleep van het Benthem-arrest van 23 oktober $1985^{37}$ namelijk tot 1 januari 1988 niet slechts een beroep op de Kroon, maar ook een beroep op de civiele rechter worden gedaan. ${ }^{38}$ Bovendien blijkt op grond van het ongeschreven égalitébeginsel door de civiele rechter gewezen jurisprudentie soms relevant voor de wijze waarop regelgevers, uitvoerende bestuursorganen en/of de bestuursrechter invulling geven aan nadeelcompensatieregelingen. Ook zal uit paragraaf 2.4.2.1 blijken dat de ingewikkelde competentieverdeling tussen civiele rechter en bestuursrechter een belangrijke aanleiding was tot het vaststellen van titel 4.5 Awb. Wat betreft de rol die de civiele rechter na inwerking van titel 4.5 Awb in het nadeelcompensatierecht zal spelen, verwijs ik naar de bijdrage van Tjepkema en mijzelf aan de bundel 25 jaar $A w b .{ }^{39}$

Ten slotte merk ik op dat het, gelet op de aanleiding van het onderzoek, op het eerste oog voor de hand zou liggen om bij de beantwoording van de hoofdvraag hoofdzakelijk aanbevelingen aan regelgevers te doen. De al lang in voorbereiding zijnde afstemmingswetgeving is immers de voornaamste reden dat titel 4.5 Awb pas acht jaar na bekrachtiging in werking zal treden. Toch zal in dit onderzoek niet slechts worden bezien of de formele wetgever of een andere regelgever in actie moet komen om de doelstellingen en uitgangspunten van de Wns (beter) te uitgebreider worden ingegaan in paragraaf 2.2 .

37 EHRM 23 oktober 1985, ECLI:NL:XX:1985:AC9055 (Benthem).

38 Zie Van Zeben 1999, p. 562; en onderdeel b van de noot van Van Wijmen bij HR 11 juni 1993, ECLI:NL:HR:1993:ZC0995 (Ruijsch/Apeldoorn) in BR 1994, p. 763 e.v. Huijts \& Tjepkema 2019. 
behartigen. Zeker ten aanzien van criteria voor toekenning van nadeelcompensatie waarvan de invulling in grote mate afhankelijk is van een weging van de bijzondere omstandigheden van het individuele schadegeval - daarbij kan bijvoorbeeld worden gedacht aan het criterium van aanwezigheid van causaal verband - is het denkbaar dat regelgevers slechts tot op beperkte hoogte tegemoet kunnen komen aan de doelstellingen en uitgangspunten die aan de Wns ten grondslag liggen. In het bijzonder voor dit soort criteria is het van belang te benoemen hoe uitvoerende bestuursorganen en de rechter kunnen bijdragen aan de realisatie en behartiging van de doelstellingen en uitgangspunten van de Wns. De hoofdvraag laat daartoe ook ruimte doordat zij spreekt van (c) het anderszins voorzien in een bijzondere invulling, aanvulling of afwijking van de in titel 4.5 Awb vervatte materiële criteria en procedurele voorschriften.

\subsection{OPBOUW VAN HET ONDERZOEK}

Dit proefschrift is opgebouwd uit drie delen, die hierna alle zullen worden toegelicht.

\section{Deel I - Het nadeelcompensatielandschap}

Het eerste deel van dit proefschrift wordt gevormd door de eerste twee hoofdstukken van dit boek. Het eerste hoofdstuk is uiteraard opgenomen om de aanleiding, doelstelling en opzet van het proefschrift te beschrijven. In dit eerste hoofdstuk is enkele keren vooruit verwezen naar het tweede hoofdstuk. Daarin zal namelijk de eerste deelvraag worden beantwoord en de selectie van nadeelcompensatieregelingen nader worden gemotiveerd. Het tweede hoofdstuk kent echter ook een andere functie. Het beschrijft de totstandkoming van het huidige 'nadeelcompensatielandschap' en brengt de belangrijkste contouren van dat landschap in kaart. Die contouren zijn het resultaat van een samenspel tussen verschillende actoren, die gezamenlijk verantwoordelijk zijn voor de inhoud van het (algemene en bijzondere) nadeelcompensatierecht. Enig inzicht in (de totstandkoming van) deze contouren is vereist, omdat zij immers reden voor de formele wetgever vormden om titel 4.5 Awb en afd. 15.1 Ow vast te stellen.

Enig inzicht in de rol die de verschillende actoren vandaag de dag spelen ten aanzien van de toepassing en interpretatie van het égalitébeginsel (en daarop gebaseerde nadeelcompensatieregelingen) is bovendien nodig om de tweede en derde deelvraag en de hoofdvraag adequaat te kunnen beantwoorden. Van groot belang is bijvoorbeeld de rechtsvorming door de formele wetgever, die onder andere limitatieve opsommingen van schadeoorzaken in een wet opneemt (vergelijk art. 6.1 lid 2 Wro) of het normaal maatschappelijk risico nader normeert (vergelijk art. 6.2 Wro). Ook komt het geregeld voor dat een decentrale regelgever voor bijzondere projecten in een regeling voorziet (vergelijk de VNNZ) of in algemene zin specifieke materiële criteria en/of procedurele voorschriften opneemt in een regeling (vergelijk de BnIW 2019 en de AVN). Uitvoerende bestuursorganen passen 
dergelijke formele wetten en overige regelingen toe, waarna de bestuursrechter op zijn beurt kan oordelen over concrete beschikkingen inzake nadeelcompensatie.

Het is een uitdaging om in één hoofdstuk de positie te bespreken die ieder van de genoemde actoren inneemt in het nadeelcompensatielandschap. Over de rol van elk van die actoren zou namelijk eenvoudig een afzonderlijk proefschrift kunnen worden geschreven. Toch is het nodig hierop - noodzakelijkerwijs op hoofdlijnen - in te gaan. Zo zal aan bod komen welke bijzondere formeelwettelijke nadeelcompensatieregelingen en regelingen van lagere rangorde bestaan en op wat voor wijze zij uitdrukking geven aan het égalitébeginsel. Ook zal ik ingaan op de staatsrechtelijke grenzen die in acht moeten worden genomen bij de vaststelling van (formeel)wettelijke nadeelcompensatieregelingen en nadeelcompensatiebeleidsregels. Verder zal in dit hoofdstuk worden besproken hoe de bestuursrechter besluiten toetst die worden genomen op grond van deze regelingen. De bestuursrechter kan niet langer worden gezien als een rechter die slechts marginaal toetst en 'achteroverleunt': ${ }^{40}$ als de beroepsgronden hem daartoe de ruimte bieden, treedt hij soms actief op door bijvoorbeeld zelf drempels en kortingen vast te stellen. De bestuursrechter is naar huidig recht dan ook in belangrijke mate verantwoordelijk voor de invulling die wordt gegeven aan vage begrippen als 'voorzienbaarheid', 'normaal maatschappelijk risico' en 'het voldoende anderszins zijn verzekerd van schadevergoeding'. Dit wordt fraai geïllustreerd door de in een planschadegeschil door de Afdeling gewezen overzichtsuitspraak van 28 september 2016 (hierna: de Overzichtsuitspraak), die naast de thans bestaande nadeelcompensatieregelingen een belangrijke bron van normering vormt. ${ }^{41}$ Enig inzicht in de rol van de bestuursrechter in het hedendaagse nadeelcompensatierecht, is dan ook nodig om de jurisprudentie die wordt besproken in het derde tot en met tiende hoofdstuk - en bovendien in belangrijke mate bepalend is voor de toepassing van en verhouding tussen de geselecteerde regelingen - goed te kunnen plaatsen.

Deel II - Bestudering van materiële criteria en procedurele voorschriften voor de toekenning van nadeelcompensatie

In hoofdstuk drie $\mathrm{t} / \mathrm{m}$ negen zullen de tweede en derde deelvraag en de hoofdvraag worden beantwoord ten aanzien van alle in paragraaf 1.3 genoemde materiële criteria. ${ }^{42}$ Daarbij zal zoveel mogelijk worden aangesloten bij de volgorde waarin de

40 Deze woordkeuze is geïnspireerd op Damen 2006.

41 ABRvS 28 september 2016, ECLI:NL:RVS:2016:2582 (Overzichtsuitspraak).

42 Voor wat betreft de beantwoording van de hoofdvraag zal daarbij - door middel van vermelding van (a), (b), of (c) - steeds worden gerefereerd aan de onderverdeling van die vraag in (a) aanpassing van titel $4.5 \mathrm{Awb}$, (b) aanpassing van afd. $15.1 \mathrm{Ow}$ en (c) het anderszins voorzien in een bijzondere invulling, aanvulling of afwijking van titel 4.5 Awb. 
Afdeling deze criteria besprak in haar Overzichtsuitspraak. ${ }^{43}$ Respectievelijk zal worden stilgestaan bij de schadeoorzaken die schade kunnen veroorzaken die voor tegemoetkoming in aanmerking komt (hoofdstuk 3), de eisen die worden gesteld aan het causaal verband tussen de gestelde schade en beweerde schadeoorzaak (hoofdstuk 4), welke schade voor tegemoetkoming in aanmerking komt en hoe deze schade dient te worden begroot (hoofdstuk 5), de criteria van abnormale last (hoofdstuk 6) en speciale last (hoofdstuk 7), actieve- en passieve risicoaanvaarding en andere vormen van eigen schuld (hoofdstuk 8), en overige redenen om schade voor rekening van de aanvrager te laten (hoofdstuk 9). In hoofdstuk 10 zullen deze onderzoeksvragen worden beantwoord ten aanzien van de in paragraaf 1.3 genoemde procedurele voorschriften.

\section{Deel III - Alles overziende beantwoording van de hoofdvraag}

Hiervoor bleek dat de hoofdvraag in het tweede deel van dit proefschrift eerst zal worden beantwoord per materieel criterium en procedureel voorschrift voor toekenning van nadeelcompensatie. Deze gefragmenteerde beantwoording van de hoofvraag vormt de basis voor een alles overziende beantwoording van de hoofdvraag in hoofdstuk 11 - het sluitstuk van dit proefschrift.

43 ABRvS 28 september 2016, ECLI:NL:RVS:2016:2582 (Overzichtsuitspraak). Volledige aansluiting op deze volgorde was niet mogelijk, bijvoorbeeld omdat het criterium van de speciale last geen rol speelt in het hedendaagse planschaderecht. 


\section{Hoofdstuk 2}

\section{Het huidige en toekomstige nadeelcompensatierecht in vogelvlucht}

\subsection{INLEIDING}

In dit hoofdstuk wordt ingaan op enkele meer algemene kenmerken van het nadeelcompensatieleerstuk. Enig algemeen inzicht in (de totstandkoming van) het huidige en toekomstige nadeelcompensatierecht is nodig om de hoofdstukken die nog zullen volgen goed te kunnen plaatsen. Ook overigens is dit inzicht nodig om de in paragraaf 1.2 opgeworpen onderzoeksvragen op zinvolle wijze te kunnen beantwoorden. In paragraaf 2.2 wordt beschreven hoe het hedendaagse nadeelcompensatielandschap is ontstaan door een circa 150 jaar durend samenspel tussen (formele) wetgever, rechter en bestuur. Hoewel de term 'landschap' kalm en overzichtelijk klinkt, zal blijken dat niet voor niets wordt gesproken van een 'nadeelcompensatiedoolhof'. ${ }^{1}$ Inzicht in het ontstaan van dit doolhof is nodig om de hedendaagse verhoudingen tussen de daarin functionerende actoren te kunnen plaatsen. Bovendien zal in paragraaf 2.4.2.1 blijken dat de complexiteit en onoverzichtelijkheid van dit doolhof aanleiding vormde voor de formele wetgever om titel 4.5 Awb vast te stellen.

De onoverzichtelijkheid van het doolhof is enerzijds procedureel van aard: soms kan slechts één weg worden bewandeld om nadeelcompensatie te verkrijgen, terwijl daartoe soms ook tegelijkertijd meerdere wegen kunnen of zelfs moeten worden bewandeld, die al dan niet leiden tot verschillende rechters. Anderzijds wordt het doolhof gekenmerkt door materiële onoverzichtelijkheid: naar huidig recht wordt de grondslag voor toekenning van nadeelcompensatie niet slechts gevormd door het ongeschreven égalitébeginsel, maar ook door een veelvoud van daarop gebaseerde (formeel)wettelijke nadeelcompensatieregelingen en nadeelcompensatiebeleidsregels, die alle hun eigen toepassingsbereik hebben en verschillen in hun normering van het recht op nadeelcompensatie. In paragraaf 2.3 zal ik nader ingaan op deze smeltkroes van regelingen en beleidsregels, en motiveren waarom ik me bij de beantwoording van de tweede deelvraag zal richten op afd. 6.1 Wro, de BnIW 2019, de AVN, de VNNZ, en de GrS. Tevens zal ik betogen dat deze selectie van regelingen een representatieve afspiegeling van het hedendaagse, geschreven nadeelcompensatierecht vormt.

1 Deze term is ontleend aan Van Ravels 2009a. 
In paragraaf 2.4 komt het toekomstige nadeelcompensatierecht aan bod. In aanvulling op hetgeen daarover is opgemerkt in hoofdstuk 1, zal ik in paragraaf 2.4.1 kort toelichten waarom ik me voor de bestudering van het toekomstige nadeelcompensatierecht zal richten op titel 4.5 Awb en afd. 15.1 Ow. Vervolgens zal ik in paragraaf 2.4.2 de eerste deelvraag beantwoorden door aan de hand van Kamerstukken te achterhalen welke doelstellingen en uitgangspunten ten grondslag liggen aan de Wns. Zij zullen het toetsingskader van dit proefschrift vormen. Daarna zal ik in paragraaf 2.4.3 stilstaan bij de totstandkoming van afd. 15.1 Ow en enkele contouren schetsen van het uit de Ow voortvloeiende omgevingsrecht waarbinnen deze afdeling dient te functioneren. Enig inzicht daarin is nodig om de hoofdvraag te kunnen beantwoorden. Of de aan de Wns ten grondslag liggende doelstellingen en uitgangspunten aanleiding geven tot aanpassing van afd. 15.1 Ow kan immers slechts op zinvolle wijze worden beoordeeld door de eigenschappen in acht te nemen van het omgevingsrecht waarbinnen deze afdeling dient te functioneren.

In paragraaf 2.5 wordt ingegaan op de belangrijkste staatsrechtelijke grenzen die in acht moeten worden genomen bij de vaststelling van (formeel)wettelijke nadeelcompensatieregelingen en nadeelcompensatiebeleidsregels. Inzicht in die grenzen is nodig voor beantwoording van de tweede deelvraag. Bepaalde keuzes omtrent de vaststelling, of rechterlijke toetsing van de toepassing van deze regelingen en beleidsregels kunnen namelijk slechts worden verklaard door het bestaan van deze grenzen. Zo is de formeelwettelijke afbakening van het normaal maatschappelijk risico door art. 6.2 lid 2 Wro bijvoorbeeld beïnvloed door de grens van art. 1 EP EVRM. ${ }^{2}$ Ook is inzicht in deze grenzen nodig om de hoofdvraag te kunnen beantwoorden. Deze grenzen zullen immers steeds in acht moeten worden genomen bij het doen van aanbevelingen omtrent (a) aanpassing van titel 4.5 Awb, (b) aanpassing van afd. $15.1 \mathrm{Ow}$, of (c) het voorzien in een bijzondere invulling, aanvulling of afwijking van titel 4.5 Awb.

In paragraaf 2.6 komt aan bod hoe de bestuursrechter de besluiten toetst die het bestuur neemt naar aanleiding van aanvragen om nadeelcompensatie. Uit paragraaf 1.4 kan worden afgeleid dat inzicht in die wijze van toetsing nodig is voor beantwoording van de tweede deelvraag en de hoofdvraag. Zo zal de toetsingsintensiteit regelmatig kunnen verklaren waarom de Afdeling in haar jurisprudentie komt tot bepaalde oordelen. Ook kan zij bijvoorbeeld het onderwerp zijn van aanbevelingen die worden gericht aan de rechter, of anderszins van invloed zijn op dergelijke aanbevelingen.

Uit het voorafgaande blijkt ook bij welke onderwerpen ik in dit hoofdstuk niet zal stilstaan. Zo ga ik - conform de keuze van de wetgever - uit van het égalitébeginsel als dé grondslag voor nadeelcompensatie. ${ }^{3}$ Het zogenoemde 'grondslagendebat' ${ }^{4}$

2 Zie daarover paragraaf 6.2.1.2.

$3 \quad$ Zie hierover ook paragraaf 1.3.

$4 \quad$ Zie daarover in de context van de totstandkoming van titel 4.5 Awb bijvoorbeeld Tjepkema 2010, p. 870-875. 
zal ik dus laten rusten. Omdat ik mij beperk tot nadeelcompensatieregelingen die zijn gebaseerd op het égalitébeginsel, zal ik ook niet ingaan op de wijze waarop het onteigeningsrecht zich verhoudt tot het nadeelcompensatierecht. Het hoofdstuk zal in paragraaf 2.7 worden afgesloten met een conclusie.

\subsection{HOE DE TOTSTANDKOMING VAN EEN RECHT OP NADEELCOMPENSATIE IN DE NEDERLANDSE RECHTSORDE LEIDDE TOT EEN NADEELCOMPENSATIEDOOLHOF}

In deze paragraaf wordt beschreven hoe het op égalité gebaseerde, algemene recht op nadeelcompensatie stukje bij beetje voet aan de grond heeft gekregen in de Nederlandse rechtsorde. Dit biedt inzicht in het hoe en waarom van de huidige, gecompliceerde rechtsmachtverdeling tussen de civiele- en bestuursrechter in nadeelcompensatiegeschillen. Hierna zal blijken hoe deze rechtsmachtverdeling deels is ontstaan naar aanleiding van de vaststelling van nadeelcompensatiebeleid door bestuursorganen (in het bijzonder Rijkswaterstaat). Zij vormde op haar beurt echter ook een impuls voor de vaststelling van nieuwe wettelijke nadeelcompensatieregelingen en -beleidsregels. Deze procedurele onoverzichtelijkheid (de gecompliceerde rechtsmachtverdeling) en materiële onoverzichtelijkheid (het veelvoud van wettelijke en buitenwettelijke regelingen) vormen samen de reden dat het hedendaagse nadeelcompensatierecht wordt beschouwd als een 'nadeelcompensatiedoolhof'. Tevens zal in paragraaf 2.4.2.1 blijken dat deze onoverzichtelijkheid een belangrijke reden voor de formele wetgever vormde om titel 4.5 Awb vast te stellen.

\section{Formele wetgeving in de $19^{\circ}$ en begin $20^{e}$ eeuw}

Tjepkema geeft aan dat in Nederland al in de Middeleeuwen sporen waren te vinden van een recht op schadevergoeding wegens rechtmatige overheidsdaad. Vanaf de oprichting van het Koninkrijk der Nederlanden bij grondwetten van 1814 en 1815 tot 1939 bleek de rechterlijke macht niet bereid om een recht op schadevergoeding aan te nemen zonder dat daarvoor een (formeel)wettelijke grondslag bestond. De eerste formeelwettelijke bepalingen omtrent schadevergoeding wegens rechtmatige overheidsdaad werden opgenomen in de Onteigeningswet van 1841 en haar opvolger uit 1851. Beide gingen uit van toekenning van een volledige schadevergoeding omdat het recht op eigendom als onschendbaar werd aangemerkt. Hoewel deze wetten een wetenschappelijke discussie omtrent de definitie van het begrip 'onteigening' en de grondslagen voor schadevergoeding wegens rechtmatig overheidshandelen aanzwengelden, zou het tot de jaren ' 50 en '60 van de volgende eeuw duren voordat de eerste formeelwettelijke piketpaaltjes voor het hedendaagse recht op nadeelcompensatie werden geslagen. In de tussenliggende periode werden wel verschillende formeelwettelijke schadevergoedingsregelingen vastgesteld die hun grondslag vonden in bescherming van het eigendomsrecht, billijkheidsgronden, utiliteitsgronden of een combinatie daarvan. Zij gingen allemaal eveneens uit van vergoeding van het volledige schadebedrag. Enkele voorbeelden 
zijn de Kringenwet 1853, de Wet militaire inundatiën van 1896, de Verkeerswet tegen lintbebouwing van 1922, de Luchtvaarwet 1926, en de Belemmeringenwet privaatrecht 1927.5

\section{De Hoge Raad (1939-1952)}

Sinds het Guldemond/Noordwijkerhout-arrest ${ }^{6}$ d.d. december 1915 achtte de Hoge Raad zich in algemene zin bevoegd om te toetsen of overheidshandelen onrechtmatig was als bedoeld in art. $1401 \mathrm{BW}$ (oud; thans art. 6:162 BW). Bij beleidsvrij overheidshandelen werd de Hoge Raad echter steeds terughoudender in zijn toets aan deze bepaling. Desondanks bleek hij in de Voorste Stroom-arresten ${ }^{7}$ en in het Haagse Duinwaterleiding-arrest bereid ${ }^{8}$ om een recht op schadevergoeding aan te nemen bij schending van een subjectief (eigendoms)recht door "gerechtvaardigd en zelfs geboden" overheidshandelen. Daarbij was bepalend dat het bestuur de nadelige gevolgen voor eigenaren van bedreigde percelen voor zijn rekening behoorde te nemen. Door dat niet te doen had het bestuur niet "de zorgvuldigheid in acht (...) genomen, welke in het maatschappelijk verkeer ten aanzien van diens goed $^{9}$ betaamde". Deze jurisprudentie ontketende een wetenschappelijk debat waarin de hoofdrollen werden vertolkt door Bregstein en Drion. Enerzijds meenden Bregstein c.s. dat het schadeveroorzakende overheidshandelen op zichzelf als onrechtmatig moest worden beschouwd. De aanbieding van schadevergoeding werkte als een soort rechtvaardigingsgrond die deze onrechtmatigheid wegnam. Anderzijds beschouwden Drion c.s. het schadeveroorzakende overheidshandelen op zichzelf als rechtmatig. Zij zochten de grondslag voor de schadevergoeding veel meer in de billijkheid, égalité of het profijtbeginsel. Dat de Hoge Raad een dergelijke grondslag niet expliciet erkende (en dat ook verschillende decennia niet zou doen) kan worden verklaard door het (gematigd) gesloten stelsel van verbintenissen als voorgeschreven door art. 1269 BW (oud; thans art. 6:1 BW). Voor een uitgebreide bespreking van het debat rond deze jurisprudentie verwijs ik naar de proefschriften van Tjepkema en De Jongh. ${ }^{10}$ Ik volsta hier met de opmerkingen dat deze jurisprudentie van significant belang was voor de gedachtevorming omtrent

5 Zie Tjepkema 2010, p. 21 e.v.; De Jongh 2012, p. 45 e.v. en p. 449; en Tjepkema 2017, p. 69.

6 HR 31 december 1915, ECLI:NL:HR:1915:AG1773 (Guldemond/Noordwijkerhout).

7 Zie HR 17 februari 1939, ECLI:NL:HR:1939:81 (Voorste Stroom IV); HR 20 december 1940, ECLI:NL:HR:1940:106 (Voorste Stroom V); HR 19 maart 1943, ECLI:NL:HR:1943:66 (Voorste Stroom VI); en HR 19 december 1952, ECLI:NL:PR:1952:AG1997 (Voorste Stroom VII).

$8 \quad$ HR 18 februari 1944, ECLI:NL:HR:1944:33 (Haagse Duinwaterleiding).

9 Dit slaat terug op de onroerende zaak van de benadeelde.

10 Zie Tjepkema 2010, p. 60-68; De Jongh 2012, p. 206-219; en Tjepkema 2017, p. 69-71. 
nadeelcompensatie, én (beperkte) ${ }^{11}$ uitkomst bood aan burgers die schade leden door rechtmatig overheidshandelen ten aanzien waarvan geen formeelwettelijke compensatiegrondslag bestond.

\section{De formele wetgever (jaren '50 en '60 van de 20e eeuw)}

Een volgende mijlpaal voor de totstandkoming van het hedendaagse recht op nadeelcompensatie was de introductie van de zogenoemde 'redelijkerwijsformule' in de Boswet, Monumentenwet en de WRO. Deze formule houdt in dat de burger die "schade lijdt of zal lijden, welke redelijkerwijs niet of niet geheel te zijnen laste behoort te blijven (...) op aanvraag een naar billijkheid te bepalen schadevergoeding" wordt toegekend. Ik ben het met Tjepkema eens dat het belang van de introductie van deze formule moeilijk kan worden onderschat. ${ }^{12}$ Zonder uitputtend te willen zijn, noem ik hier drie argumenten ter onderbouwing daarvan, die grotendeels zijn ontleend aan de proefschriften van Tjepkema, De Jongh en Van den Broek.

Ten eerste was de totstandkoming van de redelijkerwijsformule het resultaat van een breder debat omtrent de grondslag van het recht op schadevergoeding wegens rechtmatige overheidsdaad én de voorwaarden waaraan moest worden voldaan om voor dergelijke schadevergoeding in aanmerking te komen. In algemene zin kwam in dit debat de gedachte naar voren dat aan het hebben van eigendom ook bepaalde risico's zijn verbonden, waardoor slechts een recht op compensatie zou moeten bestaan voor schade die correspondeert met 'extrarisico'. Hoewel daarin de gedachte van het aan égalité verbonden criterium van de abnormale last is te herkennen, heeft lange tijd discussie bestaan over de vraag welke rechtsgrondslag aan de redelijkerwijsformule ten grondslag lag. Dat kan deels worden verklaard doordat beide Kamers en de regering deze grondslag nooit expliciet hebben benoemd. Deels kan dit ook worden verklaard doordat de formule onder de WRO anders werd ingevuld dan in de Bos- en Monumentenwet - conform de wil van de Tweede Kamer. Hoewel het oorspronkelijke regeringsvoorstel nog aan het égalitébeginsel deed denken, ontstond gedurende de behandeling van het wetsvoorstel in de Tweede Kamer namelijk het uitgangspunt van vergoeding van het volledige schadebedrag - en dus niet slechts van schade die verband hield met 'extrarisico'. ${ }^{13}$ De Kroon en later de Afdeling geschillen kenden in meer respectievelijk mindere mate belang toe aan de gedachte van het normaal maatschappelijk risico. Vanaf de inwerkingtreding van de Awb in 1994 werd de Afdeling bestuursrechtspraak de rechter die in hoger beroep oordeelde over planschadegeschillen. ${ }^{14}$ Hoewel in haar vroege jurisprudentie nog enige sporen van het criterium van de abnormale

11 Er werd immers slechts uitkomst geboden bij schending van een subjectief (eigendoms)recht.

12 Zie Tjepkema 2010, p. 101-102 en 126; en Tjepkema 2017, p. 75.

13 Zie Van den Broek 2002, p. 150-172; Tjepkema 2010, p. 83-102; De Jongh 2012, p. 219-238 en 250-279; en Tjepkema 2017, p. 75-76. 
last waren te vinden, zou de Afdeling de toepassing van dit criterium in het planschaderecht uiteindelijk uitdrukkelijk van de hand wijzen. ${ }^{15}$ In haar jurisprudentie werd daardoor de vraag of een recht op schadevergoeding bestond hoofdzakelijk beantwoord aan de hand van het criterium van risicoaanvaarding. ${ }^{16}$ Thans is het daarom algemeen geaccepteerd dat de grondslag van art. $49 \mathrm{WRO}$ in de materiële rechtszekerheid moest worden gevonden. ${ }^{17}$ Volgens de Afdeling houdt deze aansprakelijkheidsgrond in...

“(...) dat de koper van een onroerende zaak ervan mag uitgaan dat de bestemming die ten tijde van de aankoop op zijn zaak rust, maar ook de bestemmingen die op nabijgelegen onroerende zaken rusten, niet zullen wijzigen. Ingeval een bestemming toch wordt gewijzigd, dan moet de schending van de rechtszekerheid worden gecompenseerd door middel van een volledige vergoeding van de schade." 18

Het voorafgaande laat echter onverlet dat thans bestaande regelingen met een redelijkerwijsformule door zowel bestuur als rechter worden toegepast conform de eisen die het égalitébeginsel aan de toekenning van nadeelcompensatie stelt. ${ }^{19}$ Ook de planschadeafdeling uit de Wro (de opvolger van de WRO) bevat een redelijkerwijsformule die als een uiting van het égalitébeginsel wordt beschouwd door zowel de rechter als de formele wetgever - ondanks dat zij qua toepassing van het criterium van de speciale last nog steeds afwijkt van het overige nadeelcompensatierecht. ${ }^{20}$

Ten tweede blijkt dat de wetgever zich ervan bewust was dat de keuzes die met betrekking tot schadevergoeding wegens rechtmatige beperkingen ${ }^{21}$ van het eigendomsrecht zouden worden gemaakt bij de totstandkoming van de schadebepa-

15 Zie paragraaf 6.1 onder het kopje 'Het normaal maatschappelijk risico en de tekst van de geselecteerde, thans geldende regelingen'.

16 Zie Van den Broek 2002, p. 172-207; en Van Ravels 2006a, p. 29. Zie bijvoorbeeld ook ABRvS 6 mei 2004, ECLI:NL:RVS:2004:AO8857, r.o. 2.7; en ABRvS 19 april 2006, ECLI:NL:RVS:2006:AW2291, r.o. 2.8. Zie verder in algemene zin over het criterium van risicoaanvaarding paragraaf 8.2.

17 Zie bijvoorbeeld Polak e.a. 2008, p. 110; Polak 2010, p. 317, 322; Dijkshoorn 2011b, p. 498; en Van Ettekoven 2011, p. 11.

18 ABRvS 19 november 2014, ECLI:NL:RVS:2014:4203, r.o. 7.1.

19 Zie ten aanzien van art. 7.14 Waterwet en de RnVW 1999 bijvoorbeeld ABRvS 2 juli 2014, ECLI:NL:RVS:2014:2396, r.o. 4.1 (Dijkverhoging). Zie ook ABRvS 29 november 2006, ECLI:NL:RVS:2006:AZ3259, r.o. 2.4.1 e.v.; en Tjepkema 2010, p. 101.

20 Zie Kamerstukken II 2011/12, 33 135, nr. 3, p. 13 (MvT, Wet tot wijziging van de Crisis- en herstelwet); ABRvS 31 juli 2013, ECLI:NL:RVS:2013:558, r.o. 5.1; en ABRvS 1 juli 2015, ECLI:NL:RVS:2015:2071, r.o. 11 (Mook \& Middelaar). Zie minder duidelijk ook Kamerstukken II 2002/03, 28 916, nr. 3, p. $62-63$ (MvT, Wro). Zie daarover onder andere Van Ravels 2014b, p. 38; en Dijkshoorn 2011b, p. 499. Zie in algemene zin over het criterium van de speciale last ook hoofdstuk 7. En dus niet het volledig ontnemen van eigendom. 
lingen uit de Boswet, Monumentenwet en WRO van principiële aard zouden zijn, en daarom in algemene zin van belang voor de ontwikkeling van het vraagstuk van schadevergoeding wegens rechtmatige overheidsdaad. Tjepkema spreekt in dit verband van het ontstaan van een "beginsel van behoorlijke wetgeving": bij wetgeving omtrent schadevergoeding wegens vergelijkbare, rechtmatige beperkingen van eigendom werd namelijk steeds uitgegaan van de redelijkerwijsformule (waarbij de passage over billijkheid overigens niet altijd werd vermeld). ${ }^{22}$ Dat blijkt niet alleen het geval te zijn voor formele wetgeving, maar ook voor nadeelcompensatieregelingen van lagere rangorde. ${ }^{23}$ De redelijkerwijsformule zou bovendien van invloed zijn op de jurisprudentiële ontwikkeling van het leerstuk van nadeelcompensatie. ${ }^{24}$

Ten slotte is van belang dat een bestuursrechtelijke rechtsgang in het leven werd geroepen voor geschillen omtrent schadevergoeding op grond van de Boswet, Monumentenwet en WRO. Die keuze kan worden verklaard doordat de schadebepalingen uit deze regelingen uitgingen van de rechtmatigheid van het schadeveroorzakende overheidshandelen. Mogelijk heeft ook de angst een rol gespeeld dat de civiele rechter deze bepalingen te ruimhartig zou uitleggen. ${ }^{25}$ Hoe dan ook, liet dit zien dat de bestuursrechter de meest geëigende nadeelcompensatierechter was. Anders dan de civiele rechter, kon hij het nadeelcompensatierecht ontwikkelen zonder te worden beperkt door het keurslijf van art. 6:162 BW en het (gematigd) gesloten stelsel van verbintenissen van art. 6:1 BW.

\section{De praktijk van Rijkswaterstaat vanaf de jaren '70 van de $20^{e}$ eeuw}

In het begin van de jaren '70 ontwikkelde Rijkswaterstaat een buitenwettelijk stelsel van 'bestuurscompensatie'. Dit stelsel was duidelijk geïnspireerd door de redelijkerwijsformule, ook al kende het beslist eigen kenmerken door de belangrijke rol die het draagkrachtbeginsel speelde. Het stelsel werd voor het eerst op persoonlijke titel beschreven door het toenmalig hoofd van het 'Bureau Grondverwerving van de Rijkswaterstaat', J.A.C. van der Gouwe. Hij was van mening dat schade door rechtmatig overheidshandelen niet vanuit privaatrechtelijk, maar vanuit publiekrechtelijk perspectief moest worden beschouwd. Het door hem beschreven stelsel omvatte tevens andere financiële instrumenten en maatregelen, waaronder subsidiëring, het bieden van belastingvoordelen, en de ondersteuning van de verplaatsing van een bedrijf. Dat is ook de reden dat dit stelsel als 'beWaterwet.

23 Zie bijvoorbeeld art. 2 RnVW 1999. Zie daarover ook paragraaf 2.3.2.

24 Zie Tjepkema 2010, p. 73-74, 83-102 en 125-126; en Tjepkema 2017, p. 75-76.

25 Het eerder besproken onteigeningsrecht werd destijds als iets privaatrechtelijks gezien, omdat een ernstige inbreuk op het subjectieve eigendomsrecht tot volledige schadevergoeding diende te leiden. Zie Tjepkema 2010, p. 99-100. 
stuurscompensatie' werd aangeduid en niet als 'nadeelcompensatie' - een term die pas in 1985 zou worden geïntroduceerd door Winter. ${ }^{26}$

Van der Gouwe achtte het égalitébeginsel niet geschikt als grondslag voor bestuurscompensatie en was van mening dat vergoeding slechts op zijn plaats is "indien en voor zover de schade in redelijkheid niet of niet geheel ten laste van de getroffene behoort te blijven." ${ }^{27}$ Hij vulde deze norm echter subjectiever in dan de (door de regering voorgestane) geobjectiveerde invulling van de hiervoor besproken redelijkerwijsformule uit de Boswet, Monumentenwet en WRO. Dat laat onverlet dat het gedachtegoed van Van der Gouwe een belangrijke bijdrage aan de ontwikkeling van het hedendaagse recht op nadeelcompensatie heeft geleverd. Tjepkema spreekt in dit verband van het ontstaan van een nieuw beginsel van behoorlijk bestuur. ${ }^{28}$ Zowel Tjepkema als Polak benadrukken bovendien dat het stelsel van bestuurscompensatie niet is ontwikkeld door de bestuursrechter, maar slechts door hem is aanvaard.$^{29}$ Hierna zal inderdaad blijken dat de door Van der Gouwe ingezette trend van vaststelling van beleid omtrent nadeelcompensatie aanleiding voor de bestuursrechter vormde om (steeds meer) rechtsbescherming aan de benadeelde burger te bieden. De publicaties van Van der Gouwe en de praktijk van bestuurscompensatie vormden bovendien een van de redenen waarom de toenmalig minister van Verkeer \& Waterstaat in 1991 overging tot vaststelling van de Regeling nadeelcompensatie Rijkswaterstaat (hierna: RnR 1991):

“(...) bij de toekenning van nadeelcompensatie (...) de uitganspunten en maatstaven, zoals deze door J.AC. van der Gouwe zijn geformuleerd, niet (meer) alleen bepalend voor de beantwoording van de vraag of in een bepaald geval een benadeelde voor vergoeding in aanmerking komt. De praktijk komt er thans - kortgezegd - op neer, dat de schade die het gevolg is van een rechtmatig handelen van Rijkwaterstaat, indien deze schade redelijkerwijs niet of niet geheel ten laste van door dat handelen getroffen particulieren behoort te blijven, door Rijkswaterstaat naar billijkheid wordt vergoed, ten minste voor zover niet op een andere wijze in vergoeding van de schade is voorzien." ${ }^{30}$

Ten slotte heeft het gedachtegoed van Van der Gouwe ook in meer algemene zin bijgedragen aan de ontwikkeling van het nadeelcompensatierecht, bijvoorbeeld door zijn bijdrage aan de concretisering van relatief vage begrippen als 'normaal maatschappelijk risico' en 'risicoaanvaarding'. ${ }^{31}$

Zie Tjepkema 2010, p. 2, onder verwijzing naar Winter 1985.

28 Tjepkema 2010, p. 102, 105-107 en 126.

29 Zie Polak 1992, p. 297; en Tjepkema 2010, p. 105.

30 Stcrt. 1991, nr. 251, p. 26.

31 Zie nader Polak 1992, p. 291-296; Tjepkema 2010, p. 104-107; De Jongh 2012, p. 233-236; en Tjepkema 2017, p. 76-80. 


\section{De wet Arob en de Krugerbrug-uitspraak (1976-1982)}

Onder de op 1 juli $1976^{32}$ in werking getreden wet Arob $^{33}$ kon bezwaar bij het bestuursorgaan, eventueel gevolgd door beroep bij de Afdeling rechtspraak, worden ingesteld tegen een beschikking. Daaronder werd verstaan een "schriftelijk besluit van een administratief orgaan, gericht op enig rechtsgevolg." Dit besluit mocht bovendien geen besluit van algemene strekking zijn of een rechtshandeling naar burgerlijk recht. ${ }^{34}$ In de Paul Krugerbrug-uitspraak uit $1982^{35}$ werd de rechtmatigheid aangevochten van een door de minister van Verkeer en Waterstaat verleende beschikking. Het betrof de verlening van een vergunning die het mogelijk maakte dat de destijds opklapbare Paul Krugerbrug werd vervangen door een vaste brug, zodat over die brug een railverbinding ten behoeve van een sneltram kon worden aangelegd. Dit had tot gevolg dat de hoogte en breedte van schepen die scheepswerf de Liesbosch konden bereiken aanzienlijk afnam. De minister, onder andere bijgestaan door Van der Gouwe, erkende dat...

“(..) in het kader van de belangenafweging welke aan de vergunningverlening ten grondslag ligt, er reden is om aan de Liesbosch de ten gevolge van het bestreden vergunningbesluit te lijden schade, die, gelet op het door de Liesbosch zelf te dragen maatschappelijke bedrijfsrisico, in redelijkheid niet te haren laste behoort te blijven, naar billijkheid te vergoeden."

Hij was echter van mening dat hij voldoende zorg had gedragen voor deze vergoeding door aan de beschikking de voorwaarde te verbinden voor de gemeente Utrecht (de vergunninghoudster) de...

“(...) redelijkerwijs mogelijke maatregelen te nemen ten einde te voorkomen, dat het Rijk dan wel derden ten gevolge van het gebruik maken van de vergunning schade lijden."

Ondanks de nadien door de gemeente toegezegde en daadwerkelijk betaalde vergoeding van ongeveer $40 \%$ van de schade, kwam de Afdeling rechtspraak tot het oordeel dat de beschikking de toets van het willekeurverbod niet kon doorstaan. De minister had namelijk...

“(...) bij afweging van de betrokken belangen onvoldoende gewicht (...) toegekend aan het gerechtvaardigde belang van de Liesbosch om voor het verlenen van de vergunning te weten welk bedrag haar als schadevergoeding zal worden aangeboden."

Stb. 1976, nr. 234.

33 Stb. 1975, nr. 284.

34 Zie art. 2 jo. art. 7 jo. art. 8 Wet Arob.

35 ARRvS 12 januari 1982, ECLI:NL:RVS:1982:AM7845 (Paul Krugerbrug I). Zie voor een bespreking van deze uitspraak en de vervolguitspraak ook Polak 1992, p. 296-299; Tjepkema 2010, p. 105-109; en De Jongh 2012, p. 321-325. 
Dit oordeel introduceerde de constructie van het zogenoemde 'onzuiver schadebesluit'. Naar huidig recht houdt zij in dat het schadeveroorzakende besluit langs bestuursrechtelijke weg wordt aangevochten terwijl wordt aangevoerd dat de onrechtmatigheid van dit besluit erin is gelegen dat het toekennen van geen of te weinig nadeelcompensatie een schending van art. 3:4 lid 2 Awb veroorzaakt, waarover later meer. Hier merk ik nog op dat deze uitspraak onder andere vanuit procesrechtelijk perspectief van groot belang was. Voortaan bestond bij schade door appellabele schadeoorzaken immers ook een administratiefrechtelijke route om nadeelcompensatie te verkrijgen als geen wettelijke schadevergoedingsregeling van toepassing was. ${ }^{36}$

\section{De wet Arob en de Metroschade-jurisprudentie (1986)}

De publicaties van Van der Gouwe vormden een belangrijke aanzet voor bestuursorganen om beleid omtrent schadevergoeding wegens rechtmatig overheidshandelen vast te stellen. ${ }^{37}$ In haar Metroschade-uitspraak van 1986 diende de Afdeling rechtspraak te oordelen over een schadegeschil waarin dergelijk beleid centraal stond. B\&W hadden afwijzend beslist op een verzoekschrift om schadevergoeding wegens de aanleg van een metro. Als deze beslissing moest worden aangemerkt als rechtshandeling naar burgerlijk recht, diende de benadeelde zijn heil te zoeken bij de burgerlijke rechter. Kwalificeerde de beslissing echter niet als rechtshandeling naar burgerlijk recht - en dus wel als beschikking - dan had de benadeelde hiertegen bezwaar bij B\&W moeten indienen. De benadeelde had echter direct een beroepschrift ingediend bij de Afdeling rechtspraak. Zij besloot dit beroepschrift op grond van art. 15 wet Arob $^{38}$ als bezwaarschrift aan te merken en als dusdanig door te sturen naar B\&W. Hiertoe overwoog zij eerst dat...

“(...) in het publieke recht geen in een algemeen verbindend voorschrift neergelegde (algemene) rechtsregel valt aan te wijzen op grond waarvan een overheidsorgaan gehouden is schade ontstaan als gevolg van rechtmatig overheidshandelen te vergoeden."

Toch moest de beslissing van $\mathrm{B} \& \mathrm{~W}$ niet als een rechtshandeling naar burgerlijk recht - en dus wel als een beschikking - worden aangemerkt. Deze beslissing was namelijk een uitvloeisel van het in de 'Nota inzake tegemoetkoming bij inkomensderving ten gevolge van de metrobouw' vastgestelde beleid om in het desbetreffende gedeelte van de gemeente Rotterdam niet over te gaan tot het toekennen van een tegemoetkoming in bedrijfsschade door de aanleg van de metro. Uit de later gewezen uitspraken Kromhout/Rijkswaterstaat en Toonen/Rijkswaterstaat bleek

36 Zie hierover bijvoorbeeld ook Tjepkema 2010, p. 108-109.

37 Zie hierover onder andere Polak 1992, p. 296.

38 Deze bepaling is vergelijkbaar met het huidige art. 6:15 Awb. 
dat de Afdeling rechtspraak wel de eis hanteerde dat het beleidsdocument waarop de beslissing werd gebaseerd afdoende was gepubliceerd. ${ }^{39}$

Deze jurisprudentie introduceerde de constructie van het buitenwettelijk zuiver schadebesluit. Zij gaf daarmee een nieuwe impuls aan de ontwikkeling van het nadeelcompensatierecht, omdat zij voor bestuursorganen (een extra) reden kon vor$\mathrm{men}^{40} \mathrm{om}$ het hedendaagse equivalent van een beleidsregel over nadeelcompensatie vast te stellen. Bij afwezigheid van een wettelijke grondslag voor toekenning van compensatie, werd de benadeelde burger hierdoor immers een - relatief laagdrempelige - bestuursrechtelijk rechtsgang geboden tegen de beslissing op zijn aanvraag om nadeelcompensatie. Uit de daarbij behorende toelichting blijkt dat ook $^{41}$ dit een van de redenen was waarom de minister van Verkeer \& Waterstaat de RnR 1991 vaststelde. ${ }^{42}$ Hierna zal bovendien nog blijken dat de Afdeling bestuursrechtspraak de Metroschade-lijn zou doorzetten onder de Awb, en zelfs bereid was de constructie van het buitenwettelijk zuiver schadebesluit onder bepaalde voorwaarden uit te breiden naar beslissingen op aanvragen om nadeelcompensatie die hun grondslag niet vonden in een afdoende gepubliceerde beleidsregel, maar in het ongeschreven égalitébeginsel.

\section{Erkenning van égalité door de Hoge Raad}

Een volgende belangrijke mijlpaal voor het ontstaan van het hedendaagse recht op nadeelcompensatie was het Leffers-arrest van 1991. De Hoge Raad overwoog dat de minister van Landbouw en Visserij jegens varkensmester Leffers onrechtmatig had gehandeld door de 'Regeling verbod voedsel- en slachtafvallen (varkens)' 43

“(...) uit te vaardigen en uit te voeren zonder dat hij daarbij tevens voor de hiervoor bedoelde varkensmesters die hun bedrijf, zoals Leffers, geheel op vervoedering van swill hadden ingericht, een regeling [had] getroffen die het hun financieel mogelijk maakte hun bedrijf aan te passen of, zo zulks onmogelijk zou blijken, hun te dier zake op andere wijze in hun economische belangen tegemoet kwam."

39 Zie ARRvS 14 mei 1986, ECLI:NL:RVS:1986:AM9085 (Metroschade); ARRvS 18 november 1987, ECLI:NL:RVS:1987:AM9615 (Kromhout/Rijkswaterstaat); en ARRvS 5 januari 1988, ECLI:NL:RVS:1988:AM9847 (Toonen/Rijkswaterstaat).

40 Ik spreek hier van 'kon vormen', omdat er ongetwijfeld ook overheden waren die welbewust afzagen van de vaststelling van een nadeelcompensatiebeleidsregel om zo te voorkomen dat de schadelijdende burger de - relatief laagdrempelige - bestuursrechtelijke weg kon volgen.

41 Een andere reden werd besproken onder het kopje 'De praktijk van Rijkswaterstaat

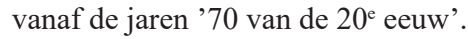

42 Zie Stcrt. 1991, nr. 251, p. 27. Daarin wordt verwezen naar Van Wijmen \& Van Ravels 1988.

43 Stcrt. 1986, nr. 66. 
Hoewel de Hoge Raad het égalitébeginsel als dusdanig niet noemde, is algemeen geaccepteerd dat dit beginsel wel aan dit arrest ten grondslag lag. De Hoge Raad hechtte namelijk veel waarde aan het criterium van de speciale last - één van de criteria die het égalitébeginsel typeert. ${ }^{44}$ In latere rechtspraak heeft de civiele rechter het égalitébeginsel wel expliciet erkend, nadat de Afdeling dat eerder, in 1997, reeds expliciet had gedaan. ${ }^{45}$ Vanwege het (gematigd) gesloten stelsel van verbintenissen van art. 6:1 BW kan schadevergoeding op grond van het égalitébeginsel in het civiele recht vandaag de dag echter nog steeds slechts via de band van art. 6:162 BW worden gevorderd en toegekend. ${ }^{46}$ Niet de op zichzelf rechtmatige overheidshandeling als dusdanig, maar het daarmee toebrengen van onevenredige schade wordt dan aangemerkt als onrechtmatig jegens de benadeelde. ${ }^{47}$

\section{Intermezzo}

Na de Leffers-uitspraak stond vast dat bij gebreke van een (formeel)wettelijke nadeelcompensatieregeling of nadeelcompensatiebeleidsregel een beroep op de civiele rechter kon worden gedaan voor nadeelcompensatie wegens schade door een niet-appellabele schadeoorzaak. Het moest nog blijken of die route ook openstond in andere schadegevallen. Wel was duidelijk dat bij appellabele schadeoorzaken gebruik kon worden gemaakt van de constructie van het onzuiver schadebesluit. Bovendien bestond soms de mogelijkheid van het zuiver schadebesluit gebaseerd op een (formeel)wettelijke nadeelcompensatieregeling of nadeelcompensatiebeleidsregel. Hierna zal ik bespreken hoe de constructie van het buitenwettelijk zuiver schadebesluit werd uitgebreid na de inwerkingtreding van de Awb. Daarna zal ik beschrijven hoe het hedendaagse nadeelcompensatiedoolhof is ontstaan doordat de verhouding tussen deze routes en de daarbij betrokken rechters steeds verder kristalliseerde.

Inwerkingtreding van de Awb, reactie van de formele wetgever op de Krugerbrug-uitspraak, en voortzetting van de Metroschade-jurisprudentie (1994)

Op 1 januari 1994 trad de Awb in werking. ${ }^{48}$ In de passage uit de memorie van toelichting behorende bij art. 3:4 Awb werd kort aandacht besteed aan nadeelcompensatie. De wetgever merkte op dat er specifieke wettelijke bepalingen waren die voorzagen in compensatie, zoals art. 49 WRO. Onder verwijzing naar de Krugerbrug-uitspraak en enkele daarna gewezen uitspraken werd tevens opgemerkt dat "de onevenredigheid ${ }^{49}$ van de gevolgen van een besluit voor een of meer belanghebbenden soms kan worden weggenomen doordat een financiële compen-

HR 18 januari 1991, ECLI:NL:HR:1991:AC4031, r.o. 3.1 en 3.7 (Leffers/Staat). Zie over de speciale last ook hoofdstuk 7.

45 Zie hierover het kopje 'De Beurskens- \& Van Vlodrop-uitspraken (1997)'.

46 Zie hierover meer uitgebreid Kortmann 2006, p. 84-87 en 156-157.

47 HR 30 maart 2001, ECLI:NL:HR:2001:AB0801, r.o. 3.6, 3.8 (Staat/Lavrijsen).

48 Stb. 1993, nr. 693.

49 Hiermee wordt gedoeld op onevenredigheid in de zin van art. 3:4 lid 2 Awb. 
satie wordt aangeboden. ${ }^{" 50}$ Verder is van belang dat de Awb niet aansloot bij het beschikkingsbegrip van de Wet Arob, maar het hedendaagse besluitbegrip introduceerde. Volgens art. 8:1 Awb jo. art. 7:1 Awb staat bestuursrechtelijke rechtsbescherming slechts open tegen appellabele besluiten. Daardoor kan een beslissing op een aanvraag om nadeelcompensatie slechts via bezwaar en beroep worden aangevochten als zij kwalificeert als 'schriftelijke beslissing van een bestuursorgaan, inhoudende een publiekrechtelijke rechtshandeling' (vergelijk art. 1:3 lid $1 \mathrm{Awb}$ ) die niet van beroep is uitgezonderd (vergelijk art. 8:3 t/m 8:5 Awb). Een rechtshandeling wordt aangemerkt als publiekrechtelijk als zij is gebaseerd op een publiekrechtelijke grondslag. Als hoofdregel geldt dat daarvoor is vereist dat het bestuursorgaan de bevoegdheid tot het verrichten van die handeling ontleent aan een specifiek wettelijk voorschrift. ${ }^{51}$

Het voorafgaande zou de gedachte kunnen doen ontstaan dat een beslissing op een aanvraag om nadeelcompensatie in beginsel niet kwalificeert als besluit in de zin van art. 1:3 Awb indien een (formeel)wettelijke nadeelcompensatieregeling ontbreekt. De Afdeling bestuursrechtspraak bleek echter bereid om de jurisprudentielijn die door de Afdeling rechtspraak onder de Wet Arob was ingezet met de Metroschade-uitspraak, voort te zetten onder de Awb: een afdoende gepubliceerde nadeelcompensatiebeleidsregel kan dienen als de publiekrechtelijke grondslag die art. 1:3 lid 1 Awb vereist om een schriftelijke reactie op een aanvraag om nadeelcompensatie als appellabel besluit aan te merken bij gebrek aan een (formeel) wettelijke nadeelcompensatieregeling. ${ }^{52}$ Dat lag ook voor de hand vanuit het perspectief van efficiënte rechtsbescherming, omdat de benadeelde burger anders in te veel gevallen zou zijn aangewezen op de civiele rechter. Hierna zal ik aandacht besteden aan de uitspraken Beurskens en Van Vlodrop, waarin de Afdeling bereid bleek om een tweede uitzondering aan te nemen op het uitgangspunt dat het publiekrechtelijke karakter van de rechtshandeling dient voort te vloeien uit een wettelijk voorschrift.

\section{De Beurskens- \& Van Vlodrop-uitspraken (1997)}

Een volgende mijlpaal voor de totstandkoming van het hedendaagse recht op nadeelcompensatie stamt uit 1997. De Afdeling bestuursrechtspraak wees toen de

50 Zie Kamerstukken II 1988/89, 21 221, nr. 3, p. 70 (MvT, Awb), onder verwijzing naar: ARRvS 12 januari 1982, ECLI:NL:RVS:1982:AM7845 (Paul Krugerbrug I); ARRvS 19 augustus 1983, ECLI:NL:RVS:1983:AM7349; en ARRvS 22 november 1983, ECLI:NL:RVS:1983:AM7385 (Paul Krugerbrug II).

51 Zie ABRvS 24 oktober 2018, ECLI:NL:RVS:2018:3431, r.o. 2.1; Barkhuysen e.a. 2018, p. 48-49, 76-78; en Bröring e.a. 2019, p. 131-133, 178-180.

52 Een voorteken daarvan was reeds te zien in ABRvS 25 februari 2000, ECLI:NL:RVS:2000:AN6317, r.o. 2.2. Expliciet volgde dit bijvoorbeeld uit ABRvS 20 augustus 2003, ECLI:NL:RVS:2003:AI1268, r.o. 2.3.2; en ABRvS 2 juni 2004, ECLI:NL:RVS:2004:AP0376, r.o. 2.3. 
uitspraken Beurskens ${ }^{53}$ en Van Vlodrop. ${ }^{54}$ Deze uitspraken waren enerzijds van groot materieelrechtelijk belang voor de totstandkoming van het hedendaagse nadeelcompensatierecht. De Afdeling erkende namelijk dat de bevoegdheid tot toekenning van nadeelcompensatie kan worden gebaseerd op het ongeschreven "mede aan artikel 3:4, tweede lid, van de Awb ten grondslag liggende" égalitébeginsel, op grond waarvan...

“(...) bestuursorganen [zijn] gehouden tot compensatie van onevenredige - buiten het normale maatschappelijke risico vallende en op een beperkte groep burgers of instellingen drukkende - schade die is ontstaan in een door de uitoefening van een aan het publiekrecht ontleende bevoegdheid ontstane rechtsverhouding."

Het verband dat de Afdeling legde tussen égalitébeginsel en art. 3:4 lid 2 Awb lijkt te kunnen worden gekwalificeerd als een reactie op de toelichting die de wetgever gaf op art. 3:4 lid 2 Awb naar aanleiding van de Krugerbrug-uitspraak. Het zou nog tot 2003 duren voordat de Afdeling het égalitébeginsel expliciet zou 'ontkoppelen' van art. 3:4 lid 2 Awb. ${ }^{55}$

De uitspraken Beurskens en Van Vlodrop waren anderzijds ook van groot procesrechtelijk belang. De bestuursrechtelijke rechtsbescherming werd namelijk uitgebreid tot beslissingen op aanvragen om nadeelcompensatie waarin geen (formeel) wettelijke nadeelcompensatieregeling of nadeelcompensatiebeleidsregel van toepassing is. Daarvoor moet wel worden voldaan aan een tweetal eisen. Allereerst moet worden voldaan aan de eis van 'materiële connexiteit': de beslissing op de aanvraag om schadevergoeding kan bij gebreke aan een wettelijke nadeelcompensatieregeling of nadeelcompensatiebeleidsregel slechts als besluit in de zin van art. 1:3 Awb - een zogenoemd 'buitenwettelijk zuiver schadebesluit' - worden aangemerkt als de schade is veroorzaakt binnen het kader van de uitoefening van een aan het publiekrecht ontleende bevoegdheid. De schade dient dus te zijn veroorzaakt door overheidshandelen dat is gebaseerd op een (formeel)wettelijk voorschrift. Ten tweede dient te zijn voldaan aan de eis van 'processuele connexiteit': het buitenwettelijk zuiver schadebesluit is slechts appellabel als de schadeoorzaak dat ook was, én het beroep dient aanhangig te zijn gemaakt bij de bestuursrechter die bevoegd was te oordelen over een (hypothetisch) beroep tegen deze schadeoorzaak. In latere jurisprudentie is deze eis nog aangevuld. Zij houdt ook in dat tegen een zuiver schadebesluit slechts ontvankelijk bezwaar kan worden gemaakt door degene die ook ontvankelijk bezwaar heeft gemaakt of had kunnen maken

53 ABRvS 18 februari 1997, ECLI:NL:RVS:1997:ZF2587 (Beurskens).

54 ABRvS 6 mei 1997, ECLI:NL:RVS:1997:AA6762 (Van Vlodrop).

55 ABRvS 12 november 2003, ECLI:NL:RVS:2003:AN7851, r.o. 2.7 (Prostitutiezone Heerlen/Ontkoppelingsuitspraak). Zie hierover ook paragraaf 5.3.1. 
tegen de beweerde schadeoorzaak. Hieraan wordt ook wel gerefereerd als 'belanghebbendeconnexiteit'. ${ }^{56}$

\section{Het hedendaagse nadeelcompensatiedoolhof}

Dat het appellabel, buitenwettelijk zuiver schadebesluit geleidelijk aan terrein heeft gewonnen, wordt over het algemeen als positief ervaren. De rechtmatigheid van op zichzelf wenselijke overheidsmaatregelen hoeft daardoor namelijk niet te worden aangevochten om nadeelcompensatie te verkrijgen. Dit wordt ook wel aangeduid als de 'smeermiddelfunctie' van het nadeelcompensatierecht. ${ }^{57}$ Het hiervoor beschreven samenspel van wetgever, bestuur en rechter had echter wel tot gevolg dat stukje bij beetje een 'nadeelcompensatiedoolhof' ontstond. Met name de vraag of de civiele rechter of bestuursrechter kon en/of moest worden geadieerd, bleek een regelmatig in de jurisprudentie terugkerend twistpunt. Hierna zal ik kort de belangrijkste gangen van het doolhof beschrijven, waarbij ik zal verwijzen naar de daarvoor relevante rechterlijke uitspraken.

Eerst besteed ik enige aandacht aan gevallen waarin art. 3:4 lid 2 Awb in stelling wordt gebracht om nadeelcompensatie te verkrijgen. Beweert de benadeelde dat de door hem gestelde schade is veroorzaakt door een niet-appellabele schadeoorzaak, dan zal hij de burgerlijke rechter moeten adiëren onder aanvoering van het argument dat wegens schending van art. 3:4 lid 2 Awb sprake is van een onrechtmatige daad in de zin van art. 6:162 BW. Is de beweerde schadeoorzaak appellabel, dan leidt de gang van het onzuivere schadebesluit altijd naar de bestuursrechter. Zolang bestuursrechtelijke rechtsmiddelen tegen de schadeoorzaak kunnen worden aangewend, zal de civiele rechter de benadeelde immers niet-ontvankelijk verklaren omdat de bestuursrechtelijke procedure een "met voldoende waarborgen omklede rechtsgang" biedt. ${ }^{58}$ Wanneer de termijn voor het aanwenden van deze rechtsmiddelen onbenut is verstreken, óf deze rechtsmiddelen onsuccesvol tegen de schadeoorzaak zijn aangewend, zal het betoog dat wegens een schending van art. 3:4 lid 2 Awb sprake is van een onrechtmatige daad in de zin van art. 6:162 BW stuklopen op de formele rechtskracht die de schadeoorzaak inmiddels heeft verkregen. ${ }^{59}$ Wordt tijdig een bestuursrechtelijke procedure gestart, dan kan daarin nog discussie bestaan over de vraag of het bestuur het schadegeschil mag 'doorschuiven' door de aanvrager tegen te werpen dat hij zijn wens tot schadevergoeding moet proberen te realiseren door een (buiten)wettelijk zuiver schadebesluit

Zie bijvoorbeeld CRvB 16 september 2003, ECLI:NL:CRVB:2003:AM2447; en ABRvS 18 augustus 2004, ECLI:NL:RVS:2004:AQ7003, r.o. 2.3-2.3.2 (Schadevergoeding jachtvergunning).

57 Zie bijvoorbeeld Tjepkema 2017, p. 78.

58 Vergelijk art. 70 Rv; HR 28 februari 1992, ECLI:NL:HR:1992:ZC0527 (Changoe) Staat); en HR 3 juni 2016, ECLI:NL:HR:2016:1049, r.o. 4.1 .5 (Universiteiten/ SCAU).

59 HR 6 december 2002, ECLI:NL:HR:2002:AE8182, r.o. 3.7 (Pannenkoekenhuis De Kabouter). 
aan te vragen. Aangezien ik mij in dit proefschrift richt op verschillen tussen nadeelcompensatieregelingen, zal ik hier niet verder op ingaan. Voor een analyse van de voorwaarden waaronder mag worden doorgeschoven, verwijs ik naar de door Tjepkema en mijzelf geschreven bijdrage aan de 25 jaar Awb-bundel. ${ }^{60}$

Hoe zit de vork in de steel als niet art. 3:4 lid 2 Awb maar het égalitébeginsel wordt aangewezen als grondslag voor nadeelcompensatie? Uit het op 28 maart 2008 gewezen Asha-arrest volgt dat de taakverdeling tussen de burgerlijke rechter en de bestuursrechter meebrengt dat de burgerlijke rechter het oordeel of een benadeelde op grond van het égalitébeginsel recht heeft op vergoeding van de schade die hij beweerdelijk heeft geleden als gevolg van een of meer appellabele besluiten dient over te laten aan de bestuursrechter. Daarbij lijkt doorslaggevend te zijn dat - vanwege het voldaan zijn van de eisen van materiële en processuele connexiteit - een met voldoende waarborgen omklede bestuursrechtelijke rechtsgang openstaat om nadeelcompensatie op grond van het égalitébeginsel te verkrijgen, namelijk het aanvragen en eventueel aanvechten van een zuiver schadebesluit. ${ }^{61}$ Ik ben het met Van Ravels eens dat er om dezelfde redenen geen rol voor de civiele rechter is weggelegd als niet het ongeschreven égalitébeginsel, maar een (formeel)wettelijke nadeelcompensatieregeling of een afdoende gepubliceerde nadeelcompensatiebeleidsregel kan worden aangewend als grondslag voor nadeelcompensatie. ${ }^{62}$

De twee voorafgaande alinea's zouden de indruk kunnen wekken dat het nadeelcompensatiedoolhof (inmiddels) een betrekkelijk overzichtelijk doolhof is, of zelfs helemaal geen doolhof. Toch is de kwalificatie als doolhof mijns inziens op zijn plaats. Daarbij is van belang dat sinds het Leffers-arrest twee rechters uitspraken deden over wat naar huidige inzichten als nadeelcompensatie wordt beschouwd. Hierna heeft een periode van onzekerheid bestaan waarin de civiele rechter en bestuursrechter afhankelijk waren van de beroepsgronden die partijen aanvoerden om hun onderlinge rechtsmachtsverdeling af te bakenen en hun jurisprudentie ook overigens op elkaar af te stemmen. Dat de bestuursrechter zich niet heeft opgeworpen als de enige rechter om over nadeelcompensatiegeschillen te beslissen, kan worden verklaard door de hoofdregel dat een publiekrechtelijke bevoegdheid - dus ook de bevoegdheid tot het toekennen van nadeelcompensatie - op een wettelijke grondslag dient te zijn gebaseerd. Met de Metroschade-uitspraak, en de uitspraken Beurskens en Van Vlodrop rekte de Afdeling de staatsrechtelijke grenzen van art. 1:3 jo. 8:1 jo. 7:1 Awb op teneinde de mate van bestuursrechtelijke rechtsbescherming te bieden die maximaal haalbaar was zonder deze staatsrechtelijke grenzen

60 Huijts \& Tjepkema 2019, p. 194-197. Zie ook Tjepkema 2010, p. 603-604.

61 HR 28 maart 2008, ECLI:NL:HR:2008:BC0256, r.o. 3.4.2 (Asha). Deze passage is overgenomen uit eigen werk, namelijk: Huijts \& Tjepkema 2019, p. 197-198. Van Ravels 2009a, p. 155-156. 
(volledig) te overschrijden. ${ }^{63}$ Ten slotte is ook van belang dat zich in de praktijk combinaties van appellabele en niet-appellabele schadeoorzaken kunnen voordoen die bovendien in verschillende mate onder de reikwijdte van (formeel)wettelijke nadeelcompensatieregelingen en/of nadeelcompensatiebeleidsregels vallen, waarvoor al dan niet soms meer dan één bestuursorgaan verantwoordelijk is. ${ }^{64}$ Dat kan onder andere tot gevolg hebben dat een benadeelde gelijktijdig meerdere procedures moet doorlopen om het onevenredige deel van zijn schade volledig vergoed te krijgen. Tussen die procedures kunnen ook (aanzienlijke) materieelrechtelijke verschillen bestaan, omdat - zoals uit de navolgende hoofdstukken nog zal blijken - tussen nadeelcompensatieregelingen verschillen in normering van het recht op nadeelcompensatie bestaan. In paragraaf 2.4.2 zal blijken dat deze procedurele en materiële onoverzichtelijkheid aanleiding vormde voor de formele wetgever om een algemene formeelwettelijke nadeelcompensatieregeling in het leven te roepen in de vorm van titel $4.5 \mathrm{Awb}$. Ter afsluiting van deze paragraaf is op de volgende pagina een schematische weergave opgenomen van het nadeelcompensatiedoolhof.

63 Zie hierover bijvoorbeeld ook Tjepkema 2017, p. 83-84. Hennekens was bijvoorbeeld wel van mening dat de Afdeling staatsrechtelijke grenzen schond. Zie onderdeel $6 \mathrm{t} / \mathrm{m} 8$ van zijn noot behorende bij ABRvS 25 februari 2000, ECLI:NL:RVS:2000:AN6317 in Gst. 2000, no. 7121, p. 311-314. Zie hierover bijvoorbeeld ook Tjepkema 2017, p. 84. 


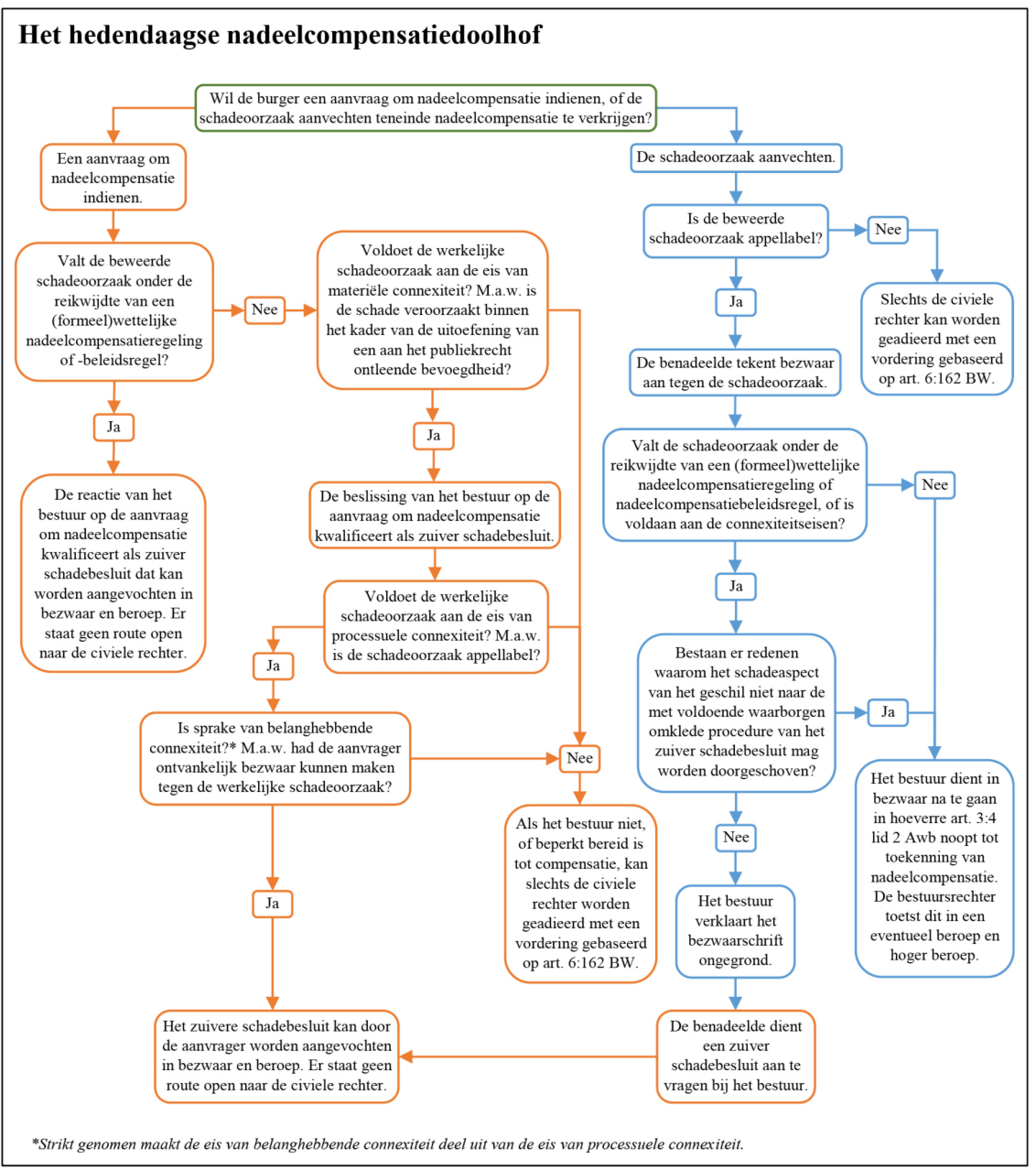

\section{3}

\section{SElEctie VAN HeDENDAAGSE NADEELCOMPENSATIEREGELINGEN}

Het Nederlandse recht kent vele nadeelcompensatieregelingen. Als het aankomt op formeelwettelijke regelingen kan onder andere worden gedacht aan art. 22 Tracéwet, art. 7.14 Waterwet, art. 4.2 Wabo, art. 15.20 jo. 15.21 Wet milieubeheer, art. 17 Spoedwet wegverbreding, art. 26 t/m 28 Ontgrondingenwet, art. 17 Boswet en afd. 6.1 Wro. Ook lagere regelgevers, zowel op centraal als decentraal niveau hebben wettelijke nadeelcompensatieregelingen vastgesteld. Soms zijn die regelingen gebaseerd op een specifieke formeelwettelijke attributiegrondslag om nadeelcompensatieregelgeving vast te stellen. Het bekendste voorbeeld daarvan is het Besluit ruimtelijke ordening (hierna: Bro) dat op basis van art. 6.7 Wro is vastgesteld. In art. 6.1.3.3 Bro is bovendien een verplichting opgenomen voor onder andere gemeenten en provincies om een verordening vast te stellen "over de 
aanwijzing van een adviseur en de wijze waarop deze tot een advies komt." ${ }^{65}$ De modelverordening die de VNG hiervoor heeft opgesteld, zal een rol spelen bij de beantwoording van de tweede deelvraag in hoofdstuk 10.

Ook zijn veel wettelijke nadeelcompensatieregelingen en nadeelcompensatiebeleidsregels vastgesteld zonder dat daartoe een wettelijke plicht bestond. Dat kan historisch worden verklaard door de initiatieven die Van der Gouwe ondernam vanwege het gebrek aan een algemene formeelwettelijke nadeelcompensatieregeling, en de acceptatie daarvan door de bestuursrechter in onder andere de Metroschadejurisprudentie. Bij het vaststellen van wettelijke nadeelcompensatieregelingen en nadeelcompensatiebeleidsregels hadden de desbetreffende regelgevers respectievelijk bestuursorganen niet alleen de bescherming van de burger op het oog, maar ook hun eigen belangen. Een breed toepasbare nadeelcompensatieregeling verkleint immers de noodzaak tot het voeren van meerdere procedures over één schadecomplex. Ook verkleint een dergelijk regeling in algemene zin de weerstand tegen schadeveroorzakende overheidsmaatregelen (de smeermiddelfunctie) ${ }^{66}$ Enkele bekende voorbeelden op centraal overheidsniveau zijn de 'Beleidsregel nadeelcompensatie Infrastructuur \& Waterstaat 2019', de 'Nadeelcompensatieregeling verleggen kabels en leidingen in en buiten rijkswaterstaatswerken en spoorwegwerken 1999' en de 'Beleidsregel schadevergoeding Ruimte voor de Rivier'. Wat betreft het decentrale overheidsniveau resulteert een zoekopdracht via www.overheid.nl op regelingen met 'nadeelcompensatie' in de titel in 14 treffers op het provinciale niveau, 13 treffers op het niveau van het waterschap en 66 treffers op gemeentelijk niveau. ${ }^{67}$ Er bestaan overigens nog meer van dergelijke regelingen, omdat de term 'nadeelcompensatie' regelmatig niet wordt opgenomen in de titels van nadeelcompensatieregelingen. Een voorbeeld daarvan betreft de 'Regeling Tegemoetkoming Omwonenden Sanering Olasfa 2016'. ${ }^{68}$

In paragraaf 1.4 bleek dat de tweede deelvraag slechts kan worden beantwoord ten aanzien van een selectie van nadeelcompensatieregelingen. Voor wat betreft de hedendaagse nadeelcompensatieregelingen is gekozen voor afd. 6.1 Wro, de BnIW 2019, de Grs, de VNNZ en de AVN. Hierna zal ik deze regelingen kort introduceren en toelichten waarom juist zij zijn geselecteerd voor dit onderzoek. Daarbij zal blijken dat de redenen voor selectie onder andere verband houden met de waardevolle geschiedenis ${ }^{69}$ en het praktisch belang van deze regelingen, en/ of de wijze waarop zij zich verhouden tot overige nadeelcompensatieregelingen.

65 De bepalingen omtrent planschadeadvisering zijn soms ondergebracht in een meer omvattende verordening. Daarbij kan worden gedacht aan de 'Omgevingsverordeningen' van de provincies Groningen, Zuid-Holland en Drenthe.

66 Zie paragraaf 2.2 voor een uitgebreidere bespreking van zowel dit historische als praktische perspectief.

67 Deze zoekopdracht is uitgevoerd op 4 april 2019.

68 Zie over deze regeling ook ABRvS 6 maart 2019, ECLI:NL:RVS:2019:729 (Olas$f a)$.

69 Dat kan zowel de ontstaans- als de toepassingsgeschiedenis betreffen. 


\subsubsection{Afdeling 6.1 Wet ruimtelijke ordening}

Op het formeelwettelijke niveau is de keuze gevallen op de planschaderegeling van afd. 6.1 Wro. Deze regeling ziet op schade die wordt geleden door de vaststelling of wijziging van de bestemming van een onroerende zaak en/of de planologische voorschriften die bij het gebruik van die zaak in acht moeten worden genomen. Daarbij wordt onderscheid gemaakt tussen schade doordat de bouw- en/ of gebruiksmogelijkheden van het perceel van de aanvrager worden gewijzigd (directe planschade) ${ }^{70}$ en schade doordat de bouw- en/of gebruiksmogelijkheden van omliggende percelen worden gewijzigd (indirecte planschade).$^{71}$

\section{Waardevolle geschiedenis}

Een eerste reden voor selectie van afd. 6.1 Wro is de lange, meer dan 50 jaar beslaande geschiedenis van deze regeling. De eerste Kamerstukken inzake haar voorloopster (art. $49 \mathrm{WRO}$ ) dateren uit 1955. ${ }^{72}$ In paragraaf 2.2 heb ik betoogd waarom deze regeling van groot belang was voor de totstandkoming van het hedendaagse nadeelcompensatierecht. Voor dit proefschrift kan in het bijzonder van toegevoegde waarde zijn dat het oorspronkelijke regeringsvoorstel voor art. 49 WRO aan het égalitébeginsel deed denken, maar de grondslag van deze bepaling uiteindelijk de materiële rechtszekerheid bleek te zijn. Het daaraan verbonden uitgangspunt van een volledige vergoeding lijkt een belangrijke reden te zijn geweest voor de vaststelling van de wel op égalité gebaseerde afd. 6.1 Wro. ${ }^{73}$ Dat blijkt overigens niet expliciet uit de bij de Wro behorende memorie van toelichting. Daarin wordt bijvoorbeeld opgemerkt dat "de tijd niet rijp [werd geacht] voor een brede hercodificatie van het schadevergoedingsrecht, inclusief een definitieve regeling van de nadeelcompensatie, bij ruimtelijke beslissingen." 74 Er zou dan ook geen sprake zijn van "een principiële inperking van het recht op planschadevergoeding", maar het onveranderd voortbestaan van de destijds bestaande schadevergoedingsregeling werd eveneens onwenselijk bevonden door de regering, mede gelet op de bestuurlijke en maatschappelijke effecten van art. 49 WRO. ${ }^{75}$ Wel blijkt dit uit de redactionele wijziging dat niet langer wordt gesproken van een 'schadevergoeding' maar van een 'tegemoetkoming in de schade'. Bovendien stelt de Wro inhoudelijk zwaardere eisen aan de toekenning van compensatie. Zo komt schade die tot het normaal maatschappelijk risico behoort niet voor tegemoetkoming in aanmerking vanwege art. 6.2 Wro. Ook worden bepalingen waarmee flexibiliteit

70 Zie bijvoorbeeld ABRvS 4 mei 2016, ECLI:NL:RVS:2016:1200 (Bergen) en ABRvS 17 mei 2017, ECLI:NL:RVS:2017:1293 (De Lunet).

71 Zie bijvoorbeeld ABRvS 2 maart 2016, ECLI:NL:RVS:2016:530 (Rijsbergen) en ABRvS 1 juli 2015, ECLI:NL:RVS:2015:2071 (Mook \& Middelaar).

72 Kamerstukken II 1955/56, 4233, nr. 1-2.

73 Zie bijvoorbeeld Van Buuren e.a. 2017, p. 242; en Van Ravels 2013a, p. 103.

74 Daarin lijkt, gelet op het regeringsvoorstel voor afd. $15.1 \mathrm{Ow}$, verandering te zijn gekomen. Zie daarover paragraaf 2.4.3. 
in een bestemmingsplan kan worden aangebracht niet langer aangemerkt als schadeoorzaken die kunnen leiden tot tegemoetkoming. Slechts schade door besluiten waarmee toepassing wordt gegeven aan dergelijke 'flexibiliteitsbepalingen' komt voor tegemoetkoming in aanmerking. ${ }^{76}$

\section{Praktisch belang}

Een tweede reden voor selectie van afd. 6.1 Wro is gelegen in haar praktische belang, dat ook wordt benadrukt in de memorie van toelichting behorende bij de Wns. Daarin wordt afd. 6.1 Wro namelijk genoemd als "de bekendste en belangrijkste variant" van formeelwettelijke nadeelcompensatieregelingen waarop de aanpassingswetgeving zal zien die nodig is voor inwerkingtreding van titel 4.5 Awb. Ook in de literatuur wordt de planschaderegeling uit de Wro gezien als (een van) de meest bewandelde weg(en) ter verkrijging van nadeelcompensatie. ${ }^{77}$ Haar praktische belang is daarnaast gelegen in de omstandigheid dat zij ziet op schade door een permanente wijziging van de directe woon-, werk- en/of leefomgeving van de benadeelde. ${ }^{78}$

Empirische informatie over de hoeveelheid compensatie die op grond van afd. 6.1 Wro wordt toegekend is schaars. In 2017 is ter voorbereiding van het wetsvoorstel voor de IOw een enquête uitgezet door het ministerie van Infrastructuur en Milieu bij provincies, waterschappen en gemeenten. ${ }^{79}$ Bij de beantwoording van de gestelde vragen bleken de meeste respondenten geen onderscheid te hebben gemaakt tussen planschadetegemoetkoming en nadeelcompensatie. Uit de verkregen resultaten lijkt daarom bijvoorbeeld voor gemeenten slechts te kunnen worden afgeleid dat in de afgelopen 5 jaar circa 30 miljoen euro aan tegemoetkoming in planschade of nadeelcompensatie is toegekend.$^{80}$ Dit zou neerkomen op 6 miljoen euro op jaarbasis. Dat zou significant minder zijn dan de schatting die de regering in het vergaderjaar 2002/2003 maakte ten opzichte van art. 49 WRO. Die schatting hield namelijk in dat destijds 20 miljoen euro op jaarbasis aan planschadevergoeding zou worden toegekend. ${ }^{81}$ Van Buuren c.s. heeft - mijns inziens terecht $\mathrm{t}^{82}$ - aangevoerd dat onduidelijk is waarop de regering deze schatting

76 Zie paragraaf 3.2.4 onder het kopje 'Keuze van de wetgever' en paragraaf 4.2.3.1.

77 Zie bijvoorbeeld Polak e.a. 2008, p. 110 (destijds nog ten aanzien van art. 49 WRO).

78 In hoofdstuk 5 zal nader op het schadebegrip van de Wro worden ingegaan.

79 Na lang wachten is een rapport over de enquête gepubliceerd op www.omgevingswetportaal.nl. Zoek op 'Resultaten enquête nadeelcompensatie'.

80 Van de benaderde gemeenten reageerden $47 \%$. Zij beslisten positief op 1.411 aanvragen en keerden per aanvraag gemiddeld 10.250 euro toe: $((1.411 \times 10.250) / 47)$ x $100=30.771 .809$ euro.

$81 \quad$ Kamerstukken II 2002/03, 28 916, nr. 3, p. 61 (MvT, Wro).

82 Het Nederlandse planschadestelsel is één van de ruimhartigste planschadestelsels ter wereld. Zie hieromtrent onder andere Van Geest e.a. 2000, p. 37-38; Alterman 2010, p. 343 en 34-35; en Huijts \& Backes 2015, p. 133-134. 
baseerde en dat deze schatting aan de lage kant lijkt te zijn. ${ }^{83}$ Het grote verschil tussen de schatting ten aanzien van de WRO en de enquêteresultaten omtrent de Wro kan worden verklaard doordat afd. 6.1 Wro het bestuur niet verplicht tot een volledige vergoeding van de geleden schade, maar slechts tot vergoeding van het onevenredige deel daarvan.

\section{Invloed op toekomstige wetgeving}

Een laatste reden voor selectie is dat afd. 6.1 Wro enerzijds (deels) de aanleiding vormde voor vaststelling van afd. 15.1 Ow. Uit verschillende Kamerstukken blijkt namelijk dat het kabinet afd. 6.1 Wro in algemene zin als een belemmering ziet voor de doelen die het met afd. $15.1 \mathrm{Ow}$ wil bereiken, en in het bijzonder voor het van de grond krijgen van uitnodigingsplanologie. ${ }^{84}$ Dat is een vorm van planologie waarbij de overheid op hoofdlijnen bepaalt waar veranderingen wel of niet wenselijk zijn vanuit ruimtelijk perspectief, maar zich binnen deze globale kaders "uitnodigend en faciliterend" opstelt tegenover initiatiefnemers. ${ }^{85}$ Anderzijds zal in de navolgende hoofdstukken blijken dat bij het opstellen van afd. $15.1 \mathrm{Ow}$ ook regelmatig aansluiting is gezocht bij de systematiek van afd. 6.1 Wro en de praktijk die onder art. 49 WRO en afd. 6.1 Wro is ontstaan, alsmede de jurisprudentie die daarover is gewezen. ${ }^{86}$

\subsubsection{Beleidsregel nadeelcompensatie Infrastructuur \& Waterstaat 2019}

Op het centrale, niet formeelwettelijke overheidsniveau is de BnIW 2019 geselecteerd. Ook deze regeling is geselecteerd vanwege haar geschiedenis, praktische belang, en invloed op toekomstige regelgeving.

\section{Waardevolle geschiedenis}

De oorsprong van de BnIW 2019 moet worden gevonden in de praktijk van bestuurscompensatie die ontstond in de jaren ' 70 van de vorige eeuw. In paragraaf 2.2 beschreef ik hoe deze praktijk en het gedachtegoed van Van der Gouwe in 1991 leidden tot de vaststelling van de RnR 1991. ${ }^{87}$ Hoewel het égalitébeginsel werd gezien als één van de mogelijke grondslagen van deze regeling, wees de minister bij vaststelling van de RnR 1991 geen grondslag aan voor deze rege-

83 Van Buuren e.a. 2014, p. 254.

84 Zie Kamerstukken II 2015/16, 33 962, nr. 185 (Inleidende brief, IOw); en Kamerstukken II 2016/17, 33 962, nr. 190, p. 23-25 en 28.

85 Zie voor een uitgebreidere definitie Kamerstukken II 2013/14, 33 962, nr. 3, p. 275 276 (MvT, Ow). Hierin wordt verwezen naar Van Rooy 2011; Planbureau voor de Leefomgeving \& Urhahn Urban Design 2012; Rijksvastgoed- en ontwikkelingsbedrijf 2012; en Ministerie van Binnenlandse Zaken 2012.

86 Zie hierover bijvoorbeeld ook expliciet Kamerstukken II 2018/19, 34 986, nr. 3, p. 226, 234, 243 (MvT, IOw) en MvT IOw als voorgelegd aan de AARvS, p. 185. Stcrt. 1991, nr. 251, p. 26-29. 
ling. Hij zag dit namelijk "primair" als een "doctrinaire aangelegenheid". Er werd met name beoogd om "vorm te geven aan de sedert jaren bestaande nadeelcompensatiepraktijk van Rijkswaterstaat" en om laagdrempelige, bestuursrechtelijke rechtsbescherming te bieden aan benadeelden die zich niet konden beroepen op een (formeel)wettelijke nadeelcompensatieregeling. ${ }^{88}$

De RnR 1991 werd opgevolgd door de Regeling nadeelcompensatie Verkeer \& Waterstaat 1999 (hierna: RnVW 1999). Hiermee werd onder andere beoogd de reikwijdte van de regeling uit te breiden. De RnR 1991 zag namelijk slechts op rechtmatig publiekrechtelijk handelen van het 'directoraat-generaal Rijkswaterstaat', terwijl de RnVW 1999 zag op het rechtmatig publiekrechtelijk handelen van de minister van Verkeer en Waterstaat. ${ }^{89}$ Tevens werd beoogd om de RnR 1991 aan te passen aan nieuwe ontwikkelingen op het gebied van wetgeving en jurisprudentie..$^{90}$ De vraag of nadeelcompensatie op zijn plaats was, werd door de RnR 1991 namelijk slechts in zoverre beantwoord dat een vergoeding moest worden toegekend voor zover de schade redelijkerwijze niet of niet geheel ten laste van de aanvrager behoorde te blijven en voor zover de vergoeding niet, of niet voldoende, anderszins was verzekerd. ${ }^{91}$ In de RnVW 1999 werd deze redelijkerwijsformule ingevuld door art. 3 t/m 11. De RnVW 1999 was daarmee een van de eerste regelingen die criteria inzake abnormale- en speciale last en risicoaanvaarding codificeerde. Daarmee staat mijns inziens ook vast dat deze beleidsregel zijn grondslag vond in het égalitébeginsel, ook al werd in de toelichting nog aangesloten bij de formulering die de Afdeling gebruikte in haar uitspraken Beurskens en Van Vlodrop: "het mede aan art. 3:4 tweede lid Awb ten grondslag liggende, algemene rechtsbeginsel van égalité devant les charges publique (gelijkheid voor openbare lasten). ${ }^{.92}$

In juni 2014 werd de RnVW 1999 aangevuld en van naam veranderd door de BnIM 2014. Deze wijziging diende ertoe nadere normering te verschaffen voor de afbakening van het normaal ondernemersrisico ${ }^{93}$ bij aanvragen om nadeelcompensatie naar aanleiding van infrastructurele maatregelen van de minister. In de praktijk zou behoefte bestaan aan kenbaar beleid ten aanzien van deze afbakening. Voor het overige nam de BnIM 2014 de tekst van de RnVW 1999 bijna geheel

92 Stcrt. 1999, nr. 172, p. 8-11 (digitaal, p. 4-5 en 7-11). Zie over de genoemde uitspra-

ken ook paragraaf 2.2 .

Stcrt. 1991, nr. 251, p. 26-27.

Vergelijk art. 2 RnR 1991 met art. 2 RnVW 1999.

Stcrt. 1999, nr. 172, p. 8 (digitaal, p. 3-4). De RnVW 1999 en de daarbij behorende toelichting zijn destijds gepubliceerd op p. $8 \mathrm{t} / \mathrm{m} 12$ van deze editie van de Staatscourant. Wanneer de bekendmaking van de RnVW in de Staatscourant in pdfvorm wordt geraadpleegd via www.overheid.nl kan echter gedetailleerder worden verwezen, aangezien deze publicatie uit meer pagina's bestaat. Naar die pagina's zal tussen haakjes worden verwezen onder vermelding van de term 'digitaal'.

Art. 2 RnR 1991.

3 Dit is het normaal maatschappelijk risico van ondernemers. 
over. ${ }^{94}$ De tekst van de BnIM 2014 werd op zijn beurt grotendeels overgenomen in de BnIW 2019. Die regeling werd vastgesteld naar aanleiding van de op 20 juli 2018 door de minister van I\&W aan de Tweede Kamer aangeboden 'Handleiding nadeelcompensatie bij infrastructurele maatregelen'.$^{95}$ Deze handleiding was reeds in 2012 aan de Eerste Kamer beloofd door de voorganger van de minister. ${ }^{96}$ Aan de aanleiding daarvoor zal ik aandacht besteden in paragraaf 6.3.1. Hier volsta ik met de opmerking dat implementatie van de door de handleiding voorgeschreven methode van afbakening van het normaal ondernemersrisico de belangrijkste reden was voor vaststelling van de BnIW 2019. Daarnaast zijn enkele wijzigingen doorgevoerd om de efficiëntie te verhogen van de procedure die de minister in acht moet nemen als hij op een aanvraag om nadeelcompensatie besluit. ${ }^{97}$

De passages uit de toelichtingen op de RnVW 1999 en BnIM 2014 die geen betrekking hebben op het normaal ondernemersrisico of de doorgevoerde procedurele wijzigingen zullen hun relevantie blijven behouden voor de uitleg en toepassing van de BnIW 2019. Hetzelfde geldt voor de onder deze regelingen gewezen jurisprudentie. Om niet te vervallen in onnodig formalisme, zal ik daarom in het vervolg van dit proefschrift regelmatig spreken van 'de toelichting op de BnIW 2019' of een 'uitspraak gewezen onder de BnIW 2019' terwijl ik verwijs naar de toelichting op de RnVW 1999 of BnIM 2014, respectievelijk rechterlijke uitspraken die onder deze regelingen zijn gewezen.

\section{Praktisch belang}

Het praktische belang van de RnVW 1999 is onder andere onderschreven door Tjepkema en De Jongh. ${ }^{98}$ Mijns inziens zijn de desbetreffende publicaties ook representatief voor het praktische belang van de BnIW 2019. Ook los daarvan kan worden beredeneerd dat de BnIW 2019 een belangrijke nadeelcompensatieregeling is. Zij is namelijk van toepassing op schade veroorzaakt in de rechtmatige uitoefening door of namens de minister van $\mathrm{I} \& \mathrm{~W}^{99}$ van een aan het publiekrecht ontleende bevoegdheid of taak (vergelijk art. 2 BnIW 2019). Deze minister is betrokken bij de grotere infrastructurele projecten in het land en gebruikt daarbij de

Stcrt. 2014, nr. 16584, p. 3.

95 De aanbiedingsbrief kan worden geraadpleegd op www.rijksoverheid.nl/documenten/kamerstukken/2018/07/20/aanbieding-handleiding-nadeelcompensatie-bij-infrastructurele-maatregelen. De handleiding is te raadplegen op www.rijksoverheid. $\mathrm{nl} /$ documenten/brochures/2018/07/20/handleiding-nadeelcompensatie-bij-infrastructurele-maatregelen.

96 Handelingen I 2012/13, 32 621, nr. 15, item 6.

97 Stcrt. 2018, nr. 66154.

98 Zie Tjepkema 2010, p. 885; en De Jongh 2012, p. 379.

99 Voorheen betrof dit de minister van Infrastructuur en Milieu. Voorafgaand aan 14 oktober 2010 - de datum waarop het ministerie van Verkeer en Waterstaat fuseerde met het ministerie van Volkshuisvesting, Ruimtelijke Ordening en Milieubeheer werd deze minister nog aangeduid als de minister van Verkeer en Waterstaat. 
BnIW 2019 om schadegeschillen af te handelen. ${ }^{100}$ Juist door dit soort projecten zal een relatief groot aantal burgers dusdanig worden getroffen in hun woon-, werken/of leefsituatie dat zij onevenredige schade lijden en dus in aanmerking komen voor nadeelcompensatie. Het is niet eenvoudig dit met statistische gegevens te onderbouwen, omdat deze weinig (consequent) zijn verzameld door het ministerie. Navraag bij Rijkswaterstaat leerde dat ten aanzien van enkele wat grotere projecten wel wat gegevens bekend zijn. Zo werden in het kader van grootschalig onderhoud aan de 'Hollandse brug' - een brug nabij Muiderberg die Flevoland met Noord-Holland verbindt - 58 aanvragen om nadeelcompensatie ingediend voor een totaalbedrag van $€ 9.015 .000 .{ }^{101}$ Naar aanleiding hiervan werd in totaal $€ 1.479 .308$ aan compensatie toegekend. In het kader van de uitbreiding van een sluizencomplex te Eefde werden 47 aanvragen om nadeelcompensatie ingediend voor een totaalbedrag van $€ 2.572 .908$. Naar aanleiding daarvan werd in totaal $€ 1.047 .775$ aan compensatie toegekend.

\section{Invloed op (toekomstige) regelgeving}

Het belang van de BnIW 2019 is niet alleen praktisch van aard. Ook relevant is dat de RnVW 1999 de functie van "moederregeling" vervult: veel (buitenwettelijke) nadeelcompensatieregelingen zijn op haar gebaseerd. ${ }^{102}$ Jurisprudentie en andere inzichten inzake de RnVW 1999 kunnen derhalve ook representatief en van betekenis zijn voor de op deze regeling gebaseerde nadeelcompensatieregelingen. Daarbij is niet onbelangrijk dat ook de terminologie van art. 4:126 Awb deels is geïnspireerd op de RnVW 1999. ${ }^{103}$

\subsubsection{Twee Amsterdamse nadeelcompensatieregelingen}

Het decentrale overheidsniveau wordt in dit onderzoek vertegenwoordigd door de Algemene Verordening Nadeelcompensatie Amsterdam (AVN) en de Verordening Nadeelcompensatie Noord/Zuidlijn (VNNZ). Beide regelingen vinden hun grondslag in het égalitébeginsel. ${ }^{104} \mathrm{Zij}$ zijn vastgesteld om op voorhand duidelijkheid te verschaffen over de materiële criteria en procedurele voorschriften die van toepassing zijn op een aanvraag om nadeelcompensatie. Tevens dienen zij laagdrempelige, bestuursrechtelijke rechtsbescherming te garanderen. ${ }^{105} \mathrm{De}$ AVN is in algemene zin van toepassing op rechtmatig handelen van het Amsterdamse ge-

100 Zie overeenkomstig ook Polak 2002, p. 123.

101 Zie over deze casuïstiek ook paragraaf 6.3.1 onder het kopje 'Ontvangst van de Wouwse Tol-uitspraak en verdere ontwikkelingen in de jurisprudentie'.

102 Zie Franssen 2010, p. 5; en Tjepkema 2010, p. 893.

103 Kamerstukken I 2012/13, 32 621, nr. C, p. 2 (MvA I, Wns).

104 Zie de toelichting op art. 2 lid 1 VNNZ; en paragraaf 1.1 van de algemene toelichting op de AVN en de toelichting op art. 1 jo. art. 2 AVN.

105 Zie de toelichting op art. 2 lid 1 Verordening Nadeelcompensatie en Planschade Noord/Zuidlijn en onderdeel drie van de algemene toelichting op deze verordening. Zie ook paragraaf 1.2 van de algemene toelichting op de AVN. 
meentebestuur. De VNNZ ziet specifiek op schade door de aanleg van de Noord/ Zuidlijn, een metrolijn die het noorden en zuiden van Amsterdam verbindt. Met deze aanleg is aangevangen op 22 april 2003. Ruim vijftien jaar later is de metrolijn op 22 juli 2018 in gebruik genomen. ${ }^{106}$

\section{Waardevolle geschiedenis}

Ook de reden voor selectie van deze Amsterdamse regelgeving is drieledig. Allereerst verwacht ik dat de geschiedenis van de Amsterdamse verordeningen waardevolle inzichten voor dit proefschrift kan opleveren. De Amsterdamse gemeenteraad besloot in 1996 niet slechts tot de aanleg van de Noord/Zuidlijn, maar ook tot vaststelling van de 'Schaderegeling Noord/Zuidlijn'. ${ }^{107} \mathrm{Zij}$ beoogde hiermee 'de afhandeling van alle mogelijke schade te vereenvoudigen door daarvoor één loket in te stellen, alsmede de ontstane schade verantwoord te compenseren." Dit loket betrof het 'Schadebureau Noord-Zuidlijn', dat onder andere bevoegd was om aanvragen om planschadevergoeding en nadeelcompensatie in behandeling te nemen. ${ }^{108}$ Voor de behandeling van die aanvragen stelde de gemeenteraad op 20 juli 2000 de 'Verordening Nadeelcompensatie en Planschade Noord/Zuidlijn' vast. ${ }^{109}$ Deze regeling zou later echter met de uitputtend bedoelde planschaderegeling uit de Wro botsen en is daarom in oktober 2011 ingetrokken. Zij werd opgevolgd door de VNNZ. Uit het verschil in titel blijkt al dat laatstgenoemde verordening slechts in nadeelcompensatie voorziet. Afhankelijk van het overgangsrecht van art. 9.1.18 Invoeringswet Wro dienden aanvragen om planschadetegemoetkoming de weg van art. 49 WRO dan wel afd. 6.1 Wro te volgen. Verder zijn bij de vaststelling van de VNNZ de tien jaar aan ervaring met de Verordening Nadeelcompensatie en Planschade Noord/Zuidlijn en enkele adviezen van onder andere de gemeentelijke Rekenkamer, de gemeentelijke Ombudsman en de Commissie Veerman ${ }^{110}$ meege-

106 Zie www.parool.nl/amsterdam/noord-zuidlijn-gaat-definitief-rijden-op-22-juli2018 a4589029/.

107 Zie ook Van Manen 2003 over deze regeling en het begin met de afhandeling van schadegeschillen naar aanleiding van de aanleg van de Noord/Zuidlijn.

108 Zie art. 1, aanhef en onder k Verordening Planschade en Nadeelcompensatie Noord/ Zuidlijn, en art. 1 Regeling nadeelcompensatie Noord/Zuidlijn. De oprichting van een dergelijk bureau lijkt positief te worden gewaardeerd in Handleiding nadeelcompensatie, p. 31 .

109 Gemeenteblad Amsterdam 2000, afd. 3A, nr. 89.

110 Door een overschrijding van het budget voor de aanleg van de Noord/Zuidlijn ontstond een politieke impasse. B\&W vroegen oud-minister Cees Veerman een Commissie samen te stellen die zou onderzoeken hoe het verder moest met de Noord/ Zuidlijn. Het rapport kan worden gevonden door via google te zoeken op 'commissie veerman Noord/Zuidlijn'. 
nomen. ${ }^{111}$ Deze inzichten hebben ook een rol gespeeld bij de totstandkoming van de op 15 februari 2012 vastgestelde AVN. ${ }^{112}$

Naast de Verordening Nadeelcompensatie en Planschade Noord/Zuidlijn en de VNNZ, stelde de Amsterdamse gemeenteraad ten aanzien van schade door aanleg van de Noord/Zuidlijn ook enkele verordeningen vast die niet (uitsluitend) op het égalitébeginsel waren gebaseerd. Sporadisch zal in dit proefschrift ook enige aandacht worden besteed aan een van die verordeningen, namelijk de Verordening Tegemoetkoming Bouwactiviteiten Noord/Zuidlijn. ${ }^{113}$ Dit betreft een verordening die de mogelijkheid bood tot forfaitaire compensatie wegens derving van woonen gebruiksgenot van woningen respectievelijk bedrijfsruimten door de aanleg van de Noord/Zuidlijn. De hoogte van deze compensatie werd vastgesteld aan de hand van het 'VROM-puntenstelsel'. ${ }^{114}$ De verordening lijkt met name te zijn vastgesteld op basis van coulanceoverwegingen en moest voorkomen dat aanvragen worden ingediend die onder de VNNZ dienden te worden afgedaan. Dergelijke aanvragen zijn namelijk ingrijpender voor zowel burger als bestuur. Zo moet onder de VNNZ bijvoorbeeld in beginsel advies worden ingewonnen bij een adviescommissie. ${ }^{115}$

\section{Praktisch belang}

Ook bij de selectie van decentrale regelgeving achtte ik van belang dat de desbetreffende regelingen regelmatig worden toegepast en dus een reëel praktisch belang dienen. Een focus op Amsterdamse verordeningen lag daarom voor de hand, omdat Amsterdam met 863.202 inwoners ${ }^{116}$ de grootste gemeente van $\mathrm{Ne}$ derland is. Hoewel statistische gegevens niet stelselmatig zijn bijgehouden door het Amsterdamse gemeentebestuur, bevestigen de wel beschikbare gegevens het praktische belang van beide verordeningen. Onder de AVN werden tussen 2012 en 2016 gemiddeld zestien aanvragen per jaar ingediend waarvan er gemiddeld drie

111 Zie de algemene toelichting op de VNNZ.

112 De AVN is vastgesteld op 15 februari 2012 en op 1 april 2012 in werking getreden. Zie het Gemeenteblad 2012, afd. 3A, nr. 19/68. Zie met betrekking tot de rol die de VNNZ speelde bijvoorbeeld de toelichting op art. 5 en $6 \mathrm{AVN}$.

113 Verordening Tegemoetkoming Bouwactiviteiten Noord/Zuidlijn (Gemeenteblad 2010, afd. 3A, nr. 128/294). Deze regeling kende verschillende voorgangsters: Tegemoetkomingsregeling bouwactiviteiten Noord-Zuidlijn, ruwbouwfase 20082010 (Gemeenteblad 2008, afd. 3A, nr. 199/501); Bijdrageregeling bouwactiviteiten Noord-Zuidlijn (Gemeenteblad 2004, afd. 3A, nr. 252/628 en wijziging in Gemeenteblad 2005, afd. 3A, nr. 228/520); Kaderverordening bijdrage bouwactiviteiten (Gemeenteblad 2006, afd. 3A, nr. 155/310).

114 Zie paragraaf 5.7.1.3 voor meer informatie over dit stelsel.

115 Zie zowel de algemene toelichting op de VNNZ als de algemene toelichting op de Verordening Tegemoetkoming Bouwactiviteiten Noord/Zuidlijn. Zie over de raadpleging van een adviescommissie ook paragraaf 10.6.1.

116 Dit was volgens het CBS het aantal inwoners op 1 januari 2019, zie www.opendata.cbs.nl. 
werden toegewezen en elf werden afgewezen. Gemiddeld werd per jaar 37 duizend euro aan nadeelcompensatie toegekend. ${ }^{117}$ Wegens de aanleg van de Noord/ Zuidlijn was eind 2014 ruim 42 miljoen euro aan planschadevergoeding en nadeelcompensatie verstrekt en 5,5 miljoen euro aan tegemoetkomingen op grond van de Verordening Tegemoetkoming Bouwactiviteiten Noord/Zuidlijn. ${ }^{118}$

\section{Onderlinge verhouding en verhouding tot overige regelgeving}

De keuze beide Amsterdamse verordeningen te selecteren is ingegeven door de gedachte dat hun onderlinge verhouding waardevolle inzichten kan opleveren voor dit proefschrift. Eén en dezelfde regelgever heeft immers noodzaak gezien om een andere invulling aan het égalitébeginsel te geven in een algemene compensatieregeling (de AVN) dan de invulling die hij daaraan geeft in geval van een regeling die ziet op één specifiek schadeveroorzakend overheidsproject (de VNNZ). Bijzonder aan beide regelingen is bovendien dat zij niet uitgaan van de redelijkerwijsformule. Zij wijken daarmee af van de trend die de formele wetgever inzette in de jaren ' 50 van de vorige eeuw. Ook wordt afgeweken van de systematiek van de RnVW 1999, terwijl deze regeling voor veel andere regelgevers juist functioneerde als 'moederregeling'. ${ }^{119}$ Het verbaast daarom niet dat de AVN door Van Ettekoven is aangemerkt als een nadeelcompensatieregeling die vanuit "oogpunt van juridische innovatie (...) spannend" is. Daarbij speelde tevens een rol dat de AVN een van de eerste nadeelcompensatieregelingen was die een gedifferentieerde afbakening van het normaal ondernemersrisico voorschreef. ${ }^{120}$

Bijzonder aan beide Amsterdamse verordeningen is ten slotte dat bij hun vaststelling rekening is gehouden met (het voorontwerp van) het wetsvoorstel inzake de Wns. In de VNNZ beperkt zich dat tot de duur van de maximum beslistermijn, ${ }^{121}$ maar in de AVN is dit ook te herkennen aan verschillende inhoudelijke en redactionele keuzes van de Amsterdamse gemeenteraad. ${ }^{122}$ Het valt op dat veel van de doelstellingen die de formele wetgever met de Wns op nationaal niveau nastreeft door de Amsterdamse gemeenteraad met de AVN op gemeentelijk niveau worden

117 Tijdens het opmaken van deze statistieken waren zes aanvragen uit 2016 nog in behandeling. Mogelijk is in een of meerdere van die zaken ook nog compensatie toegekend.

118 Deze gegevens zijn verkregen via juristen van de gemeente Amsterdam.

119 Zie daarover paragraaf 2.3.2.

120 Van Ettekoven 2012, p. 345-346. Zie verder paragraaf 6.3.1 m.b.t. het ondernemersrisico onder de AVN.

121 Zie paragraaf 10.11.1 onder het kopje 'Verschillen en verklaringen daarvoor', onder verwijzing naar ad 3 op p. 4 van de toelichting op de VNNZ, en Gemeenteblad, afdeling 1, nr. 577, bijlage I, p. 4.

122 Zie paragraaf 1.4 van de algemene toelichting op de AVN. Voorts zijn gedeelten van de (toelichting op de) AVN vrijwel letterlijk overgenomen uit de (MvT bij de) Wns. Vergelijk bijvoorbeeld (de toelichting op) art. 3 lid 1, aanhef en onder c AVN met (de toelichting op) art. 4:126 lid 2, aanhef en onder c Awb. 
nagestreefd. Daarbij kan worden gedacht aan het bijdragen aan een "éénduidige wijze van behandeling", een "laagdrempelige bestuursrechtelijke rechtsbeschermingsprocedure" en "betere, goedkopere en eenduidige rechtsbescherming". ${ }^{123}$ Mogelijk kan deze anticipatie van toegevoegde waarde zijn voor dit proefschrift.

\section{Afsluitende opmerking}

Naar aanleiding van de voltooiing van de Noord/Zuidlijn is het Schadebureau Noord/Zuidlijn inmiddels opgeheven. Lopende zaken zijn overgenomen door het 'Bureau Schadepreventie en Nadeelcompensatie'. ${ }^{124}$ Het ligt voor de hand dat de VNNZ zal worden ingetrokken als deze zaken zijn afgehandeld. Het voorafgaande doet echter niet af aan de belangrijke plaats die de VNNZ de afgelopen decennia heeft ingenomen binnen het nadeelcompensatierecht, en dus ook niet aan de argumenten voor selectie van deze verordening voor dit proefschrift.

\subsubsection{De Gemeenschappelijke regeling Schadeschap Luchthaven Schiphol}

Ten slotte heb ik een regeling geselecteerd waarin toekenning van nadeelcompensatie (waaronder ook planschadevergoeding) op grond van formele wetgeving samenkomt met toekenning van nadeelcompensatie op grond van lagere regelgeving en het ongeschreven égalitébeginsel. ${ }^{125}$ Het betreft de GrS. Deze regeling werd vastgesteld in 1998, ${ }^{126}$ nadat in 1995 werd besloten tot de uitbreiding van Schiphol met een vijfde start- en landingsbaan (de Polderbaan). ${ }^{127}$ Door de vaststelling van de GrS werd het 'Schadeschap Luchthaven Schiphol' (hierna: het Schadeschap) in het leven geroepen, een openbaar lichaam als bedoeld in art. 8 lid 1 Wet gemeenschappelijke regelingen. Conform die bepaling hebben de bestuursorganen van de betrokken (deel)gemeenten, de provinciale staten van de provincie NoordHolland, het algemeen bestuur van het waterschap Groot-Haarlemmermeer ${ }^{128}$ en de minister van Verkeer en Waterstaat ${ }^{129}$ hun bevoegdheid om te besluiten op aanvragen om planschadevergoeding en nadeelcompensatie wegens schade door de uitbreiding van Schiphol gedelegeerd aan het algemeen bestuur van het Schadeschap. Het algemeen bestuur heeft deze bevoegdheid op zijn beurt gedelegeerd

123 Deze citaten zijn afkomstig uit paragraaf 1.2 van de algemene toelichting op de AVN. Zie paragraaf 2.4.2 van dit proefschrift over de doelstellingen van de formele wetgever.

124 Zie www.amsterdam.nl/bestuur-organisatie/organisaties/organisaties/schadeloketalgemene/.

125 Het betreft, kort gezegd, de toekenning van nadeelcompensatie op grond van art. 8.31 Wlv, art. 49 WRO, art. 21 Aanwijzingsbesluit 1996, de BnIW 2019, en het ongeschreven égalitébeginsel. Zie voor een nadere uitleg paragraaf 3.2.1.

126 Stcrt. 1998, nr. 223.

127 Zie art. 1, aanhef en onder g GrS.

128 Thans onderdeel van het Hoogheemraadschap van Rijnland.

129 Thans de minister van Infrastructuur \& Waterstaat. 
aan een besliscommissie. ${ }^{130}$ In 2015 bleek dat slechts besluitvorming afkomstig van de gemeente Haarlemmermeer en de minister van Infrastructuur en Milieu had geleid tot aanvragen om compensatie. Daarom is destijds tot uittreding van enkele overige deelnemers besloten. ${ }^{131}$ De eerste reden voor selectie van de GrS is de hier beschreven samenloop tussen planschadevergoeding en nadeelcompensatie, formeelwettelijke en overige grondslagen voor compensatie, en centraal en decentraal bestuur. Daarnaast blijkt de GrS een waardevolle geschiedenis te hebben en een groot praktisch belang te hebben gediend.

\section{Waardevolle geschiedenis}

De besliscommissie van het Schadeschap werd op 14 januari 1999 ingesteld. Eind mei stuurde de besliscommissie een 'Basisdocument' 132 (hierna: het Basisdocument) aan de deskundigen die deel uitmaakten van de door haar ingestelde adviescommissies. In dit document ging de commissie uitgebreid in op de grondslagen op basis waarvan volgens art. 9 GrS compensatie kan worden toegekend, en de materiële criteria en procedurele voorschriften die daarbij volgens haar in acht moeten worden genomen. ${ }^{133}$ Ook los van het Basisdocument is de besliscommissie blijven denken over het nadeelcompensatierecht. Dat leidde bijvoorbeeld tot een forfaitaire vorm van schadebegroting. ${ }^{134}$ Ook is advies ingewonnen bij Van Ettekoven en Tjepkema omtrent de vraag hoe de doelmatigheid zou kunnen worden verbeterd van de procedure waarlangs de aanvragen om compensatie worden behandeld. Naar aanleiding van dit advies zijn verschillende wijzigingen doorgevoerd in de op grond van de GrS vastgestelde procedureverordening. ${ }^{135}$ Ook overigens is de GrS belangrijk geweest voor de ontwikkeling van het nadeelcompensatierecht. Zo gaf een op 9 april 2008 onder de GrS gewezen Afdelingsuitspraak een nieuwe impuls aan de discussie over de vergelijksmaatstaf die in het nadeelcompensatierecht moet worden aangelegd ter vaststelling van causaal verband en schade. ${ }^{136}$ Ik verwacht dat dit soort inzichten een waardevolle bijdrage aan dit proefschrift zullen leveren.

130 Besluit van 14 januari 1999, Stcrt. 2002, nr. 27.

131 Stcrt. 2015, nr. 16721, p. 4.

132 Te raadplegen via http://schadelab.mcnolia.nl/images/pdf/basisdocument.pdf.

133 Zie hierover ook de voortgangsrapportage uit 2000 over de Planologische kernbeslissing Schiphol en Omgeving, die destijds ter inzage is gelegd bij het Centraal Informatiepunt Tweede Kamer (zie Kamerstukken II 2001/02, 23 552, nr. 78). De concept voortgangsrapportage is te raadplegen op www2.vlieghinder.n1/naslagdocs/CDrom_PKB/PKBA_voortgang_2000.pdf (zie p. 50).

134 Zie paragraaf 5.7.1.1 onder het kopje 'De Grs'.

135 Zie paragraaf 10.10.1 onder het kopje 'Inspraak op het (concept)advies', en ook de aanhef van hoofdstuk 10 onder het kopje 'Introductie van enkele tot op heden nog niet besproken regelingen'. 


\section{Praktische belang}

Een laatste reden voor de selectie van de GrS is haar praktische belang, dat blijkt uit het grote aantal aanvragen dat onder deze regeling is ingediend en de totale hoeveelheid compensatie die naar aanleiding hiervan is toegekend. In 2012 waren in totaal 5.100 aanvragen om nadeelcompensatie ingediend. Aan de 2.800 aanvragen die destijds waren afgehandeld, werd 59 miljoen euro besteed. Slechts ongeveer de helft daarvan bestond uit daadwerkelijk uitgekeerde compensatie. Het overige gedeelte bestond uit organisatorische kosten en dan met name kosten van schadeadviescommissies. ${ }^{137}$ In 2015 was het 'overgrote deel' van alle aanvragen om compensatie afgehandeld. ${ }^{138}$ Eind 2017 bedroegen de totale kosten van het Schadeschap ongeveer 108 miljoen euro. ${ }^{139}$ Met ingang van 1 juli 2018 werd ondermandaat verleend aan het Directoraat-Generaal Rijkswaterstaat om toekomstige aanvragen in behandeling te nemen. ${ }^{140}$ Op 1 juni 2019 is officieel besloten dat het Schadeschap wordt opgeheven, hetgeen geschiedt door intrekking van de GrS per 1 juni 2020. ${ }^{141}$

\subsubsection{Conclusie}

Hiervoor heb ik toegelicht waarom beantwoording van de tweede deelvraag zal plaatsvinden door bestudering van afd. 6.1 Wro, de BnIW 2019, de AVN, de VNNZ en de GrS. Redenen voor selectie van deze regelingen zijn gelegen in hun geschiedenis die waardevolle inzichten kan opleveren voor dit proefschrift, praktische belang, en bijzondere verhouding ten opzichte van overige (al dan niet toekomstige) nadeelcompensatieregelingen. ${ }^{142}$ Los daarvan, kan deze selectie worden verdedigd doordat zij resulteert in een mooie dwarsdoorsnede van het hedendaagse nadeelcompensatierecht. Ten eerste zorgt deze selectie namelijk voor een spreiding tussen formele wetgeving (afd. 6.1 Wro en via de band van de GrS ook art. 8.31 Wlv) en regelingen van lagere rangorde (BnIW 2019, AVN, VNNZ, en de overige achterliggende grondslagen om onder de GrS nadeelcompensatie toe te kennen). Ten tweede zorgt deze selectie voor een spreiding tussen het centrale (BnIW 2019) en decentrale overheidsniveau (AVN en VNNZ). Afd. 6.1 Wro kan zowel op centraal als decentraal overheidsniveau worden toegepast (vergelijk art. 6.6 Wro) en de GrS is opgesteld om samenwerking te faciliteren tussen het centrale en decentrale overheidsniveau.

137 Van den Berg 2012.

138 Stcrt. 2015, nr. 16721, p. 4.

139 ABRvS 6 december 2017, ECLI:NL:RVS:2017:3304, r.o. 1 en 4 (BARIN).

140 Stcrt. 2018, nr. 31798, p. 3.

141 Stcrt. 2019, nr. 35320.

142 Ik sluit niet uit dat er ook andere regelingen zijn die goed hadden gescoord op (sommige van) deze punten. Om de genoemde redenen, is de gemaakte selectie mijns inziens echter in ieder geval representatief voor het hedendaagse nadeelcompensatierecht. 
Ten slotte resulteert de gemaakte selectie in een tweedeling tussen algemene compensatieregelingen (AVN) en regelingen gericht op één specifieke bron van schade (GrS en VNNZ). Afdeling 6.1 Wro zou als een tussenvorm daarvan kunnen worden gezien. Zij fungeert namelijk als algemene regeling voor schade veroorzaakt door een breed scala aan omgevingsrechtelijk georiënteerde schadeoorzaken. Ook de BnIW 2019 laat zich wat dit betreft lastig classificeren. In beginsel heeft deze beleidsregel namelijk een algemeen karakter omdat hij van toepassing is op al het rechtmatig, publiekrechtelijk schadeveroorzakend handelen van de minister van Infrastructuur \& Waterstaat, maar in de praktijk wordt hij hoofdzakelijk toegepast bij schade door infrastructurele werkzaamheden onder verantwoordelijkheid van deze minister. Een combinatie van de hier weergegeven argumenten en inzichten opgedaan tijdens gesprekken met wetgevingsjuristen werkzaam op ministeries en praktijkjuristen, hebben de indruk doen ontstaan dat de in het kader van dit onderzoek gemaakte selectie van regelingen voldoende representatief is om handreikingen en aanbevelingen te kunnen doen ten aanzien van de afstemming van het algemene nadeelcompensatierecht van titel 4.5 Awb tot het overige nadeelcompensatierecht - oftewel de hoofdvraag te kunnen beantwoorden.

\section{4}

\section{HeT TOEKOMSTIGE NADEELCOMPENSATIERECHT}

In deze paragraaf zal ik ingaan op de twee nadeelcompensatieregelingen die het toekomstige nadeelcompensatierecht zullen vertegenwoordigen in dit proefschrift, titel 4.5 Awb en afd. 15.1 Ow. In paragraaf 2.4.1 zal ik kort stilstaan bij de vraag waarom juist deze regelingen zijn geselecteerd. Vervolgens zal ik in paragraaf 2.4.2 de eerste deelvraag beantwoorden door in kaart te brengen welke doelstellingen en uitgangspunten aan de Wns ten grondslag liggen. Zij zullen het toetsingskader vormen van dit proefschrift. Daarna zal ik in paragraaf 2.4.3 ingaan op de totstandkoming van de IOw. Daarbij zal ik ook enige aandacht schenken aan de juridische wereld waarbinnen afd. $15.1 \mathrm{Ow}$ dient te functioneren. Dat is nodig om de hoofdvraag te kunnen beantwoorden. Onderdeel van die vraag is immers of de aan de Wns ten grondslag liggende doelstellingen en uitgangspunten aanleiding geven tot aanpassing van afd. $15.1 \mathrm{Ow}$.

\subsubsection{Selectie van regelingen}

In hoofdstuk 1 bleek dat ik me voor wat betreft de bestudering van het toekomstige nadeelcompensatierecht zal beperken tot titel 4.5 Awb en afd. 15.1 Ow. Daarvoor is gekozen omdat deze regelingen naar toekomstig recht de belangrijkste regelingen omtrent toekenning van nadeelcompensatie zullen vormen. De spanning tussen beide regelingen en de verhouding van deze regelingen tot het thans bestaande nadeelcompensatierecht vormen bovendien de aanleiding voor dit proefschrift en de onderzoeksvragen die ik in paragraaf 1.2 heb gesteld. Gedurende het schrijven van dit proefschrift werd duidelijk dat naast titel 4.5 Awb en afd. $15.1 \mathrm{Ow}$ ook nog enkele andere formeelwettelijke nadeelcompensatieregelingen zullen blijven bestaan, al dan niet tijdelijk. Uit art. II van de consultatieversie van het voorstel 
voor de 'Wet wijziging van de Algemene wet bestuursrecht en enkele andere wetten in verband met het nieuwe omgevingsrecht en het nieuwe nadeelcompensatierecht' (hierna: Wet wijziging Awb) blijkt bijvoorbeeld dat een aangepaste versie van art. 49e Kernenergiewet als aanvulling op titel 4.5 Awb zal functioneren. Deze bepaling kent echter een beperkte reikwijdte en zal titel 4.5 Awb ook inhoudelijk slechts beperkt aanvullen. Bovendien is het gedeeltelijke behoud van deze bepaling slechts beperkt toegelicht. ${ }^{143} \mathrm{Zij}$ is daarom niet geselecteerd voor dit onderzoek. Verder blijkt uit art. 2.44, onderdeel $\mathrm{N}$ van het voorstel voor de IOw dat een aangepaste versie van art. 8.31 Wlv eveneens als aanvulling op titel 4.5 Awb zal functioneren. Hoewel het vanwege de uitbreiding van de vliegvelden van Lelystad en Eindhoven ${ }^{144}$ aannemelijk lijkt dat deze bepaling vaker zal worden toegepast, is ook zij niet geselecteerd voor dit onderzoek. Zij komt namelijk grotendeels overeen met bepalingen uit afd. $15.1 \mathrm{Ow}$ en is bovendien slechts summier toegelicht. ${ }^{145}$ Bestudering zou daarom niet van (grote) meerwaarde zijn voor dit onderzoek.

\subsubsection{Doelstellingen en uitgangspunten die aan de Wns ten grondslag liggen}

In paragraaf 1.2 is toegelicht dat de aan de Wns ten grondslag liggende doelstellingen en uitgangspunten het toetsingskader van dit proefschrift vormen. Teneinde dat toetsingskader te kunnen vaststellen, is de eerste deelvraag geformuleerd: Welke doelstellingen en uitgangspunten liggen ten grondslag aan de Wns? Deze deelvraag zal hier worden beantwoord door aan de hand van Kamerstukken te onderzoeken welke verschillende doelstellingen (paragraaf 2.4.2.1), en uitgangspunten (paragraaf 2.4.2.2) aan de Wns ten grondslag liggen. Doelstellingen hebben betrekking op hetgeen de wetgever beoogde te bereiken door de toevoeging van een algemene regeling omtrent nadeelcompensatie aan de Awb. Onder uitgangspunten versta ik de eisen waaraan die algemene regeling zelf (zoveel mogelijk) moet voldoen.

\subsubsection{De aan de Wns ten grondslag liggende doelstellingen}

\section{Vereenvoudiging, uniformering en harmonisering van het nadeelcompensatie- recht}

De materiële en procedurele onoverzichtelijkheid van het in paragraaf 2.2 beschreven nadeelcompensatiedoolhof was een "belangrijke aanleiding" voor de vast-

143 Zie de toelichting op p. 16 van de memorie van toelichting behorende bij de consultatieversie van het voorstel voor de Wet wijziging Awb. Het voorstel en de memorie van toelichting zijn te raadplegen op www.internetconsultatie.nl/awbomgevingswet.

144 Zie daarover bijvoorbeeld www.rijksoverheid.nl/onderwerpen/luchtvaart/ontwikkeling-lelystad-airport.

145 Kamerstukken II 2018/19, 34 986, nr. 3, p. 389-391 (MvT, IOw). 
stelling van titel 4.5 Awb. ${ }^{146}$ Het huidige nadeelcompensatierecht (en de daarop gebaseerde praktijk) wordt door de wetgever aangemerkt als "onvoldoende overzichtelijk [en daardoor] moeilijk kenbaar", "nodeloos ingewikkeld", een "voor alle betrokkenen (...) onoverzichtelijk geheel van nadeelcompensatieregelingen, procedures en rechtsbescherming", en als een "betrekkelijk onoverzichtelijke situatie". De wetgever acht die onoverzichtelijkheid niet alleen "lastig" voor burgers die schade ondervinden door rechtmatig overheidsoptreden, maar ook voor het bestuur dat aanvragen om nadeelcompensatie dient te behandelen en rechters die deze behandeling dienen te toetsen. Met de "algemene, uniforme regeling" van titel 4.5 Awb beoogt de wetgever een einde aan de thans bestaande onoverzichtelijkheid te maken door het nadeelcompensatierecht te vereenvoudigen, uniformeren en harmoniseren. In paragraaf 1.1 refereerde ik in dat verband al aan de tijdens de totstandkoming van de Wns door de wetgever uitgesproken wens om titel $4.5 \mathrm{Awb}$ in de plaats te laten treden van een groot deel van de thans bestaande nadeelcompensatieregelingen. Titel 4.5 Awb zorgt er daardoor voor dat "het nadeelcompensatierecht zoveel mogelijk wordt geharmoniseerd en gestroomlijnd." Dat leidt niet alleen tot een vergroting van de rechtszekerheid binnen het nadeelcompensatierecht, maar ook tot een vergroting van de doelmatigheid en toegankelijkheid van dat nadeelcompensatierecht. ${ }^{147}$

Met name ten aanzien van formeelwettelijke nadeelcompensatieregelingen betrachtte de wetgever destijds al enige voorzichtigheid: het zou "waarschijnlijk mogelijk zijn deze bepalingen te vereenvoudigen of te laten vervallen." Het uitgangspunt blijft echter dat bepalingen in bijzondere wetten waarin titel $4.5 \mathrm{Awb}$ voorziet, kunnen vervallen. Voor bepalingen die het recht op nadeelcompensatie nader invullen of normeren moet worden bezien of zij kunnen blijven bestaan "al dan niet in de vorm van wettelijke voorschriften of beleidsregels." "148 Uit paragraaf 2.4.1 kan worden afgeleid dat het kabinet in zijn voorstellen voor de Wet wijziging Awb en de IOw tot de conclusie is gekomen dat enkele bijzondere formeelwettelijke regelingen dienen te blijven bestaan als aanvulling, en deels ook als uitzondering, op titel 4.5 Awb. Dat neemt niet weg dat het ernaar uitziet dat een groot deel van de thans bestaande (formeelwettelijke) nadeelcompensatieregelingen daadwerkelijk zal komen te vervallen. ${ }^{149}$ Materieelrechtelijk zorgt dit voor een vereenvoudiging van het nadeelcompensatierecht doordat art. 4:126 lid 1 Awb in beginsel steeds als grondslag voor nadeelcompensatie zal dienen als de schadeoorzaak kwalificeert als een rechtmatige uitoefening van een publiekrechtelijke

146 Zie Kamerstukken II 2010/11, 32 621, nr. 4, p. 2 (RvS, Wns); en Kamerstukken II 2010/11, 32 621, nr. 3, p. 8-9 en 11 (MvT, Wns).

147 Zie Kamerstukken II 2010/11, 32 621, nr. 3, p. 2, 4-5, 8, 11 (MvT, Wns); Kamerstukken II 2010/11, 32 621, nr. 4, p. 2 (RvS, Wns); Kamerstukken II 2010/11, 32 621, nr. 6, p. 2, 8, 12 (NV II, Wns); Kamerstukken I 2012/13, 32 621, nr. C, p. 9 (MvA I, Wns); en Handelingen I 2012/13, 32 621, nr. 15, item 6, p. 53.

148 Zie Kamerstukken II 2010/11, 32 621, nr. 3, p. 7, 17-18 (MvT, Wns); en Kamerstukken II 2010/11, 32 621, nr. 6, p. 15-16 (NV II, Wns). Zie daarover ook paragraaf 2.4.3. 
bevoegdheid of taak door een bestuursorgaan. Op de precieze reikwijdte van titel 4.5 Awb zal ik ingaan in paragraaf 3.3.1. Hier kan echter al worden gesteld dat de ruime reikwijdte van titel 4.5 Awb ertoe zal leiden dat discussie over de beantwoording van de vraag of de grondslag voor nadeelcompensatie in een individueel schadegeval moet worden gevonden in het égalitébeginsel, of een of meerdere (formeel)wettelijke nadeelcompensatieregelingen of nadeelcompensatiebeleidsregels, of een combinatie daarvan (grotendeels) tot het verleden zal behoren. De materieelrechtelijke vereenvoudiging bestaat er bovendien uit dat de belangrijkste criteria voor de toekenning van nadeelcompensatie uniform zullen gelden in het nadeelcompensatierecht door hun codificatie in art. 4:126 en art. 4:129 Awb

Op procedureel vlak vindt vereenvoudiging plaats doordat de hoofdlijnen van de procedure ter verkrijging van nadeelcompensatie zijn vastgelegd in art. 4:127, art. 4:128, art. 4:130 en art. 4:131 Awb. Verder is van belang dat de rol van de connexiteitseisen zal veranderen. De eis van materiële connexiteit zal geen rol meer spelen. Art. 4:126 Awb dient namelijk niet alleen als geschreven, publiekrechtelijke grondslag voor besluiten omtrent de toekenning van nadeelcompensatie bij schade die beweerdelijk wordt veroorzaakt door een bestuursorgaan in de rechtmatige uitoefening van zijn publiekrechtelijk bevoegdheid, maar ook bij schade die beweerdelijk wordt veroorzaakt door een bestuursorgaan in de rechtmatige uitoefening van zijn publiekrechtelijke taak. De eis van processuele connexiteit was in het oorspronkelijke regeringsvoorstel voor de Wns neergelegd in art. 8.2a Awb als toegangspoort ${ }^{150}$ tot de bestuursrechter. Daarop bestond echter veel kritiek ${ }^{151}$ en uiteindelijk heeft het amendement Taverne deze bepaling geschrapt, omdat zij in de ogen van de Tweede Kamer bijdroeg "aan onnodige juridisering, rechtsongelijkheid, gebrek aan rechtseenheid en de toegang tot de rechter [belemmerde]." De Kamer was van mening dat de onduidelijkheid omtrent de te volgen rechtsgang moest worden weggenomen door de creatie van een "laagdrempelige bestuursrechtelijke rechtsgang". ${ }^{152}$ Toch zal de processuele connexiteit niet helemaal naar de geschiedenisboeken worden verwezen. Indien een bijzondere bestuursrechter of rechtbank bevoegd is te oordelen over de schadeoorzaak, zal een beroep tegen een op grond van art. 4:126 Awb genomen besluit namelijk moeten worden ingediend bij diezelfde bijzondere bestuursrechter of rechtbank. ${ }^{153}$

150 Dit is een veelgebruikte beeldspraak. Zie bijvoorbeeld Barkhuysen \& Den Ouden 2017, p. 1002.

151 Zie Van Ettekoven, Van Ravels \& Tjepkema 2011, p. 58; Kamerstukken II 2010/11, 32 621, nr. 4, p. 2-3 (RvS, Wns); en Kamerstukken II 2011/12, 32 621, nr. 11 (Amendement Taverne c.s.).

152 Zie Kamerstukken II 2011/12, 32 621, nr. 11 (Amendement Taverne c.s.); en $\mathrm{Ka}$ merstukken II 2010/11, 32 621, nr. 3, p. 5-6, (MvT, Wns).

153 Zie paragraaf 10.12 .2$. 


\section{Vergroting van de rechtszekerheid en rechtsgelijkheid}

Hiervoor bleek al dat de wetgever de rechtszekerheid van gelaedeerden probeert te vergroten door in titel 4.5 Awb een algemene grondslag voor toekenning van nadeelcompensatie en een regeling omtrent de belangrijkste daarmee samenhangende materiële en procedurele aspecten op te nemen. ${ }^{154}$ Ook heeft de verantwoordelijk minister op aandringen van verschillende Eerste Kamerfracties benadrukt dat het "vanuit het oogpunt van rechtszekerheid en rechtsgelijkheid belangrijk is" dat de uitkomst van een aanvraag om nadeelcompensatie "redelijk en voorspelbaar" is. ${ }^{155}$ Uit de Kamerstukken blijkt dat niet slechts wordt beoogd de rechtszekerheid van burgers, maar ook de rechtszekerheid van het bestuur te vergroten. Zo wordt het opnemen van de verjaringsregeling van art. 4:131 BW gepresenteerd als nuttig vanuit een oogpunt van rechtszekerheid, omdat daarmee wordt voorkomen dat het bestuur nog geruime tijd na het nemen van een schadeveroorzakend besluit tot de verstrekking van nadeelcompensatie kan worden verplicht. ${ }^{156}$

De vergroting van de rechtszekerheid en rechtsgelijkheid zal volgens de wetgever niet alleen plaatsvinden door titel 4.5 Awb zelf, maar ook door de nadere invulling van de criteria uit titel $4.5 \mathrm{Awb}$ in andere wetten in formele zin, overige regelgeving en/of beleidsregels. Zo zou het bijvoorbeeld door de grote reikwijdte van titel 4.5 Awb niet goed mogelijk zijn het normaal maatschappelijke risico te vatten in een algemeen te hanteren drempel. ${ }^{157}$ Daarom moet in aanpassingswetgeving worden bezien in hoeverre behoefte bestaat om dergelijke concretisering in formele wetgeving te laten plaatsvinden voor "gevallen waarin veelvuldig dezelfde situaties om een beslissing over nadeelcompensaties vragen." De wetgever benadrukt echter ook het belang van wetsinterpreterende (beleids)regels voor grote aantallen op elkaar gelijkende gevallen. ${ }^{158}$

\section{Codificatie van het nadeelcompensatierecht}

De codificatie van het nadeelcompensatierecht wordt wenselijk geacht vanwege "het steeds toenemende maatschappelijke belang en de vele ontwikkelingen op dit terrein in de jurisprudentie". ${ }^{159}$ Uit de toelichtende stukken behorende bij de Wns wordt niet duidelijk of de codificatie van jurisprudentie als een zelfstandig doelstelling van de wetgever moet worden gezien, of als een middel om overige doelstellingen te bereiken, zoals de vereenvoudiging, uniformering en harmonise-

154 Kamerstukken II 2010/11, 32 621, nr. 3, p. 8 (MvT, Wns).

155 Handelingen I 2012/13, 32 621, nr. 15, item 6, p. 53. Zie ook de vragen van Kamerleden Lokin-Sassen en Broekers-Knol in Handelingen I 2012/13, 32 621, nr. 15, item 2.

156 Kamerstukken II 2010/11, 32 621, nr. 3, p. 21 (MvT, Wns).

157 Kamerstukken I 2012/13, 32 621, nr. C, p. 8 (MvA I, Wns).

158 Zie Kamerstukken II 2010/11, 32 621, nr. 3, p. 17-18 (MvT, Wns); en Kamerstukken II 2010/11, 32 621, nr. 6, p. 10-11 (NV II, Wns). 
ring van het nadeelcompensatierecht, en het vergroten van de rechtszekerheid en rechtsgelijkheid. In deze dissertatie wordt ervan uitgegaan dat de codificatie van het recht op nadeelcompensatie ook een zelfstandig doelstelling betreft. Daarbij is van belang dat het wetsvoorstel mede is ontstaan naar aanleiding van de meermaals uitgesproken wens tot "codificatie van het bestuursrechtelijk schadevergoedingsrecht". Bovendien beoogt de wetgever te voorzien in een regeling van de belangrijkste met het égalitébeginsel "samenhangende materiële en procedurele aspecten". In de Kamerstukken wordt verder bijvoorbeeld benadrukt dat "de materiële vereisten om in aanmerking te komen voor nadeelcompensatie, door het wetsvoorstel niet gewijzigd worden" en wordt regelmatig opgemerkt dat aansluiting wordt gezocht bij de praktijk en rechtspraak. ${ }^{160}$

\section{Vergroting van de doelmatigheid van het nadeelcompensatierecht en verminde- ring van bestuurslasten}

Tijdens de totstandkoming van de Wns heeft de toenmalig minister van Veiligheid en Justitie benadrukt dat de transactiekosten voor de toekenning van nadeelcompensatie zo laag mogelijk moeten zijn. ${ }^{161}$ De codificatie van de belangrijkste (inhoudelijke) regels zou tot uniformering en vereenvoudiging van werkprocessen en procedures leiden en zo een lastenvermindering meebrengen. Deze vereenvoudiging zou bovendien de doelmatigheid van de afwikkeling van aanvragen om nadeelcompensatie vergroten, hetgeen van groot belang wordt geacht voor de bestuurlijke praktijk. ${ }^{162}$ Ook de vergroting van de doelmatigheid van het nadeelcompensatierecht en het verminderen van bestuurslasten is daarom een aan de Wns ten grondslag liggende doelstelling.

\subsubsection{Uitganspunten van de Wns}

\section{Uitsluitend codificeren van het égalitébeginsel}

Uit de bij de Wns behorende Kamerstukken blijkt dat slechts is beoogd het op het égalitébeginsel voortvloeiende recht op nadeelcompensatie in titel $4.5 \mathrm{Awb}$ vast te leggen. Expliciet wordt opgemerkt dat deze titel niet van toepassing zal zijn op "onverplichte tegemoetkomingen en overcompensatie." Ook wordt opgemerkt dat compensatie die wordt verstrekt vanuit het oogpunt van solidariteit buiten de werkingssfeer van deze titel valt. ${ }^{163}$ Voorts wordt geen koppeling met art. 3:4 lid 2 Awb (en de constructie van het onzuiver schadebesluit) beoogd. ${ }^{164}$

160 Zie Kamerstukken II 2010/11, 32 621, nr. 6, p. 4 (NV II, Wns); en Kamerstukken II 2010/11, 32 621, nr. 3, p. 3, 8, 11-12, 16, 28, 51-52 (MvT, Wns).

161 Handelingen I 2012/13, 32 621, nr. 15, item 6, p. 53.

162 Kamerstukken II 2010/11, 32 621, nr. 3, p. 6 en 8 (MvT, Wns).

163 Zie Kamerstukken II 2010/11, 32 621, nr. 3, p. 8, 12-14, 16, 23 (MvT, Wns); en Handelingen I 2012/13, 32 621, nr. 15, item 6, p. 53. 


\section{Aansluiting bij het besluitmodel}

Ten tijde van de totstandkoming van de Wns gaf de AARvS in overweging om de verkrijging van nadeelcompensatie te laten verlopen via een verzoekschriftprocedure (vergelijk titel $8.4 \mathrm{Awb}$ ). ${ }^{165}$ De wetgever heeft er echter bewust voor gekozen om aansluiting te zoeken bij het besluitmodel van de Awb, omdat dit "goed werkt" bij aanvragen om nadeelcompensatie. ${ }^{166}$ Het wordt wenselijk geacht dat het bestuursorgaan eerst zelf beoordeelt of het aansprakelijk is op grond van titel 4.5 Awb. Het bestuursorgaan zou namelijk in een betere positie verkeren om die inschatting te maken, de feitelijke situatie en de posities van andere mogelijke benadeelden in onderlinge samenhang te bezien, én na te gaan of er reden is om de schade anders dan in geld te compenseren. Daarbij heeft het eveneens de mogelijkheid om deskundigen of een schadecommissie in te schakelen. Het werd onwenselijk geacht dat de rechter zich "rauwelijks" zou kunnen uitspreken over nadeelcompensatieclaims. ${ }^{167}$ Met de keuze voor het besluitmodel beoogt de wetgever voorts de besluitvorming over op zichzelf wenselijk geachte ontwikkelingen niet op te houden, én de betekenis van het onzuiver schadebesluit en de civiele rechter als restrechter verder te laten afnemen. ${ }^{168}$ Hierdoor zal de behandeling van aanvragen om nadeelcompensatie immers in een "afzonderlijk besluitvormingsproces" plaatsvinden, al dan niet gevolgd door een "afzonderlijke, uniforme bestuursrechtelijke rechtsgang". Dit komt de efficiëntie van het nadeelcompensatierecht en de voortgang van onder andere infrastructurele projecten ten goede. ${ }^{169}$

\section{Aansluiting bij de Awb en het BW}

In de bij de Wns behorende memorie van toelichting wordt vermeld dat de Wns een belangrijke bijdrage zal leveren aan het bereiken van de doelstellingen die aan de Awb ten grondslag liggen. Titel 4.5 Awb bevordert namelijk de eenheid van bestuursrechtelijke wetgeving, draagt bij aan de systematisering en vereenvoudiging van deze wetgeving, en codificeert ontwikkelingen in de bestuursrechtelijke jurisprudentie. ${ }^{170}$ Het past niet binnen het streven naar eenheid en systematiek binnen het recht dat onnodige verschillen tussen het civiele recht en het bestuursrecht ontstaan of blijven bestaan. Dergelijke onnodige verschillen maken het recht immers "ingewikkelder en minder geloofwaardig". Bij de totstandkoming van titel 4.5 Awb is daarom bezien in hoeverre bepalingen uit het BW - en dan met name afd. 6.1.10 BW - bruikbaar zijn binnen het bestuursrechtelijke nadeelcompensatierecht. Afd. 6.1.10 BW leende zich naar het oordeel van de wetgever niet voor

165 Kamerstukken II 2010/11, 32 621, nr. 4, p. 4 (RvS, Wns).

166 Kamerstukken II 2010/11, 32 621, nr. 3, p. 4 (MvT, Wns).

167 Zie Kamerstukken II 2010/11, 32 621, nr. 4, p. 4-5 (RvS, Wns); Kamerstukken I 2012/13, 32 621, nr. C, p. 4 (MvA I, Wns); Kamerstukken II 2010/11, 32 621, nr. 6, p. 13 (NV II, Wns); en Handelingen I 2012/13, 32 621, nr. 15, item 6, p. 54.

168 Kamerstukken II 2010/11, 32 621, nr. 3, p. 11-12 (MvT, Wns).

169 Kamerstukken II 2010/11, 32 621, nr. 6, p. 6 (NV II, Wns).

170 Kamerstukken II 2010/11, 32 621, nr. 3, p. 11-12 (MvT, Wns). 
overeenkomstige toepassing, maar titel 4.5 Awb bevat wel enkele bepalingen die op deze afdeling zijn geïnspireerd. ${ }^{171}$ Zo is met art. 4:129, aanhef en onder a Awb aansluiting gezocht bij art. 6:96 lid 2 onder a BW. ${ }^{172}$ Ook sluit de verjaringsregeling van art. 4:131 Awb zoveel mogelijk aan op de verjaringsregeling van art. 3:310 e.v. BW. ${ }^{173}$

\subsubsection{Een eerste, algemene reflectie op de doelstellingen en uitgangspunten}

Met de beantwoording van de hoofdvraag wordt niet beoogd een waardeoordeel te geven omtrent de vraag of de wetgever erin is geslaagd zijn eigen doelstellingen en uitgangspunten te bereiken. Een dergelijk oordeel zou tot op zekere hoogte ook subjectief van aard zijn. Uit de opmerking dat met titel 4.5 wordt voorzien in een algemene grondslag voor toekenning van nadeelcompensatie en de belangrijkste daarmee samenhangende materiële en procedurele aspecten, kan immers worden afgeleid dat de wetgever de rechtszekerheid heeft willen vergroten, maar niet welke maatregelen hij bereid zou zijn geweest daartoe te treffen als hij volledig inzicht zou hebben gehad in de verhouding van titel 4.5 Awb tot het huidige nadeelcompensatierecht en afd. 15.1 Ow. Met beantwoording van de onderzoeksvragen wordt wel beoogd meer inzicht in die verhoudingen te verschaffen, en op basis daarvan na te gaan hoe het toekomstige nadeelcompensatierecht zo kan worden vormgegeven dat de door de wetgever nagestreefde waarden zo optimaal mogelijk worden behartigd.

Een eerste, globale bestudering van titel 4.5 Awb leert dat deze titel op materieel vlak hoofdzakelijk de criteria voor toekenning van nadeelcompensatie opsomt, zonder die criteria ook inhoudelijk te normeren. Ook op procedureel vlak valt op dat in vergelijking met andere nadeelcompensatieregelingen relatief weinig wordt geregeld over bepaalde onderwerpen, zoals de behandeling van de aanvraag om nadeelcompensatie in algemene zin. Op voorhand lijkt het daarom aannemelijk dat de doelstellingen van vergroting van de rechtszekerheid en codificatie van het nadeelcompensatierecht regelmatig voor vaststelling van regelgeving zullen pleiten. Aanvullend zal de doelstelling van vereenvoudiging, uniformering en harmonisering van het nadeelcompensatierecht er dan in beginsel voor pleiten dat deze regelgeving wordt opgenomen in titel 4.5 Awb. Dat vermindert immers de noodzaak voor lagere regelgevers om titel $4.5 \mathrm{Awb}$-interpreterende regelgeving vast te stellen, en de noodzaak om titel $4.5 \mathrm{Awb}$ aan te vullen in bijzondere formele wetgeving.

De hier beschreven, potentiële tendens tot vaststelling van (formele) wetgeving zou kunnen botsen met de hedendaagse trend van deregulering, decentralisatie en

171 Zie Kamerstukken II 2010/11, 32 621, nr. 3, p. 19-20 (MvT, Wns); en Kamerstukken I 2012/13, 32 621, nr. C, p. 5-6 (MvA I, Wns).

172 Kamerstukken II 2010/11, 32 621, nr. 3, p. 20, 27-28 (MvT, Wns).

173 Kamerstukken II 2010/11, 32 621, nr. 3, p. 21, 29 (MvT, Wns). 
participatie. ${ }^{174}$ Hoewel deze trend van invloed is geweest op het wetgevingsproces inzake de Omgevingswet, ${ }^{175}$ heeft deze invloed zich niet uitgestrekt tot afd. 15.1 Ow. Dat is ook niet verwonderlijk, omdat deze afdeling functioneert als een aanvulling op titel 4.5 Awb. Daardoor zijn in deze afdeling slechts bepalingen opgenomen ten aanzien van onderwerpen waarvan de wetgever dacht dat titel 4.5 Awb ontoereikend zou zijn voor het goed functioneren van het in de Ow vervatte omgevingsrecht. De dereguleringsgedachte is slechts expliciet te herkennen in de bij de Wns behorende Kamerstukken in zoverre zij is te herleiden tot de doelstelling van vereenvoudiging, uniformering en harmonisering van het nadeelcompensatierecht: titel 4.5 Awb moet in beginsel zoveel mogelijk in de plaats treden van de thans bestaande, al dan niet formeelwettelijke nadeelcompensatieregelgeving.

Hoewel ik het belang van een gebalanceerde regeldruk onderschrijf, zal ik mij bij beantwoording van de hoofdvraag slechts laten leiden door de doelstellingen en uitgangspunten die ten grondslag liggen aan de Wns. Dat zijn immers de waarden die de wetgever centraal heeft gesteld tijdens de totstandkoming van titel $4.5 \mathrm{Awb}$, de hoofdbron van het toekomstige nadeelcompensatierecht. Dit heeft tot gevolg dat de dereguleringsgedachte slechts een rol in dit onderzoek kan spelen in zoverre zij voortvloeit uit deze doelstellingen en uitgangspunten. De hiervoor al aangehaalde doelstelling van vereenvoudiging, uniformering en harmonisering van het nadeelcompensatierecht biedt geen houvast ten aanzien van de vraag welke regels al dan niet in titel 4.5 Awb moeten worden opgenomen. ${ }^{176}$ Via de band van het uitgangspunt van aansluiting bij de Awb zou deze houvast in theorie wel kunnen worden gevonden in de aan de Awb ten grondslag liggende doelstelling dat in de Awb voorzieningen worden getroffen "ten aanzien van onderwerpen die zich naar hun aard niet voor regeling in een bijzondere wet lenen." 177 Praktisch gezien, blijkt dit echter niet het geval te zijn omdat de wetgever zelf is ingegaan tegen deze Awbdoelstelling. Het nadeelcompensatierecht kan namelijk net als het subsidierecht "als een bijzonder deelterrein van het bestuursrecht (...) worden beschouwd." 178 Gelet daarop hadden beide onderwerpen ook kunnen worden geregeld in een afzonderlijke 'Wet nadeelcompensatie' respectievelijk 'Wet op het subsidierecht' hetgeen niet wegneemt dat die wetten algemeen van karakter hadden kunnen zijn.

Wel zullen de (overige) aan de Wns ten grondslag liggende doelstellingen en uitgangspunten tot op zekere hoogte een zelfcorrigerend effect hebben op een eventuele tendens tot vaststelling van (formele) wetgeving. De doelstelling tot codificatie

174 Een tamelijk recent voorbeeld in het sociaal domein betreft de vaststelling van de Wet maatschappelijke ondersteuning, de Participatiewet en de Jeugdwet. Een belangrijk gevolg van deze wetten is de overheveling van taken van het Rijk naar gemeenten.

175 Zie bijvoorbeeld het adviesrapport 'Sneller \& Beter' van de commissie Elverding, te vinden op www.rijksoverheid.nl/zoeken.

176 Ook de Aanwijzingen voor de regelgeving bieden daaromtrent geen uitkomst.

177 Kamerstukken II 1988/89, 21 221, nr. 3, p. 4 en 10 (MvT, Awb).

178 Van den Brink \& Den Ouden 2019, p. 213-214. 
van het nadeelcompensatierecht kan immers slechts voor vaststelling van regelgeving pleiten als er iets te codificeren valt. Daarvan zal bijvoorbeeld geen sprake zijn als de desbetreffende jurisprudentielijnen nog weinig uitgekristalliseerd zijn. Ook is denkbaar dat het uitgangspunt tot aansluiting bij het BW er bijvoorbeeld voor zal pleiten om niet al te gedetailleerde regels omtrent schadebegroting vast te leggen in regelgeving. In art. 6:97 BW is immers op grond van goede argumenten de keuze gemaakt om slechts voor te schrijven dat de schade wordt begroot op de wijze die het meest met de aard ervan in overeenstemming is, en zo nodig wordt geschat. ${ }^{179}$ Voorts is goed denkbaar dat bijvoorbeeld een forfaitaire wijze van schadebegroting zich niet leent voor opname in titel $4.5 \mathrm{Awb}$, maar wel voor opname in een lokale verordening of beleidsregel. De invloed van overheidshandelen op de waarde van woningen verschilt immers naar gelang het type overheidshandelen, het type woning, en de omgeving van die woning. ${ }^{180}$

Wanneer de hier beschreven zelfcorrigerende werking zich naar het oordeel van de formele wetgever te weinig zou voordoen, kan dat reden voor hem zijn om, naast de aan de Wns ten grondslag liggende doelstellingen en uitgangspunten, aanvullende waarde te hechten aan de eerder genoemde trend van deregulering, decentralisatie en participatie. Op basis hiervan zou de wetgever ervoor kunnen kiezen bepaalde voorstellen tot regelgeving niet in titel $4.5 \mathrm{Awb}$ of afd. 15.1 Ow op te nemen, maar bijvoorbeeld door de regering te laten verwerken in een amvb. ${ }^{181}$ Wanneer de wetgever ook daar geen heil in zou zien, en dus helemaal niet overgaat tot vaststelling van regelgeving, zal het in de regel goed bij de aan de Wns ten grondslag liggende doelstellingen en uitgangspunten passen als lagere regelgevers, uitvoerende bestuursorganen en rechters nagaan in hoeverre zij alsnog gehoor zouden kunnen geven aan de desbetreffende aanbeveling. In de navolgende hoofdstukken zal ik hier niet stelselmatig op ingaan. ${ }^{182}$ Beantwoording van de hoofdvraag heeft immers tot doel om aan te geven hoe de aan de Wns ten grondslag liggende doelstellingen en uitgangspunten het best kunnen worden bereikt. Wel zal ik hierop terugkomen in het slothoofdstuk van dit proefschrift. Voorts merk ik hier al op dat de desbetreffende actoren steeds de nog in paragraaf 2.5 te bespreken, staatsrechtelijke grenzen in acht dienen te nemen. Verder volsta ik met het voorbeeld dat de wetgever geen gevolg zou geven aan een aanbeveling om het criterium van de speciale last nader te normeren. In een dergelijk geval zullen de genoemde staatsrechtelijke grenzen er in beginsel niet aan in de weg staan dat de voorgestelde normering wordt voorgeschreven in een wetsinterpreterende gemeentelijke verordening of beleidsregel. Ook zouden uitvoerende bestuursorganen de voorgestelde invulling

179 Zie daarover paragraaf 5.7.3.1.

180 Zie SAOZ en Kraan \& De Jong 2018 voor een inventarisatie van factoren die van invloed zijn op de waarde(daling) van onroerende zaken.

181 Zoals de wetgever het bijvoorbeeld ook meer opportuun achtte om bepaalde procedurele regels omtrent tegemoetkoming in planschade niet op te nemen in afd. 6.1 Wro, maar in afd. 6.1 Bro.

182 Net zo min als ik zal ingaan op de vraag wat de overige actoren kunnen doen als een aan de rechter of het bestuur gerichte aanbeveling niet zou worden opgepakt. 
kunnen overnemen in hun nadeelcompensatiebesluiten, en zou de rechter de voorgestelde invulling als toetsingsmaatstaf kunnen overnemen.

\subsubsection{Tussenconclusie: beantwoording van de eerste deelvraag}

Uit deze paragraaf volgt de volgende beantwoording van de eerste deelvraag. Aan de Wns liggen vier doelstellingen ten grondslag: (1) vereenvoudiging, uniformering en harmonisering van het nadeelcompensatierecht; (2) vergroting van de rechtszekerheid en rechtsgelijkheid; (3) codificatie van het nadeelcompensatierecht; en (4) vergroting van de doelmatigheid van het nadeelcompensatierecht en vermindering van bestuurslasten. Bij beantwoording van de hoofdvraag zal soms slechts aan een deel van een doelstelling worden gerefereerd, bijvoorbeeld door te spreken van 'de doelstelling van vergroting van de rechtszekerheid'. Daardoor is het namelijk duidelijker welke aanbeveling beoogt bij te dragen aan het bereiken van welk deel van een bepaalde doelstelling. Naast deze doelstellingen kent de Wns een drietal uitgangspunten. Titel 4.5 Awb dient (1) uitsluitend het égalitébeginsel te codificeren; (2) aan te sluiten op het besluitmodel; en (3) waar mogelijk aan te sluiten bij de Awb en het BW.

\subsubsection{De Omgevingswet}

Het huidige omgevingsrecht is verspreid over tientallen wetten. ${ }^{183}$ In de memorie van toelichting behorende bij de Ow wordt opgemerkt dat de huidige wettelijke regels zich nog onvoldoende richten op duurzame ontwikkeling. Ze zouden onvoldoende rekening houden met "regionale verschillen, de behoefte aan maatwerk in concrete projecten en het belang van vroegtijdige betrokkenheid van belanghebbenden bij de besluitvorming over projecten." Verder acht de wetgever het huidige omgevingsrecht te versnipperd en onvoldoende inzichtelijk. De balans zou bovendien te veel liggen "bij zekerheid en te weinig bij groei die gericht is op duurzame ontwikkeling." 184 Op 23 maart 2016 is daarom de Omgevingswet aangenomen. ${ }^{185}$ De wetgever beoogt daarmee het omgevingsrecht zoveel mogelijk in één wet te bundelen en streeft de volgende vier verbeterdoelen na:

"1. het vergroten van de inzichtelijkheid, de voorspelbaarheid en het gebruiksgemak van het omgevingsrecht;

2. het bewerkstelligen van een samenhangende benadering van de fysieke leefomgeving in beleid, besluitvorming en regelgeving;

3. het vergroten van de bestuurlijke afwegingsruimte door een actieve en flexibele aanpak mogelijk te maken voor het bereiken van doelen voor de fysieke leefomgeving; en

183 Zonder uitputtend te willen zijn, noem ik de Wro, de Wet natuurbescherming, de Wet milieubeheer, de Onteigeningswet, de Wabo en de Ontgrondingenwet. Zie nader Kamerstukken II 2013/14, 33 962, nr. 3, p. 8 (MvT, Ow).

184 Kamerstukken II 2013/14, 33 962, nr. 3, p. 6 (MvT, Ow).

185 Stb. 2016, 156. 
4. het versnellen en verbeteren van besluitvorming over projecten in de fysieke leefomgeving." 186

Voordat de Ow in werking kan treden moet de wetgever keuzes maken. Zo dient er overgangsrecht te worden vastgesteld, dient de verhouding tot andere wetten te worden geregeld, dient de Ow op bepaalde onderdelen nog te worden gewijzigd, en dienen bepaalde gereserveerde gedeelten van de Ow nog te worden ingevuld. ${ }^{187}$ Voor deze dissertatie is vooral van belang dat hoofdstuk $15 \mathrm{Ow}$ is gereserveerd voor schaderegelingen. ${ }^{188}$ In afd. $15.1 \mathrm{OW}$ zal een regeling worden opgenomen omtrent wat vandaag de dag tegemoetkoming in planschade en nadeelcompensatie wordt genoemd. Zij zal in de plaats treden van een groot aantal thans bestaande formeelwettelijke nadeelcompensatieregelingen, waaronder afd. 6.1 Wro. ${ }^{189}$ Afd. 15.1 Ow zal zo worden vormgegeven dat "de regeling goed aansluit op de verbeterdoelen van de Omgevingswet en uitnodigingsplanologie ${ }^{190}$ faciliteert." ${ }^{\prime 191}$ Nadat de minister van Infrastructuur \& Milieu op 19 mei 2016 zijn plannen voor afd. 15.1 Ow aankondigde, is op 5 januari 2017 een voorstel voor de IOw in consultatie gegaan. ${ }^{192}$ In juni 2017 is een conceptversie van het wetsvoorstel voor advies naar de Raad van State gestuurd. ${ }^{193}$ Vervolgens is eind juni 2018 het 'officiële' wetsvoorstel ingediend bij de Tweede Kamer. ${ }^{194}$ Dat voorstel is op 7 maart 2019 aangenomen door de Tweede Kamer. ${ }^{195}$ Aangezien de tekst van het wetsvoorstel niet door de Eerste Kamer kan worden gewijzigd, ${ }^{196}$ zal ik in dit proefschrift als

Zie Kamerstukken II 2013/14, 33 962, nr. 3, p. 6-7 (MvT, Ow); en Kamerstukken II 2018/19, 34 986, nr. 3, p. 6-7 (MvT, IOw).

187 Kamerstukken II 2018/19, 34 986, nr. 3, p. 3 (MvT, IOw).

188 Kamerstukken II 2013/14, 33 962, nr. 3, p. 28 (MvT, Ow).

189 De volgende formeelwettelijke nadeelcompensatieregelingen zullen eveneens opgaan in afd. $15.1 \mathrm{Ow}$ : art. $26 \mathrm{t} / \mathrm{m} 28$ Ontgrondingenwet, art. 17 Spoedwet wegverbreding, art. 22 Tracéwet, art. 7.14 Waterwet, art. 4.2 Wabo, art. 40 lid 11 Mijnbouwwet, art. $22 \mathrm{t} / \mathrm{m} 29$ jo. 58 Monumentenwet 1988. Dat geldt ook gedeeltelijk voor art. $8.31 \mathrm{Wlv}$ en art. 15.20 jo. $15.21 \mathrm{Wm}$. Zie Kamerstukken II 2018/19, 34 986, nr. 3, p. 35-36 (MvT, IOw).

190 Zie paragraaf 2.3.1 onder het kopje 'Invloed op toekomstige wetgeving' voor een definitie van uitnodigingsplanologie.

191 Kamerstukken II 2015/16, 33 962, nr. 185, p. 2 (Inleidende brief).

192 De consultatieversie van de IOw, de bijbehorende memorie van toelichting en de reacties op de consultatie zijn te raadplegen op www.internetconsultatie.nl/invoering_omgevingswet/. De bepalingen die worden voorgesteld voor afd. $15.1 \mathrm{Ow}$, zijn te vinden in art. $\mathrm{CZ}$ van de consultatieversie.

193 Deze versie en de bijbehorende memorie van toelichting zijn te raadplegen op www.omgevingswetportaal.nl. De bepalingen die worden voorgesteld voor afd. 15.1 Ow, zijn te vinden in art. DS van deze versie.

194 Kamerstukken II 2018/19, 34 986, nr. 2 (Wetsvoorstel IOw).

195 Handelingen II 2018/19, nr. 60, item 7.

196 De Eerste Kamer beschikt niet over het recht van amendement, vergelijk art. 84 GW. Ik zal niet ingaan op de mogelijkheid van een novelleprocedure. Zie daarover in algemene zin Heringa e.a. 2018, p. 164-165. 
art. 15.x Ow refereren aan de bepalingen uit het wetsvoorstel als aangenomen door de Tweede Kamer en gezonden aan de Eerste Kamer. ${ }^{197}$ Op (reacties op) eerdere versies van het wetsvoorstel zal slechts worden ingegaan als dat relevant is voor de beantwoording van de in paragraaf 1.2 gestelde onderzoeksvragen.

Afd. 15.1 Ow neemt titel 4.5 Awb als uitgangspunt. Dat heeft tot gevolg dat art. 4:126 lid 1 Awb de grondslag vormt om onder afd. 15.1 Ow nadeelcompensatie toe te kennen. In beginsel zijn ook de overige materiële criteria en procedurele voorschriften van titel 4.5 Awb van toepassing op een aanvraag om nadeelcompensatie die onder de reikwijdte van afd. $15.1 \mathrm{Ow}$ valt. Omdat het wetsvoorstel voor de Ow is ingediend nadat het parlement het wetsvoorstel voor de Wns heeft aangenomen, kon bij de totstandkoming van titel 4.5 Awb echter geen rekening worden gehouden met de doelstellingen van de Ow. Het kabinet is van mening dat het onder de thans geldende wetgeving bestaande risico dat schadevergoeding moet worden toegekend "een van de belemmeringen voor het maken van globale plannen" vormt. ${ }^{198}$ Met name de planschaderegeling van afd. 6.1 Wro wordt door de minister genoemd als "één van de oorzaken waarom uitnodigingsplanologie en organische gebiedsontwikkeling niet goed van de grond komt." ${ }^{199}$ De onder deze afdeling gehanteerde planvergelijking ${ }^{200}$ zou het risico scheppen dat tegemoetkoming dient te worden betaald voor "mogelijkheden die in werkelijkheid niet worden benut". De minister vreest dat "omgevingsplannen uitnodigingsplanologie en organische groei niet [zullen] faciliteren" als deze vergelijkingsmethode wordt voortgezet onder de Ow. ${ }^{201}$ Daarom wijkt afd. $15.1 \mathrm{Ow}$ op bepaalde punten af van titel $4.5 \mathrm{Awb}$ en vult zij deze titel op bepaalde punten aan. ${ }^{202}$ In de ogen van het kabinet zijn de drie belangrijkste afwijkingen dat:

1. slechts nadeelcompensatie kan worden toegekend wegens rechtmatig op de Ow gebaseerd overheidshandelen als de schade is veroorzaakt door één van de limitatief in art. $15.1 \mathrm{Ow}$ opgesomde schadeoorzaken, die rechten en plichten voor burgers scheppen; ${ }^{203}$

2. art. 15.1 lid 2 jo. art. 15.3 lid 1 jo. 15.4 lid 1 Ow zorgen voor een "generieke verschuiving" ${ }^{204}$ van het moment vanaf wanneer het bestuur aansprakelijk kan zijn uit hoofde van afd. 15.1 Ow. Bij schade door een omgevingsvergunning of door een vergunningvrije activiteit wordt dat moment namelijk verschoven naar het moment van vergunningverlening respectievelijk het moment waarop

197 Kamerstukken I 2018/19, 34 986, nr. A.

198 Kamerstukken II 2018/19, 34 986, nr. 3, p. 18 (MvT, IOw).

199 Zie hierover ook Nijmeijer 2017, p. 78.

200 Zie paragraaf 4.2.3.1 over deze vergelijking.

201 Zie Kamerstukken II 2015/16, 33 962, nr. 185 (Inleidende brief, IOw); en Kamerstukken II 2016/17, 33 962, nr. 190, p. 23-25 en 28.

202 Kamerstukken II 2018/19, 34 986, nr. 3, p. 16-23 (MvT, IOw).

203 Zie hierover paragrafen 3.3.2.1 en 3.3.2.2.

204 Dit citaat is afkomstig uit Kamerstukken II 2018/19, 34 986, nr. 3, p. 229 (MvT, IOw). 
het bevoegd gezag kennis heeft gegeven van de informatie die degene die de activiteit gaat verrichten aan het bevoegd gezag over die activiteit heeft verstrekt, of het tijdstip waarop met de activiteit is begonnen als deze informatie niet is verstrekt; ${ }^{205} \mathrm{en}$

3. art. 15.7 lid $1 \mathrm{Ow}$ de aftrek wegens normaal maatschappelijk risico bij indirecte schade bestaande uit waardedaling van een onroerende zaak fixeert op een bedrag gelijk aan 4\% van de waarde van de onroerende zaak onmiddellijk voorafgaand aan het ontstaan van de schade..$^{206}$

Een afwijking die het kabinet niet afzonderlijk noemt, maar mijns inziens wel kenmerkend is voor afd. 15.1 Ow, betreft de opname van bijzondere regels over risicoaanvaarding. Teneinde negatieve gevolgen van de verschuiving van het schademoment - meer specifiek: de uitbreiding van de hedendaagse schaduwschadeproblematiek ${ }^{207}$ - te beperken, wordt de tegenwerping van risicoaanvaarding aan banden gelegd door art. 15.5 Ow. $^{208}$ In art. 15.6 Ow worden de voorwaarden geconcretiseerd waaronder passieve risicoaanvaarding kan worden tegengeworpen. Daarmee beoogt het kabinet te voorkomen dat de beëindiging of wijziging van onbenutte bouw- en/of gebruiksmogelijkheden uit een omgevingsplan geen doorgang vindt uit vrees voor het risico dat nadeelcompensatie moet worden toegekend. ${ }^{209}$

\section{Het nieuwe omgevingsrecht}

Hiervoor is beschreven hoe afd. 15.1 Ow is vastgesteld om een globaler, meer op uitnodigingsplanologie toegespitst omgevingsrecht van de grond te krijgen. Afd. 15.1 Ow moet volgens het kabinet aansluiten op de doelen en uitgangspunten van de Omgevingswet en ervoor zorgen dat "het systeem van de wet" goed functioneert. Volgens de memorie van toelichting was daarbij vooral van belang dat:

1. de omgevingswet het mogelijk maakt dat globale, uitnodigende omgevingsplannen worden vastgesteld, waarin wordt gewerkt met open normen;

2. het omgevingsplan een bredere reikwijdte zal kennen dan het bestemmingsplan;

3. de wijze waarop de Ow taken en bevoegdheden verdeelt, kan leiden tot getrapte besluitvorming;

4. met de Ow "een brede participatie van burgers en bedrijven bij de totstandkoming van besluiten [wordt] nagestreefd." 210

Zie hierover paragraaf 3.3.2.3.

206 Zie hierover paragraaf 6.2.2.2. De informatie uit deze opsomming is afkomstig uit Kamerstukken II 2018/19, 34 986, nr. 3, p. 18-19 (MvT, IOw).

207 Op deze problematiek wordt ingegaan in paragraaf 3.2.3 e.v.

208 Zie paragraaf 8.2.2.2.

209 Zie paragraaf 8.2.2.3.

210 Kamerstukken II 2018/19, 34 986, nr. 3, p. 18 (MvT, IOw). 
Het gaat de bedoeling van dit proefschrift te buiten om een oordeel te vellen over de wenselijkheid van de wijze waarop de Ow dit nieuwe omgevingsrecht vormgeeft en/of voorstellen te doen ter wijziging van de Ow - anders dan afd. 15.1 Ow. Het moet echter niet uit het oog worden verloren dat afd. $15.1 \mathrm{Ow}$ zelf ook dient te functioneren binnen het nieuwe omgevingsrecht van de Ow. Bij de beantwoording van het deel van de hoofdvraag dat betrekking heeft op de mate waarin de aan de Wns ten grondslag liggende doelstellingen en uitgangspunten aanleiding geven tot aanpassing van afd. $15.1 \mathrm{Ow}$, zal ik daarom uitgaan van de wijze waarop deze afdeling functioneert binnen het door de Omgevingswet gereguleerde omgevingsrecht, én hoe zich dat verhoudt tot het nadeelcompensatierecht van titel 4.5 Awb. Daarom acht ik het nodig hier enige aandacht te schenken aan de wijze waarop het omgevingsrecht als vormgegeven door de Ow zal verschillen van het huidige omgevingsrecht - daarmee beoog ik overigens niet uitputtend te zijn.

Anders dan naar huidig recht, zal de ruimtelijke ordening van het gemeentegebied niet worden bepaald door meerdere bestemmingsplannen, maar door één omgevingsplan dat het gehele grondgebied van de gemeente omvat. Aan de Ow ligt het streven ten grondslag dat een dergelijk omgevingsplan zoveel mogelijk "globaal en flexibel" wordt ingericht. ${ }^{211}$ Dit wordt onder andere mogelijk gemaakt doordat de regels uit het omgevingsplan niet slechts betrekking mogen hebben op een goede ruimtelijke ordening (vergelijk art. 3.1 Wro), maar op 'de fysieke leefomgeving' (vergelijk art. $2.4 \mathrm{Ow}){ }^{212}$ Het omgevingsplan krijgt (mede) daardoor in vergelijking met huidige bestemmingsplannen "meer het karakter van een verordening met daarin open normen en uiteenlopende regels (...)." ${ }^{213}$ Dit wordt geïllustreerd door de volgende open norm, die de gemeente Stadskanaal voornemens is in haar omgevingsplan op te nemen:

"Alle activiteiten die een bijdrage leveren of geen afbreuk doen aan de ambities, waarden en kwaliteiten van de gemeente Stadskanaal zijn toegestaan."214

Dat is conform de paradigmawisseling die de wetgever voor ogen staat:

“(...) een verandering in de werkwijze binnen de bestuurscultuur bij de overheid. Het is van een "nee, tenzij" naar een "ja, mits", van het verschuilen achter regels naar het lef om besluiten te nemen." 215

211 Het citaat is afkomstig uit Kamerstukken II 2018/19, 34 986, nr. 4, p. 49 (AARvS, IOw). Zie bijvoorbeeld ook Kamerstukken II 2013/14, 33 962, nr. 3, p. 264 e.v. (MvT, Ow); Kamerstukken II 2018/19, 34 986, nr. 3, p. 58 e.v. (MvT, IOw); en Stb. 2018, nr. 190, p. 90-91 en 101-102 (Nota van toelichting, Omgevingsbesluit).

212 Zie hierover ook Kamerstukken II 2018/19, 34 986, nr. 3, p. 58 e.v. (MvT, IOw).

213 Zie bijvoorbeeld Stb. 2018, nr. 190, p. 98-99 (Nota van toelichting, Omgevingsbesluit); Kamerstukken II 2018/19, 34 986, nr. 4, p. 49-50 (AARvS, IOw); en Kamerstukken II 2016/17, 33 962, nr. 190, p. 28.

214 https://www.stadskanaal.nl/inwoners/bouwen-en-wonen/omgevingswet.html.

215 Handelingen I 2015/16, 23, item 8, p. 20. 
De wens naar meer globaliteit en flexibiliteit strekt zich ook uit tot bouwactiviteiten. ${ }^{216}$ De vergunningplicht voor de bouwactiviteit zal worden gesplitst in een technische vergunning en een ruimtelijke vergunning. Of een bouwtechnische vergunning is vereist, zal blijken uit afd. 2.3 Besluit bouwwerken leefomgeving (hierna: Bbl). Overeenkomstig art. 5.1 lid 2, aanhef en onder a Ow gaat zij uit van een bouwtechnische vergunningplicht. Wel worden bepaalde bouwactiviteiten van deze vergunningplicht uitgezonderd. Daarbij kan bijvoorbeeld worden gedacht aan de bouw van een recreatief nachtverblijf dat op de grond staat, niet hoger is dan vijf meter en een oppervlakte van niet meer dan $70 \mathrm{~m}^{2}$ heeft. ${ }^{217}$ Voor bijvoorbeeld de bouw van een woning zal echter steeds een bouwtechnische vergunning nodig zijn. Voor wat betreft de ruimtelijke vergunning is van belang dat het overgangsrecht ervoor zal zorgen dat van rechtswege een omgevingsplan ontstaat dat bestaat uit het thans bestaande planologische regime aangevuld met twee op grond van art. 22.1, aanhef en onder b Ow vastgestelde, tijdelijke hoofdstukken. Deze tijdelijke hoofdstukken staan bekend als 'de bruidsschat' en bevatten onder andere het uitgangspunt dat voor bouwactiviteiten ook een ruimtelijke vergunning is vereist. Zij wijzen echter ook een categorie bouwwerken aan waarvoor geen ruimtelijke vergunning ${ }^{218}$ nodig is. ${ }^{219}$ Iedere gemeenteraad moet het planologische regime dat door dit overgangsrecht ontstaat vóór 2029 omvormen tot een volwaardig omgevingsplan. Daarbij is het de bedoeling dat een andere vorm wordt gegeven aan de regeling omtrent de categorie van bouwwerken waarvoor geen ruimtelijke vergunning is vereist. Het kabinet zou graag zien dat deze regeling meer wordt toegespitst op verschillende locaties binnen de gemeente, zodat het aantal gevallen waarin geen ruimtelijke vergunningplicht geldt kan worden vergroot. ${ }^{220}$ Hierbij kan eveneens worden gewerkt met open normen. In de nota van toelichting behorende bij het Omgevingsbesluit wordt het volgende voorbeeld gegeven:

216 Of al dan niet een of meerdere vergunningen nodig zijn voor een bouwactiviteit is een complex vraagstuk. Voor een relatief goed te volgen uitleg verwijs ik naar Kamerstukken II 2018/19, 34 986, nr. 3, p. 49-53 (MvT, IOw) en de brief waarin de ABRvS reageert op de consultatie van het voorstel voor het Invoeringsbesluit Omgevingswet. Deze brief is te raadplegen op www.raadvanstate.nl/publicaties/ consultaties/invoeringsbesluit/. Zie verder ook Kamerstukken II 2018/19, 34 986, nr. 3, p. 70-72 (MvT, IOw).

217 Zie art. 2.15d, aanhef en onder c Bbl als vormgegeven in het ontwerp van het Invoeringsbesluit Omgevingswet dat is aangeboden aan de Tweede Kamer. Zowel dit ontwerp als de aanbiedingsbrief zijn te raadplegen op www.omgevingswetportaal. nl/wet-en-regelgeving/invoeringsbesluit.

218 In termen van de Ow: een binnenplanse vergunning omgevingsplanactiviteit bouwwerken.

219 Zie paragraaf 2.2.7 van het tweede hoofdstuk dat tijdelijk aan ieder omgevingsplan zal worden toegevoegd door art. 7.1 van het Invoeringsbesluit Omgevingswet. Ook hier ben ik uitgegaan van het ontwerp van dit besluit dat aan de Tweede Kamer is aangeboden.

220 Kamerstukken II 2018/19, 34 986, nr. 3, p. $70-71$ (MvT, IOw). 
"De bebouwingshoogte op een locatie moet aansluiten op het bebouwingspatroon in de omgeving waarbij rekening moet worden gehouden met schaduwwerking op belendende percelen." 221

Het is binnen deze context van een globaler, flexibeler en meer vergunningvrij omgevingsrecht waarin het nadeelcompensatierecht van afd. 15.1 Ow zal moeten functioneren. Op de gevolgen die dat heeft, zal ik nader ingaan in paragraaf 3.4.2.3.

\subsection{STAATSRECHTELIJKE GRENZEN AAN (FORMEEL) \\ WETTELIJKE NADEELCOMPENSATIEREGELINGEN EN NADEELCOMPENSATIEBELEIDSREGELS}

In deze paragraaf zal ik in algemene zin ingaan op de positie die titel $4.5 \mathrm{Awb}$ en afd. 15.1 Ow vanuit staatsrechtelijk perspectief innemen ten opzichte van overige vormen van recht. Hoe verhouden deze regelingen zich bijvoorbeeld tot de eisen die art. 1 EP EVRM aan de bescherming van het recht op eigendom stelt, of tot het ongeschreven égalitébeginsel? Ook wordt gekeken naar de grenzen die lagere regelgevers en bestuursorganen in acht moeten nemen bij het vaststellen van nietformeelwettelijke nadeelcompensatieregelingen respectievelijk nadeelcompensatiebeleidsregels.

\subsubsection{Verhouding van de formele wet tot art. 1 EP EVRM}

Uit art. 93 jo. $94 \mathrm{GW}$ volgt dat nationaal recht geen toepassing vindt als die toepassing niet verenigbaar is met een bekendgemaakte verdragsbepaling die naar haar inhoud een ieder kan verbinden. Het égalitébeginsel heeft geen verdragsrechtelijke status. Wel dienen de formele wetgever, lagere regelgevers, uitvoerende bestuursorganen en de rechter art. 1 EP EVRM (het recht op ongestoord genot van eigendom) in acht te nemen. Bij een toets aan art. 1 EP EVRM dient eerst een reikwijdtevraag te worden gesteld: kwalificeert het overheidshandelen als een inbreuk op het eigendomsrecht van de aanvrager? Is dat het geval, dan is relevant of die inbreuk als ontneming of regulering van eigendom moet worden aangemerkt. Als sprake is van ontneming van eigendom zal een schadevergoeding moeten worden toegekend én dient een procedure te bestaan die waarborgt dat een volledige beoordeling van de gevolgen van de ontneming plaatsvindt, waaronder de toekenning van deze vergoeding. ${ }^{222}$

Titel 4.5 Awb en afd. 15.1 Ow zien echter niet op de ontneming maar op de regulering van eigendom. Ten aanzien daarvan is het EHRM minder streng. Bij regulering van eigendom kan aan art. 1 EP EVRM geen aanspraak op een volledige

221 Stb. 2018, nr. 190, p. 107 (Nota van toelichting, Omgevingsbesluit).

222 EHRM 25 oktober 2012, ECLI:CE:ECHR:2012:1025JUD007124301, r.o. 111 (Vistiņš en Perepjolkins t. Letland). 
schadeloosstelling worden ontleend. ${ }^{223}$ De wetgeving die het gebruik van eigendom reguleert, hoeft bovendien niet noodzakelijkerwijs een recht op compensatie te bevatten. Voor de onder art. 1 EP EVRM te verrichten fair balance-toets zal het wel relevant zijn of compensatie 'beschikbaar' is. ${ }^{224}$ Die toetst dient ertoe een rechtvaardig evenwicht te waarborgen tussen het algemeen belang en de fundamentele rechten van de benadeelde, en overlapt in belangrijke mate met de toets bij een direct beroep op het égalitébeginsel. ${ }^{225}$ Van den Broek \& Tjepkema merken op dat het EHRM bij de fair balance-toets een ruime 'margin of appreciation' toekent aan het nationale bestuur als het aankomt op ruimtelijke ordening. ${ }^{226}$ Het verbaast dan ook niet dat de Afdeling meermaals heeft geoordeeld dat een (forfaitaire) aftrek wegens normaal maatschappelijk risico niet in strijd was met art. 1 EP EVRM. ${ }^{227}$ Uit haar Overzichtsuitspraak blijkt verder dat art. 1 EP EVRM niet eraan in de weg staat dat de benadeelde geen compensatie wordt toegekend als hem risicoaanvaarding kan worden tegengeworpen, of hij niet heeft voldaan aan zijn schadebeperkingsplicht. ${ }^{228}$ In meer algemene zin overweegt de Afdeling bovendien dat de toepassing van wetten die noodzakelijk kunnen worden geacht om het gebruik van eigendom te reguleren in overeenstemming met het algemeen belang, onverlet wordt gelaten door art. 1 EP EVRM. ${ }^{229}$

Gelet op het voorafgaande lijkt het onwaarschijnlijk dat de grens van art. 1 EP EVRM (snel) zal worden overschreden door titel 4.5 Awb en afd. 15.1 Ow. Dat neemt niet weg dat deze grens wel in het oog moet worden gehouden bij de beantwoording van de in paragraaf 1.2 gestelde onderzoeksvragen. Zij zal met name aan bod komen in paragraaf 6.2 , omdat de wetgever bij de totstandkoming van

223 Zie ABRvS 12 juni 2013, ECLI:NL:RVS:2013:CA2858, r.o. 6.2; en ABRvS 6 maart 2002, ECLI:NL:RVS:2002:AE0350, r.o. 2.2.1.

224 Zie ECieRM 9 maart 1989, ECLI:CE:ECHR:1989:0309DEC001176385 (Banér t. Zweden). Zie eveneens EHRM 30 augustus 2007, ECLI:CE:ECHR:2007:0830 JUD004430202, r.o. 79 (Pye Land Ltd t. Verenigd Koninkrijk) voor een voorbeeld van een zaak waaruit volgt dat bij regulering van eigendom op grond van art. $1 \mathrm{EP}$ EVRM niet automatisch recht op compensatie bestaat.

225 Zie Tjepkema 2010, p. 609, 617-618, 649-650 en 703-705; en Barkhuysen \& Van Emmerik 2002, p. 106.

226 Zie Van den Broek 2004, p. 648-649; en Van den Broek \& Tjepkema 2017, p. 3132.

227 Zie ABRvS 12 juni 2013, ECLI:NL:RVS:2013:CA2858, r.o. 6.2; ABRvS 6 maart 2002, ECLI:NL:RVS:2002:AE0350, r.o. 2.2.1; en ABRvS 7 september 2016, ECLI:NL:RVS:2016:2399, r.o. 12.3. Zie in algemene zin ook ABRvS 28 september 2016, ECLI:NL:RVS:2016:2582, r.o. 5.5 (Overzichtsuitspraak).

228 ABRvS 28 september 2016, ECLI:NL:RVS:2016:2582, r.o. 5.22 (Overzichtsuitspraak).

229 Zie bijvoorbeeld ABRvS 14 april 2010, ECLI:NL:RVS:2010:BM1021, r.o. 2.5.1 (Risicoaanvaarding planschade Bloemendaal); ABRvS 12 juni 2013, ECLI:NL:RVS:2013:CA2858, r.o. 6.2; ABRvS 10 juni 2015, ECLI:NL:RVS:2015:1837, r.o. 26.3; en ABRvS 7 september 2016, ECLI:NL:RVS:2016:2399, r.o. 12.3. 
zowel afd. 6.1 Wro als afd. 15.1 Ow enige vrees voor schending van art. 1 EP EVRM heeft gehad wegens de door die afdelingen voorgeschreven afbakeningen van het normaal maatschappelijk risico. Uiteraard kan art. 1 EP EVRM ook als zelfstandige grondslag voor schadevergoeding worden ingeroepen. Daar zal ik niet nader op ingaan, aangezien ik mij in dit proefschrift focus op nadeelcompensatieregelingen die zijn gebaseerd op het égalitébeginsel. ${ }^{230}$ Voor beantwoording van de vraag in hoeverre het bestuur een op art. 1 EP EVRM gebaseerde aanvraag om compensatie kan afdoen onder verwijzing naar titel $4.5 \mathrm{Awb}$ (en afd. 15.1 Ow), verwijs ik naar de bijdrage van Tjepkema en mij aan de 25 jaar Awb-bundel. ${ }^{231}$

\subsubsection{Verhouding van de formele wet tot het ongeschreven égalitébeginsel}

Sinds het in 1989 gewezen Harmonisatiewet-arrest is duidelijk dat de rechter wetten in formele zin niet mag toetsen aan fundamentele rechtsbeginselen, omdat dit strijd zou opleveren met het toetsingsverbod van art. 120 GW. ${ }^{232}$ De rechter kan titel 4.5 Awb, afd. 15.1 Ow en eventuele andere formeelwettelijke nadeelcompensatieregelingen daarom niet toetsen aan het ongeschreven égalitébeginsel. Ook lijkt een incidentele contra legem toepassing van het égalitébeginsel - die het Harmonisatiewet-arrest in theorie wel zou toestaan ${ }^{233}$ - weinig waarschijnlijk. Ik zie niet waaruit de daarvoor benodigde 'niet verdisconteerde omstandigheden' zouden kunnen bestaan bij een algemene regeling over nadeelcompensatie die een algemeen rechtsbeginsel, namelijk het égalitébeginsel, codificeert. Bovendien oordeelt de Afdeling, anders dan de overige hoogste Nederlandse rechtscolleges, dat strijd met een rechtsbeginsel niet kan leiden tot het buiten toepassing laten van een dwingendrechtelijk formeelwettelijk voorschrift. ${ }^{234}$ Dat betekent overigens niet dat het ongeschreven égalitébeginsel geenszins in acht hoeft te worden genomen bij vaststelling van formeelwettelijke wetgeving. De gedachte achter het toetsingsverbod is namelijk hoofdzakelijk gelegen in machtenscheiding. Het past niet bij de traditionele plaats van de rechter in het Nederlandse constitutionele bestel dat de rechter treedt in de beoordeling van formele wetgeving. Van de formele wetgever wordt desalniettemin verwacht dat voorstellen tot formele wetgeving worden gecontroleerd op rechtmatigheid, en dus ook op overeenstemming met ongeschreven rechtsbeginselen. Daarbij is in het bijzonder een plaats weggelegd voor de Eerste Kamer. Bovendien wordt de wetgever hierin bijgestaan door de

230 Zie hierover ook paragraaf 1.3.

231 Huijts \& Tjepkema 2019, p. 199-201. Bepaalde zinnen uit deze publicatie heb ik overgenomen in deze deelparagraaf. Omwille van de leesbaarheid heb ik niet telkens aanhalingstekens geplaatst.

232 HR 14 april 1989, ECLI:NL:HR:1989:AD5725, r.o. 3.1 (Harmonisatiewet).

233 HR 14 april 1989, ECLI:NL:HR:1989:AD5725, r.o. 3.9 (Harmonisatiewet).

234 Zie Bröring e.a. 2019, p. 416-419 onder verwijzing naar onder andere ABRvS 26 oktober 2005, ECLI:NL:RVS:2005:AU4988, r.o. 2.3; ABRvS 18 januari 2006, ECLI:NL:RVS:2006:AU9838, r.o. 2.4.3; en ABRvS 22 februari 2012, ECLI:NL:RVS:2012:BV6535, r.o. 2.5.1. 
AARvS. ${ }^{235}$ Het voorafgaande laat onverlet dat het feitelijk gezien de formele wetgever is die met titel 4.5 Awb, afd. 15.1 Ow, en eventuele overige formeelwettelijke nadeelcompensatieregelingen de werkingssfeer ${ }^{236}$ van het égalitébeginsel én de inhoudelijke grenzen ${ }^{237}$ voor toekenning van nadeelcompensatie op grond van dat beginsel zal bepalen.

\subsubsection{De algemene verhouding van titel 4.5 Awb tot overige regelgeving}

De Awb bevat vier soorten recht: (1) dwingend recht, (2) regelend recht, (3) aanvullend recht en (4) facultatief recht. ${ }^{238}$ Facultatief recht is slechts van toepassing als dat wordt bepaald in een wettelijk voorschrift of bij besluit van een bestuursorgaan (vergelijk bijvoorbeeld art. 3:10 lid 1 Awb). Titel 4.5 Awb bevat geen bepalingen van facultatief recht. Regelend recht kan worden herkend aan de formule 'tenzij bij wettelijk voorschrift anders is bepaald'. De Awb-wetgever geeft daarmee aan dat de hoofdregel in de desbetreffende Awb-bepaling staat, maar dat daarvan bij wettelijk voorschrift - en dus niet bij beleidsregel ${ }^{239}$ - kan worden afgeweken door de formele wetgever of lagere regelgevers (vergelijk bijvoorbeeld art. 4:1 Awb). Titel 4.5 Awb kent slechts één bepaling van regelend recht, namelijk art. 4:130 lid $1 \mathrm{Awb}$, een bepaling omtrent de door het bestuur in acht te nemen besluittermijn (zie paragraaf 10.11.2). Bijzonder aan deze bepaling is dat wordt bepaald dat "bij of krachtens wettelijk voorschrift" een andere termijn mag worden bepaald. Daardoor kan bijvoorbeeld de gemeenteraad zijn bevoegdheid tot het stellen van een bijzondere termijn bij gemeentelijke verordening delegeren aan het college van $\mathrm{B} \& \mathrm{~W}$. Bepalingen van aanvullend recht worden ook wel 'restbepalingen' of 'vangnetbepalingen' genoemd. Aanvullend recht kan worden herkend doordat uit de formulering van de desbetreffende Awb-bepaling blijkt dat zij slechts van toepassing is als in een bijzonder wettelijk voorschrift geen regeling is getroffen over het desbetreffende onderwerp (vergelijk art. 4:13 lid 1 Awb). Titel 4.5 Awb bevat geen bepalingen van aanvullend recht.

Bij regelend en aanvullend recht geeft de Awb-wetgever dus zelf aan dat, en in hoeverre, er ruimte bestaat om de desbetreffende materie anders te regelen dan de Awb doet. Bij facultatief recht heeft de Awb-wetgever er zelfs voor gekozen om de keuze of bepalingen uit de Awb van toepassing zijn aan een andere regelgever of het bestuur te laten. Eigenlijk kan daardoor niet van afwijking van de Awb worden gesproken. ${ }^{240}$ Alle overige bepalingen van titel 4.5 Awb zijn van dwingendrechtelijke aard, omdat zij niet kwalificeren als regelend, aanvullend of facultatief recht.

235 Zie Heringa e.a. 2018, p. 430-437, 444-452 en p. 161 e.v.

236 Zie bijvoorbeeld paragraaf 3.2.3 over het exclusieve karakter van afd. 6.1 Wro.

237 Zie bijvoorbeeld paragraaf 8.2.2.2 over een formeelwettelijke beperking van de bevoegdheid om actieve risicoaanvaarding tegen te werpen aan de aanvrager.

238 Zie in algemene zin over dit onderwerp bijvoorbeeld Zijlstra 2017; Barkhuysen e.a. 2018, p. 19-21; en Bröring e.a. 2019, p. 58-60.

239 ABRvS 29 oktober 2008, ECLI:NL:RVS:2008:BG1839, r.o. 2.3-2.3.1.

240 Aldus ook Zijlstra 2017, p. 202. 
Dat heeft tot gevolg dat geen ruimte voor lagere regelgevers of bestuursorganen bestaat om van deze bepalingen af te wijken. ${ }^{241}$ Afwijking in een bijzondere wet in formele zin is wel toegestaan, zij het dat daarvoor enkele 'spelregels' zijn vastgelegd in de Aanwijzingen voor de regelgeving (hierna: Ar). Titel 4.5 Awb maakt deel uit van een algemene wet. Uit art. 2.46 Ar volgt dat in bijzondere wetten slechts wordt afgeweken van algemene wetten indien dit noodzakelijk is. Een afwijking dient op grond van deze aanwijzing bovendien te worden gemotiveerd in de memorie van toelichting bij de bijzondere wet. Uit de toelichting op art. 3.35 Ar blijkt voorts dat een dergelijke afwijking moet worden geëxpliciteerd door gebruik van de zinsnede 'in afwijking van'. ${ }^{242}$ Deze spelregels zijn niet bindend. Een afwijking van titel 4.5 Awb is dus bijvoorbeeld ook rechtsgeldig als in de memorie van toelichting van de bijzondere wet niet wordt toegelicht waarom deze afwijking noodzakelijk is. Desalniettemin neemt de wetgever deze spelregels doorgaans wel in acht. Voorts is voor dit proefschrift van belang dat zij goed aansluiten op de aan de Wns ten grondslag liggende doelstelling van vereenvoudiging, uniformering en harmonisering van het nadeelcompensatierecht, en het uitgangspunt van aansluiting bij de Awb.

\subsubsection{De regelgevende bevoegdheid van de regering en ministers}

In art. $89 \mathrm{GW}$ attribueert de grondwetgever in algemene zin de bevoegdheid tot vaststelling van amvb's aan de regering. Uit rechtspraak van de Hoge Raad kan echter worden afgeleid dat een amvb slechts kan worden vastgesteld als de formele wetgever daartoe een deel van zijn (veelal op grond van art. $81 \mathrm{GW}$ verkregen) regelgevende bevoegdheid delegeert in een wet in formele zin - uitzonderingen daargelaten. De Grondwet gaat niet in op de mogelijkheid om een ministeriële regeling vast te stellen. Het legaliteitsbeginsel brengt daarom mee dat een dergelijke regeling slechts bevoegd kan worden vastgesteld in twee situaties:

1. De formele wetgever delegeert een deel van zijn regelgevende bevoegdheid door in een formele wet te bepalen dat een minister over het desbetreffende onderwerp regels mag stellen bij ministeriële regeling (vergelijk bijvoorbeeld art. 41 Algemene nabestaandenwet).

2. In de bepaling waarin de formele wetgever een deel van zijn regelgevende bevoegdheid aan de regering delegeert, gebruikt hij de formule 'bij of krachtens algemene maatregel van bestuur', waarmee hij aangeeft dat subdelegatie is toegestaan. Vervolgens stelt de regering een amvb vast waarin zij bepaalt dat over het desbetreffende onderwerp regels bij ministeriële regeling (mogen) worden vastgesteld (vergelijk bijvoorbeeld art. 76 lid 1, aanhef en onder e Luchtvaartwet jo. art. 3 lid 2 sub b Besluit beperking geluidhinder luchtvaartuigen).

241 Zie hierover ook Kamerstukken 1988/89, 21 221, nr. 3, p. 17-18 (MvT, eerste tranche Awb).

242 Dat geldt overigens niet als in een bijzondere formele wet een andere regeling wordt getroffen dan in een niet-dwingendrechtelijke Awb-bepaling. 
Vooralsnog komen beide varianten niet voor in titel 4.5 Awb of afd. 15.1 Ow. Wel bevat afd. $15.1 \mathrm{Ow}$ meerdere bepalingen op grond waarvan de regering bij amvb regels mag stellen over een bepaald onderwerp. Zo volgt uit art. 15.9 lid 2, aanhef en onder a Ow dat in een amvb regels kunnen worden gesteld over "de wijze van beoordeling van een aanvraag om schadevergoeding."

Bij het vaststellen van een amvb of ministeriële regeling dienen de regering respectievelijk minister altijd te blijven binnen de grenzen van de bepaling die hen daartoe de bevoegdheid toekent. ${ }^{243}$ Zo kunnen op grond van art. 15.9 lid 2, aanhef en onder a Ow geen regels worden gesteld over een ander onderwerp dan de wijze van beoordeling van een aanvraag om schadevergoeding. Verder dient art. 1 EP EVRM in acht te worden genomen vanwege art. 93 jo. $94 \mathrm{GW} .{ }^{244}$ Bovendien volgt uit de algemene normenhiërarchie, in het bijzonder de Lex superior regel, dat een amvb of ministeriële regeling niet in strijd mag zijn met hoger recht. ${ }^{245}$ De regering mag op grond van art. 15.9 lid 2, aanhef en onder a Ow dus bijvoorbeeld niet in een amvb afwijken van het dwingendrechtelijke art. 3:2 Awb, dat bepaalt dat het bestuursorgaan bij de voorbereiding van een besluit de nodige kennis vergaart omtrent de relevante feiten en de af te wegen belangen. Ook mag de amvb het systeem van formele wetten niet doorkruisen. Daarvan kan bijvoorbeeld sprake zijn als een amvb de formele wet aanvult op een onderwerp dat de formele wet nou net uitputtend beoogde te regelen. Hierop zal ik uitgebreider ingaan in paragraaf 2.5.5, omdat het doorkruisingsvraagstuk vooral speelt bij autonome decentrale regelgeving. ${ }^{246}$

Ten slotte mag een amvb of ministeriële regeling niet in strijd zijn met ongeschreven rechtsbeginselen. Bovendien geldt het toetsingsverbod van art. $120 \mathrm{GW}$ niet ten aanzien van regelgeving van lagere rangorde dan formele wetgeving. In 1986 bevestigde de Hoge Raad dat dit meebrengt dat de rechter dit soort regelgeving ook kan toetsen aan algemene rechtsbeginselen. ${ }^{247}$ Of een algemeen verbindend voorschrift rechtskracht moet worden ontzegd wegens strijd met een hoger wettelijk voorschrift, wordt vol getoetst door de rechter. ${ }^{248}$ De verenigbaarheid van niet formeelwettelijke, algemeen verbindende voorschriften met algemene rechts-

243 Zie Heringa e.a. 2018, p. 264-265 onder verwijzing naar HR 22 juni 1973, ECLI:NL:HR:1973:AD2208 (Fluoridering) en HR 27 juni 1986, ECLI:NL:HR:1986:AM9331 (Methadonbrief).

244 Zie paragraaf 2.5.1.

245 Zie voor strijd met de Grondwet bijvoorbeeld HR 24 januari 1969, ECLI:NL:HR:1969:AC4903 (Pocketbooks II). Zie voor strijd met formele wetgeving bijvoorbeeld HR 1 juli 1983, ECLI:NL:HR:1983:AD5666 (Staat/LSV, ook wel bekend als Prijzenbescherming medisch specialisten).

246 Zijlstra e.a. 2012, p. 252-253. Ik vermoed dat dit deels kan worden verklaard doordat de AARvS ex art. 73 lid $1 \mathrm{GW}$ moet worden gehoord over ontwerpen van amvb's.

247 HR 16 mei 1986, ECLI:NL:HR:1986:AC9354, r.o. 6.1 (Landbouwvliegers).

248 ABRvS 6 maart 2013, ECLI:NL:RVS:2013:BZ3338, r.o. 6.1. 
beginselen is echter omgeven door discussie: aan welke beginselen mag worden getoetst, en met welke intensiteit dient te worden getoetst? De Hoge Raad ging in zijn Landbouwvliegers-arrest uit van een zogenoemde 'willekeurssluis'. De Hoge Raad achtte het bevestigend antwoord op de vraag of mocht worden getoetst aan algemene rechtsbeginselen namelijk juist in zoverre dat...

“(...) geen rechtsregel eraan in de weg staat dat de rechter een (...) niet door de formele wetgever gegeven voorschrift onverbindend en in verband daarmee de vaststelling en uitvoering daarvan onrechtmatig kan oordelen op de grond dat sprake is van willekeur in dier voege dat het betreffende overheidsorgaan, in aanmerking genomen de belangen die aan dit orgaan ten tijde van de totstandbrenging van het voormelde uitvoeringsbesluit bekend waren of behoorden ten zijn, in redelijkheid niet tot het betreffende voorschrift is kunnen komen." 249

Ook de standaardoverweging van de Afdeling doet aan een willekeurstoets denken:

"Een zodanig voorschrift kan voorts wegens strijd met een algemeen rechtsbeginsel buiten toepassing worden gelaten indien het desbetreffende overheidsorgaan, in aanmerking genomen de feitelijke omstandigheden en de belangen die aan dit orgaan ten tijde van de totstandbrenging van het voorschrift bekend waren of op grond van deugdelijk onderzoek behoorden te zijn, in redelijkheid niet tot vaststelling van dat voorschrift heeft kunnen komen." 250

Deze overweging doet bovendien vermoeden dat de toets aan algemene rechtsbeginselen met name loopt via de band van de zorgvuldigheid, motivering en evenredigheid. A-G Widdershoven bepleit dat de willekeurssluis "niet langer als extra horde" zou moeten fungeren. Er zou direct moeten kunnen worden getoetst aan zowel materiële als formele rechtsbeginselen. Die toets zou bovendien ook intensiever moeten plaatsvinden. ${ }^{251}$ Het is koffiedik kijken in hoeverre de Afdeling daadwerkelijk gehoor aan deze oproep zal geven. ${ }^{252}$ Eveneens kan niet met zekerheid worden gesteld in hoeverre een al dan niet directe toets aan het égalitébeginsel ertoe kan leiden dat een nadeelcompensatieregeling buiten toepassing wordt gelaten of onverbindend wordt geacht. Dat hierover nauwelijks jurisprudentie is

249 HR 16 mei 1986, ECLI:NL:HR:1986:AC9354, r.o. 6.1 (Landbouwvliegers).

250 Zie bijvoorbeeld ABRvS 29 november 2017, ECLI:NL:RVS:2017:3271, r.o. 3.2.

251 Conclusie A-G Widdershoven in ECLI:NL:RVS:2017:3557. Zie over dit onderwerp bijvoorbeeld ook Hirsch Ballin 2015; Schutgens 2017; Voermans 2017; en Çapkurt \& De Poorter 2017.

252 Voorzichtig optimistisch met betrekking tot het omgevingsrecht lijkt te zijn Kegge 2018, p. 4 en 14-15. De precieze gevolgen van CRvB 1 juli 2019, ECLI:NL:CRVB:2019:2016 (en 2017 t/m 2019), waarin expliciet wordt ingegaan op de conclusie van Widdershoven, zijn nog onduidelijk. 
gewezen, ${ }^{253}$ kan waarschijnlijk worden verklaard door de in de voorafgaande paragrafen besproken motieven om nadeelcompensatieregelingen vast te stellen: het bieden van een laagdrempelige bestuursrechtelijke rechtsgang en de smeermiddelfunctie. Met name dat laatste motief maakt het weinig waarschijnlijk dat een regeling wordt vastgesteld die strengere voorwaarden aan toekenning van nadeelcompensatie stelt dan het ongeschreven égalitébeginsel. Bovendien zijn er buiten het planschaderecht doorgaans geen draagplichtige derden die rechtsmiddelen zullen aanwenden ${ }^{254}$ omdat een regeling te ruimhartig is. Ik zal op deze plaats geen verdere aandacht besteden aan de toets van nadeelcompensatieregelgeving aan het ongeschreven égalitébeginsel, omdat deze toets waarschijnlijk van ondergeschikt belang zal zijn aan de toets aan geschreven recht van hogere rangorde. Lagere algemeen verbindende voorschriften en de daarop gebaseerde besluitvorming zullen namelijk in ieder geval moeten voldoen aan de codificatie van het égalitébeginsel in titel 4.5 Awb (en aan art. 1 EP EVRM).

\subsubsection{De regelgevende bevoegdheid van gemeenten, provincies en waterschappen}

Ingevolge art. $127 \mathrm{GW}$ ligt de verordenende bevoegdheid op gemeentelijk onderscheidenlijk provinciaal niveau in beginsel bij de gemeenteraad respectievelijk provinciale staten. Dat blijkt ook uit art. 147 jo. art. 149 Gemw respectievelijk art. 143 jo. art. 145 PW. Op grond van art. 133 lid 2 GW jo. 56 lid 1 Waterschapswet rust de verordenende bevoegdheid op het niveau van het waterschap bij het waterschapsbestuur. Aan deze bevoegdheid zijn een aantal algemene grenzen verbonden. Zo is er bijvoorbeeld de territoriale ofwel geografische grens: een gemeenteraad kan geen verordening vaststellen die werking heeft buiten het grondgebied van de desbetreffende gemeente. Voor dit proefschrift is vooral de zogenoemde 'bovengrens' van belang. Deze grens ziet op de verenigbaarheid van de verordening met hoger recht. Zij volgt in algemene zin uit de Lex superior regel. ${ }^{255}$ Verordeningen van gemeenten, provincies en waterschappen dienen dus verenigbaar te zijn met art. 1 EP EVRM, het ongeschreven égalitébeginsel en overige ongeschreven algemene rechtsbeginselen, en op schrift gesteld nationaal recht van hogere orde. Voor de grens van art. 1 EP EVRM verwijs ik naar paragraaf 2.5.1. Voor de grens van het ongeschreven égalitébeginsel verwijs ik naar paragraaf 2.5.4. In deze deelparagraaf zal ik ingaan op de grens van het op schrift gestelde nationale recht van hogere orde. Deze grens is voor gemeentelijke verordeningen deels gecodificeerd in art. 121 jo. art. 122 Gemw. Deze artikelen gaan in op het bestaansrecht van bepalingen uit gemeentelijke verordeningen met hetzelfde onderwerp

253 Zie voor een zaak waarin de goedkeuring van een bestemmingsplan in strijd met art. 3:4 lid 2 Awb werd geacht omdat in de plantoelichting voor wat betreft schadeverhaal werd verwezen naar een (concept)nadeelcompensatieverordening die volledige vergoeding op voorhand uitsloot: ABRvS 20 februari 2001, ECLI:NL:RVS:2001:AL3065, r.o. 2.13.2.

254 Zie daarover paragraaf 10.4.1 en 10.12.1.

255 Heringa e.a. 2018, p. 356. 
als bepalingen uit formele wetten, amvb's en provinciale verordeningen. Vergelijkbare bepalingen (die ook vergelijkbaar worden toegepast) zijn opgenomen in art. 118 jo. art. 119 PW en art. 59 Waterschapswet. Deze conflictbepalingen zullen ook van toepassing zijn op de verhouding van verordeningen tot titel $4.5 \mathrm{Awb}$ en afd. 15.1 Ow, tenzij de formele wetgever alsnog een bijzondere regeling zou treffen om daarvan af te wijken. ${ }^{256}$ Omwille van de leesbaarheid zal ik hier slechts ingaan op de conflictbepalingen uit de Gemw.

Voor toepassing van deze conflictbepalingen dient een onderscheid te worden gemaakt tussen verordeningen die al voor inwerkingtreding van de hogere regeling golden (anterieure verordeningen) en verordeningen die pas daarna worden vastgesteld (posterieure verordeningen). Uit art. $122 \mathrm{Gemw}$ volgt dat een bepaling uit een anterieure verordening die in hetzelfde onderwerp voorziet als de hogere regeling van rechtswege komt te vervallen. Uit art. $121 \mathrm{Gemw}$ volgt dat in een posterieure verordening slechts een bepaling over hetzelfde onderwerp als de hogere regeling kan worden opgenomen als de bepaling uit de verordening niet in strijd is met de bepaling uit de hogere regeling. Sinds het Emmense baliekluiversarrest is duidelijk dat het 'onderwerp' uiteenvalt in enerzijds de materie die wordt geregeld en anderzijds het motief waarmee dat gebeurt. ${ }^{257}$ Art. 121 en art. 122 Gemw regelen dus niet wat rechtens is als een bepaling uit een gemeentelijke verordening wel dezelfde materie regelt als de hogere regeling, maar dat doet met een ander motief. Uit de jurisprudentie volgt echter dat dergelijke bepalingen uit verordeningen slechts bestaansrecht hebben als zij de hogere regeling niet doorkruisen. Het is lastig om in algemene zin een uitputtende beschrijving te geven van gevallen waarin kan worden gesproken van doorkruising. ${ }^{258}$ Voor dit proefschrift is met name van belang dat sprake zal zijn van doorkruising als een gemeentelijke verordening bepalingen bevat ten aanzien van materie die de hogere regelgever uitputtend beoogde te regelen, of het systeem van de hogere regeling frustreert. ${ }^{259}$

In hoofdstuk 10 zal blijken dat zowel titel 4.5 Awb als afd. 15.1 Ow nauwelijks sturing bieden met betrekking tot de procedure die moet worden gevolgd bij de behandeling van een aanvraag om nadeelcompensatie. Ten aanzien van de meeste $^{260}$ procedurele voorschriften in thans bestaande nadeelcompensatieverordeningen kan daarom niet worden gesteld dat in hun materie - en dus ook niet in hun

256 Gelet op de consultatieversie van het voorstel voor de Wet wijziging Awb ligt dat niet in de lijn der verwachtingen.

257 HR 4 maart 1952, ECLI:NL:HR:1952:AG1979 (Emmense baliekluivers).

258 Aldus ook Schilder \& Brouwer 2015, p. 34.

259 Zie met betrekking tot de conflictbepalingen uit de gemeentewet en de daarover gewezen jurisprudentie bijvoorbeeld Dölle, Elzinga \& Engels 2004, p. 187-193; Zijlstra e.a. 2012, p. 367-376; Schilder \& Brouwer 2015, p. 29-42; en Heringa e.a. 2018, p. 353-356.

260 Dit geldt bijvoorbeeld niet voor procedurele voorschriften omtrent de maximale besluittermijn of verjaring. Daarin wordt namelijk voorzien door art. 4:130 respectievelijk art. 4:131 Awb. 
onderwerp - wordt voorzien door titel 4.5 Awb of afd. 15.1 Ow. Daarom kunnen deze bepalingen rechtens blijven bestaan en zullen dergelijke bepalingen ook na inwerkingtreding van titel 4.5 Awb en afd. 15.1 Ow in verordeningen kunnen worden opgenomen.

Bepalingen uit anterieure verordeningen die materiële criteria voor toekenning van nadeelcompensatie bevatten, zullen echter van rechtswege komen te vervallen op grond van art. $122 \mathrm{Gemw}^{261}$ In die materie wordt immers voorzien door titel 4.5 Awb (en afd. 15.1 Ow). Bovendien lijkt het weinig waarschijnlijk dat het motief om deze criteria in een verordening vast te leggen niet deels zou zijn om op voorhand duidelijkheid aan de burger te verschaffen ${ }^{262}$ terwijl dat ook één van de motieven is die ten grondslag ligt aan titel $4.5 \mathrm{Awb}^{263} \mathrm{Zal}$ er wel ruimte bestaan om materiële bepalingen vast te stellen na inwerkingtreding van titel 4.5 Awb en afd. 15.1 Ow? Ervan uitgaande dat materie en motief gelijk zijn, lijkt doorslaggevend te zijn in hoeverre titel 4.5 Awb en afd. 15.1 Ow uitputtend zijn bedoeld. Tijdens de behandeling van het voorstel voor de Wns in de Eerste Kamer merkte de toenmalig minister van Veiligheid \& Justitie hierover op:

"Naar het oordeel van de regering bevat het voorgestelde artikel 4:126 Awb een uitputtende regeling. Daarmee vervallen op grond van artikel 122 Gemeentewet de materiële bepalingen uit de gemeentelijke verordening inzake nadeelcompensatie (...). Wel bestaat er ruimte voor verordeningen waarin procedurele aspecten worden geregeld, zoals leges of de voorbereiding van besluiten en de advisering over aanvragen. Materiële normen uit dergelijke verordeningen kunnen, voor zover niet in strijd met artikel 4:126 Awb, als wetsinterpreterende beleidsregel opnieuw worden vastgesteld. ${ }^{264}$

Dit wekt de suggestie dat materiële bepalingen in posterieure verordeningen titel 4.5 Awb per definitie zouden doorkruisen - en dus onverbindend moeten worden geacht. Het lijkt er echter op dat het regeringsstandpunt van destijds onvoldoende genuanceerd is verwoord. Uit de bij de Wns behorende Kamerstukken blijkt namelijk dat de regering zich heeft gerealiseerd dat titel 4.5 Awb onvoldoende sturing biedt als het bijvoorbeeld aankomt op de afbakening van het normaal maatschappelijk risico. Ten aanzien van die afbakening wordt namelijk meermaals opgemerkt dat behoefte kan bestaan aan wetsinterpreterende beleidsregels. ${ }^{265}$ Daardoor ontstaat het vermoeden dat titel 4.5 Awb niet uitputtend is bedoeld als het aankomt op de invulling van veel van de daarin opgenomen criteria, waaronder het crite-

261 Zie ten aanzien van redelijkerwijsformules ook p. 2 en 6 van de memorie van toelichting behorende bij de consultatieversie van het voorstel voor de Wet wijziging Awb.

262 Vergelijk paragraaf 2.3.3.

263 Vergelijk paragraaf 2.4.2.1.

264 Handelingen I 2012/13, 32 621, nr. 15, item 6, p. 53.

265 Zie Kamerstukken I 2012/13, 32 621, nr. C, p. 8 (MvA I, Wns); Kamerstukken II 2010/11, 32 621, nr. 3, p. 17-18 (MvT, Wns); en Kamerstukken II 2010/11, 32 621, nr. 6, p. 10-11 (NV II, Wns). 
rium van de abnormale last. Tjepkema en ik stelden hierover een vraag in onze reactie op de consultatie van het voorstel voor de Wet wijziging Awb. ${ }^{266}$ Uit de beantwoording daarvan door het huidige kabinet blijkt dat dit vermoeden juist is. Titel 4.5 Awb is uitputtend bedoeld in zoverre hij het égalitébeginsel codificeert als grondslag voor toekenning van nadeelcompensatie. Er zal echter ruimte bestaan voor "een nadere invulling van bepaalde begrippen en aanvulling op enkele onderwerpen" in posterieure verordeningen of beleidsregels, waarbij "uiteraard" rekening moet worden gehouden met de inhoud van afd. 15.1 Ow. ${ }^{267}$

\subsubsection{Grenzen aan de opstelling van beleidsregels}

In paragraaf 2.5.5 refereerde ik aan de opmerking van de toenmalig minister van Veiligheid \& Justitie dat art. 4:126 Awb een "uitputtende regeling” bevat. Gelet op de Lex superior regel moet de grondslag voor toekenning van nadeelcompensatie daarom niet in een beleidsregel worden gevonden, maar in art. 4:126 lid 1 Awb. Als de minister van Infrastructuur \& Waterstaat na inwerkingtreding van titel 4.5 Awb bijvoorbeeld de BnIW 2019 in stand zou willen houden, zou hij deze daarom in ieder geval zo moeten aanpassen dat daaruit blijkt dat de beleidsregel uitdrukking geeft aan de wijze waarop de minister toepassing geeft aan zijn bevoegdheid om nadeelcompensatie toe te kennen op grond van art. 4:126 lid 1 Awb.

De inhoud van een nadeelcompensatiebeleidsregel wordt verder beperkt door titel 4.5 Awb (en/of afd. 15.1 Ow of eventuele overige formeelwettelijke nadeelcompensatieregelingen), niet-formeelwettelijke voorschriften en fundamentele rechtsbeginselen. ${ }^{268}$ In algemene zin vloeit dat voort uit de Lex superior regel en het daaruit voortvloeiende verbod van strijdigheid en doorkruising. Verder vloeit uit art. 4:81 lid 1 Awb voort dat een beleidsregel dient te blijven binnen de grenzen van de wettelijke bevoegdheid waarop deze beleidsregel ziet. In de navolgende hoofdstukken zal blijken dat titel 4.5 Awb inhoudelijk relatief weinig sturing biedt met betrekking tot de wijze waarop invulling moet worden gegeven aan de eisen die deze titel aan de toekenning van nadeelcompensatie stelt. Beleidsregels lijken daarom vooral in strijd met titel 4.5 Awb te kunnen zijn als zij inhoudelijke criteria bevatten die ertoe zouden leiden dat een aanvrager een beperkter recht op nadeelcompensatie toekomt dan uit titel 4.5 Awb voortvloeit. Wellicht kan ook worden gedacht aan beleidsregels die niet, of te beperkt motiveren waarom een criterium uit titel 4.5 Awb altijd voldaan zal worden geacht. Een beleidsregel die strijdig is

266 Zie paragraaf 3 van bijlage 892701 bij Kamerstukken II 2018/19, 35 256, nr. 3 (MvT, Wet wijziging Awb).

267 Kamerstukken II 2018/19, 35 256, nr. 3, p. 32-33 (MvT, Wet wijziging Awb).

268 Voorbeelden uit de jurisprudentie van een toets van een beleidsregel aan het ongeschreven égalitébeginsel zijn schaars. Dat kan grotendeels op dezelfde wijze worden verklaard als in paragraaf 2.5.4 werd gedaan voor de toetsing van algemeen verbindende voorschriften aan dit beginsel. Een spaarzaam en bovendien impliciet voorbeeld betreft ABRvS 1 december 1995, ECLI:NL:RVS:1995:AN5048. Zie ook de bijbehorende noot van N. Verheij in $A B$ 1996/240. 
met afd. 15.1 Ow is eerder denkbaar. Zo sluit art. 15.5 Ow de tegenwerping van actieve risicoaanvaarding uit voor een specifieke categorie van schadegevallen. Daardoor kan niet in een beleidsregel worden bepaald dat de aanvrager in dergelijke gevallen toch actieve risicoaanvaarding zal worden tegengeworpen.

\subsection{TOTSTANDKOMING VAN ZUIVERERE SCHADEBESLUITEN EN DE TOETSING DAARVAN DOOR DE BESTUURSRECHTER}

In deze paragraaf zal ik stilstaan bij de ruimte die uitvoerende bestuursorganen hebben bij de toepassing van titel 4.5 Awb en afd. 15.1 Ow, en de wijze waarop de rechter deze toepassing toetst. Inzicht daarin is enerzijds nodig voor beantwoording van de tweede deelvraag. Verschillen in toepassing van de huidige nadeelcompensatieregelingen kunnen immers slechts op waarde worden geschat als duidelijk is in hoeverre een oordeel van de rechter moet worden beschouwd als de in zijn ogen ideale invulling van het desbetreffende criterium voor nadeelcompensatie, óf juist als een invulling die gelet op de door partijen aangevoerde beroepsgronden als niet onredelijk moet worden beschouwd. Anderzijds is dit inzicht nodig voor de beantwoording van de hoofdvraag. Aanbevelingen met betrekking tot de invulling van titel 4.5 Awb kunnen immers ook betrekking hebben op de wijze waarop de rechter toetst of de daarin opgenomen bepalingen correct zijn toegepast door het bestuur.

\section{Enkele observaties van algemene aard}

Door de jaren heen is met enige regelmaat gepubliceerd over de wijze waarop de rechter besluiten inzake de toekenning van nadeelcompensatie dient te toetsen. Bepaalde auteurs verdedigen de opvatting dat het bestuur beleids- of beoordelingsvrijheid toekomt bij de beoordeling van een aanvraag om nadeelcompensatie, hetgeen een terughoudende rechterlijke toets zou moeten meebrengen. ${ }^{269}$ Andere auteurs verdedigen juist de opvatting dat het bestuur die vrijheid niet toekomt. De rechter zou daardoor zijn oordeel omtrent de aansprakelijkheid van het bestuur volledig in de plaats kunnen stellen van het oordeel van het bestuur omtrent die aansprakelijkheid. ${ }^{270}$ In het verdere verloop van deze paragraaf zal ik per criterium voor nadeelcompensatie nagaan welke mate van beslissingsruimte het bestuur toekomt. Alvorens daartoe over te gaan, plaats ik een aantal meer algemene opmerkingen over deze beslissingsruimte.

Ten eerste is in paragraaf 2.5 de verhouding tussen verschillende typen recht beschreven. Op basis daarvan kan worden geconcludeerd dat zowel het bestuur als de rechter binnen de grenzen van formele wetgeving dienen te blijven. Ook is nog niet duidelijk in welke mate en met welke intensiteit de rechter nadeelcompensa-

269 Zie bijvoorbeeld Verheij 2002, p. 125; en Tjepkema 2010, p. 423-428.

270 Zie Schlössels 1998, p. 371-372, met name voetnoot 124; en Van Ettekoven 2011, p. 21-23. 
tieverordeningen en nadeelcompensatiebeleidsregels toetst aan het ongeschreven égalitébeginsel. Ten tweede is duidelijk dat het eerste oordeel omtrent de aanvraag om nadeelcompensatie - en dus de toepassing van (een op) het égalitébeginsel (gebaseerde beleidsregel of verordening) - altijd aan het bestuur toekomt. Dat is immers inherent aan het besluitmodel. Ten derde bestaat geen beleidsvrijheid ten aanzien van het nemen van nadeelcompensatiebesluiten. Het bestuur heeft immers niet de vrijheid om een aanvraag om nadeelcompensatie als uitkomst van een belangenafweging af te wijzen terwijl aan alle voorwaarden voor toekenning van nadeelcompensatie is voldaan. ${ }^{271}$ Ten vierde kan de rechter een zuiver schadebesluit slechts toetsen in zoverre de door partijen aangevoerde beroepsgronden en het verbod van reformatio in peius hem dat toestaan. Ten slotte kan in algemene zin worden opgemerkt dat uit de Overzichtsuitspraak volgt dat de intensiteit van de rechterlijke toetsing verschilt per criterium voor toekenning van nadeelcompensatie. Daarbij is bepalend in welke mate het bestuursorgaan bij toepassing van het desbetreffende criterium beoordelingsruimte toekomt en in hoeverre voor de beoordeling van dat criterium "specialistische kennis of ervaring [is] vereist, waarover slechts een deskundige beschikt." In het resterende deel van deze paragraaf zal hier nader op worden ingegaan.

\section{Causaal verband, risicoaanvaarding en overige vormen van eigen schuld}

Ten aanzien van de criteria van causaal verband, en risicoaanvaarding en overige vormen van eigen schuld ${ }^{272}$ komt het bestuur geen beoordelingsruimte toe. De toepassing van deze criteria vereist namelijk geen specialistische kennis of ervaring waarover slechts een deskundige beschikt. De rechter dient de wijze waarop het bestuur invulling geeft aan deze criteria dan ook "zonder terughoudendheid te toetsen." 273

\section{De taxatie van schade}

Uit de Overzichtsuitspraak volgt dat de taxatie van schade slechts terughoudend wordt getoetst. Die taxatie vindt namelijk niet slechts plaats door toepassing van een taxatiemethode. Ook de "kennis, ervaring en intuïtie van de desbetreffende deskundige" spelen een rol. De rechter dient na te gaan...

271 Zie voor vergelijkbare redeneringen Van Ettekoven 2012, p. 335-336; en Tjepkema 2010, p. 424-425. Zie in algemene zin over beleidsvrijheid Bröring e.a. 2019, p. 296-298 en Barkhuysen e.a. 2018, p. 101.

272 Voor wat betreft de overige vormen van eigen schuld blijkt dit niet uit de overwegingen uit de Overzichtsuitspraak die ik hierna zal aanhalen, maar wel uit de jurisprudentie die ik zal bespreken in paragrafen 8.3 en 8.4.

273 ABRvS 28 september 2016, ECLI:NL:RVS:2016:2582, r.o. 8.8-8.9 (Overzichtsuitspraak). 
"(...) of grond bestaat voor het oordeel dat het bestuursorgaan, gelet op de motivering van het advies van de door het bestuursorgaan ingeschakelde deskundige, zich bij de besluitvorming niet in redelijkheid op dat deskundigenoordeel heeft kunnen baseren."

De Afdeling benadrukt dat dit niets eraan afdoet dat het nadeelcompensatiebesluit moet voldoen aan eisen van zorgvuldigheid en motivering, en dat de rechter het besluit daaraan dient te toetsen. ${ }^{274}$ In later verschenen jurispudentie voegt de Afdeling nog hieraan toe dat niet in alle gevallen kan worden verlangd dat een nadere toelichting wordt gegeven op inzichten van een deskundige die mede zijn gebaseerd op diens kennis, ervaring en intuïtie. Dat laat echter onverlet dat de gedachtegang van de deskundige "duidelijk en voldoende controleerbaar" dient te zijn en het verslag van diens onderzoek "voldoende basis" dient te bieden voor verdere besluitvorming. ${ }^{275}$ Dit lijkt erop te duiden dat de Afdeling de motivering van het door het bestuur ingewonnen taxatieadvies strenger is gaan toetsen. ${ }^{276}$

\section{Het normaal maatschappelijk risico}

In de literatuur werd regelmatig opgemerkt dat de afbakening van het normaal maatschappelijk risico in zekere mate een politieke of politiek-bestuurlijke aard kent, hetgeen zou leiden tot een wat afstandelijkere rechterlijke toets. ${ }^{277}$ Die afstandelijkere toets bleek onder andere uit de rechtspraak waarin de tegenwerping van een omzet- of kostendrempel ${ }^{278}$ van $15 \%$ van de omzet respectievelijk kosten op jaarbasis 'rechtens aanvaardbaar' werd geacht. ${ }^{279}$ De keuze voor $15 \%$ als hoogte van de drempel werd nooit door het bestuur gemotiveerd ${ }^{280}$ en de rechter ging doorgaans slechts na of de door het bestuur gekozen drempel niet 'onrede-

274 ABRvS 28 september 2016, ECLI:NL:RVS:2016:2582, r.o. 8.11 (Overzichtsuitspraak).

275 ABRvS 7 maart 2018, ECLI:NL:RVS:2018:778, r.o. 11.2; en ABRvS 28 augustus 2019, ECLI:NL:RVS:2019:2953, r.o. 8.1-8.2 (Grubbenvorst).

276 Zie hierover ook onderdeel $7 \mathrm{t} / \mathrm{m} 10$ van de annotatie van Van den Broek bij ABRvS 28 augustus 2019, ECLI:NL:RVS:2019:2953 (Grubbenvorst) in OGR Updates 2019/0163. Daarin wordt ook verwezen naar ABRvS 25 juli 2018, ECLI:NL:RVS:2018:2517 en ABRvS 1 mei 2019, ECLI:NL:RVS:2019:1436.

277 Zie Tjepkema 2010, p. 426; en Van Ettekoven 2012, p. 334.

278 Zie bijvoorbeeld ABRvS 2 april 2008, ECLI:NL:RVS:2008:BC8472, r.o. 2.5, waarin wordt verwezen naar ABRvS 21 juni 2006, ECLI:NL:RVS:2006:AX9047, r.o. 2.6.2.

279 Zie bijvoorbeeld ABRvS 19 december 2007, ECLI:NL:RVS:2007:BC0536 inzake de Verordening Schadecompensatieregeling Aanleg HOV-baan en (voor een relatief vroege uitspraak) ABRvS 5 september 2001, ECLI:NL:RVS:2001:AD3527, r.o. 2.2 (Verordening nadeelcompensatie Den Haag).

280 Zie bijvoorbeeld onderdeel 2 en 6 van de annotatie van Tjepkema bij ABRvS 5 juni 2013, ECLI:NL:RVS:2013:CA2052 (Hollandse Brug, tussenuitspraak) in $A B$ $2013 / 222$. 
lijk' was. ${ }^{281}$ In het juridische discours is gaandeweg echter steeds meer draagvlak voor een meer indringende toets ontstaan. ${ }^{282}$ Die ontwikkeling is ook zichtbaar in de planschade- en nadeelcompensatiejurisprudentie, waarin de Afdeling zich steeds nadrukkelijker is gaan uitlaten over de ruimte die het bestuur toekomt bij de afbakening van het normaal maatschappelijk risico en de wijze waarop de bestuursrechter die afbakening toetst.

De Afdeling oordeelde sinds 2012 dat het bestuur beoordelingsvrijheid toekwam bij de afbakening van het normaal maatschappelijk risico. ${ }^{283}$ Die term suggereerde dat de bestuursrechter zijn eigen oordeel niet zomaar in de plaats diende te stellen van het oordeel van het bestuur, maar dat slechts diende te doen als hij van mening was dat het bestuur niet in redelijkheid tot zijn oordeel had kunnen komen. Sinds de in 2014 gewezen uitspraak Planschade Lisse oordeelt de Afdeling echter dat het bestuur beoordelingsruimte toekomt ten aanzien van de afbakening van het normaal maatschappelijk risico. ${ }^{284}$ Deze term suggereerde destijds dat het bestuur weliswaar het eerste oordeel toekwam omtrent de afbakening van het normaal maatschappelijk risico, maar de bestuursrechter dit oordeel zonder terughoudendheid zou toetsen en desnoods zijn eigen oordeel in de plaats zou stellen van het oordeel van het bestuur. ${ }^{285}$

Het is onduidelijk hoe deze wijziging in terminologie moet worden geïnterpreteerd. Enerzijds is denkbaar dat de Afdeling van mening was dat de grenzen waarbinnen het bestuur het normaal maatschappelijk risico dient af te bakenen dermate zijn aangescherpt met het toenemen van jurisprudentie op het gebied van de abnormale last dat niet langer van beoordelingsvrijheid dient te worden gesproken. Anderzijds is denkbaar dat de Afdeling in 2014 vooruitliep op een terminologische wijziging die zij enkele jaren later in meer algemene zin zou doorvoeren. Uit het jaarverslag van de Raad van State over 2017 blijkt namelijk dat de Afdeling de ter-

281 Zie ABRvS 18 mei 2011, ECLI:NL:RVS:2011:BQ4941, r.o. 2.5.1; Rb. Zwolle-Lelystad 9 maart 2012, ECLI:NL:RBZLY:2012:BV8409, r.o. 4.1; en Tjepkema 2010, p. 449.

282 Zie voor een overzicht Van den Broek \& Tjepkema 2015, p. 87.

283 Zie ABRvS 5 december 2012, ECLI:NL:RVS:2012:BY5105, r.o. 7.2 (Wouwse Tol, tussenuitspraak); ABRvS 22 mei 2013, ECLI:NL:RVS:2013:CA0631, r.o. 6.1; ABRvS 5 juni 2013, ECLI:NL:RVS:2013:CA2051, r.o. 7.1; ABRvS 5 juni 2013, ECLI:NL:RVS:2013:CA2052, r.o. 7.1 (Hollandse Brug, tussenuitspraak); ABRvS 10 juli 2013, ECLI:NL:RVS:2013:192, r.o. 10.3; ABRvS 25 september 2013, ECLI:NL:RVS:2013:1222, r.o. 6.1 (Bodyfashion Zwanenburg, hoger beroep); ABRvS 19 februari 2014, ECLI:NL:RVS:2014:572, r.o. 10.2 (Risicolocatie Schiphol); en ABRvS 9 april 2014, ECLI:NL:RVS:2014:1198, r.o. 3.3.1 (Kustversterking Noordwijk).

284 Zie ABRvS 24 december 2014, ECLI:NL:RVS:2014:4668, r.o. 5.3 (Planschade Lisse) en ABRvS 15 juni 2016, ECLI:NL:RVS:2016:1652, r.o. 14.1 (Supermarkt Haarlem, waarin wordt verwezen naar Planschade Lisse); en ABRvS 28 september 2016, ECLI:NL:RVS:2016:2582, r.o. 5.10 (Overzichtsuitspraak). Zie Bröring e.a. 2019, p. 285-296; en Barkhuysen e.a. 2018, p. 99-102. 
men 'beleidsvrijheid' en 'beoordelingsvrijheid' heeft ingeruild voor 'beleidsruimte' respectievelijk 'beoordelingsruimte'. De term 'vrijheid' zou namelijk verwarrend werken, omdat geen enkele toepassing van een publiekrechtelijke bevoegdheid geheel vrij is. Voor wat voorheen als 'beoordelingsruimte' werd aangemerkt, lijkt in de nieuwe terminologie van de Afdeling geen afzonderlijke benoeming meer te bestaan. Haar aanwezigheid blijkt eruit dat de bevoegdheidstoepassing vol wordt getoetst door de rechter. ${ }^{286}$

Ik vermoed dat deze tweede verklaring het meeste hout snijdt. In haar Overzichtsuitspraak vat de Afdeling namelijk op de volgende wijze samen hoe zij de bestuurlijke afbakening van het normaal maatschappelijk risico toetst:

"De vaststelling van de omvang van het normaal maatschappelijk risico is in de eerste plaats aan het bestuursorgaan, dat daarbij beoordelingsruimte toekomt (...) Het bestuursorgaan dient deze vaststelling naar behoren te motiveren. Indien de beroepsgronden daartoe aanleiding geven, toetst de rechter deze motivering en kan hij, indien de gegeven motivering niet volstaat, in het kader van de definitieve beslechting van het geschil op grond van artikel 8:41a van de Algemene wet bestuursrecht (hierna: de Awb) de omvang van het normale maatschappelijke risico zelf vaststellen door in een concreet geval zelf te bepalen welke drempel of korting redelijk is, met inachtneming van het bepaalde in het tweede lid van artikel 6.2 van de Wro (...)."287

Deze uitleg is eveneens verenigbaar met de opmerking van de regering tijdens het wetgevingsproces inzake de Wns dat "het vaststellen van de hoogte van de nadeelcompensatievergoeding geen discretionaire bevoegdheid betreft. De rechter beoordeelt uiteindelijk deze hoogte en toetst daarbij niet marginaal."288

Wat betekent dit nu concreet voor de nadeelcompensatiepraktijk? Als een aanvrager aanvoert dat het bestuursorgaan een te hoge aftrek wegens normaal maatschappelijk risico heeft toegepast, dan kan de bestuursrechter deze aftrek natuurlijk naar beneden bijstellen als de omstandigheden van het geval dat rechtvaardigen. ${ }^{289}$ Eventueel kan de aftrek in hoger beroep weer naar boven worden bijgesteld, maar niet hoger dan in het besluit op bezwaar. ${ }^{290}$ Als de bestuursrechter van mening is dat de aftrek eigenlijk hoger had moeten zijn dan in het besluit op bezwaar, dan

286 Jaarverslag Raad van State 2017, p. 60-61. Zie hierover bijvoorbeeld Bröring e.a. 2019, p. 287-288; Barkhuysen e.a. 2018, p. 103; en Kegge 2018, p. 7-8.

287 ABRvS 28 september 2016, ECLI:NL:RVS:2016:2582, r.o. 8.10 (Overzichtsuitspraak).

288 Kamerstukken II 2010/11, 32 621, nr. 6, p. 13 (NV II, Wns).

289 Zie bijvoorbeeld ABRvS 9 april 2014, ECLI:NL:RVS:2014:1198, r.o. 3.3.3 (Kustversterking Noordwijk); ABRvS 25 november 2015, ECLI:NL:RVS:2015:3608, r.o. 7.2 (Oirschot); en ABRvS 13 maart 2019, ECLI:NL:RVS:2019:776, r.o. 7-7.3 en 10.

290 Zie bijvoorbeeld ABRvS 14 maart 2018, ECLI:NL:RVS:2018:849, r.o. 7.2-7.3 (Ooststellingwerf). 
wordt hij namelijk beperkt door het verbod van reformatio in peius. In beginsel kan hij daardoor slechts oordelen dat het bestuursorgaan in redelijkheid tot deze aftrek kon komen. ${ }^{291}$ Dat is slechts anders als een draagplichtige derde (tegelijkertijd) heeft aangevoerd dat de door het bestuur toegepaste aftrek te laag was. ${ }^{292}$ Voorts mag de Afdeling zich niet ambtshalve uitlaten over de afbakening van het normaal maatschappelijk risico, aangezien dit geen punt van openbare orde betreft. $^{293}$

Ten slotte hanteert de Afdeling als algemene stelregel dat er zwaardere eisen aan de motivering worden gesteld naarmate het bestuur een hogere aftrek wegens normaal maatschappelijk risico hanteert. Dat is op het eerste oog een heel redelijk en logisch uitgangspunt. Toch zal de in hoofdstuk 6 te bespreken jurisprudentie weinig tot geen verschil laten zien in de indringendheid waarmee de bestuursrechter een drempel van 2, 3, 4, of 5 procent van de waarde van de onroerende zaak van de aanvrager toetst. Tjepkema heeft soortgelijke signaleringen gedaan en mijns inziens terecht opgemerkt dat...

\begin{abstract}
"(...) de bestuursrechter [in beginsel] in alle zaken waarin de motivering van een forfait niet deugt en de beroepsgronden daartoe aanleiding geven, zelf [zou] moeten vaststellen wat dan wel de meest redelijke omvang van het normaal maatschappelijk risico is en zelf in de zaak [zou] moeten voorzien." ${ }^{294}$
\end{abstract}

Als de beroepsgronden dat toestaan, zie ik namelijk geen reden waarom de rechter minder snel zou moeten ingrijpen bij een ondeugdelijk gemotiveerde, relatief lage aftrek wegens normaal maatschappelijk risico.

291 Zie bijvoorbeeld ABRvS 9 september 2015, ECLI:NL:RVS:2015:2828, r.o. 5.3 (Best); ABRvS 23 augustus 2017, ECLI:NL:RVS:2017:2248, r.o. 4.5; ABRvS 14 september 2016, ECLI:NL:RVS:2016:2487, r.o. 4.5 (Lankes); ABRvS 7 november 2018, ECLI:NL:RVS:2018:3601, r.o. 4-4.1 (Voorst); en ABRvS 25 oktober 2017, ECLI:NL:RVS:2017:2903, r.o. 8.4-8.5 (Hoogezand-Sappemeer).

292 Zie voor geslaagde beroepen van draagplichtige derden: ABRvS 29 februari 2012, ECLI:NL:RVS:2012:BV7254 (Tilburg/Vugts); ABRvS 5 september 2012, ECLI:NL:RVS:2012:BX6492 (Heiloo); ABRvS 1 juli 2015, ECLI:NL:RVS:2015:2071 (Mook \& Middelaar, de draagplichtige derde kreeg reeds gelijk van de rechtbank en de Afdeling ging daarin mee); ABRvS 21 september 2016, ECLI:NL:RVS:2016:2502 (Schoonrewoerd); ABRvS 28 september 2016, ECLI:NL:RVS:2016:2543; en ABRvS 10 oktober 2018, ECLI:NL:RVS:2018:3272 (Gemzelaar). Zie voor niet geslaagde beroepen: ABRvS 11 februari 2015, ECLI:NL:RVS:2015:349, r.o. 4.2 (De Wolden); ABRvS 9 december 2015, ECLI:NL:RVS:2015:3721 (Wijdemeren); en ABRvS 21 maart 2018, ECLI:NL:RVS:2018:973 (Lochem). Zie verder Van den Broek \& Tjepkema 2015, p. 89, 99 en 109.

293 ABRvS 1 augustus 2012, ECLI:NL:RVS:2012:BX3259, r.o. 2.9.1.

294 Zie onderdeel 8 van de annotatie van Tjepkema bij ABRvS 9 september 2015, ECLI:NL:RVS:2015:2828 (Best) in $A B$ 2016/440. 


\section{De speciale last}

Aangezien in het nadeelcompensatierecht wordt uitgegaan van het besluitmodel komt ook het eerste oordeel omtrent het criterium van de speciale last toe aan het bestuursorgaan. Uit de in hoofdstuk 7 te bespreken jurisprudentie lijkt voorzichtig te kunnen worden afgeleid dat het bestuursorgaan hierbij - net als het geval is bij de afbakening van het normaal maatschappelijk risico - enige beoordelingsruimte toekomt. De bestuursrechter zal de motivering van dit oordeel van het bestuur toetsen als de beroepsgronden daartoe aanleiding geven, en indien zij niet volstaat zelf oordelen hoe het criterium moet worden toegepast. ${ }^{295}$ Dit kan echter niet met zekerheid worden gesteld, omdat er relatief weinig jurisprudentie omtrent het criterium van de speciale last is gewezen. Deze schaarste aan jurisprudentie lijkt te kunnen worden verklaard doordat het criterium in de praktijk weerbarstig en niet altijd even eenvoudig toe te passen is, waarover meer in hoofdstuk $7 .{ }^{296}$

\subsection{CONCLUSIE}

In dit hoofdstuk is (de totstandkoming van) het huidige en toekomstige nadeelcompensatierecht besproken in vogelvlucht. De daardoor opgedane inzichten zijn in algemene zin nodig om de hoofdstukken die hierna zullen volgen te kunnen plaatsen. Meer in het bijzonder zijn zij ieder op hun eigen manier nodig voor een zinvolle beantwoording van de in paragraaf 1.2 opgeworpen onderzoeksvragen. In paragraaf 2.2 is beschreven hoe het égalitébeginsel stukje bij beetje voet aan de grond heeft gekregen in het Nederlandse recht. Met name de totstandkoming van de redelijkerwijsformule in de Boswet, Monumentenwet en de WRO heeft een decennialange ontwikkeling in gang gezet van een steeds verdere uitbreiding van de bestuursrechtelijke rechtsbescherming in nadeelcompensatiegeschillen. De bestuursrechter diende daarbij de grenzen van het besluitbegrip van de Awb te respecteren, waardoor in het nadeelcompensatierecht ook een rol bleef weggelegd voor de civiele rechter. Het gebrek aan een algemene, formeelwettelijke nadeelcompensatieregeling in combinatie met het samenspel tussen deze rechters en het bestuur was debet aan het ontstaan van het hedendaagse nadeelcompensatiedoolhof. De materiële en procedurele onoverzichtelijkheid van dat doolhof vormde aanleiding voor de formele wetgever om titel 4.5 Awb vast te stellen.

In paragraaf 2.3 is toegelicht waarom ik me in dit proefschrift voor de bestudering van het huidige nadeelcompensatierecht zal richten op afd. 6.1 Wro, de BnIW 2019, de AVN, de VNNZ, en de GrS. Deze regelingen kennen allemaal een waardevolle ontstaans- en/of toepassingsgeschiedenis, dienen een significant praktisch belang, en/of verhouden zich op bijzondere wijze tot overige nadeelcompensatieregelingen. Bovendien resulteert hun selectie in een representatieve afspiegeling van het hedendaagse nadeelcompensatierecht, mede doordat zij zorgt voor een spreiding tussen (1) formeelwettelijke regelingen en regelingen van lagere 
rangorde, (2) regelingen van centrale en decentrale overheden, en (3) algemene regelingen en regelingen gericht op één specifieke bron van schade.

In paragraaf 2.4 is nader toegelicht waarom ik me voor de bestudering van het toekomstige nadeelcompensatierecht zal richten op titel 4.5 Awb en afd. $15.1 \mathrm{Ow}$ (paragraaf 2.4.1.). Ook is enig inzicht verschaft in de totstandkomingsgeschiedenis van afd. 15.1 Ow en het door de Ow in het leven geroepen omgevingsrecht waarbinnen deze afdeling zal moeten functioneren (paragraaf 2.4.3). De belangrijkste functie van deze paragraaf was echter de beantwoording van de eerste deelvraag: Welke doelstellingen en uitgangspunten liggen ten grondslag aan de Wns? (paragraaf 2.4.2). Aan de Wns liggen vier doelstellingen ten grondslag: (1) vereenvoudiging, uniformering en harmonisering van het nadeelcompensatierecht; (2) vergroting van de rechtszekerheid en rechtsgelijkheid; (3) codificatie van het nadeelcompensatierecht; en (4) vergroting van de doelmatigheid van het nadeelcompensatierecht en vermindering van bestuurslasten. Naast deze doelstellingen kent de Wns een drietal uitgangspunten. Titel 4.5 Awb dient (1) uitsluitend het égalitébeginsel te codificeren; (2) aan te sluiten op het besluitmodel; en (3) waar mogelijk aan te sluiten bij de Awb en het BW. Deze doelstellingen en uitgangspunten zullen het toetsingskader vormen van dit proefschrift.

In paragraaf 2.5 is stilgestaan bij de belangrijkste staatsrechtelijke grenzen die in acht moeten worden genomen bij de vaststelling van (formeel)wettelijke nadeelcompensatieregelingen en nadeelcompensatiebeleidsregels. Die grenzen zullen eveneens in acht moeten worden genomen bij beantwoording van de hoofdvraag en zullen soms ook verschillen kunnen verklaren tussen thans bestaande nadeelcompensatieregelingen en -beleidsregels. Allereerst is er de grens van art. 1 EP EVRM. Deze grens zal naar verwachting weinig problemen opleveren omdat het in het nadeelcompensatierecht gaat om regulering van eigendom. Daardoor laat het EHRM een ruime 'margin of appreciation' aan de nationale overheden. Ten tweede is er de grens van het ongeschreven égalitébeginsel. Wetten in formele zin, zoals titel 4.5 Awb en afd. 15.1 Ow, kunnen door de rechter niet aan dit beginsel worden getoetst vanwege het toetsingsverbod van art. $120 \mathrm{GW}$. Daardoor is het uiteindelijk de formele wetgever die de werkingssfeer van het égalitébeginsel én de inhoudelijke grenzen voor toekenning van nadeelcompensatie op grond van dat beginsel zal bepalen. De bestuursrechter kan wel ingrijpen als lagere regelgeving of beleidsregels het égalitébeginsel schenden. Tot op heden is echter onduidelijk in hoeverre hij daartoe bereid is en welke toetsingsintensiteit hij daarbij zal hanteren. Naar toekomstig recht zal de (exceptieve) toets aan het égalitébeginsel bovendien van ondergeschikt belang zijn, omdat de rechter vol kan toetsen aan de codificatie daarvan in titel 4.5 Awb.

Ten derde zullen lagere regelgevers binnen de grenzen moeten blijven van de bepaling waarin hen regelgevende bevoegdheid wordt toegekend. Bij het opstellen van beleidsregels vloeit een soortgelijke grens voort uit art. 4:81 Awb: de beleidsregel moet de grenzen respecteren van de bevoegdheid waarop hij betrekking heeft. Daarnaast moet steeds het algemene rechtsbeginsel dat lager recht niet in 
strijd mag zijn met hoger recht (Lex superior) in acht worden genomen. ${ }^{297}$ Nietformeelwettelijke nadeelcompensatieregelingen en nadeelcompensatiebeleidsregels mogen daardoor niet direct in strijd zijn met titel 4.5 Awb en afd. 15.1 Ow. Bovendien mogen zij deze wetten niet doorkruisen. Daarvan zal met name sprake zijn als zij bepalingen bevatten ten aanzien van materie die de formele wetgever uitputtend beoogde te regelen, of als zij het systeem van titel 4.5 Awb en afd. 15.1 Ow frustreren. Deze 'bovengrens' is deels vastgelegd in de Gemeente-, Provincie-, en Waterschapswet voor verordeningen op gemeentelijk, provinciaal, respectievelijk waterschapsniveau. Zij brengt mee dat de materieelrechtelijke bepalingen uit thans bestaande (anterieure) nadeelcompensatieverordeningen van rechtswege zullen komen te vervallen. Thans bestaande beleidsregels zullen in ieder geval zo moeten worden aangepast dat zij niet langer als grondslag voor toekenning van nadeelcompensatie zullen dienen. Titel 4.5 Awb is namelijk uitputtend bedoeld in zoverre hij het égalitébeginsel codificeert als grondslag voor toekenning van nadeelcompensatie. Wel zal ruimte bestaan voor "een nadere invulling van bepaalde begrippen en aanvulling op enkele onderwerpen" in posterieure verordeningen of beleidsregels, waarbij "uiteraard" rekening moet worden gehouden met de inhoud van afd. $15.1 \mathrm{Ow} .^{298}$

Ten slotte is in paragraaf 2.6 ingegaan op de totstandkoming van zuivere schadebesluiten en de toetsing daarvan door de bestuursrechter. Vanwege het besluitmodel komt het bestuur altijd het eerste oordeel toe omtrent zijn eigen aansprakelijkheid uit hoofde van titel 4.5 Awb (en afd. 15.1 Ow). De rechter toetst dit oordeel voor zover de door partijen aangevoerde beroepsgronden en het verbod van reformatio in peius hem dat toestaan. De intensiteit van zijn toets verschilt per criterium voor toekenning van nadeelcompensatie. Daarbij is van belang of het bestuur ten aanzien van het desbetreffende criterium beoordelingsruimte toekomt en of voor de toepassing van het criterium specialistische kennis is vereist waarover slechts een deskundige beschikt. Dit heeft tot gevolg dat de rechter vol toetst hoe het bestuur invulling heeft gegeven aan de criteria inzake causaal verband, en risicoaanvaarding en overige vormen van eigen schuld. De taxatie van de schade wordt terughoudend getoetst. Ook de bestuurlijke invulling van het normaal maatschappelijk risico wordt met enige terughoudendheid getoetst. Het bestuur komt namelijk beoordelingsruimte toe bij deze invulling. Slechts als de motivering daarvan niet volstaat, kan de rechter zijn eigen oordeel in de plaats stellen van de invulling gegeven door het bestuur. Waarschijnlijk gaat hetzelfde op voor (de toetsing van) de invulling van het criterium van de speciale last. 



\section{Hoofdstuk 3}

\section{De reikwijdte en exclusiviteit van nadeelcompensatieregelingen}

\subsection{INLEIDING}

In dit hoofdstuk sta ik stil bij de reikwijdte van de geselecteerde nadeelcompensatieregelingen. Onder reikwijdte versta ik het scala aan rechtmatige overheidshandelingen ten aanzien waarvan de desbetreffende regeling kan dienen als grondslag voor toekenning van nadeelcompensatie. ${ }^{1}$ De vraag naar de reikwijdte van een nadeelcompensatieregeling komt in de praktijk doorgaans pas aan bod als vaststaat dat aan de vereisten voor het in behandeling nemen van een aanvraag om nadeelcompensatie is voldaan (zie hoofdstuk 10). Bij de inhoudelijke beoordeling van deze aanvraag dient te worden nagegaan of de beweerde schadeoorzaak kwalificeert als een schadeoorzaak die onder de reikwijdte van de ingeroepen regeling valt. Is dat het geval, dan dient te worden nagegaan of de aanvrager daadwerkelijk schade heeft geleden (hoofdstuk 5) die in causaal verband staat tot deze beweerde schadeoorzaak (hoofdstuk 4). Ook zal deze schade moeten voldoen aan de overige criteria die de ingeroepen regeling stelt aan de toekenning van nadeelcompensatie (hoofdstuk $6 \mathrm{t} / \mathrm{m}$ 9). ${ }^{2}$ Kwalificeert de beweerde schadeoorzaak niet als een schadeoorzaak die onder de reikwijdte van de ingeroepen regeling valt, dan zal het bestuur de aanvraag afwijzen. Dit laat onverlet dat deze afwijzing kwalificeert als appellabel zuiver schadebesluit. Als de aanvrager de bestuursrechter adieert, zal deze bevestigen dat de afwijzing rechtmatig was omdat de schadeoorzaak niet onder de reikwijdte van de regeling viel. Het hangt vervolgens af van de omstandigheden van het geval welke routes nog openstaan voor de aanvrager. Valt de werkelijke schadeoorzaak onder de reikwijdte van een andere nadeelcompensatieregeling, dan kan de aanvrager proberen zijn schade alsnog vergoed te zien door een aanvraag onder die regeling in te dienen. Valt de werkelijke schadeoorzaak niet onder de reikwijdte van een andere regeling, en is niet voldaan aan de connexiteitseisen, dan kan de aanvrager slechts een beroep doen op de civiele rechter. ${ }^{3}$

1 Vergelijk Kamerstukken II 2010/11, 32 621, nr. 3, p. 14 (MvT, Wns).

2 Zie in algemene zin ook ABRvS 28 september 2016, ECLI:NL:RVS:2016:2582, r.o. 1.2 en 2 (Overzichtsuitspraak); en Stcrt. 1999, nr. 172, p. 9 (digitaal, p. 5).

3 Zie paragraaf 2.2 voor een bespreking van de connexiteitseisen en de vraag wanneer de reactie op een aanvraag om nadeelcompensatie kwalificeert als appellabel besluit. 
De reikwijdte van een nadeelcompensatieregeling wordt deels bepaald door de in paragraaf 2.5 besproken, algemene staatsrechtelijke grenzen die zijn verbonden aan de bevoegdheid om een algemeen verbindend voorschrift of beleidsregel vast te stellen. Losstaand van dit soort algemene grenzen is het gebruikelijk om de reikwijdte van nadeelcompensatieregelingen af te bakenen door aan te geven welk rechtmatig overheidshandelen schade kan veroorzaken die op grond van de desbetreffende regeling voor compensatie in aanmerking komt. In dit hoofdstuk zal ik slechts ingaan op deze meer specifieke afbakeningen van reikwijdte. Voor dit onderzoek zijn zij in het bijzonder van belang omdat de wetgever tijdens de totstandkoming van de Wns het standpunt innam dat na inwerkingtreding van titel $4.5 \mathrm{Awb}$ niet langer mocht worden gewerkt met limitatieve opsommingen van schadeoorzaken die een exclusief karakter dragen. ${ }^{4}$ Daarop lijkt echter te worden teruggekomen. Het wetsvoorstel voor art. 15.1 Ow bevat namelijk toch een limitatieve, exclusieve opsomming van schadeoorzaken. Dat het exclusieve karakter van dit soort opsommingen zo een heikel punt vormt, komt met name doordat het leidt tot de als onwenselijk ervaren onvergoedbaarheid van zogenoemde 'schaduwschade'. Ook schaduwschade zal daarom een belangrijke rol spelen in dit hoofdstuk.

\subsection{DEELVRAAG 2: VERSCHILLEN TUSSEN DE GESELECTEERDE, THANS GELDENDE REGELINGEN EN VERKLARINGEN DAARVOOR}

\subsubsection{Verschillende methoden om de reikwijdte af te bakenen}

Een van de meest gebruikte methoden ${ }^{5}$ om de reikwijdte van een nadeelcompensatieregeling af te bakenen, kan worden teruggevonden in art. 2 lid 1 BnIW 2019. Daarin is bepaald dat onder deze regeling slechts compensatie wordt toegekend wegens schade die het gevolg is van de "rechtmatige uitoefening door of namens de minister van een aan het publiekrecht ontleende bevoegdheid of taak." Deze methode is ook gebezigd door de Amsterdamse gemeenteraad in art. 2 lid 1 jo. art. 1, aanhef en onder a AVN. Uit deze bepalingen volgt namelijk dat de schade door de gemeenteraad, het college van B\&W of de burgemeester van Amsterdam moet zijn veroorzaakt in de rechtmatige uitoefening van hun publiekrechtelijke bevoegdheid of taak. Van een publiekrechtelijke bevoegdheid kan worden gespro-

$4 \quad$ Zie paragraaf 3.3.1 onder het kopje 'Limitatieve opsommingen van schadeoorzaken niet langer toegestaan?'.

5 Een op 29 april 2019 op overheid.nl ingevoerde zoekopdracht naar lokale regelgeving met het woord 'nadeelcompensatie' in de titel en een tekst die 'publiekrechtelijke bevoegdheid of taak' bevat, levert 38 resultaten op; waarvan 4 op provinciaal-, 3 op waterschaps- en 30 op gemeentelijk niveau. Zie bijvoorbeeld de 'Verordening nadeelcompensatie provincie Fryslân', de 'Verordening nadeelcompensatie Rijnland' (een verordening van het Hoogheemraadschap van Rijnland), respectievelijk de 'Verordening nadeelcompensatie gemeente Leiden 2014'. 
ken als een bestuursorgaan handelt op grond van een wettelijk voorschrift. ${ }^{6}$ Het begrip publiekrechtelijke taak kent geen duidelijk omlijnde definitie, waarover meer in paragraaf 3.3.1.

Er bestaan ook andere methoden om de reikwijdte van een nadeelcompensatieregeling af te bakenen. De reikwijdte van art. 49 WRO was oorspronkelijk beperkt tot schade "ten gevolge van de bepalingen van een bestemmingsplan." " Gedurende enkele decennia hebben verschillende wetswijzigingen de reikwijdte uitgebreid, waardoor de bepaling uiteindelijk een lijst van limitatief onder a $\mathrm{t} / \mathrm{m}$ f opgesomde schadeoorzaken is gaan bevatten. ${ }^{8}$ Aan deze systematiek is vastgehouden in art. 6.1 lid 2 Wro. Op de inhoud van deze opsommingen en het bijzondere karakter daarvan zal in het vervolg van deze paragraaf nog nader worden ingegaan.

Weer een andere methode om de reikwijdte af te bakenen, kan worden gevonden in art. 1, aanhef en onder d VNNZ. Daarin is namelijk bepaald dat onder "nadeel' slechts wordt verstaan "de schade als gevolg van de aanleg van de Noord/ Zuidlijn, veroorzaakt door rechtmatig overheidshandelen." Onder 'aanleg van de Noord/Zuidlijn' dient blijkens art. 1 aanhef en onder a VNNZ de "bouw van de Noord/Zuidlijn en de daarbij behorende werken, evenals de rechtstreeks daarmee in verband staande besluiten of handelingen" te worden verstaan. Tevens is in art. 3 lid 1, aanhef en onder d VNNZ een weigeringsgrond opgenomen voor situaties waarin "het nadeel naar het oordeel van het college geen gevolg is van de aanleg van de Noord/Zuidlijn."

Ten slotte is er art. $9 \mathrm{GrS}$. Deze bepaling vormt geen zelfstandige grondslag voor toekenning van nadeelcompensatie, maar dient ertoe al bestaande bevoegdheden tot toekenning van nadeelcompensatie over te dragen aan het algemeen bestuur van het Schadeschap. In paragraaf 2.3.4 is beschreven hoe het algemeen bestuur deze bevoegdheden op zijn beurt heeft overgedragen aan de besliscommissie van het Schadeschap. In art. $9 \mathrm{GrS}$ is limitatief opgesomd om welke bevoegdheden het gaat. Allereerst betreft het de bevoegdheid tot toekenning van planschadevergoeding ex art. 49 WRO voor zover de daartoe strekkende aanvraag verband houdt met de aanwijzing tot luchthaventerrein ex art. 27 jo. 24 Lvw, ${ }^{9}$ de aanwijzing van de geluidzonering ex art. 26 Lvw jo. 37 WRO en de planologische kernbeslissing 'Schiphol en omgeving' (hierna: PKB, zie art. 9 lid 1 jo. lid 2, aanhef en onder a

6 Dat mag bijvoorbeeld ook een gemeentelijke verordening zijn. Vanuit staatsrechtelijk perspectief vereist het legaliteitsbeginsel wel dat het desbetreffende algemeen verbindende voorschrift kan worden herleid tot een attributiebepaling in de Grondwet, zoals art. 81 Grondwet. Zie ook ABRvS 24 oktober 2018, ECLI:NL:RVS:2018:3431, r.o. 2.1; Barkhuysen e.a. 2018, p. 48-49, 76-78; en Bröring e.a. 2019, p. 131-133, 178-180.

$7 \quad$ Stb. 1962, nr. 286.

8 Zie hieromtrent Van den Broek 2002, p. 21 e.v.

9 Deze wetsbepalingen zijn vervallen per 24 december 2008, zie Stb. 2008, nr. 561, art. III, onderdeel C en Stb. 2008, nr. 562. 
GrS), of planologische maatregelen - met name bestemmingsplannen - bedoeld om het gebied in Haarlemmermeer Noord in overeenstemming te brengen met de in de PKB (Hoofdstuk Vlll) beschreven ruimtelijke inrichting (zie art. 9 lid 2, aanhef en onder b jo. onder c GrS). De reeds aan deze bevoegdheid verbonden beperkingen blijven onverkort van toepassing. Daardoor bestaat slechts ruimte tot planschadevergoeding als de beweerde schadeoorzaak kwalificeert als één van de limitatief in art. 49 WRO opgesomde schadeoorzaken. ${ }^{10}$

Ten tweede betreft het de bevoegdheid om nadeelcompensatie toe te kennen op grond van art. $8.31 \mathrm{Wlv}$ (art. 9 lid 3, aanhef en onder e GrS) ${ }^{11}$ voor zover de aanvraag daartoe is ingediend voor 1 juli 2018. In het derde lid van art. $8.31 \mathrm{Wlv}$ is een voorrangsregeling opgenomen voor gevallen waarin luchthavenindelingsbesluiten doorwerken in gemeentelijke bestemmingsplannen. Ik ga ervan uit dat zij meebrengt dat de aanvraag om schadevergoeding in dergelijke gevallen conform het planschaderecht zal worden afgedaan, echter niet door B\&W maar door de minister. Dat baseer ik op jurisprudentie inzake de vergelijkbare regeling van art. 22 lid 2 Tracéwet, ${ }^{12}$ die is geïnspireerd op de voorrangsregeling uit de Wlv. ${ }^{13}$ Ten aanzien van alle aanvragen ingediend voor 1 juli 2018 zal dus in dergelijke gevallen de besliscommissie van het Schadeschap bevoegd zijn, maar zal zij het planschaderecht moeten toepassen.

Ten derde betreft het de bevoegdheid om nadeelcompensatie toe te kennen op grond van art. 21 van het op de Luchtvaartwet gebaseerde Aanwijzingsbesluit Luchtvaartterrein Schiphol van 23 oktober 1996 (hierna: Aanwijzingsbesluit 1996; art. 9 lid 3, aanhef en onder a GrS). Ten slotte betreft het de bevoegdheid om nadeelcompensatie toe te kennen op grond van de RnVW 1999 (art. 9 lid 3, aanhef en onder b GrS) of het ongeschreven égalitébeginsel (art. 9 lid 3, aanhef en onder c, d, en f GrS), maar slechts voor zover de aanvraag betrekking heeft op specifiek genoemd schadeveroorzakend overheidshandelen, afhankelijk waarvan ook de eis kan gelden dat de aanvraag voor 1 juli 2018 is ingediend.

\section{Verklaringen}

In paragraaf 2.2 schetste ik hoe de Afdeling in de Beurskens en Van Vlodrop uitspraken ${ }^{14}$ bestuursrechtelijke rechtsbescherming openstelde tegen toepassing van

10 Zie voor een voorbeeld van een zaak waarin dat niet het geval was ABRvS 20 augustus 2003, ECLI:NL:RVS:2003:AI1217, r.o. 2.5.3.

11 Zie de wijziging van de GrS van 21 januari 2004 (Stcrt. 2004, nr. 20, p. 16).

12 Zie ABRvS 25 april 2012, ECLI:NL:RVS:2012:BW3907, r.o. 2.7.1; ABRvS 28 november 2012, ECLI:NL:RVS:2012:BY4394, r.o. 8.3-8.4; ABRvS 3 juli 2013, ECLI:NL:RVS:2013:160, r.o. 2; en ABRvS 4 november 2015, ECLI:NL:RVS:2015:3350, r.o. 1.

13 Kamerstukken II 2004-2005, 29 859, nr. 3, p. 9 (MvT, Wijziging van de Tracéwet).

14 Zie ABRvS 18 februari 1997, ECLI:NL:RVS:1997:ZF2587 (Beurskens); en ABRvS 6 mei 1997, ECLI:NL:RVS:1997:AA6762 (Van Vlodrop). 
het ongeschreven égalitébeginsel op schade die wordt "veroorzaakt binnen het kader van de uitoefening van een aan het publiekrecht ontleende bevoegdheid" (materiële connexiteit) waartegen beroep bij de bestuursrechter kan worden ingesteld (processuele connexiteit). Hoewel de connexiteitseisen onder de BnIW 2019 en AVN niet de rol vervullen van toegangspoort tot het traject van bestuursrechtelijke rechtsbescherming, lijkt de in deze regelingen gebruikte formule van de publiekrechtelijke bevoegdheid en taak wel te zijn geïnspireerd op de terminologie die de Afdeling in de Van Vlodrop-uitspraak gebruikte. De publiekrechtelijke taak lijkt vooral in de formule te zijn opgenomen om ervoor te zorgen dat ook schade door rechtmatig feitelijk handelen dat niet op een expliciete bevoegdheidstoedeling in een wettelijk voorschrift is gebaseerd, onder het bereik van deze nadeelcompensatieregelingen valt. ${ }^{15}$ Voor de AVN geldt de aanvullende verklaring dat voor de formulering daarvan rekening is gehouden met de formulering van art. 4:126 lid 1 Awb. Ook daarin is namelijk de formule van een publiekrechtelijke bevoegdheid en taak opgenomen. ${ }^{16}$ Daarbij heeft de formele wetgever weer inspiratie ontleend aan de RnVW 1999. ${ }^{17}$

Ik heb geen expliciete verklaring kunnen vinden voor de keuze van de Amsterdamse gemeenteraad om de reikwijdte van de VNNZ op een andere wijze af te bakenen. Ook de voorganger van deze verordening bakende zijn reikwijdte al af met de formule dat slechts nadeel "als gevolg van de aanleg van de Noord-Zuidlijn" tot nadeelcompensatie kon leiden. ${ }^{18} \mathrm{Al}$ speculerend, kan ik me voorstellen dat de Amsterdamse gemeenteraad de formule van een publiekrechtelijke bevoegdheid of taak te burgeronvriendelijk vond voor een compensatieregeling die van toepassing zou zijn op een project dat op onvrede bij de Amsterdamse bevolking stuitte. ${ }^{19}$ Met name de publiekrechtelijke taak is namelijk een lastig te vatten term. Dat laat onverlet dat een materieelrechtelijk vergelijkbare ${ }^{20}$ afbakening had kunnen worden gerealiseerd door te bepalen dat de schade door het Amsterdamse gemeentebestuur moest zijn veroorzaakt in de rechtmatige uitoefening van zijn publiekrechtelijke bevoegdheid of taak bij de aanleg van de Noord/Zuidlijn. ting op de AVN; en Tjepkema 2010, p. 880-881.

16 Zie hierover paragraaf 3.3.1.

17 Zie paragraaf 2.3.2 onder het kopje 'Invloed op (toekomstige) regelgeving', onder verwijzing naar Kamerstukken I 2012/13, 32 621, nr. C, p. 2 (MvA I, Wns).

18 Vergelijk art. 2 lid 1 jo. art. 1, aanhef en onder a Verordening Nadeelcompensatie en Planschade Noord-Zuidlijn.

19 Zie over die onvrede bijvoorbeeld https://nos.nl/artikel/2116356-noord-zuidlijnhet-probleemkind-dat-amsterdam-ooit-niet-eens-wilde.html.

20 Ik spreek hier van 'vergelijkbaar' omdat de VNNZ thans, strikt genomen, niet uitsluit dat compensatie wordt toegekend voor schade door rechtmatige civielrechtelijke handelingen van het gemeentebestuur. Dat was overigens anders onder de voorganger van de VNNZ, zie art. 1 aanhef en onder b Verordening Nadeelcompensatie en Planschade Noord-Zuidlijn. 
Waarom de reikwijdte in art. 49 lid 1 WRO en art. 6.1 lid 2 Wro wordt afgebakend door middel van een limitatieve opsomming van schadeoorzaken is ten tijde van de totstandkoming van deze regelingen nooit geëxpliciteerd door de wetgever. ${ }^{21}$ Waarschijnlijk komt dit doordat de opsomming is ontstaan als gevolg van de eerder beschreven, geleidelijke uitbreiding van de reikwijdte van art. 49 WRO. In de literatuur is mijns inziens echter overtuigend beargumenteerd dat de keuze voor een limitatieve opsomming kan worden verklaard doordat de wetgever slechts planschadevergoeding wilde toekennen voor schade door planologische besluiten die zowel het bestuur als de burger binden en/of inhoudelijk al dermate concreet zijn dat de gevolgen van het besluit en het moment van inwerkingtreding voldoende bepaalbaar zijn. ${ }^{22} \mathrm{Om}$ dat doel te bereiken, lijkt een limitatieve opsomming van schadeoorzaken inderdaad het meest geschikt. Waarom de wetgever het recht op planschadevergoeding wilde beperken tot schade door dit type schadeoorzaken zal nog worden besproken in het vervolg van deze paragraaf.

In de GrS is gekozen voor een limitatieve opsomming van bevoegdheden, die al dan niet is beperkt tot bepaalde schadeoorzaken. Dit kan worden verklaard doordat de GrS een ander karakter draagt dan de overige geselecteerde regelingen: zij dient ertoe de reeds op grond van verschillende grondslagen bestaande - en aan verschillende bestuursorganen toekomende - bevoegdheden om nadeelcompensatie toe te kennen, binnen een specifieke context over te dragen aan het algemeen bestuur van het Schadeschap.

\subsubsection{Het uitputtende karakter van de afbakeningen van reikwijdte}

De in paragraaf 3.2.1 besproken afbakeningen van reikwijdte kennen allemaal een limitatief karakter: slechts als de schadeoorzaak binnen de reikwijdte van de ingeroepen nadeelcompensatieregeling valt, kan deze regeling aanleiding geven tot toekenning van compensatie. ${ }^{23}$ Uit de jurisprudentie volgt dat de limitatieve opsommingen van art. 49 lid 1 WRO en art. 6.1 lid 2 Wro daarnaast een uitputtend karakter dragen. Daarmee wordt bedoeld dat schade die wel als gevolg van een van de limitatief in art. 49 WRO of art. 6.1 Wro opgesomde schadeoorzaken aan het gemeentebestuur valt toe te rekenen, uitsluitend voor planschadetegemoetkoming in aanmerking komt. Een bij het gemeentebestuur wegens deze schade ingediende aanvraag om nadeelcompensatie bij wege van buitenwettelijk zuiver schadebesluit, kan onder verwijzing naar de regeling van art. 49 WRO respectievelijk afd. 6.1 Wro worden afgewezen. Beide geven namelijk een "uitputtende

21 Impliciet zou dit wellicht kunnen worden afgeleid uit het Rapport Commissie Samkalden 1983, p. 66, waarnaar wordt verwezen in Kamerstukken II 1983/84, 14 889, nr. 122. Zie voorts Kamerstukken II 2002/03, 28 916, nr. 3, p. 112 (MvT, Wro): “(...) De opsomming spreekt voor zich."

22 Zie Van Ravels 2013b, p. 8; Van Ravels 1999, p. 209-211; Van den Broek 2002, p. 22-23 en 140; en Rapport Commissie Samkalden 1983, p. 66.

23 ABRvS 28 september 2016, ECLI:NL:RVS:2016:2582, r.o. 2 (Overzichtsuitspraak). 
regeling" voor de vergoeding van schade veroorzaakt door de in art. 49 WRO respectievelijk art. 6.1 Wro opgesomde schadeoorzaken. ${ }^{24}$ De civiele rechter gaat hierin mee, omdat in dergelijke gevallen een met voldoende waarborgen omklede rechtsgang voor het verkrijgen van schadevergoeding openstaat, namelijk art. 49 WRO of afd. 6.1 Wro. ${ }^{25}$

De vraag naar uitputtendheid lijkt zich niet voor te doen onder de overige geselecteerde, thans geldende regelingen. Zeker in geval van nadeelcompensatiebeleidsregels ligt dat ook niet voor de hand. Zij strekken immers ertoe aan te geven hoe het desbetreffende bestuursorgaan gebruik zal maken van zijn bevoegdheid om nadeelcompensatie toe te kennen op grond van het égalitébeginsel. Zolang de desbetreffende nadeelcompensatiebeleidsregel in overeenstemming met het égalitébeginsel is, bestaat dan ook geen reden waarom het bestuur een aanvraag op grond van ongeschreven égalité zou moeten behandelen. Ik zie niet in waarom dit anders zou zijn voor nadeelcompensatieverordeningen. Sterker nog, in haar Supermarkt Haarlem-uitspraak oordeelde de Afdeling dat het in het kader van een zorgvuldige besluitvorming (vergelijk art. 3:2 Awb) op de weg van het college lag om te bezien of de gemeentelijke nadeelcompensatieverordening - waaraan het égalitébeginsel ten grondslag lag - van toepassing was. Daaraan deed niet af dat de aanvrager geen beroep op deze verordening had gedaan. ${ }^{26}$ Gelet op de rangorde van nadeelcompensatiebeleidsregels- en verordeningen spreekt het ten slotte voor zich dat zij niet als materieelrechtelijke grondslag voor toekenning van nadeelcompensatie kunnen dienen als in een wet in formele zin een (uitputtend bedoelde) zelfstandige compensatieregeling is opgenomen. ${ }^{27}$

24 ABRvS 18 december 2008, ECLI:NL:RVS:2008:BG8265, r.o. 2.7; ABRvS 12 november 2003, ECLI:NL:RVS:2003:AN7851, r.o. 2.6 (Prostitutiezone Heerlen/Ontkoppelingsuitspraak); ABRvS 17 juli 2002, ECLI:NL:RVS:2002:AE5401, r.o. 2.5.

25 Zie HR 11 april 2008, ECLI:NL:HR:2008:BC1649, r.o. 3.10 .4 (Zandwinning Maasbommel) onder verwijzing naar het in paragraaf 2.2 besproken arrest HR 28 maart 2008, ECLI:NL:HR:2008:BC0256, r.o.3.4.2(Asha).Zie hierover ook onderdeel 4.33 van de conclusie van A-G Keus bij HR 6 maart 2009, ECLI:NL:HR:2009:BG5051. Zie voorts HR 9 november 2007, ECLI:NL:HR:2007:BB3776 (Planschade Egmond) en de bijbehorende annotatie van Van den Broek in TBR 2008/58.

26 ABRvS 15 juni 2006, ECLI:NL:RVS:2016:1652, r.o. 8 (Supermarkt Haarlem). Zie voor een onder de BnIM 2014 gewezen uitspraak waarin de Afdeling nog een stapje verder lijkt te gaan: ABRvS 13 april 2016, ECLI:NL:RVS:2016:963, r.o. 5.1 (Vereniging Stop Awacs Overlast/Minister van $I \& M)$. Zie ook de bij beide uitspraken behorende annotatie van Tjepkema in $A B$ 2016/365.

27 Vergelijk de beschrijving van het oordeel van de rechtbank in ABRvS 2 juli 2014, ECLI:NL:RVS:2014:2396, r.o. 5 (Dijkverhoging). 
3.2.3 Schaduwschade en het exclusieve karakter van de opsommingen uit de WRO en Wro

De in art. 49 lid 1 WRO en art. 6.1 lid 2 Wro opgesomde schadeoorzaken ont$\operatorname{staan}^{28}$ niet vanuit het niets. $\mathrm{Zij}$ 'werpen hun schaduw vooruit' doordat zij worden voorafgegaan door indicatieve besluitvorming zoals een structuurvisie (art. 2.1 e.v. Wro), voorbereidingsbesluit (art. 3.7 e.v. Wro), of ontwerpbesluit (3.9a e.v. Wro). Los van deze in de wet genoemde - en soms zelfs voorgeschreven - besluiten, kondigt het bestuur vaak ook in informele publicaties aan dat het voornemens is een bepaalde planologische maatregel te treffen. Soms wordt daarmee slechts beoogd om het draagvlak voor de voorgenomen maatregel te polsen. Vaak speelt ook een rol dat uit dit soort informele publicaties - net als uit een structuurvisie, of voorbereidings- of ontwerpbesluit - de voorzienbaarheid kan worden afgeleid die nodig is om een latere aanvraag om tegemoetkoming in planschade die is veroorzaakt door de destijds aangekondigde planologische besluitvorming, af te wijzen wegens risicoaanvaarding. ${ }^{29}$

Aan het hiervoor beschreven geheel van voorbereidende besluiten, informele publicaties en eventuele overige voorbereidingshandelingen zal ik hierna refereren als 'indicatief overheidshandelen'. Dit indicatief overheidshandelen kan zogenoemde schaduwschade teweegbrengen: schade die ontstaat voorafgaand aan de inwerkingtreding van de aangekondigde, in art. 49 lid 1 WRO of art. 6.1 lid 2 Wro opgesomde planologische maatregel(en). ${ }^{30}$ Deze schade komt echter niet in aanmerking voor vergoeding op grond van art. 49 WRO en art. 6.1 Wro. Indicatief overheidshandelen komt immers niet voor in de daarin opgenomen, limitatieve opsommingen van schadeoorzaken. Deze schade kan eveneens niet als gevolg van de bindende planologische maatregel die wel voorkomt in art. 49 lid 1 WRO of art. 6.1 lid 2 Wro aan het bestuur worden toegerekend, omdat de schade voorafgaand aan de inwerkingtreding daarvan is ontstaan. ${ }^{31}$ Dijkshoorn ${ }^{32}$ heeft meermaals betoogd dat een dergelijke toerekening wel mogelijk zou zijn, maar zijn theorie heeft - mijns inziens terecht - geen navolging gevonden in de juridische praktijk en doctrine. ${ }^{33}$ Zo leidt zij bijvoorbeeld tot complexe problemen als compensatie is toegekend naar aanleiding van een planologische maatregel die in indicatieve be-

28 Ter bevordering van de leesbaarheid zal ik ook ten aanzien van art. 49 lid 1 WRO de tegenwoordige tijdsvorm hanteren.

29 Zie nader paragraaf 8.2.

30 In plaats van schaduwschade wordt soms gesproken van 'voorbereidingsschade', zie bijvoorbeeld Van den Broek 2002, p. 134; en Van Ravels 1999, p. 197.

31 ABRvS 28 september 2016, ECLI:NL:RVS:2016:2582, r.o. 3.2 (Overzichtsuitspraak). Zie ook Van Ravels 2009b, p. 110-111; Van den Broek 2002, p. 147-148; en Tjepkema 2010, p. 319-320.

32 Zie Dijkshoorn 2009, p. 105 e.v.; en Dijkshoorn 2011a, p. 33-35.

33 Zie ook Kortmann 2016, p. 167: "Hoewel Dijkshoorn heeft betoogd dat de tekst van artikel 6.1 Wro niet in de weg staat aan toerekening 'met terugwerkende kracht' van schaduwschade aan het nadien genomen planologische besluit, is dat niet de weg die in de rechtspraak en de literatuur tot nu toe is gekozen." 
sluitvorming werd aangekondigd, maar uiteindelijk nooit is doorgevoerd, of wel werd doorgevoerd maar vervolgens werd vernietigd door de bestuursrechter. Er moet dan worden gewerkt met abstracte kunstgrepen ${ }^{34}$ om tot de gewenste uitkomst te komen. ${ }^{35}$

Dat schaduwschade niet voor planschadevergoeding in aanmerking komt, zou geen probleem zijn als zij wel op grond van het ongeschreven égalitébeginsel kon worden vergoed. Aanvankelijk sloot de Afdeling dit expliciet uit. In een uitspraak van 17 juli 2002 oordeelde zij bijvoorbeeld dat een aanvraag om schadevergoeding in de vorm van een buitenwettelijk zuiver schadebesluit terecht was afgewezen omdat "art. 49 WRO een uitputtende regeling geeft voor de vergoeding van schade, veroorzaakt door op de WRO gebaseerd veroorzaakt [sic] bestuursoptreden." ${ }^{\text {"36 }}$ Thans hanteert de Afdeling een formulering die iets meer ruimte lijkt te laten. Vanwege de in paragraaf 3.2.2 besproken jurisprudentie worden de regelingen van art. 49 WRO en afd. 6.1 Wro nog steeds als uitputtend aangemerkt voor schade die als gevolg van in art. 49 lid 1 WRO respectievelijk art. 6.1 lid 2 Wro opgesomde schadeoorzaken aan het gemeentebestuur kan worden toegerekend. In een uitspraak van 31 maart 2004 oordeelde de Afdeling echter dat...

“(...) voor nadeelcompensatie slechts plaats zou kunnen zijn, voorzover appellante schade heeft geleden door andere besluiten dan die welke op grond van artikel 49 van de Wet op de Ruimtelijke Ordening een titel voor schadevergoeding kunnen vormen." ${ }^{37}$

Van Ravels concludeerde in 2012 dat een dergelijke aanspraak bij zijn weten nog nooit was gehonoreerd. ${ }^{38}$ Vandaag de dag zijn mij nog steeds geen voorbeelden daarvan bekend. Ik ga er daarom vanuit dat de opsommingen van art. 49 lid 1 WRO en art. 6.1 lid 2 Wro een exclusief karakter toekomt: schade door handelen gebaseerd op de WRO respectievelijk Wro die niet op grond van de daarin vervatte regelingen in aanmerking komt voor tegemoetkoming, komt dat ook niet op grond van een andere grondslag. ${ }^{39}$ Daarbij neem ik in acht dat de Afdeling steevast overweegt dat...

Van den Broek merkt in haar dissertatie iets vergelijksbaars op omtrent de theorie van Van Zeben waaraan Dijkshoorn inspiratie heeft ontleend. Zie Van den Broek 2002, p. 138: “Zo'n op de redelijkheid gebaseerde fictie wekt in mijn ogen een tamelijk gekunstelde indruk. Het vertroebelt mijns inziens het huidige heldere systeem dat is ontwikkeld in de planschadejurisprudentie." De theorie van Van Zeben wordt beschreven in Van Zeben 1999.

35 Zie daarover - naast de publicaties van Dijkshoorn - bijvoorbeeld ook Schueler 2005, p. 213 en Van der Schans 2004, p. 12-17.

36 ABRvS 17 juli 2002, ECLI:NL:RVS:2002:AE5401, r.o. 2.5.

37 ABRvS 31 maart 2004, ECLI:NL:RVS:2004:AO6524, r.o. 2.6.1.

38 Van Ravels 2012c, p. 101.

39 Van den Broek \& Tjepkema lijken wel enige ruimte voor compensatie op grond van het ongeschreven égalitébeginsel te zien in Van den Broek \& Tjepkema 2015, p. 12-16. 
“(...) voor zover schade als gevolg van een voorbereidingsbesluit tot onbillijkheden leidt, wordt overwogen dat het aan de wetgever is om zo nodig te overwegen en te beslissen of hierin, door wetswijziging, verandering dient te worden gebracht." 40

In een uitspraak van 23 mei 2018 werd ook een beroep op de redelijkheid en billijkheid afgedaan onder vermelding van deze overweging ${ }^{41}$ - na inwerkingtreding van afd. 6.1 Wro is bij mijn weten nog geen beroep op het égalitébeginsel aan de Afdeling voorgelegd. ${ }^{42}$ Het heeft er veel van weg dat ook de civiele rechter niet bereid is om in dit soort gevallen een helpende hand toe te steken. ${ }^{43}$ Wel lijkt in de literatuur enige concencus te bestaan dat gevallen van zeer zware (directe) schaduwschade denkbaar zijn waarin het niet toekennen van compensatie tot een schending van art. 1 EP EVRM zou kunnen leiden. ${ }^{44}$ Bij mijn weten bestaan daarvan echter nog geen praktijkvoorbeelden.

\section{Problemen door de onvergoedbaarheid van schaduwschade}

De aanwezigheid van schaduwschade wordt vooral problematisch als de eigenaar van een onroerende zaak "activiteiten onderneemt waarvoor de (markt)waarde van zijn eigendom relevant is." 45 In het meest extreme geval is een onroerende zaak helemaal niet meer te verkopen door de dreiging die uitgaat van het indicatieve overheidshandelen. ${ }^{46}$ Het komt echter vaker voor dat de aanvrager zijn onroerende zaak wel weet te verkopen voorafgaand aan de inwerkingtreding van de in art. 49 lid 1 WRO of art. 6.1 lid 2 Wro opgesomde schadeoorzaak, maar dan wordt geconfronteerd met de vaste jurisprudentielijn dat...

“(...) onder de criteria voor planschade uitsluitend voor vergoeding in aanmerking kan komen waardevermindering van onroerend goed waarvan de verzoeker eigenaar is ten

40 ABRvS 23 mei 2018, ECLI:NL:RVS:2018:1698, r.o. 5.1. Zie voor vergelijkbare overwegingen ABRvS 17 juli 2002, ECLI:NL:RVS:2002:AE5405, r.o. 2.6.2; en ABRvS 24 februari 2010, ECLI:NL:RVS:2010:BL5383, r.o. 2.4.1. Zie eveneens Van Ravels 2010b, p. 250, voetnoot 39.

41 ABRvS 23 mei 2018, ECLI:NL:RVS:2018:1698, r.o. 5-5.1.

42 Zie voor art. 49 WRO de eerder besproken uitspraak ABRvS 17 juli 2002, ECLI:NL:RVS:2002:AE5401, r.o. 2.5.

43 HR 11 april 2008, ECLI:NL:HR:2008:BC1649, r.o. 3.10 .4 (Zandwinning Maasbommel). Zie hierover ook onderdeel 4.33 van de conclusie van A-G Keus bij HR 6 maart 2009, ECLI:NL:HR:2009:BG5051. Zie voorts HR 9 november 2007, ECLI:NL:HR:2007:BB3776 (Planschade Egmond) en de bijbehorende annotatie van Van den Broek in TBR 2008/58.

44 Zie Van den Broek \& Tjepkema 2015, p. 45-48 voor een bespreking van relevante publicaties.

$45 \quad$ Kortmann 2017, p. 192.

46 Gevangenen van een Tracé 2013, p. 6: "Het is evident dat hun huis - mede gelet op de zwakke huizenmarkt - al die tijd onverkoopbaar is, zodat zij in feite in hun huis gegijzeld zijn en hun toekomstplannen elders niet kunnen verwezenlijken." 
tijde van de peildatum, omdat alleen het vermogen van de eigenaar daardoor rechtstreeks wordt getroffen." ${ }^{47}$

De eigenaar die zijn onroerende zaak wil verkopen, wordt hierdoor als het ware verplicht om daarmee te wachten tot een planologische maatregel als opgesomd in art. 49 lid $1 \mathrm{WRO}$ of art. 6.1 lid 2 Wro in werking is getreden (de peildatum ${ }^{48}$ ), of zijn verlies te nemen door zijn woning tegen een lagere prijs te verkopen. Een redelijk handelend en denkend koper zal namelijk niet bereid zijn het volle pond te betalen, omdat hem actieve risicoaanvaarding zal worden tegengeworpen indien hij na aankoop van de woning een aanvraag om planschadetegemoetkoming indient in geval van schade door de in art. 49 lid 1 WRO of art. 6.1 lid 2 Wro opgesomde, definitieve planologische besluitvorming. ${ }^{49}$ Daarbij is van belang dat aanspraken op planschadetegemoetkoming niet bij wijze van privaatrechtelijke overeenkomst door de verkoper op de volgende eigenaar kunnen worden overgedragen. ${ }^{50}$

Schaduwschade kan nooit de vorm van derving van woongenot aannemen. Indicatief overheidshandelen verandert immers niets aan de fysieke leefomgeving van de aanvrager en legitimeert dergelijke veranderingen ook niet. Om diezelfde reden zal schaduwschade ook minder snel de vorm van inkomensschade aannemen. De consument zal zich bijvoorbeeld niet enkel door de kennis van het voornemen tot realisatie van een energiecentrale ervan laten weerhouden plaats te nemen op een terrasje van een horecagelegenheid. Indicatief overheidshandelen lijkt daarom vooral inkomensschade in de vorm van 'negatieve ontwikkelingsschade' te kunnen veroorzaken. Daaronder wordt schade verstaan die wordt geleden doordat een bedrijf zich niet of slechts verminderd kan ontwikkelen, bijvoorbeeld doordat investeerders terughoudender zullen zijn vanwege het vooruitzicht van de mogelijke komst van een nadelige overheidsmaatregel. ${ }^{51}$ Omdat indicatief overheidshandelen ook een waardedaling van onroerende zaken van het bedrijf kan veroorzaken,

Zie voor art. 6.1 Wro de uitspraken ABRvS 23 mei 2018, ECLI:NL:RVS:2018:1698, r.o. 5.1 en Rb. Gelderland 13 december 2016, ECLI:NL:RBGEL:2016:6639, r.o. 4. Zie voor een tweetal Afdelingsuitspraken onder art. 49 WRO: ABRvS 13 augustus 2008, ECLI:NL:RVS:2008:BD9961, r.o. 2.4.1; en ABRvS 16 maart 2005, ECLI:NL:RVS:2005:AT0554, r.o. 2.6.1.

$48 \quad$ Zie paragraaf 5.7.1.1

49 Zie daarover paragraaf 8.2.1.

50 Deze rechtsregel is in uitspraken inzake art. 6.1 Wro (vooralsnog) slechts terug te vinden in $\mathrm{Rb}$. Gelderland 13 december 2016, ECLI:NL:RBGEL:2016:6639, r.o. 4 en in uitspraken onder art. 49 WRO in ABRvS 13 augustus 2008, ECLI:NL:RVS:2008:BD9961, r.o. 2.4.1. Ik verwacht niet dat dit betekent dat de Afdeling thans een andere mening zou zijn toegedaan. Het ligt veel meer voor de hand dat de 'regel' zo duidelijk is dat de toepassing daarvan in de praktijk niet meer fout gaat, of in ieder geval niet tot in hoger beroep wordt bediscussieerd. Deze term is ontleend aan De Haan 1975, p. 328. 
is eveneens denkbaar dat een geldverstrekker de rente over een hypotheek verhoogt, aanvullend onderpand eist, of geen hypotheek meer verstrekt. ${ }^{52}$

\section{Schaduwschade en de overige geselecteerde, thans geldende regelingen}

Hiervoor beschreef ik hoe de schaduwschadeproblematiek in het planschaderecht wordt veroorzaakt door het exclusieve karakter van de limitatieve opsommingen van schadeoorzaken uit art. 49 lid 1 WRO en art. 6.1 lid 2 Wro. Hierna zal ik in een aparte deelparagraaf zoeken naar verklaringen voor de keuze van de rechterlijke macht om deze opsommingen als exclusief aan te merken en de keuze van de wetgever om daarin geen verandering aan te brengen. Alvorens daartoe over te gaan, sta ik eerst kort stil bij de overige geselecteerde, thans geldende regelingen.

Discussies over schaduwschade en een al dan niet exclusief karakter van de afbakening van de reikwijdte van een nadeelcompensatieregeling doen zich niet voor onder de BnIW 2019 en de Amsterdamse verordeningen. Dat kan worden verklaard door de ruime reikwijdte van de BnIW 2019 en AVN. Indicatief overheidshandelen kan immers onder de noemer van een publiekrechtelijke bevoegdheid of taak worden gebracht. Ook onder de VNNZ doet zich het probleem van schaduwschade niet voor, omdat Amsterdamse nadeelcompensatiegeschillen die niet onder het bereik van deze regeling vallen, worden afgedaan onder de AVN. Bovendien kan als verklaring worden gewezen op het niet-formeelwettelijke karakter van deze regelingen. Uit paragraaf 2.5 volgde immers dat het recht op compensatie op grond van het ongeschreven égalitébeginsel slechts mag worden ingeperkt door de formele wetgever, die daarbij wel de ruime grenzen van art. 1 EP EVRM in acht dient te nemen. Dit brengt mee dat een beroep op het ongeschreven égalitébeginsel kan worden gedaan als schade niet onder het bereik van een nadeelcompensatieverordening of -beleidsregel valt.

De GrS vergroot of verkleint het probleem van schaduwschade niet, maar verplaatst het slechts. Voor zover de GrS bijvoorbeeld de bevoegdheid om planschadevergoeding toe te kennen overdraagt van $B \& W$ aan het algemeen bestuur van het Schadeschap, dienen niet langer B\&W maar de besliscommissie ${ }^{53}$ van het Schadeschap een aanvraag om planschadevergoeding af te wijzen als de gestelde schade (beweerdelijk) werd veroorzaakt door handelen dat niet voorkomt in de opsomming van art. 49 lid 1 WRO. Dit deed zich onder andere voor in een Afdelingsuitspraak van 20 augustus 2003, waarin de schade werd veroorzaakt door de 'PKB Schiphol en omgeving' én de daarin opgenomen veiligheidszones alsmede de (gedeeltelijke) onthouding van goedkeuring aan het bestemmingsplan 'Molen-

52 Zie voor een voorbeeld van de moeilijkheden die een ondernemer kan ondervinden: ABRvS 14 december 2000, ECLI:NL:RVS:2000:AA9544 (Schaduwschade aanwijzing luchtvaartterrein Maastricht). Zie voor een opsomming van relevante literatuur: Van den Broek \& Tjepkema 2015, p. 21, voetnoot 40.

53 Op zijn beurt heeft het algemeen bestuur deze bevoegdheid gedelegeerd aan de besliscommissie, zie paragraaf 2.3.4. 
vliet-Noord 1996' ${ }^{54}$ Hiervoor werd reeds opgemerkt dat zich onder de BnIW 2019 geen schaduwschadeproblematiek voordoet vanwege de brede reikwijdte van deze regeling. Dat is niet anders als deze regeling de achterliggende grondslag vormt om compensatie toe te kennen onder de GrS. Ook onder art. 21 Aanwijzingsbesluit 1996 zal zich geen schaduwschadeproblematiek voordoen. Die regeling is namelijk van toepassing op alle schade die het Aanwijzingsbesluit 1996 veroorzaakt. Voor zover mij bekend, heeft zich ook onder art. 8.31 Wlv geen discussie omtrent schaduwschade voorgedaan.

\subsubsection{Op het planschaderecht toegespitste verklaringen}

\section{Keuze van de rechter}

Waarom wordt in de rechtspraak exclusieve werking toegekend aan de planschaderegelingen van de WRO en Wro? De Afdeling lijkt de vraag naar exclusieve werking bij andere formeelwettelijke compensatieregelingen te beantwoorden aan de hand van de inhoud en totstandkomingsgeschiedenis van de desbetreffende regeling. ${ }^{55}$ Van Ravels droeg in 1999 al aan dat uit de wetsgeschiedenis van art. 49 WRO mogelijk moet worden geconcludeerd dat art. 49 WRO een uitputtende regeling bood voor schade door op de WRO gebaseerd bestuursoptreden. Gedurende het wetgevingsproces ter uitbreiding van de reikwijdte van art. $49 \mathrm{WRO}^{56}$ is namelijk uitvoerig gedebatteerd over de vraag welke besluiten in de limitatieve opsomming van art. 49 lid $1 \mathrm{WRO}$ moesten worden opgenomen. ${ }^{57}$ In het verlengde daarvan kan worden opgemerkt dat de schaduwschadeproblematiek destijds met name door Tweede Kamerleden Eversdijk en Te Veldhuis onder de aandacht is gebracht van de toenmalig minister van Volkshuisvesting, Ruimtelijke ordening en Milieubeheer. Het debat spitste zich toen vooral toe op de vraag of er een wettelijke regeling voor de vergoeding van schaduwschade moest komen. De minister vond de problematiek te complex om "en passant" te kunnen oplossen. Daarom werd in 1984 aan de kamer een notitie beloofd waarin zou worden ingegaan op voor- en nadelen van 'schaduwregelingen' ${ }^{58}$ De komst van deze notitie is meermaals uitgesteld en lijkt na 1987 in de vergetelheid te zijn geraakt. ${ }^{59}$

54 ABRvS 20 augustus 2003, ECLI:NL:RVS:2003:AI1217, r.o. 2.5.3. Deze besluiten vormden de vooraankondiging van een groot aantal planologische maatregelen die wel onder de reikwijdte van art. 49 WRO vielen.

55 ABRvS 24 maart 2004, ECLI:NL:RVS:2004:AO6051, r.o. 2.6 .4 (Infiltratieschade Leiduin).

56 Zie paragraaf 3.2.1. De reikwijdte van art. 49 WRO was oorspronkelijk beperkt tot schade "ten gevolge van de bepalingen van een bestemmingsplan".

57 Van Ravels 1999, p. 208.

58 Handelingen II 1983/84, p. 3821-3825.

59 De notitie wordt voor het laatst genoemd in Kamerstukken II 1987/88, 20 201, nr. $1-2$, p. 10 . 
Ten tijde van de totstandkoming van de limitatieve opsomming van art. 49 lid 1 WRO bestond er nog geen reden voor de wetgever om zich uit te laten over de exclusiviteit van de planschaderegeling. De constructie van het onzuiver schadebesluit werd immers pas in 1982 geïntroduceerd door de bestuursrechter, en de constructie van het op het ongeschreven égalitébeginsel gegronde zuiver schadebesluit pas in $1997 .{ }^{60}$ Ten tijde van de totstandkoming van de Wro had de wetgever echter alle reden zich uit te laten over de exclusiviteit van afd. 6.1 Wro. Desondanks is destijds slechts aangegeven dat geen regeling inzake schaduwschade in de Wro zou worden opgenomen omdat de wetgever van mening was dat deze problematiek niet eigen is aan planologische besluitvorming. Schaduwschadeproblematiek is in die visie verwant aan schadevergoeding bij rechtmatige (overheids) handelingen in het algemeen. ${ }^{61}$ Gelet op de omvang van de schaduwschadeproblematiek lijkt het weinig waarschijnlijk dat de wetgever destijds niet zou hebben opgemerkt dat schade door op de Wro gebaseerd overheidshandelen dat niet in art. 6.1 lid 2 Wro is opgesomd wel voor vergoeding in aanmerking zou komen op grond van het ongeschreven égalitébeginsel, als hij geen exclusieve werking van afd. 6.1 Wro zou hebben beoogd. ${ }^{62}$ Dit zal ook de Afdeling niet zijn ontgaan.

\section{Keuze van de wetgever}

Uit paragraaf 3.2.1 bleek dat in art. 49 lid 1 WRO en art. 6.1 lid 2 Wro slechts planologische besluiten zijn opgenomen die zowel het bestuur als de burger binden en/of inhoudelijk dermate concreet zijn dat de gevolgen van het besluit en het moment van inwerkingtreding voldoende bepaalbaar zijn. ${ }^{63}$ Waarom zou de wetgever het recht op schadevergoeding voor schade door op de WRO respectievelijk de Wro gebaseerd overheidshandelen willen beperken tot schade door dit soort definitieve besluitvorming? Hoewel dat nooit door de desbetreffende formele wetgevers is geëxpliciteerd, lijkt het waarschijnlijk dat op deze manier werd beoogd het systeem hanteerbaar te houden. Zeker in het ruimtelijke ordeningsrecht lijkt behoefte aan opsommingen met een exclusief karakter te bestaan, omdat binnen dit rechtsgebied veel wordt gewerkt met getrapte besluitvorming en de publicatie van beleidsvoornemens.

Kortmann heeft in 2017 beschreven hoe de waardedaling van een onroerende zaak niet statisch is in die zin dat zij pas op het moment van inwerkingtreding van de

60 Zie paragraaf 2.2 voor de bespreking van ARRvS 12 januari 1982, ECLI:NL:RVS:1982:AM7845 (Paul Krugerbrug I) respectievelijk ABRvS 18 februari 1997, ECLI:NL:RVS:1997:ZF2587 (Beurskens) en ABRvS 6 mei 1997, ECLI:NL:RVS:1997:AA6762 (Van Vlodrop).

61 Kamerstukken II 2002/03, 28 916, nr. 3, p. 66 (MvT, Wro).

62 Zie voor een vergelijkbare redenering het vierde onderdeel van de annotatie van A.R. Neerhof bij ABRvS 17 juli 2002, ECLI:NL:RVS:2002:AE5401 in $A B$ 2002/395.

63 Zie Van Ravels 2013b, p. 8; Van den Broek 2002, p. 22-23 en 140; en Van Ravels 1999, p. 209-211. 
definitieve planologische besluitvorming ontstaat en altijd dezelfde omvang heeft. Er is juist sprake van een dynamische waardeontwikkeling gedurende een bepaald tijdvak. Dat tijdvak vangt aan op het moment "waarop voor het eerst sprake is van een waardedrukkend effect door een aangekondigd overheidsbesluit". De 'einddatum' is het moment waarop de schade volledig is uitgekristalliseerd. Bij directe schade is dat het moment van inwerkingtreding van de definitieve planologische maatregel en bij indirecte schade het moment waarop de nieuwe mogelijkheden van de definitieve planologische maatregel daadwerkelijk zijn benut. ${ }^{64}$

Als ook schade door indicatief overheidshandelen - zoals een structuurvisie - voor compensatie in aanmerking zou komen, dan bestaat het risico op overcompensatie en ondercompensatie. ${ }^{65}$ Overcompensatie zal zich voordoen als de definitieve besluitvorming minder ingrijpend is - en daardoor een kleiner waardedrukkend effect heeft - dan de aangekondigde besluitvorming, of in zijn geheel wordt afgezien van deze besluitvorming. De aanvrager die direct na de vergoeding naar aanleiding van de structuurvisie verkoopt, krijgt niet meer compensatie dan de waardevermindering die hij destijds ondervond. Kortmann spreekt daarom niet van overcompensatie. Ik kies ervoor dat wel te doen omdat ik niet redeneer vanuit het perspectief van de individuele rechthebbende, maar vanuit het perspectief van het bestuursorgaan dat meer vergoeding zal moeten toekennen dan wanneer zou zijn gewacht tot de einddatum. ${ }^{66}$

Ondercompensatie duidt erop dat de benadeelde minder schade vergoed krijgt dan hij uiteindelijk blijkt te lijden. Dit kan zich voordoen als de definitieve besluitvorming ingrijpender is - en daardoor een groter waardedrukkend effect heeft - dan de aangekondigde besluitvorming. Tenzij de aanvrager zijn onroerende zaak direct na de vergoeding wegens de structuurvisie verkoopt, ${ }^{67}$ zal hij een nieuwe aanvraag om compensatie indienen als na de structuurvisie bijvoorbeeld een voorbereidingsbesluit wordt genomen dat een ingrijpendere wijziging van het geldende bestemmingsplan aankondigt, en weer een aanvraag als de definitieve wijziging van het bestemmingsplan nog ingrijpender blijkt. Het herhaaldelijk indienen van aanvragen trekt zijn wissel op de bestuurslasten en is in strijd met wat Kortmann het 'integratieprincipe' noemt. Daaronder verstaat hij de praktische noodzaak om alle waardeveranderingen op een goed gekozen moment te compenseren als "één waardeverandering per saldo over het gehele tijdvak." ${ }^{68}$

65 Kortmann 2017, p. 192-193. Kortmann spreekt dan van vergoeding voor de peildatum.

66 Kortmann 2017, p. 191.

67 De kopende partij komt vervolgens niet voor compensatie in aanmerking, omdat haar naar huidig recht actieve risicoaanvaarding kan worden tegengeworpen. Zie daarover paragraaf 8.2.1. 
Door in art. 49 lid 1 WRO en art. 6.1 lid 2 Wro slechts definitieve besluitvorming op te sommen, heeft de wetgever ervoor gezorgd dat het bestuur ineens kan afrekenen met gelaedeerden. Tevens worden allerlei ingewikkelde vragen over causaliteit en de begrootbaarheid van schade vermeden. ${ }^{69}$ Uit paragraaf 4.2.3.1 zal blijken dat de vraag of de aanvrager door deze besluitvorming in een nadeligere positie is komen te verkeren, wordt beantwoord aan de hand van een vergelijking van de maximale planologische mogelijkheden van het nieuwe en het oude planologische regime: er mocht bijvoorbeeld voorheen een dakkapel op een woning worden aangebracht en onder het nieuwe regime is die mogelijkheid komen te vervallen. Dergelijke verslechteringen laten zich relatief eenvoudig uitdrukken in een waardedaling van de desbetreffende woning. Bovendien bestaat er door deze vergelijkingsmethodiek geen risico op ondercompensatie. Er wordt immers een vergoeding toegekend voor alle planologische mogelijkheden waarmee de aanvrager kan worden geconfronteerd op grond van het nieuwe planologische regime. Een veel gehoorde klacht van het bestuur betreft echter het risico op overcompensatie bij indirecte schade. ${ }^{70}$ Inherent aan deze vergelijkingssystematiek is namelijk dat ook vergoeding wordt toegekend voor planologische mogelijkheden die het nieuwe planologische regime in theorie biedt, maar waarvan in de praktijk (waarschijnlijk) nooit gebruik zal worden gemaakt. Mochten op een naburig perceel bijvoorbeeld onder het oude regime slechts drie bouwlagen worden aangebracht en onder het nieuwe regime tien bouwlagen, dan wordt het onevenredige deel vergoed van de schade die correspondeert met de mogelijkheid om zeven aanvullende bouwlagen aan te brengen, ook als daarvan niet of slechts beperkt gebruik zal worden gemaakt. ${ }^{71}$

De wetgever had het risico op overcompensatie kunnen voorkomen door het moment van vergoeding van indirecte planschade uit te stellen tot het moment waarop daadwerkelijk wordt gebruikgemaakt van een nieuwe planmogelijkheid op een naburig perceel (de einddatum). Dat hij dit destijds niet heeft gedaan, kan waarschijnlijk worden verklaard door wat Kortmann bestempelt als het 'integratieprincipe' ${ }^{72}$ Inherent aan de keuze om de vergoeding van indirecte schade uit te stellen tot de einddatum zou immers zijn dat bij iedere benutting van een nieuwe planmogelijkheid een afzonderlijke aanvraag om planschadevergoeding zou kunnen worden ingediend. Dat zou niet alleen leiden tot een verhoging van administratieve bestuurslasten, maar bijvoorbeeld ook meebrengen dat de thans gebezigde verjaringssystematiek zou moeten worden herzien.

De wetgever heeft het risico op overcompensatie desalniettemin enigszins proberen te verkleinen. Op grond van art. 3.6 Wro kunnen in een bestemmingsplan bepalingen worden opgenomen die het $\mathrm{B} \& \mathrm{~W}$ toestaan om het plan binnen be-

69 Dergelijke vragen worden onder andere besproken in Van Ravels $2013 \mathrm{~b}$.

70 Zie bijvoorbeeld Van Ravels 2012a, p. 117; Van Ravels 2011c, p. 134-135; en Van Ettekoven 2011, p. 12-13, 15 en 17.

71 Zie hierover ook Huijts \& Backes 2015, p. 138.

72 Kortmann 2017, p. 191-192. 
paalde grenzen te wijzigen; van dat plan af te wijken bij omgevingsvergunning; ten aanzien van in het plan omschreven onderwerpen of onderdelen nadere eisen te stellen; of verplichten het plan uit te werken. In art. 6.1 lid 2, aanhef en onder a Wro wordt bepaald dat alle bepalingen van een bestemmingsplan, behalve deze zogenoemde 'flexibiliteitsbepalingen' (ook wel: 'flexbepalingen') ${ }^{73}$ als schadeoorzaak in de zin van art. 6.1 lid 1 Wro worden aangemerkt. Uit art. 6.1 lid 2 jo. lid 6 Wro blijkt dat het besluit waarmee toepassing wordt gegeven aan een flexbepaling wel als schadeoorzaak wordt aangemerkt. ${ }^{74}$ Dit heeft bijvoorbeeld tot gevolg dat een in het nieuwe bestemmingsplan opgenomen binnenplanse afwijkingsbevoegdheid om een omgevingsvergunning voor een activiteit als bedoeld in art. 2.1 lid 1, aanhef en onder $\mathrm{b}, \mathrm{c}$ of $\mathrm{g} \mathrm{Wabo}^{75}$ te verlenen niet tot schadevergoeding kan leiden, maar de daadwerkelijke verlening van die vergunning wel. De wetgever heeft geexpliciteerd dat hiermee wordt beoogd slechts de "werkelijke schade" in plaats van "theoretische schade" te vergoeden. ${ }^{76}$

\section{3}

\section{DEELVRAAG 3: HET TOEKOMSTIGE RECHT}

Ter beantwoording van de derde deelvraag zal ik in deze paragraaf onderzoeken hoe de wetgever de reikwijdte afbakent van titel 4.5 Awb (paragraaf 3.3.1) en afd. 15.1 Ow (paragraaf 3.3.2). In paragraaf 3.3.3 zal ik de beantwoording van deze deelvraag afsluiten door schematisch weer te geven welke regeling wanneer kan worden aangewend als grondslag voor toekenning van nadeelcompensatie.

\subsubsection{De reikwijdte van titel 4.5 Awb}

Ingevolge art. 4:126 lid $1 \mathrm{Awb}$ is titel 4.5 Awb slechts van toepassing indien de schade wordt veroorzaakt door een bestuursorgaan in de rechtmatige uitoefening van zijn publiekrechtelijke bevoegdheid of taak. Schadeveroorzakend handelen door niet-bestuursorganen valt dus niet binnen de reikwijdte van titel 4.5 Awb. Dat betekent onder andere dat schade veroorzaakt door formele wetten niet in aanmerking komt voor vergoeding op grond van deze titel (vergelijk art. 1:1 lid 2 Awb). De vraag of compensatie gepast is, zal door de formele wetgever worden meegenomen bij de totstandkoming van de formele wet in kwestie. Tevens kan in bepaalde gevallen via de civiele rechter een vergoeding op grond van art. $1 \mathrm{EP}$ EVRM worden afgedwongen. Een verdere beperking van de reikwijdte volgt uit art. 1:6, aanhef en onder a Awb. Deze bepaling sluit de hoofdstukken $2 \mathrm{t} / \mathrm{m} 8$ en 10 - en dus ook titel 4.5 Awb - uit van toepassing op de opsporing en vervolging van

73 Zie over deze bepalingen ook paragraaf 4.2.3.1.

74 Zie omtrent de omgang met flexbepalingen onder de WRO Van Ravels 2009b, p. 105-106; en Van den Broek 2013b, p. 82-87.

75 Kort gezegd: een omgevingsvergunning voor het uitvoeren van een werk, geen bouwwerk zijnde, of van werkzaamheden, óf het gebruiken van gronden of bouwwerken in strijd met een bestemmingsplan, óf het slopen van een bouwwerk.

76 Kamerstukken II, 2011/12, 33 135, nr. 3, p. 14 (MvT, Wet tot wijziging van de Crisis- en herstelwet). 
strafbare feiten, alsmede de tenuitvoerlegging van strafrechtelijke beslissingen. In bepaalde gevallen zal het strafrecht zelf mogelijkheden tot compensatie bieden, bijvoorbeeld op grond van art. 89 Wetboek van Strafvordering. Voor de overige strafvorderlijke gevallen kan de benadeelde een beroep doen op de civiele rechter als restrechter. ${ }^{77}$

\section{Rechtmatigheid}

Titel 4.5 Awb kan alleen tot nadeelcompensatie nopen indien het schadeveroorzakende overheidshandelen rechtmatig is. Indien het bestuur een aanvraag om schadevergoeding ontvangt, terwijl niet duidelijk is of deze aanvraag is gestoeld op art. 6:162 BW dan wel art. 4:126 Awb, zal het bestuur "zich van de bedoeling van de aanvrager moeten vergewissen". Vervolgens zal de aanvrager eventueel naar de te volgen juridische procedure moeten worden verwezen. Hoewel de Kamerstukken niet uitblinken in duidelijkheid, kan daaruit worden opgemaakt dat het bestuur wel het verweer mag voeren dat het schadeveroorzakende handelen onrechtmatig was, maar de wetgever ervan uitgaat dat zich dit in de praktijk niet zal voordoen. Het bestuur zou zich door erkenning van de onrechtmatigheid immers blootstellen aan een groter aansprakelijkheidsrisico. Anders dan het égalitébeginsel, verplicht art. 6:162 BW namelijk ook tot vergoeding van het niet-onevenredige deel van de schade. ${ }^{78}$

\section{Een publiekrechtelijke taak}

De Afdeling bestuursrechtspraak van de Raad van State deed in haar reactie op het voortonwerp van de Wns een oproep aan de wetgever om "zo duidelijk mogelijk" uiteen te zetten wat onder de uitoefening van een publiekrechtelijke taak dient te worden verstaan. Op de jurisprudentie over het publieke taak-criterium zou niet zonder meer kunnen worden teruggevallen, omdat zij primair ziet op de vraag wanneer een schriftelijk handeling van een bestuursorgaan als besluit kan worden aangemerkt bij absentie van een grondslag in een publiekrechtelijke wet. ${ }^{79}$ Als namens de wegbeheerder wegwerkzaamheden worden uitgevoerd, is duidelijk dat sprake is van een publiekrechtelijke taak. Daarvan is duidelijk geen sprake als de wegbeheerder een overeenkomst sluit voor de aankoop van apparatuur. De Afdeling vraagt zich echter af onder welke voorwaarden het "sluiten van een overeenkomst met duidelijk publiekrechtelijke trekken” zou kunnen worden

77 Zie in algemene zin Kamerstukken II 2010/11, 32 621, nr. 3, p. 14 (MvT, Wns). Zie ook de daarin opgenomen verwijzingen naar HR 30 maart 2001, ECLI:NL:HR:2001:AB0801 (Staat/Lavrijsen) en HR 18 november 2005, ECLI:NL:HR:2005:AT7755 (Politieregio Amsterdam-Amstelland).

78 Zie Kamerstukken II 2010/11, 32 621, nr. 3, p. 17 (MvT, Wns); en Kamerstukken II 2010/11, 32 621, nr. 6, p. 14 (NV II, Wns).

79 Overigens is ook het begrip 'publieke taak' niet scherp omlijnd. Zie bijvoorbeeld Peters 2017 over de "ledigheid van de publieke taak". 
aangemerkt als de uitoefening van een publiekrechtelijke taak ${ }^{80}$ Daarbij worden geen voorbeelden gegeven, maar ik neem aan dat bijvoorbeeld wordt gedoeld op (de rechtmatige eenzijdige opzegging van) een bevoegdhedenovereenkomst, of andere overeenkomsten met een gemengd karakter. ${ }^{81}$ Naar aanleiding van de reactie van de Afdeling heeft Tjepkema de vraag gesteld hoe moet worden aangekeken tegen privaatrechtelijk overheidsoptreden. ${ }^{82}$

De wetgever heeft (in eerste instantie) geen gehoor gegeven aan de oproep van de Afdeling. ${ }^{83}$ Net als uit de toelichting op het voorontwerp voor de Wns, blijkt uit de memorie van toelichting behorende bij de $\mathrm{Wns}^{84}$ namelijk slechts dat de formule van de publiekrechtelijke bevoegdheid of taak meebrengt dat in beginsel zowel schade door rechtmatige besluitvorming als schade door rechtmatige feitelijke handelingen onder de reikwijdte van titel 4.5 Awb valt. Hierdoor zou ook om nadeelcompensatie kunnen worden verzocht "in verband met een samenhangend geheel aan overheidshandelingen die schade veroorzaken en dat deels bestaat uit besluiten en deels uit feitelijke handelingen." Uiteindelijk wordt geconcludeerd dat rechtmatige feitelijke handelingen, beschikkingen, besluiten van algemene strekking, beleidsregels en algemeen verbindende voorschriften onder de reikwijdte van titel 4.5 Awb vallen. ${ }^{85}$ Uit de memorie van antwoord blijkt echter wel dat schade door de rechtmatige beëindiging van een bevoegdheden- of beleidsovereenkomst niet onder de reikwijdte van titel 4.5 Awb valt. Of zij voor vergoeding in aanmerking komt, moet worden beoordeeld aan de hand van het civielrechtelijke overeenkomstenrecht. ${ }^{86}$

In het voorlopig verslag wordt verder nog vermeld dat de terminologie van art. 4:126 Awb is geïnspireerd op de RnVW 1999. Beoogd is aan te geven dat niet alleen rechtmatige besluitvorming, maar ook ander rechtmatig handelen dat niet op een besluit in de zin van art. 1:3 Awb berust, een schadeoorzaak is die binnen de reikwijdte van titel 4.5 Awb valt. Als voorbeeld van dergelijk handelen wordt het doorsteken van een dijk in verband met extreem zware regenval genoemd. ${ }^{87}$ Dat niet alleen feitelijk handelen dat accessoir is aan een besluit maar ook zelfstandig feitelijk handelen als uitoefening van een publiekrechtelijke taak

80 Zie de eerste twee pagina's van het als bijlage 99930 bij Kamerstukken II 2010/11, 32 621, nr. 3 (MvT, Wns) gepubliceerde advies van de ABRvS.

81 Zie bijvoorbeeld ook Bierens de Haan 2014 over vaststellingsovereenkomsten met de fiscus voorafgaand aan de invoering van art. 64 AWR.

82 Zie Tjepkema 2010, p. 880-882; en Tjepkema 2011, p. 1376-1379.

83 Zie voor een vergelijkbare constatering, en een ook overigens zeer lezenswaardig stuk over deze materie Van den Broek 2011, p. 986-987.

84 Kamerstukken II 2010/11, 32 621, nr. 3, p. 14-15 (MvT, Wns).

85 Voorontwerp Wns, p. 17-18.

86 Kamerstukken I 2012/13, 32 621, nr. C, p. 2 (MvA I, Wns).

87 Zie voor de vraagstelling Kamerstukken I 2011/12, 32 621, nr. B, p. 2 (VV I, Wns). Zie voor het antwoord Kamerstukken I 2012/13, 32 621, nr. C, p. 2 (MvA I, Wns), waarin wordt verwezen naar ABRvS 23 juli 2003, ECLI:NL:RVS:2003:AI0248. 
kan kwalificeren, ${ }^{88}$ kon ook al worden afgeleid uit de opname van art. 8:2a Awb in het oorspronkelijke regeringsvoorstel voor de Wns. ${ }^{89}$ Deze bepaling codificeerde namelijk de eis van processuele connexiteit, maar maakte daarop onder andere een uitzondering voor schade "veroorzaakt door een handeling ter uitvoering van een besluit waartegen beroep bij de bestuursrechter kan worden ingesteld." 90 Dat was niet nodig geweest als de publiekrechtelijke taak van oorsprong al beperkt zou zijn tot zelfstandig feitelijk handelen.

Van den Broek stelde in 2011 dat de bestuursrechter in zijn nadeelcompensatiejurisprudentie "een eigen invulling [zal] moeten geven aan het begrip 'uitoefening van een publiekrechtelijke taak'." Gelet op het voorafgaande lijkt mij dat een terechte constatering. Ik verwacht niet dat dit de bestuursrechter voor onoverkomelijke problemen zal stellen, aangezien hij die invulling ook al moet geven sinds de invoering van de RnVW 1999. Zo oordeelde de Afdeling bijvoorbeeld in de Uptown-uitspraak dat de plaatsing van een geluidsscherm kon worden aangemerkt als de uitoefening van de publiekrechtelijke taak door Rijkswaterstaat om als wegbeheerder bij het wijzigen, aanleggen en het dagelijks beheer van rijkswegen erop toe te zien dat het geluid binnen de wettelijk gestelde grenzen blijft. ${ }^{91}$

\section{Limitatieve opsommingen van schadeoorzaken niet langer toegestaan?}

In de bij de Wns behorende memorie van toelichting zijn enkele opmerkingen te vinden die een uitwerking vormen van het in paragraaf 2.4.2.2 beschreven uitgangspunt van het uitsluitend codificeren van het égalitébeginsel. In algemene zin wordt aangegeven dat de ruime reikwijdte van titel 4.5 Awb meebrengt dat "de in sommige thans geldende wetten en beleidsregels gevolgde systematiek, waarbij een limitatieve opsomming wordt gegeven van schadeoorzaken die aanleiding kunnen vormen voor nadeelcompensatie, onder de nieuwe regeling niet meer mogelijk" zal zijn. ${ }^{92}$ Dit wordt in het bijzonder benadrukt voor de limitatieve opsomming van art. 6.1 lid 2 Wro:

"De voorwaarden voor toekenning van planschade vallen blijkens de memorie van toelichting van de Wro (Kamerstukken II 2002/03, 28 916, nr.3, blz. $62-63$ in belangrijke mate samen met de voorwaarden voor toekenning van schadevergoeding op grond van het égalitébeginsel. Het is dan ook gewenst de regeling van de planschade in lijn te

88 Zie over dit onderscheid Van der Meulen 1991, p. 267. Ook Tjepkema spreekt onder verwijzing naar Van der Meulen van dit onderscheid, zie Tjepkema 2010, p. 223.

89 Kamerstukken II 2011/12, 32 621, nr. 11 (Amendement Taverne c.s.). Zie voor kritiek op deze bepaling bijvoorbeeld Van Ettekoven, Van Ravels \& Tjepkema 2011, p. 58; Van den Broek 2011, p. 987; en Kamerstukken II 2010/11, 32 621, nr. 4, p. 2-3 (RvS, Wns).

90 Kamerstukken I 2012/13, 32 621, nr. 2, art. 1, onderdeel B (Wetsvoorstel, Wns).

91 ABRvS 16 november 2016, ECLI:NL:RVS:2016:3047, r.o. 7 (Uptown).

92 Kamerstukken II 2010/11, 32 621, nr. 3, p. 14-15 (MvT, Wns). 
brengen met de voorgestelde nieuwe bepalingen in de Awb. Nu in een algemene grondslag voor schadevergoeding terzake van rechtmatig overheidsoptreden wordt voorzien, behoort het verschil dat de Wro maakt tussen schadeoorzaken die wel onder de planschade regeling vallen - wel tegemoetkoming in de schade - en gevallen die daarbuiten vallen - geen tegemoetkoming - te verdwijnen. De algemene grondslag betekent immers dat er aanspraak bestaat op vergoeding van schade steeds indien het égalitébeginsel daartoe noopt, ongeacht de oorzaak van de schade." ${ }^{93}$

Uit het voorafgaande kan niet worden afgeleid dat de wetgever beoogt dat na inwerkingtreding van titel 4.5 Awb helemaal geen gebruik meer zal worden gemaakt van limitatieve opsommingen van schadeoorzaken. Integendeel zelfs: in paragraaf 2.4.2.1 ${ }^{94}$ bleek dat de wetgever het belang benadrukt van wetsinterpreterende (beleids)regels voor grote aantallen op elkaar gelijkende gevallen. Vaststelling van dergelijke (beleids)regels zal dikwijls slechts realiseerbaar zijn door met behulp van een limitatieve opsomming van schadeoorzaken aan te geven op welke categorie gevallen de desbetreffende (beleids)regel van toepassing is. Uit de aangehaalde citaten kan echter wel worden afgeleid dat dergelijke limitatieve opsommingen geen exclusief karakter mogen hebben: titel 4.5 Awb geeft steeds aanspraak op nadeelcompensatie "indien het égalitébeginsel daartoe noopt, ongeacht de oorzaak van de schade."

Hoewel het afzien van limitatieve opsommingen met een exclusief karakter een einde zou maken aan de onvergoedbaarheid van schaduwschade, lijkt dat niet iets te zijn geweest dat de wetgever destijds expliciet voor ogen stond. Het woord 'schaduwschade' komt namelijk geen enkele keer voor in de bij de Wns behorende Kamerstukken. Evenmin is in die Kamerstukken aandacht geschonken aan de praktische problemen die mogelijk zullen ontstaan als voor het gehele nadeelcompensatierecht zou worden afgezien van limitatieve opsommingen met een exclusief karakter. ${ }^{95}$

\subsubsection{De reikwijdte van afd. $15.1 \mathrm{Ow}$}

\subsubsection{Behoud van een limitatieve, exclusieve opsomming}

Het huidige kabinet blijkt het standpunt van de wetgever ten tijde van de totstandkoming van de Wns niet te delen. De reikwijdte van afd. 15.1 Ow wordt namelijk afgebakend door middel van een limitatieve, exclusieve opsomming van schadeoorzaken. Volgens art. 15.1 lid 1 Ow komt slechts schade voor compensatie in aanmerking die wordt veroorzaakt door de rechtmatige uitoefening van een publiekrechtelijke bevoegdheid of taak op grond van de Ow. Die rechtmatige uitoefening dient te bestaan uit "het vaststellen, verlenen, stellen, treffen of, voor zover van toepassing, wijzigen of intrekken" van de limitatief onder a t/m n opge- 
somde besluiten. Bij het opstellen van deze opsomming is leidend geweest dat de daarin vervatte besluiten en maatregelen "rechten of verplichtingen voor burgers of bedrijven kunnen bevatten, of (...) rechtstreeks gevolgen voor hen kunnen hebben door wijziging van de fysieke leefomgeving." ${ }^{96}$ De gedachte is dat besluiten die dat niet doen, zoals een omgevingsvisie of een instructieregel van Rijk of een provincie, na een "integrale afweging" worden verwerkt in het omgevingsplan. ${ }^{97}$

Het kabinet heeft expliciet aangegeven dat de opsomming van schadeoorzaken van art. 15.1 Ow "limitatief en exclusief" is ten opzichte van titel 4.5 Awb. Als overheidshandelen gebaseerd op de Ow schade veroorzaakt terwijl dat handelen niet wordt genoemd in de opsomming van art. 15.1 lid $1 \mathrm{Ow}$, kan geen vergoeding op grond van titel $4.5 \mathrm{Awb}$ worden verkregen. ${ }^{98}$ Het kabinet erkent expliciet dat het probleem van onvergoedbare schaduwschade hierdoor ook onder het toekomstige recht van afd. $15.1 \mathrm{Ow}$ zal bestaan..$^{99}$ Uit zowel de memorie van toelichting als de nota naar aanleiding van het verslag blijkt namelijk dat de opsomming van artikel 15.1 lid $1 \mathrm{Ow}$ "betekent dat de voorbereiding van een activiteit of besluit die zijn «schaduw vooruitwerpt» op de waarde van een onroerende zaak niet voor vergoeding in aanmerking komt." 100 In combinatie met de opmerking uit de memorie van toelichting dat "grosso modo" de systematiek van de Wro wordt gevolgd, ${ }^{101} \mathrm{kom}$ ik tot de conclusie dat daadwerkelijk een exclusief karakter als beschreven in paragraaf 3.2.3 is bedoeld. Ik ga daarom ervan uit dat in dit soort gevallen een beroep op ongeschreven égalité ${ }^{102}$ via de band van art. 6:162 BW bij de civiele rechter eveneens geen succesvolle route voor compensatie zal zijn. ${ }^{103}$

96 Deze opsomming is reeds, en zal mogelijk nog worden, aangevuld met schadeoorzaken die aan dit criterium voldoen. Zie daarover Kamerstukken II 2018/19, 34 986, nr. 8, p. 18 (nota van wijziging, IOw) respectievelijk Kamerstukken II 2018/19, 34 986, nr. 3, p. 231-232 (MvT, IOw).

97 Kamerstukken II 2018/19, 34 986, nr. 3, p. 18, 21-22, 225-226 en 230 (MvT, IOw).

98 Hierbij verwijst het kabinet naar ABRvS 2 november 2011, ECLI:NL:RVS:2011:BU3111. Ik neem aan dat wordt gedoeld op r.o. 2.3.1. Daarin overweegt de Afdeling dat voor tegemoetkoming in planschade buiten de in art. 6.1 lid 2 Wro opgesomde gevallen geen plaats is. Zie Kamerstukken II 2018/19, 34 986, nr. 3, p. 22 en 226 (MvT, IOw)

99 Zie Kamerstukken II 2018/19, 34 986, nr. 3, p. 22-23 (MvT, IOw); en Kamerstukken II 2018/19, 34 986, nr. 7, p. 27-28 (NV II, IOw).

100 Het citaat is afkomstig uit Kamerstukken II 2018/19, 34 986, nr. 7, p. 27 (NV II, IOw). Een opmerking van vergelijkbare strekking is te vinden in Kamerstukken II 2018/19, 34 986, nr. 3, p. 30 (MvT, IOw).

101 Kamerstukken II 2018/19, 34 986, nr. 3, p. 226 (MvT, IOw).

102 Een succesvol beroep op art. 1 EP EVRM kan in gevallen van zeer zware (directe) schaduwschade niet worden uitgesloten. Zie daarover paragraaf 3.2.3 onder verwijzing naar Van den Broek \& Tjepkema 2015, p. 45-48.

103 Van den Broek en Tjepkema lijken wel ruimte voor een claim bij de burgerlijke rechter te zien. Zie Van den Broek \& Tjepkema 2017, p. 26. 


\subsubsection{Argumenten van het kabinet voor behoud van een limitatieve, exclusieve opsomming}

In paragraaf 3.3.2.1 bleek dat het kabinet zich ervan bewust is dat de keuze voor een limitatieve en exclusieve opsomming tot gevolg heeft dat de schaduwschadeproblematiek onder afd. 15.1 Ow zal blijven bestaan. Het kabinet kiest toch voor een dergelijke opsomming omdat het van mening is dat de brede reikwijdte van titel 4.5 Awb niet past bij (1) de verbeterdoelen van de stelselherziening die de Omgevingswet teweeg moet brengen; (2) het instrumentarium van de Omgevingswet; en (3) bij keuzes die zijn gemaakt over de verdeling van taken en bevoegdheden over Rijk, provincie, waterschap en gemeente. Ter onderbouwing hiervan wordt gewezen op het getrapte karakter van op de Ow gebaseerde besluitvorming. Wanneer geen exclusieve opsomming in art. 15.1 Ow zou worden opgenomen, zou de brede reikwijdte van titel 4.5 Awb meebrengen dat op ieder moment in dat besluitvormingsproces een aanvraag om nadeelcompensatie kan worden ingediend, terwijl de "integrale besluitvorming" over de nieuwe ontwikkelingen nog niet is afgerond. Het kabinet vreest dat dit tot "een aanzuigende werking" zou leiden. Daarmee wordt gedoeld op een toename van het aantal aanvragen om compensatie. Los van de vraag of deze aanvragen tot toekenning van nadeelcompensatie zouden leiden, zouden zij tot een toename van bestuurslasten leiden. Dit zou ertoe kunnen leiden dat het bestuur zich belemmerd voelt om beleidsvoornemens te openbaren vanwege de vrees dat het naar aanleiding daarvan compensatie zal moeten toekennen. ${ }^{104}$ Dit zou op zijn beurt een "transparant en interactief" besluitvormingsproces belemmeren, terwijl nu net wordt beoogd de burger in een vroeg stadium te betrekken bij nieuwe ontwikkelingen. ${ }^{105}$

Desgevraagd geeft de minister aan dat er geen empirische onderbouwing bestaat voor deze aanzuigende werking, maar dat de aanzuigende werking en de effecten daarvan wel worden beschreven in enkele juridische publicaties. Het valt op dat daarbij ook wordt verwezen naar auteurs die de vrees voor een aanzuigende werking slechts deels of vrijwel niet als gegrond aanmerken. ${ }^{106}$ Hoewel niet op voorhand valt uit te sluiten dat het schrappen en/of niet aanwezig zijn van limitatieve, exclusieve opsommingen van schadeoorzaken zal leiden tot enige aanzuigende werking op aanvragen om compensatie, verwacht ik niet dat deze aanzuigende werking groot zal zijn. Besselink en Procee achten die kans ook klein. Zij wijzen daarbij op de in 2009 in werking getreden nadeelcompensatieregeling van art. 7.14 Waterwet. Zij bevat geen limitatieve opsomming van schadeoorzaken, maar verving wel verschillende aan water gerelateerde wetten die elk een eigen schadever-

104 Dergelijke beleidsvoornemens vallen immers onder de reikwijdte van titel 4.5 Awb.

105 Kamerstukken II 2018/19, 34 986, nr. 3, p. 21-22 (MvT, IOw).

106 Kamerstukken II 2016/17, 33 962, nr. 190, p. 26-27. De auteurs waarop ik doel zijn: Tieman \& Krans 2010 (zie met name p. 80-81); Van Ravels 2013b (zie met name p. 12 en 16); en Van den Broek \& Tjepkema 2015 (zie met name p. 112-114). 
goedingsregeling met limitatieve opsomming van schadeoorzaken kenden. ${ }^{107}$ Dit heeft echter geen "substantiële toename" van het aantal aanvragen om compensatie teweeg gebracht. Er lijken bovendien geen aanvragen te worden ingediend naar aanleiding van de "meer beleidsmatige" beslissingen van waterschappen. Ook de praktijk van de BnIW 2019 laat weinig aanvragen zien die betrekking hebben op schade door "structuurvisies of voorkeursbeslissingen van de minister". ${ }^{108}$ Raadpleging van een senior jurist van Rijkswaterstaat leert eveneens dat burgers doorgaans afwachten of de definitieve besluitvorming daadwerkelijk schade veroorzaakt. Ten tijde van de totstandkoming van de Wns werd bovendien opgemerkt dat een eventuele aanzuigende werking kan worden tegengaan door een recht te heffen voor het in behandeling nemen van de aanvraag om compensatie ${ }^{109}$ en andere kosten die de aanvrager eventueel (denkt te) moet(en) maken. ${ }^{110}$

Ook voert het kabinet aan dat de ruime reikwijdte van titel 4.5 Awb nadelig zou kunnen uitpakken voor de benadeelde burger. Met afd. 15.1 Ow wil het kabinet voorkomen dat de overheid en de burger, of overheden onderling in debat raken over de vraag of schade is ontstaan. Doordat art. 15.1 Ow duidelijk afbakent wanneer om nadeelcompensatie kan worden verzocht in het proces van getrapte besluitvorming moeten ingewikkelde rechtsvragen worden voorkomen, waaronder de vraag aan welk bestuursorgaan welk deel van de schade moet worden toegerekend. Tevens wordt van belang geacht dat de schade bij een getrapt besluitvormingsproces pas redelijkerwijs kan worden begroot als beleid, programma's, instructies en instructieregels in bindende regels of besluiten zijn verwerkt. Dan is immers pas duidelijk welke activiteiten al dan niet zijn toegestaan op de desbetreffende locatie en welke regels daarbij gelden. ${ }^{111}$

\subsubsection{Vergroting van de schaduwschadeproblematiek}

De schaduwschadeproblematiek zal onder afd. 15.1 Ow niet alleen behouden blijven, maar ook worden vergroot. Het kabinet staat namelijk een "generieke verschuiving" voor ogen "van het moment dat een aanvraag om schadevergoeding kan worden gedaan" (hierna: het schademoment). Die verschuiving zou noodzakelijk zijn vanwege de "verbrede reikwijdte van het omgevingsplan ten opzichte van het bestemmingsplan." Daarbij merkt het kabinet op dat in het omgevingsplan regels worden opgenomen die naar huidig recht zijn verspreid over verschillende wettelijke regelingen. Daarbij kan onder andere worden gedacht aan regels over geluid, geurhinder, externe veiligheid en cultureel erfgoed. Tevens kan worden gedacht aan regels over welstand, parkeren, het kappen van bomen, en uitwegen, ten aanzien waarvan vaak wordt gewerkt met open normen. Uit door de minister

107 Het betreft de Wet op de waterhuishouding, de Wet verontreiniging oppervlaktewateren, de Waterstaatswet 1900 en de Grondwaterwet.

108 Besselink \& Procee 2015, p. 79.

109 Zie hierover paragraaf 10.4.

110 Kamerstukken II 2010/11, 32 621, nr. 3, p. 6 (MvT, Wns).

111 Kamerstukken II 2018/19, 34 986, nr. 3, p. 18 en 22, 225-226 (MvT, IOw). 
uitgevoerde botsproeven zou zijn gebleken dat deze integratie van regels in het omgevingsplan tot gevolg heeft "dat een reële inschatting van de schade die het gevolg is van een omgevingsplan" niet goed mogelijk is ten tijde van de vaststelling van dat omgevingsplan. ${ }^{12}$

Een dergelijke inschatting zou ook niet mogelijk zijn doordat het omgevingsplan meer ruimte laat tot globale- en uitnodigingsplanologie dan het hedendaagse bestemmingsplan. Daardoor kan de concrete toepassing van de in het omgevingsplan opgenomen randvoorwaarden afhankelijk worden gesteld van een nader afwegingsmoment. Ten tijde van de vaststelling van het omgevingsplan hoeft dus nog niet duidelijk te zijn of, en zo ja in hoeverre, gebruik zal worden gemaakt van de mogelijkheden die het omgevingsplan biedt. Als het schademoment niet zou worden verlegd, zou de schade moeten worden vastgesteld aan de hand van een vergelijking tussen het oude en het nieuwe omgevingsplan - net als in het huidige planschaderecht. Een nadeel daarvan is dat ook vergoeding wordt toegekend voor ontwikkelingen die zich in de werkelijkheid niet voordoen. ${ }^{113}$ Het kabinet beschouwt deze vergelijkingssystematiek daarom als "één van de oorzaken waarom betrekkelijk weinig globale bestemmingsplannen worden vastgesteld."114

Al met al beoogt het kabinet met de verschuiving van het schademoment dus een bijdrage te leveren aan het aan de Ow en IOw ten grondslag liggende uitgangspunt dat "schade wordt vergoed als duidelijk is welke gevolgen een besluit of activiteit voor de fysieke leefomgeving heeft." Schade dient te worden vastgesteld op basis van de "werkelijke gevolgen" van de activiteiten in kwestie. ${ }^{115}$ Hoewel dat niet met zoveel woorden wordt gezegd, lijkt hiermee in belangrijke mate te worden beoogd de kans op overcompensatie zoveel mogelijk te beperken ${ }^{116}$ teneinde uitnodigingsplanologie zo aantrekkelijk mogelijk te maken. ${ }^{117}$ Het huidige planschaderecht en dan in het bijzonder de daarin gehanteerde planologische vergelijking staan volgens het kabinet in de weg aan de doelen die het met de Ow wil bereiken. ${ }^{118}$

\section{De omgevingsvergunning als exclusieve schadeoorzaak}

Als voor een activiteit op grond van een regel in een omgevingsplan, een omgevingsverordening, een waterschapsverordening of een algemene maatregel van

\footnotetext{
112 Kamerstukken II 2018/19, 34 986, nr. 3, p. 23, 229-230 (MvT, IOw).

113 Vergelijk paragraaf 3.2.4.

114 Kamerstukken II 2018/19, 34 986, nr. 3, p. 18-19, 23-24, 237 (MvT, IOw). Zie ook Kamerstukken II 2018/19, 34 986, nr. 4, p. 79-80 (AARvS, IOw).

115 Kamerstukken II 2018/19, 34 986, nr. 3, p. 24, 228-229, 236-237 (MvT, IOw).

116 Zie daarover ook Kortmann 2017, p. 192.

117 Zie Kamerstukken II 2015/16, 33 962, nr. 185 (Inleidende brief, IOw); en Kamerstukken II 2016/17, 33 962, nr. 190, p. 24-25 en 28.

118 Nijmeijer merkt op dat de minister terecht "constateert dat de huidige schaderegeling een belemmering is voor de totstandkoming van meer globale bestemmingsplanregelingen." Zie Nijmeijer 2017, p. 78.
} 
bestuur een omgevingsvergunning is vereist, dan wordt de omgevingsvergunning op grond van art. 15.1 lid $2 \mathrm{Ow}$ als exclusieve schadeoorzaak aangemerkt - zowel bij directe- als indirecte schade. De achterliggende gedachte is dat de schadeveroorzakende activiteit niet direct uit het omgevingsplan voortvloeit, maar afhankelijk is gesteld van een "nader afwegingsmoment" in de vorm van een vergunningverlening. Pas vanaf het moment van vergunningverlening is volgens het kabinet voldoende aannemelijk dat de activiteit in kwestie daadwerkelijk zal worden uitgevoerd en kan de daardoor veroorzaakte schade worden begroot. ${ }^{119}$

Het omgevingsplan wordt bij directe schade wel als schadeveroorzakende besluit aangemerkt als deze schade rechtstreeks het gevolg is van een regel in een omgevingsplan, omdat een nader afwegingsmoment dan ontbreekt. Daarbij kan bijvoorbeeld worden gedacht aan een regel in een omgevingsplan die een bestaande functie op het perceel van de aanvrager wijzigt of beëindigt. ${ }^{120}$ Een voorbeeld van een geval van directe schade waarin de omgevingsvergunning als schadeoorzaak wordt aangemerkt, betreft de situatie waarin in een omgevingsplan het verbod wordt opgenomen om op eigen perceel bepaalde werkzaamheden uit te voeren zonder aanlegvergunning. De weigering van de aanlegvergunning vormt dan de schadeoorzaak. ${ }^{121}$

Het is inherent aan het aanmerken van de omgevingsvergunning als exclusieve schadeoorzaak dat pas een schadevergoeding kan worden verkregen op het moment dat de vergunning in werking is getreden. Dit wordt voor indirecte schade geëxpliciteerd in art. 15.3 lid $1 \mathrm{Ow}$. Onder het huidige recht was dit slechts het geval voor enkele specifiek in art. 6.1 lid 2, aanhef en onder c Wro genoemde omgevingsvergunningen waarmee invulling werd gegeven aan een binnenplanse afwijkingsbevoegdheid (vergelijk art. 6.1 lid 6 Wro). Die regeling lijkt ook als inspiratiebron te hebben gediend voor de verschuiving van het schademoment onder afd. 15.1 Ow. $^{122}$

\section{Indirecte schade door vergunningvrije activiteiten}

Het is uiteraard ook mogelijk dat een omgevingsplan activiteiten legitimeert zonder tussenkomst van een omgevingsvergunning. Ook voor indirecte schade door deze zogenoemde vergunningsvrije activiteiten wordt het schademoment verschoven. Door art. 15.1 lid 1 Ow wordt het omgevingsplan, de waterschaps- of omgevingsverordening, de algemene maatregel van bestuur of het maatwerkvoorschrift

119 Kamerstukken II 2018/19, 34 986, nr. 3, p. 232 (MvT, IOw).

120 Kamerstukken II 2018/19, 34 986, nr. 3, p. 232 (MvT, IOw).

121 Kamerstukken II 2018/19, 34 986, nr. 3, p. 232 (MvT, IOw). Aanvankelijk is vergeten de weigering van een omgevingsvergunning als schadeoorzaak op te nemen, maar dat is hersteld door de tweede nota van wijziging. Zie daarover Kamerstukken II 2018/19, 34 986, nr. 9, p. 2, onderdeel ES, en p. 15, 17.

122 Kamerstukken II 2018/19, 34 986, nr. 3, p. 237 (MvT, IOw). Zie ook Van den Broek \& Tjepkema 2017, p. 24. 
op grond waarvan deze activiteit kan worden verricht als schadeoorzaak aangemerkt. De uitvoering van een vergunningsvrije activiteit wordt als 'uitwerking' daarvan gezien, omdat het bestuursorgaan bij het vaststellen van de schadeoorzaak heeft afgewogen welke activiteiten vergunningsvrij zijn. De verschuiving van het schademoment wordt dus niet bereikt door de uitvoering van de activiteit als (exclusieve) schadeoorzaak aan te merken. Zij wordt gerealiseerd doordat art. 15.4 lid 1 Ow het moment waarop een aanvraag om compensatie voor deze schade kan worden ingediend, verschuift naar het moment waarop het bevoegd gezag kennis heeft gegeven van de informatie die degene die de activiteit gaat verrichten aan het bevoegd gezag over die activiteit heeft verstrekt, óf het tijdstip waarop met de activiteit is begonnen als deze informatie niet is verstrekt. De achterliggende gedachte is dat de vraag of de vergunningvrije mogelijkheden die een omgevingsplan biedt schade veroorzaken, pas kan worden beantwoord op het moment dat duidelijk is van welke van die mogelijkheden daadwerkelijk gebruik wordt gemaakt. ${ }^{123}$

\subsubsection{Schematisch overzicht}

Ter afsluiting van deze paragraaf is op de volgende pagina een schematische weergave van het toekomstige nadeelcompensatierecht opgenomen. Die weergave gaat uit van de werkelijke schadeoorzaak, omdat wordt beoogd aan te geven wanneer welke regeling als grondslag kan dienen voor toekenning van nadeelcompensatie. Dit laat onverlet dat een afwijzing van een aanvraag onder titel 4.5 Awb of afd. 15.1 Ow kwalificeert als appellabel besluit, zelfs als de reden voor afwijzing is gelegen in de omstandigheid dat de werkelijke schadeoorzaak - anders dan de beweerde schadeoorzaak - niet onder de reikwijdte van die regeling(en) valt. De bestuursrechter kan in dergelijk gevallen niet anders dan bevestigen dat de afwijzing rechtmatig was, omdat de schadeoorzaak niet onder de reikwijdte van titel 4.5 Awb en/of afd. 15.1 Ow viel. Het hangt vervolgens af van de omstandigheden van het individuele geval welke routes nog openstaan voor de aanvrager. Valt de werkelijke schadeoorzaak onder het bereik van een andere nadeelcompensatieregeling, dan staat het de aanvrager vrij om onder die regeling alsnog een aanvraag om nadeelcompensatie in te dienen. Valt de werkelijke schadeoorzaak niet onder het bereik van een andere regeling, dan kan de aanvrager slechts een beroep doen op de civiele rechter. 


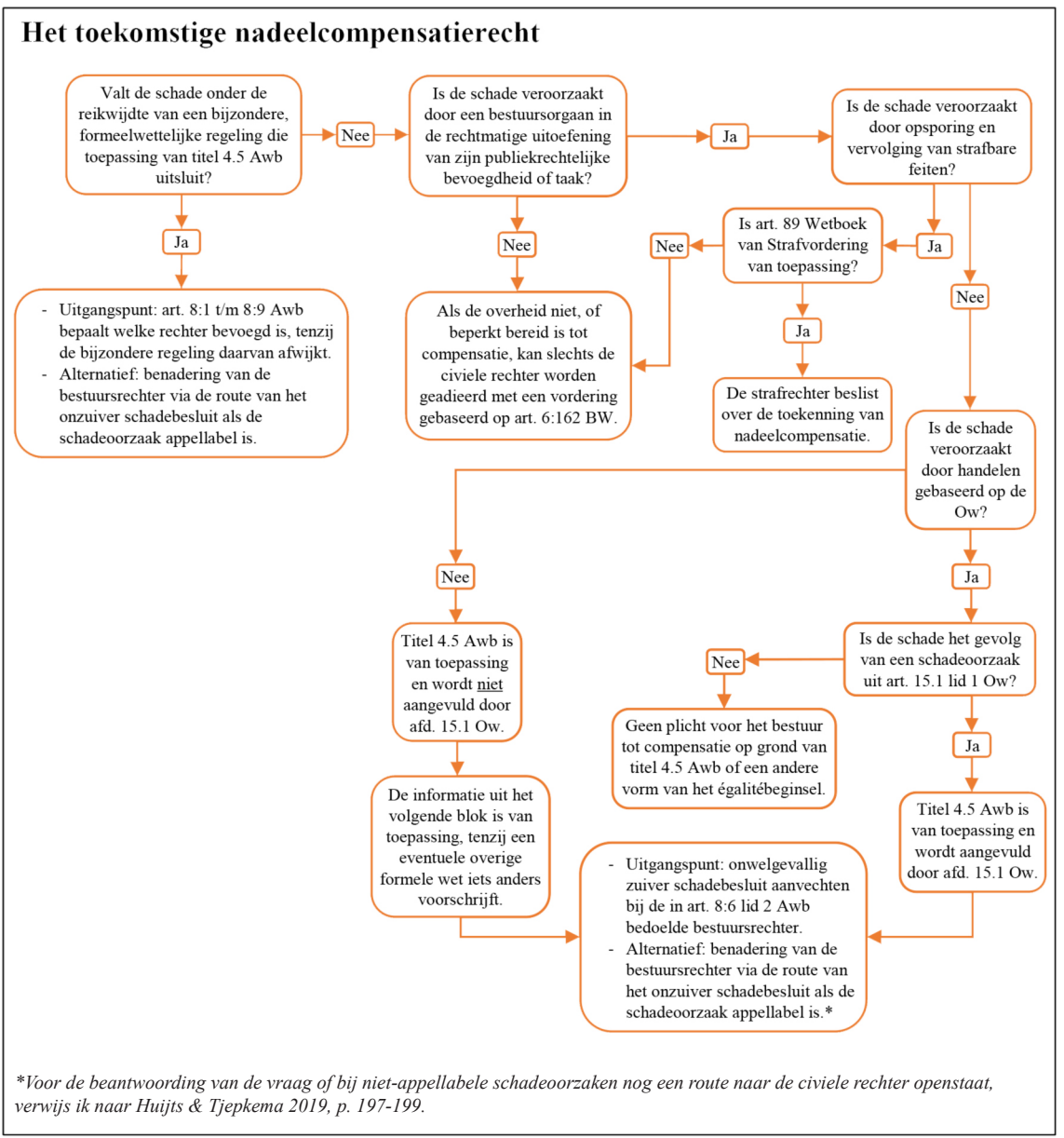

\subsection{HOOFDVRAAG: SPIEGELING AAN DE DOELSTELLINGEN EN UITGANGSPUNTEN DIE TEN GRONDSLAG LIGGEN AAN DE WNS}

\subsubsection{Titel 4.5 Awb}

Titel 4.5 Awb kent een brede reikwijdte: hij dient als grondslag voor toekenning van nadeelcompensatie bij schade veroorzaakt door een bestuursorgaan in de rechtmatige uitoefening van zijn publiekrechtelijke bevoegdheid of taak. Het gebruik van deze formule past goed bij een regeling die de algemene grondslag voor toekenning van nadeelcompensatie moet gaan vormen. Zo kunnen bepalingen in bijzondere regelingen die als grondslag voor toekenning van nadeelcompensatie dienen, komen te vervallen. Ook zorgt de ruime reikwijdte van titel 4.5 Awb ervoor dat in beginsel dezelfde basisregels van toepassing zullen zijn in het grootste deel van het nadeelcompensatierecht. Bovendien heeft zij tot gevolg dat burgers niet 
langer verstrikt zullen raken in het nadeelcompensatiedoolhof. In onze reactie op de consultatie van het voorstel voor de Wet wijziging Awb signaleerden Tjepkema en ik dat dit naar huidig recht nog steeds met enige regelmaat gebeurt. ${ }^{124}$ Dat lot was bijvoorbeeld toebedeeld aan de exploitant van een snackbar in Leusden (die stelde schade te lijden door uitvoeringshandelingen zonder duidelijk te maken of daaraan vergunningen ten grondslag lagen), ${ }^{125}$ de exploitant van een tankstation in Sint-Oedenrode (die stelde schade te lijden door de fysieke afsluiting van een weg, wederom een feitelijke handeling dus), ${ }^{126}$ een bewoner van Den Bosch (die stelde schade te lijden door een voornemen om handhavend op te treden) ${ }^{127}$ en een inwoner van Zeist (die klaagde over de verminderde bereikbaarheid van zijn woning door feitelijke werkzaamheden). ${ }^{128} \mathrm{Zij}$ dachten het doolhof te hebben doorgrond doordat ze bij een rechter terecht kwamen, maar bleken destijds al dermate te zijn verdwaald in het nadeelcompensatiedoolhof dat ze uiteindelijk niet-ontvankelijk werden verklaard door de hoogste bestuursrechter omdat niet werd voldaan aan de connexiteitseisen. Zij maakten dus kosten zonder dat aan inhoudelijke behandeling van hun geschil door een rechter werd toegekomen, terwijl over de materiële kant van de zaak had kunnen worden geprocedeerd als titel 4.5 Awb reeds had gegolden. Ook de uitoefening van een publiekrechtelijke taak valt immers onder de reikwijdte van die titel, waardoor de bestuursrechter doorgaans de bevoegde rechter zal zijn bij schade door rechtmatig overheidshandelen.

Uit het voorafgaande blijkt dat de brede reikwijdte van titel 4.5 Awb in beginsel goed aansluit op de doelstellingen van vereenvoudiging, uniformering en harmonisering van het nadeelcompensatierecht, vergroting van de rechtszekerheid, en vergroting van de doelmatigheid van het nadeelcompensatierecht en vermindering van bestuurslasten. Zij lijkt ook verenigbaar met de overige aan de Wns ten grondslag liggende doelstellingen en uitgangspunten. In paragraaf 3.3.2 beschreef ik echter dat het huidige kabinet voornemens is de reikwijdte van titel 4.5 Awb in te perken voor het omgevingsrecht. De brede reikwijdte van titel 4.5 Awb zou namelijk niet goed passen bij de karakteristieken van het omgevingsrecht, dat bijvoorbeeld wordt gekenmerkt door getrapte besluitvorming. Hierna zal ik ingaan op de vraag hoe die inperking zich verhoudt tot de aan de Wns ten grondslag liggende doelstellingen en uitgangspunten (paragraaf 3.4.2). Eerst werp ik nog de vraag op of de reikwijdte van titel 4.5 Awb ook te ruim zou kunnen zijn voor het overige nadeelcompensatierecht. Die vraag is thans nog lastig te beantwoorden. Dat komt bijvoorbeeld deels doordat vanwege de connexiteitseisen nog relatief weinig ervaring is opgedaan met op het égalitébeginsel gegronde aanvragen om nadeelcompensatie wegens schade door algemeen verbindende voorschriften en beleidsregels. De jurisprudentie gewezen onder nadeelcompensatieverordeningen

124 Zie paragraaf 2 van bijlage 892701 bij Kamerstukken II 2018/19, 35 256, nr. 3 (MvT, Wet wijziging Awb).

125 ABRvS 14 februari 2018, ECLI:NL:RVS:2018:480.

126 ABRvS 23 augustus 2017, ECLI:NL:RVS:2017:2241.

127 ABRvS 8 februari 2017, ECLI:NL:RVS:2017:321.

128 ABRvS 8 juli 2015, ECLI:NL:RVS:2015:2153. 
en -beleidsregels die een vergelijkbare reikwijdte als titel 4.5 Awb kennen, geeft echter geen aanleiding om aan te nemen dat de brede reikwijdte van titel $4.5 \mathrm{Awb}$ onoverkomelijke problemen zal meebrengen voor het algemene nadeelcompensatierecht. De doelstellingen en uitgangspunten die ten grondslag liggen aan de Wns geven mijns inziens daarom thans onvoldoende aanleiding om de reikwijdte van titel 4.5 Awb op bepaalde punten preventief in te perken. Dat geldt te meer omdat ook de gevolgen daarvan lastig zijn te voorspellen. Desgevraagd door Tjepkema en mijzelf, blijkt dat ook de mening van het huidige kabinet te zijn. ${ }^{129}$ Wel geven deze doelstellingen en uitgangspunten aanleiding om te evalueren of zich inderdaad geen problemen zullen voordoen. Stel dat die evaluatie zou leiden tot de conclusie dat dit wel het geval is, dan zou het - mede gelet op de doelstelling van vergroting van de doelmatigheid van het nadeelcompensatierecht en vermindering van bestuurslasten - in de rede liggen oplossingen te treffen, al dan niet voor een specifiek deelgebied van het nadeelcompensatierecht. Daarbij kan mogelijk aansluiting worden gezocht bij oplossingen die zijn voorgesteld in publicaties waarin is geïnventariseerd welke problemen zich in theorie zouden kunnen gaan voordoen. ${ }^{130}$

\subsubsection{Afd. $15.1 \mathrm{Ow}$}

\subsubsection{Het exclusieve karakter van art. 15.1 lid $1 \mathrm{Ow}$}

Waar ik een algemene inperking van de reikwijdte van titel 4.5 Awb thans voorbarig zou vinden, ligt een inperking van de reikwijdte van titel 4.5 Awb voor het omgevingsrecht mijns inziens meer voor de hand. Sinds de inwerkingtreding van de WRO is het recht op planschadevergoeding namelijk beperkt tot schade door definitieve planologische besluitvorming. ${ }^{131}$ Het kabinet kiest ervoor deze inperking van de reikwijdte van titel 4.5 Awb vorm te geven door de limitatieve opsomming van schadeoorzaken in art. 15.1 Ow een exclusief karakter toe te dichten. Hoe verhoudt zich dat tot de doelstellingen en uitgangspunten van titel 4.5 Awb? Het exclusieve karakter van de opsomming van schadeoorzaken in art. 15.1 Ow sluit niet goed aan op het uitgangspunt van het uitsluitend codificeren van het égalitébeginsel. Uit paragraaf 3.3.1 ${ }^{132}$ volgde namelijk dat de wetgever ten tijde van de totstandkoming van de Wns het standpunt heeft ingenomen dat titel 4.5 Awb aanspraak moet bieden op vergoeding van schade indien het égalitébeginsel daartoe noopt, ongeacht de oorzaak van de schade. Bovendien lijkt dit exclusieve karakter te botsen met de doelstelling van uniformering en harmonisering van het

129 Zie voor het antwoord: Kamerstukken II 2018/19, 35 256, nr. 3, p. 33 (MvT, Wet wijziging Awb). De vraag werd gesteld in paragraaf 4 van de hierbij behorende bijlage 892701 .

130 Zie bijvoorbeeld Van den Broek \& Tjepkema 2015, p. 48-52.

131 Zie paragraaf 3.2.1.

132 Zie het kopje 'Limitatieve opsommingen van schadeoorzaken niet langer toegestaan?'. 
nadeelcompensatierecht. Titel 4.5 Awb sluit de vergoeding van schade door indicatief overheidshandelen immers niet op voorhand uit.

Het exclusieve karakter van de opsomming van art. 15.1 Ow verhoudt zich ambivalent tot de doelstelling van vergroting van de rechtszekerheid. Enerzijds zorgt het ervoor dat voor zowel burger als bestuur duidelijk is naar aanleiding van welke schadeoorzaken (en op welke momenten) een aanvraag om compensatie kan worden ingediend. Anderzijds wordt de materiële rechtszekerheid van de burger aangetast. In afwachting van de definitieve besluitvorming (en/of de uitvoering van een vergunningvrije activiteit) kan hij immers gedurende lange tijd in onzekerheid verkeren over de waarde van zijn onroerende zaak en de vergoedbaarheid van de daling daarvan. De enkele belofte van beter omgevingsmanagement en snellere besluitvorming ${ }^{133}$ biedt hieraan te weinig tegenwicht. Dit is wellicht niet het type rechtszekerheid waarop deze doelstelling in eerste instantie zag, omdat de wetgever bijvoorbeeld sprak van zekerheid in die zin dat de uitkomst van een aanvraag om nadeelcompensatie "redelijk en voorspelbaar" is. ${ }^{134}$ Dat laat echter onverlet dat ook de materiële rechtszekerheid een belangrijke legitimerende factor is voor het recht in een democratische rechtsstaat.

De argumenten die het kabinet aanvoert voor het exclusieve karakter van de opsomming van art. 15.1 lid $1 \mathrm{Ow}$, komen in essentie overeen met de verklaringen die in paragraaf 3.2.4 werden benoemd voor het opnemen van een exclusieve opsomming in de Wro en WRO: het schadevergoedingsrecht moet hanteerbaar en uitvoerbaar zijn binnen een door getrapte besluitvorming gekenmerkt omgevingsrecht. Dit uit zich onder andere in het zoveel mogelijk voorkomen van onder- en overcompensatie. Verder brengt het integratieprincipe mee dat niet iedere (indicatieve) overheidshandeling aanleiding moet kunnen geven tot nadeelcompensatie. Dit voorkomt tevens allerlei ingewikkelde vragen over causaliteit en de begrootbaarheid van schade, hetgeen de hanteerbaarheid en uitvoerbaarheid van het systeem eveneens ten goede komt. Deze gedachte van een hanteerbaar en uitvoerbaar systeem past goed bij de doelstelling van vergroting van de doelmatigheid van het nadeelcompensatierecht en vermindering van bestuurslasten. De overige doelstellingen en uitgangspunten pleiten niet nadrukkelijk voor of tegen het exclusieve karakter van de opsomming.

\section{Intermezzo}

Uit het voorafgaande volgt dat er doelstellingen en uitgangspunten zijn die tegen het exclusieve karakter van de opsomming van art. 15.1 Ow pleiten. Het betreft de doelstelling van uniformering en harmonisering van het nadeelcompensatierecht, en het uitgangspunt van het uitsluitend codificeren van het égalitébeginsel. Tevens zijn er doelstellingen en uitgangspunten die pleiten vóór dit exclusieve karakter. 
Dat geldt tot op zekere hoogte voor de doelstelling van vergroting van de rechtszekerheid, hoewel een kanttekening dient te worden geplaatst ten aanzien van de materiële rechtszekerheid. Ook de doelstelling van vergroting van de doelmatigheid van het nadeelcompensatierecht en vermindering van bestuurslasten pleit voor het exclusieve karakter. De keuze van het huidige kabinet om de opsomming van art. 15.1 Ow als exclusief te beschouwen, is dan ook niet onverdedigbaar. Daarbij benadruk ik dat het de formele wetgever vrij staat om terug te komen op het algemene standpunt uit de memorie van toelichting behorende bij de Wns dat in bijzondere wetten niet meer met dergelijke opsommingen zou moeten worden gewerkt. ${ }^{135}$ Daar bestaan bovendien goede redenen voor omdat het hier niet gaat om algemeen nadeelcompensatierecht, maar om nadeelcompensatierecht toegespitst op het door getrapte besluitvorming gekenmerkte omgevingsrecht. Gelet op het conflicteren van de genoemde doelstellingen en uitgangspunten, verdient het mijns inziens echter wel aanbeveling dat de wetgever de keuze voor het exclusieve karakter van art. 15.1 Ow doet vergezellen van een regeling voor de schaduwschadeproblematiek die daardoor zal worden veroorzaakt. De inhoud van die regeling zal in belangrijke mate afhankelijk zijn van politieke keuzes. Daarom zal ik hierna kort stilstaan bij de argumenten die het kabinet heeft aangevoerd om een dergelijke regeling niet te treffen (paragraaf 3.4.2.2). Vervolgens zal ik ingaan op de vraag hoe de verschuiving van het schademoment zich verhoudt tot de doelstellingen en uitgangspunten die ten grondslag liggen aan de Wns (paragraaf 3.4.2.3). Omdat de verschuiving van het schademoment de schaduwschadeproblematiek vergroot, kan de beantwoording van deze vraag immers relevantie hebben voor de keuzes die moeten worden gemaakt bij het treffen van een regeling voor de schaduwschadeproblematiek. Ten slotte zal ik een eerste aanzet doen voor een dergelijke regeling, die ik zowel politiek haalbaar acht als verenigbaar met de aan de Wns ten grondslag liggende doelstellingen en uitgangspunten (paragraaf 3.4.2.4).

\subsubsection{Argumenten van het kabinet om geen regeling voor de schaduwschadeproblematiek te treffen}

Het kabinet is tot op heden niet bereid gebleken een regeling voor de schaduwschadeproblematiek te treffen. De argumenten die het daarvoor aanvoert, overtuigen onvoldoende. Zo voert het kabinet aan dat een zekere periode van onzekerheid inherent is aan besluitvorming en als normaal maatschappelijk risico moet worden gezien. ${ }^{136}$ Daarop valt in beginsel weinig af te dingen, ${ }^{137}$ maar tegelijkertijd moet worden opgemerkt dat schaduwschade ook dusdanige vormen kan aannemen dat zij niet door tegenwerping van het normaal maatschappelijk risico kan worden

135 Zie ook paragraaf 2.5.3.

136 Kamerstukken II 2018/19, 34 986, nr. 3, p. 22-23 en 33 (MvT, IOw).

137 Zie Backes \& Huijts 2015, p. 140 voor een vergelijkbare redenering in een andere context.Zie eveneens Rb. 's-Gravenhage20 juli2000, ECLI:NL:RBSGR:2000:AA6588, r.o. 3.7: "Gedaagde heeft terecht aangevoerd dat het wel vaker voorkomt dat nog uit te voeren voornemens van de regering hun schaduw vooruitwerpen, en dat zulks een normaal maatschappelijk risico is." 
afgedaan. Een van de meest in het oog springende voorbeelden kan worden gevonden in een rapport van de Nationale ombudsman waarin de situatie wordt beschreven van woningeigenaren die hun woning al 23 jaar niet kunnen verkopen vanwege onzekerheid over de ligging van het tracé van de Betuwelijn. ${ }^{138}$ Het argument van het kabinet pleit dan ook niet voor categorische uitsluiting van vergoeding van schaduwschade, maar hooguit voor invoering van een (ingangs)drempel wegens normaal maatschappelijk risico die is toegespitst op schaduwschade. ${ }^{139}$

Ook zou een wettelijke regeling volgens het kabinet een belemmering vormen voor een "interactief en open proces, een van de belangrijke doelen van de [omgevings]wet." De schaduwschadeproblematiek zou moeten worden opgelost door middel van maatwerk. Ook daar zou een wettelijke regeling aan in de weg kunnen staan. Bovendien zou geen noodzaak tot een dergelijke regeling bestaan. ${ }^{140}$ Een oplossing zou in de eerste plaats moeten worden gezocht in "beter omgevingsmanagement en snellere besluitvorming." Hierbij baseert het kabinet zich op de in paragraaf 2.3.1 $1^{141}$ besproken, door het ministerie bij lagere overheden afgenomen enquête. Daaruit zou zijn gebleken dat het aantal gevallen van schaduwschade beperkt is, namelijk $1 \%$ van alle aanvragen. ${ }^{142} \mathrm{Ik}$ heb mijn twijfels bij deze uitkomst van de enquête. Is alleen gevraagd naar aanvragen die betrekking hadden op schaduwschade, of is daarbij ook een uitleg verschaft van wat onder schaduwschade wordt verstaan? Het is mijns inziens niet onaannemelijk dat de gemeenteambtenaar die de enquête invult, behoefte heeft aan een dergelijke uitleg. Daarbij refereer ik aan de Kamervraag van leden van de VVD-fractie "hoe nadeelcompensatie zich verhoudt tot schaduwschade? Is schaduwschade een onderdeel van nadeelcompensatie?"143 Voorts wijst niets erop dat bij het afnemen van de enquête rekening is gehouden met de omstandigheid dat het naar huidig recht niet zinvol is om een aanvraag om tegemoetkoming in schaduwschade in te dienen, hetgeen waarschijnlijk ook op voorhand door het bestuur aan de burger wordt gecommuniceerd.

Het kabinet voerde in de memorie van toelichting behorende bij de versie van het voorstel voor de IOw dat aan de AARvS is voorgelegd aan dat "de afgelopen jaren is gebleken dat schrijnende gevallen in de praktijk vrijwel altijd worden opgelost." ${ }^{144}$ In de aan de Tweede Kamer aangeboden memorie van toelichting

138 Gevangenen van een Tracé 2013.

139 Zie voor een dergelijke oplossing bijvoorbeeld Van Heijst 2017, p. 154.

140 Kamerstukken II 2018/19, 34 986, nr. 7, p. 31 (NV II, IOw).

141 Zie meer specifiek het kopje 'Praktisch belang'.

142 Na lang wachten is een rapport over de enquête gepubliceerd op www.omgevingswetportaal.nl. Zoek op 'Resultaten enquête nadeelcompensatie'.

143 Kamerstukken II 2018/19, 34 986, nr. 5, p. 8 (Verslag II, IOw).

144 Zie p. 27 van de aan de AARvS voorgelegde versie van de bij de IOw behorende memorie van toelichting. 
wordt opgemerkt dat uit interviews ${ }^{145}$ kan worden geconcludeerd dat schrijnende gevallen in de praktijk "geregeld" worden opgelost. ${ }^{146}$ In de nota naar aanleiding van het verslag wordt in dit verband gewezen op uitkoopregelingen die door de minister van Economische Zaken en Klimaat zijn vastgesteld bij de aanleg, verplaatsing of wijziging van hoogspanningslijnen. Ook wordt gewezen op de door de gemeente Moerdijk bij beleidsregel vastgestelde 'Moerdijkregeling'. Daarin geeft de gemeente een algemene verkoopgarantie van $95 \%$ van de taxatiewaarde voor woningen gelegen in de kern Moerdijk. ${ }^{147}$ In meer algemene zin wijst het kabinet erop dat het bestuur op grond van de Awb verplicht is de belangen van zittende eigenaren bij besluitvorming te betrekken. Ten slotte stelt het kabinet het beeld te hebben dat "bestuursorganen en initiatiefnemers ook los van deze verplichting in toenemende mate de belangen van zittende eigenaren betrekken bij de vormgeving van hun plannen en initiatieven." Daartoe zouden ook handvatten worden aangereikt in de Handleiding nadeelcompensatie. ${ }^{148}$

Ook dit betoog overtuigt mijns inziens onvoldoende. De regeling Moerdijk houdt, voor zover ik kan overzien, geen verband met een specifiek beleidsvoornemen voor een potentieel nadelige ontwikkeling. Ook zijn mij geen gevallen bekend waarin art. 3:4 lid 2 Awb tot de conclusie leidde dat indicatieve besluitvorming niet zou mogen worden vastgesteld vanwege de negatieve invloed die zij op de waarde van onroerende zaken van zittende eigenaren zou kunnen hebben. Het door het kabinet geschetste beeld wijkt bovendien af van het beeld dat door de praktijk en wetenschap wordt geschetst. Dat schrijnende gevallen doorgaans minnelijk worden afgedaan, wordt bijvoorbeeld in twijfel getrokken door de Vereniging Eigen Huis onder verwijzing naar het eerder genoemde rapport van de $\mathrm{Na}$ tionale ombudsman. ${ }^{149}$ Ook Van den Broek en Tjepkema refereren daaraan als zij cynisch stellen:

"Het is zeer de vraag welke waarborg 'goed onderling overleg' de burger biedt. Wellicht doelt de minister op de 'oplossing' die zij bood aan omwonenden van een tracé, die drieëntwintig jaar in onzekerheid verkeerden over de gevolgen van de voorgenomen aanleg van een snelweg voor hun woonsituatie, waar uiteindelijk de Nationale ombudsman aan te pas moest komen?"150

145 Het betreft op schaduwschade gerichte interviews die zijn afgenomen bij vertegenwoordigers van overheden, burgers en bedrijven. Het is onbekend of er transcripties van deze interviews zijn. Deze zijn in ieder geval niet gepubliceerd.

146 Kamerstukken II 2018/19, 34 986, nr. 3, p. 31 (MvT, IOw). Op p. 128 van dit document wordt gesproken van 'meestal'. Zie voor een vergelijkbare opmerking ook Kamerstukken II 2018/19, 34 986, nr. 7, p. 31 (NV II, IOw).

147 Zie https://dorpmoerdijk.nl/moerdijkregeling. De precieze geografische afbakening volgt uit de kaart die als eerste bijlage is gevoegd bij de beleidsregel.

148 Kamerstukken II 2018/19, 34 986, nr. 7, p. 28-29 (NV II, IOw).

149 Vereniging Eigen Huis 2017, p. 3.

150 Van den Broek \& Tjepkema 2016, p. 2822. Zie minder cynisch geformuleerd ook Van den Broek \& Tjepkema 2017, p. 27. 
Ten slotte is van belang dat schaduwschadeproblematiek niet beperkt is tot schrijnende gevallen. Veel vaker komt het voor dat schaduwschade wordt geleden omdat onroerende zaken tegen een lagere prijs worden verkocht in de periode tussen het indicatieve overheidshandelen en de definitieve besluitvorming. ${ }^{151}$

\subsubsection{Verschuiven van het schademoment}

In paragraaf 3.3.2.3 beschreef ik hoe het kabinet de ruimere reikwijdte en het globalere karakter van het omgevingsplan ten opzichte van het hedendaagse bestemmingsplan aanvoert als redenen voor verschuiving van het schademoment. Deze en andere verschillen ten opzichte van het huidige ruimtelijke ordeningsrecht zijn toegelicht in paragraaf 2.4.3. ${ }^{152}$ Zowel door de Afdeling advisering van de Raad van State als in de literatuur zijn bedenkingen geuit bij de wenselijkheid van een omgevingsplan met een dermate globaal karakter als het kabinet voor ogen staat. ${ }^{153}$ In de literatuur over afd. $15.1 \mathrm{Ow}$ is met name aangevoerd dat het huidige planschaderecht voldoende ruimte laat om flexibiliteit in een bestemmingsplan in te bouwen zonder grote aansprakelijkheidsrisico's te lopen. Daarbij wordt gewezen op de "veelvuldig"154 door de praktijk gebruikte, in art. 3.6 Wro neergelegde bevoegdheid om flexibiliteitsbepalingen in bestemmingsplannen op te nemen. Tevens wordt in twijfel getrokken dat de (niet empirisch onderbouwde) vrees voor aansprakelijkheidsrisico's naar huidig recht een wezenlijke belemmering voor uitnodigingsplanologie vormt. ${ }^{155}$ Ook ik heb mijn bedenkingen bij de wenselijkheid van het globalere karakter van het omgevingsplan, mede bezien vanuit de aan de Wns ten grondslag liggende doelstellingen en uitgangspunten. Het doel van dit onderzoek is echter niet om de wenselijkheid te beoordelen van de wijze waarop de Ow het omgevingsrecht zal vormgeven. Bij de beantwoording van de in paragraaf 1.2 opgeworpen onderzoeksvragen - en dus ook de hoofdvraag - zal ik daarom moeten uitgaan van de wijze waarop deze afdeling functioneert binnen het door de Ow gereguleerde omgevingsrecht, en hoe zich dat verhoudt tot het nadeelcompensatierecht van titel $4.5 \mathrm{Awb}$.

Uitgaande van de ruimere reikwijdte en het globale karakter van het omgevingsplan onder de Ow voorzie ik problemen als het schademoment niet wordt verschoven. Daarbij roep ik de in paragraaf 3.3.2.3 aangehaalde opmerking van de minister in herinnering dat uit botsproeven is gebleken "dat een reële inschatting van de schade die het gevolg is van een omgevingsplan" niet goed mogelijk is ten tijde van de vaststelling van dat omgevingsplan. ${ }^{156}$ Bovendien zie ik geen voor

151 Zie daarover ook Kortmann 2016, p. 167.

152 Zie meer specifiek het kopje 'Het nieuwe omgevingsrecht'.

153 Zie Kamerstukken II 2018/19, 34 986, nr. 4, p. 8-10 en 49-52 (AARvS, IOw), respectievelijk Groothuijse \& Kegge 2017, p. 111-131.

154 Van den Broek \& Tjepkema 2017, p. 23-24.

155 Zie SAOZ 2017, p. 8; Van den Broek \& Tjepkema 2016, p. 2824; en Planken \& Hazen 2017, p. 37-39. Zie anders: Nijmeijer 2017, p. 78. 
de hand liggend alternatief voor de verschuiving van het schademoment, omdat bijvoorbeeld ook een 'redelijke invulling' van het omgevingsplan lastig tot niet is vast te stellen wanneer bijvoorbeeld de "ambities, waarden en kwaliteiten van de gemeente" 157 bepalend zijn voor de vraag welke activiteiten door het omgevingsplan worden toegestaan. De problemen die bij toepassing van afd. 15.1 Ow zouden ontstaan als het schademoment niet zou worden doorgeschoven, sluiten in ieder geval slecht aan op de doelstellingen van vergroting van de doelmatigheid van het nadeelcompensatierecht en vermindering van bestuurslasten, en vergroting van de rechtszekerheid. Bovendien kan niet worden uitgesloten dat afd. $15.1 \mathrm{Ow}$ in dat scenario dermate onhanteerbaar zou worden dat het niet doorschuiven zich slecht zou verhouden tot alle aan de Wns ten grondslag liggende doelstellingen en uitgangspunten. Praktisch beschouwd, bestaat uiteindelijk immers weinig verschil tussen een onhanteerbaar systeem en geen systeem.

Dat ik niet zal aanbevelen af te zien van de verschuiving van het schademoment, betekent niet dat deze verschuiving geen problemen zal meebrengen. De verschuiving van het schademoment kwam het kabinet immers te staan op veel kritiek. Daarbij leek de verschuiving van het schademoment bij schade door een omgevingsvergunning wat welwillender te worden ontvangen, omdat deze schade wordt gezien als het gevolg van de nadere afweging die wordt gemaakt in het besluit omtrent de vergunningverlening. ${ }^{158}$ Naast enkele dogmatische bezwaren, ${ }^{159}$ werden veel praktische bezwaren aangevoerd. Zo brengt de verschuiving mee dat het recht op compensatie "in de tijd" wordt gefragmenteerd, omdat voor iedere feitelijke activiteit een afzonderlijke aanvraag kan worden ingediend. ${ }^{160}$ Ook kan een "inhoudelijke fragmentatie" ontstaan als een omgevingsplan voor uitvoering van bepaalde activiteiten deels een vergunning vereist en deels niet. ${ }^{161}$ Beide vormen van fragmentatie verhouden zich slecht tot de doelstellingen van vergroting van de doelmatigheid van het nadeelcompensatierecht en vermindering van bestuurslasten, en vergroting van de rechtszekerheid. In plaats van ineens met elkaar af te rekenen (het integratieprincipe), worden de benadeelde burger, het bestuur, en eventuele draagplichtige derden immers afhankelijk van de mate waarin, en de momenten waarop de eigenaar van een naburig perceel besluit gebruik te maken van de mogelijkheden die het omgevingsplan biedt. Voorts zijn enkele kanttekeningen geplaatst die betrekking hebben op de vaststelling en begroting van schade. Zo merken Planken \& Hazen op dat zich wat dit betreft problemen kunnen voordoen als een aanvraag jaren na de inwerkingtreding van een omgevingsvergunning of uitvoering van feitelijke bouwactiviteiten wordt ingediend. ${ }^{162}$ Ook dit

157 Zie paragraaf 2.4.3 onder het kopje 'Het nieuwe omgevingsrecht'.

158 Zie bijvoorbeeld Van den Broek \& Tjepkema 2017, p. 24.

159 Zie Van den Broek \& Tjepkema 2016, p. 2821; en Van den Broek \& Tjepkema 2017, p. 25.

160 Zie Nijmeijer 2017, p. 79; Van den Broek \& Tjepkema 2016, p. 2822; en Van den Broek \& Tjepkema 2017, p. 25-26.

161 Nijmeijer 2017, p. 80.

162 Planken \& Hazen 2017, p. 39. 
verhoudt zich op het eerste oog slecht tot de doelstellingen van vergroting van de doelmatigheid van het nadeelcompensatierecht en vermindering van bestuurslasten, en vergroting van de rechtszekerheid. Gelet op het voorafgaande is het dan ook positief dat het kabinet reeds heeft gepoogd een oplossing te bieden voor een groot deel van de aangevoerde knelpunten. ${ }^{163}$ Dit laat echter onverlet dat de aan de Wns ten grondslag liggende doelstellingen mogelijk ook andere, of aanvullende oplossingen vereisen. Voor zover dat het geval is, zal ik met name in hoofdstuk 4 en 5 bijdragen aan het daarvoor noodzakelijke gedachteproces.

Een ander punt van kritiek is dat de verschuiving van het schademoment de schaduwschadeproblematiek zal vergroten. ${ }^{164}$ Het kabinet heeft daarvoor wel een oplossing willen bieden door een beperkte afschaffing van tegenwerping van actieve risicoaanvaarding (vergelijk art. $15.5 \mathrm{Ow}$ ), maar de doctrine is eensgezind dat deze oplossing te weinig zoden aan de dijk zet. ${ }^{165}$ Met name de beperkte reikwijdte van de geboden oplossing is problematisch. Kort geparafraseerd, komt zij erop neer dat een consument die zijn woning ná vaststelling of wijziging van het omgevingsplan heeft gekocht, geen actieve risicoaanvaarding krijgt tegengeworpen bij een aanvraag om nadeelcompensatie wegens de waardedaling van zijn woning door een vergunningplichtige of vergunningvrije activiteit. Hiermee wordt dus bijvoorbeeld geen oplossing geboden aan iemand die zijn woning verkoopt aan een bedrijfs- of beroepsmatig handelende koper. Op deze en andere knelpunten zal nog worden ingegaan in paragraaf 8.2.2.2. Op deze plaats volsta ik met de opmerking dat uit paragraaf 3.4.2.1 volgde dat de doelstellingen en uitgangspunten van de Wns mijns inziens aanleiding geven tot het treffen van een oplossing van de schaduwschadeproblematiek. Bij de bespreking van mogelijke oplossingen zal ik daarom ook de nieuwe categorie van schaduwschade betrekken die ontstaat door de verschuiving van het schademoment.

\subsubsection{Een oplossing voor de schaduwschadeproblematiek}

In deze deelparagraaf zal ik bijdragen aan het gedachteproces over een oplossing voor de schaduwschadeproblematiek. Daarbij zal ik in acht nemen dat de oplossing die ik voorstel zowel vanuit politiek aspect enige kans van slagen moet hebben alsook verenigbaar moet zijn met de aan de Wns ten grondslag liggende doelstellingen en uitgangspunten. Bovendien zal ik mij in eerste instantie richten op twee vormen van schaduwschade: de tijdelijke onverkoopbaarheid van onroe-

163 Zo heeft het kabinet bijvoorbeeld met art. 15.7 lid 2 jo. lid 3 Ow een oplossing willen bieden voor de nadelige gevolgen van de fragmentatie van het recht op nadeelcompensatie. Zie Kamerstukken II 2018/19, 34 986, nr. 4, p. 81-82 (AARvS, IOw).

164 Zie Planken \& Hazen 2017, p. 38; Van Oosten \& Span 2016, p. 317-318; SAOZ 2017, p. 2-3; Van den Broek \& Tjepkema 2017, p. 26-27; Van den Broek \& Tjepkema 2016, p. 2822; en Nijmeijer 2017, p. 79.

165 Zie Van den Broek \& Tjepkema 2017, p. 27; Vereniging eigen huis 2017, p. 4; SAOZ 2017, p. 2-3; Planken \& Hazen 2017, p. 38; en Van der Lee \& Wiersema 2017, p. 605-606. 
rende zaken en tijdelijke waardedaling van onroerende zaken. Ten slotte zal ik kort stilstaan bij schaduwschade die (slechts) door ondernemers wordt ondervonden. Uit paraaf 3.2.3 volgde dat schaduwschade nooit de vorm van gederfd woongenot kan aannemen.

\section{Tijdelijke onverkoopbaarheid van onroerende zaken}

Het is denkbaar dat indicatief overheidshandelen een dermate ingrijpende (of anderszins afschrikwekkende) planologische ontwikkeling aankondigt dat derden het niet aandurven te investeren in een onroerende zaak in het beoogde plangebied. De eigenaar van een onroerende zaak in dit gebied zal hier met name problemen van ondervinden als hij zijn onroerende zaak wil verkopen. Toekenning van geldelijke nadeelcompensatie zal het eigenlijke probleem van de eigenaar niet oplossen, maar wel een groot risico op onder- en overcompensatie introduceren voor het bestuur. Het lijkt daarom erop dat in dit soort situaties slechts uitkomst kan worden geboden door een recht op uitkoop door de overheid, dat ontstaat na het verstrijken van een zekere tijdsperiode waarin de eigenaar tevergeefs heeft gepoogd zijn onroerende zaak te verkopen. ${ }^{166}$ Mocht de wetgever een dergelijk recht willen introduceren dan lijkt opname in hoofdstuk $11 \mathrm{Ow}$ - het hoofdstuk over onteigening - het meest voor de hand te liggen. Dat is wellicht niet helemaal zuiver omdat het niet gaat om een eenzijdige rechtshandeling van het bestuur die leidt tot een verplichte overgang van eigendom. Duidelijk is echter dat het recht op uitkoop niet kan worden aangemerkt als uiting van het op het égalitébeginsel gebaseerde nadeelcompensatierecht en daarom niet thuishoort in titel $4.5 \mathrm{Awb}$ of afd. 15.1 Ow. Dat is ook de reden waarom ik hier geen suggesties zal doen voor de verdere vormgeving van een dergelijk recht. ${ }^{167}$ Wel verdient het vermelding dat de grondslag van het voorgestelde recht op uitkoop mogelijk (deels) zou kunnen worden gezocht in art. 1 EP EVRM. ${ }^{168}$

166 Deze conclusie wordt ook bereikt in Vereniging eigen huis 2017, p. 4. Voor overcompensatie hoeft niet te worden gevreesd. Als de ontwikkeling die werd aangekondigd in de indicatieve besluitvorming - en daardoor tot onverkoopbaarheid van de onroerende zaak leidde - toch geen doorgang zal vinden, zal de onroerende zaak weliswaar weer in waarde stijgen, maar is zij door de uitkoop eigendom van de overheid geworden.

167 Voor die verdere vormgeving zou onder andere inspiratie kunnen worden ontleend aan de 'bewonersregeling' van art. $56 \mathrm{t} / \mathrm{m} 63$ Wet bodembescherming; Sanderink 2013, p. 845; Sanderink 2015, p. 482-488; en Van Ravels 1999, p. 214-215. 


\section{Tijdelijke waardedaling van onroerende zaken}

Gedurende verschillende decennia zijn oplossingen voorgesteld voor schaduwschade in de vorm van tijdelijke waardedaling van onroerende zaken. ${ }^{169} \mathrm{Ik}$ zal deze niet allemaal bespreken. Sommige oplossingen acht ik onwenselijk, zoals de in paragraaf 3.2.3 besproken oplossing van toerekening met terugwerkende kracht als voorgesteld door Dijkshoorn. Andere oplossingen zijn niet geschikt voor een algemene wettelijke regeling, bijvoorbeeld omdat zij uitgaan van de bereidwilligheid van koper en verkoper om er onderling uit te komen. Daarbij kan bijvoorbeeld worden gedacht aan een contractueel beding in de koopovereenkomst dat de uiteindelijk te bepalen koopprijs afhankelijk stelt van de vraag of bepaalde ruimtelijke ontwikkelingen daadwerkelijk zullen plaatsvinden. Ook kan worden gedacht aan de garantie van de koper dat hij een aanvullend bedrag aan de verkoper zal overmaken als blijkt dat een op het moment van de koop in het vooruitzicht liggende ontwikkeling toch geen doorgang zal vinden.

Bepaalde oplossingen zijn wel geschikt voor een algemene wettelijke regeling, maar lijken weinig kansrijk vanwege de houding die het kabinet ten aanzien daarvan heeft aangenomen. Daarbij kan worden gedacht aan het afzien van het exclusieve karakter van de opsomming van art. 15.1 lid $1 \mathrm{Ow}^{170}$ - bovendien bleek uit het voorafgaande deel van dit hoofdstuk dat voor behoud van die opsomming enkele belangrijke argumenten bestaan. Ook kan worden gedacht aan de oplossing van het door de AARvS, onder verwijzing naar een stuk van Backes en mij uit 2015, voorgestelde 'hybride stelsel'. Deze oplossing zou slechts uitkomst bieden voor de extra categorie van schaduwschade die zal ontstaan door de verschuiving van het schademoment, maar zou wellicht kunnen worden geëxtrapoleerd voor het overige deel van de schaduwschadeproblematiek. Zij gaat uit van het behoud van het exclusieve karakter van de opsomming van art. 15.1 lid $1 \mathrm{Ow}$ en de verschuiving van het schademoment, maar zou vergoeding bij wijze van uitzondering mogelijk maken als een onroerende zaak wordt verkocht in de periode tussen vaststelling van het omgevingsplan en verlening van een omgevingsvergunning of feitelijke uitvoering van een activiteit. De achterliggende gedachte is dat de waardedaling van de onroerende zaak door de nog onbenutte planmogelijkheden zich reeds manifesteert op het moment van verkoop van de onroerende zaak. ${ }^{171}$ De invoering van een dergelijke oplossing lijkt niet onhaalbaar, al zal daartoe nog

169 Een inventarisatie van oplossingen kan worden gevonden in Van Ravels 1999, p. 202-216. Zie meer recent bijvoorbeeld ook Kortmann 2016; Kortmann 2017; Ten Kate 2013; Van den Broek \& Tjepkema 2015, p. 42, 101-102, 106-107; en Van Heijst 2017, p. 154.

170 Ook - al dan niet op art. 1 EP EVRM geïnspireerde - oplossingen om pas na een langdurige periode van onzekerheid een uitzondering te maken op de exclusiviteit van de opsomming van art. $15.1 \mathrm{lid} 1 \mathrm{Ow}$ zal ik daarom niet nader onderzoeken. Zie Van den Broek \& Tjepkema 2015, p. 42, 101-102, 106-107 voor een zeer lezenswaardig voorbeeld van een dergelijke oplossing.

171 Zie Kamerstukken II 2018/19, 34 986, nr. 4, p. 78 (AARvS, IOw), onder verwijzing naar Huijts \& Backes 2015. 
verder denkwerk moeten worden verricht, mede omdat Backes en ik uitgingen van het planschade- en omgevingsrecht van de Wro en dus bijvoorbeeld nog geen rekening hielden met het globalere karakter van het omgevingsplan. ${ }^{172}$ Hoewel de motivering van het kabinet om niet voor deze oplossing te kiezen mijns inziens niet overtuigend is, is zij dermate principieel dat ik ook deze oplossing hier niet verder zal onderzoeken. ${ }^{173}$

Uit paragraaf 3.4.2.3 volgde dat het kabinet de uitbreiding van de schaduwschadeproblematiek, die wordt teweeggebracht door de verschuiving van het schademoment, heeft proberen te voorkomen door de beperking van de tegenwerping van actieve risicoaanvaarding. Mede daarom, stel ik voor een oplossing voor de bredere schaduwschadeproblematiek ook te zoeken in de sfeer van de afschaffing of slechts gedeeltelijke tegenwerping van actieve risicoaanvaarding. De achterliggende gedachte is dat indicatief overheidshandelen daardoor minder of zelfs geen waardedaling zal veroorzaken, omdat een potentiële koper de mogelijkheid van realisatie van de in een concreet beleidsvoornemen aangekondigde maatregel niet zal verdisconteren in de prijs die hij bereid is voor de onroerende zaak te betalen, als hem zijn kennis van dat beleidsvoornemen niet zal worden tegengeworpen wanneer hij een aanvraag om nadeelcompensatie indient als de daarin aangekondigde maatregel daadwerkelijk wordt gerealiseerd. Een kanttekening hierbij is dat deze koper wel zal verdisconteren dat hij in deze situatie geen vergoeding zal krijgen voor schade kleiner dan 4\% van de waarde van de onroerende zaak, omdat dat deel van de schade door art. 15.7 lid $1 \mathrm{Ow}$ als normaal maatschappelijk risico van vergoeding wordt uitgesloten. In hoofdstuk 6 zal ik ingaan op de vraag hoe dit percentage zich verhoudt tot de aan de Wns ten grondslag liggende doelstellingen en uitgangspunten. Hier volsta ik met de opmerking dat deze verdiscontering mijns inziens niet problematisch hoeft te zijn. Als de verkopende partij niet zou verkopen was dit deel van de schade immers ook voor zijn rekening gekomen. Bovendien kan hij met de koper overeenkomen dat bijvoorbeeld ieder $2 \%$ voor zijn rekening neemt en/of hij van de koper een bepaald bedrag zal ontvangen als de aangekondigde ontwikkeling niet blijkt te worden gerealiseerd binnen een periode van een aantal jaren.

Voor de gedachtevorming over deze oplossingsrichting is relevant dat Kortmann in 2017 het voorstel deed om de afschaffing van tegenwerping van risicoaanvaarding te combineren met een systeem van een zaaksgebonden recht op compensatie; recht op een voorschot; plicht tot eventuele terugbetaling van het teveel verstrekte; en zekerheidsstelling voor deze terugbetaling. Beknopt samengevat, stelde hij voor de waardedaling door indicatief overheidshandelen te ondervangen

172 Ook destijds benoemden wij al dat de door ons gedane voorstellen op bepaalde punten nog verdere uitwerking zouden behoeven. Het was niet ons doel een sluitende oplossing te bieden, maar een oproep te doen om na te denken over de verdere ontwikkeling van het planschaderecht en een eerste aanzet tot een mogelijke ontwikkelingsrichting te geven. Zie Huijts en Backes 2015, p. 141. 
door de verkoper te bewegen een marktconforme koopprijs - waarin het indicatieve overheidshandelen dus is verdisconteerd - te accepteren onder toekenning van een door het bestuur te betalen voorschot. De koper en zijn rechtsopvolgers staan garant voor het geval later blijkt dat het voorschot groter was dan de onevenredige schade die werd veroorzaakt door de definitieve maatregelen en activiteiten. Blijkt de onevenredige schade uiteindelijk kleiner dan het toegekende voorschot, dan ontvangen de koper en zijn rechtsopvolgers nadeelcompensatie voor het resterende deel van de onevenredige schade. Dit is een mooie aanzet tot een oplossing, die met name beoogt bij alle betrokken partijen vertrouwen te wekken in een redelijke uitkomst van het schadegeschil. Dat neemt niet weg dat deze aanzet nog nadere uitwerking behoeft, zoals Kortmann ook zelf aangeeft. ${ }^{174}$

Gelet op de terughoudendheid van het kabinet om een generieke regeling voor schaduwschade te treffen, verwacht ik echter dat een algehele afschaffing van de tegenwerping van actieve risicoaanvaarding een brug te ver zal zijn. Risicoaanvaarding vormt naar huidig recht immers een belangrijk criterium voor het bestuur om aansprakelijkheid af te wenden, en het kabinet lijkt aansprakelijkheidsrisico's juist zo beperkt mogelijk te willen houden om globale- en uitnodigingsplanologie te promoten. Ook op het voorstel van Kortmann zal ik daarom niet nader ingaan. Bezien vanuit de aan de Wns ten grondslag liggende doelstellingen en uitgangspunten is bovendien problematisch aan dat voorstel dat het slecht aansluit op de doelstellingen van vergroting van de doelmatigheid van het nadeelcompensatierecht en vermindering van bestuurslasten, en vereenvoudiging van het nadeelcompensatierecht. Bovendien denk ik dat enkel de afschaffing van tegenwerping van actieve risicoaanvaarding in combinatie met het bestaan van de formeelwettelijke nadeelcompensatieregelingen van titel $4.5 \mathrm{Awb}$ en afd. $15.1 \mathrm{Ow}$ reeds voldoende vertrouwen bij de koper zal wekken om hem te bewegen indicatief overheidshandelen niet (meer dan als hiervoor beschreven) in de koopprijs te verdisconteren.

Gelet op art. 15.5 Ow lijkt het kabinet slechts bereid om de tegenwerping van risicoaanvaarding te beperken voor gevallen van waardedaling van tot woning bestemde onroerende zaken. De achterliggende gedachte is dat beroeps- of bedrijfsmatige kopers bij investeringsbeslissingen worden geacht rekening te houden met mogelijk nadelige ontwikkelingen in de omgeving van het perceel waarop de onroerende zaak is gelegen. Omdat een generieke regeling voor de schaduwschadeproblematiek ook van toepassing zou zijn op schaduwschade die geen verband houdt met het doorschuiven van het schademoment, lijkt het aannemelijk dat het kabinet de reikwijdte van een dergelijke regeling nog verder zal willen beperken. Dat zou kunnen door niet slechts te vereisen dat de onroerende zaak tot woning is bestemd, maar ook daadwerkelijk daarvoor wordt gebruikt. Daartoe zou kunnen worden bepaald dat de onroerende zaak tot woning moet zijn bestemd en de aanvrager haar volgens de gemeentelijke basisadministratie als hoofdverblijf in gebruik moet hebben op zowel de peildatum voor het ontstaan van de schade door 
de definitieve maatregel/activiteit als op het moment van beslissen op de aanvraag om nadeelcompensatie. De achterliggende gedachte zou zijn dat personen met meerdere onroerende zaken ook rekening dienen te houden met mogelijk nadelige ontwikkelingen in de omgeving van de percelen waarop de onroerende zaken zijn gelegen, zeker als zij een woning aankopen met een andere reden dan permanente bewoning. Deze aanvullende voorwaarde lijkt bovendien dermate weinig extra inspanning van het bestuur te verlangen dat zij verenigbaar is met de doelstellingen van vergroting van de doelmatigheid van het nadeelcompensatierecht en vermindering van bestuurslasten, vereenvoudiging van het nadeelcompensatierecht, en overige aan de Wns ten grondslag liggende doelstellingen en uitgangspunten. Ook in meer algemene zin lijkt een beperking van de tegenwerping van actieve risicoaanvaarding verenigbaar met de aan de Wns ten grondslag liggende doelstellingen en uitgangspunten. Daarbij merk ik op dat inherent aan iedere oplossing voor schaduwschadeproblematiek is dat de bestuurslasten zullen stijgen, en de rechtszekerheid die de burger wint ten koste zal gaan van de rechtszekerheid van het bestuur.

Ten slotte zou de wetgever de reikwijdte van de regeling inzake afschaffing van tegenwerping van actieve risicoaanvaarding nog verder kunnen beperken conform een publicatie van Ten Kate uit 2013. Hij merkt op dat "bij een eenvoudige koop en verkoop van een onroerende zaak het nadeel dat door het schadeveroorzakend besluit wordt toegebracht niet toeneemt." Het nadeel door de definitieve maatregel of activiteit verschuift slechts van verkoper naar koper. Dat de koper desondanks in beginsel actieve risicoaanvaarding wordt tegengeworpen, leidt "tot het onbevredigende resultaat dat de gemeente de lachende partij is." Geïnspireerd door het onteigeningsrecht oppert Ten Kate daarom om actieve risicoaanvaarding slechts tegen te werpen als, "bezien vanuit het perspectief van de overheid, de schade als gevolg van handelen van de benadeelde is toegenomen." 175

Ook deze beperking van de tegenwerping van actieve risicoaanvaarding lijkt mij niet onverenigbaar met de aan de Wns ten grondslag liggende doelstellingen en uitgangspunten of overigens onredelijk. Bij keuze voor deze beperking, verdient het wel aanbeveling dat de wetgever zich op voorhand in toelichtende stukken uitlaat over de vraag wanneer de schade wordt vermoed als gevolg van handelen van de benadeelde te zijn toegenomen. Ten Kate stelt bijvoorbeeld de vraag hoe dient te worden omgegaan met een verbouwing van de onroerende zaak direct na aankoop daarvan, terwijl ten tijde van de aankoop reeds een concreet beleidsvoornemen van overheidswege was gepubliceerd. ${ }^{176}$ In een uitspraak van 16 april 2014 beslechtte de Afdeling een geschil waarin ten tijde van de aankoop van een woning nog geen rekening kon worden gehouden met de komst van een bedrijventerrein en dus geen risicoaanvaarding kon worden tegengeworpen. Toen de komst van dat terrein wel voorzienbaar was, verbouwde aanvrager zijn woning. B\&W

175 Ten Kate 2013, p. 108-111.

176 Ten Kate 2013, p. 111. 
besloten de schade die was te herleiden tot het verbouwde deel van de woning daarom wegens risicoaanvaarding voor rekening van de aanvrager te laten. De Afdeling haalde daar echter een streep door. ${ }^{177} \mathrm{Ik}$ kan me voorstellen dat het zinvol is anders te oordelen wanneer de oplossing van Ten Kate zou worden ingevoerd. Zo lijkt de koper zijn (op dat moment nog potentiële) schade onnodig te vergroten als hij bijvoorbeeld zijn woning direct na aankoop uitbreidt met een volledig glazen serre terwijl voorzienbaar is dat de woning kan worden omringd met hoogbouw. ${ }^{178}$

\section{Schaduwschade en ondernemers}

De voorstellen die ik hiervoor heb gedaan, hebben slechts betrekking op onverkoopbare onroerende zaken en tijdelijk in waarde verminderde woningen. Zij bieden dus geen uitkomst aan de ondernemer wiens bedrijfspand door indicatief overheidshandelen in waarde daalt en daardoor minder geschikt wordt als onderpand voor het verkrijgen van financiering. Ook vormen zij geen oplossing voor andere vormen van schaduwschade die ondernemers kunnen ondervinden, zoals negatieve ontwikkelingsschade. ${ }^{179}$ Zou de wetgever wel een oplossing willen bieden voor door ondernemers ondervonden schaduwschade, dan lijkt deze met name te moeten worden gezocht in het als niet exclusief aanmerken van de opsomming van art. 15.1 Ow voor schade in de vorm van inkomensderving en misgelopen voordeel. Ik verwacht niet dat dit grote problemen voor het bestuur zal veroorzaken. Inkomensschade wordt namelijk doorgaans niet als gevolg van bindende planologische besluitvorming aan het bestuur toegerekend, maar gezien als gevolg van het handelen en keuzes van derden. ${ }^{180}$ Bovendien ligt de bewijslast voor het causaal verband bij de ondernemer, die het bestuur van financiële stukken zal moeten voorzien waarin de gestelde inkomensderving is geconcretiseerd en onderbouwd. ${ }^{181}$ Wegens normaal maatschappelijk risico zou voorts een relatief hoog percentage van de gemiddelde jaaromzet van de onderneming als (ingangs)drem-

177 ABRvS 16 april 2014, ECLI:NL:RVS:2014:1300, r.o. 6.1.

178 Een ander voorbeeld kan mogelijk worden gevonden in ABRvS 18 mei 2011, ECLI:NL:RVS:2011:BQ4893, r.o. 2.8: de uitbreiding van een winkel terwijl de exploitant van de winkel "rekening moest houden met het mogelijk vervallen van parkeerplaatsen in de nabijheid van de winkel".

179 Zie hierover paragraaf 3.2.3.

180 Zie de bespreking van ABRvS 9 juni 2004, ECLI:NL:RVS:2004:AP1102, r.o. 2.6.1 (Eneco) in paragraaf 4.2.4; ABRvS 28 september 2016, ECLI:NL:RVS:2016:2582, r.o. 2.11 (Overzichtsuitspraak); en Dijkshoorn 2011a, p. 47. Zie voor enkele spaarzame voorbeelden van inkomensschade in het planschaderecht: ABRvS 9 december 2015, ECLI:NL:RVS:2015:3767, r.o. 3.1-3.2; en ABRvS 16 december 2015, ECLI:NL:RVS:2015:3819 (Urilift, einduitspraak). Voor bestudering van deze uitspraak verwijs ik ook naar ABRvS 23 oktober 2013, ECLI:NL:RVS:2013:1621 (Urilift, eerste tussenuitspraak) en ABRvS 10 december 2014, ECLI:NL:RVS:2014:4033 (Urilift, tweede tussenuitspraak).

181 ABRvS 23 oktober 2013, ECLI:NL:RVS:2013:1621, r.o. 9 (Urilift, eerste tussenuitspraak). Zie ook Van Ravels 2010a, p. 544. 
pel kunnen worden tegengeworpen. ${ }^{182}$ Dit zou kunnen worden gecombineerd met de regel dat schade die correspondeert met een $\mathrm{x}$ aantal jaren onzekerheid ${ }^{183}$ niet voor vergoeding in aanmerking komt, omdat deze nu eenmaal inherent is aan het zijn van ondernemer in een dichtbevolkt land als Nederland. ${ }^{184}$ Ten slotte merk ik op dat het risico op overcompensatie nauwelijks aanwezig is, omdat inkomensderving niet het dynamische karakter van waardedaling van onroerende zaken kent: de definitieve planologische besluitvorming of uitvoering van een planactiviteit kan niets meer veranderen aan het feit dat gedurende een periode van onzekerheid minder omzet is gedraaid of anderszins inkomsten zijn misgelopen. Zeker wanneer de bovenstaande 'randvoorwaarden' op voorhand duidelijk worden gecommuniceerd en eventueel een recht als bedoeld in art. 4:128 Awb wordt geheven ter in behandeling name van de aanvraag om compensatie, acht ik deze oplossing verenigbaar met de aan de Wns ten grondslag liggende doelstellingen en uitgangspunten. ${ }^{185}$ Een concreet voorstel voor een wettelijke bepaling waarmee zij kan worden geïmplementeerd, zal ik doen in paragraaf 3.5.

\subsection{CONCLUSIE}

Uit het voorafgaande kan worden afgeleid dat de aan de Wns ten grondslag liggende doelstellingen en uitgangspunten mijns inziens geen aanleiding geven tot (a) aanpassing van titel 4.5 Awb. Wel geven zij aanleiding (c) anderszins te voorzien in een bijzondere invulling of aanvulling van titel $4.5 \mathrm{Awb}$. Na inwerkingtreding van titel 4.5 Awb zou mijns inziens namelijk moeten worden geëvalueerd of de brede reikwijdte van titel 4.5 Awb tot problemen leidt buiten het omgevingsrecht. De aan de Wns ten grondslag liggende doelstellingen en uitgangspunten geven mijns inziens ook aanleiding tot (b) aanpassing van afd. 15.1 Ow. Er bestaat voldoende grond om het exclusieve karakter van de limitatieve opsomming van schadeoorzaken van art. 15.1 lid 1 Ow te behouden, mits een generieke oplossing wordt getroffen voor de daardoor veroorzaakte schaduwschadeproblematiek. Die oplossing verschilt naar gelang het type schaduwschade. Voor schaduwschade in de vorm van tijdelijke onverkoopbaarheid van onroerende zaken heb ik voorgesteld een bepaling in hoofdstuk $11 \mathrm{Ow}$ in te voeren. Zij zou een recht op uitkoop moeten verschaffen aan de eigenaar die zijn onroerende zaak gedurende een zekere periode niet heeft weten te verkopen als gevolg van indicatief overheidshandelen.

182 Vergelijk Van Heijst 2017, p. 154

183 Zie voor een gelijkenis vertonend voorstel dat niet is beperkt tot door ondernemers geleden schaduwschade ook Van den Broek \& Tjepkema 2015, p. 42, 101-102, 106-107.

184 Zie Backes \& Huijts 2015, p. 140 voor een vergelijkbare redenering in een andere context.

185 Dat laat onverlet dat aan iedere oplossing voor schaduwschadeproblematiek inherent is dat de bestuurslasten zullen stijgen, en de rechtszekerheid die de burger wint ten koste zal gaan van de rechtszekerheid van het bestuur. 
Voor schaduwschade in de vorm van een tijdelijke waardevermindering van onroerende zaken is aanbevolen de tegenwerping van actieve risicoaanvaarding te beperken. Daartoe zou art. 15.5 Ow moeten worden geschrapt en worden vervangen door een bepaling die een uitzondering maakt op art. 4:126 lid 2, aanhef en onder a Awb. Die uitzondering houdt in dat geen actieve risicoaanvaarding wordt tegengeworpen aan de indiener van een aanvraag om nadeelcompensatie wegens waardedaling van een onroerende zaak die (1) tot woning is bestemd en die (2) de aanvrager volgens de gemeentelijke basisadministratie als hoofdverblijf in gebruik heeft op zowel de peildatum voor het ontstaan van de schade door de definitieve maatregel/activiteit als op het moment van beslissen op de aanvraag om compensatie. De wetgever zou er bovendien voor kunnen kiezen als extra voorwaarde op te nemen dat de aanvrager de schade, bezien vanuit het perspectief van de overheid, niet heeft doen toenemen ten opzichte van de situatie waarin degene van wie hij de woning heeft gekocht ervoor had gekozen de woning niet te vervreemden. Een concreet voorstel voor een dergelijke bepaling zal ik doen in paragraaf 8.5 .

Voorts heb ik aandacht besteed aan schaduwschade die ondernemers ondervinden in de vorm van negatieve ontwikkelingsschade en misgelopen inkomsten. Naar aanleiding daarvan heb ik aanbevolen de limitatieve opsomming van art. 15.1 lid $1 \mathrm{Ow}$ niet als exclusief aan te merken voor inkomensschade. Dat kan worden gerealiseerd door middel van de volgende bepaling:

\section{Artikel 15.x Ow}

1. In afwijking van artikel 15.1 van deze wet is titel 4.5 van de Algemene wet bestuursrecht ook van toepassing op de toekenning van vergoeding van schade als bedoeld in artikel 4:126, eerste lid, van die wet indien een bestuursorgaan inkomensschade veroorzaakt in de rechtmatige uitoefening van zijn op deze wet gebaseerde publiekrechtelijke bevoegdheid of taak die niet wordt genoemd in artikel 15.1, eerste lid, van deze wet.

2. De in het eerste lid bedoelde schade komt slechts voor vergoeding in aanmerking in zoverre zij:

a. groter is dan ... procent van de omzet die naar redelijke verwachting behaald zou zijn, indien de in het eerste lid bedoelde gebeurtenis niet had plaatsgevonden; ${ }^{186}$ en

b. is geleden nadat ... jaren zijn verstreken sinds de in het eerste lid bedoelde gebeurtenis.

186 Deze formulering is geïnspireerd op de definitie van 'normomzet' in art. 1 BnIW 2019. 



\section{Hoofdstuk 4}

\section{Causaal verband}

\subsection{INLEIDING}

Als is geconstateerd dat het beweerdelijk schadeveroorzakende overheidshandelen kwalificeert als een schadeoorzaak die onder de reikwijdte van de toepasselijke nadeelcompensatieregeling valt (zie hoofdstuk 3), dient te worden vastgesteld of er causaal verband bestaat tussen dat overheidshandelen en de gestelde schade. ${ }^{1}$ In dit hoofdstuk zullen de tweede en derde deelvraag en de hoofdvraag in drie opeenvolgende paragrafen worden beantwoord ten aanzien van dit criterium van causaal verband. In hoofdstuk 5 zal vervolgens worden ingegaan op de vraag hoe de schade dient te worden begroot. Deze vraag komt doorgaans pas aan de orde nadat het causaal verband tussen de beweerde schadeoorzaak en de gestelde schade is vastgesteld.

\subsection{DeElvRaAg 2: Verschillen tuSSEN DE GESELECTEERDE, THANS GELDENDE REGELINGEN EN VERKLARINGEN DAARVOOR}

\subsubsection{De tekst van de regelingen en de daarbij behorende toelichtingen}

De meeste regelingen geven slechts blijk van het criterium van causaal verband doordat in algemene zin wordt vermeld dat enkel schade "als gevolg van" (art. 6.1 lid 1 Wro en art. 2 lid 1 BnIW 2019), "ten gevolge van" (art. 49 WRO en art. 8.31 Wlv), of "door" (art. 21 Aanwijzingsbesluit 1996) een schadeoorzaak die binnen de reikwijdte ${ }^{2}$ van de desbetreffende regeling valt voor vergoeding in aanmerking komt. Dergelijke formuleringen komen ook terug in de $\mathrm{VNNZZ}^{3}$ en $\mathrm{AVN},{ }^{4}$ maar in die regelingen is het criterium van causaal verband een prominentere positie gegeven doordat het is opgenomen in een opsomming van weigeringsgronden. In art. 3 lid 1, aanhef en onder d VNNZ is namelijk bepaald dat de aanvraag om

1 ABRvS 28 september 2016, ECLI:NL:RVS:2016:2582, r.o. 1.2 en 4.3 (Overzichtsuitspraak).

2 Zie paragraaf 3.2.

3 Uit de definitie van nadeel in art. 1, aanhef en onder d VNNZ blijkt dat de schade moet zijn veroorzaakt door rechtmatig overheidshandelen en het gevolg moet zijn van de aanleg van de Noord/Zuidlijn.

4 Art. 2 lid 1 AVN bezigt net als art. 49 WRO en art. 21 Aanwijzingsbesluit 1996 de formulering "ten gevolge". 
nadeelcompensatie dient te worden afgewezen indien "het nadeel naar het oordeel van het college geen gevolg is van de aanleg van de Noord/Zuidlijn." Art. 3 lid 1, aanhef en onder a AVN bepaalt dat het bestuursorgaan de aanvraag om nadeelcompensatie dient af te wijzen indien "de schade redelijkerwijs niet kan worden toegerekend (eigen cursivering) aan een door hem genomen besluit of verrichte handeling."

Het is opmerkelijk dat in art. 3 lid 1, aanhef en onder d VNNZ de formulering 'naar het oordeel van het college' is gebruikt. Die formulering suggereert namelijk dat het bestuur beoordelingsruimte toekomt bij de beoordeling van het causaal verband. Dat is volgens vaste jurisprudentie echter niet het geval. ${ }^{5}$ Afgaande op de toelichtende stukken behorende bij de VNNZ en haar voorgangster lijkt de Amsterdamse gemeenteraad niet te hebben beoogd van deze jurisprudentie af te wijken. Ik zie bovendien geen reden waarom de Afdeling een dergelijke afwijking zou toestaan. Ik ga daarom ervan uit dat het hier slechts een ongelukkige formulering betreft die niet tot een materieel verschil met de overige geselecteerde, thans geldende regelingen leidt. Ook voor overige verschillen in terminologie heb ik geen duidelijke verklaringen kunnen vinden. ${ }^{6}$ Dat bijvoorbeeld soms wordt gesproken van "als gevolg van" en soms van "ten gevolge van" lijkt slechts te kunnen worden verklaard doordat de regelingen gedurende enkele decennia door verschillende regelgevers ${ }^{7}$ zijn opgesteld, terwijl die regelgevers ten aanzien van dit onderwerp geen aandacht lijken te hebben gehad voor afstemming op andere nadeelcompensatieregelingen en/of overleg met elkaar, laat staan een materieelrechtelijk verschil in het leven beoogden te roepen.

Dat het ontbreken van causaal verband slechts in de Amsterdamse verordeningen als weigeringsgrond is opgenomen, kan waarschijnlijk (ook) worden verklaard door de vanzelfsprekendheid van het criterium: schade die niet door het bestuur is veroorzaakt, kan ook niet tot aansprakelijkheid van het bestuur leiden. ${ }^{8}$ Dat de Amsterdamse gemeenteraad er desondanks voor heeft gekozen deze weigeringsgrond wel expliciet op te nemen, kan wellicht worden verklaard doordat dit de enige van de bestudeerde regelgevers is die met zoveel woorden heeft uitgesproken dat hij aansluiting heeft gezocht bij art. 6:98 BW. Voor wat betreft de VNNZ

5 Zie paragraaf 2.6, onder verwijzing naar ABRvS 28 september 2016, ECLI:NL:RVS:2016:2582, r.o. 8.8 (Overzichtsuitspraak).

6 Zie voor een vergelijkbare conclusie met betrekking tot verschillen in formulering tussen andere regelingen ook Hoitink \& De Looij 2007, p. 74.

7 Om niet in onnodig formalisme te vervallen zal ik in het vervolg van dit boek steeds spreken van 'regelgevers'. Technisch gezien, betreft het echter niet alleen regelgevers maar ook uitvoerende bestuursorganen die een beleidsregel hebben vastgesteld.

8 Niet alleen in de tekst van de meeste nadeelcompensatieregelingen, maar ook in de juridische literatuur blijkt het criterium van causaal verband in de schaduw te staan van de andere eisen die het égalitébeginsel stelt aan toekenning van nadeelcompensatie. Zie hierover ook Drupsteen 1988, p. 36; en Tjepkema 2010, p. 316. 
blijkt dit slechts uit de toelichting behorende bij de Verordening Nadeelcompensatie en Planschade Noord-Zuidlijn. ${ }^{9}$ Voor wat betreft de AVN blijkt dit uit de bij die regeling behorende toelichting en de tekst van art. 3 lid 1, aanhef en onder a AVN. Door in deze bepaling te spreken van 'toegerekend' heeft de Amsterdamse gemeenteraad expliciet aansluiting willen zoeken bij de causaliteitsleer van art. 6:98 BW, waarin toerekening naar redelijkheid een belangrijke rol speelt. Daarbij had overigens meer precisie kunnen worden betracht. Zo geeft art. 6:98 BW een niet-limitatieve opsomming van toerekeningsfactoren, namelijk de aard van de aansprakelijkheid en van de schade, terwijl de AVN dat niet doet. Bovendien spreekt art. 6:98 BW van toerekening van de schade aan de schuldenaar als een gevolg van een gebeurtenis waarop diens aansprakelijkheid berust, terwijl de schade volgens de AVN dient te worden toegerekend aan die gebeurtenis. Dit gebeurt overigens ook in zowel nadeelcompensatie- als onrechtmatigedaadsjurisprudentie ${ }^{10}$ en in de juridische literatuur. ${ }^{11}$ Waarschijnlijk kan dit worden verklaard vanuit praktische motieven. Het is nou eenmaal korter om te spreken van 'schade die aan de schadeoorzaak kan worden toegerekend' dan 'schade die aan het bestuur kan worden toegerekend als gevolg van de schadeoorzaak'. Ik heb dan ook niet de indruk dat de Amsterdamse gemeenteraad op dit punt heeft willen afwijken van de causaliteitsleer van art. 6:98 BW.

Zowel uit de toelichting behorende bij de BnIW 2019 als uit het door de besliscommissie van het Schadeschap opgestelde Basisdocument volgt dat aansluiting bij afd. 6.1.10 BW en afd. 6.1.11 BW kan worden gezocht. ${ }^{12}$ Aansluiting bij art. 6:98 BW ligt daarom ook onder deze regelingen voor de hand, aldus ook de auteur ${ }^{13}$ van de RnVW 1999, zijnde Van Ravels. ${ }^{14}$ De Kamerstukken behorende bij de Wro en WRO geven geen informatie prijs omtrent de inhoudelijke invulling van het criterium van causaal verband. Uit hierna nog te bespreken jurisprudentie blijkt echter dat de Afdeling zowel in het planschaderecht als het overige nadeel-

9 Zie ad 3 van de toelichting op art. 2 Verordening Nadeelcompensatie en Planschade Noord-Zuidlijn. Ik zie geen aanleiding om aan te nemen dat dit deel van de toelichting niet ook zou opgaan voor de invulling van het causaal verband onder de VNNZ.

10 Zie ABRvS 15 december 2004, ECLI:NL:RVS:2004:AR7586, r.o. 2.3.1 (Grim/ Meerssen); ABRvS 9 juli 2014, ECLI:NL:RVS:2014:2510, r.o. 4.1 (Bloemendaal); en ABRvS 30 augustus 2017, ECLI:NL:RVS:2017:2300, r.o. 20.

11 Zie Hoitink \& Koetser 2007, p. 342-343; Van den Broek \& Groothuijse 2007, p. 155; Tjepkema 2010, p. 329; en Van Ravels 2013b, p. 12 en 15.

12 Zie Stcrt. 1999, nr. 172, p. 9 (digitaal, p. 5), respectievelijk Basisdocument, p. 22.

13 Dit is niet op te maken uit de regeling of de toelichting daarop, maar wordt vermeld in Polak 2002, p. 121. Eveneens wordt dit vermeld in het voorwoord bij de uitgave van de regeling door het ministerie in boekvorm: "Daarbij noem ik met name de heer mr. B.P.M. van Ravels, die de regeling in belangrijke mate inhoudelijk heeft vormgegeven." Uiteindelijk blijft het uiteraard de regeling van de minister.

14 Zie het vijfde onderdeel van de annotatie van Van Ravels bij ABRvS 3 februari 2010, ECLI:NL:RVS:2010:BL1791 in $A B$ 2010/338 en onderdeel 5-7 van zijn annotatie bij ABRvS 28 januari 2009, ECLI:NL:RVS:2009:BH1100 in $A B$ 2009/410. 
compensatierecht aansluiting zoekt bij art. 6:98 BW. Uit de toelichting behorende bij de Verordening Nadeelcompensatie en Planschade Noord-Zuidlijn blijkt dat dit ook de reden is dat de Amsterdamse gemeenteraad aansluiting bij deze causaliteitsleer heeft gezocht:

"In de rechtspraak en de literatuur wordt, impliciet dan wel expliciet, aangenomen dat wat betreft de bepaling van het causaal verband tussen schade en rechtmatig overheidshandelen dient te worden aangesloten bij art. 6:98 van het Burgerlijk Wetboek. Dat houdt in dat de zogenaamde leer van de redelijke toerekening van toepassing is." ${ }^{15}$

\subsubsection{De causaliteitsleer van art. 6:98 BW}

De aan art. 6:98 BW ten grondslag liggende causaliteitsleer bestaat uit twee fasen. Allereerst dient een condicio sine qua non-verband (hierna: csqn-verband) te worden vastgesteld tussen de gestelde schade en beweerde schadeoorzaak. ${ }^{16}$ De vraag naar de aanwezigheid van csqn-verband wordt beantwoord door na te gaan of de schade ook zou zijn ingetreden indien het beweerdelijk schadeveroorzakend handelen niet had plaatsgevonden. Is dat het geval, dan bestaat er geen csqn-verband tussen de schade en dit handelen. Soms is beantwoording van de csqn-vraag al voldoende om tot de conclusie te komen dat geen causaal verband bestaat. Er zijn echter ook situaties denkbaar waarin de csqn-toets onvoldoende onderscheidende werking heeft. Dat zal zich sneller voordoen naarmate de schade verder van de schadeoorzaak is verwijderd. Er bestaat immers ook een csqn-verband tussen het benoemingsbesluit van het college van B\&W en de schade die wordt veroorzaakt door een verkeersbesluit van datzelfde college. Ook biedt de csqn-toets soms onvoldoende uitkomst in gevallen waarin verschillende handelingen, in al dan niet verschillende mate, hebben bijgedragen aan het ontstaan van de schade. In de literatuur is in dit verband aangegeven dat de csqn-toets slechts draait om de vaststelling van een feitelijk causaal verband. Zonder nadere normatieve of juridische normering zou een veel te ruime (maar soms ook juist een te beperkte overheidsaansprakelijkheid) ontstaan. Deze juridische normering wordt geboden door de tweede fase van de causaliteitstoets: de toerekening naar redelijkheid. ${ }^{17}$

De leer van de toerekening naar redelijkheid is in 1970 door de HR aangenomen en wordt gekenmerkt door een 'multifactor-benadering'. ${ }^{18}$ Dat volgt ook uit de wijze waarop de wetgever deze leer in 1992 in art. 6:98 BW heeft gecodificeerd:

15 Zie ad 3 van de toelichting op art. 2 Verordening Nadeelcompensatie en Planschade Noord-Zuidlijn.

16 Dit volgt niet expliciet uit de tekst van art. 6:98 BW, maar werd wel geëxpliciteerd in HR 9 april 2004, ECLI:NL:HR:2004:AO3170, r.o. 3.4.2 (Fibromyalgie).

17 Zie bijvoorbeeld Klaassen 2017, p. 33-49; Asser/Sieburgh 6-II 2017, nr. 50-51; en Drupsteen 1988, p. 35.

18 Zie HR 20 maart 1970, ECLI:NL:HR:1970:AC5007 (Schade waterwinning); en Boonekamp, in GS Schadevergoeding, art. 6:98 BW, aant. 4.1. 
"Voor vergoeding komt slechts in aanmerking schade die in zodanig verband staat met de gebeurtenis waarop de aansprakelijkheid van de schuldenaar berust, dat zij hem, mede gezien de aard van de aansprakelijkheid en van de schade, als een gevolg van deze gebeurtenis kan worden toegerekend."

Uit het woordje 'mede' kan worden afgeleid dat de opsomming van art. 6:98 BW niet limitatief is. Dat betekent dat iedere omstandigheid van het individuele geval een rol kan spelen bij de beantwoording van de vraag of de gestelde schade al dan niet als gevolg van de beweerde schadeoorzaak aan de laedens kan worden toegerekend. De wetgever noemt zelf al de aard van de aansprakelijkheid en de aard van de schade. ${ }^{19}$ Door civielrechtelijke auteurs zijn regelmatig opsommingen gepubliceerd van factoren die kunnen dienen als aanvulling op deze twee expliciet door de wetgever genoemde factoren. Hierbij kan worden gedacht aan de voorzienbaarheid van de schade, de verwezenlijking van een geschapen risico, de processuele houding van de aangesprokene en de draagkracht van partijen, ${ }^{20}$ óf "de zwaarte van de verwijtbaarheid (opzet, zware en lichte schuld); verdisconteerde en niet-verdisconteerde risico's en de omstandigheid dat de dader aan de benadeelde onbaatzuchtig een dienst heeft bewezen." ${ }^{21}$ Dit soort opsommingen lenen zich doorgaans slechts beperkt voor toepassing in het planschade- en nadeelcompensatierecht. Zij vormden echter wel een inspiratiebron voor Tjepkema en mij om in 2017 een tiental vuistregels te formuleren die wel zijn toegespitst op dit rechtsgebied. ${ }^{22}$ Ik verwijs naar die publicatie voor een beschrijving van de belangrijkste causaliteitsjurisprudentie en de lijnen die daaruit kunnen worden gedestilleerd. In het navolgende deel van deze paragraaf zal ik deze jurisprudentie slechts bespreken voor zover nodig is om verschillen tussen de geselecteerde, thans geldende regelingen in kaart te brengen (oftewel: voor de beantwoording van de tweede deelvraag).

\subsubsection{Condicio sine qua non in het planschade- en nadeelcompensatierecht}

\subsubsection{De planvergelijking}

De zogenoemde 'planvergelijking', oftewel 'planologische vergelijking', speelt een belangrijke rol in het planschaderecht. De Afdeling beschrijft deze vergelijking als volgt:

Zie voor de rol van deze factoren in het planschade- en nadeelcompensatierecht bijvoorbeeld Van Ravels 2006b, p. 261-262; het tweede onderdeel van Van Ravels' annotatie bij ABRvS 19 april 2006, ECLI:NL:RVS:2006:AW2297 in AB 2006, 251; en Huijts \& Tjepkema 2017, p. 293-295.

20 Zie Boonekamp, GS Schadevergoeding, art. 6:98 BW, aant. 4.3, waarin ook nog andere factoren worden genoemd.

21 Zie Asser/Sieburgh 6-II 2017, nr. 63-64; en Dijkshoorn 2011a, p. 67-68.

22 Huijts \& Tjepkema 2017. 


\begin{abstract}
"Voor de beoordeling van een aanvraag om een tegemoetkoming in planschade dient te worden onderzocht of de aanvrager als gevolg van de desbetreffende wijziging van het planologische regime in een nadeliger positie is komen te verkeren en ten gevolge daarvan schade lijdt of zal lijden. Hiertoe dient de desbetreffende wijziging, waarvan gesteld wordt dat deze planschade heeft veroorzaakt, te worden vergeleken met het oude planologische regime. Daarbij is niet de feitelijke situatie van belang, maar hetgeen maximaal op grond van het oude planologische regime kon worden gerealiseerd, ongeacht of verwezenlijking heeft plaatsgevonden. Slechts ingeval realisering van de maximale mogelijkheden met aan zekerheid grenzende waarschijnlijkheid kan worden uitgesloten, kan aanleiding bestaan om van dit uitgangspunt af te wijken." 23
\end{abstract}

Deze vergelijking vervult een dubbele functie. Enerzijds functioneert zij als (onderdeel van de) csqn-toets: (1) als er geen sprake is van een planologische verslechtering kan de als schadeoorzaak aangewezen planologische maatregel geen schade hebben veroorzaakt en dus geen causaal verband tussen die maatregel en de gestelde schade bestaan; ${ }^{24}$ en (2) is wel sprake van een planologische verslechtering dan is geen sprake van causaal verband in zoverre de schade niet te herleiden is tot deze verslechtering. ${ }^{25}$ Anderzijds vormt de planvergelijking de basis voor vaststelling van de omvang van schade in de vorm van permanente waardedaling van onroerende zaken. Bij de begroting van deze schade is namelijk maatgevend welke prijs een redelijk denkend en handelend koper onmiddellijk voor de inwerkingtreding van het nieuwe planologische regime en op het tijdstip direct daarna voor de beweerdelijk in waarde gedaalde onroerende zaak zou hebben geboden, uitgaande van hetgeen maximaal op grond van het oude en nieuwe planologische regime kon worden gerealiseerd. ${ }^{26}$

Dat de feitelijke situatie in deze vergelijking in beginsel niet relevant is, kan worden verklaard doordat het planschaderecht ziet op schade door wijziging van juri-

ABRvS 28 september 2016, ECLI:NL:RVS:2016:2582, r.o. 2.1 en 2.3 (Overzichtsuitspraak). In de Overzichtsuitspraak heeft de passage over 'aan zekerheid grenzende waarschijnlijkheid' zijn eigen rechtsoverweging gekregen. Uit uitspraken van zowel vóór (ABRvS 17 april 2013, ECLI:NL:RVS:2013:BZ7707, r.o. 5) als na (ABRvS 16 maart 2018, ECLI:NL:RVS:2018:888, r.o. 11.1) de Overzichtsuitspraak blijkt dat beide passages doorgaans gezamenlijk als één standaardoverweging worden gepresenteerd. Zie voor een uitspraak onder de WRO: ABRvS 22 februari 2006, ECLI:NL:RVS:2006:AV2272, r.o. 2.3 (Emmen).

Zie voor voorbeelden van deze situatie: ABRvS 15 maart 2017,

ECLI:NL:RVS:2017:691, r.o. 3.2; en ABRvS 30 maart 2011, ECLI:NL:RVS:2011:BP9544, r.o. 2.3.2.

25 Zie voor voorbeelden van de tweede situatie: ABRvS 5 maart 1996, ECLI:NL:RVS:1996:AN5056 (Snackbar Lemsterland) en ABRvS 17 maart 1995, ECLI:NL:RVS:1995:AS5927 (Benzinestation Meppel). Beide zaken worden besproken in Van den Broek 2002, p. 79-80.

26 ABRvS 28 september 2016, ECLI:NL:RVS:2016:2582, r.o. 4.6 (Overzichtsuitspraak). Zie hierover ook paragraaf 5.7.1.1 onder het kopje 'De vergelijkingsmethode'. 
dische regimes. Zowel het oude als nieuwe planologische regime dienen daarom per schadefactor maximaal te worden ingevuld op de wijze die het meest nadelig is voor de aanvrager. ${ }^{27}$ Hiervan wordt slechts afgeweken als realisering van de maximale mogelijkheden met aan zekerheid grenzende waarschijnlijkheid kan worden uitgesloten. Dit betreft een uitzondering die slechts zelden wordt aangenomen in de jurisprudentie. ${ }^{28}$ Wel heeft de Afdeling in twee uitspraken van 18 oktober 2017 geoordeeld dat de planologische vergelijking weliswaar "in hoge mate een abstract karakter" heeft, maar dat dit niet zo ver kan gaan dat een planologisch regime zo wordt ingevuld dat hetzelfde object andere afmetingen heeft naar gelang de schadefactor, bijvoorbeeld een geluidscherm van 2 meter hoog bij de factor geluidstoename door verkeersbewegingen en 15 meter hoog bij de factor uitzicht. ${ }^{29}$ Ten slotte betreft het vaste jurisprudentie dat in een bestemmingsplan opgenomen flexibiliteitsbepalingen ${ }^{30}$ (in beginsel) ${ }^{31}$ buiten beschouwing worden gelaten bij de maximale invulling van dat bestemmingsplan. ${ }^{32}$ Indien het besluit waarmee toepassing is gegeven aan een flexibiliteitsbepaling als schadeoorzaak wordt aangemerkt, dient het uit dat besluit voortvloeiende planologische regime te worden vergeleken met het bestemmingsplan waarin de flexibiliteitsbepaling is opgenomen, zonder dat die bepaling bij de planvergelijking wordt betrokken. ${ }^{33}$

ABRvS 28 september 2016, ECLI:NL:RVS:2016:2582, r.o. 2.2 (Overzichtsuitspraak).

28 Zie Berns 2015, p. 78; en Van Ravels 2009b, p. 101-102. Dat de Afdeling streng is, blijkt onder andere uit ABRvS 22 februari 2006, ECLI:NL:RVS:2006:AV2272, r.o. 2.7.1 (Emmen) en ABRvS 30 mei 2007, ECLI:NL:RVS:2007:BA6022, r.o. 2.7.2. Zie voor voorbeelden waarin de uitzondering wel werd aangenomen: ABRvS 9 december 2015, ECLI:NL:RVS:2015:3726, r.o. 4-5 en 9-9.2 (Planschade Harkema, eerste tussenuitspraak) en ABRvS 12 april 2017, ECLI:NL:RVS:2017:1022, r.o. 1-2 en 11-11.1 (Planschade Kerkrade).

29 Zie ABRvS 18 oktober 2017, ECLI:NL:RVS:2017:2802, r.o. 14-14.5; en ABRvS 18 oktober 2017, ECLI:NL:RVS:2017:2805, r.o. 17-17.5.

30 Zie daarover ook paragraaf 3.2.4 onder het kopje 'Keuze van de wetgever'.

31 De Afdeling heeft een grillige koers gevaren inzake de wijze waarop uitwerkingsplichten als bedoeld in art. 3.6 lid 1, aanhef en onder b Wro al dan niet in de planvergelijking moeten worden betrokken. Zie daarover bijvoorbeeld Lam \& Gerritsen 2015. Vergelijk ook ABRvS 7 november 2012, ECLI:NL:RVS:2012:BY2475, r.o. 8.2; ABRvS 17 april 2013, ECLI:NL:RVS:2013:BZ7707, r.o. 13-13.2; ABRvS 4 december 2013, ECLI:NL:RVS:2013:2232, r.o. 10-10.4; ABRvS 24 september 2014, ECLI:NL:RVS:2014:3485, r.o. 6-6.4 (Uitwerkingsplicht Veenendaal); en ABRvS 9 maart 2016, ECLI:NL:RVS:2016:593, r.o. 5.1-5.2. Zie voor een beschrijving van de uiteindelijke lijn ook ABRvS 28 september 2016, ECLI:NL:RVS:2016:2582, r.o. 2.9-2.10 (Overzichtsuitspraak).

32 Zie ABRvS 28 september 2016, ECLI:NL:RVS:2016:2582, r.o. 2.6-2.8 (Overzichtsuitspraak); en ABRvS 7 februari 2018, ECLI:NL:RVS:2018:427, r.o. 6.2-6.3.

33 ABRvS 28 september 2016, ECLI:NL:RVS:2016:2582, r.o. 2.7 (Overzichtsuitspraak). Zie ook Franssen \& Van de Sande 2018b, p. 331 voor de conclusie dat er geen einde komt aan de vragen die de Afdeling hierover moet beantwoorden. 


\section{Verwevenheid met de toerekeningsvraag of het relativiteitsvereiste}

Het is vaste jurisprudentie dat slechts 'ruimtelijke gevolgen' en 'objectief te verwachten gevolgen' van de te vergelijken planologische regimes mogen worden betrokken in de planvergelijking. ${ }^{34}$ Het is niet altijd eenvoudig vast te stellen of daarvan sprake is. ${ }^{35}$ Zo kan de aard van de bebouwing of het gebruik een rol spelen "bij de beoordeling of bebouwing of gebruik in ruimtelijk opzicht een nadelige invloed heeft op de omgeving," ${ }^{36}$ maar wordt lichtschittering beschouwd als een niet-objectiveerbare schadeoorzaak. ${ }^{37}$ In de literatuur wordt deze jurisprudentielijn uiteenlopend gekwalificeerd..$^{38}$ Bepaalde auteurs zien haar als een toepassing van de toerekening naar redelijkheid: niet-ruimtelijke gevolgen kunnen wel in csqn-verband met een planologische maatregel staan, maar worden niet als gevolg daarvan aan het bestuur toegerekend. ${ }^{39}$ Andere auteurs zien haar als een toepassing van het relativiteitsvereiste. Daarbij wordt doorgaans een verband gelegd met art. 3.1 lid 1 Wro, dat bepaalt dat de gemeenteraad ten behoeve van een goede ruimtelijke ordening de bestemming van de in het plan begrepen grond aanwijst en met het oog op die bestemming regels geeft. ${ }^{40}$ De term "goede ruimtelijke ordening" brengt namelijk mee dat slechts regels kunnen worden gesteld die "ruimtelijk relevant" zijn. ${ }^{41}$

Bij mijn weten heeft de Afdeling nooit geëxpliciteerd welke kwalificatie de juiste is. ${ }^{42}$ In combinatie met de wisselende mate van motivering van het oordeel of een

34 ABRvS 28 september 2016, ECLI:NL:RVS:2016:2582, r.o. 2.11-2.12 (Overzichtsuitspraak).

35 Zie bijvoorbeeld Van Ravels 2009c, p. 23; en Van Ravels 2011a, p. 106. Het schiet het doel van deze dissertatie voorbij om hier een uitgebreide verhandeling op te nemen over wat allemaal wel en niet als objectief, ruimtelijk gevolg kan worden aangemerkt. Zie, naast de reeds genoemde publicaties, bijvoorbeeld ook de noot van Van Heijst bij ABRvS 11 maart 2009, ECLI:NL:RVS:2009:BH5487 (Planschade Ohé en Laak) in BR 2009/135; Van Ravels 2011c, p. 141-144; en Van den Broek 2002, 92-94 voor een analyse van relevante jurisprudentie.

36 ABRvS 13 oktober 2010, ECLI:NL:RVS:2010:BO0241, r.o. 2.4.

37 ABRvS 31 juli 2013, ECLI:NL:RVS:2013:566, r.o. 7.1.

38 Zie hierover in algemene zin Dijkshoorn 2011a, p. 73; en Van Ravels 2011c, p. 141144.

39 Zie bijvoorbeeld Tjepkema 2010, p. 330; het eerste onderdeel van de noot van Van den Broek bij ABRvS 18 december 2008, ECLI:NL:RVS:2008:BG8265 in $A B$ 2009/34; en het tweede onderdeel van de noot van Teunissen bij ABRvS 8 augustus 2007, ECLI:NL:RVS:2007:BB1304 in Gst. 2007/150.

40 Ook de Afdeling legt een verband met de eis van een goede ruimtelijke ordening. Zie daarvoor ABRvS 30 oktober 2013, ECLI:NL:RVS:2013:1727, r.o. 5.2.

41 Zie bijvoorbeeld De Graaf \& Tolsma 2014, p. 85; en Van Ravels 2011c, p. 143-144.

42 Die vraag is de Afdeling bij mijn weten overigens ook nooit voorgelegd. Zie voor een vergelijkbare conclusie Van Ravels 2011c, p. 143. 
gevolg als ruimtelijk kan worden aangemerkt, ${ }^{43}$ is het daardoor lastig in te schatten welke stroming in de literatuur het bij het juiste eind heeft. Dat is ook niet nodig gelet op de in deze paragraaf te beantwoorden deelvraag. Voor beantwoording van die deelvraag is wel relevant dat uit het voorafgaande kan worden opgemaakt dat de planologische vergelijking de csqn-toets combineert met toerekeningsvragen en/of het relativiteitsvereiste. Een dergelijke verwevenheid tussen de verschillende fasen van de causaliteitstoets (en/of met het relativiteitsvereiste) is mij niet gebleken bij bestudering van het overige nadeelcompensatierecht. Waarschijnlijk kan zij worden verklaard doordat in het planschaderecht wordt gewerkt met een limitatieve opsomming van specifiek genoemde schadeoorzaken die gemeen hebben dat ze planologisch van aard zijn, én zowel het bestuur als de burger binden en/of inhoudelijk al dermate concreet zijn dat de gevolgen van het besluit en het moment van inwerkingtreding voldoende bepaalbaar zijn. ${ }^{44}$ Dat maakt het immers goed mogelijk om op voorhand in algemene zin aan te geven welke gevolgen van deze schadeoorzaken (in ieder geval geen) aanleiding kunnen geven tot toekenning van compensatie. Zo is het bijvoorbeeld betrekkelijk zinloos om inkomensschade door concurrentietoename te betrekken in de csqn-toets, omdat dergelijke schade niet kwalificeert als ruimtelijk gevolg en dus nooit tot planschadetegemoetkoming kan leiden. ${ }^{45}$

\subsubsection{Schade door wijziging van juridische regimes in het nadeelcompensatierecht}

Een onder art. 8.31 Wlv gewezen Afdelingsuitspraak van 19 februari 2014 bevestigt dat ook in het nadeelcompensatierecht een vergelijking moet worden gemaakt tussen opeenvolgende rechtsregimes als de aanvrager stelt schade te hebben geleden door de wijziging van een juridisch regime. ${ }^{46}$ Door middel van deze vergelijking wordt nagegaan of de aanvrager door de beweerde schadeoorzaak een verslechtering heeft ondervonden, en wordt een eerste stap gezet in het vaststellen van de omvang van de schade. ${ }^{47}$ Zo bracht de door de minister van Landbouw en Visserij afgekondigde 'Regeling verbod voedsel- en slachtafvallen (varkens)' in het in paragraaf 7.1 nog te bespreken Leffers-arrest de verslechtering mee dat var-

43 Voorbeelden van geen, of een beperkte motivering: ABRvS 28 september 2016, ECLI:NL:RVS:2016:2582, r.o. 2.11 (Overzichtsuitspraak); en ABRvS 31 juli 2013, ECLI:NL:RVS:2013:566, r.o. 7.1. Voorbeelden van een uitgebreide(re) motivering: ABRvS 17 augustus 2016, ECLI:NL:RVS:2016:2255, r.o. 12.1-12.2 (Kabeldansen); en ABRvS 24 december 2013, ECLI:NL:RVS:2013:2578 (en 2580), r.o. 7.2, alinea 2.

$44 \quad$ Zie paragraaf 3.2.1.

45 Dat wel sprake is van csqn-verband blijkt expliciet uit ABRvS 28 september 2016, ECLI:NL:RVS:2016:2582, r.o. 2.11 (Overzichtsuitspraak): “Toegenomen concurrentie kan onder omstandigheden weliswaar worden aangemerkt als een gevolg van een planologische mutatie, maar dit is geen ruimtelijk relevant gevolg daarvan."

46 ABRvS 19 februari 2014, ECLI:NL:RVS:2014:572, r.o. 9.2 (Risicolocatie Schiphol).

47 Zie binnen de context van het planschaderecht ook Van Ravels 2011c, p. 133-134. 
kensmesters hun vee niet langer met slachtafval mochten vervoederen. ${ }^{48}$ Slechts de schade die daarmee correspondeerde, kon in causaal verband tot dit verbod staan en voor vergoeding in aanmerking komen.

De uitspraak van 19 februari 2014 makte een einde aan de verwarring ${ }^{49}$ die was ontstaan naar aanleiding van een onder art. 21 Aanwijzingsbesluit 1996 gewezen uitspraak van 9 april 2008. Daarin had de Afdeling een vergelijkingsmaatstaf voorgeschreven die niet deed denken aan de beoordeling van causaliteit, maar aan het criterium van de speciale last. ${ }^{50}$ De Afdeling oordeelde namelijk dat een op het égalitébeginsel gebaseerde aanvraag om nadeelcompensatie...

“(...) een andere benadering dan een verzoek om planschadevergoeding [vergt]. Dit verschil in benadering komt onder meer tot uitdrukking in de aan te leggen vergelijkingsmaatstaf. Anders dan bij een verzoek om planschadevergoeding dient bij een verzoek om nadeelcompensatie gebaseerd op het rechtsbeginsel geen vergelijking van opvolgende juridische regimes te worden gemaakt, maar een vergelijking van het juridische regime dat is vastgesteld voor een beperkte groep burgers met het juridische regime dat is vastgesteld voor burgers die zich in een vergelijkbare situatie bevinden. (...)

De besliscommissie heeft ten onrechte volstaan met een vergelijking van opvolgende juridische regimes. Dat klemt te meer nu eerst in 1996 bij het aanwijzingsbesluit is voldaan aan de reeds in de in 1978 in werking getreden Lvw opgenomen plicht tot het vaststellen van geluidzones rond luchtvaartterreinen, welke langdurige nalatigheid in het voldoen aan deze wettelijke plicht tot het stellen van juridische beperkingen aan de geluidsbelasting vanwege de luchthaven Schiphol, thans in de door de besliscommissie verrichte vergelijking van opvolgende juridische regimes aan de bewoners van woningen die binnen de geluidszones zijn komen te liggen wordt tegengeworpen." ${ }^{\text {I }}$

In de uitspraak van 19 februari 2014 maakte de Afdeling echter duidelijk dat zij een afwijkende vergelijkingsmaatstaf hanteert bij aanvragen om nadeelcompensatie naar aanleiding van schade door het Aanwijzingsbesluit 1996. Daartoe is doorslaggevend dat dit besluit een einde maakte aan de "langdurige nalatigheid in het voldoen aan een wettelijke plicht tot het stellen van juridische beperkingen aan de geluidbelasting veroorzaakt door de luchthaven Schiphol." ${ }^{52}$ Wanneer de Afdeling had vastgehouden aan de reguliere vergelijkingsmaatstaf, had namelijk de voorheen geldende, nagenoeg regelloze toestand moeten worden vergeleken met

48 HR 18 januari 1991, ECLI:NL:HR:1991:AC4031 (Leffers/Staat).

49 Zie onder andere Veenhof \& Keus 2013, p. 8; Sluysmans zijn annotatie bij de uitspraak in TBR 2009/13; Botter \& Franssen 2013, p. 62; Van den Broek 2014, p. 30-31; Van Ravels 2008, p. 135-136; en Franssen e.a. 2014, p. 225-226.

50 Zie hierover ook paragraaf 7.2.2.

51 ABRvS 9 april 2008, ECLI:NL:RVS:2008:BC9040, r.o. 2.6. Dit oordeel werd herhaald in ABRvS 10 november 2010, ECLI:NL:RVS:2010:BO3436, r.o. 2.8-2.8.1

52 ABRvS 19 februari 2014, ECLI:NL:RVS:2014:572, r.o. 9.2 (Risicolocatie Schip$h o l)$. 
de toestand die ontstond door het Aanwijzingsbesluit 1996. Dat zou hebben geleid tot de conclusie dat geen sprake was van een verslechtering, maar juist van een verbetering: een vrijwel ongelimiteerde geluidsbelasting werd immers gelimiteerd door de normen van het Aanwijzingsbesluit 1996. Het lijkt erop dat de Afdeling het niet redelijk vond dat de minister er ten koste van de burger van zou profiteren dat hij zijn wettelijke plicht om degelijke geluidsnormering vast te stellen gedurende ongeveer 18 jaar had verzaakt. ${ }^{53}$

Een soortgelijk oordeel kan worden gevonden in een uitspraak van 2 juli 2014. De Afdeling oordeelde daarin dat aan de afwijzing van een aanvraag om nadeelcompensatie op grond van art. 7.14 lid 1 Waterwet niet ten grondslag kon worden gelegd dat de aanvrager niet in een nadeligere positie was komen te verkeren omdat het vigerende bestemmingsplan de beweerdelijk schadeveroorzakende dijkverhoging reeds mogelijk maakte. In het bestemmingsplan waren namelijk "in het geheel geen grenzen aan de dijkverhoging gesteld". Hierdoor achtte de Afdeling een vergelijking tussen de maximale mogelijkheden van het bestemmingsplan en het projectplan dat voorzag in de dijkverhoging niet goed mogelijk. Een dergelijke vergelijking zou bovendien altijd tot de conclusie hebben geleid dat zich geen nadeligere situatie had voorgedaan. Daarom moest volgens de Afdeling een vergelijking worden gemaakt tussen de "feitelijke situaties met en zonder de uitvoering van het projectplan." ${ }^{54}$

\subsubsection{Schade door feitelijk overheidshandelen in het nadeelcompensatierecht}

In paragrafen 3.2.1 en 3.3.1 bleek dat ook feitelijk overheidshandelen kan kwalificeren als schadeoorzaak die onder de reikwijdte van een nadeelcompensatieregeling valt. Dergelijk handelen kan in het hedendaagse planschaderecht niet leiden tot tegemoetkoming in planschade. Het betreft namelijk vaste jurisprudentie dat tijdelijke hinder als gevolg van werkzaamheden ter uitvoering van een planologische maatregel niet als gevolg van een in art. 6.1 lid 2 Wro genoemde schadeoorzaak aan het bestuur kan worden toegerekend. ${ }^{55}$ Feitelijk overheidshandelen kan wel aanleiding geven tot toekenning van nadeelcompensatie. Ik heb geen aanwijzingen gevonden dat de geselecteerde, thans geldende nadeelcompensatieregelingen de vaststelling van het daarvoor benodigde csqn-verband verschillend zouden

53 Bij andere Aanwijzingsbesluiten kan in beginsel dus 'gewoon' een vergelijking tussen het regime van het Aanwijzingsbesluit in kwestie en het daaraan voorafgaande juridische regime worden gemaakt. Zie bijvoorbeeld ABRvS 13 maart 1997, ECLI:NL:RVS:1997:AN5427 (Vliegveld Welschap) en de bespreking daarvan in Huijts \& Tjepkema 2017, p. 290.

54 ABRvS 2 juli 2014, ECLI:NL:RVS:2014:2396, r.o. 6.1 (Dijkverhoging). Zie voor een vergelijkbaar oordeel onder de 'Verordening Schadevergoeding Rijnland 2005’: ABRvS 9 april 2014, ECLI:NL:RVS:2014:1198, r.o. 3.1 (Kustversterking Noordwijk).

55 ABRvS 28 september 2016, ECLI:NL:RVS:2016:2582, r.o. 3.1 (Overzichtsuitspraak). 
aanvliegen. Het dient voldoende aannemelijk te zijn dat de schade niet zou zijn ontstaan wanneer het feitelijk handelen niet had plaatsgevonden. Heeft de aanvrager niet het feitelijk handelen als schadeoorzaak aangewezen, maar het besluit dat het feitelijk handelen zijns inziens legitimeert, dan dient voldoende aannemelijk te zijn dat de schade niet (rechtmatig) zou zijn ontstaan zonder het desbetreffende besluit. $^{56}$

\subsubsection{Toerekening naar redelijkheid in het planschade- en nadeelcompensatierecht}

De Kroon oordeelde onder art. 49 WRO dat slechts ruimte was voor vergoeding van de gevolgen van de "overheersende en rechtstreekse" werking van een bestemmingsplan. ${ }^{57}$ Dat had onder andere tot gevolg dat indirecte schade niet als gevolg van een bestemmingsplan aan het bestuur kon worden toegerekend. ${ }^{58} \mathrm{De}$ Afdeling voor de geschillen van bestuur van de Raad van State oordeelde dat dit criterium te streng was en sloot aan bij de civiele causaliteitsleer van de toerekening naar redelijkheid. ${ }^{59}$ Ook deze leer wordt in het planschade- en nadeelcompensatierecht echter relatief streng ingevuld. Er wordt namelijk een "rechtstreeks causaal verband" vereist. ${ }^{60}$ In een Afdelingsuitspraak van 9 juni 2004 werd deze eis gemotiveerd met de overweging dat de schadeoorzaak het algemeen belang diende en het ging om schadevergoeding naar aanleiding van rechtmatige daad. In deze uitspraak stond een door energieleverancier Eneco ingediende aanvraag om nadeelcompensatie centraal, waarin het tracébesluit dat de aanleg van de HSLZuid mogelijk maakte als schadeoorzaak werd aangewezen. De Afdeling oordeelde dat de schade van Eneco weliswaar in verband stond tot de aanleg van de HSLZuid, de aankoop door NS Railinfrabeheer BV van de gronden en opstallen van acht betrokken tuinders en de daaropvolgende opzegging door deze tuinders van de met Eneco gesloten distributieovereenkomsten, maar niet in een rechtstreeks verband. De schade was namelijk het "directe gevolg" van de opzegging van de overeenkomsten. ${ }^{61}$ De eis van een rechtstreeks verband zorgt dus ervoor dat de schade niet in redelijkheid aan het bestuur kan worden toegerekend als de schade

56 Dat beide constructies mogelijk zijn, volgt onder andere uit ABRvS 22 augustus 2018, ECLI:NL:RVS:2018:2764, r.o. 10.2.

57 KB 20 mei 1975, ECLI:NL:XX:1975:AR9927.

58 Zie Van den Broek 2002, p. 71-72, onder verwijzing naar het Rapport Commissie Samkalden 1983 en KB 7 september 1971, BR 1971, p. 645-647 (Leersum).

59 Zie hieromtrent bijvoorbeeld Van den Broek 2002, p. 71-75; het tweede onderdeel van de annotatie van Van Buuren bij AGRvS 31 oktober 1991, ECLI:NL:RVS:1991:AN2436 (Mossel/Borne) in $A B$ 1992, 269; en het derde onderdeel van de annotatie van Teunissen bij ABRvS 8 augustus 2007, ECLI:NL:RVS:2007:BB1304 in Gst. 2007/150.

60 ABRvS 28 september 2016, ECLI:NL:RVS:2016:2582, r.o. 3 (Overzichtsuitspraak).

61 ABRvS 9 juni 2004, ECLI:NL:RVS:2004:AP1102, r.o. 2.6.1 (Eneco). 
in een "te ver verwijderd verband" ${ }^{62}$ met de beweerde schadeoorzaak staat. ${ }^{63}$ Soms licht de Afdeling expliciet toe waarom het verband te ver verwijderd is, zoals zij deed in de Eneco-uitspraak. ${ }^{64}$ Soms volstaat de Afdeling echter ook met de enkele overweging dat de gestelde schade geen rechtstreeks gevolg van de beweerde schadeoorzaak was. ${ }^{65}$

Vaak kan slechts uit termen als 'rechtstreeks gevolg' ${ }^{66}$ en 'direct gevolg' ${ }^{67}$ worden afgeleid dat een bepaalde rechtsoverweging dient te worden gelezen als een toepassing van de leer van de redelijke toerekening. Het komt echter ook regelmatig voor dat de Afdeling nadrukkelijker aansluit bij de formulering van art. 6:98 BW. Zij overweegt dan dat de gestelde schade...

"(...) in een zodanig (nauw) verband met de beweerde schadeoorzaak staat, dat de schade het [bestuursorgaan], mede gezien de aard van de aansprakelijkheid en van de schade, als een (rechtstreeks) gevolg van deze schadeoorzaak kan worden toegerekend." ${ }^{\prime 68}$

Ook als deze formule wordt gebruikt, verschilt de mate waarin de Afdeling haar oordelen motiveert. Het algemene beeld is dat de Afdeling wel aangeeft welke omstandigheden van het aan haar voorgelegde geschil een rol hebben gespeeld bij de beantwoording van de toerekeningsvraag, maar niet welk (onderling) gewicht die omstandigheden toekomt. Ook wordt niet altijd geëxpliciteerd onder de

ABRvS 30 oktober 2013, ECLI:NL:RVS:2013:1727, r.o. 5.2; zie ook Rb. Amsterdam 1 maart 2013, ECLI:NL:RBAMS:2013:BZ5716, r.o. 2 (eerste aanleg) en ABRvS 12 maart 2014, ECLI:NL:RVS:2014:831, r.o. 5.1 (hoger beroep).

63 Zie hierover ook Huijts \& Tjepkema 2017, p. 293-294; Tjepkema 2010, p. 326330, 352, 582; onderdeel 5-7 van de noot van Van Ravels bij ABRvS 28 januari 2009, ECLI:NL:RVS:2009:BH1100 in $A B$ 2009/410; en de noot van Van Ravels in $A B$ 2010/338 bij ABRvS 3 februari 2010, ECLI:NL:RVS:2010:BL1791, waarnaar wordt verwezen in Kamerstukken I 2012/13, 32 621, nr. C, p. 5-6 (MvA I, Wns).

64 Zie ook ABRvS 13 februari 2008, ECLI:NL:RVS:2008:BC4221, r.o. 2.6.1; en Rb. Amsterdam 1 maart 2013, ECLI:NL:RBAMS:2013:BZ5716, r.o. 2.

65 ABRvS 3 februari 2010, ECLI:NL:RVS:2010:BL1791, r.o. 2.4.

66 Zie bijvoorbeeld ABRvS 3 februari 2010, ECLI:NL:RVS:2010:BL1791, r.o. 2.4.

67 Zie bijvoorbeeld Rb. Haarlem 19 april 2012, ECLI:NL:RBHAA:2012:BW5717, r.o. 2.6.2 (Bodyfashion Zwanenburg, eerste aanleg); en ABRvS 25 september 2013, ECLI:NL:RVS:2013:1222, r.o. 5.5 (Bodyfashion Zwanenburg, hoger beroep).

Ik heb de woorden 'nauw' en 'rechtstreeks' tussen haakjes geplaatst, omdat zij niet altijd worden gebruikt. Beide termen worden gebruikt in: ABRvS 18 december 2013, ECLI:NL:RVS:2013:2499, r.o. 4.2; ABRvS 5 augustus 2015, ECLI:NL:RVS:2015:2462, r.o. 5.2; en ABRvS 30 augustus 2017, ECLI:NL:RVS:2017:2300, r.o. 20. Slechts 'nauw' wordt gebruikt in: ABRvS 13 februari 2013, ECLI:NL:RVS:2013:BZ1221, r.o. 5.1; en ABRvS 24 december 2013, ECLI:NL:RVS:2013:2578 (en 2580), r.o. 7.2, alinea 2. Beide termen worden niet gebruikt in: ABRvS 19 november 2014, ECLI:NL:RVS:2014:4198, r.o. 7.1; ABRvS 30 augustus 2017, ECLI:NL:RVS:2017:2340, r.o. 5.2 (Expert Soest); en ABRvS 30 oktober 2013, ECLI:NL:RVS:2013:1727, r.o. 5.2 (waarin ook in algemene zin een beknoptere formulering wordt gebruikt). 
noemer van welke 'toerekeningsfactor' de desbetreffende omstandigheid wordt meegewogen. ${ }^{69}$ Daardoor is bovendien slechts duidelijk dat de twee in de formule genoemde factoren (de aard van de aansprakelijkheid en de aard van de schade) een rol kunnen spelen, maar niet of de Afdeling nog andere algemene factoren onderscheidt. ${ }^{70}$ Wel kan uit de Eneco-uitspraak en andere jurisprudentie worden afgeleid dat zowel de aard van de aansprakelijkheid als de aard van de schade in algemene zin pleiten voor terughoudendheid bij de beantwoording van de toerekeningsvraag. In het planschade- en nadeelcompensatierecht gaat het namelijk om compensatie van zuivere vermogensschade naar aanleiding van een rechtmatige daad die het algemeen belang dient. ${ }^{71}$

\section{Enkele 'problematische' uitspraken}

Het causaliteitsoordeel van de Afdeling is niet altijd eenvoudig te plaatsen. Zo vormen termen als 'rechtstreeks verband' en 'direct gevolg' een sterke aanwijzing dat een bepaalde overweging uit de jurisprudentie dient te worden geplaatst binnen de toerekening naar redelijkheid. Toch blijkt dat niet altijd het geval. Zo overwoog de Afdeling in een uitspraak van 9 december 2015 dat de gestelde schade niet het 'rechtstreeks gevolg' was van de beweerde schadeoorzaak, terwijl uit de uitspraak kan worden afgeleid dat geen sprake was van csqn-verband, omdat het als schadeoorzaak aangewezen vrijstellingsbesluit niet leidde tot een beperking van de bedrijfsvoering van appellant die niet reeds uit het bestemmingsplan voortvloeide. ${ }^{72}$ Het zou duidelijker zijn als de Afdeling in dergelijke gevallen zou spreken van 'gevolg', of anderszins duidelijk zou maken in hoeverre de overweging in kwestie al dan niet dient te worden gelezen als een beantwoording van de toerekeningsvraag. Daarbij kan zij een voorbeeld nemen aan haar eigen uitspraak van 19 november 2014:

"Ook als aangenomen moet worden dat [appellante] zonder de inwerkingtreding van het bestemmingsplan niet zou zijn verhuisd, dan brengt dat niet met zich dat de gestelde schade in zodanig verband met het bestemmingsplan staat dat deze als gevolg daarvan moet worden toegerekend (...)." ${ }^{73}$

69 Zij doet dat bijvoorbeeld wel nadrukkelijk in ABRvS 30 augustus 2017, ECLI:NL:RVS:2017:2340, r.o. 5.2 (Expert Soest).

$70 \mathrm{Na}$ afronding van het jurisprudentieonderzoek voor dit proefschrift verscheen ABRvS 26 juni 2019, ECLI:NL:RVS:2019:2025. In r.o. 40 refereert de Afdeling expliciet aan onder andere "de aard en strekking van het schadeveroorzakende handelen." De tijd zal leren of dit een algemene factor is die een vaste rol toebedeeld krijgt in de Afdelingsjurisprudentie.

71 Zie hierover ook Huijts \& Tjepkema 2017, p. 293-295, onder verwijzing naar onder andere ABRvS 9 juni 2004, ECLI:NL:RVS:2004:AP1102, r.o. 2.6.1 (Eneco) en ABRvS 30 augustus 2017, ECLI:NL:RVS:2017:2340, r.o. 5.2 (Expert Soest).

72 ABRvS 9 december 2015, ECLI:NL:RVS:2015:3743, r.o. 2 en 5.2.

73 ABRvS 19 november 2014, ECLI:NL:RVS:2014:4198, r.o. 7.1. 
Het omgekeerde doet zich ook voor: de rechter geeft toepassing aan de leer van de redelijke toerekening, maar expliciteert dat niet. Dit wordt geïllustreerd door een Afdelingsuitspraak van 16 maart 2016. Daarin overwoog de Afdeling dat de rechtbank met juistheid had overwogen dat de staatssecretaris zich terecht op het standpunt had gesteld dat de gestelde schade "niet het gevolg" was van de door de staatssecretaris ingevoerde verplichting om een Air Operator Certificate (hierna: AOC) te hebben, maar "het gevolg" was van de keuze van appellant als ondernemer om geen AOC aan te vragen, waardoor hij zijn rondvluchtbedrijf niet meer mocht exploiteren. Het was zuiverder geweest als de Afdeling hier had gesproken van een 'rechtstreeks gevolg', of anderszins duidelijk had gemaakt dat wel sprake was van csqn-verband ${ }^{74}$ maar niet van schade die in redelijkheid aan de staatssecretaris kon worden toegerekend. ${ }^{75}$ In dit geval zou de Afdeling nog kunnen betogen dat zij slechts het oordeel van de rechtbank bevestigde. Dat verweer gaat echter niet op in een vergelijkbare uitspraak van 25 september 2013, waarin duidelijk sprake was van csqn-verband. De rechtbank merkte de schade - terecht - niet aan als "direct gevolg" van de beweerdelijk schadeveroorzakende wegafsluitingen. Desondanks overwoog de Afdeling dat de exploitant niet aannemelijk had gemaakt dat zijn financieringsproblemen en de door hem ondervonden gevolgen daarvan "het gevolg" van de wegafsluitingen waren. ${ }^{76}$

Ten slotte wijs ik op de Uptown-uitspraak van 16 november 2016. De Afdeling gaf daarin een uitgebreide opsomming van omstandigheden die ten grondslag lagen aan haar oordeel dat de minister van Infrastructuur \& Milieu zich ten onrechte op het standpunt had gesteld dat de gestelde schade alleen het directe gevolg was van gemeentelijke besluiten. Daarbij gaf zij echter niet aan welk deel van de genoemde omstandigheden relevant was voor de onderbouwing van (1) de publiekrechtelijke taak waarop het beweerdelijk schadeveroorzakende handelen van de minister was gebaseerd; (2) de aanwezigheid van csqn-verband; en (3) het oordeel dat de schade in redelijkheid als gevolg van zijn handelen aan de minister kon worden toegerekend. Het causaliteitsoordeel werd hierdoor dermate onduidelijk dat het tot uiteenlopende lezingen leidde in de literatuur. ${ }^{77}$

74 Als de verplichting tot het hebben van een AOC niet was ingevoerd, had appellant zijn rondvluchtbedrijf immers kunnen blijven exploiteren.

75 ABRvS 16 maart 2016, ECLI:NL:RVS:2016:729, r.o. 4.3 (Air Operator Certificate).

76 Zie Rb. Haarlem 19 april 2012, ECLI:NL:RBHAA:2012:BW5717, r.o. 2.62.6.2 (Bodyfashion Zwanenburg, eerste aanleg); en ABRvS 25 september 2013, ECLI:NL:RVS:2013:1222, r.o. 5.5 (Bodyfashion Zwanenburg, hoger beroep). Zie voor een ander voorbeeld: ABRvS 27 oktober 2004, ECLI:NL:RVS:2004:AR4607, r.o. 2.8.1.

77 Zie ABRvS 16 november 2016, ECLI:NL:RVS:2016:3047, r.o. 7 (Uptown) en onderdeel acht van de bijbehorende noot van Tjepkema en mijzelf in $A B$ 2017/331. 


\section{Verschillen en verklaringen}

De in deze deelparagraaf gesignaleerde verschillen in formulering en motivering van het rechterlijk toerekeningsoordeel heb ik niet kunnen herleiden tot de planschade- of nadeelcompensatieregelingen die van toepassing waren in de desbetreffende uitspraken. Soms lijken zij te kunnen worden verklaard doordat de Afdeling aansluit bij de terminologie die is gebezigd door het bestuur in zijn besluitvorming, door partijen in hun processtukken, of door de rechter in zijn uitspraak in eerste aanleg. Vaak lijken zij echter ook willekeurig te zijn. Ik heb geen aanwijzingen gevonden dat de verschillen in gebruikte terminologie zouden leiden tot verschillen in de materieelrechtelijke uitkomst van de causaliteitstoets. Ook overigens heb ik geen aanwijzingen gevonden dat onder de geselecteerde regelingen verschil zou bestaan in de wijze waarop invulling wordt gegeven aan de toerekening naar redelijkheid.

\subsection{DEELVRAAG 3: HET TOEKOMSTIGE RECHT}

\subsubsection{Titel 4.5 Awb}

Uit de tekst van art. 4:126 lid 1 Awb kan worden afgeleid dat de gestelde schade een gevolg moet zijn van de als schadeoorzaak aangewezen, rechtmatige uitoefening van een publiekrechtelijke bevoegdheid of taak door een bestuursorgaan. Titel 4.5 Awb gaat echter niet in op de inhoudelijke eisen die aan dit causaal verband worden gesteld. Eerste Kamerleden van de D66-fractie hebben aangegeven dat opmerkelijk te vinden en de vraag gesteld of bij nadeelcompensatie "een van het civiele recht afwijkende causaliteitsleer" geldt. ${ }^{78}$ De minister antwoordde als volgt:

"Het onderwerp causaal verband vergde geen afzonderlijke regeling. Uit de jurisprudentie blijkt niet van een behoefte aan een specifieke bestuursrechtelijke causaliteitsleer op het gebied van de nadeelcompensatie. De bestuursrechter zoekt reeds aansluiting bij de maatstaf van artikel 6:98 BW."79

Aangezien in de overige Kamerstukken niet meer wordt gesproken over het causaal verband en het wetsvoorstel uiteindelijk is aangenomen, kan de wetgever zich kennelijk vinden in dit antwoord. Ook onder titel 4.5 Awb wordt het criterium van causaal verband dus vormgegeven door een combinatie van de csqn-toets en de toerekening naar redelijkheid.

79 Ter onderbouwing hiervan verwijst de minister naar ABRvS 19 april 2006, ECLI:NL:RVS:2006:AW2297, r.o. 2.6 en de bijbehorende noot van Van Ravels in $A B$ 2006, 251; en ABRvS 3 februari 2010, ECLI:NL:RVS:2010:BL1791 en de bijbehorende noot van Van Ravels in AB 2010, 338. Zie Kamerstukken I 2012/13, 32 621, nr. C, p. 5-6 (MvA I, Wns). 


\subsubsection{Afd. $15.1 \mathrm{Ow}$}

In paragraaf 3.3.2 bleek dat onder afd. 15.1 Ow slechts schade voor vergoeding in aanmerking komt die het gevolg is van een in art. 15.1 lid $1 \mathrm{Ow}$ opgesomde schadeoorzaak. In de bij de IOw behorende memorie van toelichting wordt onder verwijzing naar de in paragraaf 4.3.1 aangehaalde Kamerstukken ${ }^{80}$ opgemerkt dat het samenspel tussen art. 4:126 lid 1 Awb en art. 15.1 lid 1 Ow ervoor zorgt dat schade slechts voor vergoeding in aanmerking komt als...

“(...) de schade redelijkerwijs valt toe te rekenen aan de regel of het samenstel van regels, het besluit of de maatregel die aan de aanvraag om schadevergoeding ten grondslag is of zijn gelegd. Ook moet zijn voldaan aan het vereiste dat de overheidshandeling een noodzakelijke voorwaarde voor het optreden van de schade is (het conditio sine qua non-vereiste).

Daarbij moet in de eerste plaats worden gedacht aan schade die het rechtstreekse gevolg is van de regel, het besluit of de maatregel, zoals de bouw van een woning of de aanleg van een weg die mogelijk wordt gemaakt door een omgevingsvergunning respectievelijk een projectbesluit.

Het kan echter ook gaan om schade die zich later manifesteert of openbaart. Schade als gevolg van de feitelijke uitvoering van de activiteit (zogenoemde uitvoeringsschade), zoals tijdelijke hinder als gevolg van bouwwerkzaamheden of een tijdelijke wegafsluiting, komt ook voor vergoeding op grond van afdeling 15.1 in aanmerking. Verder kan gevolgschade voor vergoeding in aanmerking komen, als deze schade het gevolg is van het verrichten van de activiteit, maar zich pas later openbaart. Daarbij kan worden gedacht aan schade als gevolg van een grondwateronttrekking die zich een aantal jaren kan openbaren nadat de activiteit is verricht." $" 11$

Dat ook uitvoeringsschade als gevolg van de in art. 15.1 lid $1 \mathrm{Ow}$ opgesomde schadeoorzaken aan het bestuur kan worden toegerekend, wijkt af van het huidige planschaderecht. ${ }^{82}$ In paragraaf 4.4 .3 zal ik hier nog nader op ingaan.

Voor het overige lijkt onder afd. 15.1 Ow te moeten worden vastgehouden aan de thans geldende jurisprudentielijnen omtrent de toerekening naar redelijkheid. Zo merkt het kabinet op dat alleen "objectief te verwachten gevolgen die de regel, het besluit of de maatregel heeft voor de fysieke leefomgeving en overlast die inherent is aan de schadeoorzaak (...) aan de overheid [kunnen] worden toegerekend." Het kabinet lijkt dus vast te willen houden aan de in paragraaf 4.2.3.1 besproken

Specifiek wordt verwezen naar Kamerstukken I 2011/12, 32 621, nr. B, p. 4 (VV I, Wns). Daarin wordt echter niets opgemerkt over causaal verband. Mede gelet op de uitleg verschaft in Kamerstukken II 2018/19, 34 986, nr. 3, p. 227 voetnoot 106 (MvT, IOw) ga ik echter ervan uit dat werd gedoeld op de vraag in Kamerstukken I 2011/12, 32 621, nr. B, p. 5 (VV I, Wns) en het antwoord in Kamerstukken I 2012/13, 32 621, nr. C, p. 5-6 (MvA I, Wns).

81 Kamerstukken II 2018/19, 34 986, nr. 3, p. 227 (MvT, IOw).

$82 \quad$ Vergelijk paragraaf 4.2.3.3. 
jurisprudentielijnen inzake ruimtelijke en objectieve gevolgen. Zij lijkt deze lijnen bovendien niet te kwalificeren als een uiting van het relativiteitsvereiste, maar als een uiting van de toerekening naar redelijkheid. Voorts merkt het kabinet op dat schade alleen voor vergoeding in aanmerking komt als deze het gevolg is van rechtmatig gebruik van de toestemming. Daarvan is bijvoorbeeld geen sprake bij schade door "fouten tijdens de bouw of illegaal gebruik van locaties." 83 Ook dat betreft onder het huidige planschaderecht een vaste jurisprudentielijn. ${ }^{84}$

Door de verschuiving van het schademoment als besproken in paragraaf 3.3.2.3 zullen wel veranderingen plaatsvinden in de toepassing van de csqn-toets. Hoe die veranderingen er precies zullen uitzien, blijkt niet altijd duidelijk uit de bij de IOw behorende Kamerstukken. Deels komt dit doordat soms weinig of niets wordt opgemerkt over de vergelijkingsmaatstaf die ten aanzien van een bepaalde schadeoorzaak moet worden aangelegd. Deels is dit echter ook eraan te wijten dat de toelichtingen op de verschillende versies van het wetsvoorstel voor de IOw die naar verloop van tijd zijn gepubliceerd, van elkaar verschillen zonder dat daarvoor een verklaring door het kabinet wordt gegeven. ${ }^{85}$ Desalniettemin zal ik op basis van de tot op heden verschenen stukken aangeven hoe de csqn-toets er waarschijnlijk zal gaan uitzien.

\title{
Directe schade door een omgevingsplan
}

In de aan de AARvS voorgelegde memorie van toelichting behorende bij de IOw is de volgende opmerking te vinden over directe schade door een omgevingsplan:

\begin{abstract}
"Bij een nadelige wijziging van een functie in een omgevingsplan die voor de eigenaar zonder nader afwegingsmoment tot directe schade leidt, gaat afdeling 15.1, net als de Wro, ervan uit dat bij het vaststellen van de omvang van de schade de maximale mogelijkheden voor en na het nemen van het besluit worden vergeleken. Hierbij kan worden gedacht aan een regel die de mogelijkheid om woningen of kantoren te bouwen, beëindigt." $\$ 6$
\end{abstract}

Een vergelijkbare opmerking kan worden gevonden in de memorie van toelichting behorende bij de consultatieversie van de IOw. ${ }^{87}$ Bovendien zijn beide opmerkingen verenigbaar met de beantwoording van Kamervragen in een brief van 3

83 Kamerstukken II 2018/19, 34 986, nr. 3, p. 227 en 29 (MvT, IOw).

84 ABRvS 28 september 2016, ECLI:NL:RVS:2016:2582, r.o. 2.14 (Overzichtsuitspraak). Dit laatste betreft bovendien geen toerekening naar redelijkheid maar het ontbreken van csqn-verband. Ook zonder de planologische maatregel kunnen burgers immers een onroerende zaak op onrechtmatige wijze gebruiken.

85 Zie over de onduidelijkheid die dit met zich brengt bijvoorbeeld ook Ten Have \& Thoonen 2017, p. 16. Zie over andere onvolkomenheden in de toelichtende stukken bijvoorbeeld Nijmeijer 2017, p. 78 en Van den Broek \& Tjepkema 2017, p. 22.

86 MvT IOw als voorgelegd aan de AARvS, p. 185.

87 MvT consultatieversie IOw, p. 123. 
november $2016{ }^{88} \mathrm{Zij}$ zijn echter niet terug te vinden in de versie van de memorie van toelichting die naar de Tweede Kamer is gestuurd. Daarvoor heb ik geen expliciete verklaring kunnen ontdekken. Aangezien deze memorie van toelichting wel enkele opmerkingen bevat die deze vergelijkingsmaatstaf (met enig verbeeldingsvermogen) impliceren ${ }^{89}$ en een andere vergelijking onwaarschijnlijk lijkt, is het onaannemelijk dat het kabinet thans een andere visie zou zijn toegedaan. Ik ga daarom ervan uit dat in geval van directe schade door een omgevingsplan ook onder afd. 15.1 Ow in beginsel een vergelijking tussen de maximale, meest ongunstige invulling van zowel het oude als nieuwe planologische regime dient te worden gemaakt.

\section{Directe schade door een omgevingsvergunning}

Uit paragraaf 3.3.2.3 volgde dat de omgevingsvergunning soms de exclusieve schadeoorzaak vormt bij directe schade. Het betreft gevallen waarin een activiteit op eigen perceel volgens het omgevingsplan vergunningplichtig is en in het besluit tot vergunningverlening een nadere afweging van belangen dient te worden gemaakt. In dergelijke situaties lijkt slechts directe schade te kunnen ontstaan als de vergunningaanvraag wordt afgewezen. Het is immers lastig voor te stellen dat de eigenaar van een perceel een vergunning aanvraagt die zijn perceel in waarde zal doen dalen. Over de wijze waarop de csqn-toets in dit soort gevallen moet worden ingevuld, wordt niets opgemerkt in de bij de IOw behorende memorie van toelichting. Een vergelijking tussen de feitelijke situatie voor en na de weigering van de vergunning lijkt echter te moeten worden uitgesloten. Bij een dergelijke weigering zal immers niets veranderen in de fysieke leefomgeving. Een vergelijking tussen de maximale invulling van de aangevraagde vergunning en de feitelijke situatie voor weigering van die vergunning ${ }^{90}$ óf de maximale invulling van het geldende omgevingsplan ${ }^{91}$ lijkt het meest voor de hand te liggen.

\section{Indirecte schade door een omgevingsvergunning}

Voor wat betreft de csqn-toets bij indirecte schade door een omgevingsvergunning is relevant dat in de toelichting op art. 15.3 lid $1 \mathrm{Ow}$ wordt vermeld dat...

“(...) de waardevermindering van een onroerende zaak wordt vastgesteld aan de hand van de feitelijke situatie voor en na de verlening van de omgevingsvergunning. Als onmiddellijk na de peildatum een waardevermindering optreedt, kan dat een aanwijzing zijn dat de schade wordt veroorzaakt door de omgevingsvergunning. Voor vergoeding

88 Kamerstukken II 2016/17, 33 962, nr. 190, p. 21, antwoord 42.

89 Zie bijvoorbeeld de laatste alinea van Kamerstukken II 2018/19, 34 986, nr. 3, p. 28 (MvT, IOw).

90 Analoog aan hetgeen ik hierna zal opmerken over indirecte schade door omgevingsvergunningen.

91 Analoog aan hetgeen ik hiervoor opmerkte over directe schade door een omgevingsplan. 
van schade moet worden voldaan aan het conditio sine qua non-vereiste, wat inhoudt dat de overheidshandeling een noodzakelijke voorwaarde voor het optreden van de schade is. Voor vergoeding komt daarnaast alleen schade in aanmerking die redelijkerwijs kan worden toegerekend aan de omgevingsvergunning." ${ }^{92}$

Ook deze opmerking blinkt niet uit in duidelijkheid. Doorgaans zal de vergunninghouder wachten tot het besluit tot vergunningverlening onherroepelijk is geworden alvorens op grond daarvan veranderingen in de fysieke leefomgeving aan te brengen. Handelt hij eerder, dan kan hij de kosten om dat ongedaan te maken als het besluit tot vergunningverlening wordt herroepen of vernietigd immers niet op het bestuur verhalen..$^{33}$ Bovendien treden vergunningen die toestemming verlenen voor activiteiten met onomkeerbare gevolgen in de regel pas na vier weken in werking (vergelijk art. 16.79 lid 2 Ow). Gedurende die periode kan de fysieke leefomgeving dus niet eens rechtmatig worden gewijzigd. De door het kabinet genoemde "aanwijzing" zal zich naar verwachting dus lang niet altijd voordoen. Wellicht moet het woord 'onmiddellijk' daarom niet letterlijk worden opgevat, maar als 'relatief kort na inwerkingtreding van de omgevingsvergunning' of als 'binnen korte tijd na onherroepelijkheid van de omgevingsvergunning'.

Bovendien geeft het kabinet in het aangehaalde citaat slechts aan dat de waardevermindering wordt vastgesteld aan de hand van de feitelijke situatie voor en na vergunningverlening. Heeft het hiermee ook willen aangeven dat de csqn-toets op die manier dient te worden ingevuld? Het zou zomaar kunnen dat dit niet het geval is. Ook uit de consultatieversie van de IOw bleek namelijk dat de waarde van de onroerende zaak onmiddellijk voor en na de bekendmaking van de omgevingsvergunning moest worden vergeleken. Desondanks werd in de daarbij behorende memorie van toelichting opgemerkt dat een vergelijking dient te worden gemaakt tussen de feitelijke situatie voor vergunningverlening en "de mogelijkheden die de omgevingsvergunning biedt." ${ }^{94}$ Een vergelijkbare, maar minder duidelijke opmerking is te vinden in de toelichting op de versie van de IOw die aan de AARvS is voorgelegd. ${ }^{95}$ Deze opmerkingen zijn echter zonder opgave van redenen geschrapt uit de memorie van toelichting behorende bij de versie van de IOw die aan de Tweede Kamer is voorgelegd. Uiteindelijk kan dus niet met zekerheid worden gezegd hoe de csqn-toets dient te worden ingevuld bij indirecte schade door een omgevingsvergunning.

\section{Indirecte schade door vergunningvrije activiteiten}

In paragraaf 3.3.2.3 bleek dat het omgevingsplan als schadeoorzaak wordt gezien bij indirecte schade door vergunningvrije activiteiten. Omdat bij het vaststellen 
van het omgevingsplan de afweging is gemaakt welke activiteiten vergunningvrij zijn, wordt het verrichten van deze activiteiten als "een uitwerking" van het omgevingsplan gezien. In de bij de IOw behorende memorie van toelichting wordt de open deur ingetrapt dat de schade aan de overheid kan worden toegerekend voor zover het verrichten van de vergunningvrije activiteit het gevolg is van het omgevingsplan. Zo kan bijvoorbeeld schade door het vergunningvrij bouwen van een woning dus als gevolg van het omgevingsplan dat daar toestemming voor geeft aan het gemeentebestuur worden toegerekend. ${ }^{96}$ Als het aankomt op de vraag hoe de csqn-toets dient te worden ingevuld, lijkt met name te moeten worden teruggevallen op de volgende opmerking uit de memorie van toelichting behorende bij de consultatieversie van de IOw:

\begin{abstract}
"Als de uitvoering van de activiteit is gekoppeld aan een melding wordt bij het vaststellen van de omvang van de schade de feitelijke situatie voor de melding vergeleken met de situatie die is gemeld. Indien voor het verrichten van de activiteit geen melding is vereist wordt de feitelijke situatie voor het uitvoeren van de activiteit vergeleken met de feitelijke situatie na het verrichten van de activiteit." 97
\end{abstract}

Gelet op art. 15.4 lid 2, aanhef en onder b Ow zou het voor de hand liggen dat eveneens een vergelijking tussen de feitelijke situatie voor en na uitvoering van de activiteit wordt gemaakt als een activiteit wel had moeten worden gemeld, maar de uitvoerder dat heeft nagelaten.

\title{
Schade door een projectbesluit
}

Door middel van een projectbesluit kan een bestuursorgaan zelf de regie nemen over de besluitvorming van een project waarvoor het verantwoordelijk is, zoals de aanleg van een snelweg. Op grond van art. 5.52 lid $1 \mathrm{Ow}$ wijzigt dit projectbesluit ook direct het omgevingsplan voor zover dat nodig is voor het project. ${ }^{98}$ In dergelijke gevallen wordt het projectbesluit op grond van art. 15.1 lid 3 Ow aangemerkt als exclusieve schadeoorzaak. De wetgever heeft hiermee willen voorkomen dat het college van $B \& W$ bevoegd zou zijn om te beslissen op aanvragen om nadeelcompensatie, terwijl bijvoorbeeld de minister van Infrastructuur en Waterstaat verantwoordelijk is voor het projectbesluit (vergelijk art. 15.8 lid $2 \mathrm{Ow}$ ). ${ }^{99}$

Van begin af aan heeft onduidelijkheid bestaan over de wijze waarop de csqn-toets dient te worden ingevuld als een projectbesluit de schadeoorzaak vormt. Wellicht heeft dit te maken met de lange tijd uitblijvende beantwoording van de vraag of het schademoment bij indirecte schade door een projectbesluit ook zou moeten worden doorgeschoven naar een later moment. De redactie van art. 15.4 lid 1

97 Zie MvT consultatieversie IOw, p. 122; en minder duidelijk ook MvT IOw als voorgelegd aan de AARvS, p. 186 en 196.

98 Kamerstukken II 2018/19, 34 986, nr. 3, p. 9 en 205-206 (MvT, IOw).

99 Kamerstukken II 2018/19, 34 986, nr. 3, p. 233 (MvT, IOw). 
Ow die is aangenomen door de Tweede Kamer leert dat deze vraag ontkennend moet worden beantwoord. De reden daarvoor lijkt te zijn dat de uitvoering van het projectbesluit doorgaans niet onzeker is en het besluit zelf "heel concreet" is. ${ }^{100}$ Daardoor kunnen de gevolgen voor de fysieke leefomgeving reeds afdoende worden ingeschat op het moment van inwerkingtreding van het projectbesluit. De toelichtende stukken behorende bij de eerste versies van het voorstel voor de IOw deden vermoeden dat de csqn-toets diende te worden ingevuld door de maximale invulling van het projectbesluit te vergelijken met de feitelijke situatie voorafgaand aan dat besluit. ${ }^{101}$ Uit de memorie van toelichting behorende bij de IOw als voorgelegd aan de Tweede Kamer lijkt echter te kunnen worden opgemaakt dat de maximale invulling van de regels uit het projectbesluit moet worden vergeleken met de maximale invulling van het direct daaraan voorafgaande planologische regime. Daarin wordt namelijk opgemerkt dat schade in de vorm van waardevermindering van een onroerende zaak...

“(...) in ieder geval [wordt] bepaald aan de hand van de maximale invulling van de regels uit het projectbesluit. De schade wordt begroot aan de hand van een vergelijking van de juridisch maximaal toegestane situatie direct voor de inwerkingtreding van het projectbesluit met de maximale invulling van het projectbesluit direct na de inwerkingtreding, zij het dat de vergelijking wordt toegesneden op het concrete project dat de schade veroorzaakt. Wat betreft geluidproductieplafonds bij een weg bijvoorbeeld, wordt beoordeeld wat het maximale gebruik van een weg kan zijn in vergelijking met het juridisch regime voordat het projectbesluit de weg toestond.”102

Ook hier moet echter een slag om de arm worden gehouden omdat het bovenstaande citaat strikt genomen niet ziet op de vaststelling van causaal verband, maar op de begroting van schade.

\section{Conclusie}

De bij de IOw behorende memorie van toelichting is allesbehalve duidelijk als het aankomt op de invulling van de csqn-toets. Vaak kan slechts een gefundeerde inschatting van de aan te leggen vergelijkingsmaatstaf worden gemaakt. Daartoe moet doorgaans een beroep worden gedaan op (conflicterende informatie uit) een mengeling van elkaar opvolgende toelichtingen in combinatie met gezond verstand.

100 Zie bijvoorbeeld Kamerstukken II 2016/17, 33 962, nr. 190, p. 27, antwoord 57; en Kamerstukken I 2015/16, 33 118, nr. A, p. 5.

101 Zie MvT consultatieversie IOw, p. 122; en minder duidelijk ook MvT IOw als voorgelegd aan de AARvS, p. 186. 
Het past goed bij de doelstelling van vereenvoudiging, uniformering en harmonisering van het nadeelcompensatierecht, en het uitgangspunt van aansluiting bij het BW dat zowel onder titel 4.5 Awb als afd. 15.1 Ow aansluiting zal worden gezocht bij art. 6:98 BW voor de invulling van het causaliteitscriterium. Dat is ook verenigbaar met de overige aan de Wns ten grondslag liggende doelstellingen en uitgangspunten. Deze aansluiting volgt thans echter geenszins uit de tekst van titel 4.5 Awb (en afd. 15.1 Ow). Dat laat mogelijk ruimte voor overige regelevers en bestuursorganen om (licht) uiteenlopende invullingen aan het causaliteitscriterium te geven, hetgeen niet goed verenigbaar is met de doelstellingen van vergroting van de rechtsgelijkheid, en vereenvoudiging, uniformering en harmonisering van het nadeelcompensatierecht. Dit lijkt echter tot op grote hoogte een theoretisch risico, omdat de rechter de invulling van het criterium zonder terughoudendheid dient te toetsen. ${ }^{103}$

Het wringt wel met de doelstellingen van vergroting van de rechtszekerheid en codificatie van het nadeelcompensatierecht, en het uitgangspunt van aansluiting bij het BW dat de aansluiting bij art. 6:98 BW niet uit de tekst van titel 4.5 Awb blijkt. Bovendien kan de vraag worden gesteld of deze doelstellingen slechts aanleiding geven om deze aansluiting te expliciteren, of ook aanleiding geven om meer inhoudelijke sturing te bieden als het aankomt op de invulling van het causaliteitscriterium. Mijns inziens is dat eerste het geval. In theorie zou in de Awb best kunnen worden opgenomen dat bij schade veroorzaakt door de wijziging van een juridisch regime een vergelijking dient te worden gemaakt tussen het nieuwe en oude regime. Dat is echter een open deur en bovendien bleek uit paragraaf 4.2.3.2 dat het karakter van het besluit dat het juridische regime wijzigt en de omstandigheden waaronder dat besluit tot stand is gekomen, aanleiding kunnen geven om een andere vergelijking te maken.

Ook voel ik er weinig voor om allerlei toerekeningsregels in titel 4.5 Awb te codificeren. Uit paragraaf 4.2.2 volgde namelijk dat de toerekeningsleer moet worden gezien als een 'multifactor-benadering', waardoor nooit een uitputtende opsomming kan worden gegeven van de factoren die moeten worden meegewogen in de toerekeningsvraag. In meer algemene zin kunnen wel algemene vuistregels worden geformuleerd, zoals "hoe actiever een bestuursorgaan zich opstelt om een bepaald resultaat te bereiken en hoe groter zijn belang bij dat resultaat, hoe eerder de schade aan hem zal kunnen worden toegerekend." Samen met Tjepkema heb ik tien van dit soort vuistregels geformuleerd. ${ }^{104}$ Daarbij hebben wij een selectie

103 ABRvS 28 september 2016, ECLI:NL:RVS:2016:2582, r.o. 8.8 (Overzichtsuitspraak). 
gemaakt van de in onze ogen meest uitgekristalliseerde en belangrijke jurisprudentielijnen. Dat neemt niet weg dat we ook tot vijftien of meer vuistregels hadden kunnen komen. Dat laat op zijn beurt zien dat het tot op zekere hoogte arbitrair zou zijn welke vuistregels wel of niet in de wet zouden worden opgenomen. Bovendien past het mijns inziens niet bij het karakter van dit soort vuistregels om deze in een wettelijk voorschrift op te nemen. Afhankelijk van de omstandigheden van het individuele geval kan er immers reden bestaan om van een vuistregel af te wijken. Bovendien is gebleken dat gedurende verloop van tijd uiteenlopend wordt gedacht over dit soort vuistregels door de wetenschap, ${ }^{105}$ de rechter en de formele wetgever. Zo is de Afdeling in 2010 van mening veranderd over de toerekenbaarheid van belastingschade. ${ }^{106}$ Voorts bleek uit paragraaf 4.3.2 dat tijdelijke hinder als gevolg van werkzaamheden ter uitvoering van de in art. 15.1 Ow opgesomde schadeoorzaken aan het bestuur zal kunnen worden toegerekend, anders dan het geval is in het huidige planschaderecht. ${ }^{107}$

Hoewel ik dus van mening ben dat het niet wenselijk is om allerlei algemene bepalingen over de csqn-toets en de toerekening naar redelijkheid in titel 4.5 Awb op te nemen, zal ik hierna wel nagaan hoe de aansluiting bij art. 6:98 BW het best in titel 4.5 Awb kan worden geëxpliciteerd. Daarbij zal ik niet slechts inspiratie ontlenen aan de civielrechtelijke bepaling, maar ook nagaan waaraan de praktijk behoefte heeft en hoe de wetgever daarin zou kunnen voorzien. Om dat in kaart te brengen, ga ik in paragraaf 4.4.1 in algemene zin in op de motivering van het rechterlijk causaliteitsoordeel. In paragraaf 4.4.2 sta ik stil bij de regulering van gevallen van meervoudige causaliteit. Vervolgens plaats ik in paragraaf 4.4.3 nog een aantal resterende opmerkingen met betrekking tot de toerekening van schade door uitvoeringswerkzaamheden en de csqn-toets onder afd. 15.1 Ow. In paragraaf $4.5 \mathrm{zal}$ ik mijn aanbevelingen samenvatten en waar mogelijk omzetten in concrete voorstellen voor regelgeving.

\subsubsection{De motivering van het rechterlijk causaliteitsoordeel}

Dijkshoorn heeft zich meermaals kritisch uitgelaten over de wijze waarop de Afdeling haar causaliteitsoordelen motiveert. Volgens hem zouden causaliteitsoordelen in het planschaderecht niet worden gemotiveerd: "de ABRvS volstaat met rechtstreeks 'ja/nee' en haalt door wat naar haar idee niet van toepassing is. Het zijn de juridische auteurs die in hun publicaties zoeken naar argumenten die deze oordelen zouden kunnen onderbouwen." ${ }^{108}$ Deze kritiek is mijns inziens slechts deels op zijn plaats. In het planschade- en nadeelcompensatierecht is doorgaans relatief duidelijk of de gestelde schade het gevolg is van de beweerde schadeoor-

105 Zie bijvoorbeeld Holthuijsen-van der Kop 2015 en Hartlief 2014 over de vuistregels uit Brunner 1981.

106 ABRvS 3 februari 2010, ECLI:NL:RVS:2010:BL1791, r.o. 2.4.

107 ABRvS 28 september 2016, ECLI:NL:RVS:2016:2582, r.o. 3.1 (Overzichtsuitspraak). 
zaak. ${ }^{109}$ Bij grote infrastructurele projecten komt dat soms doordat met nulmetingen wordt gewerkt, ${ }^{110}$ maar in meer algemene zin komt dit doordat doorgaans geen of weinig schakels tussen de beweerde schadeoorzaak en de gestelde schade zitten. In dergelijke gevallen is het causaal verband meestal niet in geschil, of volstaat een beknopte motivering. Zo kon in een uitspraak van 19 april 2017 worden volstaan met de constatering dat een bedrijf ten onrechte dacht zijn belangrijkste toegangsweg kwijt te raken, omdat door het bestuur slechts werd beoogd de functie van die weg te veranderen van rijksweg naar gemeentelijke weg. ${ }^{11}$

De jurisprudentie laat zien dat met name wordt geprocedeerd over gevallen waarin meerdere schakels tussen de beweerde schadeoorzaak en de gestelde schade zitten. Daarbij kan worden gedacht aan gevallen waarin (het ontstaan van) de schade mogelijk deels afhankelijk is van handelen van de aanvrager (zoals in de Air Operator Certificate-uitspraak); ${ }^{112}$ handelen van derden (zoals in de Eneco-uitspraak); ${ }^{113}$ of andere overheidshandelingen, al dan niet van hetzelfde bestuursorgaan (zoals in de Uptown-uitspraak). ${ }^{114}$ In dergelijke gevallen bestaat wel behoefte aan uitgebreide motivering van het causaliteitsoordeel. Ik heb de indruk dat de Afdeling uitgebreider motiveert dan Dijkshoorn destijds stelde. Dat laat echter onverlet dat ik in paragraaf 4.2.4 aan de hand van 'enkele problematische uitspraken' heb laten zien dat de motivering van het causaliteitsoordeel nog niet optimaal is. Soms kan inderdaad slechts uit termen als 'rechtstreeks' of 'direct' gevolg worden afgeleid dat een overweging moet worden gelezen als beantwoording van de toerekeningsvraag. De Afdeling blijkt echter niet geheel consequent in het gebruik van die terminologie. Bovendien laat zij deze terminologie soms geheel achterwege, waardoor de desbetreffende overwegingen slechts kunnen worden geplaatst met behulp van uitgebreide kennis van het causaliteitsrecht. Er zijn echter ook uitspraken waarin expliciet wordt aangegeven dat wordt ingegaan op de toerekeningsvraag. Daarbij is dan weer niet altijd duidelijk welke omstandigheid onder welke toerekeningsfactor wordt meegewogen en welk gewicht daaraan wordt toegekend.

Uiteraard bepalen de beroepsgronden welke causaliteitsvragen een rechter kan beantwoorden. Gelet op de doelstelling van vergroting van de rechtszekerheid doe ik

109 Drupsteen bereikte ongeveer 30 jaar geleden dezelfde conclusie in Drupsteen 1988, p. 37-38.

110 Zie bijvoorbeeld Aanhangsel Handelingen II 2016/17, 176, p. 3, antwoord 5 over nulmetingen bij de aanleg van een tunnel op de Gaasperdammerweg in Amsterdam. Zie voorts Van Manen 2003, p. 867-869 over de rol van "bouwkundige opnames", waaronder nulmetingen, bij de aanleg van de Noord/Zuidlijn. Ten slotte is mij door mijn voormalige werkzaamheden voor het Infopunt Schade A2 Maastricht bekend dat ook nulmetingen zijn uitgevoerd bij de ondertunneling van de A2 te Maastricht.

111 ABRvS 19 april 2017, ECLI:NL:RVS:2017:1052, r.o. 9.4.

112 ABRvS 16 maart 2016, ECLI:NL:RVS:2016:729, r.o. 4.3 (Air Operator Certificate).

113 ABRvS 9 juni 2004, ECLI:NL:RVS:2004:AP1102, r.o. 2.6.1 (Eneco).

114 ABRvS 16 november 2016, ECLI:NL:RVS:2016:3047, r.o. 7 (Uptown). 
echter de aanbeveling dat de rechter bij beantwoording van die vragen altijd expliciteert welke causaliteitsvraag hij wanneer beantwoordt én welke omstandigheden hij daarbij in welke mate relevant acht. ${ }^{115}$ In het verlengde hiervan doe ik de aanbeveling dat de rechter zoveel mogelijk één uniforme formule hanteert om invulling te geven aan de toerekeningsvraag. Daarbij zou kunnen worden gedacht aan:

"Schade die in zodanig verband met [de beweerde schadeoorzaak] staat dat zij [het bestuursorgaan] mede gezien de aard van de aansprakelijkheid en van de schade, als een rechtstreeks gevolg van [de beweerde schadeoorzaak] kan worden toegerekend."

Ik ben me ervan bewust dat het bij de toerekeningsvraag niet gaat om digitaal rekenen maar om toerekenen, oftewel het wegen van relevante omstandigheden om tot een redelijke uitkomst te komen. Dat laat echter onverlet dat - binnen de grenzen opgeworpen door de beroepsgronden - meer inzicht in de gedachtegang van de rechter zou kunnen worden geboden dan gebeurde in veel van de door mij bestudeerde uitspraken. De onderstaande overweging uit een uitspraak van 30 augustus 2017 illustreert dat dit daadwerkelijk mogelijk is, en laat bovendien zien dat de Afdeling dit soms al doet:

"De gestelde schade die verband houdt met het uitlopen van de werkzaamheden in de van Weedestraat staat niet in zodanig verband met het verkeersbesluit, dat deze schade het college, als een gevolg van het verkeersbesluit kan worden toegerekend en daarom voor nadeelcompensatie in aanmerking komt. Daarbij neemt de Afdeling, naast de aard van de aansprakelijkheid (aansprakelijkheid op grond van het beginsel van de gelijkheid voor de openbare lasten) en van de schade (zuivere vermogensschade in de vorm van winstderving), in aanmerking dat er een te ver verwijderd verband bestaat tussen het verkeersbesluit van 13 maart 2013 en de gestelde schade, nu dit verkeersbesluit geen betrekking had op de Korte Melmweg en de werkzaamheden in de Korte Melmweg niet werden verricht door of in opdracht van het college, maar, voor zover hier van belang, in opdracht van de waterleidingbeheerder en het uitlopen van de werkzaamheden verband hield met een gesprongen waterleiding." 116

Ook laat deze overweging zien dat met weinig moeite veel inzicht kan worden geboden in het causaliteitsoordeel, bijvoorbeeld door tussen haakjes te vermelden waarop wordt gedoeld met een bepaalde toerekeningsfactor. Uit een op dezelfde dag gewezen uitspraak en de overige in paragraaf 4.2.4 besproken jurisprudentie blijkt echter dat dit tot op heden nog te weinig gebeurt. ${ }^{117}$

Opvolging van deze aanbevelingen zou niet alleen bijdragen aan de vergroting van de rechtszekerheid doordat het causaliteitsoordeel daardoor inzichtelijker en voorspelbaarder wordt. Tevens zou zij de rechtszekerheid, en bovendien ook de

115 Zie ook Huijts \& Tjepkema 2017, p. 302.

116 ABRvS 30 augustus 2017, ECLI:NL:RVS:2017:2340, r.o. 5.2 (Expert Soest).

117 ABRvS 30 augustus 2017, ECLI:NL:RVS:2017:2300, r.o. 20. Beide uitspraken worden besproken in Franssen \& Van de Sande 2018a, p. 92-93. 
rechtsgelijkheid, vergroten doordat overlap kan worden voorkomen tussen het causaliteitscriterium en andere eisen die titel 4.5 Awb aan de toekenning van nadeelcompensatie stelt. Dat dergelijke overlap thans bestaat, is reeds meermaals gesignaleerd in de literatuur. Zo kan schade die als bedrijfsrisico wordt gezien voor rekening van de aanvrager worden gelaten omdat zij behoort tot het normaal ondernemersrisico, maar is tegelijkertijd denkbaar dat zij niet in redelijkheid als gevolg van het overheidshandelen aan het bestuur is toe te rekenen omdat zij wordt gezien als het directe gevolg van de ondernemerskeuze om een bedrijf op een bepaalde manier in te richten. ${ }^{118}$

\subsubsection{Meervoudige causaliteit}

Uit paragraaf 4.4.1 bleek dat vooral over causaliteit wordt geprocedeerd in geschillen waarin extra schakels bestaan tussen de gestelde schade en beweerde schadeoorzaak. Het zou goed passen bij de doelstellingen van vergroting van de rechtszekerheid en rechtsgelijkheid, vereenvoudiging, uniformering en harmonisering van het nadeelcompensatierecht, en vergroting van de doelmatigheid van het nadeelcompensatierecht en vermindering van bestuurslasten als de praktijk betere handvatten zou hebben om met dit soort gevallen om te gaan. Die handvatten zijn moeilijk te bieden in gevallen waarin de extra schakels bestaan uit handelen van de aanvrager of derden. Daar heeft het bestuur immers weinig inzicht in en bovendien ook weinig invloed op. Hooguit kan in algemene zin de vuistregel worden geformuleerd dat de aard van de aansprakelijkheid in het nadeelcompensatierecht meebrengt dat de schade doorgaans minder snel als gevolg van de rechtmatige overheidshandeling aan het bestuur zal worden toegerekend als deze is gevolgd door een of meer andere, van het overheidshandelen losstaande handelingen van de aanvrager of derden die ieder voor zich ook een bijdrage (kunnen) hebben geleverd aan het ontstaan van de schade. ${ }^{119}$

Wanneer problemen ontstaan als meerdere handelingen van hetzelfde bestuursorgaan aan de schade hebben bijgedragen, verdient het aanbeveling dat het bestuursorgaan zich meedenkend opstelt bij beantwoording van de vraag welk deel van de beweerdelijk schadeveroorzakende overheidshandelingen onder het bereik van titel 4.5 Awb en/of afd. 15.1 Ow kan worden gebracht. Uit paragraaf 3.2.2 volgde dat het bestuur daartoe ook verplicht kan zijn wegens de uit art. 3:2 Awb en het zorgvuldigheidsbeginsel voortvloeiende plicht tot zorgvuldige besluitvorming.

De meeste winst lijkt echter te kunnen worden geboekt in gevallen waarin handelingen van twee of meer bestuursorganen hebben bijgedragen aan het ontstaan van

118 Zie bijvoorbeeld Drupsteen 1988, p. 36-38; Hoitink \& Koetser 2007, p. 341-342; en Tjepkema 2010, p. 328, 331-332.

119 Zie hierover ook Huijts \& Tjepkema 2017, p. 293-294 onder verwijzing naar onder andere ABRvS 9 juni 2004, ECLI:NL:RVS:2004:AP1102, r.o. 2.6.1 (Eneco). Zie bijvoorbeeld ook ABRvS 9 december 2015, ECLI:NL:RVS:2015:3735 en ABRvS 26 juni 2019, ECLI:NL:RVS:2019:2025, r.o. 40. 
de gestelde schade. Dan bestaat namelijk het risico dat de burger door de betrokken bestuursorganen van het kastje naar de muur wordt gestuurd in een poging om aansprakelijkheid te ontlopen, zoals ook in de Uptown-uitspraak het geval was. ${ }^{120}$ Dat past niet alleen slecht bij de genoemde doelstellingen, maar is ook slecht voor de door de burger ervaren procedurele rechtvaardigheid. Hierna zal ik enkele aanbevelingen doen die uitkomst kunnen bieden in deze categorie gevallen.

\section{Incidentele interbestuurlijke samenwerking}

Allereerst doe ik enkele aanbevelingen aan bestuursorganen die gezamenlijk een project aangaan dat potentieel tot aanvragen om nadeelcompensatie zou kunnen leiden. Zij zouden mijns inziens zo vroeg mogelijk in contact moeten treden met elkaar én met potentiële benadeelden. Dit vergroot de kans dat reeds voorafgaand aan het ontstaan van de schade, of ten tijde daarvan, duidelijk wordt welk bestuursorgaan verantwoordelijk is voor het ontstaan van welke schade. Deze duidelijkheid kan op zijn beurt bijdragen aan de bereidheid van alle betrokken partijen om op een laagdrempelige (buitengerechtelijke) manier te komen tot een redelijke afhandeling van het schadegeschil. ${ }^{121}$ Verder zouden de betrokken bestuursorganen er goed aan doen om een eventuele aanvraag om nadeelcompensatie gezamenlijk te behandelen, en gezamenlijk één rechterlijke procedure te voeren als de aanvrager zich niet kan vinden in de uitkomst van de primaire besluitvorming en de besluitvorming in de bezwaarfase. Een voorbeeld waarin dit soort interbestuurlijke samenwerking op incidentele basis werd aangegaan, kan worden gevonden in de uitspraak Knooppunt Kunderberg. Daaruit blijkt dat de gemeentebesturen van Heerlen en Voerendaal beide een bestemmingsplan hadden vastgesteld ter realisatie van een verbindingslus tussen de A76 en A79. Beide gemeentebesturen wonnen gezamenlijk advies in naar aanleiding van een aanvraag om tegemoetkoming in planschade. Conform dat advies besloten zij dat de gemeente Heerlen voor $60 \%$ en de gemeente Voerendaal voor $40 \%$ zou opdraaien voor de toe te kennen tegemoetkoming. ${ }^{122}$

Het is positief dat dit soort incidentele samenwerking eenvoudiger zal worden gemaakt doordat art. 15.8 lid $3 \mathrm{Ow}$ voorziet in een zogenoemde 'vrijwillige overnamebevoegdheid': de bevoegdheid om te beslissen op een aanvraag om schadevergoeding kan worden gedelegeerd aan een ander bestuursorgaan, als dat

120 Zie ABRvS 16 november 2016, ECLI:NL:RVS:2016:3047, r.o. 7 (Uptown) en de bijbehorende noot van Tjepkema en mijzelf in $A B$ 2017/331.

121 De voordelen van het vroeg in contact treden met betrokkenen worden ook besproken op p. 26-33 van de Handleiding nadeelcompensatie.

122 Zie Rb. Limburg 8 september 2015, ECLI:NL:RBLIM:2015:7633, r.o. 1-2 en 28 (Knooppunt Kunderberg, eerste aanleg) en ABRvS 24 augustus 2016, ECLI:NL:RVS:2016:2315, r.o. 1 en 4 (Knooppunt Kunderberg, hoger beroep). 
bestuursorgaan daarmee instemt. ${ }^{123}$ Op grond van het vierde lid van deze bepaling kunnen bij amvb regels worden gesteld over de toepassing van het derde lid. Volgens de bijbehorende passage uit de memorie van toelichting moet daarbij worden gedacht aan regels van procedurele of administratieve aard. ${ }^{124}$ De wetgever beloofde de komst van deze overnamebevoegdheid reeds ten tijde van de totstandkoming van de Wns. ${ }^{125}$ Uit de memorie van toelichting behorende bij de consultatieversie van de IOw blijkt dat ervoor is gekozen deze bevoegdheid niet in titel 4.5 Awb maar in afd. 15.1 Ow op te nemen, omdat met name bij grote projecten in het omgevingsrecht behoefte zou bestaan aan een wettelijke overnamebevoegdheid. ${ }^{126}$ Die redenering is op zich goed te volgen, maar gelet op de doelstelling van vereenvoudiging, uniformering en harmonisering van het nadeelcompensatierecht doe ik de aanbeveling de vrijwillige overnamebevoegdheid toch te verplaatsen naar titel 4.5 Awb. Zeker gelet op de brede reikwijdte van deze titel kan immers niet op voorhand worden uitgesloten dat ook in bepaalde niet-omgevingsrechtelijke schadegeschillen behoefte bestaat aan delegatie van de bevoegdheid om op aanvragen om nadeelcompensatie te beslissen.

Het zwakke punt van deze overnamebevoegdheid is dat twee of meer bestuursorganen bereid moeten zijn tot samenwerking. Dat die bereidheid soms bestaat blijkt uit de Knooppunt Kunderberg-uitspraak. Ik heb echter de indruk dat deze bereidheid ook vaak ontbreekt, getuige bijvoorbeeld de Uptown-uitspraak. ${ }^{127}$ Dat is ook niet vreemd, omdat een bestuursorgaan zich doorgaans immers wel twee keer zal bedenken voordat het zich 'extra kosten' en een verhoogde (administratieve) werklast op de hals haalt. ${ }^{128}$ Art. 15.8 Ow lijkt niet te voorzien in een oplossing hiervoor: het bestuursorgaan dat instemt met delegatie op grond van art. 15.8 lid 3 Ow lijkt namelijk niet alleen de beslissingsbevoegdheid, maar ook de financiële verplichting die daaruit voortvloeit over te nemen. Wel lijkt het aannemelijk dat een verdeling van de met de delegatie gepaard gaande kosten doorgaans 'vanzelf' ter sprake zal komen wanneer partijen in onderling overleg dienen te beslissen of de bevoegdheid tot het besluiten op aanvragen om nadeelcompensatie zal worden overgedragen. Dit probleem lijkt inherent aan het karakter van de vrijwillige overnamebevoegdheid, omdat de wetgever niet op voorhand kan bepalen welke onderlinge verdeling van de schadelast rechtvaardig is. Dat zal namelijk steeds af-

123 Deze term is ontleend aan MvT consultatieversie IOw, p. 128. De mogelijkheid tot delegatie bestaat naar huidig recht niet altijd, omdat art. 10:15 Awb daartoe een expliciete grondslag in een wettelijk voorschrift vereist.

124 Kamerstukken II 2018/19, 34 986, nr. 3, p. 247 (MvT, IOw).

125 Kamerstukken II 2010/11, 32 621, nr. 3, p. 24 (MvT, Wns).

126 MvT consultatieversie IOw, p. 127.

127 Zie ABRvS 16 november 2016, ECLI:NL:RVS:2016:3047, r.o. 7 (Uptown) en de bijbehorende noot van Tjepkema en mijzelf in $A B$ 2017/331.

128 Zie voor argumenten met een vergelijkbaar karakter Tjepkema 2010, p. 337: "Een niet ondenkbaar scenario is dat zij veeleer zullen proberen de schadelast juist af te schuiven in plaats van deze op zich te nemen." Zie eveneens Huijts \& Tjepkema 2017, p. 303. 
hankelijk zijn van de bijzondere omstandigheden van het individuele schadegeval, zoals het onderlinge aandeel dat de bestuursorganen hadden in het ontstaan van de schade. Wel zou het kabinet of een partij als de VNG een 'model delegatiebesluit' kunnen opstellen, waarin ook een passage is opgenomen over de verdeling van de schadelast. Dat past ook in algemene zin goed bij de doelstelling van vergroting van de doelmatigheid van het nadeelcompensatierecht en vermindering van bestuurslasten. Ook zal ik hierna nog bespreken hoe de invoering van een bepaling omtrent hoofdelijke aansprakelijkheid een prikkel voor bestuursorganen zou kunnen vormen om gebruik te maken van de vrijwillige overnamebevoegdheid.

\section{Structurele interbestuurlijke samenwerking}

Bestuursorganen lijken meer bereid tot structurele samenwerking, met name bij projecten waar grote aantallen aanvragen om nadeelcompensatie worden verwacht. De oprichting van het Schadeschap Luchthaven Schiphol vormt daar een voorbeeld van. Tevens kan worden gedacht aan het 'Schadevergoedingsschap HSL-Zuid, A16 en A4', een bestuursorgaan dat op grond van de Wet gemeenschappelijke regelingen is opgericht door de toenmalig minister van Verkeer en Waterstaat en de raden van meer dan vijftien gemeenten. Hiermee werd beoogd de behandeling van aanvragen om schadevergoeding die verband hielden met de aanleg van de HSL-Zuid en de verbreding, verlegging en reconstructie van de A16 en A4 doelmatig, deskundig en op gelijke wijze te laten plaatsvinden. ${ }^{129}$ De mogelijkheid tot het oprichten van dit soort samenwerkingsverbanden zal ook na inwerkingtreding van de Ow blijven bestaan. ${ }^{130}$ Het kabinet stelt echter dat het "overbodig" zal worden om schadeschappen op te richten, omdat in art. 15.8 lid 2 Ow is bepaald dat het bestuursorgaan dat een projectbesluit vaststelt bij uitsluiting bevoegd zal zijn om te beslissen op aanvragen om schadevergoeding die betrekking hebben op een besluit ter uitvoering van een projectbesluit. Dit is mijns inziens een ontwikkeling die goed aansluit op de aan de Wns ten grondslag liggende doelstellingen en uitganspunten. Bovendien is deze bepaling niet afhankelijk van de bereidwilligheid van bestuursorganen tot onderlinge samenwerking, omdat geen keuzevrijheid bestaat voor het bestuursorgaan dat het projectbesluit in kwestie heeft genomen. Financiële bezwaren van dat bestuursorgaan zouden dus hooguit ertoe kunnen leiden dat in het geheel wordt afgezien van het projectbesluit. Ik verwacht echter niet dat dit zich vaak zal voordoen, omdat dit soort projectbesluiten doorgaans door de minister van Infrastructuur en Waterstaat zullen worden genomen. De voorganger van deze minister bleek in de Knooppunt Kunderberg-casus bijvoorbeeld bereid om een planschadeverhaalsovereenkomst als bedoeld in art.

129 Zie art. 1 jo. 2 Gemeenschappelijke regeling schadevergoedingsschap HSL-Zuid, A16 en A4.

130 Zie bijvoorbeeld Kamerstukken II 2013/14, 33 962, nr. 3, p. 74 en 124 (MvT, Ow), en https://aandeslagmetdeomgevingswet.nl/omgevingswet/abc-omgevingswet/begrippen/decentraal-tenzij/. 
6.4a Wro aan te gaan met de gemeenten waarvan de raden bestemmingsplannen vaststelden die de aanleg van het knooppunt mogelijk maakten. ${ }^{131}$

\section{Hoofdelijke aansprakelijkheid}

In de literatuur is meermaals voorgesteld om een mogelijkheid tot hoofdelijke aansprakelijkheidsstelling in titel 4.5 Awb op te nemen. ${ }^{132}$ De benadeelde zou daardoor een aanvraag kunnen indienen bij elk bestuursorgaan dat een aandeel had in het ontstaan van zijn schade, terwijl dit bestuursorgaan niet kan volstaan met vergoeding van slechts een deel van de onevenredige schade onder aanvoering van het argument dat het slechts gedeeltelijk verantwoordelijk is voor het ontstaan van de schade. Het aangesproken bestuursorgaan kent dus in beginsel ${ }^{133}$ een volledige vergoeding toe voor het onevenredige deel van de schade en kan vervolgens (al dan niet achter de schermen) regres nemen op de overige betrokken bestuursorganen naar gelang hun onderlinge aandeel in het ontstaan van de schade. ${ }^{134}$ Het is echter niet altijd duidelijk of de desbetreffende auteurs slechts beogen om hoofdelijke aansprakelijkheid te realiseren in gevallen van alternatieve causaliteit of ook voor overige gevallen van meervoudige causaliteit.

Alternatieve causaliteit wordt in het civiele recht geregeld door art. 6:99 BW. Het gaat om gevallen waarin de gedraging die de gedaagde wordt verweten de gehele schade kan hebben veroorzaakt, terwijl hetzelfde geldt voor een aan een andere persoon verweten gedraging, maar niet kan worden vastgesteld wiens gedraging de schade in werkelijkheid heeft veroorzaakt. Het klassieke voorbeeld betreft de casus van twee schutters waarvan minimaal één het slachtoffer heeft geraakt. Beide schutters zijn dan hoofdelijk aansprakelijk, tenzij een van hen kan bewijzen dat zijn kogel niet heeft bijgedragen aan de schade. ${ }^{135}$ Ook bij overige vormen van meervoudige causaliteit kan hoofdelijke aansprakelijkheid worden aangenomen, maar dan via de band van art. 6:102 BW. De voor het nadeelcompensatierecht meest relevante variant is waarschijnlijk de situatie dat...

131 ABRvS 24 augustus 2016, ECLI:NL:RVS:2016:2315, r.o. 1 (Knooppunt Kunderberg, hoger beroep).

132 Zie bijvoorbeeld Hoitink \& Koetser 2007, p. 342-343; en Tjepkema 2010, p. 338339. Teunissen 1997 lijkt geen voorstander te zijn van de oplossing van hoofdelijke aansprakelijkheid.

133 Hiermee beoog ik aan te geven dat uiteraard geen vergoeding hoeft te worden toegekend in zoverre de overige criteria van titel 4.5 Awb in de weg staan aan toekenning van nadeelcompensatie.

134 Het gaat meer specifiek om een verdeling van de schadelast conform de maatstaven van art. 6:101 BW. Zie daarover ook hoofdstuk 8.

135 Zie hierover bijvoorbeeld Tjong Tjin Tai 2010, p. 98-99, waarin ook een overzicht wordt gegeven van andere relevante literatuur. 
“(...) een schade is ontstaan door (...) gedragingen van twee of meer personen terwijl voor elk van die gedragingen geldt dat de schade zonder die gedraging niet zou zijn ingetreden, en derhalve door een samenloop van oorzaken."

Deze overweging is afkomstig uit een arrest van de Hoge Raad waarin een huis verzakte doordat de ene buurman een zandpakket aanbracht in zijn kruipruimte en de andere buurman een naast de woning gelegen toegangsweg liet verhogen (waarvoor een grote hoeveelheid zand en ander materiaal werd gestort door zware vrachtwagens). De aansprakelijk gestelde buurman was hoofdelijk aansprakelijk, ondanks dat zijn handelen volgens deskundigen slechts voor een derde deel had bijgedragen aan het ontstaan van de schade. ${ }^{136}$

Gelet op de doelstellingen van vergroting van de rechtszekerheid en rechtsgelijkheid, vereenvoudiging, uniformering en harmonisering van het nadeelcompensatierecht, vergroting van de doelmatigheid van het nadeelcompensatierecht en vermindering van bestuurslasten, en het uitgangspunt van aansluiting bij het BW doe ik de aanbeveling ook in titel 4.5 Awb een bepaling omtrent hoofdelijke aansprakelijkheid op te nemen. ${ }^{137} \mathrm{Ik}$ acht dat ook verenigbaar met de overige aan de Wns ten grondslag liggende doelstellingen en uitgangspunten. Daarbij plaats ik de kanttekening dat het lastig is in te schatten hoe dit zich verhoudt tot de doelstelling van codificatie van het nadeelcompensatierecht. In geval van een samenloop tussen gemeentelijke planologische besluitvorming en sectorale besluitvorming op rijksniveau lijkt de schade naar huidig recht bijvoorbeeld in zijn geheel als gevolg van elk van die besluiten aan elk van de daarvoor verantwoordelijke bestuursorganen te kunnen worden toegerekend. ${ }^{138}$ Op basis van de huidige stand van de jurisprudentie valt echter lastig te zeggen of hoofdelijke aansprakelijkheid bijvoorbeeld ook tot de mogelijkheden had behoord als de bestuursorganen in de Knooppunt Kunderberg-casus niet bereid waren geweest tot incidentele samenwerking. ${ }^{139}$

Tevens plaats ik de kanttekening dat een bepaling inzake hoofdelijke aansprakelijkheid tot op zekere hoogte de rechtszekerheid van het bestuursorgaan verruilt voor rechtszekerheid van de burger. Dat acht ik echter niet onredelijk, omdat het voor de burger doorgaans lastiger zal zijn om te achterhalen welke overheidsmaatregel heeft bijgedragen aan welk deel van de schade. Bovendien worden bestuursorganen door een dergelijke bepaling geprikkeld om mijn eerdere aanbeveling op te volgen: het zo vroeg mogelijk in contact treden met andere betrokken bestuursorganen én met de burger. Tevens verwacht ik dat een bepaling inzake hoofdelijke aansprakelijkheid ertoe zal leiden dat bestuursorganen de vrijwillige overnamebe-

136 Zie HR 24 december 1999, ECLI:NL:HR:1999:AA4004, r.o. 3.7 (Nugteren/Meskes) en de verhelderende noot van Brunner in NJ 2000/351.

137 Zie paragraaf 4.5 voor een concreet voorstel daartoe.

138 Zie Huijts \& Tjepkema 2017, p. 299-300, vuistregel 8, voor een bespreking van relevante jurisprudentie en verwijzingen naar relevante literatuur. Zie daarover ook Huijts \& Tjepkema 2017, p. 298. 
voegdheid vaker zullen benutten. Het op voorhand afspraken maken over de schadelast en efficiënt afhandelen van de aanvraag om nadeelcompensatie is immers een aanlokkelijker perspectief dan het volledige bedrag aan nadeelcompensatie (in eerste instantie) zelf te moeten ophoesten, om vervolgens te proberen een deel van het uitgekeerde bedrag en de behandelingskosten te verhalen op andere betrokken bestuursorganen.

\subsubsection{Enkele losse opmerkingen omtrent afd. 15.1 Ow}

\section{Schade door uitvoeringswerkzaamheden}

Uit paragraaf 4.3.2 volgde dat tijdelijke hinder als gevolg van werkzaamheden ter uitvoering van de in art. 15.1 Ow opgesomde schadeoorzaken aan het bestuur kan worden toegerekend, anders dan het geval is in het huidige planschaderecht. ${ }^{140}$ Die ontwikkeling acht ik verenigbaar met de aan de Wns ten grondslag liggende doelstellingen en uitgangspunten. In het bijzonder sluit zij goed aan bij de doelstellingen van vereenvoudiging, uniformering en harmonisering van het nadeelcompensatierecht, en vergroting van de doelmatigheid van het nadeelcompensatierecht en vermindering van bestuurslasten. Bij een samenloop van schade in de vorm van permanente waardedaling van onroerende zaken door de wijziging van de planologische voorschriften met schade in de vorm van tijdelijke derving van woongenot door werkzaamheden ter uitvoering daarvan, kan het schadegeschil hierdoor immers worden afgedaan met één aanvraag, op de behandeling waarvan één wettelijk regime van toepassing is.

\section{De verschuiving van het schademoment en de csqn-toets}

In paragraaf 3.4.2.3 werd geconstateerd dat de verschuiving van het schademoment bepaalde problemen met zich brengt. Een van die problemen werd besproken in paragraaf 4.3.2: op basis van de bij de IOw behorende Kamerstukken is niet altijd duidelijk welke vergelijkingsmaatstaf dient te worden gehanteerd ter invulling van de csqn-toets. Dit verhoudt zich slecht tot de aan de Wns ten grondslag liggende doelstellingen van vergroting van de rechtszekerheid, en vergroting van de doelmatigheid van het nadeelcompensatierecht en vermindering van bestuurslasten. ${ }^{141}$ Gelet daarop doe ik de aanbeveling dat het kabinet of de wetgever zich duidelijker uitlaat over de vergelijking die bij toepassing van afd. 15.1 Ow dient te worden gemaakt om csqn-verband vast te stellen (waarover hierna meer). Tevens zou duidelijk moeten worden gemaakt in hoeverre de uitkomst van deze vergelijking nog van invloed dient te zijn op de schadebegroting. ${ }^{142}$

140 ABRvS 28 september 2016, ECLI:NL:RVS:2016:2582, r.o. 3.1 (Overzichtsuitspraak).

141 De kans is immers groot dat deze onduidelijkheid zal leiden tot foutieve besluiten op aanvragen om nadeelcompensatie, en onnodige aanwending van rechtsmiddelen tegen besluiten die wel correct zijn. 
Indien daadwerkelijk wordt beoogd om bij indirecte schade te vergelijken met de voormalige feitelijke situatie, zou mijns inziens bovendien moeten worden aangeven hoe moet worden omgegaan met de problemen die dat veroorzaakt. Ter illustratie noem ik het probleem dat door bij schade door vergunningvrije activiteiten slechts met de voormalige feitelijke situatie te vergelijken onduidelijkheid kan ontstaan over wat nu de precieze schadeoorzaak is. In paragraaf 3.3.2.3 bleek immers dat niet de melding of uitvoering van de activiteit, maar het omgevingsplan dat die activiteit toestaat als schadeoorzaak dient te worden aangemerkt. Hoe dient echter te worden omgegaan met de situatie dat meerdere opeenvolgende omgevingsplannen elk deels hebben bijgedragen aan de mogelijkheid tot realisatie van de uitgevoerde activiteit? Bestemmingsplan 1 stond bijvoorbeeld vergunningvrij een geluidsbelasting tot $80 \mathrm{~dB}$ toe; bestemmingsplan 2 een belasting tot $83 \mathrm{~dB}$; en bestemmingsplan 3 een belasting tot $86 \mathrm{~dB}$. Naar huidig recht zouden deze bestemmingsplannen elk als afzonderlijke schadeoorzaak worden aangemerkt en 'dakpansgewijs' worden vergeleken. ${ }^{143}$ Hoe zit dit naar toekomstig recht als pas na inwerkingtreding van het derde plan met de betreffende activiteit wordt aangevangen? Wordt dan slechts het derde plan als schadeoorzaak aangemerkt, of wordt bijvoorbeeld uitgegaan van de fictie van een niet nader te benoemen geheel van schadeoorzaken? Ten aanzien van dit soort vragen wordt thans onvoldoende sturing geboden door de bij de IOw behorende Kamerstukken.

Ten aanzien van zowel vergunningplichtige als vergunningvrije activiteiten kan bovendien worden opgemerkt dat een vergelijking met een feitelijke situatie ertoe leidt dat de schade groter kan uitvallen dan naar huidig recht het geval zou zijn. In de literatuur is namelijk meermaals erop gewezen dat de vergelijking met een voorafgaand juridisch regime ook ${ }^{144}$ een beperkende werking op de schadeomvang kan hebben. De mogelijkheden die dat regime bood, worden immers ook maximaal ingevuld, ongeacht of die mogelijkheden daadwerkelijk waren gerealiseerd. Bovendien wordt geen csqn-verband aangenomen als de schadeveroorzakende ontwikkeling zich ook had kunnen voordoen onder het oude regime. ${ }^{145}$ Vergelijking met de feitelijke situatie zoals die direct voor de peildatum was, zal naar verwachting altijd tot de conclusie leiden dat sprake is van een verslechtering. Een burger zal doorgaans immers niet de moeite doen een aanvraag om nadeelcompensatie in te dienen als de fysieke leefomgeving niet daadwerkelijk is verslechterd, of een vergunning aanvragen voor iets dat geen invloed heeft op de fysieke leefomgeving. Is de wetgever zich hiervan bewust, en staat dit niet haaks

143 Zie daaromtrent ABRvS 28 september 2016, ECLI:NL:RVS:2016:2582, r.o. 2.5 (Overzichtsuitspraak); Van Ravels 2006b, p. 259; en het eerste onderdeel van de annotatie van Van den Broek bij ABRvS 25 november 2015, ECLI:NL:RVS:2015:3626 in StAB 2016/29, p. 104.

144 In paragraaf 3.2.4 (zie het kopje 'Keuze van de wetgever') en de aanhef van paragraaf 3.3.2.3 werd reeds ingegaan op de overcompensatie waartoe de planvergelijking kan leiden.

145 Zie Van den Broek \& Tjepkema 2016, p. 2822-2823; Van den Broek \& Tjepkema 2017, p. 23; en Planken \& Hazen 2017, p. 39. 
op de aan afd. 15.1 Ow ten grondslag liggende wens om overcompensatie te voorkomen en aansprakelijkheidsrisico's te beperken ter bevordering van globale- en ontwikkelingsplanologie?

Het kan best zijn dat dit nadelen zijn die op de koop moeten worden toegenomen. Uit de in paragraaf 4.2.3.2 besproken jurisprudentie over dijkverhogingen en het Aanwijzingsbesluit 1996 kan immers worden afgeleid dat een regelloze toestand die ten aanzien van een bepaald onderwerp onder het voormalige juridisch regime bestond, kan bijdragen aan het oordeel dat niet kan óf moet worden vergeleken met de maximale invulling van dat juridische regime. Dat vertoont op zijn minst enige gelijkenis met een globaal omgevingsplan dat veel en vergaande vergunningvrije activiteiten toestaat. ${ }^{146}$ Dat door het globale karakter van het omgevingsplan mogelijkerwijs noodzaak ontstaat om (meer dan onder huidig recht) te vergelijken met de voormalige feitelijke situatie, laat echter onverlet dat het aanbeveling verdient dat het kabinet of de wetgever zich uitspreekt over deze nadelen en hoe daarmee dient te worden omgegaan. Dat draagt immers bij aan de realisatie van de doelstellingen van vergroting van de rechtszekerheid, en vergroting van de doelmatigheid van het nadeelcompensatierecht en vermindering van bestuurslasten.

\subsection{CONCLUSIE EN CONCRETE VOORSTELLEN}

Uit het voorafgaande volgt dat de aan de Wns ten grondslag liggende doelstellingen en uitgangspunten mijns inziens aanleiding geven tot (a) wijziging van titel 4.5 Awb. Zo is aanbevolen in titel $4.5 \mathrm{Awb}$ een bepaling op te nemen die de aansluiting bij art. 6:98 BW expliciteert. Verder verdient het de voorkeur om de vrijwillige overnamebevoegdheid van art. 15.8 lid 3 jo. lid 4 Ow naar titel 4.5 Awb te verplaatsen. Ten slotte is aanbevolen een bepaling inzake hoofdelijke aansprakelijkheid in titel 4.5 Awb op te nemen. Deze aanbevelingen zouden kunnen worden opgevolgd door invoering van de volgende bepalingen:

\section{Artikel 4.12x}

1. Schade blijft in elk geval voor rekening van de aanvrager voor zover zij, mede gezien de aard van de aansprakelijkheid en van de schade, redelijkerwijs niet aan het bestuursorgaan kan worden toegerekend als gevolg van een gebeurtenis als bedoeld in artikel 4:126, eerste lid.

2. Indien meerdere bestuursorganen betrokken zijn bij het ontstaan van de schade, dan rust de verplichting om de schade te vergoeden op ieder van deze bestuursorganen als:

a. de schade een gevolg kan zijn van twee of meer uitoefeningen van een publiekrechtelijke bevoegdheid of taak voor elk waarvan een ander bestuursor-

146 Zie daarover ook paragraaf 2.4.3 onder het kopje 'Het nieuwe omgevingsrecht' en paragraaf 3.4.2.3. 
gaan aansprakelijk is, en vaststaat dat de schade door ten minste één van deze uitoefeningen is ontstaan; ${ }^{147}$ of

b. de schade het gevolg is van de uitoefeningen van een publiekrechtelijke bevoegdheid of taak door deze bestuursorganen terwijl voor elk van deze uitoefeningen geldt dat de schade zonder die uitoefening niet zou zijn ingetreden, en derhalve is ontstaan door een samenloop van oorzaken. ${ }^{148}$

3. De in het tweede lid genoemde bestuursorganen zijn hoofdelijk verbonden. Voor de bepaling van hetgeen zij in hun onderlinge verhouding jegens elkaar moeten bijdragen, wordt de toegekende schadevergoeding en de in redelijkheid bij de toekenning daarvan gemaakte kosten over hen verdeeld in evenredigheid met de mate waarin de aan ieder toe te rekenen omstandigheden tot de schade hebben bijgedragen, met dien verstande dat een andere verdeling plaatsvindt, indien de billijkheid dit wegens de omstandigheden van het geval eist. ${ }^{149}$

4. De bestuursrechter bij wie het beroep tegen een besluit op de aanvraag als bedoeld in artikel 4:126, eerste lid kan worden ingesteld, beslist over geschillen ten aanzien van de door het derde lid voorgeschreven verdeling. ${ }^{150}$

\section{Artikel 4:13x}

1. Een bestuursorgaan kan de bevoegdheid om te beslissen op een aanvraag om schadevergoeding overdragen aan een ander bestuursorgaan, als dat bestuursorgaan daarmee instemt.

2. Bij algemene maatregel van bestuur kunnen regels worden gesteld over de toepassing van het eerste lid.

De verplaatsing van de vrijwillige overnamebevoegdheid van afd. 15.1 Ow naar titel 4.5 Awb bevestigt dat de aan de Wns ten grondslag liggende doelstellingen en uitgangspunten mijns inziens ook aanleiding geven tot (b) aanpassing van afd. $15.1 \mathrm{Ow}$. Voor verdere aanpassingen van deze afdeling zie ik geen aanleiding. Wel geven de aan de Wns ten grondslag liggende doelstellingen en uitgangspunten aanleiding om (c) anderszins in een bijzondere invulling of aanvulling van titel $4.5 \mathrm{Awb}$ te voorzien. In dat verband heb ik een vijftal aanbevelingen gedaan. Allereerst heb ik aanbevolen dat de rechter altijd expliciteert welke causaliteitsvraag hij beantwoordt, én welke omstandigheden hij daarbij in welke mate relevant acht.

147 Deze formulering is ontleend aan art. 6:99 BW.

148 Deze formulering is ontleend aan HR 24 december 1999 , ECLI:NL:HR:1999:AA4004, r.o. 3.7 (Nugteren/Meskes). Daarvoor is gekozen omdat de formulering van art. 6:102 BW minder duidelijk is.

149 Deze formulering is geïnspireerd op art. 6:102 BW jo. art. 6:10 BW jo. art. 6:101 BW.

150 Deze formulering is geïnspireerd op titel 8.4 Awb, en art. 8:6 lid 2 Awb zoals dat zal luiden na inwerkingtreding van titel 4.5 Awb (zie paragraaf 10.12.2). Mogelijk is het ook zinvol iets in de voorgestelde bepaling op te nemen omtrent mogelijkheden tot vrijwaring. Dat heb ik vooralsnog niet gedaan, omdat ook het BW geen (algemene) bepalingen hieromtrent bevat. 
In het verlengde hiervan deed ik de aanbeveling dat de rechter zoveel mogelijk één uniforme formule hanteert om invulling te geven aan de toerekeningsvraag:

"Schade die in zodanig verband met [de beweerde schadeoorzaak] staat dat zij [het bestuursorgaan] mede gezien de aard van de aansprakelijkheid en van de schade, als een rechtstreeks gevolg van [de beweerde schadeoorzaak] kan worden toegerekend."

Ten tweede heb ik aanbevolen dat het bestuursorgaan zich meedenkend opstelt bij beantwoording van de vraag welk deel van de beweerdelijk schadeveroorzakende overheidshandelingen onder het bereik van titel 4.5 Awb en/of afd. 15.1 Ow kan worden gebracht als meerdere handelingen van dit bestuursorgaan aan de schade hebben bijgedragen.

Ten derde heb ik enkele aanbevelingen gedaan aan bestuursorganen die gezamenlijk een project aangaan dat potentieel tot aanvragen om nadeelcompensatie zou kunnen leiden. Zij zouden mijns inziens zo vroeg mogelijk in contact moeten treden met elkaar én met potentiële benadeelden. Verder zouden zij een eventuele aanvraag om nadeelcompensatie gezamenlijk moeten behandelen, en gezamenlijk één rechterlijke procedure moeten voeren als de aanvrager zich niet kan vinden in de uitkomst van de primaire besluitvorming en de besluitvorming in de bezwaarfase. Ten vierde heb ik aanbevolen dat het kabinet of een organisatie als de VNG een model delegatiebesluit opstelt dat kan worden gebruikt om toepassing te geven aan de vrijwillige overnamebevoegdheid. Ten slotte is aanbevolen dat het kabinet of de formele wetgever duidelijker aangeeft welke vergelijking bij toepassing van afd. 15.1 Ow dient te worden gemaakt om csqn-verband vast te stellen, en in hoeverre de uitkomst van die vergelijking nog van invloed is op de schadebegroting. Daarbij dient mijns inziens in ieder geval aandacht te worden besteed aan enkele in paragraaf 4.4 .3 benoemde nadelen en knelpunten die zich kunnen voordoen doordat onder deze afdeling in sommige gevallen een vergelijking met de voormalige feitelijke situatie dient te worden gemaakt. Deze verduidelijking leent zich naar mijn mening niet voor uitwerking in de tekst van afd. 15.1 Ow, maar zou bijvoorbeeld kunnen geschieden in een Kamerbrief of een ander toelichtend stuk. 



\section{Hoofdstuk 5}

\section{Schade}

\section{$5.1 \quad$ INLEIDING}

Als eenmaal is vastgesteld dat een schadeoorzaak die onder de reikwijdte van een nadeelcompensatieregeling valt (hoofdstuk 3 ) tot een verslechtering voor de aanvrager heeft geleid (hoofdstuk 4), zal de vraag moeten worden beantwoord of die verslechtering ook schade heeft teweeggebracht, ${ }^{1}$ en zo ja, hoeveel. ${ }^{2}$ Toch zal in dergelijke situaties niet altijd tot begroting van schade worden overgegaan. Soms is het schadebegrip van de toepasselijke nadeelcompensatieregeling namelijk beperkt tot specifieke schadesoorten. Zo blijkt bijvoorbeeld uit art. 6.1 lid 1 Wro dat slechts schade in de vorm van een waardedaling van onroerende zaken of inkomensschade tot toekenning van compensatie kan leiden. Als een schadeoorzaak uit art. 6.1 lid 2 Wro een andere soort schade tot gevolg heeft, is het dus niet zinvol deze te begroten omdat zij op voorhand van vergoeding is uitgesloten. In paragraaf 5.2 zal ik ingaan op de verschillen die wat dit betreft tussen de geselecteerde regelingen bestaan.

Vervolgens zal in paragraaf 5.3 aandacht worden besteed aan een andere beperking van het schadebegrip, namelijk de vraag of de schade het gevolg moet zijn van een belangenafweging om voor compensatie in aanmerking te komen. De hieromtrent gewezen jurisprudentie is schaars, maar in de doctrine is relatief veel discussie omtrent deze vraag gevoerd. ${ }^{3}$ Voorts zal achtereenvolgens worden ingegaan op enkele schadeaspecten die slechts voor vergoeding in aanmerking komen als de aanvraag om compensatie wordt toegewezen. Het betreft kosten van schadebeperkende maatregelen (paragraaf 5.4), kosten van deskundigenbijstand (paragraaf 5.5) en de wettelijke rente over het toegekende bedrag aan compensatie (paragraaf 5.6).

1 Dat niet iedere verslechtering hoeft te resulteren in schade wordt geillustreerd door ABRvS 13 juli 2011, ECLI:NL:RVS:2011:BR1397, r.o. 2.7.1.

2 ABRvS 28 september 2016, ECLI:NL:RVS:2016:2582, r.o. 4.3 (Overzichtsuitspraak).

3 Zie bijvoorbeeld de noot van Schueler bij ABRvS 12 november 2003, ECLI:NL:RVS:2003:AN7882 in $A B$ 2004, 244; de noot van De Graaf bij ABRvS 15 december 2004, ECLI:NL:RVS:2004:AR7552, in $A B$ 2005/67; Tjepkema 2010, p. 207-216, 549-559; en Van Ravels zijn noot bij ABRvS 16 maart 2005, ECLI:NL:RVS:2005:AT0552 in $A B$ 2007/11. Aan de verhouding tussen égalité en art. 3:4 lid 2 Awb is ook andacht besteed in de in 2002 voor de VAR uitgebrachte preadviezen van Van Maanen, Van Ravels \& Schueler (VAR-reeks 128). 
In paragraaf 5.7 zal ik ingaan op de wijzen waarop de drie meest voorkomende schadesoorten worden begroot. Het betreft achtereenvolgens de permanente waardedaling van onroerende zaken, inkomensschade en de tijdelijke derving van woongenot. ${ }^{4}$ Ten slotte zal dit hoofdstuk in paragraaf 5.8 worden afgesloten met een conclusie en enkele concrete voorstellen tot aanpassing van titel 4.5 Awb. De keuze om deze voorstellen pas aan het eind van dit hoofdstuk te doen, is ingegeven door de gedachte dat aanbevelingen die ten aanzien van het ene onderwerp worden gedaan dikwijls ook gevolgen zullen hebben voor de regulering van een of meer van de overige onderwerpen.

\subsection{VOOR COMPENSATIE IN AANMERKING KOMENDE SCHADESOORTEN}

5.2.1 Deelvraag 2: verschillen tussen de geselecteerde, thans geldende regelingen en verklaringen daarvoor

\section{Het civiele en bestuursrechtelijke schadebegrip}

Over het algemeen wordt aangenomen dat in het bestuursrecht hetzelfde schadebegrip wordt gehanteerd als in het civiele recht. ${ }^{5}$ Het BW geeft geen definitie van de term 'schade', maar uit art. 6:95 BW volgt wel dat een onderscheid wordt gemaakt tussen vermogensschade en 'ander nadeel'. Het BW geeft eveneens geen sluitende definities van deze termen. Wel volgt uit art. 6:96 BW dat vermogensschade zowel geleden verlies als gederfde winst omvat, en dat redelijke kosten ter voorkoming of beperking van schade, vaststelling van schade en aansprakelijkheid, en verkrijging van voldoening buiten rechte als vermogensschade mede voor vergoeding in aanmerking komen. Uit art. 6:106 BW kan voorts worden opgemaakt dat ander nadeel bijvoorbeeld kan bestaan uit nadeel door de aantasting van iemands goede eer of naam dat niet in vermogensschade bestaat. In de literatuur wordt aangenomen dat onder vermogensschade de schade dient te worden verstaan die een vermogen raakt, en dus objectief in geld kan worden uitgedrukt. Soms wordt daarvoor aansluiting gezocht bij de definitie van vermogensrechten in art. 3:6 BW. Dat lijkt echter niet veel meerwaarde te hebben omdat deze definitie ruim en niet uitputtend is. Ander nadeel wordt omschreven als de schade die wordt ondervonden in de gevoelswereld van de gelaedeerde. Zij bestaat uit gevoelens

4 Dit zijn tevens de drie schadesoorten die - naast de categorie 'bijkomende schade' - worden onderscheiden in Handleiding nadeelcompensatie, p. 16-17. Met 'meest voorkomende' doel ik op 'hoofdvormen' van schade. Ik sluit bijvoorbeeld niet uit dat bepaalde 'bijkomende schades', zoals kosten van schadebeperkende maatregelen, vaker voorkomen dan schade in de vorm van gederfd woongenot.

5 Zie Tjepkema 2010, p. 296 en Van den Broek 2002, p. 11, en de daarin aan te treffen verwijzingen naar overige literatuur. Eén van de weinige tegenstanders van aansluiting bij het civielrechtelijke schadebegrip lijkt te kunnen worden gevonden in Van den Berk 1991, p. 247. 
van "leed of onlust" en is niet objectief in geld uit te drukken. De vergoeding van ander nadeel wordt daarom ook wel aangeduid als smartengeld. ${ }^{6}$

\section{Aansluiting bij het civiele schadebegrip onder de meeste van de geselecteerde, thans geldende regelingen}

Uit de tekst van de BnIW 2019, VNNZ en GrS (inclusief de tekst van art. 49 WRO, art. 21 Aanwijzingsbesluit 1996 en art. 8.31 Wlv) volgt geen definitie van schade. Een dergelijke definitie is wel te vinden in art. 1 lid 1 onder b AVN, ${ }^{7}$ maar de in deze bepaling te vinden opsomming van voor tegemoetkoming in aanmerking komende schadesoorten is niet uitputtend bedoeld volgens de daarbij behorende toelichting. Uit deze toelichting kan bovendien worden afgeleid dat onder de AVN aansluiting wordt gezocht bij het civielrechtelijke schadebegrip. Ook wordt daarin aangegeven dat de schade doorgaans zal bestaan uit vermogensschade, maar "in zeer uitzonderlijke gevallen" ook ander nadeel kan worden vergoed. Hoewel het naar aanleiding van de GrS door de besliscommissie van het Schadeschap opgestelde Basisdocument, en de toelichtingen behorende bij de BnIW 2019 en VNNZ op dit punt minder duidelijk zijn dan de toelichting op de AVN, lijkt ook onder deze regelingen aansluiting bij het civielrechtelijke schadebegrip te worden gezocht. ${ }^{8}$ Er bestaat dus geen materieelrechtelijk verschil tussen deze regelingen voor wat betreft de schadesoorten die voor vergoeding in aanmerking kunnen komen.

\section{Het beperkte schadebegrip van afd. 6.1 Wro}

Anders dan de hiervoor besproken regelingen, beperkt afd. 6.1 Wro op voorhand welke schadesoorten tot tegemoetkoming kunnen leiden. In art. 6.1 lid 1 Wro is namelijk bepaald dat enkel schade in de vorm van inkomensderving of een vermindering van de waarde van een onroerende zaak voor tegemoetkoming in aanmerking komt. Dit heeft tot gevolg dat slechts twee specifiek genoemde vormen van vermogensschade voor tegemoetkoming in aanmerking komen, terwijl immateriële schade op voorhand van tegemoetkoming is uitgesloten. In de bij de Wro behorende memorie van toelichting wordt dan ook ten onrechte opgemerkt dat de begrenzing van de mogelijkheid tot tegemoetkoming die voortvloeit uit art. 6.1 lid 1 Wro materieelrechtelijk niet zou afwijken van de begrenzing die voortvloeide uit art. 49 WRO. ${ }^{9}$ Gelet op deze opmerking, verbaast het echter niet dat uit de bij

6 Zie Barendrecht e.a. 1995, p. 44-45; en Tjepkema 2010, p. 296.

7 In deze bepaling wordt schade gedefinieerd als: "weloverwogen schade, veroorzaakt door bepaalde overheidsbesluiten of -handelingen, waar een afweging van belangen aan is voorafgegaan, waaronder valt geleden verlies, winst- of inkomensderving, of het derven van huurinkomsten dan wel een lagere opbrengst bij verkoop van een onroerende zaak of een bedrijf."

8 Zie Stcrt. 1999, nr. 172, p. 9 (digitaal, p. 5); de toelichting op art. 1 onder d VNNZ; en Basisdocument, p. 22.

$9 \quad$ Kamerstukken II 2002/03, 28 916, nr. 3, p. 112 (MvT, Wro). 
de Wro behorende Kamerstukken niet duidelijk wordt waarom de wetgever voor deze beperking van het schadebegrip heeft gekozen.

De beperking van het schadebegrip door art. 6.1 lid 1 Wro zou kunnen worden gezien als symbolische uiting van de bezuinigingsgedachte die is te herkennen in de bij de Wro behorende Kamerstukken. ${ }^{10}$ Ook is denkbaar dat - zoals Willems al opperde in 2008 - de wetgever duidelijkheid aan gelaedeerden heeft willen verschaffen door middel van deze beperking. ${ }^{11}$ Aan deze gedachte ligt ten grondslag dat immateriële schade praktisch geen rol speelde in het planschaderecht van art. 49 WRO, ondanks dat zij door de Afdeling niet principieel van vergoeding werd uitgesloten. ${ }^{12}$ Ook in het hedendaagse nadeelcompensatierecht wordt immateriële schade praktisch nooit vergoed, terwijl vergoeding theoretisch gezien wel tot de mogelijkheden behoort. ${ }^{13}$ Vrijwel altijd wordt namelijk ervoor gekozen om een derving van woongenot te beschouwen als vermogensschade. ${ }^{14}$ Zo wordt een permanente aantasting van woongenot, bijvoorbeeld door een toename van geluidsbelasting of verslechtering van luchtkwaliteit, in beginsel slechts gecompenseerd in zoverre zij resulteert in een waardedaling van de onroerende zaak van de aanvrager. ${ }^{15}$ Een tijdelijke aantasting van woongenot kan niet op overeenkomstige wijze worden vergoed, omdat het vaste jurisprudentie is dat...

“(...) een waardedaling van een onroerende zaak van tijdelijke aard in beginsel geen aanspraak [geeft] op een tegemoetkoming. Een voor mogelijke tegemoetkoming in

10 Zie hierover paragraaf 2.3.1 onder het kopje 'Waardevolle geschiedenis'.

11 Willems 2008, p. 9.

12 Zie ook Van Ravels 2009b, p. 115.

13 Zie Tjepkema 2010, p. 296-302; en Van Ravels 2009b, p. 115.

14 Wellicht speelt ook een rol dat de Afdeling onder - het inmiddels vervallen - art. 8:73 Awb strenge eisen stelde aan de vergoeding van onrechtmatig veroorzaakte, immateriële schade. Zie bijvoorbeeld ABRvS 15 januari 1998, NJB 1998, afl. 9, p. 405, nr. 18. Zie ook de bespreking van deze uitspraak in Van den Broek 2002, p. 44-45, en de annotatie van Van Ravels bij ABRvS 30 mei 2000, ECLI:NL:RVS:2000:AL3239 in $B R 2001 / 93$.

15 ABRvS 30 mei 2000, ECLI:NL:RVS:2000:AL3239, r.o. 2.3 respectievelijk ABRvS 21 januari 2004, ECLI:NL:RVS:2004:AO2002, r.o. 2.4. Zie ook de verwijzingen in ABRvS 28 september 2016, ECLI:NL:RVS:2016:2582, r.o. 2.4 (Overzichtsuitspraak) naar ABRvS 16 april 2014, ECLI:NL:RVS:2014:1292, r.o. 6.1 (Verslechtering luchtkwaliteit) en ABRvS 24 september 2014, ECLI:NL:RVS:2014:3480, r.o. 5 (Toename geluidsbelasting). Zie voorts ABRvS 26 juli 2017, ECLI:NL:RVS:2017:2025, r.o. 7.5; en ABRvS 4 november 2015, ECLI:NL:RVS:2015:3350, r.o. 7.1. Zie ten slotte: Kamerstukken II 2002/03, 28 916, nr. 3, p. 63 (MvT, Wro). 
aanmerking komende waardevermindering van een onroerende zaak kan alleen voortvloeien uit een oorzaak met een duurzaam karakter."16

Toch wordt ook schade door tijdelijk gederfd woongenot vergoed als vermogensschade. ${ }^{17} \mathrm{Zij}$ wordt doorgaans namelijk berekend aan de hand van een vergelijking van de objectieve huurwaarde van de desbetreffende onroerende zaak met en zonder de negatieve effecten van het schadeveroorzakende overheidshandelen. ${ }^{18}$

\subsubsection{Deelvraag 3: het toekomstige recht}

Uit de tekst van titel 4.5 Awb blijkt niet dat het schadebegrip van deze regeling beperkt zou zijn tot bepaalde schadesoorten. Wel zijn er verschillende aanwijzingen dat ook voor toepassing van titel 4.5 Awb dient te worden aangesloten bij het civielrechtelijke schadebegrip. In de bij de Wns behorende memorie van toelichting zijn bijvoorbeeld verschillende verwijzingen naar afd. $6.1 .10 \mathrm{BW}$ te vinden. ${ }^{19}$ Voorts heeft de wetgever met art. 4:129 Awb aansluiting gezocht bij onder andere art. 6:96 BW. ${ }^{20}$ Ten slotte had het voor de hand gelegen als de wetgever een afwijking van het civielrechtelijke schadebegrip had geëxpliciteerd, omdat in het bestuursrecht in algemene zin wordt aangesloten bij dit schadebegrip. ${ }^{21}$

Afd. 15.1 Ow kent een beperkter schadebegrip dan titel 4.5 Awb. In art. 15.2 Ow is namelijk het volgende bepaald:

"Voor de toepassing van deze afdeling heeft de vergoeding van schade als bedoeld in artikel 4:126, eerste lid, van de Algemene wet bestuursrecht geen betrekking op immateriële schade."

Een rechtvaardiging voor deze beperking van het schadebegrip wordt niet gegeven in de bij de IOw behorende Kamerstukken. In de bij de IOw behorende memorie van toelichting wordt slechts opgemerkt dat "schade die bestaat uit immateriële schade, waartoe bijvoorbeeld ook de derving van woongenot behoort, niet afzon-

Het citaat is afkomstig uit ABRvS 30 november 2016, ECLI:NL:RVS:2016:3168, r.o. 6.3 (Wegafsluiting Hoevelaken). Uit r.o. 6.2 blijkt dat het een nadeelcompensatiegeschil betrof. Dat de Afdeling dezelfde jurisprudentielijnen hanteert in het planschaderecht blijkt onder andere uit ABRvS 19 december 2018, ECLI:NL:RVS:2018:4170, r.o. 38, en ABRvS 28 september 2016, ECLI:NL:RVS:2016:2582, r.o. 4.5 (Overzichtsuitspraak). Zie ook Van Ravels 2009b; p. 121-122, Tjepkema 2010, p. 298299; en Dijkshoorn 2011a, p. 48-50. Zie voor uit een tijdelijke waardedaling voortvloeiende schade: ABRvS 23 oktober 2013, ECLI:NL:RVS:2013:1621, r.o. 6.1 (Urilift, eerste tussenuitspraak).

17 Zie met betrekking tot art. 49 WRO ook de annotatie van Van den Broek bij ABRvS 6 juni 2007, ECLI:NL:RVS:2007:BA6794 in AB 2008/44.

18 Zie daarover paragraaf 5.7.1.3 en Van Ravels 2009b, p. 121-122.

19 Kamerstukken II 2010/11, 32 621, nr. 3, p. 19-20 (MvT, Wns).

20 Zie paragraaf 5.4.2.

21 Zie paragraaf 5.2.1. 
derlijk ${ }^{22}$ voor vergoeding in aanmerking komt." ${ }^{23}$ Hiermee lijkt te worden bedoeld dat dergelijke schade slechts kan worden gecompenseerd in zoverre zij kan worden begroot als een vorm van vermogensschade. Een permanente derving van woongenot komt dus voor vergoeding in aanmerking voor zover zij zich vertaalt in een lagere waarde van een onroerende zaak. Een tijdelijke derving van woongenot kan worden vergoed in zoverre zij zich vertaalt in een lagere objectieve huurwaarde van een onroerende zaak. ${ }^{24}$

In de bij de IOw behorende memorie van toelichting wordt verder nog benadrukt dat de thans in art. 6.1 lid 1 Wro genoemde schadesoorten van inkomensderving of waardevermindering van een onroerende zaak ook onder afd. 15.1 Ow voor compensatie in aanmerking komen. Deze schadesoorten vallen immers onder het schadebegrip van titel $4.5 \mathrm{Awb}$ en worden niet van vergoeding uitgesloten door art. 15.2 Ow. Tevens wordt opgemerkt dat onder schade als bedoeld in art. 4:126 lid 1 Awb ook "de kosten worden begrepen die een benadeelde maakt ter voldoening aan voorschriften verbonden aan een omgevingsvergunning of aan eisen die opgenomen zijn in algemene regels." Ten slotte blijkt dat aansluiting wordt gezocht bij art. 4:129 Awb voor de beantwoording van de vraag welke overige kosten voor vergoeding in aanmerking komen. ${ }^{25}$

\subsubsection{Hoofdvraag: spiegeling aan de doelstellingen en uitgangspunten die ten grondslag liggen aan de Wns}

De vraag hoe de categorische uitsluiting van vergoeding van immateriële schade door art. 15.2 Ow zich verhoudt tot de aan de Wns ten grondslag liggende doelstellingen en uitgangspunten is niet eensluidend te beantwoorden. ${ }^{26}$ Enerzijds past deze uitsluiting goed bij de doelstelling van vergroting van de rechtszekerheid. Ondanks dat de mogelijkheid daartoe meer dan een halve eeuw bestond, is op grond van art. 49 WRO immers nooit een afzonderlijke vergoeding voor immateriële schade toegekend. Bovendien kan deze uitsluiting bijdragen aan het bereiken van de doelstelling van vergroting van de doelmatigheid van het nadeelcompensatierecht en vermindering van bestuurslasten. Zij voorkomt immers dat onnodige procedures worden gevoerd over de compensatie van dit soort schade, al zal waarschijnlijk altijd worden geprocedeerd over grensgevallen.

22 Deze term lijkt ontleend aan uitspraken als AGRvS 20 oktober 1993, ECLI:NL:RVS:1993:AN3433: "Voor een afzonderlijke vergoeding van immateriële schade is daarnaast geen plaats aangezien het verminderde woongenot, voor zover objectief aanwezig, tot uitdrukking komt in een geringere waarde van het perceel."

23 Kamerstukken II 2018/19, 34 986, nr. 3, p. 234 (MvT, IOw).

24 Zie hierover ook paragraaf 5.7.1.3.

25 Kamerstukken II 2018/19, 34 986, nr. 3, p. 234 (MvT, IOw). Op art. 4:129 Awb zal nog worden ingegaan in paragrafen 5.4.2, 5.5.2, 5.6.2 en 10.4.2.

26 Op het uitgangspunt van aansluiting bij het besluitmodel zal hier niet worden ingegaan, omdat het niet voor of tegen art. 15.2 Ow pleit. 
Anderzijds past de categorische uitsluiting van vergoeding van immateriële schade door art. 15.2 Ow niet goed bij het uitgangspunt van aansluiting bij de $\mathrm{Awb}^{27}$ en het BW. Tevens past deze uitsluiting niet goed bij de doelstelling van codificatie van het nadeelcompensatierecht en wringt zij wellicht enigszins met het uitgangspunt van het uitsluitend codificeren van het égalitébeginsel. De Afdeling heeft de mogelijkheid tot vergoeding van immateriële schade immers altijd opengehouden, terwijl een beperking van het schadebegrip ook niet volgt uit het ongeschreven égalitébeginsel. Voorts kunnen ook bezien vanuit de doelstelling van vergroting van de rechtsgelijkheid vraagtekens worden geplaatst bij de uitsluiting van immateriële schade door art. 15.2 Ow. Is het bijvoorbeeld redelijk om compensatie van immateriële schade door een omgevingsplan op voorhand uit te sluiten, terwijl dergelijke schade veroorzaakt door een op basis van art. $147 \mathrm{Gemw}$ vastgestelde verordening $^{28}$ (al dan niet van vergelijkbare abstracte aard als het omgevingsplan) in beginsel wel voor compensatie in aanmerking komt? Ten slotte lijkt art. 15.2 Ow ook in meer algemene zin niet goed te passen bij de doelstelling van vereenvoudiging, uniformering en harmonisering van het nadeelcompensatierecht. Titel 4.5 Awb kent immers een open schadebegrip. Dat zou overigens ook reden kunnen zijn om immateriële schade tevens in titel 4.5 Awb van vergoeding uit te zonderen. Dat lijkt echter onwenselijk vanwege de brede reikwijdte van deze regeling en de overige in deze alinea genoemde doelstellingen en uitgangspunten.

Persoonlijk ben ik van mening dat onwenselijke vergoedingen van immateriële schade beter zouden kunnen worden tegengegaan met behulp van criteria die uit het égalitébeginsel voortvloeien dan met de categorische uitsluiting van vergoeding van immateriële schade voor het gehele omgevingsrecht. Hiervoor bleek echter dat de aan de Wns ten grondslag liggende doelstellingen en uitgangspunten niet eensluidend voor of tegen deze categorische uitsluiting pleiten. Ik acht het behoud van art. 15.2 Ow daarom niet onverdedigbaar en zal dan ook geen aanbevelingen doen tot aanpassing van (a) titel 4.5 Awb of (b) afdeling $15.1 \mathrm{Ow}$, of het (c) anderszins voorzien in een bijzondere invulling, aanvulling of afwijking van titel 4.5 Awb. Wel verdient nog vermelding dat uit de staatsrechtelijke grenzen als beschreven in paragraaf 2.5 voortvloeit dat geen ruimte zal bestaan voor lagere regelgevers om bepaalde schadesoorten op voorhand van vergoeding uit te zonderen, bijvoorbeeld in verordeningen of beleidsregels. Daardoor zou immers worden afgeweken van het dwingendrechtelijke art. 4:126 Awb. ${ }^{29}$ Wel bestaat ruimte om een lagere regeling slechts van toepassing te verklaren op specifieke schadesoorten teneinde ten aanzien daarvan te voorzien in specifieke normering van de criteria uit titel 4.5 Awb. ${ }^{30}$ Daarbij kan bijvoorbeeld worden gedacht aan

27 Uit paragraaf 5.2.1 volgde immers dat in algemene zin wordt aangenomen dat het bestuursrechtelijke schadebegrip niet afwijkt van het civielrechtelijke schadebegrip.

28 Daarop is enkel titel 4.5 Awb van toepassing.

29 Vergelijk Hoitink \& Koetser 2007, p. 342.

30 Zie hierover ook paragraaf 3.3.1 onder het kopje 'Limitatieve opsommingen van schadeoorzaken niet langer toegestaan?'. 
een wetsinterpreterende beleidsregel waarin is opgenomen hoe inkomensschade zal worden begroot.

\subsection{DE EIS VAN EEN BELANGENAFWEGING}

5.3.1 Deelvraag 2: verschillen tussen de geselecteerde, thans geldende regelingen en verklaringen daarvoor

In de literatuur is relatief veel discussie gevoerd omtrent de vraag of aan het schadeveroorzakende overheidshandelen een belangenafweging ten grondslag moet liggen waarin het belang waarin de gelaedeerde is getroffen al dan niet moet zijn meegewogen. ${ }^{31}$ Van de geselecteerde, thans geldende regelingen stelt slechts de AVN een dergelijke eis. Uit de definitie van schade die door art. 1 onder b AVN wordt gegeven, volgt namelijk dat slechts "weloverwogen schade, veroorzaakt door bepaalde overheidsbesluiten of -handelingen, waar een afweging van belangen aan is voorafgegaan" voor vergoeding in aanmerking komt. Uit de toelichting op deze bepaling volgt dat het nadeel een "noodzakelijk dan wel onvermijdelijk"32 gevolg dient te zijn van het schadeveroorzakende overheidshandelen. Aan het schadeveroorzakende overheidshandelen moet bovendien een rechtmatige belangenafweging vooraf kunnen zijn gegaan en die afweging moet ook daadwerkelijk hebben plaatsgevonden. Hiermee zou invulling worden gegeven aan de relatie tussen égalité en art. 3:4 lid 2 Awb zoals die "in vaste jurisprudentie [is] gelegd". ${ }^{33}$

De soep lijkt uiteindelijk minder heet te worden gegeten als zij wordt opgediend. In de toelichting op de bepaling wordt namelijk ook opgemerkt dat aan de uitoefening van een publiekrechtelijke bevoegdheid "per definitie een (rechtmatige) afweging van belangen ten grondslag" ligt. Ook bij de uitoefening van een publiekrechtelijke taak door feitelijk handelen zou dit het geval zijn vanwege art. 3:1 lid 2 Awb. Het heeft daarom veel ervan weg dat het Amsterdamse gemeentebestuur een belangenafweging aanwezig zal achten als bij uitoefening van het schadeveroorzakende overheidshandelen maar mogelijkheid tot het afwegen van belangen bestond. Wel wordt daadwerkelijk nagegaan of de schade een noodzakelijk en onvermijdelijk gevolg van het overheidshandelen is. Schade zou daarom niet worden vergoed in zogenoemde "risicogevallen". Het gaat dan om gevallen

31 Zie bijvoorbeeld de noot van Schueler bij ABRvS 12 november 2003, ECLI:NL:RVS:2003:AN7882 in $A B$ 2004, 244; de noot van De Graaf bij ABRvS 15 december 2004, ECLI:NL:RVS:2004:AR7552, in $A B$ 2005/67; Tjepkema 2010, p. 207-216, 549-559; en Van Ravels zijn noot bij ABRvS 16 maart 2005, ECLI:NL:RVS:2005:AT0552 in $A B$ 2007/11. Aan de verhouding tussen égalité en art. 3:4 lid 2 Awb is ook aandacht besteed in de in 2002 voor de VAR uitgebrachte preadviezen van Van Maanen, Van Ravels \& Schueler (VAR-reeks 128).

32 Deze formulering komt niet voort uit planschade- en nadeelcompensatiejurisprudentie, maar lijkt te zijn ontleend aan het proefschrift van Tjepkema. Vergelijk bijvoorbeeld Tjepkema 2010, p. 200 e.v.

Zie de toelichting op art. 1 onder b AVN. 
waarin "het intreden van nadelige gevolgen altijd onbekend en afhankelijk van een onzekere, toekomstige gebeurtenis" is. Zo zou schade door rellen bij een huldiging van voetbalclub Ajax niet op grond van de AVN voor vergoeding in aanmerking komen, omdat dergelijke schade niet "op de koop toe" zou zijn genomen. ${ }^{34}$

De eis van een belangenafweging komt niet terug in de overige geselecteerde, thans geldende regelingen. In geval van de Wro lijkt dat deels te kunnen worden verklaard door de limitatieve opsomming van schadeoorzaken uit art. 6.1 lid 2 Wro. Daarin zijn immers alleen schadeoorzaken opgenomen bij de vaststelling waarvan het bestuur een belangenafweging diende te maken. Ik sluit niet uit dat de in paragraaf 4.2.3. $1^{35}$ besproken jurisprudentielijn dat slechts objectief te verwachten, ruimtelijke gevolgen van planologische maatregelen tot tegemoetkoming in planschade kunnen leiden ook deels als verklaring kan dienen. De eerstgenoemde verklaring gaat ook op voor de meeste achterliggende grondslagen om onder de GrS compensatie toe te kennen. Zo zal steeds een belangenafweging ten grondslag dienen te liggen aan de vaststelling of wijziging van een bestemmingsplan (art. 49 WRO), een besluit tot aanwijzing van een luchtvaartterrein (art. 21 Aanwijzingsbesluit 1996), en een luchthavenindelingbesluit of luchthavenverkeerbesluit (art. 8.31 Wlv). Mij zijn voorts geen onder de GrS behandelde aanvragen bekend waarin de BnIW 2019 of het ongeschreven égalitébeginsel de achterliggende grondslag voor nadeelcompensatie vormde en de schade werd veroorzaakt door een gebonden bevoegdheid. Het verbaast dan ook niet dat in de bij de Wro behorende Kamerstukken en in het door de besliscommissie van het Schadeschap opgestelde Basisdocument niet wordt gesproken van een eis van een belangenafweging.

Dat de Amsterdamse gemeenteraad de eis wel in de AVN heeft opgenomen maar niet in de VNNZ, kan waarschijnlijk worden verklaard doordat de AVN - anders dan de VNNZ - niet voortbouwde op een voorganger. De AVN is namelijk een geheel nieuwe regeling en de daarin opgenomen eis van "weloverwogen schade" lijkt te zijn ontleend aan de dissertatie van Tjepkema. ${ }^{36}$ Waarom Tjepkema vindt dat deze eis dient te worden gehanteerd en hoe hij deze eis invult, zal in het resterende deel van deze paragraaf slechts worden besproken voor zover dat van belang is voor de beantwoording van de in paragraaf 1.2 gestelde onderzoeksvragen. Een aanvullende verklaring voor het niet opnemen van de eis van een belangenafweging in de VNNZ zou kunnen zijn dat zich bij de aanleg van de Noord/Zuidlijn niet tot nauwelijks schadeoorzaken hebben voorgedaan waarbij geen ruimte tot belangenafweging bestond. Die verklaring lijkt ook op te gaan voor de BnIW 2019: zeker wanneer de minister verantwoordelijk is voor infrastructurele werkzaamheden, maar vaak ook bij andere uitoefeningen van zijn publiekrechtelijke bevoegdheid of taak, zal ruimte tot belangenafweging bestaan.

34 Zie de toelichting op art. 1 onder b AVN.

35 Zie het kopje 'Verwevenheid met de toerekeningsvraag of het relativiteitsvereiste'. Zie bijvoorbeeld ook Van Ravels 2011c, p. 141-144. 
Ik sluit deze paragraaf af met een algemene verklaring voor het gegeven dat de eis van een belangenafweging niet op een later moment alsnog in een van de overige regelingen is opgenomen: de relatie tussen égalité en art. 3:4 lid 2 Awb is minder duidelijk dan de Amsterdamse gemeenteraad in zijn toelichting op de AVN doet vermoeden door te stellen dat art. 1 onder b AVN invulling zou geven aan de wijze waarop deze relatie "in vaste jurisprudentie [is] gelegd". ${ }^{37}$ Ter onderbouwing daarvan refereer ik aan de jurisprudentie uit 1997 waarin de constructie van het zelfstandig schadebesluit werd erkend. ${ }^{38}$ Daarin oordeelde de Afdeling namelijk dat nadeelcompensatie in dergelijke besluiten wordt toegekend op grond van "het mede aan artikel 3:4, tweede lid, van de Awb ten grondslag liggende - rechtsbeginsel van 'égalité devant les charges publiques' (gelijkheid voor openbare lasten)." ${ }^{39}$ Deze koppeling tussen het evenredigheidsbeginsel en het égalitébeginsel werd pas zes jaar later verbroken door de Afdeling in haar Heerlen-uitspraak van 12 november 2003:

"Nu het gaat om een verzoek om schadevergoeding naar aanleiding van het reeds onherroepelijk geworden aanwijzingsbesluit is bovendien niet toetsing aan artikel 3:4 van de Awb en het daarin gecodificeerde evenredigheidsbeginsel aan de orde, maar dient de vraag of aanspraak bestaat op nadeelcompensatie aan de hand van het algemeen rechtsbeginsel van gelijkheid voor de openbare lasten te worden beantwoord." ${ }^{40}$

Deze ontkoppeling blijkt ook uit een uitspraak van 8 november 2006, waarin de Afdeling overweegt dat...

\begin{abstract}
"(...) de omstandigheid dat er geen sprake is van onevenredige schade in de zin van artikel 3:4, tweede lid, van de Awb, in de zin dat de gestelde schade niet bij voorbaat in de weg staat aan het nemen van een rechtmatig besluit, niet [betekent] dat er evenmin aanleiding is voor schadevergoeding op grond van het égalité-beginsel. Die laatste vraag vergt dus een andere beoordeling." 41
\end{abstract}

Sinds de ontkoppeling in 2003 zijn, voor zover mij bekend, slechts twee uitspraken gewezen waarin de Afdeling sanctioneerde dat een op het ongeschreven éga-

37 Zie de toelichting op art. 1 onder b AVN.

38 Zie hierover ook paragraaf 2.2 onder het kopje 'De Beurskens- \& Van Vlodropuitspraken (1997)'.

39 Zie ABRvS 18 februari 1997, ECLI:NL:RVS:1997:ZF2587 (Beurskens); en ABRvS 6 mei 1997, ECLI:NL:RVS:1997:AA6762 (Van Vlodrop). Onder verwijzing naar deze jurisprudentie is de geciteerde passage meermaals overgenomen in de toelichting op de RnVW 1999, bijvoorbeeld ter motivering van de grondslag van deze regeling. Zie daarvoor Stcrt. 1999, nr. 172, p. 9 (digitaal, p. 4). Niets wijst echter erop dat de eis van een belangenafweging werd gehanteerd onder de RnVW 1999, of wordt gehanteerd onder de BnIM 2014 of BnIW 2019. Zie ook Stcrt. 2014, nr. 16584, p. 3 respectievelijk Stcrt. 2019, nr. 66154, p. 6.

40 ABRvS 12 november 2003, ECLI:NL:RVS:2003:AN7851, r.o. 2.7 (Prostitutiezone Heerlen/Ontkoppelingsuitspraak).

41 ABRvS 8 november 2006, ECLI:NL:RVS:2006:AZ1762, r.o. 2.6. 
litébeginsel gebaseerde aanvraag om nadeelcompensatie werd afgewezen omdat het bestuur geen ruimte tot belangenafweging toekwam bij het nemen van de schadeveroorzakende overheidsmaatregel. Op beide uitspraken zal nog nader worden ingegaan in paragraaf 5.3.2.

\subsubsection{Deelvraag 3: het toekomstige recht}

De eis van een belangenafweging komt niet voor in de tekst van titel 4.5 Awb en afd. 15.1 Ow. Ook in de bij de IOw behorende Kamerstukken wordt niet ingegaan op deze eis. Dat ligt mijns inziens ook voor de hand omdat in art. 15.1 lid $1 \mathrm{Ow}$ slechts schadeoorzaken zijn opgenomen bij de vaststelling waarvan het bestuur een belangenafweging dient te maken. Tevens bleek in paragraaf $2.4 .3^{42}$ dat bij het vaststellen van een omgevingsplan een groter scala aan belangen mag worden meegewogen dan naar huidig recht mag bij de vaststelling van een bestemmingsplan. Daardoor is de kans kleiner dat het belang waarin de aanvrager is getroffen niet mocht worden meegewogen. Ten slotte was in de bij titel 4.5 Awb behorende Kamerstukken reeds aandacht besteed aan de eis van een belangenafweging. Zo merkte de minister van Veiligheid \& Justitie tijdens de behandeling van het wetsvoorstel voor de Wns in de Tweede Kamer op dat art. 3:4 lid 2 Awb "niet goed is toegesneden op de vraag of aanspraak bestaat op nadeelcompensatie." Daarom is er in navolging van de $\mathrm{ABRvS}^{43}$ voor gekozen om...

“(...) een «knip» te maken tussen het schadeveroorzakende besluit en de eventuele aanspraak op nadeelcompensatie. Dit voorstel codificeert daartoe een zelfstandige grondslag voor vergoeding van schade in de vorm van het égalitébeginsel in artikel 4:126 Awb." 44

Uit het voorafgaande lijkt op het eerste oog te kunnen worden afgeleid dat de eis van een belangenafweging geen rol zal spelen onder titel 4.5 Awb en afd. 15.1 Ow. Om na te gaan of dat beeld terecht is, zal hierna worden ingegaan op de beantwoording van enkele vragen omtrent de eis van een belangenafweging die zijn gesteld tijdens de behandeling van het wetsvoorstel in de Eerste Kamer.

\section{In het geheel geen ruimte tot belangenafweging}

Leden van de VVD-fractie stelden de vraag of onder titel 4.5 Awb de eis van een belangenafweging dient te worden gehanteerd. Daarbij merkten zij onder andere op dat deze eis zou volgen uit "vaste jurisprudentie" en dat Tjepkema het niet op-

Zie het kopje 'Het nieuwe omgevingsrecht'.

43 Daarbij wordt verwezen naar ABRvS 8 november 2006, ECLI:NL:RVS:2006:AZ1762, r.o. 2.6. Zie over deze uitspraak ook paragraaf 5.3.1.

44 Kamerstukken II 2010/11, 32 621, nr. 6, p. 4-5 (NV II, Wns). Zie in algemene zin ook Kamerstukken II 2010/11, 32 621, nr. 3, p. 9-14 (MvT, Wns). 
nemen van deze eis "een omissie van formaat" 45 heeft genoemd. ${ }^{46}$ De minister van Veiligheid \& Justitie antwoordde dat in de jurisprudentie "aanknopingspunten" zichtbaar zijn voor de conclusie dat geen ruimte voor nadeelcompensatie bestaat als het bestuur bij het nemen van het schadeveroorzakende besluit geen ruimte tot belangenafweging had. ${ }^{47}$ Het lijkt aannemelijk dat hij daarmee doelde op de twee op 16 maart 2005 gewezen Afdelingsuitspraken die de Kamerleden in hun vraag aanhaalden. In de eerste zaak vorderde appellante onder andere nadeelcompensatie op grond van het égalitébeginsel wegens het weigeren van een aanvraag van een bouwvergunning. De Afdeling overwoog:

"Vanwege het limitatief en imperatief karakter van art. 44 Woningwet was er bij het nemen van de beslissing op de aanvraag om bouwvergunning dan ook geen ruimte voor een belangenafweging en mitsdien evenmin voor nadeelcompensatie." ${ }^{48}$

In de tweede zaak werd de aanvraag om nadeelcompensatie gebaseerd op art. 31 Wet op de openluchtrecreatie. De schade zou zijn ontstaan doordat het college van $\mathrm{B} \& \mathrm{~W}$ weigerde een kampeervergunning te verlenen, omdat het gebied in kwestie door het ter plaatse geldende bestemmingsplan niet mede de functie van kampeerterrein vervulde. De Afdeling overwoog:

\begin{abstract}
"Gelet op de vigerende bestemming en op het bepaalde in artikel 10, eerste lid, aanhef en onder $b$, van de WOR, moest het college de aanvraag van appellante om vergunning afwijzen. Daar waar voor het college bij het nemen van het besluit van 3 maart 1998 de discretionaire ruimte ontbrak om belangen af te wegen, is er geen grond voor compensatie van mogelijk door dat besluit veroorzaakt nadeel. Reeds daarom is het verzoek om schadevergoeding op grond van artikel 31 van de WOR terecht afgewezen." 49
\end{abstract}

De minister gaf voorts aan dat er bij gebonden beschikkingen geen ruimte tot belangenafweging bestaat, omdat die afweging reeds is gemaakt bij het nemen van een "anterieur" besluit. De schade veroorzaakt door de gebonden beschikking kan aan het bestuur worden "toegerekend" als gevolg van deze anterieure besluiten, "waaraan de aanvraag ${ }^{50}$ volgens de wet getoetst moet worden en die dus aan de gebonden beschikking voorafgaan." ${ }^{51}$ Het is volgens de minister derhalve "aangewezen" de vraag of nadeelcompensatie op zijn plaats is te beoordelen op grond van de anterieure besluitvorming. Zo kan in geval van een omgevingsvergunning bijvoorbeeld worden nagegaan of er reden tot tegemoetkoming in planschade be-

45 Tjepkema 2011, p. 1374 e.v.

46 Kamerstukken I 2011/12, 32 621, nr. B, p. 2 (VV I, Wns).

47 Kamerstukken I 2012/13, 32 621, nr. C, p. 1-2 (MvA I, Wns).

48 ABRvS 16 maart 2005, ECLI:NL:RVS:2005:AT0552, r.o. 2.5.1.

49 ABRvS 16 maart 2005, ECLI:NL:RVS:2005:AT0553, r.o. 2.2-2.3.

$50 \quad$ Hiermee wordt gedoeld op de aanvraag van de gebonden beschikking.

51 Een omgevingsvergunning (gebonden beschikking) dient bijvoorbeeld getoetst te worden aan art. 2.10 Wabo, het bestemmingsplan, het Bouwbesluit 2012 en de gemeentelijke welstandsnota (de anterieure besluiten). 
staat wegens wijziging van het bestemmingsplan. Naarmate het anterieure besluit algemener van aard wordt, zou echter minder snel zijn voldaan aan de eisen inzake de abnormale- en speciale last. ${ }^{52}$ Deze opmerking sluit goed aan op de hedendaagse jurisprudentielijn dat schade door feitelijk gebruik van planologische mogelijkheden aan het bestuur dient te worden toegerekend als gevolg van de planologische maatregel die deze mogelijkheden in het leven heeft geroepen, en dus niet als gevolg van de op basis daarvan verleende vergunningen ter realisatie van dit feitelijke gebruik. ${ }^{53}$ Destijds kon de minister uiteraard nog niet weten dat meer dan vijf jaar later de keuze zou worden gemaakt om de omgevingsvergunning op grond van art. 15.1 lid $2 \mathrm{Ow}$ als exclusieve schadeoorzaak aan te merken. ${ }^{54}$

\section{Beperkte ruimte tot belangenafweging en het specialiteitsbeginsel}

De VVD-fractieleden stelden ook een vraag omtrent de invloed van het specialiteitsbeginsel op de verplichting tot nadeelcompensatie: kan het bestuur gehouden zijn nadeelcompensatie uit te keren aan iemand wiens belang niet in de schadeveroorzakende besluitvorming mocht worden meegewogen ${ }^{55}$ De minister antwoordde dat de mogelijkheid nadeelcompensatie uit te keren in beginsel niet door het specialiteitsbeginsel wordt beperkt - ook het huidige kabinet blijkt die mening toegedaan. ${ }^{56}$ Het égalitébeginsel ziet namelijk "in beginsel" op alle belangen die onevenredig zwaar door de rechtmatige besluitvorming worden getroffen en dus ook op belangen die niet in deze besluitvorming mochten worden meegewogen. Wel kan het specialiteitsbeginsel met zich brengen dat bepaalde schade niet in redelijkheid als gevolg van het schadeveroorzakende overheidshandelen aan het bestuur valt toe te rekenen, waardoor er geen sprake zal zijn van causaal verband. Dit zou zowel spelen bij volledig gebonden overheidshandelen als overheidshandelen waarbij het getroffen belang niet mag worden meegewogen. ${ }^{57}$

Ter illustratie hiervan verwees de minister naar een uitspraak van 12 november 2003. Appellante stelde daarin schade te lijden doordat de wijze waarop een naburig gemeenschapshuis door een nieuwe beheerder werd geëxploiteerd (een toename van) geluidsoverlast meebracht. Als schadeoorzaak wees zij een vergunning aan die was verleend op grond van de Drank- en Horecawet. Slechts de tenaamstelling van de vergunning was gewijzigd. Qua inhoud was zij ongewijzigd ten opzichte van de vergunning van de vorige beheerder. In combinatie met het gegeven dat de Drank- en Horecawet geen ruimte liet om bij de wijziging van de

52 Kamerstukken I 2012/13, 32 621, nr. C, p. 1-2 (MvA I, Wns).

53 Zie ABRvS 14 juli 2010, ECLI:NL:RVS:2010:BN1157, r.o. 2.8.3; en ABRvS 15 januari 2014, ECLI:NL:RVS:2014:28, r.o. 6.1. Een analyse van de eerstgenoemde uitspraak is te vinden in Huijts \& Tjepkema 2017, p. 300.

54 Zie paragraaf 3.3.2.3 onder het kopje 'De omgevingsvergunning als exclusieve schadeoorzaak'.

$55 \quad$ Kamerstukken I 2011/12, 32 621, nr. B, p. 2 (VV I, Wns).

56 Kamerstukken II 2018/19, 34 986, nr. 3, p. 225 (MvT, IOw).

57 Kamerstukken I 2012/13, 32 621, nr. C, p. 2-3 (MvA I, Wns). 
tenaamstelling exploitatievoorwaarden aan de vergunning te verbinden, ${ }^{58}$ vormde dit reden voor de Afdeling om te oordelen dat de andere wijze van exploitatie "niet het rechtstreekse gevolg van deze vergunning" was. ${ }^{59}$ Op basis van deze uitspraak concludeerde de minister dat het "niet de bedoeling [is] dat de overheid aansprakelijk is voor de gevolgen van allerlei handelingen van vergunninghouders, ook als zij niet bevoegd is om die handelingen te reguleren of als de schade om andere redenen moet worden toegerekend aan de vergunninghouder, zijnde de primaire veroorzaker." 60

\section{Voorzienbaarheid van de schade ten tijde van de belangenafweging}

Onder verwijzing naar het proefschrift van Tjepkema ${ }^{61}$ en een strafrechtelijk vonnis van de rechtbank Assen ${ }^{62}$ stelden de VVD-fractieleden vervolgens de vraag of ook schade die niet het gevolg is van een "gerichte rechtmatige afweging van belangen", maar "veeleer een incidenteel en onverwacht bijproduct" van het rechtmatige overheidshandelen vormt, ${ }^{63}$ krachtens titel 4.5 Awb in aanmerking komt voor nadeelcompensatie. ${ }^{64}$ Het ging de Kamerleden dus niet om het onderscheid tussen gebonden en vrije bevoegdheden, maar om het onderscheid tussen beoogde en niet-beoogde gevolgen van het schadeveroorzakende overheidshandelen. Het antwoord van de minister liet weinig aan de verbeelding over. Allereerst merkte hij op dat strafvorderlijk overheidshandelen vanwege art. 1:6 Awb in ieder geval niet onder de reikwijdte van titel 4.5 Awb valt. ${ }^{65}$ Risicovol handelen doet zich echter ook in het bestuursrecht voor en daarop is art. 4:126 Awb wel van toepassing. De vereisten van een abnormale- en speciale last "lenen zich [immers] ook om te worden toegepast op schade die het gevolg is van noodzakelijk overheidsoptreden waaraan inherente risico's zijn verbonden." Voor een nieuwe categorie claims bij de bestuursrechter zou niet te hoeven worden gevreesd "zolang het gaat om schade die is veroorzaakt door rechtmatig overheidshandelen in een bestuursrechtelijke context." 66

In dezelfde lijn als de vraag van de VVD-fractieleden ligt een vraag van de D66fractie. Zij voerde aan dat het "omstreden" is of "voor de toepassing van artikel

58 Zie bijvoorbeeld art. 8 jo. 9 jo. 10 Drank- en Horecawet. Deze bepalingen laten hoofdzakelijk ruimte om factoren als 'sociale hygiëne' en het 'levensgedrag van leidinggevenden' mee te wegen.

59 ABRvS 12 november 2003, ECLI:NL:RVS:2003:AN7882.

60 Kamerstukken I 2012/13, 32 621, nr. C, p. 2-3 (MvA I, Wns).

61 Tjepkema 2010, p. 259 e.v.

62 Rb. Assen 13 februari 2001, ECLI:NL:RBASS:2001:AA9980 (Schietpartij bij C1000).

63 De Kamerleden spreken daarbij van een schadeoorzaak met "gevaarzettend karakter”, zie Kamerstukken I 2011/12, 32 621, nr. B, p. 3 (VV I, Wns).

64 Kamerstukken I 2011/12, 32 621, nr. B, p. 3-4 (VV I, Wns).

65 Zie hierover ook paragraaf 3.3.1.

66 Kamerstukken I 2012/13, 32 621, nr. C, p. 5 (MvA I, Wns). 
4:126 Awb als voorwaarde geldt dat het voor de overheid voorzienbaar was dat onevenredig nadeel zou ontstaan." De Hoge Raad ${ }^{67}$ zou deze voorwaarde wel stellen, terwijl de Afdeling ${ }^{68}$ dat juist expliciet niet zou doen. ${ }^{69}$ Het antwoord van de minister ligt op één lijn met het antwoord op de hiervoor besproken vraag. Soms zal het voor de overheid niet voorzienbaar zijn dat een bepaalde maatregel schade met zich zal brengen en/of wat de omvang van deze schade zal zijn. Ook in die gevallen, waarin de schade "niet een noodzakelijk of onvermijdelijk gevolg van een belangenafweging" vormt, kan er reden zijn nadeelcompensatie toe te kennen. Als voorbeeld wordt "noodzakelijk overheidsoptreden waaraan inherente risico's zijn verbonden (zoals een verplichte vaccinatie)" genoemd. Dit voorbeeld is mijns inziens enigszins wonderlijk, aangezien het woord 'inherent' altijd enige mate van voorzienbaarheid lijkt te suggereren. Beter te volgen is de opmerking dat de schade wel moet worden veroorzaakt door het bestuursorgaan, zodat het voor het causaal verband vereiste toerekeningsverband kan worden aangenomen. ${ }^{70} \mathrm{Bij}$ de vaststelling van dit toerekeningsverband kan de voorzienbaarheid van de schade uiteraard wel een rol spelen. ${ }^{71}$

\section{Conclusie}

De eis van een belangenafweging vloeit niet voort uit de tekst van titel 4.5 Awb en afd. 15.1 Ow. Uit bij de Wns behorende Kamerstukken kan bovendien worden afgeleid dat deze eis hooguit zou kunnen worden tegengeworpen bij volledig gebonden overheidshandelen. Dat lijkt echter niet te worden beoogd door de wetgever, aangezien deze juist een knip voor ogen staat tussen het égalitébeginsel en art. 3:4 lid 2 Awb. Verder blijkt de wetgever van mening dat voor toekenning van nadeelcompensatie niet is vereist dat het belang waarin de gelaedeerde is getroffen kon worden betrokken in de belangenafweging die ten grondslag lag aan de schadeveroorzakende overheidshandeling. Wanneer het belang waarin de gelaedeerde is getroffen niet kon worden meegewogen, kan dat echter wel tot gevolg hebben dat diens schade niet als gevolg van deze overheidshandeling aan het bestuur kan worden toegerekend. Ten slotte is voor toekenning van nadeelcompensatie niet vereist dat het bestuur ten tijde van de belangenafweging kon voorzien dat zijn handelen het getroffen belang zou schaden. Deze voorzienbaarheid kan uiteraard wel een rol spelen bij de beantwoording van de causale toerekeningsvraag.

67 HR 17 september 2004, ECLI:NL:HR:2004:AO7887 (Uzi).

68 ABRvS 28 juni 2006, ECLI:NL:RVS:2006:AX9484.

69 Kamerstukken I 2011/12, 32 621, nr. B, p. 8 (VV I, Wns).

70 Kamerstukken I 2012/13, 32 621, nr. C, p. 10 (MvA I, Wns).

71 Zie bijvoorbeeld HR 10 februari 2017, ECLI:NL:HR:2017:214, 4.1.1-4.1.3 (Avi) Verweerder), onder verwijzing naar Parl. Gesch. Boek 6, p. 345. 


\subsubsection{Hoofdvraag: spiegeling aan de doelstellingen en uitgangspunten die ten grondslag liggen aan de Wns}

Hoe verhoudt het zich tot de aan de Wns ten grondslag liggende doelstellingen en uitgangspunten dat in titel 4.5 Awb niet de eis is opgenomen dat aan de schadeoorzaak een belangenafweging ten grondslag ligt (waarin het getroffen belang is meegewogen)? De uitgangspunten van aansluiting bij de Awb en het BW, en aansluiting bij het besluitmodel pleiten niet voor of tegen het opnemen van deze eis. Dat geldt ook voor de doelstellingen van vereenvoudiging, uniformering en harmonisering van het nadeelcompensatierecht, en vergroting van de rechtsgelijkheid. Laatstgenoemde doelstellingen pleiten er namelijk hooguit voor dat de eis óf voor het hele planschade- en nadeelcompensatierecht moet gelden, óf helemaal niet.

Het spreekt voor zich dat geen schadevergoeding wegens een schending van het in art. 3:4 lid 2 Awb vervatte evenredigheidsbeginsel kan worden toegekend als er voor het bestuur geen ruimte bestond om het getroffen belang in de aan de schadeoorzaak ten grondslag liggende belangenafweging te betrekken. ${ }^{72}$ De twee in paragraaf 5.3.2 besproken uitspraken van 16 maart 2005 zijn de enige mij bekende uitspraken waarin een op het égalitébeginsel gegronde aanvraag om nadeelcompensatie werd afgewezen vanwege het gebonden karakter van de schadeveroorzakende bevoegdheid. Dit roept de vraag op of de uit deze uitspraken te destilleren jurisprudentielijn nog steeds geldt, of veeleer moet worden beschouwd als een historisch restant van de in de Heerlen-uitspraak doorbroken koppeling van het égalitébeginsel en art. 3:4 lid 2 Awb. ${ }^{73}$ In elk geval vormen deze uitspraken mijns inziens een onvoldoende solide basis om het criterium in de Awb op te nemen mede omdat twijfelachtig is in hoeverre de doelstelling van codificatie van het nadeelcompensatierecht daardoor daadwerkelijk zou worden behartigd. Bovendien pleit het uitgangspunt van het uitsluitend codificeren van het égalitébeginsel tegen opname van de eis van een belangenafweging in titel 4.5 Awb. Uit paragrafen 2.4.2.2 en 5.3.2 volgde immers dat de wetgever met titel 4.5 Awb beoogt aan te sluiten bij de ontkoppeling die voortvloeit uit de Heerlen-uitspraak.

Dan resteren nog de doelstellingen van vergroting van de rechtszekerheid, en vergroting van de doelmatigheid van het nadeelcompensatierecht en vermindering van bestuurslasten. Wellicht zou kunnen worden betoogd dat deze doelstellingen worden behartigd door de eis van een belangenafweging, aangezien daarmee onwenselijke aansprakelijkheden kunnen worden voorkomen of althans de aansprakelijkheid op de juiste wijze kan worden 'gekanaliseerd'. Met onwenselijke aansprakelijkheden wordt doorgaans gedoeld op situaties waarin het bestuur aansprakelijk zou zijn terwijl het vanwege het toepasselijke wettelijke afwegingskader

72 Vergelijk de tekst van art. 3:4 lid 2 Awb. Zie ter illustratie ABRvS 11 januari 2006, ECLI:NL:RVS:2006:AU9408, r.o. 2.1.2; en ABRvS 15 december 2004, ECLI:NL:RVS:2004:AR7552, r.o. 2.11. 
geen mogelijkheden heeft om de schade te voorkomen of beperken. ${ }^{74}$ In dat soort situaties zou het op de weg van de gelaedeerde liggen om niet het bestuur, maar bijvoorbeeld de vergunninghouder aan te spreken. Ik zie echter - mede in het licht van de in paragraaf 5.3.2 besproken Afdelingsuitspraak van 12 november 2003 meer in het causaliteitscriterium (en dan met name de toerekeningsvraag) om het nadeelcompensatiegeschil naar het 'meest geëigende besluitvormingskader' 75 te dirigeren. Ook het planschaderecht laat zien dat het causaliteitscriterium met dit doel kan worden ingezet. Het is immers vaste jurisprudentie dat schade door feitelijk gebruik van planologische mogelijkheden aan het bestuur wordt toegerekend als gevolg van de planologische maatregel die deze mogelijkheden in het leven heeft geroepen, en dus niet als gevolg van de op basis daarvan verleende vergunningen ter realisatie van dit feitelijke gebruik. Tevens kan worden gedacht aan de vaste jurisprudentielijn dat schade in de vorm van tijdelijke hinder als gevolg van werkzaamheden ter uitvoering van een besluit als bedoeld in art. 6.1 lid 2 Wro of een wegaanpassingsbesluit niet als gevolg van een dergelijk besluit, maar als gevolg van de feitelijke werkzaamheden ter uitvoering van de planologische mogelijkheden die dit besluit biedt aan het bestuursorgaan wordt toegerekend. ${ }^{76}$

Een ander probleem met betrekking tot de eis van een belangenafweging is de mogelijkheid dat op papier ruimte bestaat voor een belangenafweging, maar in de praktijk slechts één uitkomst mogelijk is. In Duitstalige literatuur wordt in dit kader ook wel gesproken van 'Ermessensreduzierung auf Null'. ${ }^{77}$ Ter illustratie verwijs ik naar het in paragraaf 7.1 nog te bespreken Leffers-arrest. Daarin overwoog de Hoge Raad namelijk dat de minister...

"(...) in redelijkheid tot het oordeel kon komen dat slechts (eigen cursivering) met een verbod als in de Regeling vervat op voldoende wijze zou kunnen worden tegengegaan dat ongekookte voedsel- en slachtafvallen zouden worden vervoederd zodat slechts aldus de daarin gelegen besmettingsbron doeltreffend kon worden uitgeschakeld." ${ }^{\prime 7}$

Tot op heden heeft echter niemand in de juridische doctrine aangevoerd dat daarom aan Leffers - die door dit verbod een abnormale en speciale last ondervond - geen nadeelcompensatie had moeten (kunnen) worden toegekend. Sterker nog,

74 Zie onder andere Tjepkema 2010, p. 558 en Kamerstukken I 2012/13, 32 621, nr. C, p. 2-3 (MvA I, Wns).

75 Deze term wordt onder andere gebruikt in Tjepkema 2010, p. 558-559.

76 Beide jurisprudentielijnen zijn uitgebreider beschreven in Huijts \& Tjepkema 2017, p. 300-302. Daarbij wordt onder andere verwezen naar ABRvS 14 juli 2010, ECLI:NL:RVS:2010:BN1157, r.o. 2.8.3 en ABRvS 15 januari 2014, ECLI:NL:RVS:2014:28, r.o. 6.1, respectievelijk ABRvS 28 september 2016, ECLI:NL:RVS:2016:2582, r.o. 3.1 (Overzichtsuitspraak) en ABRvS 30 november 2016, ECLI:NL:RVS:2016:3168, r.o. 6.2 (Wegafsluiting Hoevelaken).

77 Zie Hemmer e.a. 2013, nr. 371-373; en Müller 2013, p. 23-24.

78 HR 18 januari 1991, ECLI:NL:HR:1991:AC4031, r.o. 3.6 (Leffers/Staat). 
het Leffers-arrest is een van de schoolvoorbeelden van een geval waarin de toekenning van nadeelcompensatie op zijn plaats was.

Met betrekking tot de doelstelling van vergroting van de doelmatigheid van het nadeelcompensatierecht en vermindering van bestuurslasten zou wellicht aanvullend kunnen worden gewezen op het zogenoemde 'floodgate-argument' ${ }^{79}$ Dit argument is gebaseerd op de gedachte dat het afzien van de eis van een belangenafweging zal leiden tot een toename van het aantal (gehonoreerde) nadeelcompensatieaanvragen. Ook dat argument overtuigt mijns inziens onvoldoende. Het afzien van de eis van een belangenafweging leidt namelijk niet automatisch tot de honorering van een nadeelcompensatieaanvraag. De overige eisen die aan de toekenning van nadeelcompensatie worden gesteld, blijven immers nog steeds gelden. Zo zal er sprake moeten zijn van concreet vaststelbare, abnormale en speciale schade die in redelijkheid als een gevolg van het gebonden of slechts beperkt discretionaire besluit/overheidshandelen - dat bovendien binnen de reikwijdte van titel 4.5 Awb dient te vallen - aan het bestuur moet kunnen worden toegerekend, zonder dat er sprake is van risicoaanvaarding of een andere vorm van eigen schuld. Verder kent dit floodgate-argument ook een keerzijde. De overheid die het afwegingskader van een potentieel schadeveroorzakende bevoegdheid vaststelt, kan namelijk geprikkeld worden om een (latere) aansprakelijkheid uit hoofde van het égalitébeginsel te vermijden - bijvoorbeeld door het afwegingskader minder te beperken, of de mogelijkheid te scheppen bepaalde voorwaarden aan de bevoegdheidsuitoefening te verbinden.

Wanneer ik het voorafgaande afweeg, kom ik tot de conclusie dat het goed verenigbaar is met de aan de Wns ten grondslag liggende doelstellingen en uitgangspunten dat de eis van een belangenafweging niet in titel $4.5 \mathrm{Awb}$ of afd. $15.1 \mathrm{Ow}$ is opgenomen. In beginsel zou het daarom ook voor de hand liggen om geen verdergaande eisen te stellen, zoals de eis dat de geleden schade weloverwogen moet zijn. Aangezien uit paragraaf 5.3.1 bleek dat deze eis wel voorkomt in de AVN, zal ik hierna desondanks nagaan hoe zij zich verhoudt tot de aan de Wns ten grondslag liggende doelstellingen en uitgangspunten. Daarbij zal ik niet uitgaan van de - op dit punt summiere en weinig theoretisch onderbouwde - toelichting op de AVN, maar van de toelichting op deze eis die Tjepkema op basis van rechtsvergelijkend onderzoek geeft in zijn proefschrift.

\section{Een openbare last?}

In zijn proefschrift doet Tjepkema het voorstel het recht op nadeelcompensatie te beperken tot schade die kan worden gekwalificeerd als een 'openbare last'. Daaronder verstaat hij “"een door enig overheidshandelen 'weloverwogen' veroor-

79 Boom \& Giesen 2001, p. 1680. Dit argument wordt vooral gebruikt binnen de context van "veronderstelde beleidskeuzes", maar kan ook daarbuiten relevant zijn voor de eis van een belangenafweging. Zie omtrent de voornoemde context bijvoorbeeld Tjepkema 2010, p. 215. 
zaakt nadeel, dat noodzakelijk en onvermijdelijk is voor de behartiging van het algemeen belang." Tjepkema doet zijn voorstel voor deze eis tegen de achtergrond van het grondslagendebat. Hij signaleert daarbij onder andere dat de eisen van abnormale en speciale last niet aansprakelijkheidsbeperkend functioneren bij overheidsaansprakelijkheid wegens strafvorderlijk optreden of schending van gerechtvaardigd vertrouwen. Met de eis van een openbare last beoogt Tjepkema dit soort 'atypische gevallen' buiten het toepassingsbereik van het égalitébeginsel te houden. Kort gezegd, zou dit toepassingsbereik volgens hem moeten worden beperkt tot "besluitenrecht en (accessoire) feitelijke handelingen." 80

Wat moet precies worden verstaan onder "een door enig overheidshandelen 'weloverwogen' veroorzaakt nadeel, dat noodzakelijk en onvermijdelijk is voor de behartiging van het algemeen belang"? Het criterium dat het nadeel noodzakelijk en onvermijdelijk is, lijkt het eenvoudigst te vatten. Tjepkema beoogt daarmee aan te geven dat sprake moet "zijn van een doel-middel-relatie tussen de schade en het dienen van het algemeen belang: het door de overheid met haar rechtmatige daad beoogde resultaat kan slechts worden bereikt door het nadeel aan de burger toe te brengen." Dat is het evidentst als het geschade belang wel moest worden getroffen om het algemeen belang te behartigen. Een verbod op een product dat schadelijk is voor de volksgezondheid zal immers altijd nadelige gevolgen hebben voor de producenten, importeurs en verkopers van dat product. Het criterium kan echter ook voldaan zijn als de schade slechts een neveneffect is van het overheidshandelen. Daarvan is bijvoorbeeld sprake als omliggende ondernemers inkomensderving ondervinden door een wegomleiding ter bevordering van de verkeersveiligheid. Het criterium is echter niet voldaan als de schade een "te vermijden karakter" heeft. Daarbij kan worden gedacht aan de schotwond die een onschuldige bijstander oploopt bij de aanhouding van een vuurwapengevaarlijke wegpiraat. ${ }^{81}$

Aan het criterium van weloverwogenheid is voldaan wanneer de schade een 'noodzakelijk en onvermijdelijk karakter' heeft in relatie tot de schadeoorzaak. In de meeste in het nadeelcompensatierecht bekende gevallen valt dit samen met de voorzienbaarheid van de schade vanuit het perspectief van de overheid. De eis brengt echter niet mee dat het égalitébeginsel slechts van toepassing zou zijn op voorzienbare aantastingen van belangen. De meerwaarde van het égalitébeginsel is immers juist dat de concrete gevolgen van het overheidshandelen bepalend zijn voor de vraag of het bestuur compensatieplichtig is. Met het criterium beoogt Tjepkema "bovenal uit te drukken dat de overheid het ontstaan van nadeel 'op de koop toe' neemt, omdat dit nadeel nu eenmaal een onvermijdelijk gevolg is van de keuze om met het schadeveroorzakend besluit een algemeen (deel)belang te behartigen." Het kan in een uiterst geval zelfs gaan om schade die ten tijde van de belangenafweging 'onkenbaar' en 'onvoorzienbaar' was. In dat verband geeft Tjepkema een voorbeeld ontleend aan een Afdelingsuitspraak van 18 januari

81 Tjepkema 2010, p. 216-217. 
$2006 .{ }^{82}$ Een landbouwer die schade leed doordat ganzen zijn witlof consumeerden, wees een jachtverbod op ganzen aan als schadeoorzaak. In het handboek Faunaschade kan worden teruggevonden dat ganzen normaliter geen witlof eten. Het uitzonderlijke gedrag van de ganzen in kwestie bleek te kunnen worden verklaard door de combinatie van het jachtverbod met uitzonderlijk weer. ${ }^{83}$ Tjepkema stelt dat de schade van de witlofteler op een abstract niveau kan worden geacht op de koop toe te zijn genomen ter behartiging van het algemeen belang. Het zou dan niet zozeer gaan om de hier beschreven concrete gevolgen, maar om de afweging dat bepaalde personen mogelijk onevenredig nadeel door het besluit zouden ondervinden, maar dit nadeel niet dusdanig zwaar woog dat tot de conclusie werd gekomen dat het besluit niet moest worden genomen. ${ }^{84}$

Het motief van Tjepkema om de reikwijdte van het égalitébeginsel te beperken tot schadegevallen waarin de eisen van abnormale en speciale last uniform kunnen worden ingevuld, ${ }^{85}$ past op zichzelf goed bij de doelstellingen van uniformering en harmonisering van het nadeelcompensatierecht, en vergroting van de rechtszekerheid en rechtsgelijkheid. Toch zal ik niet aanbevelen tot overname van de eis van een openbare last. Daartoe is van belang dat deze eis in het perspectief van dit proefschrift, dat zich richt op de codificatie van het nadeelcompensatierecht in titel 4.5 Awb en afd. 15.1 Ow, niet nodig is. Uit paragraaf 3.3.1 kan immers worden afgeleid dat veel van de gevallen die Tjepkema als atypisch aanmerkt om andere redenen niet onder de reikwijdte van titel 4.5 Awb vallen. Zo is deze titel niet van toepassing op de opsporing en vervolging van strafbare feiten, alsmede de tenuitvoerlegging van strafrechtelijke beslissingen. Ook is de titel slechts van toepassing op rechtmatig overheidshandelen, waardoor hij niet van toepassing is op onzuivere schadebesluiten (gebaseerd op een schending van het mede aan art. 3:4 lid 2 Awb ten grondslag liggende evenredigheidsbeginsel of een schending van het vertrouwensbeginsel). Op voorhand kan uiteraard niet worden uitgesloten dat onder titel 4.5 Awb geprocedeerd zal worden over enkele restcategorieën van atypische gevallen. Mede gelet op de tot op heden opgedane ervaringen met andere (formeelwettelijke) nadeelcompensatieregelgeving en nadeelcompensatiebeleidsregels met een vergelijkbare reikwijdte, verwacht ik echter niet dat dit tot grote problemen zal leiden. Mocht uit de in paragraaf 3.4.1 aanbevolen evaluatie van de reikwijdte van titel 4.5 Awb blijken dat deze inschatting onjuist zou zijn, dan kan alsnog worden nagegaan of, en zo ja hoe, een oplossing moet worden getroffen voor bepaalde (categorieën van) problematische atypische gevallen - bijvoorbeeld

82 De mogelijkheid tot vergoeding was hier gebaseerd op art. 2 'Regelen vergoeding door wild aangerichte schade'. Dit betreft een ministeriële regeling die compensatie mogelijk maakte bij rechtmatig besloten jachtverboden. Hoewel ik geen expliciete bevestiging daarvan door de minister heb kunnen vinden, ben ik het met Tjepkema eens dat de grondslag van deze regeling (waarschijnlijk) in de égalité dient te worden gevonden.

83 ABRvS 18 januari 2006, ECLI:NL:RVS:2006:AU9810.

84 Tjepkema 2010, p. 207-215.

85 Tjepkema 2010, p. 902-903. 
in de vorm van een al dan niet op coulance gebaseerde bijzondere wettelijke regeling.

In aanvulling hierop acht ik van belang dat de eis van weloverwogen veroorzaakt nadeel, dat noodzakelijk en onvermijdelijk is voor de behartiging van het algemeen belang ook niet altijd eenvoudig zal zijn toe te passen. Het is evident dat omzetderving door wegwerkzaamheden naar aanleiding van een verkeersbesluit aan deze eis voldoet. Ook is evident dat zaak en/of letselschade door ontploffing van een vuurwerkopslag niet aan deze eis voldoet. Als bestuurders dat soort schade op de koop toe nemen bij het verlenen van een vergunning voor een dergelijke opslag, of de weigering van een aanvraag om handhaving van de daarin opgenomen voorwaarden, maken zij zich immers schuldig aan ernstige strafbare feiten. Het door Tjepkema voorgestelde criterium kent echter ook een zekere mate van ongrijpbaarheid. Ter onderbouwing daarvan verwijs ik naar het eerder aangehaalde voorbeeld van de witlof etende ganzen. De mate van abstrahering die daarin nodig is om het gewenste resultaat te bereiken, is mijns inziens dermate hoog dat zij niet goed past bij de doelstelling van vergroting van de rechtszekerheid. Een dergelijk hoog abstractieniveau zet bovendien de deur open voor allerlei procedures over de vraag of de mogelijkheid dat het getroffen belang zou worden geschaad nu wel of niet moet worden geacht op de koop te zijn toegenomen. Dat past niet goed bij de doelstelling van vergroting van de doelmatigheid van het nadeelcompensatierecht en vermindering van bestuurslasten. Alles afwegende, zie ik daarom onvoldoende reden om de eis van een openbare last aan titel 4.5 Awb of afd. 15.1 Ow toe te voegen.

\section{Conclusie}

Op basis van het voorafgaande kom ik tot de conclusie dat de aan de Wns ten grondslag liggende doelstellingen geen aanleiding geven om (a) titel 4.5 Awb aan te passen. Ook geven zij geen aanleiding om (b) afd. 15.1 Ow aan te passen. Vanwege de limitatieve opsomming van schadeoorzaken in art. 15.1 lid $1 \mathrm{Ow}$ zou het bovendien ook praktisch gezien weinig zinvol zijn om de eis van een belangenafweging in deze afdeling op te nemen. Ten slotte geven deze doelstellingen en uitgangspunten ook geen aanleiding om (c) anderszins te voorzien in een bijzondere invulling, aanvulling of afwijking van titel 4.5 Awb. Sterker nog, gelet op de informatie uit paragraaf 2.5 zie ik geen ruimte voor lagere regelgevers om de eis van een belangenafweging op te nemen in wetsinterpreterende verordeningen of beleidsregels - zoals thans het geval is in de AVN. Daardoor zou immers een beperkter recht op nadeelcompensatie ontstaan dan voortvloeit uit het dwingendrechtelijke art. 4:126 Awb. ${ }^{86}$ 


\subsection{VERGOEDING VAN KOSTEN VAN SCHADEBEPERKENDE MAATREGELEN}

5.4.1 Deelvraag 2: verschillen tussen de geselecteerde, thans geldende regelingen en verklaringen daarvoor

In paragraaf 8.3 zal worden ingegaan op de algemene plicht van benadeelden om binnen de grenzen van het redelijke schadebeperkende maatregelen te treffen. De keerzijde van deze plicht is dat de kosten die met dit soort maatregelen zijn gemoeid voor vergoeding in aanmerking kunnen komen. ${ }^{87}$ In deze paragraaf zal ik ingaan op de eisen die de geselecteerde regelingen aan deze vergoeding stellen.

\subsubsection{Gaan de geselecteerde, thans geldende regelingen in op de} mogelijkheid tot vergoeding?

Slechts drie van de geselecteerde, thans geldende regelingen gaan expliciet in op het vergoeden van kosten van schadebeperkende maatregelen:

\section{Art. 8 lid 2 BnIW 2019}

De redelijke kosten van maatregelen ter voorkoming of beperking van schade behoren tot de te vergoeden schade.

\section{Art. 7, aanhef en onder c AVN}

Voor vergoeding komen tevens in aanmerking de redelijke kosten van maatregelen ter beperking of voorkoming van schade.

\section{Art. 10 lid 1 jo. lid 2 AVN}

1. Degene die in aanmerking wil komen voor vergoeding van kosten als bedoeld in artikel 7, eerste lid, onder c, vraagt het bestuursorgaan goedkeuring voor het maken van de met die maatregelen gemoeide kosten onder overlegging van alle voor de beoordeling van zijn aanvraag noodzakelijke gegevens.

2. Geen goedkeuring is vereist, indien de benadeelde aannemelijk kan maken dat de maatregelen met spoed moesten worden getroffen.

\section{Art. 7 VNNZ}

1. Indien een aanvrager maatregelen wil treffen ter voorkoming of beperking van het nadeel, legt hij met gebruikmaking van een door het college vastgesteld aanvraagformulier de plannen omtrent de te nemen maatregelen, met inbegrip van een kostenraming, ter goedkeuring aan het college voor.

2. In afwijking van het eerste lid, worden de kosten die zijn gemaakt ter voorkoming of beperking van het nadeel zonder goedkeuring van het college vergoed, indien het college de door de aanvrager getroffen maatregelen redelijk acht in verband met de onmiddellijke voorkoming of beperking van dat nadeel.

87 Vergelijk bijvoorbeeld Kamerstukken II 2010/11, 32 621, nr. 3, p. 25, 27-28 (MvT, Wns) en de toelichting op art. 7 onder c AVN. 
3. De compensatie voor bedoelde kosten kan niet meer bedragen dan het bedrag van de nadeelcompensatie waarop de aanvrager recht zou hebben, indien hij de maatregelen niet zou hebben getroffen.

\section{De overige regelingen}

Wanneer de BnIW 2019 de achterliggende grondslag vormt om onder de GrS compensatie toe te kennen, kan een vergoeding van kosten van schadebeperkende maatregelen worden verkregen door middel van een beroep op art. 8 lid 2 BnIW 2019. Uit jurisprudentie kan worden afgeleid dat vergoeding van deze kosten ook tot de mogelijkheden behoort als het ongeschreven égalitébeginsel, art. 21 Aanwijzingsbesluit 1996, of art. 8.31 Wlv de achterliggende grondslag voor toekenning van nadeelcompensatie vormt. ${ }^{88}$ Dat de kosten van schadebeperkende maatregelen ook in het planschaderecht voor vergoeding in aanmerking komen, blijkt eveneens uit de jurisprudentie. ${ }^{89}$

Dat in de GrS geen bepaling is opgenomen omtrent de vergoeding van deze kosten kan worden verklaard door de in paragraaf 3.2.1 beschreven, bijzondere aard van deze regeling: zij dient ertoe de reeds op grond van verschillende grondslagen bestaande - en aan verschillende bestuursorganen toekomende - bevoegdheden om nadeelcompensatie toe te kennen, binnen een specifieke context over te dragen aan het algemeen bestuur van het Schadeschap. Dat art. 49 WRO, art. 21 Aanwijzingsbesluit 1996 en art. 8.31 Wlv niets bepalen omtrent de vergoeding van de kosten van schadebeperkende maatregelen, lijkt met name te worden verklaard doordat het ten tijde van de totstandkoming van deze regelingen nog niet gebruikelijk was om in nadeelcompensatieregelingen uit te werken wanneer aan de daarin vervatte redelijkerwijsformule werd voldaan. Bovendien is voor de formulering van zowel art. 21 Aanwijzingsbesluit 1996 als art. 8.31 Wlv aansluiting gezocht bij art. 49 WRO, en in geval van art. 8.31 Wlv ook bij art. 15.20 Wet milieubeheer. ${ }^{90}$

Wellicht heeft ook een rol gespeeld dat de schadebeperkingsplicht nauwelijks een rol speelde in de onder art. 49 WRO gewezen jurisprudentie. Die verklaring lijkt

88 Zie ABRvS 14 april 2004, ECLI:NL:RVS:2004:AO7460, r.o. 2.10.2: "Indien de benodigde zoetwaterleiding door KPE zelf zou zijn gerealiseerd, zouden de met de aanleg daarvan gemoeide kosten voor vergoeding in aanmerking zijn gekomen." Het geschil werd afgedaan onder de redelijkerwijsformule die is opgenomen in de RnR 1991. Die regeling kende - net als art. 21 Aanwijzingsbesluit 1996 en art. 8.31 Wlv - geen bepaling omtrent vergoeding van kosten van schadebeperkende maatregelen.

89 Zie voor art. 49 WRO: ABRvS 21 maart 1995, ECLI:NL:RVS:1995:AS5925 (Waardevermindering Dronten) en ABRvS 22 juli 1994, ECLI:NL:RVS:1994:AS6114 (Restaurant Nijmegen). Zie voor afd. 6.1 Wro: ABRvS 24 augustus 2016, ECLI:NL:RVS:2016:2315, r.o. 7.2.3 (Planschade knooppunt Kunderberg, hoger beroep) en ABRvS 1 augustus 2012, ECLI:NL:RVS:2012:BX3290, r.o. 2.10.1.

90 Zie Stcrt. 1998, nr. 223, p. 11 (digitaal) respectievelijk Kamerstukken II 00/01, 27 603, nr. 3, p. 69 en 15. 
overigens hooguit verminderd op te gaan voor het ontbreken van een bepaling omtrent de vergoeding van kosten van schadebeperkende maatregelen in afd. 6.1 Wro. De beperkte rol van de schadebeperkingsplicht onder de WRO weerhield de wetgever er namelijk niet van om deze plicht in art. 6.3, aanhef en onder b Wro te codificeren. ${ }^{91}$ Juist daarom had het mijns inziens voor de hand gelegen als een bepaling omtrent vergoeding van kosten van schadebeperkende maatregelen eveneens in deze afdeling was opgenomen. Dat de wetgever dit niet heeft gedaan, lijkt slechts te kunnen worden verklaard doordat een dergelijke bepaling strikt genomen niet nodig is om deze kosten te vergoeden. Zoals hierna nog zal blijken, worden de kosten van schadebeperkende maatregelen namelijk geacht onderdeel uit te maken van de schade. Deze verklaring gaat eveneens op voor art. 49 WRO, art. 21 Aanwijzingsbesluit 1996 en art. 8.31 Wlv.

\subsubsection{Een dubbele redelijkheidstoets}

Uit de jurisprudentie volgt dat een dubbele redelijkheidstoets dient te worden gehanteerd om te bepalen of de kosten van schadebeperkende maatregelen voor vergoeding in aanmerking komen. Dat houdt in dat zowel de gekozen schadebeperkende maatregel als de daarmee gemoeide kosten redelijk moeten zijn. Ter uitleg hiervan, kan worden verwezen naar een onder art. 49 WRO gewezen Afdelingsuitspraak van 22 juli 1994. Daarin oordeelde de Afdeling dat de kosten "een als noodzakelijk aan te merken uitvloeisel" van de schadeoorzaak moeten vormen. ${ }^{92}$ In de literatuur wordt aangenomen dat hieruit twee voorwaarden zijn te destilleren. ${ }^{93}$ De eerste voorwaarde blijkt eveneens uit de uitspraak van 22 juli 1994. Zij houdt in dat de kosten van de maatregel niet hoger mogen uitvallen dan de schade die zou zijn ontstaan indien de schadebeperkende maatregel niet zou zijn getroffen. De tweede voorwaarde houdt in dat de getroffen maatregel de door de schadeoorzaak veroorzaakte schade daadwerkelijk heeft beperkt. Dit wordt geïllustreerd door een uitspraak van 21 maart 1995, waarin de Afdeling oordeelde dat slechts de kosten voor vergoeding in aanmerking kwamen die waren gemaakt om voorzieningen aan te brengen die de door de planologische vrijstelling mogelijk gemaakte zend- en antennemast daadwerkelijk aan het zicht onttrokken. ${ }^{94}$

Uit een uitspraak van 15 juni 2016 blijkt dat deze jurisprudentie nog steeds actueel is. De Afdeling oordeelde in algemene zin dat redelijke kosten die een benadeelde heeft gemaakt om schade te beperken of te voorkomen deel uitmaken van de schade en voor vergoeding in aanmerking komen. Het dient te gaan om "extra kosten die werkelijk ter beperking" van schade kunnen worden aangemerkt en "een incidenteel of buitengewoon" karakter hebben. Wordt bijvoorbeeld vergoeding gevraagd van kosten van advertenties die omzetschade zouden hebben beperkt, dan

$91 \quad$ Zie paragraaf 8.3.1.

92 ABRvS 22 juli 1994, ECLI:NL:RVS:1994:AS6114 (Restaurant Nijmegen).

93 Zie Van den Broek 2002, p. 57; en Dijkshoorn 2011a, p. 116-117.

94 ABRvS 21 maart 1995, ECLI:NL:RVS:1995:AS5925 (Waardevermindering Dronten). 
dient te worden vastgesteld in hoeverre die kosten afwijken van de gebruikelijke advertentiekosten en in hoeverre zij direct aan de schadeoorzaak zijn te relateren. ${ }^{95}$

Wanneer een vergelijking wordt gemaakt tussen de regelingen die expliciet ingaan op de vergoeding van kosten van schadebeperkende maatregelen, valt op dat het dubbele onderwerp van de redelijkheidstoets niet expliciet volgt uit de daarin opgenomen bepalingen. In de BnIW 2019 en AVN wordt slechts gesproken van 'redelijke kosten'. Art. 7 VNNZ noemt niet expliciet de redelijkheid van de kosten, maar het derde lid verwoordt wel het uitgangspunt dat de compensatie van deze kosten niet meer kan bedragen dan het bedrag van de nadeelcompensatie waarop de aanvrager recht zou hebben indien hij de maatregelen niet zou hebben getroffen. Ook kan uit het tweede lid van deze bepaling met enige goede wil worden afgeleid dat de maatregel zelf redelijk moet zijn.

Het voorafgaande laat onverlet dat uit de bij de BnIW 2019 en Amsterdamse verordeningen behorende toelichtingen met zekerheid kan worden opgemaakt dat de dubbele redelijkheidstoets dient te worden toegepast. Zo is daarin bijvoorbeeld de vuistregel terug te vinden dat de kosten van de schadebeperkende maatregel in ieder geval niet groter mogen zijn dan de schade die zonder die maatregel zou zijn ontstaan. ${ }^{96}$ Bovendien volgt uit de toelichtingen behorende bij art. 8 BnIW 2019 en art. 7 VNNZ dat onder 'redelijke kosten' slechts wordt verstaan de kosten van "maatregelen die nodig en passend zijn om de schade te voorkomen of te beperken." Uit de toelichting op art. 8 BnIW 2019 blijkt dat hiermee wordt beoogd de vergoeding uit te sluiten van kosten van maatregelen die niet nodig, of niet geschikt zijn om het nadeel te beperken. ${ }^{97}$ Dergelijke opmerkingen zijn ook terug te vinden in het door de besliscommissie van het Schadeschap opgestelde Basisdocument. ${ }^{98}$ Ten slotte vermelden het Basisdocument en de toelichtingen op de AVN en VNNZ dat aansluiting wordt gezocht bij art. 6:96 BW. ${ }^{99}$ Ook bij toepassing van die bepaling wordt een dubbele redelijkheidstoets gehanteerd. ${ }^{100}$

95 ABRvS 15 juni 2016, ECLI:NL:RVS:2016:1651, r.o. 9.1 (Bandencentrum Eindhoven). Deze uitspraak lijkt te zijn gewezen in een geschil waarin de 'Regeling nadeelcompensatie voor werkzaamheden aan de weg' van de gemeente Eindhoven van toepassing was. Daarin is een bepaling opgenomen die letterlijk overeenkomt met art. 8 lid 2 BnIW 2019. De aangehaalde overweging is zo algemeen verwoord dat ik haar van toepassing acht op het gehele (planschade- en) nadeelcompensatierecht.

96 Zie Stcrt. 1999, nr. 172, p. 11 (digitaal, p. 11); de toelichting op art. 7 onder c AVN; en de toelichting op art. 7 VNNZ.

97 Zie Stcrt. 1999, nr. 172, p. 11 (digitaal, p. 11); en de toelichting op art. 7 VNNZ.

98 Basisdocument, p. 29.

99 Zie de toelichting op art. 1 onder b AVN en art. 7 onder $\mathrm{c}$ AVN; de toelichting op art. 1, aanhef en onder d VNNZ; en Basisdocument, p. 29. In de toelichting op de RnVW 1999 wordt in algemene zin vermeld dat aansluiting kan worden gezocht bij afd. 6.1.10 BW. Zie Stcrt. 1999, nr. 172, p. 9 (digitaal, p. 5).

100 Zie bijvoorbeeld Parl. Gesch. Boek 6, p. 334-335; en Lindenbergh, GS Schadevergoeding, art. 6:96 BW, aant. 11.2.2. 
Deze aansluiting bij het BW kan ook dienen als verklaring voor de constatering dat uit de BnIW 2019 en de Amsterdamse verordeningen niet expliciet volgt dat zowel de getroffen maatregel als de daarmee gepaard gaande kosten redelijk dienen te zijn. Hoewel de dubbele redelijkheidstoets onder art. 6:96 BW wordt gehanteerd, spreekt die bepaling - net als de BnIW $2019^{101}$ en de AVN - slechts van "redelijke kosten". Dat die term niet voorkomt in de VNNZ kan worden verklaard doordat art. 7 lid 3 VNNZ een beschrijving geeft van kosten die als redelijk kunnen worden aangemerkt, namelijk kosten die niet groter zijn dan de schade die door de schadebeperkende maatregel wordt voorkomen. Een verdere verklaring voor het verschil in formulering tussen de BnIW 2019 en AVN enerzijds en de VNNZ anderzijds, is dat de bepaling uit de VNNZ er zowel toe dient een plicht voor de benadeelde in het leven te roepen om voorafgaand aan het nemen van een schadebeperkende maatregel een melding te maken van het voornemen daartoe, ${ }^{102}$ als iets te bepalen over de vergoedbaarheid van de kosten van die maatregel. De focus van de bepaling uit de VNNZ lijkt daarom minder te liggen op vergoeding van deze kosten dan het geval is bij de bepalingen uit de BnIW 2019 en AVN.

\subsubsection{Zijn de kosten van de schadebeperkende maatregel onderdeel van de schade?}

Uit de bespreking van de uitspraak van 15 juni 2016 in paragraaf 5.4.1.2 volgde dat de Afdeling oordeelt dat de kosten van schadebeperkende maatregelen "deel uitmaken van de schade", mits is voldaan aan de dubbele redelijkheidstoets. ${ }^{103}$ Een vergelijking van de bepalingen uit de BnIW 2019, AVN en VNNZ leert dat dit slechts expliciet tot uitdrukking komt in art. 8 BnIW 2019. Daarin is namelijk bepaald dat de redelijke kosten van de schadebeperkende maatregel "behoren tot de te vergoeden schade". In de toelichting op de AVN wordt opgemerkt dat de in die regeling vervatte bepaling omtrent de vergoeding van kosten van schadebeperkende maatregelen ertoe strekt "buiten twijfel te stellen dat de redelijke kosten ter voorkoming of beperking van schade, eveneens schade zijn." 104 Ook uit de toelichting op de VNNZ lijkt te kunnen worden opgemaakt dat kosten van schadebeperkende maatregelen als schade worden aangemerkt. ${ }^{105}$ Dit is niet anders onder art. 49 WRO, art. 21 Aanwijzingsbesluit 1996, art. 8.31 Wlv en afd. 6.1 Wro. In die regelingen is immers geen afzonderlijke bepaling gewijd aan de vergoeding van kosten van schadebeperkende maatregelen, maar bij hun toepassing wordt toch vergoeding van deze kosten toegekend. Dat zou niet mogelijk zijn als deze kosten niet als schade zouden worden aangemerkt. Ik heb geen verklaring gevonden voor

101 Desondanks komt de dubbele redelijkheid wel expliciet tot uitdrukking in art. 10 BnIW 2019 (de bepaling over vergoeding van kosten van deskundigenbijstand). Zie daarover paragraaf 5.5.1.3.

102 Zie paragraaf 5.4.1.4.

103 ABRvS 15 juni 2016, ECLI:NL:RVS:2016:1651, r.o. 9.1 (Bandencentrum Eindhoven).

104 Zie de toelichting op art. 7 onder c AVN.

105 Zie de toelichting op art. 1, aanhef en onder d VNNZ. 
het verschil dat op dit punt tussen de BnIW 2019 en de Amsterdamse regelingen bestaat. ${ }^{106}$ Dat de bepalingen uit de AVN en VNNZ niet expliciteren dat kosten van schadebeperkende maatregelingen als schade worden aangemerkt, is opmerkelijk omdat in de toelichtingen behorende bij deze regelingen aansluiting bij art. 6:96 BW wordt bepleit. ${ }^{107}$

\subsubsection{Is voorafgaande goedkeuring vereist voor het treffen van de maatregel?}

Een laatste verschil dat in het oog springt, is dat de AVN en VNNZ als enige regelingen een beginselplicht kennen tot het vragen van goedkeuring voor het treffen van de voorgenomen schadebeperkende maatregel (en de daarmee gemoeide kosten). Onder de AVN bestaat deze plicht niet indien het nemen van de maatregel "spoedeisend" is. Onder de VNNZ bestaat een soortgelijke uitzondering op de beginselplicht tot het vragen van voorafgaande goedkeuring indien het college de door de aanvrager getroffen maatregel redelijk acht in verband met de "onmiddellijke voorkoming of beperking" van dat nadeel. Navraag bij juristen van de gemeente Amsterdam leert dat de term 'onmiddellijke' niet zozeer te maken heeft met tijdsdruk (al kan dat wel), maar vooral met de doeltreffendheid van de getroffen maatregel zelf. Naarmate de relatie tussen inspanningen en (verwachte) opbrengst directer is, zou het beter te rechtvaardigen zijn om de kosten toch te vergoeden, ook al is van tevoren niet om goedkeuring gevraagd. Daarbij wordt de praktische vuistregel gehanteerd dat maatregelen die een ondernemer bereid is te treffen zonder dat daar een vergoeding of goedkeuring tegenover staat, doorgaans het eenvoudigst zullen kwalificeren als redelijk in verband met de onmiddellijke voorkoming of beperking van het nadeel. De Amsterdamse gemeenteraad lijkt dus met name te hebben willen benadrukken dat aan de dubbele redelijkheidstoets moet worden voldaan, ook - en misschien zelfs wel in het bijzonder - als geen voorafgaande goedkeuring aan het gemeentebestuur is gevraagd.

Door de eis van voorafgaande goedkeuring te stellen, zijn de twee Amsterdamse verordeningen aanmerkelijk strenger dan de overige onderzochte regelingen. De (toelichtingen behorende bij de) verordeningen geven hiervoor geen verklaring. Omdat deze plicht niet voortvloeit uit het égalitébeginsel, lijkt het waarschijnlijk dat de bepalingen zijn opgenomen om het gemeentebestuur voorafgaand inzicht te bieden in de schadebeperkende maatregelen die zullen worden getroffen. Hiermee krijgt het bestuur ook enig, maar zeker geen volledig, ${ }^{108}$ inzicht in het aantal aan-

106 Dat de overige geselecteerde, thans geldende regelingen niet ingaan op de vraag of de kosten als schade worden aangemerkt, wordt verklaard door de informatie uit paragraaf 5.4.1.1.

107 Zie de toelichting op art. 1 onder b AVN en art. 7 onder c AVN, en de toelichting op art. 1, aanhef en onder d VNNZ.

108 Zo zullen er bijvoorbeeld ook aanvragers zijn die geen schadebeperkende maatregelen hebben genomen, of wel dergelijke maatregelen hebben genomen maar niet vooraf om goedkeuring hebben gevraagd. 
vragen om compensatie die mogelijkerwijs zullen worden ingediend en de kans van slagen daarvan. Wellicht dienen deze bepalingen ook als een handreiking aan de burger die onzeker is over de schadebeperkende maatregelen die kunnen en misschien wel moeten worden genomen en/of de vergoedbaarheid van de daaraan verbonden kosten. Het is echter niet nodig daarvoor de eis van voorafgaande goedkeuring te hanteren. Het staat de benadeelde immers altijd vrij om het bestuur te verzoeken voorafgaand inzicht te verschaffen omtrent de vergoedbaarheid van de kosten van schadebeperkende maatregelen. ${ }^{109}$

\subsubsection{Deelvraag 3: het toekomstige recht}

Art. 4:129, aanhef en onder a Awb luidt:

"Indien het bestuursorgaan een vergoeding als bedoeld in artikel 4:126 toekent, vergoedt het tevens redelijke kosten ter voorkoming of beperking van schade."

Aangezien afd. 15.1 Ow niet hiervan afwijkt, zal deze bepaling ook van toepassing zijn op aanvragen om nadeelcompensatie die onder het bereik van afd. 15.1 Ow vallen. ${ }^{110}$ In de bij de Wns behorende memorie van toelichting wordt expliciet vermeld dat de dubbele redelijkheidstoets dient te worden toegepast, en dat wordt beoogd de bestaande jurisprudentielijnen voort te zetten. ${ }^{111}$ Net als in de toelichting op de VNNZ wordt opgemerkt dat de bepaling ertoe strekt "buiten twijfel te stellen dat de redelijke kosten ter voorkoming of beperking van schade, eveneens schade zijn en voor vergoeding op grond van deze regeling in aanmerking komen." Ten slotte wordt vermeld dat met deze bepaling aansluiting wordt gezocht bij art. 6:96 BW. ${ }^{112}$

5.4.3 Hoofdvraag: spiegeling aan de doelstellingen en uitgangspunten die ten grondslag liggen aan de Wns

\section{Eén grondslag}

Aangezien de kosten van schadebeperkende maatregelen kwalificeren als schade is het strikt genomen niet noodzakelijk om expliciet in een nadeelcompensatieregeling te verankeren dat deze kosten voor vergoeding in aanmerking komen. Dat de wetgever dat toch heeft gedaan in art. 4:129, aanhef en onder a Awb past echter goed bij de doelstellingen van vergroting van de rechtszekerheid en codificatie van het nadeelcompensatierecht. Bovendien past het goed bij de doelstelling van vereenvoudiging, uniformering en harmonisering van het nadeelcompensa-

109 Zie hierover ook paragraaf 5.4.3.

110 Kamerstukken II 2018/19, 34 986, nr. 3, p. 235 (MvT, IOw).

111 Kamerstukken II 2010/11, 32 621, nr. 3, p. 28 (MvT, Wns). Op p. 25 wordt bovendien verwezen naar de reeds in paragraaf 5.4.1.2 besproken uitspraak ABRvS 22 juli 1994, ECLI:NL:RVS:1994:AS6114 (Restaurant Nijmegen). Kamerstukken II 2010/11, 32 621, nr. 3, p. 27-28 (MvT, Wns). 
tierecht dat deze bepaling onder het toekomstige recht de enige bepaling zal zijn die als grondslag kan worden aangewend voor de toekenning van een vergoeding in deze kosten. Het opnemen van een bepaling over dit onderwerp is bovendien verenigbaar met de overige aan de Wns ten grondslag liggende doelstellingen en uitgangspunten.

\section{Onderdeel van de schade}

Bezien vanuit het uitgangspunt van aansluiting bij het BW en de doelstelling van codificatie van het nadeelcompensatierecht zou het goed zijn als in de formulering van de Awb-bepaling tot uitdrukking zou komen dat de redelijke kosten van schadebeperkende maatregelen onderdeel van de schade vormen. Dit zal ook in beperkte mate bijdragen aan het bereiken van de doelstelling van vergroting van de rechtszekerheid. Bovendien is dit verenigbaar met de overige aan de Wns ten grondslag liggende doelstellingen en uitgangspunten. Op dit punt zie ik dus aanleiding tot (a) aanpassing van titel 4.5 Awb.

\section{Codificatie van het dubbele karakter van de redelijkheidstoets?}

In paragraaf 5.4.2 bleek dat kosten van schadebeperkende maatregelen slechts voor vergoeding op grond van art. 4:129, aanhef en onder a Awb in aanmerking komen als zij de dubbele redelijkheidstoets doorstaan. De vraag kan worden gesteld of het dubbele karakter van deze toets niet nadrukkelijker zou moeten blijken uit de formulering van de Awb-bepaling. Daarin wordt immers slechts gesproken van "redelijke kosten ter voorkoming of beperking van schade". Enerzijds dient deze vraag ontkennend te worden beantwoord wanneer zij wordt bezien vanuit het uitgangspunt van aansluiting bij het BW. In art. 6:96 BW wordt namelijk eveneens slechts gesproken van "redelijke kosten". Dit blijkt een bewuste keuze van de wetgever te zijn geweest. Uit de Kamerstukken behorende bij deze bepaling volgt namelijk dat dit "insluit" dat de kosten "niet alleen binnen een redelijke omvang moeten blijven, maar ook dat het in de gegeven omstandigheden redelijk was ze te maken." ${ }^{\prime 13}$ Anderzijds lijkt de doelstelling van codificatie van het nadeelcompensatierecht te pleiten voor een bevestigende beantwoording van de hier opgeworpen vraag. Dat geldt in theorie ook voor de doelstelling van vergroting van de rechtszekerheid. Het is echter maar de vraag of de uitsplitsing van de redelijkheid van de maatregel en de redelijkheid van de daaraan verbonden kosten daadwerkelijk tot een significante vergroting van de rechtszekerheid zal leiden. Bij bestudering van de jurisprudentie is mij namelijk niet gebleken dat het ontbreken van deze uitsplitsing in de geselecteerde, thans geldende regelingen tot (wezenlijke) problemen heeft geleid. Dat kan worden verklaard doordat ook in het dagelijks taalgebruik moet worden aangenomen dat kosten slechts redelijk kunnen zijn als hun omvang redelijk is én de reden waarom zij zijn gemaakt als redelijk kwalificeert. Aangezien de aan de Wns ten grondslag liggende doelstellingen en 
uitgangspunten ${ }^{114}$ niet eensluidend voor of tegen codificatie van het dubbele karakter van de redelijkheidstoets pleiten, zie ik geen aanleiding om (a) titel $4.5 \mathrm{Awb}$ op dit punt aan te passen.

\section{De invulling van de dubbele redelijkheidstoets}

Het valt op dat de Afdeling de dubbele redelijkheidstoets in het planschade- en nadeelcompensatierecht strenger invult dan de civiele rechter doet in het onrechtmatigedaadsrecht. Zo wordt in het civiele recht niet vereist dat de getroffen maatregel de schade daadwerkelijk heeft beperkt. Uit bij art. 6:96 BW behorende Kamerstukken kan namelijk worden opgemaakt dat "voldoende is dat de kosten tot het bedoelde doel ${ }^{115}$ zijn gemaakt en dat zij met het oog op dat doel 'redelijk' waren." Bovendien kunnen de gemaakte kosten in het civiele recht ook voor vergoeding in aanmerking komen als zij hoger uitvallen dan de schade die de aanvrager met de maatregel probeerde te voorkomen. ${ }^{116}$ Daarbij lijkt vooral bepalend te zijn of voorafgaand aan het nemen van de schadebeperkende maatregel in redelijkheid kon worden verwacht dat de kosten groter zouden uitvallen dan de schade. ${ }^{117}$

Ik heb geen aanwijzingen gevonden dat de bestuursrechter op dit punt bewust van het civiele recht is afgeweken. Ook overigens zie ik geen goede redenen om dit verschil met het civiele recht in stand te houden. Hoewel het een zinnig uitgangspunt is dat de kosten van een schadebeperkende maatregel in beginsel niet groter moeten zijn dan de schade die door deze maatregel wordt voorkomen, zijn immers omstandigheden denkbaar waaronder een dergelijke maatregel en de daaraan verbonden kosten toch als redelijk moeten worden gekwalificeerd. Daarbij kan worden gedacht aan de situatie waarin de aanvrager de desbetreffende maatregel in goede trouw heeft genomen - bijvoorbeeld op advies van het bestuur. Bezien vanuit het uitgangspunt van aansluiting bij het BW, stel ik daarom voor om (c) een bijzondere invulling aan titel 4.5 Awb te geven: de bestuursrechter zou een einde moeten maken aan dit soort onwenselijke verschillen met de civielrechtelijke invulling van de dubbele redelijkheidstoets. Ook stel ik (a) een kleine aanpassing van titel 4.5 Awb voor, namelijk dat - analoog aan art. 6:96 BW - in art. 4:129 Awb tot uitdrukking wordt gebracht dat de schadebeperkende maatregel betrekking dient te hebben op schade die als gevolg van de schadeoorzaak ${ }^{118}$ mocht worden verwacht. Beide aanbevelingen acht ik ook verenigbaar met de overige aan de Wns ten grondslag liggende doelstellingen en uitgangspunten.

114 De niet genoemde doelstellingen en uitgangspunten pleiten niet voor of tegen een dergelijke codificatie en blijven daarom onbesproken.

115 Lees: de beperking van de schade.

116 Zie Parl. Gesch. Boek 6, p. 334-335; en Lindenbergh, GS Schadevergoeding, art. 6:96 BW, aant. 11.2.2.

117 Dijkshoorn 2011a, p. 121.

118 De bepaling uit het BW spreekt van "de gebeurtenis waarop de aansprakelijkheid berust”. Bij toepassing van titel 4.5 Awb is dat altijd de schadeoorzaak. 
De aan de Wns ten grondslag liggende doelstellingen en uitgangspunten geven op dit punt geen aanleiding tot (a) verdere aanpassing van titel 4.5 Awb of (b) aanpassing van afd. 15.1 Ow. Daarbij verdient opmerking dat het in beginsel goed bij de doelstellingen van codificatie van het nadeelcompensatierecht en vergroting van de rechtszekerheid zou passen wanneer titel 4.5 Awb de invulling van de dubbele redelijkheidstoets nader zou normeren. Het voorafgaande illustreert echter dat dit - vanwege het karakter van deze toets en het brede scala aan scenario's waarop deze toets moet kunnen worden toegepast - niet goed mogelijk is in een formeelwettelijke nadeelcompensatieregeling met een brede reikwijdte. Wel geven deze doelstellingen en uitgangspunten aanleiding tot (c) het anderszins voorzien in een bijzondere invulling van titel $4.5 \mathrm{Awb}$. Indien een maatregel of project tot schade voor een grote groep burgers zal leiden en dit type schade doorgaans kan worden voorkomen door een bepaald type schadebeperkende maatregel, verdient het aanbeveling dat in een wetsinterpreterende beleidsregel wordt vastgelegd dat het nemen van een dergelijke maatregel in elk geval redelijk zal worden geacht tot een bepaald bedrag aan kosten. Dat past ook goed bij de doelstelling van vergroting van de doelmatigheid van het nadeelcompensatierecht en vermindering van bestuurslasten. Een dergelijke bepaling kan immers bijdragen aan de beperking van geschillen omtrent de voorgoedbaarheid van dit soort kosten. Bovendien laat art. 4:84 Awb genoeg ruimte tot afwijking als de benadeelde misbruik zou proberen te maken van een bepaling als hier voorgesteld.

\section{Voorafgaande goedkeuring van de voorgenomen schadebeperkende maatregel?}

Naar aanleiding van de bepalingen uit de Amsterdamse verordeningen kan de vraag worden opgeworpen of in titel $4.5 \mathrm{Awb}$ of afd. 15.1 Ow een plicht voor de aanvrager zou moeten worden opgenomen om voorafgaande goedkeuring aan het bestuur te vragen voor het nemen van een schadebeperkende maatregel. De doelstelling van vergroting van de rechtszekerheid biedt hier mijns inziens onvoldoende draagvlak voor. De aanvrager zal namelijk nooit volledige zekerheid over de vergoedbaarheid van zijn kosten krijgen. Deze kosten komen immers alleen voor vergoeding in aanmerking als de aanvraag om nadeelcompensatie (deels) wordt toegewezen. Uit paragraaf 5.4.1.4 volgde voorts dat ook het bestuur slechts beperkte zekerheid aan een plicht tot voorafgaande goedkeuring kan ontlenen. Opname van een dergelijke plicht zou zich bovendien ambivalent verhouden tot de doelstelling van vergroting van de doelmatigheid van het nadeelcompensatierecht en vermindering van bestuurslasten. Zo kan het vroegtijdig in contact treden met de aanvrager enerzijds leiden tot een beter verlopend besluitvormingsproces. ${ }^{119}$ Anderzijds zal ook inhoudelijk moeten worden gereageerd op iedere melding van een voorgenomen schadebeperkende maatregel. Ten slotte vloeit een plicht tot het vragen van voorafgaande goedkeuring niet voort uit het égalitébeginsel en

119 Mede vanuit het oogpunt van procedurele rechtvaardigheid, wordt het in een vroeg stadium in contact treden met de burger ook aanbevolen in Handleiding nadeelcompensatie, p. 26-28 en 118. 
de daarover gewezen jurisprudentie. Ook de doelstelling van codificatie van het nadeelcompensatierecht pleit daarom niet voor opname van een dergelijke verplichting in titel 4.5 Awb of afd. 15.1 Ow. Nu de overige doelstellingen en uitgangspunten dit eveneens niet doen, zie ik op dit punt geen aanleiding om (a) titel 4.5 Awb of (b) afd. 15.1 Ow te wijzigen.

Gelet op het voorafgaande zie ik bovendien geen ruimte voor bestuursorganen om een plicht tot voorafgaande goedkeuring op te nemen in wetsinterpreterende verordeningen of beleidsregels. Daardoor zou namelijk een beperkter recht op vergoeding van kosten van schadebeperkende maatregelen ontstaan dan voortvloeit uit het dwingendrechtelijke art. 4:129, aanhef en onder a Awb. Wanneer de aanvrager zou nalaten om voorafgaande goedkeuring te vragen, zou het bestuur immers kunnen besluiten geen vergoeding toe te kennen voor kosten van de door aanvrager genomen schadebeperkende maatregel, terwijl die maatregel en de daaraan verbonden kosten wel de dubbele redelijkheidstoets doorstaan.

Ik acht het wel verenigbaar met titel 4.5 Awb dat een bestuursorgaan zich in een wetsinterpreterende beleidsregel zou verplichten om binnen een bepaald aantal weken te reageren als een benadeelde de vraag stelt of een bepaalde maatregel de dubbele redelijkheidstoets zou doorstaan. Daartoe doe ik echter geen aanbeveling, omdat uit het voorafgaande kan worden afgeleid dat ook dit zich wisselend zou verhouden tot de doelstellingen en uitgangspunten die aan de Wns ten grondslag liggen. Ook betwijfel ik of een bepaling als hier beschreven echt meerwaarde heeft. Om zichzelf niet onnodig bloot te stellen aan extra bezwaar- en beroepsprocedures, zou het bestuur daarin immers moeten opnemen dat aan zijn reactie geen rechten kunnen worden ontleend. Anders zou deze reactie immers mogelijk als beschikking kwalificeren. Bovendien staat het de benadeelde ook zonder een dergelijke bepaling vrij om voorafgaand aan het treffen van de schadebeperkende maatregel bij het bestuur te informeren of de dubbele redelijkheidstoets naar verwachting zal worden doorstaan. Al met al geven de aan titel 4.5 Awb ten grondslag liggende doelstellingen en uitgangspunten dus eveneens geen aanleiding om (c) op dit punt in een bijzondere invulling, aanvulling of afwijking van titel $4.5 \mathrm{Awb}$ te voorzien.

\section{Conclusie}

Gelet op het voorafgaande zie ik reden om (a) titel 4.5 aan te passen. Bezien vanuit het uitgangspunt van aansluiting bij het BW en de doelstelling(en) van codificatie van het nadeelcompensatierecht (en vergroting van de rechtszekerheid) zou het goed zijn als in de formulering van de Awb-bepaling tot uitdrukking zou komen dat de redelijke kosten van schadebeperkende maatregelen onderdeel van de schade vormen. Gelet op het uitgangspunt van aansluiting bij het BW is ook aanbevolen om - analoog aan art. 6:96 BW - in art. 4:129 Awb tot uitdrukking te brengen dat de schadebeperkende maatregel betrekking dient te hebben op schade die als gevolg van de schadeoorzaak mocht worden verwacht. Een concreet voorstel om 
deze aanbevelingen om te zetten in regelgeving zal ik doen in paragraaf 5.8. Mijns inziens geven de aan de Wns ten grondslag liggende doelstellingen en uitgangspunten geen aanleiding (b) afd. $15.1 \mathrm{Ow}$ aan te passen. Wel geven zij aanleiding (c) anderszins in een bijzondere invulling van titel 4.5 Awb te voorzien. Ten eerste zou de bestuursrechter een einde moeten maken aan onwenselijke verschillen met de civielrechtelijke invulling van de dubbele redelijkheidstoets. Een tweede aanbeveling ziet op de situatie dat één maatregel of project tot schade voor een grote groep burgers zal leiden en dit type schade doorgaans kan worden voorkomen door een bepaald type schadebeperkende maatregel. In dergelijke gevallen zouden bestuursorganen er goed aan doen in wetsinterpreterende beleidsregels vast te leggen welke schadebeperkende maatregel tot welk bedrag aan kosten in elk geval als redelijk zal worden beschouwd.

\subsection{VERGOEDING VAN KOSTEN VAN DESKUNDIGENBIJSTAND}

5.5.1 Deelvraag 2: verschillen tussen de geselecteerde, thans geldende regelingen en verklaringen daarvoor

5.5.1.1 Gaan de geselecteerde, thans geldende regelingen in op de mogelijkheid tot vergoeding?

Het merendeel van de geselecteerde, thans geldende regelingen kent een bepaling omtrent de vergoeding van kosten van deskundigenbijstand:

\section{Art. 6.5, aanhef en onder a Wro}

Indien burgemeester en wethouders een tegemoetkoming als bedoeld in artikel 6.1 toekennen, vergoeden burgemeester en wethouders daarbij tevens de redelijkerwijs gemakkte kosten van rechtsbijstand en andere deskundige bijstand.

\section{Art. 10 BnIW 2019}

1. Indien bij de indiening en de behandeling van het verzoek zowel het inroepen van rechts dan wel andere deskundigenbijstand, als de kosten daarvan redelijk zijn te achten, kunnen deze kosten voor vergoeding in aanmerking komen.

2. Indien een commissie wordt ingesteld, worden de kosten van deskundigenbijstand die zijn gemaakt voordat een conceptadvies als bedoeld in artikel 18, vijfde lid, is uitgebracht, in ieder geval niet redelijk geacht.

\section{Art. 7, aanhef en onder a AVN}

Voor vergoeding komen tevens in aanmerking de kosten van het inschakelen van deskundigen tot een door het bestuursorgaan vast te stellen bedrag, voor zover het inroepen van bijstand van deskundigen redelijkerwijze noodzakelijk was. 


\section{Art. 8, aanhef en onder a VNNZ}

Voor nadeelcompensatie komen tevens in aanmerking een bijdrage in de kosten van het inschakelen van deskundigen tot een door het college vast te stellen bedrag, voor zover het inroepen van de bijstand van deskundigen redelijkerwijze noodzakelijk was.

\section{De GrS}

Wanneer de BnIW 2019 de achterliggende grondslag vormt om onder de GrS compensatie toe te kennen, kunnen deskundigenkosten worden vergoed op grond van art. 10 lid 1 BnIW 2019. Uit de jurisprudentie kan worden afgeleid dat deze kosten ook kunnen worden vergoed als het ongeschreven égalitébeginsel, art. 21 Aanwijzingsbesluit 1996, of art. 8.31 Wlv de achterliggende grondslag voor nadeelcompensatie vormen. De Afdeling overweegt namelijk dat...

“(...) indien bij de schadevaststelling in het kader van nadeelcompensatie zowel het inroepen van rechts dan wel deskundigenbijstand als de kosten daarvan redelijk zijn te achten, deze kosten deel moeten kunnen uitmaken van de te vergoeden schade."120

Ook uit onder art. 49 WRO gewezen planschadejurisprudentie volgt dat kosten van deskundigenbijstand voor vergoeding in aanmerking kunnen komen. ${ }^{121}$

Dat in de GrS geen bepaling is opgenomen omtrent de vergoeding van kosten van deskundigenbijstand kan worden verklaard door de in paragraaf 3.2.1 beschreven, bijzondere aard van deze regeling: zij dient ertoe de reeds op grond van verschillende grondslagen bestaande - en aan verschillende bestuursorganen toekomende - bevoegdheden om nadeelcompensatie toe te kennen, binnen een specifieke context over te dragen aan het algemeen bestuur van het Schadeschap. Dat art. 49 WRO, art. 21 Aanwijzingsbesluit 1996 en art. 8.31 Wlv niets bepalen omtrent de vergoeding van deze kosten, lijkt met name te worden verklaard doordat het ten tijde van de totstandkoming van deze regelingen nog niet gebruikelijk was om in nadeelcompensatieregelingen uit te werken wanneer aan de daarin vervatte redelijkerwijsformule werd voldaan. Bovendien is voor de formulering van zowel art. 21 Aanwijzingsbesluit 1996 als art. $8.31 \mathrm{Wlv}$ aansluiting gezocht bij art. 49 WRO,

120 Zie voor ongeschreven égalité: ABRvS 29 november 2006, ECLI:NL:RVS:2006:AZ3259, r.o. 2.5.1. In deze uitspraak wordt verwezen naar de onder de RnR 1991 gewezen uitspraak ABRvS 1 augustus 1997, ECLI:NL:RVS:1997:AN5515. Die regeling bevat - net als art. 21 Aanwijzingsbesluit 1996 en art. $8.31 \mathrm{Wlv}$ - slechts een redelijkerwijsformule en enkele procedurele voorschriften. Zie voorts ABRvS 27 september 2017, ECLI:NL:RVS:2017:2600, r.o. 21.1 voor een uitspraak onder de GrS waarin art. $8.31 \mathrm{Wlv}$ de grondslag voor compensatie lijkt te hebben gevormd.

121 ABRvS 20 januari 1998, ECLI:NL:RVS:1998:ZF3150. Zie over deze uitspraak ook Van den Broek 2002, p. 58-60. Zie voorts Basisdocument p. 30-31. 
en in geval van art. 8.31 Wlv ook bij art. 15.20 Wet milieubeheer. ${ }^{122}$ Ook zou een verklaring kunnen zijn dat een bepaling omtrent vergoeding van deskundigenkosten strikt genomen niet nodig is om deze kosten te vergoeden. Zoals hierna nog zal blijken, worden de kosten van deskundigenbijstand namelijk geacht onderdeel uit te maken van de schade.

\subsubsection{Rechtsbijstand en andere deskundigenbijstand}

Het valt op dat de bepalingen uit de Wro en BnIW 2019 een onderscheid maken tussen rechtsbijstand en deskundigenbijstand. De Afdeling maakt dit onderscheid al sinds 1 augustus 1997. ${ }^{123}$ De aan dit onderscheid ten grondslag liggende gedachte kan worden gevonden in de jurisprudentie waarin wordt geoordeeld dat de functies van deskundige en gemachtigde onverenigbaar zijn. Een deskundige wordt namelijk geacht onpartijdig te adviseren, terwijl een gemachtigde de belangen van één procespartij dient te behartigen en daarmee dus per definitie partijdig is. Dit is ook de reden dat de Afdeling oordeelt dat kosten voor een gemachtigde niet voor vergoeding in aanmerking komen voor zover zij tevens diens optreden als deskundige betreffen. ${ }^{124}$

Ik heb er geen verklaring voor kunnen vinden dat de Amsterdamse gemeenteraad in zijn verordeningen geen aansluiting heeft gezocht bij dit onderscheid en slechts spreekt van 'deskundigenkosten'. Tenzij anders aangeduid, worden in deze paragraaf zowel de kosten voor een deskundige als een gemachtigde bedoeld wanneer wordt gesproken van 'deskundigenkosten' of 'kosten van deskundigenbijstand'. Daaronder wordt echter niet verstaan de deskundigenkosten die zijn gemaakt tijdens de bezwaarschrift- of beroepsprocedure. Vergoeding van dergelijke kosten dient namelijk altijd te worden verkregen via art. 7:15 lid 2 respectievelijk art. 8:75 jo. art. 8:75a Awb en het bijbehorende Besluit proceskosten bestuursrecht. ${ }^{125}$

\subsubsection{De dubbele redelijkheidstoets}

Uit de jurisprudentie ${ }^{126}$ kan worden opgemaakt dat de vergoedbaarheid van de deskundigenkosten dient te worden bepaald aan de hand van de dubbele redelijkheidstoets: zowel het inroepen van deskundigenbijstand als de kosten daarvan

122 Zie Stcrt. 1998, nr. 223, p. 11 (digitaal) respectievelijk Kamerstukken II 00/01, 27 603, nr. 3, p. 69 en 15.

123 ABRvS 1 augustus 1997, ECLI:NL:RVS:1997:AN5515.

124 ABRvS 28 september 2016, ECLI:NL:RVS:2016:2582, r.o. 6.9 (Overzichtsuitspraak).

125 Zie bijvoorbeeld Van Buuren e.a. 2017, p. 266. Zie ter illustratie tevens Rb. Haarlem 19 april 2012, ECLI:NL:RBHAA:2012:BW5717, r.o. 2.8.1 (Bodyfashion Zwanenburg, eerste aanleg).

126 Zie bijvoorbeeld ABRvS 29 november 2006, ECLI:NL:RVS:2006:AZ3259, r.o. 2.5.1; en ABRvS 1 augustus 1997, ECLI:NL:RVS:1997:AN5515. 
dienen redelijk te zijn. ${ }^{127}$ Ter beoordeling van de redelijkheid van het inroepen van de deskundigenbijstand wordt de algemene maatstaf gehanteerd of...

“(...) de aanvrager, gezien de feiten en omstandigheden zoals die bestonden ten tijde van de inroeping, ervan mocht uitgaan dat de deskundige een relevante bijdrage zou leveren aan een voor hem gunstige beantwoording door het bestuursorgaan van een voor de beslissing op de aanvraag mogelijk relevante vraag." ${ }^{128}$

Aan deze maatstaf is bijvoorbeeld niet voldaan als de ingeschakelde persoon of instantie weliswaar als deskundig is aan te merken ter zake van de specifieke vragen die in de procedure aan de orde zijn, maar het door die deskundige uitgebrachte advies op geen van die specifieke vragen betrekking heeft. ${ }^{129}$ Niet van belang is voorts of het commentaar van de door aanvrager ingeschakelde deskundige leidde tot aanpassing van het advies van de door het bestuur geraadpleegde deskundige. ${ }^{130}$ Voor de beoordeling van de redelijkheid van de omvang van de door aanvrager gemaakte kosten is bepalend "of deze in verhouding tot de verrichte werkzaamheden staan en redelijk zijn." 131

De hantering van deze toets blijkt het duidelijkst uit de formulering van art. 10 BnIW 2019. Daarin wordt namelijk letterlijk vermeld dat zowel het inroepen van de deskundigenbijstand als de kosten van die bijstand redelijk moeten zijn. De tekst van art. 7 onder a AVN spreekt van het maken van "redelijke kosten", terwijl de tekstuele nadruk in art. 6.5 onder a Wro en art. 8 onder a VNNZ meer ligt op het redelijk zijn van de inschakeling van de deskundige. Daarin wordt namelijk gesproken van "redelijkerwijs gemaakte kosten" respectievelijk kosten die voor vergoeding in aanmerking komen "voor zover het inroepen van de bijstand van deskundigen redelijkerwijze noodzakelijk was." Uit de toelichtingen behorende bij alle geselecteerde, thans geldende regelingen blijkt echter dat wordt beoogd de

127 Deze toets is tot stand gekomen in het civiele recht. Zie bijvoorbeeld HR 3 april 1987, ECLI:NL:HR:1987:AG5568, r.o. 3.2 (geschil tussen particulieren); en HR 17 november 1989, ECLI:NL:HR:1989:ZB1084, r.o. 3.4.1 en 3.4.3 (administratief geschil).

128 ABRvS 28 september 2016, ECLI:NL:RVS:2016:2582, r.o. 6.6 (Overzichtsuitspraak).

129 ABRvS 28 september 2016, ECLI:NL:RVS:2016:2582, r.o. 6.6 (Overzichtsuitspraak).

130 ABRvS 28 september 2016, ECLI:NL:RVS:2016:2582, r.o. 6.7 (Overzichtsuitspraak).

131 ABRvS 28 september 2016, ECLI:NL:RVS:2016:2582, r.o. 6.10 (Overzichtsuitspraak). 
dubbele redelijkheidstoets te hanteren. ${ }^{132} \mathrm{Ik}$ heb geen expliciete verklaring kunnen vinden voor de gevonden verschillen in formulering. Zij lijken slechts te kunnen worden verklaard doordat de regelingen gedurende enkele decennia door verschillende regelgevers zijn opgesteld, terwijl die regelgevers ten aanzien van dit onderwerp geen aandacht lijken te hebben gehad voor afstemming op andere nadeelcompensatieregelingen en/of overleg met elkaar, laat staan een materieelrechtelijk verschil in het leven beoogden te roepen.

\subsubsection{Zijn de kosten onderdeel van de schade?}

Uit de jurisprudentie van de Afdeling volgt dat de kosten van deskundigenbijstand "deel moeten kunnen uitmaken van de te vergoeden schade" als voldaan is aan de dubbele redelijkheidstoets. ${ }^{133} \mathrm{Ik}$ heb geen verklaring kunnen vinden voor het gegeven dat dit niet tot uitdrukking is gebracht in de bepalingen uit de Wro, BnIW 2019, AVN en VNNZ. Dat deze kosten door de desbetreffende regelgevers wel als schade worden beschouwd, blijkt doordat in de bij de Wro en BnIW 2019 behorende toelichtingen naar deze jurisprudentie wordt verwezen. ${ }^{134}$ Ten aanzien van de Amsterdamse verordeningen kan slechts worden gewezen op de passages uit de daarbij behorende toelichtingen waarin aansluiting bij art. 6:96 BW wordt bepleit. ${ }^{135}$ Kosten van deskundigenbijstand komen op grond van art. 6:96, lid 2 aanhef en onder $\mathrm{b}$ en $\mathrm{c}$ BW immers als vermogensschade voor vergoeding in aanmerking. ${ }^{36}$

132 Zie voor de Wro: Kamerstukken II 2002/03, 28 916, nr. 3, p. 65 (MvT, Wro) onder verwijzing naar onder andere ABRvS 1 augustus 1997,

ECLI:NL:RVS:1997:AE0422. Zie ten aanzien van deze regeling ook ABRvS 28 september 2016, ECLI:NL:RVS:2016:2582, r.o. 6.5 (Overzichtsuitspraak). Zie Stcrt. 1999, nr. 172, p. 11 (digitaal, p. 11) en ABRvS 16 mei 2012, ECLI:NL:RVS:2012:BW5932, r.o. 2.7.2 (Benzinestation gemeente Hulst, tussenuitspraak) ten aanzien van de BnIW 2019. Zie de toelichting op art. 7 onder a AVN, en de toelichting op art. 8 onder a VNNZ voor de Amsterdamse verordeningen. De toelichting op de VNNZ is op dit punt wat minder expliciet, maar een Amsterdamse gemeentejurist bevestigde dat de dubbele redelijkheidstoets daadwerkelijk wordt toegepast. Zie ten slotte Basisdocument, p. 30 en ABRvS 27 september 2017, ECLI:NL:RVS:2017:2600, r.o. 21.1 voor de GrS.

133 Zie bijvoorbeeld ABRvS 29 november 2006, ECLI:NL:RVS:2006:AZ3259, r.o. 2.5.1; ABRvS 1 augustus 1997, ECLI:NL:RVS:1997:AN5515; en ABRvS 20 januari 1998, ECLI:NL:RVS:1998:ZF3150.

134 Zie de verwijzing naar ABRvS 1 augustus 1997, ECLI:NL:RVS:1997:AE0422 in Kamerstukken II 2002/03, 28 916, nr. 3, p. 65, voetnoot 110 (MvT, Wro) en Stcrt. 1999, nr. 172, p. 11 (digitaal, p. 11). Zie ook Basisdocument, p. 30, voetnoot 30.

135 Zie de toelichting op art. 1 onder b AVN en art. 7 onder $\mathrm{c} A V N$, en de toelichting op art. 1, aanhef en onder d VNNZ.

136 Zie hierover bijvoorbeeld Lindenbergh, GS Schadevergoeding, art. 6:96 BW, aant. 11.3.1. In CBb 22 mei 2017, ECLI:NL:CBB:2017:188, r.o. 6.3 wordt ook expliciet de link gelegd met art. 6:96, lid 2, aanhef en onder c BW. 


\subsubsection{Forfaitaire stelsels}

Het Amsterdamse college van B\&W heeft op grond van art. 15, aanhef en onder c VNNZ de 'Regeling nadeelcompensatie Noord/Zuidlijn' vastgesteld. Art. 3 van deze regeling - waarop wordt aangesloten voor de toepassing van art. 7, aanhef en onder a $\mathrm{AVN}^{137}$ - luidt als volgt:

"Voor bijstand door deskundigen word [sic], mits de deskundigenkosten daadwerkelijk zijn gemaakt en redelijk te achten zijn, de volgende bijdrage verleend:

a. voor het indienen van aanvraag: $€ 600,-;$

b. voor het verstrekken van nadere gegevens op verzoek van de adviescommissie voorafgaand aan het conceptadvies: $€ 600,-$;

c. voor het kenbaar maken van een zienswijze op het conceptadvies van de adviescommissie: $€ 600,-. "$

Uit deze bepaling en de toelichting op art. 8 VNNZ volgt dat de deskundigenkosten daadwerkelijk moeten zijn gemaakt en redelijk moeten zijn om voor vergoeding in aanmerking te komen. Dit suggereert dat de bepaling slechts aangeeft tot welk maximum deskundigenkosten worden vergoed. Zowel uit de toelichting op art. $8 \mathrm{VNNZ}$ als de toelichting op art. 7 onder a VNNZ volgt echter ook dat het Amsterdamse gemeentebestuur de hierboven weergegeven regeling beschouwt als een forfaitair stelsel: beoogd is te voorkomen "dat per aanvraag telkens de deskundigenkosten waarvoor een bijdrage wordt gevraagd diepgaand moeten worden onderzocht." Dit wekt de suggestie dat relatief snel tot toekenning van het maximumbedrag voor deskundigenbijstand in de beschreven fases van de procedure wordt overgegaan, mits aannemelijk is dat de aanvrager in de desbetreffende fases daadwerkelijk deskundigenbijstand heeft ingewonnen.

Dat in de overige regelingen geen vergelijkbare bepalingen zijn opgenomen, kan worden verklaard doordat het op voorhand verschaffen van duidelijkheid omtrent de kosten die voor vergoeding in aanmerking komen niet voortvloeit uit een rechtsplicht. Het Amsterdamse gemeentebestuur lijkt daar toch voor te hebben gekozen omdat in zijn praktijk onduidelijkheid bestond over de vergoedbaarheid van deskundigenkosten. ${ }^{138}$ Een aanvullende verklaring voor het verschil met de overige regelingen kan worden gevonden in de Afdelingsjurisprudentie waaruit volgt dat in beginsel geen aansluiting bij een forfaitaire regeling kan worden gezocht als de aanvrager de daadwerkelijk door hem gemaakte kosten aannemelijk weet te maken. ${ }^{139}$ Ook aansluiting bij het Besluit proceskosten bestuursrecht lijkt slechts onder bijzondere omstandigheden te worden toegestaan, bijvoorbeeld als de aanvrager zijn kosten niet inzichtelijk heeft gemaakt. ${ }^{140}$ De Afdeling heeft er

137 Zie de toelichting op art. 7 onder a AVN.

138 Zie onderdeel 7 van ad 1 van de toelichting op de VNNZ.

139 ABRvS 31 oktober 2012, ECLI:NL:RVS:2012:BY1724, r.o. 13.2.

140 ABRvS 28 september 2016, ECLI:NL:RVS:2016:2582, r.o. 6.10 (Overzichtsuitspraak). 
echter geen principieel bezwaar tegen dat de besliscommissie onder de GrS het uitgangspunt hanteert dat voor de kosten van het inroepen van juridische bijstand voor het geven van een reactie op een conceptadvies of een advies in beginsel een vergoeding wordt toegekend van $€ 1.750,00$ (10 uren tegen een gemiddeld tarief van $€ 175,00$ ). Hetzelfde geldt voor het uitgangspunt dat voor de kosten van andere deskundigenbijstand bestaande uit het opstellen van een schaderapport in beginsel een vergoeding wordt toegekend van $€ 1.250,00$ (10 uren tegen een gemiddeld tarief van $€ 125,00)$. Daarbij lijkt met name van belang te zijn dat de Afdeling die uurtarieven niet onredelijk acht én de besliscommissie een vergoeding voor meer uren toekent als bijzondere omstandigheden dat vereisen. ${ }^{141}$

\subsubsection{De redelijkheid van deskundigenkosten die de aanvrager heeft gemaakt met betrekking tot de indiening van zijn aanvraag om nadeelcompensatie}

Een laatste verschil dat bespreking behoeft, heeft betrekking op de redelijkheid van de deskundigenkosten die de aanvrager heeft gemaakt met betrekking tot de indiening van zijn aanvraag om nadeelcompensatie. Aan deze kosten wordt aandacht geschonken door art. 10 lid 2 BnIW 2019: als de minister een adviescommissie instelt, worden deskundigenkosten die de aanvrager voorafgaand aan het conceptadvies van de adviescommissie heeft gemaakt (hierna: 'de voorafgaand aan het conceptadvies gemaakte deskundigenkosten') in ieder geval niet redelijk geacht. Dit artikellid kwam nog niet voor in de RnVW 1999 en BnIM 2014. Voor de invoering daarvan heeft de minister verschillende redenen aangevoerd. Zo mag ervan worden uitgegaan dat de adviescommissie de aanvraag om nadeelcompensatie op onafhankelijke en onpartijdige wijze zal beoordelen. Ook is het indienen van een aanvraag relatief eenvoudig, zodat daarvoor "evenmin bijstand vereist is". Voorts dient bij indiening van de aanvraag gebruik te worden gemaakt van een formulier, terwijl verder slechts gegevens ter bepaling van de schade dienen te worden overgelegd. Ten slotte zou "in de jurisprudentie [zijn] uitgekristalliseerd wanneer de kosten als 'redelijk' te kwalificeren zijn en voor vergoeding in aanmerking komen."

Dit laatste argument verbaast, ${ }^{143}$ aangezien op dit punt nou net twee lijnen in de jurisprudentie leken te bestaan. In onder de RnVW 1999 gewezen uitspraken oordeelde de Afdeling namelijk meermaals dat het bestuur ten onrechte geen vergoeding had toegekend voor deskundigenkosten die voorafgaand aan het conceptadvies waren gemaakt. Aan dergelijke oordelen lag ten grondslag dat "vergoeding

141 ABRvS 27 september 2017, ECLI:NL:RVS:2017:2600, r.o. 21.2-21.5.

142 Stcrt. 2019, nr. 66154, p. 14.

143 Wellicht is de minister uitgegaan van de opsomming van jurisprudentie in Handleiding nadeelcompensatie, p. 108, voetnoot 122. De meest recente uitspraak die daarin wordt genoemd, stamt echter uit 2005. 
van die kosten, gelet op art. 10 RnVW 1999, niet was uitgesloten." ${ }^{144}$ Ook leek relevant "of de inbreng van de deskundige [had] bijgedragen aan het tot stand gekomen conceptadvies." ${ }^{145}$ In het planschaderecht en een onder de $\mathrm{GrS}^{146}$ gewezen uitspraak oordeelt de Afdeling echter dat...

“(...) kosten die de aanvrager met betrekking tot de indiening van de aanvraag om schadevergoeding heeft gemaakt [in de regel] niet voor vergoeding in aanmerking [komen], omdat de aanvrager kan weten dat het bestuursorgaan gehouden is advies te vragen aan een onafhankelijke deskundige ${ }^{147}$ en het redelijkerwijs niet nodig is, zonder dat advies af te wachten, een eigen adviseur in te schakelen. Kosten die de aanvrager heeft gemaakt vanaf het moment dat de door het bestuursorgaan ingeschakelde deskundige een conceptadvies of advies heeft uitgebracht tot het moment dat het bestuursorgaan op de aanvraag een besluit heeft genomen waartegen rechtsmiddelen kunnen worden ingesteld, ${ }^{148}$ kunnen voor vergoeding in aanmerking komen, indien het inroepen van bijstand redelijk was, de kosten van het opstellen van een zienswijze redelijk zijn en de aanvraag geheel of gedeeltelijk wordt ingewilligd." 149

Deze jurisprudentielijn verschilt duidelijk van de lijn die werd gesignaleerd onder de RnVW 1999. Voor dit verschil heb ik geen duidelijke verklaring kunnen vinden. Uit de volgorde waarin de relevante uitspraken zijn gewezen volgt bijvoorbeeld geen duidelijk omslagpunt in de jurisprudentie. Bovendien ging het argument dat de RnVW 1999 vergoeding van de desbetreffende kosten niet zou uitsluiten net zo goed op voor art. 6.5, aanhef en onder a Wro en de (in de) GrS (vervatte grondslagen voor toekenning van compensatie). ${ }^{150}$ Het ten aanzien van de Wro en GrS gebezigde argument dat het bestuur verplicht een onafhankelijke deskundige dient

144 Zie ABRvS 20 april 2011, ECLI:NL:RVS:2011:BQ1889, r.o. 2.8.1; en ABRvS 16 mei 2012, ECLI:NL:RVS:2012:BW5932, r.o. 2.7 .2 (Benzinestation gemeente Hulst, tussenuitspraak).

145 ABRvS 23 januari 2013, ECLI:NL:RVS:2013:BY9196, r.o. 2 en 4.1.

146 Zie ook Basisdocument, p. 30-31.

147 Zie paragraaf 10.6.1.

148 Daarna dient een vergoeding van deskundigenkosten immers te worden verkregen via art. 7:15 lid 2 respectievelijk 8:75 jo. 8:75a Awb en het bijbehorende Besluit proceskosten bestuursrecht. Zie hieromtrent paragraaf 5.5.1.2.

149 Deze overweging is afkomstig uit de onder de GrS gewezen uitspraak ABRvS 27 september 2017, ECLI:NL:RVS:2017:2600, r.o. 21-21.5. Voor het planschaderecht is zij nagenoeg letterlijk terug te vinden in ABRvS 28 september 2016, ECLI:NL:RVS:2016:2582, r.o. 6.4-6.5 (Overzichtsuitspraak). Zie voor het planschaderecht voorts nog ABRvS 11 juli 2012, ECLI:NL:RVS:2012:BX1032, r.o. 8.1 . 
te raadplegen, ging destijds ook op voor de RnVW $1999 .{ }^{151}$ Deze plicht is namelijk pas komen te vervallen bij de overgang van BnIM 2014 naar BnIW 2019. ${ }^{152}$

De minister lijkt met de invoering van art. 10 lid 2 BnIW 2019 aansluiting te hebben willen zoeken bij de hiervoor besproken planschadejurisprudentie. Mede gelet op het principiële karakter van de Overzichtsuitspraak valt daar wat voor te zeggen. Bovendien stamde de laatste onder de RnVW 1999 gewezen uitspraak die hiervan afweek uit 2013. De wijze waarop de minister deze aansluiting heeft gezocht, is echter tamelijk ongelukkig. De redelijkheid van de voorafgaand aan het conceptadvies gemaakte deskundigenkosten is immers afhankelijk gesteld van de in een later stadium door de minister te nemen beslissing om al dan niet een adviescommissie in te stellen. Bij die beslissing komt de minister bovendien beleidsruimte toe. ${ }^{153}$ De benadeelde dient dus te voorspellen hoe de minister deze beleidsruimte zal invullen om te bepalen of het de toets der redelijkheid zal doorstaan als hij deskundigenbijstand inwint met betrekking tot de indiening van zijn aanvraag. Bovendien geeft art. 10 lid 2 BnIW 2019 een perverse prikkel aan de minister om een onnodige adviesopdracht aan een adviescommissie te geven teneinde (een deel van) de door aanvrager gemaakte deskundigen niet te hoeven vergoeden.

Uit het forfaitaire stelsel van art. 3 Regeling nadeelcompensatie Noord/Zuidlijn ${ }^{154}$ blijkt dat het onder de Amsterdamse verordeningen redelijk wordt geacht om deskundigenbijstand in te winnen met betrekking tot de indiening van een aanvraag om nadeelcompensatie. Ik heb geen expliciete verklaring kunnen vinden waarom het Amsterdamse gemeentebestuur op dit punt een ruimhartigere lijn volgt dan de overige geselecteerde, thans geldende regelingen. Mede gelet op het forfaitaire karakter van deze bepaling, lijkt het echter niet onwaarschijnlijk dat het gemeentebestuur discussies heeft willen voorkomen over het al dan niet redelijk zijn van deze kosten.

\subsubsection{Deelvraag 3: het toekomstige recht}

Art. 4:129, aanhef en onder b Awb luidt:

"Indien het bestuursorgaan een vergoeding als bedoeld in artikel 4:126 toekent, vergoedt het tevens redelijke kosten ter zake van door een derde beroepsmatig verleende rechtsbijstand of andere deskundige bijstand bij de vaststelling van de schade."

151 Zowel de plicht tot raadpleging van een deskundige als de eisen die aan diens advies werden gesteld, waren vergelijkbaar. Zie paragraaf 10.6.1 respectievelijk 10.8.1.

152 Deze plicht bestond ook onder de BnIM 2014, maar is geschrapt bij de overgang naar de BnIW 2019. Vergelijk art. 15 RnVW 1999 en art. 15 BnIM 2014 met art. 15 lid 1 jo. art. 14 lid 3 BnIW 2019.

153 Vergelijk art. 15 BnIM 2014 met art. 15 lid 1 jo. art. 14 lid 3 BnIW 2019.

154 Zie paragraaf 5.5.1.5. 
Aangezien afd. 15.1 Ow niet hiervan afwijkt, zal deze bepaling ook van toepassing zijn op aanvragen om nadeelcompensatie die onder het bereik van afd. 15.1 Ow vallen. ${ }^{155}$ Met de formulering "bij de vaststelling van de schade" heeft de wetgever tot uitdrukking willen brengen dat kosten van deskundigenbijstand die zijn gemaakt in bezwaar en beroep niet op grond van deze bepaling worden vergoed, maar op grond van art. 7:15 Awb respectievelijk art. 8:75 jo. art. 8:75a Awb. Voorts volgt uit de memorie van toelichting dat wordt vastgehouden aan de dubbele redelijkheidstoets en wordt beoogd aan te sluiten bij de hierover gewezen jurisprudentie. ${ }^{156}$

Het valt op dat de wetgever in art. 4:129, onder b Awb twee eisen stelt die niet uit het planschade- of nadeelcompensatierecht afkomstig zijn. Rechtsbijstand moet namelijk beroepsmatig zijn verleend en zijn verleend door een derde om voor vergoeding in aanmerking te komen. Waarschijnlijk zijn deze eisen overgenomen uit het in bezwaar en beroep van toepassing zijnde art. 1 sub a Besluit proceskosten bestuursrecht. Uit de bijbehorende nota van toelichting kan worden afgeleid dat het gelet op de verscheidenheid aan rechtsbijstandsverleners niet mogelijk werd geacht "wettelijke eisen van vakbekwaamheid" te stellen. De eis van beroepsmatigheid zorgt ervoor dat de kwaliteit van de bijstand toch enigszins wordt gewaarborgd. Zo kunnen bijvoorbeeld personen zonder enige juridische scholing geen beroepsmatige bijstand verlenen. Het is niet vereist dat het verlenen van rechtsbijstand het hoofdbestanddeel is van iemands beroep, maar wel dat deze verlening behoort tot zijn beroepsmatige taak. ${ }^{157}$ Zo volgt uit jurisprudentie bijvoorbeeld dat een taxateur die enkele malen per jaar juridische bijstand verleent niet wordt gezien als iemand die beroepsmatig rechtsbijstand verleent in de zin van het Besluit proceskosten bestuursrecht. ${ }^{158}$

Dat de bijstand door derden moet worden verleend, heeft verder tot gevolg dat kosten die worden gemaakt doordat de interne juridische afdeling van een getroffen bedrijf uren aan de aanvraag om compensatie heeft besteed, niet voor vergoeding in aanmerking komen. Blijkens de nota van toelichting is daarvoor gekozen omdat een zelfstandig procederende particulier ook slechts zijn "verletkosten" vergoed kan krijgen. Bovendien wordt niet beoogd proceskosten volledig te vergoeden, omdat zij deels behoren tot de "normale risico's van het maatschappelijk verkeer." 159 Het is niet duidelijk of de wetgever heeft beoogd dat de in art. 4:129, onder $\mathrm{b}$ Awb opgenomen eisen dat rechtsbijstand beroepsmatig en door een derde

156 Zie Kamerstukken II 2010/11, 32 621, nr. 3, p. 28 (MvT, Wns) waarin onder andere wordt verwezen naar ABRvS 16 april 2003, ECLI:NL:RVS:2003:AF7337, r.o. 2.4.3.

157 Stb. 1993, nr. 763, p. 6.

158 ABRvS 23 januari 2008, ECLI:NL:RVS:2008:BC2532, r.o. 2.13.

159 Verletkosten zijn kosten door tijdverzuim vanwege het persoonlijk bijwonen van de zitting. De informatie uit deze alinea is gebaseerd op Stb. 1993, nr. 763, p. 7. 
zijn verleend, overeenkomstig het voorafgaande dienen te worden uitgelegd. Dat lijkt echter wel voor de hand te liggen.

5.5.3 Hoofdvraag: spiegeling aan de doelstellingen en uitgangspunten die ten grondslag liggen aan de Wns

\section{Eén grondslag}

Aangezien de kosten van deskundigenbijstand kwalificeren als schade, is het strikt genomen niet noodzakelijk om expliciet in een nadeelcompensatieregeling op te nemen dat deze kosten voor vergoeding in aanmerking komen. Dat de wetgever dat toch heeft gedaan in art. 4:129, aanhef en onder b Awb past echter goed bij de doelstellingen van vergroting van de rechtszekerheid en codificatie van het nadeelcompensatierecht. Bovendien past het goed bij de doelstelling van vereenvoudiging, uniformering en harmonisering van het nadeelcompensatierecht dat deze bepaling onder het toekomstige recht de enige bepaling zal zijn die als grondslag kan worden aangewend voor de toekenning van een vergoeding in deze kosten. Het opnemen van een bepaling over dit onderwerp is bovendien verenigbaar met de overige aan de Wns ten grondslag liggende doelstellingen en uitgangspunten.

\section{Onderdeel van de schade}

Bezien vanuit het uitgangspunt van aansluiting bij het BW en de doelstelling van codificatie van het nadeelcompensatierecht zou het goed zijn als in de formulering van de Awb-bepaling tot uitdrukking zou komen dat redelijke deskundigenkosten onderdeel van de schade vormen. Dit zal ook in beperkte mate bijdragen aan het bereiken van de doelstelling van vergroting van de rechtszekerheid. Bovendien is dit verenigbaar met de overige aan de Wns ten grondslag liggende doelstellingen en uitgangspunten. Op dit punt zie ik dus aanleiding tot (a) aanpassing van titel 4.5 Awb.

\section{Enkele overige, taalkundige observaties}

Het past goed bij de doelstelling van codificatie van het nadeelcompensatierecht dat in art. 4:129, aanhef en onder b Awb wordt aangesloten bij het in de jurisprudentie gemaakte onderscheid tussen rechtsbijstand en deskundigenbijstand. Omdat dit ook verenigbaar is met de overige doelstellingen en uitgangspunten, doe $\mathrm{ik}$ de aanbeveling dit onderscheid te behouden.

Art. 4:129, aanhef en onder b Awb bepaalt dat kosten van rechtsbijstand slechts voor vergoeding in aanmerking kunnen komen als deze bijstand beroepsmatig en door een derde is verleend. Enerzijds passen deze eisen niet goed bij het uitgangspunt van aansluiting bij het BW. In het civiele recht kunnen namelijk ook intern 
gemaakte bedrijfskosten voor vergoeding in aanmerking komen. ${ }^{160}$ Anderzijds passen deze eisen wel goed bij het uitgangspunt van aansluiting bij de Awb. Zij zijn namelijk (naar alle waarschijnlijkheid) overgenomen uit het Besluit proceskosten bestuursrecht. Bovendien passen de eisen goed bij de doelstellingen van vergroting van de doelmatigheid van het nadeelcompensatierecht en vermindering van bestuurslasten. Zij dragen immers bij aan de kwaliteit van het besluitvormingsproces door een zekere minimumkwaliteit van de advisering te waarborgen. Dit vergroot bijvoorbeeld de kans dat onregelmatigheden en/of onjuistheden in door het bestuur ingewonnen deskundigenadvies in een vroeg stadium worden gesignaleerd. Omdat de eisen ook verenigbaar zijn met de overige aan de Wns ten grondslag liggende doelstellingen en uitgangspunten zie ik onvoldoende reden om voor te stellen (a) titel 4.5 Awb op dit punt te wijzigen.

Ten slotte is in art. 4:129, aanhef en onder b Awb bepaald dat deskundigenkosten slechts voor vergoeding in aanmerking komen als zij zijn gemaakt "bij de vaststelling van de schade". Uit paragraaf 5.5.2 volgde dat deze zinsnede is opgenomen om aan te geven dat deskundigenkosten die in bezwaar en beroep worden gemaakt niet onder het bereik van art. 4:129 sub b Awb vallen. Dat is mijns inziens overbodig omdat dit al voldoende blijkt uit de gelaagde structuur van de Awb. ${ }^{161}$ Bovendien wekt deze zinsnede ten onrechte de indruk dat geen vergoeding zal worden toegekend als het door de aanvrager ingewonnen deskundigenadvies niet ziet op de vaststelling, maar op bijvoorbeeld de vergoedbaarheid van de schade. Een dergelijke regel volgt immers niet uit de planschade- en nadeelcompensatiejurisprudentie, waarbij de wetgever beoogt aan te sluiten. Ik doe daarom de aanbeveling (a) titel 4.5 Awb te wijzigen, namelijk door schrapping van deze zinsnede. Zij sluit immers slecht aan op de doelstellingen van vergroting van de rechtszekerheid en codificatie van het nadeelcompensatierecht. Bovendien pleiten ook de overige aan de Wns ten grondslag liggende doelstellingen en uitgangspunten niet voor haar behoud.

\section{Codificatie van de dubbele redelijkheidstoets en aansluiting bij het $B W$}

In paragraaf 5.5.2 bleek dat deskundigenkosten slechts voor vergoeding op grond van art. 4:129, aanhef en onder b Awb in aanmerking komen als zij de dubbele redelijkheidstoets doorstaan. Het dubbele karakter van deze toets blijkt echter niet uit deze bepaling. Daarin wordt immers slechts gesproken van "redelijke kosten ter zake van door een derde beroepsmatig verleende rechtsbijstand of andere deskundige bijstand bij de vaststelling van de schade". Voor beantwoording van de vraag of het dubbele karakter van de redelijkheidstoets niet nadrukkelijker uit de

160 Zie Lindenbergh, in: T\&C BW, art. 6:96 BW, aant. 3.

161 Zie ter illustratie hiervan Rb. Haarlem 19 april 2012, ECLI:NL:RBHAA:2012:BW5717, r.o. 2.8.1 (Bodyfashion Zwanenburg, eerste aanleg). 
Awb-bepaling zou moeten blijken, geldt hetzelfde als in paragraaf 5.4.3 $3^{162}$ is aangevoerd ten aanzien van kosten van schadebeperkende maatregelen: het uitgangspunt van aansluiting bij het BW botst met de doelstelling(en) van codificatie van het nadeelcompensatierecht (en vergroting van de rechtszekerheid), waardoor ik onvoldoende grond zie om (a) titel 4.5 Awb op dit punt te wijzigen.

\section{Voorafgaand aan het conceptadvies gemaakte deskundigenkosten en invulling van de dubbele redelijkheidstoets}

In paragraaf 5.5.1.6 bleek dat de Afdeling gedurende enige tijd tegenstrijdige jurisprudentielijnen bezigde ten aanzien van de vergoeding van deskundigenkosten gemaakt voorafgaand aan het conceptadvies, zonder dat daarvoor een logische verklaring kan worden aangedragen. De doelstellingen van vereenvoudiging, uniformering en harmonisering van het nadeelcompensatierecht, en vergroting van de rechtszekerheid pleiten mijns inziens ervoor dat onder het toekomstige recht een duidelijk en eenduidig standpunt wordt ingenomen ten aanzien van de vraag of, en zo ja in hoeverre, deze kosten voor vergoeding in aanmerking komen. Dat zou eveneens goed passen bij de doelstelling van vergroting van de doelmatigheid van het nadeelcompensatierecht en vermindering van bestuurslasten, omdat hierdoor onnodige aanwending van rechtsmiddelen tegen nadeelcompensatiebesluiten kan worden voorkomen.

De aan de Wns ten grondslag liggende doelstellingen en uitgangspunten pleiten echter niet duidelijk voor of tegen de vergoedbaarheid van voorafgaand aan het conceptadvies gemaakte deskundigenkosten. Uit de in paragraaf 5.5.1.6 besproken jurisprudentie kunnen wel enkele inzichten worden ontleend op basis waarvan een standpunt omtrent de vergoedbaarheid van deze kosten kan worden ingenomen. Allereerst sluit titel 4.5 Awb noch afd. $15.1 \mathrm{Ow}$ de vergoeding van voorafgaand an het conceptadvies gemaakte deskundigenkosten uit. Ten tweede is van belang dat beide regelingen niet de plicht aan het bestuur opleggen om een adviseur in te schakelen. Beide punten pleiten ervoor voorafgaand aan het conceptadvies gemaakte deskundigenkosten niet categorisch op voorhand van vergoeding uit te sluiten. Daarvoor pleit ook het advies dat de AARvS heeft uitgebracht naar aanleiding van het aan haar voorgelegde voorstel voor de Wns. Daarin werd namelijk aanbevolen...

“(...) de verwijzing naar de bekritiseerde jurisprudentie in planschadezaken, waarbij deze kosten in beginsel niet worden vergoed indien de benadeelde, zonder het advies van een adviseur als bedoeld in afdeling 3.3 af te wachten, zelf een adviseur heeft ingeschakeld, [te] laten vervallen, aangezien deze jurisprudentie in nadeelcompensatie-

162 Zie meer specifiek het kopje 'Codificatie van het dubbele karakter van de redelijkheidstoets?'. 
zaken geen navolging heeft gevonden en ook het nieuwe artikel 6.5 Wro spreekt over de «redelijke kosten»."

Gelet op het voorafgaande doe ik aanbeveling tot (c) een bijzondere invulling van titel 4.5 Awb, namelijk dat de rechter de jurisprudentielijn verlaat dat voorafgaand aan het conceptadvies gemaakte deskundigenkosten nooit voor vergoeding in aanmerking komen. Hij zou de redelijkheid van deze kosten steeds aan de hand van de omstandigheden van het individuele schadegeval moeten bepalen. Zonder uitputtend te willen zijn, noem ik een aantal factoren die daarbij in ieder geval van belang kunnen zijn - waarbij ik inspiratie ontleen aan de in paragraaf 5.5.1.6 besproken jurisprudentie. Ten eerste is relevant dat titel 4.5 Awb en afd. 15.1 Ow geen gedetailleerde eisen aan de aanvraag om nadeelcompensatie stellen. ${ }^{164}$ Daarom lijkt raadpleging van een deskundige zeker niet altijd noodzakelijk te zijn om een aanvraag in te dienen. Ten tweede is van belang of dit soort eisen wel zijn opgenomen in lagere wettelijke voorschriften of wetsinterpreterende beleidsregels. Ten derde is relevant of het bestuur ingevolge art. 4:4 Awb een formulier heeft vastgesteld waarmee een aanvraag om nadeelcompensatie moet worden ingediend, en zo ja, welke gegevens daarop moeten worden ingevuld. Ten slotte is van belang of het bestuur op voorhand heeft gecommuniceerd of het deskundigenadvies zal inwinnen, en zo ja, op welke punten advies zal worden ingewonnen.

In paragraaf 5.4.3 concludeerde ik ten aanzien van kosten van schadebeperkende maatregelen dat het niet goed mogelijk is de dubbele redelijkheidstoets nader te normeren in titel 4.5 Awb of afd. 15.1 Ow. Daarbij speelde vooral een rol dat deze toets sterk afhankelijk is van de omstandigheden van het individuele geval, en bovendien op een breed scala aan scenario's moet kunnen worden toegepast. Dat is niet anders wanneer deze toets wordt toegepast op deskundigenkosten. Dat wordt geïllustreerd door de hiervoor opgesomde factoren, maar bijvoorbeeld ook door de standaardoverweging uit de jurisprudentie dat voor de redelijkheid van de omvang van deskundigenkosten bepalend is "of deze in verhouding tot de verrichte werkzaamheden staan en redelijk zijn." ${ }^{65}$ Dit is de reden waarom ik de voorafgaande aanbeveling niet heb gericht tot de wetgever maar tot de rechter. Eveneens is dit de reden waarom ik ook overigens niet tot nadere normering van de dubbele redelijkheidstoets in titel 4.5 Awb of afd. 15.1 Ow zal adviseren, terwijl dit in theorie wel goed zou aansluiten op de doelstellingen van codificatie van het nadeelcompensatierecht en vergroting van de rechtszekerheid. Dergelijke normering is wel denkbaar als niet langer wordt uitgegaan van een dubbele redelijkheidstoets die is toegespitst op de omstandigheden van het individuele geval, maar van een forfaitaire benadering. Daarom zal ik hierna nog ingaan op de vraag of een dergelijke benadering aanbeveling verdient.

163 Kamerstukken II 2010/11, 32 621, nr. 4, p. 14 (RvS, Wns).

164 Vergelijk paragraaf 10.3.2.

165 ABRvS 28 september 2016, ECLI:NL:RVS:2016:2582, r.o. 6.10 (Overzichtsuitspraak). 


\section{Forfaitaire stelsels}

Uit paragraaf 5.5.1.5 bleek dat het Amsterdamse gemeentebestuur een forfaitair stelsel in het leven heeft geroepen voor de vergoeding van deskundigenkosten. Tevens bleek de besliscommissie onder de GrS uit te gaan van bepaalde richtlijnen. Voor het geven van een reactie op een conceptadvies of een advies kent zij bijvoorbeeld in beginsel een vergoeding toe van $€ 1$.750,00 (10 uren tegen een gemiddeld tarief van $€ 175,00)$. In meer algemene zin heeft Van Zundert bepleit om onder art. 6.5 Wro aan te sluiten bij het Besluit proceskosten bestuursrecht voor wat betreft de omvang van de te vergoeden deskundigenkosten. ${ }^{166}$ Naar aanleiding van het voorafgaande kan de vraag worden opgeworpen of titel 4.5 Awb de vergoeding van deskundigenkosten niet eveneens forfaitair zou moeten benaderen.

Vóór een forfaitaire benadering pleiten de doelstellingen van vergroting van de rechtszekerheid, en vergroting van de doelmatigheid van het nadeelcompensatierecht en vermindering van bestuurslasten. Hiermee wordt immers voorkomen dat onderzoek moet worden gedaan naar de daadwerkelijk gemaakte kosten en discussies moeten worden gevoerd omtrent de redelijkheid daarvan. Tegen een forfaitaire benadering pleit echter de doelstelling van codificatie van het nadeelcompensatierecht. Tenzij zich bijzondere omstandigheden voordoen, blijkt de Afdeling in haar planschadejurisprudentie immers niet te accepteren dat aansluiting bij het Besluit proceskosten bestuursrecht wordt gezocht. Bij een volledig forfaitaire benadering bestaat bovendien het risico dat kosten worden vergoed die thans de dubbele redelijkheidstoets niet zouden doorstaan. Ten slotte verhoudt de doelstelling van vergroting van de rechtsgelijkheid zich ambivalent tot een forfaitaire benadering. Enerzijds zal iedere aanvrager in beginsel dezelfde vergoeding voor de door hem gemaakte deskundigenkosten ontvangen. Anderzijds heeft dat ook tot gevolg dat gevallen die niet volledig gelijk zijn, wel gelijk zullen worden behandeld.

Kortom: de aangehaalde doelstellingen en uitgangspunten geven geen eenduidig antwoord op de vraag of de voorkeur zou moeten worden gegeven aan een forfaitaire benadering. De overige aan de Wns ten grondslag liggende doelstellingen en uitgangspunten verhouden zich neutraal ten opzichte van een dergelijke benadering. Gelet hierop zie ik onvoldoende draagvlak om tot opname van een forfaitaire benadering in titel $4.5 \mathrm{Awb}$ te adviseren. Toch zie ik reden om (a) titel 4.5 Awb te wijzigen. Het zou namelijk goed passen bij de doelstelling van vereenvoudiging, uniformering en harmonisering van het nadeelcompensatierecht als in titel 4.5 Awb zou worden opgenomen dat bij amvb nadere regels kunnen worden gegeven omtrent de vergoeding van deskundigenkosten. Hierdoor zou het namelijk relatief eenvoudig zijn om landelijk een forfaitair stelsel in te voeren ${ }^{167}$ als op een gegeven moment zou blijken dat in veel wetsinterpreterende verordeningen of beleidsregels zou worden overgegaan tot vaststelling van forfaitaire normen of

166 Van Zundert, in T\&C Ruimtelijk bestuursrecht, art. 6.5 Wro, onderdeel a.

167 Het uitgangspunt van aansluiting bij de Awb zou er dan voor pleiten zoveel mogelijk aan te sluiten bij het Besluit proceskosten bestuursrecht. 
richtlijnen. Daarbij merk ik op dat daartoe mijns inziens voldoende ruimte bestaat, mits voldoende mogelijkheid wordt ingebouwd om van deze normen of richtlijnen af te wijken als de omstandigheden van het individuele geval dat vereisen. ${ }^{168}$ Ik zal echter (c) niet aanbevelen tot vaststelling van dergelijke verordeningen of beleidsregels, omdat de aan de Wns ten grondslag liggende doelstellingen en uitgangspunten daar te weinig draagvlak voor bieden vanwege hun ambivalente verhouding tot de forfaitaire vergoeding van deskundigenkosten.

\section{Conclusie}

Gelet op het voorafgaande zie ik reden tot (a) aanpassing van titel 4.5 Awb. Bezien vanuit het uitgangspunt van aansluiting bij het BW en de doelstelling(en) van codificatie van het nadeelcompensatierecht (en vergroting van de rechtszekerheid) zou het goed zijn als in de formulering van de Awb-bepaling tot uitdrukking zou komen dat de redelijke deskundigenkosten onderdeel van de schade vormen. Voorts zou de zinsnede "bij de vaststelling van de schade" moeten worden geschrapt uit art. 4:129 onder b Awb. Ten slotte zou het goed passen bij de doelstelling van vereenvoudiging, uniformering en harmonisering van het nadeelcompensatierecht als in titel 4.5 Awb zou worden opgenomen dat bij amvb nadere regels kunnen worden gegeven omtrent de vergoeding van deskundigenkosten. In paragraaf 5.8 zal een concreet voorstel worden gedaan om deze aanbevelingen te implementeren. De aan de Wns ten grondslag liggende doelstellingen en uitgangspunten geven mijns inziens geen aanleiding tot (b) aanpassing van afd. 15.1 Ow. Wel geven zij aanleiding (c) anderszins te voorzien in een bijzondere invulling van titel 4.5 Awb. De rechter zou namelijk de jurisprudentielijn moeten verlaten dat voorafgaand aan het conceptadvies gemaakte deskundigenkosten nooit voor vergoeding in aanmerking komen. In plaats daarvan zou de redelijkheid van deze kosten steeds moeten worden bepaald aan de hand van de omstandigheden van het individuele schadegeval.

\subsection{VERGOEDING VAN WETTELIJKE RENTE}

5.6.1 Deelvraag 2: verschillen tussen de geselecteerde, thans geldende regelingen en verklaringen daarvoor

Regelingen met een bepaling inzake de vergoeding van wettelijke rente

Het merendeel van de geselecteerde, thans geldende regelingen kent een bepaling omtrent de vergoeding van wettelijke rente:

168 Vergelijk in een andere context bijvoorbeeld ABRvS 28 september 2016, ECLI:NL:RVS:2016:2582, r.o. 5.7 (Overzichtsuitspraak) en ABRvS 5 december 2012, ECLI:NL:RVS:2012:BY5105, r.o. 7.2 (Wouwse Tol, tussenuitspraak). 


\section{Art. 6.5, aanhef en onder b Wro}

Indien burgemeester en wethouders een tegemoetkoming als bedoeld in artikel 6.1 toekennen, vergoeden burgemeester en wethouders daarbij tevens de wettelijke rente, te rekenen met ingang van de datum van ontvangst van de aanvraag.

\section{Art. 11 BnIW 2019}

Een vergoeding van wettelijke rente als bedoeld in artikel 6:119 van het Burgerlijk Wetboek kan deel uitmaken van de toe te kennen vergoeding. Het tijdstip waarop de wettelijke rente ingaat wordt gesteld op de datum van ontvangst van het verzoek door de minister.

\section{Art. 7, aanhef en onder b AVN}

Voor vergoeding komen tevens in aanmerking (...) de wettelijke rente vanaf de ontvangst van de aanvraag of indien het nadeel op een later tijdstip is ontstaan, vanaf dat tijdstip.

\section{Art. 8, aanhef en onder b VNNZ}

Voor nadeelcompensatie komen tevens in aanmerking (...) de wettelijke rente vanaf de ontvangst van de aanvraag, of indien het nadeel op een later tijdstip ontstaat, vanaf dat tijdstip.

\section{Vergoeding van wettelijke rente onder de GrS}

Wanneer de BnIW 2019 de achterliggende grondslag vormt om onder de GrS compensatie toe te kennen, kan wettelijke rente worden vergoed op grond van art. 11 BnIW 2019. Uit jurisprudentie volgt dat wettelijke rente ook onderdeel van de vergoeding kan uitmaken bij nadeelcompensatie op grond van het ongeschreven égalitébeginsel. ${ }^{169}$ Tevens volgt uit de jurisprudentie dat wettelijke rente ook onder de overige achterliggende grondslagen van de GrS wordt vergoed door de Besliscommissie. ${ }^{170}$ Dat art. 49 WRO, art. 21 Aanwijzingsbesluit 1996 en art. $8.31 \mathrm{Wlv}$ niets bepalen omtrent de vergoeding van wettelijke rente, lijkt met name te worden verklaard doordat het ten tijde van de totstandkoming van deze regelingen nog niet gebruikelijk was om in nadeelcompensatieregelingen uit te werken wanneer aan de daarin vervatte redelijkerwijsformule werd voldaan. Bovendien is voor de formulering van zowel art. 21 Aanwijzingsbesluit 1996 als art. 8.31 Wlv aansluiting gezocht bij art. 49 WRO, en in geval van art. 8.31 Wlv ook bij art. 15.20 Wet milieubeheer. ${ }^{171}$ Dat in de GrS zelf geen bepaling is opgenomen omtrent de

169 Zie bijvoorbeeld ABRvS 17 juni 2009, ECLI:NL:RVS:2009:BI8464, r.o. 2.9.3.

170 Art. 49 WRO:ABRvS 27 september 2017, ECLI:NL:RVS:2017:2600, r.o. 3 en 8. Art. 21 Aanwijzingsbesluit: ABRvS 10 november 2010, ECLI:NL:RVS:2010:BO3436, r.o. 2.12.1. Art. 8.31 Wlv: ABRvS 6 november 2013, ECLI:NL:RVS:2013:1821, onder het procesverloop. Zie in algemene zin ook ABRvS 19 december 2018, ECLI:NL:RVS:2018:4170, r.o. 49.

171 Zie Stcrt. 1998, nr. 223, p. 11 (digitaal) respectievelijk Kamerstukken II 00/01, 27 603 , nr. 3, p. 69 en 15. 
vergoeding van wettelijke rente kan worden verklaard door de in paragraaf 3.2.1 beschreven, bijzondere aard van deze regeling: zij dient ertoe de reeds op grond van verschillende grondslagen bestaande - en aan verschillende bestuursorganen toekomende - bevoegdheden om nadeelcompensatie toe te kennen, binnen een specifieke context over te dragen aan het algemeen bestuur van het Schadeschap.

\section{Aansluiting bij het $B W$}

Het valt op dat slechts in art. 11 BnIW 2019 een expliciete verwijzing is opgenomen naar art. 6:119 BW. Uit de toelichtingen behorende bij de Amsterdamse verordeningen en het door de besliscommissie van het Schadeschap opgestelde Basisdocument inzake de GrS kan echter worden opgemaakt dat ook onder die regelingen wordt aangesloten bij deze civielrechtelijke bepaling. ${ }^{172}$ Dit ligt ook voor de hand omdat in de term 'wettelijke rente' al een inherente verwijzing naar art. 6:119 BW besloten ligt. Een verdere verklaring voor de overeenkomst die op dit punt tussen de regelingen bestaat, kan worden gevonden in een Afdelingsuitspraak van 29 september 1994. Daaruit volgt namelijk dat art. 6:119 BW weliswaar niet rechtstreeks van toepassing is, maar de Afdeling "op praktische gronden van oordeel [is] dat genoemd artikel, wat de wijze van renteberekening betreft, van overeenkomstige toepassing dient te zijn." ${ }^{173}$ Dat niet iedere regeling expliciet naar art. 6:119 BW verwijst, lijkt te kunnen worden verklaard doordat de regelingen gedurende enkele decennia door verschillende regelgevers zijn opgesteld, terwijl die regelgevers ten aanzien van dit onderwerp geen aandacht lijken te hebben gehad voor afstemming op andere nadeelcompensatieregelingen en/of overleg met elkaar, laat staan een materieelrechtelijk verschil in het leven beoogden te roepen.

\section{Plicht tot vergoeding van wettelijke rente?}

Het valt op dat de bepaling uit de Wro imperatief is geformuleerd: als een tegemoetkoming in planschade wordt toegekend, moet ook de wettelijke rente worden vergoed. De formuleringen van de Amsterdamse regelingen (wettelijke rente komt voor vergoeding in aanmerking) en de BnIW 2019 (wettelijke rente kan deel uitmaken van de toe te kennen vergoeding) lijken in theorie wat meer ruimte voor discretie te bevatten. Niets wijst er echter op dat de opstellers van deze regelingen en de bestuursorganen belast met de uitvoering daarvan, ervan uitgaan dat op dit punt daadwerkelijk discretie bestaat. Voor dit verschil in formulering heb ik dan ook geen specifieke verklaring kunnen ontwaren. Het heeft er veel van weg dat ook dit verschil is ontstaan doordat de regelingen gedurende enkele decennia door verschillende regelgevers zijn opgesteld, terwijl die regelgevers ten aanzien van

172 Zie de toelichting op art. 7 onder b AVN; de toelichting op art. 8, aanhef en onder b VNNZ; en Basisdocument, p. 31.

173 ABRvS 29 september 1994, ECLI:NL:RVS:1994:AN4171. Het van toepassing zijnde rentepercentage kan dus worden teruggevonden in art. 1 Besluit wettelijke rente, dat zijn grondslag vindt in art. 6:120 lid $1 \mathrm{BW}$. 
dit onderwerp geen aandacht lijken te hebben gehad voor afstemming op andere nadeelcompensatieregelingen en/of overleg met elkaar, laat staan een materieelrechtelijk verschil in het leven beoogden te roepen.

\section{Aanvang van de renteperiode}

De Wro en BnIW 2019 bepalen dat de renteperiode aanvangt op het moment van ontvangst van de aanvraag om compensatie. Dit kan eveneens worden verklaard door de uitspraak van 29 september 1994, ${ }^{174}$ waarnaar expliciet wordt verwezen in de toelichting behorende bij de BnIW 2019. ${ }^{175}$ In deze uitspraak overwoog de Afdeling namelijk dat een "redelijke toepassing" van art. 49 WRO meebrengt dat het tijdstip waarop de renteperiode ingaat, wordt gesteld op de datum van ontvangst van de aanvraag door het bestuur. Daarbij was van belang dat het bestuur ingevolge art. 49 WRO niet tot vaststelling van een schadevergoeding kon overgaan alvorens deze aanvraag door het bestuur was ontvangen. Dat is natuurlijk niet anders onder de overige door mij onderzochte regelingen.

Als de Wro en BnIW 2019 naar de letter worden toegepast, kan zich echter de onwenselijke situatie voordoen dat wettelijke rente moet worden betaald over de periode waarin reeds een aanvraag was ingediend maar nog geen schade werd geleden. ${ }^{176}$ In de praktijk leidt dit soms ertoe dat een 'vroegtijdig' ingediende aanvraag vrijwel direct wordt afgewezen onder vermelding dat deze opnieuw kan worden ingediend als de schade zich daadwerkelijk heeft voorgedaan en/of het schadeveroorzakende besluit onherroepelijk is geworden. ${ }^{177}$ Pas vanaf dat laatste moment staat immers vast dat de schadeoorzaak rechtmatig is en kan inhoudelijk worden beslist op de aanvraag om schadevergoeding. ${ }^{178}$ Deze 'oplossing' verdient, mede bezien vanuit een perspectief van procedurele rechtvaardigheid, niet de schoonheidsprijs. ${ }^{179}$

Het lijkt aannemelijk dat de Amsterdamse gemeenteraad dit soort kunstgrepen heeft willen voorkomen door in de Amsterdamse verordeningen te bepalen dat wettelijke rente pas wordt vergoed vanaf het moment dat een aanvraag is ingediend én daadwerkelijk schade is geleden. Ik sluit niet uit dat de Amsterdamse gemeenteraad zich hierbij heeft laten inspireren door een onder de RnVW 1999

174 ABRvS 29 september 1994, ECLI:NL:RVS:1994:AN4171.

175 Stcrt. 1999, nr. 172, p. 11 (digitaal, p. 11).

176 Dat een aanvraag dan al kan worden ingediend, volgt uit paragraaf 10.5.1 onder het kopje 'Het eerst mogelijke moment van indiening van de aanvraag'.

177 Zie bijvoorbeeld ABRvS 27 juni 2012, ECLI:NL:RVS:2012:BW9562, r.o. 2.52.5.1. Daarin werden in één geschil meerdere aanvragen om vergoeding van planschade afgewezen omdat zij waren ingediend voor het moment van onherroepelijkheid van de schadeoorzaak.

178 Zie ook hiervoor ABRvS 27 juni 2012, ECLI:NL:RVS:2012:BW9562, r.o. 2.5.1.

179 Deze onwenselijkheid zal worden betrokken in de aanbevelingen die worden gedaan in paragraaf 5.6.3. 
gewezen Afdelingsuitspraak van 26 april 2006. ${ }^{180}$ Daarin sanctioneerde de Afdeling namelijk via de band van de inherente afwijkingsbevoegdheid van art. 8:84 Awb dat de wettelijke rente pas vanaf meer dan een jaar na indiening van de aanvraag om nadeelcompensatie werd berekend. Daarvoor was onder andere van belang dat zich ten tijde van de aanvraag "slechts een beperkt deel van de schade had gerealiseerd." Uit latere jurisprudentie kan worden opgemaakt dat de Afdeling in dergelijke gevallen wel streng toetst in hoeverre de schade ook daadwerkelijk later dan het moment van ontvangst van de aanvraag is ontstaan. ${ }^{181}$

Volgens art. 6.5, aanhef en onder b Wro vangt de renteperiode aan met ingang van de datum van ontvangst van de aanvraag. Mede omdat de Wro tot stand is gekomen na de uitspraak van 26 april 2006, is het opmerkelijk dat de wetgever geen rekening heeft gehouden met de mogelijkheid dat een aanvraag al wordt ingediend voordat schade is geleden. ${ }^{182}$ Hiervoor heb ik geen verklaring kunnen vinden. Bovendien lijkt dit problematischer dan onder de BnIW 2019, omdat de Wro een wet in formele zin is. Daardoor zou geen ruimte tot afwijking moeten bestaan in gevallen waarin nog geen schade is geleden op het moment van ontvangst van de aanvraag. Daarom is het opvallend dat de Afdeling in haar Overzichtsuitspraak overweegt dat zij de aanvangsdatum voor de rentetermijn bij aanvragen die zijn ingediend voordat het schadeveroorzakende besluit onherroepelijk is geworden niet stelt op de datum van ontvangst van de aanvraag, maar op de datum van onherroepelijkheid van de schadeoorzaak. ${ }^{183}$ Daarbij verwijst zij vreemd genoeg naar een onder art. 49 WRO gewezen uitspraak waarin niet overeenkomstig werd geoordeeld. ${ }^{184}$ Het moment van onherroepelijkheid wordt wel als aanvangsdatum aangemerkt in een onder de GrS gewezen uitspraak van 6 november 2013, waarin de Afdeling oordeelde dat...

"(...) de wettelijke rente wordt vergoed met ingang van de datum van ontvangst van het verzoek om nadeelcompensatie, waarbij de wettelijke rente op zijn vroegst begint te lopen op het moment van het onherroepelijk worden van het aanwijzingsbesluit 1996." (...) $\mathrm{Er}$ is geen grond voor het oordeel dat hiervan zou moeten worden afgeweken. Voor zover [appellant A] en [appellant B] in dit verband nog hebben gewezen op artikel 4:129 van de Algemene wet bestuursrecht is van belang, nog daargelaten of toepassing

180 ABRvS 26 april 2006, ECLI:NL:RVS:2006:AW4004, r.o. 2.5.1 (Verkoopwagen Via Delta).

181 ABRvS 14 augustus 2013, ECLI:NL:RVS:2013:737, r.o. 16.1.

182 Dat die mogelijkheid bestaat, volgt uit paragraaf 10.5.1 onder het kopje 'Het eerst mogelijke moment van indiening van de aanvraag'.

183 ABRvS 28 september 2016, ECLI:NL:RVS:2016:2582, r.o. 4 (Overzichtsuitspraak). 
van dit artikel verschil zou uitmaken voor deze zaak, dat dit artikel nog niet in werking is getreden." 185

Ik neem aan dat de Afdeling met haar laatste zin slechts heeft willen aangeven dat zij voorafgaand aan de inwerkingtreding van art. 4:129 Awb geen oordeel omtrent de toepassing van deze bepaling wil geven. Mijns inziens kan namelijk niet succesvol worden verdedigd dat toepassing van die bepaling niet tot een andere uitkomst zou leiden. Zij bepaalt immers dat wettelijke rente wordt vergoed vanaf de ontvangst van de aanvraag, of indien de schade op een later tijdstip ontstaat, vanaf dat tijdstip. ${ }^{186}$ Omdat de inwerkingtreding van het aanwijzingsbesluit niet werd opgeschort tot het moment waarop het onherroepelijk werd, zie ik niet waarom de schade niet reeds zou zijn ontstaan - en de verjaringstermijn dus op grond van art. 4:129 Awb zou zijn aangevangen - op het moment van inwerkingtreding van het aanwijzingsbesluit. Voor het verschil dat op dit punt bestaat tussen de onder de Wro en GrS gewezen jurisprudentie enerzijds, en de tekst van de Wro en de in een vroeger stadium gewezen jurisprudentie anderzijds, heb ik dan ook geen verklaring kunnen vinden. Dat geldt eens te meer nu de vergoeding van wettelijke rente ertoe strekt de schade te vergoeden die het gevolg is van de duur van de nadeelcompensatieprocedure. ${ }^{187}$

\subsubsection{Deelvraag 3: het toekomstige recht}

Op grond van art. 4:129, aanhef en onder d Awb komt "wettelijke rente vanaf de ontvangst van de aanvraag, of indien de schade op een later tijdstip ontstaat, vanaf dat tijdstip" voor vergoeding in aanmerking. Aangezien afd. 15.1 Ow niet hiervan afwijkt, zal deze bepaling ook van toepassing zijn op aanvragen die onder de reikwijdte van afd. $15.1 \mathrm{Ow}$ vallen. ${ }^{188}$ Uit de bij de Wns behorende memorie van toelichting blijkt dat de wetgever met deze bepaling aansluiting heeft gezocht bij de praktijk en de rechtspraak van de Afdeling. Ter onderbouwing van het eerste wordt verwezen naar art. 11 RnVW 1999. Ter onderbouwing van het tweede verwijst de wetgever naar de in paragraaf 5.6.1 besproken uitspraak van 26 april $2006^{189}$ over wettelijke rente in situaties waarin nog geen schade is geleden op het moment van indiening van de aanvraag om nadeelcompensatie. Volgens de memorie van toe-

185 ABRvS 6 november 2013, ECLI:NL:RVS:2013:1824, r.o. 5.1. De Afdeling verwijst daarbij naar ABRvS 10 november 2010, ECLI:NL:RVS:2010:BO3436, r.o. 2.12-2.12.1. In deze uitspraak werd weer verwezen naar ABRvS 8 februari 2006, ECLI:NL:RVS:2006:AV1254. Daarin komt deze overweging echter niet terug. De aanvraag werd in die zaak ingediend $n a$ het ontstaan van de schade, die bovendien werd veroorzaakt door feitelijke werkzaamheden. Wel werd het moment van onherroepelijkheid als aanvangsdatum aangewezen in het Basisdocument, p. 31, 42, 153 en 156.

186 Zie paragraaf 5.6.2.

187 ABRvS 27 juni 2012, ECLI:NL:RVS:2012:BW9537, r.o. 2.7.1, onder verwijzing naar ABRvS 12 december 2001, 200101227/1, StAB 2002/143, r.o. 2.5.

188 Kamerstukken II 2018/19, 34 986, nr. 3, p. 224-225 (MvT, IOw).

189 ABRvS 26 april 2006, ECLI:NL:RVS:2006:AW4004 (Verkoopwagen Via Delta). 
lichting zou het in dergelijke gevallen "ongerijmd" zijn als het bestuur wettelijke rente zou moeten vergoeden vanaf de indiening van de aanvraag. ${ }^{190}$

\subsubsection{Hoofdvraag: spiegeling aan de doelstellingen en uitgangspunten die ten grondslag liggen aan de Wns}

In paragraaf 5.6.1 zijn enkele tekstuele verschillen geconstateerd tussen de geselecteerde, thans geldende regelingen. Het past goed bij de doelstelling van vereenvoudiging, uniformering en harmonisering van het nadeelcompensatierecht dat deze verschillen komen te vervallen doordat onder het toekomstige recht nog slechts één bepaling zal dienen als grondslag voor de vergoeding van wettelijke rente, namelijk art. 4:129, aanhef en onder d Awb. Ook past het goed bij deze doelstelling en de doelstelling van vergroting van de rechtszekerheid en rechtsgelijkheid dat de Awb-bepaling een einde zal maken aan de vastgestelde materieelrechtelijke verschillen in aanvangsdatum van de renteperiode. Dat geldt eens te meer nu de verklaringen voor deze materieelrechtelijke verschillen niet pleiten voor instandhouding daarvan. Zij pleiten er hooguit voor dat de aanvangsdatum die volgt uit art. 4:129, aanhef en onder d Awb niet leidt tot onwenselijke situaties. Het is daarom positief dat de Awb-bepaling in ieder geval voorkomt dat wettelijke rente moet worden vergoed over een periode waarin nog geen schade was geleden. $\mathrm{Zij}$ bepaalt immers dat de rentetermijn aanvangt vanaf de ontvangst van de aanvraag, of indien de schade op een later tijdstip ontstaat, vanaf dat tijdstip.

Kan het wel als onwenselijk worden gezien dat art. 4:129, aanhef en onder d Awb de rentetermijn bij appellabele schadeoorzaken reeds laat aanvangen voorafgaand aan de onherroepelijkheid daarvan? Gelet op het uitgangspunt van aansluiting bij het BW lijkt deze vraag bevestigend te moeten worden beantwoord. Met de vaststelling van het nieuwe BW werd het uitgangspunt dat de rentetermijn aanvangt vanaf het moment van dagvaarding namelijk ingeruild voor het uitgangspunt dat de rentetermijn aanvangt vanaf het moment van verzuim van de schuldenaar. Bij een verbintenis die voortvloeit uit onrechtmatige daad is de schuldenaar in verzuim als de verbintenis niet terstond wordt nagekomen (vergelijk art. 6:83, aanhef en onder b BW). Strekt deze verbintenis tot schadevergoeding, dan is dus wettelijke rente verschuldigd vanaf het moment van opeisbaarheid van de vordering tot schadevergoeding. ${ }^{191}$

In de bij de Wns behorende memorie van toelichting valt te lezen dat ten tijde van het indienen van een aanvraag om nadeelcompensatie nog geen sprake is van "een invorderbare schuld", omdat het bestuur eerst een besluit moet nemen tot toekenning van nadeelcompensatie. ${ }^{192}$ De grootst mogelijke aansluiting op het BW zou dus worden bereikt door de rentetermijn te laten aanvangen vanaf het moment waarop dit zuiver schadebesluit is genomen. Het bestuur zou hierdoor

190 Kamerstukken II 2010/11, 32 621, nr. 3, p. 28 (MvT, Wns).

191 Parl. Gesch. Boek 6, p. 467 en 475.

192 Kamerstukken II 2010/11, 32 621, nr. 3, p. 29 (MvT, Wns). 
echter niet worden geprikkeld om het besluitvormingsproces vlot te laten verlopen. Nog belangrijker is dat dit ook niet goed zou passen bij de doelstelling van codificatie van het nadeelcompensatierecht. Uit de meest recente uitspraken die werden besproken in paragraaf 5.6.1 volgde immers dat de Afdeling de rentetermijn bij schade door een appellabele schadeoorzaak pas laat aanvangen vanaf het moment van onherroepelijkheid van deze schadeoorzaak. Bovendien volgt uit de jurisprudentie dat de vergoeding van wettelijke rente ertoe strekt de schade te vergoeden die het gevolg is van de duur van de nadeelcompensatieprocedure. ${ }^{193} \mathrm{Ik}$ stel daarom voor (a) titel 4.5 Awb zo aan te passen dat de rentetermijn bij schade door een appellabele schadeoorzaak aanvangt vanaf de onherroepelijkheid van deze schadeoorzaak. Dat is immers het eerste moment waarop inhoudelijk kan worden beslist op de aanvraag om compensatie. ${ }^{194}$ Om dezelfde redenen kan bij schade door niet-appellabele schadeoorzaken wel worden vastgehouden aan de huidige regeling van art. 4:129, aanhef en onder $d$ Awb: de rentetermijn vangt aan op het moment waarop een aanvraag om nadeelcompensatie is ingediend én de schade reeds is ingetreden.

Deze aanbeveling tot (a) wijziging van titel 4.5 Awb acht ik ook verenigbaar met de overige aan de Wns ten grondslag liggende doelstellingen en uitgangspunten. In paragraaf $5.8 \mathrm{zal}$ ik een concreet voorstel tot haar implementatie doen. Ten slotte geven de aan de Wns ten grondslag liggende doelstellingen en uitgangspunten mijns inziens geen aanleiding tot (b) wijziging van afd. $15.1 \mathrm{Ow}$ of (c) het anderszins voorzien in een bijzondere invulling, aanvulling of afwijking van titel 4.5 Awb.

\subsection{SCHADEBEGROTING}

In deze paragraaf zullen de tweede en derde deelvraag en de hoofdvraag worden beantwoord ten aanzien van de begroting van schade in de vorm van permanente waardedaling van onroerende zaken, inkomensderving, en tijdelijke derving van woongenot.

\subsubsection{Deelvraag 2: verschillen tussen de geselecteerde, thans geldende} regelingen en verklaringen daarvoor

\subsubsection{Permanente waardedaling van onroerende zaken}

Van de geselecteerde, thans geldende regelingen gaan slechts de Amsterdamse verordeningen expliciet in op de begroting van schade in de vorm van waardedaling van onroerende zaken:

193 ABRvS 27 juni 2012, ECLI:NL:RVS:2012:BW9537, r.o. 2.7.1, onder verwijzing naar ABRvS 12 december 2001, 200101227/1, StAB 2002/143, r.o. 2.5.

194 ABRvS 28 september 2016, ECLI:NL:RVS:2016:2582, r.o. 8 (Overzichtsuitspraak). 


\begin{abstract}
Art. 6 AVN
Indien de schade bestaat uit een lagere opbrengst bij de verkoop van een bedrijf of onroerende zaak, komt voor vergoeding in aanmerking het verschil tussen deze opbrengst, voor zover deze opbrengst reëel is te achten en de opbrengst die redelijkerwijze had kunnen worden verkregen, indien geen sprake was geweest van een nadelige invloed op de opbrengst door het schadeveroorzakend besluit of handeling.
\end{abstract}

\title{
Art. 6 VNNZ
}

1. Indien het nadeel bestaat uit een lagere verkoopprijs van een bedrijf of een onroerende zaak, wordt de omvang van dat nadeel bepaald door het verschil in de verkoopprijs wanneer geen sprake zou zijn geweest van de aanleg van de Noord/ Zuidlijn en de verkoopprijs tijdens de aanleg van de Noord/Zuidlijn.

2. Het verschil tussen de verkoopprijzen, komt voor nadeelcompensatie in aanmerking, mits uit een taxatie blijkt dat de verkoopprijs waarvoor het bedrijf of de onroerende zaak is verkocht, als een reële verkoopprijs daarvoor kan worden aangemerkt.

De bepaling uit de AVN is geïnspireerd op de bepaling uit de VNNZ. ${ }^{195}$ Verschillen in redactie tussen de bepalingen uit beide regelingen lijken te moeten worden verklaard door het algemenere karakter van de AVN. De toepassing van deze bepalingen is bij mijn weten nog niet aan een rechter voorgelegd. Uit de toelichting uit de AVN kan bovendien worden opgemaakt dat de bepaling uit de VNNZ niet vaak is toegepast. Dat kan worden verklaard doordat waardevermindering van onroerende zaken doorgaans onder afd. 6.1 Wro dient te worden afgedaan. ${ }^{196}$ Bovendien zijn de bepalingen uit de Amsterdamse verordeningen slechts toepasbaar op in waarde gedaalde onroerende zaken die na inwerkingtreding van de beweerde schadeoorzaak zijn verkocht. Uit de bij de regelingen behorende toelichtingen blijkt niet of waardevermindering van nog niet verkochte onroerende zaken voor vergoeding in aanmerking komt, en zo ja, hoe deze dient te worden begroot. Hoewel dat niet uit de tekst van de bepalingen volgt, ga ik ervan uit dat zij - conform de in paragraaf 5.2.1 besproken jurisprudentie ${ }^{197}$ - niet van toepassing zijn op tijdelijke waardedalingen van onroerende zaken. ${ }^{198}$

In de toelichting op de VNNZ wordt nauwelijks ingegaan op de toepassing van art. 6 VNNZ. Uit de toelichting op de AVN blijkt wel hoe art. 6 AVN dient te worden toegepast. Er wordt gezocht naar vergelijkbare referentieobjecten die buiten het werkingsgebied van de schadeoorzaak, maar wel in hetzelfde postcodegebied als de door aanvrager verkochte onroerende zaak zijn gelegen. Aan de hand van

195 Zie de toelichting op art. 6 AVN.

196 Zie de toelichting op art. 2 lid 5 AVN. Zie eveneens de toelichting op art. 3, eerste lid en onder f VNNZ.

197 Zie het kopje 'Het beperkte schadebegrip van afd. 6.1 Wro' voor de bespreking van ABRvS 30 november 2016, ECLI:NL:RVS:2016:3168, r.o. 6.3 (Wegafsluiting Hoevelaken). 
de prijzen die in dezelfde periode voor de referentieobjecten zijn betaald, wordt een gemiddelde prijs per vierkante meter vastgesteld. Deze prijs wordt vermenigvuldigd met het aantal vierkante meters dat de oppervlakte van de woning van de aanvrager beslaat. Na eventuele correcties gebaseerd op "kennis, ervaring en intuïtie van deskundigen" ontstaat de "referentieverkoopprijs". Het verschil tussen die referentieprijs en de daadwerkelijk verkregen verkoopprijs vormt in beginsel de schade.

In art. 3 lid 1 Verordening Nadeelcompensatie en Planschade Noord-Zuidlijn de voorloper van de VNNZ - waren enige regels opgenomen over de begroting van inkomensschade. ${ }^{199}$ De reden voor hun opname volgt uit de bijbehorende toelichting: in door het gemeentebestuur gevoerd maatschappelijk overleg werd "een duidelijke behoefte kenbaar (...) gemaakt aan duidelijkheid op voorhand omtrent de wijze van schadebegroting en de hoogte van de nadeelcompensatie." Deze duidelijkheid op voorhand moest in de praktijk echter niet tot problemen leiden. Daarom bepaalde art. 3 lid 3 Verordening Nadeelcompensatie en Planschade Noord-Zuidlijn dat de adviescommissie een "zo objectief mogelijke" andere begrotingsmethode diende toe te passen als het niet mogelijk was de schade te begroten conform de methode uit het eerste lid. ${ }^{200}$ Het is aannemelijk dat deze wens naar duidelijkheid op voorhand ook de reden is dat de huidige Amsterdamse verordeningen - anders de overige geselecteerde, thans geldende regelingen - ingaan op de begroting van schade (in de vorm van waardedaling van onroerende zaken).

\section{Tekst van de overige regelingen}

In de overige geselecteerde, thans geldende regelingen is geen wijze van schadebegroting voorgeschreven. In geval van de BnIW 2019 blijkt dit te kunnen worden verklaard door een bewuste keuze van de minister ten tijde van de totstandkoming van de RnVW 1999:

"Voor wat de wijze van schadebegroting betreft worden in deze nadeelcompensatieregeling geen regels gegeven. Dat zou gelet op de veelheid van schadeoorzaken en mogelijke schadegevolgen waarop deze regeling betrekking heeft niet alleen niet wel mogelijk zijn, doch bovendien zijn bij toepassing van deze regeling, net zoals dat bij wettelijke schadevergoedingsregelingen het geval is, al naar gelang de omstandigheden van het geval, meerdere methoden denkbaar met behulp waarvan in de praktijk de schade begroot kan worden. De schade dient dus te worden begroot op de wijze die het

199 Blijkens de bijbehorende toelichting waren deze regels geïnspireerd op de wijze van schadebegroting als voorgeschreven door de 'Willemsspoorregeling Rotterdam'.

200 Zie ook de toelichting op art. 2 Verordening Nadeelcompensatie en Planschade Noord-Zuidlijn onder het kopje 'Ad 4. Begroting van de schade'. 
meest met de aard ervan in overeenstemming is, terwijl zo nodig de omvang van de schade dient te worden geschat (art. 6:97 BW)." ${ }^{201}$

Dezelfde overweging is vrijwel letterlijk terug te vinden in het door de besliscommissie van het Schadeschap opgestelde Basisdocument. ${ }^{202} \mathrm{Zij}$ sluit goed aan bij de overweging uit de Overzichtsuitspraak dat bij het begroten van schades altijd keuzes moeten worden gemaakt:

"Het gaat erom dat die keuzes redelijk en aanvaardbaar zijn." Voor de beoordeling daarvan, kan bijvoorbeeld een rol spelen of de keuzes "duidelijk" en "controleerbaar" en daarmee goed gemotiveerd zijn. ${ }^{203}$

Dat in de tekst van de GrS niets is bepaald omtrent schadebegroting kan worden verklaard door de in paragraaf 3.2.1 beschreven, bijzondere aard van deze regeling: zij dient ertoe de reeds op grond van verschillende grondslagen bestaande - en aan verschillende bestuursorganen toekomende - bevoegdheden om nadeelcompensatie toe te kennen, binnen een specifieke context over te dragen aan het algemeen bestuur van het Schadeschap. Dat art. 49 WRO, art. 21 Aanwijzingsbesluit 1996 en art. 8.31 Wlv niets bepalen omtrent de begroting van schade, lijkt met name te worden verklaard doordat het ten tijde van de totstandkoming van deze regelingen nog niet gebruikelijk was om in nadeelcompensatieregelingen uit te werken wanneer aan de daarin vervatte redelijkerwijsformule werd voldaan. Bovendien is voor de formulering van zowel art. 21 Aanwijzingsbesluit 1996 als art. 8.31 Wlv aansluiting gezocht bij art. $49 \mathrm{WRO}$, en in geval van art. 8.31 Wlv ook bij art. 15.20 Wet Milieubeheer. ${ }^{204}$

De bij de Wro behorende Kamerstukken bevatten geen informatie omtrent schadebegroting. Een expliciete verklaring voor het ontbreken van bepalingen omtrent schadebegroting in afd. 6.1 Wro heb ik daarom niet kunnen vinden. Een potentiële verklaring zou kunnen zijn dat het bestuur op grond van art 6.1.3.2 Bro verplicht advies moet inwinnen bij een adviseur, die ingevolge art. 6.1.3.4 lid 1, aanhef en onder b Bro ook advies dient te geven over de omvang van de schade. ${ }^{205}$ Wellicht was de wetgever van mening dat die adviseur zelf in staat moest worden geacht

201 Stcrt. 1999, nr. 172, p. 9 (digitaal, p. 5). Een deels vergelijkbare opmerking is aan te treffen in de toelichting op art. 2 Verordening Nadeelcompensatie en Planschade Noord-Zuidlijn onder het kopje 'Ad 4. Begroting van de schade'.

202 Basisdocument, p. 22.

203 Zie ABRvS 28 september 2016, ECLI:NL:RVS:2016:2582, r.o. 4 (Overzichtsuitspraak); en ABRvS 16 december 2015, ECLI:NL:RVS:2015:3819, r.o. 5 (Urilift, einduitspraak).

204 Zie Stcrt. 1998, nr. 223, p. 11 (digitaal) respectievelijk Kamerstukken II 00/01, 27 603, nr. 3, p. 69 en 15.

205 Zie hierover paragrafen 10.6.1 en 10.8.1. Een vergelijkbare verklaring ging ook op voor de RnVW 1999 en BnIM 2014, maar niet voor de BnIW 2019. Vergelijk art. 14 lid 3 jo. art. 15 lid 1 BnIW 2019 en de bespreking daarvan in paragraaf 10.6.1. 
om tot een degelijke schadebegroting te komen. ${ }^{206}$ Verder sluit ik niet uit dat de verklaring die werd aangevoerd ten aanzien van de BnIW 2019 ook opgaat voor de Wro: codificatie van één begrotingsmethode is niet goed mogelijk, mede omdat het afhankelijk is van de omstandigheden van het individuele schadegeval welke methoden (het best) kunnen worden toegepast.

\section{De vergelijkingsmethode}

De Afdeling heeft sinds 2005 herhaaldelijk geoordeeld dat op een aanvraag om compensatie wegens schade door (onderdelen van) besluiten die planologisch van aard zijn maar niet in art. 6.1 lid 2 Wro worden genoemd, zoals tracébesluiten en wegaanpassingsbesluiten, toch de criteria voor planschadetegemoetkoming van afd. 6.1 Wro van toepassing zijn. ${ }^{207}$ Juist omdat het vaak de besluiten van planologische aard zijn die permanente waardedalingen van onroerende zaken veroorzaken, lijken aanvragen om dergelijke schade zelden te worden behandeld volgens de inhoudelijke criteria van de BnIW 2019. In de gevallen waarin dat wel gebeurt, lijkt voor wat betreft de schadebegroting te worden aangesloten bij de in het planschaderecht veel gebruikte 'vergelijkingsmethode'. ${ }^{208}$

Het is vaste planschadejurisprudentie dat bij de bepaling van de waardevermindering van een onroerende zaak maatgevend is welke prijs een redelijk denkend en handelend koper onmiddellijk voor de inwerkingtreding ${ }^{209}$ van het nieuwe planologische regime en op het tijdstip direct daarna voor de beweerdelijk in waarde gedaalde onroerende zaak zou hebben geboden, uitgaande van hetgeen maximaal op grond van het oude en nieuwe planologische regime kon worden gerealiseerd. ${ }^{210}$ De zogenoemde vergelijkingsmethode achterhaalt de prijs die een redelijk denkend en handelend koper voor én na de peildatum bereid is te betalen door de prijs van referentieobjecten te bestuderen. Deze referentieobjecten moeten vergelijkbaar zijn met de te taxeren onroerende zaak qua ligging, grootte, kwaliteit, bouwjaar et cetera. Vaak wordt het gemiddelde van de daadwerkelijke verkoopwaardes van deze referentieobjecten 'teruggerekend' naar de peildatum in kwestie. ${ }^{211}$ Hierbij wordt niet veel waarde gehecht aan de WOZ-waarde van de onroerende zaak.

206 Dat de bepaling van de schadeomvang als complex en typisch iets voor deskundigen wordt gezien, volgt ook uit de toelichting op de BnIW 2019; zie Stcrt. 2019, nr. 66154, p. 14.

207 Zie hierover Huijts \& Tjepkema 2017, p. 301.

208 Zie bijvoorbeeld ABRvS 16 mei 2012, ECLI:NL:RVS:2012:BW5932, r.o. 2.7.1.12.7.1.2 (Benzinestation gemeente Hulst, tussenuitspraak).

209 De datum van inwerkingtreding van de schadeoorzaak vormt ook onder de BnIW 2019 de peildatum, zie ABRvS 16 mei 2012, ECLI:NL:RVS:2012:BW5932, r.o. 2.4-2.4.1 (Benzinestation gemeente Hulst, tussenuitspraak). Zie voor het overige nadeelcompensatierecht bijvoorbeeld Tjepkema 2010, p. 314-316.

210 ABRvS 28 september 2016, ECLI:NL:RVS:2016:2582, r.o. 4.6 (Overzichtsuitspraak).

211 Van Ravels 2011c, p. 147. 
Die waarde wordt namelijk niet vastgesteld aan de hand van een vergelijking van planologische mogelijkheden, maar hoofdzakelijk gebaseerd op de feitelijke situatie. ${ }^{212} \mathrm{Na}$ de peildatum betaalde verkoopprijzen kunnen volgens de Afdeling "niet zonder meer buiten beschouwing worden gelaten, nu deze onder omstandigheden een indicatie kunnen geven van wat een goed geïnformeerde, redelijk denkend en handelend koper op de peildatum bereid zou zijn geweest te betalen." ${ }^{213}$ De prijs die de aanvrager daadwerkelijk voor zijn onroerende zaak heeft ontvangen, is echter lang niet altijd relevant, omdat deze het resultaat kan zijn van "allerlei andere factoren, waarin geen inzicht bestaat." ${ }^{214}$ Het valt op dat de Amsterdamse begrotingsmethode overeenkomsten met deze vergelijkingsmethode vertoont. Het grootste verschil lijkt te zijn dat de bepalingen uit de Amsterdamse verordeningen meer belang toekennen aan de daadwerkelijk verkregen koopprijs. Dat lijkt te kunnen worden verklaard doordat deze bepalingen zijn geschreven met het oog op situaties waarin de onroerende zaak daadwerkelijk is verkocht.

De vergelijkingsmethode kent (minimaal) twee pijnpunten. Allereerst is het niet altijd mogelijk om geschikte referentieobjecten te vinden. Dit wordt geïllustreerd door een uitspraak van 16 mei 2012, waarin de Afdeling accepteerde dat de waardedaling van een tankstation werd bepaald met behulp van de 'Taxatiewijzer Motorbrandstofverkooppunten van het landelijk Taxatie Overleg'. Daarbij was doorslaggevend dat de door de Afdeling geraadpleegde StAB adviseerde dat...

“(..) het lastig is om de marktwaarde van een tankstation op basis van de gebruikelijke vergelijkingsmethode vast te stellen gelet op het relatief beperkte aantal verkoop- en verhuurtransacties en het mogelijke gebrek aan representativiteit ervan, alsmede de monopolieposities van bepaalde marktpartijen en overheden (...). ${ }^{215}$

Een ander veel gehoord punt van kritiek op de vergelijkingsmethode wordt door Van Ravels als volgt samengevat:

“(..) het is buitengewoon lastig een relatie te leggen tussen feitelijke transactieprijzen en hetgeen een goed geïnformeerde, redelijk denkend en handelend koper op de peildatum bereid zou zijn geweest te betalen voor een bepaalde onroerende zaak, mét en zonder de beweerdelijk schadeveroorzakende planologische maatregel. Het verschil

212 ABRvS 28 september 2016, ECLI:NL:RVS:2016:2582, r.o. 4.7 (Overzichtsuitspraak).

213 ABRvS 5 december 2007, ECLI:NL:RVS:2007:BB9458, r.o. 2.5.1. Zie voor een onder de GrS gewezen uitspraak waarin art. 49 WRO de achterliggende grondslag voor compensatie vormde: ABRvS 19 november 2014, ECLI:NL:RVS:2014:4193, r.o. 7.

214 ABRvS 3 november 2010, ECLI:NL:RVS:2010:BO2722, r.o. 2.3.1.

215 ABRvS 16 mei 2012, ECLI:NL:RVS:2012:BW5932, r.o. 2.7.1.1 en 2.7.1.2 (Benzinestation gemeente Hulst, tussenuitspraak). 
tussen theorie en feiten wordt veelal overbrugd door de - lastig te objectiveren - deskundigheid, ervaring en intuïtie van deskundigen." 216

Dit beeld wordt bevestigd door de praktijk van planschadeadviseurs. ${ }^{217}$

\section{De schadefactorenmethode}

Dat de vergelijkingsmethode niet altijd even goed toepasbaar is, heeft ertoe geleid dat een tweede begrotingsmethode is ontstaan in de planschadepraktijk. Deze zogenoemde 'schadefactorenmethode" ${ }^{218}$ heeft als voordeel dat slechts een geschikt referentieobject voor óf na de peildatum dient te worden gevonden. Aan de hand daarvan wordt een 'ankerwaarde' vastgesteld. Vervolgens worden de aanwezige schadefactoren (bijvoorbeeld geluidstoename of vermindering van privacy) en de ernst (beperkt tot zeer ingrijpend) daarvan geïnventariseerd om te worden gebundeld tot een kwalitatief schadeoordeel (variërend van lichte tot bovenmatige schade), waaraan een bepaald percentage aan waardevermindering (bijvoorbeeld 1 tot 4 procent voor lichte schade) wordt ontleend. Door dit percentage te vermenigvuldigen met de ankerwaarde kan de waardevermindering in geld worden berekend. Zag de ankerwaarde op de onroerende zaak onder het oude planologische regime, dan dient de berekende waardevermindering hiervan te worden afgetrokken om de marktwaarde onder het nieuwe regime te berekenen. Zag de ankerwaarde op de onroerende zaak onder het nieuwe planologische regime, dan dient de berekende waardevermindering hierbij te worden opgeteld om de marktwaarde onder het oude regime te berekenen. ${ }^{219}$

Het nadeel van deze methode is dat de waardes van de onroerende zaak vóór en na de peildatum niet onafhankelijk van elkaar worden vastgesteld. Door de wijze waarop de planschadeadviesbureaus hun adviezen motiveren, blijkt dit volgens Nentjes echter niet altijd even duidelijk uit de motivering van het planschadebesluit en de daaraan ten grondslag liggende deskundigenadviezen. De Afdeling zou zich volgens Nentjes mede daardoor nooit expliciet hebben uitgelaten over de toelaatbaarheid van deze wijze van vaststelling van marktwaarden, waardoor de schadefactorenmethode inmiddels een "gangbare werkwijze" is geworden. Nentjes is van mening dat de schadefactorenmethode strijdig is met de methode van begroting die "zo dicht mogelijk aansluit bij de definitie" van planschade, waarvoor de Afdeling herhaaldelijk haar voorkeur zou hebben uitgesproken. ${ }^{220} \mathrm{Hij}$ verwijst daarbij niet naar uitspraken, maar ik neem aan dat Nentjes hiermee doelt

216 Van Ravels 2011c, p. 147-148.

217 Zie bijvoorbeeld Van Montfoort 2010, p. 94.

218 Zie in algemene zin over deze methode Nentjes 2008 en Nentjes 2010, en de discussie die met hem wordt aangegaan in Van Ravels 2009c, p. 23-24 en Van Montfoort 2010.

219 Nentjes 2010, p. 25. Dit gedeelte is deels geparafraseerd en deels geciteerd. Ter bevordering van de leesbaarheid zijn aanhalingstekens achterwege gelaten. Nentjes 2010, p. 25-26. 
op de eerder aangehaalde overweging dat maatgevend is welke prijs een redelijk denkend en handelend koper onmiddellijk voor de inwerkingtreding van het nieuwe planologische regime en op het tijdstip direct daarna voor de onroerende zaak zou hebben geboden. ${ }^{221}$ Eveneens is denkbaar dat Nentjes doelde op jurisprudentie waarin het gebruik van percentages gekoppeld aan een kwalitatief schadeoordeel werd gesanctioneerd, omdat deze percentages slechts de rol van controlemiddel vervulden. ${ }^{222}$ Ook Van den Broek spreekt van een "methode die in de praktijk wel wordt toegepast, maar geen grondslag vindt in de jurisprudentie." 223

\section{De GrS}

Naar aanleiding van zijn kritiek heeft Nentjes voorstellen gedaan om de schadefactorenmethode meer "transparant, objectief en controleerbaar" te maken, hetgeen zou meebrengen dat de begrote schade dichter in de buurt zou komen te liggen van de daadwerkelijk geleden schade. Een van Nentjes' voorstellen is om aan de hand van empirisch onderzoek de waardedrukkende invloed van iedere schadefactor vast te stellen. Concreet zou dat bijvoorbeeld betekenen dat per decibel toename van geluidsoverlast of per lux vermindering van lichtinval een bepaald percentage waardevermindering wordt aangenomen. ${ }^{224}$ Een dergelijke benadering wordt thans al gehanteerd onder de GrS. Onder die regeling wordt doorgaans namelijk de maatstaf van $1 \%$ waardedaling per toename van 1 Ke geluidsbelasting ${ }^{225}$ gehanteerd. ${ }^{226}$ Deze maatstaf is gebaseerd op empirisch onderzoek dat door de Afdeling als "uitvoerig onderzoek" werd gekwalificeerd. ${ }^{227}$

Op 5 juli 2018 oordeelde de rechtbank Noord-Holland dat deze maatstaf "uiteraard zeer behulpzaam kan zijn" bij het bepalen van de prijs die een redelijk denkend en handelend koper onmiddellijk voor de inwerkingtreding van de planologische wijziging en op het tijdstip direct daarna voor een woning of perceel zou hebben geboden. ${ }^{228}$ Een dergelijke maatstaf zou echter "een hulpmiddel [blijven] dat niet voor alle situaties bruikbaar is." Bijzondere omstandigheden kunnen daarom ma-

221 ABRvS 28 september 2016, ECLI:NL:RVS:2016:2582, r.o. 4.6 (Overzichtsuitspraak).

222 ABRvS 16 december 2013, ECLI:NL:RVS:2013:916, r.o. 5.1 (Raalte). Zie hierover bijvoorbeeld ook Van Ravels 2009c, p. 24.

223 Van den Broek 2012, p. 442 e.v.

224 Nentjes 2010, p. 28-30 in combinatie met Nentjes 2008, p. 2363-2364.

225 Zie over de vaststelling van de geluidsbelasting Basisdocument, p. 26.

226 Eerst hanteerde de besliscommissie een ondergrens van $35 \mathrm{Ke}$, maar de Afdeling achtte die onvoldoende gemotiveerd. Zie ABRvS 5 december 2007, ECLI:NL:RVS:2007:BB9458, r.o. 2.5.1.

227 Zie ABRvS 10 november 2010, ECLI:NL:RVS:2010:BO3436, r.o. 2.8-2.8.1 en 2.14; enABRvS 18 november 2015, ECLI:NL:RVS:2015:3493, r.o. 4.1-4.2.

228 Vergelijk ABRvS 28 september 2016, ECLI:NL:RVS:2016:2582, r.o. 4.6 (Overzichtsuitspraak). 
ken dat van toepassing van deze maatstaf dient te worden afgezien. ${ }^{229}$ Aan deze uitspraak lijkt een vergelijkbare gedachte ten grondslag te liggen als aan een uitspraak van 11 mei 2011 waarin de Afdeling sanctioneerde dat de besliscommissie bij schade door het Aanwijzingsbesluit 1996 niet de hiervoor besproken maatstaf hanteerde, maar een maatstaf van $1 \%$ tot $6 \%$ waardedaling per 5 Ke toename in geluidbelasting. Naast het verbod van reformatio in peius, speelde daarbij een rol dat het causaal verband tussen het Aanwijzingsbesluit 1996 en de hierdoor veroorzaakte schade op een andere wijze dan gebruikelijk wordt vastgesteld. In paragraaf 4.2.3.2 bleek de reden daarvoor: pas na circa 18 jaar voldeed de minister met dit besluit aan zijn plicht om degelijke geluidsnormering vast te stellen. ${ }^{230}$

\subsubsection{Inkomensderving}

Van de geselecteerde, thans geldende regelingen gaan slechts de Amsterdamse verordeningen in op de begroting van inkomensschade:

\section{Art. 4 AVN}

1. Indien de schade bestaat uit winst- of inkomstenderving, wordt de omvang daarvan in beginsel bepaald door:

a. de gemiddelde omzet gedurende een periode van zo mogelijk drie jaar te vergelijken met de omzet in het jaar waarin de schade is geleden. Daarbij wordt een inflatiecorrectie toegepast en waar mogelijk een branchecorrectie of een trendcorrectie;

b. van de vastgestelde gemiste omzet worden afgetrokken de kosten van het product of de dienst alsmede de kosten die ten gevolge van de omzet- of inkomstenderving bespaard zijn of redelijkerwijs bespaard hadden kunnen worden.

2. Indien sprake is van omzetverplaatsing wordt dat bij de vaststelling van de winst- of inkomstenderving in aanmerking genomen.

\section{Art. 4 VNNZ}

1. Indien het nadeel bestaat uit winstderving, wordt de omvang van het nadeel bepaald door de gemiddelde omzet of winst gedurende een in beginsel op vijf jaar te stellen en aan een schadejaar voorafgaande referentieperiode te vergelijken met de omzet of winst behaald tijdens het schadejaar.

2. Indien binnen de referentieperiode eerdere schadejaren vallen, worden de cijfers van deze schadejaren waar nodig gecorrigeerd conform de inzake die schadejaren reeds genomen collegebesluiten, teneinde een uit deze schadejaren voortvloeiende negatieve invloed op de omzet- of winstverwachting voor het te beoordelen schadejaar te elimineren.

229 Rb. Noord-Holland 5 juli 2018, ECLI:NL:RBNHO:2018:6314, r.o. 9.4.

230 Zie voor een samenvatting van relevante jurisprudentie: ABRvS 18 november 2015, ECLI:NL:RVS:2015:3493, r.o. 4.1-4.2. Zie tevens ABRvS 10 november 2010, ECLI:NL:RVS:2010:BO3436, r.o. 2.8-2.8.1; en ABRvS 11 mei 2011, ECLI:NL:RVS:2011:BQ4066, r.o. 2.3. 
3. Indien sprake is van een naar het oordeel van het college significante stijging van de omzet of winst in de laatste jaren van de referentieperiode voorafgaand aan het eerste schadejaar en de redelijke verwachting bestaat dat deze stijging zich in de daarop volgende jaren voortzet, kan worden afgeweken van het uitgangspunt dat de gemiddelde omzet in een referentieperiode waarin schadejaren vallen, bepalend is voor de te verwachten omzet in de schadeperiode.

4. De cijfers uit de referentieperiode worden gecorrigeerd met een inflatiecorrectie, waarbij als inflatiecorrectie de consumentenprijsindex van het Centraal Bureau voor de Statistiek wordt gebruikt.

5. Het aldus verkregen resultaat, wordt gecorrigeerd aan de hand van ontwikkelingen in de branche waarin de aanvrager werkzaam is of, bij gebreke van bruikbare gegevens daaromtrent, aan de hand van ontwikkelingen binnen het bedrijf van de aanvrager of binnen het concern waartoe het bedrijf van de aanvrager behoort.

6. Indien gegevens als bedoeld in het vijfde lid ontbreken, wordt op de omzet in het schadejaar een inflatiecorrectie toegepast, waarbij als inflatiecorrectie de consumentenprijsindex van het Centraal Bureau voor de Statistiek wordt gebruikt.

7. Uit het gecorrigeerde resultaat van het vijfde of het zesde lid wordt afgeleid of, en zo ja in hoeverre, van een door de aanleg van de Noord/Zuidlijn veroorzaakte winstderving sprake is.

8. Indien de nadeelcompensatie niet kan worden bepaald aan de hand van de winstderving, bepaalt de adviescommissie een zo objectief mogelijke andere methode op grond waarvan de nadeelcompensatie kan worden vastgesteld.

Hoewel de bepaling uit de VNNZ gedetailleerder is, komen de voorgeschreven methoden van schadebegroting grotendeels overeen. Dat laat onverlet dat ook enkele verschillen bestaan. Zo gaat de AVN in beginsel uit van een referentieperiode van drie jaar, terwijl de VNNZ uitgaat van een referentieperiode van vijf jaar. Ook laat de VNNZ explicieter ruimte voor correcties, bijvoorbeeld doordat zij verdisconteert dat de referentieperiode deels kan samenvallen met eerdere schadejaren. Tevens wordt er rekening gehouden met de verwachting dat een "significante stijging van de omzet of winst in de laatste jaren van de referentieperiode voorafgaand aan het eerste schadejaar" zich voortzet in het schadejaar. De AVN laat die ruimte slechts impliciet doordat art. 4 AVN bepaalt dat de schadeomvang "in beginsel" op de door het artikel voorgeschreven wijze wordt bepaald. Ik heb geen verklaringen voor deze verschillen kunnen vinden.

\section{De overige regelingen}

Uit paragraaf 5.7.1.1 volgde dat afd. 6.1 Wro, de BnIW 2019 en (de achterliggende grondslagen voor toekenning van nadeelcompensatie onder) de GrS niet ingaan op de begroting van schade. Tevens werd in die paragaaf ingegaan op de verklaringen die hiervoor kunnen worden aangedragen. Hoe inkomensschade onder deze regelingen wordt begroot, lijkt daarom met name te moeten worden opgemaakt uit de onder deze regelingen verschenen jurisprudentie. Die jurisprudentie schept echter 
het beeld dat onder afd. 6.1 $\mathrm{Wro}^{231}$ en de $\mathrm{GrS}^{232}$ nauwelijks (succesvolle) aanvragen om compensatie van inkomensschade worden ingediend. ${ }^{233}$ Dat lijkt anders te zijn onder de BnIW 2019. Ook de onder deze regeling en zijn voorlopers gewezen jurisprudentie schept echter geen volledig beeld. Doorgaans wordt daarin namelijk niet de hele schadeberekening aan de rechter voorgelegd, maar slechts één of enkele aspecten daarvan. Van Ravels deed in 2009 een vergelijkbare constatering: "in de rechtspraak van de Afdeling bestuursrechtspraak wordt zelden uitvoerig ingegaan op de vaststelling van inkomensschade." ${ }^{234}$

Uit de literatuur kan wel een volledig beeld van de methode van begroting van inkomensschade in het planschaderecht worden gedestilleerd. Volgens Van Ravels bestaat het begrotingsproces uit drie fasen. Allereerst wordt de brutowinstderving berekend. Daartoe wordt eerst de omzetderving bepaald door de daadwerkelijk na de planologische maatregel gedraaide omzet te vergelijken met de omzet die zou zijn gedraaid als deze maatregel niet was genomen. Laatstgenoemde, hypothetische omzet wordt gebaseerd op de omzet die in de drie of vijf aan de planologische maatregel voorafgaande referentiejaren is gedraaid. Vaak wordt hierop nog een branche- en/of inflatiecorrectie toegepast. De uit deze vergelijking volgende omzetderving wordt vervolgens vermenigvuldigd met een brutowinstpercentage. ${ }^{235}$ In de tweede fase worden "besparingen op de vaste kosten en andere voordelen" verrekend met de brutowinst. In de derde fase worden "eventuele extra kosten ter voorkoming of beperking van de schade in de beoordeling betrokken." Het uiteindelijke resultaat is de nettowinstderving. De nettowinstderving bestaat dus kortgezegd uit "de brutowinstderving verminderd met de bespaarde vaste kosten, maar vermeerderd met de extra kosten." ${ }^{236}$

De eerste twee fasen zijn ook te herkennen in de bepalingen uit de Amsterdamse verordeningen. Dat de derde fase daarin niet voorkomt, lijkt te kunnen worden verklaard doordat deze verordeningen afzonderlijke bepalingen kennen voor de vergoeding van kosten van schadebeperkende maatregelen. ${ }^{237}$ Afgaande op de rechterlijke uitspraken die zijn gewezen onder de voorlopers van de BnIW 2019 lijkt de door Van Ravels beschreven methode ook onder de BnIW 2019 te worden gehanteerd. Uit deze uitspraken kan namelijk onder andere worden afgeleid dat een vergelijking dient te worden gemaakt tussen de schadeperiode en een refe-

231 Een uitzondering betreft ABRvS 16 december 2015, ECLI:NL:RVS:2015:3819, r.o. 5 (Urilift, einduitspraak).

232 ABRvS 27 september 2017, ECLI:NL:RVS:2017:2600, r.o. 15-16.

233 Zie paragraaf 3.4.2.4 onder het kopje 'Schaduwschade en ondernemers'; en Dijkshoorn 2011a, p. 47. Dit zou overigens een aanvullende verklaring kunnen zijn waarom afd. 6.1 Wro niet ingaat op de begroting van inkomensschade.

234 Van Ravels 2009b, p. 122.

235 Brutowinst bestaat uit de opbrengst uit bedrijfsactiviteiten minus variabele kosten.

236 Van Ravels 2009b, p. 122. Zie over de begroting van inkomensschade in het planschaderecht bijvoorbeeld ook Dijkshoorn 2011a, p. 133-134.

237 Zie paragraaf 5.4.1. 
rentieperiode die enkele jaren beslaat, ${ }^{238}$ en gewoonlijk drie tot vijf jaar blijkt te zijn. ${ }^{239}$ Tevens wordt rekening gehouden met factoren die de omvang van de schade kunnen beperken. ${ }^{240}$ Daarbij kan worden gedacht aan de mogelijkheid om de bedrijfsvoering ongewijzigd voort te zetten, en dus ongewijzigd inkomen te kunnen verdienen, gedurende de periode van besluitvorming tot feitelijke uitvoering daarvan. ${ }^{241}$ Bovendien is de door Van Ravels beschreven methode verenigbaar met de passage over begroting van inkomensschade die is opgenomen in de Handleiding nadeelcompensatie. ${ }^{242}$ Deze handleiding vormde de directe aanleiding voor wijziging van de BnIM 2014. ${ }^{243}$

Aangezien de beperkte informatie over schadebegroting uit de toelichting op de RnVW 1999 rechtstreeks is overgenomen in het Basisdocument, lijkt het onwaarschijnlijk dat de besliscommissie een andere methode zou hanteren bij toepassing van de GrS. Ook buiten de context van de door mij onderzochte regelingen lijkt deze methode breed te worden gedragen. Ten aanzien van de eerste fase spreekt de Afdeling zelfs van "een binnen het stelsel van nadeelcompensatie gangbare en door de Afdeling geaccepteerde methode om de schade te berekenen." ${ }^{244}$ Dat geldt waarschijnlijk ook voor de andere fases, maar die vormden in de desbetreffende uitspraken geen onderdeel van het geschil.

\section{Huurderving en andere specifieke vormen van inkomensschade}

In de Amsterdamse verordeningen blijken ook bepalingen te zijn opgenomen over de begroting van huurderving, een bijzondere vorm van inkomensschade:

\section{Art. 5 AVN}

1. Indien de schade bestaat uit gederfde huurinkomsten, wordt de omvang daarvan bepaald door het verschil tussen de huurprijs, die redelijkerwijs had kunnen worden gevraagd indien er geen sprake was van een schadeveroorzakend besluit of hande-

238 ABRvS 10 juli 2013, ECLI:NL:RVS:2013:192, r.o. 11.

239 Drie jaar: ABRvS 10 juli 2013, ECLI:NL:RVS:2013:192, r.o. 11; Rb. Haarlem 19 april 2012, ECLI:NL:RBHAA:2012:BW5717, r.o. 2.5.2 (Bodyfashion Zwanenburg, eerste aanleg); en ABRvS 25 september 2013, ECLI:NL:RVS:2013:1222, r.o. 5.3 (Bodyfashion Zwanenburg, hoger beroep). Vijf jaar: ABRvS 11 februari 2015, ECLI:NL:RVS:2015:336, r.o. 4.3 (Fietstunnel Rijksweg 7 bij Sneek).

240 Stcrt. 2014, nr. 16584, p. 5-6.

241 ABRvS 12 oktober 2011, ECLI:NL:RVS:2011:BT7434, r.o. 2.4.

242 Handleiding nadeelcompensatie, p. 104 e.v.

243 Stcrt. 2019, nr. 66154, p. 5.

244 ABRvS 15 juni 2016, ECLI:NL:RVS:2016:1650, r.o. 11 (Nadeelcompensatie Eindhoven/AH Cassandraplein). Zie eveneens Rb. Midden-Nederland 2 september 2016, ECLI:NL:RBMNE:2016:4828, r.o. 15. Het hier relevante deel van het oordeel van de rechtbank werd niet bestreden in hoger beroep, zie ABRvS 25 oktober 2017, ECLI:NL:RVS:2017:2902, r.o. 5.4-5.5. 
ling en de huurprijs die redelijkerwijs kan worden gevraagd in de situatie waarin daarvan wel sprake is.

2. Niet voor schadevergoeding komen in aanmerking de gederfde huurinkomsten gedurende de periode waarin onroerende zaken in de omgeving van het verhuurde, gemiddeld leeg staan.

\section{Art. 5 VNNZ}

1. Indien het nadeel bestaat uit gederfde huurinkomsten, wordt de omvang van het nadeel bepaald door het verschil tussen de huurprijs die zou kunnen worden gevraagd indien geen sprake was van de aanleg van de Noord/Zuidlijn en de huurprijs die redelijkerwijs kan worden gevraagd in de situatie met de aanleg van de Noord/ Zuidlijn.

2. De gevolgen van een binnen de vastgoedmarkt in Amsterdam tijdens de schadeperiode gebruikelijke leegstandperiode kunnen bij het vaststellen van het verschil, bedoeld in het eerste lid, betrokken worden.

3. Voor nadeelcompensatie komt het verschil tussen de twee huurprijzen, bedoeld in het eerste lid, en na toepassing van het tweede lid, in aanmerking.

De bepaling uit de AVN is geïnspireerd op de bepaling uit de VNNZ. ${ }^{245}$ Verschillen in redactie lijken met name te worden verklaard doordat de AVN een breder toepassingsbereik heeft dan de VNNZ. Uit de Handleiding nadeelcompensatie volgt dat soms met dit soort meer specifieke methoden van schadebegroting kan worden volstaan als de inkomensschade enkel bestaat uit de derving van één specifieke soort inkomsten, of alleen bestaat uit een toename van kosten. ${ }^{246}$ Het is niet onaannemelijk dat in dergelijke gevallen ook onder de overige geselecteerde, thans geldende regelingen voor dit soort meer specifieke methoden wordt gekozen - in plaats van voor de hiervoor beschreven drie-fasen-methode.

\section{Kapitalisatie}

Zowel in het planschaderecht- als het nadeelcompensatierecht is het gebruikelijk om jaarlijks terugkerende (inkomens)schade ineens te compenseren. Daartoe wordt het schadebedrag in het jaar waarop de aanvraag ziet, vermenigvuldigd met bepaalde kapitalisatiefactoren. ${ }^{247}$ Joling stelt dat een factor 10 gebruikelijk is in het planschaderecht. ${ }^{248}$ Ook onder de BnIW 2019 lijkt dit de te hanteren factor

245 Zie de toelichting op art. 5 AVN. De bepaling uit de VNNZ is geïnspireerd op de methode van schadebegroting die de Schadecommissie Noord/Zuidlijn heeft ontwikkeld. Zie daarover de eerste alinea van de algemene toelichting op de VNNZ; de toelichting op art. 5 VNNZ; en Rb. Amsterdam 5 november 2010, ECLI:NL:RBAMS:2010:BP2179 (JSA/Amsterdam).

246 Handleiding nadeelcompensatie, p. 94.

247 Zie in algemene zin bijvoorbeeld Dijkshoorn 2011a, p. 134.

248 Joling 2005, p. 211. 
te zijn. ${ }^{249}$ Is de benadeelde echter geen eigenaar, maar erfpachter ${ }^{250}$ of huurder ${ }^{251}$ dan wordt een factor van 9 respectievelijk 7 toegepast. Het gebruik van een kapitalisatiefactor heeft tot voordeel dat wordt voorkomen dat ieder jaar een nieuwe aanvraag om compensatie dient te worden ingediend. Ik heb geen aanleiding om aan te nemen dat deze factoren principieel uiteenlopend zouden worden toegepast naar gelang de van toepassing zijnde nadeelcompensatieregeling. Wel lijkt het Amsterdamse gemeentebestuur geen voorstander te zijn van het ineens compenseren van terugkerende schade door de aanleg van de Noord/Zuidlijn. Volgens art. 11 lid 1 VNNZ en de daarbij behorende toelichting dient namelijk per schadejaar een aanvraag om nadeelcompensatie te worden ingediend. Ik vermoed dat dit kan worden verklaard doordat lange tijd onzekerheid heeft bestaan over de tijd die de aanlegwerkzaamheden nog in beslag zouden nemen. ${ }^{252}$ Dat laat onverlet dat dergelijke onzekerheden in beginsel niet in de weg hoeven te staan aan een afrekening ineens door toepassing van een kapitalisatiefactor. ${ }^{253}$

\subsubsection{Tijdelijke derving van woongenot}

Uit paragraaf 5.7.1.1 volgde dat afd. 6.1 Wro, de BnIW 2019 en (de achterliggende grondslagen voor toekenning van nadeelcompensatie onder) de GrS niet ingaan op de begroting van schade. Ook werd in die paragraaf besproken hoe dit kan worden verklaard. Ten aanzien van afd. 6.1 Wro kan als aanvullende verklaring worden aangedragen dat een tijdelijke derving van woongenot onder deze regeling niet tot compensatie kan leiden. Art. 6.1 Wro voorziet immers slechts in de compensatie van schade in de vorm van waardevermindering van een onroerende zaak of inkomensderving. ${ }^{254}$

Uit de onder de BnIW 2019 verschenen jurisprudentie kan niet worden opgemaakt hoe schade in de vorm van tijdelijk gederfd woongenot wordt begroot. In de meeste uitspraken wordt namelijk geoordeeld dat de benadeelde niet of onvoldoende aannemelijk heeft gemaakt dat de geleden schade het normaal maatschappelijk risico ontstijgt, óf niet dan wel onvoldoende heeft "onderbouwd waaruit de specifieke overlast zou hebben bestaan, die maakt dat er gelet op de aard en de ernst van

249 Zie bijvoorbeeld ABRvS 27 juni 2007, ECLI:NL:RVS:2007:BA8139, r.o. 2.4 en 2.6.1.

250 ABRvS 12 oktober 2011, ECLI:NL:RVS:2011:BT7434, r.o. 2.4.

251 Van den Broek 2002, p. 56.

252 Zie daarover ook paragraaf 8.2.1.2 onder het kopje 'De tabel uit de VNNZ'.

253 Zie Van Mierlo \& Van Ravels 2011 over de rol van onzekerheden bij toepassing van een kapitalisatiefactor. Zie in meer algemene zin over kapitalisatiefactoren ook Van Mierlo 2014.

254 Zie uitgebreider hierover paragraaf 5.2.1 onder het kopje 'Het beperkte schadebegrip van afd. 6.1 Wro'. 
die overlast aanleiding zou bestaan de tijdelijke schade te vergoeden." 255 In een enkele zaak heeft de minister wel compensatie toegekend voor deze schadesoort maar blijkt niet hoe de schade is begroot. ${ }^{256}$ Door mijn voormalige werkzaamheden voor het Infopunt Schade A2 Maastricht is mij echter bekend dat Rijkswaterstaat dit soort schade bij toepassing van de BnIW 2019 begrootte conform de huurwaardemethode, ook wel methode van huurwaardevergelijking genoemd. Deze methode wordt onder andere beschreven in de 'Kennisgids 1. Schadevergoeding bij rechtmatig overheidshandelen', die is uitgegeven onder verantwoordelijkheid van de Raad voor Vastgoed Rijksoverheid. Uit de kennisgids blijkt dat deze methode is geïntroduceerd bij grote projecten - zoals de aanleg van de Betuweroute en HSL-Zuid. Zij gaat uit van "het verschil tussen de huuropbrengst per tijdseenheid met en zonder de schadeveroorzakende maatregel, vermenigvuldigd met het aantal tijdseenheden dat de overlast heeft geduurd." ${ }^{257}$ Uit de kennisgids blijkt niet hoe deze huuropbrengst wordt vastgesteld. Bij de ondertunneling van de A2 te Maastricht pleegde Rijkswaterstaat hiervoor aansluiting te zoeken bij het VROMpuntenstelsel. Dit is een door het ministerie van Volkshuisvesting, Ruimtelijke Ordening en Milieubeheer (VROM) ${ }^{258}$ als onderdeel van het Besluit huurprijzen woonruimte ontwikkeld waarderingsstelsel voor zelfstandige woonruimten. Het stelsel is gebaseerd op de toekenning van punten aan een woning om tot de vaststelling van een redelijke huurprijs te komen. ${ }^{259}$

In een onder de GrS gewezen uitspraak waarin art. 8.31 Wlv de achterliggende grondslag voor compensatie vormde, heeft de rechtbank Haarlem overwogen dat schade in de vorm van tijdelijke derving van woongenot kan worden bepaald op basis van de huurwaardemethode. ${ }^{260}$ Onder verwijzing naar een Afdelingsuitspraak van 12 januari 2005 oordeelde de rechtbank voorts dat deze huurwaarde mag worden vastgesteld op basis van de waarde van de woning in kwestie. In deze

255 ABRvS 28 november 2012, ECLI:NL:RVS:2012:BY4393, r.o. 8.1 (Randweg Eindhoven); Rb. Amsterdam 18 december 2014, ECLI:NL:RBAMS:2014:9829, r.o. 8.5; Rb. Amsterdam 21 april 2015, ECLI:NL:RBAMS:2015:2740, r.o. 19; en Rb. Amsterdam 21 april 2015, ECLI:NL:RBAMS:2015:2741, r.o. 23. Zie Rb. Amsterdam 27 juni 2014, ECLI:NL:RBAMS:2014:3930, r.o. 3.4.4 voor een geval waarin de minister niet voldoende inzichtelijk had gemaakt waarom de schade tot het normaal maatschappelijk risico zou behoren.

256 Rb. Den Haag 12 juli 2017, ECLI:NL:RBDHA:2017:7424, r.o. 2.14.

257 Kennisgids Schadevergoeding bij rechtmatig overheidshandelen, p. 94-95. De gids gaat ook in op de onwenselijkheid van enkele andere (in het verleden gehanteerde) methoden.

258 Dit ministerie is eind 2010 opgegaan in de ministeries die thans bekend staan als Economische zaken en Klimaat, Binnenlandse Zaken en koninkrijksrelaties, en Infrastructuur en Waterstaat.

259 Zie bijlage 1 van het Besluit huurprijzen woonruimte.

260 Rb. Haarlem 14 november 2012, ECLI:NL:RBHAA:2012:BZ3738, r.o. 13. Ter onderbouwing daarvan verwijst de rechtbank naar een Afdelingsuitspraak die werd gewezen onder de Regeling Nadeelcompensatie Betuweroute (Stcrt. 1996, nr. 189), namelijk ABRvS 20 september 2006, ECLI:NL:RVS:2006:AY8507, r.o. 2.10. 
Afdelingsuitspraak speelde de waarde van de woning echter juist geen rol bij de vaststelling van de schade. ${ }^{261} \mathrm{Ik}$ zie dan ook niet hoe zij kan dienen ter onderbouwing van de stelling dat een benadering waarin de huurwaarde wordt vastgesteld op basis van de waarde van de woning, eveneens door de Afdeling is aanvaard. Dit laat onverlet dat uit de uitspraak van de rechtbank kan worden afgeleid dat de huurwaardemethode ook onder de GrS wordt gebruikt voor de begroting van schade in de vorm van tijdelijke derving van woongenot.

Anders dan het geval was bij permanente waardedaling van onroerende zaken en inkomensschade, blijken de Amsterdamse verordeningen geen bepalingen te bevatten omtrent de begroting van schade in de vorm van tijdelijke derving van woongenot. Ook uit de bij deze regelingen behorende toelichtingen wordt niet duidelijk hoe deze schade dient te worden begroot. Voor wat betreft de VNNZ lijkt een verklaring daarvoor te kunnen worden gevonden in de bij die regeling behorende toelichting. Daarin wordt namelijk vermeld dat schade bestaande uit een derving van woongenot in beginsel op grond van de Verordening tegemoetkoming bouwactiviteiten Noord/Zuidlijn ${ }^{262}$ wordt afgedaan. Uit art. 3 van deze verordening blijkt dat de hoogte van de vergoeding van deze schade wordt gebaseerd op het VROM-puntenstelsel. Is een benadeelde echter van mening dat zijn schade de hoogte van deze forfaitaire vergoeding ontstijgt, dan staat het hem vrij een aanvraag in te dienen om nadeelcompensatie op grond van de VNNZ. Dat dit soms ook gebeurde, blijkt uit een Afdelingsuitspraak van 6 juni 2007. Daaruit kan echter niet worden opgemaakt hoe de schade werd begroot. ${ }^{263}$ Navraag bij een Amsterdamse gemeentejurist leert dat toepassing van de huurwaardemethode ook onder de Amsterdamse verordeningen tot de mogelijkheden behoort. Ik heb geen verklaring kunnen vinden voor het gegeven dat de AVN en de daarbij behorende toelichting hierover geen informatie bevatten.

\subsubsection{Conclusie}

Uit de voorafgaande deelparagrafen is gebleken dat slechts de Amsterdamse verordeningen ingaan op de begroting van schade. De verklaring daarvoor lijkt hoofdzakelijk historisch te zijn: ten tijde van de opstelling van de eerste Amsterdamse nadeelcompensatieverordening constateerde het gemeentebestuur een maatschappelijke behoefte aan duidelijkheid op voorhand omtrent de begroting van schade. Dat de andere regelingen niet ingaan op schadebegroting kent deels eveneens een historische verklaring: ten tijde van de totstandkoming van art. 49 WRO, art. 21 Aanwijzingsbesluit en art. $8.31 \mathrm{Wlv}$ was het nog niet gebruikelijk om in een nadeelcompensatieregeling vast te leggen hoe de daarin vervatte redelijkerwijsformule moest worden toegepast. Deels is er ook een verklaring van meer praktische aard. Zoals onder andere wordt aangevoerd in de toelichting op de RnVW 1999, is het vanwege de veelheid van schadeoorzaken en mogelijke schadesoorten waarop

261 ABRvS 12 januari 2005, ECLI:NL:RVS:2005:AS2148.

262 Zie paragraaf 2.3.3 voor nadere informatie over deze verordening.

263 ABRvS 6 juni 2007, ECLI:NL:RVS:2007:BA6794, r.o. 2.6. 
een nadeelcompensatieregeling betrekking kan hebben veelal niet goed mogelijk om daarin algemene regels omtrent schadebegroting op te nemen. Afhankelijk van de omstandigheden van het geval is in de praktijk soms slechts één methode geschikt om de schade te begroten, maar zullen soms ook juist meerdere methoden denkbaar zijn met behulp waarvan de schade kan worden begroot. Dit verklaart ook waarom onder de regelingen die niet ingaan op de begroting van schade soms verschillende begrotingsmethoden worden toegepast ten aanzien van één schadesoort. Bestuursorganen en de daardoor geraadpleegde deskundigen zullen doorgaans immers opteren voor de begrotingsmethode die het meeste recht doet aan de omstandigheden van het individuele schadegeval.

\subsubsection{Deelvraag 3: het toekomstige recht}

\subsubsection{Titel 4.5 Awb}

Titel 4.5 Awb bevat geen bepalingen omtrent schadebegroting. Tijdens de behandeling van het voorstel voor de Wns in de Eerste Kamer zijn wel enkele vragen gesteld over de begroting van schade. ${ }^{264}$ Deze vragen zijn echter nooit beantwoord door de toenmalig minister van Veiligheid \& Justitie, waarschijnlijk doordat het debat zich vrij snel toespitste op de vraag of er een handleiding omtrent de toekenning van nadeelcompensatie moest komen. Ongeveer vijfeneenhalf jaar nadat zij door de minister werd toegezegd, ${ }^{265}$ zou op 20 juli 2018 de Handleiding nadeelcompensatie bij infrastructurele maatregelen aan de Tweede Kamer worden aangeboden. ${ }^{266}$ Deze handleiding besteedt geen aandacht aan schade in de vorm van waardedaling van onroerende zaken en schade wegens gederfd woongenot. ${ }^{267} \mathrm{Uit}$ paragraaf 5.7.1.2 bleek dat zij wel kort ingaat op de begroting van inkomensschade. Op basis daarvan ligt het in de lijn der verwachtingen dat dergelijke schade onder titel 4.5 Awb wordt begroot conform de in die paragraaf beschreven driefasen-methode. Hiervan kan worden afgeweken als de omstandigheden van het individuele schadegeval daartoe nopen. Daarvan kan bijvoorbeeld sprake zijn als de inkomensschade enkel bestaat uit de derving van één specifieke soort inkomsten, of alleen bestaat uit een toename van kosten. Dat zou ook verenigbaar zijn met de algemene opmerking uit de bij de Wns behorende memorie van toelichting dat aansluiting kan worden gezocht bij de maatstaven neergelegd in afd. 6.1.10

264 Zie met name de vragen van Broekers-Knol in Handelingen I 2012/13, 32 621, nr. 15 , item 2, p. 5.

265 Handelingen I 2012/13, 32 621, nr. 15, item 6.

266 De aanbiedingsbrief kan worden geraadpleegd op www.rijksoverheid.nl/documenten/kamerstukken/2018/07/20/aanbieding-handleiding-nadeelcompensatie-bij-infrastructurele-maatregelen. De handleiding is te raadplegen op www.rijksoverheid. $\mathrm{nl} /$ documenten/brochures/2018/07/20/handleiding-nadeelcompensatie-bij-infrastructurele-maatregelen. Zie hierover ook paragraaf 2.3.2 onder het kopje 'Waardevolle geschiedenis'.

267 Handleiding nadeelcompensatie, p. 16-17. 
BW en afd. 6.1.11 BW. ${ }^{268}$ Gelet daarop lijkt het immers niet onaannemelijk dat aansluiting dient te worden gezocht bij art. 6:97 BW: schade wordt begroot op de wijze die het meest met de aard ervan in overeenstemming is en zo nodig geschat. Dat geldt uiteraard niet slechts voor inkomensschade, maar ook voor alle andere schadesoorten.

\subsubsection{Afd. 15.1 Ow}

Wegens gebrek aan signalen van het tegendeel, lijkt het aannemelijk dat ook onder afd. 15.1 Ow aansluiting dient te worden gezocht bij art. 6:97 BW. De hoofdregel is immers dat afd. 15.1 Ow aansluit op titel 4.5 Awb tenzij zij daar expliciet van afwijkt. ${ }^{269}$ De bij de IOw behorende memorie van toelichting vermeldt voorts dat wordt verwacht dat overheden de Handleiding nadeelcompensatie zullen toepassen. Die opmerking wordt geplaatst in de context van het normaal maatschappelijk risico bij inkomensschade. ${ }^{270} \mathrm{Ik}$ zie echter geen reden waarom zij niet eveneens zou opgaan voor de begroting van schade. Het lijkt dus aannemelijk dat inkomensschade ook onder afd. $15.1 \mathrm{Ow}$ in beginsel conform de drie-fasen-methode zal worden begroot. Daarvoor pleit ook het grote draagvlak dat deze methode heeft binnen de thans bestaande nadeelcompensatiepraktijk. ${ }^{271}$ Bovendien zijn in de bij de IOw behorende memorie van toelichting ook overigens voorzichtige signalen te vinden dat aansluiting bij deze praktijk dient te worden gezocht voor de begroting van inkomensschade. ${ }^{272}$ Ten slotte gaan afd. 15.1 Ow en de daarbij behorende Kamerstukken slechts in op de begroting van schade in de vorm van waardevermindering van onroerende zaken. In het navolgende deel van deze deelparagraaf zal ik stilstaan bij hetgeen daaruit kan worden afgeleid.

\section{Indirecte schade door een omgevingsvergunning of vergunningvrije activiteiten}

Afd. $15.1 \mathrm{Ow}$ stelt enkele peildata vast voor de begroting van indirecte schade in de vorm van waardevermindering van een onroerende zaak. Wordt deze schade veroorzaakt door een activiteit waarvoor een omgevingsvergunning is vereist, dan dient de waardevermindering ingevolge art. 15.3 lid $1 \mathrm{Ow}$ te worden bepaald aan de hand van een vergelijking van de waarde van de onroerende zaak onmiddellijk voor en na het tijdstip waarop het bevoegd gezag mededeling heeft gedaan van het besluit tot het verlenen of wijzigen van de omgevingsvergunning. De term mededeling dient te worden uitgelegd conform art. 16.64 lid 3 jo. art. 16.63 Ow: een kennisgeving in een of meer dag-, nieuws- of huis-aan-huisbladen of op een andere geschikte wijze. ${ }^{273}$ Art. 15.4 lid 2 Ow bepaalt de peildatum voor indirecte schade in de vorm van waardevermindering van een onroerende zaak door een 
activiteit die vergunningvrij is op grond van een omgevingsplan, waterschapverordening, omgevingsverordening of amvb. Deze schade dient te worden vastgesteld door vergelijking van de waarde van de onroerende zaak onmiddellijk voor en na het tijdstip waarop het bevoegd gezag kennis heeft gegeven van de informatie die degene die de activiteit gaat verrichten aan het bevoegd gezag over die activiteit heeft verstrekt. Is deze informatie niet verstrekt, dan dient deze schade te worden vastgesteld door een vergelijking van de waarde van de onroerende zaak onmiddellijk voor en na het tijdstip waarop met de activiteit is begonnen.

In de toelichting op art 15.3 lid $1 \mathrm{Ow}$ wordt vermeld dat bij indirecte schade door vergunningplichtige activiteiten...

“(...) de waardevermindering van een onroerende zaak wordt vastgesteld aan de hand van de feitelijke situatie voor en na de verlening van de omgevingsvergunning." 274

De toelichting op art. 15.4 lid $1 \mathrm{Ow}$ is minder expliciet ten aanzien van indirecte schade door vergunningvrije activiteiten. Mede gelet op toelichtende stukken bij eerdere versies van het voorstel voor de IOw en (de reactie van het kabinet op) het advies van de AARvS lijkt het echter onwaarschijnlijk dat daarbij niet zou worden uitgegaan van de feitelijke situatie voor en na de kennisgeving van de activiteit door het bestuur of, bij gebrek daaraan, de feitelijke situatie voor en na de feitelijke aanvang/afronding van de activiteit. ${ }^{275}$

\section{Schade door een projectbesluit en directe schade door een omgevingsplan of -vergunning}

In geval van zowel directe- als indirecte schade in de vorm van waardevermindering van een onroerende zaak door een projectbesluit, of directe schade in de vorm van waardevermindering van een onroerende zaak door overige in art. 15.1 lid 1 jo. lid 2 Ow genoemde schadeoorzaken lijkt de peildatum te moeten worden gevonden in het moment van inwerkingtreding van het schadeveroorzakende besluit. ${ }^{276}$ Ten aanzien van waardevermindering van een onroerende zaak door een projectbesluit wordt in de bij de IOw behorende memorie van toelichting opgemerkt dat...

“(...) de schade wordt begroot aan de hand van een vergelijking van de juridisch maximaal toegestane situatie direct voor de inwerkingtreding van het projectbesluit met de maximale invulling van het projectbesluit direct na de inwerkingtreding, zij het dat

274 Wel zou een uitzondering moeten worden gemaakt voor schade door een legaliserende omgevingsvergunning. Zie Kamerstukken II 2018/19, 34 986, nr. 3, p. 236 (MvT, IOw).

275 Zie MvT consultatieversie IOw, p. 23 en 27; en MvT IOw als voorgelegd aan de AARvS, p. 29-30. Zie ook Kamerstukken II 2018/19, 34 986, nr. 4, p. 77 en 79 (AARvS, IOw).

276 Kamerstukken II 2018/19, 34 986, nr. 3, p. 227, 233 (MvT, IOw). 
de vergelijking wordt toegesneden op het concrete project dat de schade veroorzaakt. Wat betreft geluidproductieplafonds bij een weg bijvoorbeeld, wordt beoordeeld wat het maximale gebruik van een weg kan zijn in vergelijking met het juridisch regime voordat het projectbesluit de weg toestond. De waarde van een onroerende zaak kan verder ook beïnvloed worden door het feitelijke project dat wordt toegestaan in het projectbesluit, zoals de gevolgen voor de situeringswaarde van de onroerende zaak. Die feitelijke gevolgen worden meegenomen in de schadeberekening, voor zover deze aan het projectbesluit redelijkerwijs kunnen worden toegerekend." 277

De bij de IOw behorende memorie van toelichting laat zich niet expliciet uit over de begroting van directe schade door een omgevingsplan of -vergunning. Het lijkt echter niet onwaarschijnlijk dat daarbij eveneens (deels) ${ }^{278}$ zal worden uitgegaan van de maximale invulling van juridische regimes. ${ }^{279}$

\section{De begrotingsmethode}

Zowel uit afd. 15.1 Ow als de daarbij behorende Kamerstukken blijkt niet aan de hand van welke begrotingsmethode de waarde van een onroerende zaak op de hiervoor beschreven momenten dient te worden vastgesteld. Dat was anders in de memorie van toelichting behorende bij de consultatieversie van de IOw. Daarin werd namelijk opgemerkt dat de voor het bestuur op grond van art 6.1.3.2 Bro geldende plicht om een deskundige in te schakelen, komt te vervallen onder de Ow. Daarom leek het kabinet erop aan te sturen dat bij de schadebegroting meer gebruik zou worden gemaakt van WOZ-waardes. Voor niet-woningen zouden er...

“(...) methodes zijn die aansluiten bij het object, zoals de huurwaarde kapitalisatiemethode en het bepalen van de vervangingswaarde (bijvoorbeeld bij oude of historische objecten). Ook andere algemeen beschikbare gegevens over de waarde van woningen in open databanken, zoals de waarden die in het Kadaster zijn opgenomen, kunnen worden gebruikt."'280

Deze informatie komt niet meer voor in de versies van de memorie van toelichting die naar de AARvS en de Tweede Kamer zijn gestuurd. Het is onduidelijk of hieruit moet worden opgemaakt dat het kabinet thans een andere visie zou zijn toegedaan. Wel is duidelijk dat het aansluiten op de WOZ-waarde niet onverdeeld positief werd ontvangen door de praktijk en doctrine. Met name Van der Lee heeft zich hierover kritisch uitgelaten in zijn reactie op het consultatievoorstel. Daarbij was onder andere van belang dat de WOZ-taxatie plaatsvindt met een ander doel; doorgaans uitgaat van afwijkende peildata; uitgaat van verschillende ficties; en

277 Zie bijvoorbeeld Kamerstukken II 2018/19, 34 986, nr. 3, p. 236 (MvT, IOw).

278 Zie hetgeen in paragraaf 4.3.2 werd opgemerkt omtrent de vaststelling van csqnverband tussen de gestelde schade en dit soort schadeoorzaken.

279 Zie bijvoorbeeld de laatste alinea van Kamerstukken II 2018/19, 34 986, nr. 3, p. 28 (MvT, IOw).

280 MvT consultatieversie IOw, p. 27. 
mogelijk ook schaduwschade al in de taxatie betrekt, waardoor de taxatie "onzuiver" wordt. ${ }^{281}$ Uit paragraaf 5.7.1.1 ${ }^{282}$ volgde bovendien dat de Afdeling zich onder het huidige recht eveneens terughoudend opstelt als het aankomt op het gebruik van WOZ-waardes bij de schadebegroting. ${ }^{283}$

\subsubsection{Hoofdvraag: spiegeling aan de doelstellingen en uitgangspunten die} ten grondslag liggen aan de Wns

\subsubsection{Titel 4.5 Awb}

Het lijkt zich op het eerste oog ambivalent te verhouden tot de aan de Wns ten grondslag liggende doelstellingen en uitgangspunten dat titel $4.5 \mathrm{Awb}$ niet ingaat op de begroting van schade. Enerzijds past dit namelijk in beginsel niet goed bij de doelstellingen van vereenvoudiging, uniformering en harmonisering van het nadeelcompensatierecht, vergroting van de rechtszekerheid, en codificatie van het nadeelcompensatierecht. Anderzijds past dit wel goed bij het uitgangspunt van aansluiting bij het BW. In het civiele recht moet schade immers in beginsel worden berekend met inachtneming van alle omstandigheden van het concrete schadegeval. ${ }^{284}$ Met de eerste zin van art. 6:97 BW heeft de wetgever echter expliciet ruimte willen laten voor "abstracte en andere wijzen van schadebegroting". De wetgever achtte het moeilijk een algemeen antwoord te geven op de vraag wanneer een abstracte wijze van begroting op zijn plaats is. Daarom is beantwoording van die vraag in beginsel aan de rechter overgelaten en zijn slechts "voor een aantal belangrijke gevallen bijzondere regels" over schadebegroting opgenomen in het BW. ${ }^{285}$

De aan art. 6:97 BW ten grondslag liggende gedachte dat het niet goed mogelijk is om op voorhand te bepalen welke begrotingsmethode wanneer moet worden toegepast, blijkt ook (een van) de reden(en) te zijn geweest dat het merendeel van de geselecteerde, thans geldende regelingen niet ingaat op schadebegroting. Dat maakt mijns inziens dat genuanceerder moet worden gekeken naar de doelstellingen die in beginsel pleiten voor codificatie van begrotingsmethoden. Om te kunnen codificeren in titel 4.5 Awb zou er per schadesoort immers één begrotingsmethode moeten zijn die zich leent voor uniforme toepassing. Mijns inziens is dat niet het geval. Alle in paragraaf 5.7.1 besproken begrotingsmethoden kennen immers hun eigen voor- en nadelen, waardoor zij goed of juist minder goed toepasbaar zijn naar gelang de omstandigheden van het individuele schadegeval. In

281 SAOZ 2017, p. 6-7. Zie ook Planken \& Hazen 2017, p. 39.

282 Zie het kopje 'De vergelijkingsmethode'.

283 ABRvS 28 september 2016, ECLI:NL:RVS:2016:2582, r.o. 4.7 (Overzichtsuitspraak).

284 Zie HR 5 december 2008, ECLI:NL:HR:2008:BE9998, r.o. 3.3 (Rijnstate/R.); en HR 26 maart 2010, ECLI:NL:HR:2010:BL0539, r.o. 4.3.

285 Parl. Gesch. Boek 6, p. 339. Lindenbergh, in: T\&C BW, art. 6:97 BW, aant. 1 geeft een opsomming van dit soort bijzondere regels. 
de in die paragraaf besproken jurisprudentie leidde dat regelmatig tot de conclusie dat van de doorgaans door het desbetreffende bestuur gebruikte methode diende te worden afgeweken. Ik zie daarom onvoldoende mogelijkheid om codificatie van specifieke methodes aan te bevelen. ${ }^{286}$

De eerlijkheid gebied te vermelden dat de bestudering van jurisprudentie gewezen onder de geselecteerde, thans geldende regelingen geen gevallen heeft laten zien waarin de huurwaardemethode niet kon worden ingezet voor de begroting van schade in de vorm van tijdelijke derving van woongenot. ${ }^{287}$ Toch lijkt het aannemelijk dat ook deze methode niet altijd zal kunnen worden toegepast. Dat zou bijvoorbeeld het geval kunnen zijn als de daling in huurwaarde niet representatief is voor de achteruitgang in woongenot, omdat de getroffen onroerende zaak deels wordt gebruikt als bedrijfspand. Ook kan in meer algemene zin de vraag worden gesteld of de huurwaardemethode altijd tot een redelijke uitkomst leidt. Zo kan zij ertoe leiden dat de bewoner van een luxe villa een veel hogere vergoeding ontvangt dan de bewoner van een rijtjeshuis, terwijl beiden worden geconfronteerd met vergelijkbare overlast door dezelfde overheidsmaatregel. ${ }^{288}$

Dat codificatie van één begrotingsmethode per schadesoort in een algemene formeelwettelijke regeling niet mogelijk is, kan ook worden afgeleid uit Afdelingsjurisprudentie omtrent gevallen waarin de in waarde gedaalde onroerende zaak tevens werd gebruikt om een inkomen te verwerven. ${ }^{289}$ Uit deze jurisprudentie volgt dat in gevallen waarin de waarde van de onroerende zaak in hoge mate afhankelijk is van de exploitatiemogelijkheden van de onroerende zaak, eerst een gekapitaliseerde vergoeding voor de inkomensschade dient te worden toegekend. Een waardedaling van de onroerende zaak komt dan slechts voor vergoeding in aanmerking in zoverre zij niet al is verdisconteerd in deze gekapitaliseerde in-

286 Vergelijk Van Montfoort 2010, p. 94: in “meer dan 30 jaar (...) ben ik nog geen hanteerbare formule tegengekomen die in de plaats zou kunnen komen van onderzoek, overleg en afweging, mede gebaseerd op ervaring en intuïtie, kortom zorgvuldig maatwerk, mede afgestemd op lokale omstandigheden en marktverhoudingen."

287 De jurisprudentie die ziet op begroting van deze schadesoort is vrij gering in omvang.

288 Eventueel zou de wetgever de huurwaardemethode als voorkeursmethode kunnen voorschrijven. Gelet op deze kanttekeningen zal ik daartoe echter geen aanbeveling doen, mede omdat hiermee slechts beperkt aan rechtszekerheid zou worden gewonnen.

289 Deze jurisprudentie komt de Afdeling overigens regelmatig op kritiek te staan. Zie bijvoorbeeld Van Heesbeen 2014; en Van Mierlo 2014, p. 101-103. 
komensvergoeding. ${ }^{290}$ De Afdeling heeft in een uitspraak van 11 juli 2012 echter toegestaan dat eerst een vergoeding voor de waardedaling van de onroerende zaak werd toegekend en vervolgens werd nagegaan of de inkomensschade voldoende daarin was verdisconteerd. Daarbij lijkt bepalend te zijn geweest dat de waarde van de onroerende zaak in mindere mate afhankelijk was van de exploitatiemogelijkheden daarvan. ${ }^{291}$

Ten slotte is ook de codificatie van op wetenschap gebaseerde, forfaitaire begrotingsmaatstaven niet goed mogelijk. Ter onderbouwing daarvan refereer ik aan publicaties van Van Montfoort en Van den Broek waarin (empirisch) onderzoek onder de aandacht wordt gebracht waaruit blijkt dat het lastig is om in algemene zin een lineair verband vast te stellen tussen bijvoorbeeld een toename van geluidsbelasting en de waardedaling van een woning. ${ }^{292}$ Zo kan een toename van vijf decibel een heel ander effect op de waarde van een herenhuis hebben dan op de waarde van een rijtjeshuis. Gelet op al het voorafgaande zie ik dus geen aanleiding tot (a) wijziging van titel $4.5 \mathrm{Awb}$.

\subsubsection{Afd. 15.1 Ow}

Uit hetgeen in paragraaf 5.7.3.1 is overwogen, volgt mijns inziens dat de aan de Wns ten grondslag liggende doelstellingen en uitgangspunten eveneens niet in algemene zin nopen tot codificatie van begrotingsmethoden in afd. 15.1 Ow. Bovendien ondersteunen de bij deze afdeling behorende Kamerstukken de gedachte dat het in algemene zin niet goed mogelijk is een of meerdere begrotingsmethodes voor te schrijven. Zo wordt opgemerkt dat geen regels worden gegeven over begroting van tijdelijke inkomensschade omdat "de peildata uiteenlopend kunnen zijn". Schadeberekening zou daarom de "huidige praktijk" moeten volgen. ${ }^{293}$ Ook in meer algemene zin wordt opgemerkt dat "de diverse typen schade (...) te uiteenlopend van aard [zijn] om daarvoor peildata in de wet vast te leggen."294 Desondanks zijn in art. 15.3 lid 1 en art. 15.4 lid 2 Ow peildata voorgeschreven voor de begroting van indirecte schade in de vorm van waardevermindering van een onroerende zaak die wordt veroorzaakt door een omgevingsvergunning of een

290 Zie voor een planschadegeschil: ABRvS 26 augustus 2015, ECLI:NL:RVS:2015:2688, r.o. 7.3. Zie voor een geschil onder de RnVW 1999: ABRvS 16 mei 2012, ECLI:NL:RVS:2012:BW5932, r.o. 2.7.1.1 en 2.7.1.4 (Benzinestation gemeente Hulst, tussenuitspraak); en ABRvS 28 november 2012, ECLI:NL:RVS:2012:BY4355, r.o. 3 (Benzinestation gemeente Hulst, einduitspraak). Zie voor een nadeelcompensatiegeschil buiten het bereik van de RnVW 1999: ABRvS 30 mei 2012, ECLI:NL:RVS:2012:BW6926, r.o. 2.38 en 2.45 (Tankstation gemeente Hardenberg, tussenuitspraak); en ABRvS 6 februari 2013, ECLI:NL:RVS:2013:BZ0707, r.o. 7 (Tankstation gemeente Hardenberg, einduitspraak).

291 ABRvS 11 juli 2012, ECLI:NL:RVS:2012:BX1032, r.o. 2.7.

292 Zie Van den Broek 2012, p. 440-453; en Van Montfoort 2010.

293 Kamerstukken II 2018/19, 34 986, nr. 3, p. 234 (MvT, IOw).

294 Kamerstukken II 2018/19, 34 986, nr. 3, p. 227-228 (MvT, IOw). 
vergunningvrije activiteit. Daarvoor lijkt met name te zijn gekozen omdat in de consultatiefase en tijdens botsproeven vragen rezen omtrent de vaststelling van schade in gevallen waarin het schademoment werd verschoven. ${ }^{295}$ Het voorschrijven van deze peildata acht ik niet onverenigbaar met de aan de Wns ten grondslag liggende doelstellingen en uitgangspunten. Dat geldt ook voor het uitgangspunt van aansluiting bij het BW, omdat het BW "voor een aantal belangrijke gevallen bijzondere regels" bevat. Mijns inziens is de categorie van gevallen waarin het schademoment wordt verschoven van groot genoeg belang om de bijzondere regelingen van art. 15.3 lid 1 en art. 15.4 lid 2 Ow te rechtvaardigen. Een significant deel van de aanvragen die onder afd. 15.1 Ow zullen worden ingediend, zal namelijk betrekking hebben op deze categorie van schadegevallen. Bovendien bestaat relatief veel onduidelijkheid omtrent de begroting van schade in dit soort gevallen. Mede gelet op de doelstellingen van vergroting van de rechtszekerheid, en vergroting van de doelmatigheid van het nadeelcompensatierecht en vermindering van bestuurslasten zou het daarom onwenselijk zijn als de wetgever helemaal geen sturing zou bieden.

\section{Onvoldoende sturing}

Het voorafgaande laat onverlet dat de wetgever mijns inziens te weinig sturing heeft geboden in afd. $15.1 \mathrm{Ow}$ en de daarbij behorende Kamerstukken. Daartoe is onder andere van belang dat in paragraaf 3.4.2.3 bleek dat de verschuiving van het schademoment bepaalde complicaties met zich brengt. Een van die complicaties kwam aan bod in paragraaf 4.4.3:296 er bestaat onduidelijkheid over de vergelijking die bij toepassing van afd. $15.1 \mathrm{Ow}$ dient te worden gemaakt om csqn-verband vast te stellen, én over de mate waarin de uitkomst van deze vergelijking nog van invloed dient te zijn op de schadebegroting. Ook in paragraaf 5.7.2.2 bleek dat onduidelijkheid bestaat over de begroting van schade onder afd. 15.1 Ow. Dit verhoudt zich slecht tot de aan de Wns ten grondslag liggende doelstellingen van vergroting van de rechtszekerheid, en vergroting van de doelmatigheid van het nadeelcompensatierecht en vermindering van bestuurslasten. ${ }^{297}$ Gelet daarop herhaal ik de in paragraaf 4.4.3 gedane aanbeveling tot (c) het anderszins voorzien in een bijzondere invulling van titel 4.5 Awb: het kabinet of de wetgever zou uitleg moeten verschaffen omtrent de hier genoemde onduidelijkheden.

Voor wat betreft de schadebegroting ${ }^{298}$ zal deze uitleg in ieder geval moeten zien op de begroting van directe schade door een omgevingsplan- en/of omgevingsvergunning. Daarbij zou mijns inziens duidelijk moeten worden gemaakt in hoeverre

295 Kamerstukken II 2018/19, 34 986, nr. 3, p. 27-29 en 227-228 (MvT, IOw).

296 Zie het kopje 'De verschuiving van het schademoment en de csqn-toets'.

297 De kans is immers groot dat deze onduidelijkheid zal leiden tot foutieve besluiten op aanvragen om nadeelcompensatie, en onnodige aanwending van rechtsmiddelen tegen besluiten die wel correct zijn.

298 Het deel van deze aanbeveling dat ziet op de csqn-toets werd toegelicht in paragraaf 4.4.3 onder het kopje 'De verschuiving van het schademoment en de csqn-toets'. 
daarbij - net als onder huidig recht - moet worden uitgegaan van de prijs die een redelijk denkend en handelend koper onmiddellijk voor de inwerkingtreding van het nieuwe planologische regime en op het tijdstip direct daarna voor de beweerdelijk in waarde gedaalde onroerende zaak zou hebben geboden, uitgaande van hetgeen maximaal op grond van het oude en nieuwe planologische regime kon worden gerealiseerd ${ }^{299}$ In hoeverre mag en/of moet daarbij rekening worden gehouden met de feitelijke situatie?

Ook zou in ieder geval uitleg moeten worden verschaft over de begroting van schade in de vorm van waardedaling van een onroerende zaak in gevallen waarin het schademoment wordt verschoven. Uit paragraaf 5.7.2.2 volgt namelijk dat bij toepassing van art. 15.3 lid $1 \mathrm{Ow}$ en art. 15.4 lid $2 \mathrm{Ow}$ een waardevergelijking dient plaatsvinden waarbij wordt uitgegaan van de feitelijke situatie onmiddellijk voor en na de mededeling van het besluit tot vergunningverlening, respectievelijk kennisgeving door het bestuur van een vergunningvrije activiteit of de daadwerkelijk aanvang met die activiteit. Planken \& Hazen gaven echter in 2017 al aan dat dit discussie zal doen ontstaan...

“(...) over het vaststellen en waarderen van de feitelijke situatie. Als een aanvraag jaren na de inwerkintreding van een omgevingsvergunning of na feitelijke bouwactiviteiten wordt ingediend, is niet duidelijk hoe de oude feitelijke situatie wordt vastgesteld en gewaardeerd. Anders dan in de MvT is gesteld, is de WOZ-waarde daarvoor niet in alle gevallen bruikbaar en betrouwbaar." 300

Uit de aanbevolen verduidelijking zou mijns inziens moeten blijken hoe met dit soort problemen dient te worden omgegaan.

\section{Niet redelijke sturing?}

Een ander nadeel van de door het kabinet met art. 15.3 lid 1 Ow jo. art. 15.4 lid 2 Ow voorgestane begrotingsmethode is dat zij geen rekening houdt met de waardedaling die op de peildatum reeds heeft plaatsgevonden door (indicatief overheidshandelen en) de vaststelling van een omgevingsplan dat de mogelijkheid tot vergunningverlening bevat respectievelijk een activiteit vergunningvrij toestaat. De AARvS kwalificeert dit als "niet redelijk en (...) waarschijnlijk niet de bedoeling." ${ }^{301}$ Aan de hand van een rekenvoorbeeld liet Van Heijst eerder al zien dat deze begrotingsmethode ertoe kan leiden dat de aanvrager een significant lagere vergoeding ontvangt dan hij naar huidig recht zou doen. Geïnspireerd door het onteigeningsrecht, stelt hij als oplossing voor om in afd. 15.1 Ow te bepalen dat "bij de waardering van de woning in de oude feitelijke situatie per datum ver-

299 ABRvS 28 september 2016, ECLI:NL:RVS:2016:2582, r.o. 4.6 (Overzichtsuitspraak).

$300 \quad$ Planken \& Hazen 2017, p. 39.

301 Kamerstukken II 2018/19, 34 986, nr. 4, p. 77-78 (AARvS, IOw). 
lening omgevingsvergunning de invloed van de 'nieuwe planologie' (= invloed omgevingsplan) moet worden weggedacht" - een vergelijkbare oplossing lijkt denkbaar voor de begroting van schade door uitvoering van een vergunningvrije activiteit. Als nadeel van deze oplossing noemt Van Heijst dat de waarde in de oude situatie "niet rechtstreeks" kan worden afgeleid uit op de peildatum beschikbare marktgegevens, zoals WOZ-waarden of recente verkoopprijzen. ${ }^{302}$ Zie ik het goed, dan kan de waarde van een onroerende zaak echter vrijwel nooit rechtstreeks worden afgeleid uit dergelijke marktgegevens. Ik ga daarom ervan uit dat 'niet rechtstreeks' moet worden gelezen als 'minder eenvoudig'.

In beginsel ben ik het eens met de ARRvS en Van Heijst dat het buiten beschouwing laten van de invloed van het omgevingsplan en daaraan voorafgaand indicatief overheidshandelen onwenselijk is. Bovendien overtuigen de argumenten die het kabinet aanvoert om geen oplossing voor dit probleem te treffen mijns inziens onvoldoende. ${ }^{303}$ Toch zal ik niet aanbevelen tot overname van de oplossing die Van Heijst aandraagt. Zij lost het geconstateerde probleem namelijk onvoldoende op, terwijl zij ook nieuwe knelpunten meebrengt. Zo kan de bevoegdheid tot vergunningverlening of het niet vergunningplichtig zijn van een activiteit immers voortvloeien uit een samenspel van meerdere opeenvolgende omgevingsplannen. ${ }^{304}$ Door enkel het omgevingsplan op het moment van vergunningverlening of uitvoering van de activiteit weg te denken, wordt geen rekening gehouden met de waardedrukkende invloed van de eerdere omgevingsplannen. Het wegdenken van alle eerdere plannen - zodat wordt vergeleken met het plan dat nog helemaal geen mogelijkheid bood om de vergunning te verlenen of de activiteit zonder vergunning uit te voeren - zal waarschijnlijk ook niet altijd mogelijk zijn. Dit zou immers tot gevolg hebben dat soms moet worden vergeleken met de waarde die de onroerende zaak een of meerdere decennia geleden had.

Bovendien verwacht ik dat het door de AARvS en Van Heijst benoemde probleem zich niet - of minstens significant minder - zal voordoen als de in paragrafen 3.4.2.4 $4^{305}$ en $8.5^{306}$ voorgestelde beperking van tegenwerping van actieve risicoaanvaarding zou worden doorgevoerd. De mogelijkheid tot vergunningverlening of het vergunningvrij uitvoeren van een activiteit is immers niet - of minstens minder - bepalend voor de prijs die een koper bereid is te betalen voor een woning als deze koper weet dat hij te zijner tijd een vergoeding kan krijgen voor zijn schade door een eventuele verlening van die vergunning respectievelijk uitvoering van deze activiteit. Ten slotte is van belang dat art. $15.3 \mathrm{Ow}$ en art. $15.4 \mathrm{Ow}$ slechts een peildatum voorschrijven en geen begrotingsmethode. Hoewel uit de bij de IOw behorende memorie van toelichting inderdaad lijkt te moeten worden afgeleid dat

302 Van Heijst 2017, p. 152-153.

303 Kamerstukken II 2018/19, 34 986, nr. 4, p. 79-80 (AARvS, IOw).

304 Zie met betrekking tot de vergunningvrije activiteit ook paragraaf 4.4.3 onder het kopje 'De verschuiving van het schademoment en de csqn-toets'.

305 Zie het kopje 'Tijdelijke waardedaling van onroerende zaken'.

306 Zie het kopje 'Aanpassing van art. 15.5 Ow'. 
indirecte schade dient te worden begroot aan de hand van de oude feitelijke situatie, bestaat hierdoor genoeg ruimte voor deskundigen, het bestuur en de rechter om daarvan te abstraheren als dat nodig is om tot een (redelijke) begroting van de schade te komen.

Gelet op het voorafgaande zal ik met betrekking tot het hier geconstateerde probleem geen voorstel doen tot (a) wijziging van titel 4.5 Awb of (b) afd. 15.1 Ow. Onder het kopje 'onvoldoende sturing' werd aanbevolen tot (c) het anderszins voorzien in een bijzondere invulling van titel $4.5 \mathrm{Awb}$ : het kabinet of de wetgever zou uitleg moeten verschaffen omtrent onduidelijkheden met betrekking tot de wijze van schadebegroting. Mijns inziens zou het kabinet er goed aan doen hetgeen hier is besproken te betrekken in deze verduidelijking.

\subsubsection{Overige aanbevelingen}

De in paragraaf 5.7.3.1 gemaakte afweging tussen de aan de Wns ten grondslag liggende doelstellingen en uitgangspunten gaat grosso modo ook op voor de codificatie van begrotingsmethoden in titel $4.5 \mathrm{Awb}$-interpreterende verordeningen of beleidsregels. Een nuanceverschil is wellicht dat het uitgangspunt van aansluiting bij het BW minder nadrukkelijk tegen codificatie pleit, omdat het gaat om codificatie op een lager niveau dan de formele wet. Hoewel dat niet één op één vergelijkbaar is, biedt het BW namelijk ruimte om op een lager niveau beslissingen te nemen omtrent schadebegroting. Art. 6:97 BW is immers van regelend recht, waardoor het partijen in beginsel vrijstaat om te contracteren omtrent de wijze waarop schade zal worden begroot. ${ }^{307}$ Deze nuance is echter niet van doorslaggevend belang, omdat ik het in algemene zin ook voor lagere regelgeving en beleidsregels niet goed mogelijk acht één begrotingsmethode per schadesoort voor te schrijven. Hoewel die bepaling tot op heden niet tot onoverkomelijke problemen lijkt te hebben geleid, ${ }^{308}$ wordt dit geïllustreerd door art. 4 VNNZ. Zo maakt deze bepaling niet duidelijk welke omzet bepalend is voor de begroting van inkomensschade. Is dat bijvoorbeeld de omzet van het getroffen filiaal, of de omzet van de economische eenheid waartoe dat filiaal behoort? Ook stuurt de bepaling sterk aan op een referentieperiode bestaande uit vijf aan het schadejaar voorafgaande jaren. Die periode hoeft echter niet representatief te zijn voor alle bedrijven die een aanvraag om compensatie indienen. Bovendien kan er goede reden bestaan om schadevrije periodes na de schadeperiode (eveneens) als referentie te nemen. Verder kunnen het tweede en derde lid in de praktijk tot discussie leiden omtrent de vraag of de daarin vervatte correctiemogelijkheden limitatief zijn bedoeld. Zo laat het derde lid bijvoorbeeld slechts ruimte tot een correctie wegens een omzetstijging in de laatste referentiejaren die zich daarna waarschijnlijk nog zou voortzetten. Dit roept de vraag op waarom een dergelijke correctie niet eveneens zou moeten plaatsvinden als zich in de laatste referentiejaren een omzetdaling

307 Zie hierover Klaassen 2017, p. 10, nr. 8.

308 Dat komt waarschijnlijk deels door het gebruik van zinsneden als 'in beginsel', maar mogelijk ook door de hardheidsclausule van art. 17 VNNZ. 
voordeed die zich waarschijnlijk zou voortzetten. Zonder uitputtend te willen zijn, noem ik ten slotte de inflatiecorrectie van het vierde lid. Zij wordt gebaseerd op de consumentenprijsindex van het CBS, waardoor zij bijvoorbeeld niet geschikt lijkt voor bedrijven die geen diensten aan consumenten leveren - zoals groothandels of producenten van halffabricaten.

Op basis van het voorafgaande zie ik geen aanleiding om in algemene zin (c) een bijzondere invulling en/of aanvulling van titel 4.5 Awb voor te stellen. Wel zie ik reden tot een dergelijke invulling als schadeveroorzakend overheidshandelen een duidelijk af te bakenen groep burgers op min of meer gelijke wijze beïnvloedt. In dergelijke gevallen zou namelijk in een titel 4.5 Awb-interpreterende verordening of beleidsregel een forfaitaire begrotingsmaatstaf kunnen worden neergelegd die is gebaseerd op empirisch onderzoek. De onder de GrS gewezen jurisprudentie leert dat dergelijke forfaitaire regelingen wel voldoende ruimte tot afwijking in het individuele schadegeval moeten laten. In algemene zin sluiten dit soort regelingen goed aan op de doelstellingen van vergroting van de rechtszekerheid, codificatie van het nadeelcompensatierecht, en vergroting van de doelmatigheid van het nadeelcompensatierecht en vermindering van bestuurslasten. Een bijkomend voordeel zou zijn dat een veelvoud aan de voorgestelde 'micro-onderzoekjes' er op termijn aan zouden kunnen bijdragen dat genoeg data beschikbaar komt om een algemener toepasbaar forfaitair stelsel vast te stellen op nationaal niveau.

\subsubsection{Conclusie}

Uit het voorafgaande volgt dat de aan de Wns ten grondslag liggende doelstellingen en uitgangspunten mijns inziens geen aanleiding geven tot (a) wijziging van titel 4.5 Awb of (b) wijziging van afd. 15.1 Ow. Wel geven zij aanleiding (c) anderszins in een bijzondere invulling van titel 4.5 Awb te voorzien. Allereerst is de aanbeveling uit paragraaf 4.4.3 herhaald dat het kabinet of de formele wetgever zou moeten verduidelijken welke vergelijking bij toepassing van afd. 15.1 Ow dient te worden gemaakt om csqn-verband vast te stellen, en in hoeverre de uitkomst van die vergelijking nog van invloed is op de schadebegroting. Voor wat betreft de schadebegroting zou daarbij mijns inziens in ieder geval aandacht moeten worden besteed aan de in paragraaf 5.7.3.2 besproken onduidelijkheden. Een dergelijke verduidelijking leent zich naar mijn mening niet voor uitwerking in de tekst van afd. $15.1 \mathrm{Ow}$, maar zou bijvoorbeeld kunnen geschieden in een Kamerbrief of een ander toelichtend stuk. Ten tweede is aanbevolen dat - waar mogelijk - een op empirisch onderzoek gebaseerde, forfaitaire begrotingsmaatstaf wordt neergelegd in titel 4.5 Awb-interpreterende verordeningen of beleidsregels die betrekking hebben op schadeveroorzakend overheidshandelen dat een duidelijk af te bakenen groep burgers op min of meer gelijke wijze beïnvloedt. Dergelijke forfaitaire regelingen dienen wel steeds voldoende ruimte te laten tot afwijking in het individuele schadegeval. 
In dit hoofdstuk zijn de tweede en derde deelvraag en de hoofdvraag beantwoord ten aanzien van verschillende aspecten van het schadebegrip van de geselecteerde regelingen, en de wijzen waarop de drie meest voorkomende vormen van schade onder deze regelingen worden begroot. Ten aanzien van beide onderwerpen zal ik kort in herinnering roepen welke aanbevelingen zijn gedaan, om vervolgens concrete voorstellen te doen tot implementatie daarvan.

\section{Het schadebegrip}

In paragraaf 5.2 is ingegaan op de schadesoorten die onder de geselecteerde regelingen voor vergoeding in aanmerking komen. Vervolgens is in paragraaf 5.3 onderzocht of de geselecteerde regelingen de eis stellen dat aan de schadeoorzaak een belangenafweging ten grondslag ligt (waarin het getroffen belang is meegewogen). Met betrekking tot deze onderwerpen geven de aan de Wns ten grondslag liggende doelstellingen en uitgangspunten geen aanleiding om (a) titel 4.5 Awb aan te passen, (b) afd. $15.1 \mathrm{Ow}$ aan te passen, en/of (c) anderszins in een bijzondere invulling, aanvulling of afwijking van titel $4.5 \mathrm{Awb}$ te voorzien.

In paragraaf $5.4 \mathrm{t} / \mathrm{m} 5.6$ is aandacht besteed aan de vergoedbaarheid van kosten van schadebeperkende maatregelen, deskundigenkosten en wettelijke rente. Daarbij zijn enkele aanbevelingen gedaan tot (a) aanpassing van titel 4.5 Awb. Ten eerste zou het goed zijn als in titel 4.5 Awb zou worden opgenomen dat bij amvb nadere regels kunnen worden gegeven omtrent de vergoeding van deskundigenkosten. Ten tweede is aanbevolen om in art. 4:129 Awb tot uitdrukking te brengen dat de redelijke kosten van schadebeperkende maatregelen en redelijke deskundigenkosten onderdeel van de schade vormen. Ten derde is voorgesteld om - analoog aan art. 6:96 BW - in art. 4:129 Awb tot uitdrukking te brengen dat de schadebeperkende maatregel betrekking dient te hebben op schade die als gevolg van de schadeoorzaak mocht worden verwacht. Ten vierde verdient het mijns inziens aanbeveling de zinsnede "bij de vaststelling van de schade" te schrappen uit art. 4:129 onder b Awb. Ten slotte is aanbevolen om de rentetermijn bij schade door een appellabele schadeoorzaak te laten aanvangen vanaf de onherroepelijkheid van deze schadeoorzaak. Bij schade door niet-appellabele schadeoorzaken kan worden vastgehouden aan de huidige regeling van art. 4:129, aanhef en onder $\mathrm{d}$ Awb - die inhoudt dat de rentetermijn aanvangt op het moment waarop een aanvraag om nadeelcompensatie is ingediend én de schade reeds is ingetreden. Deze aanbevelingen zouden kunnen worden geïmplementeerd door middel van de volgende redactie van art. 4:129 Awb:309

309 In paragraaf 10.4.3 stel ik voor de terugbetaling van het ex art. 4:128 Awb van de aanvrager geheven recht in art. 4:128 Awb te regelen. Daarom gaat de hier voorgestelde bepaling niet in op deze terugbetaling - anders dan de huidige redactie van art. 4:129 Awb. 


\section{Artikel 4:129 Awb}

1. Indien het bestuursorgaan een vergoeding als bedoeld in artikel 4:126 toekent, vergoedt het tevens de schade die bestaat uit:

a. redelijke kosten ter voorkoming of beperking van schade die als gevolg van de schadeoorzaak mocht worden verwacht; en

b. redelijke kosten ter zake van door een derde beroepsmatig verleende rechtsbijstand of andere deskundige bijstand.

2. Indien het bestuursorgaan een vergoeding als bedoeld in artikel 4:126 toekent, vergoedt het tevens de wettelijke rente vanaf de ontvangst van de aanvraag, of indien de schade op een later tijdstip ontstaat, vanaf dat tijdstip. Indien de schade mede is veroorzaakt door een besluit waartegen beroep kan worden ingesteld, vangt de rentetermijn niet aan voordat het besluit onherroepelijk is geworden. ${ }^{310}$

3. Bij algemene maatregel van bestuur kunnen nadere regels worden gesteld omtrent de vergoeding van de kosten als bedoeld in het eerste lid, aanhef en onder b.'

De aan de Wns ten grondslag liggende doelstellingen en uitgangspunten geven geen aanleiding om (b) afd. $15.1 \mathrm{Ow}$ te wijzigen met betrekking tot deze onderwerpen. Wel geven zij aanleiding tot (c) enkele bijzondere invullingen van titel 4.5 Awb. Ten eerste zou de bestuursrechter een einde moeten maken aan onwenselijke verschillen met de civielrechtelijke invulling van de dubbele redelijkheidstoets. Een tweede aanbeveling ziet op de situatie dat één maatregel of project tot schade voor een grote groep burgers zal leiden en dit type schade doorgaans kan worden voorkomen door een bepaald type schadebeperkende maatregel. In dergelijke gevallen zouden bestuursorganen er goed aan doen in wetsinterpreterende beleidsregels vast te leggen welke schadebeperkende maatregel tot welk bedrag aan kosten in elk geval als redelijk zal worden beschouwd. Ten slotte is aanbevolen dat de rechter de jurisprudentielijn verlaat dat voorafgaand aan het conceptadvies gemaakte deskundigenkosten nooit voor vergoeding in aanmerking komen. In plaats daarvan zou de redelijkheid van deze kosten steeds moeten worden bepaald aan de hand van de omstandigheden van het individuele schadegeval.

\section{Schadebegroting}

In paragraaf 5.7 is ingegaan op de begroting van de drie meest voorkomende vormen van schade. Daarbij is geconcludeerd dat de aan de Wns ten grondslag liggende doelstellingen en uitgangspunten geen aanleiding geven tot (a) wijziging van titel 4.5 Awb of (b) wijziging van afd. 15.1 Ow. Wel geven zij aanleiding (c) anderszins in een bijzondere invulling van titel 4.5 Awb te voorzien. Allereerst is de aanbeveling uit paragraaf 4.4.3 herhaald dat het kabinet of de formele wetgever zou moeten verduidelijken welke vergelijking bij toepassing van afd. 15.1 Ow dient te worden gemaakt om csqn-verband vast te stellen, en in hoeverre de uitkomst van die vergelijking nog van invloed is op de schadebegroting. Voor wat betreft de schadebegroting zou daarbij mijns inziens in ieder geval aandacht moe- 
ten worden besteed aan de in paragraaf 5.7.3.2 besproken onduidelijkheden. Een dergelijke verduidelijking leent zich naar mijn mening niet voor uitwerking in de tekst van afd. 15.1 Ow, maar zou bijvoorbeeld kunnen geschieden in een Kamerbrief of een ander toelichtend stuk. Ten tweede is aanbevolen dat - waar mogelijk - een op empirisch onderzoek gebaseerde, forfaitaire begrotingsmaatstaf wordt neergelegd in titel 4.5 Awb-interpreterende verordeningen of beleidsregels die betrekking hebben op schadeveroorzakend overheidshandelen dat een duidelijk af te bakenen groep burgers op min of meer gelijke wijze beïnvloedt. Dergelijke forfaitaire regelingen dienen wel steeds voldoende ruimte te laten tot afwijking in het individuele schadegeval. 



\section{Hoofdstuk 6}

\section{Abnormale last}

\subsection{INLEIDING}

Als wordt geconcludeerd dat de aanvrager schade lijdt als gevolg van een door hem aangewezen schadeoorzaak die onder de reikwijdte van de toepasselijke nadeelcompensatieregeling valt, zal de vergoedbaarheid van deze schade moeten worden onderzocht. ${ }^{1}$ In hoofdstuk $6 \mathrm{t} / \mathrm{m} 9$ zullen de tweede en derde deelvraag en de hoofdvraag worden beantwoord ten aanzien van de criteria die hierbij van belang zijn. Het betreft achtereenvolgens de criteria inzake abnormale last (hoofdstuk 6), speciale last (hoofdstuk 7), eigen schuld van de aanvrager (hoofdstuk 8), en enkele resterende criteria, zoals het niet voldoende anderszins verzekerd mogen zijn van schadevergoeding (hoofdstuk 9).

Aan het leven in een samenleving zijn zowel voor- als nadelen verbonden. Het criterium van de abnormale last brengt tot uitdrukking dat deze nadelen in beginsel voor eigen rekening blijven. Schade kan slechts voor compensatie in aanmerking komen in zoverre zij de "normaal te dulden schade", oftewel het normaal maatschappelijk risico, ontstijgt. ${ }^{2}$ Het betreft vaste jurisprudentie dat het normaal maatschappelijk risico moet worden afgebakend "met inachtneming van alle van belang zijnde omstandigheden van het geval." ${ }^{\prime 3}$ Het verbaast dan ook niet dat de vaagheid van het begrip normaal maatschappelijk risico regelmatig is benadrukt in de literatuur. ${ }^{4}$ Van Ravels spreekt zelfs van een "vage norm bij uitstek":

"Het begrip blijkt vooral te functioneren als een 'gemeenteplaats' in de zin van de antieke retoriek; als een vindplaats van argumenten en gezichtspunten, die elkaar afhankelijk van de concrete omstandigheden van het geval soms versterken en soms verzwakken." ${ }^{5}$

1 ABRvS 28 september 2016, ECLI:NL:RVS:2016:2582, r.o. 1.2 (Overzichtsuitspraak).

2 Zie bijvoorbeeld Kamerstukken II 2002/03, 28 916, nr. 3, p. 62-63 (MvT, Wro); en Tjepkema 2016, p. 623.

3 Deze overweging is afkomstig uit HR 17 september 2004, ECLI:NL:HR:2004:AO7887, r.o. 3.3 ( $U z i)$ en is overgenomen door de Afdeling. Zie bijvoorbeeld ABRvS 28 september 2016, ECLI:NL:RVS:2016:2582, r.o. 5.9 (Overzichtsuitspraak); ABRvS 25 september 2013, ECLI:NL:RVS:2013:1222, r.o. 6.1 (Bodyfashion Zwanenburg, hoger beroep); en ABRvS 19 februari 2014, ECLI:NL:RVS:2014:572, r.o. 10.3 (Risicolocatie Schiphol).

$4 \quad$ Zie Tjepkema 2014a, p. 115-116 voor een beknopt overzicht.

5 Van Ravels 2002, p. 413. Zie voor vergelijkbare opmerkingen Van Ravels 2014a, p. 5; en Van Ravels 2008, p. 145. 
Ten slotte heeft Tjepkema betoogd dat de abnormale last eigenlijk meer zou moeten omvatten dan de vraag of de schade het normaal maatschappelijk risico ontstijgt. ${ }^{6}$ Deze opvatting heeft echter geen voet aan de grond gekregen in de rechtspraktijk. In deze dissertatie wordt er daarom van uitgegaan dat sprake is van een abnormale last als de schade het normaal maatschappelijk risico ontstijgt. Ook de wetgever pleegt dat te doen. ${ }^{7}$

Het normaal maatschappelijk risico en de tekst van de geselecteerde, thans geldende regelingen

Van de geselecteerde, thans geldende regelingen bevatten slechts afd. 6.1 Wro, de BnIW 2019, en de Amsterdamse verordeningen een bepaling waaruit blijkt dat schade slechts voor compensatie in aanmerking komt als zij het normaal maatschappelijk risico ontstijgt:

\section{Art. 6.2 lid 1 Wro}

Binnen het normale maatschappelijke risico vallende schade blijft voor rekening van de aanvrager.

\section{Art. 3 lid 1 BnIW 2019}

Binnen het normaal maatschappelijk risico of het normaal ondernemersrisico vallende schade komt niet voor vergoeding in aanmerking.

\section{Art. 2 lid 2 AVN 8}

Niet voor vergoeding komt in aanmerking schade die behoort tot het normaal maatschappelijk risico of het normaal ondernemersrisico.

\section{Art. 2 lid 1 VNNZ}

Het college kent een aanvrager nadeelcompensatie toe, indien het nadeel uitgaat boven het normaal maatschappelijk risico of het normaal ondernemersrisico.

Dat in de Wro geen onderscheid wordt gemaakt tussen 'normaal maatschappelijk risico' en 'normaal ondernemersrisico' kan worden verklaard doordat 'normaal ondernemersrisico' het normaal maatschappelijk risico is zoals dat door ondernemers moet worden geaccepteerd. ${ }^{9}$ Het afzonderlijk benoemen van het normaal ondernemersrisico is daarom niet strikt noodzakelijk. Dat laat onverlet dat het afzonderlijk benoemen van het ondernemersrisico een handige manier kan zijn

6 Tjepkema 2010, p. 420-423.

7 Zie bijvoorbeeld Kamerstukken II 2010/11, 32 621, nr. 3, p. 13 (MvT, Wns).

8 In het eerste lid van deze bepaling wordt ook nog vermeld dat de aanvrager "in abnormale mate" moet zijn getroffen.

9 Zie daarover bijvoorbeeld Kamerstukken II 2010/11, 32 621, nr. 3, p. 23 (MvT, Wns). 
om aan te geven dat bepaalde normering van de abnormale last slechts is gericht tot ondernemers. ${ }^{10}$

Ondanks het ontbreken van zelfstandige bepalingen daaromtrent, kan het normaal maatschappelijk risico ook worden tegengeworpen bij aanvragen gebaseerd op art. 21 Aanwijzingsbesluit 1996, ${ }^{11}$ art. $8.31 \mathrm{Wlv}^{12}$ en het ongeschreven égalitébeginsel. ${ }^{13}$ In geval van art. 21 Aanwijzingsbesluit 1996 en art. 8.31 Wlv gaat dit via de band van de in deze regelingen opgenomen redelijkerwijsformules. Het ontbreken van een zelfstandige bepaling omtrent het normaal maatschappelijk risico in deze regelingen lijkt met name te worden verklaard doordat het ten tijde van de totstandkoming van deze regelingen nog niet gebruikelijk was om in nadeelcompensatieregelingen uit te werken wanneer aan de daarin vervatte redelijkerwijsformule werd voldaan. Voorts is voor de formulering van zowel art. 21 Aanwijzingsbesluit 1996 als art. 8.31 Wlv aansluiting gezocht bij art. $49 \mathrm{WRO}$, en in geval van art. 8.31 Wlv ook bij art. 15.20 Wet milieubeheer. ${ }^{14}$ Dat in de GrS geen vermelding van het criterium van de abnormale last wordt gemaakt, kan worden verklaard door de in paragraaf 3.2.1 beschreven, bijzondere aard van deze regeling: zij dient ertoe de reeds op grond van verschillende grondslagen bestaande - en aan verschillende bestuursorganen toekomende - bevoegdheden om nadeelcompensatie toe te kennen, binnen een specifieke context over te dragen aan het algemeen bestuur van het Schadeschap.

Tegenwerping van het normaal maatschappelijk risico is niet mogelijk als art. 49 WRO de achterliggende grondslag voor planschadevergoeding vormt. De Afdeling ${ }^{15}$ heeft namelijk meermaals overwogen dat de...

“(...) maatstaf, dat voor vergoeding van planschade noodzakelijk is dat sprake is van overschrijding van het normaal maatschappelijk risico, niet juist [is]. Naar de Afdeling meermalen heeft overwogen, heeft de wetgever met artikel 49 van de WRO de schade

10 Zie bijvoorbeeld art. 2 lid 3 jo. lid 4 AVN. Zie ook art. 3a BnIW 2019. Dergelijke normering ontbrak overigens in de RnVW 1999, maar ook in art. 3 van die beleidsregel werd het ondernemersrisico apart benoemd.

11 ABRvS 9 april 2008, ECLI:NL:RVS:2008:BC9040, r.o. 2.6.

12 ABRvS 19 februari 2014, ECLI:NL:RVS:2014:572, r.o. 10-10.5 (Risicolocatie Schiphol).

13 ABRvS 6 september 2017, ECLI:NL:RVS:2017:2416, r.o. 4.

14 Zie Stcrt. 1998, nr. 223, p. 11 (digitaal) respectievelijk Kamerstukken II 00/01, 27 603, nr. 3, p. 69 en 15.

15 De Kroon was aanvankelijk een andere mening toegedaan. Zie daarover Van den Broek 2002, p. 173-179. 
die een belanghebbende lijdt ten gevolge van een planologische wijziging die hem in een nadeliger positie brengt, in beginsel niet voor diens rekening willen laten." 16

In paragraaf 6.4.1 zullen enkele uitspraken worden aangehaald waaruit blijkt dat de Afdeling bereid was hierop een uitzondering te maken bij schade in de vorm van tijdelijke derving van woongenot.

Hoewel de tekst van de VNNZ anders doet vermoeden, speelt het normaal maatschappelijk risico geen rol bij toepassing van deze regeling. Dat was anders onder de Verordening Nadeelcompensatie en Planschade Noord/Zuidlijn, bij toepassing waarvan de aanvrager doorgaans een korting van $20 \%$ op het schadebedrag wegens normaal maatschappelijk risico werd tegengeworpen. ${ }^{17} \mathrm{Bij}$ toepassing van de VNNZ gaat het Amsterdamse college van B\&W echter ervan uit dat aanvragers reeds gedurende "een substantieel aantal jaren nadeel hebben geleden" terwijl dat vanwege de tegenwerping van risicoaanvaarding veelal niet (volledig) werd gecompenseerd onder de Verordening Nadeelcompensatie en Planschade Noord/ Zuidlijn. Het wordt daarom onredelijk geacht deze aanvragers "op het moment dat zij alsnog in aanmerking komen voor nadeelcompensatie nogmaals aan een korting op deze nadeelcompensatie te onderwerpen." Op grond hiervan is het gemeentebestuur van mening dat "niet voor twijfel vatbaar is dat van een abnormale last kan worden gesproken." 18

\section{De afbakening van het normaal maatschappelijk risico}

Het voorafgaande zegt slechts iets over de vraag of het criterium van de abnormale last wordt gehanteerd onder de geselecteerde, thans geldende regelingen. Nadeelcompensatieregelingen kunnen de afbakening van het normaal maatschappelijk risico echter ook in meer detail normeren ten aanzien van bepaalde schadesoorten. Voorts betreft het vaste jurisprudentie dat...

“(...) de vraag of in een bepaald geval de gevolgen van een overheidshandeling buiten het normale maatschappelijk risico of het normale bedrijfsrisico vallen, moet wor-

16 Zie ABRvS 6 mei 2004, ECLI:NL:RVS:2004:AO8857, r.o. 2.7; en ABRvS 19 april 2006, ECLI:NL:RVS:2006:AW2291, r.o. 2.8. Hieraan werd doorgaans nog toegevoegd dat de schade wel redelijkerwijs geheel of gedeeltelijk ten laste van de aanvrager diende te blijven als sprake was van risicoaanvaarding of de vergoeding van de schade voldoende anderszins was verzekerd.

17 Zie bijvoorbeeld ABRvS 8 september 2004, ECLI:NL:RVS:2004:AQ9948; en Rb. Amsterdam 5 september 2007, ECLI:NL:RBAMS:2007:BB7627.

18 Zie de toelichting op art. 2 lid 1 VNNZ en de bespreking van de vijfde aanbeveling in de algemene toelichting op de VNNZ. 
den beantwoord met inachtneming van alle van belang zijnde omstandigheden van het geval." 19

Dit samenspel tussen normering van het normaal maatschappelijk risico in nadeelcompensatieregelingen en de jurisprudentie zal ook aan bod komen bij de beantwoording van de tweede en derde deelvraag en de hoofdvraag. Die beantwoording zal geschieden in drie afzonderlijke paragrafen omtrent permanente waardevermindering van onroerende zaken (paragraaf 6.2), inkomensderving (paragraaf 6.3), en tijdelijke derving van woongenot (paragraaf 6.4). ${ }^{20} \mathrm{Bij}$ de beantwoording van de tweede deelvraag zal niet inhoudelijk worden ingegaan op art. $49 \mathrm{WRO}^{21}$ en de VNNZ, omdat hiervoor bleek dat het normaal maatschappelijk risico onder deze regelingen praktisch geen rol van betekenis speelt.

Ten slotte merk ik hier al op dat een aantal van de geselecteerde, thans geldende regelingen een of meerdere absolute bagateldrempels bevat. Het betreft art. 3 lid 2 onder a en b BnIW 2019 ( $€ 500$ voor particulieren, respectievelijk $€ 1.000$ voor ondernemers), art. 3 lid 2 BnIM 2014 (€1.000) en art. 3 lid 4 AVN (€750). De desbetreffende regelgevers hebben hiermee tot uitdrukking willen brengen dat bagatelschade altijd tot het normaal maatschappelijk risico behoort. ${ }^{22}$ In paragraaf 6.3.3 zal ter sprake komen in hoeverre de aan de Wns ten grondslag liggende doelstellingen en uitgangspunten aanleiding geven dergelijke drempels ook in titel 4.5 Awb of afd. 15.1 Ow op te nemen.

19 Deze overweging is afkomstig uit HR 17 september 2004, ECLI:NL:HR:2004:AO7887, r.o. 3.3 ( $U z i)$ en is overgenomen door de Afdeling. Zie bijvoorbeeld ABRvS 28 september 2016, ECLI:NL:RVS:2016:2582, r.o. 5.9 (Overzichtsuitspraak); ABRvS 25 september 2013, ECLI:NL:RVS:2013:1222, r.o. 6.1 (Bodyfashion Zwanenburg, hoger beroep); en ABRvS 19 februari 2014, ECLI:NL:RVS:2014:572, r.o. 10.3 (Risicolocatie Schiphol).

20 Daarvoor is gekozen omdat dit de meest voorkomende schadesoorten zijn. Dat was ook de reden dat voor wat betreft schadebegroting afzonderlijk op deze schadesoorten is ingegaan in paragraaf 5.7.

21 Wel zullen enkele onder art. 49 WRO gewezen rechterlijke uitspraken in paragraaf 6.4.1 worden betrokken bij de inventarisatie van jurisprudentielijnen omtrent het normaal maatschappelijk risico bij tijdelijke derving van woongenot.

22 Zie Stcrt. 2019, nr. 66154, p. 9; Stcrt. 2014, nr. 16584, p. 8; en de toelichting op art. 3 lid 4 AVN. 


\subsection{PERMANENTE WAARDEVERMINDERING VAN ONROERENDE ZAKEN}

6.2.1 Deelvraag 2: verschillen tussen de geselecteerde, thans geldende regelingen en verklaringen daarvoor

\subsubsection{Specifieke normering ten aanzien van permanente waardevermindering van onroerende zaken}

Van de geselecteerde, thans geldende regelingen bevatten slechts afd. 6.1 Wro en de AVN specifieke normering met betrekking tot het normaal maatschappelijk risico bij permanente waardevermindering van onroerende zaken. Op grond van art. 6.2 lid 2, aanhef en onder b Wro respectievelijk art. 2 lid 5 AVN blijft een gedeelte van de schade gelijk aan twee procent van de waarde van de onroerende zaak onmiddellijk voor het ontstaan van de schade "in ieder geval" voor rekening van de aanvrager. Het heeft er veel van weg dat de Amsterdamse gemeenteraad met zijn bepaling uit de AVN heeft willen aansluiten bij de bepaling uit de Wro. ${ }^{23}$ Dit is verenigbaar met later gewezen jurisprudentie waarin de Afdeling sanctioneert dat aansluiting wordt gezocht bij de drempel van art. 6.2 lid 2 Wro bij toekenning van nadeelcompensatie op grond van het égalitébeginsel als "de aard van de toegebrachte schade overeenkomstig is." Daarvan was bijvoorbeeld sprake bij een aanvraag om nadeelcompensatie die werd ingediend nadat de verlening van vergunningen voor de exploitatie van twee coffeeshops omliggende woningen in waarde liet dalen. ${ }^{24}$ Soms blijkt de Afdeling om die reden ook zelf aansluiting te zoeken bij de drempel uit de Wro. ${ }^{25}$

In paragraaf 6.1 bleek waarom in de GrS, art. 49 WRO, art. $8.31 \mathrm{Wlv}$, art. 21 Aanwijzingsbesluit 1996 en de VNNZ geen bijzondere normering omtrent de afbakening van het normaal maatschappelijk risico is opgenomen. Dat in de BnIW 2019 geen specifieke normering omtrent normaal maatschappelijk risico bij permanente waardevermindering van onroerende zaken is opgenomen, kan waarschijnlijk worden verklaard doordat deze schade doorgaans als gevolg van in art. 6.1 lid 2 Wro opgesomde planologische besluitvorming aan het bestuur wordt toegerekend. Soms gebruikt de minister de BnIW 2019 echter om invulling te geven aan zijn uit art. 17 Spoedwet wegverbreding of art. 22 Tracéwet voortvloeiende plicht tot

23 De formulering komt nagenoeg letterlijk overeen. Een verschil is dat de drempel uit de AVN op grond van art. 2 lid 7 AVN naar beneden zou kunnen worden bijgesteld. Dat verschil laat ik hier rusten, omdat het op grond van ABRvS 11 februari 2015, ECLI:NL:RVS:2015:336, r.o. 4.3 (Fietstunnel Rijksweg 7 bij Sneek) onaannemelijk lijkt dat het bevoegd gezag gebruik zal maken van deze mogelijkheid.

24 ABRvS 31 juli 2013, ECLI:NL:RVS:2013:558, r.o. 5.1. Zie ook ABRvS 4 mei 2016, ECLI:NL:RVS:2016:1205, r.o. 10.3 (Orac).

25 ABRvS 11 februari 2015, ECLI:NL:RVS:2015:336, r.o. 4.3 (Fietstunnel Rijksweg 7 bij Sneek). 
nadeelcompensatie. ${ }^{26}$ Onder deze grondslagen lijkt een permanente waardevermindering van onroerende zaken zich slechts te kunnen voordoen in zoverre een tracé- of wegaanpassingsbesluit ingrijpt in het ter plaatse geldende planologische regime (vergelijk art. 13 lid 10 Tracéwet respectievelijk art. 11 lid 8 Spoedwet wegverbreding). De Afdeling heeft geoordeeld dat de aanvraag om compensatie dan niet dient te worden behandeld conform de criteria uit de BnIW 2019, maar conform de criteria uit het planschaderecht. ${ }^{27}$ De achterliggende ratio lijkt te zijn dat de aard van dergelijke tracé- en wegaanpassingsbesluiten overeenkomt met de aard van de in art. 6.1 lid 2 Wro opgesomde schadeoorzaken. ${ }^{28}$ Ook dit soort situaties geven dus geen aanleiding om bijzondere normering in de BnIW 2019 op te nemen.

\subsubsection{De minimumdrempel uit de Wro}

De in de Wro opgenomen drempel is slechts van toepassing op indirecte schade, omdat de wetgever eventuele strijdigheid met art. 1 EP EVRM wilde uitsluiten. ${ }^{29}$ De gegrondheid van de vrees voor deze strijdigheid is destijds terecht ${ }^{30}$ in twijfel getrokken door onder andere Van den Broek en Tjepkema. ${ }^{31}$ Het door de wetgever gekozen drempelpercentage lijkt tot op grote hoogte een willekeurig karakter te dragen. In het voorontwerp werd nog een drempel van $10 \%$ van de waarde van de onroerende zaak voorgesteld. ${ }^{32}$ De AARvS uitte inhoudelijke kritiek op deze drempel, omdat deze een vorm van "object-gerichte draagkracht" zou meebrengen. Het destijds zittende kabinet werd hierdoor niet overtuigd, maar besloot desondanks $10 \%$ in $5 \%$ te veranderen om enigszins tegemoet te komen aan de kritiek van de AARvS. Daarbij werd erkend dat (de percentuele hoogte van) iedere drempel of norm "onvermijdelijk arbitrair" zou zijn. Een lager percentage zou echter

26 Zie naast de jurisprudentie die ik hierna zal aanhalen ook Van den Broek 2013a, p. 180.

27 Zie voor tracébesluiten: ABRvS 16 maart 2005, ECLI:NL:RVS:2005:AT0572, r.o. 2.7-2.7.1; ABRvS 28 november 2012, ECLI:NL:RVS:2012:BY4394, r.o. 8-8.4; ABRvS 3 juli 2013, ECLI:NL:RVS:2013:160, r.o. 2; ABRvS 4 november 2015, ECLI:NL:RVS:2015:3350, r.o. 1; en ABRvS 18 oktober 2017, ECLI:NL:RVS:2017:2805, r.o. 8-8.1. Zie voor wegaanpassingsbesluiten: ABRvS 31 maart 2010, ECLI:NL:RVS:2010:BL9576, r.o. 2.2; ABRvS 6 juni 2012, ECLI:NL:RVS:2012:BW7613, r.o. 2.3; ABRvS 25 november 2015, ECLI:NL:RVS:2015:3612, r.o. 1.1; en ABRvS 30 november 2016, ECLI:NL:RVS:2016:3168, r.o. 6.2 (Wegafsluiting Hoevelaken).

28 Dat is overigens ook zo als een luchthavenindelingbesluit afwijkt van het ter plaatse geldende bestemmingsplan (vergelijk art. $8.8 \mathrm{Wlv}$ ). Toch heeft de Afdeling het planschaderecht nooit van overeenkomstige toepassing verklaard op art. $8.31 \mathrm{Wlv}$.

29 Kamerstukken II 2002/03, 28 916, nr. 3, p. 63-64, 114 (MvT, Wro).

$30 \quad$ Vergelijk paragraaf 2.5.1.

31 Zie bijvoorbeeld Van den Broek 2004, p. 648-649; en Van den Broek \& Tjepkema 2017, p. 31-32.

32 Dit voorontwerp is destijds ter inzage gelegd bij het Centraal Informatiepunt Tweede Kamer. Zie hieromtrent Kamerstukken II 1999/2000-2001/02, 27 029, nr. 1-6. 
ertoe leiden dat een van de beoogde effecten van de drempel teniet zou gaan, namelijk het voorkomen van "schadeclaims van te geringe omvang". ${ }^{33}$ Vervolgens hebben Tweede Kamerleden Lenards, Van Bochove en Verdaas op 7 februari 2006 een amendement ingediend waarin werd voorgesteld het drempelpercentage te verlagen naar $2 \%$. Hiermee werd beoogd het "eigen risico" van de aanvrager te beperken. Tegelijkertijd moest indiening van bagatelaanvragen onaantrekkelijk blijven. ${ }^{34}$ Tijdens de beraadslaging in de Kamer gaf Verdaas aan het "heel lastig" te vinden om "het juiste evenwicht" te vinden. Vijf procent zou te veel zijn, terwijl bij nul procent - afgezien van de politieke haalbaarheid daarvan - geen sprake meer zou zijn van een drempel. ${ }^{35}$ De verantwoordelijk minister gaf aan dat het zijn overtuiging was dat de hoogte van 5\% "een goede zaak was". Ondanks dat hij twijfelde aan de "dempende werking" van een $2 \%$-drempel liet hij het oordeel omtrent het amendement aan de Kamer. Wel kondigde hij aan dat de 2\%-drempel zou worden geëvalueerd, en bijstelling van het drempelpercentage zou volgen als $2 \%$ te laag zou blijken. ${ }^{36}$ Het amendement werd zonder stemming aangenomen op 21 februari $2006 .{ }^{37}$ De hoogte van de daardoor ontstane $2 \%$-drempel maakte echter geen onderdeel uit van de twee evaluaties van de Wro die sindsdien hebben plaatsgevonden. ${ }^{38}$

Na inwerkingtreding van de Wro bestond onduidelijkheid omtrent de verhouding tussen het eerste en tweede lid van art. 6.2 Wro. Veelal op advies van een deskundige, stelde het bestuur het normaal maatschappelijk risico daarom doorgaans onder verwijzing naar art. 6.2 lid 2, aanhef en onder b Wro vast op 2\% van de waarde van de onroerende zaak onmiddellijk voor het ontstaan van de schade, zonder daarbij in te gaan op de omstandigheden van het concrete schadegeval. ${ }^{39}$ Deze praktijk werd op 5 september 2012 een halt toegeroepen in de Heiloo-uitspraak. Op grond van een wetshistorische interpretatie kwam de Afdeling daarin namelijk tot de conclusie dat het eerste lid van art. 6.2 Wro "zelfstandige betekenis" heeft: niet kan worden volstaan met de toets of bijzondere omstandigheden zijn gebleken op grond waarvan meer dan $2 \%$ van de waarde van diens onroerende zaak voor rekening van de aanvrager zou moeten blijven. ${ }^{40}$

33 Zie Kamerstukken II 2002/03, 28 916, nr. A, p. 21-22 (Advies RvS, Wro); en Kamerstukken II 2002/03, 28 916, nr. A, p. 23 (Nader rapport, Wro).

34 Zie Kamerstukken II 2005/06, 28 916, nr. 17 (Amendement Lenards c.s.); en Handelingen II 2005/06, 28 916, nr. 47, p. 3110.

35 Handelingen II 2005/06, 28 916, nr. 47, p. 3114.

36 Zie Kamerstukken II 2005/06, 28 916, nr. 31, p. 5; en Handelingen II 2005/06, 28 916, nr. 47, p. 3132.

37 Handelingen II 2005/06, 28 916, nr. 52, p. 3425.

38 Zie ten aanzien van de eerste evaluatie: Planbureau voor de Leefomgeving 2009, p. 8 en 10, voetnoot 3 én Planbureau voor de Leefomgeving 2010. Zie voor de tweede evaluatie: Planbureau voor de Leefomgeving 2012.

39 Dijkshoorn voorspelde deze praktijk al in Dijkshoorn 2011a, p. 27.

40 ABRvS 5 september 2012, ECLI:NL:RVS:2012:BX6492, r.o. 10.1 (Heiloo). 
Deze jurisprudentie maakt dat art. 6.2 lid 2 Wro een relatief beperkte functie kent. Ten eerste functioneert deze bepaling als minimumdrempel: de omvang van het normaal maatschappelijk risico bij indirecte schade in de vorm van permanente waardevermindering van onroerende zaken kan nooit minder bedragen dan $2 \%$ van de waarde van de getroffen onroerende zaak onmiddellijk voor het ontstaan van de schade. Daarbij is van belang dat art. 6.2 lid 2 Wro een formeelwettelijke bepaling van dwingend recht is, waardoor het bestuur het minimumforfait steeds zal moeten tegenwerpen ${ }^{41}$ omdat anders een "keuze van de wetgever" zou worden genegeerd. ${ }^{42}$ Ten tweede functioneert art. 6.2 lid 2 Wro als bagateldrempel: als de schade niet groter is dan $2 \%$ van de waarde van de onroerende zaak onmiddellijk voor het ontstaan van de schade, ${ }^{43}$ kan de aanvraag zonder uitgebreide motivering worden afgewezen. ${ }^{44}$ Lenards c.s. lijkt met name deze functie voor ogen te hebben gestaan. ${ }^{45}$ Ten derde functioneert art. 6.2 lid 2 Wro als waarschuwing aan de aanvrager: hij zal in ieder geval geen vergoeding ontvangen, en bovendien het door hem op grond van art. 6.4 Wro betaalde recht ${ }^{46}$ kwijtraken, als zijn indirecte schade niet uitstijgt boven het $2 \%$-minimumforfait. ${ }^{47}$ Ten slotte vervult dit $2 \%$-forfait soms ook "de functie van een criterium dat verondersteld wordt het normaal maatschappelijk risico volledig te weerspiegelen." ${ }^{48}$ Dat is het geval als toepassing van art. 6.2 lid 1 Wro niet leidt tot de conclusie dat de aanvrager een grotere aftrek wegens normaal maatschappelijk risico dient te worden tegengeworpen. ${ }^{49}$ In het hiernavolgende deel van deze paragraaf zal aandacht worden besteed aan de vraag hoe dat artikellid dient te worden toegepast, en in hoeverre dat verschilt of overeenkomt met de wijze waarop het normaal maatschappelijk risico onder de overige regelingen wordt afgebakend.

41 ABRvS 28 september 2016, ECLI:NL:RVS:2016:2582, r.o. 5.4 (Overzichtsuitspraak).

42 ABRvS 19 februari 2014, ECLI:NL:RVS:2014:518, r.o. 7.1.

43 Dat deed zich bijvoorbeeld voor in ABRvS 19 februari 2014,

ECLI:NL:RVS:2014:518, r.o. 5; en ABRvS 24 juni 2015, ECLI:NL:RVS:2015:1971, r.o. 2. Zie voor een uitgebreidere opsomming van dergelijke gevallen Van den Broek \& Tjepkema 2015, p. 68, voetnoot 28.

44 Op deze functie wordt ook ingaan in MvT consultatieversie IOw, p. 24; Van den Broek \& Tjepkema 2015, p. 67; en Van Ravels 2008, p. 138-140.

45 Kamerstukken II 2005/06, 28 916, nr. 17 (Amendement Lenards c.s.).

$46 \quad$ Zie daarover paragraaf 10.4.1.

47 Van Ravels 2013a, p. 106.

48 Deze formulering is ontleend aan Van den Broek \& Tjepkema 2015, p. 67.

49 Zie bijvoorbeeld: ABRvS 9 december 2015, ECLI:NL:RVS:2015:3721, r.o. 7.3 (Wijdemeren); ABRvS 11 februari 2015, ECLI:NL:RVS:2015:349, r.o. 4.2 (De Wolden); en ABRvS 29 oktober 2014, ECLI:NL:RVS:2014:3851, r.o. 17-17.1. Zie verder paragraaf 6.2.1.3 onder het kopje 'omzetting in percentages'. 


\title{
6.2.1.3 Toepassing van de Heiloo-factoren op indirecte schade
}

Sinds het begin van $2012^{50}$ zijn uitspraken verschenen waarin de Afdeling zich in algemene zin uitlaat over de afbakening van het normaal maatschappelijk risico onder de Wro. Uiteindelijk is de onderstaande standaardoverweging ontstaan:

\begin{abstract}
"De vraag of schade als gevolg van een planologische ontwikkeling als bedoeld in artikel 6.1, tweede lid, van de Wro tot het normale maatschappelijke risico behoort, moet worden beantwoord met inachtneming van alle van belang zijnde omstandigheden van het geval. Van belang is onder meer of de planologische ontwikkeling als een normale maatschappelijke ontwikkeling kan worden beschouwd waarmee de benadeelde rekening had kunnen houden in die zin dat de ontwikkeling in de lijn der verwachtingen lag, ook al bestond geen concreet zicht op de omvang waarin, de plaats waar en het moment waarop de ontwikkeling zich zou voordoen. ${ }^{51}$ In dit verband komt betekenis toe aan de mate waarin de ontwikkeling naar haar aard en omvang binnen de ruimtelijke structuur van de omgeving en het in een reeks van jaren gevoerde planologische beleid past. Omstandigheden die verder van belang kunnen zijn, zijn de afstand van de locatie waar de ontwikkeling heeft plaatsgevonden tot de onroerende zaak van de aanvrager en de aard en de omvang van het door de ontwikkeling veroorzaakte nadeel." ${ }^{, 52}$
\end{abstract}

Uit deze standaardoverweging kunnen de zogenoemde Heiloo-factoren ${ }^{53}$ worden gedestilleerd. Naar verloop van tijd is de verhouding tussen deze factoren steeds duidelijker geworden. Ik zal de factoren en hun onderlinge verhouding hierna van nadere toelichting voorzien.

\section{Normale maatschappelijke ontwikkeling}

Als eerste dient te worden vastgesteld of de schade het gevolg is van een normale maatschappelijke ontwikkeling. Inmiddels kan uit de Afdelingsjurisprudentie een

50 Zie ABRvS 29 februari 2012, ECLI:NL:RVS:2012:BV7254, r.o. 2.11 .1 (Tilburg/Vugts); en ABRvS 5 september 2012, ECLI:NL:RVS:2012:BX6492, r.o. 12 (Heiloo).

51 Ik sluit niet uit dat deze zin deels is gebaseerd op Stcrt. 1999, nr. 172, p. 10 (digitaal, p. 7-8).

52 ABRvS 13 april 2016, ECLI:NL:RVS:2016:986, r.o.6.1 (Wierden). Zie ook ABRvS 28 september 2016, ECLI:NL:RVS:2016:2582, r.o. 5.10 (Overzichtsuitspraak).

53 In Van den Broek \& Tjepkema 2015 wordt gesproken van "Heiloo-criteria". Aangezien het niet gaat om harde, cumulatieve voorwaarden maar om toerekening op basis van bepaalde gezichtspunten, heeft het mijn voorkeur om van 'factoren' te spreken (vergelijkbaar met bijvoorbeeld de 'Kelderluik-factoren'). 
palet van normale maatschappelijke ontwikkelingen worden gedestilleerd. ${ }^{54}$ Daar dient echter niet blind op te worden gestaard. In de Overzichtsuitspraak wordt namelijk overwogen dat...

“(...) de omstandigheid dat een bepaalde functie in een bepaald gebied thuis hoort (..) op zichzelf nog niet [betekent] dat als uitgangspunt heeft te gelden dat nieuwvestiging van deze functie in dat gebied als een normale maatschappelijke ontwikkeling kan worden beschouwd." ${ }^{5}$

Uiteindelijk zijn de omstandigheden van het concrete schadegeval dus altijd doorslaggevend bij beantwoording van de vraag of de schadeoorzaak kwalificeert als normale maatschappelijke ontwikkeling. ${ }^{56} \mathrm{Mij}$ zijn geen voorbeelden bekend waarin permanente waardevermindering van onroerende zaken werd veroorzaakt door een niet-normale ontwikkeling. ${ }^{57}$ Ik vermoed dat dit komt doordat (de wijziging van) een bestemmingsplan dient te voldoen aan de eisen van een goede ruimtelijke ordening (art. 3.1 Wro) en een evenredige belangenafweging (art. 3:4 lid 2 Awb) om een eventuele rechtmatigheidstoets bij de rechter te kunnen doorstaan. ${ }^{58}$

54 Zie bijvoorbeeld ABRvS 28 september 2016, ECLI:NL:RVS:2016:2582, r.o. 5.14 (Overzichtsuitspraak); ABRvS 1 juli 2015, ECLI:NL:RVS:2015:2074, r.o. 4.3; ABRvS 28 september 2016, ECLI:NL:RVS:2016:2583, r.o. 17.3-17.4; ABRvS 26 augustus 2015, ECLI:NL:RVS:2015:2680; ABRvS 3 juni 2015, ECLI:NL:RVS:2015:1720, r.o. 6.3 (Twenterand); ABRvS 21 september 2016, ECLI:NL:RVS:2016:2502, r.o. 8.4 (Schoonrewoerd); ABRvS 4 maart 2015, ECLI:NL:RVS:2015:617, r.o. 8.2; ABRvS 27 januari 2016,

ECLI:NL:RVS:2016:143, r.o. 12.4 (Twenterand); ABRvS 25 november 2015, ECLI:NL:RVS:2015:3611,r.o. 8.4; enABRvS 10juli2013,ECLI:NL:RVS:2013:216, r.o. 11.3.

55 ABRvS 28 september 2016, ECLI:NL:RVS:2016:2582, r.o. 5.11 (Overzichtsuitspraak).

56 Zie bijvoorbeeld ook ABRvS 20 februari 2019, ECLI:NL:RVS:2019:495, r.o. 26.4 (Meierijstad). Dat neemt overigens niet weg dat bepaalde algemene tendensen wel mogen worden meegewogen. Zie bijvoorbeeld ABRvS 22 februari 2012, ECLI:NL:RVS:2012:BV6510, r.o. 2.5.1; ABRvS 4 juni 2014, ECLI:NL:RVS:2014:2033, r.o. 7.4; ABRvS 13 augustus 2014, ECLI:NL:RVS:2014:3005, r.o. 5.3; en ABRvS 1 juli 2015,

ECLI:NL:RVS:2015:2075, r.o. 7.3. Zie ook Van Ravels 2014a, p. 6; en Van Ravels 2008, p. 131-135 en 141-142.

57 Ook in Van den broek \& Tjepkema 2015, p. 94 wordt geconcludeerd dat toepassing van deze Heiloo-factor doorgaans weinig problemen oplevert.

58 Buiten het planschaderecht doen niet-normale ontwikkelingen zich vaker/wel voor. Vaak betreft het ontwikkelingen die in beginsel normaal zijn, maar zodanig worden uitgevoerd dat zij toch als abnormaal kwalificeren. Een bekend voorbeeld betreft ABRvS 5 juni 2013, ECLI:NL:RVS:2013:CA2052, r.o. 7.2 (Hollandse Brug, tussenuitspraak). 


\section{Lijn der verwachtingen}

Ten tweede dient te worden vastgesteld of de schadeveroorzakende ontwikkeling ook ter plaatse in de lijn der verwachtingen lag. Bij beantwoording van deze vraag is doorslaggevend of de ontwikkeling naar haar aard en omvang past binnen de ruimtelijke structuur van de omgeving van het plangebied, ${ }^{59}$ en het in een reeks van jaren gevoerde ${ }^{60}$ planologische beleid. Er bestaan ongetwijfeld nog veel vragen omtrent deze factoren die nog niet aan de Afdeling zijn voorgelegd. Moet het gevoerde beleid bijvoorbeeld planologisch van aard zijn, of zou bijvoorbeeld ook beleid omtrent subsidiëring van bepaalde (ruimtelijke) ontwikkelingen kunnen volstaan ${ }^{61}$ Toch is relatief ver uitgekristalliseerd hoe deze factoren moeten worden ingevuld. Zo is "niet de feitelijke situatie, maar het ter plaatse toepasselijke planologische regime leidend" voor de beoordeling van de aansluiting op de ruimtelijke structuur van de omgeving. ${ }^{62}$ Tevens is bijvoorbeeld duidelijk hoe moet worden omgegaan met ontwikkelingen die herleidbaar zijn tot uitzonderingsmogelijkheden in het gevoerde planologische beleid..$^{63}$

In de Rijsbergen-uitspraak van 2 maart 2016 overwoog de Afdeling dat aan de korte afstand van de schadeveroorzakende ontwikkeling tot het perceel van de aanvrager geen "zelfstandige betekenis" toekwam. Het diende namelijk ervoor te worden gehouden dat deze afstand reeds was verdisconteerd in de waardevermindering van de woning van de aanvrager. Omdat de afstand tot de woning van de aanvrager doorgaans altijd van invloed zal zijn op de schadeomvang, leek de afstandsfactor sinds deze uitspraak niet langer zelfstandig voor een verlaging van de aftrek wegens normaal maatschappelijk risico te kunnen pleiten. Het verbaasde dan ook dat dit toch regelmatig gebeurde in uitspraken van zowel rechtbanken ${ }^{64}$ als de Afdeling. ${ }^{65}$ De rechtbank Oost-Brabant verwierp zelfs expliciet een beroep

59 Dat het gaat om de omgeving van het plangebied blijkt bijvoorbeeld uit ABRvS 2 maart 2016, ECLI:NL:RVS:2016:530, r.o. 5.3 (Rijsbergen); ABRvS 14 september 2016, ECLI:NL:RVS:2016:2487, r.o. 4.3 (Lankes); en ABRvS 13 juni 2018, ECLI:NL:RVS:2018:1935, r.o. 4.3.

60 ABRvS 4 juni 2014, ECLI:NL:RVS:2014:2033, r.o. 7.4: het enkele doen van onderzoek naar een locatie is onvoldoende.

61 Deze vraag stel ik naar aanleiding van jurisprudentie omtrent risicoaanvaarding: ABRvS 25 januari 2006, ECLI:NL:RVS:2006:AV0284, r.o. 2.6.1 (Planschade Hengelo). Dat in ieder geval bepaalde financiële overwegingen een rol mogen spelen, volgt uit ABRvS 4 juni 2014, ECLI:NL:RVS:2014:2033, r.o. 7.4. ABRvS 2 maart 2016, ECLI:NL:RVS:2016:530, r.o. 5.3 (Rijsbergen). Zie voor een soortgelijke overweging: ABRvS 14 september 2016, ECLI:NL:RVS:2016:2487, r.o. 4.3 (Lankes). 14 september 2016, ECLI:NL:RVS:2016:2487, r.o. 4.4-4.5 (Lankes). 20.

Zie bijvoorbeeld ABRvS 21 juni 2017, ECLI:NL:RVS:2017:1653, r.o. 5.4 (Beuningen); ABRvS 13 april 2016, ECLI:NL:RVS:2016:986, r.o. 7.3 (Wierden); en ABRvS 28 september 2016, ECLI:NL:RVS:2016:2543, r.o. 6.6. 
op de Rijsbergen-uitspraak. Zij overwoog dat de korte afstand tot het perceel van de aanvrager "natuurlijk" van invloed was op de schadeomvang. Desondanks oordeelde de rechtbank dat de deskundige van het bestuur wel gewicht had mogen toekennen aan de korte afstand tot het perceel van de aanvrager. Zij beschouwde deze afstand namelijk als een van de in de Overzichtsuitspraak "genoemde omstandigheden die van belang kunnen zijn." ${ }^{\prime 66}$

Het heeft er veel van weg dat de Afdeling paal en perk hieraan heeft willen stellen in twee relatief recente uitspraken. In een uitspraak van 1 mei 2019 vat zij namelijk duidelijk samen wat de rol is van de afstand van de locatie van de ontwikkeling tot de onroerende zaak van de aanvrager, en de aard en omvang van de schade:

"In dat kader is van belang dat deze aspecten enkel een rol kunnen spelen bij het antwoord op de vraag of de ontwikkeling een normale maatschappelijke ontwikkeling betreft die in de lijn der verwachting lag, maar dat aan deze aspecten geen zelfstandige betekenis toekomt, omdat deze aspecten reeds zijn verdisconteerd in de hoogte van de geleden planschade." ${ }^{97}$

In iets minder algemene bewoordingen werd dit ook al overwogen in de Stolwijkuitspraak van 8 augustus $2018 .{ }^{68}$ Uit deze uitspraak blijkt bovendien duidelijk wat de achterliggende ratio van deze jurisprudentielijn is: het moet worden voorkomen dat dubbele correcties worden aangebracht op de hoogte van het normaal maatschappelijk risico. De factoren van afstand en aard en omvang van de schade lijken naar huidig recht dus nog slechts een rol te mogen spelen bij de beoordeling of de schade is veroorzaakt door een normale maatschappelijke ontwikkeling ${ }^{69}$ die paste binnen de ruimtelijke structuur van de omgeving van het plangebied ${ }^{70}$ en het in een reeks van jaren gevoerde planologische beleid.

66 Rb. Oost-Brabant 8 november 2017, ECLI:NL:RBOBR:2017:5843, r.o. 5.5.

67 ABRvS 1 mei 2019, ECLI:NL:RVS:2019:1438, r.o. 7.5.

68 ABRvS 8 augustus 2018, ECLI:NL:RVS:2018:2620, r.o. 9.8 (Stolwijk). Naar aanleiding van deze uitspraak wordt ook in Franssen \& Van de Sande 2019, p. 91-92 geconcludeerd dat de Afdeling "zelf veelvuldig [heeft] gezondigd, door bij het bepalen van de drempel betekenis toe te kennen aan omstandigheden die bij uitstek waren verdisconteerd in de omvang van de schade."

69 Een voorbeeld hiervan was al te vinden in ABRvS 24 december 2014, ECLI:NL:RVS:2014:4668, r.o. 5.4 (Planschade Lisse). Zie voorts ABRvS 2 maart 2016, ECLI:NL:RVS:2016:530, r.o. 5.3 (Rijsbergen).

70 Voorbeelden daarvan waren al te vinden in onder ander ABRvS 29 februari 2012, ECLI:NL:RVS:2012:BV7254, r.o. 2.11.2 (Tilburg/Vugts); ABRvS 27 januari 2016, ECLI:NL:RVS:2016:143, r.o. 12.2-12.4 (Twenterand); en ABRvS 8 juni 2016, ECLI:NL:RVS:2016:1602 en 1603, r.o. 27-28 (Boskoop I en II). 


\section{Omzetting in percentages}

De Afdeling heeft meermaals overwogen dat de afbakening van het normaal maatschappelijk risico geen vorm van kansberekening betreft. ${ }^{71}$ Het betreft juist een vorm van toerekening aan de hand van de Heiloo-factoren. Zonder de indruk van 'harde en snelle regels' ${ }^{72}$ te willen wekken, zal ik hierna desondanks een 'globaal beeld' pogen te schetsen van de wijze waarop de toets aan deze factoren zich vertaalt in een bepaalde omvang van het normaal maatschappelijk risico. ${ }^{73}$

Uit de jurisprudentie volgt dat een aftrek van $2 \%$ op zijn plaats is bij schade door een normale maatschappelijke ontwikkeling die in zijn geheel niet in de lijn der verwachting ligt. Daarvan kan sprake zijn als deze ontwikkeling niet goed aansluit op zowel het gedurende een reeks van jaren gevoerde planologische beleid als de ruimtelijke structuur van de omgeving van het plangebied. ${ }^{74}$ Dit kan zich echter ook voordoen als de ontwikkeling niet goed aansluit op slechts een van beide factoren. ${ }^{75}$ Zowel het slecht aansluiten op de structuur van de omgeving ${ }^{76}$ als het slecht aansluiten op een reeks van jaren gevoerd beleid ${ }^{77}$ kan echter ook tot de conclusie leiden dat de schadeveroorzakende ontwikkeling niet geheel in de lijn der verwachtingen ligt. In dergelijke gevallen lijkt een aftrek van 3\% het meest voor de hand te liggen. In een uitspraak van 12 juni 2019 stelde de Afdeling het normaal maatschappelijk risico echter voor het eerst vast op $4 \%$ van de waarde van de getroffen onroerende zaak. Daartoe was van belang dat de schadeveroorzakende ontwikkeling slechts gedeeltelijk afweek van de ruimtelijke structuur van de omgeving, terwijl de ontwikkeling geheel in het gevoerde planologische beleid paste. ${ }^{78}$ Een aftrek van $4 \%$ lijkt daarom op zijn plaats bij normale maatschappe-

71 Zie ABRvS 12 november 2014, ECLI:NL:RVS:2014:4033, r.o. 10.2; en ABRvS 25 oktober 2017, ECLI:NL:RVS:2017:2889, r.o. 4.8.

72 Deze formulering ontleen ik aan Van Ravels 2012b.

73 Bij een overeenkomsten vertonend overzicht in Van Ettekoven e.a. 2018, p. 78 wordt eveneens van een 'globaal beeld' gesproken.

74 Zie bijvoorbeeld ABRvS 11 februari 2015, ECLI:NL:RVS:2015:349, r.o. 4.2 (De Wolden).

75 Zie ten aanzien van de factor van beleid bijvoorbeeld ABRvS 25 november 2015, ECLI:NL:RVS:2015:3608, r.o. 6-7.2 (Oirschot). Zie met betrekking tot een afwijking van de structuur van de omgeving bijvoorbeeld ABRvS 9 december 2015, ECLI:NL:RVS:2015:3721, r.o. 7.3 (Wijdemeren).

76 Zie bijvoorbeeld ABRvS 9 september 2015, ECLI:NL:RVS:2015:2828, r.o. 5.3 (Best); ABRvS 8 juni 2016, ECLI:NL:RVS:2016:1602 en 1603, r.o. 24-28 (Boskoop I en II); ABRvS 27 januari 2016, ECLI:NL:RVS:2016:143, r.o. 12.4 (Twenterand); en ABRvS 25 oktober 2017, ECLI:NL:RVS:2017:2903, r.o. 8.4-8.5 (HoogezandSappemeer).

77 Zie bijvoorbeeld ABRvS 30 maart 2016, ECLI:NL:RVS:2016:858, r.o. 8.3-8.5 (Nunspeet); en ABRvS 23 augustus 2017, ECLI:NL:RVS:2017:2248, r.o. 4.5. Zie ook ABRvS 21 september 2016, ECLI:NL:RVS:2016:2502, r.o. 8.4 en 10 (Schoonrewoerd) en onderdeel $4 \mathrm{t} / \mathrm{m} 7$ van de bijbehorende annotatie van Tjepkema in $A B$ 2016/440. 
lijke ontwikkelingen die zich goed verhouden tot het gevoerde beleid en slechts in (zeer) beperkte mate afwijken van de structuur van de omgeving, en vice versa. ${ }^{79}$

Een aftrek van 5\% is op zijn plaats bij een normale maatschappelijke ontwikkeling die geheel in de lijn der verwachtingen ligt. Sinds de Rijsbergen-uitspraak oordeelt de Afdeling namelijk stelselmatig dat...

“(...) een waardevermindering tot vijf procent van de waarde van de onroerende zaak, in verhouding tot de waarde van de onroerende zaak onmiddellijk vóór het ontstaan van de schade, substantieel, maar niet zodanig zwaar [is] dat deze schade niet voor rekening van de aanvrager kan worden gelaten. Dit betekent dat een waardevermindering tot vijf procent van de waarde van de onroerende zaak in deze categorie gevallen in beginsel tot het normale maatschappelijke risico van de aanvrager behoort." ${ }^{90}$

Pogingen van het bestuur om in dit soort gevallen een hogere aftrek toe te passen, heeft de Afdeling tot op heden steeds van de hand gewezen. ${ }^{81}$

\subsubsection{Toepassing van de Heiloo-factoren op directe schade}

Tot op heden zijn relatief weinig rechterlijke uitspraken gewezen over de afbakening van het normaal maatschappelijk risico bij directe planschade. Waarschijnlijk komt dit doordat slechts een klein percentage van de aanvragen om tegemoetko-

79 Dit percentage komt vooralsnog vrijwel uitsluitend voor in rechtbankuitspraken. Zelf in de zaak voorziend: Rb. Limburg 5 december 2018,

ECLI:NL:RBLIM:2018:11437, r.o. 19-26. Zie voor de bevestiging van een aftrek van 4\%: Rb. Gelderland 8 juni 2018, ECLI:NL:RBGEL:2018:2538, r.o. 4.2-4.4. Zie voor de weerlegging van de door een draagplichtige derde voorgestelde aftrek van 4\%: Rb. Limburg 2 februari 2017, ECLI:NL:RBLIM:2017:898, r.o. 17 en 20. Zie ook Rb. Oost-Brabant 8 november 2017, ECLI:NL:RBOBR:2017:5843, r.o. 6 . Eerder bleek onder het kopje 'lijn der verwachtingen' dat de afstandsfactor verkeerd werd toegepast in deze uitspraak.

80 ABRvS 2 maart 2016, ECLI:NL:RVS:2016:530, r.o. 5.7 (Rijsbergen). Voortekenen waren al te zien in ABRvS 1 juli 2015, ECLI:NL:RVS:2015:2071, r.o. 11 (Mook \& Middelaar). Daarin werd verwezen naar ABRvS 19 februari 2014, ECLI:NL:RVS:2014:572, r.o. 10.4 (Risicolocatie Schiphol); ABRvS 9 april 2014, ECLI:NL:RVS:2014:1198, r.o. 3.3.3 (Kustversterking Noordwijk); en ABRvS 2 juli 2014, ECLI:NL:RVS:2014:2396, r.o. 6.2 (Dijkverhoging). Zie sinds de Rijsbergen-uitspraak bijvoorbeeld ook: ABRvS 28 september 2016, ECLI:NL:RVS:2016:2582, r.o. 5.14 (Overzichtsuitspraak); ABRvS 28 september 2016, ECLI:NL:RVS:2016:2543, r.o. 6.6; ABRvS 24 mei 2017, ECLI:NL:RVS:2017:1402, r.o. 10; en ABRvS 21 juni 2017, ECLI:NL:RVS:2017:1653, r.o. 5.4 (Beuningen).

81 Zie bijvoorbeeld ABRvS 9 april 2014, ECLI:NL:RVS:2014:1198, r.o. 3.3 .3 en 4 (Kustversterking Noordwijk). 
ming in planschade ziet op directe planschade. ${ }^{82}$ Dat kan op zijn beurt worden verklaard doordat het bestuur doorgaans zal proberen directe planschade in algemene zin, en de tegemoetkoming daarin in het bijzonder, te voorkomen ${ }^{83}$ - bijvoorbeeld door compensatie in natura ${ }^{84} \mathrm{Bij}$ directe schades gaat het namelijk vaak om grote schadebedragen. ${ }^{85}$ Door de schaarste aan jurisprudentie over dit onderwerp, bestaat nog relatief veel onduidelijkheid over de afbakening van het normaal maatschappelijk risico bij directe planschade. Wel is duidelijk dat het bestuur alle van belang zijnde omstandigheden van het concrete schadegeval in acht dient te nemen. Dat geschiedt door toetsing aan de Heiloo-factoren. ${ }^{86}$ De Afdeling laat de afstandsfactor echter regelmatig achterwege in haar standaardoverweging over normaal maatschappelijk risico bij directe schade. ${ }^{87}$ Dat doet zij waarschijnlijk omdat de schadeveroorzakende ontwikkeling bij directe schade nou juist plaatsvindt op het perceel van de aanvrager.

In een uitspraak van 19 september 2018 bevestigt de Afdeling dat een duidelijk verschil bestaat met het normaal maatschappelijk risico bij indirecte schade, doordat een volledige vergoeding van directe planschade niet op voorhand is uitgesloten (vergelijk art. 6.2 lid 2 Wro). Ook lijkt uit deze uitspraak te kunnen worden opgemaakt dat de schade slechts geheel of gedeeltelijk als normaal maatschappelijk risico voor rekening van de aanvrager mag worden gelaten als de schadeveroorzakende ontwikkeling in de lijn der verwachtingen lag. ${ }^{88}$ Tot op heden lijken bestuursorganen moeite te hebben om voldoende te onderbouwen dat daarvan

82 Van Ravels gaf in 2006 - en dus voor inwerkingtreding van de Wro - aan dat ongeveer $85 \%$ van de Afdelingsjurisprudentie inzake planschade op indirecte planschade zag. Zie Van Ravels 2006b, p. 262.

83 Soms wijst de rechtspraak ook expliciet op deze mogelijkheid. Zie bijvoorbeeld ABRvS 8 februari 2017, ECLI:NL:RVS:2017:326, r.o. 7; en ABRvS 2 maart 2016, ECLI:NL:RVS:2016:526 en 529, r.o. 6 (Planschade Deurne I en II).

84 ABRvS 13 januari 2016, ECLI:NL:RVS:2016:50, r.o. 10-10.1 (Achtkarspelen). Ook kan de schadeoorzaak ruim van tevoren worden aangekondigd, zodat uiteindelijke benadeelden vaker risicoaanvaarding kan worden tegengeworpen. Zie daarover De Vries 2015, p. 116-118.

85 Zie bijvoorbeeld $€ 54.175$ in ABRvS 4 mei 2016, ECLI:NL:RVS:2016:1200 (Bergen); en $€ 240.240$ in ABRvS 11 januari 2017, ECLI:NL:RVS:2017:18 (PijnackerNootdorp). Een uitzondering betreft bijvoorbeeld een schadebedrag van $€ 7.200$ in ABRvS 28 november 2018, ECLI:NL:RVS:2018:3871.

86 Zie bijvoorbeeld ABRvS 18 juli 2018, ECLI:NL:RVS:2018:2420, r.o. 8.2 (Koekelberg); ABRvS 27 september 2017, ECLI:NL:RVS:2017:2598, r.o. 8.5 (Bedrijfswoning Zaanstad); en Van Ettekoven e.a. 2018, p. 79.

87 Zie bijvoorbeeld ABRvS 11 januari 2017, ECLI:NL:RVS:2017:18, r.o. 36 (Pijnacker-Nootdorp); en ABRvS 19 september 2018, ECLI:NL:RVS:2018:3026, r.o. 5.1.

88 ABRvS 19 september 2018, ECLI:NL:RVS:2018:3026, r.o. 5.5-5.6. Zie hierover ook Franssen \& Van de Sande 2019, p. 92-93, waarin terecht wordt opgemerkt dat situaties denkbaar zijn waarin een (beperkte) uitzondering hierop in de rede ligt. 
sprake is.$^{89}$ Dat komt doordat de Afdeling in algemene zin hogere eisen lijkt te stellen aan de motivering van de afbakening van het normaal maatschappelijk risico bij directe planschade. ${ }^{90}$ Illustratief daarvoor is de Planschade Deurne-uitspraak, waarin de Afdeling oordeelde dat het onder het persoonsgebonden gebruiksovergangsrecht brengen van het gebruik van een onroerende zaak als woning niet in de lijn der verwachtingen lag, omdat een persoonsgebonden overgangsrecht "niet de meest voor de hand liggende keuze" was. ${ }^{91}$ Dit is een intensieve toets, die contrasteert met de overweging uit een uitspraak omtrent indirecte planschade dat de omstandigheid dat...

“(...) een tegengestelde ontwikkeling zich vaker voordoet (...) niet [betekent] dat de gesignaleerde ontwikkeling niet te verwachten was." ${ }^{92}$

Het bestaan van een strengere houding ten opzichte van directe schade blijkt ook doordat de Afdeling meer terughoudendheid betracht met het (sanctioneren van het) tegenwerpen van hoge drempels. ${ }^{93}$ Het lijkt niet onaannemelijk dat de defensieve functie van het eigendomsrecht daarbij een rol speelt. ${ }^{94}$

\subsubsection{De Heiloo-factoren zijn ook van toepassing buiten het planschaderecht}

Anders dan door het 2\%-minimumforfait van art. 6.2 lid 2 Wro, heeft de wetgever geen sturing geboden omtrent de afbakening van het normaal maatschappelijk risico onder afd. 6.1 Wro. Het verbaast dan ook niet dat in de praktijk geschillen ontstonden omtrent de hoogte van de door het bestuur toegepaste aftrek wegens normaal maatschappelijk risico. Omstreeks 2012 bereikten dergelijke geschillen voor het eerst de Afdeling. Het was vervolgens aan haar om maatstaven of criteria ter afbakening van het normaal maatschappelijk risico te bedenken - iets waarvan de wetgever had afgezien, omdat hij dit zag als iets dat "moeilijk" was. ${ }^{95}$ In paragraaf 6.2.1.3 bleek dat de Afdeling hiertoe de Heiloo-factoren heeft geïntroduceerd. Deze factoren kwamen niet uit het niets. In eerder gewezen nadeelcompensatiejurisprudentie zijn namelijk al voortekenen van deze factoren te herken-

89 Zie onderdeel acht en negen van de annotatie van Tjepkema en mij bij ABRvS 17 mei 2017, ECLI:NL:RVS:2017:1293 (De Lunet) in AB 2017/427.

90 Zie ook Van Ettekoven e.a. 2018, p. 79.

91 ABRvS 2 maart 2016, ECLI:NL:RVS:2016:526 en 529, r.o. 4-6 (Planschade Deurne I en II).

92 ABRvS 7 februari 2018, ECLI:NL:RVS:2018:380, r.o. 5.4.

93 Zie bijvoorbeeld ABRvS 18 juli 2018, ECLI:NL:RVS:2018:2420, r.o. 8.6 (Koekelberg); ABRvS 27 september 2017, ECLI:NL:RVS:2017:2598, r.o. 8.8 (Bedrijfswoning Zaanstad); en ABRvS 17 mei 2017, ECLI:NL:RVS:2017:1293, r.o. 9.2 (De Lunet).

94 Zie hierover onder andere Van den Broek \& Tjepkema 2017, p. 31.

95 Kamerstukken II 2002/03, 28 916, nr. 3, p. 63 (MvT, Wro). 
nen. ${ }^{96}$ Zo sanctioneerde de Afdeling in een onder de GrS gewezen uitspraak van 10 november 2010 dat wegens normaal maatschappelijk risico een korting van $50 \%$ op het schadebedrag werd toegepast, omdat...

“(...) bewoners van huizen binnen de invloedssfeer van Schiphol rekening dienen te houden met een toename van geluidbelasting die samenhangt met de groei van de luchthaven, ook al bestaat geen zicht op de omvang en vorm waarin, de plaats waar en het moment waarop deze ontwikkelingen zich zullen concretiseren en de omvang van het nadeel dat daar mogelijkerwijs uit zal voortvloeien." ${ }^{97}$

Met de kennis van nu, zou deze overweging zo kunnen worden gelezen dat de Afdeling de uitbreiding van een (goed lopende) luchthaven kwalificeerde als een normale maatschappelijke ontwikkeling die ook ter plaatse in de lijn der verwachtingen lag vanwege de ruimtelijke structuur van de omgeving (de invloedssfeer van een luchthaven).

Nadat zij de Heiloo-uitspraak had gewezen, is de Afdeling haar standaardoverweging inzake de Heiloo-factoren ook gaan gebruiken in nadeelcompensatiegeschillen. ${ }^{98}$ Toch ontstaat het beeld dat deze factoren vaak niet, of op zijn minst minder stelselmatig, worden nagelopen door degenen die zich in deze geschillen als deskundigen aandienen. Dat geldt a fortiori voor de bestuursorganen die zich op de adviezen van deze deskundigen baseren. ${ }^{99}$ Dit lijkt slechts te kunnen worden verklaard doordat deze ontwikkeling in de jurisprudentie nog niet volledig is opgemerkt door deze actoren. Bovendien kan de Afdeling slechts iets hiervan zeggen als de door partijen aangevoerde beroepsgronden haar dat mogelijk maken. ${ }^{100}$ Ook dan lijkt zij echter niet zwaar hieraan te (kunnen) tillen. ${ }^{101}$ De Afdeling kan immers slechts toetsen of de beroepsgronden tot de conclusie leiden dat het bestuur de vaststelling van het normaal maatschappelijk risico niet naar behoren heeft gemotiveerd. Die conclusie lijkt niet te kunnen worden bereikt als het bestuur alle van belang zijnde omstandigheden van het concrete schadegeval in acht heeft genomen, maar die omstandigheden niet heeft gerubriceerd met behulp van de

96 Ook vroeg onder art. 49 WRO genomen Kroonbesluiten en rechterlijke uitspraken zullen mogelijk als inspiratie hebben gediend voor de Heiloo-factoren. Vergelijk bijvoorbeeld Van den Broek 2002, p. 173-189.

97 ABRvS 10 november 2010, ECLI:NL:RVS:2010:BO3436, r.o. 2.14.

98 Zie bijvoorbeeld ABRvS 9 april 2014, ECLI:NL:RVS:2014:1198, r.o. 3.3 .3 (Kustversterking Noordwijk); ABRvS 2 juli 2014, ECLI:NL:RVS:2014:2396, r.o. 6.2 (Dijkverhoging); ABRvS 4 mei 2016, ECLI:NL:RVS:2016:1205, r.o. 10.2 (Orac); ABRvS 19 februari 2014, ECLI:NL:RVS:2014:572, r.o. 10.3 (Risicolocatie Schiphol); en ABRvS 1 juni 2016, ECLI:NL:RVS:2016:1467, r.o. 4.4.

99 Zie bijvoorbeeld ABRvS 4 mei 2016, ECLI:NL:RVS:2016:1205, r.o. 10.3 (Orac).

100 In bijvoorbeeld ABRvS 5 januari 2011, ECLI:NL:RVS:2011:BO9791, r.o. 2.3.1 expliciteerde zij dat dit niet het geval was.

101 Zie bijvoorbeeld ABRvS 4 mei 2016, ECLI:NL:RVS:2016:1205, r.o. 10.4 (Orac). Zie in meer algemene zin over de verhouding tussen deskundigen en de rechter bij toepassing van de Heiloo-factoren ook Van den Broek \& Tjepkema 2015, p. 78-99. 
Heiloo-factoren. ${ }^{102}$ Dat geldt eens te meer nu de Afdeling ook zelf niet altijd duidelijk onderscheidt welke omstandigheid zij onder welke Heiloo-factor meeweegt en welk gewicht ze daaraan toekent. ${ }^{103}$

De door mij bestuurde jurisprudentie schept niet het beeld dat de Heiloo-factoren in het nadeelcompensatierecht structureel anders zouden worden toegepast en/of tot een andere omvang van het normaal maatschappelijk risico zouden leiden dan in het planschaderecht. Sterker nog, de Afdeling blijkt in planschadegeschillen regelmatig aansluiting te zoeken bij uitspraken die zij deed in nadeelcompensatiegeschillen en vice versa. ${ }^{104}$ Een van de meest treffende voorbeelden hiervan is dat de met de Rijsbergen-uitspraak in het planschaderecht geïntroduceerde vuistregel dat een 5\%-drempel is toegestaan bij schade door een normale maatschappelijke ontwikkeling die geheel in de lijn der verwachtingen ligt, afkomstig is uit nadeelcompensatiejurisprudentie. Uit de jurisprudentie blijkt duidelijk dat een belangrijke voorwaarde voor dit soort kruisbestuiving is dat zowel de aard van de schade als de grondslag voor compensatie overeenkomstig zijn. ${ }^{105}$ Ook lijkt van belang te zijn dat de aard van de schadeoorzaak overeenkomstig is. ${ }^{106}$ Gelet daarop, lijkt het aannemelijk dat zich in het nadeelcompensatierecht soms gevallen zullen voordoen waarin niet alle Heiloo-factoren kunnen worden toegepast, of toepassing van deze factoren tot een afwijkende uitkomst dient te leiden. Daarbij kan worden gedacht aan schadeoorzaken die niet erop zijn gericht wijzigingen in de fysieke leefomgeving te faciliteren, maar desondanks een permanente waardevermindering van een onroerende zaak tot gevolg hebben. Een voorbeeld hiervan betreft de waardeda-

102 Vergelijk ABRvS 28 september 2016, ECLI:NL:RVS:2016:2582, r.o. 8.10 en 5.9 (Overzichtsuitspraak).

103 Zie voor het nadeelcompensatierecht bijvoorbeeld: ABRvS 19 februari 2014, ECLI:NL:RVS:2014:572, r.o. 10.4 (Risicolocatie Schiphol); en ABRvS 1 juni 2016, ECLI:NL:RVS:2016:1467, r.o. 4.4. Zie ook Van den Broek \& Tjepkema 2015, p. 90-95.

104 Zie bijvoorbeeld de in paragraaf 6.2.1.1 besproken jurisprudentie omtrent aansluiting bij art. 6.2 lid 2 Wro. Soms wordt ook aansluiting gezocht met betrekking tot een ander onderwerp dan het normaal maatschappelijk: ABRvS 5 december 2018, ECLI:NL:RVS:2018:3938, r.o. 7.1 (overeenkomstige toepassing art. 6.4a lid 2 Wro). Zie ten slotte nog ABRvS 29 november 2006, ECLI:NL:RVS:2006:AZ3259, r.o. 2.4.2 voor aansluiting binnen het nadeelcompensatierecht.

105 Voortekenen van deze vuistregel waren namelijk al te zien in ABRvS 1 juli 2015, ECLI:NL:RVS:2015:2071, r.o. 11 (Mook \& Middelaar). Daarin werd verwezen naar de volgende nadeelcompensatiejurisprudentie: ABRvS 19 februari 2014, ECLI:NL:RVS:2014:572, r.o. 10.4 (Risicolocatie Schiphol); ABRvS 9 april 2014, ECLI:NL:RVS:2014:1198, r.o. 3.3.3 (Kustversterking Noordwijk); en ABRvS 2 juli 2014, ECLI:NL:RVS:2014:2396, r.o. 6.2 (Dijkverhoging).

106 Zie in algemene zin de in paragraaf 6.2.1.1 besproken jurisprudentie waaruit volgt dat art. 17 Spoedwet wegverbreding en art. 22 Tracéwet soms moeten worden toegepast conform de criteria voor tegemoetkoming in planschade. Zie voorts ABRvS 26 september 2018, ECLI:NL:RVS:2018:3120, r.o. 13.3 (Leusden) voor een voorbeeld van een uitspraak waarin de aard van de schadeoorzaak niet overeenkomstig was. 
ling van een varkenshouderij als gevolg van een algemeen verbindend voorschrift inhoudende een verbod op een bepaalde vervoedermethode. ${ }^{107}$

\subsubsection{Conclusie}

In deze deelparagraaf is onderzocht in hoeverre de geselecteerde, thans geldende regelingen verschillen met betrekking tot de afbakening van het normaal maatschappelijk risico bij permanente waardevermindering van onroerende zaken. Afd. 6.1 Wro en de AVN bevatten beide een minimumforfait van 2\% van de waarde van de getroffen onroerende zaak onmiddellijk voor het ontstaan van de schade. In paragraaf 6.1 bleek dat het normaal maatschappelijk risico onder de overige regelingen slechts een rol van betekenis speelt onder de BnIW 2019 en de GrS uiteraard niet als art. 49 WRO de achterliggende grondslag voor toekenning van compensatie vormt bij toepassing van de GrS. Tevens bleek waarom in de GrS (en art. 8.31 Wlv en art. 21 Aanwijzingsbesluit 1996) in algemene zin geen bijzondere normering is opgenomen omtrent het normaal maatschappelijk risico. Dat in de BnIW 2019 geen specifieke normering omtrent normaal maatschappelijk risico bij permanente waardevermindering van onroerende zaken is opgenomen, kan waarschijnlijk worden verklaard doordat deze schade doorgaans als gevolg van in art. 6.1 lid 2 opgesomde planologische besluitvorming aan het bestuur wordt toegerekend.

Als het aankomt op de geselecteerde, thans geldende regelingen lijkt permanente waardevermindering van onroerende zaken zich met name te hebben voorgedaan onder afd. 6.1 Wro en de GrS. Uit de daarop betrekking hebbende jurisprudentie volgt dat alle van belang zijnde omstandigheden van het concrete schadegeval in acht moeten worden genomen bij de vaststelling van het normaal maatschappelijk risico - hetgeen in de praktijk wordt gerealiseerd door spiegeling aan de Heiloofactoren. Dit lijkt niet alleen zo te zijn onder deze regelingen, maar ook in algemene zin het geval te zijn in het planschade- en nadeelcompensatierecht. Ik heb dan ook geen reden om aan te nemen dat de Heiloo-factoren niet van toepassing zouden zijn als zich schade in de vorm van een permanente waardevermindering van een onroerende zaak zou voordoen die onder de reikwijde van de BnIW 2019 of AVN zou vallen. Wat dat betreft bestaat dus geen verschil met afd. 6.1 Wro of de GrS.

Ten aanzien van de GrS in het bijzonder, en het nadeelcompensatierecht in algemene zin, valt voorts op dat de Heiloo-factoren niet, of op zijn minst minder stelselmatig, worden nagelopen door het bestuur en de daardoor geraadpleegde deskundigen. Dit lijkt slechts te kunnen worden verklaard doordat deze actoren

107 Een voorbeeld geïnspireerd op HR 18 januari 1991, ECLI:NL:HR:1991:AC4031 (Leffers/Staat). Ook kan worden gedacht aan waardedaling van een nertsenfokkerij door een verbod op het fokken van nertsen. Zie daaromtrent HR 16 december 2016, ECLI:NL:HR:2016:2888 (Nertsenhouders); en www.nu.nl/economie/5733732/ nertsenfokkers-laten-lege-stallen-en-miljoenenomzet-achter.html. 
nog onvoldoende hebben opgemerkt dat de in de planschadejurisprudentie geïntroduceerde standaardoverweging omtrent de Heiloo-factoren inmiddels ook een vast onderdeel vormt van de Afdeling haar nadeelcompensatiejurisprudentie. Voor het overige ben ik geen verschillen tegengekomen tussen de wijze waarop onder afd. 6.1 Wro, en de GrS, BnIW 2019, en AVN wordt omgaan met de afbakening van het normaal maatschappelijk risico bij permanente waardevermindering van onroerende zaken. Daarbij moet een kleine slag om de arm worden gehouden. De hoeveelheid nadeelcompensatiejurisprudentie over dit onderwerp is namelijk schaars in vergelijking met de hoeveelheid planschadejurisprudentie die hierover gaat. Bovendien is de jurisprudentie omtrent directe (plan)schade nog verre van uitgekristalliseerd. Ten slotte is denkbaar dat zich soms situaties zullen voordoen waarin het vanwege de bijzondere aard van de schade en/of de schadeoorzaak niet mogelijk is om de Heiloo-factoren volledig uniform toe te passen onder alle (geselecteerde, thans geldende) regelingen.

\subsubsection{Deelvraag 3: het toekomstige recht}

\subsubsection{Titel 4.5 Awb}

In art. 4:126 lid $1 \mathrm{Awb}$ is slechts bepaald dat de schade boven het normaal maatschappelijk risico moet uitgaan om voor vergoeding in aanmerking te komen. Uit de bij de Wns behorende memorie van antwoord volgt dat het destijds zittende kabinet de mening was toegedaan dat het normaal maatschappelijk risico zich "door de grote variëteit in schadeoorzaken niet laat vatten in een algemeen te hanteren drempel voor alle gevallen van nadeelcompensatie." 108 In paragraaf 2.4.2.1 $1^{109}$ bleek dat de wetgever daarom noodzaak ziet tot wetsinterpreterende beleidsregels. In de overige bij de Wns behorende Kamerstukken wordt onder verwijzing naar de destijds beschikbare jurisprudentie volstaan met een opsomming van factoren die een rol kunnen spelen bij de afbakening van het normaal maatschappelijk risico:

“(...) de aard van de schadeveroorzakende gebeurtenis, het bestaan van gerechtvaardigde verwachtingen, de ernst en omvang van de schade, de aard van het getroffen belang, de voorzienbaarheid van de handeling en de gevolgen daarvan voor de benadeelde, de eventuele voordelige positie waarin betrokkene als gevolg van overheidshandelen of -nalaten verkeerde en de mogelijkheid om het nadeel door te berekenen." ${ }^{110}$

108 Kamerstukken I 2012/13, 32 621, nr. C, p. 8 (MvA I, Wns).

109 Zie het kopje 'Vergroting van de rechtszekerheid en rechtsgelijkheid'.

110 Kamerstukken II 2010/11, 32 621, nr. 3, p. 23 (MvT, Wns). Zie eveneens Kamerstukken II 2010/11, 32 621, nr. 6, p. 5 (NV II, Wns). 
Deze opsomming is niet-limitatief bedoeld en niet beperkt tot permanente waardevermindering van onroerende zaken. ${ }^{111}$ Ondanks dat de aangehaalde Kamerstukken dateren van voor de Heiloo-jurisprudentie, zou het goed bij de bedoeling van het toenmalige kabinet passen als de afbakening van het normaal maatschappelijk risico bij permanente waardevermindering van onroerende zaken onder titel 4.5 Awb zou geschieden aan de hand van de Heiloo-factoren. In paragraaf 6.2.2.2 zal echter blijken dat art. 15.7 lid 1 Ow de afbakening van het normaal maatschappelijk risico bij indirecte schade in de vorm van permanente waardevermindering van onroerende zaken rigoureus op de schop zal nemen. Ik sluit niet uit dat dit ook gevolgen zal hebben voor de afbakening van het normaal maatschappelijk risico bij directe schade in de vorm van permanente waardevermindering van onroerende zaken die onder de reikwijdte van afd. 15.1 Ow valt. Bovendien zou dit gevolgen kunnen hebben voor de wijze waarop het normaal maatschappelijk risico bij zowel directe als indirecte schade in de vorm van permanente waardevermindering van onroerende zaken wordt afgebakend als afd. 15.1 Ow niet van toepassing is. Hieraan zal nadere aandacht worden besteed in paragraaf 6.2.3.1.

\subsubsection{Afd. 15.1 Ow - de invoering van een gefixeerd forfait van $4 \%$}

\section{De consultatieversie van het wetsvoorstel: een minimumforfait van 5\%}

In de consultatieversie van de IOw stelde het kabinet een bepaling voor waarin was opgenomen dat in ieder geval $5 \%$ van de waarde van de onroerende zaak voor rekening van de aanvrager zou blijven. ${ }^{112}$ Dit wijkt af van de in paragraaf 6.2.1 besproken jurisprudentie, waarin een aftrek van $5 \%$ slechts wordt toegestaan als alle Heiloo-factoren op groen staan. ${ }^{113}$ Toch presenteerde het kabinet zijn voorstel voor invoering van een minimumforfait van $5 \%$ als een codificatie van, of aansluiting op deze jurisprudentie. ${ }^{114}$ Die wijze van presentatie is des te opmerkelijker nu uit de desbetreffende Kamerstukken kan worden afgeleid dat het kabinet zich ook

111 Kamerstukken I 2012/13, 32 621, nr. C, p. 7 (MvA I, Wns). Zie tevens Kamerstukken I 2011/12, 32 621, nr. B, p. 6 (VV I, Wns). Als voorbeeld wordt een factor genoemd die niet door de Afdeling wordt gehanteerd en mijns inziens terecht is bekritiseerd in de literatuur. Zie daarvoor Van Ravels 2014a, p. 5; onderdeel vijf van de noot van Van Ravels bij HR 17 september 2004, ECLI:NL:HR:2004:AO7887 (Uzi) in $A B$ 2006, 41; en Tjepkema 2010, p. 203-204.

112 Zie art. 15.6 lid $1 \mathrm{Ow}$ als vormgegeven in de consultatieversie van het wetsvoorstel voor de IOw.

113 De beeldspraak 'op groen staan' wordt bijvoorbeeld ook gebruikt door Tjepkema in het vierde onderdeel van zijn annotatie bij ABRvS 21 september 2016, ECLI:NL:RVS:2016:2502 (Schoonrewoerd) in $A B$ 2016/440.

114 Zie bijvoorbeeld Kamerstukken I 2015/16, 33 118, nr. D, p. 14; Kamerstukken II 2015/16, 33 962, nr. 185, p. 4 (Inleidende brief); en MvT consultatieversie IOw, p. 126. 
moet hebben gerealiseerd dat het geen één op één codificatie betrof. ${ }^{115} \mathrm{Zij}$ kwam het kabinet dan ook op veel kritiek te staan. ${ }^{116}$

In de brief waarmee de minister de IOw aankondigde, presenteerde zij het 5\%-minimumforfait als middel om "uitnodigingsplanologie van de grond te krijgen":

"Een verhoging ${ }^{117}$ van het forfait nodigt gemeenten uit om globale omgevingsplannen vast te stellen, waardoor er meer ruimte ontstaat voor initiatieven van ontwikkelaars, burgers en overheden." 118

In latere Kamerstukken wordt dit verpakt als een bijdrage aan de "voorspelbaarheid over de uitkomsten van een nadeelcompensatieprocedure, aan de rechtszekerheid en aan een gelijke toepassing van het normale maatschappelijke risico."119 Ook zou het percentage van 5\% beter aansluiten op de verbrede reikwijdte van het omgevingsplan. Een hoger minimumforfait zou namelijk bijdragen aan het voorkomen van "een verhoogde instroom van schadeverzoeken ten opzichte van het geldende recht." Bovendien beoogt het kabinet met dit forfait tegengas te geven aan de omstandigheid dat de nieuwe methode van schadevaststelling bij indirecte schade in algemene zin tot gevolg zou kunnen hebben dat de schadeomvang doorgaans groter uitvalt dan naar huidig recht. ${ }^{120}$ Kortom: het kabinet is bang voor een aanzuigende werking en probeert die te beperken door op voorhand aan te geven dat het slechts bij aanzienlijke schades zinvol is een aanvraag om compensatie in te dienen. Ook deze inhoudelijke argumenten voor een hoger minimumforfait kwamen het kabinet op veel kritiek te staan, waarbij zowel het risico op een onaanvaardbare aanzuigende werking als de mate waarin het huidige planschaderecht een beperking vormt voor uitnodigingsplanologie in twijfel werden getrokken. ${ }^{121}$

115 Zie bijvoorbeeld de verwijzing naar de uitspraken Mook \& Middelaar en Rijsbergen in MvT consultatieversie IOw, p. 126. Zie ook Kamerstukken II 2016/17, 33 962, nr. 190, p. 25-26, 28; en Kamerstukken II 2016/17, 33 962, nr. 190, p. 28.

116 Zie bijvoorbeeld Van den Broek \& Tjepkema 2016, p. 2824-2825; Planken \& Hazen 2017, p. 37-38; en Van Oosten \& Span 2016, p. 318.

117 Hiermee wordt gedoeld op een verhoging ten opzichte van het $2 \%$-minimumforfait uit art. 6.2 lid 2, aanhef en onder b Wro.

118 Kamerstukken II 2015/16, 33 962, nr. 185, p. 4 (Inleidende brief).

119 Zie MvT IOw als voorgelegd aan de AARvS, p. 32-33; en MvT consultatieversie IOw, p. 25, 125.

120 Zie paragraaf 4.4.3 onder het kopje 'De verschuiving van het schademoment en de csqn-toets' en paragraaf 5.7.3.2 over deze wijze van schadevaststelling. Zie verder MvT IOw als voorgelegd aan de AARvS, p. 196; en MvT consultatieversie IOw, p. 126.

121 Zie daarover paragraaf 3.3.2.2 respectievelijk paragraaf 3.4.2.3, inclusief de daarin opgenomen literatuurverwijzingen. 
Het wetsvoorstel als voorgelegd aan de AARvS: nog steeds een minimumforfait van $5 \%$

Ondanks de hiervoor beschreven kritiek, legde het kabinet een wetsvoorstel voor aan de AARvS waarin een minimumforfait van 5\% was opgenomen. ${ }^{122}$ Wel werd dit forfait minder sterk gepresenteerd als de enkele codificatie van bestaande jurisprudentie. Ook werd verduidelijkt dat het forfait slechts zou gelden voor indirecte schades. ${ }^{123}$ De AARvS adviseerde dat de codificatie van een minimumforfait niet zou leiden tot de door het kabinet gewenste vergroting van rechtszekerheid en voorspelbaarheid. Net als het $2 \%$-minimumforfait uit de Wro, zou het voorgestelde 5\%-minimumforfait immers ruimte laten om een hogere aftrek wegens normaal maatschappelijk risico toe te passen. De AARvS gaf daarom in overweging om de aftrek wegens normaal maatschappelijk risico bij indirecte schade te fixeren op $5 \%$ van de waarde van de onroerende zaak onmiddellijk voor het ontstaan van de schade. Het kabinet zou daarbij kunnen nagegaan of reden bestaat tot differentiatie in de vorm van andere vaste percentages voor andere categorieën van schade.

Het wetsvoorstel als ingediend bij de Tweede Kamer: een gefixeerde drempel van $5 \%$

In zijn reactie op het advies van de AARvS bevestigde het kabinet dat het inderdaad beoogt de voorspelbaarheid van nadeelcompensatieprocedures te vergroten, hetgeen onder andere zou moeten voorkomen dat "procedures worden gevoerd die achterafgezien minder kans van slagen hadden." In art. 15.7 lid 1 Ow als voorgesteld aan de Tweede Kamer implementeerde het kabinet daarom het advies om het karakter van de voorgestelde drempel te veranderen van een minimumdrempel in een gefixeerde drempel: bij indirecte schade zou het normaal maatschappelijk risico dus altijd bestaan uit $5 \%$ van de waarde van de onroerende zaak onmiddellijk voor het ontstaan van de schade, ongeacht de omstandigheden van het concrete schadegeval. Differentiatie werd niet nodig geacht, omdat het forfait slechts zag op indirecte planschade en "elke differentiatie of uitzondering" afbreuk zou doen aan de beoogde verschaffing van duidelijkheid omtrent de uitkomst van schadeprocedures. Daarom is het kabinet ook geen voorstander van een forfait dat binnen een bepaalde bandbreedte gemotiveerd kan verschillen, zoals thans onder art. 6.2 Wro het geval is. Het ziet eveneens niets in een vast forfait dat geen toepassing vindt als zich bijzondere omstandigheden voordoen. ${ }^{124}$

Het kabinet achtte de hoogte van het 5\%-minimumforfait redelijk, mede omdat dit zou aansluiten op "waarde schommelingen [sic] in het maatschappelijk verkeer."

122 Zie art. 15.6 lid 1 van de versie van het wetsvoorstel die in juni 2017 aan de AARvS werd voorgelegd.

123 MvT IOw als voorgelegd aan de AARvS, p. 196. Ook hierover waren vragen gesteld in de literatuur. Zie bijvoorbeeld Van den Broek \& Tjepkema 2017, p. 31.

124 Zie Kamerstukken II 2018/19, 34 986, nr. 4, p. $82-84$ (RvS, IOw); en Kamerstukken II 2018/19, 34 986, nr. 3, p. 25-26 (MvT, IOw). 
Bovendien zou de rechtspraak een aftrek van 5\% van de waarde van de onroerende zaak bij schade door normale maatschappelijke ontwikkelingen kwalificeren als "substantieel, maar niet zo zwaar dat deze schade niet voor rekening van de aanvrager kan blijven." 125 Deze argumenten overtuigen mijns inziens onvoldoende. Zo wordt niet uitgelegd waarom een forfait van bijvoorbeeld vier of zes procent minder goed zou aansluiten op waardeschommelingen in het maatschappelijk verkeer. Ook laat het kabinet wel erg eenvoudig achterwege dat de aangehaalde lijn in de rechtspraak ziet op normale maatschappelijke ontwikkelingen die volledig in de lijn der verwachtingen liggen, oftewel situaties waarin alle Heiloo-factoren op groen staan. ${ }^{126}$

Ter onderbouwing van de keuze voor de hoogte van het 5\%-minimumforfait verwijst het kabinet ten slotte naar de in paragraaf 2.3.1 ${ }^{127}$ besproken, door het ministerie bij lagere overheden afgenomen enquête. Op basis daarvan stelt het kabinet namelijk dat de meeste aanvragen om nadeelcompensatie zien op schade door "woningbouw in inbreidingslocaties, uitbreidingslocaties die aansluiten op bestaande bebouwing, kleinschalige naburige woningbouwuitbreidingen en infrastructurele ingrepen." ${ }^{128}$ Dat verrast, omdat de jurisprudentie omtrent de afbakening van het normaal maatschappelijk risico een ander beeld schetst. ${ }^{129}$ De door het ministerie gepubliceerde samenvatting van de enquêteresultaten biedt echter te weinig inzicht in het verkregen cijfermateriaal, en de wijze waarop dat door het kabinet is geïnterpreteerd, om deze discrepantie te kunnen verklaren. ${ }^{130}$

\section{Amendement}

Op 19 februari 2019 dienden Tweede Kamerleden Ronnes en Smeulders een amendement in om vast te houden aan de systematiek van art. 6.2 lid 2 Wro: een minimumdrempel van $2 \%$ van de waarde van de onroerende zaak onmiddellijk voor het ontstaan van de schade die tot maximaal 5\% kan worden bijgesteld naar gelang de omstandigheden van het concrete schadegeval. ${ }^{131}$ Daarbij lijkt van belang te zijn geweest dat in de literatuur meermaals was betoogd dat een gefixeerde waardedrempel van $5 \%$ de facto gelijk zou staan aan de afschaffing van

125 Kamerstukken II 2018/19, 34 986, nr. 3, p. 26 (MvT, IOw).

126 Vergelijk ABRvS 28 september 2016, ECLI:NL:RVS:2016:2582, r.o. 5.14 (Overzichtsuitspraak).

127 Zie het kopje 'Praktisch belang'.

128 Kamerstukken II 2018/19, 34 986, nr. 3, p. 26 (MvT, IOw).

129 Dat was ook al het geval voordat de Afdeling zich in ABRvS 2 maart 2016, ECLI:NL:RVS:2016:530, r.o. 5.7 (Rijsbergen) relatief expliciet en principieel uitliet over schade door normale maatschappelijke ontwikkelingen die in de lijn der verwachtingen liggen.

130 Na lang wachten is een rapport over de enquête gepubliceerd op www.omgevingswetportaal.nl. Zoek op 'Resultaten enquête nadeelcompensatie'.

131 Zie Kamerstukken II 2018/19, 34 986, nr. 16, 40, 41, 48. 
de mogelijkheid tot vergoeding van indirecte planschade. ${ }^{132}$ Dit amendement werd ontraden door de minister van Binnenlandse Zaken en Koninkrijksrelaties. ${ }^{133}$ Vervolgens werd het amendement zo gewijzigd dat het voorstelde om het gefixeerde karakter van het forfait uit art. 15.7 lid 1 Ow te behouden, maar de hoogte van het forfait te verlagen naar 4\%. ${ }^{134}$ De minister gaf aan dit "acceptabel" te vinden, omdat zij van mening is dat met een dergelijk forfait "de doelstellingen van de Omgevingswet, waaronder de vergroting van de voorspelbaarheid van het omgevingsrecht, nog steeds [kunnen] worden bereikt." ${ }^{135}$ De Tweede Kamer nam dit amendement aan op 7 maart 2019. ${ }^{136} \mathrm{Na}$ inwerkingtreding van de IOw, volgt dus uit art. 15.7 lid 1 Ow dat het normaal maatschappelijk risico bij indirecte schade in de vorm van waardedaling van onroerende zaken altijd $4 \%$ van de waarde van de onroerende zaak onmiddellijk voor het ontstaan van de schade bedraagt, ongeacht de omstandigheden van het concrete schadegeval.

\section{Andere vormen van schade}

Het forfait van art. 15.7 lid 1 Ow geldt slechts voor indirecte schade in de vorm van permanente waardevermindering van onroerende zaken. Dat neemt niet weg dat op grond van art. 4:126 lid 1 Awb ook een deel van andersoortige schades als normaal maatschappelijk risico voor rekening van de aanvrager kan - en soms ook moet - worden gelaten. Daarbij kan worden gedacht aan inkomensschade, schade bestaande uit een tijdelijke derving van woongenot, of directe schade in de vorm van permanente waardevermindering van onroerende zaken. Op de afbakening van het normaal maatschappelijk risico bij de twee eerstgenoemde schadesoorten wordt aandacht besteed in paragrafen 6.3 en 6.4. Met betrekking tot directe schade in de vorm van permanente waardevermindering van onroerende zaken doet het kabinet enkele uitspraken onder verwijzing naar de De Lunet-uitspraak. ${ }^{137}$ Eerst geeft het kabinet aan dat een hogere aftrek dan 2\% van de waarde van de onroerende zaak onmiddellijk voor het ontstaan van de schade, of een generieke aftrek minder voor de hand zou liggen. Vervolgens merkt het kabinet op dat het niet redelijk zou zijn bij directe schade een vast forfait te hanteren. Daarbij zou een rol spelen dat directe schade "veel vormen [kan] aannemen, die soms relatief diep ingrijpen op bestaande rechten van burgers en bedrijven." ${ }^{138}$ Naar mijn mening overtuigen deze argumenten niet. In de De Lunet-uitspraak werd weliswaar overwogen dat een aftrek van 5\% "betrekkelijk hoog" is voor directe planschade, maar daarbij hechtte de Afdeling belang aan het gegeven dat de wetgever in de

132 Zie bijvoorbeeld Van den Broek \& Tjepkema 2016, p. 2824-2825; en Planken \& Hazen 2017, p. 37-38.

133 Zie p. 4 van bijlage 875197 bij Kamerstukken II 2018/19, 34 986, nr. 54.

134 Kamerstukken II 2018/19, 34 986, nr. 52.

135 Kamerstukken II 2018/19, 34 986, nr. 55, p. 2.

136 Handelingen II 2018/19, 34 986, nr. 60, item 7, p. 1.

137 ABRvS 17 mei 2017, ECLI:NL:RVS:2017:1293, r.o. 9.2 (De Lunet). Deze uitspraak werd ook aangehaald in paragraaf 6.2.1.4.

138 Kamerstukken II 2018/19, 34 986, nr. 3, p. 26-27 (MvT, IOw). 
Wro voor directe planschade geen forfaitaire drempel heeft vastgesteld. Bovendien bleek uit paragraaf 6.2.1.4 dat de jurisprudentie omtrent de afbakening van het normaal maatschappelijk risico bij directe planschade nog weinig is uitgekristalliseerd. Ten slotte sanctioneerde de Afdeling in de Bergen-uitspraak een aftrek van $5,3 \%$ van de woningwaarde. ${ }^{139}$

\subsubsection{Afd. 15.1 Ow - anticumulatiebepalingen}

In paragraaf 3.4.2.3 bleek hoe het doorschuiven van het schademoment kan leiden tot fragmentatie van het recht op schadevergoeding. Om de scherpe kantjes van deze fragmentatie weg te nemen, heeft het kabinet de volgende anticumulatiebepalingen opgenomen in art. 15.7 lid 2 jo. lid 3 Ow:

2. Als de aanvraag om schadevergoeding betrekking heeft op verschillende besluiten met onderlinge samenhang daartussen, past het bevoegd gezag het eerste lid toe op de schade voortvloeiend uit die besluiten gezamenlijk.

3. Het bevoegd gezag kan bij de behandeling van een aanvraag om schadevergoeding het eerste lid buiten toepassing laten als dat lid van toepassing is geweest bij de beslissing op een eerder ingediende aanvraag om vergoeding van schade die bestaat uit waardevermindering van de onroerende zaak.

Omdat deze bepalingen gaan over de toepassing van het vaste 4\%-forfait uit het eerste lid, zijn zij slechts relevant bij indirecte schade. Soms is een activiteit afhankelijk van verschillende "overheidstoestemmingen". De benadeelde kan dan afzonderlijke aanvragen om nadeelcompensatie indienen, maar mag volgens de bij de IOw behorende memorie van toelichting ook een gebundelde aanvraag indienen "als hij te maken heeft met meerdere schadeveroorzakende besluiten die samenhangen en waarvoor hetzelfde bestuursorgaan bevoegd is om over elk van de aanvragen om schadevergoeding te beslissen."140

Voor toepassing van art. 15.7 lid 2 Ow zal op basis van "de concrete feitelijke omstandigheden" moeten worden nagegaan of sprake is van voldoende samenhang. Daarbij kan worden gelet op "functionele samenhang", maar bijvoorbeeld ook op de geografische locatie waar de activiteiten plaatsvinden. ${ }^{141}$ In de consultatieversie van de $\mathrm{IOw}^{142}$ leek te worden aangesloten bij de jurisprudentie waarin voor- en nadeel uit nauw verweven overheidshandelingen wordt verrekend, en op het daaruit resulterende schadebedrag één aftrek wegens normaal maatschappelijk risico

139 ABRvS 4 mei 2016, ECLI:NL:RVS:2016:1200, r.o. 10.1 (Bergen).

140 Kamerstukken II 2018/19, 34 986, nr. 3, p. 244 (MvT, IOw).

141 Kamerstukken II 2018/19, 34 986, nr. 3, p. 244 (MvT, IOw).

142 Zie art. 15.6 lid 3 Ow als voorgesteld door de consultatieversie van de IOw en de daarbij behorende toelichting in MvT consultatieversie IOw, p. 25. 
wordt toegepast. ${ }^{143}$ Dat is naar huidig recht slechts toegestaan als de desbetreffende overheidshandelingen dermate nauw zijn verweven dat het voor- en nadeel moet worden geacht voort te vloeien uit hetzelfde planologische regime (en is voldaan aan twee overige voorwaarden). ${ }^{144}$ Het lijkt echter erop dat een minder strenge invulling aan de in het tweede lid opgenomen eis van samenhang moet worden gegeven. ${ }^{145}$ Ondanks dat het derde lid niet de eis van samenhang stelt, is ook dit lid gebaseerd op de gedachte dat het "niet redelijk" is het forfait uit het eerste lid toe te passen op iedere afzonderlijke schadeoorzaak als deze schadeveroorzakende activiteiten een bepaalde mate van samenhang vertonen. Daarbij kan worden gedacht aan de situatie dat een woning geleidelijk in waarde daalt doordat stapsgewijs nieuwe woningen worden gebouwd op een naastgelegen inbreidingslocatie. ${ }^{146}$

\subsubsection{Afd. 15.1 Ow - algemene maatregelen van bestuur}

Op grond van art. 15.7 lid 4 Ow kunnen bij amvb gevallen worden aangewezen waarin de schade wordt geacht niet uit te gaan boven het normaal maatschappelijke risico. Uit de bijbehorende passage uit de memorie van toelichting blijkt dat deze bevoegdheid zijn grens vindt in art. 4:126 lid 1 Awb. Dat brengt mee dat slechts gevallen mogen worden aangewezen "waarvan op voorhand zeker is dat de schade niet uitstijgt boven het normaal maatschappelijk risico (de abnormale last) en die niet kan leiden tot onevenredige gevolgen voor benadeelden ten opzichte van andere burgers." Als voorbeeld worden activiteiten genoemd die vergunningvrij zijn op grond van art. 2 van bijlage II bij het Besluit omgevingsrecht, zoals de plaatsing van dakkapellen in het achterdakvlak of het doorvoeren van kozijn- en gevelwijzigingen. ${ }^{147}$

\subsubsection{Hoofdvraag: spiegeling aan de doelstellingen en uitgangspunten die} ten grondslag liggen aan de Wns

Dat titel 4.5 Awb geen bijzondere normering bevat omtrent de afbakening van het normaal maatschappelijk risico bij permanente waardevermindering van onroerende zaken verhoudt zich slecht tot de doelstellingen van vereenvoudiging,

143 Zie over deze jurisprudentie paragraaf 9.1.1 onder het kopje 'Verrekening met voordeel uit nauw verweven overheidshandelingen'. Zie ook ABRvS 28 september 2016, ECLI:NL:RVS:2016:2582, r.o. 4.9-4.10 (Overzichtsuitspraak) onder verwijzing naar ABRvS 24 december 2003, ECLI:NL:RVS:2003:AO0820, r.o. 2.3; en Nijmeijer 2017, p. 79-80.

144 Zie hierover eveneens paragraaf 9.1.1 onder het kopje 'Verrekening met voordeel uit nauw verweven overheidshandelingen'.

145 Dat zou ook in overeenstemming zijn met hetgeen tijdens de studiedag "Globale omgevingsplannen en schadevergoeding" van 10 maart 2017 aan de Universiteit Utrecht werd betoogd door verschillende voor afdeling $15.1 \mathrm{Ow}$ belangrijke wetgevingsjuristen. Zie verder Kamerstukken II 2018/19, 34 986, nr. 3, p. 244-246 (MvT, IOw).

146 Kamerstukken II 2018/19, 34 986, nr. 3, p. 245-246 (MvT, IOw).

147 Kamerstukken II 2018/19, 34 986, nr. 3, p. 246 (MvT, IOw). 
uniformering en harmonisering van het nadeelcompensatierecht. Zoals de wetgever zelf ook aangeeft, ontstaat hierdoor immers behoefte aan titel 4.5 Awb-interpreterende beleidsregels en regelgeving. ${ }^{148}$ Wanneer bestuursorganen niet bereid zijn dit soort beleidsregels of regelgeving vast te stellen, kan de burger slechts een inschatting van de omvang van het normaal maatschappelijk risico maken door de (lang niet altijd eenvoudig te plaatsen) Afdelingsjurisprudentie te analyseren. Dat past niet goed bij de doelstelling van vergroting van de rechtszekerheid. Dat titel 4.5 Awb geen inhoudelijke sturing biedt met betrekking tot de afbakening van het normaal maatschappelijk risico past ten slotte ook niet goed bij de doelstelling van codificatie van het nadeelcompensatierecht. ${ }^{149}$

Toch hoeft het voorafgaande niet noodzakelijkerwijs te leiden tot aanbeveling van aanpassing van titel 4.5 Awb. Het is namelijk waarschijnlijk dat de meeste gevallen van permanente waardevermindering zullen worden veroorzaakt door formele wetgeving ${ }^{150}$ - in welk geval titel 4.5 Awb niet van toepassing is ${ }^{151}$ - en besluitvorming die onder de reikwijdte van afd. 15.1 Ow valt. In paragraaf 6.2.3.1 zal ik daarom eerst ingaan op de vraag hoe het gefixeerde 4\%-waardeforfait van art. 15.7 lid 1 Ow zich verhoudt tot de aan de Wns ten grondslag liggende doelstellingen en uitgangspunten. Op basis daarvan zal ik aan het einde van deze subparagraaf ingaan op de vraag of titel 4.5 Awb aanpassing behoeft. Vervolgens zal nog kort aandacht worden besteed aan de in art. 15.7 lid 2 en lid 3 Ow opgenomen anticumulatiebepalingen (paragraaf 6.2.3.2) en de in art. 15.7 lid 4 Ow opgenomen mogelijkheid om bepaalde schades bij amvb categorisch als normaal maatschappelijk risico aan te merken (paragraaf 6.2.3.3).

\subsubsection{Het gefixeerde forfait van art. 15.7 lid $1 \mathrm{Ow}$}

\section{Codificatie}

In paragraaf 6.1 bleek dat alle van belang zijnde omstandigheden van het concrete schadegeval in acht moeten worden genomen bij de afbakening van het normaal maatschappelijk risico. Uit paragraaf 6.2.1 volgde dat dit bij permanente waardevermindering van onroerende zaken geschiedt door differentiatie aan de hand van de Heiloo-factoren. Uit paragraaf 6.3.1 zal blijken dat de Afdeling bij inkomensschade een trend heeft ingezet van differentiatie aan de hand van bijzondere eigenschappen van de getroffen onderneming. Ten slotte zal in paragraaf 6.4.1 blijken dat bij tijdelijke derving van woongenot dient te worden gedifferentieerd naar ge-

148 Zie paragraaf 2.4.2.1 onder het kopje 'Vergroting van de rechtszekerheid en rechtsgelijkheid'.

149 Dat codificatie in ieder geval tot op zekere hoogte mogelijk is, wordt bewezen door art. 6.2 lid 2, aanhef en onder b Wro, art. 2 lid 5 AVN, en art. 15.7 Ow.

150 Zie bijvoorbeeld HR 16 december 2016, ECLI:NL:HR:2016:2888 (Nertsenhouders); en www.nu.nl/economie/5733732/nertsenfokkers-laten-lege-stallen-en-miljoenenomzet-achter.html.

151 Zie paragraaf 3.3.1 omtrent de reikwijdte van titel 4.5 Awb. 
lang de aard, ernst en duur van de ondervonden overlast. Het gefixeerde karakter van het 4\%-forfait van art. 15.7 lid 1 Ow past daarom niet goed bij de doelstelling van codificatie van het nadeelcompensatierecht. Dat geldt waarschijnlijk ook voor veel potentiële alternatieve codificaties van het normaal maatschappelijk risico. Er lijkt echter nauwelijks een groter contrast denkbaar dan dat tussen het volledig gefixeerde $4 \%$-forfait enerzijds, en het huidige stelsel van differentiatie aan de hand van alle van belang zijnde omstandigheden van het concrete schadegeval anderzijds.

\section{Doelmatigheid en bestuurslasten}

In de thans bestaande praktijk baseren bestuursorganen zich bij afbakening van het normaal maatschappelijk risico in belangrijke mate op deskundigenadviezen. ${ }^{152}$ Van den Broek \& Tjepkema stellen zelfs dat deskundigen in het planschaderecht vaak "de facto" de inhoud van de besluitvorming bepalen als het aankomt op de invulling van het normaal maatschappelijk risico. ${ }^{153}$ De invoering van het gefixeerde 4\%-forfait zorgt ervoor dat geen enkele discussie meer kan bestaan omtrent de hoogte van de aftrek wegens normaal maatschappelijk risico bij indirecte schade. Dat heeft tot gevolg dat het bestuur hieromtrent niet langer deskundigenadvies hoeft in te winnen. Bovendien vervalt de noodzaak tot het voeren van juridische procedures over de hoogte van het normaal maatschappelijk risico. Beide ontwikkelingen verhouden zich goed tot de doelstelling van vergroting van de doelmatigheid van het nadeelcompensatierecht en vermindering van bestuurslasten. De versobering van het recht op compensatie van indirecte schade die het gevolg is van het gefixeerde $4 \%$-forfait, kan echter ook een effect teweeg brengen dat niet goed aansluit op deze doelstelling. Zij verkleint namelijk de smeermiddelfunctie ${ }^{154}$ van het nadeelcompensatierecht, hetgeen zou kunnen leiden tot een toename van het aantal bezwaar- en beroepschriften tegen schadeveroorzakende besluitvorming. Dat zou niet alleen tot een toename van bestuurslasten leiden, maar ook tot frustratie van de ruimtelijke ontwikkelingen die de minister nu juist wil stimuleren. ${ }^{155}$

\section{Rechtszekerheid}

In beginsel lijkt een gefixeerd forfait zich goed te verhouden tot de doelstelling van vergroting van de rechtszekerheid. Alle betrokkenen weten immers op voorhand waaraan zij toe zijn. Wel kan de vraag worden gesteld of het gekozen drem-

152 Dat zowel bestuur als burgers de afbakening van het normaal maatschappelijk risico als complex ervaren, zou ook volgen uit de door het ministerie afgenomen enquête. Zie p. 5-6 van het Enquêterapport (dat is te vinden door op www.omgevingswetportaal.nl te zoeken op 'Resultaten enquête nadeelcompensatie').

153 Van den Broek \& Tjepkema 2015, p. 86.

154 Zie daarover paragraaf 2.2 onder het kopje 'Het hedendaagse nadeelcompensatiedoolhof' en de aanhef van paragraaf 2.3.

155 Vergelijkbare observaties zijn onder andere gedaan in SAOZ 2017, p. 8; en Van den Broek \& Tjepkema 2016, p. 2825. 
pelpercentage materieelrechtelijk gezien niet vooral echte zekerheid biedt aan het bestuur en de draagplichtige projectontwikkelaar, maar slechts schijnzekerheid aan de getroffen burger. Het kabinet stelt dat "de verhouding tussen alle betrokken belangen in balans" is en doet het voorkomen alsof de getroffen burger een groot plezier wordt gedaan ten opzichte van het huidige recht. Dat dit op zijn minst twijfelachtig is, blijkt alleen al uit het gegeven dat het normaal maatschappelijk risico naar huidig recht regelmatig slechts bestaat uit twee of drie procent van de waarde van de getroffen onroerende zaak onmiddellijk voor het ontstaan van de schade. ${ }^{156}$ Voorts zijn naar aanleiding van de consultatieversie van het voorstel voor de IOw meerdere publicaties verschenen waarin de kritiek werd geventileerd dat indirecte schades zelden zouden leiden tot waardeverminderingen groter dan 5\%. Daardoor zou het destijds voorgestelde 5\%-minimumforfait de facto tot een afschaffing van het recht op tegemoetkoming in indirecte schade leiden. ${ }^{157}$ In de desbetreffende publicaties werd hiervoor geen empirisch bewijs aangeleverd, terwijl dat bewijs ook niet kan worden gevonden in de samenvatting van de resultaten van de in paragraaf 2.3.1 ${ }^{158}$ besproken, door het ministerie bij lagere overheden afgenomen enquête. Dat maakt het lastig in te schatten in hoeverre deze kritiek terecht was, en in hoeverre vergelijkbare kritiek zou kunnen worden geuit op het gefixeerde $4 \%$-forfait. Hooguit kan worden vastgesteld dat in de jurisprudentie ook indirecte schades voorkomen die groter zijn dan $4 \%$ van de waarde van de getroffen onroerende zaak onmiddellijk voor het ontstaan van de schade. ${ }^{159}$

\section{Rechtsgelijkheid}

Ten aanzien van het uitgangspunt van vergroting van de rechtsgelijkheid ontstaat een tweeledig beeld. Enerzijds kan worden vastgesteld dat de rechtsgelijkheid tot op zekere hoogte wordt vergroot. In alle gevallen van indirecte schade die onder het bereik van afd. $15.1 \mathrm{Ow}$ vallen, zal immers hetzelfde gefixeerde 4\%-forfait worden toegepast. Anderzijds kan worden opgemerkt dat dit ook ervoor zorgt dat niet gelijke gevallen wel gelijk worden behandeld. De aanvrager die wordt geconfronteerd met zeer grote schade door een abnormale ontwikkeling die geenszins in de lijn der verwachtingen lag, krijgt immers hetzelfde forfait tegengeworpen als de aanvrager die wordt geconfronteerd met een relatief kleine schade door een normale maatschappelijke ontwikkeling die geheel in de lijn der verwachtingen lag. De vraag kan echter worden gesteld of het huidige recht niet onnodig veel dif-

156 Zie paragraaf 6.2.1.3 onder het kopje 'Omzetting in percentages'.

157 Zie Van den Broek \& Tjepkema 2016, p. 2824-2825; Planken \& Hazen 2017, p. 37-38; SAOZ 2017, p. 8; en Vereniging eigen huis 2017, p. 1. Kortmann lijkt iets milder gestemd in Kortmann 2016, p. 169.

158 Zie het kopje 'Praktisch belang'.

159 Zonder uitputtend te willen zijn, noem ik: ABRvS 8 oktober 2014, ECLI:NL:RVS:2014:3636, r.o. 10.1-10.2 (schade van 9,52\%); en ABRvS 24 december 2014, ECLI:NL:RVS:2014:4668, r.o. 5.4 (Planschade Lisse, schade van 4,5 tot 5\%). Zie ook ABRvS 28 september 2016, ECLI:NL:RVS:2016:2543, r.o. 3, 6 en 6.6 voor een schade van $4 \%$. 
ferentieert. De term normaal maatschappelijk risico suggereert immers dat er een bepaalde hoeveelheid schade is die iedere burger voor lief dient te nemen, omdat zij nou eenmaal onlosmakelijk is verbonden aan het leven in een (dichtbevolkte) samenleving. Waarom zou die hoeveelheid schade moeten verschillen naar gelang de mate waarin de schadeveroorzakende ontwikkeling in de lijn der verwachtingen lag? Zou niet afdoende moeten zijn dat ontwikkelingen die niet in de lijn der verwachtingen liggen doorgaans een grotere schade teweeg zullen brengen, waardoor deze schade sneller boven een gefixeerd forfait uitkomt?

Dit soort vragen klemt te meer omdat een gefixeerd waardeforfait op zichzelf reeds voor enige differentiatie zorgt. Naarmate de in waarde gedaalde onroerende zaak meer waard is, wordt de eigenaar daarvan immers in absolute zin een groter bedrag aan normaal maatschappelijk risico tegengeworpen. In paragraaf 6.2.1.2 werd in dat verband opgemerkt dat de AARvS ten tijde van de totstandkoming van de Wro kritisch tegenover de figuur van een waardedrempel stond, omdat hierin een element van 'object-gerichte draagkracht' verscholen ligt. ${ }^{160}$ Het gaat het doel van deze dissertatie te buiten om uitgebreid in te gaan op de discussie omtrent draagkracht. Voor een overzicht van die discussie en duidelijke analyse van de rol van draagkracht binnen het nadeelcompensatierecht verwijs ik graag naar de bijdrage van Van Viegen aan de bundel Coulant Compenseren. ${ }^{161}$ Ik volsta hier met de opmerking dat de invloed van draagkracht binnen het nadeelcompensatierecht niet per se goed of slecht hoeft te zijn. Voor zover ik kan inschatten, heeft de 2\%-drempel van art. 6.1 lid 2 Wro niet tot evident onredelijke uitkomsten geleid doordat daarin een element van object-gerichte draagkracht is verankerd. ${ }^{162}$ Dat eigenaren van dure woningen in absolute zin meer schade voor hun rekening zouden moeten nemen, acht ik bovendien niet onredelijk. Daarbij trek ik voorzichtig een parallel met jurisprudentie waarin ondernemers een groter normaal maatschappelijk risico wordt tegengeworpen als het risico op de door hen ondervonden schade inherent is aan hun type bedrijf of bedrijfsvoering. ${ }^{163}$ Uit een rapport van de SAOZ en Kraan \& De Jong blijkt namelijk dat de waarde van woningen in lagere prijsklassen minder sterk wordt beïnvloedt door "omgevingsfactoren (omgevingsplannen daaronder te begrijpen)", omdat hun functie om in woonbehoefte te voorzien meer op de voorgrond staat. ${ }^{164}$

160 Kamerstukken II 2002/03, 28 916, nr. A, p. 21-22 (RvS, Wro).

161 Van Viegen 2012, p. 493 e.v.

162 Aldus ook Van Viegen 2012, p. 513.

163 Zie paragraaf 6.3.1 en bijvoorbeeld ook Kamerstukken II 2010/11, 32 621, nr. 6, p. 16-17 (NV II, Wns); HR 20 juni 2003, ECLI:NL:HR:2003:AF7902, r.o. 3.6.2 (Harrida); en ABRvS 5 december 2012, ECLI:NL:RVS:2012:BY5105, r.o. 7.3 (Wouwse Tol, tussenuitspraak). 


\section{Vereenvoudiging, uniformering en harmonisering}

Art. 15.7 lid 1 Ow kan spanning veroorzaken met de doelstelling van vereenvoudiging, ${ }^{165}$ uniformering en harmonisering van het nadeelcompensatierecht. In beginsel zullen namelijk verschillende regimes gaan gelden voor indirecte schade door maatregelen die onder de reikwijdte van afd. $15.1 \mathrm{Ow}$ vallen en indirecte schade door maatregelen waarop slechts titel 4.5 Awb van toepassing is. ${ }^{166}$ Een voorbeeld van het laatstgenoemde type schade betreft de permanente waardedaling van een woning doordat B\&W op grond van art. 15 lid 1 jo. art. 18 lid 1, aanhef en onder d WVW 1994 een parkeerverbod instellen. ${ }^{167}$ Aangezien afd. 15.1 Ow in dergelijke gevallen niet van toepassing is, ${ }^{168}$ zal het normaal maatschappelijk risico uitsluitend op grond van art. 4:126 lid 1 Awb moeten worden vastgesteld. Vooralsnog bestaan er geen aanwijzingen dat daarbij van de thans bestaande jurisprudentielijnen zal worden afgeweken: en ligt een gedifferentieerde, op de omstandigheden van het individuele schadegeval toegespitste benadering. Kortom: er zouden uiteenlopende juridische regimes gelden voor gevallen waarin de aard van zowel de schade als de schadeoorzaak overeenkomstig is. Al in 2011 stelde Van Ettekoven in een andere context - en mijns inziens terecht - dat het niet zou moeten uitmaken of de benadeelde "door de hond van de planologie wordt gebeten, of door de kat van het verkeersbesluit óf door het feitelijk handelen."169 Het zou echter zomaar kunnen dat de soep uiteindelijk minder heet wordt gegeten als zij wordt opgediend. Het lijkt namelijk niet onaannemelijk dat het bestuur en de rechter in dit soort gevallen aansluiting zullen zoeken bij het gefixeerde $4 \%$-forfait van art. 15.7 lid 1 Ow. Uit paragraaf 6.2.1.1 volgde immers dat ook naar huidig recht aansluiting wordt gezocht bij het minimumforfait van art. 6.2 lid 2 Wro in nadeelcompensatiegeschillen waarin de aard van de schade(oorzaak) overeenkomstig is. ${ }^{170}$ Aan het eind van deze deelparagraaf zal ik daarom ingaan op de vraag of het 4\%-forfait van art. 15.7 lid 1 Ow niet verplaatst zou moeten worden naar titel $4.5 \mathrm{Awb}$, zodat het zou gelden voor een groter deel van het nadeelcompensatierecht.

165 Bezien vanuit de doelstelling van vereenvoudiging van het nadeelcompensatierecht, zou wel positief kunnen zijn dat een gefixeerd forfait de noodzaak voor wetsinterpreterende verordeningen en beleidsregels omtrent het normaal maatschappelijk risico zou kunnen doen afnemen.

166 Zie daaromtrent ook Van den Broek \& Tjepkema 2016, p. 2825.

167 Zie voor schade door de opheffing van een dergelijk verbod ABRvS 15 februari 2012, ECLI:NL:RVS:2012:BV5105, r.o. 2.6.2. Ook kan worden gedacht aan een verkeersbesluit dat de oprichting van een bushalte nabij de woning van de aanvrager mogelijk maakt. Zie bijvoorbeeld ABRvS 14 februari 2018, ECLI:NL:RVS:2018:504.

168 Zie art. 15.1 Ow en Kamerstukken II 2018/19, 34 986, nr. 3, p. 36 (MvT, IOw).

169 Van Ettekoven 2011, p. 16. Hij bezigt die beeldspraak in het kader van inkomensschade. In Lagerweij-Duits 2017, p. 2 wordt ook gerefereerd aan deze beeldspraak.

170 Zie bijvoorbeeld ABRvS 11 februari 2015, ECLI:NL:RVS:2015:336, r.o. 4.3 (Fietstunnel Rijksweg 7 bij Sneek); ABRvS 31 juli 2013, ECLI:NL:RVS:2013:558, r.o. 5.1; en ABRvS 27 februari 2013, ECLI:NL:RVS:2013:BZ2513, r.o. 4.3. 


\section{De aan de Wns ten grondslag liggende uitgangspunten}

De aan de Wns ten grondslag liggende uitgangspunten pleiten niet duidelijk voor of tegen het gefixeerde 4\%-forfait. Bezien vanuit het uitgangspunt van het uitsluitend codificeren van het égalitébeginsel is relevant dat de vraag wat als normaal maatschappelijk risico moet worden aangemerkt niet alleen een juridisch, maar deels ook een politiek karakter draagt. ${ }^{171}$ Mede gelet op de in paragraaf 2.5.2 beschreven verhouding tussen de formele wetgever en het ongeschreven égalitébeginsel, verzet dit beginsel zich daarom niet ertegen dat de formele wetgever bewust de keuze zou maken dat de beantwoording van "de vraag of een recht op nadeelcompensatie bestaat (...) ten opzichte van de huidige rechtspraak minder afhankelijk [zal] zijn van de concrete omstandigheden van het geval en meer van het wettelijke forfait". ${ }^{172}$ Bovendien is in Nederland omringende landen veelal de keuze gemaakt om indirecte schade helemaal niet voor nadeelcompensatie in aanmerking te laten komen. Indirecte schade wordt in deze landen namelijk niet gezien als het rechtstreekse gevolg van planologische besluitvorming, maar als het rechstreeks gevolg van het handelen van derden die gebruik maken van de mogelijkheden die door deze besluitvorming in het leven worden geroepen. ${ }^{173}$

\section{Aanbevelingen en conclusies}

Het voorafgaande laat zien dat verschillend kan worden gedacht over de verhouding van het gefixeerde 4\%-forfait van art. 15.7 lid 1 Ow tot de aan de Wns ten grondslag liggende doelstellingen en uitgangspunten. Uiteraard zijn ook andere methoden denkbaar waarmee de afbakening van het normaal maatschappelijk risico op een zinvolle wijze zou kunnen worden gereguleerd door een formele wet. ${ }^{174}$ Die methoden zouden zich anders verhouden tot de aan de Wns ten grondslag liggende doelstellingen en uitgangspunten en de wensen die het kabinet nastreeft met het gefixeerde forfait. Op voorhand is echter lastig in te schatten of 'anders' ook 'beter' is. Dat komt mede door de schaarste aan verifieerbaar cijfermateriaal over de huidige planschade- en nadeelcompensatiepraktijk. Op basis van de thans bestaande inzichten ben ik echter van mening dat de aan de Wns ten grondslag

171 Tjepkema 2016, p. 623-25. Zie tevens onderdeel zeven van de noot van Tjepkema bij ABRvS 15 juni 2016, ECLI:NL:RVS:2016:1650 (Nadeelcompensatie Eindhoven/AH Cassandraplein) in $A B$ 2016/363.

172 Kamerstukken II 2016/17, 33 962, nr. 190, p. 29.

173 Zie daarover Huijts \& Backes 2015, p. 133-137; en Alterman 2010, p. 343 en 34-35. In Van den Broek \& Tjepkema 2016, p. 2826 wordt in twijfel getrokken hoeveel gewicht moet worden toegekend aan dit buitenlandse recht.

174 Zie bijvoorbeeld Van den Broek \& Tjepkema 2015, p. 107-112. Hun voorkeursvariant wordt nader uitgewerkt in Van den Broek \& Tjepkema 2017, p. 30. Zie ook Huijts \& Backes 2015, p. 139-142 voor het voorstel om het normaal maatschappelijk risico afhankelijk te stellen van de leeftijd van planmogelijkheden. Iets dat ik thans door de verschuiving van het schademoment praktisch minder goed mogelijk acht voor indirecte schade. 
liggende doelstellingen en uitgangspunten onvoldoende aanleiding geven om af te zien van het gefixeerde 4\%-forfait van art. 15.7 lid 1 Ow.

Wel zie ik reden om nadere normering te bieden voor de afbakening van het normaal maatschappelijk risico bij directe schade. Daarbij is van belang dat in paragraaf 6.2.1.4 bleek dat naar huidig recht nog relatief weinig duidelijk is omtrent de toepassing van de Heiloo-factoren bij directe planschade. Ondanks dat de Afdeling daartoe bij indirecte schade in staat is gebleken, zou het mijns inziens niet goed bij de doelstelling van vergroting van de rechtszekerheid passen als de wetgever de nog benodigde ontwikkeling van de normering van het normaal maatschappelijk risico bij directe schade volledig zou afschuiven op de Afdeling. Gelet op deze doelstelling en de doelstelling van vereenvoudiging, uniformering en harmonisering van het nadeelcompensatierecht, doe ik daarom de aanbeveling dat art. 15.7 lid $1 \mathrm{Ow}$ zo wordt aangepast dat het daarin vervatte forfait ook op directe schade van toepassing zal zijn. Dat voorkomt bovendien dat de vreemde situatie zou ontstaan dat bij een samenloop van directe en indirecte schade voor de afbakening van het normaal maatschappelijk risico deels een uitgebreid deskundigenonderzoek nodig is, ${ }^{175}$ en deels kan worden volstaan met verwijzing naar een gefixeerd wettelijk forfait. Mede gelet op de informatie uit paragraaf 2.5.1, hoeft mijns inziens niet te worden gevreesd dat de voorgestelde aanpassing van art. 15.7 lid $1 \mathrm{Ow}$ zou leiden tot strijdigheid met art. 1 EP EVRM. ${ }^{176}$ Voorts acht ik deze aanpassing ook niet onverenigbaar met de overige aan de Wns ten grondslag liggende doelstellingen en uitgangspunten. Hetgeen hiervoor is opgemerkt over hoe toepassing van het gefixeerde forfait op indirecte schade zich verhoudt tot deze doelstellingen en uitgangspunten gaat namelijk ook grotendeels op voor de toepassing van dit forfait op directe schade. ${ }^{177}$

Bezien vanuit de doelstelling van vereenvoudiging, uniformering en harmonisering van het nadeelcompensatierecht doe ik ten slotte de aanbeveling dat het kabinet of de formele wetgever in een toelichtend stuk aangeeft dat bestuursorganen en rechters bij toepassing van titel 4.5 Awb zoveel mogelijk moeten aansluiten bij het gefixeerde $4 \%$-forfait in gevallen van permanente waardevermindering van onroerende zaken die niet onder het bereik van afd. 15.1 Ow vallen. Mede gelet op de in paragraaf 6.2.1.5 besproken jurisprudentie, zullen rechters en bestuursorganen daar met name gehoor aan kunnen geven als de aard van de schade en de schadeoorzaak overeenkomstig is. Dat zal bijvoorbeeld het geval zijn in het eerder gegeven voorbeeld van een woning die permanent in waarde daalt doordat

175 Hetgeen zich bovendien slecht zou verhouden tot de doelstelling van vergroting van de doelmatigheid van het nadeelcompensatierecht en vermindering van bestuurslasten.

176 Zie hierover ook Van den Broek \& Tjepkema 2017, p. 31-32; Van den Broek 2004, p. 648-649; en MvT IOw als voorgelegd aan de AARvS, p. 197.

177 Een verschil zou bijvoorbeeld zijn dat wel relatief veel voorbeelden beschikbaar zijn waarin de directe schade groter is dan $5 \%$ van de waarde van de onroerende zaak. Zie daarvoor paragraaf 6.2.1.4. 
B\&W op grond van art. 15 lid 1 jo. art. 18 lid 1, aanhef en onder d WVW 1994 een parkeerverbod afkondigen. Eventueel zou natuurlijk kunnen worden overwogen het gefixeerde 4\%-waardeforfait van art. 15.7 lid 1 Ow te verplaatsen naar titel 4.5 Awb. Daartoe zal ik echter geen aanbeveling doen, omdat ik niet kan uitsluiten dat reden bestaat tot tegenwerping van een hoger of lager forfait bij schade die niet omgevingsrechtelijk van aard is. Aan het begin van deze paragraaf bleek bovendien dat de meeste gevallen van permanente waardevermindering die onder de reikwijdte van titel $4.5 \mathrm{Awb}$ vallen, naar verwachting zullen worden afgedaan met toepassing van de bepalingen uit afd. 15.1 Ow.

\subsubsection{Anticumulatiebepalingen}

In paragraaf 3.4.2.3 bleek dat de verschuiving van het schademoment bepaalde complicaties met zich brengt, waaronder de fragmentatie van het recht op schadevergoeding. Deze fragmentatie werkt onder andere in de hand dat één persoon naar aanleiding van één planologisch besluit meerdere aanvragen om tegemoetkoming zal indienen, namelijk steeds als een van zijn buren gebruikmaakt van de nieuwe mogelijkheden die het planologische besluit biedt. De anticumulatiebepaling van art. 15.7 lid 2 Ow expliciteert dat een gebundelde aanvraag mogelijk is, en maakt de benadeelde bovendien duidelijk dat het indienen van een dergelijke aanvraag voordelig kan uitpakken bij de vaststelling van het normaal maatschappelijk risico. Het lijkt daarom aannemelijk dat deze bepaling zal uitnodigen tot het bundelen van aanvragen om tegemoetkoming. Dat past goed bij de doelstelling van vergroting van de doelmatigheid van het nadeelcompensatierecht en vermindering van bestuurslasten. Ook past het goed bij deze doelstelling dat een dergelijke bundeling van aanvragen voorkomt dat het bestuur meermaals een recht als bedoeld in art. 4:128 Awb van de aanvrager dient te heffen. Dit sluit bovendien goed aan op de doelstelling van vergroting van de rechtszekerheid, omdat het voor minder bedeelde huishoudens problematisch kan zijn een dergelijke recht (meermaals) te voldoen (binnen een relatief korte periode). ${ }^{178}$

Op het eerste oog lijkt art. 15.7 lid 3 Ow afbreuk te doen aan de mate waarin het tweede lid uitnodigt tot de indiening van gebundelde aanvragen. Op grond van het derde lid kan de voordeligere invulling van het normaal maatschappelijk risico immers ook worden verkregen zonder een gebundelde aanvraag in te dienen. Toch brengt de doelstelling van vergroting van de rechtszekerheid en rechtsgelijkheid mijns inziens mee dat het derde lid niet kan worden geschrapt. Ik zie namelijk onvoldoende rechtvaardiging om de aanvrager die kiest voor de indiening van afzonderlijke aanvragen op voorhand uit te sluiten van de gunstigere behandeling die zal worden toegekend aan de indiener van een gebundelde aanvraag. Er kunnen immers allerlei redenen zijn waarom een gebundelde aanvraag geen reële optie is voor de benadeelde. Daarbij kan bijvoorbeeld worden gedacht aan financiële redenen, maar ook aan de naderende verstrijking van de verjaringstermijn van het 
recht op compensatie van schade die is ondervonden naar aanleiding van een of meerdere activiteiten. ${ }^{179}$

Dat art. 15.7 lid 2 Ow niet aansluit bij de jurisprudentie omtrent voordeelverrekening bij nauw verweven overheidshandelingen is mijns inziens niet onverenigbaar met de doelstelling van codificatie van het nadeelcompensatierecht. Anders dan die jurisprudentie, ziet deze bepaling namelijk niet slechts op schade die wordt veroorzaakt door verschillende planologische besluiten die elk hun eigen vooren nadelen voor de aanvrager meebrengen én moeten worden geacht samen één planologisch regime te vormen. ${ }^{180}$ Gelet op de doelstelling van vergroting van de rechtszekerheid verdient het mijns inziens wel aanbeveling de formulering van art. 15.7 lid 2 Ow aan te passen. Grammaticaal gezien, ziet zij thans namelijk slechts op schade door "verschillende besluiten met onderlinge samenhang daartussen." De bepaling zou echter ook een oplossing moeten bieden voor schades die ontstaan doordat verschillende personen op verschillende momenten gebruik maken van de vergunningvrije mogelijkheden die één planologische maatregel in het leven heeft geroepen. Dat geldt te meer nu bij vergunningvrije activiteiten niet altijd duidelijk zal zijn welk (samenspel van) achterliggend(e) besluit(en) aan de schade ten grondslag ligt. ${ }^{181}$ Bovendien zou het goed bij deze doelstelling passen als uit de formulering van art. 15.7 lid 2 Ow zou volgen dat slechts enige samenhang onvoldoende is. De samenhang dient dermate groot te zijn dat zij het rechtvaardigt dat het vaste forfait van het eerste lid niet wordt toegepast op ieder afzonderlijk schadebedrag. Deze verbeteringen zouden kunnen worden bewerkstelligd door middel van de volgende formulering:

"Als de aanvraag om schadevergoeding strekt tot vergoeding van meerdere schades door verschillende activiteiten óf strekt tot vergoeding van schade door één activiteit gebaseerd op meerdere besluiten, past het bevoegd gezag het eerste lid toe op het totale voor vergoeding in aanmerking komende bedrag, mits deze activiteiten respectievelijk besluiten daartoe voldoende samenhang vertonen."

Bezien vanuit de doelstelling van vergroting van de rechtszekerheid zou voorts uit art. 15.7 lid 3 Ow de zinsnede "die bestaat uit waardevermindering van de onroerende zaak" kunnen worden geschrapt. Doordat het rechtsgevolg van deze bepaling is dat art. 15.7 lid $1 \mathrm{Ow}$ buiten toepassing wordt gelaten, is immers reeds duidelijk dat het enkel kan gaan om situaties waarin de schade bestaat uit een waardedaling van onroerende zaken. Zowel deze aanbevelingen als de bepalingen die bij opvolging daarvan in art. 15.7 Ow zouden worden opgenomen, acht ik

179 Zie over verjaring ook paragraaf 10.5. In paragraaf 10.5.3 wordt voorgesteld de mogelijkheid tot stuiting van de verjaringstermijn te codificeren in titel $4.5 \mathrm{Awb}$.

180 Zie paragraaf 9.1.1 onder het kopje 'Verrekening met voordeel uit nauw verweven overheidshandelingen'.

181 Zie daarover paragraaf 4.4.3 onder het kopje 'De verschuiving van het schademoment en de csqn-toets'. 
verenigbaar met de overige aan de Wns ten grondslag liggende doelstellingen en uitgangspunten.

\subsubsection{Art. 15.7 lid 4 Ow}

Dat art. 15.7 lid 4 Ow de mogelijkheid biedt om bij amvb gevallen aan te wijzen waarin de schade wordt geacht niet boven het normaal maatschappelijke risico uit te gaan, sluit goed aan op de doelstellingen van vergroting van de rechtszekerheid, en vergroting van de doelmatigheid van het nadeelcompensatierecht en vermindering van bestuurslasten. Ook lijkt dit verenigbaar met de overige aan de Wns ten grondslag liggende doelstellingen en uitgangspunten. Gelet op de doelstelling van uniformering en harmonisering van het nadeelcompensatierecht is het wel aanbevelenswaardig om dit artikellid te verplaatsen naar titel 4.5 Awb. Ik zie namelijk geen reden waarom de mogelijkheid om bij amvb extra rechtszekerheid te bieden, beperkt zou moeten blijven tot het omgevingsrecht. Hierna zal in paragraaf 6.3.3 en 6.4.3 worden aanbevolen om in titel 4.5 Awb te bepalen dat bij amvb in algemene zin regels kunnen worden gesteld omtrent het normaal maatschappelijk risico. Als de wetgever daaraan gehoor zou geven, zou de hier gedane aanbeveling omtrent de verplaatsing van art. 15.7 lid $4 \mathrm{Ow}$ daarin opgaan. Het volstaat immers als titel 4.5 Awb één algemene grondslag bevat om amvb's over het normaal maatschappelijk risico vast te stellen.

\subsubsection{Conclusie}

Uit het voorafgaande volgt dat de aan de Wns ten grondslag liggende doelstellingen en uitgangspunten mijns inziens aanleiding geven tot (b) wijziging van afd. 15.1 Ow. Gelet op de doelstellingen van vergroting van de rechtszekerheid, en vereenvoudiging, uniformering en harmonisering van het nadeelcompensatierecht is aanbevolen dat art. 15.7 lid $1 \mathrm{Ow}$ zo wordt aangepast dat het daarin vervatte forfait ook van toepassing zal zijn op directe schade. Bezien vanuit de doelstelling van vergroting van de rechtszekerheid, zijn vervolgens enkele redactionele wijzigingen van art. 15.7 lid 2 en lid 3 Ow voorgesteld. Gelet op de doelstelling van uniformering en harmonisering van het nadeelcompensatierecht is voorts aanbevolen art. 15.7 lid 4 Ow te verplaatsen naar titel 4.5 Awb. Dat kwalificeert uiteraard ook als (a) wijziging van titel 4.5 Awb. Bezien vanuit de doelstelling van uniformering en harmonisering van het nadeelcompensatierecht is ten slotte een aanbeveling gedaan die kwalificeert als (c) het anderszins voorzien in een bijzondere invulling van titel 4.5 Awb. Het zou namelijk goed bij deze doelstelling passen als het kabinet of de formele wetgever in een toelichtend stuk zou aangeven dat bestuursorganen en rechters bij toepassing van titel 4.5 Awb zoveel mogelijk moeten aansluiten bij het gefixeerde 4\%-forfait van art. 15.7 lid $1 \mathrm{Ow}$ in gevallen van permanente waardevermindering van onroerende zaken die niet onder de reikwijdte van afd. $15.1 \mathrm{Ow}$ vallen. 


\subsection{INKOMENSDERVING}

6.3.1 Deelvraag 2: verschillen tussen de geselecteerde, thans geldende regelingen en verklaringen daarvoor

Aan de hand van een chronologische bespreking van ontwikkelingen in beleid, regelgeving en jurisprudentie wordt hierna toegelicht welke verschillen bestaan tussen de geselecteerde, thans geldende regelingen met betrekking tot de afbakening van het normaal maatschappelijk risico bij inkomensderving, en hoe deze verschillen kunnen worden verklaard. Van deze regelingen bevatten slechts afd. 6.1 Wro, de BnIW 2019 en de AVN specifieke normering ten aanzien van deze vorm van het normaal maatschappelijk risico. In paragraaf 6.1 is besproken waarom in de overige regelingen geen bijzondere normering is opgenomen. Onder de GrS blijkt ook nauwelijks te zijn geprocedeerd omtrent de afbakening van het normaal maatschappelijk risico bij inkomensschade. ${ }^{182}$ Niets wijst echter erop dat deze afbakening anders geschiedt dan conform de hierna te bespreken jurisprudentielijnen. Dat is uiteraard anders als art. $49 \mathrm{WRO}$ de achterliggende grondslag voor compensatie vormt. In paragraaf 6.1 bleek immers dat het normaal maatschappelijk risico geen rol speelt onder zowel art. $49 \mathrm{WRO}^{183}$ als de VNNZ.

\section{De RnVW 1999}

Veel van de nadeelcompensatierechtspraak tussen de erkenning van de constructie van het onzuiver schadebesluit in $1982^{184}$ en de vaststelling van de RnVW 1999 had betrekking op schade door infrastructurele maatregelen van overheidswege. ${ }^{185}$ Regelmatig werd in deze rechtspraak ingegaan op de vraag welke schade tot het normaal maatschappelijk risico van een ondernemer moest worden gerekend. Onder andere de mate waarin schade aan afnemers kon worden doorberekend, de verhouding van de omzetdaling in relatie tot de totale omzet, en de mate waarin de schade inherent was aan de normale bedrijfsactiviteiten speelden een rol bij de afbakening van het normaal ondernemersrisico. ${ }^{186}$ Ondanks dat enige houvast kon worden gevonden in deze rechterlijke uitspraken, lijkt destijds niet één uniforme methode te hebben bestaan om het normaal ondernemersrisico af te bakenen. Dat lijkt ook te verklaren waarom geen specifieke normering werd opgenomen in de RnVW 1999.

182 ABRvS 13 oktober 2004, ECLI:NL:RVS:2004:AR3796 is een van de weinige uitspraken die mij bekend is. Daarin bestond echter geen causaal verband tussen de gestelde schade en de beweerde schadeoorzaak.

183 Ook bleek dat onder art. 49 WRO wel een kleine uitzondering bestond voor schade in de vorm van tijdelijk gederfd woongenot.

184 Zie hierover paragraaf 2.2.

185 Stcrt. 1999, nr. 172, p. 10 (digitaal, p. 8).

186 Zie Stcrt. 1999, nr. 172, p. 10 (digitaal, p. 7-9) voor een inventarisatie van destijds relevante jurisprudentie. 
Introductie van een gefixeerde 15\%-omzetdrempel (eind jaren '90)

Eind jaren '90 introduceerde het gemeentebestuur van Den Haag een gefixeerde drempel van $15 \%$ van de omzet op jaarbasis. ${ }^{187}$ Ondanks dat de hoogte daarvan nooit is gemotiveerd, ${ }^{188} \mathrm{kreeg}$ dit forfait al snel vaste voet aan de grond in het nadeelcompensatierecht. ${ }^{189}$ De Afdeling hanteerde namelijk als vaste lijn dat afbakening door middel van een 15\%-omzetdrempel "rechtens aanvaardbaar" was. ${ }^{190} \mathrm{Zij}$ toetste de tegenwerping van de 15\%-drempel dus terughoudend, hetgeen treffend wordt geïllustreerd door haar overweging uit een uitspraak van 18 mei 2011 dat...

“(..) in uitzonderlijke gevallen kan worden afgezien van het hanteren van die drempel als de toepassing daarvan tot een onredelijke of onbillijke situatie lijdt. Met de rechtbank wordt overwogen dat [appellante] geen feiten en omstandigheden heeft gesteld die het college aanleiding hadden moeten geven af te zien van toepassing van een ondergrens van $15 \%$ van de omzet op jaarbasis." 191

Voor het bestuur was de 15\%-drempel dan ook een middel om het normaal ondernemersrisico zonder al te veel gevaar op eenvoudige wijze te kunnen afbakenen. Ook een gefixeerde drempel van $15 \%$ van de (transport)kosten op jaarbasis werd door de Afdeling geaccepteerd. ${ }^{192}$ Desondanks bakende het bestuur het normaal ondernemersrisico soms ook af door middel van een korting op het schadebedrag.

187 Rb. 's-Gravenhage 9 juli 1999, ECLI:NL:RBSGR:1999:AA3745, r.o. 4.3.194.3.20.

188 Zie daarover bijvoorbeeld onderdeel zes van de annotatie van Tjepkema bij ABRvS 5 juni 2013, ECLI:NL:RVS:2013:CA2052 (Hollandse Brug, tussenuitspraak) in $A B$ $2013 / 222$.

189 Zie voor de RnVW 1999 bijvoorbeeld: Rb. Utrecht 10 oktober 2012, ECLI:NL:RBUTR:2012:BY4681, r.o. 23; Rb. Zwolle-Lelystad 9 maart 2012, ECLI:NL:RBZLY:2012:BV8409, r.o. 4.1; en Rb. Roermond 7 juli 2008, ECLI:NL:RBROE:2008:BD7739, r.o. 3.6.

190 Zie bijvoorbeeld ABRvS 19 december 2007, ECLI:NL:RVS:2007:BC0536, r.o. 2.9; ABRvS 14 april 2004, ECLI:NL:RVS:2004:AO7483, r.o. 2.5.1; en ABRvS 5 september 2001, ECLI:NL:RVS:2001:AD3527, r.o. 2.2 (Verordening nadeelcompensatie Den Haag).

191 ABRvS 18 mei 2011, ECLI:NL:RVS:2011:BQ4941, r.o. 2.5.1. Zie bijvoorbeeld ook Rb. Zwolle-Lelystad 9 maart 2012, ECLI:NL:RBZLY:2012:BV8409, r.o. 4.1; en Tjepkema 2010, p. 449.

192 Zie bijvoorbeeld ABRvS 2 april 2008, ECLI:NL:RVS:2008:BC8472, r.o. 2.5, waarin wordt verwezen naar ABRvS 21 juni 2006, ECLI:NL:RVS:2006:AX9047, r.o. 2.6.2. 
Het lijkt erop dat de Afdeling de motivering daarvan wat minder terughoudend toetste. ${ }^{193}$

\section{Afd. 6.1 Wro (juli 2008)}

In art. 6.2 lid 2, aanhef en onder a Wro heeft de wetgever een minimumdrempel van $2 \%$ van het inkomen onmiddellijk voor het ontstaan van de schade opgenomen. Voor de hoogte van het drempelpercentage geldt hetzelfde als in paragraaf 6.2.1 is opgemerkt over de in art. 6.2 lid 2, aanhef en onder b Wro opgenomen minimumdrempel van $2 \%$ van de waarde van de onroerende zaak: aanvankelijk werd ingezet op 10\%, maar de hoogte van deze drempel is uiteindelijk vrij arbitrair op $2 \%$ uitgekomen. Waarom niet is vastgehouden aan de in de praktijk gebruikelijke, gefixeerde $15 \%$-omzetdrempel is nooit toegelicht. De uitwerking van beide drempels is lastig te vergelijken, omdat de drempel uit de Wro geen betrekking heeft op omzet, maar op inkomen. ${ }^{194}$ Een vergelijking wordt bovendien bemoeilijkt doordat inkomensschade doorgaans niet als gevolg van planologische besluitvorming aan het bestuur wordt toegerekend, maar wordt gezien als het gevolg van ondernemersbeslissingen of keuzes van derden. ${ }^{195}$ Ten slotte wordt de 15\%-omzetdrempel doorgaans toegepast op tijdelijke inkomensschade (veelal door werkzaamheden ter uitvoering van infrastructurele maatregelen), terwijl zich onder afd. 6.1 Wro met name permanente inkomensschade zal voordoen. ${ }^{196}$ Dat neemt overigens niet weg dat de Afdeling in het op égalité gebaseerde nadeelcompensatierecht heeft geaccepteerd dat analoog aan art. 6.2 lid 2, aanhef en onder a Wro een minimuminkomensdrempel van $2 \%$ wordt gehanteerd bij tijdelijke inkomensschade, zelfs als de schade wordt veroorzaakt door een niet-normale ontwikkeling. ${ }^{197}$ Dat is op zijn beurt weer een sterke aanwijzing dat de drempel uit de Wro - net als zijn equivalent voor schade in de vorm van waardedaling van een onroerende zaak $^{198}$ hoofdzakelijk de functie van bagateldrempel vervult.

193 Zie voor voorbeelden van kortingen die de Afdeling ontoereikend gemotiveerd achtte: ABRvS 15 mei 2002, ECLI:NL:RVS:2002:AE2594, r.o. 2.10; ABRvS 8 september 2004, ECLI:NL:RVS:2004:AQ9948, r.o. 2.3; en ABRvS 8 mei 2013, ECLI:NL:RVS:2013:BZ9769, r.o. 4.2. In ABRvS 18 mei 2011, ECLI:NL:RVS:2011:BQ4893, r.o. 2.10 werd een korting van 15\% wel toereikend gemotiveerd.

194 Zie paragraaf 5.7.1.2 voor het verschil tussen beide grootheden.

195 Zie paragraaf 3.4.2.4 onder het kopje 'Schaduwschade en ondernemers'; en Dijkshoorn 2011a, p. 47.

196 Zie ABRvS 16 december 2015, ECLI:NL:RVS:2015:3819 (Urilift, einduitspraak) voor een uitzondering waarin de inkomensschade tijdelijk van aard was, omdat deze aanving met de feitelijke plaatsing van een zogenoemde 'urilift' en stopte door de feitelijke verplaatsing van de urilift naar een andere locatie. Zie hierover ook het vierde onderdeel van de annotatie van Tjepkema en mijzelf bij ABRvS 16 november 2016, ECLI:NL:RVS:2016:3047 (Uptown) in AB 2017/331.

197 ABRvS 11 februari 2015, ECLI:NL:RVS:2015:336, r.o. 4.3 (Fietstunnel Rijksweg 7 bij Sneek).

198 Zie paragraaf 6.2.1.2. 


\title{
De AVN (april 2012)
}

De Amsterdamse gemeenteraad gooit het over een andere boeg. In art. 2 lid 3 jo. lid $4 \mathrm{AVN}$ is namelijk een minimum omzetdrempel van $8 \%$ respectievelijk een minimum kostendrempel van $6 \%$ opgenomen. De toelichting op de AVN geeft geen antwoord op de vraag waarom wordt afgeweken van het in de praktijk gebruikelijke percentage van $15 \%$. Ook geeft zij geen antwoord op de vraag waarom verschillende percentages voor kosten en omzet worden gebruikt. Op de laatste vraag heb ik geen voor de hand liggend antwoord. Ik sluit niet uit dat de eerste vraag moet worden beantwoord door verwijzing naar de destijds toenemende kritiek op de gefixeerde $15 \%$-omzetdrempel in zowel de literatuur als de praktijk. ${ }^{199}$ Zo stelt Van Ettekoven in zijn - meer dan een jaar voor vaststelling van de AVN - te Amsterdam uitgesproken oratierede dat alle deskundigen die hij heeft gesproken...

\begin{abstract}
“(...) het erover eens [zijn] dat een drempel van $15 \%$ zeer onbillijk uitpakt en de lokale ondernemers de das om doet, zeker als een project meerdere jaren schade veroorzaakt. ${ }^{200}$ Goede ondernemers houden rekening met financiële tegenvallers, maar geen enkele ondernemer trekt het om jaar op jaar een schadebedrag gelijk aan 15\% van zijn omzet voor eigen rekening te moeten nemen. Die drempel is zo hoog, dat de ondernemer of vertrekt, of failliet gaat."'201
\end{abstract}

Het blijft echter gissen of dit daadwerkelijk een beweegreden was voor de Amsterdamse gemeenteraad. Mogelijk heeft ook een rol gespeeld dat de drempelsystematiek van de AVN niet beperkt lijkt te zijn tot tijdelijke inkomensschade (door infrastructurele werkzaamheden).

Dat onder de AVN eveneens geen aansluiting is gezocht bij de 2\%-inkomensdrempel uit de Wro, kan waarschijnlijk worden verklaard doordat die drempel hoofdzakelijk functioneert als bagateldrempel. De Amsterdamse gemeenteraad beoogt echter "maatwerk te leveren" door middel van een combinatiestelsel van drempels en kortingen. Op grond van art. 2 lid 6 AVN kan het bestuur namelijk per schadeoorzaak een korting wegens normaal ondernemersrisico toepassen op het deel van de schade dat uitstijgt boven de drempel van art. 2 lid 3 jo. lid 4 AVN. Bij het bepalen van de hoogte van deze korting zijn alle omstandigheden van het concrete schadegeval van belang en speelt met name de voorzienbaarheid in abstracto een belangrijke rol. Als de overheidsmaatregel en de gevolgen daarvan beter te voorzien waren, zal de korting in de regel hoger uitvallen. Indien de geleden schade in grote mate tot het normale verwachtingspatroon behoorde, zal dus - zelfs als deze

199 Daarop lijkt ook te worden gehint in Planken \& Tjepkema 2015, p. 9.

200 Uit ABRvS 14 april 2004, ECLI:NL:RVS:2004:AO7483, r.o. 2.5.1 blijkt dat het in beginsel niet nodig werd geacht om van deze drempel af te zien bij over meerdere jaren geleden inkomensschade. Uit ABRvS 15 juni 2016, ECLI:NL:RVS:2016:1650, r.o. 10.3 (Nadeelcompensatie Eindhoven/AH Cassandraplein) blijkt dat dit thans genuanceerder ligt.

201 Van Ettekoven 2011, p. 8. Hij verwijst daarbij naar Horlings 2007. 
schade de relevante drempel passeerde - een hoog kortingspercentage worden gehanteerd. Die korting kan in dergelijke gevallen in beginsel zelfs zo hoog uitvallen dat de volledige schade voor rekening van de benadeelde blijft. ${ }^{202}$ Een gesprek met een jurist van de gemeente Amsterdam leert echter dat in beginsel een korting van $20 \%$ wordt toegepast op het deel van de schade dat uitstijgt boven de in casu gehanteerde drempel, als de schade is veroorzaakt door een normale maatschappelijke ontwikkeling die in de lijn der verwachting lag. Als de omstandigheden van het geval daartoe aanleiding geven, wordt de hoogte van deze korting naar boven of beneden bijgesteld. ${ }^{203}$

Voorts kan het bestuur op grond van art. 2 lid 7 AVN per schadeoorzaak bepalen dat 'in bijzondere omstandigheden' wordt afgeweken van de drempelpercentages uit het derde en vierde lid. ${ }^{204}$ Ook kan het op grond van deze bepaling besluiten om de aanvrager over een bepaalde periode geen aftrek wegens normaal maatschappelijk risico tegen te werpen. Ten aanzien van de mogelijkheid om van de drempelpercentages af te wijken, stelt de toelichting dat het gezien het "brede toepassingsbereik van de verordening" niet mogelijk is om de genoemde percentages altijd te hanteren. De effecten van deze percentages zijn namelijk niet altijd (op voorhand) te overzien. ${ }^{205}$ De Amsterdamse gemeenteraad lijkt hiermee op welhaast profetische wijze te hebben geanticipeerd op de hierna te bespreken Wouwse Tol-uitspraak.

\section{De Wouwse tol (december 2012)}

Op 5 december 2012 deed de Afdeling tussenuitspraak in de zaak Wouwse tol. De exploitant van een aan de A58 gelegen hotel-restaurant (De Wouwse tol) diende een aanvraag om nadeelcompensatie in, omdat hij inkomsten zou zijn misgelopen door groot onderhoud aan de A4, A17 en A58. De minister van Infrastructuur \& Milieu wees deze aanvraag af, omdat de omzetderving de gefixeerde $15 \%$-omzetdrempel niet ontsteeg. In hoger beroep voerde de exploitant aan dat toepassing van deze drempel onredelijk was, omdat zij zou leiden tot "onvoldoende differentiatie binnen verschillende branches." Naar aanleiding hiervan overwoog de Afdeling dat bestuursorganen in beginsel mogen werken met drempels, kortingen of combinaties daarvan, omdat dit bijdraagt aan de uniformiteit en de voorspelbaarheid van het nadeelcompensatierecht - en dus ten goede komt van de rechtszekerheid. Wel dient het bestuur na te gaan of de drempel, korting, of combinatie daarvan onverkort toepassing kan vinden in de omstandigheden van het geval "als daartoe

202 Zie de toelichting op art. 2 lid 6 AVN.

203 Die praktijk ontstond al onder de Verordening Nadeelcompensatie en Planschade Noord-Zuidlijn. Zie daarover paragraaf 6.1.

204 In Amsterdam is in enkele gevallen waarin de schadeveroorzakende overheidsmaatregel niet als een normale maatschappelijke ontwikkeling kon worden gekwalificeerd daadwerkelijk besloten om geen drempel te hanteren. Zie daarover Planken \& Tjepkema 2015, p. 11, voetnoot 41.

205 Zie de toelichting op art. 2 lid 7 AVN. 
op grond van de door de benadeelde verschafte gegevens aanleiding bestaat." 206 De Afdeling vervolgde haar uitspraak met het oordeel...

\begin{abstract}
“(...) dat niet zonder meer, dat wil zeggen niet zonder nadere motivering, valt in te zien dat het hanteren van een vaste ondergrens van $15 \%$ van de omzet redelijk is in een geval zoals hier, waarin de weggebonden onderneming een horecabedrijf is. De Wouwse Tol heeft terecht betoogd dat het hanteren van een ondergrens van $15 \%$ van de omzet op jaarbasis, tot onvoldoende differentiatie tussen verschillende branches leidt en daarmee tot uiteenlopende gevolgen voor verschillende typen ondernemingen. Op dit punt zou een differentiatie op zijn plaats kunnen zijn, waarbij onder meer de kostenstructuur en de verhouding tussen kosten en omzet aan de orde komt. Het is aan het bestuursorgaan om een gemotiveerd oordeel te geven over de vraag of differentiatie in een geval als dit gerechtvaardigd is en zo ja, wat deze differentiatie betekent voor de invulling van het normale ondernemersrisico." ${ }^{207}$
\end{abstract}

De minister kreeg de opdracht om met inachtneming van het voorafgaande een nieuw besluit te nemen. Mede omdat de minister een onjuiste invulling aan deze opdracht gaf, besloot de Afdeling uiteindelijk zelf in de zaak te voorzien door het drempelpercentage in de einduitspraak te stellen op $10 \%$ van de gemiddelde jaaromzet. Aan dat percentage lijkt geen precedentwerking toe te komen: het was voorgesteld door de Wouwse Tol en onvoldoende bestreden door de minister. In algemene zin is wel van belang dat het volgens de Afdeling voor de hand ligt om verschillende omzetdrempels te hanteren bij verschillende typen weggebonden ${ }^{208}$ ondernemingen. Dezelfde schadeoorzaak kan namelijk tot aanzienlijk verschillende schadebedragen leiden voor ondernemingen met een uiteenlopende kostenstructuur en/of een "wezenlijk andere verhouding tussen omzet en kosten."209

\title{
Ontvangst van de Wouwse Tol-uitspraak en verdere ontwikkelingen in de juris- prudentie
}

Tjepkema trok in 2016 de "sombere conclusie" dat door de Wouwse Tol-uitspraak "de onzekerheid voor de praktijk eerder is vergroot dan verkleind." ${ }^{10}$ Zowel uit deze uitspraak als uit latere jurisprudentie volgt dat toepassing van een 15\%-drempel nog steeds tot de mogelijkheden behoort - ook gedurende het tweede jaar dat

206 Dat de bewijslast echt op de aanvrager rust, blijkt onder andere uit ABRvS 30 juli 2014, ECLI:NL:RVS:2014:2865, r.o. 8.4 (Audio Design t. Utrecht); en ABRvS 15 juni 2016, ECLI:NL:RVS:2016:1650, r.o. 10.2 (Nadeelcompensatie Eindhoven/AH Cassandraplein).

207 ABRvS 5 december 2012, ECLI:NL:RVS:2012:BY5105, r.o. 7-7.5 (Wouwse Tol, tussenuitspraak).

208 Niets wijst erop dat dit niet ook zou opgaan voor andersoortige ondernemingen.

209 ABRvS 28 mei 2014, ECLI:NL:RVS:2014:1868, r.o. 5-6 (Wouwse Tol, einduitspraak).

210 Tjepkema 2016, p. 626-627. 
inkomensschade wordt geleden. ${ }^{211}$ Er bestaat echter onduidelijkheid over de mate waarin het bestuur de keuze voor dit drempelpercentage al van begin af aan dient te motiveren en in hoeverre daarbij ook andere omstandigheden tot differentiatie kunnen nopen dan de kostenstructuur van de getroffen onderneming en de verhouding tussen kosten en omzet. Uit de op 15 juni 2016 gewezen AH Cassandrapleinuitspraak blijkt weliswaar dat het bestuur bij schade door "reguliere infrastructurele werkzaamheden" een omzetdrempel van $8 \%$ kan toepassen zonder "verhoogde motiveringsplicht", maar dit laat de vraag open of thans wel een verhoogde motiveringsplicht geldt voor toepassing van een 15\%-drempel. De Afdeling lijkt zich daarover ook liever niet in algemene bewoordingen uit te laten. ${ }^{212}$ Wel is duidelijk dat een 15\%-drempel niet langer voor de hand ligt als hantering van een lager drempelpercentage in algemene zin deel uitmaakt van door het bestuur gevoerd nadeelcompensatiebeleid. ${ }^{213}$

Onder andere uit de op 11 december 2013 gewezen einduitspraak in de Hollandse brug-zaak blijkt voorts dat aan de vraag naar differentiatie niet wordt toegekomen als het bestuur in een individueel geval niet is uitgegaan van een vaste ondergrens, maar de aftrek wegens normaal ondernemersrisico direct heeft gebaseerd op de van belang zijnde omstandigheden van het desbetreffende geval. ${ }^{214}$ In dezelfde lijn ligt de jurisprudentie waarin de Afdeling een systeem accepteert...

“(...) waarbij niet expliciet een percentuele ondergrens wordt gehanteerd, maar de gestelde schade wordt afgezet tegen de gemiddelde jaarlijkse kosten ten behoeve van het oordeel of de schade al dan niet als relatief gering kan worden beschouwd."

Relatief geringe schade behoort namelijk per definitie tot het normaal maatschappelijk risico, waardoor het bestuur zich bij dergelijke schade niet hoeft uit te laten over de hoogte van een drempel of toepassing van een korting. ${ }^{215}$

Ten slotte is er nog de tussenuitspraak in de Hollandse brug-zaak d.d. 5 juni 2013. Daaruit volgt dat toepassing van een drempel niet "in de rede" ligt als de

211 De Afdeling overweegt in de Audio Design-uitspraak expliciet dat dit "op zichzelf" niet in strijd is met het égalitébeginsel. Zie m.b.t. drempels van $15 \%$ en $8 \%$ gedurende het tweede jaar: ABRvS 30 juli 2014, ECLI:NL:RVS:2014:2865, r.o. 8-8.4 (Audio Design t. Utrecht) respectievelijk ABRvS 15 juni 2016, ECLI:NL:RVS:2016:1650, r.o. 10.3 (Nadeelcompensatie Eindhoven/AH Cassandraplein).

212 ABRvS 15 juni 2016, ECLI:NL:RVS:2016:1652, r.o. 14.1 (Supermarkt Haarlem).

213 ABRvS 15 juni 2016, ECLI:NL:RVS:2016:1651, r.o. 4 (Bandencentrum Eindhoven).

214 ABRvS 11 december 2013, ECLI:NL:RVS:2013:2317, r.o. 5.1 (Hollandse brug, einduitspraak). Duidelijker is echter: ABRvS 29 januari 2014, ECLI:NL:RVS:2014:226, r.o. 5.1. Zie ook ABRvS 17 september 2014, ECLI:NL:RVS:2014:3378, r.o. 13.1.

215 ABRvS 17 september 2014, ECLI:NL:RVS:2014:3378, r.o. 12, onder verwijzing naar ABRvS 21 juni 2006, ECLI:NL:RVS:2006:AX9047, r.o. 2.6.2. Zie ook ABRvS 22 mei 2013, ECLI:NL:RVS:2013:CA0631, r.o. 6.2. 
schadeoorzaak niet als een normale maatschappelijke ontwikkeling kan worden beschouwd. In dergelijke gevallen lijkt het normaal maatschappelijk risico dus te moeten worden verdisconteerd door middel van een korting op het schadebedrag. ${ }^{216}$ Hoewel de Afdeling dat niet met zoveel woorden overweegt, lijkt de achterliggende gedachte te zijn dat in dergelijke gevallen in ieder geval een deel van de schade moet worden vergoed. ${ }^{217}$

\section{De BnIM 2014}

De onzekerheid die de Wouwse Tol-jurisprudentie met zich bracht, heeft ook zijn invloed gehad op de wijze waarop bestuursorganen het normaal ondernemersrisico afbakenen. Uit een raadsbrief blijkt bijvoorbeeld dat de gemeente Eindhoven voor een omzetdrempel van $8 \%$ kiest, omdat het beter is...

“(...) een percentage te kiezen dat niet ter discussie staat en recht doet aan het égalité beginsel dan [te] wachten op de vernietiging van een nadeelcompensatiebesluit door de bestuursrechter."218

Ook de minister van Infrastructuur \& Milieu zag in deze jurisprudentie "noodzaak" om de RnVW 1999 aan te passen. De regeling werd omgedoopt tot de BnIM 2014 en in het nieuw toegevoegde art. 3a BnIM 2014 werd nadere normering opgenomen omtrent het normaal maatschappelijk risico bij schade door tijdelijke infrastructurele werkzaamheden. De minister sloot niet uit dat aansluiting bij deze normering kon worden gezocht bij andere schadeoorzaken. ${ }^{219}$ De afbakening van het normaal maatschappelijk risico door toepassing van art. 3a BnIM 2014 verliep volgens vier stappen:

1. Een ingangsdrempel van $15 \%$ van de gemiddelde omzet of kosten uit voorafgaande referentiejaren.

2. Verlaging van de ingangsdrempel als de infrastructurele maatregel naar aard, duur of voorzienbaarheid bijzonder dan wel uitzonderlijk was.

3. Verlaging van de ingangsdrempel naar aanleiding van door de aanvrager aangevoerde bijzondere omstandigheden met betrekking tot de ernst van de schade voor zijn onderneming.

216 ABRvS 5 juni 2013, ECLI:NL:RVS:2013:CA2052, r.o. 7.2 (Hollandse brug, tussenuitspraak). Zie anders: Stcrt. 2014, nr. 16584, p. 5. Zie ten slotte ABRvS 17 september 2014, ECLI:NL:RVS:2014:3378, r.o. 12 voor de explicitering dat een drempel wel is toegestaan bij schade door een normale maatschappelijke ontwikkeling.

217 Tenzij een andere voorwaarde voor toekenning van nadeelcompensatie roet in het eten van de aanvrager zou gooien, bijvoorbeeld omdat sprake is van risicoaanvaarding.

218 De raadsbrief is te vinden door met behulp van google te zoeken op 'Raadsnummer 15R6600'.

219 Stcrt. 2014, nr. 16584, p. 5. 
4. Bij passeren van de ingangsdrempel kwam de gehele schade voor vergoeding in aanmerking, minus een op de omstandigheden van het geval toegespitste korting. ${ }^{220}$

Art. 3a BnIM 2014 werd kritisch ontvangen in de literatuur. Daarbij was met name van belang dat onduidelijk was in hoeverre de motivering van de korting van de vierde stap zou (moeten) verschillen van de motivering van de drie eerdere stappen. Ook werd de redelijkheid van deze bepaling in twijfel getrokken. Een omzetdaling van $14,9 \%$ zou immers geen aanspraak op nadeelcompensatie geven, terwijl bij een omzetdaling van $15,1 \%$ in theorie ${ }^{221}$ de gehele omzetdaling voor compensatie in aanmerking kwam. ${ }^{222}$ Vooralsnog is uit de jurisprudentie niet gebleken dat de toepassing van art. 3a BnIM 2014 in de praktijk tot problemen heeft geleid. Ik zal in deze dissertatie ook niet verder op deze bepaling ingaan, omdat zij inmiddels alweer is ingeruild voor een nieuwe bepaling uit de BnIW 2019. ${ }^{223}$

\section{De Handleiding nadeelcompensatie bij infrastructurele maatregelen}

In paragraaf 5.7.2.1 bleek dat tijdens de behandeling van het voorstel voor de Wns in de Eerste Kamer de Handleiding nadeelcompensatie werd toegezegd door de toenmalig minister van Veiligheid \& Justitie. De directe aanleiding voor die toezegging was gelegen in een brief van VNO-NCW en MKB-Nederland waarin kritiek werd geuit op de berekening van de toe te kennen nadeelcompensatie in algemene zin, en de destijds gebruikelijke, gefixeerde 15\%-omzetdrempel in het bijzonder. ${ }^{224}$ De door de minister ingestelde werkgroep introduceert in de handleiding een methode voor de afbakening van het normaal maatschappelijk risico die als uitgangspunten heeft dat zij overeenstemt met de Afdelingsjurisprudentie, praktisch hanteerbaar is, transparant is, geschikt is voor een 'quick scan'-beoordeling vooraf, en lage transactiekosten kent. ${ }^{225}$ Deze methode ziet slechts op tijde-

220 De stappen worden toegelicht in Stcrt. 2014, nr. 16584.

221 Uiteraard moest op grond van de vierde stap wel nog een korting op het schadebedrag worden toegepast.

222 Zie Franssen e.a. 2014, p. 227-228; Van Doorn-Hoekveld in het negende onderdeel van haar annotatie bij ABRvS 29 januari 2014, ECLI:NL:RVS:2014:226 in $A B$ 2014/394; en Planken \& Tjepkema 2015 (zie deze publicatie ook in meer algemene zin voor een beschrijving en analyse van art. 3a BnIM 2014).

223 De regeling is hier wel kort aangestipt omdat zij (1) inzicht verschaft in de wijze waarop verschillen tussen de geselecteerde, thans geldende regelingen zijn ontstaan; en (2) zij van toepassing zal blijven op aanvragen ingediend voor 1 januari 2019 (vergelijk Stcrt. 2019, nr. 66154, art. II jo. art. III).

224 De brief is te raadplegen via www.assurance.nl/Uploaded_files/Zelf/brief $\% 20$ VNO-NCW-MKB-Nederland-17-1-2013.pdf. Zie ook Handleiding nadeelcompensatie, p. 11-12; Handelingen I 2012/13, 32 621, nr. 15, item 2, p. 5; Handelingen I 2012/13, 32 621, nr. 15, item 6, p. 53-54 en 56-57; en Tjepkema \& Mijnheer 2019, p. 3-4.

225 Handleiding nadeelcompensatie, p. 52. 
lijke inkomensschade door infrastructurele maatregelen. Kort samengevat, houdt zij het volgende in:

\section{Bepaal de aard van de maatregel}

In wezen komt deze stap neer op beantwoording van de vraag of de schade wordt veroorzaakt door een normale maatschappelijke ontwikkeling. Alleen dan worden de volgende stappen gezet. Bij schade door een niet-normale ontwikkeling stelt de werkgroep een relatief lage korting op het schadebedrag voor. Die korting zou in het eerste schadejaar bijvoorbeeld tussen de 0 en $15 \%$ kunnen liggen, en dient te worden gemotiveerd aan de hand van alle van belang zijnde omstandigheden van het concrete schadegeval. Als de schade meerdere schadejaren bestrijkt, zou moeten worden bezien of dit aspect van 'duur' vanaf het eerste schadejaar noopt tot verlaging van deze korting, of het geenszins hanteren van een korting. Wel zou altijd de bagateldrempel van de tweede stap moeten worden gehanteerd.

\section{Hanteer een bagateldrempel en ga na of de schade deze overstijgt}

De werkgroep stelt een relatieve bagateldrempel voor van $2 \%$ van het jaarinkomen van de aanvrager. Tevens wordt een absolute bagateldrempel voorgesteld van $€ 500$ voor particulieren en $€ 1.000$ voor ondernemers. ${ }^{226}$

\section{Combineer een ingangsdrempel (fase 1) met een algemeen en variabel for- fait (fase 2)}

Fase 1

Met de ingangsdrempel wordt beoogd een quick-scan mogelijk te maken: doorgaans kan zonder raadpleging van deskundigen worden nagegaan of de omzetderving uitkomt boven de ingangsdrempel. Deze ingangsdrempel betreft in beginsel een minimumpercentage van de normjaaromzet (de gemiddelde jaaromzet over de drie aan het schadejaar voorafgaande jaren) en is afhankelijk gesteld van de brutowinstmarge (omzet minus inkoopwaarde) van de onderneming. Daarbij worden drie categorieën onderscheiden: een brutowinstmarge van $0-35 \%, 36-64 \%$ en $65-100 \%$ correspondeert met een ingangsdrempel van respectievelijk $13 \%, 11 \%$ en $8 \%$ van de normjaaromzet. Een onderneming met een brutowinstmarge van bijvoorbeeld $30 \%$ komt dus niet voor nadeelcompensatie in aanmerking als zij een omzetderving ondervindt van minder dan $13 \%$. Met name in de transportsector kan het zich voordoen dat een onderneming in de schadeperiode dezelfde omzet blijft draaien, maar daarvoor hogere kosten moet maken. In dat geval heeft de ingangsdrempel geen betrekking op de normjaaromzet, maar op de normjaarkosten. ${ }^{227}$ Een brutowinstmarge van

226 Handleiding nadeelcompensatie, p. 72-73 wekt de indruk dat deze bagateldrempels ook van toepassing dienen te zijn op permanente inkomensschade.

227 Deze term komt niet voor in de handleiding en ook overigens is de handleiding op dit punt niet geheel duidelijk. Ik neem daarom aan dat het - net als bij de normjaaromzet - gaat om de gemiddelde kosten over de drie aan het schadejaar voorafgaande jaren. 
0-35\%, 36-64\% en 65-100\% correspondeert dan met respectievelijk 4\%, 6\% en $8 \%$ van de normjaarkosten. De werkgroep kiest hier voor lagere percentages dan bij de ingangsdrempel die betrekking heeft op de normjaaromzet, omdat hantering van dezelfde percentages veel zwaarder zou uitvallen voor de aanvrager.

Fase 2

Als de ingangsdrempel is gepasseerd, wordt de aanvrager een 'forfait' tegengeworpen. Daarmee wordt bewerkstelligd dat een gedeelte van de schade wegens normaal ondernemersrisico voor rekening van de aanvrager wordt gelaten. De hoogte van het forfait wordt bepaald conform de formule:

$$
" \text { Forfait }=(\text { normjaaromzet } \mathrm{x} \text { normbrutowinstpercentage }) \times(n \%) "
$$

Het forfait wordt dus berekend door het gemiddelde van de omzet over de drie aan het schadejaar voorafgaande jaren te vermenigvuldigen met het gemiddelde brutowinstpercentage over de drie aan het schadejaar voorafgaande jaren, en de uitkomst daarvan te vermenigvuldigen met de waarde $n$. Deze waarde is de uitkomst van een politieke keuze die het bevoegd gezag binnen zekere grenzen kan maken door invulling te geven aan zijn beoordelingsruimte. Ook deze grenzen corresponderen weer met de brutowinstmarge van de onderneming: een brutowinstmarge van $0-35 \%, 36-64 \%$ en $65-100 \%$ correspondeert met een $n$ van respectievelijk $14-15 \%, 11-13 \%$ en $8-10 \%$.

\section{Toepassing van een bijzonder forfait}

Het algemene forfait als bepaald tijdens de tweede fase van de derde stap geldt alleen gedurende het eerste schadejaar. Daarna acht de werkgroep het wenselijk om de duur van de werkzaamheden afzonderlijk mee te wegen. Daartoe worden geen concrete maatstaven aangereikt. Wel wordt het voorbeeld gegeven dat het tweede schadejaar slechts $50 \%$ van het algemene forfait wordt tegengeworpen. In daarop volgende jaren zou het normaal maatschappelijk risico een nog kleiner deel van het algemene forfait kunnen bedragen, of zelfs helemaal geen aftrek wegens normaal ondernemersrisico kunnen worden toegepast.

\section{Hantering van een hardheidsclausule}

Ten slotte beveelt de werkgroep aan dat een hardheidsclausule wordt opgenomen in regelingen waarmee de handleiding wordt geïmplementeerd. Op voorhand kan namelijk niet worden uitgesloten dat onverkorte toepassing van de voorgestelde benadering in een bijzonder geval toch onredelijk zou uitpakken. Om ongewenste precedentwerking te voorkomen, zou toepassing van de hardheidsclausule wel altijd goed moeten worden gemotiveerd. ${ }^{228}$

228 Deze beschrijving is gebaseerd op hoofdstuk 4 van de Handleiding nadeelcompensatie. 


\section{De BnIW 2019}

De minister van Infrastructuur en Waterstaat zag aanleiding in de Handleiding nadeelcompensatie om de BnIM 2014 te wijzigen. De beleidsregel gaat sinds 1 januari 2019 als de BnIW 2019 door het leven. De belangrijkste inhoudelijke wijziging realiseert de implementatie van de in de handleiding aanbevolen methode om het normaal ondernemersrisico af te bakenen bij tijdelijke inkomensschade door infrastructurele maatregelen. Dit deel van de handleiding is namelijk nagenoeg ongewijzigd omgezet in concreet toepasbare bepalingen. Implementatie van een hardheidsclausule was echter niet nodig, omdat ten aanzien van beleidsregels reeds de inherente afwijkingsbevoegdheid van art. 8:84 Awb geldt. Bovendien gaat de BnIW 2019 ervan uit dat het algemene forfait van de derde stap ook gedurende het tweede schadejaar aan de aanvrager wordt tegengeworpen. Voor bespreking van enkele andere, kleine afwijkingen verwijs ik naar de toelichting op de BnIW 2019 en een publicatie van Tjepkema \& Mijnheer uit 2019. ${ }^{229}$

\section{Permanente inkomensderving}

De jurisprudentie omtrent de afbakening van het normaal ondernemersrisico heeft zich tot op heden met name toegespitst op tijdelijke inkomensderving (door infrastructurele maatregelen). Daardoor is nog relatief weinig bekend over de afbakening van het normaal ondernemersrisico bij permanente inkomensschade. In het planschaderecht geldt uiteraard de 2\%-minimumdrempel uit art. 6.2 lid 2, aanhef en onder a Wro. Ook de drempel- en kortingssystematiek van de AVN is niet op voorhand uitgesloten van toepassing op permante inkomensderving. Behalve de verschillen die hierdoor tussen de Wro en AVN bestaan, ben ik bij bestudering van de wel beschikbare jurisprudentie geen verschillen tegengekomen die zijn te herleiden tot de van toepassing zijnde nadeelcompensatieregeling.

Vanwege de geringe omvang van deze jurisprudentie en de omstandigheid dat niet altijd wordt gewerkt met een omzet- of kostendrempel, is het niet eenvoudig om algemene lijnen uit deze jurisprudentie te destilleren. ${ }^{230}$ Hooguit lijkt te kunnen worden gesteld dat de algemene jurisprudentielijnen van toepassing zijn: de omvang van het normaal ondernemersrisico dient te worden bepaald met inachtneming van alle van belang zijnde omstandigheden van het concrete schadegeval. Naarmate het bestuur een hogere aftrek wegens normaal ondernemersrisico toe-

229 Zie Stcrt. 2019, nr. 66154, p. 9-14 en 16-17; en Tjepkema \& Mijnheer 2019, p. 11.

230 Zie voor een vergelijkbare opmerking bij permanente waardevermindering van onroerende zaken: Van den Broek \& Tjepkema 2015, p. 95-97. 
past, worden zwaardere eisen ${ }^{231}$ aan de motivering daarvan gesteld. ${ }^{232}$ Vanwege de aansluiting die de Afdeling in het nadeelcompensatierecht zoekt bij art. 6.2 lid 2, aanhef en onder a Wro is het ten slotte aannemelijk dat het normaal ondernemersrisico bij permanente inkomensschade in het nadeelcompensatierecht ook altijd minimaal $2 \%$ van het inkomen onmiddellijk voor het ontstaan van de schade zal bedragen. ${ }^{233}$

\section{Conclusie}

In deze deelparagraaf is het samenspel tussen beleid, regelgeving en jurisprudentie inzake het normaal ondernemersrisico op chronologische wijze beschreven. Dit samenspel verklaart in belangrijke mate hoe de geconstateerde verschillen tussen de geselecteerde, thans geldende regelingen zijn ontstaan. In de jaren ' 80 en '90 bestond vrijwel geen houvast met betrekking tot de afbakening van het normaal ondernemersrisico. Daarin kwam verandering toen rond de millenniumwisseling bleek dat de Afdeling een gefixeerde 15\%-omzetdrempel terughoudend toetste. Deze drempel werd daardoor een aantrekkelijk middel voor het bestuur om het normaal ondernemersrisico af te bakenen. Er kwam echter steeds meer maatschappelijke en wetenschappelijke kritiek op de gefixeerde 15\%-omzetdrempel. Tevens wijzigde de houding van de Afdeling ten opzichte van deze drempel: de nadruk werd juist gelegd op differentiatie naar gelang de van belang zijnde omstandigheden van het individuele schadegeval. Deze ontwikkeling zorgde voor veel onduidelijkheid in het nadeelcompensatierecht. Het lijkt niet onaannemelijk dat deze onduidelijkheid in ieder geval deels kan worden weggenomen door implementatie van de Handleiding nadeelcompensatie, die de directe aanleiding vormde voor de overgang van de BnIM 2014 naar de BnIW 2019. De beschreven tendens van differentiatie lijkt minder invloed te hebben gehad op de afbakening van het normaal ondernemersrisico in het planschaderecht. Dat kan met name worden verklaard doordat inkomensschade slechts zelden als gevolg van de in art. 6.1 lid 2 Wro opgesomde schadeoorzaken aan het bestuur kan worden toegerekend. Wellicht heeft ook een rol gespeeld dat art. 6.2 lid 2, aanhef en onder a Wro - anders dan veel overige regelingen - niet aangrijpt op de omzet, maar het inkomen van de aanvrager.

231 Tjepkema uit - mijns inziens terecht - kritiek op deze jurisprudentielijn in onderdeel acht van zijn annotatie bij ABRvS 9 september 2015, ECLI:NL:RVS:2015:2828 (Best) in $A B$ 2016/440.

232 Zie bijvoorbeeld ABRvS 30 mei 2012, ECLI:NL:RVS:2012:BW6926, r.o. 2.35 e.v. (Tankstation gemeente Hardenberg, tussenuitspraak), waarin de Afdeling zelf in de zaak voorzag door de door het bestuur toegepaste korting op het schadebedrag te verlagen van $40 \%$ naar $30 \%$.

233 ABRvS 11 februari 2015, ECLI:NL:RVS:2015:336, r.o. 4.3 (Fietstunnel Rijksweg 7 bij Sneek). 


\subsubsection{Deelvraag 3: het toekomstige recht}

In paragraaf 6.2.2 bleek waarom titel 4.5 Awb geen bijzondere normering omtrent de afbakening van het normaal maatschappelijk risico bevat. Anders dan bij permanente waardevermindering van onroerende zaken, bevat ook afd. 15.1 Ow geen bijzondere normering inzake het normaal maatschappelijk risico bij inkomensschade. Vanwege de uiteenlopende oorzaken en diverse vormen van inkomensschade zou het namelijk niet mogelijk zijn om bij voorbaat in algemene zin aan te geven welke inkomensschade behoort tot het normaal maatschappelijk risico. Ook acht het kabinet van belang dat de hoogte van de drempel of korting wegens normaal maatschappelijk risico bij tijdelijke inkomensschade door infrastructurele maatregelen nog in beweging is. Voorts geeft het kabinet aan te verwachten dat overheden de Handleiding nadeelcompensatie gaan toepassen op dit type inkomensschade. Daarom acht het kabinet het niet "opportuun" een forfait voor dit soort inkomensschade in afd. $15.1 \mathrm{Ow}$ op te nemen. ${ }^{234}$

\subsubsection{Hoofdvraag: spiegeling aan de doelstellingen en uitgangspunten die ten grondslag liggen aan de Wns}

Dat titel 4.5 Awb en afd. 15.1 Ow geen bijzondere normering bevatten omtrent de afbakening van het normaal ondernemersrisico, lijkt zich op het eerste oog slecht te verhouden tot de doelstellingen van vereenvoudiging, uniformering en harmonisering van het nadeelcompensatierecht, vergroting van de rechtszekerheid, en codificatie van het nadeelcompensatierecht. Dat geldt te meer, nu er sinds de Wouwse Tol-uitspraak onduidelijkheid bestaat over de mate waarin bij de afbakening van het normaal ondernemersrisico dient te worden gedifferentieerd tussen verschillende soorten bedrijven. Het is echter maar de vraag of het thans mogelijk is algemene normering omtrent het normaal ondernemersrisico in titel $4.5 \mathrm{Awb}$ en/ of afd. $15.1 \mathrm{Ow}$ op te nemen. Hieronder zal ik toelichten waarom dat mijns inziens slechts in beperkte mate het geval is.

\section{Bagateldrempels}

De 2\%-drempel uit art. 6.2 lid 2, aanhef en onder a Wro, en de analoge toepassing daarvan in het nadeelcompensatierecht, lijken in de praktijk niet tot significante problemen te hebben geleid. Hetzelfde geldt voor de absolute bagateldrempels die zijn opgenomen in de BnIW 2019, BnIM 2014 en AVN. ${ }^{235}$ Bovendien sluiten deze drempels goed aan op de jurisprudentielijn dat relatief geringe schade per definitie tot het normaal maatschappelijk risico behoort. ${ }^{236}$ Daarom verdient het aanbeve-

234 Kamerstukken II 2018/19, 34 986, nr. 3, p. 27 (MvT, IOw).

235 Zie daaromtrent paragraaf 6.1 onder het kopje 'De afbakening van het normaal maatschappelijk risico'.

236 ABRvS 17 september 2014, ECLI:NL:RVS:2014:3378, r.o. 12. Daarin wordt verwezen naar ABRvS 21 juni 2006, ECLI:NL:RVS:2006:AX9047, r.o. 2.6.2. Zie ook ABRvS 22 mei 2013, ECLI:NL:RVS:2013:CA0631, r.o. 6.2. 
ling dat een relatieve bagateldrempel van $2 \%$ van het jaarinkomen onmiddellijk voor het ontstaan van de schade, en absolute bagateldrempels van $€ 1.000$ voor ondernemers en $€ 500$ voor particulieren worden opgenomen in titel 4.5 Awb. Dat sluit immers goed aan op alle aan de Wns ten grondslag liggende doelstellingen. Voorts lijkt deze aanbeveling ook verenigbaar met de aan de Wns ten grondslag liggende uitgangspunten. Tevens komt de hoogte van de voorgestelde drempels overeen met de percentages die worden voorgesteld in de Handleiding nadeelcompensatie, terwijl in paragraaf 6.3.2 bleek dat het kabinet verwacht dat bestuursorganen die handleiding gaan toepassen.

\section{Geen codificatie van verdere normering in titel $4.5 \mathrm{Awb}$ of afd. $15.1 \mathrm{Ow}$}

In paragraaf 6.3.1 bleek dat de jurisprudentie omtrent afbakening van het normaal ondernemersrisico hoofdzakelijk is toegespitst op tijdelijke inkomensschade door infrastructurele maatregelen. Dat pleit niet voor codificatie van deze jurisprudentie in een formeelwettelijke regeling die het grootste deel van het nadeelcompensatierecht in algemene zin normeert (titel 4.5 Awb), of een formeelwettelijke regeling die aanvullende normering bevat voor het grootste deel van het omgevingsrecht (afd. 15.1 Ow). Dat geldt te meer nu tevens bleek dat deze jurisprudentie nog niet is uitgekristalliseerd, hetgeen ook een rol lijkt te hebben gespeeld in de afweging van het kabinet om in het wetsvoorstel voor de IOw geen aandacht te besteden aan de afbakening van het normaal ondernemersrisico.

Ook acht ik de tijd nog niet rijp om de in de Handleiding nadeelcompensatie voorgestelde systematiek van afbakening van het normaal ondernemersrisico te codificeren in titel 4.5 Awb of afd. 15.1 Ow. ${ }^{237}$ Er is namelijk nog nauwelijks ervaring opgedaan met de toepassing van deze systematiek, waardoor nog geen inzicht bestaat in de praktische knelpunten die zich daarbij zullen gaan voordoen. Hoewel haar bedenkers aansluiting beoogden te zoeken bij de destijds gepubliceerde jurisprudentie, is bovendien nog onduidelijk in hoeverre deze systematiek en haar toepassing de toets van de Afdeling zullen doorstaan. Ten slotte kent de in de handleiding voorgestelde afbakeningssystematiek een beperkt toepassingsbereik. Zij ziet immers slechts op tijdelijke inkomensschade door infrastructurele maatregelen. Om dezelfde redenen als werden aangevoerd ten aanzien van de jurisprudentie waarop zij is gebaseerd, maakt haar dat eveneens ongeschikt voor codificatie in titel 4.5 Awb of afd. $15.1 \mathrm{Ow}$.

\section{Codificatie van de handleiding bij wijze van titel 4.5 Awb-interpreterende amvb}

Het voorafgaande laat onverlet dat de in de handleiding voorgestelde afbakeningssystematiek in algemene zin goed aansluit op de aan de Wns ten grondslag liggende doelstellingen. Zo sluit zij goed aan op de hedendaagse jurisprudentielijnen en 
dus ook op de doelstelling van codificatie van het nadeelcompensatierecht. Voorts stelt zij zowel de getroffen ondernemer als het bestuur in staat om een quick-scan uit te voeren zonder tussenkomst van deskundigen. Ook overigens is de methode goed te begrijpen en zal zij naar verwachting veel discussie tussen bestuur, burger en draagplichtige derden voorkomen. Op voorhand is immers duidelijk welke factoren in welke mate van invloed kunnen zijn op de beantwoording van de vraag welk deel van de schade als normaal ondernemersrisico voor rekening van de aanvrager zal worden gelaten. Dit sluit goed aan op de doelstellingen van vergroting van de doelmatigheid van het nadeelcompensatierecht en vermindering van bestuurslasten, en vergroting van de rechtszekerheid. De methode uit de handleiding sluit ook goed aan op de doelstelling van vergroting van de rechtsgelijkheid. Zij zorgt immers ervoor dat bedrijven met een gelijke kostenstructuur op gelijke wijze worden behandeld. Ten slotte lijkt zij ook verenigbaar met de aan de Wns ten grondslag liggende uitgangspunten. Daartoe is met name relevant dat het goed past bij het uitgangspunt van aansluiting bij het besluitmodel dat zij het eerste oordeel omtrent het normaal ondernemersrisico laat aan het bestuur.

Vanwege het voorafgaande zie ik toch reden tot (a) wijziging van titel 4.5 Awb. De wetgever zou er namelijk goed aan doen in deze titel te bepalen dat bij algemene maatregel van bestuur nadere regels over de afbakening van het normaal maatschappelijk risico kunnen worden gesteld. Hiermee wordt de mogelijkheid gecreëerd de afbakeningssystematiek van de handleiding te codificeren in een dergelijke amvb - hetgeen zou kwalificeren als (c) een bijzondere invulling van titel 4.5 Awb. Deze constructie past wellicht iets minder goed bij de doelstelling van vereenvoudiging van het nadeelcompensatierecht dan codificatie in titel $4.5 \mathrm{Awb}$ had gedaan, maar past desondanks goed bij de doelstelling van uniformering en harmonisering van het nadeelcompensatierecht. Zij garandeert immers dat het normaal ondernemersrisico bij tijdelijke inkomensschade door infrastructurele werkzaamheden landelijk op één uniforme wijze wordt afgebakend.

In paragraaf $6.5 \mathrm{zal}$ ik een concreet voorstel doen voor bepalingen waarmee deze aanbevelingen kunnen worden geïmplementeerd. Voor wat betreft de codificatie van de afbakeningssystematiek uit de handleiding zal ik art. 3a t/m 3d BnIW 2019 als uitgangspunt nemen, omdat deze artikelen de handleiding "vrijwel één-opéén" volgen. ${ }^{238}$ Verder wordt het voorstel voor deze codificatie vormgegeven als directe invulling van titel 4.5 Awb. Hoewel schade door infrastructurele maatregelen in beginsel doet denken aan afd. 15.1 Ow, zijn namelijk ook gevallen denkbaar waarin aanvragen om compensatie van dergelijke schade niet onder deze afdeling zullen worden afgedaan. Daarbij kan bijvoorbeeld worden gedacht aan inkomensschade door op grond van de WVW 1994 genomen verkeersbesluiten tot tijdelijke wijziging van de plaatselijke verkeerssituatie ten behoeve van infrastructurele werkzaamheden. ${ }^{239}$ Ten slotte stel ik voor de aanbevolen amvb-bepalingen niet de 
status van regelend, aanvullend of facultatief recht te geven. Dit zou namelijk het risico in het leven roepen dat de afbakening van het normaal ondernemersrisico zich in verschillende richtingen zou ontwikkelen en/of uiteenlopend zou worden gecodificeerd in allerlei verschillende titel 4.5 Awb-interpreterende regelingen. Dat zou niet goed passen bij de doelstellingen van vereenvoudiging, uniformering en harmonisering van het nadeelcompensatierecht. Anders dan Tjepkema en Mijnheer verwacht ik niet dat dit (te zeer) ten koste zal gaan van de smeermiddelfunctie van het nadeelcompensatierecht. ${ }^{240}$

\section{Evaluatie en uitbreiding}

Ten slotte doe ik nog enkele aanbevelingen die eveneens kunnen worden aangemerkt als (c) het anderszins voorzien in een bijzondere invulling van titel 4.5 Awb. $\mathrm{Zij}$ zijn alle ingegeven door de doelstelling van vereenvoudiging, uniformering en harmonisering van het nadeelcompensatierecht en verenigbaar met de overige aan de Wns ten grondslag liggende doelstellingen en uitgangspunten. Allereerst verdient het mijns inziens aanbeveling dat in de toelichting op de voorgestelde amvb wordt vermeld dat rechters en bestuursorganen bij permanente inkomensschade, en tijdelijke inkomensschade die niet wordt veroorzaakt door infrastructurele werkzaamheden, zoveel mogelijk moeten aansluiten bij de in de amvb voorgeschreven bepalingen - en deze actoren dat ook daadwerkelijk doen. Verder zou het kabinet er mijns inziens goed aan doen een werkgroep in te stellen die evalueert hoe (toepassing van) de voorgestelde amvb wordt ervaren door de praktijk en wordt beoordeeld in de jurisprudentie. Ook zou de werkgroep moeten nagaan of het mogelijk is om het toepassingsbereik van de in de amvb - en dus ook in de handleiding - voorgeschreven afbakeningssystematiek verder uit te breiden. Leent zij zich, na eventuele kleine aanpassingen, bijvoorbeeld ook voor overeenkomstige toepassing op permanente inkomensschade door infrastructurele maatregelen en/of inkomensschade door niet-infrastructurele maatregelen? De bevindingen van de werkgroep zouden aanleiding kunnen geven tot bijstelling van de in de amvb voorgeschreven systematiek respectievelijk tot uitbreiding van het toepassingsbereik daarvan. Op langere termijn zouden de bevindingen van de werkgroep eventueel ook ertoe kunnen leiden dat de bepalingen uit de amvb alsnog een plaats krijgen in titel 4.5 Awb en/of afd. 15.1 Ow.

\section{Conclusie}

Uit het voorafgaande kan worden afgeleid dat de aan de Wns ten grondslag liggende doelstellingen en uitgangspunten mijns inziens aanleiding geven tot (a) wijziging van titel $4.5 \mathrm{Awb}$, en (c) het anderszins voorzien in een bijzondere invulling van titel 4.5 Awb. In paragraaf 6.5 zullen daartoe concrete voorstellen worden gedaan. De aan de Wns ten grondslag liggende doelstellingen en uitgangspunten geven mijns inziens geen aanleiding voor (b) aanpassing van afd. 15.1 Ow. 


\subsection{TIJDELIJKE DERVING VAN WOONGENOT}

6.4.1 Deelvraag 2: verschillen tussen de geselecteerde, thans geldende regelingen en verklaringen daarvoor

\subsubsection{Geen inhoudelijke normering door de regelingen}

Geen van de geselecteerde, thans geldende regelingen bevat bijzondere normering inzake het normaal maatschappelijk risico bij tijdelijke derving van woongenot. Ten aanzien van afd. 6.1 Wro kan dit worden verklaard doordat zij niet voorziet in de vergoeding van deze schade. ${ }^{241}$ In paragraaf 6.1 bleek voorts waarom de GrS, art. 49 WRO, art. 8.31 Wlv, art. 21 Aanwijzingsbesluit 1996 en de VNNZ überhaupt geen bijzondere normering bevatten omtrent de afbakening van het normaal maatschappelijk risico.

Er zijn geen duidelijke verklaringen voor het gegeven dat de BnIW 2019 en AVN geen normering bevatten inzake het normaal maatschappelijk risico bij tijdelijke derving van woongenot. Mogelijk speelt een rol dat relatief weinig jurisprudentie is gewezen over de afbakening van het normaal maatschappelijk risico bij dit type schade. Dat lijkt deels te kunnen worden verklaard doordat dergelijke schade veelal zal worden veroorzaakt door feitelijke uitvoeringswerkzaamheden, waardoor in ieder geval geen sprake is van processuele connexiteit. ${ }^{242}$ In de wetenschap dat veel burgers de toegangsdrempel naar de burgerlijke rechter te hoog vinden, zullen bestuursorganen soms proberen hun aansprakelijkheid te ontlopen door geen nadeelcompensatieregeling vast te stellen (onder de reikwijdte waarvan deze uitvoeringswerkzaamheden vallen). ${ }^{243}$ Toch is ook in de gevallen waarin een dergelijke nadeelcompensatieregeling wel voor handen is, of het schadeveroorzakende feitelijke handelen als gevolg van een appellabel besluit aan het bestuur kan worden toegerekend, ${ }^{244}$ relatief weinig jurisprudentie gewezen met betrekking tot de afbakening van het normaal maatschappelijk risico bij tijdelijke derving van woongenot. Schijnbaar weten bestuursorganen hun uitvoeringswerkzaamheden dus veelal in dusdanige banen te leiden dat relatief weinig aanvragen om nadeelcompensatie worden ingediend en/of weten zij dergelijke aanvragen dusdanig af te handelen dat aanvragers relatief weinig een beroep op de rechter doen. Het is mij bekend dat dit bij de ondertunneling van de A2 te Maastricht onder andere geschiedde door zowel praktische als juridische informatievoorziening, meldpunten ten behoeve van (excessieve) overlast, en generieke compensatie door middel van (een

241 Zie paragraaf 5.2.1 onder het kopje 'Het beperkte schadebegrip van afd. 6.1 Wro'.

242 Zie paragraaf 2.2 onder het kopje 'De Beurskens- \& Van Vlodrop-uitspraken (1997)' voor een bespreking van de connexiteitseisen.

243 In paragraaf 3.4.1 bleek dat het ontbreken van nadeelcompensatieregelingen regelmatig leidt tot niet-ontvankelijkverklaring van de aanvrager door de bestuursrechter.

244 Van dat laatste was bijvoorbeeld sprake in ABRvS 20 juni 2018, ECLI:NL:RVS:2018:2040, r.o. 30-31. 
relatief laag bedrag aan) voedselbonnen. Ook bij de aanleg van de Noord/Zuidlijn werd voorzien in een generieke compensatie van schade in de vorm van tijdelijk gederfd woongenot, namelijk door de Verordening tegemoetkoming bouwactiviteiten Noord/Zuidlijn. ${ }^{245}$ In het vervolg van deze deelparagraaf zal ik aan de hand van de wel beschikbare jurisprudentie nagaan hoe het normaal maatschappelijk risico bij dit type schade wordt afgebakend, en of daarin verschillen bestaan tussen de geselecteerde, thans geldende regelingen.

\title{
6.4.1.2 De algemene jurisprudentielijnen
}

Uit een Afdelingsuitspraak van 5 juli 2017 blijkt dat de algemene hoofdregels voor afbakening van het normaal maatschappelijk risico ook opgaan bij schade in de vorm van tijdelijke derving van woongenot:

\begin{abstract}
"Hoe groot het normale maatschappelijke risico is, dient te worden bepaald met inachtneming van de omstandigheden van het geval. Daarbij is onder meer van belang of de overheidshandeling als een normale maatschappelijke ontwikkeling kan worden beschouwd waarmee de benadeelde rekening had kunnen houden in de zin dat de ontwikkeling in de lijn der verwachtingen lag, ook al bestond geen concreet zicht op de omvang waarin, de plaats waar en het moment waarop de ontwikkeling zich zou voordoen. Verder zijn onder meer de aard en de duur van de overheidshandeling en de aard en de omvang van de toegebrachte schade van belang."
\end{abstract}

In casu diende een omwonende van een jaarlijks terugkerend, ééndaags evenement een aanvraag in om nadeelcompensatie wegens derving van woongenot. De burgemeester wees deze aanvraag af, omdat de door aanvrager geleden schade tot het normaal maatschappelijk risico zou behoren. In hoger beroep kwam de burgemeester onder andere op tegen het oordeel van de rechtbank dat wel sprake was van onevenredige schade. De Afdeling oordeelde dat de schade van de aanvrager tot het normaal maatschappelijk risico behoorde. Daarbij was van belang dat geen grond bestond voor het oordeel dat de verlening van de voor het evenement benodigde vergunningen niet in de lijn der verwachtingen lag, mede omdat het evenement sinds 2005 jaarlijks op de desbetreffende locatie werd georganiseerd. De aard en ernst van de schade (een tijdelijke aantasting van woongenot gedurende één dag per jaar) en de door de aanvrager gestelde schadeomvang van $€ 400$ gaven eveneens geen aanleiding om te oordelen dat de schade het normaal maatschappelijk risico ontsteeg. In navolging van de burgemeester achtte de Afdeling ten slotte van belang dat aan de verleende vergunningen overlast beperkende voorschriften en maatregelen waren verbonden, die zo nodig werden herzien of aangevuld aan de hand van de resultaten van jaarlijkse evaluatiebijeenkomsten, terwijl op de naleving daarvan werd gecontroleerd. 
Ik ben het eens met Tjepkema dat dit laatste argument opmerkelijk is, omdat overlast beperkende maatregelen een belangrijke rol spelen bij de beoordeling van de rechtmatigheid van de schadeoorzaak, ${ }^{246}$ maar niet relevant lijken voor de beantwoording van de vraag of de schade die ondanks deze maatregelen is ontstaan het normaal maatschappelijk risico wel of niet ontstijgt. ${ }^{247}$ Toch lijkt dit argument regelmatig een rol te spelen in de rechtspraak omtrent de afbakening van het normaal maatschappelijk risico. ${ }^{248}$

\subsubsection{Derving van woongenot door uitvoeringswerkzaamheden}

Voor tijdelijke derving van woongenot door uitvoeringswerkzaamheden heeft het Amsterdamse gemeentebestuur tijdens de aanleg van de Noord/Zuidlijn het criterium geïntroduceerd dat...

“(...) een overlastperiode van twaalf maanden redelijkerwijs ten laste van omwonenden dient te blijven en dat alleen de gevolgen van de overlast, voor zover die langer dan één jaar duren, aan omwonenden dient te worden vergoed." 249

De Afdeling lijkt dit in beginsel geen onredelijk criterium te vinden. ${ }^{250}$ Toch zal dit criterium niet altijd onverkort (kunnen) gelden. ${ }^{251}$ Het betreft namelijk vaste jurisprudentie dat niet alleen de duur, maar ook de aard en ernst van de schade van invloed zijn op de omvang van het normaal maatschappelijk risico. ${ }^{252}$ Deze factoren worden niet altijd uniform toegepast in die zin dat hetzelfde type omstandigheid altijd onder dezelfde factor wordt meegewogen. Het gaat de Afdeling uiteindelijk om het totaalplaatje dat het bestuur aan de hand van deze factoren schetst. Ondanks dat er relatief weinig jurisprudentie is om uit te putten, zal ik hierna enkele algemene lijnen beschrijven. Bestudering van deze jurisprudentie biedt niet alleen het inzicht dat nodig is voor beantwoording van de vraag of tussen

246 Zie bijvoorbeeld ABRvS 11 mei 2016, ECLI:NL:RVS:2016:1250, r.o. 5.1.

247 Zie ABRvS 5 juli 2017, ECLI:NL:RVS:2017:1787, r.o. 6-6.1 en onderdeel zes van de bijbehorende noot van Tjepkema in $A B$ 2017/322.

248 Zie bijvoorbeeld Rb. Arnhem 19 juni 2003, ECLI:NL:RBARN:2003:AH9171, evenals AG9390, AH2446 en AH9172. Zie ook ABRvS 23 december 2015, ECLI:NL:RVS:2015:3986, r.o. 5.4 (Kermis Leiderdorp). Deze zaak zal ik verder buiten beschouwing laten omdat de schade daarin werd gepresenteerd als waardedaling van een onroerende zaak. Het heeft er echter veel van weg dat het eigenlijk om (een op een jaarlijks moment terugkerende vorm van) tijdelijke derving van woongenot ging.

249 ABRvS 6 juni 2007, ECLI:NL:RVS:2007:BA6794, r.o. 2.9. Het citaat is afkomstig uit ABRvS 3 december 2014, ECLI:NL:RVS:2014:4410, r.o. 6.

250 Zie bijvoorbeeld ook Rb. Oost-Brabant 24 mei 2017, ECLI:NL:RBOBR:2017:2820, r.o. 16.1 en 16.4.

251 Van den Broek kwam reeds in 2008 tot deze conclusie in haar annotatie bij ABRvS 6 juni 2007, ECLI:NL:RVS:2007:BA6794 in $A B$ 2008/44.

252 Zie onder andere ABRvS 23 maart 2005, ECLI:NL:RVS:2005:AT1990, r.o. 2.10; en ABRvS 6 juni 2007, ECLI:NL:RVS:2007:BA6794, r.o. 2.6. 
de geselecteerde, thans geldende regelingen verschillen bestaan in afbakening van het normaal maatschappelijk risico (zie paragraaf 6.4.1.4), maar is ook relevant voor de beantwoording van de hoofdvraag in paragraaf 6.4.3.

\section{Aard van de schade}

In een geschil dat werd beslist door een Afdelingsuitspraak van 17 september 2014 bestond de schade uit permanente waardedaling van onroerende zaken. De Afdeling overwoog:

"De aard van de schade, uitzichtschade die zich manifesteert in waardevermindering van de woningen, staat op zichzelf niet in de weg aan het toepassen van een drempel of korting vanwege het normale maatschappelijke risico."

Daarbij lijkt van belang te zijn geweest dat de ligging van de desbetreffende woningen vanwege de ruimtelijke structuur van de omgeving een verhoogde kans op uitzichtschade als gevolg van uitbreiding van de bestaande woonkern meebracht. ${ }^{253}$ Deze uitspraak vertoont gelijkenis met jurisprudentie omtrent het normaal maatschappelijk risico bij tijdelijke derving van woongenot. In een uitspraak van 6 juni 2007 bestond de schade "uit een tijdelijke vermindering van het woongenot, door overlast, zij het beperkt, van stof en geluidhinder en enige aantasting van het uitzicht vanuit [een] woning." Vanwege de "aard van de schade, de geringe ernst en de beperkte duur daarvan" oordeelde de Afdeling dat het bestuur terecht een deel van de schade voor rekening van de aanvrager had gelaten. Dit suggereert dat ook schade in de vorm van tijdelijke overlast op zichzelf niet in de weg staat aan een aftrek wegens normaal maatschappelijk risico. Uit andere uitspraken blijkt bovendien dat - net als in de uitspraak van 17 september 2014 - belang moet worden gehecht aan predisposities van de getroffen onroerende zaak - zoals haar ligging - die de kans op het intreden van bepaalde schade(factoren) in de hand werken. Doorgaans pleiten dit soort predisposities ervoor een groter deel van de schade als normaal maatschappelijk risico aan te merken. Dat is bijvoorbeeld het geval bij overlast door infrastructurele werkzaamheden in een grootstedelijke omgeving, zoals de binnenstad van Amsterdam. ${ }^{254}$ Ook kan worden gedacht aan overlast door dijkversterkingswerkzaamheden die wordt ervaren door de bewoner van een aan een dijk gelegen woning. ${ }^{255}$ Soms pleit de ligging van de getroffen onroerende zaak echter voor een minder grote omvang van het normaal maatschap-

253 ABRvS 17 september 2014, ECLI:NL:RVS:2014:3382, r.o. 3.2. Zie voor een vergelijkbare overweging in het nadeelcompensatierecht: ABRvS 9 april 2014, ECLI:NL:RVS:2014:1198, r.o. 3.3.3 (Kustversterking Noordwijk). Ook onder de GrS speelt de locatie van de getroffen onroerende zaak een belangrijke rol: ABRvS 19 februari 2014, ECLI:NL:RVS:2014:572, r.o. 10.3 (Risicolocatie Schiphol); en ABRvS 1 juni 2016, ECLI:NL:RVS:2016:1467, r.o. 4.4.

254 ABRvS 3 december 2014, ECLI:NL:RVS:2014:4410, r.o. 6.

255 ABRvS 6 februari 2019, ECLI:NL:RVS:2019:343, r.o. 12.4. 
pelijk risico, bijvoorbeeld als de overlast wordt ondervonden in een "voorheen rustige en landelijke omgeving". 256

In planschade- en nadeelcompensatie geschillen gaat het doorgaans niet om personen- of zaakschade, maar om zuivere vermogensschade. ${ }^{257}$ Voor zover mij bekend, maakt de Afdeling (nog) geen structureel onderscheid op basis van de schadefactoren die deze vermogensschade teweegbrengen, zoals geluidshinder of vermindering van uitzicht. Een dergelijk onderscheid lijkt mij overigens ook niet wenselijk. De mate van ingrijpendheid van de schadefactor zal zich namelijk ook vertalen in de ernst van de schade en wordt daardoor dus al in de afbakening van het normaal maatschappelijk risico betrokken. ${ }^{258}$ Eveneens kan de wenselijkheid in twijfel worden getrokken van lagere rechtspraak waarin de omstandigheid dat schade werd geleden door een groot project werd ingezet als argument voor een grotere omvang van het normaal maatschappelijk risico. ${ }^{259}$ Dergelijke projecten zullen doorgaans namelijk grotere schade teweegbrengen, hetgeen zich eveneens zal vertalen in de ernst van de schade. Bovendien lijkt het een perverse prikkel dat het bestuur minder aansprakelijkheidsrisico zou lopen naarmate het projecten grootser aanpakt.

\section{Ernst van de schade}

De ernst van de overlast wordt deels bepaald door de afstand van de bron van de overlast tot de woning van de aanvrager. Het kan daarom voor een grotere omvang van het normaal maatschappelijk risico pleiten als de overlast veroorzakende werkzaamheden plaatsvinden op grotere afstand van de getroffen woning. ${ }^{260} \mathrm{De}$ ruimtelijke uitstraling van het type overlast veroorzakende werkzaamheid dient echter niet uit het oog te worden verloren. Ook zij bepaalt immers deels de ernst van de overlast. In een uitspraak van 16 maart 2005 droeg de omstandigheid dat boor- en heimachines op korte afstand van de getroffen woning waren ingezet bijvoorbeeld bij aan het oordeel dat de schade niet volledig tot het normaal maatschappelijk risico behoorde. ${ }^{261}$ Ook in een uitspraak van 20 september 2006 achtte

256 ABRvS 20 september 2006, ECLI:NL:RVS:2006:AY8507, r.o. 2.8.1-2.10.

257 Van Ravels 2006b, p. 261-262.

258 De onwenselijkheid van dubbele correcties op de omvang van het normaal maatschappelijk risico blijkt ook uit ABRvS 10 oktober 2018, ECLI:NL:RVS:2018:3272, r.o. 14.6 (Gemzelaar); en ABRvS 2 maart 2016, ECLI:NL:RVS:2016:530, r.o. 5.7 (Rijsbergen).

259 Zie Rb. Amsterdam 18 december 2014, ECLI:NL:RBAMS:2014:9829, r.o. 8.4-8.5; en Rb. Arnhem 19 juni 2003, ECLI:NL:RBARN:2003:AH9171, evenals AG9390, AH2446 en AH9172.

260 ABRvS 6 februari 2019, ECLI:NL:RVS:2019:343, r.o. 12.4. Dat het tegenovergestelde geldt voor een korte afstand, volgt uit Rb. Amsterdam 27 juni 2014, ECLI:NL:RBAMS:2014:3930, r.o. 3.4.3 ("relatief korte afstand" zonder "enkele natuurlijke of kunstmatige demping van het geluid"). 
de Afdeling van belang dat zware hei- en graafmachines waren ingezet. ${ }^{262}$ Uit een rechtbankuitspraak van 18 december 2014 kan ten slotte worden afgeleid dat de toepassing van een aangepaste, minder overlast veroorzakende heimethode juist ervoor kan pleiten een groter deel van de schade tot het normaal maatschappelijk risico te rekenen. ${ }^{263}$

\section{Duur van de schade}

Ook de duur van de overlast lijkt te moeten worden bezien in samenhang met de ruimtelijke uitstraling van het type overlast veroorzakende werkzaamheid. ${ }^{264}$ Bovendien lijkt het moment van de dag waarop de overlast wordt ondervonden een rol te kunnen spelen. Zo zal het dag en nacht uitvoeren van werkzaamheden doorgaans pleiten voor een kleinere omvang van het normaal maatschappelijk risico. ${ }^{265}$ Verder laat de rechtspraak een wisselend beeld zien ten opzichte van werkzaamheden die slechts overdag worden uitgevoerd. In een uitspraak van de rechtbank Amsterdam d.d. 27 juni 2014 pleitte het bijvoorbeeld niet voor een groter normaal maatschappelijk risico dat de werkzaamheden werden uitgevoerd "van 's-ochtends vroeg tot het begin van de avond."266 In een uitspraak van dezelfde rechtbank pleitte wel voor een groter normaal maatschappelijk risico dat vooral doordeweeks en overdag werd gewerkt, en slechts incidenteel en overdag in het weekend. ${ }^{267}$ Voorts oordeelde de rechtbank Oost-Brabant in een uitspraak van 24 mei 2017 dat de door het bestuur ingestelde schadecommissie ten onrechte ervan was uitgegaan dat "iedere overlast door werkzaamheden overdag tot het normaal maatschappelijk risico behoort." 268 Ten slotte pleitte in een uitspraak van 6 februari 2019 voor een groter normaal maatschappelijk risico dat de "periode waarin de meest aanmerkelijke overlast plaatsvond, vijf wintermaanden betrof en dat gedurende deze periode enkel overdag [was] gewerkt." ${ }^{269}$

262 ABRvS 20 september 2006, ECLI:NL:RVS:2006:AY8507, r.o. 2.8.1-2.10.

263 Rb. Amsterdam 18 december 2014, ECLI:NL:RBAMS:2014:9829, r.o. 8.4-8.5.

264 Geheel tot het normaal maatschappelijk risico behorende overlast: Rb. Amsterdam 18 december 2014, ECLI:NL:RBAMS:2014:9829, r.o. 8.4-8.5 (18 maanden). Gedeeltelijk tot het normaal maatschappelijk risico behorende overlast: ABRvS 16 maart 2005, ECLI:NL:RVS:2005:AT0572, r.o. 2.7.3 (18 maanden); en Rb. Amsterdam 27 juni 2014, ECLI:NL:RBAMS:2014:3930, r.o. 3.4.2-3.4.4 en 3.5.4 (18 maanden, waarvan gedurende 2 maanden heiwerkzaamheden). Geenszins tot het normaal maatschappelijk risico behorende overlast: ABRvS 20 september 2006, ECLI:NL:RVS:2006:AY8507, r.o. 2.8.1-2.10 (2 jaar, waarvan de aanvrager slechts 10 maanden verbleef in het vakantieverblijf). ABRvS 16 maart 2005, ECLI:NL:RVS:2005:AT0572, r.o. 2.7.3.

266 Rb. Amsterdam 27 juni 2014, ECLI:NL:RBAMS:2014:3930, r.o. 3.4.3.

267 Rb. Amsterdam 18 december 2014, ECLI:NL:RBAMS:2014:9829, r.o. 8.4-8.5.

268 Rb. Oost-Brabant 24 mei 2017, ECLI:NL:RBOBR:2017:2820, r.o. 16.4.

269 ABRvS 6 februari 2019, ECLI:NL:RVS:2019:343, r.o. 12.4. 


\subsubsection{Geen evidente verschillen tussen de regelingen}

Bij de bestudering van de in de voorafgaande deelparagrafen besproken jurisprudentie ben ik geen verschillen tegengekomen die zijn te herleiden tot de van toepassing zijnde nadeelcompensatieregeling. Ook overigens heb ik geen aanwijzingen gevonden dat onder bepaalde regelingen een principieel andere invulling aan het normaal maatschappelijk risico zou worden gegeven bij een tijdelijke derving van woongenot - behoudens het niet tegenwerpen van normaal maatschappelijk risico onder de VNNZ. ${ }^{270}$

\subsubsection{Deelvraag 3: het toekomstige recht}

In paragraaf 6.2.2 bleek waarom titel 4.5 Awb geen bijzondere normering omtrent de afbakening van het normaal maatschappelijk risico bevat. Anders dan bij permanente waardevermindering van onroerende zaken, bevat ook afd. $15.1 \mathrm{Ow}$ geen normering omtrent het normaal maatschappelijk risico bij tijdelijke derving van woongenot. Gelet op de algemene informatie uit de bij deze regelingen behorende toelichtende stukken, is aannemelijk dat wordt beoogd de thans bestaande jurisprudentielijnen voort te zetten. ${ }^{271}$

\subsubsection{Hoofdvraag: spiegeling aan de doelstellingen en uitgangspunten die} ten grondslag liggen aan de Wns

Dat titel 4.5 Awb en afd. 15.1 Ow geen bijzondere normering bevatten omtrent de afbakening van het normaal maatschappelijk risico bij schade in de vorm van tijdelijke derving van woongenot, lijkt zich op het eerste oog slecht te verhouden tot de doelstellingen van vereenvoudiging, uniformering en harmonisering van het nadeelcompensatierecht, vergroting van de rechtszekerheid, en codificatie van het nadeelcompensatierecht. Dat geldt te meer nu er relatief weinig jurisprudentie bestaat omtrent de afbakening van het normaal maatschappelijk risico bij dit type schade waaraan zekerheid kan worden ontleend. Het is echter maar de vraag of het thans mogelijk is algemene normering omtrent het normaal maatschappelijk risico bij tijdelijke derving van woongenot op te nemen in titel $4.5 \mathrm{Awb}$ en/of afd. 15.1 Ow. Hieronder zal ik toelichten waarom dat mijns inziens slechts in beperkte mate het geval is.

\section{Een absolute bagateldrempel}

De in paragraaf 6.3.3 voorgestelde, absolute bagateldrempel van $€ 500$ voor particulieren kan ook worden toegepast bij schade in de vorm van tijdelijke derving van woongenot. Dit zou ook goed aansluiten op de doelstellingen van vereenvoudiging, uniformering en harmonisering van het nadeelcompensatierecht, vergroting van de doelmatigheid van het nadeelcompensatierecht en vermindering van 
bestuurslasten, vergroting van de rechtszekerheid, en codificatie van het nadeelcompensatierecht. Met betrekking tot die laatste doelstelling is relevant dat geen reden bestaat om aan te nemen dat de jurisprudentielijn dat relatief geringe schade per definitie tot het normaal maatschappelijk risico behoort, niet zou opgaan voor deze vorm van schade. ${ }^{272}$ Voorts lijkt deze aanbeveling verenigbaar met de aan de Wns ten grondslag liggende uitgangspunten.

\section{Geen verdere normering in titel $4.5 \mathrm{Awb}$ en/of afd. $15.1 \mathrm{Ow}$}

De in paragraaf 6.4 .1 besproken jurisprudentielijnen lenen zich mijns inziens niet voor codificatie in titel 4.5 Awb en/of afd. 15.1 Ow. Zo zou nauwelijks meer rechtszekerheid ontstaan door te codificeren dat de aard, ernst en duur van de schade dient te worden betrokken bij de afbakening van het normaal maatschappelijk risico bij tijdelijke derving van woongenot. Ook vuistregels als "het 's nachts uitvoeren van werkzaamheden pleit voor een kleiner normaal maatschappelijk risico", lenen zich niet voor codificatie in een formeelwettelijke regeling. In theorie zou wel kunnen worden gecodificeerd dat de overlast die gedurende het eerste schadejaar wordt ondervonden altijd tot het normaal maatschappelijk risico behoort. Dat sluit echter niet goed aan op de doelstelling van codificatie van het nadeelcompensatierecht. De Afdeling accepteert weliswaar dat een periode van een jaar tot uitganspunt wordt genomen, maar vereist ook dat rekening wordt gehouden met alle van belang zijnde omstandigheden van het individuele geval, waaronder de aard en ernst van de schade.

Bovendien lijkt een algemene uitsluiting van compensatie van gedurende het eerste jaar geleden schade niet wenselijk, omdat de gevolgen daarvan niet goed zijn te overzien. Enerzijds kent het recht waarborgen die zouden kunnen voorkomen dat overlast door uitvoeringswerkzaamheden (gedurende dit eerste jaar) onaanvaardbare proporties aanneemt. Daarbij kan worden gedacht aan het uit art. 3:4 lid 2 Awb voortvloeiende vereiste van een evenredige belangenafweging - dat ook van toepassing is op feitelijk overheidshandelen. Tevens kan worden gedacht aan het civielrechtelijke onrechtmatigedaadsrecht, en dan meer specifiek aan de leerstukken van onrechtmatige hinder en bouwschade. ${ }^{273}$ Anderzijds kan niet op voorhand worden uitgesloten dat een algemene uitsluiting van compensatie van gedurende het eerste jaar geleden schade soms tot onrechtvaardige uitkomsten zou leiden. Daarbij kan worden gedacht aan ernstige overlast door ingrijpende werkzaamheden nabij een recreatiewoning gedurende de volledige periode van maanden waarin die woning daadwerkelijk voor recreatiedoeleinden kan worden

272 ABRvS 17 september 2014, ECLI:NL:RVS:2014:3378, r.o. 12. Hierin wordt verwezen naar ABRvS 21 juni 2006, ECLI:NL:RVS:2006:AX9047, r.o. 2.6.2. Zie ook ABRvS 22 mei 2013, ECLI:NL:RVS:2013:CA0631, r.o. 6.2.

273 Bouwschade is "schade als gevolg van de bouwwerkzaamheden aan onroerend goed, bijvoorbeeld scheuren in de gevel, beschadigingen van panden e.d." Zij wordt (doorgaans) aangemerkt als onrechtmatig veroorzaakte schade. Zie hierover Van Manen 2003, p. 866. 
gebruikt. ${ }^{274}$ Ook kan worden gedacht aan situaties waarin door een samenspel van in art. 15.1 lid $1 \mathrm{Ow}$ opgesomde schadeoorzaken steeds een nieuwe termijn van een jaar zou gaan lopen als met een nieuwe activiteit wordt aangevangen - hetgeen zich bijvoorbeeld zou kunnen voordoen bij het stapsgewijs vernieuwen van het wegdek en de ondergrondse leidingen in een woonwijk. Ten slotte zou de enkele uitsluiting van compensatie van gedurende het eerste jaar geleden schade geen zekerheid bieden omtrent de wijze waarop het normaal maatschappelijk risico na dit jaar dient te worden afgebakend.

\section{Een werkgroep}

Naar aanleiding van het voorafgaande doe ik de aanbeveling dat het kabinet een werkgroep instelt die onderzoekt hoe (door middel van regelgeving of beleid) meer rechtszekerheid aan burger, bestuur en/of rechter zou kunnen worden geboden omtrent de afbakening van het normaal maatschappelijk risico bij tijdelijke derving van woongenot. Uit paragraaf 6.2.2.2 bleek dat het huidige kabinet rechtszekerheid verkiest boven maatwerk voor wat betreft de afbakening van het normaal maatschappelijk risico bij permanente waardedaling van onroerende zaken. Uit de in paragraaf 6.3.2 besproken opmerking van het kabinet dat wordt verwacht dat bestuursorganen aansluiting zoeken bij de Handleiding nadeelcompensatie voor de afbakening van het normaal maatschappelijk risico bij inkomensschade, kan echter worden afgeleid dat het kabinet wel openstaat voor de mogelijkheid van maatwerk. De werkgroep zou daarom moeten onderzoeken of maatwerk wenselijk is bij de afbakening van het normaal maatschappelijk risico bij tijdelijke derving van woongenot, en zo ja, hoe dat maatwerk kan worden gerealiseerd terwijl zo min mogelijk wordt ingeleverd op rechtszekerheid en efficiëntie.

Wellicht zou - analoog aan art. 15.7 lid $1 \mathrm{Ow}$ - kunnen worden bepaald dat het normaal maatschappelijk risico altijd bestaat uit een vast percentage van de objectieve huurwaarde ${ }^{275}$ direct voorafgaand aan de aanvang van de overlast. De werkgroep zou daartoe in ieder geval moeten onderzoeken of de objectieve huurwaarde daadwerkelijk een geschikt aanknopingspunt vormt. ${ }^{276}$ Ook zou de werkgroep bijvoorbeeld moeten nagaan wat de gemiddelde daling van de objectieve huurwaarde is bij de meest voorkomende uitvoeringswerkzaamheden. Het is echter ook denkbaar dat de werkgroep tot de conclusie komt dat het forfait niet gefixeerd zou moeten zijn, omdat zij enige differentiatie toch wenselijk acht. Gelet op de doelstellingen van vergroting van de rechtszekerheid, en vergroting van de doelmatigheid van het nadeelcompensatierecht en vermindering van bestuurslasten, zou zij er dan goed aan doen te onderzoeken hoe die differentiatie kan worden vormgegeven aan de hand van factoren voor de invulling waarvan het bestuur geen afzonderlijke

274 Dit voorbeeld is geïnspireerd op ABRvS 20 september 2006, ECLI:NL:RVS:2006:AY8507, r.o. 2.8.1-2.10.

275 Zie paragraaf 5.7.1.3 omtrent de begroting van schade in de vorm van tijdelijke derving van woongenot met behulp van de huurwaardemethode. Zie paragraaf 5.7.3.1 omtrent mogelijke knelpunten van de huurwaardemethode. 
deskundigenbijstand hoeft in te schakelen. Daartoe zou de werkgroep mogelijk inspiratie kunnen ontlenen aan de in de Handleiding nadeelcompensatie beschreven methode om het normaal ondernemersrisico vast te stellen. ${ }^{277}$ Eveneens zou inspiratie kunnen worden ontleend aan de Verordening tegemoetkoming bouwactiviteiten Noord/Zuidlijn en de 'Regeling Tegemoetkoming Omwonenden Sanering Olasfa' ${ }^{278}$ Hoewel beide regelingen ook een aspect van coulance lijken te bevatten, gaan zij namelijk uit van een forfaitaire vergoeding van tijdelijk gederfd woongenot die zonder raadpleging van deskundigen kan worden vastgesteld.

Aan de hand van de bevindingen van de werkgroep kan de regering besluiten om over te gaan tot vaststelling van regelgeving. Omwille van dezelfde argumenten als in paragraaf 6.3.3 werden aangevoerd ten aanzien van de codificatie van de afbakeningssystematiek uit de Handleiding nadeelcompensatie, zou het de voorkeur verdienen als de regering die regelgeving in eerste instantie zou opnemen in een amvb - die niet de status van regelend, aanvullend of facultatief recht heeft. Kort gezegd: de keuze voor een amvb heeft tot gevolg dat de afbakening van het normaal maatschappelijk risico bij tijdelijke derving van woongenot zoveel mogelijk wordt geharmoniseerd en geüniformeerd, terwijl - in vergelijking met een wet in formele zin - relatief eenvoudig en snel correcties kunnen worden aangebracht naar aanleiding van de ervaringen die in de praktijk worden opgedaan met de in de amvb vervatte normering. In paragraaf 6.3 .3 werd ten aanzien van het normaal ondernemersrisico reeds de aanbeveling gedaan om aan titel 4.5 Awb de formeelwettelijke grondslag toe te voegen die noodzakelijk is voor de vaststelling van een amvb inzake de afbakening van het normaal maatschappelijk risico. Vanwege het voorafgaande wordt deze aanbeveling hier herhaald met het oog op het normaal maatschappelijk risico bij tijdelijke derving van woongenot.

\section{Een overzichtsuitspraak}

Ongeacht of het kabinet besluit tot instelling van een werkgroep, zou het goed bij de doelstelling van vergroting van de rechtszekerheid passen als de Afdeling een overzicht geeft van haar jurisprudentielijnen inzake het normaal maatschappelijk risico bij tijdelijke derving van woongenot. Uiteraard moet zich daartoe een geschil voordoen dat kan worden aangegrepen als aanleiding voor het geven van een dergelijk overzicht. Ook zal de Afdeling bij het geven van het voorgestelde overzicht moeten blijven binnen de grenzen van haar rechtsprekende taak. ${ }^{279}$ De hier aanbevolen overzichtsuitspraak zal ongetwijfeld van kleinere omvang zijn dan de overzichtsuitspraak over het planschaderecht d.d. 28 september 2016. Desondanks vormt zij een middel om - in afwachting van de uitkomsten van het onderzoek

277 Zie daarover paragraaf 6.3.1 onder het kopje 'De Handleiding nadeelcompensatie bij infrastructurele maatregelen'.

278 De 'Regeling Tegemoetkoming Omwonenden Sanering Olasfa' doorstond de rechterlijke toets in ABRvS 6 maart 2019, ECLI:NL:RVS:2019:729 (Olasfa).

279 Hoe het geven van een overzichtsuitspraak zich tot deze grenzen verhoudt, wordt besproken in Van Ravels 2017. 
van de werkgroep - op korte termijn relatief veel zekerheid te verschaffen omtrent de afbakening van het normaal maatschappelijk risico bij tijdelijke derving van woongenot.

\section{Titel 4.5 Awb-interpreterende beleidsregels}

Wanneer bestuursorganen voornemens zijn het normaal maatschappelijk risico bij tijdelijke derving van woongenot op één specifieke manier te vormgeven, zou het ten slotte goed bij de doelstellingen van codificatie van het nadeelcompensatierecht en vergroting van de rechtszekerheid passen dat zij dit kenbaar maken in een titel 4.5 Awb-interpreterende beleidsregel. De keuze voor een beleidsregel is ingegeven door de gedachte dat de vaststelling van het normaal maatschappelijk risico - behoudens eventueel toekomstig ingrijpen door de formele wetgever of de regering - dient te geschieden aan de hand van alle van belang zijnde omstandigheden van het individuele schadegeval. Het is daarom wenselijk dat van de door het bestuur kenbaar gemaakte benadering kan worden afgeweken indien bijzondere omstandigheden dat rechtvaardigen (vergelijk art. 4:84 Awb). Bij het opstellen van de voorgestelde beleidsregels zou de aanbevolen overzichtsuitspraak als inspiratiebron kunnen dienen.

\section{Conclusie}

Uit het voorafgaande kan worden afgeleid dat de aan de Wns ten grondslag liggende doelstellingen en uitgangspunten mijns inziens aanleiding geven tot (a) wijziging van titel 4.5 Awb. Ook vanuit het perspectief van schade in de vorm van tijdelijke derving van woongenot is het namelijk wenselijk dat de in paragraaf 6.3.3 aanbevolen, absolute bagateldrempel van $€ 500$ voor particulieren én een grondslag voor vaststelling van amvb's over het normaal maatschappelijk risico worden toegevoegd aan titel 4.5 Awb. Verder geven de doelstellingen en uitgangspunten geen aanleiding tot (b) wijziging van afd. $15.1 \mathrm{Ow}$. Wel geven zij aanleiding tot verschillende aanbevelingen die kwalificeren als (c) het anderszins voorzien in een bijzondere invulling van titel 4.5 Awb. Het betreft allereerst de instelling van een werkgroep door het kabinet. Tot aan het moment waarop de regering de bevindingen van die werkgroep bij amvb zou omzetten in concrete normering, zou rechtszekerheid kunnen worden geboden door vaststelling van een overzichtsuitspraak door de Afdeling. Tevens zou dit kunnen geschieden door de vaststelling van titel 4.5 Awb-interpreterende beleidsregels door bestuursorganen die voornemens zijn het normaal maatschappelijk risico bij tijdelijke derving van woongenot op één specifieke manier te vormgeven.

\subsection{CONCLUSIES EN CONCRETE VOORSTELLEN}

In dit hoofdstuk zijn de tweede en derde deelvraag en de hoofdvraag beantwoord ten aanzien van de afbakening van het normaal maatschappelijk risico bij de drie meest voorkomende vormen van schade. Hierna volgt een beknopte samenvatting 
van de aanbevelingen die zijn gedaan bij beantwoording van de hoofdvraag, en worden concrete voorstellen gedaan omtrent de implementatie van deze aanbevelingen.

\section{Permanente waardevermindering van onroerende zaken}

In paragraaf 6.2.3 zijn een aantal aanbevelingen gedaan die betrekking hebben op het normaal maatschappelijk risico bij schade in de vorm van permanente waardevermindering van onroerende zaken. Het grootste deel van die aanbeveling ziet op (b) wijziging van afd. 15.1 Ow. Allereerst is aanbevolen dat art. 15.7 lid $1 \mathrm{Ow}$ zo wordt aangepast dat het daarin vervatte forfait ook van toepassing zal zijn op directe schade. Deze bepaling zou daardoor als volgt komen te luiden:

1. Bij een aanvraag om vergoeding van schade die bestaat uit waardevermindering van een onroerende zaak wordt een deel ter grootte van vier procent van de waarde van de onroerende zaak onmiddellijk voor het ontstaan van de schade aangemerkt als behorend tot het normale maatschappelijke risico als bedoeld in artikel 4:126, eerste lid, van de Algemene wet bestuursrecht.

Vervolgens zijn enkele redactionele wijzigingen van art. 15.7 lid 2 en lid 3 Ow aanbevolen. Deze bepalingen zouden daardoor als volgt komen te luiden:

2. Als de aanvraag om schadevergoeding strekt tot vergoeding van meerdere schades door verschillende activiteiten óf strekt tot vergoeding van schade door één activiteit gebaseerd op meerdere besluiten, past het bevoegd gezag het eerste lid toe op het totale voor vergoeding in aanmerking komende bedrag, mits deze activiteiten respectievelijk besluiten daartoe voldoende samenhang vertonen.

3. Het bevoegd gezag kan bij de behandeling van een aanvraag om schadevergoeding het eerste lid buiten toepassing laten als dat lid van toepassing is geweest bij de beslissing op een eerder ingediende aanvraag om vergoeding van schade.

Voorts is een aanbeveling gedaan die zowel zou leiden tot (a) wijziging van titel 4.5 Awb als (b) wijziging van afd. 15.1 Ow. Het betreft de verplaatsing van art. 15.7 lid 4 Ow naar titel 4.5 Awb. In paragraaf 6.2.3.3 bleek dat deze aanbeveling dient te worden bezien in samenhang met de aanbevelingen uit paragraaf 6.3.3 en 6.4.3 om in titel $4.5 \mathrm{Awb}$ te bepalen dat bij amvb in algemene zin regels kunnen worden gesteld omtrent het normaal maatschappelijk risico. Ten slotte is een aanbeveling gedaan die kwalificeert als (c) het anderszins voorzien in een bijzondere invulling van titel 4.5 Awb, namelijk dat het kabinet of de formele wetgever in een toelichtend stuk aangeeft dat bestuursorganen en rechters bij toepassing van titel $4.5 \mathrm{Awb}$ zoveel mogelijk moeten aansluiten bij het gefixeerde 4\%-forfait van art. 15.7 lid $1 \mathrm{Ow}$ in gevallen van permanente waardevermindering van onroerende zaken die niet onder het bereik van afd. 15.1 Ow vallen. Dit zal met name mogelijk zijn als de aard van de schade en de schadeoorzaak overeenkomstig is. 


\section{Inkomensderving}

In paragraaf 6.3.3 zijn aanbevelingen gedaan ten aanzien van het normaal maatschappelijk risico bij inkomensderving. In algemene zin is aanbevolen om (a) titel 4.5 Awb aan te passen door daarin voor inkomensschade een minimumdrempel van $2 \%$ van het inkomen onmiddellijk voor het ontstaan van de schade op te nemen. Bovendien zou een algemene bagateldrempel van $€ 1.000$ voor ondernemers en $€ 500$ voor particulieren kunnen worden opgenomen. Deze aanbeveling zou kunnen worden geïmplementeerd door het volgende lid toe te voegen aan art. 4:126 Awb:

Tot het normaal normale maatschappelijke risico als bedoeld in het eerste lid behoort in ieder geval:

a. schade kleiner dan $€ 500$ als de aanvrager een particulier is;

b. schade kleiner dan $€ 1.000$ als de aanvrager een ondernemer is; en

c. een bedrag gelijk aan twee procent van het inkomen onmiddellijk voor het ontstaan van de schade als de schade bestaat uit inkomensschade.

Ook is aanbevolen om in titel 4.5 Awb te bepalen dat bij amvb nadere regels over de afbakening van het normaal maatschappelijk risico kunnen worden gesteld. Deze aanbeveling kan worden geïmplementeerd door onderstaand lid aan art. 4:126 Awb toe te voegen:

Bij algemene maatregel van bestuur kunnen nadere regels worden gesteld omtrent het normale maatschappelijke risico als bedoeld in het eerste lid.

De aan de Wns ten grondslag liggende doelstellingen en uitgangspunten geven mijns inziens geen aanleiding om (b) afd. $15.1 \mathrm{Ow}$ te wijzigen met betrekking tot dit onderwerp. Wel zijn een aantal aanbevelingen gedaan om (c) anderszins te voorzien in een bijzondere invulling van titel $4.5 \mathrm{Awb}$. Ten eerste is aanbevolen dat de regering - op grond van de hiervoor aanbevolen attributiebepaling - een amvb vaststelt waarin de door de Handleiding nadeelcompensatie voorgestelde systematiek voor afbakening van het normaal ondernemersrisico uniform wordt voorgeschreven bij tijdelijke inkomensschade door infrastructurele activiteiten. Dat zou kunnen worden gerealiseerd met behulp van de volgende bepalingen:280

\section{Artikel 1 - Begripsomschrijvingen}

Voor de toepassing van artikel 2 tot en met 5 wordt verstaan onder:

- Infrastructurele activiteit: activiteiten die strekken tot de aanleg, de wijziging, het beheer en het onderhoud van wegen, spoor- en vaarwegen; ${ }^{281}$

280 De formulering van deze bepalingen is geïnspireerd op art. 1 jo. art. $3 \mathrm{a} \mathrm{t} / \mathrm{m} 3 \mathrm{~d} \mathrm{BnIW}$ 2019. De formuleringen zijn aangepast om beter aan te sluiten op de aan de Wns ten grondslag liggende doelstellingen en uitgangspunten. Deze definitie is deels geïnspireerd op Handleiding nadeelcompensatie, p. 16. 
- Normale infrastructurele activiteit: infrastructurele activiteit die kwalificeert als een normale maatschappelijke ontwikkeling;

- Normkosten: kosten op jaarbasis die naar redelijke verwachting gemaakt zouden zijn als de schadeveroorzakende infrastructurele activiteit niet had plaatsgevonden;

- Normomzet: omzet op jaarbasis die naar redelijke verwachting behaald zou zijn als de schadeveroorzakende infrastructurele activiteit niet had plaatsgevonden.

\section{Artikel 2 - Ondernemersrisico en tijdelijke omzetdaling door normale infrastruc- turele maatregelen}

1. Onverminderd artikel 4:126, eerste lid, van de Algemene wet bestuursrecht, valt schade ten gevolge van een normale infrastructurele activiteit in ieder geval binnen het normaal maatschappelijk risico indien de schade het gevolg is van een tijdelijke omzetdaling die niet uitgaat boven de ingangsdrempel, bedoeld in het tweede lid.

2. De hoogte van de ingangsdrempel is gelijk aan het bedrag van de normomzet vermenigvuldigd met het drempelpercentage omzetdaling, dat als volgt afhankelijk is van de hoogte van de normbrutowinstmarge van de onderneming van de aanvrager:

\begin{tabular}{|c|c|}
\hline Normbrutowinstmarge & Drempelpercentage omzetdaling \\
\hline $0-36 \%$ & $13 \%$ \\
\hline $36-65 \%$ & $11 \%$ \\
\hline $65-100 \%$ & $8 \%$ \\
\hline
\end{tabular}

3. Indien de omzetdaling de ingangsdrempel, bedoeld in het tweede lid, overstijgt, wordt het normaal maatschappelijk risico van de aanvrager bepaald door de normomzet te vermenigvuldigen met de normbrutowinstmarge van de onderneming van de aanvrager en het percentage ' $n$ '. Dit percentage is als volgt afhankelijk van de hoogte van de normbrutowinstmarge van de onderneming van de aanvrager:

\begin{tabular}{|c|c|}
\hline Normbrutowinstmarge & Drempelpercentage omzetdaling \\
\hline $0-36 \%$ & $15 \%{ }^{*}$ \\
\hline $36-65 \%$ & $13 \%$ \\
\hline $65-100 \%$ & $10 \%$ \\
\hline \multicolumn{2}{|c|}{$\begin{array}{l}\text { "Ik ga ervan uit dat de wetgever de hoogste percentages uit de handleiding zal aanhouden, anders dan hetgeen } \\
\text { het geval is onder de BnIW 2019. Vergelijk Handleiding nadeelcompensatie, p. 62. }\end{array}$} \\
\hline
\end{tabular}

4. Onder normbrutowinstmarge als bedoeld in het tweede en derde lid wordt voor de toepassing van dit artikel verstaan: omzet minus de inkoopwaarde van de afzet op jaarbasis, uitgedrukt in een percentage van de omzet, dat naar redelijke verwachting zou zijn behaald, als de schadeveroorzakende infrastructurele activiteit niet had plaatsgevonden. 
Artikel 3 - Ondernemersrisico en tijdelijke kostenverhoging door normale infrastructurele maatregelen

1. Onverminderd artikel 4:126, eerste lid, van de Algemene wet bestuursrecht, valt schade ten gevolge van een normale infrastructurele activiteit in ieder geval binnen het normaal maatschappelijk risico indien de schade het gevolg is van een tijdelijke kostenverhoging die niet uitgaat boven de ingangsdrempel, bedoeld in het tweede lid.

2. De hoogte van de ingangsdrempel is gelijk aan het bedrag van de normkosten vermenigvuldigd met het drempelpercentage kostenverhoging, dat als volgt afhankelijk is van de hoogte van de normbrutowinstmarge van de onderneming van de aanvrager:

\begin{tabular}{|c|c|}
\hline Normbrutowinstmarge & $\begin{array}{c}\text { Drempelpercentage kostenverho- } \\
\text { ging }\end{array}$ \\
\hline $0-36 \%$ & $4 \%$ \\
\hline $36-65 \%$ & $6 \%$ \\
\hline $65-100 \%$ & $8 \%$ \\
\hline
\end{tabular}

3. Indien de kostenverhoging de ingangsdrempel, bedoeld in het tweede lid, overstijgt, wordt het normaal maatschappelijk risico van de aanvrager bepaald door de normomzet te vermenigvuldigen met de normbrutowinstmarge van de onderneming van de aanvrager en het percentage ' $n$ '. Dit percentage is als volgt afhankelijk van de hoogte van de normbrutowinstmarge van de onderneming van de aanvrager:

\begin{tabular}{|c|c|}
\hline Normbrutowinstmarge & Drempelpercentage omzetdaling \\
\hline $0-36 \%$ & $15 \%{ }^{*}$ \\
\hline $36-65 \%$ & $13 \%$ \\
\hline $65-100 \%$ & $10 \%$ \\
\hline $\begin{array}{l}\text { * Ik ga ervan uit dat de regering de hoogste percentages uit de handleiding zal aanhouden, anders dan hetgeen } \\
\text { het geval is onder de BnIW 2019. Vergelijk Handleiding nadeelcompensatie, p. } 62 .\end{array}$ \\
\hline
\end{tabular}

4. Onder normbrutowinstmarge als bedoeld in het tweede en derde lid wordt voor de toepassing van dit artikel verstaan: de omzet minus de som van de inkoopwaarde van de afzet plus de overige variabele kosten op jaarbasis, uitgedrukt in een percentage van de omzet, dat naar redelijke verwachting zou zijn behaald, als de infrastructurele activiteit niet had plaatsgevonden.

\section{Artikel 4 - Ondernemersrisico en tijdelijke omzetdaling of tijdelijke kostenverho- ging door niet-normale infrastructurele maatregelen \\ Als de schade ten gevolge van een niet-normale infrastructurele activiteit het bedrag bedoeld in artikel 4:126, lid $\mathrm{x}^{282}$ van de Algemene wet bestuursrecht overstijgt, wordt}

282 Hiermee wordt verwezen naar de eerder voorgestelde bagateldrempels. 
het normaal ondernemersrisico verdisconteert door middel van een korting ten hoogte van maximaal $15 \%$ van de schade.

\section{Artikel 5 - Langdurige tijdelijke schade}

1. Als sprake is van langdurige schade als gevolg van een tijdelijke infrastructurele activiteit, worden met ingang van het derde jaar waarin de schade wordt geleden een lagere ingangsdrempel en een lager percentage ' $n$ ' gehanteerd dan genoemd in artikel 2 en 3.

2. Als sprake is van langdurige schade als gevolg van een tijdelijke, niet-normale infrastructurele activiteit, wordt met ingang van het derde jaar waarin schade wordt geleden een lager kortingspercentage gehanteerd dan genoemd in artikel 4.

3. Bij langdurige schade door een samenspel van verschillende activiteiten als bedoeld in het eerste of tweede lid, wordt het eerste respectievelijk tweede lid toegepast op het geheel aan schade veroorzaakt door deze activiteiten, mits deze activiteiten daartoe voldoende samenhang vertonen. ${ }^{283}$

Vervolgens is aanbevolen dat in de toelichting op de voorgestelde amvb wordt vermeld dat rechters en bestuursorganen bij permanente inkomensschade, en tijdelijke inkomensschade die niet wordt veroorzaakt door infrastructurele werkzaamheden, zoveel mogelijk moeten aansluiten bij de in de amvb voorgeschreven bepalingen - en deze actoren dat ook daadwerkelijk doen. Verder zou het kabinet er mijns inziens goed aan doen een werkgroep in te stellen die evalueert hoe (toepassing van) de voorgestelde amvb wordt ervaren door de praktijk en wordt beoordeeld in de jurisprudentie. Ook zou de werkgroep moeten nagaan of het mogelijk is om het toepassingsbereik van de in de amvb - en dus ook in de Handleiding nadeelcompensatie - voorgeschreven afbakeningssystematiek verder uit te breiden. De bevindingen van de werkgroep zouden aanleiding kunnen geven tot bijstelling van de in de amvb voorgeschreven systematiek respectievelijk tot uitbreiding van het toepassingsbereik daarvan. Op langere termijn zouden de bevindingen van de werkgroep eventueel ook ertoe kunnen leiden dat de bepalingen uit de amvb alsnog een plaats krijgen in titel 4.5 Awb en/of afd. 15.1 Ow.

\section{Tijdelijke derving van woongenot}

In paragraaf 6.4.3 zijn ten slotte enkele aanbevelingen gedaan met betrekking tot het normaal maatschappelijk risico bij schade in de vorm van tijdelijke derving van woongenot. Allereerst zijn twee in paragraaf 6.3.3 gedane aanbevelingen om (a) titel 4.5 Awb te wijzigen, herhaald. Het betreft de aanbevelingen om in titel 4.5 Awb een bagateldrempel van $€ 500$ voor particulieren op te nemen en in titel 4.5 Awb te bepalen dat bij amvb nadere regels over de afbakening van het normaal

283 Deze bepaling komt niet voor in de BnIW 2019 of de Handleiding nadeelcompensatie, maar is mijns inziens nodig om ervoor te zorgen dat niet telkens een nieuwe termijn begint te lopen bij inkomensschade door elkaar opvolgende activiteiten die allemaal plaatsvinden ter uitvoering van één infrastructureel project. 
maatschappelijk risico kunnen worden gesteld. Onder het kopje 'Inkomensschade' werden concrete voorstelen gedaan ter implementatie van deze aanbevelingen.

De aan de Wns ten grondslag liggende doelstellingen en uitgangspunten geven mijns inziens geen aanleiding om (b) afd. 15.1 Ow te wijzigen met betrekking tot dit onderwerp. Wel zijn enkele aanbevelingen gedaan om (c) anderszins te voorzien in een bijzondere invulling van titel $4.5 \mathrm{Awb}$. Het betreft allereerst de aanbeveling dat het kabinet een werkgroep instelt die onderzoekt hoe (door middel van regelgeving of beleid) meer rechtszekerheid aan burger, bestuur en/of rechter zou kunnen worden geboden omtrent de afbakening van het normaal maatschappelijk risico bij tijdelijke derving van woongenot. Als de bevindingen van de werkgroep zich daartoe lenen, zou de regering er goed aan doen deze bevindingen om te zetten in concrete normering. Die normering kan het best worden toegevoegd aan de eerder voorgestelde amvb omtrent het normaal ondernemersrisico. Ten tweede is voorgesteld dat de Afdeling in een overzichtsuitspraak haar jurisprudentielijnen inzake het normaal maatschappelijk risico bij tijdelijke derving van woongenot samenvat. Daarmee wordt in ieder geval rechtszekerheid verschaft tot aan het eventuele moment waarop de regering zou besluiten tot vaststelling van de voorgestelde amvb. Met betrekking tot deze periode is ook aanbevolen tot vaststelling van titel 4.5 Awb-interpreterende beleidsregels door bestuursorganen die voornemens zijn het normaal maatschappelijk risico bij tijdelijke derving van woongenot op één specifieke manier te vormgeven. 


\section{Hoofdstuk 7}

\section{De speciale last}

\subsection{INLEIDING}

In hoofdstuk 6 is stilgestaan bij het criterium van de abnormale last. In dit hoofdstuk zullen de tweede en derde deelvraag en de hoofdvraag in elkaar opvolgende paragrafen worden beantwoord ten aanzien van het andere criterium dat typerend is voor het égalitébeginsel, ${ }^{1}$ zijnde het criterium van de speciale last. In deze paragraaf zal een inleiding op dit criterium worden gegeven, waarbij onder andere wordt stilgestaan bij de terminologie die nodig is om dit criterium op zinvolle wijze te kunnen bespreken.

\section{Wat wordt verstaan onder een speciale last?}

Om te voldoen aan het criterium van de speciale last dient de benadeelde in vergelijking met anderen onevenredig zwaar te worden getroffen door de schade die hij lijdt door het schadeveroorzakende overheidshandelen. ${ }^{2}$ Dit kan worden geïllustreerd door bespreking van het klassieke Harrida-arrest. Daarin stond de schade van Harrida, een importeur van ossenvlees uit (Noord) Ierland, centraal. Deze schade werd veroorzaakt door de afkondiging van een import- en handelsverbod op rundvlees uit het Verenigd Koninkrijk ter voorkoming van besmetting met de ziekte van Creutzfeldt-Jacob. De HR sanctioneerde dat "de groep van ondernemers die dierlijke producten uit het Verenigd Koninkrijk importeerden, hetzij in de vorm van levende dieren die in Nederland werden vetgemest en geslacht, hetzij in de vorm van reeds in het Verenigd Koninkrijk geslacht rundvee" als referentiegroep werd aangemerkt. Harrida leed onevenredige schade in verhouding tot de ondernemers uit deze referentiegroep "doordat zij als kleine onderneming, die zich geheel had toegelegd op de import van ossenvlees van hoge kwaliteit grotendeels uit Noord Ierland, bij gebreke van tijd en geld in de betrokken - korte - periode niet kon overschakelen op van elders afkomstig vlees en haar leveranciers- en klantenbestand niet kon veranderen." ${ }^{3}$

Er bestaat relatief weinig jurisprudentie omtrent het criterium van de speciale last. Dat lijkt te kunnen worden verklaard doordat het criterium - anders dan het Harrida-arrest doet vermoeden - in de praktijk weerbarstig en niet altijd even

1 Zie paragraaf 1.1, waarin wordt verwezen naar Kamerstukken II 2010/11, 32 621, nr. 3, p. 13 (MvT, Wns).

2 Deze definitie is ontleend aan art. 4:126 lid 1 Awb.

3 HR 20 juni 2003, ECLI:NL:HR:2003:AF7902, r.o. 3.7.1-3.7.3 (Harrida). 
eenvoudig toe te passen is. ${ }^{4}$ Met name over de wijze waarop de referentiegroep dient te worden afgebakend, lopen de meningen al vele decennia uiteen. ${ }^{5}$ Illustratief daarvoor is de wijze waarop het - eveneens klassieke - Leffers-arrest in de doctrine is ontvangen. In dit arrest stond de schade centraal die varkensmester Leffers leed door de 'Regeling verbod voedsel- en slachtafvallen (varkens)' ${ }^{6}$. Deze regeling verbood "aan eigenaren, houders of hoeders van varkens (...) voedsel- of slachtafvallen voorhanden te hebben of te vervoederen." Zij werd vastgesteld naar aanleiding van een constatering van Afrikaanse varkenspest bij een bedrijf waar varkens met swill werden gevoerd. Ten aanzien van het criterium van de speciale last overwoog de Hoge Raad:

\begin{abstract}
"De voormelde Regeling strekt ertoe de belangen te beschermen van al diegenen die zich bezighouden met het fokken, verhandelen en exporteren van varkens, waarbij in het bijzonder het mesten soms bedrijfsmatig, soms niet bedrijfsmatig geschiedt. Juist door deze bescherming wordt evenwel, naar de Staat niet heeft bestreden, een naar verhouding kleine groep van bedrijfsmatige varkensmesters die, anders dan het overgrote deel van hun concurrenten, hun bedrijf geheel hadden ingericht op vervoedering van swill en niet van de ene dag op de andere op een ander vervoederingsstelsel hebben kunnen overschakelen zonder dat daardoor de winstgevendheid van hun bedrijf verloren zou gaan, in onevenredige mate in haar belangen getroffen, en wel in de onderhavige zaak naar de stellingen van Leffers in dier voege dat het bedrijf van Leffers is moeten worden geliquideerd met aanzienlijke vermogensschade."7
\end{abstract}

Tjepkema verdedigde in zijn proefschrift het standpunt dat de referentiegroep bestond uit "varkensboeren die uitsluitend of deels met swill vervoederen." Afgaande op de memorie van toelichting behorende bij de IOw lijkt dat ook de mening van het huidige kabinet te zijn. ${ }^{9}$ Van Ravels verdedigde echter het standpunt dat de referentiegroep bestond uit "al diegenen die zich bezighouden met het fokken, verhandelen en exporteren van varkens." ${ }^{10}$ Koopmans (A-G in de Leffers-zaak) verdedigde een vergelijkbaar standpunt in zijn noot bij het Varkensmester Meiland-arrest van 3 april 1998. ${ }^{11}$

Ongeacht welk van de bovenstaande visies de juiste is, kan in ieder geval worden vastgesteld dat de Hoge Raad niet duidelijk is geweest als het aankomt op de afbakening van de referentiegroep. De zinsnede "(...) een naar verhouding kleine groep van bedrijfsmatige varkensmesters die, anders dan het overgrote deel van

$4 \quad$ Zie ook Tjepkema 2010, p. 405 en 938.

$5 \quad$ Zie ter illustratie Backes 1993, p. 253 en 259.

6 Stcrt. 1986, nr. 66.

7 HR 18 januari 1991, ECLI:NL:HR:1991:AC4031, r.o. 3.1 en 3.7 (Leffers/Staat).

8 Tjepkema 2010, p. 367-371.

$9 \quad$ Kamerstukken II 2018/19, 34 986, nr. 3, p. 212 (MvT, IOw).

$10 \quad$ Van Ravels 2002, p. 278.

11 Zie het eerste onderdeel van de annotatie van Koopmans bij HR 3 april 1998, ECLI:NL:HR:1998:ZC2622 (Varkensmester Meiland) in NJ 1998/726. 
hun concurrenten, hun bedrijf geheel hadden ingericht op vervoedering van swill (...)" laat zowel ruimte voor de visie van het kabinet en Tjepkema als voor de visie van Koopmans en Van Ravels. Immers zouden onder "het overgrote deel van hun concurrenten" zowel de varkensmesters die deels met swill vervoederden als alle varkensmesters kunnen worden geschaard. Zelf sluit ik niet uit dat deze zinsnede dient te worden gelezen in het licht van de overweging dat de schadeveroorzakende regeling strekt tot de bescherming van belangen van "al diegenen die zich bezighouden met het fokken, verhandelen en exporteren van varkens, waarbij in het bijzonder het mesten soms bedrijfsmatig, soms niet bedrijfsmatig geschiedt." Dat zou pleiten voor een benadering waarbij de referentiegroep bestaat uit alle varkensmesters.

\section{Strenge en rekkelijke interpretaties van het criterium van de speciale last}

De hiervoor besproken interpretaties van het Leffers-arrest hebben gemeen dat zij alle kunnen worden gekwalificeerd als 'strenge' interpretaties van het criterium van de speciale last. Dergelijke interpretaties gaan ervan uit dat dient te worden vergeleken met andere getroffenen - al dan niet van dezelfde overheidsmaatregel. Dit heeft onder meer tot gevolg dat slechts een relatief beperkt aantal personen compensatie zal ontvangen. In de doctrine wordt soms echter ook een 'rekkelijke' interpretatie van de speciale last verdedigd. Auteurs die een rekkelijke visie aanhangen, zijn van mening dat een vergelijking met niet-getroffenen volstaat. Daarbij komen regelmatig formuleringen als "de overige leden van de samenleving" en "alle overige burgers" aan de orde. ${ }^{12}$ In dit proefschrift zal ik mij naast de kwalificaties 'strenge' en 'rekkelijke' ook bedienen van de kwalificatie 'gematigde' interpretatie van de speciale last. Daarmee beoog ik aan te geven dat zowel een strengere als een meer rekkelijke interpretatie denkbaar was geweest dan de interpretatie waarvoor het bestuur in het desbetreffende geval heeft gekozen.

Voor een strenge invulling van de speciale last kunnen enkele argumenten worden aangedragen. Allereerst is er het argument dat een niet-strenge invulling ertoe leidt dat van het criterium van de speciale last weinig tot niets overblijft. Wanneer gelaedeerden worden vergeleken met personen die geen schade hebben geleden, zal immers al snel de conclusie moeten worden getrokken dat sprake is van een speciale last. ${ }^{13}$ Dit argument leidt mijns inziens tot de conclusie dat in ieder geval soms een strenge invulling aan de speciale last moet worden gegeven. Anders kan dit criterium immers net zo goed worden geschrapt. Dit argument biedt echter geen houvast als het aankomt op de vraag of in een bepaald geval een strenge invulling op zijn plaats is, en zo ja, hoe streng die invulling dient te zijn.

In het verlengde van het eerstgenoemde argument ligt het rechtspolitieke argument dat van een rekkelijke invulling een verlammende werking op het bestuur 
zou kunnen uitgaan. Tjepkema stelt in dit kader dat "de eis van een speciale last wordt gesteld om te voorkomen dat de rechter het bestuur hindert door telkens wanneer een overheidshandeling een groep in de samenleving dupeert, te verlangen dat het bestuur een redelijke compensatie biedt voor al het dientengevolge geleden nadeel." 14 Ook voor dit argument geldt dat het geen houvast biedt als het aankomt op de vraag of in een bepaald geval een strenge invulling op zijn plaats is, en zo ja, hoe streng die invulling dient te zijn. Dit argument lijkt bovendien weinig rekening te houden met de aansprakelijkheidsbeperkende invloed van de andere criteria voor toekenning van nadeelcompensatie. Het tijdig publiceren van concrete beleidsvoornemens, voeren van een duurzaam beleid en het creatief omspringen met mogelijkheden om schade te beperken, kan naar huidig recht immers ervoor zorgen dat het aansprakelijkheidsrisico van het bestuur aanzienlijk wordt beperkt. ${ }^{15}$ Ook zal een deel van de gedupeerde groep bijvoorbeeld geen abnormale last ondervinden. Bovendien is meermaals in twijfel getroffen of aansprakelijkheidsrisico's daadwerkelijk in de weg staan aan besluitvorming, ${ }^{16}$ en zo ja, in hoeverre het terecht is dat het bestuur zich door die risico's laat beïnvloeden. ${ }^{17}$

Ten slotte is er een rechtsstatelijk argument. Op het moment dat een democratisch gekozen regelgever een bepaalde verdeling van lasten teweegbrengt, is het niet aan de rechter die deze democratische legitimering ontbeert om deze lastenverdeling door de toekenning van schadevergoeding (vrijwel geheel) terug te draaien. Het zou aan de regelgever moeten zijn om voor grote groepen gelaedeerden een schadevergoedingsregeling in het leven te roepen, waarbij doorgaans niet zozeer het égalitébeginsel maar solidariteit doorslaggevend is. Als de democratisch gelegitimeerde regelgever dat nalaat, zou de rechter slechts tot schadevergoeding moeten besluiten als sprake is van een onevenredige verdeling van lasten binnen de groep van gelaedeerden aan wie de desbetreffende regelgever deze lasten heeft opgelegd. ${ }^{18}$ Het rechtsstatelijk argument moet serieus worden genomen, maar roept tegelijkertijd ook vragen op. Wat betekent dit bijvoorbeeld voor lasten die voortvloeien uit besluiten genomen door bestuursorganen die niet (rechtstreeks) democratisch zijn gelegitimeerd? Is het wenselijk dat de inhoud van één van de criteria die het égalitébeginsel typeren wordt bepaald door het antwoord op de vraag of het schadeveroorzakende bestuursorgaan al dan niet democratisch is gelegitimeerd? Hoe zit het met niet-verdisconteerde schadeposten (die worden ondervonden door een grote groep personen)? Is het terecht dat het ontbreken van een schadevergoedingsregeling wordt gezien als reden om een strenge invulling aan

14 Zie Tjepkema 2010, p. 360-362; en Van Ravels 2002, p. 275-277.

15 Zie met name De Vries 2015 ten aanzien van het tijdig publiceren van beleidsvoornemens teneinde in een later stadium risicoaanvaarding tegen te kunnen tegenwerpen.

16 Zie in het kader van de totstandkoming van de IOw bijvoorbeeld SAOZ 2017, p. 8; Van den Broek \& Tjepkema 2016, p. 2824; en Planken \& Hazen 2017, p. 37-39. Zie anders: Nijmeijer 2017, p. 78.

17 Huijts \& Backes 2015, p. 138.

18 Zie Tjepkema 2010, p. 360-362; en Van Ravels 2002, p. 275-277. 
de speciale last te geven, of zou het beter zijn dat slechts te doen als de regelgever expliciet heeft aangegeven dat dit zijn bedoeling was? In het verdere verloop van dit hoofdstuk zal slechts op deze vragen worden ingegaan voor zover dat nodig is om de in paragraaf 1.2 opgeworpen onderzoeksvragen te beantwoorden.

\subsection{DEELVRAAG 2: VERSCHILLEN TUSSEN DE GESELECTEERDE, THANS GELDENDE REGELINGEN EN VERKLARINGEN DAARVOOR}

In deze paragraaf zal de tweede deelvraag worden beantwoord ten aanzien van het criterium van de speciale last. Daartoe zal allereerst worden nagegaan of dit criterium een rol speelt onder de geselecteerde regelingen, en zo ja, of en hoe het criterium in de desbetreffende regelingen is gecodificeerd (paragraaf 7.2.1). Daarbij zal onderscheid worden gemaakt tussen (1) regelingen waaronder de speciale last een rol speelt en waarin het criterium afzonderlijk wordt vermeld; (2) regelingen waaronder de speciale last een rol speelt, maar waarin het criterium niet afzonderlijk wordt vermeld; en (3) regelingen waaronder de speciale last geen rol speelt. Ten tweede wordt ingegaan op de wijze waarop de referentiegroep wordt afgebakend bij toepassing van de regelingen waaronder het criterium van de speciale last een rol speelt (paragraaf 7.2.2).

\subsubsection{De rol en codificatie van het criterium van de speciale last}

\section{Regelingen waaronder het criterium van de speciale last een rol speelt en waarin het ook afzonderlijk wordt vermeld}

Het criterium van de speciale last is gecodificeerd in art. 4 BnIW 2019. Deze bepaling lijkt qua formulering zowel een strenge als rekkelijke opvatting te behelzen:

"Schade (...) komt alleen voor vergoeding in aanmerking wanneer deze in belangrijke mate afwijkt van de schade die dientengevolge op een ieder drukt (rekkelijk), dan wel wanneer deze schade op een naar verhouding gering aantal natuurlijke of rechtspersonen die in vergelijkbare positie verkeren drukt (streng)." ${ }^{19}$

Onder de AVN wordt het criterium van de speciale last vertolkt door art. 2 lid 1 AVN. Dit artikel bepaalt dat schade slechts wordt vergoed voor zover de aanvrager "in het bijzonder" door het schadeveroorzakende overheidshandelen is getroffen. In tegenstelling tot de tekst van de BnIW 2019, biedt de tekst van de AVN dus geen aanwijzingen omtrent de afbakening van de referentiegroep.

Een verklaring voor het hierboven beschreven verschil tussen beide regelingen zou kunnen zijn gelegen in het moment waarop deze regelingen tot stand zijn

19 De tussen haakjes geplaatste woorden heb ik toegevoegd ter verduidelijking. Zie voor een vergelijkbare observatie: Tjepkema 2004, p. 13. 
gekomen. Afgaande op de bijbehorende toelichting heeft het er namelijk veel van weg dat de minister bij vaststelling van de RnVW 1999 met name het Leffersarrest heeft willen codificeren. ${ }^{20}$ Uit paragraaf 7.1 volgde dat uit dit arrest wel kan worden afgeleid dat een vergelijking met een referentiegroep moet worden gemaakt, maar tegelijkertijd discussie bestond - en thans nog steeds bestaat - omtrent de vraag waaruit die referentiegroep bestond en zou moeten bestaan. Het verbaast dan ook niet dat in de RnVW 1999 in ieder geval een element van vergelijking is neergelegd. Uit de toelichting op de AVN blijkt dat de Amsterdamse gemeenteraad er bewust (doch ongemotiveerd) voor heeft gekozen geen informatie in de AVN op te nemen omtrent de afbakening van de referentiegroep. ${ }^{21}$ De in art. 2 lid 1 AVN gebezigde formulering van "in het bijzonder" getroffen zijn, sluit goed aan op deze keuze. Ik sluit niet uit dat de Amsterdamse gemeenteraad zich bij de vaststelling van deze formulering heeft laten inspireren door het (twee jaar voor vaststelling van de AVN verschenen) proefschrift van Tjepkema. Hij stelt daarin voor om in titel 4.5 Awb de formulering van "in het bijzonder" getroffen zijn te hanteren, omdat daardoor meer rekening zou kunnen worden gehouden met de verscheidenheid van de onder deze titel te behandelen gevallen. Tjepkema merkt daarbij op dat het criterium van de speciale last zich "slecht leent voor een al te 'sturende' verwoording", omdat een vergelijking met anderen niet altijd een toegevoegde waarde heeft. ${ }^{22}$

2. Regelingen waaronder het criterium van de speciale last een rol speelt, maar waarin dit criterium niet wordt vermeld

\section{VNNZ}

In de tekst van de VNNZ is het criterium van de speciale last nergens terug te vinden. Uit de toelichting op de regeling blijkt dat dit een bewuste keuze van de Amsterdamse gemeenteraad is. Het gaat weliswaar om een relatief grote groep getroffenen, maar die groep ondervindt toch een speciale last omdat "de overgrote meerderheid van de Amsterdammers geen schade lijden [sic] als gevolg van de aanleg van de Noord/Zuidlijn. ${ }^{\prime 23}$ Deze rekkelijke invulling van het criterium heeft tot gevolg dat het criterium altijd voldaan zal zijn voor aanvragers die abnormale schade door de aanleg van de Noord/Zuidlijn ondervinden. Waarschijnlijk heeft de Amsterdamse gemeenteraad het criterium van de speciale last daarom niet in de VNNZ opgenomen. 


\section{Nadeelcompensatiecomponent van de GrS}

Van de verschillende grondslagen die volgens art. 9 lid $3 \mathrm{GrS}$ tot toekenning van nadeelcompensatie kunnen leiden, kent slechts de BnIW 2019 een bepaling die het criterium van de speciale last vertolkt. Dat laat onverlet dat de in art. 21 Aanwijzingsbesluit 1996 en art. 8.31 Wlv vervatte redelijkerwijsformules worden gezien als codificaties van het ongeschreven égalitébeginsel ${ }^{24}$ en dus ruimte laten tot toepassing van het criterium van de speciale last. Dat daar ook daadwerkelijk gebruik van wordt gemaakt, blijkt onder andere uit hierna nog te bespreken jurisprudentie waarin art. 21 Aanwijzingsbesluit 1996 de achterliggende grondslag voor toekenning van nadeelcompensatie vormde.

Dat in de GrS geen vermelding van het criterium van de speciale last wordt gemakkt, kan worden verklaard door de in paragraaf 3.2.1 beschreven, bijzondere aard van deze regeling: zij dient ertoe de reeds op grond van verschillende grondslagen bestaande - en aan verschillende bestuursorganen toekomende - bevoegdheden om nadeelcompensatie toe te kennen, binnen een specifieke context over te dragen aan het algemeen bestuur van het Schadeschap. Dat het criterium van de speciale last niet expliciet wordt vermeld in art. 21 Aanwijzingsbesluit 1996 en art. $8.31 \mathrm{Wlv}$, lijkt met name te worden verklaard doordat het ten tijde van de totstandkoming van deze regelingen nog niet gebruikelijk was om in nadeelcompensatieregelingen uit te werken wanneer aan de daarin vervatte redelijkerwijsformule werd voldaan. Voorts is voor de formulering van zowel art. 21 Aanwijzingsbesluit 1996 als art. 8.31 Wlv aansluiting gezocht bij art. $49 \mathrm{WRO}$, en in geval van art. $8.31 \mathrm{Wlv}$ ook bij art. 15.20 Wet milieubeheer. ${ }^{25}$

\section{Regelingen waaronder het criterium van de speciale last geen rol speelt}

\section{De planschadecomponent van de GrS}

In art. 49 WRO en de verwijzing daarnaar in art. 9 lid 1 jo. lid 2 GrS komt het criterium van de speciale last niet voor. Uit het door de besliscommissie van het Schadeschap opgestelde Basisdocument volgt dat de besliscommissie aansluiting zoekt bij de onder de WRO gewezen planschadejurisprudentie door het criterium van de speciale last niet te hanteren bij op art. 49 WRO gebaseerde aanvragen om planschadevergoeding. ${ }^{26}$ In die jurisprudentie lijkt het criterium van de speciale last inderdaad niet tot nauwelijks een rol te hebben gespeeld. Er zijn slechts enkele exotische uitspraken door de Hoge Raad gewezen en Koninklijke Besluiten door

Zie ABRvS 9 april 2008, ECLI:NL:RVS:2008:BC9040, r.o. 2.6, respectievelijk ABRvS 19 februari 2014, ECLI:NL:RVS:2014:572, r.o. 10.2 (Risicolocatie Schiphol).

25 Zie Stcrt. 1998, nr. 223, p. 11 (digitaal) respectievelijk Kamerstukken II 00/01, 27 603, nr. 3, p. 69 en 15.

26 Basisdocument, p. 47. 
de Kroon genomen ${ }^{27}$ waarin de gedachte van de speciale last kan worden herkend. Het duidelijkste voorbeeld wordt geboden door een arrest van 11 juni 1993 waarin de Hoge Raad het criterium expliciet lijkt toe te passen door te overwegen dat het Hof kon...

“(...) oordelen dat de positie van Ruijsch zich wat de waardedaling betreft niet, althans niet in voldoende mate, onderscheidt van die van de andere grondeigenaren in het betrokken gebied. Hierin ligt ook besloten dat het hof de gestelde vermogensschade niet 'onevenredig' acht, welk oordeel niet blijk geeft van een onjuiste rechtsopvatting en voor het overige berust op een aan het hof als feitenrechter voorbehouden waardering van feiten." ${ }^{28}$

In 1991 overwoog de AGRvS dat de opvatting dat een planologische schadeoorzaak eerst dan aanleiding tot vergoeding van planschade zal geven wanneer een individuele burger zwaarder wordt getroffen dan andere burgers in vergelijkbare omstandigheden in het verband van art. 49 WRO "niet alleen te vaag doch ook onjuist" is. Zij baseert zich daarbij op de wetsgeschiedenis van deze bepaling. Daaruit kan namelijk worden afgeleid dat het bij vergoeding van planschade op grond van art. 49 WRO niet gaat "om een onderlinge vergelijking tussen burgers in vergelijkbare omstandigheden doch om de vraag of door de wijziging van de planologische situatie een burger zwaarder wordt getroffen dan met de algemene sociale situatie in overeenstemming is." ${ }^{29}$ De ABRvS heeft in 1994 op vergelijkbare wijze geoordeeld..$^{30}$ Dit kan worden verklaard doordat de planschaderegeling van art. 49 WRO - en dus ook de planschadecomponent van de GrS - haar grondslag niet in het égalitébeginsel, maar in de materiële rechtszekerheid vond. ${ }^{31}$ Het is dan ook niet vreemd dat het criterium van de speciale last onder deze regeling geen rol speelde.

\section{Afd. 6.1 Wro}

Ook in afd. 6.1 Wro en de daaronder gewezen jurisprudentie (inclusief de Overzichtsuitspraak) komt het criterium van de speciale last niet voor. Het criterium is bovendien onderbelicht gebleven in de bij de Wro behorende Kamerstukken en

27 Zie KB 20 mei 1975, ECLI:NL:XX:1975:AR9927. Het is twijfelachtig of de Kroon in deze zaak daadwerkelijk beoogde het criterium van de speciale last toe te passen. Zie voor alternatieve verklaringen ook de annotatie van R.A. Morzer Bruyns in BR 1975, p. 540. In Tjepkema 2012, p. 389, voetnoot 29 wordt nog KB 9 november 1976, ECLI:NL:XX:1976:AM3523 (Dalfsen) genoemd. Ook in die zaak is het mijns inziens niet duidelijk of de Kroon daadwerkelijk beoogde het criterium van de speciale last toe te passen. HR 11 juni 1993, ECLI:NL:HR:1993:ZC0995, r.o. 2.5 (Ruijsch/Apeldoorn). AGRvS 28 januari 1991, ECLI:NL:RVS:1991:AN1978.

30 ABRvS 17 oktober 1994, ECLI:NL:RVS:1994:AS6059.

31 Zie paragraaf 2.2 onder het kopje 'De formele wetgever (jaren '50 en '60 van de 20e eeuw)'. 
de literatuur over deze regeling. Dat is opmerkelijk, aangezien deze regeling - anders dan art. $49 \mathrm{WRO}$ - niet is gebaseerd op de materiële rechtszekerheid maar op het door de (abnormale en) speciale last getypeerde ${ }^{32}$ égalitébeginsel. ${ }^{33}$ Wellicht moet het niet hanteren van het criterium van de speciale last onder de Wro als een historisch overblijfsel van (de praktijk van) art. 49 WRO worden gezien. Van den Broek en Tjepkema spreken in dit verband van de "moeizame relatie" tussen het égalitébeginsel en het omgevingsrecht. ${ }^{34}$ Naast deze historische verklaring zijn in de literatuur nog een aantal andere verklaringen aangedragen.

Ten eerste is aangevoerd dat het in veel gevallen nog maar de vraag is of hantering van het criterium van de speciale last onder afd. 6.1 Wro daadwerkelijk veel verschil zou maken. ${ }^{35}$ Bepaalde omgevingsgerelateerde maatregelen moeten nou eenmaal worden genomen en veroorzaken helaas nadeel voor een relatief kleine groep burgers. Deze kleine groep zou daardoor al snel een speciale last ten opzichte van de rest van de samenleving ondervinden. ${ }^{36}$ Ten tweede kan worden gewezen op een publicatie uit 2008 waarin Van Ravels het in de jaren '90 door de AGRvS en ABRvS aangevoerde argument van vaagheid in herinnering roept. Tevens waarschuwt hij voor het risico dat hantering van het criterium van de speciale last de "praktische hanteerbaarheid" van de planschaderegeling en de mogelijkheid om de uitkomst van een planschadeprocedure in te schatten te veel zal schaden. ${ }^{37}$ Beide verklaringen leggen mijns inziens onvoldoende gewicht in de schaal, omdat zij vallen of staan met de wijze waarop de referentiegroep wordt afgebakend. Het criterium van de speciale last zal inderdaad weinig onderscheidend zijn indien de rest van de samenleving als referentiegroep wordt gehanteerd. Het eerder besproken arrest van 11 juni 1993 illustreert echter dat ook meer afgebakende referentiegroepen denkbaar zijn. Het criterium van de speciale last heeft dan duidelijk wel een onderscheidende werking. Voor (te veel) vaagheid hoeft bovendien niet te worden gevreesd zolang de wetgever en/of rechter duidelijke richtlijnen omtrent de afbakening van de referentiegroep geven. ${ }^{38}$

Ten derde wijs ik op de door Van Ravels aangedragen verklaring dat in de bij de Wro behorende toelichtende stukken niet tot nauwelijks aandacht is besteed aan het criterium van de speciale last, en geen afstand is genomen van de onder art. 49 WRO gewezen jurisprudentie waarin de Afdeling niet toestond dat dit criterium werd gehanteerd. Het hanteren van het criterium van de speciale last zou boven-

32 Zie paragraaf 1.1; Tjepkema 2012, p. 388; en Kamerstukken II 2010/11, 32 621, nr. 3, p. 13, 23 (MvT, Wns).

33 Kamerstukken II 2011/12, 33 135, nr. 3, p. 13 (MvT, Wet tot wijziging van de Crisis- en herstelwet). Zie voorts paragraaf 2.3.1 onder het kopje 'Waardevolle geschiedenis'.

$34 \quad$ Van den Broek \& Tjepkema 2015, p. 6.

35 Van Ravels 2014b, p. 38.

36 Zie voor een dergelijke redenering bijvoorbeeld Van den Broek 2007, p. 121-122.

37 Van Ravels 2008, p. 137-138.

38 Zie daarover ook paragrafen 7.4 en 7.5 . 
dien niet te verenigen zijn met passages uit de memorie van toelichting behorende bij de Wro waarin wordt aangegeven dat "de tijd niet rijp [is] voor een brede hercodificatie van het schadevergoedingsrecht, inclusief een definitieve regeling van de nadeelcompensatie, bij ruimtelijke beslissingen" en er eveneens geen sprake is van "een principiële inperking van het recht op planschadevergoeding." 39 Dat is op zich juist, al moet wel worden opgemerkt dat hier tegenover kan worden gesteld dat de geciteerde passages op zichzelf strijdig zijn met de hiervoor reeds aangehaalde wijziging in grondslag van materiële rechtszekerheid naar égalité.

Ten slotte is er de in 2011 door Van Ettekoven aangedragen verklaring dat de speciale last bij planschadezaken "oplost" in de abnormale last en derhalve "weinig" betekenis heeft. ${ }^{40}$ Het is onduidelijk hoe deze verklaring dient te worden geïnterpreteerd, mede omdat Van Ettekoven het 2\%-forfait uit art. 6.2 Wro in de desbetreffende publicatie - in afwijking van de heersende opvatting ${ }^{41}$ - aanduidde als een uiting van de speciale last. ${ }^{42}$ Misschien ging hij ervan uit dat aanvragers wiens schade uitstijgt boven het minimumforfait van art. 6.2 lid 2 Wro automatisch onevenredig zwaar worden getroffen ten opzichte van inwoners uit de desbetreffende gemeente die geen schade lijden, of schade lijden die dit minimumforfait niet ontstijgt. Dat is echter geen uitleg die overeenstemt met de bedoeling van de wetgever met art. 6.2 lid 2 Wro en de uitleg die door de rechter aan deze bepaling wordt gegeven. ${ }^{43}$

\subsubsection{De afbakening van de referentiegroep}

Hierna zal worden onderzocht hoe de referentiegroep wordt afgebakend onder de vier geselecteerde regelingen waaronder het criterium van de speciale last een rol speelt. Daartoe zal onder andere worden ingegaan op de afbakening van de referentiegroep bij schade door grote (infrastructurele) projecten. Dergelijke schade doet zich voor onder de GrS, VNNZ en BnIW 2019. De BnIW 2019 wordt - net als de AVN - echter ook toegepast op heel andere schades. Daarom zal ook in meer algemene zin aandacht worden geschonken aan de afbakening van de referentiegroep onder deze twee regelingen. Om dat op zinvolle wijze te kunnen doen, zal ik echter eerst ingaan op enkele algemene jurisprudentielijnen inzake de afbakening van de referentiegroep.

\section{Jurisprudentie omtrent beschikkingen en wettelijke voorschriften}

Vergeleken met de hoeveelheid jurisprudentie over het criterium van de abnormale last, is relatief weinig jurisprudentie omtrent het criterium van de speciale

39 Kamerstukken II 2002/03, 28 916, nr. 3, p. 62 (MvT, Wro).

$40 \quad$ Van Ettekoven 2011, p. 17.

41 Ook Van Ravels vraagt zich hardop af of de uitleg van Van Ettekoven wel correct is, zie Van Ravels 2011b, p. 258.

42 Van Ettekoven 2011, p. 22.

43 Zie paragraaf 6.2.1. 
last gewezen. De jurisprudentie die er wel is, ziet hoofdzakelijk op schade door beschikkingen en wettelijke voorschriften. De jurisprudentie omtrent beschikkingen is het duidelijkst. Zij leert dat de Afdeling het doorgaans verbonden aan bedrijfsvoering acht dat een vergunning aan een derde wordt verleend als aan de daarvoor geldende eisen wordt voldaan, of een vergunning wordt geweigerd of ingetrokken als niet (langer) wordt voldaan aan de eisen voor een dergelijke vergunning. Zij overweegt daarbij dat de positie van de aanvrager van nadeelcompensatie in zoverre niet verschilt van de positie van overige ondernemers die ook geconfronteerd kunnen worden met de toekenning van een vergunning aan een andere ondernemer, ${ }^{44}$ weigering van een eigen vergunningaanvraag, ${ }^{45}$ of intrekking van een eigen vergunning. ${ }^{46}$ Tjepkema merkt terecht op dat deze benadering ertoe leidt dat het criterium van de speciale last grotendeels overlapt met het criterium van de abnormale last. ${ }^{47}$

De jurisprudentie omtrent schade door wettelijke voorschriften is iets minder duidelijk, maar toont in ieder geval aan dat de situatie van de benadeelde doorgaans wordt vergeleken met de situatie van andere getroffenen. ${ }^{48}$ Het in paragraaf 7.1 besproken Leffers-arrest laat zien dat discussie kan bestaan omtrent de vraag wie die getroffenen zijn, of met welk deel daarvan de aanvrager dient te worden vergeleken (alle varkensboeren, of alleen de varkensboeren die deels of uitsluitend met Swill vervoederden). In dit verband kan bijvoorbeeld ook worden gewezen op een uitspraak van de rechtbank 's-Gravenhage van 3 februari 2010. De rechtbank overwoog dat de situatie van een fokster van vaarzen voor exportdoeleinden niet moest worden vergeleken met andere veehouderijen in het algemeen. Daartoe was van belang dat dergelijke bedrijven geen "volledig vergelijkbare positie" zouden hebben, omdat zij niet slechts vee fokken maar zich ook bezighouden met de productie van melk en vlees. Die productie was niet stilgelegd door de beweerdelijk schadeveroorzakende overheidsmaatregelen. Deze maatregelen hadden volgens de rechtbank "uitsluitend betrekking op het vervoer van (levend materiaal van) herkauwers en daarmee uitsluitend op de bedrijven die zich toeleggen op het fokken en verkopen van herkauwers." Deze benadering lijkt mij op zijn minst discutabel, omdat ook de eerder beschreven veehouderijen geen - al dan niet zelf gefokte - herkauwers mochten vervoeren en dus werden getroffen door de maatregelen. ${ }^{49}$

44 ABRvS 4 juni 2014, ECLI:NL:RVS:2014:2006, r.o. 7.

45 ABRvS 6 juli 2011, ECLI:NL:RVS:2011:BR0497, r.o. 2.4.

46 ABRvS 24 februari 2010, ECLI:NL:RVS:2010:BL5333, r.o. 2.4.2.

47 Tjepkema 2019, p. 467. De aangehaalde uitspraken worden allemaal besproken op p. 465 van deze publicatie.

48 Met zijn analyse van CBb 16 april 2009, ECLI:NL:CBB:2009:BI1934 laat Tjepkema zien dat soms ook andere gezichtspunten een rol lijken te kunnen spelen. Zie daarvoor Tjepkema 2019, p. 466. 
Jurisprudentie omtrent besluiten van algemene strekking, niet zijnde wettelijke voorschriften

Er bestaat nauwelijks jurisprudentie omtrent de speciale last bij andere schadeoorzaken dan beschikkingen en wettelijke voorschriften. ${ }^{50}$ Mogelijk kan de schaarste aan dit soort uitspraken deels worden verklaard doordat in algemene zin de gedachte leeft dat het criterium van de speciale last bij dit soort overige schadeoorzaken doorgaans onvoldoende onderscheidende werking heeft - in tegenstelling tot bijvoorbeeld het criterium van de abnormale last. ${ }^{51}$ Het lijkt niet onaannemelijk dat het bestuur, dat vanwege het besluitmodel het eerste oordeel omtrent de invulling van de speciale last zal moeten geven, er daarom regelmatig voor kiest het - in deze situaties weerbarstige en tot op zekere hoogte ongrijpbare - criterium van de speciale last rekkelijk in te vullen of in zijn geheel niet in te zetten. Dat lijkt zeker plausibel als het bestuur meent zijn aansprakelijkheid 'afdoende' te kunnen beperken met behulp van criteria waarop het meer grip heeft, zoals de criteria inzake abnormale last en risicoaanvaarding. Kiest het bestuur toch ervoor het criterium van de speciale last in te zetten, dan kan de daaraan gegeven invulling slechts door de rechter worden getoetst indien beroepsgronden tegen deze invulling worden ingesteld. Dat zal zich niet voordoen bij rekkelijke invullingen van de speciale last, behoudens gevallen waarin sprake is van een draagplichtige derde. ${ }^{52}$ Dergelijke gevallen doen zich echter nauwelijks voor buiten het planschaderecht, ${ }^{53}$ terwijl het criterium van de speciale last in het planschaderecht geen rol speelt.

Wordt in de jurisprudentie over dit soort schadeoorzaken wel ingegaan op de speciale last, dan geschiedt dat doorgaans niet in algemene uiteenzettingen ${ }^{54}$ over de vraag hoe in bepaalde gevallen de referentiegroep moet worden afgebakend en in welke mate de aanvrager zich van de overige leden van die referentiegroep moet onderscheiden. ${ }^{55}$ Dat maakt het voor benadeelden en hun gemachtigden lastig om in te schatten in hoeverre het zinvol is om in rechte op te komen tegen een bepaalde invulling van de speciale last. Ook bestuursorganen missen hierdoor de houvast die nodig is om het criterium meer, en met meer zelfvertrouwen in te zetten, óf juist te motiveren waarom de keuze wordt gemaakt om het criterium in een individueel geval niet aan de aanvrager tegen te werpen. Al met al lijkt

50 Onder het kopje 'De referentiegroep bij grote (infrastructurele) projecten' zal hierna nog worden ingegaan op enkele spaarzame - en bovendien duidelijk gemotiveerde - uitspraken gewezen in de context van schade door het Aanwijzingsbesluit 1996. Ook in paragraaf 7.3 komen nog enkele voorbeelden aan bod.

51 Zie bijvoorbeeld Kamerstukken II 2010/11, 32 621, nr. 3, p. 23-24 (MvT, Wns). Zie ook Kamerstukken I 2012/13, 32 621, nr. C, p. 7 (MvA I, Wns).

52 Van Ettekoven 2012, p. 336-337.

53 De reden daarvoor wordt onder verwijzing naar paragaaf 10.4.1 besproken in paragraaf 10.10.1 onder het kopje 'Horen van partijen door de adviescommissie'.

54 De hierna nog te bespreken, onder art. 21 Aanwijzingsbesluit 1996 gewezen jurisprudentie vormt wat dat betreft een uitzondering.

55 Zie bijvoorbeeld ook Schueler 2002, p. 133-134; Schueler 2005, p. 198; en Tjepkema 2010, p. 356. 
dus sprake van een vicieuze cirkel die tot gevolg heeft dat weinig duidelijkheid bestaat omtrent de wijze waarop de referentiegroep naar huidig recht moet worden vormgegeven bij dit type schadeoorzaken. Het ontstaan en de instandhouding van deze cirkel kunnen deels worden verklaard doordat de formele wetgever en lagere regelgevers tot op heden nauwelijks houvast hebben geboden omtrent de invulling van de speciale last.

\section{De toelichtingen behorende bij de BnIW 2019 en AVN}

In algemene zin valt op dat de BnIW 2019 en AVN ruimte laten voor zowel strenge als rekkelijke interpretaties van het criterium van de speciale last, maar dat de bij deze regelingen behorende toelichtingen met name in de richting van strenge interpretaties lijken te wijzen. Zo gaat de minister in de summiere toelichting op art. 4 BnIW 2019, onder verwijzing naar het Leffers-arrest, slechts in op het gedeelte van deze bepaling dat als strenge interpretatie van de speciale last kan worden aangemerkt. Naast enkele algemene overwegingen, valt te lezen dat de kring van getroffenen "beperkt en duidelijk bepaalbaar" moet zijn en dat van onevenredig nadeel in beginsel geen sprake is als "het nadeel een grotere groep van personen treft." ${ }^{56}$ Dat niet altijd wordt gekozen voor de strengst denkbare referentiegroep blijkt echter uit een op 16 maart 2016 gewezen Afdelingsuitspraak. Appellant leed schade vanwege de door de staatssecretaris van Infrastructuur en Milieu voor kleine rondvluchtbedrijven ingevoerde verplichting om een Air Operator Certificate (hierna: AOC) te hebben. Appellant had een dergelijk AOC niet aangevraagd, ondanks dat de staatssecretaris verschillende maatregelen had genomen om de lasten van de aanvraag en het behoud van een AOC voor kleine rondvluchtbedrijven te verzachten. De Afdeling overwoog met betrekking tot de speciale last slechts dat de staatssecretaris aan de afwijzing van de aanvraag om nadeelcompensatie terecht ten grondslag had gelegd dat appellant door de invoering van de AOC-verplichting niet onevenredig werd getroffen, omdat die verplichting voor alle rondvluchtbedrijven gold. ${ }^{57}$ Met andere woorden: de referentiegroep bestond uit alle rondvluchtbedrijven en appellant ondervond geen speciale last ten opzichte daarvan. Hoe de staatssecretaris tot deze referentiegroep is gekomen, blijkt niet uit de uitspraak. Wel kan worden opgemerkt dat zowel een rekkelijkere als een strengere benadering mogelijk was geweest. Immers had bijvoorbeeld ook kunnen worden vergeleken met alle luchtvaartbedrijven (vergelijk art. $4.1 \mathrm{Wlv}$ ) respectievelijk alle kleine rondvluchtbedrijven.

In de toelichting op art. 2 lid 1 AVN valt te lezen dat sprake dient te zijn van "een last die op een beperkte groep burgers of instellingen onevenredig zwaar drukt, zodat de gelijke behandeling met een vergelijkbare groep (de referentiegroep), die

57 ABRvS 16 maart 2016, ECLI:NL:RVS:2016:729, r.o. 2 en 4.3 (Air Operator Certificate). Bij mijn weten is dit een van de weinige - zo niet de enige - onder de BnIW 2019 gewezen (Afdelings)uitspraken waarin expliciet wordt ingegaan op het criterium van de speciale last. 
door de handeling wordt getroffen, wordt verstoord." De toekenning van nadeelcompensatie dient ertoe die ongelijke verhouding tussen de zwaarst getroffenen en de rest van de referentiegroep te herstellen. Nadeelcompensatie komt niet toe "aan een hele categorie van personen die een bepaald kenmerk gemeen hebben, maar alleen aan een subgroep uit deze categorie die door de overheidsmaatregel wordt getroffen." De Amsterdamse gemeenteraad geeft twee voorbeelden. Bij een wijziging van de sluitingstijden voor horeca-exploitanten kan slechts de schade van de horeca-exploitant die kan aantonen dat zijn onderneming onevenredig zwaar wordt getroffen in vergelijking met andere horecaondernemingen in aanmerking komen voor nadeelcompensatie. Het tweede voorbeeld betreft de winkelier die schade lijdt door de afsluiting van een straat voor gemotoriseerd verkeer wegens rioolwerkzaamheden. Deze winkelier zal moeten aantonen dat hij bijzonder is getroffen ten opzichte van de overige winkeliers in de straat. Naast deze voorbeelden vermeldt de toelichting ook nog dat de referentiegroep kan worden uitgebreid met benadeelden die door vergelijkbaar overheidshandelen schade lijden of hebben geleden.

De uit beide toelichtingen blijkende voorkeur voor een strenge interpretatie van de speciale last is verenigbaar met de hiervoor besproken jurisprudentie over beschikkingen en wettelijke voorschriften. In het geval van de AVN kan deze jurisprudentie mogelijk zelfs reden zijn geweest om de voorkeur voor een strenge interpretatie uit te spreken. De opmerking uit de bij deze regeling behorende toelichting dat de referentiegroep kan worden uitgebreid met benadeelden die door vergelijkbaar overheidshandelen schade lijden of hebben geleden, kan mogelijk eveneens worden verklaard door de jurisprudentie omtrent beschikkingen. Daarin wordt immers niet concreet vergeleken met degenen die daadwerkelijk door de schadeveroorzakende beschikking(en) zijn getroffen, maar abstract vergeleken met degenen die door een vergelijkbare beschikking hadden kunnen worden getroffen. Een aanvullende verklaring voor deze opmerking zou wellicht kunnen worden gevonden in de gedachte dat gemeentelijke maatregelen in vergelijking tot maatregelen op rijksniveau doorgaans slechts bij een relatief klein aantal personen tot (abnormale) schade zullen leiden. Dat zou tot gevolg kunnen hebben dat het op gemeentelijk niveau lastig(er) is een adequate invulling te geven aan de (vergelijking met een) referentiegroep.

\section{De referentiegroep bij grote (infrastructurele) projecten}

In enkele door een schadecommissie als bedoeld in art. 15 lid 1 BnIW 2019 uitgebrachte adviezen - die door de minister in zijn besluitvorming zijn overgenomen - inzake aanvragen om compensatie van schade geleden door de ondertunneling van de A2 te Maastricht wordt een strenge invulling aan het criterium van de speciale last gegeven. Daarin wordt namelijk het volgende overwogen onder het kopje 'speciale last': 
"Het plangebied van het Tracébesluit is groot. Van het Europaplein ten zuiden van Maastricht tot en met een deel van de gemeente Meerssen ten noorden van Maastricht. De maatregelen uit het Tracébesluit zijn naar aard en omvang zodanig ingrijpend dat de invloed daarvan in een groter gebied te merken is, tot ruim buiten de begrenzing van het Tracébesluit. Er is dus een grote groep personen (en/of bedrijven) die in meer of mindere mate hinder ondervindt als gevolg van de uitvoering van het Tracébesluit. De commissie moet in dit kader beoordelen of verzoeker binnen deze groep onevenredig zwaar wordt belast."

Per geval werd bekeken of het gedeelte van het plangebied waar de verzoeker woonde "relatief zwaar" werd belast met werkzaamheden ten opzichte van andere delen van het plangebied. Daarbij werd in algemene zin gelet op onder andere de intensiviteit, duur en frequentie van de werkzaamheden. ${ }^{58}$ Meer specifiek lijken met name twee factoren een belangrijke rol te hebben gespeeld. ${ }^{59}$ Enerzijds betreft dit de afstand van de werkzaamheden tot de woning van de benadeelde. Zo werd een afstand van 100 tot 120 meter als "ruim" aangemerkt in vergelijking met de afstand tot veel andere woningen langs het tracé. Anderzijds gaat het om de vraag of er bebouwing is die de woning van de benadeelde van de werkzaamheden afschermt. In de regel werd geen speciale last aangenomen indien dergelijke afschermende bebouwing aanwezig was. Door mijn voormalige werkzaamheden aan het Infopunt Schade A2 Maastricht is mij bekend dat daardoor met name bij bewoners van 'eerstelijns bebouwing' een speciale last werd aangenomen. ${ }^{60}$

Uit jurisprudentie volgt dat de Afdeling bij schade door het Aanwijzingsbesluit 1996 stelselmatig oordeelt dat een speciale last is opgelegd "aan de verhoudingsgewijs beperkte groep bewoners van woningen gelegen binnen de geluidzones" (geluidsbelasting van meer dan $35 \mathrm{Ke}$ tot meer dan $65 \mathrm{Ke}$ ), ten opzichte van "de bewoners van woningen die wel binnen de invloedsfeer van de luchthaven Schiphol, maar buiten de geluidzones liggen" (minder dan 35 Ke geluidsbelasting). ${ }^{61}$ De Afdeling heeft hiermee gekozen voor een gematigde interpretatie van de speciale last. Er was immers zowel een strengere interpretatie (vergelijking van de bena-

Wat dat betreft zie ik enige gelijkenis met de factoren 'aard, ernst en duur', die worden gebruikt om het normaal maatschappelijk risico af te bakenen bij schade in de vorm van tijdelijke derving van woongenot. Zie daarover paragrafen 6.4.1.2 en 6.4.1.3.

59 Beide factoren kunnen ook een rol spelen bij het vaststellen van de omvang van de schade. Zie bijvoorbeeld ABRvS 12 juni 2019, ECLI:NL:RVS:2019:1884, r.o. 24, respectievelijk ABRvS 19 december 2018, ECLI:NL:RVS:2018:4193, r.o. 52-60 (Grondgeluid). In de Maastrichtse casus werden deze factoren echter (ook) gebruikt ter invulling van het criterium van de speciale last.

60 Zat een 'lek' in de afscherming door deze eerstelijns bebouwing dan was denkbaar dat ook een speciale last werd aangenomen bij bewoners van tweedelijns bebouwing.

61 ABRvS 19 februari 2014, ECLI:NL:RVS:2014:572, r.o. 9.1 (Risicolocatie Schiphol); ABRvS 10 november 2010, ECLI:NL:RVS:2010:BO3436, r.o. 2.4; en ABRvS 9 april 2008, ECLI:NL:RVS:2008:BC9040, r.o. 2.6. 
deelde met personen wiens woningen zijn gelegen binnen de geluidszones) als een meer rekkelijke interpretatie (vergelijking van de benadeelde met personen wiens woningen zijn gelegen buiten zowel de geluidszones als de invloedsfeer van Schiphol) mogelijk geweest. Er is geen jurisprudentie omtrent de speciale last gewezen die betrekking heeft op de overige grondslagen die onder de GrS tot toekenning van nadeelcompensatie kunnen leiden. ${ }^{62}$ Onder die grondslagen speelt bovendien niet de bijzondere omstandigheid dat de minister gedurende 18 jaar heeft nagelaten te voldoen aan zijn wettelijke plicht om degelijke geluidsnormering vast te stellen. ${ }^{63}$ Het is daarom onbekend of onder deze grondslagen een andere invulling aan de speciale last zou zijn gegeven dan onder art. 21 Aanwijzingsbesluit 1996.

Uit paragraaf 7.2.1 bleek ten slotte dat de Amsterdamse gemeenteraad ervoor heeft gekozen het criterium van de speciale last niet in de VNNZ op te nemen. De achterliggende gedachte is dat de personen die abnormale schade door de aanleg van de Noord/Zuidlijn lijden automatisch een speciale last ondervinden ten opzichte van de Amsterdammers die dat niet doen. Dit betreft uiteraard een rekkelijke interpretatie van het criterium.

\section{Verklaringen voor de verschillen in referentiegroep bij grote (infrastructurele) projecten}

Hiervoor bleek dat het criterium van de speciale last streng werd ingevuld onder de BnIW 2019 bij de ondertunneling van de A2 te Maastricht, gematigd onder de GrS bij schade door het Aanwijzingsbesluit 1996, en rekkelijk onder de VNNZ. Deze verschillen lijken met name te kunnen worden verklaard door de eerder beschreven schaarste aan jurisprudentie over de speciale last bij andere schadeoorzaken dan beschikkingen en wettelijke voorschriften. Door deze schaarste lijkt het bestuur in dit soort gevallen namelijk - in ieder geval praktisch gezien - relatief veel ruimte toe te komen om een strenge of rekkelijke invulling aan het criterium van de speciale last te geven. De gevonden verschillen tussen (de toepassing van) de onderzochte regelingen bij grote (infrastructurele) projecten lijken dan ook tot op grote hoogte af te hangen van de voorkeur van het individuele bestuursorgaan voor een rekkelijke of strenge invulling - en dus tot op grote hoogte willekeurig te zijn. Behalve het gegeven dat deze regelingen worden toegepast door verschillende bestuursorganen, lijken er namelijk geen objectieve argumenten ${ }^{64}$ te bestaan voor de geconstateerde verschillen in referentiegroepen. Dat geldt zeker nu de

62 Uiteraard is dergelijke jurisprudentie wel gewezen onder de BnIW 2019 en het ongeschreven égalitébeginsel, maar in de desbetreffende zaken werden deze grondslagen niet toegepast in de context van de GrS.

63 Zie paragraaf 4.2.3.2.

64 Het langdurig verzaken van de plicht degelijke geluidsnormering vast te stellen had zo een objectief argument kunnen zijn voor wat betreft schade door het Aanwijzingsbesluit 1996, maar had dan eerder ervoor gepleit het criterium zo rekkelijk mogelijk in te vullen door de speciale last te veronderstellen. 
aanleg van de Noord/Zuidlijn en de ondertunneling van de A2 te Maastricht qua type werkzaamheden en grootschaligheid vergelijkbaar zijn. Er bestaat weliswaar een verschil in de tijd die de werkzaamheden in beslag namen (ongeveer vijftien jaar in Amsterdam en ongeveer zes jaar in Maastricht $)^{65}$ maar ik heb nergens uit kunnen afleiden dat de lange duur van de Amsterdamse werkzaamheden een rol speelde bij de afweging om de speciale last rekkelijk in te vullen.

\subsubsection{Conclusie}

Ter beantwoording van de tweede deelvraag is in deze paragraaf onderzoek gedaan naar de verschillen in de wijze waarop de geselecteerde, thans geldende regelingen invulling aan het criterium van de speciale last geven en de verklaringen die daarvoor kunnen worden aangedragen. Wanneer deze regelingen worden vergeleken, vallen allereerst verschillen op ten aanzien van de vraag of het criterium van de speciale last überhaupt wel wordt toegepast, en zo ja, of en op welke wijze dit criterium in de desbetreffende regelingen is gecodificeerd: (1) Zowel in de BnIW 2019 als in de AVN is een afzonderlijke bepaling aan de speciale last gewijd. Verschillen in formulering lijken met name te kunnen worden verklaard door de tijd waarin deze regelingen tot stand zijn gekomen. (2) Het criterium van de speciale last speelt ook een rol onder de VNNZ en de nadeelcompensatiecomponent van de GrS. Dat het criterium desondanks niet wordt vermeld in de VNNZ lijkt te kunnen worden verklaard door de rekkelijke invulling die onder de VNNZ aan het criterium wordt gegeven. Dat het criterium niet wordt vermeld in art. 21 Aanwijzingsbesluit 1996 en art. 8.31 Wlv lijkt met name te worden verklaard doordat het ten tijde van de totstandkoming van deze regelingen nog niet gebruikelijk was om in nadeelcompensatieregelingen uit te werken wanneer aan de daarin vervatte redelijkerwijsformule werd voldaan. (3) Het criterium van de speciale last speelt geen rol onder art. 49 WRO en afd. 6.1 Wro. Ten aanzien van de WRO moet een verklaring daarvoor worden gevonden in de rechtspraak van de AGRvS en ABRvS waarin werd bepaald dat hantering van het criterium van de speciale last "niet alleen te vaag doch ook onjuist" zou zijn. Die jurisprudentielijn kan worden verklaard vanuit de gedachte dat art. 49 WRO zijn grondslag niet in het égalitébeginsel, maar in de materiële rechtszekerheid vond. Dat het criterium van de speciale last ook geen rol speelt onder de wel op égalité gebaseerde planschaderegeling van afd. 6.1 Wro kan als een historisch overblijfsel uit het WRO-tijdperk worden gezien.

Ten tweede vallen verschillen op ten aanzien van de wijze waarop de referentiegroep wordt afgebakend onder de regelingen waaronder het criterium van de speciale last een rol speelt. Deze verschillen doen zich met name voor bij schade door grote (infrastructurele) projecten. Vanwege een gebrek aan (duidelijke en

65 Zie ten aanzien van de Noord/Zuidlijn bijvoorbeeld www.metronieuws.nl/amsterdam/2018/07/na-15-jaar-bouwen-eindelijk-open-noord-zuidlijn. Zie ten aanzien van de A2 te Maastricht bijvoorbeeld www.a2maastricht.nl/nl/mijlpalen/uitvoering-2010-2017.aspx. 
richtinggevende) jurisprudentie ten aanzien van andere schadeoorzaken dan beschikkingen en wettelijke voorschriften lijkt het bestuur in dit soort gevallen - in ieder geval praktisch gezien - relatief veel ruimte toe te komen om een strenge of rekkelijke invulling aan het criterium van de speciale last te geven. De gevonden verschillen tussen (de toepassing van) de onderzochte regelingen lijken op dit punt dan ook tot op grote hoogte te worden veroorzaakt door de voorkeur van het individuele bestuursorgaan voor een rekkelijke of strenge invulling, en daarmee tot op grote hoogte willekeurig te zijn. Dat in de toelichting op de AVN in algemene zin wordt aangegeven dat de referentiegroep kan worden uitgebreid met benadeelden die door vergelijkbaar overheidshandelen schade lijden of hebben geleden, zou wellicht eveneens kunnen worden verklaard door jurisprudentie omtrent de speciale last bij schade door beschikkingen. Een aanvullende verklaring voor deze opmerking zou kunnen worden gevonden in de gedachte dat gemeentelijke maatregelen in vergelijking tot maatregelen op rijksniveau doorgaans slechts bij een relatief klein aantal personen tot (abnormale) schade zullen leiden. Dat zou namelijk tot gevolg kunnen hebben dat het op gemeentelijk niveau lastig(er) is een adequate invulling te geven aan de (vergelijking met een) referentiegroep.

\subsection{DeElVAag 3: Het TOEKOMSTIGE RECHT}

De wetgever heeft het criterium van de speciale last gecodificeerd door in art. 4:126 lid 1 Awb te bepalen dat de "benadeelde in vergelijking met anderen onevenredig zwaar" dient te worden getroffen door de schade die hij lijdt door het schadeveroorzakende overheidshandelen. Afd. 15.1 Ow kent geen zelfstandige bepaling omtrent de speciale last en bepaalt ook niet dat op dit punt van titel 4.5 Awb wordt afgeweken. Vanuit wetssystematisch perspectief zou het criterium van de speciale last als neergelegd in art. 4:126 lid 1 Awb daarom ook van toepassing moeten zijn op aanvragen om nadeelcompensatie die onder de reikwijdte van afd. 15.1 Ow vallen. Dat wordt (impliciet) bevestigd door de bij de IOw behorende memorie van toelichting. In algemene zin wordt daarin namelijk opgemerkt dat het criterium van de speciale last inhoudt dat "sprake moet zijn van een last die op een beperkte groep burgers of bedrijven onevenredig zwaar drukt ten opzichte van een vergelijkbare groep (de referentiegroep).” Een referentiegroep zou daarom over het algemeen bestaan uit een beperkte groep, hetgeen bijvoorbeeld meebrengt dat....

“(...) de situatie van een eigenaar van een archeologisch rijksmonument wordt vergeleken met de situatie van andere eigenaren van een vergelijkbaar archeologisch rijksmonument. Alleen wanneer een specifieke groep of benadeelde zich ten opzichte van de referentiegroep zou onderscheiden waarvoor de last onevenredig hoog is, komt deze (specifieke groep van) benadeelde(n) voor nadeelcompensatie in aanmerking op grond van het égalitébeginsel." ${ }^{66}$ 
Deze opmerking is echter weinig precies en roept de vraag op of de referentiegroep bestaat uit alle eigenaren van een vergelijkbaar archeologisch rijksmonument, of slechts uit de eigenaren van een vergelijkbaar archeologisch rijksmonument die worden getroffen door dezelfde (of eventueel juist een soortgelijke) planologische maatregel.

Ook overigens roept de bij de IOw behorende memorie van toelichting vragen op. Zo wordt daarin bijvoorbeeld vermeld dat...

“(...) het vereiste van de speciale last (...) ervoor [kan] zorgen dat, ondanks het feit dat sprake is van een last die binnen het normale maatschappelijke risico valt, de schade of kosten vanwege de speciale last wel voor vergoeding in aanmerking komen." ${ }^{67}$

Dat is opmerkelijk omdat de formulering van art. 4:126 Awb geen ruimte laat om deze criteria niet als cumulatief te zien. Ook de opmerking uit de bij de Wns behorende memorie van toelichting dat de criteria van abnormale en speciale last naar gelang de omstandigheden van het geval meer of minder onderscheidende werking kunnen hebben, lijkt onvoldoende ruimte te bieden voor een dergelijke lezing van art. 4:126 Awb. ${ }^{68} \mathrm{Mij}$ is bovendien geen jurisprudentie bekend waarin het criterium van de speciale last op deze manier is toegepast. Dat is te verklaren doordat het niet logisch is om schade die tot het normaal maatschappelijk risico behoort te compenseren om de enkele reden dat bepaalde burgers meer binnen het normaal maatschappelijk risico vallende schade zouden lijden dan andere burgers die zich in een vergelijkbare positie bevinden. Ook het in de bij de IOw behorende memorie van toelichting aangehaalde Leffers-arrest biedt - in tegenstelling tot hetgeen het kabinet in een eerdere versie van deze memorie van toelichting beweer$\mathrm{de}^{69}$ - geen voorbeeld van een situatie waarin niet-abnormale schade werd vergoed vanwege de aanwezigheid van een speciale last. ${ }^{70}$ De Hoge Raad oordeelde immers dat Leffers behoorde tot een groep van ondernemers die "in onevenredige mate" in haar belangen werd getroffen én dat Leffers' schade niet tot zijn normale bedrijfsrisico behoorde. ${ }^{71}$

Al met al kan dus worden geconcludeerd dat de bij de IOw behorende memorie van toelichting niet veel duidelijkheid schept als het aankomt op de vraag (wanneer en) hoe het criterium van de speciale last onder afd. 15.1 Ow moet worden toegepast. Dat is des te opmerkelijker nu kennelijk wordt beoogd om af te wijken van de decennia bestaande planschadepraktijk waarin het criterium van de speciale last geen rol van betekenis heeft gespeeld. Kan de afwezigheid van een uitgebreide toelichting wellicht worden verklaard doordat de memorie van toelichting daarvan in Kamerstukken I 2012/13, 32 621, nr. C, p. 7 (MvA I, Wns).

69 MvT IOw als voorgelegd aan de AARvS, p. 190.

70 Kamerstukken II 2018/19, 34 986, nr. 3, p. 235 (MvT, IOw).

71 HR 18 januari 1991, ECLI:NL:HR:1991:AC4031, r.o. 3.1 en 3.7 (Leffers/Staat). 
behorende bij de Wns reeds voldoende duidelijkheid verschafte over de invulling van het criterium van de speciale last als neergelegd in art. 4:126 Awb? Ook dat is mijns inziens niet het geval, aangezien de spaarzame informatie die daarin omtrent de speciale last wordt verstrekt innerlijk tegenstrijdig is. In het algemene deel van deze memorie van toelichting lijkt een rekkelijke interpretatie te worden beschreven: er zou moeten worden vergeleken met een "vergelijkbare groep (de «referentiegroep») die niet door de handeling wordt getroffen."72 In de artikelsgewijze toelichting wordt echter een strenge interpretatie tentoongespreid: aan het criterium van de speciale last zou zijn voldaan als "de gelijke behandeling van een groep burgers of instellingen (vaak aangeduid als de «referentiegroep») wordt verstoord doordat de schade bij een klein deel van die groep terecht komt, terwijl anderen in een min of meer gelijke positie niet of veel minder getroffen worden." Deze tegenstrijdigheid viel destijds ook enkele Eerste Kamerleden op. Zij onderwierpen het toenmalige kabinet naar aanleiding daarvan aan een spervuur van vragen dat als volgt kan worden samengevat: 'Hoe dient de referentiegroep te worden afgebakend en verschilt dit naar gelang het type schadeveroorzakend besluit (algemeen verbindend voorschrift - beschikking - besluit van algemene strekking)?'73 Op 2 november 2012 deed dat kabinet een poging om deze vragen te beantwoorden aan de hand van de onderstaande categorisering van schadeoorzaken.

\section{Algemeen verbindende voorschriften}

Onder verwijzing naar de arresten Leffers en Harrida stelt het kabinet dat uit de jurisprudentie zou volgen dat...

“(...) bij schade die het gevolg is van een algemeen verbindend voorschrift, niet wordt vergeleken met allen die door dat voorschrift worden geraakt, maar dat wordt bezien of er binnen die grotere groep een of enkelen onevenredig zijn benadeeld."

Anders dan de formulering van dit citaat suggereert, bestaat er geen verschil tussen de daarin genoemde vergelijkingsmaatstaven. Om te bepalen of één of enkele personen onevenredig zijn benadeeld binnen de grotere groep personen die door het voorschrift is geraakt, moet immers worden vergeleken met iedereen binnen die groep, oftewel allen die door het voorschrift worden geraakt. ${ }^{74}$ De opmerking dat niet wordt vergeleken met allen die door het voorschrift worden geraakt, lijkt eveneens niet op zijn plaats gezien de verwijzingen naar Leffers en Harrida. Met betrekking tot het Leffers-arrest kan nog discussie bestaan omtrent wat nu de precieze referentiegroep was. Met betrekking tot het Harrida-arrest staat echter vast dat de referentiegroep bestond uit "de groep van ondernemers die dierlijke producten uit het Verenigd Koninkrijk importeerden, hetzij in de vorm van levende dieren die in Nederland werden vetgemest en geslacht, hetzij in de vorm van reeds in 
het Verenigd Koninkrijk geslacht rundvee.” De referentiegroep bestond daarmee uit alle ondernemers die door het importverbod, zijnde een algemeen verbindend voorschrift, werden getroffen. ${ }^{75}$ Afgaande op het voorafgaande zou de referentiegroep bij schade door algemeen verbindende voorschriften dus wel degelijk bestaan uit allen die door het voorschrift worden getroffen. ${ }^{76}$ Dat betreft een strenge invulling van de speciale last, aangezien slechts degenen die het zwaarst door het voorschrift worden getroffen een speciale last ondervinden ten opzichte van de overige getroffenen.

Terugverwijzend naar het hiervoor aangehaalde citaat over algemeen verbindende voorschriften, ${ }^{77}$ merkt het kabinet nog het volgende op:

“(...) wanneer een wettelijk voorschrift beoogt een bepaalde groep te treffen omdat zij bepaalde «intrinsieke eigenschappen» vertoont die de aanleiding vormden om het wettelijke voorschrift uit te vaardigen, dan dient deze groep het uit dit voorschrift voortvloeiende nadeel in beginsel te aanvaarden. Alleen een binnen die groep te onderscheiden subgroep zou zich succesvol op het égalitébeginsel kunnen beroepen, zo bleek hiervoor reeds." 78

Dit betreft eveneens een strenge invulling van de speciale last. Het kabinet legt echter niet uit wat onder 'intrinsieke eigenschappen' moet worden verstaan en welk van die eigenschappen een rol kan spelen bij de afbakening van de referentiegroep. Bovendien wordt niet vermeld hoe dient te worden omgegaan met algemeen verbindende voorschriften/wettelijke voorschriften die een bepaalde groep burgers treffen terwijl dit niet werd beoogd vanwege de intrinsieke eigenschappen van deze groep. Voor zover ik kan nagaan, komt de term intrinsieke eigenschappen niet voort uit jurisprudentie. Waarschijnlijk is deze term overgenomen uit het proefschrift van Tjepkema, waarin wordt gerefereerd aan de stelregel van Delvolvé dat "de referentiegroep moet worden bepaald aan de hand van de 'intrinsieke eigenschappen' van die groep." Volgens Tjepkema brengt deze regel mee dat "voor de afbakening van de relevante referentiegroep moet worden bezien uit hoofde van welke kenmerken een maatregel een bepaalde groep in de maatschappij beoogt te treffen." Heeft de regelgever geen bijzondere schadevergoedingsregeling getroffen, dan zouden slechts de zwaarst getroffenen uit deze referentiegroep voor

Zie paragraaf 7.1 .

76 Dat lijkt eveneens in overeenstemming te zijn met Tjepkema 2010, p. 371. Daarin wordt onder andere gesproken van de lijn "dat de referentiegroep wordt gevormd door de groep waarop een wettelijk voorschrift van toepassing is".

77 Ik ga ervan uit dat ook het kabinet de termen algemeen verbindend voorschrift en wettelijk voorschrift als synoniem gebruikt. Zie bijvoorbeeld Kamerstukken II 1994-1995, 23 700, nr. 5, p. 112, onderdeel 7.6 (NV II); en Van der Heijden 2006, p. 29. 
compensatie in aanmerking kunnen komen. ${ }^{79}$ Deze benadering hangt samen met het in paragraaf 7.1 besproken rechtsstatelijke argument.

\section{Nimby-gevallen}

De als tweede door het kabinet benoemde categorie kwalificeer ik als de "not in my backyard-gevallen' (hierna: nimby-gevallen). ${ }^{80}$ Het betreft ontwikkelingen waarvan algemeen is geaccepteerd dat deze wenselijk zijn, maar die niemand in zijn achtertuin wil hebben. ${ }^{81}$ Het kabinet spreekt zelf van maatregelen die grote groepen burgers treffen, zoals grote infrastructurele projecten. Voor schade door dit soort maatregelen zou regelmatig een nadeelcompensatieregeling in het leven worden geroepen, waarbij "mensen die nadeel ondervinden van de maatregel [plegen] te worden vergeleken met mensen die geen nadeel ondervinden van de maatregel." Het kabinet refereert in dit kader aan de 'Regeling Nadeelcompensatie Betuweroute', die is opgesteld ter compensatie van de schade die rechtmatig werd veroorzaakt door de aanleg van de Betuweroute (een door de Rijksoverheid aangelegde goederenspoorlijn van ongeveer $160 \mathrm{~km}$ tussen de Rotterdamse haven en Duitsland) ${ }^{82}$ Ook de Verordening Nadeelcompensatie en Planschade NoordZuidlijn, de voorganger van de VNNZ, ${ }^{83}$ wordt genoemd. ${ }^{84}$

\section{Overige besluiten van algemene strekking}

Met betrekking tot overige besluiten van algemene strekking zijn volgens het kabinet geen richtlijnen te geven vanwege het casuïstische karakter van de jurisprudentie. Zo zouden verkeersmaatregelen meestal een “onbepaalde groep personen" treffen. Vaak zou een aanvraag om nadeelcompensatie in dergelijke gevallen stuklopen wegens de afwezigheid van een abnormale last. ${ }^{85} \mathrm{Al}$ zouden echter ook gevallen zijn aan te wijzen waarin wel een vergelijking met anderen wordt gemaakt. ${ }^{86}$ Als voorbeeld wordt een uitspraak van de rechtbank Zutphen genoemd. ${ }^{87}$

Zie Tjepkema 2010, p. 370 en 361 e.v.

Soms wordt ook weleens de term 'NIVEA' - niet in voor en achtertuin - gebruikt, zie bijvoorbeeld Bregman \& Karens 2017.

1 Zie onder andere Schueler 2002, p. 135; Schueler 2005, p. 200; en Tjepkema 2010, p. 395-396. Zie voorts Bregman \& Karens 2017 voor een publicatie die geheel is gewijd aan "de balans tussen algemeen belang en rechtsbescherming en nadeelcompensatie voor de burger."

Stcrt. 1996, nr. 189.

Zie paragraaf 2.3.3 onder het kopje 'Waardevolle geschiedenis'. Kamerstukken I 2012/13, 32 621, nr. C, p. 7 (MvA I, Wns).

Als voorbeeld verwijst het kabinet naar ABRvS 14 juli 2004, ECLI:NL:RVS:2004:AQ1051, r.o. 2.7-2.7.1. In deze uitspraak had appellante niet voldoende aannemelijk gemaakt dat er daadwerkelijk sprake was van schade die het normaal maatschappelijk risico ontsteeg.

Kamerstukken I 2012/13, 32 621, nr. C, p. 6 (MvA I, Wns).

87 Rb. Zutphen 16 februari 1998, ECLI:NL:RBZUT:1998:AA6732, r.o. 4.4. 
Daarin stond de aanvraag centraal van een rijschoolhouder die schade had geleden door een verkeersbesluit tot tijdelijke sluiting van een brug. De rechtbank oordeelde dat deze rijschoolhouder geen onevenredig nadeel had ondervonden ten opzichte van "andere (rijschool)ondernemers" die nadeel van de brugafsluiting hadden ondervonden. Een ander voorbeeld betreft een Koninklijk Besluit uit 1990 waarin modehuizen die schade ondervonden door een verkeersmaatregel werden vergeleken met andere winkels in (de nabijheid van) het centrum. ${ }^{88}$ Noch uit de toelichting door het kabinet, noch uit de motivering door de rechtbank respectievelijk Kroon volgt echter waarom de referentiegroepen juist op deze wijze zouden moeten worden afgebakend.

Het lijkt niet onaannemelijk dat het kabinet het ook op dit punt eens was met Tjepkema. Hij stelt in zijn proefschrift dat de benadering die wordt gevolgd bij schade door algemeen verbindende voorschriften soms niet bruikbaar is bij andere besluiten van algemene strekking. Laatstgenoemde besluiten zien namelijk vaak op een "onbepaalde groep burgers" terwijl deze benadering "geen onderscheid aanbrengt tussen de verschillende hoedanigheden van de burgers binnen de groep waarop de maatregel van toepassing is." De nadelige gevolgen van de maatregel zouden bij deze andere besluiten van algemene strekking niet zozeer tot de "strekking" maar tot de "feitelijke gevolgen/neveneffecten" van de overheidsmaatregel behoren. Als voorbeeld noemt Tjepkema eveneens schadeveroorzakende verkeersmaatregelen. Hoewel de rechtspraak inzake verkeersmaatregelen onmiskenbaar zou laten zien dat er een voorkeur bestaat de aanvraag om nadeelcompensatie te beoordelen door na te gaan of de schade het normaal maatschappelijk risico ontstijgt, zou soms een "meer specifieke vergelijking" worden gemaakt waarbij de "aard van de werkzaamheden" van de getroffene als diens intrinsieke eigenschap kan worden gezien. In dit kader merkt Tjepkema op dat bij schade door een wegafsluiting een restaurant niet met een accountantskantoor moet worden vergeleken. Het inkomen van de restauranthouder is immers sterker afhankelijk van een goede bereikbaarheid dan het inkomen van de accountant. Ook de "locatie of de aard van de schade" (bijvoorbeeld omrijschade, schade door verminderde parkeergelegenheid, of schade door bemoeilijkte bevoorrading) kunnen reden zijn om met een specifiekere referentiegroep te werken. De vergelijking met andere burgers zou aan de hand van dit soort factoren worden gestuurd in de richting van anderen die zoveel mogelijk vergelijkbaar zijn doordat zij hetzelfde probleem ondervinden. ${ }^{89}$

\section{Beschikkingen}

Ten aanzien van beschikkingen stelt het kabinet slechts dat deze "in beginsel individueel en concreet" zijn..$^{90}$ Dat wekt op het eerste oog het vermoeden dat een

90 Het is onduidelijk waarom het kabinet in dit geval niet ingaat op de analyse van Tjepkema, waarin verschillende soorten beschikkingen worden onderscheiden. Vergelijk Tjepkema 2010, p. 383-390. 
speciale last altijd aanwezig zou moeten worden geacht als de schade wordt veroorzaakt door een beschikking. Het heeft echter veel ervan weg dat het kabinet die mening niet is toegedaan, aangezien het aangeeft dat in de jurisprudentie nog nooit zou zijn aangenomen dat de geadresseerde van een beschikking onevenredig zwaar zou zijn benadeeld in verhouding tot anderen die een soortgelijke beschikking ontvingen. ${ }^{11}$ Daarbij verwijst het kabinet naar een uitspraak van het $\mathrm{CBb}$ van 5 december 2007. Radio 538 diende een aanvraag om nadeelcompensatie in wegens schade geleden door de herverdeling van radiofrequenties en de in dat kader aan haar verleende vergunning voor het gebruik van een minder voordelige radiofrequentie. Het $\mathrm{CBb}$ overwoog dat niet kon worden geoordeeld dat Radio 538 onevenredig zwaar was getroffen "in vergelijking met anderen die in dezelfde positie verkeren als zij - zittende commerciële radio-omroepen”. Daarbij was bepalend dat alle radio-omroepen slechts konden blijven uitzenden door zich aan de verdelingsprocedure te onderwerpen en de daaraan verbonden kosten te maken. ${ }^{92}$

\section{Conclusie}

Het criterium van de speciale last is gecodificeerd in art. 4:126 lid 1 Awb. Omdat afd. 15.1 Ow geen bijzondere regeling omtrent de speciale last bevat, zal het criterium als neergelegd in art. 4:126 lid 1 Awb ook gelden voor aanvragen die onder het bereik van afd. 15.1 Ow vallen. De bij de IOw behorende memorie van toelichting biedt echter weinig duidelijkheid als het aankomt op de wijze waarop in dergelijke gevallen met het criterium van de speciale last dient te worden omgesprongen. Voor beantwoording van de vraag hoe het criterium van de speciale last naar toekomstig recht dient te worden ingevuld, lijkt daarom te moeten worden teruggevallen op de bij de Wns behorende Kamerstukken. Ook deze stukken blinken wat dat betreft echter niet uit in duidelijkheid: op bepaalde punten zijn ze innerlijk tegenstrijdig en op andere punten is raadpleging van het proefschrift van Tjepkema nodig om het betoog van het destijds zittende kabinet te kunnen plaatsen.

\subsection{HOOFDVRAAG: SPIEGELING AAN DE DOELSTELLINGEN EN UITGANGSPUNTEN DIE TEN GRONDSLAG LIGGEN AAN DE WNS}

Bezien vanuit de doelstelling van vereenvoudiging, uniformering en harmonisering van het nadeelcompensatierecht is het positief dat alle bijzondere bepalingen die het criterium van de speciale last codificeren na inwerkingtreding van titel 4.5 Awb kunnen komen te vervallen. Aanvragers van nadeelcompensatie kan de afwezigheid van een speciale last immers steeds worden tegengeworpen op grond van art. 4:126 lid 1 Awb. Mede bezien vanuit deze doelstelling, maar ook bezien vanuit de doelstelling van vergroting van de rechtsgelijkheid, is het bovendien positief dat het criterium ook onder afd. 15.1 Ow zal gelden. Dat geldt eens te 
meer nu de in paragraaf 7.2 gevonden verklaringen voor het ten aanzien van de speciale last bestaande verschil tussen het hedendaagse planschade- en nadeelcompensatierecht onvoldoende reden vormen om dit verschil na inwerkingtreding van het nieuwe recht te behouden. Zo leggen de verklaringen van historische aard onvoldoende gewicht in de schaal om onder een op égalité gebaseerde nadeelcompensatieregeling af te zien van hantering van één van de twee criteria die het égalitébeginsel het meest typeren. Dat geldt zeker nu titel 4.5 Awb en afd. 15.1 Ow het thans bestaande nadeelcompensatielandschap ingrijpend zullen wijzigen. Ook de verklaring van Van Ettekoven legt mijns inziens onvoldoende gewicht in de schaal om onder afd. 15.1 Ow af te zien van hantering van het criterium van de speciale last. $\mathrm{Zij}$ is immers gebaseerd op een lezing van art. 6.2 lid 2 Wro die geen steun vindt in de relevante Kamerstukken en jurisprudentie, en afwijkt van de heersende leer in de literatuur. De overige verklaringen zien op de onderscheidende werking van het criterium en de vaagheid die het criterium met zich kan brengen, en dus uiteindelijk op de hanteerbaarheid van (het criterium binnen) het omgevingsrechtelijk georiënteerde nadeelcompensatierecht. Hoewel dit belangrijke argumenten zijn, zijn het mijns inziens geen argumenten om af te zien van hantering van het criterium van de speciale last. Zij geven wel aanleiding om meer duidelijkheid te creëren omtrent de wijze waarop het criterium dient te worden toegepast. Een dergelijke verduidelijking is ook wenselijk vanwege de doelstelling van vergroting van de rechtszekerheid, en verenigbaar met de overige aan de Wns ten grondslag liggende doelstellingen en uitgangspunten. Dat geldt eens te meer nu uit de bij de IOw behorende memorie van toelichting onvoldoende blijkt hoe het - meer dan 55 jaar niet in het planschaderecht toegepaste - criterium van de speciale last onder afd. 15.1 Ow dient te worden toegepast.

Dat behoefte bestaat aan meer duidelijkheid omtrent de invulling van de speciale last kan ook worden afgeleid uit paragrafen 7.2 en 7.3. Daarin bleek immers dat er nauwelijks richtinggevende jurisprudentie bestaat omtrent de invulling van de speciale last bij andere schadeveroorzakende besluiten dan beschikkingen en wettelijke voorschriften. Dat lijkt er debet aan te zijn dat in de praktijk grote verschillen bestaan in de afbakening van de referentiegroep bij grote (infrastructurele) projecten: rekkelijk onder de VNNZ, gematigd onder de GrS bij schade door het Aanwijzingsbesluit 1996, en streng onder de BnIW 2019 bij de ondertunneling van de A2 te Maastricht. De twee laatstgenoemde benaderingen komen bovendien niet overeen met de categorische beschrijving van de invulling van het criterium van de speciale last die het kabinet in 2012 gaf. Hoewel meer jurisprudentie is gewezen over schade door wettelijke voorschriften, is ook niet altijd eenvoudig te bepalen en/of verklaren welke door het schadeveroorzakende voorschrift getroffen personen al dan niet tot de referentiegroep behoren. Illustratief daarvoor zijn de verschillende lezingen van het Leffers-arrest - een van de standaardarresten omtrent het criterium van de speciale last. 


\section{Vormen rubriceringen naar type schadeveroorzakend besluit de oplossing?}

Zal de in 2012 door het kabinet gegeven rubricering naar type besluit de gewenste duidelijkheid bieden? Ik denk van niet. Daartoe is allereerst van belang dat deze rubricering onvolledig (wat ziet het kabinet bijvoorbeeld als relevante 'intrinsieke eigenschappen') en deels innerlijk tegenstrijdig is (zie bijvoorbeeld hetgeen door het kabinet wordt gesteld omtrent schade door algemeen verbindende voorschriften). Ten tweede geeft het kabinet slechts een algemene beschrijving op hoofdlijnen die is gebaseerd op een lezing van de destijds beschikbare jurisprudentie - terwijl die jurisprudentie bovendien niet altijd duidelijkheid verschaft omtrent de vraag waarom de gevolgde afbakening van de referentiegroep de meest wenselijke was. Ook het kabinet geeft geen duidelijkheid waarom de beschreven benadering wordt gevolgd en waarom dit de juiste benadering zou betreffen. Zo wordt bijvoorbeeld niet gemotiveerd waarom belanghebbenden die worden getroffen door een reguliere verkeersmaatregel anders zouden moeten worden behandeld dan belanghebbenden die worden getroffen door een (verkeers)maatregel die een groot infrastructureel project mogelijk maakt. Kort en goed, het laten doormodderen van de rechtspraktijk aan de hand van een verslag van de worsteling die zij de afgelopen decennia heeft gevoerd, biedt weinig hoop op het bereiken van de doelstellingen van vergroting van de rechtszekerheid en rechtsgelijkheid, en vergroting van de doelmatigheid van het nadeelcompensatierecht en vermindering van bestuurslasten. Zowel het bestuur als de rechter wordt op deze wijze immers onvoldoende houvast geboden om de open norm van art. 4:126 lid 1 Awb door middel van een wetshistorische benadering op teleologische wijze te interpreteren.

Zou een beter gemotiveerde rubricering naar type besluit wel voldoende duidelijkheid bieden om deze doelstellingen te bereiken? Ook die vraag moet mijns inziens ontkennend worden beantwoord. Die rubricering is immers al sinds 2010 beschikbaar in de vorm van het proefschrift van Tjepkema. Ik heb echter niet de indruk dat zij sindsdien tot een stroomversnelling van richtinggevende (besluiten en) rechterlijke uitspraken omtrent de speciale last heeft geleid. Bovendien is er nog een ander belangrijk argument dat er tegen pleit om de invulling van de speciale last afhankelijk te maken van een rubricering naar type schadeveroorzakend besluit. Bezien vanuit de doelstelling van vergroting van de rechtsgelijkheid, zou de invulling van de speciale last namelijk niet afhankelijk moeten worden gesteld van het type besluit dat de schade veroorzaakt. Gelet op deze doelstelling zou immers als uitgangspunt moeten gelden dat een bepaalde materiële beleidskeuze altijd tot dezelfde invulling van de speciale last dient te leiden, ongeacht de vorm waarin die keuze wordt gegoten. Ik geef het voorbeeld van een gemeentebestuur dat de sluitingstijden van horecagelegenheden wil reguleren. Dat kan door een gemeentelijke verordening vast te stellen die de sluitingstijden van horecagelegenheden volledig reguleert. Dezelfde materiële sluitingstijden kunnen echter ook worden gerealiseerd door in de gemeentelijke verordening slechts een verbod op opening buiten de sluitingstijden neer te leggen, terwijl de daadwerkelijke sluitingstijden in een concretiserend besluit van algemene strekking worden vervat. Ook is een situatie denkbaar waarin in de gemeentelijke verordening het verbod op het open zijn 
van horecagelegenheden is neergelegd en in individuele beschikkingen tussen bepaalde tijdstippen ontheffing van dat verbod wordt verleend. Het valt mijns inziens niet aan de benadeelde ondernemer uit te leggen dat hij langs de door het kabinet geschetste lijnen in het eerste geval voor nadeelcompensatie in aanmerking komt in zoverre hij zich voldoende onderscheidt van de andere getroffen ondernemers, terwijl hij in het derde geval niet voor compensatie in aanmerking komt omdat ervan moet worden uitgegaan dat hij zich niet voldoende onderscheidt van ondernemers met vergelijkbare vergunningen. ${ }^{93}$ Materieelrechtelijk zou hij in beide scenario's immers met dezelfde sluitingstijden worden geconfronteerd. Overigens lijkt ook Tjepkema van mening dat het type schadeveroorzakend besluit niet bepalend zou moeten zijn voor de invulling van het criterium van de speciale last. Hij stelt namelijk dat het "in theorie niet [zou] moeten uitmaken of nadeel direct wordt toegebracht door een algemene regel of door middel van een op die algemene regel gebaseerd stelsel van beschikkingen." 94

\section{De zoektocht naar een bruikbare maatstaf}

Hoe kan de praktijk dan toch de houvast worden geboden die nodig is om de doelstellingen van vergroting van de rechtszekerheid en rechtsgelijkheid, en vergroting van de doelmatigheid van het nadeelcompensatierecht en vermindering van bestuurslasten te bereiken? Bij de zoektocht naar een bruikbare maatstaf valt op dat het overgrote deel van de materiële criteria voor de toekenning van nadeelcompensatie een zekere inherente rechtvaardiging kennen. Zo schuilt achter het criterium van de abnormale last de gedachte dat schades die inherent zijn aan het "lid zijn van de samenleving en het deelnemen aan het maatschappelijk leven" niet tot compensatie dienen te leiden omdat zij behoren tot het normaal maatschappelijk risico. ${ }^{95}$ Voorts schuilt achter het tegenwerpen van risicoaanvaarding de gedachte dat schade niet voor compensatie in aanmerking behoort te komen in zoverre deze "mede een gevolg is van een omstandigheid die aan de benadeelde kan worden toegerekend." 96

Bij het criterium van de speciale last is een dergelijke inherente rechtvaardiging hooguit in mindere mate aanwezig. Hoewel kan worden gewezen op de gedachte dat geen compensatie op zijn plaats is als de lasten van een overheidsmaatregel gelijkelijk door de gemeenschap worden gedragen, ${ }^{97}$ verklaart deze gedachte niet

93 Op basis van hetgeen het kabinet stelde omtrent 'overige besluiten van algemene strekking' durf ik geen uitspraken te doen omtrent de door het kabinet voorgestane invulling van de speciale last in de hier als tweede geschetste situatie.

94 Tjepkema 2010, p. 383.

95 Kamerstukken II 2002/03, 28 916, nr. 3, p. 62-63 (MvT, Wro).

96 Zie art. 6:101 lid $1 \mathrm{BW}$ en art. 4:126 lid 2, aanhef en onder c Awb. Zie eveneens paragraaf 8.2.1.4.

97 Zie bijvoorbeeld Kamerstukken II 2010/11, 32 621, nr. 3, p. 12-13 (MvT, Wns), waarin wordt verwezen naar HR 30 maart 2001, ECLI:NL:HR:2001:AB0801, r.o. 3.8 (Staat/Lavrijsen). 
waarom een nader onderscheid zou moeten worden aangebracht tussen benadeelden ten aanzien waarvan reeds vaststaat dat abnormale schade wordt geleden. Als slechts het onderscheid tussen benadeelden met een abnormale last en benadeelden zonder een abnormale last zou hoeven te worden gemaakt, zou immers geen speciale last te hoeven worden vereist. De rechtvaardiging voor het criterium van de speciale last lijkt dan ook met name te moeten worden gevonden in de in paragraaf 7.1 besproken argumenten voor een strenge invulling van dit criterium. Dit vormt mijns inziens reden om vrijer na te denken over de wijze waarop dit criterium dient te worden vormgegeven dan het geval is bij de overige criteria voor toekenning van nadeelcompensatie. Dat geldt te meer nu geen duidelijke grens kan worden ontleend aan het rechtspolitieke argument dat een te ruime aansprakelijkheid moet worden voorkomen. Op basis hiervan zou immers ook kunnen worden besloten het nadeelcompensatierecht helemaal af te schaffen. Hetzelfde geldt voor eventueel hieraan verbonden argumenten inzake een verlammende werking op het bestuur.

Ook over het rechtsstatelijke argument kan discussie worden gevoerd. Zo kan worden getwist over de vraag in hoeverre de invulling van het égalitébeginsel afhankelijk mag zijn van de lastenverdeling die een (democratisch gekozen) wetgever of bestuursorgaan heeft beoogd. In Engeland wordt bijvoorbeeld veel waarde gehecht aan de sovereignty of parliament, maar uit paragraaf 2.5 kan worden afgeleid dat de verhoudingen in Nederland complexer en niet zo scherp gedefinieerd zijn. Tenzij een bepaalde groep door de formele wetgever van compensatie wordt uitgesloten - dan mag vanwege art. $120 \mathrm{GW}$ immers niet aan het égalitébeginsel worden getoetst - blijft het derhalve de vraag of de enkele omstandigheid dat een al dan niet democratisch gekozen regelgever een bepaald deel van de samenleving vanwege haar intrinsieke eigenschappen een maatregel oplegt, ertoe moet leiden dat de invulling van de speciale last streng dient te zijn. Mijns inziens zou dat niet het geval moeten zijn. Deze - vanuit bestuurlijk perspectief beschouwd, enigszins narcistische - benadering zou immers ertoe kunnen leiden dat het bestuur grote groepen van benadeelden van tegemoetkoming kan uitsluiten door de enkele mededeling dat de desbetreffende lastoplegging werd beoogd met het oog op willekeurige intrinsieke eigenschappen van de desbetreffende groep. Dat zou zelfs het geval zijn indien er overduidelijk sprake is van grote schade door een abnormale ontwikkeling die geenszins in de lijn der verwachtingen lag. ${ }^{98}$ Bovendien zal de regelgever in kwestie in bepaalde gevallen helemaal niet (kunnen) hebben voorzien dat een bepaalde groep uit de samenleving (abnormale) schade van het algemeen verbindend voorschrift zou ondervinden, en dus ook niet aan de mogelijkheid van compensatie hebben gedacht. Voorts kan de legitimerende werking in twijfel worden getrokken van bijvoorbeeld gemeenteraadsverkiezingen voor de keuzes die de gemeenteraad maakt in het kader van bevoegdheden met enige afwegingsruimte. ${ }^{99}$ Ten slotte zijn argumenten zoals 'de benadeelde moet dat de 
volgende verkiezingen maar afstraffen' van tamelijk hoog theoretisch gehalte, terwijl zij de individuele benadeelde geen soelaas bieden.

\section{Een normatieve maatstaf}

Gelet op het voorafgaande, zou de maatstaf aan de hand waarvan de invulling van het criterium van de speciale last wordt bepaald mijns inziens niet praktisch, maar normatief van aard moeten zijn. Daarbij refereer ik aan het Leffers-arrest, waarin het criterium van de speciale last duidelijk een onderscheidende rol heeft gespeeld en dat door de doctrine ook als redelijk lijkt te worden ervaren. Varkensmesters die met Swill vervoederden riepen een gezondheidsrisico voor de samenleving in het leven en een verbod van overheidswege nam dit risico weg. Bovendien zou kunnen worden gesteld dat de varkensmesters deels berekend moesten zijn op deze maatregel, nu de aanwezigheid van dergelijke gezondheidsrisico's inherent is aan de bedrijfstak in kwestie. ${ }^{100}$ Een dergelijk geval staat in contrast tot een wijziging van sluitingstijden voor horecaondernemingen die louter op politieke afwegingen is gebaseerd. De enkele omstandigheid dat de sluiting een bepaalde groep ondernemers treft omdat zij de intrinsieke eigenschap van horecaondernemer bezitten, maakt mijns inziens niet dat het redelijk is om tot die groep behorende ondernemers die abnormaal zwaar worden getroffen én aan de overige criteria van titel 4.5 Awb voldoen, geen compensatie toe te kennen omdat zij wat minder zwaar zijn getroffen dan enkele concurrenten. De strenge invulling die de Amsterdamse gemeenteraad in dergelijke gevallen onder de AVN voorstaat (vergelijk paragraaf 7.2.2), is mijns inziens dan ook niet wenselijk. Dat ligt anders als een dergelijke maatregel niet (louter) om politieke redenen wordt genomen, maar juist (ook) om een door de horecaondernemers aan de samenleving toegebracht nadeel - zoals overlast of een verstoring van de openbare orde - weg te nemen. Dan ontstaat immers een situatie die vergelijkbaar is met de Leffers-casus.

Ik stel dus een normatieve maatstaf voor die onderscheid maakt tussen enerzijds maatregelen die een door de benadeelde aan de samenleving toegebracht nadeel voorkomen of beperken, en anderzijds maatregelen die hun grondslag vinden in andere motieven, zoals politieke afwegingen die net zo goed anders hadden kunnen uitvallen. Slechts in het eerste geval zie ik reden het criterium van de speciale last streng in te vullen door een vergelijking te maken met de andere benadeelden die door de maatregel worden getroffen en hetzelfde nadeel aan de samenleving hebben toegebracht. In het tweede geval zou de speciale last mijns inziens moeten worden verondersteld aanwezig te zijn. In de voorgestelde, normatieve maatstaf kan het principe van 'de vervuiler betaalt' duidelijk worden herkend. Voorts is inherent aan deze maatstaf dat de speciale last met name streng zal worden ingevuld ten aanzien van ondernemers. Dat zijn immers de deelnemers aan de samenleving die de grootste risico's voor die samenleving in het leven roepen. 
Het hier voorgestelde criterium zou meebrengen dat het in de toelichting op de AVN gegeven voorbeeld van een winkelier wiens schade door verminderde bereikbaarheid wegens rioolwerkzaamheden onevenredig moet zijn ten opzichte van de schade van overige winkeliers uit dezelfde straat, geen stand zal houden. Hetzelfde geldt voor de strenge invulling die Rijkswaterstaat aan de speciale last gaf bij de ondertunneling van de A2 te Maastricht. In beide gevallen diende de maatregel er immers niet toe een door de benadeelde aan de samenleving toegebracht nadeel weg te nemen. Bepalend bij dit soort maatregelen zou derhalve moeten zijn of de aanvrager een abnormale last heeft ondervonden en aan de overige criteria van titel 4.5 Awb voldoet. Als dat het geval is, zou een speciale last moeten worden verondersteld ten opzichte van alle andere weggebruikers en omliggende ondernemers/bewoners die weliswaar schade, maar geen abnormale last door de maatregel in kwestie ondervinden.

\subsection{CONCLUSIE EN CONCRETE VOORSTELLEN}

Het is voor discussie vatbaar of de huidige formulering van art. 4:126 lid 1 Awb voldoende ruimte laat voor toepassing van de voorgestelde, normatieve maatstaf. ${ }^{101}$ Daarom zie ik aanleiding tot (a) aanpassing van titel 4.5 Awb. Ik stel voor de zinsnede "en die een benadeelde in vergelijking met anderen onevenredig zwaar treft" uit art. 4:126 lid 1 Awb te schrappen en het volgende, nieuwe artikellid aan art. 4:126 Awb toe te voegen:

\footnotetext{
"Wordt de schade veroorzaakt door een maatregel die ertoe strekt een door de aanvrager aan de samenleving toegebracht nadeel te voorkomen of beperken, dan kent het bestuursorgaan slechts een vergoeding toe voor zover de maatregel de aanvrager onevenredig zwaar treft in vergelijking met anderen die door deze maatregel zijn getroffen en hetzelfde nadeel aan de samenleving toebrachten."
}

In het deel van de memorie van toelichting behorend bij het voorgestelde artikellid kan vervolgens worden vermeld dat 'een maatregel' ruim mag worden opgevat indien de schade wordt veroorzaakt door een beschikking. De maatregel kan dan namelijk worden gezien als het geheel van beschikkingen dat is opgelegd aan de personen die het desbetreffende nadeel aan de samenleving toebrachten. ${ }^{102}$

Ondanks dat de door mij voorgestelde, normatieve maatstaf nog onbeproefd is, acht ik het toch verdedigbaar hem meteen in titel 4.5 Awb te verankeren. Het alternatief - zijnde een algemene bepaling die toepassing van de voorgestelde maatstaf, maar ook andere invullingen van de speciale last toestaat - past immers minder goed bij de doelstellingen van vergroting van de rechtszekerheid en rechtsgelijk-

101 Zie ook Tjepkema 2010, p. 886 omtrent de ruimte die de formulering van art. 4:126 lid 1 Awb laat voor uiteenlopende invullingen van de speciale last.

102 Dat hieraan behoefte kan bestaan, volgt onder andere uit de bespreking van de $R a$ dio 538 -uitspraak in paragraaf 7.3 onder het kopje 'beschikkingen'. 
heid, en uniformering en harmonisering ${ }^{103}$ van het nadeelcompensatierecht. ${ }^{104}$ Bovendien laten de voorafgaande paragrafen zien dat er na decennia van op égalité gebaseerd nadeelcompensatierecht nog relatief veel onduidelijkheid bestaat omtrent de wijze waarop de speciale last moet worden ingevuld bij bepaalde type schadeoorzaken - zeker in vergelijking met de mate van duidelijkheid die in hetzelfde tijdsbestek is ontstaan omtrent bijvoorbeeld de tegenwerping van normaal maatschappelijk risico of risicoaanvaarding. De zekerheid die wel bestaat, wordt bovendien ontleend aan rubricering naar type schadeoorzaak, waarvan is betoogd dat zij niet goed aansluit op de doelstelling van vergroting van de rechtsgelijkheid. Voorts moet op korte termijn ineens een aanzienlijke mate van sturing worden geboden, omdat het criterium van de speciale last voor het eerst ook zal gaan gelden in het omgevingsrechtelijk georiënteerde nadeelcompensatierecht. Dit alles rechtvaardigt mijns inziens dat de formele wetgever eenmalig een duidelijk signaal afgeeft.

Vanwege zijn plaatsing in titel 4.5 Awb zou het voorgestelde artikellid rechtstreeks van toepassing zijn op aanvragen die onder het bereik van afd. 15.1 Ow vallen. Mijns inziens vormt dit geen aanleiding om (b) afd. 15.1 Ow aan te passen. De in paragraaf 7.2 gevonden verklaringen voor de huidige status aparte van het planschaderecht ten aanzien van de speciale last vormen naar mijn mening namelijk te weinig reden om die status in stand te houden. Het behoud van deze status zou bovendien niet bijdragen aan het bereiken van de doelstellingen van vereenvoudiging, uniformering en harmonisering van het nadeelcompensatierecht, en vergroting van de rechtsgelijkheid.

Geeft het voorafgaande aanleiding tot (c) het anderszins voorzien in een bijzondere invulling, aanvulling of afwijking van titel 4.5 Awb? Die vraag dient mijns inziens bevestigend te worden beantwoord. Het zou namelijk goed aansluiten op de doelstellingen van vergroting van de rechtszekerheid, en vergroting van de doelmatigheid van het nadeelcompensatierecht en vermindering van bestuurslasten als in de toelichting op titel $4.5 \mathrm{Awb}$-interpreterende verordeningen of beleidsregels zou worden aangegeven of de schadeoorzaken die onder de reikwijdte van deze regelingen vallen tot stand zijn gekomen met de intentie een (door een bepaalde groep personen of ondernemers in het leven geroepen) nadeel voor de samenleving weg te nemen. Die informatie zou ook in de toelichting op een potentieel schadeveroorzakend besluit kunnen worden opgenomen.

103 De doelstelling van vereenvoudiging noem ik niet afzonderlijk, omdat ook thans niet tot nauwelijks regelgeving of beleid wordt vastgesteld omtrent de invulling van de speciale last.

104 De doelstelling van codificatie van het nadeelcompensatierecht noem ik niet afzonderlijk, omdat het geen codificatie van een bestaande jurisprudentielijn betreft. 



\section{Risicoaanvaarding, niet voldoen aan de schadebeperkingsplicht en resterende vormen van eigen schuld}

\subsection{INLEIDING}

In dit hoofdstuk zullen de tweede en derde deelvraag en de hoofdvraag worden beantwoord ten aanzien van een drietal vormen van eigen schuld. Allereerst zal worden ingegaan op het criterium van risicoaanvaarding (paragraaf 8.2). Dit criterium heeft in belangrijke mate vorm gekregen binnen het planschaderecht. De vraag of op grond van art. 49 WRO planschadevergoeding moest worden toegekend, werd namelijk vrijwel geheel beantwoord aan de hand van het criterium van risicoaanvaarding. ${ }^{1}$ De Afdeling overwoog dat...

“(...) de wetgever met art. 49 Wet op de Ruimtelijke Ordening de schade die een belanghebbende lijdt ten gevolge van een planologische wijziging die hem in een nadeliger positie brengt niet voor diens rekening [heeft] willen laten, behoudens in zoverre de schadeveroorzakende planologische wijziging voorzienbaar was ten tijde van de aankoop van de betrokken onroerende zaak of de vergoeding van de schade anderszins is verzekerd." 2

In het huidige planschaderecht moet deze rol worden gedeeld met het criterium van de abnormale last, maar dat neemt niet weg dat risicoaanvaarding nog steeds een belangrijke grond vormt om schade voor rekening van de aanvrager te laten. ${ }^{3}$ Ondanks dat het criterium van de risicoaanvaarding voor een groot deel in het planschaderecht tot stand is gekomen, ${ }^{4}$ wordt het ook regelmatig in het nadeelcompensatierecht aangewend om schade voor rekening van de aanvrager te laten. ${ }^{5}$

1 Van Ravels 2006a, p. 29.

2 ABRvS 17 augustus 2005, ECLI:NL:RVS:2005:AU1131, r.o. 2.3.1 (Leeuwarden). Zie eveneens ABRvS 6 mei 2004, ECLI:NL:RVS:2004:AO8865, r.o. 2.8; en ABRvS 10 augustus 2000, ECLI:NL:RVS:2000:AP5434, r.o. 2.4 (Bankfiliaal Liemeer).

3 Zie ook Van Ettekoven e.a. 2018, p. 80.

$4 \quad$ Kamerstukken II 2010/11, 32 621, nr. 3, p. 24 (MvT, Wns).

5 Zie bijvoorbeeld ABRvS 9 juli 2014, ECLI:NL:RVS:2014:2554, r.o. 7-7.2; ABRvS 10 april 2013, ECLI:NL:RVS:2013:BZ7681, r.o. 5-5.4; en ABRvS 5 november 2008, ECLI:NL:RVS:2008:BG3375, r.o. 2.5 (Vingerhoedje, hoger beroep). 
Het niet voldoen aan het criterium van de schadebeperkingsplicht betreft de tweede vorm van eigen schuld die zal worden besproken (paragraaf 8.3). Het gaat om een algemene plicht om, binnen de grenzen van het redelijke, schadebeperkende maatregelen te treffen. Dit criterium wordt zowel in het planschade- als het nadeelcompensatierecht minder vaak door het bestuur ingezet dan het criterium van risicoaanvaarding. Dat lijkt ook de reden waarom de Afdeling in haar Overzichtsuitspraak niet ingaat op dit criterium. Zij beoogde met deze uitspraak immers een overzicht op hoofdlijnen te geven "van in eerdere uitspraken neergelegde oordelen over kwesties die zich in de praktijk van het planschaderecht veelvuldig voordoen. ${ }^{\prime 6}$ Ten slotte zal aandacht worden besteed aan resterende vormen van eigen schuld (paragraaf 8.4). ${ }^{7}$ Dat is met name nodig omdat art. 4:126 lid 2, aanhef en onder $\mathrm{c}$ Awb een zelfstandige regeling inzake de resterende vormen van eigen schuld bevat, terwijl deze vormen niet tot nauwelijks een rol spelen in het hedendaagse planschade- en nadeelcompensatierecht.

Om de onderzoeksvragen op zinvolle wijze te kunnen beantwoorden ten aanzien van de genoemde vormen van eigen schuld, zal ik in het vervolg van deze inleidende paragraaf nog kort stilstaan bij de verhouding tussen risicoaanvaarding en de schadebeperkingsplicht, en bij de civielrechtelijke bepaling inzake eigen schuld (art. 6:101 BW).

\section{Verhouding tussen risicoaanvaarding en de schadebeperkingsplicht}

In de civielrechtelijke doctrine is de verhouding tussen risicoaanvaarding, de schadebeperkingsplicht, en resterende vormen van eigen schuld regelmatig onderwerp van discussie geweest. Een deel van die discussie is te verklaren doordat de term risicoaanvaarding (in het civiele recht) op verschillende manieren wordt gebruikt. Soms wordt gedoeld op een feitelijke omstandigheid en soms op een juridisch begrip. Eveneens wordt niet altijd duidelijk aangegeven welke rechtsgevolgen volgens procespartijen aan risicoaanvaarding zouden moeten worden verbonden en wat daarvoor de rechtsgrondslag is. Zo kan risicoaanvaarding niet alleen via de band van art. 6:101 BW tot matiging of verval van de schadevergoedingsplicht van de laedens leiden, maar ook door de laedens worden aangedragen als een rechtvaardigingsgrond die het onrechtmatige karakter van zijn handelen wegneemt. ${ }^{8}$ Deels kan deze discussie ook worden verklaard doordat de theorievorming omtrent de schadebeperkingsplicht achter is gebleven. ${ }^{9}$ Wel lijkt overeenstemming te bestaan over het uitgangspunt dat het niet voldoen aan de schadebeperkingsplicht

ABRvS 28 september 2016, ECLI:NL:RVS:2016:2582, r.o. 1 (Overzichtsuitspraak).

7 Dat risicoaanvaarding en het niet voldoen aan de schadebeperkingsplicht beide vormen van eigen schuld betreffen, blijkt onder andere uit Tjepkema 2010, p. 343 en 346; Schueler 2005, p. 205-207; en Franssen 2014, p. 37 en 48.

8 Zie Asser/Sieburgh 6-II 2017/128-131; en Hartlief, Verbintenissen uit de wet en Schadevergoeding (SBR 5), 2018/234.

9 Asser/Sieburgh 6-II 2017/127. 
- in tegenstelling tot overige vormen van eigen schuld - geen voorwaarde voor het intreden van de schade vormt, maar enkel leidt tot vergroting van de schadelijke gevolgen van het schadeveroorzakende optreden van de laedens. ${ }^{10}$

Ik heb geen aanwijzingen kunnen vinden dat de verhouding tussen risicoaanvaarding en de schadebeperkingsplicht anders ligt in het planschade- en/of nadeelcompensatierecht. Ook in deze rechtsgebieden wordt namelijk van risicoaanvaarding gesproken in gevallen waarin het handelen of nalaten van de benadeelde een voorwaarde vormt voor het intreden van de schade. Daarbij kan worden gedacht aan het kopen van een onroerende zaak terwijl voorzienbaar was dat toekomstig overheidshandelen deze zaak in waarde zou kunnen doen dalen (actieve risicoaanvaarding). Ook kan worden gedacht aan het niet tijdig gebruikmaken van de voordelige mogelijkheden die een juridisch regime biedt, terwijl voorzienbaar is dat de overheid een maatregel zal nemen die deze mogelijkheden (gedeeltelijk) zal doen vervallen (passieve risicoaanvaarding). Voorts lijkt de schadebeperkingsplicht ook in het planschade- en nadeelcompensatierecht slechts te zien op activiteiten die geen invloed hebben op het intreden van de schade. Ter illustratie daarvan refereer ik aan Afdelingsjurisprudentie inzake het aanbrengen van geluidswerende voorzieningen ${ }^{11}$ en het uitvoeren van alternatieve werkzaamheden om inkomen te genereren. ${ }^{12}$ Dat de schadebeperkingsplicht geen betrekking heeft op het intreden van de schade betekent overigens niet dat de schadebeperkingsplicht niet reeds voorafgaand aan de schadeveroorzakende handeling van de laedens van toepassing is. ${ }^{13}$

\section{De vier stappen van art. 6:101 $\mathrm{BW}$}

Een van de aan de Wns ten grondslag liggende uitgangspunten is dat aansluiting bij het BW wordt gezocht, zodat geen onnodige verschillen tussen het bestuursrechtelijke nadeelcompensatierecht en het civiele recht ontstaan. Bezien vanuit dit uitgangspunt, is het daarom positief dat - zoals uit de hierna volgende paragrafen nog zal blijken - uit toelichtende stukken volgt dat verschillende regelgevers inspiratie hebben ontleend aan art. 6:101 BW, zijnde de civielrechtelijke bepaling inzake eigen schuld. Om zinvolle uitlatingen omtrent dit uitgangspunt en de desbetreffende regelingen te kunnen doen, zal daarom kort worden stilgestaan bij de wijze waarop in het civiele recht invulling aan art. 6:101 BW wordt gegeven. Deze bepaling kan slechts worden aangewend als er een aansprakelijkheid bestaat. Het 6-II 2017/125; en Hartlief, Verbintenissen uit de wet en Schadevergoeding (SBR 5), $2018 / 226$.

11 Zie bijvoorbeeld ABRvS 24 augustus 2016, ECLI:NL:RVS:2016:2315, r.o. 7.2.3 (Planschade knooppunt Kunderberg, hoger beroep).

12 Zie bijvoorbeeld ABRvS 26 april 2006, ECLI:NL:RVS:2006:AW4004, r.o. 2.42.4.1 (Verkoopwagen Via Delta).

13 Keirse \& Jongeneel 2013, p. 59-60. 
enkele feit dat schade is geleden, is dus onvoldoende. Indien deze eerste horde is genomen, bestaat de toepassing van art. 6:101 lid $1 \mathrm{BW}$ uit vier stappen. ${ }^{14}$

De eerste stap bestaat eruit dat aan de hand van het csqn-vereiste en de leer van de redelijke toerekening (art. 6:98 BW) dient te worden vastgesteld of de schade "mede een gevolg is van een omstandigheid aan de zijde van de benadeelde." Volgens de tweede stap moet deze omstandigheid aan de benadeelde kunnen worden toegerekend. Deze toerekening ziet op de toerekening van de desbetreffende omstandigheid aan de persoon van de benadeelde. Zij verschilt dus van de toerekening bij de eerste stap, aangezien die toerekening ziet op de toerekening van de schade aan deze omstandigheid. Een omstandigheid kan aan de persoon van de benadeelde worden toegerekend als zij aan zijn schuld is te wijten, of anderszins ${ }^{15}$ voor zijn risico komt. Schuld moet in dit geval ruimer worden opgevat dan verwijtbaarheid die tot een onrechtmatige gedraging jegens een ander zou kunnen leiden. Bepalend is of de - niet door derden afdwingbare - norm om "voldoende zorg voor eigen persoon en goed" 16 te betrachten, is geschonden door de benadeelde. ${ }^{17}$

Bij de derde stap dient te worden beoordeeld in welke mate de aan beide partijen toe te rekenen omstandigheden hebben bijgedragen aan het ontstaan van de schade. Het gaat dus om een afweging van "wederzijdse causaliteit": door ex post na te gaan welke omstandigheden in hoeverre hebben bijgedragen aan het ontstaan van de schade komt een evenredige "verdeling van de schadelast over de aansprakelijke persoon en de benadeelde vast" te staan. Bij het maken van deze afweging kan de mate van veroorzakingswaarschijnlijkheid een belangrijk richtsnoer vormen. Niet van belang zijn bijvoorbeeld de aard van de aansprakelijkheid, mate van verwijtbaarheid, en het objectieve gevaar van een gedraging (het zogenoemde abstracte Betriebsgefahr). ${ }^{18}$ Dergelijke factoren spelen namelijk pas een rol bij de vierde stap: een billijkheidscorrectie. ${ }^{19}$

Ter verduidelijking van deze theoretische beschrijving van de vier stappen, zal deze inleidende paragraaf worden afgesloten met de bespreking van een arrest van

14 Zie Keirse 2003, p. 83-86; Keirse \& Jongeneel 2013, p. 33-36; en Asser/Sieburgh 6-II 2017/114.

15 Zie bijvoorbeeld Keirse \& Jongeneel 2013, p. 84-86 omtrent de zogenoemde 'reflexwerking van kwalitatieve aansprakelijkheid voor anderen'.

16 Zie specifiek voor dit citaat Keirse 2003, p. 76-78, 98-99 en 319.

17 Zie Keirse 2003, p. 314-316; en Keirse \& Jongeneel 2013, p. 36 e.v.

18 Deze term is ontleend aan Keirse 2003, p. 216 e.v.; en Keirse \& Jongeneel 2013, p. 110.

19 Zie Keirse 2003, p. 314-316; en Keirse \& Jongeneel 2013, p. 107 e.v. 
het hof 's-Gravenhage ${ }^{20}$ omtrent civielrechtelijke risicoaanvaarding. Daarin achtte het hof voldoende aannemelijk dat het besluit van een passagier om mee te rijden met een dronken bestuurder had bijgedragen aan zijn schade door een auto-ongeval (stap 1). De passagier had kunnen weten dat een gerede kans bestond dat de bestuurder van de auto meer had gedronken dan wettelijk was toegestaan. Hem kon daarom worden verweten dat hij desondanks met de bestuurder was meegereden, te meer omdat hij wist dat de bestuurder zijn rijbewijs pas kort had, een agressieve rijstijl had en vaak te hard reed. Het besluit om mee te rijden kon dus aan de passagier worden toegerekend, ook al kon hem geen groot verwijt worden gemaakt omdat hij niet wist hoeveel de bestuurder precies had gedronken en de bestuurder geen dronken indruk maakte (stap 2). De beslissing van de passagier om mee te rijden had volgens het hof slechts "in geringe mate" bijgedragen aan het ontstaan van de schade. De schade was "in de eerste plaats en voor het grootste deel veroorzaakt door het overmatige alcoholgebruik en het agressieve rijgedrag" van de bestuurder. Dit kon aan hem worden toegerekend omdat hij niet had voldaan aan de "specifieke en essentiële verplichtingen" om mede ter bescherming van zijn passagiers niet te veel alcohol te drinken en veilig te rijden. Dit feitencomplex ex post afwegende kwam het hof tot het oordeel dat het door de passagier genomen besluit om mee te rijden slechts voor 10\% aan de schade had bijgedragen ( $\operatorname{stap} 3$ ). Omdat de ernst van de door de bestuurder gemaakte fouten zodanig was dat de fouten van de passagier daarbij in het niet vielen; de passagier door het ongeval op jeugdige leeftijd zeer ernstige, permanente schade door een dwarslaesie opliep; en de schade werd gedekt door de verzekering van de bestuurder, oordeelde het hof dat de billijkheid meebracht dat de bestuurder de schade voor $100 \%$ zou dragen $(\operatorname{stap} 4){ }^{21}$

\subsection{RISICOAANVAARDING}

8.2.1 Deelvraag 2: verschillen tussen de geselecteerde, thans geldende regelingen en verklaringen daarvoor

\subsubsection{Algemene jurisprudentielijnen}

De jurisprudentie omtrent risicoaanvaarding is relatief ver uitgekristalliseerd. Dat kan worden verklaard doordat de bestuursrechter de toepassing van het criterium zonder terughoudendheid toetst en veel over dit criterium wordt geprocedeerd. In deze deelparagraaf zullen de belangrijkste jurisprudentielijnen worden besproken, waarbij het in de rechtspraak gehanteerde onderscheid tussen actieve- en passieve risicoaanvaarding wordt aangehouden. Bespreking van deze jurisprudentielijnen

De vier stappen van art. 6:101 BW komen niet altijd even nadrukkelijk naar voren in de civielrechtelijke rechtspraak. Zie daarover bijvoorbeeld Asser/Sieburgh 6-II 2017/114. Ondanks dat het niet afkomstig is van de HR maar van een gerechtshof, heb ik voor dit arrest gekozen omdat het treffend illustreert hoe de vier stappen dienen te worden toegepast.

21 Hof 's-Gravenhage 19 juni 2008, ECLI:NL:GHSGR:2008:BD6919, r.o. 7-9. 
is in de eerste plaats nodig om een goed beeld te krijgen van wat risicoaanvaarding nu eigenlijk inhoudt in het planschade- en nadeelcompensatierecht. Ten tweede is deze bespreking nodig om vast te stellen op welke punten in ieder geval geen onderscheid bestaat tussen de geselecteerde, thans geldende regelingen. Ten slotte maakt deze bespreking het mogelijk om in paragraaf 8.2.3 zinvolle uitlatingen te kunnen doen ten aanzien van de aan de Wns ten grondslag liggende doelstellingen van codificatie van het nadeelcompensatierecht en vergroting van de rechtszekerheid.

\section{Actieve risicoaanvaarding}

Om te bepalen of sprake is van actieve risicoaanvaarding dient eerst te worden nagegaan of sprake is van voorzienbaarheid. Bepalend is of ten tijde van de investeringsbeslissing - bijvoorbeeld de aankoop door de aanvrager van zijn later door de schadeoorzaak in waarde gedaalde onroerende zaak - voor een redelijk denkend en handelend koper aanleiding bestond om rekening te houden met de mogelijkheid van de schadeveroorzakende overheidsmaatregel. Als sprake is van voorzienbaarheid, blijft de schade voor rekening van de aanvrager omdat hij in dat geval wordt geacht de mogelijkheid van verwezenlijking van de negatieve ontwikkeling te hebben aanvaard ten tijde van zijn investeringsbeslissing, bijvoorbeeld door deze te hebben betrokken bij het overeenkomen van de koopprijs. Het is dus niet vereist dat het "bewustzijn van het risico" daadwerkelijk bij de aanvrager aanwezig was. ${ }^{22}$

Bij actieve risicoaanvaarding wordt gewerkt met een specifiek peilmoment, ${ }^{23}$ zijnde het moment van investeren. ${ }^{24} \mathrm{Bij}$ aanvragen die zagen op schade in de vorm van waardedaling van een onroerende zaak, heeft de Afdeling bijvoorbeeld geoordeeld dat de voorzienbaarheid dient te worden vastgesteld "op het moment van de aankoop van de desbetreffende onroerende zaak." 25 Ten aanzien van ontwikkelingen die plaatsvinden na dit peilmoment heeft de Afdeling een wisselende

22 Zie ABRvS 28 september 2016, ECLI:NL:RVS:2016:2582, r.o. 5.21 en 5.23-5.24 (Overzichtsuitspraak); en ABRvS 10 april 2013, ECLI:NL:RVS:2013:BZ7681, r.o. 5.1-5.3.

23 De Afdeling gebruikt de term 'peildatum' soms als het moment vanaf wanneer in algemene zin voorzienbaarheid kan worden aangenomen, zie bijvoorbeeld ABRvS 5 november 2008, ECLI:NL:RVS:2008:BG3375, r.o. 2.5 (Vingerhoedje, hoger beroep). Ik gebruik de term 'peilmoment' om aan te geven op welk moment moet worden nagegaan of de schade(oorzaak) voorzienbaar was voor de aanvrager.

24 Zie ABRvS 28 september 2016, ECLI:NL:RVS:2016:2582, r.o. 5.23 (Overzichtsuitspraak); ABRvS 10 april 2013, ECLI:NL:RVS:2013:BZ7681, r.o. 5.1; ABRvS 9 april 2014, ECLI:NL:RVS:2014:1228, r.o. 5; en ABRvS 5 november 2008, ECLI:NL:RVS:2008:BG3375, r.o. 2.5 (Vingerhoedje, hoger beroep).

25 ABRvS 28 september 2016, ECLI:NL:RVS:2016:2582, r.o. 5.25 (Overzichtsuitspraak). 
koers gevaren, ${ }^{26}$ maar uiteindelijk expliciet aangegeven dat deze geen effect meer kunnen hebben op de voorzienbaarheid. ${ }^{27}$ Ook een groot tijdsverloop tussen het concrete beleidsvoornemen waar de voorzienbaarheid op wordt gebaseerd en de investeringsbeslissing en/of de uiteindelijke, bindende besluitvorming lijkt niet in de weg te staan aan tegenwerping van voorzienbaarheid. ${ }^{28}$

Het betreft vaste jurisprudentie dat een concreet beleidsvoornemen van overheidswege $^{29}$ dat openbaar ${ }^{30}$ is gemaakt "voldoende" is om voorzienbaarheid te kunnen aannemen. Niet is vereist dat een dergelijk beleidsvoornemen een formele status heeft. ${ }^{31}$ Hoewel aanvankelijk ook andere signalen waarneembaar waren, ${ }^{32}$ is het inmiddels eveneens vaste jurisprudentie dat voorzienbaarheid in beginsel ook kan worden aangenomen op basis van een concreet beleidsvoornemen dat is vastgesteld en gepubliceerd door een ander bestuursorgaan dan het bestuursorgaan dat bevoegd is tot het nemen van de besluiten die nodig zijn om dat beleidsvoornemen

Zie ABRvS 20 juli 2011, ECLI:NL:RVS:2011:BR2290, r.o. 2.3-2.3.1; en ABRvS 6 oktober 2004, ECLI:NL:RVS:2004:AR3330, r.o. 2.8 voor voorbeelden van uitspraken waarin vanwege de rechtszekerheid rekening werd gehouden met ontwikkelingen na de peildatum.

27 Zie ABRvS 28 september 2016, ECLI:NL:RVS:2016:2582, r.o. 5.29 (Overzichtsuitspraak); ABRvS 21 december 2011, ECLI:NL:RVS:2011:BU8882, r.o. 2.5.1; en ABRvS 20 februari 2013, ECLI:NL:RVS:2013:BZ1658, r.o. 7.1.

28 Zie bijvoorbeeld ABRvS 20 april 2016, ECLI:NL:RVS:2016:1049, r.o. 6.2; en ABRvS 23 maart 2011, ECLI:NL:RVS:2011:BP8755, r.o. 2.4-2.4.1. Zie in meer algemene zin ook ABRvS 28 september 2016, ECLI:NL:RVS:2016:2582, r.o. 5.29 (Overzichtsuitspraak). Zie over de rol van het tijdsverloop ook Dijkshoorn 2011a, p. 113-114, paragraaf 6.3.1.1; en onderdeel acht van de annotatie van A.R. Neerhof bij ABRvS 27 juli 2005, ECLI:NL:RVS:2005:AU0126 (Drechterland) in Gst. 2007/30. Zie voor zeldzame uitzonderingen: ABRvS 5 juni 2013, ECLI:NL:RVS:2013:CA2092, r.o. 7.2; en ABRvS 26 juli 2017, ECLI:NL:RVS:2017:2026, r.o. 8. Dat daaraan geen precedentwerking moet worden toegekend, kan worden afgeleid uit ABRvS 6 juli 2016, ECLI:NL:RVS:2016:1876, r.o. 17 (Planschade Doesburg).

29 ABRvS 26 november 2014, ECLI:NL:RVS:2014:4239, r.o. 5.3.

30 Zie voor voorbeelden van een niet-openbaar beleidsvoornemen: ABRvS 19 december 2012, ECLI:NL:RVS:2012:BY6653, r.o. 8.2; en ABRvS 17 oktober 2012, ECLI:NL:RVS:2012:BY0372, r.o. 4.1 (Bergeijk).

31 Zie bijvoorbeeld ABRvS 28 juni 2017, ECLI:NL:RVS:2017:1700, r.o. 4.1. Zie in meer algemene zin ABRvS 28 september 2016, ECLI:NL:RVS:2016:2582, r.o. 5.23 (Overzichtsuitspraak). Zie voor een uitspraak die wat betreft schade door uitvoeringswerkzaamheden waarschijnlijk onder de RnVW 1999 is afgedaan: ABRvS 11 maart 2015, ECLI:NL:RVS:2015:763 (en: 765, 767, 768 en 776), r.o. 8.1.

32 Vergelijk ABRvS 25 mei 2016, ECLI:NL:RVS:2016:1396, r.o. 8; ABRvS 29 april 2015, ECLI:NL:RVS:2015:1359, r.o. 11.2; en ABRvS 30 december 2015, ECLI:NL:RVS:2015:4047, r.o. 6.2. De jurisprudentie uit de volgende voetnoot is mijns inziens leidend, omdat deze recenter, concreter en duidelijker is. Bovendien werd daarin het verweer dat het beleidsvoornemen door een ander bestuursorgaan was vastgesteld expliciet irrelevant geacht. 
te kunnen realiseren. ${ }^{33}$ Voorts is vereist dat "een redelijk denkend en handelend" koper $^{34}$ of ondernemer ${ }^{35}$ uit de openbaarmaking van het concrete beleidsvoornemen kan begrijpen op welk gebied het beleidsvoornemen betrekking heeft, wat de zakelijke inhoud ervan is, en van de inhoud ervan kan kennisnemen. ${ }^{36}$

\section{Gedeeltelijke voorzienbaarheid}

Door de jaren heen is in de literatuur regelmatig opgemerkt dat zich veranderingen voordoen in de jurisprudentielijnen omtrent gedeeltelijke voorzienbaarheid. ${ }^{37}$ Tjepkema merkte in 2010 op dat geen duidelijke regels uit de jurisprudentie kunnen worden afgeleid. Hij sprak daarbij van "ius in causa positum bij uitstek." 38 Op basis van de huidige stand van de jurisprudentie lijken in ieder geval twee vuistregels te kunnen worden geformuleerd.

Allereerst kan volledige voorzienbaarheid worden aangenomen als de bron van voorzienbaarheid meerdere besluitvormingsopties bevat en het bestuur de keuze vestigt op één van die opties. ${ }^{39}$ Er komt dus geen betekenis toe aan de grootte van

33 Zie ABRvS 26 juli 2017, ECLI:NL:RVS:2017:2024, r.o. 5.3, waarin wordt verwezen naar: ABRvS 6 augustus 2014, ECLI:NL:RVS:2014:2950 (provinciaal streekplan); ABRvS 12 oktober 2011, ECLI:NL:RVS:2011:BT7442 (planologische kernbeslissing); en ABRvS 11 maart 2015, ECLI:NL:RVS:2015:765 (startnotitie).

34 Zie ABRvS 28 september 2016, ECLI:NL:RVS:2016:2582, r.o. 5.23 (Overzichtsuitspraak); ABRvS 26 juli 2017, ECLI:NL:RVS:2017:1988, r.o. 7.3-7.4 (OK Oliecentrale); en ABRvS 27 december 2006, ECLI:NL:RVS:2006:AZ5163, r.o. 2.6.1.

35 Zie ABRvS 10 april 2013, ECLI:NL:RVS:2013:BZ7681, r.o. 5.1; en ABRvS 5 november 2008, ECLI:NL:RVS:2008:BG3375, r.o. 2.5 (Vingerhoedje, hoger beroep).

36 ABRvS 28 september 2016, ECLI:NL:RVS:2016:2582, r.o. 5.26 (Overzichtsuitspraak). Zie omtrent de in deze alinea besproken jurisprudentielijnen ook de annotatie van Van den Broek bij ABRvS 7 juni 2017, ECLI:NL:RVS:2017:1511 (Planschade Woudenberg) in StAB 2017/81, p. 109-111. Zie bijvoorbeeld ook het tweede onderdeel van haar annotatie bij ABRvS 17 mei 2017, ECLI:NL:RVS:2017:1293 (De Lunet) in TBR 2017/149.

37 Zie Van Zundert 2014, p. 525; Dijkshoorn 2011a, p. 120; onderdeel acht van de annotatie van A.R. Neerhof bij ABRvS 27 juli 2005, ECLI:NL:RVS:2005:AU0126 (Drechterland) in Gst. 2007/30; en onderdeel twaalf van de annotatie van I.P.A. van Heijst bij ABRvS 28 november 2012, ECLI:NL:RVS:2012:BY4394 in BR 2013/45.

38 Tjepkema 2010, p. 508-509. Zie in meer algemene zin omtrent beperkte voorzienbaarheid in het planschaderecht ook Van den Broek 2002, p. 193-195.

39 Zie voor een oude uitspraak waarin mogelijk anders is geoordeeld ABRvS 29 augustus 1996, ECLI:NL:RVS:1996:AN5470. Zie ook het derde onderdeel van de bijbehorende noot van Van den Broek in $A B$ 1997/434. Daarin wordt onder andere verwezen naar twee uitspraken waarmee de huidige jurisprudentielijn beter lijkt te verenigen: AGRvS 10 oktober 1988, ECLI:NL:RVS:1988:AQ9164 (Sint-Michielsgestel) en AGRvS 14 april 1988, ECLI:NL:RVS:1988:AS7637 (Waardevermindering Heino). 
de kans dat de schade wel of niet zou ontstaan. ${ }^{40}$ Zo oordeelde de Afdeling op 28 november 2012 in de Randweg Eindhoven-uitspraak dat de verbreding van een snelweg volledig voorzienbaar was. Dat in een startnotie negen alternatieven waren beschreven die niet allemaal van eenzelfde mate van verbreding uitgingen, liet onverlet dat de aanvrager bij aankoop van zijn woning rekening had moeten houden met de mogelijkheid dat een van de voor hem meest ongunstige alternatieven zou worden gekozen. ${ }^{41}$ Dit sluit goed aan op de algemene jurisprudentielijn dat...

“(...) voor het aannemen van voorzienbaarheid (...) niet [is] vereist dat verwezenlijking van de schadeveroorzakende overheidsmaatregel volledig en onherroepelijk vaststaat, of dat deze maatregel in detail is uitgewerkt of dat de omvang van de nadelige gevolgen met nauwkeurigheid kan worden bepaald. Beslissend is of op het moment van investering de mogelijkheid van de schadeveroorzakende overheidsmaatregel zodanig kenbaar was, dat hiermee bij de beslissing tot investering rekening kon worden gehouden." ${ }^{42}$

De tweede vuistregel houdt in dat voor de beoordeling van de voorzienbaarheid een vergelijking dient te worden gemaakt...

“(...) tussen de ruimtelijke gevolgen van het planologische regime waarvan gesteld wordt dat het planschade heeft veroorzaakt en de ruimtelijke gevolgen van de voor de aanvrager meest ongunstige uitwerking van de in het beleidsvoornemen bedoelde ontwikkelingsmogelijkheden. ${ }^{43}$

40 Zie ABRvS 28 september 2016, ECLI:NL:RVS:2016:2582, r.o. 5.28 (Overzichtsuitspraak); en ABRvS 10 april 2013, ECLI:NL:RVS:2013:BZ7681, r.o. 5.2.

41 ABRvS 28 november 2012, ECLI:NL:RVS:2012:BY4393, r.o. 15 (Randweg Eindhoven). Zie ook ABRvS 27 maart 2013, ECLI:NL:RVS:2013:BZ7497, r.o. 7-8 (Hanzelijn); en ABRvS 26 maart 2014, ECLI:NL:RVS:2014:1051, r.o. 7-8.1. Zie voor een recenter voorbeeld ook ABRvS 19 september 2018, ECLI:NL:RVS:2018:3023, r.o. 9.3 (Startnotitie A2 Maastricht).

42 Zie ABRvS 28 september 2016, ECLI:NL:RVS:2016:2582, r.o. 5.30 (Overzichtsuitspraak); ABRvS 11 maart 2015, ECLI:NL:RVS:2015:763, r.o. 8.1; ABRvS 26 juli 2017, ECLI:NL:RVS:2017:1988, r.o. 7.3 (OK Oliecentrale); ABRvS 9 juli 2014, ECLI:NL:RVS:2014:2554, r.o. 8.1; en ABRvS 27 december 2006, ECLI:NL:RVS:2006:AZ5163, r.o. 2.6.2.

43 ABRvS 28 september 2016, ECLI:NL:RVS:2016:2582, r.o. 5.27 (Overzichtsuitspraak). Zie ter illustratie van deze vuistregel: ABRvS 30 december 2015, ECLI:NL:RVS:2015:4047, r.o. 10; ABRvS 6 juli 2016, ECLI:NL:RVS:2016:1876, r.o. 37-38 (Planschade Doesburg); ABRvS 6 juli 2016, ECLI:NL:RVS:2016:1882, r.o. 8-10; en ABRvS 21 maart 2018, ECLI:NL:RVS:2018:930, r.o. 8.6. Zie voor oudere, minder expliciete toepassingen van de vuistregel ook ABRvS 31 maart 2004, ECLI:NL:RVS:2004:AO6543, r.o. 2.7 (Rijssen-Holten); ABRvS 9 augustus 1995, ECLI:NL:RVS:1995:AN5100 (Wegverlegging Hellevoetsluis); ABRvS 25 augustus 2010, ECLI:NL:RVS:2010:BN4940, r.o. 2.4.3 (Bergen op Zoom); ABRvS 22 oktober 2014, ECLI:NL:RVS:2014:3796, r.o. 9.1; ABRvS 22 oktober 2014, ECLI:NL:RVS:2014:3800, r.o. 9.1; en ABRvS 27 mei 2015, ECLI:NL:RVS:2015:1626, r.o. 4.1. 
In de $O K$ Oliecentrale-uitspraak wordt de vuistregel wat bondiger geformuleerd: "de voor de aanvrager meest ongunstige uitwerking van de in een beleidsvoornemen bedoelde ontwikkelingsmogelijkheden [is] beslissend. " 44 De vuistregel is ook van toepassing buiten het planschaderecht. In geval van schade door feitelijke uitvoeringswerkzaamheden zal bijvoorbeeld moeten worden nagegaan welke werkzaamheden qua "omvang en intensiteit" nog "redelijkerwijs voorzienbaar" kunnen worden geacht. ${ }^{45}$

Toepassing van deze tweede vuistregel kan tot gevolg hebben dat de volledige schade wegens risicoaanvaarding voor rekening van de aanvrager kan worden gelaten, zelfs als de ontwikkelingsmogelijkheid uit het beleidsvoornemen een andere is dan de uiteindelijk gerealiseerde ontwikkeling. Dit deed zich voor in de Planschade Doesburg-uitspraak. Op basis van een structuurvisie was voorzienbaar dat een groot gebied zou worden gereserveerd voor samenhangende sportcomplexen. Het was dan ook niet voorzienbaar dat in de plaats hiervan een vrijstelling voor de realisatie van 105 woningen zou worden verleend. ${ }^{46}$ Toch mocht de schade die ontstond door deze vrijstelling volledig voor rekening van de aanvrager worden gelaten. De realisatie van een sportpark had namelijk "gezien de potentiele bouwen gebruiksmogelijkheden, een grotere of op zijn minst vergelijkbare planologisch nadelige uitstraling gehad als de oprichting van 105 woningen." ${ }^{47}$ Is de voor de aanvrager meest ongunstige uitwerking van de in het beleidsvoornemen bedoelde ontwikkelingsmogelijkheden echter minder nadelig dan de gevolgen van de uiteindelijk gerealiseerde ontwikkeling, dan zal toepassing van de tweede vuistregel tot gevolg hebben dat de schade slechts gedeeltelijk wegens risicoaanvaarding voor rekening van de aanvrager kan worden gelaten. ${ }^{48}$

44 ABRvS 26 juli 2017, ECLI:NL:RVS:2017:1988, r.o. 7.3 (OK Oliecentrale). De aanvraag werd ingediend onder de RnVW 1999, maar gelet op ABRvS 31 maart 2010, ECLI:NL:RVS:2010:BL9576, r.o. 2.2 en ABRvS 6 juni 2012, ECLI:NL:RVS:2012:BW7613, r.o. 2.3 waren waarschijnlijk de inhoudelijke criteria voor toekenning van tegemoetkoming in planschade van toepassing.

45 ABRvS 11 maart 2015, ECLI:NL:RVS:2015:776, r.o. 8.4.

46 De Afdeling overweegt in haar conclusie in r.o. 40 dat de realisatie van de woningen voorzienbaar was. Dat lijkt onjuist gelet op het overige deel van de uitspraak, zoals hier omschreven.

47 ABRvS 6 juli 2016, ECLI:NL:RVS:2016:1876, r.o. 37-38 (Planschade Doesburg).

48 ABRvS 30 december 2015, ECLI:NL:RVS:2015:4047, r.o. 10. 


\section{Passieve risicoaanvaarding}

In de literatuur wordt passieve risicoaanvaarding regelmatig omschreven als "riskant stilzitten". ${ }^{49}$ Buiten het planschaderecht zijn (vrijwel) ${ }^{50}$ geen gevallen van passieve risicoaanvaarding te vinden. ${ }^{51}$ Voor de beantwoording van de vraag of de benadeelde het risico op het vervallen van bouw- of gebruiksmogelijkheden op zijn perceel passief heeft aanvaard, "is van belang of de voortekenen van de nadelige planologische wijziging reeds enige tijd zichtbaar waren." ${ }^{52}$ Voldoende is dat, bezien vanuit de positie van een redelijk denkend en handelend eigenaar, aanleiding bestond rekening te houden met de kans dat de planologische situatie ter plaatse zou gaan veranderen in een voor aanvrager ongunstige zin. Hierbij dient rekening te worden gehouden met concrete beleidsvoornemens die openbaar zijn gemaakt. ${ }^{53}$ Aan deze beleidsvoornemens worden dezelfde eisen gesteld als bij actieve risicoaanvaarding. Bestond voor een redelijk denkend en handelend eigenaar inderdaad aanleiding om rekening te houden met de mogelijkheid van een nadelige planologische ontwikkeling, dan is slechts sprake van passieve risicoaanvaarding indien de aanvrager ${ }^{54}$ geen "concrete pogingen" heeft gedaan tot realisering van de bouw- en gebruiksmogelijkheden die onder het nieuwe planologische regime zijn komen te vervallen, terwijl dit vanaf de peildatum voor voorzienbaarheid ${ }^{55}$ wel van een redelijk denkend en handelend eigenaar kon worden verlangd. ${ }^{56}$

Bij de beantwoording van de vraag wat van een redelijk denkend en handelend eigenaar kan worden verlangd, is in algemene zin van belang hoeveel tijd beschikbaar was voor het ondernemen van een concrete poging. Zo oordeelde de Afdeling

49 Zie bijvoorbeeld Van der Schans 1988, p. 60; Barkhuysen \& Tjepkema 2006, p. 188; Tjepkema 2010, p. 253; Sluysmans 2012, p. 543; en het eerste onderdeel van de annotatie van Van Zundert bij ABRvS 25 februari 2004, ECLI:NL:RVS:2004:AO4344 (Planschade Hummelo \& Keppel) in BR 2004/128.

50 In Kamerstukken I 2012/13, 32 621, nr. C, p. 9 (MvA I, Wns) wordt verwezen naar CBb 10 december 2008, ECLI:NL:CBB:2008:BH0855, r.o. 5.9. In deze uitspraak lijken normaal maatschappelijk risico en risicoaanvaarding echter dusdanig door elkaar te lopen dat deze uitspraak mijns inziens geen geschikt voorbeeld vormt. Zie hierover ook het derde onderdeel van de annotatie van Van Ravels bij deze uitspraak in $A B$ 2009/90. Een beter voorbeeld betreft Rb. Haarlem 26 november 2012, ECLI:NL:RBHAA:2012:BY5380.

51 Tjepkema 2010, p. 485. Raadpleging van een senior jurist van Rijkswaterstaat bevestigt dit voor wat betreft de praktijk van de BnIW 2019.

52 Zie ABRvS 28 september 2016, ECLI:NL:RVS:2016:2582, r.o. 5.32 (Overzichtsuitspraak); en ABRvS 28 augustus 2013, ECLI:NL:RVS:2013:923, r.o. 5.1.

53 Zie ABRvS 28 september 2016, ECLI:NL:RVS:2016:2582, r.o. 5.33 (Overzichtsuitspraak); en ABRvS 28 augustus 2013, ECLI:NL:RVS:2013:923, r.o. 5.1.

54 Concrete pogingen die zijn gedaan door vorige eigenaren zijn niet relevant, zie ABRvS 2 oktober 2013, ECLI:NL:RVS:2013:1323, r.o. 5.1.

55 Zijnde het moment waarop de schade(oorzaak) voor een redelijk denkend en handelend eigenaar op grond van een concreet beleidsvoornemen voorzienbaar was.

56 ABRvS 28 september 2016, ECLI:NL:RVS:2016:2582, r.o. 5.34 (Overzichtsuitspraak). 
in een uitspraak van 16 maart 2011 dat het appellant niet kon worden verweten dat hij geen concrete poging had ondernomen, omdat hem daartoe een periode van "slechts anderhalve maand" ter beschikking stond. ${ }^{57}$ De Vries heeft aan de hand van een uitgebreide analyse van jurisprudentie laten zien dat een termijn van circa anderhalf jaar doorgaans wel toereikend wordt geacht om passieve risicoaanvaarding te mogen tegenwerpen. ${ }^{58}$ In gemeentekringen circuleert een in opdracht van het ministerie van Infrastructuur en Milieu door Bregman geschreven notitie, waarin onder verwijzing naar jurisprudentie zelfs wordt gesteld dat een termijn van minder dan één jaar toereikend is. ${ }^{59}$ Soms blijken regelgevers echter zelf voor een langere termijn te kiezen. Zo is in art. 7c lid 8 onder a jo. 7e onder a Besluit uitvoering Chw besloten tot een termijn van drie jaren.

Wanneer kan worden gesproken van een concrete poging? Dat is vrij casuïstisch. Bij een verlies van bouwmogelijkheden is het indienen van een zienswijze tegen een ontwerpbestemmingsplan in ieder geval onvoldoende, aangezien deze indiening niet is gericht op de realisatie van bouwmogelijkheden. ${ }^{60}$ Ook het enkele indienen van een schetsplan is in beginsel onvoldoende, ${ }^{61}$ omdat van de benadeelde wordt verlangd dat hij een bouwplan indient "dat zodanig is uitgewerkt dat het zich laat beoordelen op passendheid binnen het bestemmingsplan en dat in beginsel past binnen de bestaande mogelijkheden van het bestemmingsplan." ${ }^{2}$ Of het door de benadeelde ingediende bouwplan aan die eis voldoet, lijkt onder andere afhankelijk te zijn van de duidelijkheid van de relevante planvoorschriften en de informatievoorziening vanuit het bestuur. ${ }^{63}$ Het betreft vaste jurisprudentie dat het vervallen van bouwmogelijkheden die niet waren opgenomen in het ingediende bouwplan, geacht wordt passief te zijn aanvaard. ${ }^{64}$ Voorts zal een benadeelde die voor de toekomstig te vervallen bouwmogelijkheden reeds over een omgevings-

57 ABRvS 16 maart 2011, ECLI:NL:RVS:2011:BP7753, r.o. 2.5.2. In ABRvS 2 december 2009, ECLI:NL:RVS:2009:BK5083, r.o. 2.5 werd een periode van drie en een halve maand te kort geacht voor het opstellen en indienen van een "complexe en omvangrijke aanvraag om bouwvergunning."

58 De Vries 2015, p. 116-118. De termijn van anderhalf jaar stemt eveneens overeen met de conclusie van Van Zundert in het derde onderdeel van zijn annotatie bij ABRvS 14 april 2010, ECLI:NL:RVS:2010:BM1021 (Risicoaanvaarding planschade Bloemendaal) in BR 2010, 114.

59 Bregman 2012, p. 2-7. Ook in Franssen \& Van de Sande 2018a, p. $91-92$ lijkt een termijn van één jaar als doorgaans afdoende te worden aangemerkt.

60 ABRvS 25 juni 2014, ECLI:NL:RVS:2014:2287, r.o. 5.1.

61 ABRvS 14 april 2010, ECLI:NL:RVS:2010:BM1021, r.o. 2.4-2.4.2 (Risicoaanvaarding planschade Bloemendaal).

62 ABRvS 28 september 2016, ECLI:NL:RVS:2016:2582, r.o. 5.35 (Overzichtsuitspraak). De Afdeling verwijst hierin naar ABRvS 12 augustus 2015, ECLI:NL:RVS:2015:2567 (Lansingerland). Daarin is deze overweging echter niet (in zijn geheel) terug te vinden. Het meest relevant zijn r.o. 5.1-5.2.

63 ABRvS 12 augustus 2015, ECLI:NL:RVS:2015:2567, r.o. 5.2 (Lansingerland).

64 ABRvS 28 september 2016, ECLI:NL:RVS:2016:2582, r.o. 5.36 (Overzichtsuitspraak). 
vergunning voor bouwen beschikt, daar in beginsel gebruik van moeten maken. ${ }^{65}$ Bij een verlies van gebruiksmogelijkheden lijkt een concrete poging te kunnen bestaan uit het daadwerkelijk aanvangen met het desbetreffende gebruik, of uit het ondernemen van serieuze pogingen om de desbetreffende onroerende zaak voor dat doel aan derden te verkopen of verhuren. ${ }^{66}$

\subsubsection{Grondslag voor tegenwerping van risicoaanvaarding}

Het merendeel van de geselecteerde, thans geldende regelingen bevat een bepaling omtrent het tegenwerpen van risicoaanvaarding:

\section{Art. 6.3, aanhef en onder a Wro}

Met betrekking tot de voor tegemoetkoming in aanmerking komende schade betrekken burgemeester en wethouders bij hun beslissing op de aanvraag in ieder geval de voorzienbaarheid van de schadeoorzaak.

\section{Art. 5 t/m 7 BnIW 2019}

Art. 5: Schade ten gevolge van een schadeoorzaak als bedoeld in artikel 2, eerste lid, die voor de belanghebbende redelijkerwijs voorzienbaar was ten tijde van de beslissing te investeren in het geschade belang wordt niet vergoed.

Art. 6: De in artikel 5 bedoelde voorzienbaarheid kan onder meer betrekking hebben op de aard van een schadeoorzaak als bedoeld in artikel 2, eerste lid, op het tijdstip waarop deze schadeoorzaak zijn werking doet gevoelen, op de plaats waarop ze betrekking heeft, op de wijze van voltrekken of uitvoering daarvan, alsmede op de aard en omvang van de daardoor veroorzaakte schade.

Art. 7: Geen vergoeding wordt toegekend indien de verzoeker heeft nagelaten zijn belang te verwezenlijken toen hij daartoe redelijkerwijs in de gelegenheid was, terwijl hij redelijkerwijs kon voorzien dat een maatregel genomen zou worden die aan dat realiseren in de weg zou komen te staan.

66 De jurisprudentie hierover is schaars. Zie ABRvS 18 april 2012, ECLI:NL:RVS:2012:BW3066, r.o. 2.5.2 (Steenfabriek of scheepswerf?); ABRvS 20 maart 2013, ECLI:NL:RVS:2013:BZ4948, r.o. 6.1 (Horecagelegenheid Amsterdam); en ABRvS 21 augustus 2013, ECLI:NL:RVS:2013:811, r.o. 6.2 (Kollumerland en Nieuwkruisland). Een complicatie lijkt zich voor te doen als de aanvrager stelt dat zijn schade ontstaat door een verlies van diversiteit van gebruiksmogelijkheden. Zie daaromtrent Rb. Amsterdam 12 oktober 2012,

ECLI:NL:RBAMS:2012:BY6896, r.o. 3.7-3.8 (Pembroek). 


\title{
Art. 3 lid 1, aanhef en onder b AVN
}

Het bestuursorgaan wijst een aanvraag om vergoeding van de schade geheel of gedeeltelijk af, indien de benadeelde van het risico van het ontstaan van de schade op de hoogte was of had kunnen zijn.

\begin{abstract}
Art. 3 VNNZ
Art. 3 lid 1, aanhef en onder b VNNZ: Het college weigert een aanvraag om nadeelcompensatie, indien het nadeel redelijkerwijze voorzienbaar was op het moment van investeren in het geschade belang.
\end{abstract}

Art. 3 lid 2 VNNZ: In afwijking van het eerste lid, onder b, geldt voor aanvragers die langs of in de nabijheid van de Noord/Zuidlijn in een belang hebben geïnvesteerd in een jaar als genoemd in de eerste kolom van de bij deze verordening behorende bijlage, dat na het verstrijken van de voor hen geldende jaren, zoals vermeld in de laatste kolom van die bijlage, de voorzienbaarheid niet meer aan hen wordt tegengeworpen.

Dat in de GrS geen bepaling aan risicoaanvaarding is gewijd, kan worden verklaard door de in paragraaf 3.2.1 beschreven, bijzondere aard van deze regeling: zij dient ertoe de reeds op grond van verschillende grondslagen bestaande - en aan verschillende bestuursorganen toekomende - bevoegdheden om nadeelcompensatie toe te kennen, binnen een specifieke context over te dragen aan het algemeen bestuur van het Schadeschap. Dat het criterium van risicoaanvaarding eveneens niet voorkomt in art. $49 \mathrm{WRO}$, art. 21 Aanwijzingsbesluit 1996 en art. $8.31 \mathrm{Wlv}$ lijkt met name te worden verklaard doordat het ten tijde van de totstandkoming van deze regelingen nog niet gebruikelijk was om in nadeelcompensatieregelingen uit te werken wanneer aan de daarin vervatte redelijkerwijsformule werd voldaan. Voorts is voor de formulering van zowel art. 21 Aanwijzingsbesluit 1996 als art. 8.31 Wlv aansluiting gezocht bij art. $49 \mathrm{WRO}$, en in geval van art. 8.31 Wlv ook bij art. 15.20 Wet milieubeheer. ${ }^{67}$ Via de band van de daarin vervatte redelijkerwijsformules kan risicoaanvaarding desalniettemin ook worden tegengeworpen bij toepassing van art. $49 \mathrm{WRO},{ }^{68}$ art. $8.31 \mathrm{Wlv}^{69}$ en art. 21 Aanwijzingsbesluit

67 Zie Stcrt. 1998, nr. 223, p. 11 (digitaal) respectievelijk Kamerstukken II 00/01, 27 603, nr. 3, p. 69 en 15.

68 Zie onder art. 49 WRO bijvoorbeeld voor actieve risicoaanvaarding ABRvS 30 maart 2005, ECLI:NL:RVS:2005:AT2807, r.o. 2.6.1; en voor passieve risicoaanvaarding ABRvS 11 mei 2000, ECLI:NL:RVS:2000:AA6821. Zie voor een voorbeeld van risicoaanvaarding onder art. 49 WRO bij toepassing van de GrS: ABRvS 27 december 2006, ECLI:NL:RVS:2006:AZ5163, r.o. 2.6.1 e.v.

69 Zie voor voorbeelden onder de GrS: ABRvS 18 mei 2016, ECLI:NL:RVS:2016:1349, r.o. 5 (Sugar City); Rb. Haarlem 9 juli 2012, ECLI:NL:RBHAA:2012:BX2062, r.o. 2.10-2.13; Rb. Haarlem 26 november 2012, ECLI:NL:RBHAA:2012:BY5380, r.o. 8; en Rb. Noord-Holland 25 juni 2013, ECLI:NL:RBNHO:2013:6092, r.o. 9-9.1. 
$1996 .{ }^{70}$ Voorts blijkt uit de rechtspraak dat risicoaanvaarding ook kan worden tegengeworpen bij toepassing van het ongeschreven égalitébeginsel. ${ }^{71}$

\section{Verschillen in formulering}

Wanneer de bepalingen uit de Wro, BnIW 2019 en de Amsterdamse verordeningen worden vergeleken, vallen een aantal relatief kleine verschillen in formulering op. Zo verplicht de bepaling uit de Wro het bestuur slechts de voorzienbaarheid in zijn beslissing op de aanvraag om compensatie te betrekken, terwijl de overige bepalingen het bestuur verplichten de aanvraag wegens voorzienbaarheid af te wijzen. Mij is geen planschadejurisprudentie bekend waarin draagplichtige derden opkwamen tegen het niet tegenwerpen van risicoaanvaarding. Mede gelet daarop, heb ik niet de indruk dat dit terminologische verschil tussen afd. 6.1 Wro en de overige regelingen in de praktijk tot materieelrechtelijke verschillen leidt. Gelet op de in paragraaf 8.2.1.1 besproken jurisprudentie zie ik bovendien geen reden waarom de Afdeling niet zou ingrijpen als een draagplichtige derde zou opkomen tegen het niet tegenwerpen van risicoaanvaarding in gevallen waarin is voldaan aan de daarvoor geldende voorwaarden. Op dit soort terminologische verschillen - die niet tot materieelrechtelijke verschillen leiden - zal ik daarom niet verder ingaan. $\mathrm{Zij} \mathrm{lijken} \mathrm{te} \mathrm{kunnen} \mathrm{worden} \mathrm{verklaard} \mathrm{doordat} \mathrm{de} \mathrm{regelingen} \mathrm{gedurende}$ enkele decennia door verschillende regelgevers zijn opgesteld, terwijl die regelgevers wat dit betreft geen aandacht lijken te hebben gehad voor afstemming op andere nadeelcompensatieregelingen en/of overleg met elkaar, laat staan een materieelrechtelijk verschil in het leven beoogden te roepen.

\section{De tabel uit de VNNZ}

Een verschil in redactie dat wel bespreking behoeft, is dat de Amsterdamse gemeenteraad bij vaststelling van de VNNZ een tabel heeft vastgesteld als bijlage bij art. 3 VNNZ.

70 Zie voor voorbeelden onder de GrS: ABRvS 10 november 2010, ECLI:NL:RVS:2010:BO3436, r.o. 2.11.1 e.v.; en ABRvS 9 april 2014, ECLI:NL:RVS:2014:1228, r.o. 5. Zie verder ook Franssen 2014, p. 34, voetnoot 7.

71 Zie bijvoorbeeld voor actieve risicoaanvaarding ABRvS 11 november 2009, ECLI:NL:RVS:2009:BK2907, r.o. 2.7 (Insula Heerlen); en voor passieve risicoaanvaarding ABRvS 5 februari 2003, ECLI:NL:RVS:2003:AF3937, r.o. 2.6 (Onzuiver Schadebesluit Haarlemmermeer). Zie verder Tjepkema 2010, p. 180 e.v. 


\begin{tabular}{|l|l|l|l|l|}
\hline $\begin{array}{l}\text { Jaar } \\
\text { investeringsbeslissing }\end{array}$ & $\begin{array}{l}\text { Voorzienbaarheid c.q. } \\
\text { feitelijke aanvang bouw } \\
\text { Noord/Zuidlijn }\end{array}$ & $\begin{array}{l}\text { Voorzienbare } \\
\text { resterende } \\
\text { bouwperiode }\end{array}$ & $\begin{array}{l}\text { Voorzienbare } \\
\text { einddatum (jaar) } \\
\text { van de bouw }\end{array}$ & $\begin{array}{l}\text { Jaar waarin } \\
\text { korting vervalt }\end{array}$ \\
\hline $28-11-96$ t/m 22-06-00 & 2001 (prognose) & 7 jaar & 2008 & 2009 \\
\hline $23-06-00$ t/m 31-12-00 & 2001 (prognose) & 7 jaar & 2008 & 2009 \\
\hline 2001 & 2002 (prognose) & 7 jaar & 2009 & 2010 \\
\hline 2002 & 2003 (prognose) & 7 jaar & 2010 & 2011 \\
\hline 2003 & 2003 (feitelijk ) & 7 jaar & 2010 & 2011 \\
\hline 2004 & 2003 (feitelijk ) & 7 jaar & 2011 & 2012 \\
\hline 2005 & 2003 (feitelijk ) & 6 jaar & 2011 & 2012 \\
\hline 2006 & 2003 (feitelijk ) & 5 jaar & 2011 & 2012 \\
\hline 2007 & 2003 (feitelijk ) & 5 jaar & 2012 & 2013 \\
\hline 2008 & 2003 (feitelijk ) & 5 jaar & 2013 & 2014 \\
\hline 2009 & 2003 (feitelijk ) & 8 jaar & 2017 & ---- \\
\hline
\end{tabular}

Met behulp van deze tabel kunnen personen die schade door de aanleg van de Noord/Zuidlijn ondervinden, nagaan gedurende welke schadejaren hen actieve risicoaanvaarding zal worden tegengeworpen. ${ }^{72}$ Bepalend is de einddatum van de aanleg van de Noord/Zuidlijn op het maaiveld die kon worden voorzien op het moment van investeren. Zo kon iemand die in 2005 investeerde slechts tegemoetkoming verkrijgen voor schade die hij na 2011 had ondervonden, omdat destijds voorzienbaar was dat de werkzaamheden nog zes jaar in beslag zouden nemen. ${ }^{73}$ Deze benadering sluit goed aan op de in paragraaf 8.2.1.1 geformuleerde, tweede vuistregel omtrent gedeeltelijke voorzienbaarheid. Dat geen vergelijkbare tabellen in de overige, geselecteerde regelingen zijn opgenomen, kan worden verklaard doordat de reikwijdte van de VNNZ - anders dan de reikwijdte van de overige regelingen - is beperkt tot schade door één gebeurtenis/project: de aanleg van de Noord/Zuidlijn, waarvan de uitvoering onvoorzienbaar lang duurde. Daardoor was het relatief eenvoudig om in de VNNZ duidelijkheid te scheppen omtrent de vraag vanaf wanneer die aanleg voorzienbaar was en welke duur van aanlegwerkzaamheden voorzienbaar was. Wellicht was het onder de GrS ook mogelijk geweest op voorhand meer duidelijkheid over de peildatum voor voorzienbaarheid te bieden. Deze regeling heeft immers een minder algemeen karakter dan de BnIW 2019, AVN en afd. 6.1 Wro. Dat dit niet is gebeurd, lijkt met name te kunnen worden verklaard doordat bestuursorganen daartoe niet verplicht zijn. De tabel uit de VNNZ moet dan ook worden gezien als een bijzondere handreiking aan de burger, en de bestuursorganen die zijn belast met de uitvoering van deze verordening.

\section{Onderwerp van voorzienbaarheid}

Een laatste terminologisch verschil dat bespreking verdient, heeft betrekking op het onderwerp van de voorzienbaarheid. Met die term doel ik op hetgeen waarop

72 Waarom de periode van 28 november $1996 \mathrm{t} / \mathrm{m} 22$ juni 2000 apart wordt vermeld, zal nog blijken uit paragraaf 8.2.1.4 onder het kopje 'Een bijzondere billijkheidscorrectie onder de VNNZ'.

73 Uiteraard slechts in zoverre was voldaan aan de overige criteria uit de VNNZ voor toekenning van nadeelcompensatie. 
de voorzienbaarheid betrekking dient te hebben. De bepaling uit de Wro noemt bijvoorbeeld slechts de voorzienbaarheid van de schadeoorzaak, terwijl de bepalingen uit de Amsterdamse regelingen spreken van voorzienbaarheid van de schade. Art. 6 BnIW 2019 geeft op zijn beurt een niet-limitatieve opsomming ${ }^{74}$ van onderwerpen waarop de voorzienbaarheid betrekking kan hebben. ${ }^{75}$ Deze onderwerpen hebben steeds betrekking op de schadeoorzaak of de schade, zij het dat bepaalde aspecten daarvan worden uitgelicht, zoals het tijdstip waarop de schadeoorzaak zijn werking doet gevoelen en de plaats waarop de schadeoorzaak betrekking heeft. Deze terminologische verschillen wekken de suggestie dat het onderwerp van voorzienbaarheid weleens zou kunnen verschillen onder de desbetreffende regelingen.

De eerste jurisprudentie die onder de Wro werd gewezen, suggereerde dat daadwerkelijk verschil tussen de regelingen bestond als het aankwam op het onderwerp van de voorzienbaarheid. De Afdeling overwoog op 13 november 2013 namelijk "dat de voorzienbaarheid, zoals volgt uit artikel 6.3 van de Wro, betrekking heeft op de planologische wijziging en niet op de omvang van de schade."76 Dat verraste, omdat een dergelijke beperking onder de WRO niet bestond. ${ }^{77}$ Bovendien werd in de bij de Wro behorende memorie van toelichting opgemerkt dat het bij risicoaanvaarding gaat om de vraag of de aanvrager op het peilmoment "redelijkerwijs rekening had kunnen houden met de mogelijkheid van een toekomstig schadetoebrengend overheidsbesluit, of met schade van een bepaalde omvang als gevolg van dat overheidsbesluit." 78 Uit de in paragraaf 8.2.1.1 besproken jurisprudentie inzake gedeeltelijke voorzienbaarheid volgt echter dat het thans onder de Wro wel degelijk tot de mogelijkheden behoort om de voorzienbaarheid van de schadeomvang te betrekken in de tegenwerping van risicoaanvaarding. Ook onder de Wro kan de voorzienbaarheid dus betrekking hebben op zowel de schadeoorzaak als de schade.

In de toelichting op de AVN wordt opgemerkt dat het "van de specifieke omstandigheden af[hangt] of er moet worden geconcludeerd dat sprake is van

74 Stcrt. 1999, nr. 172, p. 11 (digitaal, p. 10).

75 Deze bepaling was al in de RnVW 1999 aan te treffen en is vanuit die regeling nagenoeg letterlijk overgenomen in een zestal niet nader in dit onderzoek betrokken nadeelcompensatieverordeningen. Het betreft de algemene nadeelcompensatieverordeningen van Oud-Beijerland, Vlissingen, Schieland en de Krimpenerwaard (2011) en Uithoorn (2012). Zie verder de 'Regeling nadeelcompensatie infrastructurele werken gemeente Waalwijk' en de 'Regeling nadeelcompensatie voor werkzaamheden aan de weg' van de gemeente Eindhoven.

76 ABRvS 13 november 2013, ECLI:NL:RVS:2013:1895, r.o. 7.1. Zie bijvoorbeeld ook Van Ravels 2014a, p. 6.

77 Zie bijvoorbeeld ABRvS 31 maart 2004, ECLI:NL:RVS:2004:AO6543, r.o. 2.7 (Rijssen-Holten). 
risicoaanvaarding." 79 Die opmerking doet vermoeden dat het onderwerp van de voorzienbaarheid onder de AVN eveneens niet op voorhand is beperkt. Ook de door rechtbanken onder deze regeling gewezen uitspraken geven geen aanleiding om iets anders te vermoeden. ${ }^{80}$ Ten slotte is het onderwerp van de voorzienbaarheid eveneens niet op voorhand beperkt onder de VNNZ en GrS. Zo bleek hiervoor al dat onder de VNNZ rekening werd gehouden met de voorzienbaarheid van de duur van de werkzaamheden ter aanleg van de Noord/Zuidlijn. In paragraaf 8.2.1.4 zal nog blijken dat onder de GrS rekening werd gehouden met de lange duur van de totstandkoming van geluidszonering.

Hoewel de terminologische verschillen anders deden vermoeden, lijkt er dus geen verschil tussen de regelingen te bestaan als het aankomt op het onderwerp van de voorzienbaarheid. Ik heb ook niet de indruk dat de betrokken regelgevers op dit punt een verschil beoogden. Een duidelijke verklaring voor de desbetreffende terminologische verschillen heb ik dan ook niet kunnen vinden. Mogelijk zijn zij deels ontstaan doordat de betrokken regelgevers inspiratie hebben ontleend aan de jurisprudentie. Immers zien sommige overwegingen uit die jurisprudentie op de voorzienbaarheid van de schadeoorzaak ${ }^{81}$ terwijl andere overwegingen zien op de voorzienbaarheid van de schade. ${ }^{82}$

\subsubsection{Bronnen van voorzienbaarheid}

In deze deelparagraaf zal ik aan de hand van een jurisprudentieanalyse onderzoeken of verschillen bestaan tussen de geselecteerde, thans geldende regelingen met betrekking tot de bronnen waarop het bestuur de voorzienbaarheid kan baseren die vereist is om de aanvrager risicoaanvaarding tegen te werpen. Dit is niet alleen nodig om de tweede deelvraag te kunnen beantwoorden, maar ook om in paragraaf 8.2.3 zinvolle uitlatingen te kunnen doen ten aanzien van de aan de Wns ten grondslag liggende doelstellingen van codificatie van het nadeelcompensatierecht en vergroting van de rechtszekerheid. Hierna zal ik eerst ingaan op de vraag waarom voorzienbaarheid in het hedendaagse planschade- en nadeelcompensatierecht doorgaans wordt tegengeworpen op grond van concrete beleidsvoornemens van overheidswege die ter openbare kennis zijn gebracht. Vervolgens zal ik onderzoeken welke andere bronnen tot tegenwerping van voorzienbaarheid kunnen

79 Zie de toelichting op art. 3 lid 1 onder b AVN.

80 Tot op heden betreft het slechts Rb. Amsterdam 19 maart 2019, ECLI:NL:RBAMS:2019:1962, r.o. 6.4; en Rb. Amsterdam 2 augustus 2018, ECLI:NL:RBAMS:2018:5704.

81 Zie bijvoorbeeld ABRvS 28 september 2016, ECLI:NL:RVS:2016:2582, r.o. 5.20, 5.29 en 5.34 (Overzichtsuitspraak); en ABRvS 17 mei 2017, ECLI:NL:RVS:2017:1293, r.o. 5.1 (De Lunet).

82 Zie bijvoorbeeld ABRvS 28 september 2016, ECLI:NL:RVS:2016:2582, r.o. 5.24 en 5.28 (Overzichtsuitspraak); en ABRvS 29 februari 2012, ECLI:NL:RVS:2012:BV7254, r.o. 2.10.1 (Tilburg/Vugts). 
leiden. ${ }^{83}$ In 2010 verdedigde Tjepkema de stelling dat op dit punt een verschil bestaat tussen het planschaderecht en het overige nadeelcompensatierecht. In het planschaderecht zou alleen een concreet beleidsvoornemen in de vorm van een "ter openbare kennis gebracht ruimtelijk $\mathrm{k}^{84}$ document" als bron van voorzienbaarheid kunnen gelden. Die beperking van bronnen zou "minder zichtbaar" zijn in het nadeelcompensatierecht. ${ }^{85}$ De Afdeling heeft sindsdien echter enkele overwegingen in haar planschadejurisprudentie opgenomen die doen vermoeden dat dit vandaag de dag weleens anders zou kunnen zijn. Zo wordt in de Overzichtsuitspraak overwogen dat bij beantwoording van de vraag of sprake is van voorzienbaarheid rekening dient te worden gehouden met concrete beleidsvoornemens die openbaar zijn gemaakt. ${ }^{86}$ Ook kan worden gewezen op de overweging dat om voorzienbaarheid te kunnen aannemen voldoende is dat er een concreet beleidsvoornemen is dat openbaar is gemaakt. ${ }^{87}$

\section{Voorzienbaarheid die wordt verondersteld ${ }^{88}$ op grond van concrete beleidsvoor- nemens van overheidswege die ter openbare kennis zijn gebracht}

Zowel in het planschade- als in het nadeelcompensatierecht vormen concrete beleidsvoornemens van overheidswege die ter openbare kennis zijn gebracht de meest gebruikte bron van de voorzienbaarheid die nodig is voor tegenwerping van risicoaanvaarding. ${ }^{89}$ Deze tegenwerping wordt gebaseerd op de veronder-

83 Daarbij ga ik niet in op situaties waarin andere bronnen dan een concreet beleidsvoornemen van overheidswege, zoals gespreksverslagen, slechts een ondersteunende rol vervullen. Zie voor een voorbeeld hiervan: ABRvS 20 oktober 2010, ECLI:NL:RVS:2010:BO1122, r.o. 2.7.2. Ook lijkt hiervan sprake te zijn geweest in de onder de AVN gewezen uitspraak Rb. Amsterdam 2 augustus 2018, ECLI:NL:RBAMS:2018:5704, r.o. 9 e.v.

84 Zie hierover ABRvS 25 januari 2006, ECLI:NL:RVS:2006:AV0284, r.o. 2.6.1 (Planschade Hengelo). Daarin oordeelde de Afdeling dat geen voorzienbaarheid mocht worden aangenomen op grond van gepubliceerd subsidiebeleid.

85 Tjepkema 2010, p. 499-508 en 529-531.

86 ABRvS 28 september 2016, ECLI:NL:RVS:2016:2582, r.o. 5.23 (Overzichtsuitspraak).

87 Zie bijvoorbeeld ABRvS 28 juni 2017, ECLI:NL:RVS:2017:1700, r.o. 4.1. Zie voor een uitspraak die wat betreft schade door uitvoeringswerkzaamheden waarschijnlijk onder de RnVW 1999 is afgedaan: ABRvS 11 maart 2015,

ECLI:NL:RVS:2015:763 (en: 765, 767, 768 en 776) r.o. 8.1.

88 Van Monfoort met naschrift Wiersema 2014.

89 Zie bijvoorbeeld ABRvS 28 september 2016, ECLI:NL:RVS:2016:2582, r.o. 5.23 (Overzichtsuitspraak, Wro); ABRvS 10 april 2013, ECLI:NL:RVS:2013:BZ7681, r.o. 5.1 (BnIW 2019); ABRvS 27 december 2006, ECLI:NL:RVS:2006:AZ5163, r.o. 2.6.2 (GrS); en Rb. Amsterdam 27 november 2007, ECLI:NL:RBAMS:2007:BF5171 (Vingerhoedje, eerste aanleg, VNNZ). Ten aanzien van de AVN zijn nauwelijks rechterlijke uitspraken gedaan maar uit de toelichting op art. 3 lid 1 onder b AVN blijkt dat aansluiting wordt gezocht bij de jurisprudentie van de Afdeling. 
stelling dat een redelijk en denkend handelend persoon op de hoogte zou zijn geweest van dergelijke beleidsvoornemens en zijn handelen daarop zou hebben afgestemd. Deze fictie ${ }^{90}$ is behulpzaam voor de bewijspositie van het bestuursorgaan. Dat hoeft immers niet te bewijzen dat de koper het risico op het ontstaan van schade daadwerkelijk voorzag op het peilmoment voor voorzienbaarheid. Ook stelt deze fictie de rechter regelmatig in de gelegenheid om efficiënt te motiveren. Als immers voldoende aannemelijk is dat op het peilmoment sprake was van een concreet beleidsvoornemens van overheidswege dat ter openbare kennis was gebracht, hoeft niet meer te worden ingegaan op allerlei andere potentiële bronnen van voorzienbaarheid. ${ }^{91}$

\section{Gevallen van uitdrukkelijke ${ }^{92}$ risicoaanvaarding}

Zowel in de nadeelcompensatiejurisprudentie als in de planschadejurisprudentie zijn gevallen van "uitdrukkelijke risicoaanvaarding" te herkennen. Dit betreft gevallen waarin de aanvrager zelf heeft vastgelegd dat hij op het peilmoment voor voorzienbaarheid op de hoogte was van het risico dat schade zou kunnen ontstaan door toekomstig overheidshandelen. Hiervan was bijvoorbeeld sprake in een planschadeuitspraak van 16 augustus 2006. Daarin sanctioneerde de Afdeling dat de aanvrager actieve risicoaanvaarding werd tegengeworpen, omdat hij te kennen had gegeven dat hij ten tijde van de aankoop van zijn woning op de hoogte was van een door het bestuur aan omwonenden verzonden brief inhoudende een concreet beleidsvoornemen. ${ }^{93}$

Ook zijn er twee uitspraken waarin de Afdeling uitdrukkelijke risicoaanvaarding aannam zonder na te gaan of sprake was van een concreet beleidsvoornemen van overheidswege. In een onder de RnVW 1999 gewezen Afdelingsuitspraak van 6 maart 2013 werd de exploitante van horecavoorzieningen aan boord van veerboten op de autoveerdienst Kruiningen-Perkpolder actieve risicoaanvaarding tegengeworpen. Zij had namelijk een exploitatieovereenkomst met de provincie Zeeland gesloten waarin uitdrukkelijk was bepaald dat zij het exploitatierecht voor een bepaalde tijd zou verkrijgen en de overeenkomst zou eindigen bij het openstellen van de Westerscheldetunnel. Op grond hiervan was voor haar voorzienbaar dat "haar exploitatierecht te zijner tijd niet zou worden verlengd." 94 In een planschadeuitspraak van 15 januari 2014 oordeelde de Afdeling dat actieve risicoaanvaarding kon worden tegengeworpen op grond van een "zonder enige terughoudendheid" gedane mededeling in de aanvraag om tegemoetkoming in planschade. Daarin

90 Zie daaromtrent bijvoorbeeld Sietses 2016 (Verslag jaarvergadering VBR d.d. 10 december 2015), p. 209.

91 Zie ter illustratie ABRvS 12 februari 2014, ECLI:NL:RVS:2014:402, r.o. 4.2.

92 Van Monfoort met naschrift Wiersema 2014. De term lijkt te zijn ontleend aan AGRvS 25 september 1989, ECLI:NL:RVS:1989:AS7120 (Landarbeiderswoning Den Dungen).

93 ABRvS 16 augustus 2006, ECLI:NL:RVS:2006:AY6334, r.o. 2.4.2.

94 ABRvS 6 maart 2013, ECLI:NL:RVS:2013:BZ3398, r.o. 4.1 en 6. 
werd namelijk met "een grote mate van precisie" vermeld sinds wanneer appellant op de hoogte was van de mogelijke komst van vijftien woningen nabij zijn perceel. Op basis hiervan was "voldoende aannemelijk" dat de bouw en ontsluiting van vijftien woningen nabij het desbetreffende perceel voorzienbaar waren voor de aanvrager ten tijde van de aankoop van zijn woning. ${ }^{95}$

Ten slotte kan worden gewezen op een uitspraak van 18 september 2013. Hierin stond de Afdeling toe dat risicoaanvaarding werd tegengeworpen ondanks dat op het peilmoment voor voorzienbaarheid geen concreet beleidsvoornemen van overheidswege ter openbare kennis, of kennis van de aanvrager was gebracht. Doorslaggevend was het volgende beding uit een koopovereenkomst die aanvrager was aangegaan met een initiatiefnemer met wie het bestuur later een planschadeverhaalsovereenkomst sloot:

"Het is koper bekend dat het gebied gelegen in de directe nabijheid van het verkochte bestemd ${ }^{96}$ is om in de nabije toekomst bebouwing ten behoeve van een woonwijk te realiseren. Koper aanvaardt hierbij alle consequenties welke de realisatie van voornoemde bouwplannen met zich meebrengen (...)."

Door dit beding was namelijk niet in geschil dat aanvrager tijdens het ondertekenen van de koopovereenkomst op de hoogte was van de plannen van de verkoper om "bebouwing ten behoeve van een woonwijk in het plangebied te realiseren en hij de consequenties van het realiseren van die plannen in de koopovereenkomst [had] aanvaard. ${ }^{\circ 97}$

\section{Voorzienbaarheid die wordt verondersteld op grond van andere bronnen}

De Afdeling blijkt soms ook bereid om voorzienbaarheid aan te nemen als een concreet beleidsvoornemen van overheidswege dat ter openbare kennis is gebracht ontbreekt, terwijl ook geen sprake is van uitdrukkelijke risicoaanvaarding. Dit deed zich voor in een onder de GrS gewezen uitspraak van 19 december 2018 waarin schade werd geleden sinds de Polderbaan op 1 november 2003 in gebruik werd genomen conform het 'Luchthavenverkeerbesluit Schiphol 2003'. Niet in geschil was dat een redelijk denkend en handelend koper op grond van concrete beleidsvoornemens geen rekening kon houden met door startend vliegverkeer veroorzaakt grondgeluid. De Afdeling sanctioneerde dat actieve risicoaanvaarding

96 Uit Rb. Arnhem 30 december 2012, ECLI:NL:RBARN:2012:2316 (Voorzienbaarheid door koopovereenkomst, eerste aanleg) blijkt dat het woordje 'bestemd' niet moet worden gelezen als 'is door het bestuur planologisch bestemd', maar als 'de verkopende partij heeft het plan opgevat om...'.

97 Zie ABRvS 18 september 2013, ECLI:NL:RVS:2013:1159, r.o. 4.1 (Voorzienbaarheid door koopovereenkomst, hoger beroep); en Rb. Arnhem 30 december 2012, ECLI:NL:RBARN:2012:2316, r.o. 3 (Voorzienbaarheid door koopovereenkomst, eerste aanleg). 
werd tegengeworpen aan aanvragers die na 1 november 2003 investeerden, “omdat zij de mogelijkheid van overlast door grondgeluid ten tijde van de aankoop van de onroerende zaak geacht worden te hebben aanvaard." Sinds die datum was het grondgeluid immers feitelijk hoorbaar en dus ook kenbaar voor een redelijk denkend en handelend koper, waardoor het kon worden verdisconteerd in de beslissing tot aankoop van een woning in de nabijheid van de Polderbaan. Dat ten tijde van bezichtigingen potentiële kopers het grondgeluid niet zouden hebben ervaren, stond volgens de Afdeling niet aan de voorzienbaarheid in de weg. ${ }^{98}$

Ook kan worden gewezen op de Overzichtsuitspraak. In het daarin te beslechten geschil hadden $\mathrm{B} \& \mathrm{~W}$ een brief aan aanvraagster verzonden waarin werd vermeld dat de woonbestemming van haar pand door een bestemmingsplanherziening zou worden gewijzigd in een horecabestemming. De stelling van aanvraagster dat geen gemeentelijk beleid bestond om woningen in het desbetreffende gebied weg te bestemmen, was volgens de Afdeling niet relevant omdat de brief een concreet beleidsvoornemen inhield dat "in het bijzonder" betrekking had op de onroerende zaak van appellante. Aanvraagster diende op basis hiervan rekening te houden met de kans dat de woonbestemming zou komen te vervallen. ${ }^{99}$ Dit soort situaties zal zich vooral voordoen bij passieve risicoaanvaarding. Het ligt immers weinig voor de hand dat het bestuur alle potentiële kopers van een onroerende zaak poogt te achterhalen en contacteren.

\section{Casuïstiek en bewijslastverdeling}

Wanneer voorzienbaarheid wordt gebaseerd op andere bronnen dan concrete beleidsvoornemens van overheidswege die ter openbare kennis zijn gebracht, is de jurisprudentie erg casuïstisch. In een met de uitspraak van 16 augustus 2006 vergelijkbare zaak mocht aanvrager bijvoorbeeld geen risicoaanvaarding worden tegengeworpen, omdat hij ten tijde van de aankoop van zijn onroerende zaak nog geen kennis had genomen van een brief die B\&W aan omwonenden hadden gestuurd. Daardoor was hij niet in de gelegenheid geweest om de inhoud van deze brief in de door hem te betalen koopprijs te verdisconteren. Of de verkopende partij de aanvrager van deze brief op de hoogte had moeten stellen, was volgens de Afdeling niet van belang. ${ }^{100}$

Het heeft er bovendien veel van weg dat de in deze deelparagraaf besproken jurisprudentie een element van bewijslastverdeling bevat. In de hypothetische situatie dat het bestuur ${ }^{101}$ in de hierboven besproken casus voldoende aannemelijk had weten te maken dat de aanvrager ten tijde van de aankoop wel op de hoogte was

98 ABRvS 19 december 2018, ECLI:NL:RVS:2018:4193, r.o. 76 (Grondgeluid).

99 ABRvS 28 september 2016, ECLI:NL:RVS:2016:2582, r.o. 11.2 (Overzichtsuitspraak).

100 ABRvS 15 oktober 2014, ECLI:NL:RVS:2014:3715, r.o. 4.4.

101 Dat de bewijslast rust op het bestuur volgt uit ABRvS 28 september 2016, ECLI:NL:RVS:2016:2582, r.o. 8.5 (Overzichtsuitspraak). 
geweest van de brief - bijvoorbeeld door overlegging van een verklaring van de verkopende partij - dan zie ik geen reden waarom de Afdeling zou oordelen dat de aanvrager geen risicoaanvaarding mocht worden tegengeworpen. In die situatie had voor een redelijk denkend en handelend koper immers aanleiding bestaan om rekening te houden met de mogelijkheid van de schadeveroorzakende overheidsmaatregel.

Het beeld van een casuïstische en in niet onbelangrijke mate van het bewijsrecht afhankelijke jurisprudentie wordt bevestigd door een uitspraak van 5 augustus 2015. Daarin oordeelde de Afdeling dat geen risicoaanvaarding mocht worden tegengeworpen, omdat het bestuur niet aannemelijk had weten te maken dat ten tijde van het peilmoment een concreet beleidsvoornemen van overheidswege tot wijziging van de planologische situatie in het plangebied bestond, én het bestuur eveneens niet aannemelijk had gemaakt dat aanvrager op het peilmoment "feitelijke voorkennis van een op handen zijnde planologische verandering in het plangebied had." Zij overwoog daarbij dat een verwijzing naar de reeds besproken uitspraak van 18 september 2013 het bestuur niet kon baten, omdat daarin juist werd overwogen dat de koper ten tijde van de aankoop van zijn woning rekening kon houden met woningbouw in de directe nabijheid. ${ }^{102}$

\section{Conclusie}

Gelet op de in deze deelparagraaf besproken jurisprudentie kan worden geconcludeerd dat het ook in het planschaderecht mogelijk is om voorzienbaarheid te baseren op een andere bron dan een concreet beleidsvoornemen van overheidswege dat ter openbare kennis is gebracht. Zo kan tevens risicoaanvaarding worden tegengeworpen in gevallen waarin de aanvrager de voorzienbaarheid uitdrukkelijk heeft bevestigd, en in gevallen waarin voorzienbaarheid wordt verondersteld omdat het bestuur voldoende aannemelijk heeft weten te maken dat de aanvrager beschikte of had moeten beschikken over informatie op grond waarvan een redelijk denkend en handelend koper had geanticipeerd op het mogelijke ontstaan van de schade. Bestudering van de jurisprudentie leidt dan ook tot de conclusie dat wat dit betreft geen verschil bestaat tussen het planschaderecht en de overige geselecteerde, thans geldende regelingen.

Waarschijnlijk bestaat er wel nog een verschil in die zin dat in het planschaderecht voor veronderstelde risicoaanvaarding op grond van een concreet beleidsvoornemen van overheidswege dat ter openbare kennis is gebracht, wordt vereist dat dit beleidsvoornemen een ruimtelijk beleidsvoornemen betreft. ${ }^{103}$ Uit paragraaf 8.2.1.1 bleek immers dat het vaste planschadejurisprudentie is dat een vergelijking moet worden gemaakt tussen de ruimtelijke gevolgen van het planologische

102 ABRvS 5 augustus 2015, ECLI:NL:RVS:2015:2463, r.o. 5.1.

103 Zie ook ABRvS 25 januari 2006, ECLI:NL:RVS:2006:AV0284, r.o. 2.6 .1 (Planschade Hengelo). 
regime waarvan wordt gesteld dat het planschade heeft veroorzaakt, en de ruimtelijke gevolgen van de voor aanvrager meest ongunstige uitwerking van de in het beleidsvoornemen bedoelde ontwikkelingsmogelijkheden. Het spreekt voor zich dat een vergelijkbare eis niet in het nadeelcompensatierecht kan worden gesteld bij schade die bijvoorbeeld wordt veroorzaakt door de wijziging van een subsidieregeling. De verklaring voor dit verschil is dus gelegen in het verschil tussen de deelterreinen waarop de geselecteerde, thans geldende regelingen betrekking hebben.

\subsubsection{De stappen van art. 6:101 BW}

In deze deelparagraaf zal ik onderzoeken in hoeverre de vier stappen van art. 6:101 BW ook moeten worden gezet om risicoaanvaarding tegen te werpen in het planschade- en nadeelcompensatierecht. Hiermee wordt het fundament gelegd voor de toetsing aan het uitgangspunt van aansluiting bij het BW die in paragraaf 8.2.3 zal plaatsvinden ter beantwoording van de hoofdvraag. Toch is ervoor gekozen om de vergelijking met art. 6:101 BW al op deze plaats te maken. Zij heeft namelijk ook relevantie voor de beantwoording van de tweede deelvraag. Zij maakt namelijk inzichtelijk dat onder de VNNZ en art. 21 Aanwijzingsbesluit 1996 soms een bijzondere invulling aan het criterium van risicoaanvaarding is gegeven uit coulanceoverwegingen. Dit soort bijzondere invullingen ben ik slechts tegengekomen onder deze regelingen. Mijns inziens laten de overige regelingen voldoende ruimte voor een vergelijkbare invulling. Kennelijk hebben de desbetreffende bestuursorganen echter geen reden gezien om daar gebruik van te maken bij de beoordeling van de bij hen ingediende aanvragen om nadeelcompensatie.

Stap 1 en 2: Is de schade mede het gevolg van een omstandigheid aan de zijde van de aanvrager, en kan deze omstandigheid aan de aanvrager worden toegerekend?

Ook in het planschade- en nadeelcompensatierecht vormen de eerste twee stappen van art. 6:101 BW voorwaarden om schade wegens risicoaanvaarding voor rekening van de aanvrager te laten. Inherent aan de tegenwerping van actieve risicoaanvaarding is immers dat de aanvrager door zijn investeringshandeling heeft bijgedragen aan het intreden van de schade. De schade is dus mede een gevolg van een omstandigheid aan de zijde van de benadeelde (stap 1). Het doen van een investering is echter niet genoeg om risicoaanvaarding tegengeworpen te krijgen. De investering moet namelijk ook aan de aanvrager kunnen worden toegerekend (stap 2). ${ }^{104}$ Daartoe is vereist dat op het moment van investering de mogelijkheid van de schadeveroorzakende overheidsmaatregel zodanig kenbaar was dat een re-

104 Een bekend voorbeeld uit het civiele recht betreft de aanvang met bouwwerkzaamheden voordat de daartoe verleende vergunning onaantastbaar is geworden: HR 29 april 1994, ECLI:NL:HR:1994:ZC1358 (Bouwvergunning Schuttersduin). 
delijk denkend en handelend koper, ${ }^{105}$ of ondernemer ${ }^{106}$ daarmee rekening moest houden bij zijn beslissing tot investering. Slechts dan kan een investeerder immers worden verweten dat hij - anders dan een redelijk denkend en handelend koper of ondernemer zou hebben gedaan - de mogelijkheid van de schadeveroorzakende overheidsmaatregel ten tijde van de investeringsbeslissing heeft aanvaard, ${ }^{107}$ zonder deze bijvoorbeeld te hebben betrokken bij het overeenkomen van de koopprijs. ${ }^{108}$ Om met civielrechtelijke woorden te spreken: slechts dan kan worden geconcludeerd dat de aanvrager niet "voldoende zorg voor eigen persoon en goed" heeft betracht. ${ }^{109}$

De eerste twee stappen dienen ook te worden genomen voor tegenwerping van passieve risicoaanvaarding. De omstandigheid aan de zijde van de aanvrager die de schade mede heeft veroorzaakt (stap 1), bestaat dan uit het nalaten te investeren/handelen. Deze omstandigheid moet ook aan de aanvrager kunnen worden toegerekend (stap 2). Voor tegenwerping van passieve risicoaanvaarding is immers vereist dat voortekenen van de schadeveroorzakende overheidsmaatregel reeds enige tijd zichtbaar waren ${ }^{110}$ en de aanvrager ${ }^{111}$ geen concrete pogingen heeft gedaan tot realisering van de mogelijkheden die door de schadeveroorzakende overheidsmaatregel zijn komen te vervallen, terwijl dit wel vanaf de peildatum voor voorzienbaarheid ${ }^{112}$ van een redelijk denkend en handelend eigenaar kon worden verlangd. ${ }^{113}$ Ook hier vervult de maatstaf van de wijze waarop een redelijk en denkend handelend persoon zou handelen dus de rol die in het civiele recht wordt vervuld door de norm van de persoon die "voldoende zorg voor eigen persoon en goed" betracht.

In de jurisprudentie zijn bovendien voorbeelden te vinden van situaties waarin bestuursorganen worden teruggefloten, omdat zij risicoaanvaarding tegenwerpen zonder dat de tweede stap is genomen. Het duidelijkste voorbeeld betreft de juris-

105 Zie ABRvS 28 september 2016, ECLI:NL:RVS:2016:2582, r.o. 5.23 (Overzichtsuitspraak); ABRvS 26 juli 2017, ECLI:NL:RVS:2017:1988, r.o. 7.3-7.4 (OK Oliecentrale); en ABRvS 27 december 2006, ECLI:NL:RVS:2006:AZ5163, r.o. 2.6.1.

106 Zie ABRvS 10 april 2013, ECLI:NL:RVS:2013:BZ7681, r.o. 5.1; en ABRvS 5 november 2008, ECLI:NL:RVS:2008:BG3375 (Vingerhoedje, hoger beroep).

107 ABRvS 28 september 2016, ECLI:NL:RVS:2016:2582, r.o. 5.24 (Overzichtsuitspraak).

108 ABRvS 30 november 2016, ECLI:NL:RVS:2016:3196, r.o. 4.1.

109 Zie paragraaf 8.1 onder het kopje 'De vier stappen van art. 6:101 BW'.

110 ABRvS 28 september 2016, ECLI:NL:RVS:2016:2582, r.o. 5.32 (Overzichtsuitspraak).

111 Concrete pogingen die zijn gedaan door vorige eigenaren zijn niet relevant, zie ABRvS 2 oktober 2013, ECLI:NL:RVS:2013:1323, r.o. 5.1.

112 Zijnde het moment waarop de schade(oorzaak) voor een redelijk denkend en handelend eigenaar op grond van een concreet beleidsvoornemen voorzienbaar was, zie paragraaf 8.2.1.1 onder het kopje 'Passieve risicoaanvaarding'.

113 ABRvS 28 september 2016, ECLI:NL:RVS:2016:2582, r.o. 5.34 (Overzichtsuitspraak). 
prudentielijn dat passieve risicoaanvaarding niet aan de aanvrager wordt tegengeworpen wanneer hij "als gevolg van hem niet toe te rekenen omstandigheden niet in staat is geweest" een concrete poging te ondernemen, bijvoorbeeld omdat hij niet vrijelijk over zijn perceel kon beschikken. ${ }^{114}$ In het verlengde hiervan ligt het niet tegenwerpen van passieve risicoaanvaarding aan de aanvrager die concrete pogingen heeft ondernomen om de bedreigde bouw- en/of gebruiksmogelijkheden te gaan benutten, zoals die van een redelijk denkend en handelend eigenaar kunnen worden verlangd. ${ }^{115}$ Ook kan worden gedacht aan het niet tegenwerpen van actieve risicoaanvaarding als de op het peilmoment aanwezige voorzienbaarheid wordt 'doorbroken' doordat de benadeelde gerechtvaardigd heeft vertrouwd op door het bevoegd gezag gedane toezeggingen of inlichtingen. De mogelijkheid van verwezenlijking van de schadeveroorzakende overheidsmaatregel is dan weliswaar voldoende kenbaar op het moment van investeren, maar het kan de aanvrager niet worden verweten dat hij desondanks investeerde. Op grond van de door het bestuur verstrekte inlichtingen mocht hij er namelijk van uitgaan dat deze maatregel geen doorgang zou vinden of niet nadelig voor hem zou uitpakken. ${ }^{116}$ De aanvrager handelde door deze inlichtingen immers niet anders dan een redelijk denkend en handelend persoon zou hebben gedaan.

Waarschijnlijk kan ook de jurisprudentielijn dat geen actieve risicoaanvaarding wordt tegengeworpen bij verkrijging onder algemene titel, of een verkrijging onder bijzondere titel die daarmee gelijk is te stellen, als toepassing van de tweede stap worden gezien. ${ }^{117}$ Ten slotte kan worden gedacht aan het niet tegenwerpen van actieve risicoaanvaarding bij investeringen in een reeds bestaand belang. Daarbij is namelijk niet bepalend of de mogelijkheid van de schadeveroorzakende overheidsmaatregel voorzienbaar was op het moment van de investeringsbeslissing, maar of op dat moment aanleiding bestond rekening te houden met de kans dat de

114 Zie voor verlies van bouwmogelijkheden: ABRvS 25 juni 2014, ECLI:NL:RVS:2014:2287, r.o. 5.1; ABRvS 13 augustus 2014, ECLI:NL:RVS:2014:3005, r.o. 4.5 (erfpacht); en ABRvS 16 maart 2011, ECLI:NL:RVS:2011:BP7753, r.o. 2.5.1 (vruchtgebruik). Zie voor verlies van gebruiksmogelijkheden: ABRvS 18 april 2012, ECLI:NL:RVS:2012:BW3066, r.o. 2.5.2 (Steenfabriek of scheepswerf?). Zie ten aanzien van een huurovereenkomst ook Rb. Amsterdam 1 maart 2017, ECLI:NL:RBAMS:2017:3575, r.o. 4.4.

115 Zie ABRvS 5 juli 2017, ECLI:NL:RVS:2017:1793, r.o. 6 ('t Vennewater) en de bijbehorende noot van J.W. van Zundert in BR 2005/61. Vergelijk: ABRvS 6 oktober 2004, ECLI:NL:RVS:2004:AR3365, r.o. 2.6.2 (Voorzienbaarheid Assen).

116 Zie de bespreking van ABRvS 26 juli 2017, ECLI:NL:RVS:2017:1988 (OK Oliecentrale) in Franssen \& Van de Sande 2018a, p. 91. Zie eveneens ABRvS 20 april 2016, ECLI:NL:RVS:2016:1049, r.o. 6.2.; Stcrt. 1999, nr. 172, p. 10 (digitaal, p. 10); en Basisdocument, p. 32.

117 Zie ABRvS 28 september 2016, ECLI:NL:RVS:2016:2582, r.o. 5.31 (Overzichtsuitspraak). Gelijk te stellen verkrijging onder bijzondere titel: ABRvS 10 oktober 2012, ECLI:NL:RVS:2012:BX9702, r.o. 5.1. Niet gelijk te stellen verkrijging onder bijzondere titel: ABRvS 23 november 2016, ECLI:NL:RVS:2016:3134, r.o. 6.1 (Wormerland). 
investering niet volledig rendabel zou kunnen worden gemaakt. ${ }^{118}$ De ratio lijkt te zijn dat de investeringsbeslissing niet kan worden toegerekend aan de eigenaar en/of ondernemer die er terecht van uitging dat hij zijn investering volledig kon terugverdienen, omdat hij niet anders heeft gehandeld dan een redelijk denkend en handelend eigenaar en/of ondernemer zou hebben gedaan.

\section{Stap 3 en 4: Evenredige verdeling van de schadelast en de billijkheidscorrectie}

In het planschade- en nadeelcompensatierecht draagt risicoaanvaarding een "alles of niets-karakter". ${ }^{119}$ Ter illustratie daarvan verwijs ik naar een onder de GrS gewezen uitspraak van 27 december 2006. ${ }^{120}$ Het betrof een aanvraag om planschadevergoeding door een persoon wiens op 24 maart 1994 aangekochte woning in waarde was gedaald door het op 29 april 1999 in werking getreden ${ }^{121}$ bestemmingsplan 'Schiphol-West en omgeving'. Dit bestemmingsplan voorzag in de aanleg en het gebruik van de vijfde start- en landingsbaan op het luchtvaartterrein van Schiphol. De Afdeling sanctioneerde dat de schade van aanvrager volledig voor diens rekening werd gelaten wegens actieve risicoaanvaarding. De aanleg en ingebruikneming van de vijfde start- en landingsbaan waren namelijk reeds voorzienbaar op grond van het ontwerp-PKB, met inbegrip van de bijbehorende kaarten, dat op 18 januari 1994 ter inzage was gelegd.

Uit dit oordeel van de Afdeling kan worden afgeleid dat de causale verdeling van de derde stap van art. 6:101 BW in het planschade- en nadeelcompensatierecht (feitelijk) geen rol van betekenis speelt. De schade had niet kunnen intreden zonder dat de aanvrager de desbetreffende woning had gekocht. De schade had echter ook niet kunnen intreden zonder de inwerkingtreding van het bestemmingsplan. Over de mate waarin beide gebeurtenissen hebben bijgedragen aan het ontstaan van de schade kan worden gediscussieerd. Zelfs als wordt aangenomen dat het aandeel van het bestuur klein is, bijvoorbeeld vijf procent, leidt een causale verdeling niet ertoe dat de schade volledig voor rekening van de aanvrager komt. Kennelijk wordt de schade in het planschade- en nadeelcompensatierecht dus niet naar evenredigheid van hun handelen tussen aanvrager en bestuur verdeeld, maar volledig voor rekening van de aanvrager gelaten. Het heeft daarom veel ervan weg dat de causale verdeling van de derde stap wordt overgeslagen en in beginsel altijd meteen de vierde stap van een billijkheidscorrectie wordt gezet. Die correctie wordt niet geëxpliciteerd en gemotiveerd, maar houdt in dat schade in geval van risicoaanvaarding volledig voor rekening van de aanvrager

118 ABRvS 13 oktober 2004, ECLI:NL:RVS:2004:AR3748, r.o. 2.5.1. In deze uitspraak wordt verwezen naar ABRvS 7 augustus 1997, ECLI:NL:RVS:1997:AE0422: “aanleiding bestond rekening te houden met de kans dat de investering niet volledig zou kunnen worden terugverdiend (...)."

119 Zie bijvoorbeeld Dijkshoorn 2011a, p. 118 en 120.

120 ABRvS 27 december 2006, ECLI:NL:RVS:2006:AZ5163, r.o. 2.6.1-2.6.4.

121 De datum van inwerkingtreding blijkt niet uit de uitspraak, maar wel uit ABRvS 13 februari 2013, ECLI:NL:RVS:2013:BZ1258, r.o. 3. 
wordt gelaten. Zij lijkt te kunnen worden verklaard door de bijzondere aard van het planschade- en nadeelcompensatierecht. Anders dan de laedens in het civiele onrechtmatigedaadsrecht, én anders dan de aanvrager die niet handelde zoals een redelijk denkend en handelend persoon zou hebben gedaan, heeft het bestuur immers niet onrechtmatig gehandeld respectievelijk anderszins een fout gemaakt (mate van verwijtbaarheid), maar betreft het een compensatie wegens rechtmatige overheidsdaad die wordt bekostigd uit schaarse publieke middelen ${ }^{122}$ (aard van de aansprakelijkheid). ${ }^{123}$

Slechts in bijzondere gevallen lijkt de billijkheidscorrectie ook voordelig voor de aanvrager te kunnen uitpakken. Het komt echter bijna nooit voor dat de billijkheidscorrectie ertoe leidt dat het onevenredige deel van de schade - ondanks de risicoaanvaarding - volledig voor tegemoetkoming in aanmerking komt. Een uitspraak die mogelijk wel zo zou kunnen worden geïnterpreteerd, betrof het geval van een echtgenote die een haar in mede-eigendom toekomende woning geheel in eigendom toebedeeld kreeg bij een boedelscheiding. In ruil daarvoor zag zij af van alimentatie, waardoor de toedeling plaatsvond met gesloten beurzen. Hoewel het in casu schadeveroorzakende bestemmingsplan reeds voorzienbaar was op het moment van de toedeling, oordeelde de Afdeling dat de echtgenote geen risicoaanvaarding mocht worden tegengeworpen in het besluit op haar aanvraag om tegemoetkoming in planschade. De "aard van de toedeling" stond "in een geval als dit" namelijk aan verdiscontering van de waardedaling in de weg. Voor de toenmalig echtgenoot bestond immers geen aanleiding de waardevermindering voor zijn rekening te nemen, omdat hem bij overdracht vóór inwerkingtreding van het nieuwe plan geen aanspraak op schadevergoeding zou toekomen. Van de toenmalig echtgenote kon echter "in redelijkheid niet worden gevergd" vanwege de waardevermindering van bewoning af te zien, aangezien zij al mede-eigenaar en bewoonster van de woning was. De Afdeling merkte expliciet op dat zij een andere uitkomst "onwenselijk" vond, omdat de planschade dan slechts vergoed had kunnen worden indien de boedelverdeling was uitgesteld tot inwerkingtreding van het nieuwe plan teneinde een gezamenlijke aanvraag om tegemoetkoming in planschade in te dienen. ${ }^{124}$

\section{Een bijzondere billijkheidscorrectie onder de VNNZ}

Onder de VNNZ koos het Amsterdamse gemeentebestuur ervoor om slechts de helft van het onevenredige deel van de schade wegens risicoaanvaarding voor rekening te laten van aanvragers die hun investeringsbeslissing hadden genomen

122 Zie voor een vergelijkbare redenering ten aanzien van compensatie anders dan in geld: ABRvS 9 december 2015, ECLI:NL:RVS:2015:3767.

123 In paragraaf 8.1 bleek dat zowel de aard van de aansprakelijkheid als de mate van verwijtbaarheid een rol spelen onder de vierde stap van art. 6:101 BW.

124 ABRvS 18 juni 2003, ECLI:NL:RVS:2003:AG1747, r.o. 2.4.3. Franssen trekt mijns inziens terecht - een parallel met de schaduwschadeproblematiek waarvoor de Afdeling geen oplossing wenst te bieden. Zie Franssen 2014, p. 42. 
tussen 28 november 1996 en 22 juni 2000. Daartoe werd aangevoerd dat vanaf de vaststelling van het definitieve tracé op 27 november 1996 sprake was van voorzienbaarheid van de aard en omvang van de aanlegwerkzaamheden. De gemeenteraad was echter van mening dat deze voorzienbaarheid nog niet volledig aan aanvragers kon worden 'toegerekend' (lees: de investeringshandeling niet volledig verwijtbaar was), omdat de financiering van het project nog niet was gewaarborgd. Daarin kwam verandering doordat de gemeenteraad op 21 juni 2000 een besluit nam waarin de in 1999 aangeboden rijksfinanciering werd aanvaard en aangevuld. Vanaf dat moment stond definitief vast dat het project doorgang kon vinden. De schade van aanvragers die na het financieringsbesluit van 21 juni 2000 investeerden, werd daarom geheel voor hun eigen rekening gelaten wegens risicoaanvaarding. ${ }^{125}$

In een uitspraak van de rechtbank Amsterdam van 22 oktober 2007 was 1 juli 1998 het peilmoment voor voorzienbaarheid en werd door het bestuur dus een korting van 50\% wegens risicoaanvaarding tegengeworpen. De rechtbank achtte het "niet onredelijk" een korting wegens "(beperkte) voorzienbaarheid" toe te passen. De beroepsgronden lieten de rechtbank echter geen ruimte om zich uit te laten over de hoogte van het kortingspercentage. ${ }^{126}$ Het is mijn verwachting dat de rechtbank tot een korting van 100\% was gekomen als de beroepsgronden die ruimte wel hadden gelaten. Het heeft er namelijk veel van weg dat de bovenstaande billijkheidscorrectie niet werd vereist door het recht, maar werd ingegeven door coulance. ${ }^{127} \mathrm{Uit}$ een Afdelingsuitspraak van 26 juli 2017 blijkt immers dat het nog niet rond zijn van financiering voor een bepaalde maatregel niet in de weg hoeft te staan aan de voorzienbaarheid daarvan. ${ }^{128}$ Bovendien overwoog de rechtbank Amsterdam in een uitspraak van 27 november 2007 dat de besluiten van 27 november 1996 en 21 juni 2000 voldoen aan de eisen die aan een beleidsvoornemen worden gesteld om op basis daarvan voorzienbaarheid te kunnen aannemen. ${ }^{129}$ Het hoger beroep tegen deze uitspraak werd door de Afdeling op 5 november 2008 ongegrond verklaard. ${ }^{130}$

125 Uiteraard slechts in zoverre aan de overige vereisten uit de VNNZ was voldaan. De informatie uit deze alinea is gebaseerd op de toelichting op art. 3, eerste lid, onder b VNNZ.

126 Rb. Amsterdam 22 oktober 2007, ECLI:NL:RBAMS:2007:BB7619.

127 Zie voor een opmerking van vergelijkbare aard Tjepkema 2010, p. 494-496.

128 ABRvS 26 juli 2017, ECLI:NL:RVS:2017:2024, r.o. 5.3.

129 Rb. Amsterdam 27 november 2007, ECLI:NL:RBAMS:2007:BF5171 (Vingerhoedje, eerste aanleg).

130 ABRvS 5 november 2008, ECLI:NL:RVS:2008:BG3375 (Vingerhoedje, hoger beroep). De voorzienbaarheid was ook in hoger beroep onderwerp van geschil. Zie met name r.o. 2.4-2.6. 


\section{Een bijzondere billijkheidscorrectie onder de GrS}

Onder de GrS nam de besliscommissie beperkte voorzienbaarheid aan bij schade veroorzaakt door het Aanwijzingsbesluit 1996. De verplichting tot het vaststellen van geluidzones was per 1 oktober 1978 in de Lvw opgenomen. Op 14 november 1979 werd een kaart gepubliceerd in deel a van het Structuurschema Burgerluchtvaartterreinen $1981^{131}$ met de mogelijke situering van deze geluidzones. Op 18 januari 1994 werd een ontwerp-PKB ter visie gelegd, waarvan bij de begrenzing van de geluidszones nog nauwelijks werd afgeweken in het Aanwijzingsbesluit 1996. De besliscommissie koos $^{132}$ ervoor om aanvragers die hun onroerende zaak tussen 14 november 1979 en 18 januari 1994 kochten slechts een korting van 50\% wegens risicoaanvaarding tegen te werpen. ${ }^{133}$ De Afdeling heeft deze benadering gesanctioneerd in een uitspraak van 10 november 2010 door te oordelen dat de rechtbank terecht had geoordeeld dat voorzienbaarheid mocht worden tegengeworpen en "terecht rekening [was] gehouden met de lange duur van de totstandkoming van de zonering door een korting van 50\% van het begrote schadebedrag in rekening te brengen." Daarbij lijkt, naast het hiervoor reeds opgemerkte, van belang te zijn geweest dat uit de in 1979 gepubliceerde kaart reeds de vorm en omvang van de geluidszones konden worden afgeleid en dat deze zones "grotendeels" overeenkwamen met de kaarten behorende bij het Aanwijzingsbesluit 1996. ${ }^{134}$

Net als bij de Amsterdamse casus, moet ook hier worden opgemerkt dat de beroepsgronden de Afdeling niet de ruimte boden om te beoordelen of niet eigenlijk een hogere korting dan 50\% had moeten worden tegengeworpen. Desondanks heeft het er mijns inziens veel van weg dat ook hier sprake is van een billijkheidscorrectie die niet werd vereist door het recht, maar werd ingegeven door coulance. Gelet op de informatie over gedeeltelijke voorzienbaarheid uit paragraaf 8.2.1.1, lijkt de mogelijkheid van de schadeveroorzakende overheidsmaatregelen immers ook al (in) voldoende (detail) kenbaar te zijn geweest op basis van de op 14 november 1979 gepubliceerde kaart. Er komt namelijk geen betekenis toe aan de grootte van de kans dat de schade wel of niet zou ontstaan. ${ }^{135}$ In paragraaf 8.2.1.1

131 Zie hierover ABRvS 10 november 2010, ECLI:NL:RVS:2010:BO3436, r.o. 2.11.2.

132 Deze keuze kwam tot stand naar aanleiding van een advies van een adviescommissie die werd ingesteld naar aanleiding van de in paragraaf 4.2.3.2 besproken uitspraak van ABRvS 9 april 2008, ECLI:NL:RVS:2008:BC9040. Een beknopte samenvatting van dit advies is te vinden in ABRvS 10 november 2010, ECLI:NL:RVS:2010:BO3436, r.o. 2.5. Hoe het advies door de besliscommissie werd ontvangen, blijkt uit $\mathrm{Rb}$. Haarlem 16 februari 2010, ECLI:NL:RBHAA:2010:BL5526, r.o. 2.13-2.14.

133 Zie bijvoorbeeld voor een aankoop in 1983: ABRvS 6 november 2013, ECLI:NL:RVS:2013:1821, r.o. 10.2 (Hoger beroep); en Rb. Haarlem 14 november 2012, ECLI:NL:RBHAA:2012:BZ3738, r.o. 23-24 (Eerste aanleg). Zie voor een aankoop in 1987: Rb. Haarlem 29 juni 2012, ECLI:NL:RBHAA:2012:BX0779, r.o. 2.14 .

134 ABRvS 10 november 2010, ECLI:NL:RVS:2010:BO3436, r.o. 2.11.1-2.11.2.

135 Zie ABRvS 28 september 2016, ECLI:NL:RVS:2016:2582, r.o. 5.28 (Overzichtsuitspraak); en ABRvS 10 april 2013, ECLI:NL:RVS:2013:BZ7681, r.o. 5.2. 
bleek bovendien dat een groot tijdsverloop tussen het concrete beleidsvoornemen waar de voorzienbaarheid op wordt gebaseerd en de investeringsbeslissing niet aan tegenwerping van volledige voorzienbaarheid in de weg hoeft te staan. Desondanks lijkt het aannemelijk dat de reden om hier van de gebruikelijke gang van zaken af te wijken - net als bij de vaststelling van het causaal verband tussen schade en schadeoorzaak - was gelegen in de "langdurige nalatigheid" van de minister om te voldoen aan zijn wettelijke plicht om geluidsnormering vast te stellen. ${ }^{136}$

\subsubsection{Conclusie}

Ter beantwoording van de tweede deelvraag is in deze deelparagraaf gezocht naar verschillen in de wijze waarop de geselecteerde, thans geldende regelingen het criterium van risicoaanvaarding vormgeven, en de verklaringen die daarvoor kunnen worden aangedragen. Daartoe is in paragraaf 8.2.1.1 ingegaan op de belangrijkste contouren van het criterium. Aangezien de bestuursrechter de toepassing van het criterium vol toetst, zouden deze contouren niet moeten verschillen onder de geselecteerde, thans geldende regelingen. Vervolgens is in paragraaf 8.2.1.2 aandacht besteed aan terminologische verschillen in de wijze waarop de regelingen het criterium van risicoaanvaarding hebben gecodificeerd. Veel van deze verschillen kunnen slechts worden verklaard doordat de regelingen gedurende enkele decennia door verschillende regelgevers zijn opgesteld, terwijl die regelgevers ten aanzien van dit onderwerp geen aandacht lijken te hebben gehad voor afstemming op andere nadeelcompensatieregelingen en/of overleg met elkaar, laat staan een materieelrechtelijk verschil in het leven beoogden te roepen. Dat in art. 49 WRO, art. 21 Aanwijzingsbesluit 1996 en art. 8.31 Wlv niet wordt ingegaan op risicoaanvaarding heeft een historische verklaring, maar laat onverlet dat risicoaanvaarding wel kan worden tegengeworpen door toepassing van de in deze bepalingen vervatte redelijkerwijsformule.

Aan twee terminologische verschillen is afzonderlijke aandacht besteed. Allereerst is ingegaan op de tabel die als bijlage bij art. 3 VNNZ is vastgesteld. Deze biedt op voorhand duidelijkheid omtrent de beantwoording van de vraag of, en zo ja voor hoe lang, risicoaanvaarding zal worden tegengeworpen aan een benadeelde die schade lijdt door de aanleg van de Noord/Zuidlijn. Dat in de overige regelingen niet op voorhand meer duidelijkheid omtrent de beantwoording van de voorzienbaarheidsvraag wordt verschaft, kan deels worden verklaard doordat het toepassingsbereik van die regelingen niet is beperkt tot schade door één gebeurtenis/project. Deels is een verklaring ook erin gelegen dat het op voorhand duidelijkheid verschaffen omtrent de peildata voor voorzienbaarheid niet voortvloeit uit een rechtsplicht, maar moet worden gezien als een handreiking aan de burger en uitvoerende bestuursorganen. 
Ten tweede is ingegaan op terminologische verschillen die suggereren dat onder de geselecteerde, thans geldende regelingen een materieelrechtelijk verschil zou bestaan ten aanzien van het onderwerp van voorzienbaarheid. Uit een analyse van jurisprudentie en de bij de regelingen behorende toelichtingen blijkt echter dat dit niet het geval is. Een duidelijke verklaring voor het verschil in formulering van de relevante bepalingen heb ik dan ook niet kunnen vinden. Ook hier lijkt dus te moeten worden teruggevallen op de algemene verklaring dat de regelingen gedurende enkele decennia door verschillende regelgevers zijn opgesteld, terwijl die regelgevers ten aanzien van dit onderwerp geen aandacht lijken te hebben gehad voor afstemming op andere nadeelcompensatieregelingen en/of overleg met elkaar, laat staan een materieelrechtelijk verschil in het leven beoogden te roepen. Mogelijk heeft ook een rol gespeeld dat sommige overwegingen uit de jurisprudentie zien op de voorzienbaarheid van de schadeoorzaak, terwijl andere zien op de voorzienbaarheid van de schade.

Vervolgens is in paragraaf 8.2.1.3 stilgestaan bij de vraag of verschillen bestaan tussen de geselecteerde, thans geldende regelingen met betrekking tot de bronnen waarop het bestuur de voorzienbaarheid kan baseren die vereist is om de aanvrager risicoaanvaarding tegen te werpen. In algemene zin lijkt dat niet het geval te zijn. De bestudeerde jurisprudentie laat zien dat voorzienbaarheid onder alle regelingen het meest wordt gebaseerd op een concreet beleidsvoornemen van overheidswege dat ter openbare kennis is gebracht. Dat neemt niet weg dat de regelingen ook de ruimte laten om risicoaanvaarding tegen te werpen in gevallen waarin de aanvrager de voorzienbaarheid uitdrukkelijk heeft bevestigd, én gevallen waarin voorzienbaarheid wordt verondersteld omdat het bestuur voldoende aannemelijk heeft weten te maken dat de aanvrager beschikte, of had moeten beschikken over informatie op grond waarvan een redelijk denkend en handelend koper had geanticipeerd op het mogelijke ontstaan van schade. Wordt voorzienbaarheid in het planschaderecht gebaseerd op een concreet beleidsvoornemen van overheidswege dat ter openbare kennis is gebracht, dan zal dat wel een ruimtelijk beleidsvoornemen moeten betreffen. Wat dat betreft bestaat een verschil met de overige regelingen, dat kan worden verklaard doordat deze regelingen betrekking hebben op een ander deelterrein van het nadeelcompensatierecht.

Vooruitlopend op de beantwoording van de hoofdvraag is ten slotte in paragraaf 8.2.1.4 ingegaan op de vraag of de vier stappen van art. 6:101 BW ook in het hedendaagse planschade- en nadeelcompensatierecht moeten worden gezet voor de tegenwerping van risicoaanvaarding. Ik kom tot de conclusie dat de eerste en tweede stap in ieder geval worden gezet. Aan de causale verdeling van de derde stap lijkt (feitelijk) geen belang toe te komen. Zover ik heb kunnen nagaan, wordt deze stap steeds overgeslagen: als de eerste en tweede stap zijn gezet, is het uitgangspunt dat de schade volledig voor rekening van de aanvrager wordt gelaten. Ik kwalificeer dit als een niet geëxpliciteerde en niet gemotiveerde billijkheidscorrectie (stap 4). Zij wordt verklaard door de bijzondere aard van het planschade- en nadeelcompensatierecht. Dat de billijkheidscorrectie soms ook in het voordeel van de aanvrager kan uitpakken, blijkt doordat slechts de helft van het onevenredige 
deel van de schade wegens risicoaanvaarding voor rekening werd gelaten van (1) aanvragers die schade leden door de aanleg van de Noord/Zuidlijn en hun investeringsbeslissing tussen 28 november 1996 en 22 juni 2000 hadden genomen; en (2) aanvragers die schade leden door het Aanwijzingsbesluit 1996. Gelet op de algemene jurisprudentielijnen lijken die billijkheidscorrecties echter niet voort te vloeien uit het recht, maar uit coulanceoverwegingen. Relevant voor de beantwoording van de tweede deelvraag is dat dit slechts een verschil in toepassing van de geselecteerde, thans geldende regelingen betreft. De overige regelingen bieden namelijk voldoende ruimte om een vergelijkbare, coulante invulling te geven aan het criterium van risicoaanvaarding. Kennelijk hebben de bestuursorganen die zijn belast met de uitvoering van die regelingen echter nooit aanleiding daartoe gezien.

\subsubsection{Deelvraag 3: het toekomstige recht}

\subsubsection{Een algemene bepaling in titel 4.5 Awb}

In art. 4:126 lid 2, aanhef en onder a Awb is bepaald dat...

"(...) schade (...) in elk geval voor rekening van de aanvrager [blijft] voor zover hij het risico van het ontstaan van de schade heeft aanvaard."

De bij de Wns behorende memorie van toelichting wekt het beeld dat de wetgever onder titel 4.5 Awb beoogt vast te houden aan de thans bestaande jurisprudentielijnen inzake risicoaanvaarding. Zo wordt onder verwijzing naar verschillende Afdelingsuitspraken ingegaan op het onderscheid tussen actieve en passieve risicoaanvaarding en op de jurisprudentielijnen inzake het investeren in een reeds bestaand belang. ${ }^{137}$ Dit beeld wordt bevestigd doordat in de memorie van antwoord wordt opgemerkt dat de "gezichtspunten" uit het tweede en derde lid van art. 4:126 Awb een codificatie van de jurisprudentie vormen. ${ }^{138}$

In dezelfde memorie van antwoord gaat de toenmalig minister van Veiligheid \& Justitie in op de vraag welke bronnen onder titel 4.5 Awb tot aanname van voorzienbaarheid kunnen leiden. ${ }^{139}$ Hij geeft aan dat er onder art. 49 WRO in principe slechts één bron van voorzienbaarheid voor aanname van risicoaanvaarding bestond: een concreet beleidsvoornemen uit een ruimtelijk beleidsstuk dat openbaar moest zijn gemaakt, maar geen formele status hoefde te hebben. Omdat titel 4.5 Awb een algemene nadeelcompensatieregeling betreft, dienen volgens de minister, naar gelang de schadeveroorzakende overheidsmaatregel, verschillende bronnen van voorzienbaarheid van invloed te kunnen zijn op het al dan niet aannemen van

137 Kamerstukken II 2010/11, 32 621, nr. 3, p. 24-25 (MvT, Wns).

138 Kamerstukken I 2012/13, 32 621, nr. C, p. 5 (MvA I, Wns).

139 Kamerstukken I 2011/12, 32 621, nr. B, p. 7 (VV I, Wns). De vraag of een eventuele uitbreiding van bronnen van voorzienbaarheid op zijn plaats zou kunnen zijn, is bijvoorbeeld ook opgeworpen in Van Ravels 2008, 140-141; Tjepkema 2010, p. 499-508; en Tjepkema 2012, p. 392-398. 
risicoaanvaarding. ${ }^{140}$ Het is onduidelijk wat de minister hiermee precies bedoelt. Beoogt hij slechts aan te geven dat het redelijk is dat de voorzienbaarheid van de realisering van een appartementengebouw niet kan worden gebaseerd op subsidiebeleid waaruit een wens tot woningbouw zou blijken, ${ }^{141}$ maar dat subsidiebeleid wel tot voorzienbaarheid moet kunnen leiden als bijvoorbeeld de wijziging van een subsidieverordening als schadeoorzaak wordt aangevoerd? Met andere woorden: dat de aard van het beleidsvoornemen dient te corresponderen met de aard van de schadeoorzaak. Óf dient het antwoord van de minister ruimer te worden opgevat, omdat wordt beoogd ook niet-schriftelijke beleidsvoornemens en/of nietconcrete en/of niet-openbare beleidsvoornemens als bron van voorzienbaarheid te kunnen aanmerken? Mijn visie daarop zal blijken uit de concrete voorstellen die ik doe in paragraaf 8.5 .

Om wetssystematische redenen is art. 4:126 lid 2, aanhef en onder a Awb in beginsel ook van toepassing op aanvragen die onder het bereik van afd. $15.1 \mathrm{Ow}$ vallen. ${ }^{142}$ Wel kent afd. $15.1 \mathrm{Ow}$ twee aanvullende bepalingen omtrent risicoaanvaarding. Op beide bepalingen zal hierna worden ingegaan.

\subsubsection{Geen actieve risicoaanvaarding vanwege art. $15.5 \mathrm{Ow}$}

In paragraaf 3.3.2.3 is besproken hoe het doorschuiven van het schademoment onder afd. 15.1 Ow een nieuwe categorie van schaduwschade zal meebrengen. De regering beoogt dit onwenselijk geachte ${ }^{143}$ effect tegen te gaan doordat art. 15.5 Ow voor een specifieke categorie gevallen zal afwijken van de "hoofdregel" van art. 4:126 lid 2, aanhef en onder a Awb. ${ }^{144}$ Op grond van art. $15.5 \mathrm{Ow}$ heeft de aanvrager het risico van het ontstaan van de schade als bedoeld in art. 4:126 lid 2, aanhef en onder a Awb namelijk in ieder geval niet aanvaard als is voldaan aan drie cumulatieve voorwaarden. Ten eerste dient de aanvrager na de vaststelling of wijziging van het omgevingsplan overeenkomstig art. 7:2 lid $1 \mathrm{BW}$ te zijn overgegaan tot koop van een tot woning bestemde onroerende zaak. ${ }^{145}$ Uit de bij de IOw behorende memorie van toelichting volgt niet wat precies moet worden verstaan onder 'tot koop overgaan'. Als aansluiting wordt gezocht bij onder de Wro gewezen jurisprudentie inzake het peilmoment bij actieve risicoaanvaarding, ${ }^{146} \mathrm{kan}$

140 Kamerstukken I 2012/13, 32 621, nr. C, p. 9 (MvA I, Wns).

141 Dit voorbeeld is ontleend aan ABRvS 25 januari 2006, ECLI:NL:RVS:2006:AV0284, r.o. 2.6.1 (Planschade Hengelo).

142 Zie Kamerstukken II 2018/19, 34 986, nr. 3, p. 29-30 en 240 (MvT, IOw).

143 Deze onwenselijkheid is onder andere bepleit in Planken \& Hazen 2017, p. 38; Van Oosten \& Span 2016, p. 317-318; SAOZ 2017, p. 2-3; Van den Broek \& Tjepkema 2017, p. 26-27; Van den Broek \& Tjepkema 2016, p. 2822; en Nijmeijer 2017, p. 79.

144 Zie Kamerstukken II 2018/19, 34 986, nr. 3, p. 240 (MvT, IOw); en Kamerstukken II 2016/17, 33 962, nr. 190, p. 27.

145 Art. 15.5, aanhef en onder a Ow.

146 Zie daarover paragraaf 8.2.1.1. 
daarvan in ieder geval worden gesproken vanaf het moment dat de aanvrager de koopovereenkomst heeft ondertekend. ${ }^{147}$ Ten tweede dient art. 15.1 lid 2 Ow of art. 15.3 lid $1 \mathrm{Ow}$ van toepassing te zijn op de aanvraag om compensatie. ${ }^{148}$ Het betreft dus gevallen waarin het schademoment wordt verlegd van het tijdstip van vaststelling van het omgevingsplan naar het tijdstip van de verlening van de omgevingsvergunning, respectievelijk het moment van kennisgeving door het bestuur van daaraan door de uitvoerder verstrekte informatie over een vergunningvrije activiteit óf het moment van aanvang met deze activiteit. ${ }^{149}$ Ten derde dient de schade uit waardevermindering van de onroerende zaak te bestaan. ${ }^{150}$

De oplossing van art. 15.5 Ow heeft relatief veel kritiek geoogst in de juridische doctrine. Een belangrijk en veel gehoord kritiekpunt is dat deze regeling een te beperkt bereik kent. Zij biedt namelijk slechts een beperkte oplossing voor de categorie van schaduwschade die het gevolg is van de verschuiving van het schademoment - en dus niet voor de schaduwschadeproblematiek in brede zin. ${ }^{151}$ Ook anderszins zijn kanttekeningen te plaatsen bij de reikwijdte van art. 15.5 Ow. ${ }^{152}$ Waarom wordt een koper die na vaststelling van het omgevingsplan heeft gekocht geen risicoaanvaarding tegengeworpen, terwijl wel risicoaanvaarding wordt tegengeworpen aan een koper die voorafgaand aan de vaststelling van het omgevingsplan heeft gekocht én redelijkerwijs rekening moest houden met een planologische verslechtering naar aanleiding van concrete beleidsvoornemens van overheidswege die ter openbare kennis zijn gebracht? Die vraag is fundamenteel, omdat laatstgenoemde koper in wezen een kleiner risico heeft aanvaard, maar wordt niet beantwoord in de bij de IOw behorende Kamerstukken. Dit onderscheid tussen beide soorten kopers lijkt op het eerste oog dan ook niet te kunnen worden gerechtvaardigd.

Voorts kan de vraag worden gesteld waarom art. 15.5 Ow slechts bescherming biedt als de onroerende zaak wordt gekocht door een koper als bedoeld in art. 7:2 lid $1 \mathrm{BW}$, zijnde een natuurlijk persoon die niet handelt in de uitoefening van een beroep of bedrijf. ${ }^{153}$ Het kabinet merkt hierover op dat aansluiting is gezocht bij boek $7 \mathrm{BW}$, dat soms meer bescherming biedt aan consumentkopers dan aan be-

147 Zie ABRvS 28 september 2016, ECLI:NL:RVS:2016:2582, r.o. 5.25 (Overzichtsuitspraak); en ABRvS 9 juli 2014, ECLI:NL:RVS:2014:2512, r.o. 5-5.1.

148 Art. 15.5, aanhef en onder b Ow.

149 Kamerstukken II 2018/19, 34 986, nr. 3, p. 240 (MvT, IOw).

150 Art. 15.5, aanhef en onder c Ow.

151 Zie Van den Broek \& Tjepkema 2017, p. 27; Vereniging eigen huis 2017, p. 4; SAOZ 2017, p. 2-3; en Planken \& Hazen 2017, p. 38.

152 Zie voor opmerkingen daarover bijvoorbeeld Van den Broek \& Tjepkema 2017, p. 27; SAOZ 2017, p. 3; Van der Lee \& Wiersema 2017, p. 605-606; en Planken \& Hazen 2017, p. 38.

153 Het ontbreken van een antwoord op deze vraag in de memorie van toelichting behorende bij de consultatieversie van de IOw kwam het kabinet destijds op kritiek te staan. Zie daarvoor SAOZ 2017, p. 3; en Planken \& Hazen 2017, p. 38. 
roeps- of bedrijfsmatige kopers. ${ }^{154}$ Ook wordt opgemerkt dat beroeps- of bedrijfsmatige kopers bij investeringsbeslissingen worden geacht rekening te houden met mogelijk nadelige ontwikkelingen in de omgeving van het perceel waarop de onroerende zaak is gelegen. Die redenering is in beginsel goed te volgen. Lezing van de bij de IOw behorende Kamerstukken leert echter dat niet slechts is beoogd de kopende partij, maar ook de (niet beroeps- of bedrijfsmatig handelende) verkopende partij te beschermen. ${ }^{155} \mathrm{Om}$ die verkopende partij te beschermen zou art. 15.5 Ow juist van toepassing moeten zijn als de onroerende zaak wordt aangekocht door een bedrijfsmatige koper. Van die koper wordt immers verwacht dat hij mogelijk nadelige ontwikkelingen op naburige percelen verdisconteert in de prijs die hij bereid is te betalen voor een onroerende zaak, hetgeen doorgaans zal leiden tot een lagere koopprijs. Het voorafgaande doet vermoeden dat de voorwaarde van een koop overeenkomstig art. 7:2 lid $1 \mathrm{BW}$ met name is opgenomen om te voorkomen dat bedrijfsmatige kopers zullen profiteren van de regeling van art. $15.5 \mathrm{Ow}$.

Ook valt op dat de bijzondere regeling van art. 15.5 Ow krachtens sub c slechts ziet op schade in de vorm van de waardedaling van een onroerende zaak, en dus bijvoorbeeld niet op schade in de vorm van inkomensderving. ${ }^{156}$ In de toelichtende stukken behorende bij de IOw wordt niet ingegaan op de vraag waarom niet ook een bijzondere regeling is getroffen voor schade in de vorm van inkomensderving. Het lijkt niet onaannemelijk dat ook dit kan worden verklaard doordat het kabinet slechts een regeling wilde treffen ter beperking van schaduwschade die ontstaat door het doorschuiven van het schademoment. Inkomensschade ontstaat doorgaans immers pas op het moment dat feitelijk wordt gebruikgemaakt van de nieuwe mogelijkheden die het omgevingsplan biedt. ${ }^{157}$ Dat moment valt nou net samen met het schademoment dat voortvloeit uit art. 15.1 lid 2 jo. art. 15.3 jo. art. 15.4 Ow. ${ }^{158}$ Ook kan een rol hebben gespeeld dat het kabinet geen bescherming wilde bieden aan beroeps- of bedrijfsmatig handelende actoren.

Ten slotte is meermaals opgemerkt dat art. $15.5 \mathrm{Ow}$ naar verwachting slechts in beperkte mate zal bijdragen aan het tegengaan van de nieuwe categorie van schaduwschade die ontstaat door de verschuiving van het schademoment. Daarbij

154 Kamerstukken II 2018/19, 34 986, nr. 7, p. 29 (NV II, IOw).

155 Zie Kamerstukken II 2018/19, 34 986, nr. 3, p. 30, 239-240 (MvT, IOw); en Kamerstukken II 2018/19, 34 986, nr. 7, p. 29 (NV II, IOw).

156 Zie daarover ook Planken \& Hazen 2017, p. 38.

157 Zie paragraaf 3.2.3. Zie ook het vierde onderdeel van de annotatie van Tjepkema en mijzelf bij ABRvS 16 november 2016, ECLI:NL:RVS:2016:3047 (Uptown) in $A B$ 2017/331; en de bespreking van ABRvS 20 september 2017, ECLI:NL:RVS:2017:2553, r.o. 19.2 (De Ruige Hoek) in Huijts \& Tjepkema 2017, p. 298-299.

158 Zie hierover paragraaf 3.3.2.3. In paragraaf 4.3.2 werd voorts onder het kopje 'Indirecte schade door een omgevingsvergunning' nog opgemerkt dat de vergunninghouder dikwijls pas gebruik zal maken van de vergunde mogelijkheden nadat de vergunning onherroepelijk is geworden. Dat neemt niet weg dat dit gebruik reeds is toegestaan vanaf de verlening van de vergunning. 
wordt erkend dat een redelijk denkend en handelend koper in theorie rekening zal houden met de mogelijkheid dat hij na aankoop van een onroerende zaak een tegemoetkoming kan krijgen indien op grond van het omgevingsplan negatieve ruimtelijke ontwikkelingen zullen plaatsvinden. Diezelfde koper zal zich echter ook realiseren dat art. 15.7 lid 1 Ow bepaalt dat 4\% van de waarde van de door hem aangekochte onroerende zaak wegens normaal maatschappelijk risico voor zijn rekening zal worden gelaten bij een aanvraag om compensatie van indirecte schade. Een redelijk denkend en handelend koper zal dit verdisconteren in de prijs die hij bereid is te betalen voor de onroerende zaak, waardoor de verkopende partij alsnog schaduwschade zal lijden. ${ }^{159}$ Het kabinet lijkt dat ook in te zien als het opmerkt dat het verwacht dat met de regeling van art. $15.5 \mathrm{Ow}$ een mogelijk waardedrukkend effect van nog niet benutte mogelijkheden van een omgevingsplan "ten minste in enige mate [wordt] beperkt." Vergelijkbaar is de opmerking van het kabinet dat art. $15.5 \mathrm{Ow}$ "kan bijdragen aan een beperking van eventuele nadelige effecten voor de waardeontwikkeling tussen het omgevingsplan en de omgevingsvergunning of het verrichten van de activiteit." 160

\subsubsection{Passieve risicoaanvaarding op grond van art. 15.6 Ow}

In art. 15.6 Ow is een bijzondere regeling omtrent passieve risicoaanvaarding opgenomen die zal dienen als aanvulling op art. 4:126 lid 2, aanhef en onder a Awb. ${ }^{161}$ Daaraan zou volgens het kabinet behoefte bestaan, omdat het bevoegd gezag onder het huidige recht uit vrees voor planschadeclaims terughoudend zou zijn met de beëindiging of wijziging van onbenutte bouw- en gebruiksmogelijkheden uit een bestemmingsplan. ${ }^{162}$ Dit zou komen doordat de in de jurisprudentie bepaalde voorwaarden waaronder passieve risicoaanvaarding kan worden tegengeworpen "in het concrete geval niet vastliggen." Voor het bestuur zou daarom onvoldoende zeker zijn of en wanneer passieve risicoaanvaarding kan worden tegengeworpen bij de beëindiging of wijziging van onbenutte functies. Het kabinet beoogt met de bijzondere regeling van art. 15.6 Ow de "voorspelbaarheid en

159 Zie Van den Broek \& Tjepkema 2017, p. 27; Vereniging eigen huis 2017, p. 4; en Planken \& Hazen 2017, p. 38. Dit volgt ook uit een door het kabinet ingewonnen deskundigenadvies, zie SAOZ en Kraan \& De Jong 2018, p. 21-22.

160 Kamerstukken II 2018/19, 34 986, nr. 3, p. 30 en 239-240 (MvT, IOw). Ter onderbouwing van de laatst geciteerde opmerking verwijst het kabinet naar $\mathrm{SAOZ}$ en Kraan \& De Jong 2018.

161 Daarbij heeft zowel Afdelingsjurisprudentie over passieve risicoaanvaarding als de regeling van art. 7c lid 8 Besluit uitvoering Chw als inspiratiebron gediend. Zie Kamerstukken II 2016/17, 33 962, nr. 185, p. 3-4; en Kamerstukken II 2018/19, 34 986, nr. 3, p. 33 en 240 (MvT, IOw). De regeling van art. 15.6 Ow (destijds nog art. 15.4 Ow) werd overigens positief ontvangen in Planken \& Hazen 2017, p. 39.

162 In Huijts \& Backes 2015, p. 138 wordt bepleit dat deze vrees onterecht is. Ook is meermaals in twijfel getrokken of deze vrees het besluitvormingsproces daadwerkelijk significant beïnvloedt. Zie in het kader van de totstandkoming van de IOw bijvoorbeeld SAOZ 2017, p. 8; Van den Broek \& Tjepkema 2016, p. 2824; en Planken \& Hazen 2017, p. 37-39. Zie anders: Nijmeijer 2017, p. 78. 
inzichtelijkheid te verbeteren over wanneer passieve risicoaanvaarding kan worden tegengeworpen." Enerzijds biedt de regeling meer duidelijkheid en zekerheid aan zittende eigenaren. Anderzijds zou zij het bestuur bij de vaststelling van een omgevingsplan meer inzicht in de schaderisico's moeten bieden, waardoor beter geïnformeerde keuzes kunnen worden gemaakt. Dat zou onder meer van belang zijn bij het tegengaan van overcapaciteit van bijvoorbeeld kantoren of winkels of van leegstand in krimpregio's. ${ }^{163}$ Uit beantwoording van Kamervragen blijkt dat het kabinet wil voorkomen dat gemeentebesturen (zich gedwongen voelen om) bestaande planmogelijkheden "automatisch" (te) voortzetten. Het kabinet lijkt een generieke regeling te hebben overwogen die planmogelijkheden automatisch zou wegbestemmen als zij voor een periode van tien jaar onbenut bleven. Uiteindelijk is niet daarvoor gekozen, omdat een dergelijke regeling de rechtszekerheid van de eigenaar te zeer zou aantasten. ${ }^{164}$

\section{Wijziging of intrekking planregel}

Volgens art. 15.6 Ow is sprake van passieve risicoaanvaarding in de zin van art. 4:126 lid 2, aanhef en onder a Awb als is voldaan aan vier ${ }^{165}$ cumulatieve voorwaarden. Allereerst volgt uit de aanhef van art. 15.6 Ow dat de geleden schade dient te zijn veroorzaakt door de wijziging van een of meer regels in een omgevingsplan of in een omgevingsverordening gesteld met het oog op een evenwichtige toedeling van functies aan locaties (vergelijk art. $4.2 \mathrm{Ow}$ ), die ertoe strekt dat het verrichten van bepaalde activiteiten niet meer is toegestaan. Blijkens de memorie van toelichting moet daarbij onder 'wijziging' ook een 'intrekking' van een planregel worden verstaan. ${ }^{166}$

\section{Kennisgeving conform art. 3:12 Awb}

De tweede voorwaarde heeft betrekking op de kennisgeving van het voornemen om een planregel te wijzigen. Deze kennisgeving dient zowel bij wijziging van een omgevingsplan (vergelijk art. 16.29 Ow) als wijziging van een omgevingsverordening (vergelijk art. 16.32 Ow) overeenkomstig art. 3:12 Awb te geschieden. Op grond van art. 15.6 onder a Ow kan passieve risicoaanvaarding echter alleen aan de benadeelde worden tegengeworpen als de overeenkomstig art. 3:12 Awb gedane kennisgeving ten minste een jaar aan de daadwerkelijke wijziging van de planregel is voorafgegaan. Met deze eis zou volgens het kabinet worden voorkomen "dat een eigenaar wordt geconfronteerd met het beëindigen of wijzigen van een tot dan toe onbenutte functie zonder dat hij hiervan op de hoogte is."167 Dit

163 Kamerstukken II 2018/19, 34 986, nr. 3, p. 33 (MvT, IOw).

164 Kamerstukken II 2016/17, 33 962, nr. 190, p. 7-8 en 23.

165 Het kabinet spreekt in Kamerstukken II 2018/19, 34 986, nr. 3, p. 240 (MvT, IOw) van "drie cumulatieve criteria" en ziet daarmee kennelijk over het hoofd dat de aanhef van de bepaling ook een voorwaarde bevat.

166 Kamerstukken II 2018/19, 34 986, nr. 3, p. 240 (MvT, IOw).

167 Kamerstukken II 2018/19, 34 986, nr. 3, p. 240 (MvT, IOw). 
wordt gepresenteerd als een voordeel ten opzichte van het huidige planschaderecht, waarin passieve risicoaanvaarding ook kan worden tegengeworpen indien het "bewustzijn van het risico" niet daadwerkelijk bij de aanvrager aanwezig was, zolang de mogelijkheid van de schadeveroorzakende overheidsmaatregel maar zodanig kenbaar was dat een redelijk denkend en handelend eigenaar ${ }^{168}$ daar rekening mee had kunnen houden. ${ }^{169}$

Het is mij niet duidelijk hoe het kabinet tot deze gedachtegang is gekomen. Anders dan onder het huidige recht, zal weliswaar geen risicoaanvaarding kunnen worden tegengeworpen als de schadeveroorzakende ontwikkeling minder lang dan een jaar was te voorzien, maar ook onder het nieuwe recht van afd. $15.1 \mathrm{Ow}$ zal het bewustzijn van het risico veelal een fictie ${ }^{170}$ betreffen. Bij een voornemen tot wijziging van een omgevingsplan of omgevingsverordening dient het bestuur op grond van art. 3:12 lid 1 Awb immers slechts door publicatie in een of meer dag-, nieuws-, of huis-aan-huisbladen, of op een andere geschikte wijze, kennis van het ontwerpbesluit te geven. Wellicht kan de opmerking van het kabinet worden verklaard vanuit de gedachte dat zij een overblijfsel is van de bij de consultatieversie van de IOw behorende toelichting. In de consultatieversie van het voorstel voor de IOw werd namelijk niet gesproken van een kennisgeving overeenkomstig art. 3:12 Awb, maar van het in de landelijke voorziening als bedoeld in artikel $20.22 \mathrm{Ow}$ beschikbaar stellen van gegevens over het voornemen tot wijziging van de regel. Deze voorziening is het voor iedereen toegankelijke 'Digitaal Stelsel Omgevingswet' (ook wel: DSO). ${ }^{171}$ Dit stelsel zal...

“(...) gegevens over de fysieke leefomgeving (inclusief de geldende regels) ontsluiten. De informatiehuizen, die naar verwachting onderdeel uitmaken van het DSO, maken de monitoring van de kwaliteit van de fysieke leefomgeving mogelijk. Het uitgangspunt van het DSO is dat het op termijn op basis daarvan voorziet in een dynamisch 3D-model, waarmee het effect van beleidskeuzes, planvorming en initiatieven laagdrempelig inzichtelijk gemaakt worden [sic]." ${ }^{172}$

Met publicatie in het DSO zou de (daadwerkelijke) kenbaarheid van het desbetreffende beleidsvoornemen dan ook beter zijn gewaarborgd. Anders dan het geval is wanneer de kennisgeving geschiedt conform art. 3:12 Awb, zou de aanvrager im-

168 ABRvS 28 september 2016, ECLI:NL:RVS:2016:2582, r.o. 5.33 (Overzichtsuitspraak). Zie ook paragraaf 8.2.1.1 onder het kopje 'Passieve risicoaanvaarding'.

169 Vergelijk Kamerstukken II 2018/19, 34 986, nr. 3, p. 240-241 (MvT, IOw) met ABRvS 28 september 2016, ECLI:NL:RVS:2016:2582, r.o. 5.21 en 5.33 (Overzichtsuitspraak) en ABRvS 10 april 2013, ECLI:NL:RVS:2013:BZ7681, r.o. 5.1.

170 Dat onder het huidige recht sprake is van een fictie bij 'veronderstelde risicoaanvaarding' werd besproken in paragraaf 8.2.1.3.

171 Zie art. 15.5 lid 2, aanhef en onder c Ow zoals dat werd voorgesteld door de consultatieversie van de IOw.

172 Kamerstukken II 2016/17, 33 962, nr. 190, p. 10. Zie over het DSO ook Kamerstukken II 2018/19, 34 986, nr. 3, p. 44-56 (MvT, IOw). 
mers slechts één bron hoeven te raadplegen, namelijk het DSO. ${ }^{173}$ In de memorie van toelichting behorende bij de versie van het voorstel voor de IOw die door de Tweede Kamer is aangenomen, wordt niet geëxpliciteerd waarom het kabinet is teruggevallen op de algemene regels omtrent kennisgeving van art. 3:12 Awb - en dus heeft afgezien van de voorwaarde van publicatie in het DSO. Een mogelijke verklaring zou kunnen zijn dat het DSO het bestuur aanvankelijk nog niet de mogelijkheid zal bieden beleidsvoornemens en ontwerpbesluiten te publiceren. In deze memorie van toelichting valt namelijk te lezen dat het DSO ten tijde van de inwerkingtreding van de Ow slechts enkele "basisfuncties" zal ondersteunen, zoals het inzien van de regels die op een bepaalde locatie gelden. ${ }^{174}$

\section{Functie niet benut in de drie aan de kennisgeving voorafgaande jaren}

Ten derde dient volgens onderdeel b gedurende drie jaar onmiddellijk voorafgaand aan de kennisgeving geen activiteit te zijn verricht die in overeenstemming is met de regels in het omgevingsplan of de omgevingsverordening die van toepassing waren. Tijdens de consultatiefase van de IOw gaven enkele partijen aan een termijn van drie jaar te kort te vinden. Het kabinet doet deze kritiek af met de enkele opmerking dat het een termijn van drie jaar voldoende acht om gebruik te maken van een bestaande functie. In de memorie van toelichting wordt voorts opgemerkt dat deze voorwaarde aan zowel de eigenaar als het bevoegd gezag duidelijkheid biedt. Zij heeft immers tot gevolg dat geen passieve risicoaanvaarding kan worden tegengeworpen als de desbetreffende functie nog geen drie jaar heeft gegolden. Daarbij is relevant dat de periode van drie jaar is gekoppeld aan de locatie en dus niet opnieuw aanvangt bij een eigendomsoverdracht. Beoogd is "de eigenaar enige tijd van zekerheid te geven dat hij van de geboden mogelijkheden gebruik kan maken zonder dat een wijziging van zijn vermogenspositie dreigt." De minister verwacht niet dat deze voorwaarde zal leiden tot handel in percelen met bouwmogelijkheden waarvan de driejaarstermijn nog niet is verstreken, enkel omdat ten aanzien van die percelen een mogelijkheid tot nadeelcompensatie bestaat. ${ }^{175}$ Dat lijkt mij terecht, aangezien de vermogenspositie van een burger er in planschadeen nadeelcompensatiegevallen altijd op achteruitgaat. De overige voorwaarden die titel 4.5 Awb en afd. 15.1 Ow aan de toekenning van nadeelcompensatie stellen, brengen immers mee dat slechts het onevenredige deel van de schade wordt vergoed.

De hier besproken voorwaarde heeft tot gevolg dat slechts functies die minimaal drie jaar hebben gegolden én gedurende de drie jaar voorafgaande aan de kennisgeving onbenut zijn gebleven, met tegenwerping van passieve risicoaanvaarding kunnen worden wegbestemd. Dat is op zichzelf een sympathieke geste aan

173 MvT consultatieversie IOw, p. 124.

174 Kamerstukken II 2018/19, 34 986, nr. 3, p. 45 (MvT, IOw).

175 Zie Kamerstukken II 2018/19, 34 986, nr. 3, p. 241-242 (MvT, IOw); en Kamerstukken II 2016/17, 33 962, nr. 190, p. 22. 
de burger, maar lijkt niet goed aan te sluiten op de wens van het kabinet om de beweerdelijk bij het bestuur levende vrees voor planschaderisico's te verminderen. De ruimte voor het bestuur om de planschaderisico's van het wegbestemmen van functies met de tegenwerping van passieve risicoaanvaarding op te vangen, wordt hierdoor namelijk beperkt. Naar huidig recht kan een aanvraag om planschadetegemoetkoming immers ook wegens passieve risicoaanvaarding worden afgewezen als de wegbestemde functie korter dan drie jaar bestond en/of wel kort voorafgaand aan het peilmoment voor voorzienbaarheid werd benut, zolang voor de aanvrager maar voldoende gelegenheid tot het ondernemen van een concrete poging bestond. Beschouwd vanuit de gedachte dat risicoaanvaarding een bijzondere vorm van eigen schuld betreft, is dat ook heel goed verdedigbaar. De vraag of van een redelijk denkend en handelend eigenaar kan worden verlangd dat hij een op of na het peilmoment onbenutte functie alsnog zal (pogen te) benutten alvorens deze komt te vervallen door de inwerkingtreding van een planologische maatregel, lijkt immers niet fundamenteel anders te moeten worden beantwoord als die functie kort voorafgaand aan het peilmoment nog werd gebruikt. Als die omstandigheid al een rol zou moeten spelen, lijkt zij doorgaans juist voor de aanname van passieve risicoaanvaarding te pleiten, aangezien dan al inzicht zou moeten bestaan in de beantwoording van de vraag hoe het best een concrete poging zou kunnen worden ondernomen om de desbetreffende functie weer te gaan benutten.

Dat de beantwoording van de vraag of passieve risicoaanvaarding kan worden tegengeworpen (deels) buiten de persoon van de aanvrager wordt geplaatst, omdat moet worden uitgegaan van de situatie op het desbetreffende perceel, sluit bovendien niet goed aan op het leerstuk van de eigen schuld. Ook sluit dit niet goed aan bij de thans geldende jurisprudentielijn dat geen waarde wordt gehecht aan concrete pogingen van voormalige eigenaren van de desbetreffende onroerende zaak. $^{176}$

\section{Geen activiteit na de kennisgeving}

Ten vierde bepaalt onderdeel $\mathrm{c}$ dat passieve risicoaanvaarding slechts kan worden tegengeworpen als vanaf het tijdstip van de kennisgeving tot het tijdstip van de wijziging van de regel geen activiteit is verricht die in overeenstemming is met de regels in het omgevingsplan of de omgevingsverordening die van toepassing waren, of de voor een activiteit op die locatie benodigde voorbereidingen niet zijn getroffen. Uit de bij dit onderdeel behorende toelichting lijkt te kunnen worden opgemaakt dat het kabinet de jurisprudentie omtrent het ondernemen van een concrete poging wil codificeren met de zinsnede over het treffen van voorbereidingen. Het wordt echter niet duidelijk of dit een één op één codificatie van deze jurisprudentie betreft, of dat het treffen van voorbereidingen ook ruimer of minder ruim moet worden opgevat dan het ondernemen van een concrete poging. Wel wordt duidelijk dat niet wordt verlangd dat de aanvrager "een volledig uit- 
gewerkte en ontvankelijke aanvraag om een omgevingsvergunning indient." Het kabinet voert dit aan als rechtvaardiging voor de termijn die naar toekomstig recht zal worden geboden om deze voorbereidingen te treffen. Onder vermelding dat de hedendaagse jurisprudentie "geen eenduidig antwoord" geeft op de vraag binnen welke termijn een concrete poging van de aanvrager kan worden verlangd, wordt opgemerkt dat die termijn naar toekomstig recht vanwege art. 15.6, aanhef en onder a Ow gelijk zal zijn aan de tijd die het bestuur neemt om van kennisgeving conform art. 3:12 Awb naar definitieve besluitvorming te geraken, met een minimum van één jaar. Dit zou ook deels worden gerechtvaardigd doordat "de eigenaar" op grond van art. 15.6, aanhef en onder b Ow ten minste drie jaar de gelegenheid heeft gehad om de activiteit te verrichten die na de voorgenomen wijziging niet langer zal zijn toegestaan. ${ }^{177}$

\subsubsection{Conclusie}

Onder het toekomstige recht zal de grondslag voor tegenwerping van risicoaanvaarding steeds zijn gelegen in art. 4:126 lid 2, aanhef en onder a Awb. Deze bepaling zal in beginsel ook van toepassing zijn op aanvragen die onder het bereik van afd. 15.1 Ow vallen. Deze bepaling lijkt te moeten worden toegepast conform de thans bestaande jurisprudentielijnen. Wel blijkt uit Kamerstukken dat naar gelang de schadeveroorzakende overheidsmaatregel, verschillende bronnen van voorzienbaarheid van invloed kunnen zijn op het al dan niet aannemen van risicoaanvaarding. Hoe die opmerking precies moet worden geïnterpreteerd is onduidelijk.

In afd. $15.1 \mathrm{Ow}$ zijn ook twee bepalingen omtrent risicoaanvaarding te vinden. Met behulp van art. 15.5 Ow beoogt het kabinet tegenwicht te bieden aan de extra categorie van schaduwschade die ontstaat door de verschuiving van het schademoment. Kort geparafraseerd, komt deze bepaling erop neer dat een consument die ná vaststelling of wijziging van het omgevingsplan is overgegaan tot de koop van zijn woning, geen actieve risicoaanvaarding krijgt tegengeworpen bij een aanvraag om nadeelcompensatie wegens de waardedaling van zijn woning door (de weigering van) een omgevingsvergunning, ${ }^{178}$ of uitvoering van een vergunningvrije activiteit op omliggende percelen. In de doctrine is mijns inziens terecht kritiek geuit op de beperkte reikwijdte van deze regeling.

Art. 15.6 Ow specificeert wanneer onder afd. $15.1 \mathrm{Ow}$ (in ieder geval) sprake is van passieve risicoaanvaarding in de zin van art. 4:126 lid 2, aanhef en onder a Awb. Kort geparafraseerd, dient (1) een omgevingsplan- of verordening te zijn gewijzigd; terwijl (2) het bestuur minimaal een jaar voorafgaand aan de wijziging

177 Kamerstukken II 2018/19, 34 986, nr. 3, p. 242 (MvT, IOw).

178 In de praktijk zal de schade veelal worden veroorzaakt doordat op omliggende percelen wordt gebruikgemaakt van vergunde mogelijkheden (indirecte schade). Uit paragraaf 3.3.2.3 volgde echter dat soms ook schade kan worden geleden door de weigering van een omgevingsvergunning voor het eigen perceel van de aanvrager (directe schade). 
conform art. 3:12 Awb kennis heeft gegeven van het voornemen daartoe; (3) de wegbestemde functie minstens de drie aan de kennisgeving voorafgaande jaren heeft gegolden, maar in die periode niet is benut; en (4) de aanvrager tussen het moment van kennisgeving en de daadwerkelijke wijziging van het planologische regime heeft nagelaten (om voorbereidingen te treffen) om de verloren planmogelijkheid alsnog te benutten. Het kabinet lijkt zijn doel - zijnde de beweerdelijk bij het bestuur levende vrees voor planschaderisico's te verminderen - voorbij te schieten met de derde voorwaarde. Naar huidig recht kan een aanvraag om planschadetegemoetkoming immers ook wegens passieve risicoaanvaarding worden afgewezen als de wegbestemde functie korter dan drie jaar bestond en/of wel kort voorafgaand aan het peilmoment voor voorzienbaarheid werd benut, zolang voor de aanvrager maar voldoende gelegenheid bestond tot het ondernemen van een concrete poging.

\subsubsection{Hoofdvraag: spiegeling aan de doelstellingen en uitgangspunten die} ten grondslag liggen aan de Wns

In deze deelparagraaf zal ik achtereenvolgens ingaan op de wijze waarop art. 4:126 lid 2, aanhef en onder a Awb (paragraaf 8.2.3.1), art. 15.5 Ow (paragraaf 8.2.3.2) en art 15.6 Ow (paragraaf 8.2.3.3) zich verhouden tot de aan de Wns ten grondslag liggende doelstellingen en uitgangspunten. Net als in de overige hoofdstukken van dit proefschrift zullen daarbij aanbevelingen worden gedaan om de aansluiting op deze doelstellingen en uitgangspunten te verbeteren. Concrete voorstellen om deze bepalingen te implementeren zullen echter pas worden gedaan in paragraaf 8.5. Zij zijn namelijk deels afhankelijk van de aanbevelingen die in paragraaf 8.3 en 8.4 zullen worden gedaan ten aanzien van de schadebeperkingsplicht respectievelijk resterende vormen van eigen schuld.

\subsubsection{Art. 4:126 lid 2, aanhef en onder a Awb}

Het past goed bij de doelstelling van vereenvoudiging, uniformering en harmonisering van het nadeelcompensatierecht dat de tegenwerping van risicoaanvaarding naar toekomstig recht steeds op art. 4:126 lid 2, aanhef en onder a Awb zal worden gebaseerd, ook als afd. $15.1 \mathrm{Ow}$ van toepassing is. Ook de doelstellingen van vergroting van de rechtszekerheid en codificatie van het nadeelcompensatierecht worden gediend door art. 4:126 lid 2, aanhef en onder a Awb. Door deze bepaling hoeft de mogelijkheid tot tegenwerping van risicoaanvaarding immers niet meer te worden ingelezen in redelijkerwijsformules als opgenomen in onder andere art. $49 \mathrm{WRO}$, art. 21 Aanwijzingsbesluit 1996 en art. 8.31 Wlv. De formulering van art. 4:126 lid 2, aanhef en onder a Awb is echter niet optimaal, bezien vanuit deze doelstellingen. Uit paragraaf 8.2.1 bleek immers dat de jurisprudentie omtrent risicoaanvaarding relatief ver is uitgekristalliseerd. In de formulering van de Awbbepaling zijn de lijnen uit die jurisprudentie echter niet te herkennen. Er wordt namelijk slechts vermeld dat schade voor rekening van de aanvrager blijft zover hij het risico van het ontstaan van de schade heeft aanvaard. Mijns inziens zou de wetgever er daarom goed aan doen titel 4.5 Awb dusdanig aan te passen dat daaruit 
bijvoorbeeld blijkt wanneer sprake is van actieve en passieve risicoaanvaarding. De bepalingen omtrent risicoaanvaarding uit de BnIW 2019 tonen aan dat dit daadwerkelijk mogelijk is. Ook zou het mijns inziens goed zijn als de Awb-bepaling meer duidelijkheid zou geven omtrent de bronnen waarop voorzienbaarheid kan worden gebaseerd. Voorts zou duidelijker moeten blijken dat risicoaanvaarding een vorm van eigen schuld betreft. In de huidige formulering kan dat namelijk slechts worden afgeleid uit het in art. 4:126 lid 2 onder c Awb opgenomen woordje 'anderszins'. Deze aanbevelingen acht ik eveneens verenigbaar met de overige aan de Wns ten grondslag liggende doelstellingen en uitgangspunten.

Gelet op de doelstelling van vergroting van de rechtszekerheid adviseer ik voorts om in titel 4.5 Awb, of wetsinterpreterende beleidsregels of verordeningen, geen bepalingen op te nemen met opsommingen omtrent het onderwerp van de voorzienbaarheid. ${ }^{179}$ De daarin genoemde onderwerpen zullen namelijk veelal onderlinge overlap, en overlap met de in de jurisprudentie gestelde voorwaarden voor tegenwerping van risicoaanvaarding vertonen. Zo noemt art. 6 BnIW 2019 de voorzienbaarheid van 'de wijze van voltrekken of uitvoering' van de schadeoorzaak en de voorzienbaarheid van 'de aard en omvang van de daardoor veroorzaakte schade'. Dat is onnodig en potentieel ook verwarrend, omdat de wijze van uitvoering zal doorwerken in de schadeomvang. Ook kan worden gewezen op de eveneens in deze bepaling genoemde voorzienbaarheid van 'de plaats waarop de schadeoorzaak betrekking heeft.' In wezen betreft dit immers de voorzienbaarheid van de schadeoorzaak als dusdanig. Bovendien is het vaste jurisprudentie dat niet van een concreet beleidsvoornemen kan worden gesproken als een redelijk denkend en handelend koper niet kan begrijpen op welk gebied het beleidsvoornemen betrekking heeft. ${ }^{180}$

Verder past het op het eerste oog niet goed bij het uitgangspunt van aansluiting bij het BW dat de derde stap van art. 6:101 BW (feitelijk) geen rol van betekenis speelt in het planschade- en nadeelcompensatierecht, doordat de voorzienbare schade bij wijze van billijkheidscorrectie in beginsel volledig voor rekening van de aanvrager wordt gelaten. Slechts onder bijzondere omstandigheden lijkt de billijkheidscorrectie ook in het voordeel van de burger uit te pakken. Daarbij kan worden gedacht aan de in paragraaf 8.2.1.4 besproken Afdelingsuitspraak waarin de Afdeling oordeelde dat geen risicoaanvaarding kon worden tegengeworpen bij een boedelscheiding. Toch leidt het uitgangspunt van aansluiting bij het BW mijns inziens niet tot de conclusie dat onder titel 4.5 Awb van deze praktijk zou moeten worden afgezien. Dit uitgangspunt strekt er namelijk slechts toe onnodige afwijkingen van het civiele recht te voorkomen. De gevonden verklaring voor dit verschil met het civiele recht - namelijk de bijzondere aard van het planschade- en nadeelcompensatierecht - rechtvaardigt mijns inziens dat op dit punt van het ci-

179 Deze aanbeveling acht ik ook verenigbaar met de overige aan de Wns ten grondslag liggende doelstellingen en uitgangspunten.

180 ABRvS 28 september 2016, ECLI:NL:RVS:2016:2582, r.o. 5.26 (Overzichtsuitspraak). 
viele recht wordt afgeweken. Wel brengen de doelstellingen van vergroting van de rechtszekerheid en codificatie van het nadeelcompensatierecht mijns inziens mee dat uit de formulering van de Awb-bepaling duidelijker zou moeten blijken dat de causale verdeling van de derde stap geen rol van betekenis speelt. Tevens zou deze bepaling in algemene zin beter kunnen aansluiten op de formulering van art. 6:101 BW. Deze aanbevelingen acht ik ook verenigbaar met de overige aan de Wns ten grondslag liggende doelstellingen en uitgangspunten.

Billijkheidscorrecties die niet voortvloeien uit het recht maar uit coulanceoverwegingen, zoals aangetroffen onder de VNNZ en art. 21 Aanwijzingsbesluit 1996, zouden mijns inziens ook na inwerkingtreding van titel 4.5 Awb nog mogelijk moeten zijn. Dergelijke correcties lijken namelijk niet direct in strijd te zijn met de aan de Wns ten grondslag liggende doelstellingen en uitgangspunten. De doelstelling van vergroting van de rechtszekerheid vereist mijns inziens wel dat draagplichtige derden niet de dupe worden van dergelijke correcties. Dat kan enerzijds worden gerealiseerd door van dit soort correcties af te zien als niet het bestuur maar een draagplichtige derde opdraait voor de kosten van de toekenning van nadeelcompensatie. Anderzijds is denkbaar dat deze correcties wel worden toegepast, maar hetgeen het bestuur hierdoor 'te veel' vergoedt niet in rekening wordt gebracht aan de draagplichtige derde.

Ten slotte doe ik de aanbeveling dat bestuursorganen steeds nagaan in hoeverre zij in wetsinterpreterende verordeningen of beleidsregels op voorhand zekerheid kunnen verschaffen omtrent de peildatum voor risicoaanvaarding. Als reden bestaat om aan te nemen dat werkzaamheden (veel) langer zullen duren dan oorspronkelijk was te voorzien, kan worden gewerkt met een tabel als te vinden in de VNNZ. Soms zal een tabel echter niet het meest voor de hand liggende middel zijn. Ook de enkele opmerking in een beleidsregel dat een bepaalde datum als peildatum voor veronderstelde voorzienbaarheid wordt gehanteerd bij behandeling van een bepaalde categorie aanvragen kan namelijk op voorhand al veel duidelijkheid bieden. Opvolging van deze aanbeveling zou goed passen bij de doelstelling van vergroting van de rechtszekerheid en rechtsgelijkheid. Ook kan op deze manier worden bijdragen aan het bereiken van de doelstelling van vergroting van de doelmatigheid van het nadeelcompensatierecht en vermindering van bestuurslasten. Zo is het denkbaar dat burgers hun kanttekeningen bij het door het bestuur gekozen startmoment van voorzienbaarheid al in een eerder stadium bekend zullen maken. Voorts acht ik deze aanbeveling ook verenigbaar met de overige aan de Wns ten grondslag liggende doelstellingen en uitgangspunten.

\subsubsection{Art. $15.5 \mathrm{Ow}$}

In paragraaf 3.4.2.1 heb ik bepleit dat de keuze van het huidige kabinet om de limitatieve opsomming van schadeoorzaken in art. $15.1 \mathrm{Ow}$ als exclusief te beschouwen niet onverenigbaar is met de doelstellingen en uitgangspunten die aan de Wns ten grondslag liggen. Wel brengen deze doelstellingen en uitgangspunten mijns inziens mee dat de wetgever de keuze voor het exclusieve karakter van art. 
15.1 Ow zou moeten doen vergezellen van een regeling voor de schaduwschadeproblematiek die daarvan het gevolg is. De regeling van art. $15.5 \mathrm{Ow}$ is daartoe ontoereikend, omdat zij slechts een oplossing biedt in een klein deel van de schaduwschadegevallen die zich onder de Ow zullen voordoen. In paragraaf 3.4.2.4 ${ }^{181}$ heb ik daarom aanbevelingen gedaan omtrent de vormgeving van een alternatieve bepaling. Een concreet voorstel voor een dergelijke bepaling zal ik doen in paragraaf 8.5 .

\subsubsection{Art. $15.6 \mathrm{Ow}$}

Art. 15.6 Ow bepaalt wanneer passieve risicoaanvaarding kan worden tegengeworpen aan de indiener van een aanvraag die onder het bereik van afd. $15.1 \mathrm{Ow}$ valt. Dit past goed bij de doelstelling van vergroting van de rechtszekerheid. De burger die geconfronteerd dreigt te worden met een planologische maatregel kan immers op voorhand nalezen wat hij dient te doen om tegenwerping van passieve risicoaanvaarding te vermijden. Bovendien is voor het bestuur op voorhand duidelijk hoe het planfuncties kan wegbestemmen zonder het risico te lopen daardoor nadeelcompensatie te moeten toekennen. Hierna zal ik een aantal aspecten van art. 15.6 Ow bespreken die botsen met de aan de Wns ten grondslag liggende doelstellingen en uitgangspunten.

\section{Concrete poging?}

In paragraaf 8.2.2.3 bleek dat het er veel van weg heeft dat het kabinet de jurisprudentie omtrent het ondernemen van een concrete poging heeft willen codificeren door in art. 15.6 onder c Ow te spreken van het treffen van de 'benodigde voorbereidingen'. Vanwege de doelstellingen van codificatie van het nadeelcompensatierecht en vergroting van de rechtszekerheid doe ik daarom de aanbeveling dat in deze bepaling daadwerkelijk wordt gesproken van het ondernemen van een 'concrete poging'. De term 'benodigde voorbereiding' zou slechts op zijn plaats zijn als de wetgever goede redenen heeft om een verruiming of juist een beperking door te voeren ten aanzien van de jurisprudentielijn inzake de concrete poging. Hiervan is echter niet gebleken. Bovendien zou de doelstelling van vergroting van de rechtszekerheid dan vereisen dat de wetgever duidelijk maakt waaruit deze verruiming of beperking zou bestaan.

Gelet op het casuïstische karakter van de jurisprudentie omtrent het ondernemen van concrete pogingen is het mijns inziens verdedigbaar dat het kabinet ervoor heeft gekozen om geen opsomming te geven van handelingen waaruit de concrete poging moet bestaan. Bezien vanuit de doelstellingen van codificatie van het nadeelcompensatierecht en vergroting van de rechtszekerheid, verdient het echter wel aanbeveling om in afd. $15.1 \mathrm{Ow}$ vast te leggen dat bij verlies van bouwmogelijkheden in ieder geval sprake is van een concrete poging als (1) de aanvrager een 
bouwplan heeft ingediend dat de bedreigde planmogelijkheid benut; (2) dat zich laat beoordelen op passendheid binnen het omgevingsplan; en (3) dat in beginsel past binnen de bestaande mogelijkheden van het omgevingsplan. Ten aanzien van verlies van gebruiksmogelijkheden kan worden gecodificeerd dat in ieder geval sprake is van een concrete poging als daadwerkelijk is aanvangen met het desbetreffende gebruik, of serieuze pogingen zijn ondernomen om de in waarde gedaalde onroerende zaak voor dat doel aan derden te verkopen of verhuren. Dergelijke bepalingen acht ik ook verenigbaar met de overige aan de Wns ten grondslag liggende doelstellingen en uitgangspunten.

\section{Afwijking van bestaande jurisprudentielijnen}

Door art. 15.6 Ow wordt op de onderstaande punten afgeweken van de thans geldende jurisprudentielijnen inzake passieve risicoaanvaarding:

- de vraag of passieve risicoaanvaarding kan worden tegengeworpen wordt (deels) buiten de persoon van de aanvrager geplaatst: de situatie op het desbetreffende perceel is bepalend; ${ }^{182}$

- er wordt geen recht gedaan aan de jurisprudentielijn dat geen passieve risicoaanvaarding wordt tegengeworpen als de aanvrager niet in staat was om een concrete poging te ondernemen als gevolg van hem niet toe te rekenen omstandigheden; ${ }^{183}$

- planmogelijkheden jonger dan drie jaar kunnen niet worden wegbestemd onder tegenwerping van passieve risicoaanvaarding; ${ }^{184}$

- er wordt een beperking doorgevoerd ten opzichte van de bestuursorganen die voorzienbaarheid kunnen opwekken, ${ }^{185}$ terwijl voorzienbaarheid naar huidig recht zelfs kan worden gebaseerd op een beleidsvoornemen dat voldoende kenbaar is gemaakt door een ander bestuursorgaan dan het orgaan dat bevoegd is tot het nemen van de daarin aangekondigde maatregel; ${ }^{186}$ en

- er bestaat geen mogelijkheid tot tegenwerping van passieve risicoaanvaarding in gevallen van uitdrukkelijke risicoaanvaarding. ${ }^{187}$

De bovenstaande afwijkingen verhouden zich slecht tot de doelstelling van codificatie van het nadeelcompensatierecht. Voor het grootste deel verhouden zij zich

182 Zie hierover paragraaf 8.2.2.3 onder het kopje 'Functie niet benut in de drie aan de kennisgeving voorafgaande jaren'. Vergelijk tevens art. art. 15.6, aanhef en onder b en c Ow.

183 Deze jurisprudentielijn kwam aan bod bij bespreking van de tweede stap van art. 6:101 BW in paragraaf 8.2.1.4.

184 Vergelijk art. art. 15.6, aanhef en onder b Ow.

185 Art. 15.6, aanhef en onder a Ow spreekt immers van een kennisgeving conform art. 3:12 Awb door het bevoegd gezag.

186 Zie paragraaf 8.2.1.1 onder het kopje 'actieve risicoaanvaarding' over deze jurisprudentielijn. 
ook slecht tot het uitgangspunt van aansluiting bij het BW. De geconstateerde afwijkingen botsen namelijk met de vier stappen van art. 6:101 BW. Waarom zou de voorzienbaarheid bij een aanvraag om nadeelcompensatie naar aanleiding van de wijziging van een omgevingsplan bijvoorbeeld niet mogen worden gebaseerd op ingevolge art. 2.22 Ow door gedeputeerde staten bij omgevingsverordening vastgestelde instructieregels die de gemeenteraad hebben verplicht tot de wijziging van het omgevingsplan? Ook kan bijvoorbeeld worden gedacht aan een ingevolge art. $2.33 \mathrm{Ow}$ aan de gemeenteraad gegeven instructie om een omgevingsplan aan te passen. Zeker als dergelijke instructie(regel)s ook zichtbaar zullen zijn in het DSO, bestaat er mijns inziens geen goede reden om geen passieve risicoaanvaarding tegen te werpen. Ook dit zal ik meenemen in het voorstel dat ik in paragraaf 8.5 zal doen ten aanzien van de wettelijke regeling omtrent risicoaanvaarding en de overige vormen van eigen schuld.

\section{Titel 4.5 Awb of afd. $15.1 \mathrm{Ow}$ ?}

Ten slotte is er de vraag of een bepaling omtrent passieve risicoaanvaarding zou moeten worden opgenomen in titel 4.5 Awb of afd. 15.1 Ow. Aangezien passieve risicoaanvaarding naar huidig recht vrijwel uitsluitend een rol speelt in het planschaderecht, valt wat te zeggen voor de keuze van het kabinet voor opname in afd. 15.1 Ow. Deze keuze schept echter ook het risico dat naar toekomstig recht simultaan twee afwijkende invullingen van het criterium van passieve risicoaanvaarding zullen bestaan: één invulling voor aanvragen waarop enkel titel 4.5 Awb van toepassing is, en één invulling voor aanvragen waarop ook afd. $15.1 \mathrm{Ow}$ van toepassing is. ${ }^{188}$ Dit sluit niet goed aan op de doelstellingen van vereenvoudiging, uniformering en harmonisering van het nadeelcompensatierecht, en vergroting van de rechtszekerheid en rechtsgelijkheid. Dat geldt te meer nu de brede reikwijdte van titel 4.5 Awb zou kunnen meebrengen dat het leerstuk van de passieve risicoaanvaarding ook aan belang wint buiten het omgevingsrechtelijk georiënteerde nadeelcompensatierecht. Het verdient daarom aanbeveling om de basisvoorwaarden voor passieve risicoaanvaarding in titel 4.5 Awb op te nemen - hiervoor bleek reeds waarom een dergelijke bepaling mijns inziens niet zou moeten afwijken van de thans geldende jurisprudentie omtrent passieve risicoaanvaarding. ${ }^{189}$ Dit acht ik ook verenigbaar met de overige aan de Wns ten grondslag liggende doelstellingen en uitgangspunten. Bovendien bewijst art. 7 BnIW 2019 dat dit praktisch haalbaar is. Vervolgens zou in een nieuw art. $15.6 \mathrm{Ow}$ nog een nadere toespitsing van de voorwaarden uit de Awb-bepaling op het omgevingsrecht kunnen plaatsvinden, hetgeen goed zou aansluiten op de doelstellingen van vergroting van de rechtszekerheid en codificatie van het nadeelcompensatierecht. Die toespitsing zou bestaan uit de eerder aanbevolen codificatie van de gevallen waarin ieder geval sprake is van een concrete poging. De daaraan ten grondslag liggende jurispruden-

188 Dat geldt zeker nu art. 15.6 Ow afwijkt van de thans geldende jurisprudentie omtrent passieve risicoaanvaarding.

189 De overige eisen waaraan een dergelijke bepaling zou moeten voldoen, zijn besproken in paragraaf 8.2.3.1. 
tie lijkt namelijk lastig toepasbaar buiten het omgevingsrechtelijk georiënteerde nadeelcompensatierecht. Een concreet voorstel tot implementatie van deze aanbevelingen zal worden gedaan in paragraaf 8.5.

\subsubsection{Conclusie}

Op basis van het voorafgaande zie ik reden tot (a) aanpassing van titel $4.5 \mathrm{Awb}$ en (b) aanpassing van afd. 15.1 Ow. Concrete voorstellen daartoe zullen pas in paragraaf 8.5 worden gedaan, omdat zij deels afhankelijk zijn van aanbevelingen en voorstellen die ten aanzien van de schadebeperkingsplicht en resterende vormen van eigen schuld zullen worden gedaan. Ook zie ik reden om (c) anderszins in een bijzondere invulling van titel 4.5 Awb te voorzien, namelijk door vaststelling van wetsinterpreterende verordeningen of beleidsregels waaruit blijkt wat het bestuur als peildatum voor de aanname van voorzienbaarheid beschouwt voor bepaalde categorieën van aanvragen om compensatie. Daartoe zullen echter geen concrete voorstellen worden gedaan, omdat de peildatum altijd afhankelijk is van de concrete omstandigheden waaronder de schadeveroorzakende overheidsmaatregel tot stand is gekomen en/of de wijze waarop deze maatregel is uitgevoerd. Wel is aanbevolen om in dit soort beleidsregels of verordeningen geen bepalingen op te nemen met opsommingen omtrent het onderwerp van de voorzienbaarheid.

\subsection{DE SCHADEBEPERKINGSPLICHT}

8.3.1 Deelvraag 2: verschillen tussen de geselecteerde, thans geldende regelingen en verklaringen daarvoor

\section{Regelingen die niet ingaan op de schadebeperkingsplicht}

Wanneer de geselecteerde, thans geldende regelingen worden vergeleken, valt op dat art. $49 \mathrm{WRO}$, art. 21 Aanwijzingsbesluit en art. $8.31 \mathrm{Wlv}$ niet ingaan op de schadebeperkingsplicht. Toch kan schending van deze plicht aan de aanvrager worden tegengeworpen bij toepassing van deze bepalingen. Onder art. 49 WRO is nauwelijks jurisprudentie omtrent de schadebeperkingsplicht gewezen. ${ }^{190}$ Een spaarzaam voorbeeld betreft de Barendrecht-uitspraak van 12 oktober 1988. De AGRvS oordeelde daarin dat het bestuur niet aannemelijk had gemaakt dat de exploitante van een tuinbouwbedrijf in staat moest worden geacht de door haar geleden schade "wezenlijk te beperken" door aanpassing van haar teeltplan. ${ }^{191}$ Dat de schadebeperkingsplicht ook bestaat onder art. 21 Aanwijzingsbesluit 1996 en art. 8.31 Wlv kan slechts worden afgeleid uit uitspraken die zijn gewezen onder vergelijkbare nadeelcompensatieregelingen die eveneens slechts een redelijker-

190 In ABRvS 13 maart 1997, ECLI:NL:RVS:1997:AN5427 (Vliegveld Welschap) expliciteerde het bestuur zelfs dat appellanten in redelijkheid niet zelf schadebeperkende maatregelen hadden kunnen nemen.

191 AGRvS 12 oktober 1988, ECLI:NL:RVS:1988:AN1470 (Barendrecht). 
wijsformule (en enkele bepalingen van procedurele aard) bevatten. Zo sanctioneerde de Afdeling in een op 22 januari 2014 onder de 'Nadeelcompensatieverordening Damsterdiepgarage gemeente Groningen 2007' gewezen uitspraak dat een korting van $50 \%$ werd toegepast op het schadebedrag, omdat de aanvrager tekort was geschoten in zijn schadebeperkingsplicht. ${ }^{192}$ Ook kan in meer algemene zin worden gewezen op het betoog van Van den Berk dat de schadebeperkingsplicht een plicht is die geldt voor het "gehele recht", en dus ook voor het planschade- en nadeelcompensatierecht. ${ }^{193}$

Dat de tekst van art. 49 WRO, art. 21 Aanwijzingsbesluit en art. 8.31 Wlv geen aandacht besteedt aan de schadebeperkingsplicht, kan worden verklaard doordat het ten tijde van de totstandkoming van deze regelingen nog niet gebruikelijk was om in nadeelcompensatieregelingen uit te werken wanneer aan de daarin vervatte redelijkerwijsformule werd voldaan. Bovendien is voor de formulering van zowel art. 21 Aanwijzingsbesluit 1996 als art. 8.31 Wlv aansluiting gezocht bij regelingen die niets omtrent de schadebeperkingsplicht vermelden, namelijk bij art. 49 WRO en in geval van art. 8.31 Wlv ook bij art. 15.20 Wet milieubeheer. ${ }^{194}$ Dat de schadebeperkingsplicht nauwelijks een rol speelde onder art. 49 WRO zal mogelijk ook een rol hebben gespeeld bij de keuze om geen aandacht aan deze plicht te besteden in art. 21 Aanwijzingsbesluit 1996 en art. 8.31 Wlv.

\section{Verschillen in formulering tussen bepalingen uit overige regelingen}

De overige geselecteerde, thans geldende regelingen gaan allemaal expliciet in op de schadebeperkingsplicht:

\section{Art. 6.3, aanhef en onder b Wro}

Met betrekking tot de voor tegemoetkoming in aanmerking komende schade betrekken burgemeester en wethouders bij hun beslissing op de aanvraag in ieder geval de mogelijkheden van de aanvrager om de schade te voorkomen of te beperken.

\section{Art. 8 lid 1 BnIW 2019}

Heeft verzoeker nagelaten redelijke maatregelen ter voorkoming of beperking van schade te nemen, dan blijft de schade die door het treffen van zodanige maatregelen voorkomen of beperkt had kunnen worden, ten laste van de verzoeker. Tirion).

193 Zie het derde onderdeel van de annotatie van J.A.M. van den Berk bij AGRvS 10 oktober 1988, ECLI:NL:RVS:1988:AN0391 (Binnenmaas) in AB 1989/233.

194 Zie Stcrt. 1998, nr. 223, p. 11 (digitaal) respectievelijk Kamerstukken II 00/01, 27 603, nr. 3, p. 69 en 15. 


\section{Art. 3 lid 1, aanhef en onder d AVN}

Het bestuursorgaan wijst een aanvraag om vergoeding van de schade geheel of gedeeltelijk af, indien de benadeelde heeft verzuimd redelijke maatregelen te treffen ter voorkoming of beperking van de schade.

\section{Art. 3 lid 1, aanhef en onder e VNNZ}

Het college weigert een aanvraag om nadeelcompensatie, indien de aanvrager verzuimd heeft maatregelen te treffen ter voorkoming of beperking van het nadeel.

Wanneer de bovenstaande bepalingen worden vergeleken, vallen enkele verschillen in formulering op. Zo is de bepaling uit de BnIW 2019 preciezer als het aankomt op de gevolgen van het schenden van de schadebeperkingsplicht: de vergoeding wordt geweigerd voor het deel van de schade dat was voorkomen als wel aan de schadebeperkingsplicht was voldaan. Dat voor het onevenredige deel van de overige schade wel compensatie wordt toegekend is logisch. Dit deel van de schade kan immers niet worden toegerekend aan een omstandigheid aan de zijde van de aanvrager (stap 1 van art. 6:101 BW). Ik heb geen aanwijzingen gevonden dat dit anders zou zijn onder de overige geselecteerde, thans geldende regelingen. ${ }^{195}$

Een ander verschil in formulering is dat slechts de BnIW 2019 en AVN expliciteren dat de schadebeperkingsplicht wordt begrensd door de redelijkheid. ${ }^{196}$ Uit een uitspraak van 4 december 2013 kan echter worden afgeleid dat de Afdeling eveneens in algemene zin uitgaat van begrenzing van de schadebeperkingsplicht door de redelijkheid. ${ }^{197}$ Dit brengt bijvoorbeeld mee dat de aanvrager niet kan worden tegengeworpen dat hij zijn schade niet heeft beperkt door rechtsmiddelen tegen de schadeoorzaak aan te wenden. ${ }^{198}$ Een uitzondering op dit uitgangspunt is denkbaar in situaties waarin de aanvrager in de non-contentieuze fase eenvoudig had kunnen voorzien in de kennislacune van het bestuur dat bepaalde schade zou

195 Zie ook de toelichting op art. 3 lid 1 onder b t/m d AVN en de toelichting op art. 3, lid 1 onder e VNNZ. Zie ten aanzien van de VNNZ ook nog: ABRvS 22 augustus 2012, ECLI:NL:RVS:2012:BX5293, r.o. 2.6. Zie voor een volledig beeld van het geschil ook Rb. Amsterdam 27 november 2009, ECLI:NL:RBAMS:2009:BK6517; en Rb. Amsterdam 27 september 2011, ECLI:RBAMS:2011:BU3590.

196 In de onder de RnVW 1999 gewezen uitspraak ABRvS 26 april 2006, ECLI:NL:RVS:2006:AW4004, r.o. 2.4-2.4.1 (Verkoopwagen Via Delta) stond dit bijvoorbeeld niet eraan in de weg dat de aanvrager vervangende werkzaamheden had moeten verrichtten toen hij zijn verkoopwagen tijdelijk niet kon exploiteren door werkzaamheden aan een dam.

197 ABRvS 4 december 2013, ECLI:NL:RVS:2013:2203, r.o. 5.1. Zie ook ABRvS 22 januari 2014, ECLI:NL:RVS:2014:114, r.o. 7-7.2 (Nadeelcompensatie Tirion): een verslechterde liquiditeitspositie is geen rechtvaardiging voor schending van de schadebeperkingsplicht, als een voorschot op nadeelcompensatie kan worden aangevraagd.

198 ABRvS 15 augustus 1996, ECLI:NL:RVS:1996:AN5184. Zie voor een opsomming van andere relevante uitspraken het derde onderdeel van de annotatie van Van Ravels bij ABRvS 28 juni 2006, ECLI:NL:RVS:2006:AX9484 in AB 2007/20. 
ontstaan. ${ }^{199}$ Gelet op de uitspraak van 4 december 2013 ga ik ervan uit dat de begrenzing door de redelijkheid ook geldt onder de overige geselecteerde, thans geldende regelingen. Dit wordt voor de VNNZ bovendien bevestigd in de toelichting op art. 3 lid 1, aanhef en onder e VNNZ. Ten aanzien van de Wro kan de begrenzing door de redelijkheid impliciet worden afgeleid uit planschadejurisprudentie waaruit blijkt dat van de aanvrager wiens woongenot wordt ingeperkt door ontwikkelingen op een naburig perceel, niet wordt verwacht dat hij een gedeelte van zijn eigen perceel opoffert om daarop schadebeperkende maatregelen te treffen. ${ }^{200}$

Voor zover ik kan nagaan, leiden de hier besproken, terminologische verschillen dus niet tot materieelrechtelijke verschillen. Zij lijken met name te moeten worden verklaard doordat de regelingen gedurende enkele decennia door verschillende regelgevers zijn opgesteld, terwijl die regelgevers ten aanzien van dit onderwerp geen aandacht lijken te hebben gehad voor afstemming op andere nadeelcompensatieregelingen en/of overleg met elkaar, laat staan een materieelrechtelijk verschil in het leven beoogden te roepen. Ten aanzien van het niet expliciteren van de begrenzing door de redelijkheid in art. 6.3 Wro, kan als aanvullende verklaring worden aangevoerd dat deze bepaling invulling geeft aan de redelijkerwijsformule uit art. 6.1 lid 1 Wro.

\section{Grens van de schadebeperkingsplicht}

In de toelichting behorende bij de VNNZ wordt onder verwijzing naar civielrechtelijke jurisprudentie ${ }^{201}$ opgemerkt dat de aanvrager geen verplichting tot schadebeperking kan worden tegengeworpen voor zover ook op het bestuur een verplichting tot schadebeperking rustte, en het bestuur ook daadwerkelijk schadebeperkende maatregelen had kunnen nemen. ${ }^{202}$ Mede gelet op de schaarste aan jurisprudentie omtrent de schadebeperkingsplicht is het lastig om te bepalen in hoeverre op dit punt een verschil met de overige regelingen bestaat. Het lijkt echter onaannemelijk dat een dergelijk verschil in toepassing daadwerkelijk zou bestaan. Schueler merkte in 2005 al op dat dient te worden nagegaan "op wiens weg het (primair) lag om de schadebeperkende maatregelen te nemen." 203 Steun voor die opvatting lijkt te kunnen gevonden in een uitspraak van 14 april 2004 waarin de Afdeling in een nadeelcompensatiegeschil oordeelde dat...

199 Zie Tjepkema 2010, p. 347-348; en het derde onderdeel van de annotatie van Van Ravels bij ABRvS 28 juni 2006, ECLI:NL:RVS:2006:AX9484 in AB 2007/20.

200 ABRvS 16 april 2014, ECLI:NL:RVS:2014:1294, r.o. 9-9.1 (Schadebeperkende groenstrook?).

201 HR 11 juni 2010, ECLI:NL:HR:2010:BM1733, r.o. 3.3 .2 (Fortes e.a./Van der Bie). Zie voor bespreking van het civiele recht ook Keirse 2003, p. 121-125.

202 Zie de toelichting op art. 3 lid 1 onder e VNNZ onder het kopje 'Voorbeeld'.

203 Schueler 2005, p. 166. Zie voorts ten aanzien van de vraag of het bestuur of een draagplichtige derde schadebeperkend moet optreden ABRvS 1 augustus 2012, ECLI:NL:RVS:2012:BX3259, r.o. 2.10.1. 
“(...) het niet onredelijk [is] dat partijen per voorziening bezien door welke partij deze het beste kan worden gerealiseerd, en (...) niet zonder meer [geldt] dat het aan appellant is het nadeel te compenseren door het treffen van een voorziening in natura." ${ }^{204}$

Ten slotte kan ten aanzien van het planschaderecht worden gewezen op twee Koninklijke Besluiten. De geringe voortvarendheid van de zijde van het bestuur bij de uitvoering van een voornemen tot grondaankoop, respectievelijk de omstandigheid dat het bestuur niets had ondernomen om de schade van de benadeelde te beperken, leidde daarin tot de conclusie dat de schade niet in redelijkheid geheel voor rekening van de benadeelde kon worden gelaten, ondanks dat de benadeelde zelf ook een aandeel had in het ontstaan van de schade. ${ }^{205}$

\subsubsection{Deelvraag 3: het toekomstige recht}

Tegenwerping van de schadebeperkingsplicht zal naar toekomstig recht - ook als afd. 15.1 Ow van toepassing is ${ }^{206}$ - steeds op art. 4:126 lid 2, aanhef en onder b Awb worden gebaseerd. Daarin is namelijk bepaald dat...

“(...) schade (...) in elk geval voor rekening van de aanvrager [blijft] voor zover hij de schade had kunnen beperken door binnen redelijke grenzen maatregelen te nemen, die tot voorkoming of vermindering van de schade hadden kunnen leiden."

De summiere toelichting op deze bepaling benoemt ten eerste dat de vraag of de benadeelde redelijke maatregelen heeft getroffen ter voorkoming of beperking van schade nauw samenhangt met het leerstuk van de risicoaanvaarding. Op de verhouding tussen beide criteria zal hier niet nader worden ingegaan, omdat zij reeds werd besproken in paragraaf 8.1. Voorts volgt uit deze toelichting dat de schade die door het treffen van maatregelen als bedoeld in art. 4:126 lid 2, aanhef en onder $\mathrm{b}$ Awb had kunnen worden voorkomen of beperkt, ten laste van de aanvrager moet blijven. Gelet op verschillende verwijzingen naar Afdelingsuitspraken, lijkt het aannemelijk dat de wetgever de thans bestaande jurisprudentielijnen wil voortzetten onder titel 4.5 Awb. De wetgever vestigt specifiek aandacht op de jurisprudentielijn dat het niet aanwenden van een rechtsmiddel tegen de schadeoorzaak, terwijl dit redelijkerwijs wel mogelijk was, geen reden vormt (een deel van) de schade niet voor vergoeding in aanmerking te laten komen. ${ }^{207}$

204 ABRvS 14 april 2004, ECLI:NL:RVS:2004:AO7460, r.o. 2.10.2.

205 Zie KB 29 december 1976, ECLI:NL:XX:1976:AM3540 (Velsen) respectievelijk KB 27 januari 1983, ECLI:NL:XX:1983:AS9888 (Zwijndrecht).

206 Kamerstukken II 2018/19, 34 986, nr. 3, p. 224-225 (MvT, IOw).

207 Kamerstukken II 2010/11, 32 621, nr. 3, p. 25 (MvT, Wns). 
8.3.3 Hoofdvraag: spiegeling aan de doelstellingen en uitgangspunten die ten grondslag liggen aan de Wns

Door art. 4:126 lid 2, aanhef en onder b Awb komt uniform en expliciet vast te staan dat schade voor rekening van de aanvrager wordt gelaten in zoverre hij haar had kunnen voorkomen door binnen redelijke grenzen schadebeperkende maatregelen te nemen. Dit past goed bij de doelstelling van vereenvoudiging, uniformering en harmonisering van het nadeelcompensatierecht. Ook de doelstellingen van vergroting van de rechtszekerheid, en codificatie van het nadeelcompensatierecht worden gediend door art. 4:126 lid 2, aanhef en onder b Awb. Door deze bepaling hoeft de schadebeperkingsplicht immers niet meer te worden ingelezen in redelijkerwijsformules als opgenomen in onder andere art. 49 WRO, art. 21 Aanwijzingsbesluit 1996 en art. 8.31 Wlv. Het zou echter bijdragen aan het bereiken van beide doelstellingen als uit art. 4:126 Awb duidelijker zou blijken dat het niet voldoen aan de schadebeperkingsplicht - net als risicoaanvaarding - een vorm van eigen schuld betreft. In de huidige formulering kan dat namelijk slechts worden afgeleid uit het in art. 4:126 lid 2 onder c Awb opgenomen woordje 'anderszins'. Een voorstel tot aanpassing van deze formulering kan echter niet los worden gezien van de aanbevelingen die in paragraaf 8.2 zijn gedaan met betrekking tot risicoaanvaarding en de aanbevelingen die nog in paragraaf 8.4 zullen worden gedaan ten aanzien van resterende vormen van eigen schuld. Daarom zal een dergelijk voorstel pas worden gedaan in paragraaf 8.5. Ten behoeve daarvan zal ik hierna onderzoeken in hoeverre tegenwerping van het niet voldoen aan de schadebeperkingsplicht in het planschade- en nadeelcompensatierecht verloopt volgens de vier stappen van art. 6:101 BW. ${ }^{208}$ Vervolgens zal ik kort ingaan op een overweging uit de jurisprudentie die potentieel tot verwarring zou kunnen leiden. Ter afsluiting van deze paragraaf volgt daarna een korte conclusie.

\subsubsection{De vier stappen van art. 6:101 BW}

Stap 1 en 2: Is de schade mede het gevolg van een omstandigheid aan de zijde van de aanvrager, en kan deze omstandigheid aan de aanvrager worden toegerekend?

Ook in het planschade- en nadeelcompensatierecht vormen de eerste twee stappen van art. 6:101 BW voorwaarden om schade voor rekening van de aanvrager te laten wegens de schending van diens schadebeperkingsplicht. Het zal immers steeds moeten vaststaan dat de aanvrager geen of te weinig schadebeperkende maatregelen heeft getroffen. Daardoor is het deel van de schade dat niet was ontstaan als de aanvrager wel aan zijn schadebeperkingsplicht had voldaan (hierna: de extra schade) mede een gevolg van een omstandigheid aan de zijde van de benadeelde (stap 1). Bovendien blijkt uit paragraaf 8.3.1 dat de vraag of, en zo ja in welke mate, schadebeperkende maatregelen moeten worden getroffen, wordt

208 In de toelichting op de RnVW 1999 wordt expliciet verwezen naar art. 6:101 BW, zie Stcrt. 1999, nr. 172, p. 11 (digitaal, p. 11). 
beantwoord aan de hand van de redelijkheid. Kunnen schadebeperkende maatregelen niet in redelijkheid van de aanvrager worden verlangd, dan kan de schade niet vanwege een schending van diens schadebeperkingsplicht voor zijn rekening worden gelaten. Dat duidt erop dat het niet treffen van dergelijke maatregelen aan de aanvrager moet kunnen worden toegerekend (stap 2).

\section{Stap 3 en 4: Evenredige verdeling van de schadelast en de billijkheidscorrectie}

Aanvankelijk bestond binnen de civiele doctrine de opvatting dat de verdeling naar causaliteit op basis van de derde stap zou meebrengen dat de extra schade in zijn geheel niet voor rekening van de laedens diende te komen. Er zou slechts bij wijze van uitzondering ruimte voor de billijkheidscorrectie van de vierde stap bestaan. Mede onder invloed van het proefschrift van Keirse lijkt thans de heersende opvatting te zijn (of op zijn minst evenveel draagvlak te bestaan voor de opvatting) dat bij de schadedeling op grond van de derde stap de "relatieve waarde van de veroorzakingswaarschijnlijkheid" bepalend is. Dat zal doorgaans tot gevolg hebben dat ook een deel van de extra schade voor rekening van de laedens komt. ${ }^{209}$ De uitkomst van deze schadedeling kan worden gecorrigeerd als de billijkheid dat vereist. Zo zou de extra schade geheel voor rekening van de gelaedeerde kunnen worden gelaten als hij opzettelijk achterwege heeft gelaten de schade te beperken in een poging de laedens een loer te draaien. ${ }^{210}$

Gelet op de in paragraaf 8.3 .1 besproken jurisprudentie, lijkt het planschade- en nadeelcompensatierecht op dit punt af te wijken van het civiele recht: de extra schade wordt volledig voor rekening van de aanvrager gelaten. ${ }^{211}$ Dit lijkt het gevolg te zijn van een billijkheidscorrectie die nooit is geëxpliciteerd en gemotiveerd. Ik zie namelijk niet in waarom de causale verdeling van de derde stap in het planschade- en nadeelcompensatierecht niet - net als in het civiele recht - tot de conclusie zou leiden dat slechts een deel van de extra schade voor rekening van de gelaedeerde dient te blijven. Zonder een wijziging van het ter plaatse geldende bestemmingsplan kan bijvoorbeeld geen schade door geluidsoverlast door ontplooiing van nieuwe activiteiten worden geleden. Dat geldt dus ook voor de extra schade die aanvrager door plaatsing van een geluidswal had kunnen voorkomen. De in het planschade- en nadeelcompensatierecht gemaakte keuze om de extra schade door middel van een billijkheidscorrectie volledig voor rekening van de aanvrager te laten, lijkt te kunnen worden verklaard door de bijzondere aard van het planschade- en nadeelcompensatierecht. Anders dan de laedens in het civiele onrechtmatigedaadsrecht, én anders dan de aanvrager die niet handelde zoals een redelijk denkend en handelend persoon zou hebben gedaan, heeft het bestuur immers niet onrechtmatig gehandeld respectievelijk anderszins een fout gemaakt

209 Zie Keirse 2003, p. 270 voor een duidelijk (reken)voorbeeld.

210 Zie Asser/Sieburgh 6-II 2017/127; Keirse 2003, p. 261-273; en Hartlief, Verbintenissen uit de wet en Schadevergoeding (SBR 5), 2018/235.

211 Zie bijvoorbeeld ook de toelichting op art. 3 lid 1 onder $\mathrm{d}$ AVN, en de toelichting op art. 3, lid 1 onder e VNNZ. Zie eveneens Tjepkema 2010, p. 346-348. 
(mate van verwijtbaarheid), maar betreft het een compensatie wegens rechtmatige overheidsdaad die wordt bekostigd uit schaarse publieke middelen ${ }^{212}$ (aard van de aansprakelijkheid). ${ }^{213}$

\section{Toetsing aan de doelstellingen en uitgangspunten die ten grondslag liggen aan de Wns}

Ten aanzien van het uitgangspunt van aansluiting bij het BW kan worden opgemerkt dat de beperking van de schadebeperkingsplicht door de redelijkheid goed aansluit bij de civielrechtelijke norm dat "voldoende zorg voor eigen persoon en goed" dient te worden betracht, en de equivalent daarvan in het nadeelcompensatierecht dat moet worden gehandeld zoals een redelijk denkend en handelend persoon zou doen. ${ }^{214}$ Op het eerste oog past het daarentegen niet goed bij het uitgangspunt van aansluiting bij het BW dat de derde stap van art. 6:101 BW (feitelijk) geen rol van betekenis speelt in het planschade- en nadeelcompensatierecht, omdat de extra schade in beginsel volledig voor rekening van de aanvrager wordt gelaten. De hiervoor gevonden verklaring - de bijzondere aard van dit rechtsgebied - rechtvaardigt mijns inziens echter dat op dit punt van het civiele recht wordt afgeweken. Wel merk ik op dat dit, gelet op de doelstellingen van vergroting van de rechtszekerheid en codificatie van het nadeelcompensatierecht, duidelijker zou mogen blijken uit de formulering van de Awb-bepaling. Bezien van het uitgangspunt van aansluiting bij het BW, zou deze bepaling bovendien in meer algemene zin beter kunnen aansluiten op de formulering van art. 6:101 BW. Dit zal worden meegenomen in het concrete voorstel tot wijziging van titel 4.5 Awb dat in paragraaf 8.5 zal worden gedaan.

\subsubsection{Een potentieel verwarrende overweging uit de jurisprudentie}

Bij bestudering van de planschadejurisprudentie valt op dat de rechterlijke macht soms overweegt dat de benadeelde geen gebruik heeft gemaakt van de mogelijkheid om schade te beperken doordat hij voorafgaand aan de schadeveroorzakende planologische maatregel geen concrete poging heeft ondernomen om de daardoor vervallen planologische bouw- of gebruiksmogelijkheid te benutten, waardoor hem passieve risicoaanvaarding kan worden tegengeworpen. ${ }^{215}$ Dergelijke overwegingen brengen het risico met zich dat het onderscheid tussen risicoaanvaarding en het niet voldoen aan een schadebeperkingsplicht - twee afzonderlijke

212 Zie voor een vergelijkbare redenering ten aanzien van compensatie anders dan in geld: ABRvS 9 december 2015, ECLI:NL:RVS:2015:3767.

213 Uit paragraaf 8.1 volgde dat zowel de aard van de aansprakelijkheid als de mate van verwijtbaarheid een rol spelen onder de vierde stap van art. 6:101 BW.

214 Vergelijk paragraaf 8.2.1.4.

215 Zie voor bouwmogelijkheden: ABRvS 25 mei 2016, ECLI:NL:RVS:2016:1395, r.o. 4.6; en ABRvS 1 november 2017, ECLI:NL:RVS:2017:2927, r.o. 6. Zie voor gebruiksmogelijkheden: ABRvS 28 september 2016, ECLI:NL:RVS:2016:2582, r.o. 11.2 (Overzichtsuitspraak). 
vormen van eigen schuld - onnodig wordt vertroebeld. Dat past niet goed bij de doelstelling van vergroting van rechtszekerheid. Ik doe de rechterlijke macht dan ook de aanbeveling om dergelijke overwegingen achterwege te laten bij toepassing van titel 4.5 Awb. Dat acht ik ook verenigbaar met de overige doelstellingen en uitgangspunten die aan de Wns ten grondslag liggen.

\subsubsection{Conclusie}

Op basis van het voorafgaande zie ik reden tot (a) aanpassing van titel 4.5 Awb. Uit deze titel zou duidelijker moeten blijken dat het niet voldoen aan de schadebeperkingsplicht een vorm van eigen schuld betreft, waarbij feitelijk geen belang toekomt aan de derde stap van art. 6:101 BW. Concrete voorstellen om dat te bereiken zullen pas in paragraaf 8.5 worden gedaan, omdat zij deels afhankelijk zijn van aanbevelingen en voorstellen ten aanzien van de overige vormen van eigen schuld. De aan de Wns ten grondslag liggende doelstellingen en uitgangspunten geven mijns inziens geen aanleiding tot (b) aanpassing van afd. 15.1 Ow. Wel zie $\mathrm{ik}$ reden om (c) anderszins in een bijzondere invulling van titel 4.5 Awb te voorzien. Het zou namelijk goed bij deze doelstellingen en uitgangspunten passen als rechters in hun uitspraken zouden vermijden dat overwegingen inzake (passieve) risicoaanvaarding kunnen worden gelezen als een tegenwerping van het niet voldoen aan de schadebeperkingsplicht.

\subsection{RESTERENDE VORMEN VAN EIGEN SCHULD}

8.4.1 Deelvraag 2: verschillen tussen de geselecteerde, thans geldende regelingen en verklaringen daarvoor

Van de geselecteerde, thans geldende regelingen blijkt de AVN de enige te zijn die een afzonderlijke bepaling inzake resterende vormen van eigen schuld bevat. In art. 3 lid 1, aanhef en onder c AVN is bepaald dat het bestuur een aanvraag om nadeelcompensatie geheel of gedeeltelijk afwijst indien de schade het gevolg is van een omstandigheid die geheel of gedeeltelijk aan de aanvrager kan worden toegerekend. Deze bepaling lijkt slechts te moeten worden toegepast op vormen van eigen schuld die niet kunnen worden gekwalificeerd als risicoaanvaarding of het niet voldoen aan de schadebeperkingsplicht. Aan die criteria heeft de Amsterdamse gemeenteraad immers aandacht gewijd in art. 3 lid 1, aanhef en onder b AVN respectievelijk art. 3 lid 1, aanhef en onder d AVN. ${ }^{216}$ In de toelichting op art. 3 lid 1, aanhef en onder c AVN worden geen concrete voorbeelden gegeven van situaties waarin deze bepaling van betekenis zou kunnen zijn. Wel wordt in meer algemene zin vermeld dat kan worden gedacht aan situaties waarin de benadeelde zich bewust in een onrechtmatige situatie begeeft en vervolgens schade lijdt door rechtmatige handhaving(sbesluiten). 
Dat slechts de AVN een afzonderlijke bepaling inzake eigen schuld bevat, kan worden verklaard doordat dergelijke bepalingen van oudsher niet in nadeelcompensatieregelingen voorkomen. In paragraaf 2.2 is beschreven hoe de vroege nadeelcompensatieregelingen, zoals art. $49 \mathrm{WRO}$, slechts uitgingen van een redelijkerwijsformule. In de jaren '90 was de RnVW 1999 een van de eerste regelingen die ook bepalingen bevatten die uitlegden hoe deze redelijkerwijsformule diende te worden toegepast. Dergelijke bepalingen betroffen doorgaans een poging om de tot op dat moment verschenen jurisprudentie te codificeren. In die jurisprudentie speelde het leerstuk van de risicoaanvaarding een relatief grote rol. Dat geldt zeker voor de onder art. 49 WRO verschenen jurisprudentie. Er bestaat echter nauwelijks bestuursrechtelijke nadeelcompensatiejurisprudentie waarin de schade expliciet wegens eigen schuld voor rekening van de aanvrager wordt gelaten. Het verbaast dan ook niet dat nadeelcompensatieregelingen doorgaans geen afzonderlijke bepaling inzake resterende vormen van eigen schuld bevatten.

Een aanvullende verklaring dat een afzonderlijke bepaling inzake eigen schuld in de meeste nadeelcompensatieregelingen ontbreekt, zou kunnen zijn dat in de rechtspraktijk de gedachte leeft dat schade door rechtmatige handhaving(sbesluiten) niet binnen het toepassingsbereik van het égalitébeginsel valt, of altijd tot het normaal maatschappelijk risico kan worden gerekend. Kenmerkend voor die eerste gedachte is de onderstaande overweging uit een uitspraak van het CBb van 6 juni 2007:

"Voor nadeelcompensatie is geen plaats, nu het appellante niet was en is toegestaan om op zondag haar bloemenwinkel voor het publiek geopend te hebben. Er is geen rechtsgrond aan te wijzen die verweerders zou verplichten om een vergoeding aan appellanten toe te kennen voor gederfde inkomsten die voorheen in strijd met de Wet werden verworven."

Ook kan worden gewezen op een Afdelingsuitspraak van 30 januari 2019. Daarin overwoog de Afdeling namelijk dat geen sprake was van een situatie waarop het égalitébeginsel ziet, omdat de ondervonden schade het gevolg was van handhaving wegens een door de aanvraagster overtreden norm. ${ }^{217}$

De tweede gedachte werd in ieder geval door de rechtbank Zutphen geëxpliciteerd in haar uitspraak van 13 december 2004:

"De rechtbank is met verweerder van oordeel dat bij nadeel (winst- of inkomensderving) ten gevolge van een dwangsombesluit sprake is van binnen het normaal maatschappelijk risico vallend nadeel en het égalité-beginsel derhalve niet tot nadeelcompensatie noopt. Een dwangsombesluit kan geen aanspraak op nadeelcompensatie met

217 ABRvS 30 januari 2019, ECLI:NL:RVS:2019:258, r.o. 4. Er wordt overigens uiteenlopend gedacht over de wijze waarop dit soort overwegingen moet worden geinterpreteerd. Zie daarover bijvoorbeeld de bij deze uitspraak behorende noot van Theunisse in Gst. 2019/98. 
zich brengen. Met de last is slechts kracht bijgezet dat degene tot wie de last zich richt zich, evenals ieder ander, aan de wet dient te houden." 218

De rechtbank verwees hierbij naar een Afdelingsuitspraak van 13 november 2002 waarin $\mathrm{B} \& \mathrm{~W}$ een dwangsom oplegden aan iemand die een pand in strijd met het bestemmingsplan bewoonde. De Afdeling overwoog dat...

“(...) niet valt in te zien dat de redelijkheid gebiedt dat burgemeester en wethouders appellant dienen te compenseren voor de omstandigheid dat er een einde komt aan een illegale situatie in het ontstaan waarvan hij zelf de hand heeft gehad."219

Wellicht zou deze overweging inderdaad als een impliciete toepassing van het criterium van de abnormale last kunnen worden gelezen. Steun voor een dergelijke lezing zou ook kunnen worden gevonden in de opmerking uit de bij de Wns behorende memorie van toelichting dat "vanzelfsprekend niet wordt voldaan aan het onevenredigheidsvereiste indien de betreffende schadeveroorzakende overheidsmaatregel de ongelijke verdeling van lasten juist beoogt." ${ }^{220}$ Daarvan is immers sprake bij handhaving(sbesluiten). Deze overweging kan echter ook worden gezien als een tegenwerping van eigen schuld - en wordt bijvoorbeeld ook zo gelezen door Tjepkema. ${ }^{221}$

Hoe kan dan worden verklaard dat de AVN wel een afzonderlijke bepaling inzake eigen schuld bevat? Uit de toelichting op art. 3 lid 1 onder c AVN blijkt dat de Amsterdamse gemeenteraad zich wat dit betreft heeft laten inspireren door de afzonderlijke bepaling inzake eigen schuld die in titel $4.5 \mathrm{Awb}$ is opgenomen in de vorm van art. 4:126 lid 2, aanhef en onder c Awb. Ook wordt daarin opgemerkt dat de formele wetgever het zich bevinden in een handhavingssituatie zou beschouwen als "een 'omstandigheid die aan de benadeelde zelf kan worden toegerekend' en die dus uit hoofde van eigen schuld (art.6:101 BW) - en dus niet zozeer in het kader van het 'normaal maatschappelijk risico' voor rekening van de benadeelde komt." In paragraaf 8.4.2 zal ik bespreken wat precies uit de bij de Wns behorende Kamerstukken kan worden opgemaakt.

Deze deelparagraaf sluit ik af met de opmerking dat art. 3 lid 1, aanhef en onder c AVN slechts een materieelrechtelijk verschil met de VNNZ in het leven lijkt te roepen. De overige geselecteerde, thans geldende regelingen bevatten namelijk allemaal een redelijkerwijsformule. Uit paragrafen 8.2 en 8.3 volgde dat risicoaanvaarding respectievelijk het niet voldoen aan de schadebeperkingsplicht als toepassing van een dergelijke redelijkerwijsformule aan de aanvrager kan worden tegengeworpen. Ik zie geen reden waarom dat niet ook zou opgaan voor overige vormen van eigen schuld.

218 Rb. Zutphen 13 december 2004, ECLI:NL:RBZUT:2004:AS1993.

219 ABRvS 13 november 2002, ECLI:NL:RVS:2002:AF0262.

220 Kamerstukken II 2010/11, 32 621, nr. 3, p. 13 (MvT, Wns).

221 Tjepkema 2010, p. 344-345. 


\subsubsection{Deelvraag 3: het toekomstige recht}

In de vorige deelparagraaf werd al opgemerkt dat titel 4.5 Awb een afzonderlijke bepaling inzake eigen schuld kent in de vorm van art. 4:126 lid 2, aanhef en onder c Awb:

"Schade blijkt in elk geval voor rekening van de aanvrager voor zover de schade anderszins het gevolg is van een omstandigheid die aan de aanvrager kan worden toegerekend."

Aangezien afd. 15.1 Ow niet hiervan afwijkt, zal deze bepaling ook van toepassing zijn op aanvragen om nadeelcompensatie die onder het bereik van afd. 15.1 Ow vallen.22 Uit de passage uit de memorie van toelichting die behoort bij art. 4:126 lid 2, aanhef en onder c Awb kan slechts worden afgeleid dat de wetgever heeft willen aansluiten bij art. 6:101 BW. ${ }^{223}$ Bestudering van overige Kamerstukken leert dat de afzonderlijke bepaling inzake eigen schuld nog niet voorkwam in het voorontwerp van de Wns. Gevraagd naar de reden voor deze toevoeging, verwees de toenmalig minister van Veiligheid en Justitie naar het advies van de Hoge Raad om meer aansluiting te zoeken bij art. 6:101 BW. Daarin zou namelijk zijn vermeld dat het leerstuk van de risicoaanvaarding in het nadeelcompensatierecht - in tegenstelling tot hetgeen het geval is in het civiele recht - nog wel enige zelfstandige betekenis zou moeten worden toegekend. Daarbij lijkt de minister over het hoofd te hebben gezien, of bewust niet te hebben vermeld, dat de Hoge Raad sprak van het wellicht enige zelfstandige betekenis toekomen aan het leerstuk van risicoaanvaarding. ${ }^{224}$ Verder blijkt uit het antwoord van de minister dat het niet wenselijk werd geacht dat nadeelcompensatie zou moeten worden toegekend voor schade door een andere omstandigheid dan het schadeveroorzakende overheidshandelen, die wel aan de aanvrager kan worden toegerekend maar niet onder het in art. 4:126 lid 2, aanhef en onder a Awb opgenomen leerstuk van de risicoaanvaarding valt. ${ }^{225}$

De minister geeft vier voorbeelden van dit soort situaties: ${ }^{226}$ (1) de situatie waarin de aanvrager schade lijdt doordat het bestuur een eind maakt aan een illegale situatie in het ontstaan waarvan hij zelf de hand heeft gehad; (2) schade die is geleden doordat is gestart met bouwen, terwijl de bouwvergunning nog niet onherroepelijk was, ${ }^{227}$ (3) schade die is geleden doordat een overtreder kosten moest maken om te voorkomen dat handhavend werd opgetreden; 228 en (4) schade door handha-

222 Kamerstukken II 2018/19, 34 986, nr. 3, p. 224-225 (MvT, IOw).

223 Kamerstukken II 2010/11, 32 621, nr. 3, p. 25 (MvT, Wns).

224 Zie Advies HR consultatie Wns, p. 4 waarin wordt verwezen naar HR 28 juni 1991, ECLI:NL:HR:1991:ZC0300 (Dekker/Van der Heide).

225 Kamerstukken I 2012/13, 32 621, nr. C, p. 9 (MvA I, Wns).

226 Kamerstukken I 2012/13, 32 621, nr. C, p. 9 (MvA I, Wns).

227 Onder verwijzing naar ABRvS 9 december 1996, ECLI:NL:RVS:1996:AN5533.

228 Onder verwijzing naar ABRvS 2 oktober 2000, ECLI:NL:RVS:2000:AA9029. 
vingsbesluiten die een eind maken aan een illegale situatie. ${ }^{229}$ Ter illustratie van het eerste voorbeeld verwijst de minister naar de in paragraaf 8.4.1 besproken Afdelingsuitspraak van 13 november 2002, die inderdaad kan worden gezien als een zaak waarin de schade niet werd gecompenseerd vanwege eigen schuld van de aanvrager. ${ }^{230}$ De rechterlijke uitspraken waarnaar wordt verwezen ter illustratie van de overige voorbeelden hebben allemaal een 'rafeltje'. In de uitspraak behorende bij het tweede voorbeeld werd de aanvraag om vergoeding gebaseerd op het inmiddels vervallen art. 131 lid 1 Gemw. ${ }^{231}$ Die bepaling lijkt echter niet op het égalitébeginsel te zijn gebaseerd. ${ }^{232}$ In de uitspraak behorende bij het derde voorbeeld werd een beroep gedaan op art. 14 lid 3 GW, art. 1 EP en het égalitébeginsel, terwijl uit de uitspraak niet duidelijk volgt of, en zo ja wanneer, de Afdeling ingaat op het égalitébeginsel. Bovendien speelt de notie van het normaal maatschappelijk risico ook een rol in deze uitspraak. De Afdeling overweegt namelijk dat "de kosten van het plaatsen en onderhouden van de afrastering (...) voorts niet buiten het normale maatschappelijk risico [vallen]."

Bij het vierde voorbeeld wordt verwezen naar twee uitspraken. Een daarvan is de in paragraaf 8.4.1 besproken uitspraak van het CBb van 6 juni 2007. Daarin overwoog het $\mathrm{CBb}$ niets omtrent eigen schuld, maar deed zij de vordering om compensatie af met de overweging dat er geen rechtsgrond was die daartoe verplichtte. De andere uitspraak betreft een Afdelingsuitspraak van 6 juni 2002. Daarin overwoog de Afdeling dat...

“(...) het op voorhand weigeren van klaringen voor langere tijd een besluit [is] met een correctief of punitief karakter. Het naar aanleiding hiervan toekennen van een vergoeding is geen besluit inzake nadeelcompensatie en kan dit ook niet (geweest) zijn."

Deze overweging leest ook niet als de tegenwerping van eigen schuld, maar doet denken aan de in paragraaf 8.4.1 aangehaalde passage uit de bij de Wns behorende memorie van toelichting dat niet wordt voldaan aan het onevenredigheidsvereiste als de schadeveroorzakende overheidsmaatregel de ongelijke verdeling van lasten juist beoogt. ${ }^{233}$

229 Onder verwijzing naar ABRvS 26 juni 2002, ECLI:NL:RVS:2002:AE4653 en CBb 6 juni 2007, ECLI:NL:CBB:2007:BA8636.

230 Zie ook Tjepkema 2010, p. 344-345.

231 Dit artikel bepaalde dat "de overtreder de kosten, verbonden aan de toepassing van bestuursdwang, verschuldigd [is], tenzij de kosten redelijkerwijze niet te zijnen laste behoren te komen."

232 Uit het vierde onderdeel van de noot van Damen bij ABRvS 21 september 2005, ECLI:NL:RVS:2005:AU2988 kan namelijk worden afgeleid dat de invulling van de term 'redelijkerwijs' in art. 5:25 lid 1 Awb (de opvolger van het destijds gelijkluidende art. 131 lid $1 \mathrm{Gemw}$ ) geen typische égalité invulling betreft.

233 Kamerstukken II 2010/11, 32 621, nr. 3, p. 13 (MvT, Wns). Vergelijk Tjepkema 2010, p. 203. 
Dat het in veel van de aangehaalde jurisprudentie op zijn minst onduidelijk is in hoeverre het ging om een nadeelcompensatiegeschil waarin de aanvrager eigen schuld kreeg tegengeworpen, laat onverlet dat de aanvrager in de vier door de minister genoemde voorbeelden wel eigen schuld zou kunnen worden tegengeworpen. Gelet op de schaarste aan bestuursrechtelijke jurisprudentie over dit onderwerp had de minister waarschijnlijk geen betere uitspraken ter illustratie daarvan tot zijn beschikking. ${ }^{234}$ Vandaag de dag had hij ongetwijfeld verwezen naar de volgende overweging uit een Afdelingsuitspraak van 6 november 2019 - waarin appellante stelde schade te hebben geleden doordat de sluiting van haar woning door de burgemeester haar voor extra kosten had geplaatst:

"Daargelaten of de door [appellante] gestelde schade in causaal verband staat met het besluit van 17 juli 2017, vervalt de compensatieplicht van de burgemeester geheel, omdat de schade mede een gevolg is van een omstandigheid die aan [appellante] kan worden toegerekend. Onder 17 is overwogen dat [appellante] er redelijkerwijs van op de hoogte kon zijn dat haar woning en zoon betrokken waren bij drugshandel, zodat aan haar stelling dat zij geen wetenschap had van de activiteiten van haar zoon, in dit verband geen gewicht toekomt. De gestelde schade komt voor haar risico. De burgemeester had haar derhalve geen nadeelcompensatie hoeven te betalen."235

Afgaande op de door de minister gegeven toelichting, is dit immers typisch een situatie met het oog waarop art. 4:126 lid 2, aanhef en onder c Awb is geschreven.

\subsubsection{Hoofdvraag: spiegeling aan de doelstellingen en uitgangspunten die ten grondslag liggen aan de Wns}

In paragraaf 8.4.1 bleek dat het merendeel van de geselecteerde, thans geldende nadeelcompensatieregelingen geen zelfstandige bepaling inzake eigen schuld bevat, maar via de band van de redelijkerwijsformule wel de mogelijkheid biedt om de aanvrager een andere vorm van eigen schuld dan risicoaanvaarding of het niet voldoen aan de schadebeperkingsplicht tegen te werpen. Het past goed bij de doelstelling van vereenvoudiging, uniformering en harmonisering van het nadeelcompensatierecht, codificatie van het nadeelcompensatierecht, en vergroting van de rechtszekerheid dat deze mogelijkheid zal worden geëxpliciteerd in art. 4:126 lid 2, aanhef en onder c Awb. Dit laat onverlet dat de aan de Wns ten grondslag liggende doelstellingen en uitgangspunten nog beter zouden kunnen worden gediend. Ter onderbouwing daarvan zal ik hierna ingaan op de afbakening en de formulering van art. 4:126 lid 2, aanhef en onder c Awb.

234 Zie Tjepkema 2014b, p. 411-413 voor een overzicht van relevante nadeelcompensatiejurisprudentie in een strafrechtelijke context. 


\section{De afbakening van art. 4:126 lid 2, aanhef en onder c Awb}

De in paragraaf 8.4.1 en 8.4.2 besproken jurisprudentie laat zien dat in de rechtspraktijk uiteenlopend wordt omgegaan met de gevallen waarvoor de wetgever art. 4:126 lid 2, aanhef en onder c Awb heeft geschreven. Aanvragen om nadeelcompensatie naar aanleiding van overheidsmaatregelen ter beëindiging van een door de aanvrager in het leven geroepen illegale toestand worden afgewezen omdat (1) het égalitébeginsel niet van toepassing zou zijn op schade die voortkomt uit handhavend overheidsoptreden; (2) schade door handhavend overheidsoptreden nooit tot het normaal maatschappelijk risico zou behoren; of (3) de aanvrager eigen schuld heeft aan het ontstaan van de schade, omdat hij de illegale toestand zelf in het leven heeft geroepen. Voortzetting van deze praktijk zou niet goed passen bij de doelstellingen van uniformering en harmonisering van het nadeelcompensatierecht, en vergroting van de rechtszekerheid en rechtsgelijkheid. Het kabinet zou er daarom goed aan doen zijn voorkeur voor een van deze drie varianten uit te spreken in een Kamerbrief of ander toelichtend stuk. Vervolgens is het uiteraard aan uitvoerende bestuursorganen en de rechter om in de praktijk zoveel mogelijk voorrang te geven aan deze voorkeursvariant.

Wat zou die voorkeursvariant dan moeten zijn? De variant dat het égalitébeginsel niet van toepassing zou zijn, past niet goed bij de brede reikwijdte van titel 4.5 Awb. Ook handhavend overheidsoptreden kan immers worden gekwalificeerd als de rechtmatige uitoefening van een publiekrechtelijke bevoegdheid of taak. Uit de bijdrage van Tjepkema aan de Op het grensvlak-bundel blijkt dat over de keuze tussen de twee resterende varianten meer discussie kan worden gevoerd. Ik kan me echter goed vinden in zijn betoog dat ervoor moet worden gewaakt dat het normaal maatschappelijk risico tot de "allesreiniger" van het nadeelcompensatierecht wordt verheven. Tjepkema stelt voor om de grens te trekken "daar waar burgers wettelijke normen schenden, zich inlaten met criminele of illegale activiteiten of anderszins in strijd met het algemeen belang handelen." In dergelijke gevallen is het "dominante gezichtspunt" waarom de schade redelijkerwijs voor rekening van de aanvrager moet worden gelaten namelijk niet de abstracte voorzienbaarheid van het overheidshandelen, maar "het gegeven dat burgers de schade voor eigen rekening moeten nemen wanneer zij zelf schuldig zijn aan het in het leven roepen van een illegale situatie en de overheid de situatie in een rechtmatige toestand herstelt." ${ }^{236}$ Een dergelijke grens sluit ook goed aan op de toelichting die de minister gaf op art. 4:126 lid 2, aanhef en onder c Awb.

\section{Formulering van art. 4:126 lid 2, aanhef en onder c Awb}

Bezien vanuit het uitgangspunt van aansluiting bij het BW, is de huidige formulering van art. 4:126 lid 2, aanhef en onder c Awb niet optimaal. In die bepaling zijn namelijk slechts de eerste twee stappen van art. 6:101 BW duidelijk te herkennen. Alleen met een flinke portie goede wil zou in de woorden 'voor zover' uit de aanhef 
van de bepaling een hint naar de derde stap kunnen worden gelezen. Het standpunt van Franssen dat deze woorden slechts erop duiden dat het bestaan van bijvoorbeeld risicoaanvaarding of eigen schuld een voorwaarde vormt om schade voor rekening van de aanvrager te laten - en dus geen verdeelsleutel inhouden - lijkt echter ook verdedigbaar. De billijkheidscorrectie van de vierde stap is helemaal niet in de bepaling uit de Awb te herkennen. ${ }^{237}$ Dat is problematisch omdat uit de analyse van de jurisprudentie inzake risicoaanvaarding en het niet voldoen aan de schadebeperkingsplicht blijkt dat in beginsel altijd billijkheidscorrecties worden toegepast. Doorgaans geschiedt dit doordat geen (expliciete) schadedeling aan de hand van een causale verdeling naar veroorzakingswaarschijnlijkheid plaatsvindt (stap 3), maar de voorzienbare schade respectievelijk de extra schade ${ }^{238}$ volledig voor rekening van de aanvrager wordt gelaten. Ik heb geen aanleiding om aan te nemen dat dit anders zal zijn, of zou moeten zijn, voor overige vormen van eigen schuld. Deze afwijking van het civiele recht wordt mijns inziens namelijk gerechtvaardigd door de bijzondere aard van het planschade- en nadeelcompensatierecht. Anders dan de laedens in het civiele onrechtmatigedaadsrecht, én anders dan de aanvrager die niet handelde zoals een redelijk denkend en handelend persoon zou hebben gedaan, heeft het bestuur immers niet onrechtmatig gehandeld respectievelijk anderszins een fout gemaakt (mate van verwijtbaarheid), maar betreft het een compensatie wegens rechtmatige overheidsdaad die wordt bekostigd uit schaarse publieke middelen ${ }^{239}$ (aard van de aansprakelijkheid). ${ }^{240}$ Dat neemt niet weg dat het goed bij het uitgangspunt van aansluiting bij het BW en de doelstellingen van vergroting van de rechtszekerheid en codificatie van het nadeelcompensatierecht, en in meer algemene zin ook bij het legaliteitsbeginsel zou passen als art. 4:126 lid 2, aanhef en onder c Awb (1) de mogelijkheid tot een billijkheidscorrectie zou bevatten en (2) duidelijk zou maken dat aan de causale verdeling van de derde stap van art. 6:101 BW in principe geen belang toekomt, omdat het uitgangspunt is dat de schade in zijn geheel voor rekening van de aanvrager blijft.

\section{Conclusie}

Gelet op het voorafgaande zie ik aanleiding om (a) titel 4.5 Awb aan te passen. Een concreet voorstel hiertoe zal ik doen in paragraaf 8.5. In een toelichting op deze wijziging zou de wetgever mijns inziens bovendien duidelijker moeten aangeven hoe de resterende vormen van eigen schuld zich verhouden tot het criterium van de abnormale last (en de overige criteria voor toekenning van nadeelcompensatie). De doelstellingen en uitgangspunten die aan de Wns ten grondslag liggen, geven

237 Franssen 2014, p. 38.

238 Zie paragraaf 8.3.3.1 onder het kopje inzake de eerste twee stappen van art. 6:101 BW.

239 Zie voor een vergelijkbare redenering ten aanzien van compensatie anders dan in geld: ABRvS 9 december 2015, ECLI:NL:RVS:2015:3767.

240 Uit paragraaf 8.1 volgde dat zowel de aard van de aansprakelijkheid als de mate van verwijtbaarheid een rol spelen onder de vierde stap van art. 6:101 BW. 
mijns inziens geen aanleiding om (b) afd. 15.1 Ow aan te passen, of (c) anderszins in een bijzondere invulling, aanvulling of afwijking van titel 4.5 Awb te voorzien.

\subsection{CONCLUSIE EN CONCRETE VOORSTELLEN}

In dit hoofdstuk zijn de tweede en derde deelvraag en de hoofdvraag beantwoord ten aanzien van het criterium van risicoaanvaarding (paragraaf 8.2), de schadebeperkingsplicht (paragraaf 8.3) en resterende vormen van eigen schuld (paragraaf 8.4). In deze paragraaf zal kort in herinnering worden geroepen welke aanbevelingen zijn gedaan om (a) titel 4.5 Awb aan te passen, (b) afd. 15.1 Ow aan te passen, of (c) anderszins in een bijzondere invulling, aanvulling of afwijking van titel 4.5 Awb te voorzien. Vervolgens worden concrete voorstellen gedaan om deze aanbevelingen te implementeren.

In paragraaf 8.2.3 is aanbevolen dat (c) anderszins in een bijzondere invulling van titel 4.5 Awb wordt voorzien door vaststelling van wetsinterpreterende verordeningen of beleidsregels waaruit blijkt wat het bestuur als peildatum voor aanname van voorzienbaarheid beschouwt voor bepaalde categorieën van aanvragen om nadeelcompensatie. Deze aanbeveling beoogt bij te dragen aan de doelstellingen van vergroting van de rechtszekerheid en rechtsgelijkheid, en vergroting van de doelmatigheid van het nadeelcompensatierecht en vermindering van bestuurslasten. Gelet op de casuïstische aard van de voorgestelde verordeningen en beleidsregels zal hier geen concreet voorstel worden gedaan voor nadere uitwerking van deze aanbeveling. Wel zullen concrete voorstellen worden gedaan om (a) titel 4.5 Awb en (b) afd. $15.1 \mathrm{Ow}$ aan te passen. Bezien vanuit de doelstellingen van vergroting van de rechtszekerheid, en codificatie van het nadeelcompensatierecht zou het positief zijn als de Awb-bepaling inzake risicoaanvaarding duidelijker liet blijken (1) wanneer actieve- en passieve risicoaanvaarding kan worden tegengeworpen; (2) op welke bronnen voorzienbaarheid kan worden gebaseerd; (3) dat risicoaanvaarding een vorm van eigen schuld betreft; en (4) dat aan de causale verdeling van de derde stap van art. 6:101 BW in principe geen belang toekomt, omdat het uitgangspunt is dat de voorzienbare schade in zijn geheel voor rekening van de aanvrager blijft. Ook zou de formulering van de Awb-bepaling meer op die van art. 6:101 BW moeten aansluiten om beter gehoor te geven aan het uitgangspunt van aansluiting bij het BW.

In paragraaf 3.4.2.4 $4^{241}$ is aanbevolen een generieke oplossing te treffen voor de schaduwschadeproblematiek die wordt veroorzaakt door de exclusieve, limitatieve opsomming van schadeoorzaken van art. 15.1 lid 1 Ow. Naar aanleiding daarvan is in paragraaf 8.2.3.2 aangekondigd dat ik een voorstel zal doen voor een alternatief voor art. $15.5 \mathrm{Ow}$. Naar aanleiding van art. $15.6 \mathrm{Ow}$ is voorts in paragraaf 8.2.3.3 geconcludeerd dat één set basisvoorwaarden zou moeten gelden voor tegenwerping van passieve risicoaanvaarding, ongeacht of enkel titel 
4.5 Awb van toepassing is of ook afd. 15.1 Ow. Dat sluit namelijk goed aan op de doelstellingen van vereenvoudiging, uniformering en harmonisering van het nadeelcompensatierecht, en vergroting van de rechtszekerheid en rechtsgelijkheid. Deze basisvoorwaarden zouden moeten worden opgenomen in titel 4.5 Awb. Gelet op de doelstellingen van vergroting van de rechtszekerheid en codificatie van het nadeelcompensatierecht, kan een nadere toespitsing van deze basisvoorwaarden op het omgevingsrecht plaatsvinden in art. 15.6 Ow. Die toespitsing zou inhouden dat in art. 15.6 Ow wordt vastgelegd wanneer in ieder geval sprake is van een concrete poging. Voorts zouden zowel de basisvoorwaarden in de Awb-bepaling als de nadere toespitsing in art. $15.6 \mathrm{Ow}$ niet moeten afwijken van de huidige jurisprudentielijnen omtrent passieve risicoaanvaarding. De in het kader van afd. $15.1 \mathrm{Ow}$ door de regering voorgestelde afwijkingen verhouden zich namelijk slecht tot de doelstelling van codificatie van het nadeelcompensatierecht en het uitgangspunt van aansluiting bij het BW. Bovendien heeft de regering geen overtuigende argumenten aangedragen ter rechtvaardiging van deze afwijkingen.

In paragraaf 8.3.3 is aanbevolen dat (c) rechters in hun uitspraken vermijden dat overwegingen inzake (passieve) risicoaanvaarding kunnen worden gelezen als een tegenwerping van het niet voldoen aan de schadebeperkingsplicht. Deze aanbeveling beoogt de doelstelling van vergroting van de rechtszekerheid te behartigen. In deze paragraaf zal ik niet nader op deze aanbeveling ingaan aangezien zij voor zich spreekt. Gelet op de doelstellingen van vergroting van de rechtszekerheid en codificatie van het nadeelcompensatierecht is verder aanbevolen dat (a) titel 4.5 Awb op zodanige wijze wordt aangepast dat daaruit duidelijker blijkt dat (1) het niet voldoen aan de schadebeperkingsplicht een vorm van eigen schuld betreft; en (2) dat aan de causale verdeling van de derde stap van art. 6:101 BW in principe geen belang toekomt, omdat het uitgangspunt is dat de 'extra schade" 242 in zijn geheel voor rekening van de aanvrager blijft. Ook zou de formulering van de Awb-bepaling meer op die van art. 6:101 BW moeten aansluiten om meer gehoor te geven aan het uitgangspunt van aansluiting bij het BW.

Ten slotte is in paragraaf 8.3 .4 betoogd dat het uitgangspunt van aansluiting bij het BW en de doelstellingen van vergroting van de rechtszekerheid en codificatie van het nadeelcompensatierecht vereisen dat (a) titel 4.5 Awb wordt aangepast. De Awb-bepaling zou (1) de mogelijkheid tot een billijkheidscorrectie moeten bevatten; en (2) duidelijk moeten maken dat aan de causale verdeling van de derde stap van art. 6:101 BW in principe geen belang toekomt, omdat het uitgangspunt is dat de schade in zijn geheel voor rekening van de aanvrager blijft. In een toelichting op deze wijziging zou de wetgever mijns inziens bovendien duidelijker moeten aangeven hoe de resterende vormen van eigen schuld zich verhouden tot het criterium van de abnormale last (en de overige criteria voor toekenning van nadeelcompensatie). Daarmee wordt namelijk voorkomen dat afbreuk wordt gedaan aan 
de doelstellingen van uniformering en harmonisering van het nadeelcompensatierecht, en vergroting van de rechtszekerheid en rechtsgelijkheid. Met betrekking tot dit onderwerp geven de doelstellingen en uitgangspunten die aan de Wns ten grondslag liggen mijns inziens geen aanleiding om (b) afd. $15.1 \mathrm{Ow}$ aan te passen, of (c) anderszins in een bijzondere invulling, aanvulling of afwijking van titel 4.5 Awb te voorzien.

\section{Aanpassing van titel $4.5 \mathrm{Awb}$}

De hiervoor besproken aanbevelingen tot (a) aanpassing van titel 4.5 Awb kunnen worden geïmplementeerd door het huidige art. 4:126 lid 2 onder a t/m c Awb te laten vervallen, onder invoering van een nieuw wetsartikel:

\section{Artikel 4:12x}

1. In zoverre de schade mede een gevolg is van een omstandigheid die aan de aanvrager kan worden toegerekend als de aanvaarding van een risico, het niet voldoen aan zijn schadebeperkingsplicht of een andere vorm van eigen schuld, komt de vergoedingsplicht van het bestuursorgaan te vervallen, tenzij de billijkheid een andere verdeling van de schadelast vereist.

2. Schade kan de aanvrager wegens actieve risicoaanvaarding worden toegerekend als hij aan het intreden daarvan heeft bijgedragen door in het geschade belang te investeren, terwijl redelijkerwijs voorzienbaar was dat zich schade zou kunnen voordoen ten gevolge van een gebeurtenis als bedoeld in artikel 4:126, eerste lid.

3. Schade kan de aanvrager wegens passieve risicoaanvaarding worden toegerekend als hij aan het intreden daarvan heeft bijgedragen doordat hij heeft nagelaten zijn belang te verwezenlijken, of een concrete poging hiertoe te ondernemen, toen hij daartoe redelijkerwijs in de gelegenheid was, terwijl hij redelijkerwijs kon voorzien dat zich een gebeurtenis als bedoeld in artikel 4:126, eerste lid zou kunnen voordoen die daaraan in de weg zou komen te staan.

4. Voorzienbaarheid als bedoeld in het tweede en derde lid kan blijken uit een uitdrukkelijke verklaring van de aanvrager. Tevens wordt zij verondersteld aanwezig te zijn indien:

a. een concreet beleidsvoornemen van overheidswege ter openbare kennis is gebracht op grond waarvan voor een redelijk denkend en handelend persoon aanleiding zou hebben bestaan om rekening te houden met de kans dat zich schade ten gevolge van een gebeurtenis als bedoeld in artikel 4:126, eerste lid zou voordoen; of

b. de aanvrager anderszins beschikte of had moeten beschikken over informatie op grond waarvan voor een redelijk denkend en handelend persoon aanleiding zou hebben bestaan om rekening te houden met de kans dat zich schade ten gevolge van een gebeurtenis als bedoeld in artikel 4:126, eerste lid zou voordoen.

5. Een beleidsvoornemen als bedoeld in het vierde lid, onderdeel a is voldoende concreet als een redelijk denkend en handelend persoon uit de kenbaarmaking daarvan voldoende kan begrijpen waarop het beleidsvoornemen betrekking heeft, wat de za- 
kelijke inhoud ervan is, en van de inhoud ervan kan kennisnemen om zijn handelen hierop af te stemmen.

6. Schade kan de aanvrager wegens het schenden van zijn schadebeperkingsplicht worden toegerekend indien hij heeft nagelaten maatregelen te treffen die zijn schade zouden beperken, terwijl dat wel in redelijkheid van hem kon worden verlangd.

\section{Aanpassing van art. $15.5 \mathrm{Ow}$}

In paragraaf 3.4.2.4 $4^{243}$ heb ik aanbevolen om de tegenwerping van actieve risicoaanvaarding te beperken onder afd. $15.1 \mathrm{Ow}$ teneinde een oplossing te bieden voor schaduwschade in de vorm van een tijdelijke waardevermindering van onroerende zaken. Conform de randvoorwaarden die daarbij zijn geformuleerd, stel ik voor art. 15.5 Ow te vervangen door de onderstaande bepaling:

In afwijking van artikel 4:12 $\mathrm{x}^{244}$ van de Algemene wet bestuursrecht komt de vergoedingsplicht van het bestuursorgaan niet te vervallen wegens actieve risicoaanvaarding als de aanvraag om schadevergoeding betrekking heeft op de waardedaling van een tot woning bestemde onroerende zaak die de aanvrager volgens de gemeentelijke basisadministratie als hoofdverblijf in gebruik heeft op zowel het peilmoment voor het ontstaan van de schade als op het moment van beslissen op de aanvraag.

Wanneer de wetgever het bereik van deze bepaling te ruim zou vinden, zou hij als aanvullende voorwaarde kunnen opnemen dat de aanvrager de schade, bezien vanuit het perspectief van de overheid, niet heeft doen toenemen ten opzichte van de situatie waarin degene van wie hij de woning heeft gekocht ervoor had gekozen de woning niet te vervreemden.

Aanpassing van art. $15.6 \mathrm{Ow}$

De aanbevolen toespitsing van de basisvoorwaarden uit art. 4:12 $\mathrm{x}^{245}$ op het omgevingsrecht, zou kunnen worden gerealiseerd met behulp van de volgende redactie van art. $15.6 \mathrm{Ow}$ :

243 Zie het kopje 'Tijdelijke waardedaling van onroerende zaken'.

244 Hiermee verwijs ik naar de bepaling die ik eerder deze paragraaf voorstelde onder het kopje 'Wijziging van titel 4.5 Awb'.

245 Hiermee verwijs ik naar de bepaling die ik eerder deze paragraaf voorstelde onder het kopje 'Wijziging van titel 4.5 Awb'. 


\section{Artikel 15.6}

1. Bij directe schade door het verlies van een bouwmogelijkheid is in ieder geval sprake van een concrete poging als bedoeld in artikel 4:12x, derde lid, van de Algemene wet bestuursrecht als de aanvrager:

a. een bouwplan heeft ingediend dat de bedreigde bouwmogelijkheid benut;

b. dat zich laat beoordelen op passendheid binnen het omgevingsplan; en

c. dat in beginsel past binnen de bestaande mogelijkheden van het omgevingsplan.

2. Bij directe schade door het verlies van een gebruiksmogelijkheid is in ieder geval sprake van een concrete poging als bedoeld in artikel 4:12x, derde lid, van de Algemene wet bestuursrecht als de aanvrager daadwerkelijk is aangevangen met het desbetreffende gebruik, of serieuze pogingen heeft ondernomen om zijn onroerende zaak voor dat doel aan derden te verkopen of verhuren. 



\section{Hoofdstuk 9}

\section{Overige materiële criteria voor toekenning van nadeelcompensatie}

In dit hoofdstuk zal worden ingegaan op twee nog resterende, materiële criteria die relevant zijn voor de beslissing op een aanvraag om nadeelcompensatie. Het betreft de verrekening van het door het overheidshandelen veroorzaakte nadeel met het door dit handelen veroorzaakte voordeel (paragraaf 9.1) en het reeds voldoende anderszins verzekerd zijn van vergoeding van de geleden schade (paragraaf 9.2). Eveneens zal aandacht worden geschonken aan de bevoegdheid om schade niet in geld maar in natura te compenseren (paragraaf 9.3). Het in natura compenseren van schade kan namelijk tot de conclusie leiden dat de vergoeding van schade voldoende anderszins is verzekerd.

\subsection{VOORDEELVERREKENING ${ }^{1}$}

9.1.1 Deelvraag 2: verschillen tussen de geselecteerde, thans geldende regelingen en verklaringen daarvoor

\section{Een afzonderlijke bepaling inzake voordeelverrekening}

Wanneer de geselecteerde, thans geldende regelingen worden vergeleken, valt op dat slechts de BnIW 2019 (art. 9), AVN (art. 2 lid 8) en VNNZ (art. 2 lid 2) een afzonderlijke bepaling inzake voordeelverrekening bevatten. Ook is er art 6.1.3.4 Bro, een bepaling die minimumeisen stelt aan het verplicht door het bestuur in te winnen deskundigenadvies. ${ }^{2}$ Blijkens het tweede lid van deze bepaling is een van die eisen dat voordeel dat de benadeelde ondervindt van de schadeoorzaak in aanmerking wordt genomen in het advies over de te vergoeden schade. De Afdeling heeft meermaals overwogen dat uit deze bepaling "volgt" dat voordeelverrekening tot de mogelijkheden behoort. ${ }^{3}$ Deze bepaling lijkt, mede gelet op het legaliteitsbeginsel, echter niet als materieelrechtelijke grondslag voor voordeelverrekening te

1 Soms wordt ook van 'voordeelstoerekening' gesproken. Zie bijvoorbeeld Tjepkema 2010, p. 339-343; en Dijkshoorn 2011a, p. 78. Ik kies ervoor te spreken van verrekening van voordeel, aangezien dit de terminologie is die de Afdeling bezigt. Zie bijvoorbeeld ABRvS 28 september 2016, ECLI:NL:RVS:2016:2582, r.o. 4.9 en het daarbij behorende kopje (Overzichtsuitspraak).

$2 \quad$ Zie hierover meer uitgebreid paragraaf 10.8.1.

3 Zie bijvoorbeeld ABRvS 23 april 2014, ECLI:NL:RVS:2014:1433, r.o. 6.3; en ABRvS 13 augustus 2014, ECLI:NL:RVS:2014:3022, r.o. 6.1. 
kunnen dienen. Waar die grondslag wel in is gelegen zal hierna nog blijken. Eerst zal worden ingegaan op de vraag of voordeelverrekening ook onder de GrS tot de mogelijkheden behoort.

Voor wat betreft de nadeelcompensatiecomponent van de GrS kan deze vraag met 'ja' worden beantwoord als de BnIW 2019 of het ongeschreven égalitébeginsel ${ }^{4}$ de achterliggende grondslag voor toekenning van nadeelcompensatie vormt. Aangezien de in art. 21 Aanwijzingsbesluit 1996 en art. 8.31 Wlv vervatte redelijkerwijsformules worden gezien als codificaties van het ongeschreven égalitébeginsel ${ }^{5}$ zal het ook onder deze achterliggende grondslagen mogelijk zijn om voordeel te verrekenen. ${ }^{6}$ Dat onder de GrS geen jurisprudentie is gewezen die dit bevestigt, lijkt te kunnen worden verklaard doordat de ingrijpende wijzigingen die nodig zijn om de uitbreiding van een vliegveld te realiseren doorgaans niet (snel) tot voordeel zullen leiden.

Voor wat betreft de planschadecomponent van de GrS kan worden verwezen naar een onder art. 49 WRO gewezen Afdelingsuitspraak van 14 maart 2012. De Afdeling kwam daarin tot het oordeel dat het plaatselijke college van B\&W bij het maken van de planvergelijking op goede gronden tot de conclusie was gekomen dat er "per saldo" geen sprake was van een planologische verslechtering, waardoor ook niet tot schade kon worden geconcludeerd. Daarbij was bepalend dat op grond van het nieuwe bestemmingsplan weliswaar op kortere afstand van het appartement van de aanvrager mocht worden gebouwd (nadeel), maar dat het plan eveneens de bouwhoogte maximeerde en ervoor zorgde dat een nabij gelegen garage en tankstation verdwenen (voordeel). ${ }^{7}$ In het kader van voordeelverrekening heeft de Afdeling onder afd. 6.1 Wro meermaals in algemene zin terugverwezen naar deze onder de WRO gewezen uitspraak. ${ }^{8}$ Ook uit andere onder de Wro gewezen Afdelingsuitspraken kan worden afgeleid dat de verrekening van voordeel onderdeel kan uitmaken van de planvergelijking. ${ }^{9}$ Soms overweegt de Afdeling in meer algemene zin dat de "voor- en nadelen die een planologische wijziging met

4 Zie Tjepkema 2010, p. 339-343 omtrent voordeelverrekening bij toepassing van het ongeschreven égalitébeginsel.

$5 \quad$ Zie ABRvS 9 april 2008, ECLI:NL:RVS:2008:BC9040, r.o. 2.6 respectievelijk ABRvS 19 februari 2014, ECLI:NL:RVS:2014:572, r.o. 10.2 (Risicolocatie Schiphol).

6 Ook het door de besliscommissie van het Schadeschap opgestelde Basisdocument gaat uit van de mogelijkheid van voordeelverrekening, zie Basisdocument, p. 4041.

$7 \quad$ ABRvS 14 maart 2012, ECLI:NL:RVS:2012:BV8765 en BV8766, r.o. 2.4. Zie voor een vergelijkbare onder art. 49 WRO gewezen uitspraak: ABRvS 10 december 2014, ECLI:NL:RVS:2014:4489, r.o. 9.1.

8 Zie ABRvS 23 april 2014, ECLI:NL:RVS:2014:1433, r.o. 6.3; en ABRvS 13 augustus 2014, ECLI:NL:RVS:2014:3022, r.o. 6.1.

9 Zie bijvoorbeeld ABRvS 19 juli 2017, ECLI:NL:RVS:2017:1968, r.o. 6; en ABRvS 31 januari 2018, ECLI:NL:RVS:2018:294, r.o. 5.5. 
zich brengt voor het vaststellen van de te vergoeden planschade met elkaar mogen worden verrekend." ${ }^{\prime 10}$

Deze jurisprudentie biedt mijns inziens de belangrijkste verklaring voor het ontbreken van bepalingen omtrent voordeelverrekening in art. 21 Aanwijzingsbesluit 1996, art. 8.31 Wlv en art. 49 WRO. Om nadeelcompensatie of tegemoetkoming in planschade toe te kennen, zal altijd moeten worden vastgesteld dat de aanvrager schade heeft geleden door het als schadeoorzaak aangewezen overheidshandelen. Daarvan kan slechts sprake zijn als het desbetreffende overheidshandelen meer nadeel dan voordeel voor de aanvrager heeft meegebracht. De bevoegdheid om voordeel te verrekenen met nadeel bestaat dus ook als daaraan geen afzonderlijke bepaling is gewijd. ${ }^{11} \mathrm{Zij}$ is namelijk inherent aan de beantwoording van de fundamentele vraag of de beweerde schadeoorzaak tot schade heeft geleden (hierna: 'de schadevraag'). Ik laat daarbij in het midden of de verrekening onderdeel moet uitmaken van de vaststelling van een verslechtering, ${ }^{12}$ of dat het voordeel afzonderlijk dient te worden begroot om vervolgens in mindering op het schadebedrag te worden gebracht. Gelet op de aangehaalde jurisprudentie, lijken beide routes mogelijk te zijn. ${ }^{13}$ Als aanvullende verklaring kan worden aangevoerd dat het ten tijde van de totstandkoming van deze regelingen nog niet gebruikelijk was om in nadeelcompensatieregelingen uit te werken wanneer aan de daarin vervatte redelijkerwijsformule werd voldaan. Bovendien is voor de formulering van zowel art. 21 Aanwijzingsbesluit 1996 als art. 8.31 Wlv aansluiting gezocht bij art. 49 WRO, en in geval van art. 8.31 Wlv ook bij art. 15.20 Wet milieubeheer. ${ }^{14}$ Dat in de GrS geen bepaling is opgenomen omtrent voordeelverrekening kan voorts worden verklaard door de in paragraaf 3.2.1 beschreven, bijzondere aard van deze regeling: zij dient ertoe de reeds op grond van verschillende grondslagen bestaande - en aan verschillende bestuursorganen toekomende - bevoegdheden om nadeelcompensatie toe te kennen, binnen een specifieke context over te dragen aan het algemeen bestuur van het Schadeschap.

Dat voordeelverrekening inherent is aan de beantwoording van de schadevraag lijkt ook de belangrijkste verklaring waarom in afd. 6.1 Wro geen afzonderlijke bepaling aan voordeelverrekening is gewijd. Het ontbreken van een dergelijke bepaling leverde bovendien geen problemen op onder art. 49 WRO. Kennelijk zag de wetgever dus geen aanleiding om zo een bepaling wel in de Wro op te nemen. Teneinde de tweede deelvraag op dit punt volledig te beantwoorden, merk ik nog op

10 Zie bijvoorbeeld ABRvS 13 augustus 2014, ECLI:NL:RVS:2014:3022, r.o. 6.1; en ABRvS 19 juli 2017, ECLI:NL:RVS:2017:1968, r.o. 4.2.

11 Evenmin zal ik ingaan op de discussie in de civielrechtelijke doctrine omtrent de vraag langs welke juridische route voordeel dient te worden verrekend. Zie daaromtrent bijvoorbeeld Lindenbergh, in: GS Schadevergoeding, art. 6:100 BW, aant. 1.3. Vergelijk paragraaf 4.2.3.

13 Een vergelijking met art. 6:100 BW volgt nog in paragraaf 9.1.3.

14 Zie Stcrt. 1998, nr. 223, p. 11 (digitaal) respectievelijk Kamerstukken II 00/01, 27 603, nr. 3, p. 69 en 15. 
dat in de literatuur ook een andere verklaring is te vinden. Dijkshoorn lijkt de bevoegdheid tot voordeelverrekening namelijk te lezen in art. 6.3 Wro. Uit paragrafen 8.2.1.2 en 8.3.1 bleek dat art. 6.3 Wro bepaalt dat het bestuur 'in ieder geval' de voorzienbaarheid van de schadeoorzaak en mogelijkheden van de aanvrager om schade te voorkomen of beperken in zijn beslissing op de aanvraag om planschadetegemoetkoming moet betrekken. Volgens Dijkshoorn zou de formulering 'in ieder geval' voldoende ruimte laten om de verrekening van voordeel mogelijk te maken. Deze verklaring verdient mijns inziens niet de schoonheidsprijs, mede gelet op het legaliteits- en rechtszekerheidsbeginsel. Dijkshoorn laat zich daarover iets voorzichtiger uit, maar lijkt dezelfde mening toegedaan. ${ }^{15}$ Voorts vindt deze verklaring geen steun in de bij de Wro behorende Kamerstukken en jurisprudentie. Mede hierdoor is het ook taalkundig gezien onwaarschijnlijk dat de wetgever 'in ieder geval' niet zou hebben bedoeld als 'houdt bij elke aanvraag om tegemoetkoming rekening met', maar als 'houdt bij elke aanvraag om tegemoetkoming ten minste rekening met'. Ik acht de verklaring van Dijkshoorn dan ook weinig plausibel.

In theorie zou ook nog de verklaring kunnen worden geopperd dat het voordeel dat een planologische maatregel met zich brengt ervoor zorgt dat (een deel van) de tegemoetkoming in de geleden planschade voldoende anderszins verzekerd als bedoeld in art. 6.1 lid 1 Wro moet worden geacht. Ook die verklaring acht ik niet plausibel, omdat het voordeel - behoudens gevallen waarin het bestuur in het schadeveroorzakende planologische besluit een of meerdere maatregelen heeft opgenomen om nadeel in natura te compenseren - niet voortkomt uit een tegemoetkoming in schade, maar een bijproduct is van het schadeveroorzakende overheidsoptreden. Deze verklaring lijkt daardoor bovendien niet goed te verenigen met de in paragraaf 9.2 nog te bespreken eis van 'duidelijkheid', die wordt gesteld ten aanzien van het voldoende anderszins verzekerd achten van schadevergoeding.

\section{Plicht tot voordeelverrekening voor het bestuur?}

De bepalingen uit de BnIW 2019, AVN en VNNZ zijn allemaal dwingend geformuleerd. Als het schadeveroorzakende overheidshandelen ook voordeel voor de benadeelde heeft opgeleverd, moet dit in mindering worden gebracht op het schadebedrag. Mede gelet op de verklaring dat voordeelverrekening een onderdeel vormt van de beantwoording van de schadevraag, zie ik geen reden waarom dat anders zou zijn onder de GrS of afd. 6.1 Wro. Anders dan de overige bepalingen blijkt art. 2 lid 8 AVN wel een kleine slag om de arm te houden. Volgens deze bepaling hoeft het voordeel namelijk slechts op het nadeel in mindering te worden gebracht "voor zover dit redelijk" is. Wat precies onder deze redelijkheidsclausule valt, blijkt niet uit de toelichting op de AVN. Uit de op deze bepaling gegeven toelichting kan wel worden afgeleid dat de Amsterdamse gemeenteraad met deze clausule heeft willen aansluiten op art. 6:100 BW. Ook die bepaling wordt geken- 
merkt door een plicht tot voordeelrekening die wordt beperkt door de redelijkheid. Dat de Amsterdamse gemeenteraad geen vergelijkbare redelijkheidsclausule in de VNNZ heeft opgenomen, kan wellicht worden verklaard doordat de AVN - anders dan de VNNZ - niet voortbouwde op een voorganger. Het betreft een geheel nieuwe regeling die deels is geïnspireerd op titel $4.5 \mathrm{Awb} .{ }^{16}$ Uit paragraaf 9.1.2 zal blijken dat ook onder die titel aansluiting is gezocht bij art. 6:100 BW.

Ik heb geen expliciete verklaring kunnen vinden voor het niet opnemen van een redelijkheidsclausule in art. 9 BnIW 2019. Het ontbreken van een dergelijke clausule is in zoverre opmerkelijk dat uit de toelichting op deze bepaling kan worden opgemaakt dat de regels uit art. $5 \mathrm{t} / \mathrm{m} 11$ deels zijn geïnspireerd op de in afd. 6.1.10 BW en afd. 6.1.11 BW neergelegde maatstaven, "die ook blijkens externe en interne rechtsvergelijking, hun waarde hebben bewezen." ${ }^{17}$ De meest aannemelijke verklaring lijkt mij dat de minister het niet nodig achtte om een afzonderlijke redelijkheidsclausule in art. 9 BnIW 2019 op te nemen, omdat deze bepaling invulling geeft aan de redelijkerwijsformule uit art. 2 lid 1 BnIW 2019. ${ }^{18}$

\section{Verrekening met voordeel uit nauw verweven overheidshandelingen}

In gevallen waarin het te verrekenen voordeel en nadeel uit hetzelfde overheidshandelen voortvloeit, lijkt de Afdeling vooral te vereisen dat met voldoende mate van zekerheid kan worden vastgesteld dat dit handelen ook daadwerkelijk een voordelige invloed op het vermogen ${ }^{19}$ van de benadeelde heeft, of zal hebben. Uit de onder de BnIW 2019 gewezen Hollandse Brug-uitspraak volgt bijvoorbeeld dat in geval van een toekomstig op geld waardeerbaar voordeel wordt vereist dat "in voldoende mate vaststaat" dat de vermogenspositie van de benadeelde ook daadwerkelijk in positieve zin zal worden beïnvloed door het overheidshandelen dat het nadeel veroorzaakte. Het "alleen in algemene zin veronderstellen" van de mogelijkheid dat dit overheidshandelen ook voordeel zal meebrengen, kan dus niet leiden tot voordeelverrekening. ${ }^{20} \mathrm{Ik}$ heb geen reden om aan te nemen dat op dit punt verschillen tussen de geselecteerde, thans geldende regelingen zouden bestaan. De meeste toelichtingen besteden geen aandacht aan de vereiste mate

$16 \quad$ Zie paragraaf 2.3.3.

17 Stcrt. 1999, nr. 172, p. 9 (digitaal, p. 5).

18 Stcrt. 1999, nr. 172, p. 10 (digitaal, p. 7).

19 Zie ABRvS 28 december 1995, ECLI:NL:RVS:1995:AN5020; ABRvS 12 augustus 1999, ECLI:NL:RVS:1999:AN6216, r.o. 2.6; en ABRvS 10 december 2014, ECLI:NL:RVS:2014:4489, r.o. 8.1. Zie eveneens Kamerstukken II 2002/03, 28 916, nr. 3, p. 63-64 (MvT, Wro); en Kamerstukken II 2010/11, 32 621, nr. 3, p. 26 (MvT, Wns).

20 ABRvS 11 december 2013, ECLI:NL:RVS:2013:2317, r.o. 6.2 (Hollandse Brug, einduitspraak). Dit oordeel vertoont enige gelijkenis met de in paragraaf 9.2 en 9.3 nog te bespreken jurisprudentiële eis van 'zekerheid'. Deze eis komt erop neer dat schadevergoeding slechts voldoende anderszins verzekerd kan worden geacht als zij niet afhankelijk is van een 'toekomstige, onzekere gebeurtenis'. 
van zekerheid en in de toelichting op art. 2 lid 2 VNNZ wordt opgemerkt dat toekomstig voordeel door de aanleg van de Noord/Zuidlijn niet zal worden verrekend "zolang het moment van aanvang van de exploitatie van de Noord/Zuidlijn (...) nog in een relatief ver verwijderde toekomst ligt."

Uit onder de WRO en Wro gewezen jurisprudentie volgt dat het niet slechts mogelijk is voor- en nadeel veroorzaakt door dezelfde schadeoorzaak te verrekenen, maar ook voor- en nadeel veroorzaakt door "nauw verweven" overheidshandelingen. De Afdeling is dan aanmerkelijk strenger en stelt drie aanvullende eisen aan de voordeelverrekening. Allereerst dienen de planologische maatregelen dermate nauw te zijn verweven dat de voor- en nadelen daarvan moeten worden geacht uit hetzelfde planologische regime voort te vloeien. Ten tweede dienen de besluiten in rechte onaantastbaar te zijn ${ }^{21}$ ten tijde van de indiening van de aanvraag om planschadetegemoetkoming. De vraag of ook kan worden verrekend als de nauw verweven besluiten nog niet op het moment van indiening van de aanvraag, maar wel op het moment van het besluit op de aanvraag onherroepelijk zijn, is nog niet aan de Afdeling voorgelegd. Een bevestigende beantwoording daarvan lijkt mij echter niet onwaarschijnlijk, omdat zij goed zou aansluiten op de vaste jurisprudentielijn dat "op een verzoek om tegemoetkoming in planschade (...) eerst inhoudelijk [kan] worden beslist na de datum van onherroepelijk worden van het schadeveroorzakende besluit." ${ }^{22}$ Ten derde lijkt de intentie waarmee het aanverwante besluit is genomen een rol te spelen. ${ }^{23}$ Zo kan een rol spelen dat het aanverwante besluit wordt genomen om ervoor te zorgen dat de inwerkingtreding of onherroepelijkheid van het hoofdbesluit niet hoeft te worden afgewacht. Daarvan is in het planschaderecht bijvoorbeeld sprake als door middel van een vrijstellingsbesluit ontheffing wordt verleend van het geldende planologische regime om te voorkomen dat de inwerkingtreding of onherroepelijkheid van een nieuw bestemmingsplan moet worden afgewacht. ${ }^{24}$

Het is lastig te zeggen of het onder de overige geselecteerde, thans geldende regelingen ook mogelijk is om voor- en nadeel uit nauw verweven overheidshandelingen te verrekenen. Er zijn mij hiervan geen voorbeelden bekend uit de onder deze regelingen gewezen jurisprudentie. Ik zie echter geen reden waarom de Afdeling anders zou oordelen als art. 21 Aanwijzingsbesluit 1996, art. 8.31 Wlv of het

21 Deze eis sluit eveneens goed aan bij de nog nader in paragrafen 9.2 en 9.3 te bespreken eis van 'zekerheid'.

22 ABRvS 28 september 2016, ECLI:NL:RVS:2016:2582, r.o. 8 (Overzichtsuitspraak). Zie tevens paragraaf 10.5.1 over de vraag vanaf wanneer en tot wanneer de aanvraag kan worden ingediend.

23 Zie ook Franssen, Roozendaal \& Van de Sande 2015, p. 276.

24 Zie ABRvS 28 september 2016, ECLI:NL:RVS:2016:2582, r.o. 4.10 (Overzichtsuitspraak), waarin wordt verwezen naar de onder art. 49 WRO gewezen uitspraak ABRvS 24 december 2003, ECLI:NL:RVS:2003:AO0820, r.o. 2.3. Zie voor een uitspraak onder afd. 6.1 Wro: ABRvS 18 maart 2015, ECLI:NL:RVS:2015:845, r.o. 5.1 . 
ongeschreven égalitébeginsel de achterliggende grondslag zou vormen om onder de GrS nadeelcompensatie toe te kennen. Een potentieel bezwaar zie ik wel ten aanzien van de BnIW 2019 en de Amsterdamse verordeningen. Deze regelingen spreken namelijk van 'een schadeoorzaak' (BnIW 2019 en AVN) of 'een nadeelveroorzakende omstandigheid' (VNNZ) die 'tevens' voordeel heeft opgeleverd. Grammaticaal gezien, zou verrekening tussen nauw verweven overheidshandelingen daardoor niet mogelijk moeten zijn. Het woordje 'tevens' impliceert immers dat 'een schadeoorzaak' als ‘één schadeoorzaak' moet worden gelezen. Uit de toelichting op art. 2 lid 8 AVN blijkt echter dat de Amsterdamse gemeenteraad ervan uitgaat dat verrekening met voordeel uit een nauw verweven besluit onder die regeling wel degelijk tot de mogelijkheden behoort. De toelichtingen behorende bij de overige regelingen verschaffen hierover geen informatie.

\subsubsection{Deelvraag 3: het toekomstige recht}

Het criterium van voordeelverrekening is neergelegd in art. 4:126 lid 3 Awb, dat bepaalt dat door de schadeoorzaak veroorzaakt voordeel bij de vaststelling van de te vergoeden schade in aanmerking wordt genomen. Onder afd. $15.1 \mathrm{Ow}$ zal op deze bepaling worden teruggevallen nu daarin geen afwijkende regeling omtrent voordeelverrekening is opgenomen. ${ }^{25}$ Uit de bij de Wns behorende memorie van toelichting blijkt dat aansluiting is gezocht bij art. 6:100 BW. Ook kan uit de memorie van toelichting worden afgeleid dat het bestuur geen discretie toekomt: "indien en voor zover de benadeelde (ook) gebaat is bij de overheidsmaatregel die de schade veroorzaakt, moet dit voordeel met het nadeel worden verrekend." Voorts volgt uit de memorie van toelichting dat verrekening met voordeel uit nauw verweven overheidshandelingen tot de mogelijkheden behoort - ondanks dat ook ${ }^{26}$ art. 4:126 lid 3 Awb spreekt van een schadeveroorzakende gebeurtenis die tevens voordeel oplevert. De wetgever lijkt daarbij vast te houden aan de drie in paragraaf 9.1.1 besproken, uit de planschadejurisprudentie afkomstige voorwaarden. ${ }^{27}$

9.1.3 Hoofdvraag: spiegeling aan de doelstellingen en uitgangspunten die ten grondslag liggen aan de Wns

Hoewel hiervoor bleek dat voordeelverrekening inherent is aan beantwoording van de schadevraag, past het goed bij de doelstellingen van vergroting van de rechtszekerheid en codificatie van het nadeelcompensatierecht dat de mogelijkheid van voordeelverrekening afzonderlijk in art. 4:126 lid 3 Awb wordt vermeld. Dat geldt eens te meer nu voordeelverrekening grote gevolgen kan hebben voor de aanvrager van nadeelcompensatie. Zo werd in een uitspraak van 10 december 2014 bijvoorbeeld geen tegemoetkoming in planschade toegekend in een geval

26 Zie paragraaf 9.1.1 onder het kopje 'Verrekening met voordeel uit nauw verweven overheidshandelingen'.

27 In Kamerstukken II 2010/11, 32 621, nr. 3, p. 20, 26 (MvT, Wns) wordt namelijk verwezen naar ABRvS 24 december 2003, ECLI:NL:RVS:2003:AO0820, r.o. 2.3. 
waarin een planologische maatregel vier percelen van de aanvrager met ongeveer 9 ton in waarde liet dalen, omdat vijf van zijn andere percelen door deze maatregel met ongeveer 17 ton in waarde waren gestegen. De planschade werd daardoor "per saldo nihil" geacht. ${ }^{28}$ Bezien vanuit de doelstelling van vereenvoudiging, uniformering en harmonisering van het nadeelcompensatierecht is het bovendien positief dat bepalingen uit thans bestaande nadeelcompensatieregelingen die de mogelijkheid van voordeelverrekening benoemen, kunnen komen te vervallen.

\section{Plicht tot voordeelverrekening}

Voor zover ik heb kunnen nagaan is het bestuur onder alle geselecteerde, thans geldende regelingen verplicht om tot voordeelverrekening over te gaan. De wetgever blijkt die visie ook toegedaan ten aanzien van art. 4:126 lid 3 Awb. Ik kan me echter voorstellen dat de in deze bepaling gekozen formulering niet voor iedere burger even duidelijk is. Art. 4:126 lid 3 Awb bepaalt namelijk dat het voordeel "bij de vaststelling van de te vergoeden schade in aanmerking [wordt] genomen." In het dagelijks spraakgebruik kan 'in aanmerking nemen' ook betekenen dat ergens aandacht aan moet worden besteed, zonder dat daar noodzakelijkerwijs consequenties aan moeten worden verbonden. Een formulering die dergelijke misvattingen uitsluit, zoals 'moet dit voordeel bij de vaststelling van de te vergoeden schade in rekening worden gebracht', zou daarom aanbeveling verdienen vanuit het perspectief van de doelstellingen van vergroting van de rechtszekerheid, en vergroting van de doelmatigheid van het nadeelcompensatierecht en vermindering van bestuurslasten. ${ }^{29}$ Deze formulering is geïnspireerd op art. 6:100 BW en past daarom ook goed bij het uitgangspunt van aansluiting bij het BW. Bovendien laat zij zien dat voordeelverrekening onderdeel uitmaakt van de beantwoording van de schadevraag. Dit draagt eveneens bij aan het bereiken van de doelstelling van vergroting van de rechtszekerheid. Ten slotte acht ik de voorgestelde formulering ook verenigbaar met de overige aan de Wns ten grondslag liggende doelstellingen en uitgangspunten.

\section{Redelijkheidsclausule}

Net als het geval is onder de meeste geselecteerde, thans geldende nadeelcompensatieregelingen, wordt de uit art. 4:126 lid 3 Awb voortvloeiende plicht tot voordeelverrekening niet beperkt door een redelijkheidsclausule. Gelet op het uitgangspunt van aansluiting bij het BW bestaat daartoe echter wel reden (vergelijk art. 6:100 BW). Vanwege de brede reikwijdte ${ }^{30}$ en het open schadebegrip ${ }^{31}$ van titel 4.5 Awb kan bovendien niet op voorhand worden uitgesloten dat een dergelijke

29 Eventuele misvattingen kunnen immers leiden tot het onnodig instellen van rechtsmiddelen tegen het zuiver schadebesluit.

$30 \quad$ Zie paragraaf 3.3.1.

31 Zie paragraaf 5.2.2. 
redelijkheidsclausule van toegevoegde waarde zou kunnen zijn. Ik acht een dergelijke clausule ook verenigbaar met de overige aan de Wns ten grondslag liggende doelstellingen en uitgangspunten. Bezien vanuit de doelstelling van vergroting van de rechtszekerheid lijkt het wel aanbeveling te verdienen dat de wetgever bij invoering van een redelijkheidsclausule aangeeft hoe toepassing aan deze formule dient te worden gegeven. Net als in het civiele recht, zou aansluiting bij de leer van de toerekening naar redelijkheid van art. 6:98 BW kunnen worden gezocht. Daarbij zou de omstandigheid dat het bij nadeelcompensatie gaat om schade door rechtmatig overheidshandelen dat het publieke belang behartigt ertoe kunnen leiden dat het in verhouding tot het civielrechtelijke onrechtmatigedaadsrecht eerder redelijk zal zijn om voordeel te verrekenen. Ook is denkbaar dat het niet altijd redelijk is immateriële voor- en nadelen met materiële voor- en nadelen te verrekenen. ${ }^{32}$ Die gedachte zal overigens alleen een rol spelen bij schadeveroorzakend handelen dat niet onder de reikwijdte van afd. 15.1 Ow valt. Onder die afdeling komt immateriële schade immers niet voor vergoeding in aanmerking. ${ }^{33}$

\section{Verrekening bij nauw verweven overheidshandelingen}

Onder titel 4.5 Awb dient ook voordeel uit nauw met de schadeoorzaak verweven overheidshandelen te worden verrekend. Een punt van aandacht daarbij is dat art. 4:126 lid 3 Awb spreekt van een schadeveroorzakende gebeurtenis die tevens voordeel oplevert. Ten aanzien van vergelijkbare formuleringen uit de BnIW 2019, AVN en VNNZ merkte ik op dat zij grammaticaal gezien geen ruimte tot dergelijke verrekening laten. Bezien vanuit de doelstelling van vergroting van de rechtszekerheid en vanuit een algemeen legaliteitsperspectief verdient het daarom aanbeveling om de formulering van art. 4:126 lid 3 Awb ook op dit punt aan te passen. Dat zou bijvoorbeeld kunnen worden gerealiseerd door te spreken van "een gebeurtenis als bedoeld in het eerste lid of meerdere gebeurtenissen als bedoeld in het eerste lid die nauw met elkaar zijn verweven." Een dergelijke formulering acht ik ook verenigbaar met de overige aan de Wns ten grondslag liggende doelstellingen en uitgangspunten.

\section{Codificeren van jurisprudentiële eisen}

Ten slotte lijkt de wetgever onder art. 4:126 lid 3 Awb te willen vasthouden aan de eisen die thans in de jurisprudentie aan voordeelverrekening worden gesteld. Bezien vanuit de doelstellingen van vergroting van de rechtszekerheid en codificatie van het nadeelcompensatierecht, is het aan te bevelen in de Awb te verankeren dat in voldoende mate moet vaststaan dat het overheidshandelen de vermogenspositie van de benadeelde ook in positieve zin heeft beïnvloed of zal beïnvloeden. Bezien vanuit de hiervoor genoemde doelstellingen, is codificatie van de drie voor- 
waarden voor verrekening van voordeel uit nauw met de schadeoorzaak verweven overheidshandelen eveneens wenselijk. Deze in paragraaf 9.1.1 besproken voorwaarden zijn echter tot stand gekomen in, en daardoor ook toegespitst op, het planschaderecht. Codificatie in afd. $15.1 \mathrm{Ow}$ zou mijns inziens daarom meer voor de hand liggen. Ook dit acht ik verenigbaar met de overige aan de Wns ten grondslag liggende doelstellingen en uitgangspunten.

\section{Conclusie en concrete voorstellen}

Op basis van de voorafgaande aanbevelingen zie ik (a) reden tot aanpassing van titel 4.5 Awb en (b) reden tot aanpassing van afd. 15.1 Ow. Opvolging van de aanbevelingen die daartoe zijn gedaan, zou kunnen leiden tot de volgende redactie van art. 4:126 lid 3 Awb:

Indien in voldoende mate vaststaat dat een gebeurtenis als bedoeld in het eerste lid of meerdere gebeurtenissen als bedoeld in het eerste lid die nauw met elkaar zijn verweven, naast een nadelige invloed ook een positieve invloed op de vermogenspositie van de aanvrager hebben gehad of zullen hebben, dan moet, voor zover dit redelijk is, deze positieve invloed bij de vaststelling van de te vergoeden schade in rekening worden gebracht.

In aanvulling hierop zou de volgende bepaling in afd. 15.1 Ow kunnen worden opgenomen:

Van nauw met elkaar verweven gebeurtenissen als bedoeld in artikel 4:126, derde lid, van de Algemene wet bestuursrecht is sprake als:

a. de voor- en nadelen van twee of meer in artikel 15.1 lid 1 genoemde besluiten moeten worden geacht uit hetzelfde planologische regime voort te vloeien;

b. de onder a genoemde besluiten onherroepelijk zijn op het moment van het besluit op de aanvraag ${ }^{34}$ als bedoeld in artikel 4:126, eerste lid, van de Algemene wet bestuursrecht; en

c. de intentie waarmee de onder a genoemde besluiten zijn genomen, duidt op een nauwe, onderlinge verwevenheid.

Ten slotte zie ik ook reden om (c) anderszins een bijzondere invulling aan titel 4.5 Awb te geven. Mocht de wetgever mijn voorstel voor de alternatieve redactie van art. 4:126 lid 3 Awb overnemen, dan zou hij mijns inziens op voorhand duidelijkheid moeten verschaffen over de invulling van de daarin vervatte redelijkheidsclausule.

34 Door dit moment te kiezen zou de wetgever anticiperen op een door mij in paragraaf 9.1.1 voorspelde ontwikkeling in de rechtspraak. Zou de wetgever slechts de huidige jurisprudentie willen codificeren, dan zou in deze bepaling moeten worden uitgegaan van het moment van indiening van de aanvraag. 
9.2.1 Deelvraag 2: verschillen tussen de geselecteerde, thans geldende regelingen en verklaringen daarvoor

Alle geselecteerde, thans geldende regelingen bevatten een bepaling op grond waarvan het bestuur kan besluiten geen nadeelcompensatie te verstrekken voor zover de vergoeding van de door de aanvrager geleden schade reeds voldoende anderszins is verzekerd. ${ }^{35}$ Hiervan kan bijvoorbeeld sprake zijn als de schade reeds is vergoed door aankoop, onteigening, vergoeding in natura, een vergoeding krachtens een specifieke wettelijke regeling, een vergoeding uitgekeerd door derden, of het meenemen van compensatie bij minnelijke verwerving van anders te onteigenen gronden. ${ }^{36}$ Hoewel voorbeelden daarvan uit de jurisprudentie schaars zijn, bestaat de mogelijkheid om schade waarvan de vergoeding reeds voldoende anderszins is verzekerd voor rekening van de aanvrager te laten ook bij toepassing van het ongeschreven égalitébeginsel - dat onder de GrS als achterliggende grondslag voor de toekenning van nadeelcompensatie kan dienen. ${ }^{37}$ De bepalingen inzake het niet vergoeden van schade waarvan de vergoeding reeds voldoende anderszins is verzekerd kennen een subsidiariteitsgedachte: het moet worden voorkomen dat schade meer dan eens wordt vergoed. ${ }^{38}$ Tevens wordt deze bepalingen soms een "vangnetfunctie" toegedicht: het bestuur mag de geleden schade best anders dan in geld compenseren, maar in zoverre dit niet is gebeurd - en de vergoeding van schade dus niet voldoende anderszins verzekerd kan worden geacht - dient het alsnog de aanvraag om compensatie in behandeling te nemen en een gepaste hoeveelheid geldelijke nadeelcompensatie toe te kennen. ${ }^{39}$

\section{Algemene verschillen in formulering}

Ondanks hun gemeenschappelijke doel, verschillen de onderzochte bepalingen in formulering:

35 Een dergelijke bepaling is uiteraard niet opgenomen in de GrS zelf, maar wel in de achterliggende grondslagen om onder die regeling compensatie toe te kennen. Dit wordt verklaard door de in paragraaf 3.2.1 beschreven, bijzondere aard van deze regeling.

36 Zie in algemene zin Kortmann \& Boersen 2013 voor een bespreking van voorbeelden uit de jurisprudentie. Zie voor een voorbeeld van het laatstgenoemde de bespreking van de 'Modelovereenkomst vergoeding inundatieschade landbouw' in Kamerstukken II 2010/11, 32 621, nr. 3, p. 25 (MvT, Wns).

37 Zie bijvoorbeeld HR 19 november 1999, ECLI:NL:HR:1999:AA1058, r.o. 3.5.2 (De Dommel), waarin de vergoeding voldoende anderszins verzekerd werd geacht door de aanwezigheid van een uitkoopregeling. Zie daaromtrent ook Kamerstukken II 2010/11, 32 621, nr. 3, p. 25 (MvT, Wns). Zie eveneens Tjepkema 2010, p. 509513.

38 Zie bijvoorbeeld Stcrt. 1999, nr. 172, p. 10 (digitaal, p. 7); de toelichting op art. 3 lid 1 onder e AVN; en Kamerstukken II 2010/11, 32 621, nr. 3, p. 25 (MvT, Wns). Van den Broek 2002, 65-66. 


\title{
Art. 6.1 lid 1 Wro
}

“(..$)$ kennen degene die (...) schade lijdt (...) een tegemoetkoming toe (...) voor zover de tegemoetkoming niet voldoende anderszins is verzekerd."

\author{
Art. 2 lid 1 BnIW 2019 \\ “(...) kent degene die (...) schade lijdt (...) een vergoeding toe (...) voor zover de ver- \\ goeding niet of niet voldoende anderszins is verzekerd."
}

\section{Art. 3 lid 1, aanhef en onder e AVN}

“(...) wijst een aanvraag om vergoeding van de schade geheel of gedeeltelijk af, indien de vergoeding van de schade anderszins is verzekerd."

\section{Art. 3 lid 1, aanhef en onder f VNNZ}

“(...) weigert een aanvraag om nadeelcompensatie, indien de vergoeding van het nadeel anderszins voldoende is gewaarborgd."

\section{Art. 49 WRO}

“(...) schade lijdt (...) waarvan de vergoeding niet of niet voldoende door aankoop, onteigening of anderszins is verzekerd kennen burgemeester en wethouders (...) een naar billijkheid te bepalen schadevergoeding toe."

\section{Art. 8.31 lid 1 Wlv \\ "(...) schade lijdt (...) waarvan de vergoeding niet of niet voldoende anderszins is ver- zekerd, kent Onze Minister (...) een naar billijkheid te bepalen schadevergoeding toe."}

\section{Art. 21 Aanwijzingsbesluit 1996}

“(...) wordt (...) een naar billijkheid te bepalen schadevergoeding toegekend (...) voor zover de vergoeding niet of niet voldoende door aankoop, onteigening of anderszins is verzekerd."

Het valt bijvoorbeeld op dat de Amsterdamse gemeentewetgever het anderszins zijn verzekerd van schadevergoeding heeft opgenomen in afzonderlijke bepalingen die een opsomming van weigeringsgronden bevatten, terwijl dit in de overige regelingen is thuisgebracht in de bepaling die de bevoegdheid tot het verstrekken van compensatie toekent. Dit resulteert niet in een materieelrechtelijk verschil tussen de regelingen en een duidelijke verklaring hiervoor heb ik niet kunnen vinden. Ook valt op dat door art. 49 WRO en art. 21 Aanwijzingsbesluit 1996 twee voorbeelden worden gegeven van wijzen waarop de schadevergoeding voldoende anderszins kan zijn verzekerd, namelijk aankoop en onteigening. De WRO vormde een van de eerste wetten waarmee de formele wetgever probeerde het leerstuk van schadevergoeding wegens rechtmatige overheidsdaad op eenduidige wijze te regelen. De formulering van deze regeling heeft als inspiratiebron gediend voor vele later verschenen regelingen, waaronder art. 21 Aanwijzingsbesluit $1996 .{ }^{40} \mathrm{Het}$ 
verbaast daarom niet dat in deze bepaling dezelfde voorbeelden van anderszins verzekerde schadevergoedingen worden genoemd. Ik heb geen duidelijke redenen kunnen vinden waarom daarvan is afgezien in het eveneens op de WRO geïnspireerde art. 2 BnIW 2019 en art. $8.31 \mathrm{Wlv}^{41}$ en in de overige onderzochte regelingen. Kennelijk vonden de voor die regelingen verantwoordelijke regelgevers het niet nodig voorbeelden te noemen.

Voorts wordt in sommige regelingen gesproken van het anderszins zijn verzekerd van 'vergoeding' van 'schade' of 'nadeel', terwijl in andere regelingen wordt gesproken van het verzekerd zijn van de 'tegemoetkoming' daarin. De voorganger van de VNNZ - zijnde de Verordening Nadeelcompensatie en Planschade NoordZuidlijn - zag op de vergoeding van zowel planschade als nadeelcompensatie. Uit art. 1, aanhef en onder $\mathrm{h}$, van deze regeling volgde dat onder nadeelcompensatie "de vergoeding van het nadeel" werd verstaan. Het zou mij niet verbazen als hiermee werd beoogd een duidelijk onderscheid aan te brengen tussen het gedeelte van de verordening dat zag op planschade en het gedeelte dat zag op nadeelcompensatie. Dat de VNNZ, anders dan alle overige bestudeerde regelingen, van 'nadeel' spreekt in plaats van 'schade' lijkt een historisch overblijfsel hiervan te zijn. Dat de bepaling uit de Wro de enige is die spreekt van 'tegemoetkoming' kan ook historisch worden verklaard. Tijdens de totstandkoming van de Wro is namelijk bewust de keuze gemaakt om van 'tegemoetkoming' te spreken, aangezien die term beter tot uitdrukking zou brengen dat het égalitébeginsel slechts verplicht tot vergoeding van het gedeelte van de schade dat als onevenredig kan worden aangemerkt. ${ }^{42}$

Eveneens valt op dat in de VNNZ wordt gesproken van het anderszins zijn 'gewaarborgd' van schadevergoeding, terwijl in de overige regelingen de formulering anderszins zijn 'verzekerd' wordt gehanteerd. Voor zover ik heb kunnen nagaan, wordt hiermee geen materieelrechtelijk verschil beoogd. Bovendien heb ik geen duidelijke verklaring voor deze afwijkende formulering kunnen vinden. Ten slotte signaleer ik dat in alle onderzochte regelingen iets van de gedachte kan worden herkend dat het anderszins verzekerd zijn van schadevergoeding niet noodzakelijkerwijs een alles of niets vraagstuk betreft. Hoewel er verschil bestaat in de wijze waarop én de mate waarin deze gedachte tot uitdrukking komt in de gekozen formuleringen - vergelijk bijvoorbeeld 'voor zover' en/of '(niet of) niet voldoende' - heb ik niet de indruk dat de betrokken regelgevers daarmee materieelrechtelijke verschillen hebben beoogd. Daarvoor lijkt de Afdeling ook geen ruimte te laten. Bepalend is of de aanvrager ten tijde van de beslissing op de aanvraag om

41 Zie Stcrt. 1999, nr. 172, p. 9 (digitaal, p. 7) respectievelijk Kamerstukken II 00/01, 27 603, nr. 3, p. 69 en 15. 
compensatie $^{43}$ door het bestuur of een derde ${ }^{44}$ in "een vergelijkbare positie" is gebracht als waarin hij zou verkeren als hem enkel door het bestuur een geldelijke vergoeding voor het onevenredige deel van zijn schade zou zijn toegekend, overeenkomstig het égalitébeginsel of de van toepassing zijnde nadeelcompensatieregeling. ${ }^{45}$ Zo werd in een onder art. 49 WRO gewezen uitspraak van 24 december 2013 bijvoorbeeld geoordeeld dat niet staande kon worden gehouden dat de vergoeding van schade anderszins was verzekerd, aangezien de in casu geleden schade slechts gedeeltelijk was ondervangen door de reeds op grond van de RnVW 1999 verstrekte nadeelcompensatie. ${ }^{46}$ Voor dit als laatste aangekaarte verschil in formulering heb ik geen duidelijke verklaring kunnen vinden. Het heeft er veel van weg dat het is ontstaan doordat de regelingen gedurende enkele decennia door verschillende regelgevers zijn opgesteld, terwijl die regelgevers ten aanzien van dit onderwerp geen aandacht lijken te hebben gehad voor afstemming op andere nadeelcompensatieregelingen en/of overleg met elkaar, laat staan een materieelrechtelijk verschil in het leven beoogden te roepen.

\section{Eisen van duidelijkheid en zekerheid}

In de hiervoor besproken uitspraak van 24 december 2013 was het evident dat geen sprake was van voldoende anderszins verzekerde schadevergoeding. In gevallen waarin het al dan niet voldoende anderszins verzekerd zijn minder duidelijk is, moet worden teruggevallen op algemene overwegingen uit de jurisprudentie, zoals: "bij de beantwoording van de vraag of de tegemoetkoming in schade voldoende anderszins is verzekerd moet rekening worden gehouden met alle relevante feiten en omstandigheden." ${ }^{47}$ In analyses van de jurisprudentie wordt bovendien vaak geconcludeerd dat moet zijn voldaan aan de eisen van 'duidelijkheid' en 'zekerheid' om de tegemoetkoming in schade voldoende anderszins verzekerd te kunnen achten. ${ }^{48}$ De eis van zekerheid houdt in dat het anderszins verzekerd zijn van de schadevergoeding niet afhankelijk mag zijn van een "toekomstige,

43 Zie ABRvS 28 september 2016, ECLI:NL:RVS:2016:2582, r.o. 5.42 (Overzichtsuitspraak); en ABRvS 5 februari 2014, ECLI:NL:RVS:2014:305, r.o. 6.1.

44 Zie daaromtrent ABRvS 15 maart 2006, ECLI:NL:RVS:2006:AV5061, r.o. 2.8 en de verwijzing daarnaar in ABRvS 28 september 2016, ECLI:NL:RVS:2016:2582, r.o. 5.40 (Overzichtsuitspraak).

45 ABRvS 27 april 2005, ECLI:NL:RVS:2005:AT4747, r.o. 2.6.

46 ABRvS 24 december 2013, ECLI:NL:RVS:2013:2578, r.o. 7.3.

47 ABRvS 28 september 2016, ECLI:NL:RVS:2016:2582, r.o. 5.39 (Overzichtsuitspraak). Zie voor onder art. 49 WRO gewezen uitspraken: ABRvS 29 januari 2014, ECLI:NL:RVS:2014:182, r.o. 6.1; en ABRvS 21 mei 2008, ECLI:NL:RVS:2008:BD2119, r.o. 2.5.

48 Zie hieromtrent bijvoorbeeld Van den Broek 2002, p. 66-67; en Tjepkema 2010, p. 509-513. 
onzekere gebeurtenis." ${ }^{49}$ De Afdeling overweegt dit pas expliciet sinds 2009, maar reeds daarvoor waren voortekenen van deze overweging in de jurisprudentie te herkennen. ${ }^{50}$

De eis van duidelijkheid werd vroeger streng ingevuld. Zo oordeelde de Afdeling in een uitspraak van 24 april 1995 dat uit een ruilovereenkomst niet de conclusie kon worden getrokken dat aan appellant reeds een vergoeding voor zijn schade was toegekend, omdat deze overeenkomst "geenszins op een kenbare wijze aan[gaf]" dat in het bedrag dat de gemeente op grond van de overeenkomst verschuldigd was een bedrag als schadevergoeding voor het planologische nadeel was opgenomen. Thans lijkt deze eis wat minder streng te worden ingevuld: ${ }^{51}$ voor de conclusie dat op andere wijze in schadevergoeding is voorzien is "voldoende (...) dat deze op grond van objectieve gegevens gerechtvaardigd is." ${ }^{52}$ Dit wordt geïllustreerd door een onder de GrS gewezen planschadeuitspraak van 15 maart 2006. De aankoop van verschillende percelen door Schiphol tegen een bedrag van ongeveer vier miljoen euro werd daarin geacht de vergoeding van schade voldoende anderszins te hebben verzekerd. De precieze opbouw van het bedrag was niet duidelijk, maar voor de Afdeling was voldoende dat dit bedrag "aanzienlijk hoger" was dan de getaxeerde verkoopwaarde van de percelen als vastgesteld door de in het kader van de planschadeprocedure ingeschakelde adviescommissie. Dat lijkt te kunnen worden verklaard doordat de door Schiphol voor de percelen betaalde prijs was vastgesteld zonder dat daarop de waardedaling ten gevolge van de planologische mutaties in mindering was gebracht. ${ }^{53}$

Anders dan de formuleringen van de bepalingen uit de AVN en VNNZ doen vermoeden, wordt in de toelichtingen behorende bij de Amsterdamse regelingen gesteld dat de vergoeding van schade ook voldoende anderszins verzekerd kan worden geacht indien deze schadevergoeding niet daadwerkelijk is verzekerd, maar wel had kunnen worden verzekerd. ${ }^{54}$ De Amsterdamse gemeenteraad blijkt wat dat betreft hardleers, want uit een onder de Verordening Nadeelcompensatie en Planschade Noord-Zuidlijn door de rechtbank Amsterdam gewezen uitspraak van

Zie ABRvS 28 september 2016, ECLI:NL:RVS:2016:2582, r.o. 5.46 (Overzichtsuitspraak); ABRvS 25 februari 2009, ECLI:NL:RVS:2009:BH3961, r.o. 2.6.2; en ABRvS 5 februari 2014, ECLI:NL:RVS:2014:305, r.o. 6.1.

50 ABRvS 17 augustus 1999, ECLI:NL:RVS:1999:AP5877, r.o. 2.8 (Wooneenheden Oldenzaal); ABRvS 4 februari 2000, ECLI:NL:RVS:2000:AN6495, r.o. 2.6.1; en Rb. Arnhem 24 januari 2008, ECLI:NL:RBARN:2008:BC2698.

51 Dit wordt ook gesignaleerd in Tjepkema 2010, p. 511.

52 Zie ABRvS 28 september 2016, ECLI:NL:RVS:2016:2582, r.o. 5.39 (Overzichtsuitspraak); en ABRvS 19 juli 2006, ECLI:NL:RVS:2006:AY4221, r.o. 2.7.

53 ABRvS 15 maart 2006, ECLI:NL:RVS:2006:AV5061, r.o. 2.8-2.9. Zie voor een ander voorbeeld: ABRvS 19 juli 2006, ECLI:NL:RVS:2006:AY4221, r.o. 2.6 en 2.7-2.7.2.

54 Zie de toelichting op art. 3 lid 1 onder e AVN, en de toelichting op art. 3 lid 1, aanhef en onder f VNNZ. 
5 september 2007 bleek al dat een dergelijke benadering niet strookt met de eis van zekerheid. Naar het oordeel van de rechtbank was namelijk niet, althans onvoldoende gewaarborgd dat de compensatie van het door aanvraagster geleden nadeel voldoende anderszins was verzekerd door de privaatrechtelijke aanspraak op schadevergoeding die aanvraagster volgens het bestuur jegens de verhuurder van haar woning zou hebben. Daarbij was van belang dat onvoldoende duidelijkheid bestond omtrent de vraag of de verhuurder daadwerkelijk aansprakelijk was, en zo ja, voor welk deel van de geleden schade. ${ }^{55} \mathrm{Ik}$ heb geen verklaringen voor de hier beschreven 'eigenwijsheid' van de Amsterdamse gemeenteraad kunnen ontwaren.

Ook in de toelichting op art. 2 lid 1 RnVW $1999^{56}$ staat een opmerking die op zichzelf bezien tot twijfels omtrent de verenigbaarheid met de eis van zekerheid zou kunnen leiden: "indien er een specifieke wettelijke schadevergoedingsregeling voorhanden is, die in de betreffende schade voorziet, treedt deze regeling terug. ${ }^{\circ 7}$ Ik heb echter de indruk dat de minister slechts heeft willen aangeven dat hij onder de RnVW 1999 ingediende aanvragen niet onder die regeling in behandeling zal nemen als hij daarop een hogere nadeelcompensatieregeling zoals art. 22 Tracéwet (Lex superior derogat legi inferiori) kan toepassen, of een meer op de situatie toegespitste nadeelcompensatieregeling zoals de 'Nadeelcompensatieregeling verleggen kabels en leidingen in en buiten rijkswaterstaatswerken en spoorwegwerken 1999' (Lex specialis derogat generali). Dat de minister niet duidelijker was in zijn toelichting kan worden verklaard doordat de eis van zekerheid pas sinds 2009 door de Afdeling wordt geëxpliciteerd. Dat excuus kan niet door de Amsterdamse gemeenteraad worden aangevoerd, omdat zowel de AVN als de VNNZ na 2009 zijn vastgesteld.

\subsubsection{Deelvraag 3: het toekomstige recht}

In art. 4:126 lid 2, aanhef en onder $\mathrm{d}$ Awb is bepaald dat "schade (...) in elk geval voor rekening van de aanvrager [blijft] voor zover de vergoeding van de schade anderszins is verzekerd." Onder afd. $15.1 \mathrm{Ow}$ zal op deze bepaling worden teruggevallen nu daarin geen afwijkende regeling is opgenomen. ${ }^{58}$ In de bij die afdeling behorende toelichting wordt het voorbeeld gegeven van een omgevingsplan dat meerdere uitbreidingen van bestaande bebouwing vergunningvrij toestaat. Voor elk van die uitbreidingen kan een aanvraag om schadevergoeding worden ingediend, maar niet tweemaal voor dezelfde uitbreiding. De vergoeding van de daardoor veroorzaakte schade wordt dan immers voldoende anderszins verzekerd geacht. Ook wordt het voorbeeld gegeven van omgevingsplanregels van een centrumfunctie die meerdere activiteiten toelaten die wat betreft effecten op de fysieke leefomgeving van elkaar afwijken. Maakt het plan detailhandel en horeca mogelijk op dezelfde locatie, dan kan voor die activiteiten afzonderlijk schade- 
vergoeding worden verkregen als ze na elkaar worden verricht. Vestigt zich in het pand echter slechts een andere winkel die wat betreft effect op de omgeving op één lijn is te stellen met de vorige winkel, dan kan niet opnieuw schadevergoeding worden verkregen. ${ }^{59}$ In de bij de Wns behorende memorie van toelichting valt verder nog te lezen dat...

“(...) een benadeelde slechts aanspraak [kan] maken op een vergoeding voor zover op andere wijze in een redelijke vergoeding niet is of kan $^{60}$ worden voorzien."

Uit de Kamerstukken behorende bij de Wns wordt niet duidelijk of ook daadwerkelijk is beoogd om schade die nog niet is vergoed, op grond van deze bepaling van vergoeding uit te sluiten, omdat op andere wijze in een redelijke vergoeding kan worden voorzien. De reden dat daarover kan worden getwijfeld, is dat in de memorie van toelichting enkele verwijzingen zijn opgenomen naar WRO-jurisprudentie over het voldoende anderszins verzekerd zijn van schadevergoeding. ${ }^{61}$ Ik heb geen aanwijzingen kunnen vinden dat het de wetgever voor ogen stond om af te wijken van de in die jurisprudentie tot stand gekomen eis van zekerheid.

\subsubsection{Hoofdvraag: spiegeling aan de doelstellingen en uitgangspunten die} ten grondslag liggen aan de Wns

Hoewel de geconstateerde verschillen in formulering tussen de thans geldende bepalingen omtrent het voldoende anderszins zijn verzekerd van schadevergoeding niet met die intentie tot stand lijken te zijn gekomen, zouden zij wel door bestuursorganen kunnen worden ingezet om uiteenlopende materieelrechtelijke toepassingen te rechtvaardigen. Het past daarom goed bij de doelstellingen van vereenvoudiging, uniformering en harmonisering van het nadeelcompensatierecht, en vergroting van de rechtszekerheid en rechtsgelijkheid dat deze bepalingen kunnen komen te vervallen, zodat slechts art. 4:126 lid 2, aanhef en onder d Awb zal overblijven. Gelet op de doelstellingen van codificatie van het nadeelcompensatierecht en vergroting van de rechtszekerheid, verdient het echter aanbeveling dat deze bepaling zo wordt aangepast dat daaruit zal blijken dat schadevergoeding slechts voldoende anderszins verzekerd kan worden geacht indien zij uit objectieve gegevens kan worden afgeleid (eis van duidelijkheid) en niet afhankelijk is van een toekomstige, onzekere gebeurtenis (eis van zekerheid). Bovendien zou het bijdragen aan het bereiken van deze doelstellingen als de bepaling uit titel 4.5 Awb - net als alle andere regelingen, op de AVN na - zou spreken van 'voldoende anderszins is verzekerd'. Daardoor zou immers worden benadrukt dat wel (een geldelijke) compensatie dient te worden toegekend voor het onevenredige deel van de schade waarvoor niet langs andere weg in tegemoetkoming is voorzien. Deze aanbeve-

59 Kamerstukken II 2018/19, 34 986, nr. 3, p. 230 (MvT, IOw).

60 Eigen cursivering.

61 Zo wordt onder andere verwezen naar ABRvS 3 augustus 2005, ECLI:NL:RVS:2005:AU0430 (Heemstede). Zie Kamerstukken II 2010/11, 32 621, nr. 3, p. 25-26 (MvT, Wns). 
lingen acht ik ook verenigbaar met de overige aan de Wns ten grondslag liggende doelstellingen en uitgangspunten.

\section{Conclusie en concrete voorstellen}

Gelet op het voorafgaande zie ik reden om (a) titel 4.5 Awb aan te passen, maar geen reden om (b) afd. 15.1 Ow aan te passen of (c) anderszins te voorzien in een bijzondere invulling, aanvulling of afwijking van titel 4.5 Awb. De aanbevolen aanpassing van titel 4.5 Awb kan worden vormgegeven door art. 4:126 lid 2 sub d Awb te laten vervallen onder gelijktijdige opname van een nieuw vierde ${ }^{62}$ en vijfde artikellid:

4. In zoverre vergoeding van de schade voldoende anderszins is verzekerd, wordt geen vergoeding als bedoeld in het eerste lid toegekend.

5. Schadevergoeding wordt voldoende anderszins verzekerd als bedoeld in het vierde lid geacht in zoverre zij op basis van objectieve gegevens kan worden vastgesteld en niet afhankelijk is van een toekomstige, onzekere gebeurtenis.

Ten aanzien van de in paragraaf 9.2.2 aangehaalde passage uit de bij de Wns behorende memorie van toelichting dat "een benadeelde slechts aanspraak [kan] maken op een vergoeding voor zover op andere wijze in een redelijke vergoeding niet is of kan worden ${ }^{63}$ voorzien", stel ik voor dat het gecursiveerde deel wordt geschrapt. Dat laat zich immers niet goed verenigen met de eis van zekerheid.

In mijn voorstel tot wijziging van art. 4:126 Awb heb ik rekening gehouden met de opvatting van Tjepkema ${ }^{64}$ en Van den Broek ${ }^{65}$ dat de huidige formulering van art. 4:126 lid 2, aanhef en onder d Awb taalkundig ongelukkig is: wanneer de vergoeding van schade anderszins is verzekerd, blijft deze namelijk niet voor rekening van de aanvrager. De aanvrager heeft de schade immers reeds langs andere weg weten te verhalen. Ik onderschrijf hun stelling dat het beter zou zijn te spreken van het 'niet toekennen van schadevergoeding'. ${ }^{66}$ Een dergelijke formulering is echter niet verenigbaar met de aanhef van art. 4:126 lid 2 Awb, waardoor de regeling omtrent het anderszins verzekerd zijn van schadevergoeding in afzonderlijke artikelleden moet worden opgenomen.

62 In paragraaf 9.3.3 zal ik een voorstel doen om het huidige vierde lid te vervangen door een nieuw zesde lid.

63 Eigen cursivering.

64 Tjepkema 2010, p. 925.

65 Van den Broek 2007, p. 123.

66 Tjepkema 2010, p. 921 en 925. 
9.3.1 Deelvraag 2: verschillen tussen de geselecteerde, thans geldende regelingen en verklaringen daarvoor

Alle geselecteerde, thans geldende regelingen kennen de mogelijkheid om schade in natura te compenseren. De schade wordt dan anders dan in geld gecompenseerd, hetgeen vele vormen kan aannemen. Indien de wijziging van een planologisch regime directe planschade veroorzaakt die bestaat uit een waardevermindering van de onroerende zaak van de aanvrager, kan compensatie in natura onder andere bestaan uit een herstel van de door de wijziging van het planologische regime weggevallen bouwmogelijkheid. ${ }^{67} \mathrm{Bij}$ indirecte planschade kan de compensatie in natura onder andere bestaan uit herstel van de door een planologische maatregel verruimde bouw- of gebruiksmogelijkheden van gronden van derden, of het alsnog verbinden van beperkende bouw- of gebruiksvoorschriften aan het nieuwe planologische regime. ${ }^{68}$ Compensatie in natura kan ook anders geschieden dan door de wijziging van juridische regimes. ${ }^{69}$ Zo accepteerde de Afdeling in een uitspraak van 13 maart 1997 dat de door het bestuur bij de aanbreng van geluidswerende voorzieningen gemaakte uitvoeringskosten deels in mindering werden gebracht op het te compenseren schadebedrag. De geluidswerende voorzieningen konden immers tot een waardevermeerdering van de woningen van de aanvragers leiden. Wel moest volgens de Afdeling in het oog worden gehouden dat dergelijke voorzieningen ook nadelen kunnen meebrengen, zoals "verminderde mogelijkheden tot ventilatie van de woning en isolatie ook tegen normale, niet als hinderlijk ervaren omgevingsgeluiden." Ook moest worden nagegaan in welke mate de getroffen maatregelen daadwerkelijk een oplossing voor het ondervonden nadeel boden. Zo achtte de Afdeling het van belang dat de geluidsbelasting alleen binnenshuis was afgenomen en bovendien slechts in zoverre ramen en deuren gesloten bleven. ${ }^{70}$ Uit het Basisdocument blijkt dat vanwege de uitbreiding van Schiphol een 'isolatieprogramma' is opgezet. ${ }^{71}$ Onder verwijzing naar de uitspraak van 13 maart 1997 wordt vermeld dat $25 \%$ van de kosten van de van overheidswege getroffen schadebeperkende maatregelen in mindering zullen worden gebracht op toe te kennen planschadevergoedingen. ${ }^{72}$

ABRvS 28 september 2016, ECLI:NL:RVS:2016:2582, r.o. 5.44 (Overzichtsuitspraak). Zie bijvoorbeeld ook ABRvS 27 april 2005, ECLI:NL:RVS:2005:AT4747, r.o. 2.6; en ABRvS 13 januari 2016, ECLI:NL:RVS:2016:50, r.o. 10-10.1 (Achtkarspelen).

ABRvS 28 september 2016, ECLI:NL:RVS:2016:2582, r.o. 5.45 (Overzichtsuitspraak). Zie voor een duidelijk voorbeeld ABRvS 1 mei 2013, ECLI:NL:RVS:2013:BZ9072, r.o. 6.1.

69 Zie hieromtrent ook Kamerstukken II 2010/11, 32 621, nr. 3, p. 26 (MvT, Wns).

70 ABRvS 13 maart 1997, ECLI:NL:RVS:1997:AN5427 (Vliegveld Welschap).

71 Zie Van den Berg 2012. In 2012 bleek reeds voor 662 miljoen euro te zijn uitgegeven aan de isolatie van 17.736 woningen, en de aankoop van woningen en woonboten die te dicht bij de startbanen waren gelegen.

Basisdocument, p. 28-29. 


\section{Materieelrechtelijke grondslag}

De voorwaarden voor het compenseren in natura zijn vooral in de planschadejurisprudentie tot stand gekomen. Onder art. 49 WRO oordeelde de Afdeling al sinds de jaren ' 90 dat schadevergoeding in geld achterwege kan blijven indien de schade in natura is gecompenseerd, omdat de vergoeding van schade dan voldoende anderszins verzekerd wordt geacht. ${ }^{73}$ In een uitspraak van 1 mei 2013 overwoog de Afdeling dat zij geen aanleiding ziet onder afd. 6.1 Wro van deze lijn af te wijken, hetgeen wordt bevestigd door de Overzichtsuitspraak. ${ }^{74}$ Uit een onder de RnR 1991 gewezen Afdelingsuitspraak van 14 april 2004 lijkt te kunnen worden afgeleid dat de Afdeling dezelfde lijn hanteert in het nadeelcompensatierecht. Ondanks dat deze regeling een afzonderlijke bepaling omtrent schadevergoeding anders dan in geld bevatte (vergelijk art. 2 lid 2 RnR 1991), behandelde de Afdeling het twistpunt omtrent compensatie in natura namelijk eveneens onder de noemer van het voldoende anderszins verzekerd zijn van schadevergoeding. ${ }^{75}$

Deze jurisprudentie lijkt te verklaren waarom in art. 49 WRO, afd. 6.1 Wro, art. 21 Aanwijzingsbesluit 1996 en art. 8.31 Wlv geen afzonderlijke bepaling inzake het in natura compenseren van schade is opgenomen: deze regelingen bepalen dat geen compensatie wordt toegekend als de vergoeding van schade voldoende anderszins is verzekerd, hetgeen het geval is als de schade in natura is gecompenseerd. Voor de formulering van art. 21 Aanwijzingsbesluit 1996 en art. 8.31 Wlv is bovendien aansluiting gezocht bij de formulering van art. $49 \mathrm{WRO}$, en in geval van art. 8.31 Wlv ook bij art. 15.20 Wet milieubeheer. ${ }^{76}$ Dat in de GrS geen bepaling is opgenomen omtrent compensatie in natura kan worden verklaard door de in paragraaf 3.2.1 beschreven, bijzondere aard van deze regeling: zij dient ertoe de reeds op grond van verschillende grondslagen bestaande - en aan verschillende bestuursorganen toekomende - bevoegdheden om nadeelcompensatie toe te kennen, binnen een specifieke context over te dragen aan het algemeen bestuur van het Schadeschap.

De mogelijkheid schade in natura te compenseren is wel expliciet vastgelegd in art. 2 lid 3 BnIW 2019, art. 8 lid 1 AVN en art. 9 lid 1 VNNZ. Hoewel de formuleringen van deze bepalingen licht verschillen, komen zij inhoudelijk overeen: in beginsel wordt de vergoeding bepaald in geld, maar het bestuur heeft de discretie om de vergoeding van de schade in een andere vorm dan de betaling van een

Zie AGRvS 21 juni 1990, ECLI:NL:RVS:1990:AQ4434 (Wegaanleg Groenlo); ABRvS 25 juli 1994, ECLI:NL:RVS:1994:AS6109 (Waardevermindering Doorn); en ABRvS 27 april 2005, ECLI:NL:RVS:2005:AT4747, r.o. 2.6. Zie meer recent ABRvS 5 februari 2014, ECLI:NL:RVS:2014:305, r.o. 6.1.

ABRvS 1 mei 2013, ECLI:NL:RVS:2013:BZ9072, r.o. 6.1. Naar deze uitspraak wordt verwezen in ABRvS 28 september 2016, ECLI:NL:RVS:2016:2582, r.o. 5.41 (Overzichtsuitspraak).

75 ABRvS 14 april 2004, ECLI:NL:RVS:2004:AO7460, r.o. 10.2.

76 Zie Stcrt. 1998, nr. 223, p. 11 (digitaal) respectievelijk Kamerstukken II 00/01, 27 603, nr. 3, p. 69 en 15. 
geldsom te gieten. Dat is in overeenstemming met de jurisprudentie. ${ }^{77}$ Het planschade- en nadeelcompensatierecht wijkt daarmee overigens af van art. 6:103 BW. In paragraaf 9.3.3 zal ik uitleggen waarom dat mijns inziens ook gegrond is.

\section{Toch geen volledige discretie onder de AVN en VNNZ?}

Bijzonder is dat in art. 8 lid 2 AVN en art. 9 lid 2 VNNZ is bepaald dat de waarde van de compensatie in natura niet hoger mag zijn dan het bedrag in geld waarop de benadeelde aanspraak zou kunnen maken. In de toelichting op de bepaling uit de AVN volgt slechts dat het bestuur in situaties waarin dit niet het geval is "kan (...) besluiten om alsnog nadeelcompensatie in geld uit te keren." Dat verklaart niet waarom de Amsterdamse gemeenteraad het nodig achtte om art. 8 lid 2 AVN op te nemen. De in de toelichting genoemde bevoegdheid bestond immers reeds op grond van het eerste artikellid. Bovendien suggereert deze opmerking dat het bestuur in dit soort gevallen kan kiezen voor een geldelijke vergoeding, terwijl art. 8 lid 2 AVN bepaalt dat niet in natura mag worden gecompenseerd als dat tot een vergoeding leidt die meer waard is dan waar recht op zou bestaan bij een geldelijke vergoeding. Ook uit de bij de VNNZ behorende toelichting kan niet worden opgemaakt waarom de bepaling die de hoogte van de compensatie in natura maximeert, is opgenomen. Het is aannemelijk dat de Amsterdamse gemeenteraad uitdrukking heeft willen geven aan de gedachte dat het niet wenselijk is als een grote disbalans bestaat tussen het voor compensatie in aanmerking komende deel van het schadebedrag en de waarde van de compensatie in natura. Het égalitébeginsel strekt immers slechts tot vergoeding van het gedeelte van de schade dat als onevenredig kan worden aangemerkt.

\subsubsection{Deelvraag 3: het toekomstige recht}

Ook titel 4.5 Awb kent een afzonderlijke bepaling inzake het in natura compenseren van schade. Art. 4:126 lid 4 Awb luidt namelijk: "Het bestuursorgaan kan een vergoeding toekennen in andere vorm dan betaling van een geldsom." Uit de bij de Wns behorende memorie van toelichting blijkt dat deze formulering tot uitdrukking moet brengen dat de vorm van de schadevergoeding ter discretie staat van het bestuursorgaan. De wetgever noemt als voorbeelden het aanbieden van een alternatieve bedrijfslocatie, het aanleggen van een parallelweg, of het herstellen van een bouwmogelijkheid die door een planwijziging is komen te vervallen. Voorts kan uit de memorie van toelichting worden afgeleid dat compensatie in natura ook door de wetgever wordt gezien als een vorm van het voldoende anderszins

ABRvS 28 september 2016, ECLI:NL:RVS:2016:2582, r.o. 5.41 (Overzichtsuitspraak). Zie voor art. 49 WRO: ABRvS 27 april 2005, ECLI:NL:RVS:2005:AT4747, r.o. 2.6. Zie voor het nadeelcompensatierecht: ABRvS 14 april 2004, ECLI:NL:RVS:2004:AO7460, r.o. 2.10-2.10.2. Zie Tjepkema 2010, p. 348-349 voor een bespreking van deze uitspraak en de daaraan voorafgegane uitspraak van de rechtbank Rotterdam. 
verzekerd zijn van schadevergoeding. ${ }^{78}$ Onder afd. $15.1 \mathrm{Ow}$ zal op deze bepaling worden teruggevallen nu daarin geen afwijkende regeling is opgenomen. ${ }^{79} \mathrm{Ik}$ heb ten slotte geen aanwijzingen kunnen vinden dat de wetgever niet zou willen vasthouden aan de thans bestaande jurisprudentielijnen.

\subsubsection{Hoofdvraag: spiegeling aan de doelstellingen en uitgangspunten die} ten grondslag liggen aan de Wns

Uit de in paragraaf 9.3.1 besproken jurisprudentie, waarnaar in de bij de Wns behorende memorie van toelichting wordt verwezen, volgt dat strikt genomen geen zelfstandige wettelijke grondslag nodig is om schade in natura te compenseren. Deze bevoegdheid vloeit immers voort uit de bevoegdheid om geen compensatie toe te kennen voor schade waarvan de vergoeding reeds voldoende anderszins is verzekerd (vergelijk art. 4:126 lid 2, aanhef en onder d Awb). Toch valt er vanuit de aan de Wns ten grondslag liggende doelstellingen van vergroting van de rechtszekerheid en codificatie van het nadeelcompensatierecht veel voor te zeggen dat art. 4:126 lid 4 Awb expliciteert dat compensatie in natura tot de mogelijkheden behoort. Het past bovendien goed bij de doelstelling van vereenvoudiging, uniformering en harmonisering van het nadeelcompensatierecht dat thans bestaande bepalingen die deze mogelijkheid erkennen, kunnen komen te vervallen. Dat neemt niet weg dat de doelstellingen van vergroting van de rechtszekerheid en codificatie van het nadeelcompensatierecht mijns inziens nog meer recht zouden worden gedaan door in de Awb-bepaling ook tot uitdrukking te laten komen dat het bij compensatie in natura eigenlijk gaat om het anderszins verzekeren van schadevergoeding. Daardoor wordt immers duidelijk dat de eisen van duidelijkheid en zekerheid - ten aanzien waarvan in paragraaf 9.2.3 een voorstel tot codificatie is gedaan - ook van toepassing zijn op situaties waarin het bestuur de schade in natura wil compenseren. Dit acht ik ook verenigbaar met de overige doelstellingen en uitgangspunten die ten grondslag liggen aan de Wns. Een concreet voorstel hiertoe volgt aan het einde van deze deelparagraaf. De aan de Wns ten grondslag liggende doelstellingen en uitgangspunten vereisen mijns inziens niet dat in de Awb-bepaling - net als in de Amsterdamse verordeningen - wordt bepaald dat de waarde van de compensatie in natura de hoogte van het voor compensatie in aanmerking komende deel van schadebedrag niet mag ontstijgen. Het in art. 3:4 lid 2 Awb gecodificeerde evenredigheidsbeginsel en het staatssteunrecht waarborgen namelijk voldoende dat een (onaanvaardbare) disbalans tussen beide waardes ontstaat. Enig verschil tussen beide waardes acht ik bovendien acceptabel, zolang draagplichtige derden slechts de kosten van de compensatie in natura hoeven te dragen tot aan de hoogte van het onevenredige deel van de schade. Nadeelcompensatie kan soms immers ook een smeermiddelfunctie vervullen. ${ }^{80}$

78 Kamerstukken II 2010/11, 32 621, nr. 3, p. 25-26 (MvT, Wns).

79 Kamerstukken II 2018/19, 34 986, nr. 3, p. 224-225 (MvT, IOw).

80 Zie daarover paragraaf 2.2 onder het kopje 'Het hedendaagse nadeelcompensatiedoolhof' en de aanhef van paragraaf 2.3. 


\section{Discretie voor het bestuur}

De in art. 4:126 lid 4 Awb gekozen formulering legt de keuze of in natura wordt gecompenseerd in handen van het bestuur. Dat past in beginsel niet goed bij het uitgangspunt van aansluiting bij het BW. Uit art. 6:103 BW volgt immers dat in het civiele recht slechts op vordering van de benadeelde kan worden overgegaan tot compensatie in natura. Uit paragraaf 2.4.2.2 volgt echter dat dit uitgangspunt niet absoluut is: beoogd wordt onnodige verschillen tussen het civiele recht en het bestuursrecht te voorkomen. Dat roept de vraag op of hier sprake is van een onnodig verschil. Daarover kan verschillend worden gedacht. Zo bleek de AARvS ten tijde van de totstandkoming van titel 4.5 Awb van mening dat er geen reden bestaat om op dit punt af te wijken van de hoofdregel van art. 6:103 BW. De toenmalige minister van Veiligheid \& Justitie was het daarmee oneens, omdat deze hoofdregel "passend" zou zijn voor schadevergoeding vanwege onrechtmatig handelen, maar niet evenzeer zou opgaan voor vergoeding van schade door rechtmatig overheidshandelen. Hij onderbouwde dit door te stellen dat voor dergelijke schade een "redelijke compensatie" moet worden geboden aan de getroffenen die een speciale en abnormale last ondervinden. Doorgaans zou een geldelijke compensatie het meest in de rede liggen, maar in bepaalde gevallen achtte de minister compensatie in natura "evenzeer aanvaardbaar" en soms ook "meer voor de hand liggend". ${ }^{81}$

Ik kan me goed vinden in de argumentatie van de minister. Daarbij acht ik van belang dat het - anders dan in het civiele recht - niet gaat om onrechtmatig veroorzaakte schade, maar om schade die op rechtmatige wijze is veroorzaakt door overheidshandelen dat strekt tot behartiging van het algemene belang. Dit verschil in de aard van de aansprakelijkheid (onrechtmatig versus rechtmatig) in combinatie met het gegeven dat de vergoeding wordt betaald uit schaarse publieke middelen, maakt mijns inziens dat een afwijking van art. 6:103 BW gerechtvaardigd is. Bovendien is deze afwijking ook te verenigen met de overige aan de Wns ten grondslag liggende doelstellingen en uitgangspunten. Wel is het mijns inziens het overwegen waard een redelijkheidsclausule in te bouwen. Zo is het maar de vraag of immateriële schade in natura moet kunnen worden gecompenseerd door maatregelen die (op papier) materieel voordeel opleveren. Voor de invulling van deze clausule zou aansluiting kunnen worden gezocht bij de leer van de toerekening naar redelijkheid van art. 6:98 BW en bij het in paragraaf 9.1.3 gedane voorstel voor een redelijkheidsclausule inzake voordeelverrekening.

\section{De eis van zekerheid}

De in paragraaf 9.2 besproken eis van zekerheid is deels tot stand gekomen in uitspraken omtrent compensatie in natura. Vaak gaat het in die uitspraken om de vraag of schadevergoeding voldoende anderszins verzekerd kan worden geacht in situaties waarin het vanwege de planologische procedures die moeten worden ge- 
voerd ten behoeve van het planologische regime dat voorziet in de compensatie in natura, niet geheel zeker is of dit planologische regime in werking zal treden. Het is vaste Afdelingsjurisprudentie dat compensatie in natura in dergelijke gevallen niet zinledig is. Het bestuur kan namelijk toezeggingen doen waarmee de onzekerheid over deze procedures voldoende wordt ondervangen. Daarbij komt blijkens de Overzichtsuitspraak betekenis toe aan...

\begin{abstract}
“(...) de omstandigheid of met deze toezeggingen met voldoende zekerheid vaststaat dat, mocht blijken dat compensatie in natura niet tot stand kan worden gebracht, de hoogte van het alsnog uit te betalen bedrag na inwinning van advies bij ter zake kundige, onafhankelijke planschadeadviseurs, zal worden vastgesteld en dat dit bedrag zal worden vermeerderd met de wettelijke rente vanaf de dag van de ontvangst van de aanvraag. Voorts komt in voorkomende gevallen ook betekenis toe aan de omstandigheid of de compenserende voorziening, gedurende een voldoende lange periode, ook wordt geboden aan rechtsopvolgers onder algemene en bijzondere titel." ${ }^{{ }_{2}}$
\end{abstract}

Gelet op de doelstellingen van vergroting van rechtszekerheid en codificatie van het nadeelcompensatierecht kan de vraag worden opgeworpen of deze jurisprudentielijn in afd. 15.1 Ow zou moeten worden gecodificeerd. Ik meen dat die vraag thans ontkennend moet worden beantwoord, omdat de jurisprudentie op dit punt nog onvoldoende is uitgekristalliseerd. Zo kreeg de benadeelde uit de De Lunetuitspraak in een nieuw besluit op bezwaar de mogelijkheid om binnen vijf jaar na onherroepelijkheid van het nieuwe bestemmingsplan herstel van de verloren gebruiksmogelijkheden aan te vragen, waarbij eveneens de in de Overzichtsuitspraak genoemde toezeggingen werden gedaan. De Afdeling oordeelde echter dat het nieuwe besluit op bezwaar niet aan de daaraan te stellen eisen voldeed. Er werd namelijk onvoldoende zekerheid geboden omtrent de vraag wanneer de benadeelde zou worden gecompenseerd. Vanuit het oogpunt van rechtszekerheid achtte de Afdeling het "niet aanvaardbaar" dat het, vanwege de eventuele procedures die tegen het in natura compenserende planologische regime konden worden gevoerd, nog jaren zou kunnen duren voordat de conclusie werd bereikt dat compensatie in natura niet mogelijk was en alsnog tot de uitkering van een financiële vergoeding zou moeten worden overgegaan. ${ }^{83}$ Een vergelijkbare situatie deed zich voor in de DSM-uitspraak, waarin de Afdeling oordeelde dat de vaststelling van de tegemoetkoming in planschade in compensatie in natura ten onrechte afhankelijk was gesteld van "onzekere nadere besluitvorming" over de omvang en de vergoedbaarheid van de schade. Daarbij was van belang dat het besluit op de aanvraag om tegemoetkoming geen getaxeerd schadebedrag bevatte, waardoor de situatie

82 Zie ABRvS 28 september 2016, ECLI:NL:RVS:2016:2582, r.o. 5.47 (Overzichtsuitspraak); ABRvS 9 december 2015, ECLI:NL:RVS:2015:3767, r.o. 3.1-3.3; ABRvS 18 juli 2012, ECLI:NL:RVS:2012:BX1863, r.o. 2.6; en ABRvS 27 april 2005, ECLI:NL:RVS:2005:AT4747, r.o. 2.6. 
kon ontstaan dat meer dan zes en een half jaar later ${ }^{84}$ nog steeds onzekerheid zou bestaan omtrent de mate waarin de geleden schade zou worden gecompenseerd. ${ }^{85}$

\section{Conclusie en concrete voorstellen}

Op basis van het voorafgaande zie ik geen reden om ten aanzien van compensatie in natura (b) afd. 15.1 Ow aan te passen of (c) anderszins in een bijzondere invulling, aanvulling of afwijking van titel 4.5 Awb te voorzien. Wel zie ik reden om (a) titel 4.5 Awb aan te passen. Ten opzichte van de huidige formulering van art. 4:126 lid 4 Awb zou mijns inziens behouden moeten blijven dat het bestuur discretie toekomt, maar zie ik wel reden een redelijkheidsclausule in te bouwen. Ook zou duidelijker moeten blijken dat compensatie in natura een vorm van het anderszins verzekeren van schadevergoeding betreft. In paragraaf 9.2.3 stelde ik ten aanzien van het voldoende anderszins zijn verzekerd van schadevergoeding een nieuw vierde en vijfde lid voor. In aanvulling daarop doe ik hier het voorstel het huidige vierde lid te schrappen onder invoering van een nieuw zesde lid. Daardoor zou het volgende samenspel van artikelleden ontstaan:

4. In zoverre vergoeding van de schade voldoende anderszins is verzekerd, wordt geen vergoeding als bedoeld in het eerste lid toegekend.

5. Schadevergoeding wordt voldoende anderszins verzekerd als bedoeld in het vierde lid geacht in zoverre zij op basis van objectieve gegevens kan worden vastgesteld en niet afhankelijk is van een toekomstige, onzekere gebeurtenis.

6. Het bestuursorgaan kan, voor zover dit redelijk is, besluiten de schade anders dan in geld te vergoeden, waardoor de vergoeding van schade voldoende anderszins verzekerd als bedoeld in het vierde lid wordt geacht, mits zij aan de eisen uit het vijfde lid voldoet.

\subsection{CONCLUSIE}

In dit hoofdstuk zijn de tweede en derde deelvraag en de hoofdvraag beantwoord ten aanzien van het criterium van voordeelverrekening (paragraaf 9.1) en het criterium van het niet vergoeden van schade die voldoende anderszins is verzekerd (paragraaf 9.2). In paragraaf 9.3 zijn deze vragen afzonderlijk beantwoord voor een bijzondere vorm van voldoende anderszins verzekerde schadevergoeding, namelijk schade die in natura is gecompenseerd. Dit hoofdstuk zal hier worden afgesloten met een beknopte weergave van de aanbevelingen en concrete voorstellen die zijn gedaan om (a) titel 4.5 Awb aan te passen, (b) afd. 15.1 Ow aan te passen,

84 Volgens het besluit op de aanvraag om compensatie moest de gemeenteraad namelijk uiterlijk dan het in natura compenserende bestemmingsplan hebben vastgesteld.

85 ABRvS 6 december 2017, ECLI:NL:RVS:2017:3305, r.o. 34-36 (Planschade $D S M)$. Zie over dit aspect van beide uitspraken tevens onderdeel twaalf van de annotatie van Tjepkema en mijzelf bij De Lunet-uitspraak in AB 2017/427. 
of (c) anderszins in een bijzondere invulling, aanvulling of afwijking van titel 4.5 Awb te voorzien.

In paragraaf 9.1.3 is voorgesteld (a) art. 4:126 lid 3 Awb aan te passen. In de voorgestelde formulering komt duidelijker tot uitdrukking dat het bestuur geen discretie toekomt als het aankomt op de verrekening van voordeel: staat in voldoende mate vast dat het overheidshandelen de vermogenspositie van de benadeelde ook in positieve zin heeft beïnvloed of zal beïnvloeden, dan moet dit bij de vaststelling van de te vergoeden schade in rekening worden gebracht. Ook benadrukt de voorgestelde formulering dat voordeelverrekening een onderdeel is van de beantwoording van de schadevraag. Voorts bevat de voorgestelde formulering een redelijkheidsclausule om beter op het civiele recht van art. 6:100 BW aan te sluiten. Ten slotte expliciteert de voorgestelde formulering de mogelijkheid van verrekening van voordeel uit nauw met de schadeoorzaak verweven overheidshandelen. Naast behartiging van het uitgangspunt van aansluiting bij het BW, beoogt dit voorstel bij te dragen aan het bereiken van de doelstellingen van vergroting van de rechtszekerheid en codificatie van het nadeelcompensatierecht. Ook de doelstelling van vergroting van de doelmatigheid van het nadeelcompensatierecht en vermindering van bestuurslasten speelde een bescheiden rol. In paragraaf 9.1.3 is ook voorgesteld om (b) een bepaling aan afd. 15.1 Ow toe te voegen die het nieuw voorgestelde art. 4:126 lid 3 Awb nader invult door aan te geven wanneer in het omgevingsrecht kan worden gesproken van nauw met de schadeoorzaak verweven overheidshandelen. Ook met dit voorstel wordt beoogd om bij te dragen aan de doelstellingen van vergroting van de rechtszekerheid en codificatie van het nadeelcompensatierecht. De aan de Wns ten grondslag liggende doelstellingen en uitgangspunten geven geen reden om (c) anderszins in een bijzondere invulling, aanvulling of afwijking van titel 4.5 Awb te voorzien.

In paragraaf 9.2.3 is voorgesteld (a) een nieuw vierde en vijfde lid aan art. 4:126 Awb toe te voegen, onder schrapping van het huidige art. 4:126 lid 2 onder $d$ Awb. Dit voorstel beoogt de in de jurisprudentie tot stand gekomen eisen van duidelijkheid en zekerheid te codificeren. Voorts wordt beoogd te expliciteren dat het voldoende anderszins zijn verzekerd van schadevergoeding geen alles of niets vraag betreft. Ook met dit voorstel wordt beoogd om bij te dragen aan het bereiken van de doelstellingen van vergroting van de rechtszekerheid en codificatie van het nadeelcompensatierecht. Bij de gekozen formuleringen is bovendien rekening gehouden met kritiek van Van den Broek en Tjepkema dat de redactie van het huidige art. 4:126 lid 2, aanhef en onder $\mathrm{d}$ Awb taalkundig ongelukkig is: wanneer de vergoeding van schade anderszins is verzekerd, blijft deze namelijk niet voor rekening van de aanvrager. De aan de Wns ten grondslag liggende doelstellingen en uitgangspunten geven geen aanleiding tot (b) aanpassing van afd. $15.1 \mathrm{Ow}$, of (c) het anderszins voorzien in een bijzondere invulling van titel $4.5 \mathrm{Awb}$.

In paragraaf 9.3.3 is voorgesteld (a) het huidige art. 4:126 lid 4 Awb te schrappen onder invoering van een nieuw zesde lid. Dit nieuwe zesde lid maakt duidelijk dat het bij compensatie in natura in wezen gaat om het voldoende anderszins verze- 
keren van schadevergoeding als bedoeld in het nieuw voorgestelde vierde lid. Ten opzichte van de huidige formulering van art. 4:126 lid 4 Awb zou mijns inziens behouden moeten blijven dat het bestuur discretie toekomt, maar zie ik wel reden een redelijkheidsclausule in te bouwen. Deze aanbevelingen vloeien voort uit de doelstellingen van vergroting van de rechtszekerheid en codificatie van het nadeelcompensatierecht. De aan de Wns ten grondslag liggende doelstellingen en uitgangspunten geven geen aanleiding tot (b) aanpassing van afd. $15.1 \mathrm{Ow}$, omdat de jurisprudentie nog onvoldoende is uitgekristalliseerd voor codificatie in deze afdeling. Dat blijkt met name bij situaties waarin het vanwege de planologische procedures die moeten worden gevoerd ten behoeve van het planologische regime dat voorziet in de compensatie in natura, niet geheel zeker is of dit planologische regime in werking zal treden. Ten slotte geven de aan de Wns ten grondslag liggende doelstellingen en uitgangspunten ook geen aanleiding (c) anderszins te voorzien in een bijzondere invulling, aanvulling of afwijking van titel 4.5 Awb.

\section{Concrete voorstellen}

Bij de opvolging van de in dit hoofdstuk gedane aanbevelingen, zou art. 4:126, derde $\mathrm{t} / \mathrm{m}$ zesde lid Awb er als volgt komen uit te zien:

3. Indien in voldoende mate vaststaat dat een gebeurtenis als bedoeld in het eerste lid of meerdere gebeurtenissen als bedoeld in het eerste lid die nauw met elkaar zijn verweven, naast een nadelige invloed ook een positieve invloed op de vermogenspositie van de aanvrager hebben gehad of zullen hebben, dan moet, voor zover dit redelijk is, deze positieve invloed bij de vaststelling van de te vergoeden schade in rekening worden gebracht.

4. In zoverre vergoeding van de schade voldoende anderszins is verzekerd, wordt geen vergoeding als bedoeld in het eerste lid toegekend.

5. Schadevergoeding wordt voldoende anderszins verzekerd als bedoeld in het vierde lid geacht in zoverre zij op basis van objectieve gegevens kan worden vastgesteld en niet afhankelijk is van een toekomstige, onzekere gebeurtenis.

6. Het bestuursorgaan kan, voor zover dit redelijk is, besluiten de schade anders dan in geld te vergoeden, waardoor de vergoeding van schade voldoende anderszins verzekerd als bedoeld in het vierde lid wordt geacht, mits zij aan de eisen uit het vijfde lid voldoet.

Ook zou de volgende bepaling aan afd. 15.1 Ow worden toegevoegd:

Van nauw met elkaar verweven gebeurtenissen als bedoeld in artikel 4:126, derde lid, van de Algemene wet bestuursrecht is sprake als:

a. de voor- en nadelen van twee of meer in artikel 15.1 lid 1 genoemde besluiten moeten worden geacht uit hetzelfde planologische regime voort te vloeien; 
b. de onder a genoemde besluiten onherroepelijk zijn op het moment van het besluit op de aanvraag ${ }^{86}$ als bedoeld in artikel 4:126, eerste lid, van de Algemene wet bestuursrecht; en

c. de intentie waarmee de onder a genoemde besluiten zijn genomen, duidt op een nauwe, onderlinge verwevenheid.

86 Door dit moment te kiezen zou de wetgever anticiperen op een door mij in paragraaf 9.1.1 voorspelde ontwikkeling in de rechtspraak. Zou de wetgever slechts de huidige jurisprudentie willen codificeren dan zou in deze bepaling moeten worden uitgegaan van het moment van indiening van de aanvraag. 


\section{Hoofdstuk 10}

\section{Procedurele voorschriften}

\subsection{INLEIDING}

In dit hoofdstuk worden de tweede en derde deelvraag en de hoofdvraag beantwoord ten aanzien van de belangrijkste procedurele voorschriften die de geselecteerde regelingen bevatten. In paragraaf 2.4.2.3 werd geconstateerd dat het samenspel van de aan de Wns ten grondslag liggende doelstellingen en uitgangspunten regelmatig voor vaststelling van (formeelwettelijke) regelgeving zou kunnen pleiten. In het vervolg van dit hoofdstuk zal blijken dat dit effect zich het sterkst voordoet ten aanzien van de inrichting van de nadeelcompensatieprocedure door titel $4.5 \mathrm{Awb}$. In dit hoofdstuk zal ik geen aandacht besteden aan de algemene wenselijkheid daarvan, omdat ik hier uitsluitend beoog na te gaan hoe de aan de Wns ten grondslag liggende doelstellingen en uitgangspunten het best kunnen worden gerealiseerd. Bij de alles overziende beantwoording van de hoofdvraag in hoofdstuk 11, zal in paragraaf 11.2.2 wel in algemene zin worden gereflecteerd op de vraag hoe de bevindingen uit dit hoofdstuk zich verhouden tot de eveneens in paragraaf 2.4.2.3 aangehaalde dereguleringstendens.

Ter beantwoording van de tweede en derde deelvraag en de hoofdvraag zal ik in paragraaf 10.2 ingaan op de eisen die worden gesteld aan de persoon van de aanvrager. Vervolgens wordt in paragraaf 10.3 stilgestaan bij de eisen waaraan de aanvraag dient te voldoen. In paragraaf 10.4 wordt aandacht besteed aan de bevoegdheid van het bestuur om een recht te heffen om de aanvraag in behandeling te nemen. In paragraaf 10.5 staat het leerstuk van verjaring centraal, waarbij ik tevens kort zal stilstaan bij het moment vanaf wanneer de aanvraag kan worden ingediend. Als is voldaan aan de eisen die aan de aanvrager en zijn aanvraag worden gesteld, het recht om de aanvraag in behandeling te nemen is voldaan, en de aanvraag niet is verjaard, zal het bestuursorgaan de aanvraag inhoudelijk moeten beoordelen. Daarbij speelt deskundigenadvisering naar huidig recht een rol die nauwelijks is te onderschatten. Illustratief daarvoor is de opmerking van Van den Broek \& Tjepkema dat de deskundige naar huidig recht de facto de hoogte van de tegemoetkoming in planschade bepaalt. ${ }^{1}$ Dit rechtvaardigt dat ik relatief uitgebreid zal stilstaan bij deskundigenadvisering. Daartoe ga ik in paragraaf 10.6 in op de bevoegdheid, en soms ook de plicht, tot raadpleging van een adviescommissie.

1 Van den Broek \& Tjepkema 2015, p. 86. Zie bijvoorbeeld ook Van Ravels 2015, p. 160-161; onderdeel 10 van de noot van Tjepkema en mijzelf bij ABRvS 17 mei 2017, ECLI:NL:RVS:2017:1293 (De Lunet) in $A B$ 2017/427; en mijn noot bij ABRvS 13 juli 2016, ECLI:NL:RVS:2016:1970 (Raalte) in AB 2016/454. 
Daarbij wordt geen aandacht geschonken aan de raadpleging van een adviescommissie naar aanleiding van een aanvraag om een voorschot. Op bevoorschotting zal namelijk afzonderlijk worden ingegaan in paragraaf 10.13. Eerst zal echter in paragraaf 10.7 aandacht worden besteed aan de samenstelling van de adviescommissie. Daarna wordt in paragraaf 10.8 stilgestaan bij de inhoudelijke eisen waaraan het advies van de adviescommissie dient te voldoen. In paragraaf $10.9 \mathrm{komt}$ aan bod hoe de adviescommissie de informatie kan vergaren die zij nodig heeft om haar adviestaak te kunnen verrichten. Vervolgens wordt in paragraaf 10.10 stilgestaan bij de mogelijkheden tot inspraak voor de aanvrager, het bestuur ${ }^{2}$ en/ of derde-belanghebbenden gedurende de primaire besluitvormingsprocedure. In paragraaf 10.11 ga ik in op de belangrijkste verschillen in termijnen die in acht moeten worden genomen gedurende deze besluitvormingsprocedure. In paragraaf 10.12 wordt aandacht geschonken aan de rechtsmiddelen die tegen het planschade- of nadeelcompensatiebesluit kunnen worden aangewend. Na bespreking van de mogelijkheid tot bevoorschotting in paragraaf 10.13, zal dit hoofdstuk in paragraaf 10.14 worden afgesloten met een conclusie in de vorm van een bundeling van de aanbevelingen die ik in dit hoofdstuk zal doen ter beantwoording van de hoofdvraag.

\section{Introductie van enkele tot op heden nog niet besproken regelingen}

Om de tweede en derde deelvraag en de hoofdvraag te kunnen beantwoorden, dient aandacht te worden besteed aan enkele regelingen die tot op heden nog niet of nauwelijks aan bod zijn gekomen. De procedurele voorschriften uit de Amsterdamse verordeningen zijn namelijk nader uitgewerkt in:

- het op grond van art. 13 lid 2 AVN vastgestelde 'Reglement adviescommissie nadeelcompensatie'; 3

- de op grond van art. 15 VNNZ vastgestelde 'Regeling Nadeelcompensatie Noord/Zuidlijn'; en

- het op grond van art. 84 jo. 83 Gemw vastgestelde 'Reglement Schadecommissie Noord/Zuidlijn' ${ }^{4}$

Voorts is op grond van art. $10 \mathrm{GrS}$ een procedureverordening vastgesteld voor de afhandeling van aanvragen die onder de reikwijdte van de GrS vallen. Aanvankelijk betrof dit de in 1999 vastgestelde 'Verordening schadeschap Luchthaven Schiphol' (hierna: VS 1999). Deze verordening kwam grotendeels woordelijk overeen met art. $3 \mathrm{t} / \mathrm{m} 10 \mathrm{RnR}$ 1991, omdat het inmiddels geschrapte tweede en

2 Hiermee doel ik op mogelijkheden van het bestuur om zijn standpunt kenbaar te maken bij de adviescommissie.

3 Art. $17 \mathrm{AVN}$ biedt eveneens mogelijkheid tot vaststelling van nadere regelgeving, maar daarvan is tot op heden nog geen gebruik gemaakt.

4 Zie p. 21 van de toelichting behorende bij de VNNZ onder het kopje 'Bestuurlijke achtergrond'. 
derde $^{5}$ lid van art. $10 \mathrm{GrS}$ daartoe verplichtte. ${ }^{6}$ Deze verordening werd in 2012 omgedoopt tot de 'Verordening Schadeschap Luchthaven Schiphol 2012' (hierna: VS 2012). Naar aanleiding van een op aanvraag van het Schadeschap door Van Ettekoven en Tjepkema uitgebracht rapport, werden daarbij enkele wijzigingen doorgevoerd om de "juridische doelmatigheid van de besluitvorming van het Schadeschap te verbeteren." 7

Ten slotte is in art. 6.7 Wro bepaald dat bij of krachtens algemene maatregel van bestuur regels kunnen worden gesteld omtrent de inrichting en behandeling, en nadere regels omtrent de indiening, de motivering en de wijze van beoordeling, van een aanvraag om tegemoetkoming in planschade. Op grond hiervan zijn procedurele voorschriften vastgesteld in afd. 6.1 Besluit ruimtelijke ordening (hierna: Bro). ${ }^{8}$ In art. 6.1.3.3 lid 1 Bro is bepaald dat bij gemeentelijke verordening, provinciale verordening en bij regeling van de minister van Volkshuisvesting, Ruimtelijke Ordening en Milieubeheer (thans: Infrastructuur \& Waterstaat) regels dienen te worden gegeven "over de aanwijzing van een adviseur en de wijze waarop deze tot een advies komt." Het tweede lid specificeert op welke onderwerpen deze regels in ieder geval betrekking dienen te hebben. Mij is echter niet bekend dat de minister ooit dergelijke regelgeving heeft vastgesteld. Wellicht meende hij reeds aan deze verplichting te hebben voldaan door middel van de (voorgangers van de) BnIW 2019. Omdat het onmogelijk is om iedere gemeentelijke verordening te vergelijken, zal - indien de onderzoeksvragen daar aanleiding toe geven - worden ingegaan op de modelverordening van de VNG, waarbij veel gemeenteraden aansluiting hebben gezocht. ${ }^{9}$

$5 \quad$ Op grond van het derde lid kon de in art. 5 lid 3 RnR 1991 opgenomen termijn om een adviescommissie in te stellen, worden opgeschort tot het moment van onherroepelijk worden van de schadeoorzaak.

6 Stcrt. 1998, nr. 223, art. 10 lid 2 en lid 3. Vanwege de inwerkingtreding van de RnVW 1999 werden beide artikelleden betrekkelijk laat (in 2013) en ook inhoudelijk ongelukkig - ook een deel van de materiële bepalingen uit de RnVW 1999 werd ten onrechte van overeenkomstige toepassing verklaard - aangepast. Zie Stcrt. 2013, nr. 13275, art. 10 lid 2 en lid 3. Dat zal ik hier laten rusten, omdat deze wijziging niet van invloed was op de vaststelling van de VS 2012, en de artikelleden nadien zijn geschrapt omdat zij overbodig waren geworden door de VS 2012. Zie daarvoor Stcrt. 2015, nr. 16721, onderdeel G en p. 5.

7 Dit rapport is nooit gepubliceerd. Enige informatie over de inhoud blijkt uit Stcrt. 2012, nr. 8910, p. 5 e.v., en ABRvS 6 december 2017, ECLI:NL:RVS:2017:3304 (BARIN).

$8 \quad$ Stb. 2010, nr. 145.

9 Deze modelverordening is niet gepubliceerd voor het grote publiek. Ik heb haar in juli 2016 per mail ontvangen van een medewerker van de VNG. De tekst van de verordening en de bijbehorende toelichting lijken echter woordelijk te zijn overgenomen bij vaststelling van de 'Procedureverordening voor advisering tegemoetkoming in planschade 2008' door de gemeenteraad van Wierden. 


\subsection{EISEN DIE WORDEN GESTELD AAN DE AANVRAGER}

\subsubsection{Deelvraag 2: Huidig recht}

De geselecteerde regelingen verschillen qua terminologie als het aankomt op de persoon die een aanvraag om nadeelcompensatie kan indienen. Op grond van art. 6.1 lid 1 Wro kan een 'aanvraag' worden ingediend door 'degene die (...) schade lijdt of zal lijden'. In art. 49 WRO werd nog gesproken van een 'aanvraag' van een 'belanghebbende'. In art. 9 GrS wordt gesproken van een 'aanvraag', maar de VS 2012 spreekt van een 'verzoek' dat wordt ingediend door een 'verzoeker'. ${ }^{10}$ De BnIW 2019 gaat uit van een 'verzoek' dat wordt ingediend door een 'verzoeker' die 'schade lijdt of zal lijden'. ${ }^{11}$ De VNNZ bezigt de term 'aanvrager', waaronder blijkens art. 1, aanhef en onder b VNNZ wordt verstaan een 'natuurlijke of rechtspersoon, niet zijnde een bestuursorgaan in de zin van artikel 1:1, eerste lid, aanhef en onder b, van de Algemene wet bestuursrecht.' De AVN spreekt op haar beurt van een 'aanvraag van degene die schade heeft geleden'. ${ }^{12}$

Ik heb geen expliciete verklaringen voor deze verschillen in terminologie kunnen vinden. Dat de Wro en de Amsterdamse verordeningen de voorkeur geven aan de termen 'aanvraag' en 'aanvrager' kan waarschijnlijk worden verklaard doordat art. 1:3 lid 3 Awb een aanvraag definieert als 'een verzoek van een belanghebbende, een besluit te nemen'. De Awb bestond nog niet ten tijde van de totstandkoming van art. 49 WRO, maar het is duidelijk dat de wetgever destijds van mening was dat sprake moest zijn van iemand die belang had bij het gewenste besluit omtrent planschadevergoeding. De wetgever blijkt echter bewust ervoor te hebben gekozen om in art. 6.1 Wro niet langer te spreken van een 'belanghebbende'. ${ }^{13}$ Uit de parlementaire stukken bij de Wro wordt niet duidelijk welke beweegredenen hieraan ten grondslag liggen. Mogelijk werd beoogd om onduidelijkheid over mogelijke verschillen tussen het belanghebbendebegrip van de WRO en de Awb te voorkomen of weg te nemen. ${ }^{14}$ Dat zowel de VS 2012 als de BnIW 2019 de voorkeur geven aan de termen 'verzoek' en 'verzoeker' kan worden verklaard doordat beide regelingen in de RnR 1991 een gemeenschappelijke voorouder kennen die deze terminologie bezigde. Waarom de minister daarin niet aansloot bij het destijds al aanhangige voorstel voor art. 1:3 lid $3 \mathrm{Awb}^{15}$ is niet duidelijk. ${ }^{16}$

10 Zie bijvoorbeeld art. 1 aanhef en onder e jo. art. 3 VS 2012.

11 Zie bijvoorbeeld art. 1 jo. art. 2 lid 1 BnIW 2019. In art. 13 lid 3 BnIW 2019 wordt eenmalig van 'aanvraag' gesproken.

12 Zie bijvoorbeeld art. 2 lid $1 \mathrm{AVN}$.

13 Kamerstukken II 2002/03, 28 916, nr. 3, p. 111 (MvT, Wro).

14 Zie in dit verband bijvoorbeeld Van Ravels 2006b, p. 257, voetnoot 10; en Van den Broek 2004, p. 644.

15 Kamerstukken II 1988/89, 21 221, nr. 1-2.

16 Elders in de RnR 1991 werd wel aansluiting gezocht bij het wetsvoorstel voor de Awb. Zie daarover Stcrt. 1991, nr. 251, p. 28; en paragraaf 10.9.1. 
Voor zover ik heb kunnen nagaan, beoogden de regelgevers met deze verschillen in terminologie geen materieelrechtelijke verschillen. Dergelijke verschillen blijken ook niet uit de jurisprudentie. De Afdeling is duidelijk in haar beantwoording van de vraag wie een aanvraag om vergoeding van planschade kan indienen:

"Ingevolge artikel 1:2, eerste lid, van de Algemene wet bestuursrecht (hierna: de Awb), wordt onder belanghebbende verstaan: degene wiens belang rechtstreeks bij een besluit is betrokken. $\mathrm{Nu}$ [appellanten sub 3] in het verzoek gemotiveerd hebben gesteld dat zij in persoon en als vennoten inkomens- en omzetschade lijden ten gevolge van het nieuwe bestemmingsplan, hebben zij belang bij een inhoudelijke beoordeling van hun verzoek."17

Ik heb geen aanleiding om aan te nemen dat zij anders zou oordelen in een nadeelcompensatiegeschil. Ik ga daarom ervan uit dat onder alle geselecteerde, thans geldende regelingen geldt dat iemand als belanghebbende moet kunnen worden aangemerkt om voor compensatie in aanmerking te komen. Daartoe zal de benadeelde gemotiveerd moeten stellen dat hij schade heeft geleden of zal gaan lijden. Slaagt hij daarin, dan brengt dit mee dat zijn aanvraag om nadeelcompensatie of tegemoetkoming in planschade moet worden aangemerkt als een aanvraag van een beschikking als bedoeld in art. 1:3 lid 3 jo. lid 2 Awb, die inhoudelijk door het bestuur moet worden beoordeeld. Een verzoek om nadeelcompensatie of tegemoetkoming in planschade van een niet-belanghebbende zal het 'dictum' van een afgewezen aanvraag krijgen. De Awb kent namelijk geen mogelijkheid tot het niet-ontvankelijk verklaren van een verzoek of aanvraag. ${ }^{18}$

\subsubsection{Deelvraag 3: Toekomstig recht}

De bij titel 4.5 Awb en afd. 15.1 Ow behorende Kamerstukken geven geen aanleiding om aan te nemen dat onder deze regelingen ook andere personen dan belanghebbenden een aanvraag om nadeelcompensatie kunnen indienen die inhoudelijk door het bestuur dient te worden beoordeeld. Dit lijkt te worden bevestigd doordat beide regelingen de termen 'aanvraag' en 'aanvrager' bezigen. Soms wordt echter gesproken van 'benadeelde' terwijl ook de term 'aanvrager' had kunnen worden gebezigd. ${ }^{19}$

\subsubsection{Hoofdvraag: spiegeling aan de doelstellingen en uitgangspunten die ten grondslag liggen aan de Wns}

Het past goed bij het uitgangspunt van aansluiting bij de Awb, en de doelstelling van vergroting van de doelmatigheid van het nadeelcompensatierecht en vermindering van bestuurslasten dat slechts belanghebbenden een aanvraag om nadeel- 
compensatie kunnen indienen die inhoudelijk door het bestuur dient te worden beoordeeld. Gelet op de doelstelling van vergroting van de rechtszekerheid, en het uitganspunt van aansluiting bij de Awb verdient het mijns inziens aanbeveling dat de term 'benadeelde' in zowel titel 4.5 Awb als afd. 15.1 Ow zoveel mogelijk wordt vervangen door aanvrager. Wat dat betreft zie ik dus aanleiding tot (a) aanpassing van titel 4.5 Awb en (b) aanpassing van afd. 15.1 Ow. Deze aanbeveling zal ik betrekken in de bundeling van concrete voorstellen voor regelgeving bij de alles overziende beantwoording van de hoofdvraag in hoofdstuk 11. Ik zie geen aanleiding tot (c) het anderszins voorzien in een bijzondere invulling, aanvulling of afwijking van titel 4.5 Awb.

\subsection{EISEN DIE WORDEN GESTELD AAN DE AANVRAAG}

\subsubsection{Deelvraag 2: verschillen tussen de geselecteerde, thans geldende} regelingen en verklaringen daarvoor

\section{Algemeen wettelijk kader}

De algemene eisen uit afd. 4.1.1 Awb zijn ook van toepassing op aanvragen die worden ingediend onder de geselecteerde, thans geldende regelingen. Deze afdeling bevat namelijk hoofdzakelijk bepalingen van dwingendrechtelijke aard. Zij bevat ook een aantal mogelijkheden tot afwijking bij wettelijk voorschrift, maar daarvan wordt geen gebruik gemaakt door de geselecteerde, thans geldende regelingen. Wel verwijzen deze regelingen, ${ }^{20}$ of de daarbij behorende toelichtingen naar de bepalingen uit afd. 4.1.1 Awb. ${ }^{21}$ Het van toepassing zijn van deze afdeling heeft tot gevolg dat aan iedere aanvraag enkele basiseisen worden gesteld. Zo dient de aanvraag schriftelijk te worden ingediend bij het bestuursorgaan dat bevoegd is daarop te beslissen (art. 4:1 Awb). Verder moet de aanvraag enkele algemene gegevens bevatten, namelijk de naam en het adres van de aanvrager, de dagtekening en een aanduiding van de beschikking die wordt gevraagd (art. 4:2 lid 1 Awb). Tevens dient de aanvrager alle gegevens en bescheiden die voor het beslissen op de aanvraag nodig zijn en waarover hij redelijkerwijs de beschikking kan krijgen, aan het bestuur te verschaffen (art. 4:2 lid 2 Awb). Voorts kan het bestuursorgaan dat bevoegd is op de aanvraag te beslissen op grond van art. 4:4 Awb een formulier vaststellen voor de indiening van de aanvraag en het verstrekken van gegevens. Ten slotte blijkt uit art. 4:5 Awb dat een gebrekkige aanvraag buiten behandeling kan worden gelaten nadat de aanvrager tevergeefs een termijn

20 Art. 6.1.2.2 Bro verwijst naar art. 4:2 Awb.

21 Zie bijvoorbeeld Kamerstukken II 2002/03, 28 916, nr. 3, p. 113 (MvT, Wro); Stcrt. 1999, nr. 172, p. 11 (digitaal, p. 11-12); de toelichting op art. 9 lid 3 AVN; en de toelichting op art. 11 lid 2 en art. 12 VNNZ. Voor de GrS/VS 2012 kan worden verwezen naar de toelichting op art. 2 lid 2 jo. lid 3 RnR 1991. Zie daarvoor Stcrt. 1991, nr. 251, p. 28. 
is geboden om de door het bestuur geconstateerde gebreken te herstellen. Op deze bepaling zal ik nader ingaan in paragraaf 10.11.1.

\section{Verschillen tussen de geselecteerde, thans geldende regelingen}

Een vergelijking tussen de geselecteerde, thans geldende regelingen laat allereerst zien dat deze regelingen allemaal (een deel van) art. 4:2 Awb herhalen, behalve de VNNZ. ${ }^{22}$ Voor de BnIW 2019 en VS 2012 kan dit worden verklaard doordat deze regelingen zijn gebaseerd op de RnR 1991. Uit de bij die regeling behorende toelichting blijkt dat de minister met de desbetreffende bepalingen beoogde om "het bepaalde in artikel 4.1.1.2 voorstel Algemene wet bestuursrecht (lees: art. 4:2 Awb) ${ }^{23}$ nader betekenis te geven voor verzoeken om schadevergoeding." 24 In de RnR 1991 kon niet worden volstaan met een verwijzing naar de Awb, omdat deze wet destijds nog niet in werking was getreden. Dat was wel het geval toen de RnR 1991 werd opgevolgd door de RnVW 1999 en VS 1999. Kennelijk hebben de verantwoordelijke regelgevers destijds, en ook daarna, geen aanleiding gezien om de overlap met art. 4:2 Awb op te heffen. Wellicht heeft daarbij een rol gespeeld dat deze overlap het voor de aanvrager mogelijk maakt om de belangrijkste algemene eisen waaraan zijn aanvraag dient te voldoen uit de desbetreffende nadeelcompensatieregeling af te leiden, zonder ook de Awb te hoeven raadplegen. Dit praktische argument zou ook een rol kunnen hebben gespeeld bij de totstandkoming van het Bro en de AVN. Dat de VNNZ art. 4:2 Awb helemaal niet herhaalt, kan waarschijnlijk worden verklaard doordat dit juridisch gezien niet noodzakelijk is.

Ten tweede valt op dat de bestudeerde regelingen verschillen in de mate van detail waarmee wordt beschreven aan welke eisen de aanvraag dient te voldoen. Zo geven de AVN en VNNZ per schadesoort aan welke documenten door de aanvrager moeten worden aangeleverd. Opmerkelijk is dat beide regelingen op dit punt van elkaar verschillen, terwijl zij afkomstig zijn van dezelfde regelgever. Zo eist de VNNZ bij inkomensschade de "gewaarmerkte jaarrekeningen en maandcijfers van de vijf kalenderjaren die aan het schadejaar voorafgaan, ondertekend door de directie of, bij een accountantsverklaring, ondertekend door de accountant." Bij dergelijke schade eist de AVN echter een "gewaarmerkte jaarrekening over het jaar waarin schade is geleden alsmede zo mogelijk van de jaarrekeningen over een periode van drie jaar voorafgaande aan het jaar waarin de schade is geleden. De jaarrekeningen moeten zijn voorzien van een verklaring van een accountant." ${ }^{25} \mathrm{Ik}$ heb geen verklaringen gevonden voor het verschil in gevraagde documenten en de eisen die daaraan worden gesteld. In paragraaf 5.7.1.2 bleek bovendien dat geen duidelijke verklaring bestaat voor het verschil in referentietermijn. 3 lid 2 jo. lid 3 VS 2012.

23 Eigen toevoeging.

24 Stcrt. 1991, nr. 251, p. 28.

25 Art. 11 lid 4, aanhef en onder b VNNZ en art. 9 lid 3, aanhef en onder a AVN. 
De overige geselecteerde, thans geldende regelingen bevatten geen opsomming van vereiste documenten per schadesoort. Wel zijn in deze regelingen bepalingen van meer algemene aard opgenomen. Naast een dagtekening en vermelding van de naam en het adres van de verzoeker, vereisen art. 13 lid 1 BnIW 2019 en art. 3 lid 2 VS 2012 beide: een aanduiding van het besluit of het handelen dat de schade naar het oordeel van verzoeker heeft veroorzaakt; zo redelijkerwijs mogelijk een opgave van de aard en de omvang van de schade, alsmede een specificatie van het bedrag van de schade; en een opgave van het schadebedrag dat naar het oordeel van verzoeker vergoed dient te worden. Deze eisen waren ook al terug te vinden in art. 3 RnR 1991. In de BnIW 2019 zijn nog twee extra eisen te vinden, die zijn toegevoegd bij de overgang van de RnR 1991 naar de RnVW 1999. Het betreft de vermelding van de reden of redenen waarom de minister gehouden zou zijn de schade te vergoeden die het gevolg is van de beweerde schadeoorzaak; en de omschrijving van de wijze waarop de schade naar het oordeel van verzoeker dient te worden vergoed en, zo een vergoeding in geld wordt gewenst, een opgave van het schadebedrag, dat naar het oordeel van verzoeker vergoed dient te worden. ${ }^{26}$

Ook art. 6.1 lid 3 Wro stelt slechts enkele algemene eisen aan de aanvraag. Deze dient namelijk een motivering, alsmede een onderbouwing van de hoogte van de gevraagde tegemoetkoming te bevatten. Art. 6.1.2.2 lid 1 Bro vult deze motiveringsplicht nader in. ${ }^{27}$ De aanvraag dient op grond van deze bepaling namelijk eveneens te bevatten: een aanduiding van de beweerde, in art. 6.1 lid 2 Wro voorkomende schadeoorzaak; een aanduiding van de aard van de schade; en een omschrijving van de wijze waarop aan de schade naar het oordeel van de aanvrager tegemoet dient te worden gekomen indien hij geen vergoeding in geld wenst.

Gelet op de stand van het nadeelcompensatierecht ten tijde van de totstandkoming van de RnR 1991 zal de minister mogelijkerwijs nog niet veel inzicht hebben gehad in de documenten die doorgaans noodzakelijk zijn voor de beoordeling van een aanvraag om nadeelcompensatie. Dat inzicht bestaat thans wel, maar heeft tot op heden nog niet ertoe geleid dat in de BnIW 2019, VS 2012, en/of de Wro of het Bro een concretisering is aangebracht omtrent de documenten die de aanvrager dient aan te leveren. Daarvoor heb ik geen expliciete verklaring gevonden, maar het lijkt aannemelijk dat de desbetreffende regelgevers een dergelijke concretisering vooralsnog niet noodzakelijk en/of wenselijk achten. Mogelijk speelt daarbij een rol dat formulieren als bedoeld in art. 4:4 Awb zijn opgesteld waarmee onder

26 Zie art. 13 lid 1 onder d en g BnIW 2019. Bij de overgang naar de BnIW 2019 werd een redactionele fout hersteld die was gemaakt bij de vaststelling van art. $13 \mathrm{RnVW}$ 1999. Zie daarover Stcrt. 2019, nr. 66154, p. 17.

27 Stb. 2008, nr. 145, p. 64-65. Het tweede lid biedt de mogelijkheid tot vaststelling van nadere regels bij ministeriële regeling. Bij mijn weten is daar nooit van gebruikgemaakt. 
deze regelingen een aanvraag om compensatie kan worden ingediend. ${ }^{28}$ Het bestaan van dit soort formulieren weerhield de Amsterdamse gemeenteraad er kennelijk niet van om wel gedetailleerde eisen omtrent aan te leveren documenten in zijn verordeningen op te nemen. ${ }^{29}$ Ten slotte is denkbaar dat de bewuste regelgevers het niet goed mogelijk achten om in algemene zin aan te geven welke documenten een aanvraag om compensatie dienen te vergezellen. Welke documenten nodig zijn, zal immers deels afhankelijk zijn van de wijze waarop de beweerdelijk door aanvrager geleden schade wordt begroot. In paragraaf 5.7 bleek echter dat de wijze waarop schade (het best) kan worden begroot sterk afhankelijk is van de omstandigheden van het individuele schadegeval.

\subsubsection{Deelvraag 3: Toekomstig recht}

Vanwege de gelaagde structuur van de Awb zijn de algemene bepalingen van afd. 4.1.1 Awb ook van toepassing op aanvragen om nadeelcompensatie op grond van titel 4.5 Awb. ${ }^{30}$ Dat geldt ook voor aanvragen die tevens onder de reikwijdte van afd. 15.1 Ow vallen. Deze afdeling stelt namelijk geen nadere of afwijkende eisen aan de aanvraag. ${ }^{31}$ De uit art. 4:2 lid 2 Awb voortvloeiende eis dat de aanvrager alle gegevens en bescheiden aanlevert die voor het beslissen op de aanvraag nodig zijn en waarover hij redelijkerwijs de beschikking kan krijgen, brengt onder andere mee dat de aanvrager in beginsel een kopie van het schadeveroorzakende besluit dient te overleggen. Dat kan blijkens de bij de Wns behorende memorie van toelichting echter niet altijd van de aanvrager worden verlangd, bijvoorbeeld omdat de schadeveroorzakende besluitvorming te complex en/of omvangrijk kan zijn.

De algemene bepalingen van afd. 4.1.1 Awb worden aangevuld door art. 4:127 Awb. Daarin is bepaald dat de aanvraag mede een aanduiding van de schadeveroorzakende gebeurtenis, een opgave van de aard van de geleden of te lijden schade en, voor zover redelijkerwijs mogelijk, het bedrag van de schade en een specificatie daarvan moet bevatten. In de bij de Wns behorende memorie van toelichting wordt opgemerkt dat de aanvrager hiertoe bijvoorbeeld een "taxatierapport van een deskundige" kan overleggen. Ook wordt verwezen naar Afdelingsjurispruden-

28 Zie voor de formulieren van I\&W: www.rijkswaterstaat.nl/over-ons/contact/schade-en-compensatie/nadeelcompensatie.aspx\#139316. Zie voor de Wro: Kamerstukken II 2002/03, 28 916, nr. 3, p. 113 (MvT, Wro) en zoek via google op 'formulier planschade'. Zie voor de VS 2012: Stcrt. 1998, nr. 223, p. 9 (digitaal); en http://schadelab.mcnolia.nl/images/pdf/schadeformpart.pdf.

29 De formulieren voor de indiening van een aanvraag onder de AVN zijn te vinden op www.amsterdam.nl/bestuur-organisatie/organisaties/organisaties/schadeloketalgemene/. De formulieren die betrekking hadden op de VNNZ zijn niet meer online te raadplegen. Zie bijvoorbeeld wel de toelichting op art. $11 \mathrm{VNNZ}$.

30 Zie hierover bijvoorbeeld Kamerstukken II 2010/11, 32 621, nr. 3, p. 20-21 (MvT, Wns).

31 Zie hierover ook Kamerstukken II 2018/19, 34 986, nr. 3, p. 225 (MvT, IOw). 
tie waaruit blijkt dat het op de weg van de aanvrager ligt om gegevens en bescheiden te overleggen die het bestuur nodig heeft om te kunnen vaststellen of aanvrager de door hem gestelde schade daadwerkelijk heeft geleden, en deze schade het gevolg is van de beweerde schadeoorzaak. ${ }^{32}$ Daarbij is volgens de Afdeling van belang dat "bij een op het égalité-beginsel gebaseerd verzoek om schadevergoeding (...) de bewijslast in de eerste plaats op de verzoeker" rust. ${ }^{33}$ Ten slotte volgt uit de bij de Wns behorende memorie van antwoord dat de formulering "voor zover redelijkerwijs mogelijk" is opgenomen zodat het precieze schadebedrag later nog kan worden aangepast. Het is immers mogelijk dat de omvang van de schade niet meteen duidelijk is. ${ }^{34}$ Deze mogelijkheid tot aanpassing zou eveneens in overeenstemming zijn met bestaande Afdelingsjurisprudentie. ${ }^{35}$

\subsubsection{Hoofdvraag: spiegeling aan de doelstellingen en uitgangspunten die ten grondslag liggen aan de Wns}

Dat art. 4:127 Awb in aanvulling op art. 4:2 Awb enkele basiseisen stelt aan een aanvraag om nadeelcompensatie past goed bij de doelstellingen en uitgangspunten die ten grondslag liggen aan de Wns. Dit zorgt immers in beperkte mate voor vergroting van de rechtszekerheid, en vereenvoudiging, uniformering en harmonisering van het nadeelcompensatierecht. Ook is denkbaar dat deze bepaling enigszins zal leiden tot vergroting van de doelmatigheid van het nadeelcompensatierecht en vermindering van bestuurslasten. Mogelijk zal zij er immers toe leiden dat aanvragers vaker meteen de juiste gegevens aanleveren. Dat zou ertoe leiden dat het besluitvormingsproces efficiënter verloopt, doordat aanvragers minder vaak een hersteltermijn als bedoeld in art. 4:5 Awb dient te worden geboden. Deze positieve effecten zouden zich nog sterker voordoen als art. 4:127 Awb preciezer zou aangeven welke documenten van de aanvrager worden verlangd. Vanwege een van de in paragraaf 10.3.1 gevonden verklaringen voor de verschillen tussen de geselecteerde, thans geldende regelingen lijkt dit echter praktisch niet goed mogelijk: de methode van schadebegroting bepaalt welke documenten benodigd zijn, terwijl die methode sterk afhankelijk is van de omstandigheden van het individuele schadegeval. Dat laatste was ook de reden dat in paragraaf 5.7.3 niet de aanbeveling is gedaan om specifieke methoden van schadebegroting te codificeren in titel 4.5 Awb. Ten slotte moet niet uit het oog worden verloren dat het bestuur soms zelf ook al (deels) over de benodigde informatie zal beschikken, bijvoorbeeld op grond ABRvS 13 juni 2007, ECLI:NL:RVS:2007:BA7098, r.o. 2.5.1.

34 Zie daarover ook Kamerstukken II 2010/11, 32 621, nr. 3, p. 26-27 (MvT, Wns). Kamerstukken I 2012/13, 32 621, nr. C, p. 14 (MvA I, Wns). Er wordt onder andere verwezen naar ABRvS 14 januari 2009, ECLI:NL:RVS:2009:BG9741. Zie met name r.o. 2.2.1: “(...) kunnen de ten tijde van het nemen van het besluit op bezwaar geldende feiten ook nog in beroep worden onderbouwd." Uiteraard moet daarvoor geen sprake zijn van redenen waarom de stukken reeds in de bestuurlijke besluitvormingsfase hadden moeten worden ingediend, zoals het uitgangspunt van behoorlijke procesorde. 
van eerdere aanvragen, de gemeentelijke basisadministratie, of het kadaster. Dit alles in overweging nemende, doe ik geen aanbeveling tot wijziging van (a) titel 4.5 Awb of (b) afd. $15.1 \mathrm{Ow}$.

Wel geven de aan de Wns ten grondslag liggende doelstellingen en uitgangspunten aanleiding tot (c) het anderszins voorzien in bijzondere invullingen van titel 4.5 Awb. Ten eerste verdient het aanbeveling dat regelgevers en uitvoerende bestuursorganen steeds nagaan in hoeverre het mogelijk is om in titel 4.5 Awbinterpreterende regelgeving respectievelijk beleidsregels te concretiseren welke specifieke documenten de aanvrager dient aan te leveren. Het ligt voor de hand dat de mogelijkheid daartoe met name zal bestaan als de desbetreffende regeling uitsluitend ziet op schadeveroorzakend overheidshandelen dat een duidelijk af te bakenen groep burgers op min of meer gelijke wijze beïnvloedt. Ook verdient het aanbeveling dat onder titel $4.5 \mathrm{Awb}$ en afd. $15.1 \mathrm{Ow}$ wordt gewerkt met een aanvraagformulier als bedoeld in art. 4:4 Awb. Mijns inziens zou dat op centraal overheidsniveau het best kunnen geschieden door de minister van I\&W te laten nagaan of, en zo ja in hoeverre, zijn onder de BnIW 2019 gebruikte aanvraagformulier daartoe aanpassing zou behoeven. Op basis van de bevindingen van de minister zou een organisatie als de VNG een modelformulier kunnen opstellen voor de decentrale overheden. Beide aanbevelingen zijn ingegeven door de doelstellingen van uniformering en harmonisering van het nadeelcompensatierecht, ${ }^{36}$ vergroting van de rechtszekerheid, en vergroting van de doelmatigheid van het nadeelcompensatierecht en vermindering van bestuurslasten. Naar mijn mening zijn zij ook verenigbaar met de overige aan de Wns ten grondslag liggende doelstellingen en uitgangspunten.

\subsection{HEFFING VAN EEN RECHT}

10.4.1 Deelvraag 2: verschillen tussen de geselecteerde, thans geldende regelingen en verklaringen daarvoor

\section{Het planschaderecht}

De HR oordeelde in 2003 in het arrest Nunspeet/Mulder ${ }^{37}$ dat het bestuur kosten van vergoeding van planschade slechts rechtmatig bij wijze van overeenkomst op een derde kan afwentelen als het daartoe beschikt over een formeelwettelijke grondslag. Naar aanleiding hiervan heeft de wetgever dergelijke grondslagen opgenomen in art. 49a WRO en art. 6.4a Wro. Op deze bepalingen zal met name worden ingegaan in paragraaf 10.12 . Voor de onderhavige paragraaf is van belang dat het kabinet het wetsvoorstel dat uiteindelijk tot de vaststelling van art. 49a

36 Mogelijk leidt het werken met een (model)formulier ook tot vereenvoudiging van het nadeelcompensatierecht, omdat hierdoor de noodzaak tot raadpleging van lagere regelgeving afneemt. 
WRO leidde, beperkt in omvang wilde houden. De spoedige totstandkoming van een wettelijke grondslag voor planschadeverhaalsovereenkomsten mocht namelijk niet in gevaar komen. ${ }^{38}$ De Tweede Kamer uitte echter de wens om tevens enkele bepalingen aan de WRO toe te voegen uit het destijds reeds aanhangige wetsvoorstel voor afd. 6.1 Wro. Dit leidde uiteindelijk tot de introductie van art. 49 lid 3 en lid 4 WRO, twee artikelleden die inhoudelijk overeenkomen met art. 6.4 Wro. ${ }^{39}$ Uit beide bepalingen volgt de plicht voor B\&W om een recht van $€ 300$ van de aanvrager te heffen, dat hij terugkrijgt als op zijn aanvraag geheel of ten dele positief wordt beslist.

Met de invoering van de verplichte heffing van dit recht werd beoogd te lichtvaardige indiening van aanvragen om compensatie tegen te gaan. Dat werd nodig geacht omdat onder de WRO vijftig tot zestig procent van de aanvragen om planschadevergoeding zou worden afgewezen. ${ }^{40}$ Tweede Kamerleden van de PvdAfractie gaven aan te beseffen dat "gelukszoekers ontmoedigd moeten worden", maar tegelijkertijd te hechten aan een "goede toegankelijkheid van de rechtsgang". Zij stelden daarom de vraag of de regering overwoog de hoogte van het recht te differentiëren, bijvoorbeeld aan de hand van de WOZ-waarde van de onroerende zaak van de aanvrager. ${ }^{41}$ De minister antwoordde dat werd beoogd het toenemende aantal aanvragen om planschadevergoeding "binnen redelijke grenzen te houden, zonder dat een werkelijk benadeelde daar de dupe van behoeft te worden." Hij was echter geen voorstander van differentiatie vanwege de beperkte hoogte van het recht en de plicht tot terugbetaling van het recht bij honorering van de aanvraag. ${ }^{42}$ Toch is bij amendement de mogelijkheid gecreëerd om de hoogte van het recht met maximaal twee derde deel te verhogen (tot $€ 500$ ) of verlagen (tot $€ 100$ ) bij verordening van de plaatselijke gemeenteraad. Hiervan zou gebruik moeten worden gemaakt als de lokale omstandigheden daartoe aanleiding geven. ${ }^{43}$

Op grond van art. 6.4 lid 2 Wro maken B\&W de aanvrager kenbaar dat, en hoe hij het recht dient te voldoen. Als hij het verschuldigde bedrag niet binnen vier weken na indiening van de aanvraag heeft betaald, moeten B\&W zijn aanvraag

38 Kamerstukken II 2003/04, 24 940, nr. 7, p. 1-2 (NV II). Zie bijvoorbeeld ook Kamerstukken II 2004/05, 30 218, nr. 3, p. 15 en 39 (MvT).

39 Kamerstukken II 2003/04, 29 490, nr. 6, p. 2-3 (Verslag II). Zie voor de publicatie van de uiteindelijk aangenomen wet: Stb. 2005, nr. 305 'Wet van 8 juni 2005 tot wijziging van de Wet op de Ruimtelijke Ordening (verjaring van en heffing bij planschadevergoedingsaanspraken, alsmede planschadevergoedingsovereenkomsten)'. Kamerstukken II 2002/03, 28 916, nr. 3, p. 65 (MvT, Wro). Kamerstukken II 2003/04, 29 490, nr. 6, p. 4-5 (Verslag II).

42 Kamerstukken II 2003/04, 24 940, nr. 7, p. 5 (NV II).

43 Kamerstukken II 2003/04, 29 490, nr. 11 en 12 (Amendement Verdaas \& Van Bochove). Het amendement zag op het wetsvoorstel tot aanpassing van art. $49 \mathrm{WRO}$, maar leidde ook tot aanpassing van het wetsvoorstel voor art. 6.4 Wro. Zie daarvoor Kamerstukken II 2004/05, 28 916, nr. 15, onderdeel K en de toelichting daarop op p. 7 (vierde nota van wijziging, Wro). 
niet-ontvankelijk verklaren, tenzij de aanvrager niet in verzuim was. ${ }^{44}$ De bepaling uit de Wro heeft "zelfstandige betekenis" ten opzichte van art. 4:5 Awb. Dit heeft tot gevolg dat de aanvrager geen hersteltermijn hoeft te worden geboden als het recht niet tijdig is voldaan. Tevens betreft de niet-ontvankelijkverklaring geen geheel of gedeeltelijk afwijzend besluit als bedoeld in art. 4:6 lid 1 Awb. Daardoor kan een nieuwe aanvraag van dezelfde aanvrager niet worden afgedaan met toepassing van art. 4:6 lid $2 \mathrm{Awb}^{45}$

\section{De AVN}

Op grond van art. 9 lid 4 AVN wordt eveneens een recht van $€ 300$ geheven van de aanvrager. Op grond van art. 7, aanhef en onder d AVN komt dit recht voor vergoeding in aanmerking als de aanvraag om nadeelcompensatie geheel of gedeeltelijk wordt toegewezen. Net als in het planschaderecht wordt hiermee beoogd te voorkomen dat aanvragen om compensatie te lichtvaardig worden ingediend. Voor het bedrag van $€ 300$ is gekozen omdat dit goed aansluit op art. 6.4 Wro en het voorontwerp van de Wns. ${ }^{46}$ Anders dan onder de Wro, bestaat onder de AVN geen mogelijkheid tot wijziging van de hoogte van het recht. Dat kan waarschijnlijk worden verklaard doordat de AVN slechts van toepassing is op één gemeente, waardoor geen algemene reden tot differentiatie bestaat. Net als onder de Wro, dient het recht binnen vier weken na ontvangst van de aanvraag te zijn voldaan. Is dat niet het geval dan schrijft de bepaling uit de AVN voor dat het gemeentebestuur de aanvraag buiten behandeling laat, tenzij de aanvrager niet in verzuim was. Dit verschilt in ieder geval qua terminologie van de bepaling uit de Wro. Die spreekt immers van niet-ontvankelijk verklaren van de aanvraag. Het is onduidelijk of dit verschil in terminologie ook een materieelrechtelijk verschil meebrengt. Ik sluit niet uit dat dit het geval is, aangezien de bepaling uit de AVN qua terminologie aansluit bij art. 4:5 lid 1 Awb. ${ }^{47}$

De vraag naar het bestaan van dit mogelijke verschil in rechtsgevolg is mijns inziens echter ondergeschikt aan de vraag of art. 9 lid 4 AVN wel rechtmatig is. De aanleiding tot die tweede vraag wordt gevormd door een arrest van 13 augustus 2004 waarin de HR oordeelde dat het behandelen van een aanvraag om planschadevergoeding niet kwalificeert als een dienst als bedoeld in art. 229 lid 1, aanhef en onder b Gemw. Bij de behandeling van een aanvraag om planschadevergoeding draait het namelijk "rechtstreeks en vooral om het dienen van het publieke belang". Omdat het belang van de gemeente hiermee niet minder is gediend dan

44 Mogelijk kan daaromtrent aansluiting worden gezocht bij jurisprudentie over verschoonbare termijnoverschrijding inzake art. 6:11 Awb. Zie voor een voorbeeld daarvan Hof Den Haag 20 december 2013, ECLI:NL:GHDHA:2013:5079, r.o. 8.3 en 3.6.

45 ABRvS 14 maart 2012, ECLI:NL:RVS:2012:BV8790, r.o. 2.4.1.

46 Zie art. 4.5.3 lid 1 van het voorontwerp, dat net als art. 4:128 lid 1 Awb uitgaat van een recht van $€ 500$.

$47 \quad$ Zie ook de toelichting op art. 9 lid 4 AVN. 
het belang van de aanvrager, bestaat volgens de Afdeling geen reden "een uitzondering te maken op de regel dat de kosten van publieke taakuitoefening in beginsel niet ten laste van een individuele bij die taak betrokken burger kunnen worden gebracht." ${ }^{48} \mathrm{Na}$ een analyse van deze uitspraak in samenhang met vergelijkbare jurisprudentie komt annotator De Groot tot de conclusie dat de kosten die samenhangen met publieke taakoefening niet ten laste van de individuele burger kunnen worden gebracht, tenzij de formele wet daarvoor uitdrukkelijk een grondslag biedt. ${ }^{49}$ Ik zie geen reden om aan te nemen dat dit anders is voor de behandeling van een aanvraag om nadeelcompensatie. $\mathrm{Nu}$ een dergelijke grondslag ontbreekt in geval van art. 9 lid 4 AVN, heb ik sterke twijfels omtrent de rechtmatigheid van de door deze bepaling voorschreven heffing. Daaraan zal echter geen verdere aandacht worden besteed, aangezien dit probleem door inwerkingtreding van art. 4:128 lid 1 Awb zal worden verholpen. ${ }^{50}$

\section{De VNNZ}

De VNNZ bevat geen bepaling omtrent de heffing van een recht. Mogelijk kan dit worden verklaard door het hiervoor besproken arrest van 13 augustus 2004. Dat arrest weerhield de Amsterdamse gemeenteraad echter niet ervan de mogelijkheid tot heffing van een recht wel in de AVN op te nemen. Daarom sluit ik niet uit dat mogelijk (ook) een rol heeft gespeeld dat de AVN een geheel nieuwe regeling is - die werd afgestemd op afd. 6.1 Wro en het voorontwerp van de Wns. De VNNZ is echter gebaseerd op de uit 2001 afkomstige Verordening Nadeelcompensatie en Planschade Noord/Zuidlijn, die eveneens geen bepaling omtrent de heffing van een recht bevatte. Uit de toelichtingen behorende bij deze verordeningen blijkt niet dat de Amsterdamse gemeenteraad zich zorgen maakte over een teveel aan lichtvaardig ingediende aanvragen om nadeelcompensatie.

\section{De BnIW 2019 en VS 2012}

Ook de BnIW 2019 en VS 2012 bevatten geen bepaling omtrent de heffing van een recht. Dat kan deels worden verklaard doordat een dergelijke bepaling ook niet voorkwam in de gemeenschappelijke voorouder van deze regelingen, de RnR 1991. Ook uit de toelichtingen behorende bij deze regelingen blijkt niet expliciet van een vrees voor lichtvaardig ingediende aanvragen. Impliciet is die zorg wel terug te vinden in de toelichtingen op de BnIM 2014 en BnIW 2019, maar blijkt de minister voor een andere oplossing te hebben gekozen. In art. 3 lid 2 BnIM 2014 en art. 3 lid 2 BnIW 2019 zijn namelijk bagateldrempels opgenomen. ${ }^{51}$ Het eerder

48 HR 13 augustus 2004, ECLI:NL:HR:2004:AI0408, r.o. 3.4.

49 Zie zijn annotatie in $A B$ 2005/360.

$50 \quad$ Zie paragraaf 10.4.2.

51 Zie daarover paragraaf 6.1 onder het kopje 'De afbakening van het normaal maatschappelijk risico'. Een dergelijke drempel is overigens ook opgenomen in art. 3 lid 4 AVN, maar kennelijk achtte de Amsterdamse gemeenteraad dat onvoldoende om (te) lichtvaardige indiening van aanvragen tegen te gaan. 
besproken arrest van 13 augustus 2004 verklaart waarom de minister niet in de plaats daarvan kon kiezen voor de invoering van de heffing van een recht. Die verklaring gaat niet volledig op voor de VS 2012. Bij aanvragen om tegemoetkoming in planschade die onder het bereik van de GrS vallen, kan voor de heffing van een recht namelijk worden teruggevallen op art. 49 lid 3 en 4 WRO. Naar aanleiding van de invoering van deze artikelleden is een vergelijkbare grondslag opgenomen in art. 8.31 lid 2 Wlv. ${ }^{52}$ Uit de jaarrekeningen van het Schadeschap blijkt dat ook daadwerkelijk een recht van $€ 300$ van de aanvrager werd geheven. ${ }^{53}$ Een procedurele bepaling in de VS 2012 lijkt echter niet nodig te zijn geweest, omdat de te volgen procedure reeds werd beschreven door de bepalingen uit de WRO en Wlv.

\subsubsection{Deelvraag 3: Toekomstig recht}

Uit art. 4:128 lid 1 Awb volgt dat bij wettelijk voorschrift kan worden bepaald dat van de aanvrager een recht van ten hoogste $€ 500$ kan worden geheven voor het in behandeling nemen van de aanvraag. Op grond van art. 4:129, aanhef en onder c Awb komt dit recht voor vergoeding in aanmerking als het bestuur uiteindelijk besluit tot toekenning van nadeelcompensatie. Omdat afd. 15.1 Ow niets regelt omtrent de heffing van een recht, zal onder die afdeling worden teruggevallen op deze Awb-bepalingen. ${ }^{54}$ Op grond daarvan kan bijvoorbeeld de gemeenteraad in een gemeentelijke nadeelcompensatieverordening bepalen dat het college van B\&W een recht van de aanvrager mag, of zelfs moet heffen. Art. 4:128 lid 2 Awb biedt de mogelijkheid om dit bij of krachtens algemene maatregel van bestuur te doen voor bestuursorganen van de centrale overheid. Uit de bij de Wns behorende memorie van toelichting blijkt dat wordt beoogd om op die manier één uniform tarief voor de rijksoverheid vast te stellen. Ook blijkt dat met art. 4:128 Awb hetzelfde doel wordt nagestreefd als onder de Wro en AVN: het moet worden "voorkomen dat een bestuursorgaan wordt overspoeld met een overvloed aan lichtvaardig ingediende, onvoldoende onderbouwde, aanvragen." Voorts wordt beoogd een eventuele aanzuigende werking op het aantal te behandelen nadeelcompensatiezaken te voorkomen. ${ }^{55}$

Anders dan onder de Wro en AVN, is het bestuursorgaan dat op de aanvraag om nadeelcompensatie beslist niet noodzakelijkerwijs verplicht om een recht van de aanvrager te heffen. In een wettelijk voorschrift als bedoeld in art. 4:128 lid 1 Awb kan immers worden bepaald dat per individuele aanvraag zal worden beoordeeld of een recht wordt geheven, en zo ja, wat de hoogte van dat recht zal zijn, zolang

Stb. 2005, nr. 40, art. II (Wet van 23 december 2004, houdende wijziging van de Luchtvaartwet in verband met wijziging van de heffingen voor de luchthaven Schiphol). Zie hierover ook Kamerstukken II 2004/05, 29 378, nr. 14, p. 3-4, en nr. 17-18 (Amendement Haverkamp).

53 Zie bijvoorbeeld onderdeel 5.6 van de jaarrekening van 2014: http://schadelab. mcnolia.nl/images/pdf/jaarrekening_2014.pdf.

54 Kamerstukken II 2018/19, 34 986, nr. 3, p. 224-225 (MvT, IOw).

55 Kamerstukken II 2010/11, 32 621, nr. 3, p. 27, respectievelijk p. 6 (MvT, Wns). 
dit maar niet meer dan $€ 500$ bedraagt. De wetgever lijkt deze keuze te hebben gemaakt omdat verschillende overheden in wisselende mate behoefte zullen hebben aan het heffen van een recht. De wetgever lijkt ervan uit te gaan dat deze behoefte met name zal bestaan bij overheden die vaak worden geconfronteerd met aanvragen om nadeelcompensatie, al dan niet omdat zij verantwoordelijk zijn voor "grote projecten". ${ }^{56}$ Uit de memorie van toelichting blijkt niet waarom de wetgever niet heeft volstaan met een bepaling als art. 6.4 Wro: een formeelwettelijke bepaling op grond waarvan het bestuursorgaan dat bevoegd is te beslissen op de aanvraag om nadeelcompensatie direct de bevoegdheid krijgt om een recht van de aanvrager te heffen.

Uit de bij de Wns behorende memorie van toelichting blijkt wel dat het rechtsgevolg van art. 4:128 Awb verschilt van het rechtsgevolg van art. 6.4 Wro. Anders dan onder de Wro het geval is, leidt het niet (tijdig) voldoen van het verschuldigde recht namelijk niet tot het niet-ontvankelijk verklaren van de aanvraag om nadeelcompensatie, maar tot het niet in behandeling nemen van de aanvraag ex art. 4:5, eerste lid en onder a Awb. ${ }^{57}$ Art. 4:128 Awb heeft dus geen zelfstandige betekenis ten opzichte van art. 4:5 Awb. Dit heeft onder andere tot gevolg dat de aanvrager de gelegenheid moet worden geboden om het verschuldigde recht alsnog te voldoen binnen een door het bestuur gestelde termijn.

\subsubsection{Hoofdvraag: spiegeling aan de doelstellingen en uitgangspunten die} ten grondslag liggen aan de Wns

Het grootste deel van de aan de Wns ten grondslag liggende doelstellingen en uitgangspunten pleit niet voor of tegen het heffen van een recht. Een dergelijke heffing lijkt zich in ieder geval goed te verhouden tot de doelstelling van vergroting van de doelmatigheid van het nadeelcompensatierecht en vermindering van bestuurslasten. Het is immers waarschijnlijk dat aanvragers hun aanvraag extra zorgvuldig zullen voorbereiden als zij zich ervan bewust zijn dat indiening van een onsuccesvolle aanvraag tot verlies van geld (maximaal €500) kan leiden. Bovendien zullen aanvragen minder snel (te) lichtvaardig worden ingediend, hetgeen voor het bestuur ook zou kunnen leiden tot een vergroting van de rechtszekerheid. De mate waarin dat effect zich zal voordoen, zal echter deels afhangen van de invulling van de overige criteria voor toekenning van nadeelcompensatie. Zo zal (te) lichtvaardige indiening van aanvragen bijvoorbeeld ook worden tegengegaan door de gefixeerde 4\%-waardedrempel wegens normaal maatschappelijk risico van art. 15.7 lid 1 Ow. ${ }^{58}$ Het bestuur kan de afschrikkende werking van de criteria voor toekenning van nadeelcompensatie bovendien vergroten door duidelijke voorlichting te bieden omtrent de toepassing van die criteria. Mij is bekend dat Rijkswaterstaat positieve ervaringen daarmee heeft opgedaan bij de ondertunneling van de A2 te Maastricht. De voorlichting door het Infopunt Schade A2 Maastricht droeg

$56 \quad$ Kamerstukken II 2010/11, 32 621, nr. 3, p. 27 (MvT, Wns).

57 Kamerstukken II 2010/11, 32 621, nr. 3, p. 27 (MvT, Wns).

58 Zie paragraaf 6.2.2.2. 
namelijk eraan bij dat destijds nauwelijks (lichtvaardige) compensatieaanvragen zijn ingediend. Uit de Handleiding nadeelcompensatie volgt dat ook het Amsterdamse gemeentebestuur wat dit betreft positieve ervaringen heeft opgedaan door in een vroeg stadium in contact te treden met benadeelden. ${ }^{59}$ Het voorafgaande laat echter onverlet dat het niet voldoen van een recht uiteindelijk ertoe leidt dat de desbetreffende aanvraag niet hoeft te worden behandeld, terwijl inhoudelijke behandeling bijvoorbeeld wel dient plaats te vinden als de schade mogelijk kleiner is dan 4\% van de waarde van de onroerende zaak die beweerdelijk werd getroffen door een schadeoorzaak uit art. 15.1 Ow.

Wellicht wringt de heffing van een recht enigszins met het uitgangspunt van het uitsluitend codificeren van het égalitébeginsel. Het voldoen van een recht betreft namelijk geen vereiste dat voortvloeit uit het égalitébeginsel. Belangrijker is echter dat de heffing van een recht negatief kan uitpakken voor de rechtszekerheid van de burger. Dit lijkt met name het geval voor minder bedeelde huishoudens, waarvoor een bedrag van enkele honderden euro's een serieuze som geld is. Dat geldt eens te meer nu de aanvrager er gelet op de beslistermijn van art. 4:130 Awb op bedacht dient te zijn dat hij gedurende een jaar niet over dit bedrag kan beschikken. Hoewel de wetgever stelt dat "burgers of ondernemers met een serieuze aanspraak op een vergoeding (...) zich door het recht niet [zullen] laten weerhouden van indiening van een aanvraag," ${ }^{60}$ is het niet ondenkbaar dat de heffing van een recht wel degelijk zal leiden tot een vermindering van niet te lichtvaardig, maar juist terecht ingediende aanvragen om nadeelcompensatie. Uit paragraaf 10.4.1 bleek dat een mogelijke beperking van de "goede toegankelijkheid van de rechtsgang" eveneens een punt van zorg was in de Tweede Kamer tijdens de behandeling van het voorstel voor invoering van een wettelijke grondslag voor de heffing van een recht in art. 49 WRO. Een vergelijkbaar bezwaar is ook meermaals geuit ten aanzien van het inmiddels gesneuvelde wetsvoorstel kostendekkende griffierechten. ${ }^{61}$

Uit het voorafgaande volgt dat de aan de Wns ten grondslag liggende doelstellingen en uitgangspunten niet duidelijk pleiten voor behoud of schrapping van de mogelijkheid tot heffing van een recht. Omdat de wetgever bewust heeft gekozen voor de introductie van deze mogelijkheid, zal ik daarom niet aanbevelen art. 4:128 Awb en art. 4:129, aanhef en onder c Awb te schrappen. Wel zal ik hierna onderzoeken of deze bepalingen nog beter op die doelstellingen en uitgangspunten kunnen worden afgestemd.

59 Handleiding nadeelcompensatie, p. 24-28.

60 Kamerstukken II 2010/11, 32 621, nr. 3, p. 27 (MvT, Wns).

61 Zie bijvoorbeeld De Bruijn 2011, onder 'Kritiek op het wetsvoorstel'; Jaarverslag Raad voor de rechtspraak 2011, p. 9, paragraaf 1.8; Geertjes \& Huijzer 2012, p. 5; en Baks 2011, p. 145-146. 
Is de door art. 4:128 Awb voorgeschreven tussenkomst van lagere regelgevers wenselijk?

Het zou mijns inziens beter passen bij de doelstellingen van vergroting van de rechtszekerheid en vereenvoudiging, uniformering en harmonisering van het nadeelcompensatierecht als art. 4:128 Awb de bevoegdheid tot het heffen van een recht in algemene zin zou toekennen aan de bestuursorganen die toepassing geven aan titel 4.5 Awb. Dit voorkomt immers de noodzaak tot vaststelling en raadpleging van lagere regelgeving, terwijl voor iedere benadeelde burger die titel 4.5 Awb raadpleegt op voorhand duidelijk is dat van hem een recht kan worden geheven. Deze aanbeveling past wellicht wat minder goed bij het uitgangspunt van aansluiting bij de Awb. In beginsel strekt de Awb immers slechts tot regulering van bestaande bevoegdheden en niet tot toekenning van nieuwe bevoegdheden. Dit legt mijns inziens echter onvoldoende gewicht in de schaal, omdat de wetgever er in algemene zin voor heeft gekozen de bevoegdheid tot toekenning van nadeelcompensatie in art. 4:126 Awb op te nemen. De argumenten die hij daarvoor heeft aangevoerd, lenen zich voldoende voor overeenkomstige toepassing op de attributie van een algemene bevoegdheid tot het heffen van een recht in art. 4:128 Awb. ${ }^{62}$

\section{Een gedifferentieerde, of gefixeerde hoogte van het recht?}

Tijdens de behandeling van het wetsvoorstel voor invoering van een wettelijke grondslag voor de heffing van een recht in art. 49 WRO, werd voorgesteld de hoogte van dit recht te differentiëren op basis van de WOZ-waarde van de onroerende zaak van de aanvrager. ${ }^{63}$ Een dergelijke differentiatie zou in beginsel tegemoetkomen aan het eerder geuite bezwaar dat de heffing van een recht ten koste kan gaan van de rechtszekerheid van minder bedeelde huishoudens. Toch zal ik hiertoe niet aanbevelen, omdat ik dit soort differentiatie niet praktisch haalbaar acht. Zo is de grootheid van de WOZ-waarde bijvoorbeeld niet goed bruikbaar bij aanvragen ingediend door huurders (van een deel van een woning met één adres). Uiteraard zijn ook andere grootheden denkbaar, zoals het verzamelinkomen van de aanvrager. De indruk ontstaat echter dat bij dit soort grootheden al snel wrijving zou ontstaan met de doelstelling van vergroting van de doelmatigheid van het nadeelcompensatierecht en vermindering van bestuurslasten. Bezien in samenhang met de doelstellingen van vereenvoudiging, uniformering en harmonisering van het nadeelcompensatierecht, en vergroting van de rechtszekerheid en rechtsgelijkheid, leidt dit mijns inziens tot de conclusie dat het beter is de hoogte van het te heffen recht te fixeren op $€ 300$. Daarbij is van belang dat een dergelijk bedrag afschrikkende werking zal hebben, terwijl het ook nog enigszins behapbaar is voor relatief kleine inkomens. 
Buiten behandeling laten of niet-ontvankelijk verklaren van de aanvraag?

De keuze van de wetgever om bij niet-tijdige voldoening van het recht toepassing te geven aan art. 4:5, eerste lid en onder a Awb, past beter bij het uitgangspunt van aansluiting bij de Awb dan de thans door art. 6.4 Wro voorgeschreven nietontvankelijkverklaring van de aanvraag. De Awb kent van zichzelf immers geen mogelijkheid tot het niet-ontvankelijk verklaren van een aanvraag. ${ }^{64}$ Het buiten behandeling laten van de aanvraag ex art. 4:5 Awb is mijns inziens ook verenigbaar met de doelstelling van vergroting van de doelmatigheid van het nadeelcompensatierecht en vermindering van bestuurslasten. Bij het dictum van niet-ontvankelijkheid hoeft weliswaar geen hersteltermijn te worden geboden, maar is wel de kans op indiening van een nieuwe aanvraag aanwezig - hetgeen net zo goed tot bestuurslasten zou leiden.

\section{Enkele overige kanttekeningen}

Het zou mijns inziens beter bij de doelstelling van vergroting van de rechtszekerheid passen als art. 4:128 Awb zou voorschrijven dat het bestuur de aanvrager na ontvangst van diens aanvraag dient te laten weten binnen welke termijn het recht moet zijn voldaan. Ik acht dit niet onverenigbaar met de doelstelling van vergroting van de doelmatigheid van het nadeelcompensatierecht en vermindering van bestuurslasten, al is het maar omdat dit waarschijnlijk tot gevolg zal hebben dat de aanvrager minder vaak een hersteltermijn in de zin van art. 4:5 Awb dient te worden geboden. Bovendien is het ook thans al gebruikelijk dat het bestuur de aanvrager na ontvangst van de aanvraag inlicht over de procedure waarlangs zijn aanvraag zal worden behandeld. ${ }^{65}$

Ten slotte zou het beter bij de doelstelling van vergroting van de rechtszekerheid passen als niet uit art. 4:129 onder c Awb, maar uit art. 4:128 Awb zou blijken dat het geheven recht wordt terugbetaald bij een (gedeeltelijke) toewijzing van de aanvraag om nadeelcompensatie. De uit titel $4.5 \mathrm{Awb}$ voorvloeiende voorschriften omtrent de heffing van een recht worden daardoor immers geconcentreerd in één bepaling.

\section{Conclusie en concrete voorstellen}

Uit het voorafgaande volgt dat de aan de Wns ten grondslag liggende doelstellingen en uitgangspunten mijns inziens aanleiding geven om (a) titel 4.5 Awb te wijzigen. De voorgestelde wijzigingen zouden kunnen worden geïmplementeerd door onderdeel c van art. 4:129 Awb te schrappen en art. 4:128 Awb als volgt vorm te geven:

64 Zie daarover Van Ravels 2006b, p. 257; en ABRvS 15 februari 2006, ECLI:NL:RVS:2006:AV1760, r.o. 2.4. 


\section{Artikel 4:128 Awb}

1. Het bestuursorgaan is bevoegd een recht van $€ 300$ te heffen van de indiener van de aanvraag.

2. Indien het bestuursorgaan gebruikmaakt van zijn bevoegdheid uit het eerste lid, wordt in de ontvangstbevestiging als bedoeld in artikel 4:130, eerste lid ${ }^{66}$ vermeld dat het verschuldigde bedrag binnen twee weken na de dag van verzending van deze ontvangstbevestiging dient te zijn bijgeschreven op een door het bestuursorgaan aangewezen rekening dan wel te zijn gestort op een door het bestuursorgaan aangegeven plaats.

3. Indien op de aanvraag geheel of ten dele positief wordt beslist, stort het bestuursorgaan aan de indiener het door hem betaalde recht terug.

De aan de Wns ten grondslag liggende doelstellingen en uitgangspunten geven mijns inziens geen aanleiding tot (b) aanpassing van afd. 15.1 Ow. Wel zie ik aanleiding (c) anderszins in een bijzondere invulling van titel 4.5 Awb te voorzien. Het zou namelijk goed bij de doelstellingen van vergroting van de rechtszekerheid, en vergroting van de doelmatigheid van het nadeelcompensatierecht en vermindering van bestuurslasten passen wanneer het bestuur reeds in een vroeg stadium in contact zou treden met (potentiële) benadeelden teneinde voorlichting te geven over de relatief strenge voorwaarden voor toekenning van nadeelcompensatie. In de Handleiding nadeelcompensatie wordt beschreven hoe dat het best kan worden aangepakt. ${ }^{67}$

\subsection{VERJARING}

10.5.1 Deelvraag 2: verschillen tussen de geselecteerde, thans geldende regelingen en verklaringen daarvoor

Ter beantwoording van de tweede deelvraag zal ik hierna eerst ingaan op verschillen die kunnen worden verklaard door de totstandkomingsgeschiedenis van de relevante bepalingen uit de geselecteerde, thans geldende regelingen. Vervolgens wordt stilgestaan bij enkele resterende verschillen die niet of slechts anderszins kunnen worden verklaard. Ten slotte besteed ik nog enige aandacht aan verschillen met betrekking tot het moment vanaf wanneer de aanvraag mag worden ingediend.

\section{De BnIW 2019 en VS 2012}

De minister durfde het in 1991 nog niet aan om een concrete verjaringstermijn op te nemen in de RnR 1991. Daarbij was van belang dat schade soms pas lange tijd na de schadeveroorzakende overheidshandeling of besluitvorming kan intreden,

66 Hiermee verwijs ik naar de redactie van art. 4:130 Awb die ik voorstel in paragraaf 10.11.3. In deze paragraaf zal ik ook de keuze voor een betaaltermijn van twee weken toelichten.

67 Handleiding nadeelcompensatie, p. 24-28. 
of kenbaar kan worden voor de aanvrager. Ook was de minister bang dat het stellen van een concrete termijn tot gevolg zou hebben dat soms de burgerlijke rechter moest worden geadieerd, terwijl juist werd beoogd de rechtsmacht met betrekking tot nadeelcompensatiebesluiten te concentreren bij de bestuursrechter. ${ }^{68}$ In art. 3 lid 1 RnR 1991 werd daarom slechts bepaald dat een aanvraag om nadeelcompensatie "zo spoedig als redelijkerwijs mogelijk" diende te worden ingediend. Deze bepaling werd ongewijzigd overgenomen in art. 3 lid 1 VS 1999 en niet aangepast bij de overgang naar de VS 2012. Uit Afdelingsjurisprudentie blijkt dat bij toepassing van deze bepaling het algemene uitgangspunt geldt dat voor de beoordeling van de tijdigheid van een aanvraag om nadeelcompensatie aansluiting dient te worden gezocht bij de verjaringsregeling uit het BW en het daaraan ten grondslag liggende rechtszekerheidsbeginsel. ${ }^{69}$ Geïnspireerd door civielrechtelijke jurisprudentie gaat de Afdeling daarbij ervan uit dat de verjaringstermijn in beginsel begint te lopen zodra het schadeveroorzakende besluit onherroepelijk is geworden, tenzij de aanvrager op dat moment niet daadwerkelijk bekend was met de schade en de veroorzaker daarvan. De enkele kennis dat in de toekomst mogelijk schade zal worden geleden, lijkt onvoldoende om de verjaringstermijn te laten aanvangen. ${ }^{70}$

Art. 3 lid 1 RnR 1991 werd ook ongewijzigd overgenomen in art. 12 lid 1 RnVW 1999. Anders dan onder de VS 2012, koos de minister echter ervoor om deze algemene bepaling verder uit te werken in twee nieuwe artikelleden. In art. 12 lid 2 RnVW 1999 werd een concrete verjaringstermijn opgenomen:

\footnotetext{
"De minister kan een verzoek afwijzen indien vijf jaren zijn verlopen na de aanvang van de dag, volgende op die waarop de benadeelde zowel met de schade als met de omstandigheid dat deze schade is veroorzaakt door een schadeoorzaak als bedoeld in artikel 2, eerste lid bekend is geworden, en in ieder geval door verloop van twintig jaren na de gebeurtenis waardoor de schade is veroorzaakt."
}

Bovendien werd in art. 12 lid 3 RnVW 1999 een mogelijkheid tot stuiting van de verjaringstermijn neergelegd. Deze bepalingen zijn niet aangepast bij de overgang naar de BnIM 2014 en BnIW 2019. Uit de toelichting behorende bij de RnVW 1999 blijkt dat zij zijn geïnspireerd op art. 3:310 jo. art. 3:316 e.v. BW. ${ }^{71}$ Ook lijken beide bepalingen verenigbaar met de hiervoor besproken Afdelingsjurisprudentie. $^{72}$

69 ABRvS 9 november 2011, ECLI:NL:RVS:2011:BU3719, r.o. 2.6. Daarin wordt verwezen naar ABRvS 22 april 2009, ECLI:NL:RVS:2009:BI1836, r.o. 2.4.

70 ABRvS 22 augustus 2018, ECLI:NL:RVS:2018:2764, r.o. 10-10.8.

71 Stcrt. 1999, nr. 172, p. 11 (digitaal, p. 11).

72 Zie met betrekking tot stuiting specifiek ABRvS 22 augustus 2018, ECLI:NL:RVS:2018:2764, r.o. 10.7. 


\section{De AVN en VNNZ}

De Amsterdamse gemeenteraad heeft eveneens beoogd aan te sluiten bij art. 3:310 BW. ${ }^{73}$ Beide Amsterdamse verordeningen sluiten echter niet naadloos aan op de hiervoor besproken Afdelingsjurisprudentie, die uitgaat van bekendheid met de schade en het daarvoor verantwoordelijke bestuursorgaan. Art. 11 lid 3 VNNZ bepaalt namelijk dat "een aanvraag (...) uiterlijk binnen vijf jaar na het ontstaan (eigen cursivering) van het nadeel [wordt] ingediend." Volgens art. 3 lid 2 AVN kan het bestuur de aanvraag afwijzen als deze "wordt ingediend langer dan vijf jaren na de dag waarop de benadeelde op de hoogte is geraakt van de schade." Uit het derde lid blijkt dat deze vijfjaarstermijn bij schade door een appellabele schadeoorzaak niet eerder aanvangt dan nadat de schadeoorzaak onherroepelijk is geworden. Hoewel de verordeningen dus slechts ingaan op het ontstaan van respectievelijk de bekendheid met de schade, wordt in de daarbij behorende toelichtingen vermeld dat de aanvrager bekend moet zijn met de schade en het daarvoor verantwoordelijke bestuursorgaan. ${ }^{74}$ Waarom dit - anders dan bij de BnIW 2019 niet in de tekst van de regelingen is opgenomen, wordt nergens expliciet verklaard.

Mogelijk kan voor de VNNZ een verklaring worden gevonden in de gedachte dat bij de vaststelling van de VNNZ rekening is gehouden met de omstandigheid dat destijds reeds zeven jaar werkzaamheden hadden plaatsgevonden ter realisatie van de Noord/Zuidlijn. Bovendien is in de praktijk de gewoonte ontstaan dat de schade per boek- of kalenderjaar wordt vastgesteld en afgerekend. ${ }^{75}$ Deze gewoonte is neergelegd in art. 11 lid 1 VNNZ:

"Een aanvraag om nadeelcompensatie wordt eenmaal per kalenderjaar ingediend en heeft betrekking op schade, geleden in het voorafgaande kalender jaar, aan te duiden als schadejaar, waarbij voor het laatst een aanvraag kan worden ingediend in het jaar volgend op het jaar waarin de Noord/Zuidlijn daadwerkelijk in gebruik is genomen."

Aangezien de schadeperiode van veel aanvragers omstreeks 2003 is aangevangen, lijkt het onwaarschijnlijk dat het moment van ontstaan van de schade in een bepaald schadejaar niet samenvalt met het moment van bekendheid met de schade en de veroorzaker daarvan. ${ }^{76}$

Zie de toelichting op art. 3 lid 2 AVN, en de toelichting op art. 11 lid 3 VNNZ. Zie de toelichting op art. 3 lid 2 AVN, en de toelichting op art. 11 lid 3 VNNZ. Zie hierover ook onderdeel 4 onder d van de toelichting op de Verordening Nadeelcompensatie en Planschade Noord/Zuidlijn.

Deze informatie is verkregen via juristen werkzaam voor de gemeente Amsterdam. Zij gaven ook aan dat met art. 11 lid 1 VNNZ niet is beoogd om af te wijken van de reguliere verjaringssystematiek. Hoewel het Amsterdamse gemeentebestuur ervan zou opkijken als zich omstreeks 2020 nog een geheel nieuwe schadepartij zou melden, zou in een dergelijk geval dus worden vastgehouden aan de verjaringstermijn van art. 11 lid 3 VNNZ. 


\section{De Wro}

In art. 49 WRO was aanvankelijk geen verjaringstermijn opgenomen. De Afdeling oordeelde daarom dat onder deze regeling geen verjaringsregels golden. ${ }^{77} \mathrm{Bij}$ de behandeling van het in paragraaf 10.4.1 besproken wetsvoorstel om een grondslag voor planschadeverhaalsovereenkomsten aan de WRO toe te voegen, uitten Tweede Kamerleden de wens eveneens een verjaringsregeling in de WRO op te nemen. ${ }^{78}$ Naar aanleiding hiervan werd in art. 49 lid 2 WRO een verjaringstermijn van vijf jaren opgenomen. Ook in art. 6.1 lid 4 en lid 5 Wro is voor een vijfjaarstermijn gekozen. Die termijn is gebaseerd op art. 3:310 BW en sluit volgens de wetgever aan bij het "rechtsbeginsel dat vorderingen niet oneindig zijn." " In beginsel vangt de verjaringstermijn aan bij onherroepelijkheid van de schadeoorzaak (vergelijk art. 6.1 lid 4 Wro en art. 49 lid 2 WRO). Voor zover ik heb kunnen nagaan, is nooit geëxpliciteerd waarom niet tevens wordt vereist dat de aanvrager bekend is met de schade(oorzaak) en het daarvoor verantwoordelijke bestuursorgaan. Wellicht is de verklaring gelegen in nemo censetur ignorare legem: iedereen wordt geacht de wet te kennen, en dus ook het bestemmingsplan. Vanaf het moment van onherroepelijkheid van dit plan - of besluiten die daaraan nadere invulling geven of juist hiervan afwijken - zou de burger daarom eveneens zeker moeten weten of hij schade lijdt. Deze verklaring lijkt ook aan te sluiten op de uitzondering van art. 6.1 lid 5 Wro voor schade door aanhouding van een besluit omtrent het verlenen van een omgevingsvergunning ingevolge artikel 3.3 lid 1 of art. 3.4 Wabo. ${ }^{80}$ Daarvan is veelal sprake als er geen gronden zijn om de vergunning te weigeren, maar het niet wenselijk is de vergunning op het moment van aanvraag te verlenen, omdat bijvoorbeeld wordt gewerkt aan de herziening of wijziging van een bestemmingsplan. ${ }^{81}$ De wetgever heeft daarom ervoor gekozen de verjaringstermijn in dit soort gevallen pas te laten aanvangen na terinzagelegging van het uiteindelijk vastgestelde bestemmingsplan. Eerst dan is namelijk duidelijk in hoeverre werkelijk schade is geleden door de aanhouding. ${ }^{82}$

77 ABRvS 22 augustus 2018, ECLI:NL:RVS:2018:2764, r.o. 10.3, onder verwijzing naar ABRvS 1 september 2004, ECLI:NL:RVS:2004:AQ8752, r.o. 2.3.3 (Planschade Schaesberg).

78 Kamerstukken II 2002/03, 28 916, nr. 3, p. $64-65$ (MvT, Wro). Zie over de lengte van de verjaringstermijn ook Kamerstukken II 2003/04, 29 490, nr. 6, p. 2-3 (Verslag II); en Kamerstukken II 2003/04, 24 940, nr. 7, p. 5 (NV II).

79 Kamerstukken II 2002/03, 28 916, nr. 3, p. 64-65 (MvT, Wro).

80 Een vergelijkbare regeling was te vinden in de tweede zin van art. 49 lid 2 WRO.

81 Zie over aanhoudingsplichten en - bevoegdheden Van den Broek, in: T\&C Wabo, commentaar op art. 3.3 en art. 3.4 Wabo.

82 Kamerstukken II 2002/03, 28 916, nr. 3, p. 113-114 (MvT, Wro). De aanhoudingsbesluiten die aanvankelijk in de Wro waren opgenomen, zijn vervangen door verwijzingen naar overeenkomstige besluiten op grond van de Wabo. Daarom is de toelichting waarnaar verwezen wordt nog steeds actueel ten aan zien van de huidige aanhoudingsbesluiten. Zie in dit verband Kamerstukken II 2008/09, 31 953, nr. 3, p. 125 onder CC (MvT). 


\section{Enkele nog niet besproken verschillen en verklaringen daarvoor}

De bepalingen omtrent verjaring uit de BnIW 2019 en AVN zijn geformuleerd als een discretionaire bevoegdheid: het bestuur kan de aanvraag om compensatie afwijzen als deze is ingediend na het verstrijken van de verjaringstermijn. ${ }^{83}$ Onder andere regelingen is de bepaling inzake verjaring echter gericht tot de benadeelde: de aanvraag 'wordt' (VS $2012^{84}$ en VNNZ ${ }^{85}$ ) of 'moet worden' (Wro) ${ }^{86}$ ingediend binnen een bepaalde termijn. Uit de toelichting op de VNNZ blijkt dat de Amsterdamse gemeenteraad desondanks ook met de relevante bepaling uit deze verordening een discretionaire bevoegdheid aan het bestuur heeft willen toekennen. De toelichtingen behorende bij de VS 2012 en Wro gaan niet in op de vraag of een te laat ingediende aanvraag slechts mag, of juist altijd moet worden afgewezen. Omdat uit die toelichtingen wel blijkt dat de bewuste regelgevers aansluiting beoogden te zoeken bij de verjaringssystematiek van het BW, lijkt het echter voor de hand te liggen dat ook onder deze regelingen discretie voor het bestuur bestaat als het aankomt op de tegenwerping van het verstrijken van de verjaringstermijn. In het civiele recht bestaat immers op grond van art. 3:322 lid 2 BW de mogelijkheid om afstand te doen van het recht om een beroep op verjaring te doen. Ik heb geen expliciete verklaringen gevonden voor de omstandigheid dat deze discretie niet tot uitdrukking is gebracht in de tekst van de VS 2012, VNNZ en Wro.

Een tweede verschil is dat slechts de BnIW 2019 ingaat op de stuiting van de verjaringstermijn. Ook hiervoor heb ik geen expliciete verklaringen gevonden. ${ }^{87}$ Wel kan met zekerheid worden gesteld dat onder de overige regelingen niet kan worden teruggevallen op de regels omtrent stuiting uit afd. 4.4.3 Awb. Van een bestuursrechtelijke geldschuld als bedoeld in art. 4:85 Awb is immers pas sprake zodra het bestuur het nadeelcompensatiebesluit heeft genomen. ${ }^{88}$ Desondanks lijkt het onwaarschijnlijk dat stuiting niet mogelijk zou zijn onder de overige regelingen. Zij beogen immers allemaal aan te sluiten bij de civielrechtelijke verjaringsregeling (vergelijk art. 3:316 e.v. BW). Bovendien blijkt uit een Afdelingsuitspraak van 28 november 2015 inzake de Verordening nadeelcompensatie Arnhem 2011 dat de Afdeling stuiting van de verjaringstermijn mogelijk acht als daarover

83 Zie art. 12 lid 2 jo. lid 3 BnIW 2019 respectievelijk art. 3 lid 2 jo. lid 3 AVN.

84 Art. 3 lid 1 VS 2012. Aangezien de BnIW 2019 en VS 2012 een gemeenschappelijke voorouder kennen in de RnR 1991 komt deze formulering ook voor in art. 12 lid 1 BnIW 2019. Het is echter duidelijk dat de formulering van art. 12 lid 2 en lid 3 BnIW 2019 doorslaggevend is. Zie daaromtrent ook Stcrt. 1999, nr. 172, p. 11 (digitaal, p. 11).

85 Art. 11 lid 3 VNNZ.

86 Art. 6.1 lid 4 jo. lid 5 Wro.

87 Ten aanzien van beide onder dit kopje besproken verschillen kan hooguit worden opgemerkt dat de bepaling omtrent verjaring uit de VS 2012 rechtstreeks is overgenomen uit de RnR 1991.

88 Zie in algemene zin over de verhouding tussen nadeelcompensatie en titel 4.4 Awb: Scheltema 2011; en Nuyten \& Gawronski 2013. 
niets wordt geregeld door een nadeelcompensatieregeling. ${ }^{89}$ Die benadering lijkt zij in beginsel ook te volgen bij formeelwettelijke nadeelcompensatieregelingen. ${ }^{90}$

\section{Het eerst mogelijke moment van indiening van de aanvraag}

Slechts de Wro bepaalt iets omtrent het moment vanaf wanneer een aanvraag om compensatie kan worden ingediend. Uit art. 6.1 lid 5 Wro blijkt namelijk dat een aanvraag wegens schade door aanhouding van een besluit omtrent het verlenen van een omgevingsvergunning ingevolge artikel 3.3 lid 1 of art. 3.4 Wabo eerst kan worden ingediend na terinzagelegging van het vastgestelde bestemmingsplan (tevens het moment van aanvang van de verjaringstermijn). Dit kan worden verklaard doordat de wetgever indiening van onnodige aanvragen probeerde te voorkomen. De wetgever benadrukt dat pas vanaf dit moment duidelijk is in hoeverre schade is geleden door de aanhouding van het besluit omtrent vergunningverlening. Bovendien zou de bestemmingswijziging in veel gevallen "eerder gunstig dan ongunstig" blijken uit te vallen voor de betrokkenen. ${ }^{91}$

Uit de bij de Wro behorende memorie van toelichting volgt voorts dat aanvragen die betrekking hebben op de andere in art. 6.1 lid 2 Wro genoemde schadeoorzaken reeds mogen worden ingediend voorafgaand aan het moment van aanvang van de verjaringstermijn - dat is volgens art. 6.1 lid 4 Wro het moment van onherroepelijkheid van de schadeoorzaak..$^{92}$ De mogelijkheid tot vroegtijdige indiening wordt ook erkend in de toelichtingen behorende bij de BnIW 2019 en de GrS en in het door de besliscommissie van het Schadeschap opgestelde Basisdocument. ${ }^{93}$ De toelichtingen op de Amsterdamse verordeningen gaan hier niet op in, maar $\mathrm{ik}$ zie geen aanleiding om aan te nemen dat vroegtijdige indiening niet mogelijk zou zijn onder deze regelingen. Dat vroegtijdige indiening niet wordt uitgesloten, kan worden verklaard door de vrijheid die het bestuur op dit punt wordt geboden door de Afdeling: een vroegtijdig ingediende aanvraag mag worden aangehouden, maar mag ook worden afgewezen omdat eerst inhoudelijk op de aanvraag kan worden beslist na onherroepelijk worden van de schadeoorzaak. In het tweede scenario kan na het moment van onherroepelijkheid een nieuwe aanvraag worden

89 ABRvS 28 november 2015, ECLI:NL:RVS:2015:3182, r.o. 7.1.

90 ABRvS 22 augustus 2018, ECLI:NL:RVS:2018:2764, r.o. 10.3-10.7.

91 Kamerstukken II 2002/03, 28 916, nr. 3, p. 113-114 (MvT, Wro). De aanhoudingsbesluiten die aanvankelijk in de Wro waren opgenomen, zijn vervangen door verwijzingen naar overeenkomstige besluiten op grond van de Wabo. Daarom is de toelichting waarnaar verwezen wordt nog steeds actueel ten aan zien van de huidige aanhoudingsbesluiten. Zie in dit verband Kamerstukken II 2008/09, 31 953, nr. 3, p. 125 onder CC (MvT).

92 Kamerstukken II 2002/03, 28 916, nr. 3, p. 113 (MvT, Wro).

93 Zie Stcrt. 1999, nr. 172, p. 9 (digitaal, p. 6); en Stcrt. 1998, nr. 223, p. 9 (digitaal). De relevante passage uit de toelichting op de RnVW 1999 wordt geciteerd in Basisdocument, p. 149. 
ingediend. ${ }^{94}$ Ten aanzien van het eerste scenario is relevant dat uit paragraaf 5.6.1 bleek dat de Afdeling het bestuur niet verplicht tot betaling van wettelijke rente over de periode van indiening van de aanvraag tot het moment van ontstaan van de schade, of onherroepelijkheid van de schadeoorzaak. Ten slotte kan het toestaan van het vroegtijdig indienen van aanvragen ook voordelen voor het bestuur opleveren. Zo kan bijvoorbeeld aanvullend inzicht worden verkregen in de (potentiële) veroorzaking van schade. Op basis daarvan kunnen bijvoorbeeld (aanvullende) schadebeperkende maatregelen worden getroffen, of kan in gesprek worden getreden met de aanvrager en personen die waarschijnlijk vergelijkbare schade zullen ondervinden. ${ }^{95}$

\subsubsection{Deelvraag 3: Toekomstig recht}

\section{Titel 4.5 Awb}

Om uniformering aan te brengen in de uiteenlopende verjaringsregelingen die het huidige nadeelcompensatierecht kent, is in art. 4:131 Awb een dwingendrechtelijke regeling omtrent verjaring opgenomen. ${ }^{96}$ Ingevolge het eerste lid van deze bepaling kan het bestuursorgaan een aanvraag om nadeelcompensatie afwijzen indien op het tijdstip van de aanvraag vijf jaren zijn verstreken na aanvang van de dag na die waarop de benadeelde bekend is geworden met zowel de schade als het voor de schadeveroorzakende gebeurtenis verantwoordelijke bestuursorgaan, en in ieder geval na verloop van twintig jaren nadat de schade is veroorzaakt. Met de gekozen termijnen heeft de wetgever zoveel mogelijk willen aansluiten bij de verjaringssystematiek uit het civiele recht. Het was echter niet mogelijk art. 3:310 BW rechtstreeks van toepassing te verklaren, omdat tijdens de indiening van een aanvraag om nadeelcompensatie nog geen sprake is van een 'invorderbare schuld'. Daarvan is immers pas sprake als positief wordt beslist op de aanvraag. ${ }^{97}$ In de memorie van toelichting wordt bevestigd dat de formulering ' $k a n$... afwijzen' tot gevolg heeft dat het bestuur niet verplicht is de aanvraag af te wijzen als de verjaringstermijn is verstreken. ${ }^{98}$ Uit het nader verslag blijkt dat ervoor gekozen kan worden de aanvraag ondanks het verstrijken van de verjaringstermijn toch te behandelen, omdat het bijvoorbeeld "nog volstrekt helder is hoe de omstandigheden in het verleden lagen, en het niet honoreren van het verzoek als ongerechtvaardigd wordt gevoeld." ${ }^{99}$ Uit de memorie van toelichting blijkt bovendien

94 ABRvS 28 september 2016, ECLI:NL:RVS:2016:2582, r.o. 8 (Overzichtsuitspraak). Zie voor het nadeelcompensatierecht de jurisprudentie die werd besproken in paragraaf 5.6.1 onder het kopje 'Aanvang van de renteperiode'.

95 Zie over het belang van (vroegtijdige) communicatie met burgers ook Handleiding nadeelcompensatie, p. 24-28.

96 Kamerstukken II 2010/11, 32 621, nr. 3, p. 21 (MvT, Wns).

97 Zie Kamerstukken II 2010/11, 32 621, nr. 3, p. 21-22 en 29 (MvT, Wns); en Kamerstukken II 2010/11, 32 621, nr. 6, p. 17 (NV II, Wns).

98 Kamerstukken II 2010/11, 32 621, nr. 3, p. 30 (MvT, Wns).

99 Kamerstukken II 2010/11, 32 621, nr. 6, p. 17 (NV II, Wns). 
dat een aanvraag ook al kan worden ingediend voordat de verjaringstermijn is aangevangen. ${ }^{100}$

De wetgever gaat ervan uit dat de benadeelde meestal vrij snel bekend zal zijn met de geleden schade en het daarvoor verantwoordelijke bestuursorgaan. Het is echter denkbaar dat het ontstaan van de schade pas later bekend wordt. Daarom is ervoor gekozen de vijfjaarstermijn pas vanaf dat moment te laten aanvangen. Als de schade het gevolg is van een appellabele schadeoorzaak, vangt deze termijn ingevolge art. 4:130 lid 2 Awb bovendien niet aan voor het onherroepelijk worden van deze schadeoorzaak. ${ }^{101}$ De motivering daarvan is tweeledig. Ten eerste staat pas vanaf dat moment vast dat niet titel 8.4 Awb, maar titel 4.5 Awb de aangewezen weg vormt om de schade gecompenseerd te zien. Ten tweede blijkt bij appellabele schadeoorzaken vaak pas op dit moment of, en zo ja hoeveel, schade is geleden. Dat is ook de reden dat de wetgever verwacht dat het tweede lid eraan zal bijdragen "dat schadeverzoeken niet onnodig of onnodig vroeg worden ingediend", ondanks dat het wel mogelijk is dat een aanvraag al voorafgaand aan de onherroepelijkheid van de schadeoorzaak wordt ingediend. ${ }^{102}$ Ten slotte blijkt uit de memorie van toelichting dat de absolute verjaringstermijn van twintig jaren is opgenomen omdat niet kan worden uitgesloten dat het in bepaalde gevallen lang zal duren voordat de vijfjaarstermijn intreedt. De twintigjaarstermijn waarborgt de rechtszekerheid, mede omdat "het na een dergelijk lange termijn vaak moeilijk is voldoende nauwkeurig na te gaan hoe de feiten en omstandigheden in het verleden waren." 103

\section{Afd. $15.1 \mathrm{Ow}$}

In paragraaf 3.3.2.3 kwam aan bod hoe afd. 15.1 Ow wijzigingen zal aanbrengen in het moment vanaf wanneer nadeelcompensatie kan worden verkregen. Voor indirecte schade door vergunningvrije activiteiten zal deze verschuiving worden gerealiseerd doordat art. 15.4 lid $1 \mathrm{Ow}$ het moment waarop een aanvraag om compensatie voor deze schade kan worden ingediend, verschuift naar het moment waarop het bevoegd gezag kennis heeft gegeven van de informatie die degene die de activiteit gaat verrichten aan het bevoegd gezag over die activiteit heeft verstrekt, óf het tijdstip waarop met de activiteit is begonnen als deze informatie niet is verstrekt. Uit de bij de IOw behorende memorie van toelichting blijkt dat onder afd. 15.1 Ow dient te worden aangesloten bij art. 4:131 Awb. Wel is in art. 15.4 lid 3 Ow geëxpliciteerd wanneer de verjaringstermijn aanvangt in het als eer-

100 Kamerstukken II 2010/11, 32 621, nr. 3, p. 30 (MvT, Wns).

101 In de memorie van toelichting wordt opgemerkt dat deze situatie "geen pendant in het civiele recht" kent en derhalve een eigen regeling nodig had. Zie Kamerstukken II 2010/11, 32 621, nr. 3, p. 29 (MvT, Wns).

102 Vergelijk art. 4:130 lid 3 Awb. Zie daarover ook paragraaf 10.11.2.

103 Zie Kamerstukken II 2010/11, 32 621, nr. 5, p. 7 (Verslag II); Kamerstukken II 2010/11, 32 621, nr. 6, p. 17 (NV II, Wns); en Kamerstukken II 2010/11, 32 621, nr. 3, p. 22 en 29-30 (MvT, Wns). 
ste beschreven scenario, waarin sprake is van een kennisgeving door het bevoegd gezag. Voor de toepassing van artikel 4:131 lid 1 Awb wordt namelijk de dag na die waarop de kennisgeving is gedaan, gelijkgesteld met de dag na die waarop de benadeelde bekend is geworden met de schade en met het voor de schadeveroorzakende gebeurtenis verantwoordelijke bestuursorgaan. ${ }^{104}$

\subsubsection{Hoofdvraag: spiegeling aan de doelstellingen en uitgangspunten die ten grondslag liggen aan de Wns}

Het past goed bij de doelstelling van vereenvoudiging, uniformering en harmonisering van het nadeelcompensatierecht dat door invoering van art. 4:131 Awb één uniforme verjaringsregeling zal gelden in het nadeelcompensatierecht. De verduidelijking van art. 15.4 lid $3 \mathrm{Ow}$ doet daar niet aan af, en sluit bovendien goed aan op de doelstelling van vergroting van de rechtszekerheid. Beide bepalingen zijn mijns inziens ook overigens verenigbaar met de aan de Wns ten grondslag liggende doelstellingen en uitgangspunten. Dat neemt niet weg dat ik ruimte zie om nog meer aan te sluiten op het uitgangspunt van aansluiting bij het BW en de doelstelling van codificatie van het nadeelcompensatierecht. In dat verband doe ik de aanbeveling om een drietal artikelleden omtrent stuiting van de verjaringstermijn aan art. 4:131 Awb toe te voegen:

3. Vóórdat de verjaringstermijn is verstreken na verloop waarvan het bestuursorgaan op grond van het eerste lid een aanvraag als bedoeld in artikel 4:126 kan afwijzen, kan de aanvrager deze verjaringstermijn stuiten door een schriftelijke mededeling aan het bestuursorgaan te doen waarin hij ondubbelzinnig verklaart dat hij zich het recht voorbehoudt om zo een aanvraag in te dienen.

4. Na aanvang van de dag na die waarop de schriftelijke mededeling als bedoeld in het derde lid is gedaan, begint een nieuwe verjaringstermijn van twee jaren te lopen. Niettemin treedt de verjaring in geen geval op een eerder tijdstip in dan waarop ook de oorspronkelijke termijn zonder stuiting zou zijn verstreken.

5. De aanvrager kan de verjaringstermijn slechts meermaals stuiten als het bestuursorgaan daarmee instemt.

De formulering van de voorgestelde artikelleden is gebaseerd op die van art. 4:131 Awb, art. 3:317 BW, art. 3:319 BW en art. 12 lid 3 BnIW 2019. De voorgestelde leden gaan echter uit van een nieuwe verjaringstermijn van twee jaar, terwijl deze termijn vijf jaren beslaat onder het BW en de BnIW 2019. Ook bepalen de voorgestelde leden dat herhaaldelijke stuiting slechts mogelijk is als het bestuur daarmee instemt. Een dergelijke beperking vloeit niet voort uit het BW of de BnIW 
2019. ${ }^{105}$ Beide afwijkingen veroorzaken dus enige spanning met het uitgangspunt van aansluiting bij het BW. Ik acht ze echter noodzakelijk vanwege de doelstellingen van vergroting van de rechtszekerheid, en vergroting van de doelmatigheid van het nadeelcompensatierecht en vermindering van bestuurslasten. Daarbij is onder andere van belang dat de verschuiving van het schademoment door afd. 15.1 Ow het recht op compensatie zal fragmenteren. ${ }^{106}$ Afhankelijk van de activiteiten van omwonenden kan één planologische maatregel daardoor - anders dan naar huidig recht het geval is - verschillende aanspraken op nadeelcompensatie doen ontstaan voor dezelfde burger, al dan niet naar verloop van tijd. Het bijhouden van de momenten waarop de bij elk van die aanspraken behorende verjaringstermijnen aflopen, kan al snel complex en tijdrovend worden voor zowel bestuur als burger. Een mogelijkheid tot lange en herhaaldelijke stuiting van verjaringstermijnen past daar niet bij. In theorie zou dit ook kunnen leiden tot een afwijkende regeling omtrent stuiting in afd. 15.1 Ow. Dat lijkt echter onnodig en bovendien onwenselijk vanwege de doelstelling van vereenvoudiging, uniformering en harmonisering van het nadeelcompensatierecht.

De keuze voor een termijn van twee jaar is hoofdzakelijk gebaseerd op de gedachte dat zij voldoende ademruimte biedt in situaties waarin de overheid aankondigt dat een ontwikkeling op relatief korte termijn staat te gebeuren, terwijl ongeveer vier jaar eerder een schadeveroorzakende ontwikkeling heeft plaatsgevonden. Als de aangekondigde ontwikkeling eveneens schade zal veroorzaken, wordt de benadeelde door de extra twee jaar voldoende tijd geboden om een gebundelde aanvraag voor compensatie van beide schades in te dienen. ${ }^{107}$ Ook is denkbaar dat de aangekondigde ontwikkeling een vier jaar eerder ontstane waardedaling ongedaan zal maken. In dat geval kunnen de extra twee jaar de aanvrager wellicht ertoe bewegen geheel af te zien van een aanvraag om nadeelcompensatie. Bovendien zou een termijn van twee jaar doorgaans ook voldoende moeten zijn als een aanvrager er door persoonlijke omstandigheden niet in dreigt te slagen zijn aanvraag in te dienen binnen de reguliere verjaringstermijn.

Naast de hierboven gedane aanbeveling tot (a) aanpassing van titel 4.5 Awb, geven de aan de Wns ten grondslag liggende doelstellingen en uitgangspunten mijns inziens geen aanleiding tot (b) aanpassing van afd. 15.1 Ow, of om (c) anderszins in een bijzondere invulling, aanvulling of afwijking van titel 4.5 Awb te voorzien.

105 In het civiele recht is er geen wettelijke beperking gesteld aan het aantal keren dat een verjaring kan worden gestuit. Wellicht kan een dergelijke beperking wel voortvloeien uit de redelijkheid en billijkheid. Anders dan de rechtbank, wilde het hof daar echter niet van weten in Hof 's-Hertogenbosch 26 augustus 2014, ECLI:NL:GHSHE:2014:2970, r.o. 4.7.

106 Zie paragraaf 3.4.2.3.

107 In paragrafen 6.2.2.3 en 6.2.3.2 is besproken waarom bundeling van aanvragen wenselijk is. 


\subsection{RAADPLEGING VAN EEN ADVIESCOMMISSIE}

10.6.1 Deelvraag 2: verschillen tussen de geselecteerde, thans geldende regelingen en verklaringen daarvoor

\section{Algemeen kader}

In deze paragraaf en enkele daaropvolgende paragrafen zal worden ingegaan op deskundigenadvisering. Ten aanzien van deze advisering kan in algemene zin worden gewezen op een aantal algemene normen die ook onder de geselecteerde regelingen in acht moeten worden genomen. Zo wordt de onpartijdigheid van de adviseur bijvoorbeeld gewaarborgd door het in art. 2:4 Awb vervatte verbod op vooringenomenheid (fair-play beginsel). Aan die onpartijdigheid wordt ook bijgedragen doordat art. 3:2 Awb en het daaraan ten grondslag liggende formele zorgvuldigheidsbeginsel het bestuur verplichten tot zorgvuldige voorbereiding van besluitvorming. Dit kan onder omstandigheden bovendien de plicht voor het bestuur meebrengen om een adviseur te raadplegen, zelfs als er geen wettelijk voorschrift is dat een dergelijke raadpleging expliciet voorschrijft. ${ }^{108}$

Ook kan worden gedacht aan afd. 3.3 Awb. Deze afdeling is strikt genomen slechts van toepassing op advisering die wordt voorgeschreven bij wettelijk voorschrift (vergelijk art. 3.5 lid $1 \mathrm{Awb}$ ). Uit de jurisprudentie blijkt echter dat de hierin opgenomen normering soms ook kan worden afgedwongen met een beroep op art. 3:2 Awb en het daaraan ten grondslag liggende formele zorgvuldigheidsbeginsel. Dat geldt bijvoorbeeld voor de vergewisplicht van art. 3:9 Awb. De Afdeling is namelijk van mening dat art. 3:2 Awb in algemene zin meebrengt dat het bestuur "zich dient te vergewissen van de zorgvuldigheid van ieder onderzoek, waarvan [het] de resultaten aan een besluit ten grondslag legt." ${ }^{109}$ Op grond van art. 3:2 jo. art. 3:46 jo. art. 3:49 Awb zal het bestuur zich bovendien ervan moeten vergewissen dat het ingewonnen advies inhoudelijk concludent is. Uit art. 3:46 jo. art. 3:49 Awb en het daaraan ten grondslag liggende motiveringsbeginsel vloeit immers voort dat het bestuursorgaan zijn besluit slechts afdoende kan motiveren met een verwijzing naar het ingewonnen deskundigadvies als daarin een deugdelijke motivering van het genomen besluit is opgenomen. ${ }^{110}$

108 Zie bijvoorbeeld AGRvS 21 november 1992, ECLI:NL:RVS:1992:AN3910.

109 Zie bijvoorbeeld ABRvS 23 oktober 2003, ECLI:NL:RVS:2003:AM2916, r.o. 2.3.2.

110 De beschrijving van dit algemene kader omtrent deskundigenadvisering, inclusief de daarin opgenomen verwijzingen naar jurisprudentie, zijn voor een significant deel gebaseerd op De Poorter \& Van Soest-Ahlers 2008. Zie Ook Bröring e.a. 2019, p. 313-320. 
De Wro

In art. 6.1.3.2 Bro is bepaald dat het bestuur advies moet inwinnen, tenzij toepassing wordt gegeven aan art. 4:5 Awb of art. 6.1.3.1 Bro. Die laatste bepaling ziet op de afwijzing van een aanvraag omdat deze "kennelijk ongegrond" is. Volgens de bij het Bro behorende nota van toelichting moet daarbij worden gedacht aan gevallen waarin sprake is van verjaring, gevallen waarin het evident is dat de schade tot het forfaitaire deel van het normaal maatschappelijk risico behoort, of gevallen waarin er om een andere reden "in redelijkheid geen twijfel over kan bestaan dat de schade niet voor een tegemoetkoming in aanmerking komt." 111

\section{De BnIW 2019 en VS 2012}

Een inhoudelijk met art. 6.1.3.2 Bro overeenkomende regeling was ook al terug te vinden in de RnR 1991. ${ }^{112}$ Die regeling werd ook overgenomen in de VS 1999, ${ }^{113}$ RnVW $1999^{114}$ en BnIM 2014. ${ }^{115}$ In de VS $2012^{116}$ en BnIW $2019^{117}$ is echter ervoor gekozen het bestuur meer ruimte te geven om een aanvraag te behandelen zonder inschakeling van een adviescommissie. Deze keuze werd in geval van de VS 2012 gemaakt naar aanleiding van de aanbeveling uit het rapport van Van Ettekoven \& Tjepkema ${ }^{118}$ om de VS 1999 zo te wijzigen dat "meer mogelijkheden ontstaan om te besluiten zonder inschakeling van de AC (eigen toevoeging: hiermee wordt gedoeld op een adviescommissie), dan wel met inschakeling van een AC van één of twee deskundigen." Daarbij werd - terecht - opgemerkt dat het de doelmatigheid ten goede zou komen als geen plicht tot inschakeling van een adviescommissie zou bestaan in zaken waarin dat geen toegevoegde waarde heeft, ook als geen sprake is van een kennelijk ongegronde aanvraag. Op grond hiervan, is in de VS 2012 bepaald dat geen plicht geldt tot instelling van een adviescommissie als toepassing wordt gegeven aan de in de VS 2012 opgenomen variant van

$111 S t b .2008,145$, p. 66 (Nota van toelichting bij het Bro). Zie voor een bijzonder voorbeeld uit de jurisprudentie ABRvS 23 december 2015, ECLI:NL:RVS:2015:3934, r.o. 3.4: een initiatiefnemer met wie het college van $B \& W$ een samenwerkingsovereenkomst had gesloten, diende een aanvraag om tegemoetkoming in planschade in.

112 Art. 5 lid 1 jo. art. 4 lid 1 jo. art. 4 lid 2 RnR 1991.

113 Art. 7 lid 1 jo. art. 6 lid 1 jo. art. 6 lid 2 VS 1999.

114 Art. 15 lid 1 jo. art. 14 lid 1 jo. art. 14 lid 3 RnVW 1999.

115 Art. 15 lid 1 jo. art. 14 lid 1 jo. art. 14 lid 3 BnIM 2014.

116 Art. 7 lid 1 jo. art. 6 lid 1 jo. art. 6 lid 2 VS 2012.

117 Art. 14 lid 3 jo. art. 15 lid 1 BnIW 2019.

118 Zie paragraaf 10.1 onder het kopje 'Introductie van enkele tot op heden nog niet besproken regelingen'. 
art. 4:5 Awb, ${ }^{119}$ of als dit naar het oordeel van de besliscommissie niet nodig is om op de aanvraag te beslissen. Daarvan kan sprake zijn bij kennelijk ongegronde aanvragen, maar bijvoorbeeld ook als voldoende houvast kan worden gevonden in vergelijkbare zaken waarin reeds advies is ingewonnen of uitspraak is gedaan door de bestuursrechter. ${ }^{120}$

In art. 15 lid 1 BnIW 2019 is bepaald dat het bestuur een adviescommissie kan instellen. Uit art. 14 lid 3 BnIW 2019 blijkt dat deze discretie ook bestaat als het bestuur de aanvraag wil afwijzen. Sterker nog, in dergelijke gevallen mag zelfs geen advies worden ingewonnen als de afwijzing berust op het oordeel dat de aanvraag om nadeelcompensatie kennelijk ongegrond is. De keuze om de raadpleging van een adviescommissie facultatief te maken, is gebaseerd op de gedachte dat de minister, mede gelet op de complexiteit van het schadegeval, zal moeten bepalen of uitgebreid onderzoek en het zoeken van externe expertise noodzakelijk is. Daarbij is onder andere van belang dat de gewijzigde bepalingen omtrent de vaststelling van het normaal ondernemersrisico het doorgaans mogelijk zullen maken om zonder raadpleging van een deskundige een 'quick-scan' te verrichten. ${ }^{121}$ Dit zou weinig impact hebben ten aanzien van de uit te keren nadeelcompensatie, maar wel "een belangrijke positieve impact voor het proces van het aanvragen en behandelen van verzoeken." 122

\section{De Amsterdamse verordeningen}

De procedurele voorschriften met betrekking tot instelling van een adviescommissie uit de AVN stemmen inhoudelijk grotendeels overeen met de benaderingen uit de VS 2012 en BnIW 2019. Ingevolge art. 13 lid 3 AVN vraagt het bestuur namelijk slechts advies aan een adviescommissie "indien dit naar zijn oordeel noodzakelijk is vanwege de complexiteit van de aanvraag." Ook geeft de AVN een opsomming van gevallen waarin in elk geval géén advies is vereist. Het gaat dan om aanvragen die worden afgedaan conform art. 4:5 Awb; aanvragen die grotendeels overeenkomen met andere aanvragen waarover de adviescommissie reeds advies heeft uitgebracht; en situaties waarin - kort gezegd - volgens het bestuur voldoende duidelijk is dat de in de AVN opgenomen, inhoudelijke criteria voor toekenning van nadeelcompensatie niet zijn voldaan. Aan deze bepaling ligt de

119 Het betreft art. 5 VS 2012. Die bepaling is bij vaststelling van art. 5 VS 1999 ongewijzigd overgenomen uit art. 3 lid 5 RnR 1991 en sindsdien ongewijzigd gebleven. De bepaling was in de RnR 1991 opgenomen om te anticiperen op de bepaling uit het wetsvoorstel voor de Awb die correspondeerde met art. 4:5 Awb. Dat was nodig omdat de Awb pas na de RnR 1991 in werking zou treden. Zie Stcrt. 1991, nr. 251, p. 28.

120 Stcrt. 2012, nr. 8910, p. 5-6. Dit is conform de Afdelingsjurisprudentie, zie bijvoorbeeld ABRvS 13 januari 2000, ECLI:NL:RVS:2000:AN6240, r.o. 2.4.2.

121 Zie daarover paragraaf 6.3.1 onder het kopje 'De Handleiding nadeelcompensatie bij infrastructurele maatregelen'. 
gedachte ten grondslag dat de inschakeling van een adviescommissie meer tijd en geld kost. Het uitgangspunt is daarom dat aanvragen zonder inschakeling van een adviescommissie worden afgedaan en slechts in complexe zaken om advies wordt gevraagd. ${ }^{123}$

Hoewel ook in de toelichting op de VNNZ wordt benadrukt dat het niet raadplegen van een adviescommissie een tijds- en kostenbesparing meebrengt, ${ }^{124}$ is het bestuur ingevolge art. 13 lid 1 VNNZ in beginsel verplicht de aanvraag aan een adviescommissie voor te leggen. Het uitgangspunt van deze bepaling is dus tegenovergesteld aan het uitgangspunt van art. 13 lid 3 AVN. Dat kan wellicht worden verklaard doordat de voorloopster van de VNNZ eveneens een verplichting tot inwinning van advies bevatte (vergelijk art. 11 lid 2 Verordening Nadeelcompensatie en Planschade Noord/Zuidlijn). Onder die regeling kon slechts van inwinning van advies worden afgezien bij kennelijk ongegronde aanvragen. De VNNZ kent meer uitzonderingen op de uit art. 13 lid 1 VNNZ voortvloeiende plicht tot inwinning van advies. Die bepaling is blijkens het tweede lid $^{125}$ namelijk niet van toepassing indien een aanvraag niet voldoet aan de daaraan door art. 11 VNNZ gestelde eisen, het bestuur van oordeel is dat geen advies hoeft te worden ingewonnen vanwege eerdere door de adviescommissie uitgebrachte adviezen, ${ }^{126}$ of de aanvraag wordt geweigerd op grond van art. 3 VNNZ. ${ }^{127}$ Laatstgenoemde bepaling ziet op gevallen waarin geen causaal verband bestaat tussen de schade en een rechtmatige schadeoorzaak die verband houdt met de aanleg van de Noord/ Zuidlijn; het een aanvraag betreft die ziet op een schadejaar waarover de aanvrager reeds een nadeelcompensatiebesluit heeft ontvangen; of risicoaanvaarding, het niet voldoen aan de plicht tot schadebeperking, of het anderszins gewaarborgd zijn van een tegemoetkoming in de schade leidt tot weigering van de aanvraag. Anders dan onder de AVN, dient dus in theorie wel advies te worden ingewonnen als het bestuur de aanvraag zou willen afwijzen omdat geen sprake is van een abnormale last. Uit paragraaf 6.1 bleek echter dat de aanwezigheid van een abnormale last steeds wordt verondersteld onder de VNNZ.

123 Zie de toelichting op art. 13 lid 2 AVN.

124 Zie de toelichting op art. 14 VNNZ.

125 Hetgeen nog een keer wordt herhaald in art. 4 Regeling nadeelcompensatie Noord/ Zuidlijn.

126 Deze mogelijkheid wordt nog nader uitgewerkt in art. 5 Regeling nadeelcompensatie Noord/Zuidlijn voor gevallen waarin het advies is uitgebracht ten aanzien van een eerdere aanvraag van dezelfde aanvrager. In dergelijke gevallen lijkt toepassing van art. 13 lid 2, aanhef en onder c VNNZ (ongemotiveerd) te worden beperkt tot gevallen waarin de gevraagde nadeelcompensatie lager of gelijk is aan $€ 25.000$ per boekjaar.

127 Art. 11 lid 2 Verordening Nadeelcompensatie en Planschade Noord/Zuidlijn kende deze uitzondering slechts voor kennelijk ongegronde aanvragen. 


\section{Conclusie}

De geselecteerde, thans geldende regelingen liepen aanvankelijk sterk uiteen met betrekking tot de al dan niet verplichte raadpleging van een adviescommissie. Met invoering van de VS 2012 en BnIW 2019 zijn de verschillen met de Amsterdamse verordeningen verkleind. Naar de letter genomen, wordt onder de VS 2012, BnIW 2019 en AVN iets meer aan het oordeel van het bestuur gerefereerd dan onder de VNNZ. Praktisch gezien, is dit verschil echter minder groot dan het op het eerste oog lijkt. De VNNZ maakt immers veel uitzonderingen op de beginselplicht tot inwinning van advies. Het grootste verschil bestaat dan ook tussen de hiervoor genoemde regelingen enerzijds en het Bro anderzijds. Onder het Bro kan immers slechts van inwinning van advies worden afgezien bij kennelijk ongegronde aanvragen. Dat lijkt met name te kunnen worden verklaard door de leeftijd van het Bro. Nadeelcompensatieregelingen waren namelijk van oudsher streng ten aanzien van de plicht tot deskundigenadvisering. Kennelijk ging het Bro nog net vooraf aan de later ontstane trend van meer efficiënte regels omtrent de raadpleging van een deskundige.

\subsubsection{Deelvraag 3: Toekomstig recht}

Zowel titel 4.5 Awb als afd. 15.1 Ow regelen niet wanneer het bestuur een adviescommissie dient te raadplegen. In de bij de Wns behorende memorie van toelichting wordt opgemerkt dat de praktijk leert dat het in veel gevallen noodzakelijk is een adviescommissie in te schakelen. Dat zou zeker het geval zijn als het bestuursorgaan niet over de expertise beschikt die nodig is voor de beoordeling van de aanvraag. Een eventuele plicht tot inwinning van advies kan mijns inziens dus slechts aan art. 3:2 Awb en het daaraan ten grondslag liggende formele zorgvuldigheidsbeginsel worden ontleend. ${ }^{128}$ Dat werd ook met zoveel woorden gesteld in de memorie van toelichting behorende bij de consultatieversie van het voorstel voor de IOw. Daarin werd bovendien opgemerkt dat het bestuur eveneens ervoor zou kunnen kiezen om een door de aanvrager aangeleverd deskundigenadvies aan zijn besluitvorming ten grondslag te leggen. ${ }^{129}$ De desbetreffende passages komen echter niet meer voor in de memories van toelichting behorende bij de versie van het voorstel inzake de IOw dat naar de AARvS is gestuurd en de versie die is ingediend bij de Tweede Kamer. Ten Have en Thoonen merken hier - mijns inziens terecht - over op dat...

“(...) met een ontbreken van een toelichting op het vervallen van genoemde passage (...) onduidelijk [is] of de minister haar standpunt heeft gewijzigd. Nu hoofdstuk 15 geen bepalingen bevat over een door het bestuursorgaan te consulteren adviseur en uit titel 4.5 Awb geen verplichting volgt voor het inschakelen van een deskundige door het bestuursorgaan, lijkt een zelfstandige beoordeling door het bestuursorgaan (nog) tot de

128 Zie hierover het algemene kader als beschreven in paragraaf 10.6.1; en De Poorter \& Van Soest-Ahlers 2008, p. 27-29. 
mogelijkheden te behoren. Onduidelijk is of de minister op grond van artikel 15.9 nog nadere regels wil gaan opnemen die dat anders maken." ${ }^{130}$

Wel staat vast dat afd. 3.3 Awb slechts van toepassing is als de geraadpleegde adviescommissie bij of krachtens algemeen verbindend voorschrift is belast met het uitbrengen van het ingewonnen advies (vergelijk art. 3:5 lid 1 Awb). Of dat het geval is, hangt dus bijvoorbeeld af van hetgeen de plaatselijke gemeenteraad in zijn nadeelcompensatieverordening opneemt. ${ }^{131}$

\subsubsection{Hoofdvraag: spiegeling aan de doelstellingen en uitgangspunten die} ten grondslag liggen aan de Wns

Dat titel 4.5 Awb en afd. 15.1 Ow geen normering bevatten omtrent advisering door deskundigen verhoudt zich in ieder geval slecht tot de doelstellingen van vereenvoudiging, ${ }^{132}$ uniformering en harmonisering van het nadeelcompensatierecht, vergroting van de rechtszekerheid, en codificatie van het nadeelcompensatierecht. Dat geldt te meer vanwege het grote belang dat in het planschade- en nadeelcompensatierecht aan deskundigenadvisering wordt toegekend. ${ }^{133}$ Bovendien laten de geselecteerde, thans geldende regelingen zien dat in de praktijk structurele behoefte bestaat aan dit soort normering. Ik zie dus aanleiding om (a) titel $4.5 \mathrm{Awb}$ aan te passen door daarin op te nemen wanneer het bestuur deskundigenadvies dient in te winnen. De verklaringen voor de verschillen tussen de geselecteerde, thans geldende regelingen geven geen aanleiding tot vaststelling van afwijkende normering voor aanvragen die onder de reikwijdte van afd. 15.1 Ow vallen. Dat zou ook niet goed passen bij de doelstelling van vereenvoudiging, uniformering en harmonisering van het nadeelcompensatierecht. Ik zie derhalve geen aanleiding om (b) afd. 15.1 Ow aan te passen. Ook geven de aan de Wns ten grondslag liggende doelstellingen en uitgangspunten geen aanleiding om (c) anderszins te voorzien in een bijzondere invulling, aanvulling of afwijking van titel $4.5 \mathrm{Awb}$. De aanbeveling tot aanpassing van titel 4.5 Awb zou kunnen worden geïmplementeerd door invoering van de onderstaande bepaling.

\section{Artikel 4:135 Awb $^{134}$}

1. Het bestuursorgaan wint slechts advies in bij een adviescommissie als dat naar zijn oordeel noodzakelijk is om op de aanvraag te beslissen.

2. Advies als bedoeld in het eerste lid, wordt in ieder geval niet ingewonnen als de aanvraag:

a. buiten behandeling wordt gelaten op grond van artikel 4:5, eerste lid;

130 Ten Have \& Thoonen 2017, p. 163.

131 Kamerstukken II 2010/11, 32 621, nr. 3, p. 21 en 28-29 (MvT, Wns).

132 Dergelijke normering zou immers een belangrijk procedureel onderwerp regelen, waardoor de noodzaak tot vaststelling van aanvullende regelgeving zou afnemen.

133 Zie daarover paragraaf 10.1.

134 De keuze voor dit artikelnummer is gebaseerd op de samenvoeging van alle voorgestelde bepalingen in paragraaf 11.2.1. 
b. wordt afgewezen op grond van artikel 4:131;

c. naar het oordeel van het bestuursorgaan kennelijk ongegrond is;

d. naar het oordeel van het bestuursorgaan voldoende gelijkenis vertoont met andere aanvragen waarover reeds advies als bedoeld in het eerste lid is uitgebracht; of

e. naar het oordeel van het bestuursorgaan voldoende gelijkenis vertoont met andere aanvragen waarover reeds een onherroepelijke rechterlijke uitspraak is gewezen.

Gelet op de doelstelling van vergroting van de doelmatigheid van het nadeelcompensatierecht en vermindering van bestuurslasten, is ervoor gekozen het eerste lid zo te formuleren dat als uitgangspunt geldt dat geen advies wordt ingewonnen. Paragraaf 10.6.1 liet namelijk zien dat inwinning van deskundigenadvies lang niet altijd nodig is om op zorgvuldige wijze te komen tot een inhoudelijk correct besluit. Dit kan bijvoorbeeld ook worden afgeleid uit hoofdstuk 6. Zo zal soms relatief eenvoudig zijn vast te stellen dat de schade niet groter is dan de gefixeerde 4\%-waardedrempel van art. 15.7 Ow. ${ }^{135}$ Ook de in de Handleiding nadeelcompensatie beschreven 'quick scan', die het bestuur kan uitvoeren bij de vaststelling van het normaal ondernemersrisico, zal geregeld de noodzaak tot inwinning van advies wegnemen. ${ }^{136}$

Het past goed bij het uitgangspunt van aansluiting bij het besluitmodel dat de eerste beoordeling van de noodzaak tot raadpleging van een adviescommissie aan het bestuur wordt gelaten. Ook los daarvan is dit wenselijk, omdat het bestuur doorgaans in de beste positie verkeert om te kunnen inschatten welke hulp het nodig heeft om op zorgvuldige en inhoudelijk correcte wijze te kunnen besluiten op de aanvraag om nadeelcompensatie. Geïnspireerd op de BnIW 2019, VS 2012 en AVN zijn ten slotte in het tweede lid een aantal situaties opgesomd waarin in ieder geval geen advies wordt ingewonnen. Dit past namelijk goed bij de doelstellingen van vergroting van de doelmatigheid van het nadeelcompensatierecht en vermindering van bestuurslasten, en vergroting van de rechtszekerheid en rechtsgelijkheid. Beide artikelleden acht ik bovendien verenigbaar met de overige aan de Wns ten grondslag liggende doelstellingen en uitgangspunten.

135 Zie paragraaf 6.2.2.2.

136 Zie paragraaf 6.3.1 onder het kopje 'De Handleiding nadeelcompensatie bij infrastructurele maatregelen'. 


\subsection{SAMENSTELLING VAN DE ADVIESCOMMISSIE}

10.7.1 Deelvraag 2: verschillen tussen de geselecteerde, thans geldende regelingen en verklaringen daarvoor

Geen normering in de Wro en het Bro, maar wel in de modelverordening van de $V N G$

De Wro en het Bro bevatten geen normering omtrent de samenstelling van de adviescommissie. In de modelverordening van de VNG is bepaald dat het college kan verlangen dat de adviseur "aantoont op grond van opleiding en ervaring deskundig te zijn" alvorens hij wordt aangesteld. Bovendien mag de adviseur "niet werkzaam zijn onder verantwoordelijk van de raad" en "niet betrokken zijn bij de planologische maatregel waarop de aanvraag betrekking heeft." ${ }^{137}$ In eerste instantie wordt één adviseur aangewezen "die beschikt over voldoende deskundigheid inzake advisering op het gebied van planschade." ${ }^{138}$ Het college laat zich adviseren door deze adviseur en slechts indien "er, gezien de complexiteit, aard en omvang van de aanvraag, behoefte bestaat aan extra deskundigheid wordt door het college een tweede adviseur aangewezen." In geval van inkomensderving is dat een deskundige "op het gebied van accountancy of van financieel economische bedrijfsvoering" en bij een waardedaling van een onroerende zaak is dat een deskundige "ter zake van de waardering van onroerende zaken en van waardevermindering daarvan als gevolg van een planologische verslechtering." 139 Als beide schadesoorten zich voordoen en de complexiteit, aard en omvang van de aanvraag dit vereisen, kan van ieder type één deskundige worden toegevoegd. ${ }^{140}$

De als eerste aangestelde adviseur is de voorzitter van de adviescommissie. De adviescommissie dient zelf een rapporteur aan te wijzen. ${ }^{141}$ Alvorens het college de adviesopdracht aan de commissie verstrekt, dient het college de benadeelde, andere betrokken bestuursorganen en derden met wie een planschadeverhaalsovereenkomst is gesloten op de hoogte te brengen van de aanwijzing van de adviseurs. Zij hebben vervolgens twee weken de tijd om schriftelijk een gemotiveerd wrakingsverzoek ten opzichte van één of meerdere commissieleden in te dienen. Uit de toelichting behorende bij de modelverordening volgt dat een dergelijk wrakingsverzoek gegrond moet zijn op "feiten of omstandigheden waardoor de vereiste deskundigheid en onafhankelijkheid schade zou kunnen lijden."142 Binnen twee weken na indiening daarvan beslist het college op het wrakingsverzoek. ${ }^{143}$ Uit jurisprudentie van lagere rechters volgt dat een dergelijke beslissing dient te

137 Art. 4 lid 1 jo. lid 2 modelverordening VNG.

138 Art. 3 lid 1 modelverordening VNG.

139 Art. 3 lid 2 jo. lid 3 modelverordening VNG.

140 Art. 3 lid 4 modelverordening VNG.

141 Art. 3 lid 5 jo. lid 6 modelverordening VNG.

142 Toelichting op art. 5 modelverordening VNG.

143 Art. 5 lid $1 \mathrm{t} / \mathrm{m}$ lid 3 modelverordening VNG. 
worden aangemerkt als een voorbereidingsbeslissing in de zin van art. 6:3 Awb en dus niet appellabel is. ${ }^{144}$ Tevens blijkt uit Afdelingsjurisprudentie dat uit art. 2:4 jo. art. 3:2 jo. art. 3:9 Awb en het ongeschreven zorgvuldigheidsbeginsel een vergewisplicht voor het bestuur voortvloeit die ook blijft gelden na het verstrijken van de termijn van twee weken om een wrakingsverzoek in te dienen. Wanneer bijvoorbeeld pas in bezwaar bedenkingen bij de onpartijdigheid van een van de adviseurs ontstaan, dient het college daar toch rekening mee te houden. Doet het dit niet of onvoldoende, en blijken de bedenkingen in beroep gerechtvaardigd te zijn, dan kan dit voor de rechter namelijk reden zijn om het besluit op bezwaar te vernietigen en het bestuur te verplichten alsnog onafhankelijk en onpartijdig advies in te winnen. ${ }^{145}$

\section{De BnIW 2019 en de VS 2012}

In de toelichting op de RnR 1991 wordt vermeld dat de adviescommissie gelet op de aard van de te nemen beslissingen dient te bestaan uit onafhankelijke deskundigen. Deze regeling voorzag niet in de instelling van een vaste adviescommissie, zodat de minister de samenstelling van de commissie kon afstemmen op de omstandigheden van het individuele schadegeval. In beginsel diende de commissie op grond van art. 5 lid 2 RnR 1991 uit drie onafhankelijke deskundigen te bestaan. De voorzitter moest worden aangewezen door de minister en zou blijkens de toelichting doorgaans een jurist zijn, terwijl de overige leden andere deskundigheid zouden inbrengen. De eis van onafhankelijkheid werd niet nader gedefinieerd. Wel liet deze bepaling ook ruimte voor een éénhoofdige adviescommissie in "eenvoudige gevallen." Blijkens de toelichting werd daarmee gedoeld op "eenvoudige, niet op het eerste gezicht ongegronde, gevallen." In art. 5 lid 4 RnR 1991 werd bepaald dat de minister de aanvrager een kennisgeving diende te sturen van zijn voornemen om een adviescommissie in te stellen. Die kennisgeving diende te bevatten de namen van de deskundigen, hun beroep, en de plaats waar zij hun werkzaamheden pleegden te verrichten. Ook werd bepaald dat de benadeelde binnen twee weken na verzending van de kennisgeving bedenkingen kon uiten tegen de voorgenomen samenstelling. Een beslissing van het bestuur naar aanleiding van dergelijke bedenkingen en de beslissing om een adviescommissie in te stellen, werden - net als onder de Wro het geval is - aangemerkt als een voorbereidingsbeslissing in de zin van art. 6:3 Awb. ${ }^{146}$

144 Rb. Amsterdam 15 mei 2013, ECLI:NL:RBAMS:2013:3113, r.o. 3.1-3.1.2.

145 ABRvS 13 juli 2016, ECLI:NL:RVS:2016:1970 (Raalte). Zie met name r.o. 4.2 en r.o. 5, en het negende onderdeel van mijn bijbehorende annotatie in $A B$ 2016/454. Zie daarover eveneens Schlössels 2017, p. 329-330.

146 Zie Stcrt. 1991, nr. 251, p. 28-29; en Stcrt. 1999, nr. 172, p. 12 (digitaal, p. 13). Ten tijde van de inwerkingtreding van de RnR 1991 gold art. 6:3 Awb nog niet, maar de minister anticipeerde op de corresponderende bepaling uit het voorstel voor de Awb. 
Hetgeen art. 5 lid 4 RnR 1991 bepaalde omtrent de kennisgeving van het voornemen tot instelling van een adviescommissie is (nagenoeg) $)^{147}$ letterlijk overgenomen in art. 7 lid 5 VS 1999 en art. 15 lid 5 RnVW 1999. Die bepalingen zijn niet aangepast bij de overgang naar de VS 2012 respectievelijk BnIM 2014 en BnIW 2019. Het huidige recht verschilt wel aanzienlijk van de RnR 1991 als het aankomt op de samenstelling van de adviescommissie. Een relatief klein verschil ontstond al bij de invoering van de VS 1999. Art. 7 lid 3 VS 1999 stelde namelijk een additionele eis aan de samenstelling van de adviescommissie, die ongewijzigd werd overgenomen in art. 7 lid 3 VS 2012: bij de benoeming van deskundigen dient de besliscommissie te kiezen uit personen die worden vermeld op een door het dagelijks bestuur van het Schadeschap vastgestelde lijst van deskundigen. Deze eis is nooit van motivering voorzien. Mogelijk diende zij de kwaliteit van de advisering te waarborgen. Ook is denkbaar dat zij ertoe diende het dagelijks bestuur van het Schadeschap, dat eigenlijk maar weinig invloed had op de besluitvorming, toch enige invloed toe te kennen.

De regeling uit art. 5 lid 2 RnR 1991 omtrent de samenstelling van de adviescommissie werd aanvankelijk ongewijzigd overgenomen in art. 7 lid 2 VS 1999, art. 15 lid 3 RnVW 1999 en art. 15 lid 3 BnIM 2014. Bij de vaststelling van de VS 2012 en BnIW 2019 werden echter significante wijzigingen doorgevoerd. In art. 7 lid 2 VS 2012 wordt namelijk bepaald dat een adviescommissie in beginsel slechts bestaat uit één onafhankelijke deskundige. Indien de inhoud van de aanvraag om nadeelcompensatie daartoe aanleiding geeft, kan de besliscommissie echter besluiten om twee of drie onafhankelijke deskundigen te benoemen. Deze wijziging is doorgevoerd naar aanleiding van de aanbeveling uit het rapport van Van Ettekoven en Tjepkema ${ }^{148}$ om de verordening in die zin te wijzigen "dat meer mogelijkheden ontstaan om te besluiten zonder inschakeling van de AC, dan wel met inschakeling van een AC van één of twee deskundigen." Ook niet-eenvoudige juridische vragen zouden namelijk in beginsel door één juridisch deskundige moeten kunnen worden beantwoord. Voor de benoeming van een tweede of derde commissielid zal doorgaans bepalend zijn "of het in een concreet geval aangewezen is dat verschillende expertises bij de advisering betrokken worden." Ook zou het mogelijk moeten zijn om niet twee taxateurs, maar slechts één taxateur als lid van een adviescommissie te benoemen. In het rapport wordt benadrukt dat de zorgvuldigheid niet onder deze wijzigingen hoeft te lijden, terwijl wel een kostenbesparing en tijdwinst kan worden geboekt. Een commissie van één lid zou daarom moeten bestaan uit één jurist óf één taxateur, en een commissie van twee leden uit één jurist-voorzitter en één taxateur. ${ }^{149}$

147 In de VS 1999 is het uitvoerende bestuursorgaan uiteraard niet de minister, maar de besliscommissie van het Schadeschap.

148 Zie daarover paragraaf 10.1 onder het kopje 'Introductie van enkele tot op heden nog niet besproken regelingen'.

149 Stcrt. 2012, nr. 8910, p. 5-6. 
In 2012 werd ook nog een zesde lid toegevoegd aan art. 7 VS 2012. Conform dit artikellid is de besliscommissie bevoegd...

\begin{abstract}
“(...) de benoeming van één of meer deskundigen terzake van de advisering ten aanzien van een concreet verzoek te beëindigen en de adviesopdracht aan deze deskundige of deskundigen te beëindigen, indien de wijze van taakvervulling door de betreffende deskundige of deskundigen daartoe naar het oordeel van de besliscommissie aanleiding geeft. De besliscommissie benoemt in voorkomend geval zo nodig een andere deskundige, of andere deskundigen."
\end{abstract}

Uit de bijbehorende toelichting blijkt dat deze bevoegdheid ook al bestond onder de VS 1999. Ten behoeve van de duidelijkheid werd dit echter geëxpliciteerd in het nieuwe artikellid. Bovendien werd beoogd zeker te stellen dat gevolg kon worden gegeven aan de aanbeveling van Van Ettekoven en Tjepkema "dat zaken weg dienen te worden gehaald bij adviescommissies die niet bereid of in staat zijn tijdig te adviseren, of anderszins niet goed functioneren." Er werd namelijk gewerkt met vijftien vaste adviescommissies, die niet allemaal evenveel boodschap aan tijdigheid hadden. In combinatie met afstemmings- en andere logistieke problemen leidde dit ertoe dat "in nagenoeg alle zaken termijnoverschrijdingen hebben plaatsgevonden, waardoor sprake [was] van stelselmatig onwetmatig handelen." 150 Dat leidde ook ertoe dat de luchtvaartsector (draagplichtig op grond van art. 8a.38 Wlv) een procedure tegen de minister aanspande om niet te hoeven opdraaien voor de kosten in de vorm van extra betaalde wettelijke rente en apparaatskosten. ${ }^{151}$

De wijzigingen die de BnIW 2019 doorvoert ten opzichte van de BnIM 2014 zijn minder ingrijpend. Vooral relevant is dat art. 15 lid 3 zo is gewijzigd dat de adviescommissie bestaat uit één of meer onafhankelijke deskundigen. Uit de toelichting volgt dat het in de praktijk niet altijd noodzakelijk is gebleken dat de adviescommissie uit drie personen bestond. Vaak kwam het voor dat kon worden volstaan met een 'éénmanscommissie' of een commissie die bestond uit een voorzitter met bijzondere juridische expertise en een financieel deskundige. ${ }^{152}$ Door de wijze waarop het nieuwe artikellid is geformuleerd, kunnen in theorie ook adviescommissies worden ingesteld die bestaan uit meer dan drie deskundigen. Uit de toelichting blijkt niet of de minister denkt dat hieraan behoefte kan bestaan in bijzondere gevallen.

\title{
De Amsterdamse verordeningen
}

Ingevolge het bij de AVN behorende Reglement adviescommissie nadeelcompensatie en het bij de VNNZ behorende Reglement Schadecommissie Noord/Zuidlijn dient een driehoofdige adviescommissie te worden ingesteld waarvan de voorzit-

$150 \quad$ Stcrt. 2012, nr. 8910, p. 6-7.

151 ABRvS 6 december 2017, ECLI:NL:RVS:2017:3304, r.o. 2 (BARIN).

152 Stcrt. 2019, nr. 66154, p. 14 en 17. 
ter door B\&W wordt aangewezen. ${ }^{153}$ Onder de AVN dient in ieder geval de voorzitter niet in dienst te zijn van de gemeente Amsterdam, terwijl dit onder de VNNZ geldt voor de gehele adviescommissie. ${ }^{154}$ Voorts dient onder de AVN ten minste één van de leden van de adviescommissie te beschikken over een voltooide academische juridische opleiding en dient ten minste één lid financieel deskundige te zijn. ${ }^{155}$ Onder de VNNZ wordt slechts in algemene zin de eis gesteld dat de leden van de adviescommissie deskundig en niet in enigerlei opzicht betrokken bij de aanleg van de Noord/Zuidlijn zijn. ${ }^{156}$ Voor beide verschillen heb ik geen expliciete verklaringen gevonden. Het tweede verschil kan mogelijk deels worden verklaard doordat het onder de VNNZ eenvoudiger is om aan te geven waar de adviseur allemaal niet bij betrokken mag zijn. Deze regeling ziet immers slechts op één schadeveroorzakend project.

Onder de VNNZ worden de leden van de adviescommissie benoemd voor een periode van vier jaar, waarbij telkens kan worden herbenoemd voor eenzelfde periode. Onder de AVN geldt dit slechts voor de voorzitter en de plaatsvervangend voorzitter van de adviescommissie. ${ }^{157}$ De overige leden van de commissie worden onder de AVN slechts "aangewezen" en lijken daarmee een minder duurzame positie binnen de commissie te hebben. ${ }^{158}$ Dat vermoeden wordt bevestigd doordat het bij de AVN behorende reglement slechts aandacht besteedt aan het ontslag van de voorzitter en de plaatsvervangend voorzitter. Zij kunnen op eigen verzoek worden ontslagen, of door het college uit hun "functie worden ontheven, indien op grond van feiten of omstandigheden gerede twijfel bestaat" aan hun "onafhankelijkheid of deskundigheid." 159 Dit geldt onder de VNNZ voor alle leden van de adviescommissie. Het bij de VNNZ behorende reglement expliciteert voorts nog dat de ontheffing uit functie ambtshalve of op verzoek kan geschieden. ${ }^{160} \mathrm{Ik}$ heb geen reden om aan te nemen dat dit anders zou zijn onder de AVN. Hoewel minder expliciet en aan minder voorwaarden verbonden dan in de hiervoor reeds besproken regelingen, lijkt daarom ook onder beide Amsterdamse verordeningen de mogelijkheid voor de aanvrager te bestaan om bedenkingen te uiten tegen de samenstelling van de adviescommissie.

153 Zie art. 3 lid 1 Reglement adviescommissie nadeelcompensatie; en art. 8 lid 1 Reglement Schadecommissie Noord/Zuidlijn.

154 Zie art. 3 lid 1 Reglement adviescommissie nadeelcompensatie; en art. 8 lid 2, aanhef en onder b Reglement Schadecommissie Noord/Zuidlijn. Zie ook de toelichting op art. 13 VNNZ.

155 Art. 3 lid 2 Reglement adviescommissie nadeelcompensatie.

156 Art. 8 lid 2, aanhef en onder a Reglement Schadecommissie Noord/Zuidlijn.

157 Zie art. 3 lid 3 en lid 5 Reglement adviescommissie nadeelcompensatie; en art. 9 lid 1 Reglement Schadecommissie Noord/Zuidlijn.

158 Art. 3 lid 3 Reglement adviescommissie nadeelcompensatie.

159 Art. 4 lid 1 jo. lid 2 Reglement adviescommissie nadeelcompensatie.

160 Art. 9 lid 3 t/m lid 5 Reglement Schadecommissie Noord/Zuidlijn. 
Ten slotte blijkt onder de VNNZ de mogelijkheid te bestaan dat de adviescommissie de adviesaanvraag 'verkort behandeld'. Daarop zal ik nader ingaan in paragraaf 10.11.1. Hier merk ik slechts op dat de adviescommissie in 'eenvoudige gevallen' kan beslissen om de behandeling van de aanvraag en het uitbrengen van advies op te dragen aan één van haar leden. ${ }^{161}$ Hoewel dat nergens is geëxpliciteerd, lijkt het aannemelijk dat deze mogelijkheid is ingevoerd om de doelmatigheid te bevorderen. ${ }^{162} \mathrm{Ik}$ kan niet verklaren waarom geen vergelijkbare mogelijkheid in het leven is geroepen onder de AVN. Onder die verordening dient de adviescommissiecommissie steeds voltallig te beraadslagen over het door haar uit te brengen advies. ${ }^{163}$

\section{Conclusie}

Uit het voorafgaande kan worden afgeleid dat de geselecteerde, thans geldende regelingen in niet onbelangrijke mate van elkaar verschillen als het aankomt op de normering van de samenstelling van de adviescommissie. De Amsterdamse reglementen vertonen relatief veel overeenkomst. Verschillen tussen de reglementen lijken echter grotendeels onverklaarbaar. Ook de VS 2012 en BnIW 2019 vertonen relatief veel onderlinge overeenkomst, doordat zij een gemeenschappelijke voorouder kennen in de RnR 1991. Bovendien is onder beide regelingen, ogenschijnlijk onafhankelijk van elkaar, een trend ontstaan van meer efficiënte besluitvorming. Hoewel dat destijds niet is geëxpliciteerd, lijkt ook aan de regeling uit de modelverordening een zekere efficiëntiegedachte ten grondslag te liggen. Ik heb echter geen duidelijke verklaringen kunnen vinden voor verschillen tussen de modelverordening, de VS 2012 en BnIW 2019, en de Amsterdamse verordeningen. Deze verschillen lijken met name te zijn ontstaan doordat de regelingen gedurende enkele decennia door verschillende regelgevers zijn opgesteld, terwijl die regelgevers ten aanzien van dit onderwerp geen aandacht lijken te hebben gehad voor afstemming op andere nadeelcompensatieregelingen en/of overleg met elkaar, laat staan een materieelrechtelijk verschil in het leven beoogden te roepen.

\subsubsection{Deelvraag 3: Toekomstig recht}

Titel 4.5 Awb en afd. 15.1 Ow regelen niets omtrent de samenstelling van de adviescommissie. Onder beide regelingen zal dus moeten worden teruggevallen op het algemene kader als beschreven in paragraaf 10.6.1. Voor de beperkte informatie die daarover uit de bij deze regelingen behorende memories van toelichting kan worden afgeleid, verwijs ik naar paragraaf 10.6.2.

161 Art. 7 lid 1 jo. lid 2, aanhef en onder a Reglement Schadecommissie Noord/Zuidlijn.

162 Zie met name ad $3 \mathrm{t} / \mathrm{m} 5$ op p. $4-5$ van de toelichting op de VNNZ.

163 Art. 8 lid 2 Reglement adviescommissie nadeelcompensatie. 
10.7.3 Hoofdvraag: spiegeling aan de doelstellingen en uitgangspunten die ten grondslag liggen aan de Wns

Dat titel 4.5 Awb en afd. 15.1 Ow geen normering bevatten omtrent de samenstelling van de adviescommissie verhoudt zich in ieder geval slecht tot de doelstellingen van vereenvoudiging, ${ }^{164}$ uniformering en harmonisering van het nadeelcompensatierecht, vergroting van de rechtszekerheid, en codificatie van het nadeelcompensatierecht. Dat geldt te meer vanwege het grote belang dat in het planschade- en nadeelcompensatierecht wordt toegekend aan deskundigenadvisering. ${ }^{165}$ Bovendien laten de geselecteerde, thans geldende regelingen zien dat in de praktijk structurele behoefte aan dit soort normering bestaat. Ik zie daarom aanleiding om (a) titel 4.5 Awb aan te passen door daarin op te nemen aan welke eisen de samenstelling van een adviescommissie dient te voldoen. De verklaringen voor de verschillen tussen de geselecteerde, thans geldende regelingen geven geen aanleiding om andere of aanvullende normering aan te nemen voor aanvragen die onder de reikwijdte van afd. 15.1 Ow vallen. Dat zou ook niet goed passen bij de doelstelling van vereenvoudiging, uniformering en harmonisering van het nadeelcompensatierecht. Ik zie derhalve geen aanleiding om (b) afd. 15.1 Ow aan te passen. Ook zie ik geen aanleiding om (c) anderszins in een bijzondere invulling, aanvulling of afwijking van titel 4.5 Awb te voorzien.

In paragraaf 10.6.3 stelde ik een tweeledige bepaling voor omtrent de inwinning van advies bij een adviescommissie. De in de onderhavige paragraaf voorgestelde aanpassing van titel 4.5 Awb zou kunnen worden vormgegeven door toevoeging van de onderstaande leden:

\section{Artikel 4:135}

3. Een adviescommissie als bedoeld in het eerste lid bestaat uit één of meer deskundigen die door het bestuursorgaan worden benoemd. Benoeming kan zowel geschieden voor een termijn van maximaal twee jaar waarna mogelijkheid bestaat tot herbenoeming, als voor advisering met betrekking tot een of meerdere aanvragen. Indien de commissie uit meerdere leden bestaat, wijst het bestuursorgaan de voorzitter aan.

4. Onverminderd artikel 3:9 vergewist het bestuursorgaan zich van de onafhankelijkheid en onpartijdigheid van de leden van de adviescommissie. Daarbij betrekt het in ieder geval of een lid van de adviescommissie of personen waarmee hij onderdeel uitmaakt van een samenwerkingsverband:

a. ten tijde van de indiening van de aanvraag of gedurende de vijf daaraan voorafgaande jaren het bestuursorgaan, de rechtspersoon waartoe het bestuursorgaan behoort, of andere organen die deel uitmaken van dezelfde rechtspersoon, als advocaat of gemachtigde hebben bijgestaan of geadviseerd;

164 Dergelijke normering zou immers een belangrijk procedureel onderwerp regelen, waardoor de noodzaak tot vaststelling van aanvullende regelgeving zou afnemen. 
b. betrokken waren bij de schadeoorzaak waarop de aanvraag betrekking heeft; of

c. ten tijde van de indiening van de aanvraag werkzaam waren, of gedurende de vijf daaraan voorafgaande jaren werkzaam zijn geweest, onder verantwoordelijkheid van het bestuursorgaan.

5. Het bestuursorgaan stelt de aanvrager, en eventuele andere belanghebbenden waarmee het bekend is, in kennis van zijn voornemen om advies in te winnen bij een adviescommissie. De kennisgeving bevat informatie inhoudende de namen van de beoogde leden van de adviescommissie, alsmede hun beroep, nevenfuncties, opleidingsgeschiedenis, relatie tot het bestuursorgaan en de plaats waar zij hun werkzaamheden plegen te verrichten.

6. Als een belanghebbende bedenkingen heeft tegen de voorgenomen samenstelling van de adviescommissie, brengt hij deze ter kennis van het bestuursorgaan binnen twee weken na verzending van de in het vijfde lid bedoelde kennisgeving.

7. Als een belanghebbende pas na het verstrijken van de in het zesde lid gestelde termijn bekend raakt met feiten en omstandigheden die leiden tot bedenkingen tegen de samenstelling van de adviescommissie, dan brengt hij zijn bedenkingen zo spoedig mogelijk ter kennis van het bestuursorgaan.

8. Het bestuursorgaan reageert binnen twee weken na ontvangst daarvan op bedenkingen als bedoeld in het zevende lid. Indien de belanghebbende niet tevens de aanvrager is, brengt het bestuursorgaan de aanvrager binnen dezelfde termijn op de hoogte van deze bedenkingen en zijn reactie daarop.

9. Het bestuursorgaan is bevoegd de benoeming van een lid van de adviescommissie, of de hem ter zake van de aanvraag gegunde adviesopdracht te beëindigen, indien:

a. het lid van de adviescommissie zelf daarom verzoekt;

b. naar het oordeel van het bestuursorgaan voldoende twijfel bestaat over de onafhankelijkheid, onpartijdigheid, of deskundigheid van het lid van de adviescommissie; of

c. de wijze van taakvervulling door het lid van de adviescommissie daartoe naar het oordeel van het bestuursorgaan voldoende aanleiding geeft.

Ik acht deze leden in algemene zin verenigbaar met de aan de Wns ten grondslag liggende doelstellingen en uitgangspunten. Hierna zal ik toelichten welke keuzes met het oog op welke doelstellingen of uitgangspunten zijn gemaakt.

\section{Het aantal commissieleden}

Het derde lid van de voorgestelde bepaling is gebaseerd op art. 15 lid 3 BnIW 2019. In de bijbehorende toelichting zou mijns inziens moeten worden vermeld dat niet meer commissieleden moeten worden benoemd dan nodig is om op zorgvuldige wijze een advies tot stand te laten komen dat kan dienen als deugdelijke motivering van het besluit op de aanvraag om nadeelcompensatie. Dat past immers goed bij de doelstelling van vergroting van de doelmatigheid van het nadeelcompensatierecht en vermindering van bestuurslasten. Zeker bij een samenloop van verschillende schadesoorten en/of schadeoorzaken kan op voorhand echter 
niet worden uitgesloten dat de voor de advisering benodigde expertise niet kan worden geboden door slechts drie personen. Daarom is de keuze gemaakt om de omvang van de deskundigencommissie niet te beperken tot maximaal drie personen, zoals wel het geval is in de modelverordening van de VNG, de VS 2012 en de AVN. Ook die keuze acht ik verenigbaar met de doelstelling van vergroting van de doelmatigheid van het nadeelcompensatierecht en vermindering van bestuurslasten. Problemen die ontstaan door gebrekkige advisering kunnen immers net zo goed, en zo mogelijk zelfs meer, geld kosten dan degelijke advisering door een commissie van bijvoorbeeld vier deskundigen.

\section{Onafhankelijk- en onpartijdigheid van de commissieleden}

Het vierde lid is voorgesteld met het oog op de doelstellingen van vereenvoudiging, uniformering en harmonisering van het nadeelcompensatierecht, vergroting van de rechtszekerheid en rechtsgelijkheid, en codificatie van het nadeelcompensatierecht. Zowel de in de bepaling aangehaalde vergewisplicht als de opgesomde omstandigheden die in ieder geval moeten worden betrokken bij de invulling daarvan, zijn geïnspireerd op Afdelingsjurisprudentie. Ten opzichte van deze jurisprudentie zijn enkele kleine wijzigingen voorgesteld, omdat de lijnen die de Afdeling uitzet niet altijd even duidelijk zijn. In geval van de combinatie van de functie van deskundige en gemachtigde/advocaat onderzoekt de Afdeling bijvoorbeeld of de deskundige "gelijktijdig of betrekkelijk kort voorafgaande aan de verlening van de opdracht tot advisering als deskundige" ook als advocaat of gemachtigde namens het bestuursorgaan heeft opgetreden. Het criterium 'betrekkelijk kort' roept vragen op en leidt daardoor tot onzekerheid. In de voorgestelde bepaling wordt daarom gekozen voor een termijn van vijf jaren. Voorts is bewust gekozen voor een niet-limitatieve opsomming van relevante omstandigheden, omdat de afgelopen jaren is gebleken dat de jurisprudentie omtrent deskundigenadvisering nog in ontwikkeling is. ${ }^{166}$

\section{Een disclosure statement}

Het is voor een belanghebbende niet altijd eenvoudig om informatie te achterhalen omtrent de persoon en het functioneren van de in zijn zaak benoemde deskundige(n). ${ }^{167}$ Mede gelet op de doelstellingen van vergroting van de rechtszekerheid en rechtsgelijkheid, en vergroting van de doelmatigheid van het nadeelcompensatierecht en vermindering van bestuurslasten, is daarom in het vijfde lid

166 Zie hierover uitgebreider mijn annotatie bij ABRvS 13 juli 2016, ECLI:NL:RVS:2016:1970 (Raalte) in $A B$ 2016/454. Zie ook onderdeel 10 en 11 van de annotatie van Tjepkema en mijzelf bij ABRvS 17 mei 2017, ECLI:NL:RVS:2017:1293 (De Lunet) in AB 2017/427; ABRvS 28 september 2016, ECLI:NL:RVS:2016:2582, r.o. 8.1-8.3 (Overzichtsuitspraak); Schlössels 2017, p. 329-330; en Van Ettekoven e.a. 2018, p. 80.

167 Zie hierover bijvoorbeeld ABRvS 28 september 2016, ECLI:NL:RVS:2016:2582, r.o. 8.2 (Overzichtsuitspraak). 
van de voorgestelde bepaling een informatieplicht voor het bestuur opgenomen. Een dergelijke bepaling is minstens zo oud als art. 5 lid 4 RnR 1991. De voorgestelde informatieplicht is echter uitgebreider en mede geïnspireerd op het door Van Ravels voor het planschade- en nadeelcompensatierecht bepleite 'disclosure statement'. ${ }^{168}$ Kort gezegd, betreft dit een document waarin de kwalificaties van de deskundige worden uiteengezet. Op basis daarvan is voor belanghebbenden beter na te gaan waarom de desbetreffende persoon geschikt is om als deskundige op te treden, en in hoeverre mogelijk sprake is van afhankelijk- dan wel partijdigheid.

\section{Mogelijkheden tot wraking van de (beoogde) commissieleden}

Analoog aan een groot deel van de geselecteerde, thans geldende regelingen biedt het zesde lid van de voorgestelde bepaling een wrakingsmogelijkheid gedurende enkele weken na het bekendmaken van het voornemen tot instelling van de adviescommissie. In paragraaf 10.7.1 $1^{169}$ bleek dat het verstrijken van een wrakingstermijn het bestuur niet ontslaat van zijn plicht om zich te vergewissen van de onafhankelijk- en onpartijdigheid van de leden van de adviescommissie. Met name gelet op de doelstellingen van vergroting van de rechtszekerheid en rechtsgelijkheid, codificatie van het nadeelcompensatierecht, en vergroting van de doelmatigheid van het nadeelcompensatierecht en vermindering van bestuurslasten is daarom in het zevende lid een mogelijkheid tot wraking opgenomen met betrekking tot grieven die pas later in de procedure ontstaan. Het past ook goed bij deze doelstellingen dat het achtste lid bepaalt dat het bestuursorgaan dient te reageren als een belanghebbende gebruikmaakt van de wrakingsmogelijkheid uit het zevende lid. In geval van het zesde lid is dat niet nodig, omdat bij het verstrekken van de adviesopdracht zal blijken of het bestuur wijzigingen heeft doorgevoerd in de samenstelling van de adviescommissie. ${ }^{170}$

Uiteraard kan de wraking van een of meerdere deskundigen ook tot een vertraging in de afhandeling van de aanvraag leiden. Toch acht ik de voorgestelde wrakingsmogelijkheden niet strijdig met de doelstelling van vergroting van de doelmatigheid van het nadeelcompensatierecht en vermindering van bestuurslasten en/of de overige aan de Wns ten grondslag liggende doelstellingen en uitgangspunten. Ze waarborgen immers dat het bestuur zo vroeg mogelijk op de hoogte wordt gebracht van eventuele bezwaren tegen de (beoogde) samenstelling van de adviescommissie. Zijn die bezwaren onterecht, dan zijn in het ergste geval twee weken

168 Zie Van Ravels 2010a, p. 548; en Van Ravels 2015, p. 174. Van Ravels' pleidooi is goed ontvangen in de literatuur. Zie bijvoorbeeld Van Ettekoven 2016, p. 92; Franssen, Roozendaal \& Van de Sande 2016, p. 91; en Franssen, Roozendaal \& Van de Sande 2017, p. 72.

169 Zie het kopje 'Geen normering in de Wro en het Bro, maar wel in de modelverordening van de VNG'.

170 Zie over die opdracht ook paragraaf 10.11.3. 
verloren gegaan. ${ }^{171}$ Snijden de bezwaren wel hout, dan wordt voorkomen dat op een later tijdstip - bijvoorbeeld in bezwaar of beroep - de conclusie moet worden getrokken dat (een groot deel van) de procedure moet worden overgedaan. De kosten die daarmee gemoeid zouden zijn, zullen doorgaans aanmerkelijk groter zijn dan de beperkte lastenverzwaring die de voorgestelde wrakingsmogelijkheden meebrengen.

\section{Ontslag of uitsluiting van de commissieleden}

Het negende lid van de voorgestelde bepaling is ingegeven door de doelstelling van vergroting van de rechtszekerheid. Het regelt wanneer een lid van de adviescommissie kan worden ontslagen, of van verdere betrokkenheid bij het aanhangige schadedossier kan worden uitgesloten. Hiervoor is aansluiting gezocht bij art. 7 lid 6 VS 2012 en de bij de AVN en VNNZ behorende reglementen. Ook is analoog aan die reglementen voorgesteld om in het derde lid te bepalen dat benoeming zowel kan geschieden voor een termijn van maximaal twee jaar waarna mogelijkheid bestaat tot herbenoeming, als voor advisering met betrekking tot een of meerdere aanvragen. De tweejaarstermijn zorgt ervoor dat het bestuur met enige regelmaat in algemene zin moet stilstaan bij de in het vierde lid opgenomen vergewisplicht. Dit kan bijvoorbeeld problemen voorkomen die betrekking hebben op de onafhankelijk- en/of onpartijdigheid van de commissieleden. Dit weegt mijns inziens op tegen de beperkte kosten van een besluit tot herbenoeming. Daardoor acht ik de tweejaarstermijn verenigbaar met - en mogelijk zelfs bevorderlijk voor het bereiken van - de doelstelling van vergroting van de doelmatigheid van het nadeelcompensatierecht en vermindering van bestuurslasten. Ten slotte maakt het voorgestelde artikellid duidelijk dat adviescommissies niet op ad hoc basis hoeven te worden vastgesteld, maar ook van meer permanente aard kunnen zijn. Dat past goed bij de doelstelling van vergroting van de rechtszekerheid.

\subsection{INHOUD VAN HET ADVIES}

10.8.1 Deelvraag 2: verschillen tussen de geselecteerde, thans geldende regelingen en verklaringen daarvoor

\section{Op de RnR 1991 gebaseerde regelingen}

Art. 6 lid 1 RnR 1991 bepaalde dat de adviescommissie een onderzoek diende in te stellen naar (1) de vraag of de schade het gevolg was van een schadeoorzaak die onder de reikwijdte van de regeling viel; (2) de omvang van de schade; (3) de vraag of de schade redelijkerwijs niet of niet geheel ten laste van de benadeelde behoorde te blijven; en (4) de vraag of de vergoeding van de schade niet, of niet

171 In de praktijk is het ook goed denkbaar dat alle betrokken partijen binnen enkele dagen reageren op de kennisgeving omtrent de beoogde samenstelling van de adviescommissie. 
voldoende, anderszins was verzekerd. Op grond van het tweede lid diende ook te worden geadviseerd over de hoogte van de uit te keren nadeelcompensatie. Als daar aanleiding toe bestond, moest bovendien worden ingegaan op de vraag of de schade anders dan door een geldelijke vergoeding kon worden beperkt of worden ongedaan gemaakt. Uit de bijbehorende toelichting blijkt dat niet werd beoogd verandering te brengen in de toen al bestaande praktijk dat eerst wordt onderzocht of de schade anderszins kan worden voorkomen of beperkt alvorens over te gaan tot geldelijke compensatie. Voorts blijkt uit de toelichting dat het eerste lid minder streng was dan zou worden verwacht op basis van de tekst daarvan. Viel de beweerde schadeoorzaak niet binnen de reikwijdte van de regeling, dan hoefden de overige adviesvragen namelijk niet te worden beantwoord. Ook hoefde bijvoorbeeld de omvang van de schade niet nauwkeurig te worden vastgesteld als duidelijk was dat deze tot het normaal maatschappelijk risico behoorde of sprake was van risicoaanvaarding. ${ }^{172}$

Art. 6 RnR 1991 is nagenoeg ongewijzigd overgenomen in art. 16 RnVW 1999, waarin geen veranderingen zijn aangebracht bij de overgang naar de BnIM 2014 en BnIW 2019. Een eerste afwijking ten opzichte van de bepaling uit de RnR 1991 betreft dat de in het eerste lid genoemde punten slechts hoeven te worden onderzocht "voorzover een zorgvuldige advisering daartoe noopt". Een tweede afwijking is dat de BnIW 2019 een onderscheid maakt tussen de vraag of de schade het gevolg is van de in de aanvraag aangeduide schadeoorzaak, en de vraag of die schadeoorzaak binnen de reikwijdte van de beleidsregel valt. De eerste vraag hoeft slechts door de adviescommissie te worden onderzocht als de tweede vraag bevestigend is beantwoord. Een derde afwijking brengt mee dat slechts als de minister daarom vraagt advies hoeft te worden uitgebracht over het anderszins beperken of ongedaan maken van de schade. Een laatste afwijking is dat in de BnIW 2019 wordt geëxpliciteerd dat de vraag of de schade redelijkerwijs niet of niet geheel ten laste van de benadeelde behoort te blijven, dient te worden beantwoord met inachtneming van het in artikel 3 tot en met 11 bepaalde. Deze toevoeging kan worden verklaard doordat de RnR 1991 nog geen bepalingen bevatte met inhoudelijke criteria die invulling gaven aan de in art. 2 opgenomen redelijkerwijsformule. De hier besproken afwijkingen zijn niet van toelichting voorzien. Zij lijken de eerder besproken opmerkingen uit de toelichting op de RnR 1991 te codificeren, anderszins voor meer duidelijkheid te zorgen en/of te zijn ingegeven door een efficiëntiegedachte.

Art. 6 RnR 1991 is ook nagenoeg ongewijzigd overgenomen in art. 8 VS 1999. De enige afwijking was dat in art. 8 lid 2 VS 1999 niet werd opgenomen dat moest worden geadviseerd over het anderszins beperken of ongedaan maken van de schade. De VS 2012 bracht wel enkele significante wijzigingen mee. De belangrijkste daarvan is dat de besliscommissie de bevoegdheid krijgt om een "bijzondere adviesopdracht" te geven. Deze mogelijkheid is mede ingegeven door doel- 
matigheidsredenen en geeft het bestuur de mogelijkheid om de adviesopdracht te beperken "tot een enkele vraag, of tot enige op het betreffende verzoek toegespitste vragen." Wanneer geen bijzondere adviesopdracht wordt gegeven, dient de adviescommissie te adviseren over de in het eerste en tweede lid genoemde adviesvragen. Aan de opsomming van het eerste lid is toegevoegd dat wordt geadviseerd over de vraag of het handelen of nalaten door of namens verzoeker in het kader van de behandeling van de aanvraag, gevolgen moet hebben voor de omvang van de toe te kennen vergoeding, waaronder de vergoeding van wettelijke rente. Met deze toevoeging wordt beoogd dat rekening kan worden gehouden met "de consequenties van het eerst in een later stadium beschikbaar komen van gegevens die noodzakelijk zijn voor de advisering". Met name als de oorzaak van het later beschikbaar komen van deze gegevens in de risicosfeer van verzoeker ligt, zou dat gevolgen moeten kunnen hebben voor bijvoorbeeld de vergoeding van de wettelijke rente. ${ }^{173}$ Ten slotte is in het tweede lid geëxpliciteerd dat slechts over de hoogte van de toe te kennen nadeelcompensatie wordt geadviseerd indien het onderzoek dat is uitgevoerd op grond van het eerste lid daartoe aanleiding geeft. Ik heb geen reden om aan te nemen dat dit anders was onder de RnR 1991 en de overige hiervoor besproken regelingen. In de toelichting op de RnVW 1999 wordt bijvoorbeeld opgemerkt dat slechts op de hoogte van de nadeelcompensatie wordt ingegaan "zo aansprakelijkheid moet worden aangenomen". ${ }^{174}$

\section{Het Bro}

In art. 6.1.3.4 Bro is bepaald welke onderwerpen in ieder geval moeten worden behandeld in het advies van de adviescommissie. Hoewel dat nergens wordt geëxpliciteerd, lijkt deze bepaling te zijn geïnspireerd op art. 16 RnVW 1999. De bepaling uit het Bro is namelijk eveneens ingedeeld in twee artikelleden, die bovendien deels woordelijk overeenkomen met de bepaling uit de RnVW 1999. Er zijn echter ook verschillen. Zo kent de bepaling uit het Bro bijvoorbeeld niet de toevoeging dat de vraag naar aanwezigheid van causaal verband slechts in het advies hoeft te worden betrokken indien, en voor zover, de beweerde schadeoorzaak onder de reikwijdte van afd. 6.1 Wro valt. Ook noemt de RnVW 1999 het voldoende anderszins verzekerd zijn van de tegemoetkoming in de schade nog als een afzonderlijk adviespunt, terwijl het Bro dat doet met betrekking tot voordeelverrekening. Dit soort verschillen leiden niet tot materieelrechtelijke verschillen tussen deze regelingen en kunnen hoofdzakelijk worden verklaard door de systematiek en bijzonderheden van beide regelingen. Zo wordt het niet vergoeden van schade waarvan de vergoeding voldoende anderszins is verzekerd, voorgeschreven door art. 6.1 lid 1 Wro. Die bepaling dient volgens art. 6.1.3.4 lid 1 Bro te worden betrokken bij de beantwoording van de vraag of de schade redelijkerwijs geheel of gedeeltelijk ten laste van de benadeelde behoort te blijven. Vice versa wordt voordeelverrekening voorgeschreven door art. 9 RnVW 1999, terwijl die bepaling 
ingevolge art. 16 lid 1 RnVW 1999 moet worden betrokken bij de beantwoording van de vraag of de schade redelijkerwijs geheel of gedeeltelijk ten laste van de benadeelde behoort te blijven. Dat voordeelverrekening afzonderlijk wordt genoemd in art. 6.1.3.4 lid 2 Bro lijkt te kunnen worden verklaard doordat afd. 6.1 Wro geen afzonderlijke aandacht besteedt aan voordeelverrekening. Die verrekening wordt namelijk geacht onderdeel uit te maken van de beantwoording van de vraag of, en zo ja, hoeveel schade is geleden. ${ }^{175}$

Anders dan art. 16 RnVW 1999, bepaalt art. 6.1.3.4 Bro niet dat de opgesomde onderwerpen slechts in het advies hoeven te worden betrokken "voorzover een zorgvuldige advisering daartoe noopt". In theorie zou dit wel een verschil kunnen zijn dat een materieelrechtelijke uitwerking kent. Het lijkt echter weinig waarschijnlijk dat bijvoorbeeld uitgebreid op de omvang van de schade zal worden ingegaan als de aanwezigheid van risicoaanvaarding wordt vastgesteld. Ik ga daarom ervan uit dat de soep minder heet wordt gegeten als zij wordt opgediend, net als het geval was onder de RnR 1991.

\section{De VNNZ}

In art. 3 lid 2 Reglement Schadecommissie Noord/Zuidlijn is opgesomd welke aspecten van de aanvraag om nadeelcompensatie de adviescommissie moet onderzoeken. Het betreft (1) de vraag of het nadeel in causaal verband staat met de aanleg van de Noord/Zuidlijn; (2) de omvang van het nadeel; (3) de vraag of het nadeel redelijkerwijs niet of niet geheel ten laste van de aanvrager behoort te blijven, waarbij dient te worden ingegaan op risicoaanvaarding; (4) de vraag of en in hoeverre aanleiding bestaat om een bijdrage in de deskundigenkosten toe te kennen; (5) de vraag of compensatie van het nadeel niet of niet voldoende anderszins is verzekerd; en (6) de hoogte van de door het college toe te kennen nadeelcompensatie. De opsomming lijkt grotendeels te zijn overgenomen uit art. 13 Verordening Nadeelcompensatie en Planschade Noord/Zuidlijn. In de daarbij behorende toelichting zijn opmerkingen te vinden die vergelijkbaar zijn met de eerder besproken opmerkingen uit de toelichting op art. 6 lid 1 RnR 1991. In essentie komt het erop neer dat niet altijd alle onderwerpen uit de opsomming in het advies hoeven te worden betrokken. Het heeft immers weinig zin om bijvoorbeeld op de omvang van de schade in te gaan als duidelijk is dat de schade wegens risicoaanvaarding voor rekening van de aanvrager kan worden gelaten. ${ }^{176}$

De $A V N$

Art. 2 lid 1 Reglement adviescommissie nadeelcompensatie luidt als volgt: 
"De commissie is belast met de advisering over aanvragen om nadeelcompensatie, voor zover het bestuursorgaan advies van de commissie gewenst acht. De commissie stelt een onderzoek in naar de vraag of de schade op grond van artikel 2 van de Verordening voor vergoeding in aanmerking komt en zo nodig naar de omvang van de schade."

Verder bepaalt art. 9 lid 7 van dit reglement dat de adviescommissie in haar advies verslag dient te doen van haar onderzoek naar de vraag of de aanvrager op grond van de AVN in aanmerking komt voor nadeelcompensatie. Op grond van deze bepaling dient zij tevens te beoordelen of de aanvrager in aanmerking komt voor de vergoeding van kosten van inschakeling van een gemachtigde en/of deskundigen. Gelet op dit samenspel van bepalingen is niet duidelijk of de in art. 2 lid 1 van het reglement opgenomen zinsnede 'voor zover' slechts ziet op de inschakeling van de adviescommissie, of juist ook op de punten die het advies dient te bestrijken. Gelet op de vrijheid die het bestuur onder de AVN heeft om een adviescommissie in te schakelen, ${ }^{177}$ ligt het tweede het meest voor de hand.

\section{Conclusie}

Bij vaststelling van art. 6.1.3.4 Bro lijkt art. 16 RnVW 1999 model te hebben gestaan. Aangezien de bepaling uit de RnVW 1999 niet is gewijzigd bij de overgang naar de BnIM 2014 en BnIW 2019 verbaast het niet dat art. 16 BnIW 2019 inhoudelijk vergelijkbaar is met de bepaling uit het Bro. Hoewel de redactie van art. 3 lid 2 Reglement Schadecommissie Noord/Zuidlijn net iets anders is vormgegeven dan de redactie van de bepalingen uit deze regelingen, ontstaat niet de indruk dat dit tot (significante) materieelrechtelijke verschillen leidt. Het verschil in redactie tussen de RnVW 1999 en het Bro enerzijds en art. 3 lid 2 Reglement Schadecommissie Noord/Zuidlijn anderzijds, kan waarschijnlijk worden verklaard doordat de bepaling uit het reglement is geïnspireerd op art. 13 Verordening Nadeelcompensatie en Planschade Noord/Zuidlijn en bovendien is opgesteld door een andere regelgever.

Aangezien de BnIW 2019 en VS 2012 een gemeenschappelijke voorouder kennen in de RnR 1991, verbaast het eveneens niet dat deze regelingen deels overeenkomen. Het streven naar meer efficiëntie dat is ontstaan naar aanleiding van het door Van Ettekoven en Tjepkema uitgebrachte rapport, lijkt de verklaring voor de vrijheid die het bestuur onder de VS 2012 toekomt om een bijzondere adviesopdracht te geven. In paragraaf 10.6.1 bleek dat een vergelijkbaar streven naar efficiëntie ertoe heeft geleid dat de inschakeling van een adviescommissie door de BnIW 2019 als discretionaire bevoegdheid van het bestuur wordt aangemerkt. Het heeft echter veel ervan weg dat de minister zich bij vaststelling van de BnIW 2019 niet heeft gerealiseerd dat aanpassing van art. 16 BnIW 2019 goed op deze wens had aangesloten. $\mathrm{Nu}$ is de inhoud van het advies immers tot op grote hoogte 
afhankelijk van hetgeen de adviescommissie aanmerkt als noodzakelijk voor een zorgvuldige advisering.

Voor de verschillen tussen de AVN enerzijds en het Bro, de BnIW 2019 en de VS 2012 anderzijds, kan ik slechts de algemene verklaring aandragen dat de AVN op een ander moment is opgesteld door een andere regelgever, die bovendien geen inspiratie aan de RnR 1991 of RnVW 1999 lijkt te hebben ontleend. Het Amsterdamse college van B\&W lijkt zelfstandige keuzes te hebben gemaakt bij vaststelling van het bij de AVN behorende Reglement adviescommissie nadeelcompensatie, zonder daarbij inspiratie te hebben gezocht bij overige nadeelcompensatieregelingen. Dat niet meer is aangesloten bij art. 3 lid 2 Reglement Schadecommissie Noord/Zuidlijn kan deels worden verklaard doordat de bepaling uit het bij de AVN behorende reglement niet is gebaseerd op art. 13 Verordening Nadeelcompensatie en Planschade Noord/Zuidlijn. Verder lijkt aannemelijk dat een rol heeft gespeeld dat het bestuur onder de AVN meer vrijheid toekomt bij de beslissing of een adviescommissie wordt geraadpleegd. ${ }^{178}$

\subsubsection{Deelvraag 3: Toekomstig recht}

Titel 4.5 Awb en afd. 15.1 Ow regelen niets omtrent de eisen die worden gesteld aan de inhoud van het advies van de adviescommissie. Onder beide regelingen zal dus moeten worden teruggevallen op het algemene kader als beschreven in paragraaf 10.6.1. Voor de beperkte informatie die daarover uit de bij deze regelingen behorende memories van toelichting kan worden afgeleid, verwijs ik naar paragraaf 10.6.2.

\subsubsection{Hoofdvraag: spiegeling aan de doelstellingen en uitgangspunten die ten grondslag liggen aan de Wns}

Dat titel 4.5 Awb en afd. 15.1 Ow geen normering bevatten omtrent de inhoudelijke eisen die aan het advies van de adviescommissie worden gesteld, verhoudt zich in ieder geval slecht tot de doelstellingen van vereenvoudiging, ${ }^{179}$ uniformering en harmonisering van het nadeelcompensatierecht, vergroting van de rechtszekerheid, en codificatie van het nadeelcompensatierecht. Dat geldt te meer vanwege de grote waarde die in het planschade- en nadeelcompensatierecht aan deskundigenadvisering wordt toegekend. ${ }^{180}$ Bovendien laten de geselecteerde, thans geldende regelingen zien dat in de praktijk structurele behoefte aan dit soort normering bestaat. Op grond hiervan bestaat dus aanleiding tot (a) aanpassing van titel 4.5 Awb. Hoe zou deze aanpassing het best kunnen worden vormgegeven?

178 Zie daarover paragraaf 10.6.1.

179 Het stellen van dergelijke eisen zou immers een belangrijk procedureel onderwerp regelen, waardoor de noodzaak tot vaststelling van aanvullende regelgeving zou afnemen. 
In paragraaf 10.6.3 is betoogd dat de beantwoording van de vraag of een adviescommissie dient te worden geraadpleegd, in eerste instantie aan het bestuur moet worden overgelaten. Die discretie zou zich mijns inziens ook moeten uitstrekken tot de inhoud van de adviesopdracht. Dat past namelijk goed bij het uitgangspunt van aansluiting bij het besluitmodel, en de doelstelling van vergroting van de doelmatigheid van het nadeelcompensatierecht en vermindering van bestuurslasten. Of, en zo ja ten aanzien van welke punten, behoefte bestaat aan advies is immers sterk afhankelijk van de concrete omstandigheden van het individuele schadegeval en de expertise waarover het bestuursorgaan en zijn ambtenaren zelf beschikken. Bovendien kan bijvoorbeeld de gelijkenis met vergelijkbare gevallen waarin al advies is ingewonnen of een rechterlijke uitspraak is gewezen, meebrengen dat met betrekking tot bepaalde criteria voor toekenning van nadeelcompensatie geen behoefte bestaat aan inwinning van advies. Kortom: het op de aanvraag beslissende bestuursorgaan verkeert mijns inziens in de beste positie om in te schatten op welke punten advies dient te worden ingewonnen.

Voor wrijving met de doelstelling van vergroting van de rechtszekerheid en rechtsgelijkheid hoeft mijns inziens niet te worden gevreesd. Het algemene kader als beschreven in paragraaf 10.6.1 garandeert namelijk voldoende dat het bestuur daadwerkelijk advies zal inwinnen ten aanzien van de punten waarvoor dat nodig is. Op grond daarvan kan het bestuursorgaan zijn besluit immers slechts motiveren met een verwijzing naar het ingewonnen deskundigadvies als daarin een deugdelijke motivering van het genomen besluit is opgenomen. Ook overigens acht ik de aanbeveling om de inhoud van de adviesopdracht ter discretie van het bestuur te laten verenigbaar met de aan de Wns ten grondslag liggende doelstellingen en uitgangspunten. Deze discretie zou kunnen worden geëxpliciteerd door in het eerste lid van de in paragraaf 10.6.3 voorgestelde bepaling niet te spreken van 'als' maar van 'voor zover':

\section{Artikel 4:135}

1. Het bestuursorgaan wint slechts advies in bij een adviescommissie voor zover dat naar zijn oordeel noodzakelijk is om op de aanvraag te beslissen.

Ten slotte geven de verklaringen voor de verschillen tussen de geselecteerde, thans geldende regelingen geen aanleiding om afwijkende normering vast te stellen voor aanvragen die onder de reikwijdte van afd. 15.1 Ow vallen. Dat zou ook niet goed passen bij de doelstelling van vereenvoudiging, uniformering en harmonisering van het nadeelcompensatierecht. Ik zie derhalve geen aanleiding om (b) afd. 15.1 Ow aan te passen. Ook geven de aan de Wns ten grondslag liggende doelstellingen en uitgangspunten geen aanleiding om (c) anderszins in een bijzondere invulling, aanvulling of afwijking van titel 4.5 Awb te voorzien. 


\subsection{INWINNING VAN INFORMATIE DOOR DE ADVIESCOMMISSIE}

10.9.1 Deelvraag 2: verschillen tussen de geselecteerde, thans geldende regelingen en verklaringen daarvoor

In deze deelparagraaf wordt ingegaan op de verschillende middelen die de adviescommissie volgens de geselecteerde, thans geldende regelingen heeft om de informatie te vergaren die zij nodig heeft voor de uitvoering van haar adviestaak. $\mathrm{Na}$ beschrijving van een algemeen kader dat geldt onder alle geselecteerde regelingen, ga ik achtereenvolgens in op informatieverschaffing door het bestuur, de aanvrager en derden. Ten slotte wordt stilgestaan bij de bevoegdheid, en soms ook plicht, van de adviescommissie om over te gaan tot plaatsopneming. Voordat ik overga tot de beschrijving van het algemene kader, verdient nog vermelding dat de adviescommissie onder een aantal regelingen verplicht is een hoorzitting te beleggen. Hoewel dit ook een middel is waarmee de commissie informatie kan vergaren, wordt hierop pas ingegaan in paragraaf 10.10. In die paragraaf staan namelijk de mogelijkheden tot inspraak voor de aanvrager en andere belanghebbenden centraal.

\section{Algemeen kader}

Het bestuursorgaan waaraan advies wordt uitgebracht, is op grond van art. 3:7 Awb verplicht om de adviseur, al dan niet op diens verzoek, de gegevens ter beschikking te stellen die nodig zijn voor een goede vervulling van diens taak. Daarbij is art. 10 van de Wet openbaarheid van bestuur (hierna: Wob) van overeenkomstige toepassing. Ook in meer algemene zin kan uit art. 3:2 Awb en het daaraan ten grondslag liggende formele zorgvuldigheidsbeginsel een plicht voor het bestuur worden afgeleid om medewerking te verlenen aan de adviescommissie. Die medewerking is bovendien ook in het belang van het bestuur. Het bestuur zal zijn besluit doorgaans immers niet kunnen motiveren door verwijzing naar het ingewonnen advies als het nalaat om de adviescommissie te voorzien van de informatie die zij nodig heeft om haar adviestaak op zorgvuldige wijze te kunnen vervullen (vergelijk art. 3:46 jo. 3:49 Awb).

De Awb regelt niets omtrent de mate waarin de aanvrager medewerking dient te verlenen aan de adviescommissie. Met enige creativiteit kan die plicht wel worden geconstrueerd door de uit art. 4:2 lid 2 Awb voortvloeiende plicht van de aanvrager om informatie aan het bestuur te verschaffen ${ }^{181}$ te combineren met de uit art. 3:7 Awb voortvloeiende plicht van het bestuur om informatie aan de adviescommissie te verschaffen. Laat de aanvrager na om de benodigde informatie aan te leveren, dan kan dit aanvankelijk leiden tot toepassing van art. 4:5 Awb. Ook is denkbaar dat zijn aanvraag inhoudelijk wordt afgewezen omdat hij onvoldoende bewijs heeft aangeleverd ter onderbouwing van de door hem gestelde schade, of 
ter weerlegging van het standpunt dat het bestuur (op grond van het advies) heeft ingenomen. ${ }^{182}$

\section{Informatieverschaffing door het bestuur}

Op grond van art. 17 lid 1 BnIW 2019 en art. 8 lid 3 VS 2012 stelt het bestuur de adviescommissie, al dan niet op haar verzoek, de gegevens ter beschikking die nodig zijn voor een goede vervulling van haar taak. Art. 10 Wob is daarbij van overeenkomstige toepassing. Uit de toelichting behorende bij de regelingen blijkt dat het bestuur in ieder geval de aanvraag, later toegevoegde bescheiden, en zich onder het bestuur bevindende gegevens over de schadeoorzaak zal moeten verschaffen aan de adviescommissie. Omdat de bepalingen vrijwel letterlijk overeenkomen met art. 3:7 Awb was het eigenlijk niet nodig om deze op te nemen in de BnIW 2019 en VS 2012. Dat dit toch is gebeurd, kan worden verklaard doordat zij bij vaststelling van de RnVW 1999 en VS 1999 nagenoeg woordelijk zijn overgenomen uit art. 7 lid 1 RnR 1991. Die bepaling was gebaseerd op de met art. 3:7 Awb corresponderende bepaling uit het wetsvoorstel voor de Awb. De minister zal opname van art. 7 lid 1 RnR 1991 destijds noodzakelijk hebben geacht, omdat deze beleidsregel reeds zou gelden voorafgaand aan de inwerkingtreding van de Awb. ${ }^{183}$

De Wro en het Bro regelen niet hoe de adviescommissie informatie van het bestuursorgaan kan verkrijgen. In de modelverordening van de VNG is een bepaling opgenomen die het bestuur verplicht "alle op de aanvraag betrekking hebbende informatie, alsmede de voor de beoordeling daarvan naar het oordeel van de adviseur of van de adviescommissie noodzakelijke bescheiden" te overleggen. ${ }^{184}$ Art. 6 lid 1 van het op grond van de AVN vastgestelde Reglement adviescommissie nadeelcompensatie bepaalt op zijn beurt dat het bestuursorgaan de aanvraag om nadeelcompensatie binnen twee weken na ontvangst toezendt aan de secretaris van de adviescommissie, onder overlegging van alle stukken die voor het uitbrengen van advies van belang kunnen zijn. Verder is in art. 7 lid 1 van dit reglement bepaald dat de adviescommissie partijen en derden om nadere informatie of stukken kan vragen indien zij dat nodig acht voor de goede vervulling van haar taak. Daartoe behoort dus ook het bestuursorgaan. Ook is in het tweede lid van deze bepaling een termijn gesteld waarbinnen moet worden voldaan aan dit verzoek. Mij is niet duidelijk waarom de VNG respectievelijk het college van B\&W het nodig vonden de hiervoor beschreven, grotendeels met art. 3:7 Awb overlappende bepalingen op te nemen. Dat de bepalingen qua formulering verschillen van elkaar en van de bepalingen uit de BnIW 2019 \& VS 2012, lijkt slechts te kunnen worden verklaard doordat zij op een ander tijdstip door een andere regelgever zijn vastgesteld. Deze

182 De beschrijving van dit algemene kader is deels gebaseerd op De Poorter \& Van Soest-Ahlers 2008, p. 47-49.

183 Zie Stcrt. 1991, nr. 251, p. 29; Stcrt. 1999, nr. 172, p. 12 (digitaal, p. 13); en Kamerstukken II 1988/89, 21 221, nr. 1-2. Art. 6 lid 1 modelverordening VNG. 
verschillen in formulering lijken niet te leiden tot (significante) materieelrechtelijke verschillen.

Op grond van art. 13 lid 1 VNNZ is het bestuur verplicht om "de aanvraag om nadeelcompensatie" voor te leggen aan de adviescommissie. In zowel de VNNZ als het bijbehorende Reglement Schadecommissie Noord/Zuidlijn is echter niets bepaald omtrent informatieverschaffing van het bestuur aan de adviescommissie. Daarvoor zal dus moeten worden teruggevallen op het aan het begin van deze deelparagraaf beschreven algemene kader. Dit is opmerkelijk omdat in art. 14 lid 1 Verordening Nadeelcompensatie en Planschade Noord/Zuidlijn nog werd bepaald dat het bestuur verplicht was om de adviescommissie de gegevens en bescheiden ter beschikking te stellen die zij nodig had voor een goede vervulling van haar taak. Ik heb geen expliciete verklaring gevonden waarom deze, of een daarmee vergelijkbare bepaling niet in de VNNZ of het Reglement Schadecommissie Noord/Zuidlijn is opgenomen. Mogelijk werd de onder deze regeling verplichtgestelde hoorzitting, ${ }^{185} \mathrm{en} /$ of het aan het begin van deze paragraaf besproken algemene kader verondersteld voldoende te waarborgen dat de adviescommissie de door haar benodigde informatie kan verkrijgen van het bestuur.

\section{Informatieverschaffing door de aanvrager}

Op grond van art. 17 lid 2 BnIW 2019 en art. 8 lid 4 VS 2012 verschaft de aanvrager aan de adviescommissie de gegevens en bescheiden die voor de advisering nodig zijn en waarover hij redelijkerwijs de beschikking kan krijgen. Deze bepalingen zijn nagenoeg woordelijk overgenomen uit art. 7 lid 2 RnR 1991. Die bepaling was geïnspireerd op de met art. 4:2 Awb corresponderende bepaling uit het wetsvoorstel voor de Awb. De minister zal opname van art. 7 lid 2 RnR 1991 destijds noodzakelijk hebben geacht, omdat deze beleidsregel reeds zou gelden voorafgaand aan de inwerkingtreding van de Awb. Bovendien ziet de bepaling uit de Awb niet op informatieverschaffing aan de adviescommissie maar informatieverschaffing aan het bestuursorgaan. Bij de overgang van art. 8 lid 4 VS 1999 naar art. 8 lid 4 VS 2012 werd zonder opgave van redenen toegevoegd dat de adviescommissie de aanvrager een termijn dient te stellen om de genoemde gegevens en bescheiden aan te leveren. Voorts bepaalde art. 8 lid 5 VS 1999 dat de aanvrager het uitdrukkelijk diende aan te geven als hij meende dat de door hem verstrekte gegevens strikt vertrouwelijk waren. Dit artikellid werd echter zonder opgave van redenen geschrapt bij de overgang naar de VS 2012. Dat neemt overigens niet weg dat de algemene regels omtrent vertrouwelijkheid van art. 2:5 Awb, en de strafbaarstelling van overtreding daarvan in art. 272 Wetboek van Strafrecht, onverkort van toepassing zijn onder alle geselecteerde, thans geldende regelingen.

De eerder besproken regeling uit art. 7 lid 1 jo. lid 2 van het bij de AVN behorende Reglement adviescommissie nadeelcompensatie is ook van toepassing op het ver- 
krijgen van informatie van de aanvrager. Dat deze artikelleden qua formulering verschillen van de bepalingen uit de BnIW 2019 en VS 2012 lijkt slechts te kunnen worden verklaard doordat zij op een ander tijdstip door een andere regelgever zijn vastgesteld. Het belangrijkste inhoudelijke verschil is dat uit het Reglement adviescommissie nadeelcompensatie niet blijkt hoe moet worden omgegaan met de situatie waarin de adviescommissie vraagt om informatie waarover de aanvrager niet redelijkerwijs kan beschikken. Ik verwacht echter dat analoog aan de dwingendrechtelijke bepaling van art. 4:2 lid 2 Awb zal gelden dat de aanvrager deze informatie niet hoeft te verschaffen.

De Wro, het Bro en de modelverordening van de VNG regelen niet hoe de adviescommissie informatie van de aanvrager kan verkrijgen. Hetzelfde geldt voor de VNNZ en het bijbehorende Reglement Schadecommissie Noord/Zuidlijn. Dat laatste is extra opmerkelijk, omdat art. 14 lid 1 Verordening Nadeelcompensatie en Planschade Noord/Zuidlijn bepaalde dat de aanvrager de adviescommissie de gegevens en bescheiden ter beschikking diende te stellen die nodig waren voor een goede vervulling van haar taak. Ik heb geen expliciete verklaringen gevonden voor de omstandigheid dat de Wro, het Bro, de modelverordening van de VNG, en de VNNZ en het Reglement Schadecommissie Noord/Zuidlijn niets regelen met betrekking tot dit onderwerp. Mogelijk achtten de betrokken regelgevers de hoorzittingen die op grond van deze regelingen moeten worden belegd als afdoende mogelijkheid voor de adviescommissie om informatie te verkrijgen van de aanvrager. ${ }^{186}$ Ook is denkbaar dat zij van mening waren dat kon worden volstaan met het algemene kader dat werd besproken aan het begin van deze paragraaf.

\section{Informatieverschaffing door derden}

Op grond van art. 17 lid 3 BnIW 2019 en art. 8 lid 5 VS 2012 kan de adviescommissie inlichtingen en adviezen inwinnen bij derden. Indien met het verstrekken van inlichtingen of het verlenen van adviezen door derden kosten gemoeid zijn, dient het bestuur wel eerst hiermee in te stemmen. Dat de bepalingen nagenoeg woordelijk overeenkomen, kan worden verklaard doordat zij beide zijn gebaseerd op art. 7 lid 3 RnR 1991. Die bepaling vermeldde aanvullend dat deze bevoegdheid van de adviescommissie ook gold ten opzichte van ambtenaren in dienst van het bestuursorgaan of van een dienst, bedrijf of instelling, werkzaam onder verantwoordelijkheid van het bestuursorgaan. Volgens de toelichting op de RnR 1991 zou dit in overeenstemming zijn met "hetgeen in de bestuurspraktijk gebruikelijk is". Daarbij werd onder andere verwezen naar het inmiddels vervallen art. $25 \mathrm{Mo-}$ numentenwet. ${ }^{187}$ In het tweede lid van deze bepaling werd inderdaad bepaald dat...

186 Zie daarover paragraaf 10.10.1.

187 Stcrt. 1991, nr. 251, p. 29. 
“(...) de schadebeoordelingscommissie (...) ambtenaren in dienst van het ministerie of van een dienst, bedrijf of instelling, werkzaam onder verantwoordelijkheid van Onze minister [kan] oproepen om in de openbare vergadering te verschijnen tot het geven van inlichtingen."

Het is niet duidelijk waarom het hierop gebaseerde gedeelte van art. 7 lid 3 RnR 1991 is weggelaten bij de vaststelling van de RnVW 1999 en VS 1999. Dat de toelichting op de RnVW 1999 eveneens verwijst naar art. 25 Monumentenwet suggereert dat hiermee niet werd beoogd om de bevoegdheid om informatie bij derden in te winnen niet van toepassing te laten zijn op derden die voor de minister of onder diens verantwoordelijkheid werken. ${ }^{188}$

In art. 6.1.3.5 lid 1 Bro is een regeling opgenomen die inhoudelijk en taalkundig overeenkomt met de bepalingen uit de BnIW 2019 en VS 2012. Hoewel dat niet wordt geëxpliciteerd, lijkt het aannemelijk dat zij is gebaseerd op de RnR 1991 of RnVW 1999. In art. 5 lid 2 jo. lid 3 Reglement Schadecommissie Noord/Zuidlijn is een regeling opgenomen die taalkundig afwijkt, maar inhoudelijk overeenkomt: de adviescommissie kan inlichtingen inwinnen bij derden of een externe deskundige inschakelen voor advisering op een aanvraag, maar dient voorafgaand toestemming aan het bestuur te vragen als hieraan kosten zijn verbonden. Dit onderscheid tussen inlichtingen en advisering kan worden teruggevoerd op art. 14 lid 2 Verordening Nadeelcompensatie en Planschade Noord/Zuidlijn, maar is niet toegelicht bij de vaststelling van die regeling.

Ten slotte is de eerder besproken regeling uit art. 7 lid 1 jo. lid 2 van het bij de AVN behorende Reglement adviescommissie nadeelcompensatie ook van toepassing op het verkrijgen van informatie van derden. Dat deze artikelleden qua formulering verschillen van de bepalingen uit de overige geselecteerde, thans geldende regelingen lijkt slechts te kunnen worden verklaard doordat zij op een ander tijdstip door een andere regelgever zijn vastgesteld. In theorie resulteert dit verschil in formulering tot het materieelrechtelijke verschil dat onder de AVN niet eerst toestemming aan het bestuur hoeft te worden gevraagd als met het verkrijgen van inlichtingen of inwinnen van adviezen bij derden kosten zijn gemoeid. Praktisch gezien, is het echter waarschijnlijk dat de adviescommissie deze kosten desondanks van tevoren met het bestuur zal afstemmen.

\section{Informatieverkrijging door een plaatsopneming}

Op grond van art. 17 lid 4 BnIW 2019, art. 8 lid 6 VS 2012, en art. 5 lid 1 Reglement Schadecommissie Noord/Zuidlijn kan de adviescommissie een "plaatsopneming houden, indien zij dit nodig acht." Dit komt woordelijk overeen met art. 7 lid 4 RnR 1991. In de daarbij behorende toelichting wordt vermeld dat het de commissie niet is toegestaan plaatsen te betreden tegen de wil van de rechthebbende. 
De bevoegdheid tot plaatsopneming is immers niet gebaseerd op een formeelwettelijke grondslag (die daartoe toestemming verleent). ${ }^{189}$

Op grond van art. 7 lid 3 van het bij de AVN behorende Reglement adviescommissie nadeelcompensatie kan de adviescommissie...

“(...) op de plaats waar zich het nadeel heeft gemanifesteerd, de situatie in ogenschouw nemen, indien zij van oordeel is dat dit van belang is voor het advies dat zij in de desbetreffende zaak dient uit te brengen. Van deze plaatsopneming wordt een verslag ${ }^{190}$ gemaakt dat bij het dossier wordt gevoegd."

Het verschil in formulering met de bepalingen uit de BnIW 2019 en VS 2012 lijkt slechts te kunnen worden verklaard doordat het Reglement adviescommissie nadeelcompensatie op een ander tijdstip door een andere regelgever is vastgesteld. Het is onduidelijk waarom het Amsterdamse college voor een andere formulering heeft gekozen dan het deed bij vaststelling van het Reglement Schadecommissie Noord/Zuidlijn.

Art. 6.1.3.5 lid 2 Bro wijkt zowel tekstueel als inhoudelijk af van de overige regelingen. Op grond van de bepaling uit het Bro is de adviescommissie namelijk verplicht zich ter plaatse op de hoogte van de situatie te stellen, tenzij naar haar mening uit de inhoud van de aanvraag aanstonds blijkt dat deze behoort te worden afgewezen. Voor dit verschil met de overige regelingen heb ik geen verklaringen gevonden, mede omdat uit de bij het Bro behorende toelichting niet blijkt waarom voor deze beginselplicht tot plaatsopneming is gekozen.

\subsubsection{Deelvraag 3: Toekomstig recht}

Titel 4.5 Awb en afd. 15.1 Ow regelen niets omtrent de wijze waarop de adviescommissie haar informatie dient te vergaren. Onder beide regelingen zal dus moeten worden teruggevallen op het algemene kader als beschreven aan het begin van deze paragraaf. Voor de beperkte informatie die daarover uit de bij deze regelingen behorende memories van toelichtingen kan worden afgeleid, verwijs ik naar paragraaf 10.6.2.

10.9.3 Hoofdvraag: spiegeling aan de doelstellingen en uitgangspunten die ten grondslag liggen aan de Wns

Dat titel 4.5 Awb en afd. 15.1 Ow geen normering bevatten omtrent de mogelijkheden voor de adviescommissie om informatie te vergaren, verhoudt zich in ieder

189 Zie Stcrt. 1991, nr. 251, p. 29; en Stcrt. 1999, nr. 172, p. 12 (digitaal, p. 14).

190 De geselecteerde, thans geldende regelingen verschillen als het aankomt op de mate waarin zij verslaglegging van de plaatsopneming voorschrijven. Hierop zal nog worden ingegaan in paragraaf 10.10.1 onder het kopje 'Inspraak tijdens de plaatsopneming'. 
geval slecht tot de doelstellingen van vereenvoudiging, ${ }^{191}$ uniformering en harmonisering van het nadeelcompensatierecht, vergroting van de rechtszekerheid, en codificatie van het nadeelcompensatierecht. Dat geldt te meer vanwege de grote waarde die in het planschade- en nadeelcompensatierecht aan deskundigenadvisering wordt toegekend. ${ }^{192}$ Bovendien laat een significant deel van de geselecteerde, thans geldende regelingen zien dat in de praktijk structurele behoefte aan dit soort normering bestaat. Bestudering van deze regelingen leerde dat adviescommissies in de huidige nadeelcompensatiepraktijk grofweg over vier bevoegdheden tot informatievergaring beschikken. De bevoegdheid tot het inwinnen van informatie bij het bestuur volgt reeds uit art. 3:7 Awb. De Awb bevat echter nog geen bepalingen waaruit de bevoegdheid van de adviescommissie blijkt tot inwinning van informatie van de aanvrager en derden, of tot plaatsopneming. Het zou mijns inziens goed bij de hiervoor genoemde doelstellingen passen als deze bevoegdheden alsnog zouden worden opgenomen in titel 4.5 Awb. Daarbij is van belang dat een plicht tot plaatsopneming (vergelijk art. 6.1.3.5 lid 2 Bro) niet goed zou aansluiten op de doelstelling van vergroting van de doelmatigheid van het nadeelcompensatierecht en vermindering van bestuurslasten. Bovendien zou een dergelijke plicht niet goed aansluiten op de aanbevelingen uit paragraaf 10.6.3 en 10.8.3 om het bestuur zelf te laten bepalen of, en zo ja waarover, het advies inwint. Gelet op het voorafgaande, doe ik de aanbeveling de volgende artikelleden toe te voegen aan de in paragraaf 10.7.3 voorgestelde bepaling:

\section{Artikel 4:135}

10. In aanvulling op artikel 3:7 zijn ook de aanvrager en andere belanghebbenden verplicht de adviescommissie, al dan niet op haar verzoek, de gegevens ter beschikking te stellen die nodig zijn voor een goede vervulling van haar taak.

11. De adviescommissie kan een plaatsopneming houden indien zij dit nodig acht.

Ten slotte geven de verklaringen voor de verschillen tussen de geselecteerde, thans geldende regelingen geen aanleiding om afwijkende normering vast te stellen voor aanvragen die onder de reikwijdte van afd. 15.1 Ow vallen. Dat zou ook niet goed passen bij de doelstelling van vereenvoudiging, uniformering en harmonisering van het nadeelcompensatierecht. Ik zie derhalve geen aanleiding om (b) afd. 15.1 Ow aan te passen. Ook geven de aan de Wns ten grondslag liggende doelstellingen en uitgangspunten geen aanleiding om (c) anderszins in een bijzondere invulling, aanvulling of afwijking van titel 4.5 Awb te voorzien.

191 Dergelijke normering zou immers een belangrijk procedureel onderwerp regelen, waardoor de noodzaak tot vaststelling van aanvullende regelgeving zou afnemen. 
Mogelijkheden tot inspraak voor de aanvrager, het bestuur en/of derde-belanghebbenden

\subsection{MOGELIJKHEDEN TOT INSPRAAK VOOR DE AANVRAGER, HET BESTUUR EN/OF DERDE-BELANGHEBBENDEN}

10.10.1 Deelvraag 2: verschillen tussen de geselecteerde, thans geldende regelingen en verklaringen daarvoor

In deze paragraaf zal ik ingaan op de verschillende mogelijkheden tot inspraak die de geselecteerde regelingen bieden aan de aanvrager, het bestuur en/of derdebelanghebbenden. Achtereenvolgens ga ik in op inspraak in de vorm van het horen van de aanvrager, het bestuur of derde-belanghebbenden door de adviescommissie; inspraak tijdens de plaatsopneming; inspraak op het (concept)advies van de adviescommissie; en inspraak op een conceptbesluit van het bestuursorgaan. Eerst zal ik kort een algemeen kader schetsen dat onder alle regelingen in acht dient te worden genomen.

\section{Algemeen kader}

In paragraaf 10.3 en 10.9 is beschreven welke informatie moet worden aangeleverd bij het bestuur of een daardoor ingeschakelde adviescommissie. Natuurlijk kan op ieder moment in de besluitvormingsprocedure informatie worden verschaft aan het bestuursorgaan of de adviescommissie, bijvoorbeeld door toezending van een brief of door telefonisch contact met een ambtenaar werkzaam bij het bestuursorgaan respectievelijk een lid van de adviescommissie. De aanvrager en eventuele derde-belanghebbenden kunnen echter geen officiële mogelijkheid tot inspraak ontlenen aan art. 4:7 jo. 4:8 Awb. Een besluit op een aanvraag om planschadetegemoetkoming of nadeelcompensatie is namelijk een financiële beschikking in de zin van art. 4:12 lid 1 Awb. Daardoor bestaat formeelwettelijk gezien geen plicht voor het bestuur om de aanvrager en/of andere belanghebbenden te horen in het kader van de voorbereiding van een dergelijke beschikking. ${ }^{193}$ Ook een door het bestuur ingeschakelde adviescommissie kan in beginsel niet worden gedwongen om de aanvrager en/of andere belanghebbenden gelegenheid tot inspraak te geven. ${ }^{194}$ Wel is het denkbaar dat de adviescommissie de voor de advisering benodigde gegevens slechts correct kan vaststellen door de aanvrager en/of andere belanghebbenden te raadplegen. Wanneer dit desondanks wordt nagelaten, kan dat tot gevolg hebben dat het bestuur het advies niet aan zijn besluitvorming ten grondslag kan leggen (vergelijk het algemeen kader dat werd beschreven in paragraaf 10.6.1).

\section{Horen van partijen door de adviescommissie}

Op grond van art. 18 lid 1 t/m lid 4 BnIW 2019 en art. 9 lid 1 t/m lid 4 VS 2012 dient de adviescommissie de aanvrager op de hoogte te stellen van de te volgen

193 ABRvS 11 juli 2007, ECLI:NL:RVS:2007:BA9289, r.o. 2.10.1.

194 Zie hierover De Poorter \& Van Soest-Ahlers 2008, p. 57-61. 
procedure. Voorts dienen zowel de aanvrager als het bestuur in de gelegenheid te worden gesteld om een mondelinge toelichting te geven. Zij kunnen zich hierbij laten bijstaan of vertegenwoordigen door een gemachtigde. Ook meegebrachte deskundigen moeten de gelegenheid krijgen om een toelichting te geven. Van alle toelichtingen wordt een verslag opgemaakt dat aan de aanvrager en het bestuur wordt gezonden. Dat de bepalingen vrijwel woordelijk overeenkomen, is te verklaren doordat zij vrijwel geheel zijn overgenomen uit art. 8 lid 1 t/m lid 4 RnR 1991. In het tweede lid van deze bepaling was ook nog opgenomen dat de adviescommissie tenminste vier weken voor de datum waarop de hoorzitting zou plaatsvinden een uitnodiging diende te verzenden tot het geven van de mondelinge toelichting. Dit gedeelte van het tweede lid is geschrapt bij vaststelling van de RnVW 1999, zonder dat daarvoor een reden werd gegeven. Het desbetreffende deel van het tweede lid werd wel letterlijk overgenomen bij vaststelling van de VS 1999. Bij de overgang naar de VS 2012 is de termijn echter verkort van vier naar twee weken. Deze afwijking lijkt te zijn ingegeven door het streven naar meer efficiëntie dat is ontstaan naar aanleiding van het door Van Ettekoven en Tjepkema uitgebrachte rapport. Uit de toelichting bij de VS 2012 blijkt voorts dat het in het nadeelcompensatierecht niet ongebruikelijk is dat alle partijen in elkaars aanwezigheid tijdens één hoorzitting worden gehoord door de voltallige adviescommissie. Dit wordt ervaren als inefficiënt en tijdrovend, omdat veel agenda's moeten worden afgestemd. Bovendien zou dit, met name door aanvragers die niet door een professional worden bijgestaan, soms als "enigszins 'bedreigend' ervaren" worden. De minister benadrukt daarom dat het bijvoorbeeld ook mogelijk is dat bilateraal overleg wordt gevoerd tussen de aanvrager en één lid van de adviescommissie (dat beschikt over specifieke expertise). Daarvoor is wel vereist dat "een deugdelijk en inzichtelijk verslag" wordt gemaakt van de op verschillende momenten gegeven toelichtingen, en dat alle partijen in de gelegenheid worden gesteld hierop te reageren voordat wordt geadviseerd door de adviescommissie. ${ }^{195}$

Uit het bij de AVN behorende Reglement adviescommissie nadeelcompensatie volgt dat 'partijen' door de adviescommissie worden uitgenodigd voor een hoorzitting, waar zij toelichting op de aanvraag mogen geven. Het Reglement Schadecommissie Noord/Zuidlijn bevat een soortgelijke bepaling, waarin niet wordt gesproken van 'partijen' maar het bestuur en de aanvrager afzonderlijk worden genoemd. Zij kunnen zich onder beide Amsterdamse regelingen laten vertegenwoordigen of bijstaan door een of meerdere gemachtigden en/of deskundigen. Van de hoorzitting dient een verslag te worden opgemaakt dat aan partijen dient te worden toegezonden. Ondanks redactionele verschillen, komen de Amsterdamse regelingen dus inhoudelijk grotendeels overeen met de bepalingen uit de BnIW 2019 en VS 2012. Een klein inhoudelijk verschil is dat de Amsterdamse regelingen niet voorschrijven in hoeverre de adviescommissie de aanvrager dient te informeren over de te volgen procedure. Wel schrijven zij beide voor dat de uitnodiging tot 
het horen minimaal 2 weken van tevoren dient te worden verstuurd, zoals ook de VS 2012 doet. ${ }^{196}$

De Wro en het Bro regelen niets omtrent het horen van de benadeelde, het bestuur of derden. In de modelverordening van de VNG wordt echter bepaald dat de adviescommissie één of meerdere hoorzittingen dient te organiseren waarop de aanvrager, het bestuur, eventueel andere betrokken bestuursorganen en belanghebbenden met wie een planschadeverhaalovereenkomst is gesloten, de kans dienen te krijgen om toelichting te geven of voor de advisering relevante informatie te verschaffen. Van deze hoorzitting(en) wordt een verslag opgemaakt door de adviescommissie, dat onderdeel uitmaakt van het advies. ${ }^{197}$ De verschillen van redactionele aard met de overige regelingen, lijken slechts te kunnen worden verklaard doordat de modelverordening op een ander moment door een andere entiteit is vastgesteld. Dat geldt ook voor het kleine inhoudelijke verschil dat de modelverordening - net als de BnIW 2019 - niet bepaalt wanneer de uitnodiging voor de hoorzitting dient te worden verstuurd.

Er bestaat echter ook een groter inhoudelijk verschil met de overige geselecteerde, thans geldende regelingen. De modelverordening gaat namelijk als enige regeling in op het horen van derde-belanghebbenden. Dit kan worden verklaard doordat buiten het planschaderecht nauwelijks sprake is van draagplichtige derden. Dit kan op zijn beurt worden verklaard door het in paragraaf 10.4.1 besproken arrest Nunspeet/Mulder. ${ }^{198}$ De formeelwettelijke grondslag die het bestuur op basis daarvan nodig heeft voor de afwenteling van kosten van nadeelcompensatie of planschadevergoeding op derden, wordt onder de geselecteerde, thans geldende regelingen namelijk slechts geboden door art. 6.4a Wro. ${ }^{199}$ Bovendien blijkt uit de toelichting op de modelverordening dat de VNG uitvoering wilde geven aan de opdracht uit art. 6.1.3.3 lid 2, aanhef en onder e Bro. Daarin is namelijk expliciet bepaald dat bij gemeentelijke verordening regels moeten worden gesteld over...

“(...) de wijze waarop de aanvrager, de betrokken bestuursorganen en in voorkomend geval de belanghebbenden als bedoeld in artikel 6.4a, tweede en derde lid, van de wet door de adviseur, onder verslaglegging, worden gehoord en bij de opstelling van het advies worden betrokken, en de dienaangaande geldende termijnen."200

196 Zie art. 6 jo. art. 9 lid 1 Reglement adviescommissie nadeelcompensatie; en art. 4 Reglement Schadecommissie Noord/Zuidlijn.

197 Art. 6 lid 3 jo. lid 6 modelverordening VNG.

198 HR 2 mei 2003, ECLI:NL:HR:2003:AF2848, r.o. 3.6.2-3.6.5 (Nunspeet/Mulder).

199 Zie over de vaststelling daarvan ook Kamerstukken II 2004/05, 30 218, nr. 3, p. 15 en 39. Ten aanzien van de luchtvaartsector is in art. $8 \mathrm{a} .38 \mathrm{Wlv}$ wel voorzien in een heffing.

200 Waarom juist deze onderwerpen verplicht zijn gesteld in art. 6.1.3.3 Bro wordt niet duidelijk uit de daarbij behorende nota van toelichting. 
Deze verklaring is ook relevant voor hierna nog te constateren verschillen met de overige regelingen, maar zal bij bespreking daarvan niet meer afzonderlijk worden aangehaald.

\section{Inspraak tijdens de plaatsopneming}

In paragraaf 10.9.1 bleek dat de adviescommissie slechts door het Bro wordt verplicht tot plaatsopneming. Wellicht verklaart dat deels waarom slechts de modelverordening van de VNG bepaalt dat de adviescommissie de aanvrager dient uit te nodigen voor de plaatsopneming en/of de taxatie van een bij de aanvraag betrokken onroerende zaak. ${ }^{201}$ Dat de overige regelingen geen bepalingen hieromtrent bevatten - ondanks dat zij de adviescommissie wel de bevoegdheid tot plaatsopneming toekennen - kan verder slechts worden verklaard doordat deze regelingen op andere momenten door andere regelgevers zijn vastgesteld. Het is overigens onwaarschijnlijk dat het ontbreken van dit soort bepalingen leidt tot praktische verschillen met het planschaderecht, omdat het weinig voor de hand ligt dat een adviescommissie naar de woning of het bedrijf van de aanvrager gaat zonder hem daarvan op de hoogte te stellen.

Volgens art. 6 lid 6 van de modelverordening is de adviescommissie verplicht een verslag van de plaatsopneming te maken dat zij in haar advies dient op te nemen. Een vergelijkbare verplichting volgt uit art. 7 lid 3 jo. art. 9 lid 7 Reglement adviescommissie nadeelcompensatie. Dat geen vergelijkbare bepaling is opgenomen in de VNNZ (of het daarbij behorende reglement) kan ik niet verklaren. Hooguit kan worden opgemerkt dat een dergelijke bepaling ook niet voorkwam in de Verordening Nadeelcompensatie en Planschade Noord/Zuidlijn. Het ontbreken van een bepaling omtrent verslaglegging van de plaatsopneming in de BnIW 2019 en VS 2012 kan slechts worden verklaard doordat deze regelingen op andere momenten door een andere regelgever zijn vastgesteld. Ook hier geldt echter dat zich waarschijnlijk geen noemenswaardige praktische verschillen tussen de regelingen zullen voordoen. In art. 6 lid 10 Reglement Schadecommissie Noord/Zuidlijn, art. 16 lid 2 BnIW 2019 en art. 8 lid 2 VS 2012 zijn namelijk wel algemene plichten tot rapportage opgenomen voor de adviescommissie. Op grond van het algemene kader dat werd beschreven in paragraaf 10.6.1 is het bovendien weinig aannemelijk dat een bestuursorgaan genoegen neemt met een advies waarin geen verslag wordt gedaan van een plaatsopneming die wel heeft plaatsgevonden. ${ }^{202}$

201 Vergelijk art. 6 lid 4 jo. lid 5 modelverordening VNG.

202 Vergelijk Bröring e.a. 2019, p. 318, onder verwijzing naar ARRvS 12 juli 1985, ECLI:NL:RVS:1985:AM8613; en ARRvS 12 juli 1982, ECLI:NL:RVS:1982:AM6627. 


\section{Inspraak op het (concept)advies}

Ingevolge art. 18 lid 5 BnIW 2019 maakt de adviescommissie een conceptadvies op dat aan de aanvrager en het bestuur wordt toegezonden voordat de commissie haar definitieve advies opstelt. Op grond van art. 18 lid 6 jo. lid 7 BnIW 2019 kunnen de aanvrager en het bestuur hun bedenkingen tegen dit conceptadvies schriftelijk kenbaar maken aan de adviescommissie. Daarna zal de commissie een definitief advies uitbrengen dat eveneens aan de aanvrager en het bestuur wordt toegezonden. Hierna dient het bestuursorgaan op grond van art. 19 lid 1 BnIW 2019 een besluit op de aanvraag om nadeelcompensatie te nemen dat het aan de aanvrager bekendmaakt en waarvan het eveneens een kopie aan de adviescommissie laat toekomen. De genoemde artikelleden zijn bij vaststelling van de RnVW 1999 grotendeels woordelijk overgenomen uit art. 8 lid 5 t/m lid 7 jo. art. 9 lid 1 RnR 1991. Daarna zijn zij niet meer gewijzigd bij de overgang naar de BnIM 2014 en BnIW 2019.

De bepalingen uit de RnR 1991 werden ook vrijwel woordelijk overgenomen in art. 9 lid 5 t/m lid 7 jo. art. 10 lid 1 VS 1999. ${ }^{203}$ Uit het rapport van Van Ettekoven en Tjepkema bleek echter dat in de adviesfase veel termijnoverschrijdingen plaatsvonden. De aanvragers beschouwden de mogelijkheid om op het (concept)advies te reageren als "waardevol" en lieten de kans om te reageren "veelal niet voorbijgaan". Op aanbeveling van Van Ettekoven en Tjepkema is daarom bij de vaststelling van de VS 2012 aansluiting gezocht bij de regeling van art. 8:47 Awb (advisering door deskundigen ten behoeve van de rechtbank). ${ }^{204}$ De fase van het conceptadvies werd daarom geschrapt. De adviescommissie maakt dus direct een definitief advies op, dat zij vervolgens toezendt aan de aanvrager en het bestuur. De aanvrager kan eventuele bedenkingen tegen het advies schriftelijk bekendmaken aan het bestuursorgaan. Naar aanleiding daarvan, of op eigen initiatief, kan het bestuursorgaan de adviescommissie opdragen om nader te adviseren omtrent het op de aanvraag om nadeelcompensatie te nemen besluit. Wordt deze opdracht niet verstrekt, dan neemt het bestuursorgaan een besluit op de aanvraag om nadeelcompensatie. Wordt wel opdracht verleend tot nadere advisering, dan neemt het bestuursorgaan dit besluit pas nadat de adviescommissie nader advies heeft uitgebracht - dat uiteraard eveneens wordt toegezonden aan zowel aanvrager als bestuursorgaan. Op dit nadere advies kan echter niet meer worden gereageerd door de aanvrager. Eventuele bedenkingen daartegen zullen dus in een bezwaarprocedure moeten worden aangevoerd. ${ }^{205}$

Ook het Reglement adviescommissie nadeelcompensatie en Reglement Schadecommissie Noord/Zuidlijn gaan uit van een conceptadvies dat voorafgaat aan een

203 Met name de termijnen waarbinnen de adviescommissie, aanvrager en bestuur dienden te handelen verschilden enigszins. Aan verschillen in deeltermijnen zal ik slechts aandacht besteden in paragraaf 10.11 .

204 Stcrt. 2012, nr. 8910, p. 5 en 7 (VS 2012).

205 Zie art. 9 lid 5 en lid 6 jo. art. 10 VS 2012. 
definitief advies. Inhoudelijk zijn de reglementen op dit punt vergelijkbaar met de relevante bepalingen uit de BnIW 2019. ${ }^{206}$ Tekstuele verschillen met de BnIW 2019 lijken slechts te kunnen worden verklaard doordat de reglementen op een ander moment door een andere regelgever zijn vastgesteld. Ik heb geen verklaringen gevonden voor verschillen in redactie tussen de reglementen onderling. ${ }^{207}$

De Wro en Bro regelen niets met betrekking tot inspraak op een (concept)advies. In art. 6 lid 7 t/m lid 10 van de modelverordening van de VNG is wel een regeling hierover opgenomen. De adviescommissie dient eerst een conceptadvies uit te brengen dat het laat toekomen aan de aanvrager, het bestuur, eventueel andere betrokken bestuursorganen en belanghebbenden met wie een planschadeverhaalovereenkomst is gesloten. Zij krijgen vervolgens de gelegenheid om hier schriftelijk op te reageren. De adviescommissie brengt daarna een definitief advies uit aan het bestuursorgaan waarin eventueel ingediende reacties op het conceptadvies zijn betrokken. Dat de VNG heeft gekozen voor de constructie van een conceptadvies lijkt te worden verklaard door een opmerking over art. 6.1.3.3 Bro uit de daarbij behorende nota van toelichting, namelijk dat bijvoorbeeld bij verordening kan worden bepaald dat "aanvrager in de gelegenheid wordt gesteld om binnen een bepaalde periode op het (concept-)advies kan [sic] reageren." ${ }^{208}$ Uit de nota van toelichting wordt niet duidelijk waarom juist dit voorbeeld werd gegeven. Mogelijk werd beoogd dat bij vaststelling van een gemeentelijke (of provinciale) planschadeverordening aansluiting zou worden gezocht bij de regeling uit de RnVW 1999.

\section{Inspraak op het conceptbesluit ${ }^{209}$}

Opmerkelijk is dat art. 14 lid 1 en lid 2 AVN ook bepalen dat het bestuursorgaan de aanvrager een conceptbesluit dient te sturen en hem in de gelegenheid dient te stellen daar mondeling of schriftelijk zienswijzen tegen in te dienen. Een enigszins vergelijkbare gang van zaken vindt plaats als geen adviescommissie wordt ingeschakeld bij toepassing van de VNNZ. Op grond van art. 14 VNNZ dient het bestuursorgaan dan namelijk een "voorstel tot nadeelcompensatie" te doen. Als de aanvrager daarmee instemt, wordt overeenkomstig het voorstel besloten op de aanvraag om nadeelcompensatie. Stemt de aanvrager niet in met het voorstel, dan dient het bestuur de aanvraag alsnog aan een adviescommissie voor te leggen.

De constructies uit de AVN en VNNZ, of daarmee vergelijkbare constructies, komen niet voor in de overige geselecteerde, thans geldende regelingen. Dat kan

206 Zie art. 14 AVN jo. art. 9 Reglement adviescommissie nadeelcompensatie, respectievelijk art. 13 lid 3 VNNZ jo. art. 6 Reglement Schadecommissie Noord/Zuidlijn.

207 Aangezien dat niet relevant is voor de beantwoording van de tweede deelvraag zal ik hier geen aandacht besteden aan enkele afwijkingen van art. 9 Reglement adviescommissie nadeelcompensatie ten opzichte van art. 14 lid 2 AVN.

208 Stb. 2008, nr. 145, p. 66.

209 Tegen een definitief besluit kunnen slechts de rechtsmiddelen van bezwaar en beroep worden aangewend. Zie daarover paragraaf 10.12 . 
worden verklaard doordat deze constructies niet voor de hand liggen wanneer zij worden bezien vanuit de algemene besluitvormingsprocedure van de Awb. De Awb regelt immers niets omtrent conceptbesluitvorming of voorstellen tot besluitvorming. Bovendien lijkt de constructie van een conceptbesluit op het eerste oog niet efficiënt en/of bevorderlijk voor de snelheid van de besluitvorming. Mogelijk moeten de bepalingen uit de AVN en VNNZ echter worden gezien als pogingen om invulling te geven aan de hoorplicht van art. 4:7 Awb. Naar dat artikel wordt namelijk verwezen in de toelichting op art. 14 AVN. De Amsterdamse gemeenteraad lijkt zich daarbij niet te hebben gerealiseerd dat deze hoorplicht niet van toepassing is vanwege art. 4:12 lid 1 Awb. ${ }^{210}$

\subsubsection{Deelvraag 3: Toekomstig recht}

Titel 4.5 Awb en afd. 15.1 Ow regelen niets omtrent de inspraakmogelijkheden van de aanvrager, het bestuur en/of eventuele derde-belanghebbenden. Onder beide regelingen zal dus moeten worden teruggevallen op de algemene kaders uit paragrafen 10.6.1 en 10.10.1. Voor de beperkte informatie die daarover uit de bij deze regelingen behorende memories van toelichtingen kan worden afgeleid, verwijs ik naar paragraaf 10.6.2.

10.10.3 Hoofdvraag: spiegeling aan de doelstellingen en uitgangspunten die ten grondslag liggen aan de Wns

Dat titel 4.5 Awb en afd. 15.1 Ow geen normering bevatten omtrent mogelijkheden tot inspraak voor de aanvrager, het bestuur ${ }^{211}$ en eventuele derde-belanghebbenden verhoudt zich in beginsel slecht tot de doelstellingen van vereenvoudiging, ${ }^{212}$ uniformering en harmonisering van het nadeelcompensatierecht, vergroting van de rechtszekerheid, en codificatie van het nadeelcompensatierecht. Ondanks dat de geselecteerde, thans geldende regelingen laten zien dat in de praktijk structurele behoefte aan dit soort normering bestaat, klemt dit wellicht wat minder dan vaak het geval was in voorafgaande paragrafen. Afd. 4.1.2 Awb bevat namelijk al een relatief uitgebreide, zij het algemene, regeling omtrent het horen van aanvragers en andere belanghebbenden. Dit laat onverlet dat het goed bij de genoemde doelstellingen zou passen als titel 4.5 Awb enige informatie zou verschaffen over de gebruikelijke gang van zaken bij inschakeling van een adviescommissie. Ik zie dus aanleiding tot (a) aanpassing van titel 4.5 Awb. Aanleiding tot (b) aanpassing van afd. 15.1 Ow of (c) het anderszins voorzien in een bijzondere invulling, aanvulling of afwijking van titel 4.5 Awb zie ik niet.

210 Zie daarover het algemene kader dat werd beschreven aan het begin van deze deelparagraaf.

211 Hiermee doel ik op mogelijkheden van het bestuur om zijn standpunt kenbaar te maken bij de adviescommissie.

212 Dergelijke normering zou immers een belangrijk procedureel onderwerp regelen, waardoor de noodzaak tot vaststelling van aanvullende regelgeving zou afnemen. 
Aan de regeling van art. 4:7 e.v. Awb ligt de gedachte ten grondslag dat belanghebbenden slechts worden gehoord als dat nodig is om te komen tot zorgvuldige en kwalitatief goede besluitvorming. Dat is slechts het geval als het horen noodzakelijk is om te waarborgen dat gegevens die relevant zijn voor de besluitvorming correct worden vastgesteld. ${ }^{213}$ Bij de implementatie van de aanbeveling tot wijziging van titel 4.5 Awb dient daarom te worden bedacht dat het niet goed bij het uitgangspunt van aansluiting bij de Awb zou passen als een mogelijkheid tot inspraak wordt geboden om andere redenen. Ook de constructie van een conceptbesluit past niet goed bij dit uitgangspunt. Die constructie past bovendien niet goed bij de doelstelling van vergroting van de doelmatigheid van het nadeelcompensatierecht en vermindering van bestuurslasten. Zij kost namelijk tijd, terwijl zij niet nodig is om te komen tot kwalitatief goede besluitvorming. De ervaringen die het Schadeschap heeft opgedaan onder de VS 1999 leren dat het laatste ook geldt voor de constructie van een conceptadvies.

Gelet op het voorafgaande stel ik voor om in titel 4.5 Awb te bepalen wie ervan in kennis moeten worden gesteld dat de adviescommissie beslist tot plaatsopneming. Eveneens stel ik voor te bepalen wie wanneer moeten worden gehoord door de adviescommissie, en wanneer kan worden gereageerd op het advies van de adviescommissie. Wat het laatste betreft, acht ik een benadering als beschreven in de VS 2012 het meest verenigbaar met de hiervoor besproken doelstellingen en uitgangspunten. Zij betreft immers de meest efficiënte benadering van de eerder besproken benaderingen uit de geslecteerde, thans geldende regelingen. Bezien vanuit het uitgangspunt van aansluiting bij de Awb, is bovendien relevant dat zij is geïnspireerd op art. 8:47 Awb. Een concreet voorstel voor een wetsbepaling zal ik pas doen in paragraaf 10.11.3. De inhoud van dit concrete voorstel zal namelijk ook deels afhankelijk zijn van mijn bevindingen uit paragraaf 10.11 inzake het voorschrijven van termijnen.

\subsection{TERMIJNEN}

10.11.1 Deelvraag 2: verschillen tussen de geselecteerde, thans geldende regelingen en verklaringen daarvoor

\section{Inleidende opmerkingen en algemeen kader}

Er bestaan significante verschillen tussen de geselecteerde, thans geldende regelingen met betrekking tot de termijnen die het bestuur en de adviescommissie in acht dienen te nemen. Als het aankomt op de maximale beslistermijn kan dit worden verklaard door art. 4:13 Awb. Op grond daarvan dient een beschikking namelijk te worden gegeven binnen een bij wettelijk voorschrift bepaalde termijn of, bij het ontbreken van zulk een termijn, binnen een redelijke termijn na ontvangst van de aanvraag (in beginsel acht weken). Hierna zal blijken dat in alle geselecteerde 
regelingen gebruik is gemaakt van deze mogelijkheid om een beslistermijn vast te stellen. Voor wat betreft de BnIW 2019 is dat overigens opmerkelijk, omdat beleidsregels niet kwalificeren als 'wettelijk voorschrift' in de zin van art. 4:13 lid 1 Awb. ${ }^{214}$ Tot op heden lijkt dat echter niet te zijn aangekaart in onder de BnIW 2019 en zijn voorlopers gewezen jurisprudentie.

De regelingen verschillen niet alleen qua maximale beslistermijn, maar ook in de mate waarin zij het besluitvormingsproces opdelen in deeltermijnen. In het vervolg van deze deelparagraaf zullen beide typen verschillen worden onderzocht. De bespreking van elke regeling zal worden afgesloten met een schematische weergave van de daaronder in acht te nemen termijnen. Bij de vormgeving van deze schematische weergaves is steeds uitgegaan van de situatie dat de aanvraag om compensatie is ingediend op 1 januari 2019, terwijl die aanvraag aan alle daaraan gestelde eisen voldeed. ${ }^{215}$ Bovendien is ervan uitgegaan dat de aanvrager, het bestuur en de adviescommissie de door de regelingen voorgeschreven beslis- en deeltermijnen steeds maximaal benutten.

In het vervolg van deze paragraaf zal niet afzonderlijk worden ingegaan op enkele Awb-bepalingen die vanwege hun dwingendrechtelijke aard onverkort gelden bij toepassing van de geselecteerde regelingen. Op grond van art. 4:5 Awb dient de aanvrager een termijn te worden geboden om een gebrekkige aanvraag te herstellen. In navolging van art. 3 lid 5 RnR 1991 stelt art. 5 VS 2012 deze termijn op acht weken na verzending van de brief waarin de aanvrager op het verzuim is gewezen. Geen van de overige geselecteerde regelingen bepaalt in algemene zin de duur van de hersteltermijn die de aanvrager wordt geboden. ${ }^{216}$ Als verklaring daarvoor kan slechts worden aangedragen dat art. 4:5 Awb niet vereist dat de duur van de hersteltermijn wordt geconcretiseerd in een wettelijk voorschrift of beleidsregel. Indien het bestuur besluit de aanvraag ex art. 4:5 lid 1 Awb buiten behandeling te laten, dient het dit aan de aanvrager bekend te maken binnen vier weken na aanvulling van de aanvraag of het verstrijken van de hersteltermijn. Op grond van het eveneens dwingendrechtelijke art. 4:15 lid 1, aanhef en onder a Awb wordt de reguliere beslistermijn voor het geven van een beschikking opgeschort gedurende de hersteltermijn of het deel daarvan dat de aanvrager nodig had om zijn gebrekkige aanvraag aan te vullen.

214 ABRvS 29 oktober 2008, ECLI:NL:RVS:2008:BG1839, r.o. 2.1. Zie hierover ook De Poorter, in: T\&C Awb, commentaar op art. 4:13 Awb, aant. 1.

215 Zie paragraaf 10.3 omtrent de eisen die worden gesteld aan de aanvraag om nadeelcompensatie.

216 In de toelichting op art. $12 \mathrm{AVN}$ wordt wel gesproken van een hersteltermijn van vier weken die op verzoek van de aanvrager eenmalig met vier weken kan worden verlengd. 


\section{De RnR 1991, BnIW 2019 en VS 2012}

Het begin van de procedures die worden voorgeschreven door de BnIW 2019 en VS 2012 komt sterk overeen. Het bestuursorgaan dient zo spoedig mogelijk, maar in ieder geval binnen twee weken na ontvangst van de aanvraag een ontvangstbevestiging te sturen aan de aanvrager en hem te informeren over de te volgen procedure (art. 3 lid 4 RnR 1991, art. 13 lid 2 BnIW 2019 en art. 4 VS 2012). Als het bestuur de aanvraag wil afwijzen zonder raadpleging van de adviescommissie, dan dient het besluit daartoe te worden genomen binnen acht weken na ontvangst van de aanvraag. Deze termijn kan eenmalig met maximaal acht weken worden verlengd (art. 4 lid 3 jo. lid 4 RnR 1991, art. 14 lid 4 jo. lid 5 BnIW 2019, en art. 6 lid 3 jo. lid 4 VS 2012). Vanaf dit punt beginnen de procedures licht uiteen te lopen. De VS 2012 houdt namelijk vast aan de RnR 1991 en bepaalt dat zes weken na het verstrijken van de hiervoor genoemde termijn een adviescommissie dient te worden ingesteld door het bestuur (art. 5 lid 3 RnR 1991 en art. 7 lid 5 VS 2012), terwijl dit volgens art. 15 lid 4 BnIW 2019 dient te gebeuren binnen vier weken. Waarom de minister het nodig vond om onder de BnIW 2019 een kortere termijn te hanteren, is nooit toegelicht. Na dit punt in de procedure wordt onder de BnIW 2019 het stramien van de RnR 1991 gevolgd, zij het dat soms een net iets andere termijn wordt gehanteerd. De VS 2012 wijkt echter sterk af van dit stramien, met name vanwege de afschaffing van de constructie van het conceptadvies. ${ }^{217} \mathrm{Ik}$ zal eerst het verdere verloop van de procedure onder de BnIW 2019 beschrijven en daarna dat onder de VS 2012. Daarna volgen de schematische weergaves van de procedures uit de RnR 1991, BnIW 2019 en VS 2012.

Ingevolge art. 18 lid 5 BnIW 2019 dient de adviescommissie binnen 26 weken na haar instelling een conceptadvies uit te brengen. Die termijn kan eenmalig met maximaal 26 weken worden verlengd. ${ }^{218}$ Op grond van het zesde lid kan worden gereageerd op het conceptadvies binnen acht weken na verzending daarvan. Volgens het zevende lid dient binnen acht weken na het verstrijken van deze termijn een definitief advies te worden vastgesteld, dat "terstond" wordt toegezonden aan de aanvrager en het bestuursorgaan. De adviescommissie kan dit eenmalig met maximaal acht weken uitstellen. Volgens art. 19 lid 1 BnIW 2019 dient het bestuur binnen twaalf weken na ontvangst van het definitieve advies een besluit te nemen op de aanvraag om nadeelcompensatie, en dat aan de aanvrager bekend te maken. Dit besluit kan ingevolge het tweede lid eenmalig met maximaal twaalf weken worden verdaagd. ${ }^{219}$

217 Zie daarover paragraaf 10.10.1.

218 In paragraaf 10.10 .1 beschreef ik dat aanvrager en bestuur gedurende de eerste termijn van 26 weken de mogelijkheid moeten krijgen tot het geven van een toelichting. Art. 8 lid 2 RnR 1991 geeft aan dat de uitnodiging daartoe minimaal vier weken voorafgaand aan de datum voor het geven van de toelichting moet worden verzonden. Die termijn volgt niet uit de BnIW 2019.

219 Deze termijn komt niet overeen met die uit art. 9 RnR 1991. Het eerste lid van die bepaling schreef namelijk een termijn van twee maanden voor, die eenmalig met maximaal drie maanden kon worden verlengd. 
Ingevolge art. 9 lid 5 VS 2012 dient de adviescommissie binnen 26 weken $^{220}$ na haar instelling een advies uit te brengen. Die termijn kan eenmalig met maximaal 26 weken worden verlengd. ${ }^{221}$ Volgens art. 10 lid 1 VS 2012 kan de aanvrager zijn bedenkingen tegen het advies bekendmaken binnen zes weken na verzending daarvan. Op grond van het tweede lid dient het bestuur binnen twaalf weken na verzending van het advies op de aanvraag om nadeelcompensatie te beslissen. Deze termijn kan eenmalig met maximaal zes weken worden verlengd. Op grond van het derde lid kan het bestuur er binnen twaalf weken na verzending van het advies echter ook voor kiezen een opdracht tot nadere advisering aan de adviescommissie te verstrekken. Die termijn kan niet worden verlengd. De adviescommissie dient haar nader advies krachtens het vierde lid vast te stellen binnen zes weken na verzending van de opdracht tot nadere advisering en dat "terstond" aan de aanvrager en het bestuursorgaan toe te zenden. Zij kan deze termijn eenmalig met maximaal zes weken verlengen. Volgens het vijfde lid dient de besliscommissie op de aanvraag om nadeelcompensatie te beslissen binnen zes weken na verzending van het nader advies. Deze termijn kan zij eenmalig met maximaal zes weken verlengen.
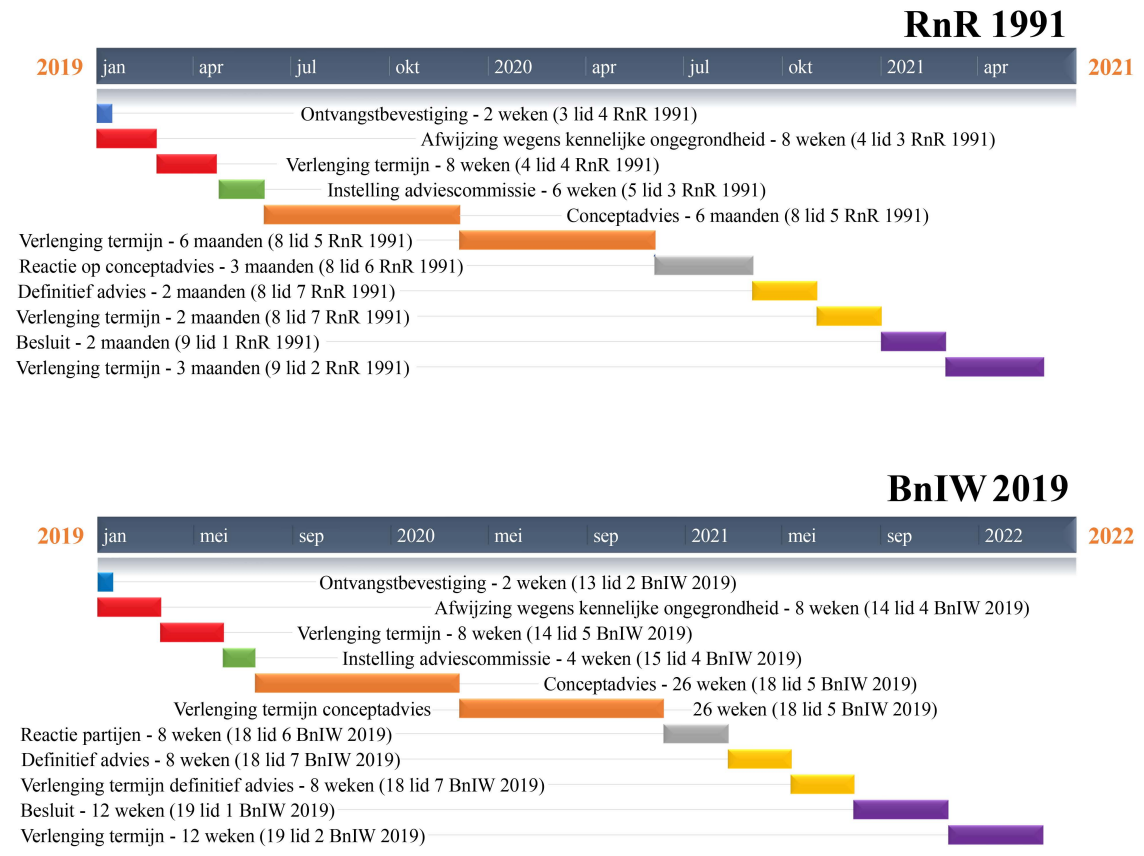

220 De verordening spreekt van zes maanden.

221 Als de aanvraag is ingediend voor onherroepelijkheid van de schadeoorzaak, kan ook worden verlengd tot zes maanden na de dag waarop de schadeveroorzakende besluiten rechtens onaantastbaar zijn geworden. 


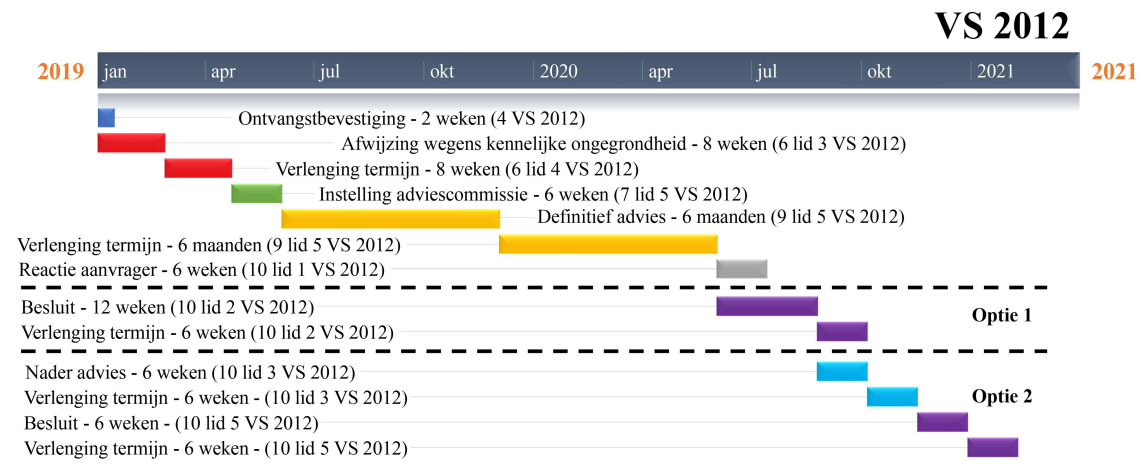

\section{De Wro}

Ingevolge art. 6.1.2.1 Bro zendt het bestuur de aanvrager onverwijld een bewijs van ontvangst van de aanvraag, waarin de datum van ontvangst wordt vermeld. Op grond van art. 6.1.3.1 lid 1 Bro kan het bestuursorgaan de aanvraag als kennelijk ongegrond afwijzen binnen de eerste vier weken na ontvangst daarvan. Wordt geen gebruik van deze mogelijkheid gemaakt, dan begint krachtens art. 2 van de modelverordening van de VNG een termijn van twaalf weken te lopen waarbinnen het bestuur een opdracht tot advisering dient te verstrekken aan een adviescommissie. Volgens art. 6 lid 7 van de modelverordening dient binnen zestien weken na dagtekening van deze opdracht een conceptadvies te worden uitgebracht. Deze termijn kan met maximaal vier weken worden verlengd. Op het conceptadvies kan worden gereageerd gedurende de vier weken na toezending daarvan. Wordt hiervan geen gebruikgemaakt, dan dient ingevolge art. 6 lid 8 van de modelverordening binnen twee weken na het verstrijken van deze termijn een definitief advies te worden uitgebracht. Is wel gereageerd op het conceptadvies, dan dient het definitieve advies binnen vier weken te worden uitgebracht. Op grond van art. 6.1.3.6 Bro dient het bestuursorgaan binnen acht weken na ontvangst van het definitieve advies een besluit te nemen op de aanvraag om tegemoetkoming in planschade. Die termijn kan eenmalig met maximaal vier weken worden verdaagd.

In paragraaf 10.4.1 bleek verder dat art. 6.4 Wro het bestuur verplicht een recht van de aanvrager te heffen. Op grond van het tweede lid van deze bepaling dient het bestuur aan de aanvrager mede te delen dat hij het recht is verschuldigd, en dient de betaling van het recht binnen vier weken na de dag van verzending van die mededeling te zijn voldaan. Uit de Wro en bijbehorende regelgeving volgt echter niet binnen welke termijn het bestuur deze mededeling dient te doen. Daardoor heb ik de heffing van het recht niet opgenomen in onderstaande schematische weergave van de procedure. Ik verwacht echter dat het bestuur de mededeling doorgaans zal doen in de ontvangstbevestiging die het onverwijld aan de aanvrager moet sturen. In dat geval dient het recht uiterlijk te zijn voldaan vlak na 
afwijzing van de aanvraag wegens kennelijke ongegrondheid of na de instelling van de adviescommissie.

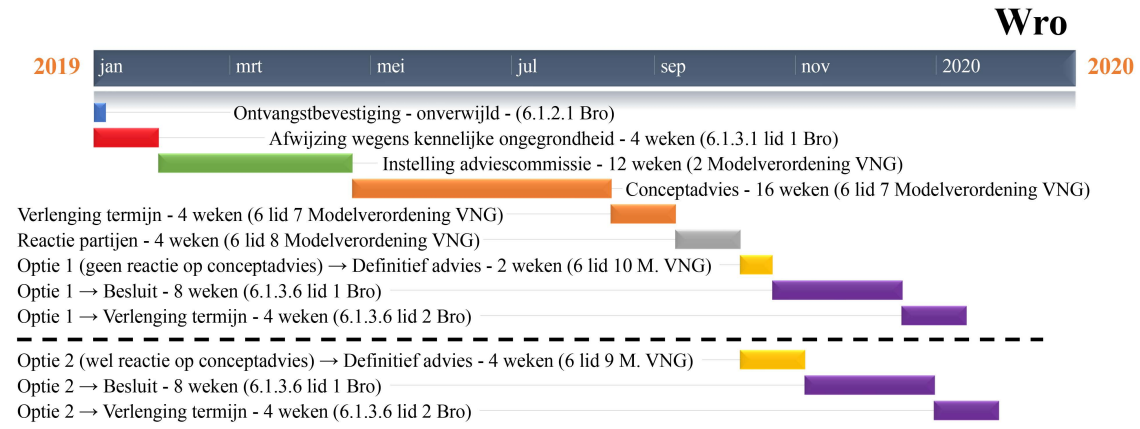

De AVN

Uit art. 12 lid 1 AVN volgt dat het bestuur de aanvrager binnen twee weken na ontvangst van de aanvraag een ontvangstbevestiging dient te sturen waarin het de aanvrager op de hoogte stelt van de te volgen procedure. Voorts bepaalt art. 16 lid 2 AVN dat het bestuursorgaan slechts binnen tien weken na de ontvangst van de aanvraag ertoe kan overgaan om zonder raadpleging van de adviescommissie een besluit op de aanvraag om nadeelcompensatie te nemen in gevallen waarin de aanvraag grotendeels overeenkomt met andere aanvragen waarover de adviescommissie reeds advies heeft uitgebracht, óf gevallen waarin - kort gezegd - volgens het bestuur voldoende duidelijk is dat de in de AVN opgenomen, inhoudelijke criteria voor toekenning van nadeelcompensatie niet zijn voldaan. ${ }^{22}$ Deze termijn kan eenmalig met maximaal acht weken worden verdaagd.

Wordt de adviescommissie wel geraadpleegd, dan dient het bestuur ingevolge art. 16 lid 1 AVN op de aanvraag te besluiten binnen zes maanden na ontvangst daarvan. Deze termijn kan eenmalig met maximaal acht weken worden verdaagd. Het Reglement adviescommissie nadeelcompensatie werkt deze situatie verder uit. Ingevolge art. 6 lid 1 van het reglement dient het bestuursorgaan de aanvraag en overige mogelijk relevante stukken aan de adviescommissie te zenden binnen twee weken na ontvangst van de aanvraag. Op grond van het tweede lid dient de adviescommissie binnen vier weken een hoorzitting te beleggen. Uit het derde lid blijkt dat de adviescommissie deze termijn eenmalig met twee weken kan verlengen als een van de partijen daarom schriftelijk verzoekt. Het is echter niet duidelijk of de termijn van het tweede lid ingaat na ontvangst van de aanvraag door het bestuursorgaan, verzending van de aanvraag aan de adviescommissie, of ontvangst van de aanvraag door de adviescommissie. Het laatste ligt mijns inziens het meest voor de hand, omdat uit het vierde lid volgt dat de adviescommissie de 
uitnodiging voor de hoorzitting minstens twee weken voor de dag van de hoorzitting aan partijen moet sturen.

Op grond van art. 9 lid 1 van het reglement dient de adviescommissie binnen zes weken na de hoorzitting een conceptadvies aan partijen toe te sturen. Deze termijn kan ingevolge het tweede lid eenmalig met maximaal vier weken worden verlengd. Op grond van het derde lid krijgen partijen vervolgens vier weken om op het conceptadvies te reageren. Op verzoek van een van de partijen kan deze termijn bovendien met twee weken worden verlengd. Krachtens het vierde lid dient de adviescommissie een definitief advies aan het bestuursorgaan uit te brengen binnen vier weken na het verstrijken van de termijn uit het derde lid. Op grond van het vijfde lid kan de adviescommissie dit eenmalig met vier weken uitstellen. Een rekensom (zie de schematische weergave) leert dat het bestuursorgaan dan nog minimaal twee weken heeft om op de aanvraag te besluiten.

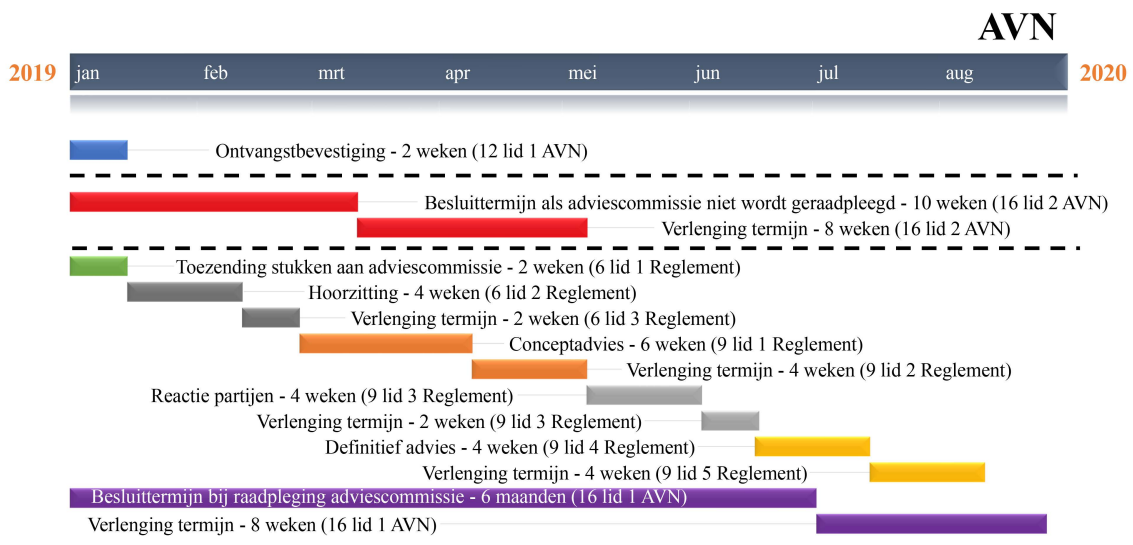

De VNNZ

Uit art. 12 lid 1 VNNZ blijkt dat het bestuursorgaan de aanvrager binnen een week na ontvangst van zijn aanvraag een ontvangstbevestiging dient te sturen waarin de aanvrager op de hoogte wordt gebracht van de te volgen procedure. Wordt de aanvraag in behandeling genomen zonder raadpleging van de adviescommissie, dan schrijft art. 14 lid 1 VNNZ voor dat het bestuursorgaan binnen zes weken na ontvangst van de aanvraag een voorstel tot nadeelcompensatie doet aan de aanvrager. Op grond van het tweede lid kan het bestuursorgaan deze termijn eenmalig met drie weken verlengen. De aanvrager dient op grond van het vierde lid binnen vier weken mede te delen of hij instemt met het voorstel van het bestuursorgaan. Op zijn verzoek kan deze termijn ingevolge het vijfde lid eenmalig met vier weken worden verlengd. Indien de aanvrager instemt met het voorstel, of niet reageert binnen de termijnen uit het vierde en vijfde lid, dan dient het college ingevolge art. 14 lid 6 VNNZ binnen twee weken overeenkomstig het gedane voorstel te besluiten. Wijst de aanvrager het voorstel af, dan komt dit te vervallen en dient 
de aanvraag op grond van het zevende lid binnen een week na afwijzing van het voorstel alsnog te worden voorgelegd aan de adviescommissie. De procedure en de behandelingstermijnen van art. 13 VNNZ zijn dan van toepassing.

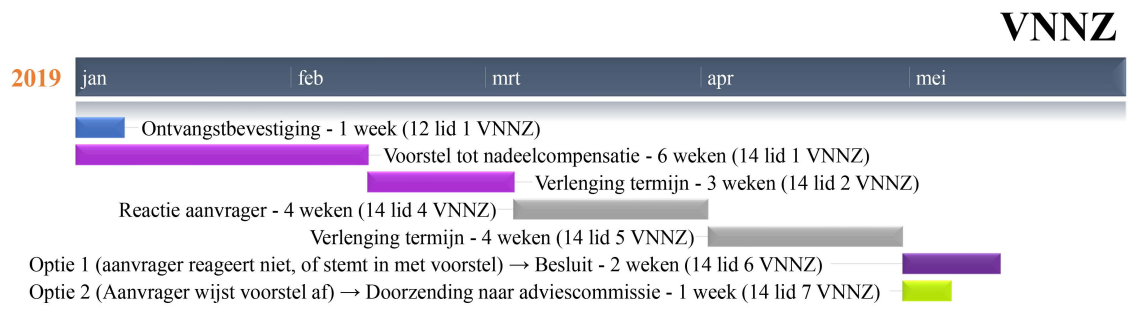

Uit art. 13 lid 3 VNNZ volgt dat het bestuursorgaan binnen 52 weken na ontvangst daarvan dient te beslissen op een aanvraag die het voorlegt aan een adviescommissie. Uit het vierde lid blijkt dat het bestuursorgaan deze termijn ${ }^{223}$ eenmalig met maximaal 52 weken mag verlengen als de aanvraag betrekking heeft op meerdere kalenderjaren. Ingevolge art. 13 lid 1 VNNZ legt het bestuursorgaan de aanvraag binnen twee weken na ontvangst daarvan voor aan de adviescommissie. Op grond van art. 4 lid 1 Reglement Schadecommissie Noord/Zuidlijn dient de adviescommissie de aanvrager en het bestuursorgaan in de gelegenheid te stellen om toelichting op de aanvraag te geven binnen zes weken nadat de commissie de aanvraag heeft ontvangen. Ingevolge het tweede lid kan deze termijn eenmalig met maximaal zes weken worden verlengd. Op grond van het derde lid dient de uitnodiging voor het geven van deze toelichting minimaal een week voorafgaand aan de hoorzitting te worden verzonden. Krachtens art. 6 lid 2 Reglement Schadecommissie Noord/Zuidlijn dient de adviescommissie een conceptadvies op te stellen binnen twaalf weken na ontvangst van de aanvraag. Volgens het derde lid kan deze termijn eenmalig met maximaal acht weken worden verlengd. Ingevolge het vijfde lid dienen de aanvrager en het bestuursorgaan hun zienswijzen hierop kenbaar te maken binnen twee weken na de bekendmaking van het conceptadvies door de adviescommissie. Deze termijn kan op grond van het zesde lid eenmalig met twee weken worden verlengd op verzoek van de aanvrager of het bestuursorgaan. Volgens het zevende lid dient de adviescommissie haar definitieve advies vast te stellen binnen zes weken na het verstrijken van de termijn voor indiening van zienswijzen tegen het conceptadvies. Deze termijn kan ingevolge het achtste lid eenmalig met maximaal zes weken worden verlengd.

223 Let wel: het vierde lid stelt letterlijk dat de termijn uit het eerste lid met 52 weken kan worden verlengd. Dat zou betekenen dat het college in geval van een aanvraag die ziet op meerdere kalenderjaren, de termijn om de aanvraag binnen twee weken aan de adviescommissie voor te leggen met 52 weken zou kunnen verlengen. Dat kan niet de bedoeling van de Amsterdamse gemeenteraad zijn geweest. Ik ga dan ook ervan uit dat dit een drukfout betreft en de mogelijkheid tot verlenging eigenlijk ziet op de termijn uit het derde lid. 
Ten slotte gaat art. 7 Reglement Schadecommissie Noord/Zuidlijn nog in op de mogelijkheid dat de adviescommissie kiest voor een "verkorte behandeling". In dergelijke gevallen wordt volgens het derde lid van deze bepaling geen conceptadvies opgesteld, en brengt de adviescommissie binnen zes weken na de hoorzitting een definitief advies uit. Als het niet mogelijk is om binnen deze termijn een definitief advies op te stellen, kan de adviescommissie volgens het vierde lid een andere termijn vaststellen. Het reglement bepaalt niet hoe lang die nieuwe termijn maximaal mag duren. Het lijkt voor de hand te liggen dat deze termijn dusdanig dient te worden gekozen dat het bestuursorgaan voldoende tijd heeft om conform art. 13 lid 3 VNNZ te besluiten op de aanvraag om nadeelcompensatie - dus binnen 52 weken na ontvangst van de aanvraag.

VNNZ

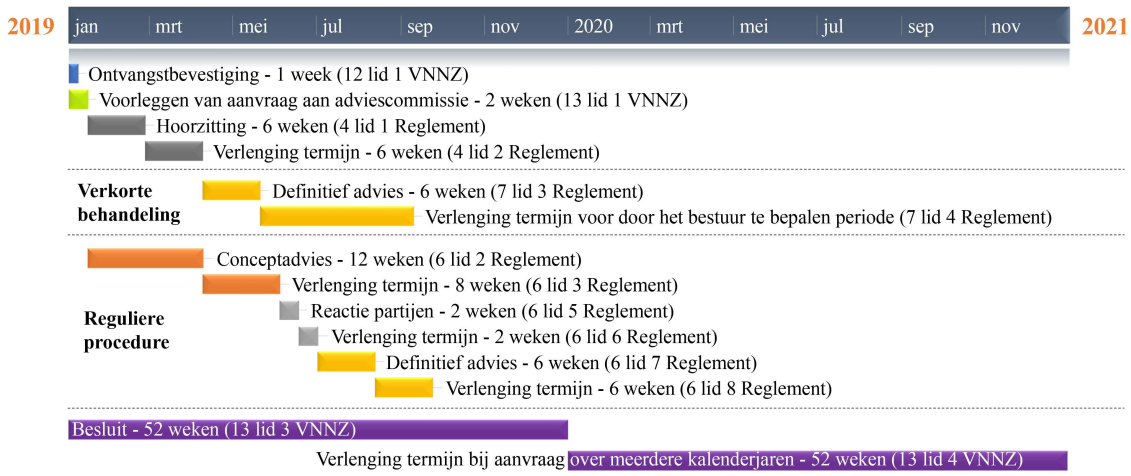

\section{Verschillen en verklaringen daarvoor}

De geselecteerde, thans geldende regelingen komen in zoverre overeen dat zij alle een langere beslistermijn kennen voor aanvragen die worden afgedaan met raadpleging van een adviescommissie. De regelingen verschillen echter significant in de beslistermijnen die zij voorschrijven. De maximale beslistermijn bij raadpleging van een adviescommissie betreft 120 weken onder de BnIW 2019; 110 weken onder de GrS; 52 weken onder de VNNZ, maar 104 weken als de aanvraag betrekking heeft op meerdere schadejaren; 56 weken onder de Wro als wordt uitgegaan van de modelverordening van de VNG; en 34 weken onder de AVN. De maximale beslistermijn bij aanvragen die zonder raadpleging van een adviescommissie worden afgedaan, betreft 19 weken onder de VNNZ; ${ }^{224} 18$ weken onder de AVN; 16 weken onder de BnIW 2019 en VS 2012; en 4 weken onder de Wro.

224 Onder ad 3 van p. 5 van de toelichting op de VNNZ wordt gesteld dat deze termijn 21 weken bedraagt. Ik zie echter niet hoe dat uit de tekst van de VNNZ zou volgen. 


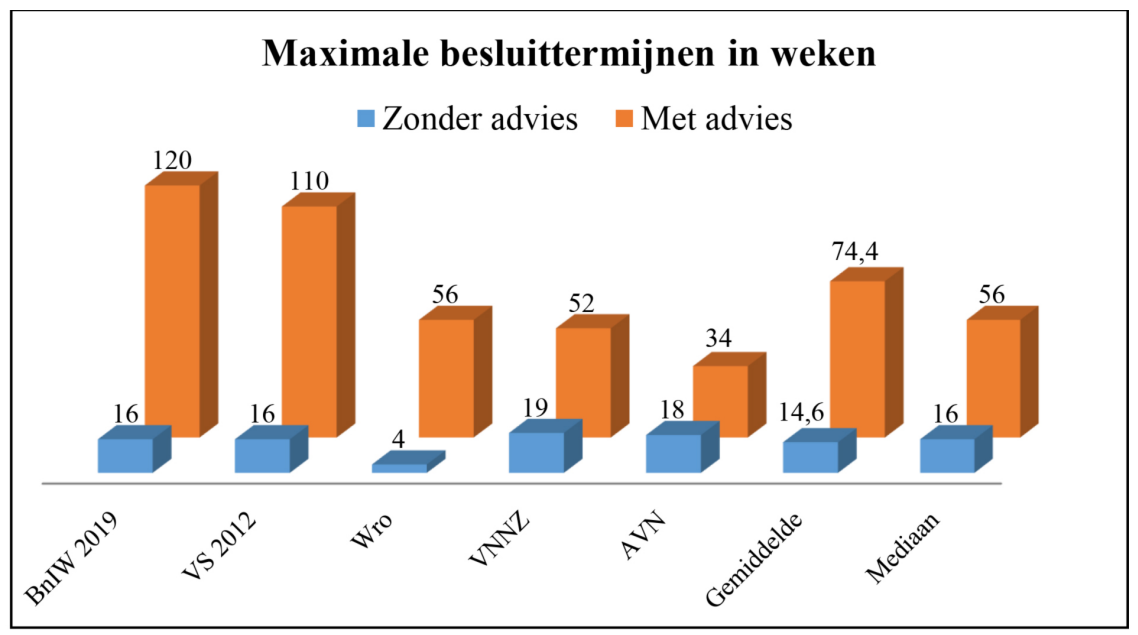

Deze verschillen kunnen tot op zekere hoogte worden verklaard. Zo komen de BnIW 2019 en GrS aan het begin van de procedure grotendeels overeen, omdat zij een gemeenschappelijke voorouder kennen in de RnR 1991. Door de afschaffing van de constructie van het conceptadvies bij vaststelling van de VS $2012^{225}$ is een significant verschil met de BnIW 2019 ontstaan. De procedure en termijnen uit de RnR 1991 zijn deels geïnspireerd op de termijnen uit de derde paragraaf van de inmiddels vervallen Monumentenwet 1988 omtrent schadevergoeding in verband met een ingevolge die wet genomen beslissing op een vergunningaanvraag. De termijnen uit deze paragraaf zijn bij mijn weten nooit van toelichting voorzien. ${ }^{226}$

Bij vaststelling van de VNNZ blijkt voor een beslistermijn van 52 weken te zijn gekozen omdat dit aansloot bij de beslistermijn uit het voorontwerp van de Wns. ${ }^{227}$ Het is onduidelijk waarom de Amsterdamse gemeenteraad voor andere termijnen heeft gekozen bij vaststelling van de AVN. Deze keuze is vooral opvallend omdat de AVN op andere punten wel nadrukkelijk aansluiting zoekt bij titel 4.5 Awb. ${ }^{228}$ Ook in meer algemene zin is niet duidelijk waarom onder de AVN en de bijbehorende regelgeving een andere procedure wordt voorgeschreven dan onder de

225 Zie daarover paragraaf 10.10.1.

226 In Kamerstukken II 1986/87, 19 881, nr. 3, p. 20-21 (MvT, Monumentenwet 1988) wordt wel verwezen naar een voorstel tot wijziging van art. 49 WRO. Welk voorstel dat betreft, is lastig te achterhalen. Ik sluit niet uit dat het gaat om Kamerstukken II 1983/84, 14 889, nr. 122. Daarin zijn echter geen bepalingen van procedurele aard opgenomen (op één indieningstermijn na). Ook geeft Van Zundert aan dat in het voorstel waarna werd verwezen "niet [was] voorzien in de procedureregeling die thans in art. 23-29 van de Monumentenwet 1988 is vervat." Zie Van Zundert, in Ruimtelijk Bestuursrecht, art. 29 Monumentenwet 1988, aant. 2.2.

227 Zie ad 3 op p. 4 van de toelichting op de VNNZ; en Gemeenteblad, afdeling 1, nr. 577, bijlage I, p. 4.

228 Zie paragraaf 8.4.1 voor een voorbeeld daarvan. 
VNNZ en de daarbij behorende regelingen. De op grond van art. 7 lid 3 Reglement Schadecommissie Noord/Zuidlijn bestaande mogelijkheid om niet eerst een conceptadvies maar meteen een definitief advies uit te brengen, ${ }^{229}$ lijkt bijvoorbeeld ook zinvol te zijn voor behandeling van aanvragen die onder de reikwijdte van de AVN vallen.

De bestudeerde regelgevers zullen ongetwijfeld allen voor ogen hebben gehad een procedure voor te schrijven die zorgvuldige besluitvorming mogelijk maakt binnen redelijke termijnen. Veel van de gesignaleerde verschillen lijken slechts te kunnen worden verklaard doordat de regelingen gedurende enkele decennia door verschillende regelgevers zijn opgesteld, terwijl die regelgevers ten aanzien van de in acht te nemen termijnen geen aandacht lijken te hebben gehad voor afstemming op andere nadeelcompensatieregelingen en/of overleg met elkaar, laat staan een materieelrechtelijk verschil in het leven beoogden te roepen. Dit heeft bijvoorbeeld het opmerkelijke gevolg dat complexe planschadedossiers moeten worden afgedaan in minder dan de helft van de tijd die wordt geboden voor behandeling van de doorgaans niet complexere (en mogelijk zelfs minder complexe) schadedossiers van de BnIW 2019.

\subsubsection{Deelvraag 3: Toekomstig recht}

De wetgever heeft enkele beslistermijnen van regelend recht opgenomen in art. 4:130 lid 1 jo. lid 2 Awb. Bij of krachtens (formeel)wettelijk voorschrift kan dus van deze termijnen worden afgeweken. Van deze mogelijkheid is geen gebruik gemaakt in afd. 15.1 Ow. Blijkens de bij de Wns behorende memorie van toelichting is voor de constructie van regelend recht gekozen, zodat een "passende beslistermijn" kan worden vastgesteld als de aanvragen om nadeelcompensatie die onder de reikwijdte van de desbetreffende regeling vallen "naar verwachting doorgaans zeer overzichtelijk of juist zeer complex zullen zijn.” Het derde lid van art. 4:130 Awb is van dwingendrechtelijke aard en stelt zeker dat het bestuur zijn beslissing op een aanvraag die betrekking heeft op schade die (mede) is veroorzaakt door een appellabel besluit altijd kan aanhouden totdat dit besluit onherroepelijk is geworden. $^{230}$

Als geen afwijkende beslistermijn is vastgesteld in een bijzonder wettelijk voorschrift, dan wordt de beslistermijn bepaald door beantwoording van de vraag of het bestuur een adviescommissie instelt waarvan de voorzitter, dan wel het enig lid, geen deel uitmaakt van en niet werkzaam is onder verantwoordelijkheid van het bestuursorgaan. In art. 4.5.5 van het voorontwerp van de Wns werd nog gesproken van een "een adviseur als bedoeld in afdeling 3.3." De wetgever heeft deze formulering verlaten, omdat hij wilde benadrukken dat naar toekomstig recht geen verandering hoeft te worden doorgevoerd ten opzichte van "de bestaande

229 Gelet op ad 3 t/m 5 op p. 4-5 van de toelichting op de VNNZ, lijkt het aannemelijk dat deze mogelijkheid is ingevoerd ter bevordering van de doelmatigheid. 
praktijk, dat de voorzitter van de adviescommissie de meer eenvoudige gevallen zelf afdoet." Dit sluit goed aan bij de aanbeveling uit paragraaf 10.7.3 om niet meer commissieleden te benoemen dan nodig is om op zorgvuldige wijze een advies tot stand te laten komen dat kan dienen als deugdelijke motivering van het besluit op de aanvraag om nadeelcompensatie. Desalniettemin zal ik in paragraaf 10.11.3 een voorstel doen voor een andere redactie van art. 4:130 lid 1 Awb.

Wordt een adviescommissie ingeschakeld als beschreven in de vorige alinea, dan volgt uit art. 4:130 lid 1 Awb dat de beslistermijn zes maanden bedraagt. Daarvoor is gekozen omdat raadpleging van een adviescommissie een langere behandelingsduur meebrengt. Wordt geen adviescommissie ingesteld, of een adviescommissie die niet aan de beschrijving van art. 4:130 lid 1 Awb voldoet, dan volgt uit hetzelfde artikellid dat het bestuur binnen acht weken dient te beslissen. De wetgever is namelijk van mening dat het "redelijkerwijs mogelijk" moet zijn om binnen deze termijn te beslissen in "eenvoudige gevallen". Blijken de termijnen uit het eerste lid onvoldoende om tot een beslissing te komen, dan biedt art. 4:130 lid 2 Awb de mogelijkheid om deze eenmalig met maximaal zes maanden respectievelijk acht weken te verdagen. ${ }^{231}$

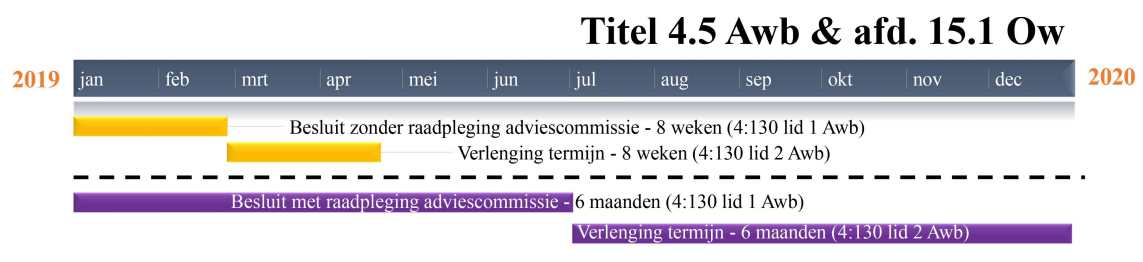

10.11.3 Hoofdvraag: spiegeling aan de doelstellingen en uitgangspunten die ten grondslag liggen aan de Wns

Het past goed bij de doelstelling van vereenvoudiging, uniformering en harmonisering van het nadeelcompensatierecht dat in art. 4:130 Awb maximum beslistermijnen zijn opgenomen. Hoewel het in beginsel nog beter bij deze doelstelling zou passen als deze termijnen van dwingendrechtelijke aard zouden zijn, is de keuze voor regelend recht mijns inziens verdedigbaar. Het is immers denkbaar dat binnen bepaalde deelterreinen van het nadeelcompensatierecht behoefte aan een langere (of juist een kortere) beslistermijn bestaat. Die behoefte zal bijvoorbeeld afhankelijk zijn van de hoeveelheid aanvragen die naar verwachting zullen worden ingediend, de complexiteit van de schadedossiers die moeten worden behandeld, en de expertise die daarvoor nodig is. Dit lijkt ook te worden bevestigd door de in paragraaf 2.3.1 besproken, door het ministerie bij lagere overheden afgenomen enquête. Uit de gepubliceerde samenvatting van enquêteresultaten blijkt dat gemeenten er gemiddeld twaalf maanden over doen om een besluit op een aanvraag om nadeelcompensatie of tegemoetkoming in planschade te nemen. Voor provin- 
cies en waterschappen zou dit zes en een halve maand, respectievelijk negentien maanden bedragen. Hoe die gemiddelden precies zijn berekend is niet duidelijk, omdat deze samenvatting weinig inzicht biedt in het verkregen cijfermateriaal en de wijze waarop dat door het kabinet is geïnterpreteerd. Wel wordt duidelijk dat rekening is gehouden met "extreme uitschieters" en dat bepaalde respondenten de doorlooptijden voor onafhankelijke adviseurs als te lang ervaren, mede omdat deze doorgaans volledig zouden worden benut. ${ }^{232}$ Gelet op deze resultaten lijkt het echter niet onredelijk dat op grond van art. 4:130 Awb als uitgangspunt zal gelden dat het bestuur maximaal binnen een jaar moet beslissen als een deskundige wordt geraadpleegd, of binnen zestien weken als dat niet het geval is.

Desalniettemin geven de aan de Wns ten grondslag liggende doelstellingen en uitgangspunten mijns inziens reden tot (a) aanpassing van titel 4.5 Awb. De huidige redactie van art. 4:130 lid 1 Awb heeft namelijk tot gevolg dat de langere beslistermijn van zes maanden ook wordt gegund aan het bestuursorgaan dat een adviescommissie inschakelt waarvan de voorzitter geen deel uitmaakt van en niet werkzaam is onder verantwoordelijkheid van het bestuursorgaan, terwijl dat niet opgaat voor een of meerdere andere leden van de adviescommissie. Dat past niet bij de doelstellingen van codificatie van het nadeelcompensatierecht, vergroting van de rechtszekerheid, en vergroting van de doelmatigheid van het nadeelcompensatierecht en vermindering van bestuurslasten. De Afdeling vereist immers dat de deskundige die het bestuur raadpleegt als onafhankelijk en onpartijdig kan worden aangemerkt. ${ }^{233}$ Deze eisen worden niet alleen gesteld vanuit het oogpunt van zorgvuldige besluitvorming, maar ook ter behartiging van de belangen van de aanvrager. Omdat de adviseur onafhankelijk- en onpartijdig is, kan de aanvrager aan de hand van diens advies immers kosteloos inschatten wat zijn positie is en op basis daarvan keuzes maken (ongelijkheidscompensatie). Dit kan onder andere tot gevolg hebben dat hij geen behoefte zal ervaren om rechtsmiddelen aan te wenden tegen het besluit op zijn aanvraag. ${ }^{234}$

Ook overigens zie ik reden tot aanpassing van art. 4:130 Awb. Het zou namelijk goed aansluiten op de doelstellingen van vergroting van de rechtszekerheid, en vereenvoudiging, ${ }^{235}$ uniformering en harmonisering van het nadeelcompensatierecht als deze bepaling niet alleen een maximum beslistermijn zou bevatten, maar ook anderszins zou aangeven welke stappen moeten worden doorlopen in het besluitvormingsproces en welke termijnen daarbij in acht moeten worden genomen. Bovendien laten de geselecteerde, thans geldende regelingen zien dat in de prak-

232 Na lang wachten is een rapport over de enquête gepubliceerd op www.omgevingswetportaal.nl. Zoek op 'Resultaten enquête nadeelcompensatie'.

233 Zie daarover paragraaf 10.7.3. Zie bijvoorbeeld ook Van Amerongen \& Schuurmans 2019; en Van Ravels 2019.

234 Van Ravels 2019, p. 186-188.

235 Dit type regulering zou immers een belangrijk procedureel onderwerp regelen, waardoor de noodzaak tot vaststelling van aanvullende regelgeving zou afnemen. 
tijk structurele behoefte aan dit soort normering bestaat. Daarom stel ik voor om art. 4:130 Awb als volgt aan te passen:

\section{Artikel 4:130 Awb}

1. Het bestuursorgaan bevestigt de ontvangst van de aanvraag schriftelijk en zo spoedig mogelijk, doch tenminste binnen twee weken na de ontvangst daarvan. Hierbij stelt het de aanvrager tevens in kennis van de te volgen procedure.

2. Het bestuursorgaan beslist binnen vier weken na ontvangst van de aanvraag of het gebruik zal maken van zijn bevoegdheid uit artikel 4:135, eerste lid. ${ }^{236}$

3. Als het bestuursorgaan beslist geen gebruik te maken van zijn bevoegdheid uit artikel 4:135, eerste lid, dan beslist het binnen acht weken na ontvangst daarvan op de aanvraag. Het kan deze termijn eenmaal met ten hoogste acht weken verlengen onder schriftelijke opgaaf van redenen aan de aanvrager en andere belanghebbenden.

4. Als het bestuursorgaan beslist gebruik te maken van zijn bevoegdheid uit artikel 4:135, eerste lid, dan:

a. verstuurt het bestuursorgaan zo spoedig mogelijk - doch uiterlijk binnen een week na de in de aanhef van dit lid bedoelde beslissing - de kennisgeving als bedoeld in artikel 4:135, vijfde lid;

b. verstrekt het bestuursorgaan een adviesopdracht aan de adviescommissie niet eerder dan nadat de aanvrager en andere belanghebbenden op deze kennisgeving hebben gereageerd binnen de daarvoor door artikel 4:135, zesde lid, gestelde termijn, doch uiterlijk binnen twee weken na het verstrijken van die termijn;

c. stelt het bestuursorgaan zo spoedig mogelijk - doch uiterlijk binnen een week na verstrekking van de adviesopdracht - ter beschikking aan de adviescommissie, alle op de aanvraag betrekking hebbende informatie, alsmede de bescheiden die naar het oordeel van de adviescommissie noodzakelijk zijn voor de beoordeling daarvan;

d. stelt de adviescommissie zo spoedig mogelijk - doch uiterlijk binnen een week na verstrekking van de adviesopdracht - de aanvrager, het bestuursorgaan en andere belanghebbenden in kennis van de te volgen procedure. Daarbij geeft de adviescommissie in ieder geval aan of, op welke wijze, en wanneer zij in de gelegenheid zullen worden gesteld om hun standpunt met betrekking tot de aanvraag toe te lichten;

e. nodigt de adviescommissie de aanvrager, het bestuursorgaan en andere belanghebbenden uit om aanwezig te zijn bij een plaatsopneming, als zij op grond van artikel 4:135, elfde lid, besluit daartoe over te gaan;

f. stelt de adviescommissie haar advies vast binnen tien weken nadat haar de adviesopdracht is verstrekt door het bestuursorgaan. Zij kan deze termijn eenmaal met ten hoogste acht weken verlengen onder schriftelijke opgaaf van redenen aan de aanvrager, het bestuursorgaan en andere belanghebbenden. $\mathrm{Zij}$

236 Hiermee verwijs ik naar de bepaling die het resultaat is van mijn aanbevelingen uit paragrafen $10.6 \mathrm{t} / \mathrm{m} \mathrm{10.9}$. $\mathrm{Zij}$ wordt in haar geheel weergegeven in paragraaf 10.14.1 onder het kopje 'Deskundigenadvisering'. 
zendt het advies terstond toe aan de aanvrager, het bestuursorgaan, en andere belanghebbenden;

g. maken de aanvrager en andere belanghebbenden eventuele bedenkingen tegen het advies uiterlijk vier weken na de verzending daarvan schriftelijk kenbaar aan het bestuursorgaan;

h. beslist het bestuursorgaan uiterlijk tien weken na de verzending van het advies op de aanvraag, tenzij het de adviescommissie overeenkomstig het bepaalde onder i opdraagt nader te adviseren omtrent het op de aanvraag te nemen besluit. Het kan deze termijn eenmaal met ten hoogste acht weken verlengen onder schriftelijke opgaaf van redenen aan de aanvrager en andere belanghebbenden;

i. is het bestuursorgaan bevoegd uiterlijk zes weken na de verzending van het advies een opdracht tot nader advies te verstrekken aan de adviescommissie;

j. stelt de adviescommissie haar nader advies vast binnen zes weken na verzending van de opdracht om nader te adviseren. Zij zendt dit nader advies terstond toe aan de aanvrager, het bestuursorgaan, en andere belanghebbenden. De adviescommissie kan deze termijn eenmaal met ten hoogste vier weken verlengen onder schriftelijke opgaaf van redenen aan de aanvrager, het bestuursorgaan en andere belanghebbenden; en

$\mathrm{k}$. beslist het bestuursorgaan uiterlijk zes weken na de verzending van het nader advies op de aanvraag. Het kan deze termijn eenmaal met ten hoogste drie weken verlengen onder schriftelijke opgaaf van redenen aan de aanvrager en andere belanghebbenden.

5. De termijnen uit het eerste tot en met vierde lid worden overeenkomstig artikel 4:15 opgeschort als toepassing wordt gegeven aan artikel 4:5.

6. Bij wettelijk voorschrift kan worden afgeweken van het tweede tot en met vierde lid.

Voor de formulering van de voorgestelde bepaling is inspiratie ontleend aan art. 4:130 Awb en de relevante procedurele voorschriften uit de BnIW 2019, VS 2012 en modelverordening van de VNG. Inhoudelijk is de voorgestelde bepaling in algemene zin ingegeven door de doelstelling van vergroting van de rechtszekerheid, terwijl ik haar ook verenigbaar acht met de overige aan de Wns ten grondslag liggende doelstellingen en uitgangspunten. Hierna zal ik voor een aantal keuzes nader toelichten hoe zij zijn beïnvloed door deze doelstellingen en uitgangspunten. Alvorens daartoe over te gaan, merk ik op dat deze doelstellingen en uitgangspunten mijns inziens geen aanleiding geven om ook nog (b) afdeling $15.1 \mathrm{Ow}$ aan te passen. Wel zie ik aanleiding voor (c) een bijzondere invulling van titel 4.5 Awb. Het kabinet of een partij als de VNG zou namelijk modelbrieven kunnen opstellen waarmee het bestuursorgaan en de adviescommissie kunnen voldoen aan hun informatieverplichtingen uit het eerste lid respectievelijk vierde lid, aanhef en onder d van de voorgestelde bepaling. Dat past immers goed bij de doelstellingen van uniformering en harmonisering van het nadeelcompensatierecht, vergroting van de rechtsgelijkheid, en vergroting van de doelmatigheid van het nadeelcompensatierecht en vermindering van bestuurslasten. 
Het eerste lid van de voorgestelde bepaling verplicht het bestuur tot het verzenden van een ontvangstbevestiging, waarin het de aanvrager informeert over de te volgen procedure. Als mijn aanbevelingen uit paragraaf 10.4.3 voor een gewijzigde redactie van art. 4:128 Awb zouden worden overgenomen, zou het bestuur in deze ontvangstbevestiging ook moeten mededelen of het gebruikmaakt van zijn mogelijkheid om een recht van $€ 300$ te heffen van de aanvrager, en zo ja, dat dit bedrag dient te zijn voldaan binnen twee weken na de dag van verzending van de ontvangstbevestiging. Deze betalingstermijn is zo gekozen dat het einde daarvan samenvalt met het einde van de termijn waarbinnen het bestuur dient te beslissen of het een adviescommissie zal raadplegen - waarover hierna meer. Een betaaltermijn van twee weken acht ik afdoende, omdat de burger reeds bij de indiening van zijn aanvraag kan weten dat mogelijk een recht zal worden geheven. Bovendien dient de aanvrager op grond van art. 4:5 lid 1 Awb een hersteltermijn te worden geboden als hij het geld niet tijdig bij elkaar zou krijgen.

Op grond van het tweede lid van de voorgestelde bepaling dient het bestuur binnen vier weken na ontvangst van de aanvraag te beslissen of het een adviescommissie wil raadplegen. Mijns inziens zou het mogelijk moeten zijn om binnen deze termijn in te schatten of externe expertise nodig is om te beslissen op de aanvraag. Het derde lid houdt vast aan de beslistermijnen die volgen uit de huidige redactie van titel 4:130 Awb. De aan de Wns ten grondslag liggende doelstellingen en uitgangspunten geven mijns inziens onvoldoende houvast om de benadering van de VNNZ voor te schrijven. Daarbij is mede van belang dat het niet goed past bij het uitgangspunt van aansluiting bij de Awb om het bestuursorgaan te verplichten om de aanvrager een voorstel te doen met betrekking tot het op zijn aanvraag te nemen besluit. Dat laat onverlet dat de ruimte tot het bieden van dit soort voorstellen wel zal blijven bestaan onder de voorgestelde bepaling. Daarvoor is gekozen omdat het doen van een dergelijk voorstel het bestuur niet veel tijd hoeft te kosten, terwijl doorgaans wel een aanzienlijke tijds- en kostenbesparing zal worden gerealiseerd als het voorstel wordt aanvaard. Dit sluit goed aan op de doelstelling van vergroting van de doelmatigheid van het nadeelcompensatierecht en vermindering van bestuurslasten.

Het vierde lid ziet op de situatie waarin het bestuur in de eerste vier weken na ontvangst van de aanvraag beslist om een adviescommissie te raadplegen. Op grond van onderdeel a dient het bestuur de aanvrager, en eventuele andere belanghebbenden waarmee het bekend is, binnen een week na die beslissing te informeren omtrent de beoogde samenstelling van de adviescommissie. De adviesopdracht mag op grond van onderdeel b pas worden verstrekt als de aanvrager en andere belanghebbenden in de gelegenheid zijn gesteld om te reageren op deze samenstelling. In paragraaf $10.7 .3^{237}$ is ingegaan op de voor- en nadelen van deze 'wrakingsmogelijkheid' en werd geconcludeerd dat zij per saldo niet strijdig is met de doelstelling van vergroting van de doelmatigheid van het nadeelcompensatierecht 
en vermindering van bestuurslasten en/of de overige aan de Wns ten grondslag liggende doelstellingen en uitgangspunten. Tegenover de beperkte vertraging die zij meebrengt, staat namelijk de verkleining van het risico dat in een later stadium blijkt dat een groot deel van de procedure moet worden overgedaan omdat de ingeschakelde deskundige niet onafhankelijk, onpartijdig en/of voldoende deskundig was. Om de procedure niet onnodig lang op te houden is bovendien bepaald dat de adviesopdracht uiterlijk dient te worden verstrekt binnen twee weken na het verstrijken van de termijn om te reageren op de samenstelling van de adviescommissie. Het spreekt voor zich dat de adviesopdracht pas kan worden gegeven als de leden van de adviescommissie zijn benoemd op grond van art. 4:135 lid 3 Awb. Daarvoor heb ik geen aparte termijn opgenomen, aangezien het ook mogelijk is dat die benoeming reeds heeft plaatsgevonden omdat wordt gewerkt met een vaste adviescommissie. ${ }^{238}$

Onderdeel c van het vierde lid de voorgestelde bepaling is met name ingegeven vanuit de doelstelling van vergroting van de doelmatigheid van het nadeelcompensatierecht en vermindering van bestuurslasten. Het zorgt er namelijk voor dat de adviescommissie zo snel mogelijk beschikt over de informatie die zij nodig heeft om haar taak te kunnen uitvoeren. De motivering van onderdeel d en e vloeit voort uit paragraaf 10.10.3: het past niet bij de doelstelling van vergroting van de doelmatigheid van het nadeelcompensatierecht en vermindering van bestuurslasten, en het uitgangspunt van aansluiting bij de Awb om de adviescommissie te dwingen tot plaatsopneming, of het bieden van gelegenheid tot inspraak. Wel past het bij de doelstelling van vergroting van de rechtszekerheid dat de adviescommissie de betrokken partijen informeert over de mate waarin aan hen gelegenheid tot inspraak zal worden geboden.

Ook onderdelen $\mathrm{ft} / \mathrm{m} \mathrm{k}$ vinden hun grondslag in paragraaf 10.10.3. Daaruit volgt namelijk dat de systematiek van de VS 2012 - geen conceptadvies en geen conceptbesluit, maar wel mogelijkheid tot inwinning van nader advies - het best aansluit bij de aan de Wns ten grondslag liggende doelstellingen en uitgangspunten. De voorgestelde termijnen zijn zo gekozen dat het nemen van een besluit op de aanvraag om nadeelcompensatie onder inwinning van advies maximaal 52 weken in beslag mag nemen - zoals ook wordt voorgeschreven door de huidige redactie van art. 4:130 Awb. Als geen nader advies wordt ingewonnen en geen gebruik wordt gemaakt van de mogelijkheden om termijnen te verlengen, wordt uiterlijk binnen 29 weken beslist. Ook dat sluit relatief goed aan op de 26 weken die de wetgever in gedachten had blijkens de huidige redactie van art. 4:130 Awb.

In het vijfde lid is geëxpliciteerd dat de termijnen uit de voorgestelde bepaling worden opgeschort gedurende de periode waarin de aanvrager in gebreke is ten aanzien van de eisen die aan zijn aanvraag worden gesteld. ${ }^{239}$ Deze bepaling is met

238 Zie daarover paragraaf 10.7.3 onder het kopje 'Ontslag of uitsluiting van de commissieleden'.

239 Deze eisen worden besproken in paragraaf 10.3. 
name opgenomen vanwege de doelstelling van vergroting van de rechtszekerheid. Art. 4:15 Awb ziet - strikt genomen - namelijk slechts op de termijn waarbinnen de beschikking op de aanvraag dient te worden gegeven. Het voorgestelde vijfde lid maakt duidelijk dat ook alle deeltermijnen worden opgeschort. Ten slotte volgt uit het zesde lid van de voorgestelde bepaling dat bij wettelijk voorschrift kan worden afgeweken van het tweede $\mathrm{t} / \mathrm{m}$ vierde lid van de voorgestelde bepaling. Ondanks dat de voorgestelde procedure geschikt zou moeten zijn voor het overgrote deel van het nadeelcompensatierecht, is het namelijk denkbaar dat bijzondere eigenschappen van een specifiek deelgebied van het nadeelcompensatierecht kunnen meebrengen dat toch behoefte bestaat aan een afwijkende regeling. Zo is het bijvoorbeeld mogelijk dat bij grote projecten die veel gelijksoortige schades veroorzaken - en waarbij al dan niet meerdere bestuursorganen zijn betrokken - behoefte kan bestaan aan de mogelijkheid om een aanvraag gedurende een bepaalde tijd aan te houden in afwachting van deskundigenadvies gevraagd in een vergelijkbaar schadegeschil. In het deel van de memorie van toelichting dat bij het voorgestelde artikellid behoort, zou mijns inziens wel moeten worden opgemerkt dat van deze afwijkingsmogelijkheid slechts gebruik moet worden gemaakt als daartoe zwaarwegende redenen bestaan. Dat is ook de reden dat ik voorstel om afwijking slechts mogelijk te maken bij wettelijk voorschrift. Op gemeentelijk, provinciaal en waterschapsniveau heeft dit immers tot gevolg dat slechts het volksvertegenwoordigende, regelgevende bestuursorgaan kan instemmen met een afwijking van de standaardprocedure. Mocht de wetgever dat een te grote beperking vinden, dan kan hij uiteraard ook kiezen voor een formulering als 'bij of krachtens wettelijkvoorschrift' of 'bij wettelijk voorschrift of bij beleidsregel'. De afwijkingsmogelijkheid ziet niet op het eerste lid van de voorgestelde bepaling, omdat het onder alle omstandigheden mogelijk zou moeten zijn om de aanvrager tijdig een ontvangsbevestiging te sturen. Bij invoering van de voorgestelde bepaling, zou de procedure als volgt komen uit te zien.

\section{Voorstel voor een nieuw art. 4:130 Awb}

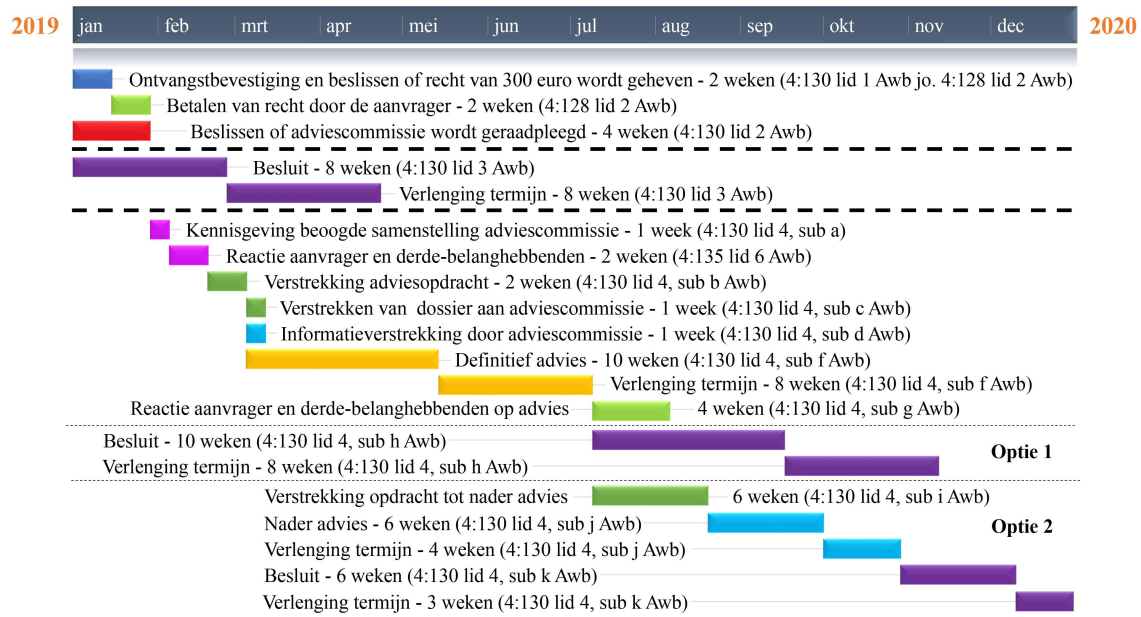




\subsection{RECHTSMIDDELEN}

10.12.1 Deelvraag 2: verschillen tussen de geselecteerde, thans geldende regelingen en verklaringen daarvoor

Onder alle geselecteerde, thans geldende regelingen kunnen belanghebbenden bezwaar (art. 7:1 Awb), beroep (art. 8:1 Awb) en ten slotte hoger beroep (art. 8:104 lid 1, aanhef en onder a Awb) aantekenen tegen het besluit op de aanvraag om nadeelcompensatie of tegemoetkoming in planschade. Deze overeenkomst kan worden verklaard doordat de aangehaalde bepalingen van dwingendrechtelijke aard zijn. Hiervan had dus slechts kunnen worden afgeweken in afd. 6.1 Wro of art. $8.31 \mathrm{Wlv}$. Het uitgangspunt is echter dat dergelijke afwijking slechts geschiedt als dit 'noodzakelijk' is (vergelijk art. 49 Aanwijzingen voor de regelgeving). Daarvan was bij deze regelingen geen sprake. Voor toepassing van de GrS is wel nog van belang dat uit art. 49a lid 2 WRO volgt dat een derde met wie het bestuur een schadeverhaalsovereenkomst heeft gesloten als belanghebbende bij het besluit op de aanvraag om tegemoetkoming zal worden aangemerkt. Dat is op grond van art. 6.4a lid 2 Wro ook het geval in het huidige planschaderecht. ${ }^{240}$ Het derde lid van deze bepaling merkt ook de derde die belang heeft bij de vaststelling of herberekening van een exploitatiebijdrage als bedoeld in art. 6.17 lid 1 Wro aan als belanghebbende. Ook deze personen kunnen dus rechtsmiddelen aanwenden tegen het besluit op de aanvraag om tegemoetkoming in planschade.

\subsubsection{Deelvraag 3: Toekomstig recht}

\section{De bevoegdheidsregeling van art. 8:6 lid $2 \mathrm{Awb}$}

In art. 8.2a Awb als vormgegeven door het oorspronkelijke wetsvoorstel voor de Wns vervulde de eis van processuele connexiteit de rol van toegangspoort tot de bestuursrechter. De Tweede Kamer schrapte deze bepaling echter door aanname van het amendement Taverne c.s. teneinde een "laagdrempelige bestuursrechtelijke rechtsgang" te creëren. ${ }^{241}$ De Kamer lijkt daarbij over het hoofd te hebben gezien dat de Wns ook een tweede lid aan art. 8:6 Awb zal toevoegen:

"Het beroep tegen een besluit op een aanvraag als bedoeld in artikel 4:126 kan worden ingesteld bij de rechtbank, tenzij de schade is veroorzaakt door een besluit als bedoeld in hoofdstuk 2 (beroep in eerste aanleg bij een bijzondere bestuursrechter) of 3 (beroep in eerste aanleg bij een andere rechtbank) ${ }^{242}$ van de bij deze wet behorende Bevoegdheidsregeling bestuursrechtspraak of door een handeling ter uitvoering van een zodanig

240 Zie daarover ook paragraaf 10.4.1.

241 Zie Kamerstukken II 2011/12, 32 621, nr. 11 (Amendement Taverne c.s.); en $\mathrm{Ka}$ merstukken II 2010/11, 32 621, nr. 3, p. 5-6 (MvT, Wns). Zie hierover ook paragraaf 2.4.2.1 onder het kopje 'Vereenvoudiging, uniformering en harmonisering van het nadeelcompensatierecht'.

242 De tussen haakjes geplaatste beschrijvingen betreffen eigen toevoegingen. 
besluit. In dat geval kan het beroep worden ingesteld bij de bestuursrechter die ingevolge het desbetreffende hoofdstuk bevoegd is." 243

Deze bij nota van wijziging ingevoegde bepaling is gebaseerd op de gedachte dat de rechterlijke beoordeling van een besluit op een aanvraag om nadeelcompensatie "kennis vraagt van de regelgeving op grond waarvan het schadeveroorzakende besluit is genomen." Het zou daarom "voor de hand" liggen dat "voor nadeelcompensatie dezelfde rechtsmacht geldt als voor het schadeveroorzakende besluit." 244

Belangrijk voor de toekomstige rechtsmachtverdeling is dat de IOw wijzigingen zal aanbrengen in art. 2 van de tweede bijlage bij de Awb - de bepaling inzake rechtstreeks beroep bij de Afdeling. Aan de lijst van in dit artikel opgesomde besluiten zullen namelijk onder andere het omgevingsplan van art. $2.4 \mathrm{Ow}$, het projectbesluit van afd. $5.2 \mathrm{Ow}$, en een besluit ter uitvoering van een projectbesluit als bedoeld in afd. 5.2 Ow worden toegevoegd. Dat heeft tot gevolg dat tegen een besluit om nadeelcompensatie naar aanleiding van schade door een van deze schadeoorzaken, na bezwaar, slechts beroep in eerste en enige instantie bij de Afdeling openstaat.

\section{Schade en kostenverhaal via art. $13.3 \mathrm{c}$ jo. art. $13.3 \mathrm{~d}$ Ow}

In art. 13.3c Ow is een soortgelijke regeling opgenomen als naar huidig recht is te vinden in art. 6.4a lid 1 en lid 2 Wro. De belangrijkste verschillen zijn dat een schadeverhaalsovereenkomst op grond van art. 13.3c Ow niet alleen betrekking kan hebben op de planschadevergoeding maar ook op de kosten die daarmee samenhangen, zoals de kosten van de planschadeprocedure. ${ }^{245}$ Bovendien kan de overeenkomst ook worden aangegaan als de derde die de schadeveroorzakende activiteit verricht niet om het treffen van de daarvoor benodigde planologische maatregel heeft verzocht. In de bijbehorende passage uit de memorie van toelichting wordt opgemerkt dat de regeling het bestuur de mogelijkheid biedt om...

“(...) tot een redelijke verdeling van de kosten te komen. Kostenverhaal zal mogelijk zijn, voor zover de vergoeding voor nadeelcompensatie toe te rekenen is aan de activiteit van de initiatiefnemer en hij daar baat bij heeft." ${ }^{246}$

Waar de eis van toerekening met enige goede wil uit art. 13.3c Ow kan worden afgeleid, geldt dat niet voor de eis van baat.

De regeling omtrent gedwongen kostenverhaal via afd. 6.4 Wro, waarnaar art. 6.4a lid 3 Wro verwijst, is slechts van toepassing op grondexploitatie/gebiedsontwikke-

Stb. 2013, nr. 50, art. Ca.

244 Kamerstukken II 2010/11, 32 621, nr. 7, p. 4 (NVW, Wns).

245 Zie voor meer informatie hierover Kamerstukken II 2003/04, 24 940, nr. 7, p. 4 (NV II). 
ling. Ook in andere gevallen waarin het niet tot een schadeverhaalsovereenkomst komt, kan echter behoefte bestaan "aan afdwingbaar - publiekrechtelijk - kostenverhaal". Voor dit verhaal is een algemene regeling opgenomen in art. 13.3d Ow. Op grond daarvan kan het bestuur dat een vergoeding heeft toegekend wegens schade door enkele specifiek genoemde schadeoorzaken uit art. 15.1 lid $1 \mathrm{Ow}$, deze vergoeding onder bepaalde voorwaarden bij beschikking in rekening brengen bij een derde die de door de schadeoorzaak toegestane activiteit heeft verricht. Deze derde wordt echter niet als belanghebbende aangemerkt bij het besluit om de aanvraag om nadeelcompensatie, anders dan naar huidig recht het geval is op grond van art. 6.4a lid 3 Wro. Waarom die keuze is gemaakt, volgt niet uit de memorie van toelichting behorende bij de IOw. ${ }^{247}$

10.12.3 Hoofdvraag: spiegeling aan de doelstellingen en uitgangspunten die ten grondslag liggen aan de Wns

\section{De bevoegdheidsregeling van art. 8:6 lid $2 \mathrm{Awb}$}

Art. 8:6 lid 2 Awb sluit mijns inziens niet goed aan op de doelstellingen en uitgangspunten die aan de Wns ten grondslag liggen. Het past immers niet goed bij de doelstelling van vergroting van de doelmatigheid van het nadeelcompensatierecht en vermindering van bestuurslasten dat relatief veel nadeelcompensatiegeschillen na de bezwaarfase direct bij de hoogste bestuursrechter aanhangig zullen worden gemaakt. Dat zal bijvoorbeeld het geval zijn voor het grootste deel van de aanvragen die onder afd. 15.1 Ow worden afgedaan. Daarbij moet onder andere worden bedacht dat het de bedoeling is dat het omgevingsplan veel globaler van aard wordt dan het huidige bestemmingsplan, hetgeen resulteert in meer schade door vergunningvrije activiteiten. ${ }^{248}$ Die schade wordt als gevolg van het omgevingsplan aan het bestuur toegerekend, ${ }^{249}$ waardoor de Afdeling in eerste en enige instantie bevoegd zal zijn. Eveneens niet bevorderlijk voor het drukken van de bestuurslasten is dat art. 8:6 lid 2 Awb de mogelijkheid tot indiening van een gebundelde aanvraag ${ }^{250}$ zal beperken. Zo kan bijvoorbeeld geen gebundelde aanvraag worden ingediend als de schade wordt veroorzaakt door een samenspel

247 Kamerstukken II 2018/19, 34 986, nr. 3, p. 217-218 (MvT, IOw).

248 Zie paragraaf 2.4.3 onder het kopje 'Het nieuwe omgevingsrecht'.

249 Zie paragrafen 3.3.2.3, 3.4.2.3 en 4.3.2 onder het kopje 'Indirecte schade door vergunningvrije activiteiten'.

250 Zie paragrafen 6.2.2.3 en 6.2.3.2. 
van vergunningvrije- en vergunningplichtige activiteiten. ${ }^{251}$ Tegen besluitvorming op een aanvraag om compensatie die betrekking heeft op schade door een omgevingsvergunning zou immers wel rechtsbescherming in twee instanties openstaan (beroep bij de rechtbank, sector bestuursrecht gevolgd door hoger beroep bij de Afdeling).

De regeling van art. 8:6 lid 2 Awb past ook niet goed bij de doelstelling van vergroting van de rechtsgelijkheid. Zou met de hiervoor genoemde omgevingsvergunning uitvoering worden gegeven aan een projectbesluit, óf wordt met een projectbesluit een ontwikkeling gerealiseerd die ook door middel van één of meerdere omgevingsvergunningen had kunnen worden gerealiseerd, dan staat immers geen rechtsbescherming in twee instanties open, maar slechts rechtsbescherming in eerste en enige aanleg bij de Afdeling. Daarvoor zie ik geen goede rechtvaardiging, mede omdat de door de wetgever aangevoerde argumenten niet overtuigen. De vraag of het bestuur tot een rechtmatig oordeel is gekomen omtrent de vraag of de aanvrager schade heeft geleden die in causaal verband staat tot de beweerde schadeoorzaak, abnormaal en speciaal is, en aan de overige criteria van titel 4.5 Awb voldoet, vereist immers geen bijzondere kennis van de regelgeving op grond waarvan het schadeveroorzakende besluit is genomen - uitzonderingen daargelaten. Dat is bijvoorbeeld voor het ruimtelijk ordeningsrecht al decennia gebleken onder art. 49 WRO en afd. 6.1 Wro, maar kan ook in meer algemene zin worden beredeneerd aan de hand van de introductie van de route van het zuiver schadebesluit, en de ontkoppeling van de toets aan het égalitébeginsel en de toets aan art. 3:4 lid 2 Awb die daarna heeft plaatsgevonden. ${ }^{252}$ Bovendien past de beschreven beperking van rechtsbescherming tot slechts één rechterlijke instantie ook niet goed bij het uitgangspunt van aansluiting bij de Awb. Schueler heeft in zijn preadvies voor de Vereniging voor Bouwrecht uit 2012 namelijk overtuigend betoogd dat voor een uitzondering op de hoofdregel van beroep in twee instanties in algemene zin slechts ruimte bestaat als "het gaat om besluiten waarbij de uitkomst van een rechterlijke procedure van belang is voor de rechtmatigheid van veel andere besluiten en andere handelingen." ${ }^{253}$ Van Ravels heeft reeds in 2013 op overtuigende wijze beargumenteerd waarom daarvan geen sprake is in het nadeelcompensatie- en planschaderecht. ${ }^{254}$

251 De Afdeling wordt naar huidig recht met een vergelijkbaar probleem geconfronteerd in geschillen waarin de schade deels wordt geleden door een tracébesluit en deels wordt geleden door uitvoeringshandelingen die niet als gevolg daarvan aan het bestuur kunnen worden toegerekend. Zie ABRvS 22 augustus 2018, ECLI:NL:RVS:2018:2764, r.o. 8. De gekozen oplossing doet denken aan de opmerking over het "bloc de compétence" in Kamerstukken II 2011/12, 32 621, nr. 7, p. 5. Niets wijst echter erop dat de Afdeling een vergelijkbare oplossing zal treffen onder afd. $15.1 \mathrm{Ow}$.

252 Zie daarover paragraaf 2.2 respectievelijk paragraaf 5.3.1.

253 Schueler 2012, p. 157-161.

254 Van Ravels 2013b, p. 7. 
Deze bespreking van nadelen van art. 8:6 lid 2 Awb illustreert ten slotte dat deze bepaling ook niet goed past bij de doelstelling van vereenvoudiging van het nadeelcompensatierecht. De rechtsmachtverdeling die op grond van dit artikel ontstaat is immers niet tot nauwelijks eenvoudiger te doorgronden dan het naar huidig recht bestaande nadeelcompensatiedoolhof. ${ }^{255} \mathrm{Ik}$ stel daarom voor om het tweede lid van art. 8:6 Awb te schrappen ${ }^{256}$ en te vervangen door art. 4.5.7 van het voorontwerp van de Wns:

"Indien hoger beroep is ingesteld tegen een uitspraak over een besluit omtrent nadeelcompensatie als bedoeld in deze titel, verwijst de Afdeling bestuursrechtspraak van de Raad van State de behandeling naar een andere hogerberoepsrechter, indien de behandeling van het hoger beroep door deze rechter naar haar oordeel gewenst is. Artikel $8: 13$, tweede en derde lid, is van overeenkomstige toepassing."

Deze bepaling is mijns inziens wel verenigbaar met de aan de Wns ten grondslag liggende doelstellingen en uitgangspunten. Hoewel dat waarschijnlijk niet vaak zal voorkomen, kan op voorhand immers niet worden uitgesloten dat zich bijzondere gevallen zullen voordoen waarin speciale expertise is vereist om een besluit op een aanvraag om nadeelcompensatie op waarde te kunnen schatten. De voorgestelde bepaling laat het aan de hoogste algemene bestuursrechter (de Afdeling) om te bepalen of er wegens een eventueel gebrek aan expertise, of anderszins reden bestaat om het hoger beroep te laten behandelen door een bijzondere bestuursrechter. Het ligt voor de hand dat hierover in algemene zin zal worden overlegd in de 'Commissie rechtseenheid bestuursrecht', waarin alle hoogste bestuursrechters zijn vertegenwoordigd.

\section{Schade- en kostenverhaal via art. 13.3c jo. $13.3 \mathrm{~d}$ Ow}

Het is lastig om situaties te bedenken die niet onder art. 15.1 Ow vallen, maar waarin wel behoefte bestaat aan verhaal van de kosten die gepaard gaan met de behandeling van een aanvraag om nadeelcompensatie en de toekenning van nadeelcompensatie. ${ }^{257} \mathrm{Ik}$ acht het daarom verenigbaar met de doelstelling van vereenvoudiging, uniformering en harmonisering van het nadeelcompensatierecht dat art. 13.3c en art. 13.3d Ow niet in titel 4.5 Awb zijn opgenomen, maar in de Ow. Het zou mijns inziens wel beter bij de doelstelling van vergroting van de rechtszekerheid passen als uit de redactie van art. 13.3c lid 1 Ow zou blijken dat de nadeelcompensatie moet zijn toegekend naar aanleiding van de activiteit die de derde uitvoerde op grond van de schadeoorzaak uit art. 15.1 lid 1 Ow (in paragraaf

255 Zie daarover paragraaf 2.2.

256 De conclusie dat dit artikellid moet worden geschrapt, wordt ook bereikt in Van Ravels 2013b, p. 3-7 en 16; en Gierveld 2018, p. 1248. Dat geschiedt deels op basis van vergelijkbare argumenten, maar ook deels op basis van andere argumenten.

257 Mogelijk is dat het geval bij toepassing van art. 8.31 Wlv, maar daar vindt verhaal plaats door middel van de heffing van art. $8 \mathrm{a} .38 \mathrm{Wlv}$. Zie daarover ook paragraaf 10.7.1 onder het kopje 'De BnIW 2019 en de VS 2012'. 
10.12.2 aangeduid als de eis van toerekenbaarheid). Dit zou kunnen worden gerealiseerd met behulp van de onderstaande redactie:

\begin{abstract}
"De rechtspersoon waartoe het bestuursorgaan behoort dat vergoeding van schade als bedoeld in artikel 4:126, eerste lid, van de Algemene wet bestuursrecht in samenhang met artikel 15.1, eerste lid, toekent, kan met degene die de activiteit verricht naar aanleiding waarvan de vergoeding is toegekend, overeenkomen dat de toe te kennen schadevergoeding en de daarmee samenhangende kosten geheel of gedeeltelijk voor zijn rekening komen."
\end{abstract}

Deze redactie acht ik ook verenigbaar met de overige aan de Wns ten grondslag liggende doelstellingen en uitgangspunten. De in paragraaf 10.12.2 besproken eis van baat, heb ik bewust niet in deze redactie verwerkt. Dat degene die de activiteit uitvoert daarmee geen baten weet te realiseren, lijkt in eerste instantie immers te wijzen in de richting van slecht ondernemerschap. Dat hoeft mijns inziens niet te worden beloond door het sluiten van een schadeverhaalsovereenkomst op voorhand onmogelijk te maken.

In paragraaf 10.12.2 bleek dat de wetgever niet heeft toegelicht waarom de derde die een beschikking ex art. 13.3d Ow krijgt opgelegd niet als belanghebbende wordt aangemerkt bij de besluitvorming op de aanvraag om nadeelcompensatie. Mogelijk is de achterliggende gedachte dat een derde die niet bereid bleek om mee te werken aan een schadeverhaalsovereenkomst het recht heeft verspeeld om invloed uit te oefenen op de besluitvorming naar aanleiding van de aanvraag om nadeelcompensatie. Tevens zou een rol kunnen spelen dat pas vaststaat dat de derde daadwerkelijk belanghebbend is bij de besluitvorming op de aanvraag om nadeelcompensatie als de beschikking die het bestuur hem op grond van art. $13.3 \mathrm{~d}$ Ow oplegt in rechte onaantastbaar is geworden. Aangezien het niet onwaarschijnlijk lijkt dat hij deze beschikking doorgaans in rechte zal aanvechten, past het mijns inziens bij de doelstelling van vergroting van de doelmatigheid van het nadeelcompensatierecht en vermindering van bestuurslasten dat hij niet als derdebelanghebbende wordt aangemerkt in de nadeelcompensatieprocedure. Ook de andere aan de Wns ten grondslag liggende doelstellingen en uitgangspunten geven mijns inziens geen aanleiding tot aanpassing van art. 13.3d Ow.

\title{
Conclusie
}

Uit het voorafgaande volgt dat de aan de Wns ten grondslag liggende doelstellingen en uitgangspunten mijns inziens aanleiding geven tot aanpassing van art. 8:6 lid 2 Awb en art. 13.3c lid 1 Ow. Beide aanpassingen kwalificeer ik als (c) het anderszins geven van een bijzondere invulling aan titel $4.5 \mathrm{Awb}$. De doelstellingen en uitgangspunten nopen mijns inziens niet tot (a) aanpassing van titel 4.5 Awb of (b) aanpassing van afd. $15.1 \mathrm{Ow}$. 


\subsection{EEN VOORSCHOT OP NADEELCOMPENSATIE OF TEGEMOETKOMING IN PLANSCHADE}

10.13.1 Deelvraag 2: verschillen tussen de geselecteerde, thans geldende regelingen en verklaringen daarvoor

In deze pararaaf wordt stilgestaan bij de mogelijkheid van de aanvrager om een voorschot aan te vragen in nadeelcompensatie- en of planschadegeschillen. $\mathrm{Na}$ bespreking van een algemeen kader dat onder alle regelingen in acht moet worden genomen, zal worden ingegaan op de verschillen tussen de geselecteerde, thans geldende regelingen en de verklaringen daarvoor.

\section{Algemeen kader}

In art. 4:95 Awb is een regeling opgenomen om vooruitlopend op de vaststelling van een verplichting tot betaling van een geldsom een voorschot te verlenen. Deze regeling is dus ook van toepassing in nadeelcompensatiegeschillen. Tenzij bij wettelijk voorschrift anders is bepaald, kan een voorschot - kort gezegd - worden toegekend als redelijkerwijs kan worden aangenomen dat een verplichting tot betaling zal worden vastgesteld. Op grond van art. 4:95 lid 3 jo. art. 4:87 lid 1 Awb dient het voorschot te worden betaald binnen zes weken nadat de beschikking tot bevoorschotting op de voorgeschreven wijze is bekendgemaakt, tenzij in deze beschikking een andere termijn is vastgesteld. Voor de termijn waarbinnen op de aanvraag om bevoorschotting moet worden beslist, moet worden teruggevallen op de algemene regeling van art. 4:13 Awb. ${ }^{258}$ Voorts bepaalt art. 4:95 lid 4 Awb dat het voorschot wordt verrekend met de uiteindelijke schadevergoeding en dat onverschuldigd betaald voorschot kan worden teruggevorderd. Op grond van art. 4:95 lid 6 Awb kan het bestuur bovendien voorschriften aan de verlening van het voorschot verbinden. Ten slotte bepaalt art. 4:96 Awb wanneer het verleende voorschot kan worden gewijzigd of ingetrokken.

\section{De geselecteerde, thans geldende regelingen}

Alle geselecteerde, thans geldende regelingen bevatten een bepaling op grond waarvan het bestuur een voorschot aan een benadeelde kan toekennen. Het betreft art. 6.1.3.7 lid 1 Bro, art. 20 BnIW 2019, art. 12 VS 2012, art. 11 AVN en art. 10 VNNZ. Deze bepalingen komen op bepaalde punten overeen. Allereerst eisen alle regelingen dat een (schriftelijke) ${ }^{259}$ aanvraag om een voorschot wordt ingediend. Ten tweede bevatten alle regelingen de mogelijkheid voor het bestuur om de be-

258 Zie paragraaf 10.11 .1 onder het kopje 'Inleidende opmerkingen en algemeen kader'.

259 Zie art. 6.1.3.7 lid 1 Bro en art. 20 BnIW 2019. De overige regelingen bepalen niet dat het verzoek schriftelijk dient te geschieden. Dat lijkt echter nagenoeg altijd wel het meest voor de hand te liggen. 
voorschotting afhankelijk te stellen van zekerheidsstelling tot terugbetaling door de aanvrager. ${ }^{260}$ Ten derde bepalen het Bro, de BnIW 2019 en de VS 2012 expliciet dat het verlenen van een voorschot geen erkenning van een aanspraak op nadeelcompensatie of planschadevergoeding inhoudt. ${ }^{261}$ Dat wordt eveneens vermeld in de toelichtingen op de Amsterdamse regelingen. ${ }^{262} \mathrm{Ik}$ heb geen expliciete verklaring gevonden waarom de Amsterdamse gemeenteraad dit niet in de tekst van zijn verordeningen heeft opgenomen. Waarschijnlijk speelt een rol dat dit soort bepalingen geen rechtsgevolg in het leven roepen.

Ten vierde vereisen het Bro, de BnIW 2019 en de VNNZ expliciet dat de aanvrager "naar redelijke verwachting in aanmerking komt" voor compensatie. ${ }^{263}$ Het Bro en de BnIW 2019 vereisen bovendien dat de aanvrager naar het oordeel van het bestuur voldoende belang heeft bij bevoorschotting. ${ }^{264} \mathrm{Ik}$ heb geen verklaring kunnen vinden voor het ontbreken van deze als laatst genoemde eis in de VNNZ. Uit de toelichting behorende bij de AVN blijkt dat het bestuur bij toepassing van de AVN beide eisen dient te hanteren, ook al blijkt dat niet uit de tekst van de AVN. Een duidelijke verklaring waarom de eisen niet in de tekst van de AVN zijn opgenomen, heb ik niet kunnen vinden. Ten aanzien van de eis dat de aanvrager naar redelijke verwachting voor nadeelcompensatie in aanmerking komt, kan hooguit worden gesteld dat opname in de AVN juridisch gezien niet strikt noodzakelijk was. $\mathrm{Zij}$ volgt immers ook uit de algemene regeling omtrent bevoorschotting uit art. 4:95 Awb. ${ }^{265}$ Dat geldt echter niet voor de eis omtrent het belang van de aanvrager bij de bevoorschotting. Beide eisen spelen wel een rol bij toepassing van de VS 2012. Op grond van art. 12 lid 2 VS 2012 dient de besliscommissie bij haar besluit omtrent bevoorschotting namelijk "in ieder geval" te betrekken of de aanvrager naar redelijke verwachting in aanmerking komt voor compensatie en "voldoende urgent financieel belang" heeft bij bevoorschotting. Dit suggereert dat het onder de GrS geen harde eisen betreft, maar dat eerder sprake is van factoren die dienen te worden meegewogen in de besluitvorming omtrent bevoorschotting. Het is onduidelijk of dat daadwerkelijk het geval is, en zo ja, hoe dit verschil met de overige regelingen kan worden verklaard. Uit de toelichting op de VS 2012 blijkt namelijk slechts dat art. 10 RnR 1991 model stond voor art. 12 VS 2012. Beide eisen komen echter niet voor in de RnR 1991. Bovendien is deze regeling op het punt van bevoorschotting nooit van toelichting voorzien. ${ }^{266}$

260 Zie art. 6.1.3.7 lid 3 Bro, art. 11 lid 3 AVN, art. 10 lid 3 VNNZ, art. 20 lid 3 BnIW 2019 en art. 12 lid 4 VS 2012.

261 Zie art. 6.1.3.7 lid 2 Bro, art. 12 lid 3 VS 2012 en art. 20 lid 2 BnIW 2019.

262 Zie de toelichting op art. 11 lid 1 AVN, en de toelichting op art. 10 VNNZ.

263 Zie art. 6.1.3.7 lid 1 Bro, art. 20 lid 1 BnIW 2019, art. 12 lid 2 VS 2012 en art. 10 lid 1 VNNZ.

264 Zie art. 20 lid 1 BnIW 2019 en art. 6.1.3.7 lid 1 Bro.

265 In de toelichting op art. 11 lid $1 \mathrm{AVN}$ wordt opgemerkt dat "het verlenen van voorschotten is gebaseerd op art. 4:95 Awb."

266 Zie Stcrt. 1999, nr. 30, p. 27 (digitaal, p. 2); en Stcrt. 1991, nr. 251, p. 29. 
Ten vijfde vereisen het Bro $^{267}$ en de BnIW $2019^{268}$ dat de aanvrager van het voorschot schriftelijk de verplichting aanvaardt tot gehele en onvoorwaardelijke terugbetaling van hetgeen ten onrechte als voorschot is uitbetaald, zulks te vermeerderen met de wettelijke rente over het teveel betaalde, te rekenen vanaf de datum van betaling van het voorschot. De VS 2012 stelt deze eis ook, zij het dat niet wordt vereist dat de wettelijke rente wordt terugbetaald. ${ }^{269}$ De AVN en VNNZ stellen de eis van aanvaarding van de verplichting tot gehele en onvoorwaardelijke terugbetaling niet. Uit de VNNZ en de daarbij behorende toelichting volgt bovendien niet dat bij terugvordering van het voorschot tevens rente dient te worden betaald over het teveel betaalde voorschot. In de toelichting op art. 11 lid 3 AVN wordt expliciet vermeld dat teveel verleende voorschotten renteloos worden teruggevorderd. Ik heb geen duidelijke verklaringen voor deze verschillen kunnen vinden.

Ten zesde vloeit uit het Bro en de BnIW 2019 de verplichting voor het bestuur voort om de adviescommissie te horen omtrent de aanvraag om bevoorschotting. ${ }^{270}$ Onder de VS 2012, VNNZ en AVN komt het bestuur juist discretie toe omtrent het horen van de adviescommissie. ${ }^{271}$ De discretie die op dit punt onder de VS 2012 bestaat, bestond ook al onder de voorganger van deze verordening. $\mathrm{Zij}$ is dus niet te herleiden tot het rapport van Van Ettekoven en Tjepkema en het daaruit voortgekomen streven naar meer doelmatigheid. Deze discretie is vooral opvallend omdat de VS 2012 en haar voorganger zijn gemodelleerd naar de RnR 1991, terwijl art. 10 lid 1 RnR 1991 - net als art. 20 lid 1 RnVW 1999, BnIM 2014 en BnIW 2019 - verplicht tot het horen van de adviescommissie. Waarom die verplichting in het leven is geroepen, is echter nooit toegelicht.

Al met al zijn een aanzienlijk deel van de hiervoor besproken verschillen dus niet of slechts beperkt te verklaren. In algemene zin kan hooguit nog worden aangedragen dat de regelingen gedurende enkele decennia door verschillende regelgevers zijn opgesteld, terwijl die regelgevers ten aanzien van de desbetreffende onderwerpen geen aandacht lijken te hebben gehad voor afstemming op andere nadeelcompensatieregelingen en/of overleg met elkaar, laat staan een materieelrechtelijk verschil in het leven beoogden te roepen. Ter afsluiting van deze deelparagraaf benoem ik nog een aantal relatief kleine verschillen waarvoor ik eveneens geen duidelijke andere verklaring heb gevonden. Zo wijkt de AVN af van de overige regelingen doordat de hoogte van het voorschot is gemaximaliseerd op $90 \%$ van de te verwachten vergoeding. ${ }^{272}$ Uit de toelichting op art. 11 lid 1 AVN blijkt dat voor een hoog percentage is gekozen, omdat het voorschot is bedoeld om de con-

Art. 6.1.3.7 lid 3 Bro.

268 Art. 20 lid 3 BnIW 2019.

269 Art. 12 lid 4 VS 2012.

270 Zie art. 6.1.3.7 lid 1 Bro en art. 20 lid 1 BnIW 2019.

271 Zie art. 12 lid 1 VS 2012, art. 10 lid 2 VNNZ en art. 2 lid 2 van het bij de AVN behorende Reglement adviescommissie nadeelcompensatie. 
tinuering van bedrijfsvoering te vergemakkelijken. ${ }^{273}$ Die gedachte sluit aan op de in verschillende toelichtingen terug te vinden opmerking dat het verlenen van een voorschot kan dienen ter beperking van de schade, bijvoorbeeld omdat hiermee schadebeperkende maatregelen kunnen worden bekostigd. ${ }^{274}$ Verder bepaalt de VNNZ dat voorschotten per schadejaar worden verleend. ${ }^{275}$ Tevens bepaalt de VNNZ dat het bestuur binnen acht weken dient te beslissen op de aanvraag om bevoorschotting, of binnen zestien weken als de adviescommissie wordt geraadpleegd. ${ }^{276}$ Volgens de VS 2012 dient het bestuur 'zo spoedig mogelijk' te beslissen op een dergelijke aanvraag. ${ }^{277}$ De andere regelingen kennen geen beslistermijn. Daaronder zal dus moeten worden teruggevallen op het vangnet van art. 4:13 Awb: in beginsel 8 weken. Ten slotte bepaalt de GrS nog dat het bestuur ambtshalve een voorschot mag verlenen gedurende bezwaar en/of beroep. ${ }^{278}$

\subsubsection{Deelvraag 3: Toekomstig recht}

Titel 4.5 Awb en afd. 15.1 Ow regelen niets omtrent bevoorschotting in nadeelcompensatie- of planschadegeschillen. Ook in de toelichtende stukken behorende bij beide regelingen is hieraan geen aandacht besteed. Waarschijnlijk kan dit worden verklaard doordat art. 4:95 jo. art. 4:96 Awb reeds voorzien in een algemene regeling inzake voorschotverlening.

10.13.3 Hoofdvraag: spiegeling aan de doelstellingen en uitgangspunten die ten grondslag liggen aan de Wns

De bevoorschottingsregeling van art. 4:95 jo. art. 4:96 Awb is van algemene aard. Zij ziet namelijk op alle vormen van bestuursrechtelijke geldschulden als bedoeld in art. 4:85 Awb - en is daardoor dus niet toegespitst op nadeelcompensatiegeschillen. De geselecteerde, thans geldende regelingen laten zien dat in de praktijk structurele behoefte bestaat aan een nadere in- en aanvulling van deze algemene eisen. Dit volgt ook uit een 'Ledenbrief advisering planschade' van 9 juli 2008, waarin de VNG stelt dat het aanbeveling verdient...

273 Dat past goed bij ABRvS 22 januari 2014, ECLI:NL:RVS:2014:114, r.o. 7-7.2 (Nadeelcompensatie Tirion): een verslechterde liquiditeitspositie is geen rechtvaardiging voor schending van de schadebeperkingsplicht, als een voorschot op nadeelcompensatie kan worden aangevraagd.

274 Zie Stcrt. 1999, nr. 172, p. 12 (digitaal, p. 14); de toelichting op art. 11 lid 1 AVN; en de toelichting op art. $10 \mathrm{VNNZ}$.

275 Art. 10 lid 6 VNNZ.

276 Art. 10 lid 4 jo. lid 5 VNNZ.

277 Art. 12 lid 1 VS 2012.

278 Art. 12 lid 5 VS 2012. 
“(...) dat de gemeente over de toekenning van voorschotten [als bedoeld in art. 6.1.3.7 Bro] ${ }^{279}$ nadere richtlijnen vaststelt om verzoeken te kunnen beoordelen." ${ }^{280}$

De VNG heeft zelf geen richtlijnen geformuleerd en ook uit de jurisprudentie kan ik geen algemene richtlijnen ontwaren. Wel hebben enkele gemeenten gehoor gegeven aan de oproep van de VNG. Zo heeft de gemeente De Ronde Venen bevoorschotting beperkt tot "aanzienlijke schade in de vorm van een inkomensderving (inkomensschade)" en vereist de gemeente Delft dat de aanvrager een bankgarantie toont. ${ }^{281}$ De gemeente Tilburg hanteert op haar beurt een 'urgentievereiste': het dient voldoende aannemelijk te zijn dat de aanvrager van het voorschot de uiteindelijke beslissing omtrent toekenning van schadevergoeding niet kan afwachten. ${ }^{282}$

Het in titel 4.5 Awb voorzien in nadere normering zou goed passen bij de doelstellingen van vergroting van de rechtszekerheid, codificatie van het nadeelcompensatierecht, ${ }^{283}$ en vereenvoudiging ${ }^{284}$ uniformering en harmonisering van het nadeelcompensatierecht. Vanwege het uitgangspunt van aansluiting bij de Awb zou dit het best als aanvulling op art. 4:95 jo. 4:96 Awb kunnen worden vormgegeven. Dit zou kunnen geschieden door middel van de onderstaande bepaling, die ik ook verenigbaar acht met de overige aan de Wns ten grondslag liggende doelstellingen en uitgangspunten:

\section{Artikel 4:139285}

1. Onverminderd artikel 4:95 wordt slechts positief beslist op een aanvraag om een voorschot op een vergoeding als bedoeld in artikel 4:126, eerste lid, als het belang van de aanvrager dit naar het oordeel van het bestuursorgaan vordert. Bij het vormen van dit oordeel houdt het bestuursorgaan in ieder geval rekening met de invloed die de schadeoorzaak naar verwachting zal hebben op de financiële positie van de aanvrager en met het doel dat de aanvrager nastreeft met het voorschot.

\section{Eigen toevoeging.}

280 Zie onderdeel e op p. 2 en 3 van de brief. Deze brief is het eenvoudigst te vinden door via google te zoeken op 'ECGR/U200801064'.

281 Zie paragraaf 6.1.1 aanhef en onder d van de door het college van B\&W van de gemeente De Ronde Venen vastgestelde 'Beleidsnota Planschade en Risicomanagement 2012', respectievelijk art. 9 Planschadeverordening 2009 van de gemeente Delft.

282 Zie de algemene toelichting op de 'Verordening Nadeelcompensatie en Planschadevergoeding Pieter Vreedeplein Tilburg 2004' onder het kopje 'Voorschotregeling'.

283 Een bepaling omtrent bevoorschotting werd in ABRvS 18 november 1997, ECLI:NL:RVS:1997:ZF3093 aangemerkt als vereiste voor een "adequate nadeelcompensatieregeling". Zie voorts paragraaf 10.13.1.

284 Dergelijke normering zou immers een belangrijk procedureel onderwerp regelen, waardoor de noodzaak tot vaststelling van aanvullende regelgeving zou afnemen.

285 De keuze voor dit artikelnummer is gebaseerd op de samenvoeging van alle voorgestelde bepalingen in paragraaf 11.2.1. 
2. Op de aanvraag als bedoeld in het eerste lid is artikel 4:135, eerste lid, ${ }^{286}$ van overeenkomstige toepassing.

3. Een besluit tot het verlenen van een voorschot is geen erkenning van een aanspraak op een schadevergoeding als bedoeld in artikel 4:126, eerste lid.

4. Bij terugvordering van onverschuldigd betaalde voorschotten als bedoeld in artikel 4:95, vierde lid, wordt geen wettelijke rente gevorderd over het teveel betaalde.

5. De voorschriften als bedoeld in artikel 4:95, zesde lid, kunnen in ieder geval inhouden dat:

a. de aanvrager van het voorschot schriftelijk de verplichting aanvaardt tot gehele en onvoorwaardelijke terugbetaling van hetgeen ten onrechte als voorschot is uitbetaald; en

b. de aanvrager zekerheidstelling verleent voor de terugbetaling als bedoeld onder a.

6. Tenzij bij wettelijk voorschrift anders is bepaald, beslist het bestuursorgaan op de in het eerste lid bedoelde aanvraag binnen acht weken of - indien een adviescommissie als bedoeld in artikel 4:135 is ingesteld - binnen twaalf weken na de ontvangst daarvan.

De voorwaarde dat naar redelijke verwachting een vergoeding als bedoeld in art. 4:126 lid 1 Awb zal worden toegekend, volgt reeds uit art. 4:95 lid 1 Awb. Vanwege de doelstellingen van vergroting van de rechtszekerheid en codificatie van het nadeelcompensatierecht voegt het eerste lid van de voorgestelde bepaling hieraan een eis toe die ook naar huidig recht wordt gesteld, namelijk dat de aanvrager voldoende belang heeft bij toekenning van een voorschot. Tevens worden twee factoren genoemd die van belang kunnen zijn bij de waardering van dit belang van de aanvrager. Omwille van dezelfde doelstellingen zijn in het vijfde lid twee mogelijke voorwaarden opgenomen die onder het huidige recht veel worden verbonden aan de toekenning van een voorschot. Beide artikelleden zijn echter niet-limitatief bedoeld. In de praktijk worden namelijk uiteenlopende eisen aan de verlening van een voorschot gesteld, terwijl de jurisprudentie nog onvoldoende inzicht biedt in de beantwoording van de vraag welk van deze eisen in algemene zin acceptabel zijn.

Ook het tweede lid is met name opgenomen vanwege de doelstelling van vergroting van de rechtszekerheid. Het maakt voor alle betrokken partijen duidelijk dat als uitgangspant geldt dat geen advies wordt ingewonnen omtrent de bevoorschotting, maar het bestuur wel bevoegd is dat te doen. Dit sluit goed aan op de doelstelling van vergroting van de doelmatigheid van het nadeelcompensatierecht en vermindering van bestuurslasten, en acht ik verenigbaar met de overige aan de Wns ten grondslag liggende doelstellingen en uitgangspunten. Dat geldt eens te meer nu de onder enkele thans geldende regelingen bestaande plicht tot raadpleging van een adviescommissie nooit is gemotiveerd.

286 Hiermee verwijs ik naar de bepaling die het resultaat is van mijn aanbevelingen uit paragrafen $10.6 \mathrm{t} / \mathrm{m} \mathrm{10.9}$. Zij wordt in haar geheel weergegeven in paragraaf 10.14.1 onder het kopje 'Deskundigenadvisering'. 
Het derde lid is strikt juridisch gezien niet noodzakelijk $\mathrm{k}^{287}$ maar maakt aan alle betrokken partijen duidelijk dat het besluit omtrent de bevoorschotting losstaat van de besluitvorming op de aanvraag om nadeelcompensatie die in een later stadium zal plaatsvinden. Dit sluit niet alleen goed aan op de doelstelling van vergroting van de rechtszekerheid, maar ook op de doelstelling van vergroting van de doelmatigheid van het nadeelcompensatierecht en vermindering van bestuurslasten. Voorkomen wordt immers dat rechtsmiddelen tegen de afwijzing van een aanvraag om nadeelcompensatie worden aangewend om de enkele reden dat in een eerder stadium wel een voorschot is toegekend.

Anders dan in de AVN, is in de voorgestelde bepaling geen maximumhoogte van het voorschot opgenomen. Inherent aan een voorschot is namelijk dat het niet hoger kan zijn dan de naar verwachting toe te kennen nadeelcompensatie. Wel gaat het vierde lid van de voorgestelde bepaling in op de vraag of wettelijke rente moet worden betaald omtrent teveel betaald voorschot. Uit paragraaf 10.13.1 bleek dat de in dit onderzoek betrokken regelgevers verschillend denken over de beantwoording van deze vraag. Gelet op de doelstelling van vergroting van de rechtszekerheid en rechtsgelijkheid, is het wenselijk dat de voorgestelde bepaling deze knoop doorhakt. Daarbij kan weinig houvast worden gevonden in de thans geldende regelingen, omdat de daarvoor verantwoordelijke regelgevers hun keuze om de wettelijke rente wel of niet te vorderen niet hebben gemotiveerd. Omdat het bestuur - anders dan in het civiele recht ${ }^{288}$ - zelf verantwoordelijk is voor de toetsing van de voorwaarden voor toekenning van een voorschot, zie ik geen reden om de aanvrager wettelijke rente te laten betalen over het teveel betaalde voorschot.

Ten slotte is in het zesde lid een maximum beslistermijn opgenomen. Dit past goed bij de doelstelling van vergroting van de rechtszekerheid. De formulering van dit lid is gebaseerd op de huidige redactie van art. 4:130 lid 1 Awb. Dat geldt ook voor de termijn die op grond van het voorgestelde lid zou gelden als geen adviescommissie wordt geraadpleegd. Als de wetgever acht weken genoeg acht om te beslissen op een aanvraag om nadeelcompensatie, moet die termijn immers ook afdoende zijn om te beslissen op een aanvraag om bevoorschotting. Verder heb ik voorgesteld die termijn slechts met vier weken te verlengen als wel een adviescommissie wordt geraadpleegd. De gedachte daarachter is dat een verzwakte financiële positie van de aanvrager vaak de reden is dat een voorschot wordt aangevraagd. Ook als het voorschot dient om schadebeperkende maatregelen te kunnen bekostigen, is het wenselijk als de beslissing op de aanvraag van dat voorschot niet al te lang op zich laat wachten.

287 Vergelijk paragraaf 10.13.1.

288 Het BW bevat geen algemene regeling omtrent bevoorschotting wegens schade door beweerdelijk onrechtmatig handelen. Wel kan een voorschot worden gevorderd in kort geding. Zie bijvoorbeeld Rb. Noord-Holland 8 december 2015, ECLI:NL:RBNHO:2015:10485. 
Naast het hiervoor gedane voorstel tot (a) aanpassing van titel 4.5 Awb, geven de aan de Wns ten grondslag liggende doelstellingen en uitgangspunten mijns inziens geen aanleiding tot (b) aanpassing van afd. 15.1 Ow, of om (c) anderszins in een bijzondere invulling, aanvulling of afwijking van titel 4.5 Awb te voorzien.

\subsection{CONCLUSIE EN CONCRETE VOORSTELLEN}

In dit hoofdstuk zijn de tweede en derde deelvraag en de hoofdvraag beantwoord ten aanzien van de belangrijkste procedurele voorschriften die de geselecteerde regelingen bevatten. Voor de beantwoording van de tweede en derde deelvraag verwijs ik naar de corresponderende deelparagrafen. Bij de beantwoording van de hoofdvraag heb ik geen aanleiding gezien om aanbevelingen te doen tot (b) aanpassing van afd. 15.1 Ow. Wel heb ik verschillende aanbevelingen gedaan tot (a) aanpassing van titel 4.5 Awb en (c) het anderszins voorzien in een bijzondere invulling, aanvulling of afwijking van titel $4.5 \mathrm{Awb}$. Ik sluit dit hoofdstuk af met een weergave van die aanbevelingen. Voor een (meer uitgebreide) toelichting daarop verwijs ik naar de corresponderende deelparagrafen.

\subsubsection{Voorstellen tot (a) aanpassing van titel 4.5 Awb}

\section{Heffing van een recht}

In paragraaf 10.4.3 is geconcludeerd dat de aan de Wns ten grondslag liggende doelstellingen en uitgangspunten niet duidelijk pleiten voor behoud of schrapping van de mogelijkheid tot heffing van een recht. Om titel 4.5 Awb beter te laten aansluiten op deze doelstellingen en uitgangspunten is wel voorgesteld onderdeel c van art. 4:129 Awb te schrappen en art. 4:128 Awb als volgt vorm te geven:

\section{Artikel 4:128 Awb}

1. Het bestuursorgaan is bevoegd een recht van $€ 300$ te heffen van de indiener van de aanvraag.

2. Indien het bestuursorgaan gebruikmaakt van de bevoegdheid uit het eerste lid, wordt in de ontvangstbevestiging als bedoeld in artikel 4:130, eerste lid ${ }^{289}$ vermeld dat het verschuldigde bedrag binnen twee weken na de dag van verzending van deze ontvangstbevestiging dient te zijn bijgeschreven op een door het bestuursorgaan aangewezen rekening dan wel te zijn gestort op een door het bestuursorgaan aangegeven plaats.

3. Indien op de aanvraag geheel of ten dele positief wordt beslist, stort het bestuursorgaan aan de indiener het door hem betaalde recht terug.

289 Hiermee verwijs ik naar de redactie van art. 4:130 Awb die ik voorstelde in paragraaf 10.11.3. 


\section{Stuiting van de verjaringstermijn}

In paragraaf 10.5.3 zijn enkele aanbevelingen gedaan om de verjaringsregeling van art. 4:131 Awb nog beter te laten aansluiten op het uitgangspunt van aansluiting bij het BW en de doelstelling van codificatie van het nadeelcompensatierecht. Naar aanleiding hiervan is voorgesteld om een drietal artikelleden omtrent stuiting van de verjaringstermijn aan deze bepaling toe te voegen:

3. Vóórdat de verjaringstermijn is verstreken na verloop waarvan het bestuursorgaan op grond van het eerste lid een aanvraag als bedoeld in artikel 4:126 kan afwijzen, kan de aanvrager deze verjaringstermijn stuiten door een schriftelijke mededeling aan het bestuursorgaan te doen waarin hij ondubbelzinnig verklaart dat hij zich het recht voorbehoudt om zo een aanvraag in te dienen.

4. Na aanvang van de dag na die waarop de schriftelijke mededeling als bedoeld in het derde lid is gedaan, begint een nieuwe verjaringstermijn van twee jaren te lopen. Niettemin treedt de verjaring in geen geval op een eerder tijdstip in dan waarop ook de oorspronkelijke termijn zonder stuiting zou zijn verstreken.

5. De aanvrager kan de verjaringstermijn slechts meermaals stuiten als het bestuursorgaan daarmee instemt.

\section{Deskundigenadvisering}

In paragrafen $10.6 \mathrm{t} / \mathrm{m} 10.9$ is onderzoek gedaan naar de raadpleging van adviescommissies, de eisen waaraan een adviescommissie en het door haar uitgebrachte advies dienen te voldoen, en de wijze waarop de adviescommissie de door haar benodigde informatie kan vergaren. Naar aanleiding hiervan is voorgesteld om de volgende bepaling aan titel 4.5 Awb toe te voegen:

\section{Artikel 4:135}

1. Het bestuursorgaan wint slechts advies in bij een adviescommissie voor zover dat naar zijn oordeel noodzakelijk is om op de aanvraag te beslissen.

2. Advies als bedoeld in het eerste lid, wordt in ieder geval niet ingewonnen als de aanvraag:

a. buiten behandeling wordt gelaten op grond van artikel 4:5, eerste lid;

b. wordt afgewezen op grond van artikel 4:131;

c. naar het oordeel van het bestuursorgaan kennelijk ongegrond is;

d. naar het oordeel van het bestuursorgaan voldoende gelijkenis vertoont met andere aanvragen waarover reeds advies als bedoeld in het eerste lid is uitgebracht; of

e. naar het oordeel van het bestuursorgaan voldoende gelijkenis vertoont met andere aanvragen waarover reeds een onherroepelijke rechterlijke uitspraak is gewezen.

3. Een adviescommissie als bedoeld in het eerste lid bestaat uit één of meer deskundigen, die door het bestuursorgaan worden benoemd. Benoeming kan zowel geschieden voor een termijn van maximaal twee jaar waarna mogelijkheid bestaat tot herbenoeming, als voor advisering met betrekking tot een of meerdere aanvragen. 
Indien de commissie uit meerdere leden bestaat, wijst het bestuursorgaan de voorzitter aan.

4. Onverminderd artikel 3:9 vergewist het bestuursorgaan zich van de onafhankelijkheid en onpartijdigheid van de leden van de adviescommissie. Daarbij betrekt het in ieder geval of een lid van de adviescommissie of personen waarmee hij onderdeel uitmaakt van een samenwerkingsverband:

a. ten tijde van de indiening van de aanvraag of gedurende de vijf daaraan voorafgaande jaren het bestuursorgaan, de rechtspersoon waartoe het bestuursorgaan behoort, of andere organen die deel uitmaken van dezelfde rechtspersoon, als advocaat of gemachtigde hebben bijgestaan of geadviseerd;

b. betrokken waren bij de schadeoorzaak waarop de aanvraag betrekking heeft; of

c. ten tijde van de indiening van de aanvraag werkzaam waren, of gedurende de vijf daaraan voorafgaande jaren werkzaam zijn geweest, onder verantwoordelijkheid van het bestuursorgaan.

5. Het bestuursorgaan stelt de aanvrager, en eventuele andere belanghebbenden waarmee het bekend is, in kennis van zijn voornemen om advies in te winnen bij een adviescommissie. De kennisgeving bevat informatie inhoudende de namen van de beoogde leden van de adviescommissie, alsmede hun beroep, nevenfuncties, opleidingsgeschiedenis, relatie tot het bestuursorgaan en de plaats waar zij hun werkzaamheden plegen te verrichten.

6. Als een belanghebbende bedenkingen heeft tegen de voorgenomen samenstelling van de adviescommissie, brengt hij deze ter kennis van het bestuursorgaan binnen twee weken na verzending van de in het vijfde lid bedoelde kennisgeving.

7. Als een belanghebbende pas na het verstrijken van de in het zesde lid gestelde termijn bekend raakt met feiten en omstandigheden die leiden tot bedenkingen tegen de samenstelling van de adviescommissie, dan brengt hij zijn bedenkingen zo spoedig mogelijk ter kennis van het bestuursorgaan.

8. Het bestuursorgaan reageert binnen twee weken na ontvangst daarvan op bedenkingen als bedoeld in het zevende lid. Indien de belanghebbende niet tevens de aanvrager is, brengt het bestuursorgaan de aanvrager binnen dezelfde termijn op de hoogte van deze bedenkingen en zijn reactie daarop.

9. Het bestuursorgaan is bevoegd de benoeming van een lid van de adviescommissie, of de hem ter zake van de aanvraag gegunde adviesopdracht te beëindigen, indien:

a. het lid van de adviescommissie zelf daarom verzoekt;

b. naar het oordeel van het bestuursorgaan voldoende twijfel bestaat over de onafhankelijkheid, onpartijdigheid, of deskundigheid van het lid van de adviescommissie; of

c. de wijze van taakvervulling door het lid van de adviescommissie daartoe naar het oordeel van het bestuursorgaan voldoende aanleiding geeft.

10. In aanvulling op artikel 3:7 zijn ook de aanvrager en andere belanghebbenden verplicht de adviescommissie, al dan niet op haar verzoek, de gegevens ter beschikking te stellen die nodig zijn voor een goede vervulling van haar taak.

11. De adviescommissie kan een plaatsopneming houden indien zij dit nodig acht. 


\section{Inrichting van de procedure}

In paragraaf 10.10 .3 is voorgesteld om een bepaling in titel 4.5 Awb op te nemen waaruit blijkt wie ervan in kennis moeten worden gesteld dat de adviescommissie beslist tot plaatsopneming, wie wanneer moet worden gehoord door de adviescommissie, en wanneer kan worden gereageerd op het advies van de adviescommissie. In paragraaf 10.11.3 is vervolgens aanbevolen de redactie van art. 4:130 Awb zo aan te passen dat deze niet suggereert dat slechts de voorzitter van de adviescommissie onafhankelijk- en onpartijdig dient te zijn. Tevens is aanbevolen in deze bepaling niet alleen een maximum beslistermijn op te nemen, maar ook anderszins aan te geven welke stappen moeten worden doorlopen in het besluitvormingsproces en welke termijnen daarbij in acht moeten worden genomen. Dit heeft geleid tot het voorstel om het huidige art. 4:130 Awb te vervangen door de onderstaande bepaling:

\section{Artikel 4:130 Awb}

1. Het bestuursorgaan bevestigt de ontvangst van de aanvraag schriftelijk en zo spoedig mogelijk, doch tenminste binnen twee weken na de ontvangst daarvan. Hierbij stelt het de aanvrager tevens in kennis van de te volgen procedure.

2. Het bestuursorgaan beslist binnen vier weken na ontvangst van de aanvraag of het gebruik zal maken van zijn bevoegdheid uit artikel 4:135, eerste lid.

3. Als het bestuursorgaan beslist geen gebruik te maken van zijn bevoegdheid uit artikel 4:135, eerste lid, dan beslist het binnen acht weken na ontvangst daarvan op de aanvraag. Het kan deze termijn eenmaal met ten hoogste acht weken verlengen onder schriftelijke opgaaf van redenen aan de aanvrager en andere belanghebbenden.

4. Als het bestuursorgaan beslist gebruik te maken van zijn bevoegdheid uit artikel 4:135, eerste lid, dan:

a. verstuurt het bestuursorgaan zo spoedig mogelijk - doch uiterlijk binnen een week na de in de aanhef van dit lid bedoelde beslissing - de kennisgeving als bedoeld in artikel 4:135, vijfde lid;

b. verstrekt het bestuursorgaan een adviesopdracht aan de adviescommissie niet eerder dan nadat de aanvrager en andere belanghebbenden op deze kennisgeving hebben gereageerd binnen de daarvoor door artikel 4:135, zesde lid, gestelde termijn, doch uiterlijk binnen twee weken na het verstrijken van die termijn;

c. stelt het bestuursorgaan zo spoedig mogelijk - doch uiterlijk binnen een week na verstrekking van de adviesopdracht - ter beschikking aan de adviescommissie, alle op de aanvraag betrekking hebbende informatie, alsmede de bescheiden die naar het oordeel van de adviescommissie noodzakelijk zijn voor de beoordeling daarvan;

d. stelt de adviescommissie zo spoedig mogelijk - doch uiterlijk binnen een week na verstrekking van de adviesopdracht - de aanvrager, het bestuursorgaan en andere belanghebbenden in kennis van de te volgen procedure. Daarbij geeft de adviescommissie in ieder geval aan of, op welke wijze, en wanneer zij in de gelegenheid zullen worden gesteld om hun standpunt met betrekking tot de aanvraag toe te lichten; 
e. nodigt de adviescommissie de aanvrager, het bestuursorgaan en andere belanghebbenden uit om aanwezig te zijn bij een plaatsopneming, als zij op grond van artikel 4:135, elfde lid, besluit daartoe over te gaan;

f. stelt de adviescommissie haar advies vast binnen tien weken nadat haar de adviesopdracht is verstrekt door het bestuursorgaan. Zij kan deze termijn eenmaal met ten hoogste acht weken verlengen onder schriftelijke opgaaf van redenen aan de aanvrager, het bestuursorgaan en andere belanghebbenden. Zij zendt het advies terstond toe aan de aanvrager, het bestuursorgaan, en andere belanghebbenden;

g. maken de aanvrager en andere belanghebbenden eventuele bedenkingen tegen het advies uiterlijk vier weken na de verzending daarvan schriftelijk kenbaar aan het bestuursorgaan;

h. beslist het bestuursorgaan uiterlijk tien weken na de verzending van het advies op de aanvraag, tenzij het de adviescommissie overeenkomstig het bepaalde onder i opdraagt nader te adviseren omtrent het op de aanvraag te nemen besluit. Het kan deze termijn eenmaal met ten hoogste acht weken verlengen onder schriftelijke opgaaf van redenen aan de aanvrager en andere belanghebbenden;

i. is het bestuursorgaan bevoegd uiterlijk zes weken na de verzending van het advies een opdracht tot nader advies te verstrekken aan de adviescommissie;

j. stelt de adviescommissie haar nader advies vast binnen zes weken na verzending van de opdracht om nader te adviseren. Zij zendt dit nader advies terstond toe aan de aanvrager, het bestuursorgaan, en andere belanghebbenden. De adviescommissie kan deze termijn eenmaal met ten hoogste vier weken verlengen onder schriftelijke opgaaf van redenen aan de aanvrager, het bestuursorgaan en andere belanghebbenden; en

k. beslist het bestuursorgaan uiterlijk zes weken na de verzending van het nader advies op de aanvraag. Het kan deze termijn eenmaal met ten hoogste drie weken verlengen onder schriftelijke opgaaf van redenen aan de aanvrager en andere belanghebbenden.

5. De termijnen uit het eerste tot en met vierde lid worden overeenkomstig artikel 4:15 opgeschort als toepassing wordt gegeven aan artikel 4:5.

6. Bij wettelijk voorschrift kan worden afgeweken van het tweede tot en met vierde lid.

\section{Bevoorschotting}

Bezien vanuit het uitgangspunt van aansluiting bij de Awb, en de doelstellingen van vergroting van de rechtszekerheid en rechtsgelijkheid, codificatie van het nadeelcompensatierecht, en vereenvoudiging, uniformering en harmonisering van het nadeelcompensatierecht is ten slotte in paragraaf 10.13.3 het voorstel gedaan de volgende bepaling omtrent bevoorschotting aan titel 4.5 Awb toe te voegen - die functioneert als aanvulling op art. 4:95 jo. art. 4:96 Awb: 


\section{Artikel 4:139}

1. Onverminderd artikel 4:95 wordt slechts positief beslist op een aanvraag om een voorschot op een vergoeding als bedoeld in artikel 4:126, eerste lid, als het belang van de aanvrager dit naar het oordeel van het bestuursorgaan vordert. Bij het vormen van dit oordeel houdt het bestuursorgaan in ieder geval rekening met de invloed die de schadeoorzaak naar verwachting zal hebben op de financiële positie van de aanvrager en met het doel dat de aanvrager nastreeft met het voorschot.

2. Op de aanvraag als bedoeld in het eerste lid is artikel $4: 135$, eerste $l i d,{ }^{290}$ van overeenkomstige toepassing.

3. Een besluit tot het verlenen van een voorschot is geen erkenning van een aanspraak op een schadevergoeding als bedoeld in artikel 4:126, eerste lid.

4. Bij terugvordering van onverschuldigd betaalde voorschotten als bedoeld in artikel 4:95, vierde lid, wordt geen wettelijke rente gevorderd over het teveel betaalde.

5. De voorschriften als bedoeld in artikel 4:95, zesde lid, kunnen in ieder geval inhouden dat:

a. de aanvrager van het voorschot schriftelijk de verplichting aanvaardt tot gehele en onvoorwaardelijke terugbetaling van hetgeen ten onrechte als voorschot is uitbetaald; en

b. de aanvrager zekerheidstelling verleent voor de terugbetaling als bedoeld onder a.

6. Tenzij bij wettelijk voorschrift anders is bepaald, beslist het bestuursorgaan op de in het eerste lid bedoelde aanvraag binnen acht weken of - indien een adviescommissie als bedoeld in artikel 4:135 is ingesteld - binnen twaalf weken na de ontvangst daarvan.

\subsubsection{Aanbevelingen om (c) anderszins te voorzien in een bijzondere} invulling, aanvulling of afwijking van titel $4.5 \mathrm{Awb}$

In dit hoofdstuk is meermaals aanbevolen om (c) anderszins te voorzien in een bijzondere invulling en/of aanvulling van titel $4.5 \mathrm{Awb}$. Allereerst werd in paragraaf 10.3.3 aanbevolen dat regelgevers en uitvoerende bestuursorganen steeds nagaan in hoeverre het mogelijk is om in titel 4.5 Awb-interpreterende regelgeving respectievelijk beleidsregels te concretiseren welke specifieke documenten de aanvrager dient aan te leveren bij zijn aanvraag om nadeelcompensatie. Het ligt voor de hand dat de mogelijkheid daartoe met name zal bestaan als de desbetreffende regeling uitsluitend ziet op schadeveroorzakend overheidshandelen dat een duidelijk af te bakenen groep burgers op min of meer gelijke wijze beïnvloedt. Ook werd aanbevolen om onder titel 4.5 Awb en afd. 15.1 Ow te werken met een aanvraagformulier als bedoeld in art. 4:4 Awb. Mijns inziens zou dat op centraal overheidsniveau het best kunnen geschieden door de minister van I\&W te laten nagaan of, en zo ja in hoeverre, zijn onder de BnIW 2019 gebruikte aanvraagformulier daartoe aanpassing zou behoeven. Op basis van de bevindingen van de minister zou een

290 Hiermee verwijs ik naar de bepaling die het resultaat is van mijn aanbevelingen uit paragrafen $10.6 \mathrm{t} / \mathrm{m} \mathrm{10.9}$. Zij wordt in haar geheel weergegeven in paragraaf 10.14.1 onder het kopje 'Deskundigenadvisering'. 
organisatie als de VNG een modelformulier kunnen opstellen voor de decentrale overheden. Beide aanbevelingen werden gedaan met het oog op de doelstellingen van uniformering en harmonisering van het nadeelcompensatierecht, ${ }^{291}$ vergroting van de rechtszekerheid, en vergroting van de doelmatigheid van het nadeelcompensatierecht en vermindering van bestuurslasten.

Ten derde is in paragraaf 10.4.3 aanbevolen dat het bestuur reeds in een vroeg stadium in contact treedt met (potentiële) benadeelden teneinde voorlichting te geven over de relatief strenge voorwaarden voor toekenning van nadeelcompensatie. In de Handleiding nadeelcompensatie wordt beschreven hoe dat het best kan worden aangepakt. ${ }^{292}$ Deze aanbeveling werd ingegeven door de doelstellingen van vergroting van de rechtszekerheid, en vergroting van de doelmatigheid van het nadeelcompensatierecht en vermindering van bestuurslasten. In paragraaf 10.11.3 werd ook aanbevolen dat het kabinet of een partij als de VNG modelbrieven opstelt waarmee het bestuur en de adviescommissie kunnen voldoen aan hun informatieverplichtingen uit het eerste lid respectievelijk vierde lid, aanhef en onder $\mathrm{d}$ van de bepaling die is voorgesteld ter vervanging van het huidige art. 4:130 Awb. Dat past immers goed bij de doelstellingen van uniformering en harmonisering van het nadeelcompensatierecht, vergroting van de rechtsgelijkheid, en vergroting van de doelmatigheid van het nadeelcompensatierecht en vermindering van bestuurslasten.

Ten vijfde werd in paragraaf 10.12 .3 betoogd dat art. 8:6 lid 2 Awb conflicteert met verschillende aan de Wns ten grondslag liggende doelstellingen en uitgangspunten. Naar aanleiding daarvan is voorgesteld deze bepaling te vervangen door een bepaling die dat niet doet, namelijk art. 4.5.7 van het voorontwerp van de Wns:

"Indien hoger beroep is ingesteld tegen een uitspraak over een besluit omtrent nadeelcompensatie als bedoeld in deze titel, verwijst de Afdeling bestuursrechtspraak van de Raad van State de behandeling naar een andere hogerberoepsrechter, indien de behandeling van het hoger beroep door deze rechter naar haar oordeel gewenst is. Artikel $8: 13$, tweede en derde lid, is van overeenkomstige toepassing."

Ten slotte is in dezelfde paragraaf een gewijzigde redactie van art. 13.3c lid $1 \mathrm{Ow}$ voorgesteld, die beter aansluit op de doelstelling van vergroting van de rechtszekerheid:

291 Mogelijk leidt het werken met een (model)aanvraagformulier ook tot vereenvoudiging van het nadeelcompensatierecht, omdat hierdoor de noodzaak tot raadpleging van lagere regelgeving afneemt. Handleiding nadeelcompensatie, p. 24-28. 
"De rechtspersoon waartoe het bestuursorgaan behoort dat vergoeding van schade als bedoeld in artikel 4:126, eerste lid, van de Algemene wet bestuursrecht in samenhang met artikel 15.1, eerste lid, toekent, kan met degene die de activiteit verricht naar aanleiding waarvan de vergoeding is toegekend, overeenkomen dat de toe te kennen schadevergoeding en de daarmee samenhangende kosten geheel of gedeeltelijk voor zijn rekening komen." 


\section{Hoofdstuk 11}

\section{Slotbeschouwing}

\subsection{INLEIDING}

In paragraaf 1.2 is de onderstaande hoofdvraag geformuleerd:

Geven de aan de Wns ten grondslag liggende doelstellingen en uitgangspunten, mede in het licht van verklaringen voor verschillen tussen thans geldende nadeelcompensatieregelingen, reden om (a) titel $4.5 \mathrm{Awb}$ aan te passen, (b) afd. $15.1 \mathrm{Ow}$ aan te passen, en/of (c) anderszins te voorzien in een bijzondere invulling, aanvulling of afwijking van titel $4.5 \mathrm{Awb}$ ?

Om deze hoofdvraag op zinvolle wijze te kunnen beantwoorden, zijn ook drie deelvragen opgeworpen. De eerste deelvraag is algemeen van aard, en ziet op het toetsingskader van dit proefschrift:

\section{Welke doelstellingen en uitgangspunten liggen ten grondslag aan de Wns?}

Uit haar beantwoording in paragraaf 2.4.2 bleek dat de Wns vier doelstellingen kent, namelijk (1) vereenvoudiging, uniformering en harmonisering van het nadeelcompensatierecht; (2) vergroting van de rechtszekerheid en rechtsgelijkheid; (3) codificatie van het nadeelcompensatierecht; en (4) vergroting van de doelmatigheid van het nadeelcompensatierecht en vermindering van bestuurslasten. Ook kent zij een drietal uitgangspunten: titel 4.5 Awb dient (1) uitsluitend het égalitébeginsel te codificeren; (2) aan te sluiten op het besluitmodel; en (3) waar mogelijk aan te sluiten bij de Awb en het BW.

$\mathrm{Na}$ vaststelling van dit toetsingskader, is de hoofdvraag gefragmenteerd beantwoord in hoofdstuk $3 \mathrm{t} / \mathrm{m} 10$ ten aanzien van alle in paragraaf 1.3 genoemde materiële criteria en procedurele voorschriften voor toekenning van nadeelcompensatie. Deze beantwoording werd steeds voorafgegaan door beantwoording van de tweede en derde deelvraag:

2. Zijn er verschillen in de wijze waarop de geselecteerde, thans geldende regelingen zijn vormgegeven, en zo ja, hoe kunnen deze verschillen worden verklaard?

3. Hoe zal het toekomstige nadeelcompensatierecht worden vormgegeven door titel $4.5 \mathrm{Awb}$ en afd. $15.1 \mathrm{Ow}$ ? 
Het zou weinig zinvol zijn te pogen de beantwoording van deze deelvragen hier op uitputtende wijze samen te vatten. Daartoe zou ik immers alle verschillen tussen de geselecteerde, thans geldende nadeelcompensatieregelingen én de daarvoor gevonden verklaringen moeten opsommen, respectievelijk een sluitend overzicht moeten geven van titel 4.5 Awb en afd. 15.1 Ow én de wijze waarop de daarin vervatte bepalingen dienen te worden toegepast. Dat zou ertoe leiden dat dit boek onnodig met minstens de helft in omvang zou toenemen. Ten aanzien van deze deelvragen volsta ik daarom met een aantal algemene opmerkingen. Voor meer gedetailleerde beantwoording, verwijs ik naar de daarvoor relevante paragrafen uit de voorafgaande hoofdstukken.

Bij beantwoording van de tweede deelvraag is opgevallen dat relatief veel verschillen tussen de geselecteerde, thans geldende regelingen slechts kunnen worden verklaard doordat de regelingen gedurende enkele decennia door verschillende regelgevers zijn opgesteld, terwijl die regelgevers ten aanzien van de desbetreffende onderwerpen geen aandacht lijken te hebben gehad voor afstemming op andere nadeelcompensatieregelingen en/of overleg met elkaar, laat staan een materieelrechtelijk verschil in het leven beoogden te roepen. Dat laat onverlet dat regelmatig ook andersoortige verklaringen zijn gevonden. Ik volsta hier met een tweetal voorbeelden daarvan. Ten eerste is in paragraaf $6.1^{1}$ en paragraaf $7.2 .1^{2}$ gebleken dat de criteria van abnormale last respectievelijk speciale last geen rol van betekenis speelden onder art. 49 WRO. Dat kan worden verklaard doordat deze bepaling haar grondslag niet vond in het ongeschreven égalitébeginsel, maar in de materiele rechtszekerheid. Een tweede voorbeeld van een andersoortige verklaring kan worden gevonden in paragraaf 4.2.3.2. Daaruit volgt namelijk dat de Afdeling een alternatieve causaliteitstoets introduceerde voor schadegeschillen die werden afgedaan onder art. 21 Aanwijzingsbesluit 1996, teneinde te voorkomen dat de minister er ten koste van de benadeelde burger van zou profiteren dat hij zijn wettelijke plicht om degelijke geluidsnormering vast te stellen gedurende ongeveer 18 jaar had verzaakt.

Door beantwoording van de derde deelvraag is duidelijk geworden dat titel 4.5 Awb relatief weinig materiële en procedurele sturing biedt voor de behandeling van een aanvraag om nadeelcompensatie. Afd. 15.1 Ow daarentegen, voorziet op het materiële vlak wel in dergelijke sturing voor het omgevingsrechtelijk georiënteerde nadeelcompensatierecht. De keuzes die het kabinet heeft gemaakt in zijn voorstel voor deze afdeling kunnen voor een groot deel worden verklaard door de wijze waarop het toekomstige omgevingsrecht zal worden vormgegeven door de Ow (waarover meer in paragraaf 11.3.2). Voorts roepen sommige bepalingen de vraag op waarom de daarin vervatte normering niet in titel 4.5 Awb is opgenomen,

1 Zie het kopje 'Het normaal maatschappelijk risico en de tekst van de geselecteerde, thans geldende regelingen'.

2 Zie het kopje '3. Regelingen waaronder het criterium van de speciale last geen rol speelt', en meer specifiek het subkopje 'De planschadecomponent van de GrS'. 
zodat zij uniform zou gelden voor het grootste deel van het nadeelcompensatierecht.

In het resterende deel van dit hoofdstuk wordt een alles overziend antwoord gegeven op de hoofdvraag van dit onderzoek. Daarbij zal dus niet alles worden herhaald wat in de voorafgaande hoofdstukken is opgemerkt bij beantwoording van de hoofdvraag per materieel criterium of procedureel voorschrift voor de toekenning van nadeelcompensatie. In plaats daarvan, zullen de daarbij opgedane inzichten en gegeven aanbevelingen nu in hun onderlinge samenhang worden bezien. In paragrafen 11.2 respectievelijk 11.3 zal daartoe eerst worden weergeven hoe titel 4.5 Awb en afd. 15.1 Ow zouden uitzien als de wetgever alle in de voorafgaande hoofdstukken gedane aanbevelingen tot aanpassing van deze regelingen zou overnemen. Daarbij zal ik niet steeds in detail herhalen welk samenspel tussen aan de Wns ten grondslag liggende doelstellingen en uitgangspunten heeft geleid tot het schrappen of wijzigen van een originele bepaling, of het introduceren van een nieuwe bepaling. Daarvoor verwijs ik naar de relevante deelparagrafen van de voorafgaande hoofdstukken. Hier volsta ik met de algemene opmerking dat de aanbevolen normering doorgaans goed aansloot op de doelstellingen van vereenvoudiging, uniformering en harmonisering van het nadeelcompensatierecht, vergroting van de rechtszekerheid, en codificatie van het nadeelcompensatierecht. Afhankelijk van het desbetreffende materiële criterium of procedurele voorschrift, hebben ook andere aan de Wns ten grondslag liggende doelstellingen of uitgangspunten een rol gespeeld. Soms waren zij van belang voor de beslissing om wel of niet aan te bevelen tot opname van normering in titel $4.5 \mathrm{Awb}$ of afd. $15.1 \mathrm{Ow}-\mathrm{zo}$ pleitte het uitgangspunt van aansluiting bij het BW bijvoorbeeld tegen opname van bijzondere normering omtrent schadebegroting. Vaak waren deze doelstellingen en uitgangspunten echter ook van invloed op de wijze waarop de aanbevolen normering werd vormgegeven - zo leidde het uitgangspunt van aansluiting bij de Awb bijvoorbeeld ertoe dat de aanbevolen bepaling omtrent bevoorschotting in titel 4.5 Awb werd vormgegeven als aanvulling op art. 4:95 Awb.

In paragraaf 11.4 zal worden samengevat welke aanbevelingen zijn gedaan om anderszins te voorzien in een bijzondere invulling, aanvulling of afwijking van titel 4.5 Awb. Daarbij komen eerst enkele aanbevelingen aan bod tot wijziging van andere formele wetgeving dan titel 4.5 Awb of afd. 15.1 Ow (paragraaf 11.4.1). Vervolgens worden de aanbevelingen gebundeld die zijn gedaan aan het kabinet of de regering (paragraaf 11.4.2), de rechter (paragraaf 11.4.3), en uitvoerende en/ of regelgevende bestuursorganen niet zijnde de regering (paragraaf 11.4.4). Ten slotte wordt dit proefschrift in paragraaf 11.5 afgesloten met een slotopmerking.

Op deze plaats roep ik eerst nog in herinnering dat bij beantwoording van de hoofdvraag steeds is onderzocht hoe de aan de Wns ten grondslag liggende doelstellingen en uitgangspunten het best kunnen worden gerealiseerd. Aanbevelingen waren daarom doorgaans gericht tot één specifieke actor in het nadeelcompensatierecht, namelijk die actor die in de beste positie verkeert om deze doelstellingen en uitgangspunten te behartigen met betrekking tot het desbetreffende materiële 
criterium of procedurele voorschrift voor toekenning van nadeelcompensatie. Wanneer deze actor geen navolging geeft aan de desbetreffende aanbeveling, zal het in de regel goed bij de aan de Wns ten grondslag liggende doelstellingen en uitgangspunten passen als de overige actoren nagaan in hoeverre zij dat alsnog kunnen doen. Het spreekt voor zich dat zij daarbij telkens de staatsrechtelijke grenzen in acht dienen te nemen die in paragraaf 2.5 zijn besproken. Zou de wetgever bijvoorbeeld geen heil zien in het voorstel voor een nieuw artikel $15.2 \mathrm{Ow}$ dat ervoor zorgt dat de limitatieve opsomming van schadeoorzaken uit art. $15.1 \mathrm{Ow}$ niet als exclusief wordt aangemerkt voor inkomensschade, dan verhinderen deze grenzen dat dit exclusieve karakter alsnog zou worden ontzegd in bijvoorbeeld een rechterlijke uitspraak, of wetsinterpreterende beleidsregel of verordening. Dat ligt anders als de wetgever geen gevolg zou geven aan mijn voorstel om het criterium van de speciale last nader te normeren in art. 4:130 Awb. In dat geval staan de genoemde staatsrechtelijke grenzen namelijk niet eraan in de weg dat de voorgestelde normering wordt voorgeschreven in een wetsinterpreterende verordening of beleidsregel. Ook bieden zij voldoende ruimte aan uitvoerende bestuursorganen om op ad hoc basis te beslissen conform de met art. 4:130 Awb voorgestelde maatstaf. Ten slotte zou ook de rechter de voorgestelde maatstaf kunnen overnemen bij de toetsing van aan hem voorgelegde nadeelcompensatiebesluiten.

\subsection{AANBEVELINGEN TOT (A) AANPASSING VAN TITEL 4.5 Awb}

In deze paragraaf wordt eerst weergegeven hoe titel 4.5 Awb eruit zou zien als de wetgever alle aanbevelingen uit de voorafgaande hoofdstukken zou opvolgen (paragraaf 11.2.1). Daarbij zijn ook een aantal relatief kleine wijzigingen doorgevoerd waartoe nog geen eerdere aanbeveling was gedaan. Het betreft steeds wijzigingen die de inzichtelijkheid en leesbaarheid van deze titel vergroten. De titel is bijvoorbeeld opgesplitst in vier afdelingen, zodat eenvoudiger is te herkennen waar moet worden gezocht naar de grondslag voor toekenning van nadeelcompensatie, bepalingen inzake de materiële criteria voor toekenning van nadeelcompensatie, bepalingen omtrent de procedure waarlangs de aanvraag dient te worden behandeld, en bijzondere regels omtrent bevoorschotting. Ook is ervoor gekozen de eisen van abnormale en speciale last niet uit te werken in art. 4:126 Awb, maar in afzonderlijke bepalingen. De bepalingen die de materiële criteria voor toekenning van nadeelcompensatie bevatten, zijn voorts gerangschikt in de volgorde waarin zij in dit proefschrift zijn behandeld - oftewel de volgorde die de Afdeling hanteerde in de Overzichtsuitspraak. Dat had tot gevolg dat sommige bepalingen moesten worden vernummerd. In paragraaf 11.4.2 zal ik kort reflecteren op de aanbevolen redactie. 


\subsubsection{De aanbevolen redactie van titel 4.5 Awb}

\section{TITEL 4.5 NADEELCOMPENSATIE}

\section{Afdeling 4.5.1 Inleidende bepaling}

\section{Artikel 4:126}

Indien een bestuursorgaan in de rechtmatige uitoefening van zijn publiekrechtelijke bevoegdheid of taak schade veroorzaakt, kent het bestuursorgaan de benadeelde desgevraagd een vergoeding toe met inachtneming van de bepalingen uit deze titel.

\section{Afdeling 4.5.2 De materiële criteria voor toekenning van nadeelcompensatie}

\section{Artikel 4:127 Awb $^{3}$}

1. Schade blijft in elk geval voor rekening van de aanvrager voor zover zij, mede gezien de aard van de aansprakelijkheid en van de schade, redelijkerwijs niet aan het bestuursorgaan kan worden toegerekend als gevolg van een gebeurtenis als bedoeld in artikel 4:126.

2. Indien meerdere bestuursorganen betrokken zijn bij het ontstaan van de schade, dan rust de verplichting om de schade te vergoeden op ieder van deze bestuursorganen als:

a. de schade een gevolg kan zijn van twee of meer uitoefeningen van een publiekrechtelijke bevoegdheid of taak voor elk waarvan een ander bestuursorgaan aansprakelijk is, en vaststaat dat de schade door ten minste één van deze uitoefeningen is ontstaan; of

b. de schade het gevolg is van de uitoefeningen van een publiekrechtelijke bevoegdheid of taak door deze bestuursorganen terwijl voor elk van deze uitoefeningen geldt dat de schade zonder die uitoefening niet zou zijn ingetreden, en derhalve is ontstaan door een samenloop van oorzaken.

3. De in het tweede lid genoemde bestuursorganen zijn hoofdelijk verbonden. Voor de bepaling van hetgeen zij in hun onderlinge verhouding jegens elkaar moeten bijdragen, wordt de toegekende schadevergoeding en de in redelijkheid bij de toekenning daarvan gemaakte kosten over hen verdeeld in evenredigheid met de mate waarin de aan ieder toe te rekenen omstandigheden tot de schade hebben bijgedragen, met dien verstande dat een andere verdeling plaatsvindt, indien de billijkheid dit wegens de omstandigheden van het geval eist.

4. De bestuursrechter bij wie het beroep tegen een besluit op de aanvraag als bedoeld in artikel 4:126 kan worden ingesteld, beslist over geschillen ten aanzien van de door het derde lid voorgeschreven verdeling.

\section{Artikel 4:128}

1. Indien in voldoende mate vaststaat dat een gebeurtenis als bedoeld in artikel 4:126, of meerdere gebeurtenissen als bedoeld in artikel 4:126 die nauw met elkaar zijn 
verweven, naast een nadelige invloed ook een positieve invloed op de vermogenspositie van de aanvrager hebben gehad of zullen hebben, dan moet, voor zover dit redelijk is, deze positieve invloed bij de vaststelling van de te vergoeden schade in rekening worden gebracht.

2. In zoverre vergoeding van de schade voldoende anderszins is verzekerd, wordt geen vergoeding als bedoeld in artikel 4:126 toegekend.

3. Schadevergoeding wordt voldoende anderszins verzekerd als bedoeld in het tweede lid geacht in zoverre zij op basis van objectieve gegevens kan worden vastgesteld en niet afhankelijk is van een toekomstige, onzekere gebeurtenis.

4. Het bestuursorgaan kan, voor zover dit redelijk is, besluiten de schade anders dan in geld te vergoeden, waardoor de vergoeding van schade voldoende anderszins verzekerd als bedoeld in het tweede lid wordt geacht, mits zij aan de eisen uit het derde lid voldoet.

\section{Artikel 4:1295}

1. Een vergoeding als bedoeld in artikel 4:126 wordt slechts toegekend in zoverre de schade uitgaat boven het normale maatschappelijke risico.

2. Bij algemene maatregel van bestuur kunnen nadere regels worden gesteld omtrent het normale maatschappelijke risico als bedoeld in het eerste lid.

3. Tot het normale maatschappelijke risico als bedoeld in het eerste lid behoort in ieder geval:

a. schade kleiner dan $€ 500$ als de aanvrager een particulier is;

b. schade kleiner dan $€ 1.000$ als de aanvrager een ondernemer is; en

c. een bedrag gelijk aan twee procent van het inkomen onmiddellijk voor het ontstaan van de schade als de schade bestaat uit inkomensschade.

\section{Artikel 4:130 $\mathrm{Awb}^{6}$}

Wordt de schade veroorzaakt door een maatregel die ertoe strekt een door de aanvrager aan de samenleving toegebracht nadeel te voorkomen of beperken, dan wordt een vergoeding als bedoeld in artikel 4:126 slechts toegekend voor zover de maatregel de aanvrager onevenredig zwaar treft in vergelijking met anderen die door deze maatregel zijn getroffen en hetzelfde nadeel aan de samenleving toebrachten.

\section{Artikel 4:131 Awb}

1. In zoverre de schade mede een gevolg is van een omstandigheid die aan de aanvrager kan worden toegerekend als de aanvaarding van een risico, het niet voldoen aan zijn schadebeperkingsplicht of een andere vorm van eigen schuld, komt de vergoedingsplicht van het bestuursorgaan te vervallen, tenzij de billijkheid een andere verdeling van de schadelast vereist.

2. Schade kan de aanvrager wegens actieve risicoaanvaarding worden toegerekend als hij aan het intreden daarvan heeft bijgedragen door in het geschade belang te inves-

$5 \quad$ Deze bepaling is voorgesteld in paragraaf 6.5.

6 Deze bepaling is voorgesteld in paragraaf 7.5.

$7 \quad$ Deze bepaling is voorgesteld in paragraaf 8.5. 
teren, terwijl redelijkerwijs voorzienbaar was dat zich schade zou kunnen voordoen ten gevolge van een gebeurtenis als bedoeld in artikel 4:126.

3. Schade kan de aanvrager wegens passieve risicoaanvaarding worden toegerekend als hij aan het intreden daarvan heeft bijgedragen doordat hij heeft nagelaten zijn belang te verwezenlijken, of een concrete poging hiertoe te ondernemen, toen hij daartoe redelijkerwijs in de gelegenheid was, terwijl hij redelijkerwijs kon voorzien dat zich een gebeurtenis als bedoeld in artikel 4:126 zou kunnen voordoen die daaraan in de weg zou komen te staan.

4. Voorzienbaarheid als bedoeld in het tweede en derde lid kan blijken uit een uitdrukkelijke verklaring van de aanvrager. Tevens wordt zij verondersteld aanwezig te zijn indien:

a. een concreet beleidsvoornemen van overheidswege ter openbare kennis is gebracht op grond waarvan voor een redelijk denkend en handelend persoon aanleiding zou hebben bestaan om rekening te houden met de kans dat zich schade ten gevolge van een gebeurtenis als bedoeld in artikel 4:126 zou voordoen; of

b. de aanvrager anderszins beschikte of had moeten beschikken over informatie op grond waarvan voor een redelijk denkend en handelend persoon aanleiding zou hebben bestaan om rekening te houden met de kans dat zich schade ten gevolge van een gebeurtenis als bedoeld in artikel 4:126 zou voordoen.

5. Een beleidsvoornemen als bedoeld in het vierde lid, onderdeel a, is voldoende concreet als een redelijk denkend en handelend persoon uit de kenbaarmaking daarvan voldoende kan begrijpen waarop het beleidsvoornemen betrekking heeft, wat de zakelijke inhoud ervan is, en van de inhoud ervan kan kennisnemen om zijn handelen hierop af te stemmen.

6. Schade kan de aanvrager wegens het schenden van zijn schadebeperkingsplicht worden toegerekend indien hij heeft nagelaten maatregelen te treffen die zijn schade zouden beperken, terwijl dat wel in redelijkheid van hem kon worden verlangd.

\section{Artikel 4:132}

1. Indien het bestuursorgaan een vergoeding als bedoeld in artikel 4:126 toekent, vergoedt het tevens de schade die bestaat uit:

a. redelijke kosten ter voorkoming of beperking van schade die als gevolg van de schadeoorzaak mocht worden verwacht; en

b. redelijke kosten ter zake van door een derde beroepsmatig verleende rechtsbijstand of andere deskundige bijstand.

2. Indien het bestuursorgaan een vergoeding als bedoeld in artikel 4:126 toekent, vergoedt het tevens de wettelijke rente vanaf de ontvangst van de aanvraag, of indien de schade op een later tijdstip ontstaat, vanaf dat tijdstip. Indien de schade mede is veroorzaakt door een besluit waartegen beroep kan worden ingesteld, vangt de rentetermijn niet aan voordat het besluit onherroepelijk is geworden.

3. Bij algemene maatregel van bestuur kunnen nadere regels worden gesteld omtrent de vergoeding van de kosten als bedoeld in het eerste lid, aanhef en onder $b$. 


\section{Afdeling 4.5.3 De behandeling van de aanvraag om nadeelcompensatie}

\section{Artikel 4:133 ${ }^{9}$}

De aanvraag bevat mede:

a. een aanduiding van de schadeveroorzakende gebeurtenis; en

b. een opgave van de aard van de geleden of te lijden schade en, voor zover redelijkerwijs mogelijk, het bedrag van de schade en een specificatie daarvan.

\section{Artikel 4:134 ${ }^{10}$}

1. Het bestuursorgaan is bevoegd een recht van $€ 300$ te heffen van de indiener van de aanvraag.

2. Indien het bestuursorgaan gebruikmaakt van de bevoegdheid uit het eerste lid, wordt in de ontvangstbevestiging als bedoeld in artikel 4:136, eerste lid, vermeld dat het verschuldigde bedrag binnen twee weken na de dag van verzending van deze ontvangstbevestiging dient te zijn bijgeschreven op een door het bestuursorgaan aangewezen rekening dan wel te zijn gestort op een door het bestuursorgaan aangegeven plaats.

3. Indien op de aanvraag geheel of ten dele positief wordt beslist, stort het bestuursorgaan aan de indiener het door hem betaalde recht terug.

\section{Art. 4:135 $5^{11}$}

1. Het bestuursorgaan wint slechts advies in bij een adviescommissie voor zover dat naar zijn oordeel noodzakelijk is om op de aanvraag te beslissen.

2. Advies als bedoeld in het eerste lid, wordt in ieder geval niet ingewonnen als de aanvraag:

a. buiten behandeling wordt gelaten op grond van artikel 4:5, eerste lid;

b. wordt afgewezen op grond van artikel 4:137, eerste lid;

c. naar het oordeel van het bestuursorgaan kennelijk ongegrond is;

d. naar het oordeel van het bestuursorgaan voldoende gelijkenis vertoont met andere aanvragen waarover reeds advies als bedoeld in het eerste lid is uitgebracht; of

e. naar het oordeel van het bestuursorgaan voldoende gelijkenis vertoont met andere aanvragen waarover reeds een onherroepelijke rechterlijke uitspraak is gewezen.

3. Een adviescommissie als bedoeld in het eerste lid bestaat uit één of meer deskundigen die door het bestuursorgaan worden benoemd. Benoeming kan zowel geschieden voor een termijn van maximaal twee jaar waarna mogelijkheid bestaat tot herbenoeming, als voor advisering met betrekking tot een of meerdere aanvragen. Indien de commissie uit meerdere leden bestaat, wijst het bestuursorgaan de voorzitter aan.

$9 \quad$ Dit betreft het huidige art. 4:127 Awb.

10 Deze bepaling is voorgesteld in paragraaf 10.14.1 onder het kopje 'Heffing van een recht'.

11 Deze bepaling is voorgesteld in paragraaf 10.14.1 onder het kopje 'Deskundigenadvisering'. 
4. Onverminderd artikel 3:9 vergewist het bestuursorgaan zich van de onafhankelijkheid en onpartijdigheid van de leden van de adviescommissie. Daarbij betrekt het in ieder geval of een lid van de adviescommissie of personen waarmee hij onderdeel uitmaakt van een samenwerkingsverband:

a. ten tijde van de indiening van de aanvraag of gedurende de vijf daaraan voorafgaande jaren het bestuursorgaan, de rechtspersoon waartoe het bestuursorgaan behoort, of andere organen die deel uitmaken van dezelfde rechtspersoon, als advocaat of gemachtigde hebben bijgestaan of geadviseerd;

b. betrokken waren bij de schadeoorzaak waarop de aanvraag betrekking heeft; of

c. ten tijde van de indiening van de aanvraag werkzaam waren, of gedurende de vijf daaraan voorafgaande jaren werkzaam zijn geweest, onder verantwoordelijkheid van het bestuursorgaan.

5. Het bestuursorgaan stelt de aanvrager, en eventuele andere belanghebbenden waarmee het bekend is, in kennis van zijn voornemen om advies in te winnen bij een adviescommissie. De kennisgeving bevat informatie inhoudende de namen van de beoogde leden van de adviescommissie, alsmede hun beroep, nevenfuncties, opleidingsgeschiedenis, relatie tot het bestuursorgaan en de plaats waar zij hun werkzaamheden plegen te verrichten.

6. Als een belanghebbende bedenkingen heeft tegen de voorgenomen samenstelling van de adviescommissie, brengt hij deze ter kennis van het bestuursorgaan binnen twee weken na verzending van de in het vijfde lid bedoelde kennisgeving.

7. Als een belanghebbende pas na het verstrijken van de in het zesde lid gestelde termijn bekend raakt met feiten en omstandigheden die leiden tot bedenkingen tegen de samenstelling van de adviescommissie, dan brengt hij zijn bedenkingen zo spoedig mogelijk ter kennis van het bestuursorgaan.

8. Het bestuursorgaan reageert binnen twee weken na ontvangst daarvan op bedenkingen als bedoeld in het zevende lid. Indien de belanghebbende niet tevens de aanvrager is, brengt het bestuursorgaan de aanvrager binnen dezelfde termijn op de hoogte van deze bedenkingen en zijn reactie daarop.

9. Het bestuursorgaan is bevoegd de benoeming van een lid van de adviescommissie, of de hem ter zake van de aanvraag gegunde adviesopdracht te beëindigen, indien:

a. het lid van de adviescommissie zelf daarom verzoekt;

b. naar het oordeel van het bestuursorgaan voldoende twijfel bestaat over de onafhankelijkheid, onpartijdigheid, of deskundigheid van het lid van de adviescommissie; of

c. de wijze van taakvervulling door het lid van de adviescommissie daartoe naar het oordeel van het bestuursorgaan voldoende aanleiding geeft.

10. In aanvulling op artikel 3:7 zijn ook de aanvrager en andere belanghebbenden verplicht de adviescommissie, al dan niet op haar verzoek, de gegevens ter beschikking te stellen die nodig zijn voor een goede vervulling van haar taak.

11. De adviescommissie kan een plaatsopneming houden indien zij dit nodig acht. 
Artikel 4:136 ${ }^{12}$

1. Het bestuursorgaan bevestigt de ontvangst van de aanvraag schriftelijk en zo spoedig mogelijk, doch tenminste binnen twee weken na de ontvangst daarvan. Hierbij stelt het de aanvrager tevens in kennis van de te volgen procedure.

2. Het bestuursorgaan beslist binnen vier weken na ontvangst van de aanvraag of het gebruik zal maken van zijn bevoegdheid uit artikel 4:135, eerste lid.

3. Als het bestuursorgaan beslist geen gebruik te maken van zijn bevoegdheid uit artikel 4:135, eerste lid, dan beslist het binnen acht weken na ontvangst daarvan op de aanvraag. Het kan deze termijn eenmaal met ten hoogste acht weken verlengen onder schriftelijke opgaaf van redenen aan de aanvrager en andere belanghebbenden.

4. Als het bestuursorgaan beslist gebruik te maken van zijn bevoegdheid uit artikel 4:135, eerste lid, dan:

a. verstuurt het bestuursorgaan zo spoedig mogelijk - doch uiterlijk binnen een week na de in de aanhef van dit lid bedoelde beslissing - de kennisgeving als bedoeld in artikel 4:135, vijfde lid;

b. verstrekt het bestuursorgaan een adviesopdracht aan de adviescommissie niet eerder dan nadat de aanvrager en andere belanghebbenden op deze kennisgeving hebben gereageerd binnen de daarvoor door artikel 4:135, zesde lid, gestelde termijn, doch uiterlijk binnen twee weken na het verstrijken van die termijn;

c. stelt het bestuursorgaan zo spoedig mogelijk - doch uiterlijk binnen een week na verstrekking van de adviesopdracht - ter beschikking aan de adviescommissie, alle op de aanvraag betrekking hebbende informatie, alsmede de bescheiden die naar het oordeel van de adviescommissie noodzakelijk zijn voor de beoordeling daarvan;

d. stelt de adviescommissie zo spoedig mogelijk - doch uiterlijk binnen een week na verstrekking van de adviesopdracht - de aanvrager, het bestuursorgaan en andere belanghebbenden in kennis van de te volgen procedure. Daarbij geeft de adviescommissie in ieder geval aan of, op welke wijze, en wanneer zij in de gelegenheid zullen worden gesteld om hun standpunt met betrekking tot de aanvraag toe te lichten;

e. nodigt de adviescommissie de aanvrager, het bestuursorgaan en andere belanghebbenden uit om aanwezig te zijn bij een plaatsopneming, als zij op grond van artikel 4:135, elfde lid, besluit daartoe over te gaan;

f. stelt de adviescommissie haar advies vast binnen tien weken nadat haar de adviesopdracht is verstrekt door het bestuursorgaan. Zij kan deze termijn eenmaal met ten hoogste acht weken verlengen onder schriftelijke opgaaf van redenen aan de aanvrager, het bestuursorgaan en andere belanghebbenden. Zij zendt het advies terstond toe aan de aanvrager, het bestuursorgaan, en andere belanghebbenden;

g. maken de aanvrager en andere belanghebbenden eventuele bedenkingen tegen het advies uiterlijk vier weken na de verzending daarvan schriftelijk kenbaar aan het bestuursorgaan;

12 Deze bepaling is voorgesteld in paragraaf 10.14.1 onder het kopje 'Inrichting van de procedure'. 
h. beslist het bestuursorgaan uiterlijk tien weken na de verzending van het advies op de aanvraag, tenzij het de adviescommissie overeenkomstig het bepaalde onder i opdraagt nader te adviseren omtrent het op de aanvraag te nemen besluit. Het kan deze termijn eenmaal met ten hoogste acht weken verlengen onder schriftelijke opgaaf van redenen aan de aanvrager en andere belanghebbenden;

i. is het bestuursorgaan bevoegd uiterlijk zes weken na de verzending van het advies een opdracht tot nader advies te verstrekken aan de adviescommissie;

j. stelt de adviescommissie haar nader advies vast binnen zes weken na verzending van de opdracht om nader te adviseren. Zij zendt dit nader advies terstond toe aan de aanvrager, het bestuursorgaan, en andere belanghebbenden. De adviescommissie kan deze termijn eenmaal met ten hoogste vier weken verlengen onder schriftelijke opgaaf van redenen aan de aanvrager, het bestuursorgaan en andere belanghebbenden; en

k. beslist het bestuursorgaan uiterlijk zes weken na de verzending van het nader advies op de aanvraag. Het kan deze termijn eenmaal met ten hoogste drie weken verlengen onder schriftelijke opgaaf van redenen aan de aanvrager en andere belanghebbenden.

5. De termijnen uit het eerste tot en met vierde lid worden overeenkomstig artikel 4:15 opgeschort als toepassing wordt gegeven aan artikel 4:5.

6. Bij wettelijk voorschrift kan worden afgeweken van het tweede tot en met vierde lid.

\section{Artikel 4:137}

1. Het bestuursorgaan kan de aanvraag afwijzen indien op het tijdstip van de aanvraag vijf jaren zijn verstreken na aanvang van de dag na die waarop de aanvrager bekend is geworden zowel met de schade als met het voor de schadeveroorzakende gebeurtenis verantwoordelijke bestuursorgaan, en in ieder geval na verloop van twintig jaren nadat de schade is veroorzaakt.

2. Indien een aanvraag betrekking heeft op schade veroorzaakt door een besluit waartegen beroep kan worden ingesteld, vangt de termijn van vijf jaren niet aan voordat dit besluit onherroepelijk is geworden.

3. Vóórdat de verjaringstermijn is verstreken na verloop waarvan het bestuursorgaan op grond van het eerste lid een aanvraag als bedoeld in artikel 4:126 kan afwijzen, kan de aanvrager deze verjaringstermijn stuiten door een schriftelijke mededeling aan het bestuursorgaan te doen waarin hij ondubbelzinnig verklaart dat hij zich het recht voorbehoudt om zo een aanvraag in te dienen.

4. Na aanvang van de dag na die waarop de schriftelijke mededeling als bedoeld in het derde lid is gedaan, begint een nieuwe verjaringstermijn van twee jaren te lopen. Niettemin treedt de verjaring in geen geval op een eerder tijdstip in dan waarop ook de oorspronkelijke termijn zonder stuiting zou zijn verstreken.

13 Artikelleden $3 \mathrm{t} / \mathrm{m} 5$ zijn voorgesteld in paragraaf 10.14 .1 onder het kopje 'Stuiting van de verjaringstermijn. De eerste twee artikelleden zijn overgenomen uit het huidige art. 4:131 Awb. 
5. De aanvrager kan de verjaringstermijn slechts meermaals stuiten als het bestuursorgaan daarmee instemt.

\section{Artikel 4:138 ${ }^{14}$}

1. Een bestuursorgaan kan de bevoegdheid om te beslissen op een aanvraag om schadevergoeding overdragen aan een ander bestuursorgaan, als dat bestuursorgaan daarmee instemt.

2. Bij algemene maatregel van bestuur kunnen regels worden gesteld over de toepassing van het eerste lid.

\section{Afdeling 4.5.4 Bevoorschotting}

\section{Artikel 4:139 15}

1. Onverminderd artikel 4:95 wordt slechts positief beslist op een aanvraag om een voorschot op een vergoeding als bedoeld in artikel 4:126, als het belang van de aanvrager dit naar het oordeel van het bestuursorgaan vordert. Bij het vormen van dit oordeel houdt het bestuursorgaan in ieder geval rekening met de invloed die de schadeoorzaak naar verwachting zal hebben op de financiële positie van de aanvrager en met het doel dat de aanvrager nastreeft met het voorschot.

2. Op de aanvraag als bedoeld in het eerste lid is artikel 4:135, eerste lid, van overeenkomstige toepassing.

3. Een besluit tot het verlenen van een voorschot is geen erkenning van een aanspraak op een schadevergoeding als bedoeld in artikel 4:126.

4. Bij terugvordering van onverschuldigd betaalde voorschotten als bedoeld in artikel 4:95, vierde lid, wordt geen wettelijke rente gevorderd over het teveel betaalde.

5. De voorschriften als bedoeld in artikel 4:95, zesde lid, kunnen in ieder geval inhouden dat:

a. de aanvrager van het voorschot schriftelijk de verplichting aanvaardt tot gehele en onvoorwaardelijke terugbetaling van hetgeen ten onrechte als voorschot is uitbetaald; en

b. de aanvrager zekerheidstelling verleent voor de terugbetaling als bedoeld onder a.

6. Tenzij bij wettelijk voorschrift anders is bepaald, beslist het bestuursorgaan op de in het eerste lid bedoelde aanvraag binnen acht weken of - indien een adviescommissie als bedoeld in artikel 4:135 is ingesteld - binnen twaalf weken na de ontvangst van de aanvraag daarvan.

14 Deze bepaling is voorgesteld in paragraaf 4.5. Het betreft een verplaatsing van art. 15.8 lid 3 jo. lid 4 Ow.

15 Deze bepaling is voorgesteld in paragraaf 10.14.1 onder het kopje 'Bevoorschotting'. 


\subsubsection{Reflectie op de aanbevolen redactie}

\section{Het materiële deel van titel $4.5 \mathrm{Awb}$}

Bij bestudering van titel $4.5 \mathrm{Awb}$ is gebleken dat deze titel op materieel vlak slechts bestaat uit een opsomming van de criteria voor toekenning van nadeelcompensatie. De titel bevat echter geen normering omtrent de wijze waarop deze criteria dienen te worden toegepast. Dat is opmerkelijk, omdat in paragraaf 2.4.2.1 is gebleken dat aan de Wns onder andere de doelstellingen ten grondslag liggen van codificatie van het nadeelcompensatierecht en vergroting van de rechtszekerheid. Tot op zekere hoogte lijkt het gebrek aan materiële sturing te kunnen worden verklaard door de ruime reikwijdte van titel 4.5 Awb. Zo is het bijvoorbeeld lastig om een afbakening van het normaal maatschappelijk risico of wijze van schadebegroting voor te schrijven die zich in algemene zin laat toepassen op alle vormen van inkomensschade, zonder het risico op onwenselijke en/of onredelijke uitkomsten in het leven te roepen. Hoewel ik daar geen concrete aanwijzingen voor heb gevonden, sluit ik niet uit dat destijds ook politieke redenen een rol hebben gespeeld bij de keuze van het kabinet om een wetsvoorstel in te dienen dat relatief weinig inhoudelijke sturing bood. Een wetsvoorstel dat slechts de criteria voor toekenning van nadeelcompensatie opsomt die al enkele decennia onomstreden zijn in de rechtspraak, loopt immers minder kans om in het parlement op weerstand te stuiten dan een wetsvoorstel waarin bijvoorbeeld nadere sturing wordt geboden omtrent de afbakening van het normaal maatschappelijk risico. Dat was destijds al bekend door het experiment ${ }^{16}$ van het wettelijke forfait van art. 6.2 lid $2 \mathrm{Wro}$, en is recent nogmaals bevestigd tijdens de parlementaire behandeling van het voorstel voor het wettelijke forfait van art. 15.7 lid $1 \mathrm{Ow}$.

De door mij voorgestelde redactie van titel 4.5 Awb biedt aanmerkelijk meer inhoudelijke sturing. In de vorm van art. 4:127 Awb kent zij bijvoorbeeld een bepaling die geheel is gewijd aan het criterium van causaal verband. Het eerste lid expliciteert de causaliteitseis op een wijze die nadrukkelijk aansluit op art. 6:98 BW. In de overige leden wordt sturing geboden ten aanzien van gevallen van meervoudige causaliteit. Vervolgens wordt in art. 4:128 Awb ingegaan op enkele vraagstukken die oorspronkelijk in art. 4:126 Awb waren te vinden. Het betreft voordeelverrekening, het voldoende anderszins verzekerd zijn van schadevergoeding, en compensatie in natura. Het voorgestelde art. 4:128 Awb biedt echter meer duidelijkheid omtrent de voorwaarden waaronder voordeel mag worden verrekend of schadevergoeding voldoende anderszins verzekerd kan worden geacht. Het betreft hoofdzakelijk een codificatie van de uitgekristalliseerde jurisprudentielijnen omtrent deze onderwerpen. Ook hier heeft het uitgangspunt van aansluiting bij het BW echter een rol gespeeld. Geïnspireerd op art. 6:100 BW, wordt verrekening van voordeel op grond van art. 4:128 lid 1 Awb namelijk begrensd door de redelijkheid. 
Art. 4:129 Awb ziet op het normaal maatschappelijk risico. Hiervoor werd al opgemerkt dat dit een onderwerp betreft dat zich lastig in algemene zin laat regelen in een formeelwettelijke regeling met een brede reikwijdte. Weinig controversieel is echter dat schade van geringe omvang altijd tot het normaal maatschappelijk risico behoort. Daarom bevat het derde lid enkele bagateldrempels. In het tweede lid wordt de regering de bevoegdheid toegekend om bij amvb nadere regels te stellen over het normaal maatschappelijk risico. In paragraaf $11.4 .2^{17}$ zal nader worden ingegaan op mijn aanbevelingen om op grond van dit artikellid over te gaan tot de vaststelling van een amvb omtrent het normaal ondernemersrisico. Afhankelijk van de bevindingen van een werkgroep, tot instelling waarvan eveneens wordt aanbevolen in die paragraaf, kunnen in deze amvb ook bepalingen worden opgenomen omtrent het normaal maatschappelijk risico bij tijdelijke derving van woongenot.

In art. 4:130 Awb is een normatieve maatstaf opgenomen die bepalend is voor de toepassing van het criterium van de speciale last. Ondanks dat de door mij voorgestelde, normatieve maatstaf nog onbeproefd is, acht ik het toch verdedigbaar hem meteen in titel 4.5 Awb te verankeren. Na decennia van op égalité gebaseerd nadeelcompensatierecht bestaat namelijk nog relatief veel onduidelijkheid omtrent de wijze waarop de speciale last moet worden ingevuld bij bepaalde type schadeoorzaken - zeker in vergelijking met de mate van duidelijkheid die in hetzelfde tijdsbestek is ontstaan omtrent bijvoorbeeld de tegenwerping van normaal maatschappelijk risico of risicoaanvaarding. De zekerheid die wel bestaat, wordt bovendien ontleend aan rubricering naar type schadeoorzaak, waarvan is betoogd dat zij niet goed aansluit op de doelstelling van vergroting van de rechtsgelijkheid. Voorts moet op korte termijn ineens een aanzienlijke mate van sturing worden geboden, omdat het criterium van de speciale last voor het eerst ook zal gelden in het omgevingsrechtelijk georiënteerde nadeelcompensatierecht. Dit alles rechtvaardigt mijns inziens dat de formele wetgever eenmalig een duidelijk signaal afgeeft.

Art. 4:131 Awb ziet op de tegenwerping van risicoaanvaarding, het niet voldoen aan de algemeen geldende schadebeperkingsplicht, en overige vormen van eigen schuld. Deze bepaling codificeert de belangrijkste en meest uitgekristalliseerde jurisprudentielijnen over dit onderwerp - terwijl in het originele art. 4:126 lid 2 Awb slechts wordt vermeld dat tegenwerping van deze vormen van eigen schuld mogelijk is. Bovendien sluit de formulering van de voorgestelde bepaling nadrukkelijker aan op art. 6:101 BW. Met betrekking tot het omgevingsrecht wordt de in art. 4:131 lid 3 Awb genoemde voorwaarde van een concrete poging nog nader uitgewerkt in art. 15.8 Ow als voorgesteld in paragraaf 11.3.1.

Voorts gaat art. 4:132 Awb in op de vergoeding van kosten van schadebeperkende maatregelen, deskundigenkosten en wettelijke rente. Oorspronkelijk kwamen

17 Zie de kopjes 'Codificatie Handleiding nadeelcompensatie en instelling werkgroep ondernemersrisico' en 'Instelling werkgroep normaal maatschappelijk risico bij tijdelijke derving woongenot en eventuele vaststelling amvb'. 
deze onderwerpen aan bod in art. 4:129 Awb. De voorgestelde bepaling sluit beter aan op de thans geldende jurisprudentielijnen en het BW. Ook voorkomt zij de onwenselijke situatie dat het bestuur wettelijke rente zou moeten betalen over de periode waarin het schadeveroorzakende besluit reeds in werking was getreden, maar nog niet onherroepelijk was - waardoor het bestuur nog niet kon beslissen op de aanvraag om nadeelcompensatie.

Ten slotte is als art. 4:139 Awb een bepaling voorgesteld omtrent bevoorschotting. $\mathrm{Zij}$ is opgenomen in een afzonderlijke afdeling, omdat zij strikt genomen niet ziet op de toekenning van nadeelcompensatie. De huidige redactie van titel 4.5 Awb ontbeert een dergelijke bepaling, terwijl de geselecteerde, thans geldende regelingen laten zien dat hier wel behoefte aan bestaat. De inhoud van de voorgestelde bepaling is grotendeels een codificatie van de meest uitgekristalliseerde jurisprudentielijnen over dit onderwerp. Vanwege het uitgangspunt van aansluiting op de Awb is de bepaling bovendien vormgegeven als een aanvulling op de algemene regeling van art. 4:95 Awb omtrent toekenning van een voorschot vooruitlopend op de vaststelling van een verplichting tot betaling van een geldsom.

\section{Het procedurele deel van titel $4.5 \mathrm{Awb}$}

Dat titel 4.5 Awb ook relatief weinig procedurele sturing biedt, kan wellicht deels worden verklaard doordat de Awb van origine een regeling is die in algemene zin procedurele normering biedt voor de totstandkoming van besluiten en de omgang met burgers die bedenkingen hebben bij de voorgenomen of reeds vastgestelde besluitvorming. In hoofdstuk 10 is echter gebleken dat alle geselecteerde, thans geldende regelingen blijk geven van behoefte aan verdergaande normering dan wordt geboden door het samenspel van hoofdstuk 3 Awb en titel 4.1 Awb met de procedurele voorschriften uit de huidige redactie van titel 4.5 Awb. Bezien in samenhang met onder andere de doelstellingen van vereenvoudiging, uniformering en harmonisering van het nadeelcompensatierecht, vergroting van de rechtszekerheid, en codificatie van het nadeelcompensatierecht, leidde dat er regelmatig toe dat ik heb aanbevolen meer procedurele normering in titel 4.5 Awb op te nemen.

Art. 4:133 Awb als voorgesteld, is een letterlijke overname van het originele art. 4:127 Awb. Art. 4:134 Awb ziet op de heffing van een recht ter in behandeling name van de aanvraag. De voorgestelde bepaling wijzigt het originele art. 4:128 Awb zodanig dat op voorhand vaststaat dat het recht altijd $€ 300$ bedraagt, en kan worden geheven zonder dat daarvoor eerst een wettelijk voorschrift dient te worden vastgesteld. Bovendien is het originele art. 4:129, aanhef en onder c Awb geïncorporeerd in de voorgestelde bepaling. Daardoor is de heffing en eventuele terugbetaling van het recht geregeld in één wetsartikel, hetgeen de rechtszekerheid en overzichtelijkheid mijns inziens ten goede komt.

In art. 4:135 Awb is een regeling omtrent deskundigenadvisering opgenomen. Zij sluit aan bij de onder verschillende van de geselecteerde, thans geldende rege- 
lingen ingezette trend van meer efficiënte regels omtrent de raadpleging van een deskundige. Zo wordt in eerste instantie aan het bestuur overgelaten wanneer en waarover deskundigenadvies wordt ingewonnen en hoeveel deskundigen daartoe worden geraadpleegd. Het vierde lid van de voorgestelde bepaling sluit aan op de jurisprudentie inzake de onafhankelijkheid en onpartijdigheid van deskundigen in het planschade- en nadeelcompensatierecht. Het zesde $\mathrm{t} / \mathrm{m}$ achtste lid schept duidelijkheid omtrent de omgang met bedenkingen van belanghebbenden bij de deskundigen die het bestuur raadpleegt, of voornemens is te gaan raadplegen. Het negende lid ziet op de beëindiging van de benoeming van een deskundige, of de aan hem verstrekte adviesopdracht. Het tiende en elfde lid normeren de wijze waarop de adviescommissie de door haar benodigde informatie kan vergaren. Dit betreft stuk voor stuk onderwerpen waarvan de geselecteerde, thans geldende regelingen aantonen dat behoefte bestaat aan regulering.

Als art. 4:136 Awb is een bepaling voorgesteld die voorziet in de inrichting van de procedure waarlangs de aanvraag om nadeelcompensatie zal worden behandeld. De geselecteerde, thans geldende regelingen tonen aan dat behoefte bestaat aan een dergelijke bepaling. In algemene zin heb ik gepoogd de procedure zo in te richten dat zij waarborgt dat besluitvorming zorgvuldig tot stand komt zonder dat dit ten koste gaat van efficiëntie en doelmatigheid. Voor de maximum beslistermijnen is aansluiting gezocht bij het originele art. 4:130 Awb. Vervolgens is er de verjaringsregeling van art. 4:137 Awb. De eerste twee artikelleden waren reeds te vinden in het originele art. 4:131 Awb. Daaraan zijn een drietal artikelleden toegevoegd die de mogelijkheid tot stuiting van de verjaringstermijn codificeren. Het bestaan van die mogelijkheid is bevestigd in de nadeelcompensatiejurisprudentie. Zij is ook terug te vinden in de BnIW 2019 en het BW. In afwijking daarvan, staan de voorgestelde artikelleden in beginsel slechts een eenmalige stuiting voor de duur van twee jaren toe. Deze afwijking acht ik nodig vanwege de doelstellingen van vergroting van de rechtszekerheid, en vergroting van de doelmatigheid van het nadeelcompensatierecht en vermindering van bestuurslasten. Ten slotte is er art. 4:138 Awb. Door deze bepaling wordt de vrijwillige overnamebevoegdheid verplaatst van het originele art. 15.8 lid 3 jo. lid 4 Ow naar titel 4.5 Awb. Mede gelet op de doelstelling van vereenvoudiging, uniformering en harmonisering van het nadeelcompensatierecht, zie ik namelijk geen goede reden om deze oplossing voor problemen van meervoudige causaliteit te reserveren voor het omgevingsrecht.

Zou de Wns niet zijn vastgesteld als een tot de Awb behorende titel, maar als een zelfstandige wet nadeelcompensatie, dan zou dit het einde zijn van mijn procedurele verhaal. Dat is echter niet het geval. Bovendien zijn de onderwerpen die worden behandeld in art. 4:135 jo. art. 4:136 Awb niet eigen aan het nadeelcompensatierecht. Zo speelt deskundigenadvisering een belangrijke rol in veel meer rechtsgebieden dan enkel het nadeelcompensatierecht. ${ }^{18}$ Ook de inrichting van de schillende rechtsgebieden waarin deskundigenadvisering een belangrijke rol speelt. 
procedure waarlangs de aanvraag om een besluit - meer specifiek een (financiële) beschikking - wordt behandeld, is een vraagstuk dat zeker niet is gelimiteerd tot het nadeelcompensatierecht. Wanneer niet enkel wordt geredeneerd vanuit de aan de Wns ten grondslag liggende doelstellingen en uitgangspunten, zou het daarom voor de hand liggen als de wetgever eerst zou nagaan in hoeverre de voorgestelde procedurele bepalingen niet aan hoofdstuk 3 Awb of titel 4.1 Awb zouden kunnen worden toegevoegd - al dan niet na enige veralgemenisering. Eens te meer bestaat daartoe reden nu ook in meer algemene zin kan worden bepleit dat afd. 3.3 Awb (de afdeling omtrent deskundigenadvisering), mede vanwege haar beperkte toepassingsbereik, eigenlijk niet voldoet aan de in de bestuursrechtelijke praktijk bestaande behoeften. ${ }^{19}$

Zou de wetgever daartoe niet bereid zijn, dan zou de in paragraaf 2.4.2.3 besproken trend van deregulering en decentralisatie aanleiding kunnen geven om de voorgestelde bepalingen omtrent deskundigenadvisering en inrichting van de procedure niet in titel 4.5 Awb op te nemen, maar in een amvb die deze titel nader uitwerkt. Daartoe zou in titel 4.5 Awb wel een grondslag moeten worden opgenomen om bij amvb nadere procedurele regels vast te stellen. ${ }^{20}$ Gelet op de doelstelling van vereenvoudiging van het nadeelcompensatierecht, zou het in dat geval bovendien voor de hand liggen dat deze procedurele bepalingen worden opgenomen in dezelfde amvb als waarin bijzondere normering wordt vastgesteld over het normaal ondernemersrisico en potentieel ook het normaal maatschappelijk risico bij tijdelijke derving van woongenot. ${ }^{21}$ Dit voorkomt immers dat de benadeelde burger of draagplichtige derde - in aanvulling op titel 4.5 Awb - meerdere amvb's dient te raadplegen om een volledig beeld te krijgen van de regels die van toepassing zijn op de voor hem relevante aanvraag om compensatie.

\subsection{AANBEVELINGEN TOT (в) AANPASSING VAN AFD. $15.1 \mathrm{OW}$}

In deze paragraaf wordt eerst weergegeven hoe afd. 15.1 Ow er zou uitzien als de wetgever alle aanbevelingen uit de voorafgaande hoofdstukken zou opvolgen (paragraaf 11.3.1). Daarbij is uitgegaan van de redactie van titel 4.5 Awb als aanbevolen in paragraaf 11.2.1. Door invoeging van enkele nieuwe bepalingen moest enige vernummering plaatsvinden ten opzichte van de originele redactie van afd. 15.1 Ow. In paragraaf 11.3.2 zal ik kort reflecteren op de aanbevolen redactie van deze afdeling. Kummeling 1988, p. 248-251.

$20 \quad$ Vergelijk paragraaf 2.5.4.

21 Vergelijk paragraaf 11.4.2 onder de kopjes 'Codificatie Handleiding nadeelcompensatie en instelling werkgroep ondernemersrisico' en 'Instelling werkgroep normaal maatschappelijk risico bij tijdelijke derving woongenot en eventuele vaststelling amvb'. 
11.3.1 De aanbevolen redactie van afd. $15.1 \mathrm{Ow}$

\section{HOOFDSTUK 15 SCHADE}

\section{AFDELING 15.1 NADEELCOMPENSATIE}

\section{Artikel 15.122}

1. Als een bestuursorgaan in de rechtmatige uitoefening van zijn publiekrechtelijke bevoegdheid of taak op grond van deze wet schade veroorzaakt, is titel 4.5 van de Algemene wet bestuursrecht alleen van toepassing op de toekenning van vergoeding van schade als bedoeld in artikel 4:126 van die wet die wordt veroorzaakt door het vaststellen, verlenen, stellen, treffen of, voor zover van toepassing, wijzigen of intrekken van:

a. een peilbesluit als bedoeld in artikel 2.41,

b. een in een programma opgenomen beschrijving van een activiteit als gevolg waarvan de activiteit is toegestaan,

c. een regel in het omgevingsplan, als het gaat om een regel als bedoeld in artikel 4.1, eerste lid,

d. een regel in een waterschapsverordening, als het gaat om een regel als bedoeld in artikel 4.1, eerste lid,

e. een regel in een omgevingsverordening, als het gaat om een regel als bedoeld in artikel 4.1, eerste lid,

f. een regel in een algemene maatregel van bestuur, als het gaat om een regel als bedoeld in artikel 4.3, eerste of tweede lid,

g. een regel in een ministeriële regeling, als het gaat om een regel als bedoeld in artikel 4.1, tweede lid, of 4.3, derde lid,

h. een maatwerkvoorschrift,

i. een toestemming om een gelijkwaardige maatregel te treffen,

j. een omgevingsvergunning of het weigeren daarvan,

k. een projectbesluit,

1. een beslissing tot het treffen van maatregelen als bedoeld in artikel 19.4,

$\mathrm{m}$. een beslissing tot het treffen van maatregelen als bedoeld in artikel 19.5,

n. een maatregel als bedoeld in artikel 19.15.

2. Als voor een activiteit een omgevingsvergunning is vereist op grond van een regel als bedoeld in het eerste lid, onder c tot en met e, of op grond van artikel 5.1, geldt alleen het besluit tot het verlenen, wijzigen, intrekken of weigeren van de omgevingsvergunning voor die activiteit als schadeveroorzakend besluit.

3. Als op grond van artikel 5.52, eerste lid, een omgevingsplan wordt gewijzigd, geldt alleen het projectbesluit als schadeveroorzakend besluit.

22 Deze bepaling is inhoudelijk ongewijzigd gebleven ten opzichte van de redactie van afd. $15.1 \mathrm{Ow}$ die werd aangenomen door de Tweede Kamer. 


\section{Artikel 15.2 Ow $^{23}$}

1. In afwijking van art. 15.1 van deze wet is titel 4.5 van de Algemene wet bestuursrecht ook van toepassing op de toekenning van vergoeding van schade als bedoeld in artikel 4:126 van die wet indien een bestuursorgaan inkomensschade veroorzaakt in de rechtmatige uitoefening van zijn op deze wet gebaseerde publiekrechtelijke bevoegdheid of taak die niet wordt genoemd in art. 15.1, eerste lid, van deze wet.

2. De in het eerste lid bedoelde schade komt slechts voor vergoeding in aanmerking in zoverre zij:

a. groter is dan ... procent van de omzet die naar redelijke verwachting behaald zou zijn, indien de in het eerste lid bedoelde gebeurtenis niet had plaatsgevonden; en

b. is geleden nadat ... jaren zijn verstreken sinds de in het eerste lid bedoelde gebeurtenis.

\section{Artikel 15.3 $3^{24}$}

Voor de toepassing van deze afdeling heeft de vergoeding van schade als bedoeld in artikel 4:126 van de Algemene wet bestuursrecht geen betrekking op immateriële schade.

\section{Artikel 15.4 $4^{25}$}

Van nauw met elkaar verweven gebeurtenissen als bedoeld in artikel 4:128, eerste lid, van de Algemene wet bestuursrecht is sprake als:

a. de voor- en nadelen van twee of meer in artikel 15.1 lid 1 genoemde besluiten moeten worden geacht uit hetzelfde planologische regime voort te vloeien;

b. de onder a genoemde besluiten onherroepelijk zijn op het moment van het besluit op de aanvraag als bedoeld in artikel 4:126 Algemene wet bestuursrecht; en

c. de intentie waarmee de onder a genoemde besluiten zijn genomen, duidt op een nauwe, onderlinge verwevenheid.

\section{Artikel 15.5 $5^{26}$}

1. Als voor een activiteit een omgevingsvergunning is vereist, wordt de schade die bestaat uit waardevermindering van een onroerende zaak bepaald aan de hand van een vergelijking van de waarde van de onroerende zaak onmiddellijk voor en na het tijdstip waarop het bevoegd gezag mededeling heeft gedaan van het besluit tot het verlenen of wijzigen van de omgevingsvergunning.

2. Dit artikel is alleen van toepassing op schade die wordt veroorzaakt door een regel op grond waarvan een activiteit is toegestaan buiten de locatie waar de onroerende zaak is gelegen of door een maatregel die buiten die locatie wordt getroffen.

23 Deze bepaling is voorgesteld in paragraaf 3.5 .

24 Dit betreft art. 15.2 van de originele redactie van afd. $15.1 \mathrm{Ow}$.

25 Deze bepaling is voorgesteld in paragraaf 9.4.

26 Dit betreft art. 15.3 van de originele redactie van afd. $15.1 \mathrm{Ow}$. 
Artikel 15.6 ${ }^{27}$

1. Als voor een activiteit die is toegestaan op grond van een regel als bedoeld in artikel 15.1, eerste lid, onder $\mathrm{c}$ tot en met g, geen omgevingsvergunning is vereist, kan een aanvraag om schadevergoeding worden ingediend als:

a. degene die de activiteit gaat verrichten aan het bevoegd gezag informatie over die activiteit heeft verstrekt en het bevoegd gezag kennis heeft gegeven van die informatie, volgens de regels die daarvoor gelden, of

b. met de activiteit is begonnen.

2. De schade die bestaat uit waardevermindering van een onroerende zaak wordt bepaald aan de hand van een vergelijking van de waarde van de onroerende zaak:

a. onmiddellijk voor en na het tijdstip waarop de kennisgeving, bedoeld in het eerste lid, onder a, is gedaan, of

b. als de informatie, bedoeld in het eerste lid, onder a, niet is verstrekt: onmiddellijk voor en na het tijdstip waarop met de activiteit is begonnen.

3. Als een kennisgeving als bedoeld in het eerste lid, onder a, is gedaan, wordt voor de toepassing van artikel 4:137, eerste lid, van de Algemene wet bestuursrecht de dag na die waarop de kennisgeving is gedaan, gelijkgesteld met de dag na die waarop de aanvrager bekend is geworden met de schade en met het voor de schadeveroorzakende gebeurtenis verantwoordelijke bestuursorgaan.

4. Dit artikel is alleen van toepassing op schade die wordt veroorzaakt door een regel op grond waarvan een activiteit is toegestaan buiten de locatie waar de onroerende zaak is gelegen of door een maatregel die buiten die locatie wordt getroffen.

\section{Artikel $15.7^{28}$}

In afwijking van artikel 4:131 van de Algemene wet bestuursrecht komt de vergoedingsplicht van het bestuursorgaan niet te vervallen wegens actieve risicoaanvaarding als de aanvraag om schadevergoeding betrekking heeft op de waardedaling van een tot woning bestemde onroerende zaak die de aanvrager volgens de gemeentelijke basisadministratie als hoofdverblijf in gebruik heeft op zowel het peilmoment voor het ontstaan van de schade als op het moment van beslissen op de aanvraag.

\section{Artikel 15.8 29 $^{29}$}

1. Bij directe schade door het verlies van een bouwmogelijkheid is in ieder geval sprake van een concrete poging als bedoeld in artikel 4:131, derde lid, van de Algemene wet bestuursrecht als de aanvrager:

a. een bouwplan heeft ingediend dat de bedreigde bouwmogelijkheid benut;

b. dat zich laat beoordelen op passendheid binnen het omgevingsplan; en

c. dat in beginsel past binnen de bestaande mogelijkheden van het omgevingsplan.

2. Bij directe schade door het verlies van een gebruiksmogelijkheid is in ieder geval sprake van een concrete poging als bedoeld in artikel 4:131, derde lid, van de Algemene wet bestuursrecht als de aanvrager daadwerkelijk is aangevangen met het

27 Dit betreft art. 15.4 van de originele redactie van afd. 15.1 Ow.

28 Deze bepaling is voorgesteld in paragraaf 8.5.

29 Deze bepaling is voorgesteld in paragraaf 8.5. 
desbetreffende gebruik, of serieuze pogingen heeft ondernomen om zijn onroerende zaak voor dat doel aan derden te verkopen of verhuren.

\section{Artikel 15.9 ${ }^{30}$}

1. Bij een aanvraag om vergoeding van schade die bestaat uit waardevermindering van een onroerende zaak wordt een deel ter grootte van vier procent van de waarde van de onroerende zaak onmiddellijk voor het ontstaan van de schade aangemerkt als behorend tot het normale maatschappelijke risico als bedoeld in artikel 4:129, eerste lid, van de Algemene wet bestuursrecht.

2. Als de aanvraag om schadevergoeding strekt tot vergoeding van meerdere schades door verschillende activiteiten óf strekt tot vergoeding van schade door één activiteit gebaseerd op meerdere besluiten, past het bevoegd gezag het eerste lid toe op het totale voor vergoeding in aanmerking komende bedrag, mits deze activiteiten respectievelijk besluiten daartoe voldoende samenhang vertonen.

3. Het bevoegd gezag kan bij de behandeling van een aanvraag om schadevergoeding het eerste lid buiten toepassing laten als dat lid van toepassing is geweest bij de beslissing op een eerder ingediende aanvraag om vergoeding van schade.

\section{Artikel 15.10}

1. Als de aanvraag om schadevergoeding betrekking heeft op een besluit van de gemeenteraad, het algemeen bestuur van een waterschap of provinciale staten of op een algemene maatregel van bestuur of ministeriële regeling, wordt als bestuursorgaan dat de schadevergoeding toekent als bedoeld in artikel 4:126 van de Algemene wet bestuursrecht, aangemerkt het college van burgemeester en wethouders, het dagelijks bestuur van het waterschap, het college van gedeputeerde staten respectievelijk Onze Minister die het aangaat, tenzij het tweede lid op die aanvraag van toepassing is.

2. Als de aanvraag om schadevergoeding betrekking heeft op een besluit ter uitvoering van een projectbesluit, is het bestuursorgaan dat het projectbesluit heeft vastgesteld, het bestuursorgaan dat de schadevergoeding toekent.

\section{Artikel 15.11 ${ }^{32}$}

1. Bij algemene maatregel van bestuur kunnen bestuursorganen of andere instanties worden aangewezen die, in daarbij aangewezen gevallen, in de gelegenheid worden gesteld om aan het bevoegd gezag advies uit te brengen over een aanvraag om schadevergoeding.

2. Bij algemene maatregel van bestuur kunnen regels worden gesteld over:

a. de wijze van beoordeling van een aanvraag om schadevergoeding, en

b. de totstandkoming van een beslissing op de aanvraag. ring van onroerende zaken') gewijzigde variant op art. 15.7 van de originele redactie van afd. $15.1 \mathrm{Ow}$.

31 Dit betreft art. 15.8 van de originele redactie van afd. $15.1 \mathrm{Ow}$, zij het dat het derde en vierde lid van die bepaling zijn verplaatst naar titel 4.5 Awb. 


\section{Artikel 15.12 ${ }^{33}$}

Bij algemene maatregel van bestuur kunnen regels worden gesteld over een in een omgevingsplan, waterschapsverordening of omgevingsverordening op te nemen verplichting tot het verstrekken van informatie en tot de kennisgeving daarvan, met het oog op de indiening van een aanvraag om schadevergoeding als bedoeld in artikel 15.6.

\subsubsection{Reflectie op de aanbevolen redactie}

\section{Bijzonderheden van het (nieuwe) omgevingsrecht}

Twee eigenschappen van het door de Ow vormgegeven omgevingsrecht zijn doorslaggevend geweest voor het regeringsvoorstel voor afd. 15.1 Ow. Ten eerste wordt dit omgevingsrecht - net als het huidige omgevingsrecht - gekenmerkt door getrapte besluitvorming. De regering is van mening dat dit karakter van getrapte besluitvorming slecht combineert met de ruime reikwijdte van titel 4.5 Awb. Daarom is in art. 15.1 lid $1 \mathrm{Ow}$ een limitatieve, exclusieve opsomming van schadeoorzaken opgenomen. Uit paragraaf 3.4.2.1 blijkt dat het exclusieve karakter van deze opsomming zich ambivalent verhoudt tot de aan de Wns ten grondslag liggende doelstellingen en uitgangspunten. Zij vormen daardoor onvoldoende aanleiding om af te zien van dit exclusieve karakter. Sterker nog, dat karakter lijkt juist wenselijk en mogelijk zelfs noodzakelijk nu het omgevingsrecht wordt gekenmerkt door een stelsel van getrapte besluitvorming. Wel vereisen de aan de Wns ten grondslag liggende doelstellingen en uitgangspunten mijns inziens dat bij behoud van het exclusieve karakter van de opsomming een oplossing wordt getroffen voor de daardoor veroorzaakte schaduwschadeproblematiek.

Ten tweede bleek in paragraaf 2.4.3 dat het door de Ow genormeerde omgevingsplan een veel globaler karakter zal dragen dan het door de Wro genormeerde bestemmingsplan. Uit paragraaf 3.4.2.3 volgt dat zowel door de Afdeling advisering van de Raad van State alsook in de literatuur kritische kanttekeningen zijn geplaatst bij de wenselijkheid van een omgevingsplan met een dermate globaal karakter. ${ }^{34}$ Ook ik heb mijn bedenkingen over de wenselijkheid van het globalere karakter van het omgevingsplan, mede bezien vanuit de aan de Wns ten grondslag liggende doelstellingen en uitgangspunten. Het doel van dit onderzoek is echter niet om de wenselijkheid te beoordelen van de wijze waarop de Ow het omgevingsrecht zal vormgeven. Bij de beantwoording van de vraag of de doelstellingen en uitgangspunten van de Wns aanleiding geven tot aanpassing van afd. 15.1 Ow, ben ik daarom uitgegaan van de wijze waarop deze afdeling functioneert binnen het door de Ow gereguleerde omgevingsrecht en hoe zich dat verhoudt tot het nadeelcompensatierecht van titel $4.5 \mathrm{Awb}$.

33 Dit betreft art. 15.10 van de originele redactie van afd. $15.1 \mathrm{Ow}$.

34 Zie Kamerstukken II 2018/19, 34 986, nr. 4, p. 8-10 en 49-52 (AARvS, IOw); respectievelijk Groothuijse \& Kegge 2017, p. 111-131. 
Vanwege het globalere karakter van het door de Ow genormeerde omgevingsplan, staat de regering een "generieke verschuiving" voor ogen "van het moment dat een aanvraag om schadevergoeding kan worden gedaan" (oftewel: het schademoment). ${ }^{35}$ Als daar niet voor wordt gekozen, sluit ik niet uit dat afd. 15.1 Ow dermate onwerkbaar zou worden dat strijd zou ontstaan met alle aan de Wns ten grondslag liggende doelstellingen en uitgangspunten. Dat neemt niet weg dat de verschuiving van het schademoment ook complicaties meebrengt, waarvan enkele betrekking hebben op de causaliteitstoets en de begroting van schade. Zij hebben met name geleid tot aanbevelingen die in paragraaf 11.4 zullen worden besproken. Een andere complicatie is dat de verschuiving van het schademoment juist tot een vergroting van de schaduwschadeproblematiek leidt. De regering heeft daarvoor een oplossing willen bieden met haar voorstel voor art. 15.5 Ow. In de doctrine bestaat echter overeenstemming dat die oplossing te weinig zoden aan de dijk zet. ${ }^{36}$ Dit heb ik uiteraard betrokken in mijn zoektocht naar de eerder aanbevolen, generieke oplossing voor de schaduwschadeproblematiek.

Voor schaduwschade in de vorm van inkomensschade is die oplossing terug te vinden in art. 15.2 Ow. Deze bepaling heft het exclusieve karakter van de limitatieve opsomming van schadeoorzaken op voor inkomensschade. Deze bepaling is onder andere ingegeven door de gedachte dat - behoudens begrotingsfouten - geen risico op overcompensatie bestaat wanneer de aanvrager aannemelijk weet te maken dat hij inkomensschade heeft geleden door indicatief overheidshandelen. Om te waarborgen dat globale- en uitnodigingsplanologie niet te veel wordt gehinderd - zoals het kabinet in algemene zin vreest - is bovendien in het tweede lid bepaald dat de schade een zekere ernst en duur moet hebben om voor compensatie in aanmerking te komen. Voor schaduwschade in de vorm van tijdelijke waardevermindering van onroerende zaken is een oplossing te vinden in art. 15.7 Ow. Door de beperking van tegenwerping van actieve risicoaanvaarding zouden potentiële kopers minder waarde moeten hechten aan indicatief overheidshandelen. Uiteraard kan niet worden uitgesloten dat een koper zal verdisconteren dat 4\% van de schade die ontstaat als de aangekondigde maatregel wordt gerealiseerd, vanwege art. 15.9 lid $1 \mathrm{Ow}$ voor zijn rekening zal blijven. Dat zal de verkopende partij echter voor lief moeten nemen, omdat die 4\% ook voor haar rekening was gebleven als zij niet zou hebben verkocht. Bovendien staat het haar vrij met de koper af te spreken dat bijvoorbeeld ieder $2 \%$ voor zijn rekening neemt. Soms zal een woning ook tijdelijk onverkoopbaar raken. Voor die situaties is aanbevolen dat in hoofdstuk 11 Ow een recht op uitkoop wordt verschaft aan de eigenaar die zijn onroerende zaak gedurende een zekere periode niet heeft weten te verkopen als gevolg van het indicatieve overheidshandelen. 


\section{Verdere normering}

Anders dan titel 4.5 Awb - biedt afd. 15.1 Ow als aangenomen door de Tweede Kamer wel enige sturing omtrent de toepassing van de criteria voor toekenning van nadeelcompensatie. Gelet op de doelstelling van vereenvoudiging, uniformering en harmonisering van het nadeelcompensatierecht (en soms ook de doelstelling van vergroting van de rechtsgelijkheid) riep dat geregeld de vraag op waarom die sturing niet is opgenomen in titel 4.5 Awb. Dit leidde tot de aanbeveling om de vrijwillige overnamebevoegdheid en de grondslag om amvb's omtrent het normaal maatschappelijk risico vast te stellen naar titel 4.5 Awb te verplaatsen. Ook leidde dit tot de aanbeveling om de basisvoorwaarden voor passieve risicoaanvaarding in titel 4.5 Awb op te nemen. ${ }^{37}$ Gelet op de doelstellingen van codificatie van het nadeelcompensatierecht en vergroting van de rechtszekerheid, zijn deze basisvoorwaarden nader toegespitst op het omgevingsrecht in art. 15.8 Ow. De door de Tweede Kamer aangenomen bepaling omtrent passieve risicoaanvaarding week om onduidelijke redenen af van de voorwaarden die thans in de jurisprudentie worden gesteld. Mede gelet op de doelstelling van codificatie van het nadeelcompensatierecht en het uitgangspunt van aansluiting bij het BW, ben ik daarom in mijn voorstel voor art. 15.8 Ow uitgegaan van de voorwaarden die uit de huidige rechtspraak kunnen worden afgeleid.

Art. 15.9 lid 1 Ow gaat - net als het door de Tweede Kamer aangenomen art. 15.7 lid $1 \mathrm{Ow}$ - uit van een gefixeerd 4\%-forfait wegens normaal maatschappelijk risico bij permanente waardevermindering van onroerende zaken. Anders dan de originele bepaling, is de door mij voorgestelde bepaling van toepassing op zowel indirecte als directe schade. Die keuze is onder andere gemaakt met het oog op de doelstellingen van vergroting van de rechtszekerheid, en vereenvoudiging, uniformering en harmonisering van het nadeelcompensatierecht. Het tweede en derde lid van de voorgestelde bepaling kwamen al voor in de originele bepaling, zij het dat enkele redactionele wijzigingen zijn doorgevoerd vanwege de doelstelling van vergroting van de rechtszekerheid.

Ten slotte ${ }^{38}$ codificeert art. 15.4 Ow de huidige planschadejurisprudentie omtrent het nauw verweven zijn van planologische besluiten. In onderdeel b wordt ervan uitgegaan dat de desbetreffende besluiten onherroepelijk moeten zijn op het moment van het besluit op de aanvraag om nadeelcompensatie. Daarmee is geanticipeerd op een ontwikkeling waarvan ik verwacht dat zij zich zal voordoen in de jurisprudentie - mits de Afdeling daartoe de juiste rechtsvraag krijgt voorgelegd. ${ }^{39}$ Zou de wetgever slechts de huidige jurisprudentie willen codificeren, dan zou in

37 Zie paragraaf 8.2.3.3 onder het kopje 'Titel 4.5 Awb of afd. 15.1 Ow?'.

38 De bepalingen uit mijn voorstel voor afd. 15.1 Ow die ik hier niet heb besproken, zijn ongewijzigd overgenomen uit de versie van deze afdeling die werd aangenomen door de Tweede Kamer - behoudens dat zij veelal zijn vernummerd.

39 Zie daarover paragraaf 9.1.1 onder het kopje 'Verrekening met voordeel uit nauw verweven overheidshandelingen'. 
deze bepaling moeten worden uitgegaan van het moment van indiening van de aanvraag.

\title{
11.4 AANBEVELINGEN OM (C) ANDERSZINS TE VOORZIEN IN BIJZONDERE INVULLINGEN, AANVULLINGEN, OF AFWIJKINGEN VAN TITEL 4.5 AWB
}

11.4.1 Inleiding en aanbevelingen tot wijziging van andere formele wetgeving dan titel $4.5 \mathrm{Awb}$ of afd. $15.1 \mathrm{Ow}$

De directe aanleiding voor dit onderzoek is gelegen in de door de formele wetgever ondervonden problematiek van afstemming van titel 4.5 Awb tot afd. $15.1 \mathrm{Ow}$ en de thans geldende nadeelcompensatieregelgeving. Mede gelet op de doelstelling van vereenvoudiging, uniformering en harmonisering van het nadeelcompensatierecht, verbaast het niet dat relatief veel van mijn aanbevelingen zijn gericht tot de formele wetgever. ${ }^{40}$ Die aanbevelingen zien doorgaans op de wijziging van titel 4.5 Awb of afd. 15.1 Ow. In geringe mate zien zij echter ook op andere delen van de Awb of de Ow. Ten eerste is er de hiervoor in paragraaf 11.3.2 besproken aanbeveling tot introductie in hoofdstuk $11 \mathrm{Ow}$ van een recht op uitkoop voor de eigenaar die zijn onroerende zaak gedurende een zekere periode niet heeft weten te verkopen als gevolg van indicatief overheidshandelen. Ten tweede is in paragraaf $10.12 .3,{ }^{41}$ bezien vanuit de doelstelling van vergroting van de rechtszekerheid, een alternatieve redactie van art. $13.3 \mathrm{c}$ lid $1 \mathrm{Ow}$ voorgesteld:

\begin{abstract}
"De rechtspersoon waartoe het bestuursorgaan behoort dat vergoeding van schade als bedoeld in artikel 4:126 van de Algemene wet bestuursrecht in samenhang met artikel 15.1, eerste lid, toekent, kan met degene die de activiteit verricht naar aanleiding waarvan de vergoeding is toegekend, overeenkomen dat de toe te kennen schadevergoeding en de daarmee samenhangende kosten geheel of gedeeltelijk voor zijn rekening komen."
\end{abstract}

Ten slotte is in paragraaf 10.12.3 betoogd dat art. 8:6 lid 2 Awb conflicteert met het uitgangspunt van aansluiting bij de Awb en de doelstellingen van vergroting van de doelmatigheid van het nadeelcompensatierecht en vermindering van bestuurslasten, vergroting van de rechtsgelijkheid, en vereenvoudiging van het nadeelcompensatierecht. Naar aanleiding daarvan is voorgesteld deze bepaling te vervangen door een bepaling die dat niet doet, namelijk art. 4.5.7 van het voorontwerp van de Wns:

"Indien hoger beroep is ingesteld tegen een uitspraak over een besluit omtrent nadeelcompensatie als bedoeld in deze titel, verwijst de Afdeling bestuursrechtspraak van de Raad van State de behandeling naar een andere hogerberoepsrechter, indien de behan-

$40 \quad$ Zie daarover meer uitgebreid paragraaf 2.4.2.3.

41 Zie het kopje 'Schade- en kostenverhaal via art. $13.3 \mathrm{c}$ jo. $13.3 \mathrm{~d}$ Ow'. 
deling van het hoger beroep door deze rechter naar haar oordeel gewenst is. Artikel $8: 13$, tweede en derde lid, is van overeenkomstige toepassing."

Soms bleek formele wetgeving echter niet het meest geschikte middel om de aan de Wns ten grondslag liggende doelstellingen en uitgangspunten te behartigen. Bepaalde onderwerpen, zoals de begroting van schade, laten zich namelijk lastig in algemene zin regelen in een nadeelcompensatieregeling met een brede reikwijdte als titel 4.5 Awb of afd. 15.1 Ow. De formele wetgever kan dus in bepaalde situaties slechts tot op beperkte hoogte optreden. Dan dient de bal te worden opgepakt door een andere actor in het nadeelcompensatierecht. Zo is bijvoorbeeld in paragraaf 4.4.1 aanbevolen dat de rechter uniform één standaardformule hanteert bij de motivering van zijn causaliteitsoordeel. Ook is denkbaar dat een bepaald onderwerp wel in een formele wet kan worden geregeld, maar een andere actor simpelweg in een betere positie verkeert om hetgeen wordt beoogd te bereiken. Zo is in paragraaf 6.3.3 aanbevolen dat de regering bij amvb de in de Handleiding nadeelcompensatie voorgestelde systematiek inzake de afbakening van het normaal ondernemersrisico vaststelt voor inkomensschade door tijdelijke infrastructurele activiteiten. In het vervolg van deze paragraaf zal ik een overzicht geven van deze - niet op formele wetgeving gerichte - aanbevelingen om (c) anderszins te voorzien in een bijzondere invulling, aanvulling of afwijking van titel $4.5 \mathrm{Awb}$.

\subsubsection{Aanbevelingen aan het kabinet of de regering}

\section{Evaluatie van de reikwijdte van titel $4.5 \mathrm{Awb}$}

In paragraaf 3.4.1 bleek dat de brede reikwijdte van titel 4.5 Awb in beginsel goed past bij de aan de Wns ten grondslag liggende doelstellingen en uitgangspunten. Het is op voorhand echter lastig in te schatten of, en zo ja in hoeverre, zij ook tot problemen zal leiden. Daarom is voorgesteld dat wordt geëvalueerd of de brede reikwijdte van titel 4.5 Awb tot problemen leidt buiten het omgevingsrecht. Het ligt het meest voor de hand dat het kabinet, vertegenwoordigd door de minister voor Rechtsbescherming of de minister van Binnenlandse Zaken en Koninkrijksrelaties, daarin het voortouw neemt. Als uit deze evaluatie knelpunten zouden blijken, dan zou het - mede gelet op de doelstelling van vergroting van de doelmatigheid van het nadeelcompensatierecht en vermindering van bestuurslasten - in de rede liggen oplossingen daarvoor te treffen, al dan niet voor een specifiek deelgebied van het nadeelcompensatierecht. Daarbij kan mogelijk aansluiting worden gezocht bij oplossingen die zijn voorgesteld in publicaties waarin is geïnventariseerd welke problemen zich in theorie zouden kunnen gaan voordoen. ${ }^{42}$ 


\section{Model delegatiebesluit}

In paragraaf 4.4.1 bleek dat causaliteitsproblemen zich met name voordoen in geschillen waarin extra schakels bestaan tussen de gestelde schade en beweerde schadeoorzaak. Het zou goed passen bij de doelstellingen van vergroting van de rechtszekerheid en rechtsgelijkheid, vereenvoudiging, uniformering en harmonisering van het nadeelcompensatierecht, en vergroting van de doelmatigheid van het nadeelcompensatierecht en vermindering van bestuurslasten als de praktijk betere handvatten zou hebben om met dit soort gevallen om te gaan. De vrijwillige overnamebevoegdheid van art. 4:138 Awb is zo een handvat. Haar succes zal echter afhankelijk zijn van de mate waarin de betrokken bestuursorganen erin slagen onderlinge afspraken te maken over de verdeling van de kosten die gepaard gaan met de toekenning van nadeelcompensatie. Daarom is voorgesteld dat het kabinet, of een partij als de VNG, een 'model delegatiebesluit' opstelt waarin ook een passage is opgenomen over de verdeling van de schadelast. Dat past ook in algemene zin goed bij de doelstelling van vergroting van de doelmatigheid van het nadeelcompensatierecht en vermindering van bestuurslasten. ${ }^{43}$

\section{Verduidelijking eisen causaal verband en schadebegroting}

In paragrafen 4.4.3 en 5.7.3.2 $2^{44}$ is aandacht besteed aan de onduidelijkheid die de verschuiving van het schademoment onder de Ow meebrengt met betrekking tot de vaststelling van causaal verband en de begroting van schade. Die onduidelijkheid verhoudt zich slecht tot de aan de Wns ten grondslag liggende doelstellingen van vergroting van de rechtszekerheid, en vergroting van de doelmatigheid van het nadeelcompensatierecht en vermindering van bestuurslasten. Daarom is aanbevolen dat het kabinet of de wetgever duidelijker aangeeft welke vergelijking bij toepassing van afd. $15.1 \mathrm{Ow}$ dient te worden gemaakt om csqn-verband vast te stellen, en in hoeverre de uitkomst van die vergelijking nog van invloed is op de schadebegroting. Daarbij dient mijns inziens in ieder geval aandacht te worden besteed aan de in deze paragrafen benoemde knelpunten. De aanbevolen verduidelijking leent zich naar mijn mening niet voor uitwerking in de tekst van afd. 15.1 Ow, maar zou bijvoorbeeld kunnen geschieden in een Kamerbrief of een ander toelichtend stuk.

\section{Aansluiting bij art. 15.7 lid 1 Ow (originele bepaling)/art. 15.9 lid $1 \mathrm{Ow}$ (als aanbevolen)}

Bezien vanuit de doelstelling van uniformering en harmonisering van het nadeelcompensatierecht, is in paragraaf 6.2.3.1 aanbevolen dat het kabinet of de formele wetgever in een toelichtend stuk aangeeft dat bestuursorganen en rechters bij toe-

43 Zie hierover paragraaf 4.4.2 onder het kopje 'Incidentele interbestuurlijke samenwerking'.

44 Zie respectievelijk de kopjes 'De verschuiving van het schademoment en de csqntoets' en 'Onvoldoende sturing'. 
passing van titel 4.5 Awb zoveel mogelijk moeten aansluiten bij het gefixeerde 4\%-forfait van art. 15.7 lid $1 \mathrm{Ow}$ (originele bepaling)/art. 15.9 lid $1 \mathrm{Ow}$ (als aanbevolen) in gevallen van permanente waardevermindering van onroerende zaken die niet onder het bereik van afd. $15.1 \mathrm{Ow}$ vallen. Mede gelet op de in paragraaf 6.2.1.5 besproken jurisprudentie, zullen rechters en bestuursorganen daar met name gehoor aan kunnen geven als de aard van de schade en de schadeoorzaak overeenkomstig is.

\section{Codificatie Handleiding nadeelcompensatie en instelling werkgroep ondernemersrisico}

In paragraaf $6.3 .3^{45}$ is betoogd dat de door de Handleiding nadeelcompensatie voorgestelde systematiek voor afbakening van het normaal ondernemersisico goed aansluit op de doelstellingen van vergroting van de doelmatigheid van het nadeelcompensatierecht en vermindering van bestuurslasten, vergroting van de rechtszekerheid en rechtsgelijkheid, en codificatie van het nadeelcompensatierecht. Ook lijkt zij verenigbaar met de aan de Wns ten grondslag liggende uitgangspunten. Daarom is aanbevolen dat de regering - op grond van art. 4:129 lid 2 Awb als aanbevolen - een amvb vaststelt waarin deze afbakeningssystematiek uniform wordt voorgeschreven bij tijdelijke inkomensschade door infrastructurele activiteiten. Codificatie in een amvb past wellicht iets minder goed bij de doelstelling van vereenvoudiging van het nadeelcompensatierecht dan codificatie in titel 4.5 Awb had gedaan - waarvoor ik de tijd nu nog niet rijp acht - maar past desondanks goed bij de doelstelling van uniformering en harmonisering van het nadeelcompensatierecht. Gelet op de doelstelling van vereenvoudiging, uniformering en harmonisering van het nadeelcompensatierecht is ten slotte aanbevolen (dit deel van) deze amvb de status van dwingend recht toe te kennen. In paragraaf $6.5^{46}$ is een concreet voorstel gedaan voor bepalingen waarmee gehoor kan worden gegeven aan deze aanbeveling.

In paragraaf 6.3.3 zijn ook nog enkele andere aanbevelingen gedaan ter behartiging van de doelstelling van vereenvoudiging, uniformering en harmonisering van het nadeelcompensatierecht. Allereerst zou in de toelichting op de voorgestelde amvb moeten worden vermeld dat bestuursorganen bij permanente inkomensschade, en tijdelijke inkomensschade die niet wordt veroorzaakt door infrastructurele werkzaamheden, zoveel mogelijk moeten aansluiten bij de in de amvb voorgeschreven bepalingen. Verder zou het kabinet er mijns inziens goed aan doen een werkgroep in te stellen die evalueert hoe (toepassing van) de voorgestelde amvb wordt ervaren door de praktijk, en wordt beoordeeld in de jurisprudentie. Ook zou de werkgroep moeten nagaan of het mogelijk is om het toepassingsbereik van de in de amvb - en dus ook in de handleiding - voorgeschreven afbakeningssystema-

45 Zie het kopje 'Codificatie van de handleiding bij wijze van titel 4.5 Awb-interpreterende amvb'.

Zie het kopje 'Inkomensschade'. 
tiek verder uit te breiden. De bevindingen van de werkgroep zouden aanleiding kunnen geven tot bijstelling van de in de amvb voorgeschreven systematiek, respectievelijk tot uitbreiding van het toepassingsbereik daarvan. Op langere termijn zouden de bevindingen van de werkgroep eventueel ook ertoe kunnen leiden dat de bepalingen uit de amvb alsnog een plaats wordt gegeven in titel $4.5 \mathrm{Awb}$ en/of afd. $15.1 \mathrm{Ow}$.

Instelling werkgroep normaal maatschappelijk risico bij tijdelijke derving woongenot en eventuele vaststelling amvb

In paragraaf 6.4 .3 bleek dat het zich op het eerste oog slecht verhoudt tot de doelstellingen van vereenvoudiging, uniformering en harmonisering van het nadeelcompensatierecht, vergroting van de rechtszekerheid, en codificatie van het nadeelcompensatierecht dat titel 4.5 Awb en afd. 15.1 Ow geen bijzondere normering bevatten omtrent de afbakening van het normaal maatschappelijk risico bij schade in de vorm van tijdelijke derving van woongenot. Het bleek echter ook dat te weinig houvast in het huidige recht kan worden gevonden om dergelijke normering vast te stellen. Daarom is aanbevolen dat het kabinet een werkgroep instelt die onderzoekt hoe (door middel van regelgeving of beleid) meer rechtszekerheid aan burger, bestuur en/of rechter zou kunnen worden geboden omtrent de afbakening van het normaal maatschappelijk risico bij tijdelijke derving van woongenot. Daarbij zou mijns inziens in ieder geval moeten worden onderzocht of maatwerk wenselijk is bij deze afbakening van het normaal maatschappelijk risico, en zo ja, hoe dat maatwerk kan worden gerealiseerd terwijl zo min mogelijk wordt ingeleverd op rechtszekerheid en efficiëntie. Aan de hand van de bevindingen van deze werkgroep kan de regering besluiten om over te gaan tot vaststelling van regelgeving. Omwille van dezelfde argumenten als zijn aangevoerd ten aanzien van de Handleiding nadeelcompensatie, ${ }^{47}$ zou het de voorkeur verdienen als de regering die regelgeving in eerste instantie zou opnemen in een amvb die de status van dwingend recht heeft. Het ligt voor de hand dit te realiseren door middel van een toevoeging aan de eerder voorgestelde amvb omtrent het normaal ondernemersrisico.

\section{Opstellen van modelbrieven}

In paragraaf 10.11.3 is aanbevolen dat het kabinet, of een partij als de VNG, modelbrieven opstelt waarmee het bestuur en de adviescommissie kunnen voldoen aan hun informatieverplichtingen uit art. 4:136 lid 1 respectievelijk lid 4, aanhef en onder d Awb (als aanbevolen). Dat past namelijk goed bij de doelstellingen van

47 Kort gezegd: de keuze voor een amvb heeft tot gevolg dat de afbakening van het normaal maatschappelijk risico bij tijdelijke derving van woongenot zoveel mogelijk wordt geharmoniseerd en geüniformeerd, terwijl - in vergelijking met een wet in formele zin - relatief eenvoudig en snel correcties kunnen worden aangebracht naar aanleiding van de ervaringen die in de praktijk worden opgedaan met de in de amvb vervatte normering. 
uniformering en harmonisering van het nadeelcompensatierecht, vergroting van de rechtsgelijkheid, en vergroting van de doelmatigheid van het nadeelcompensatierecht en vermindering van bestuurslasten.

\subsubsection{Aanbevelingen aan de rechter}

\section{Motivering causaliteitsoordeel}

In paragraaf 4.4.1 is betoogd dat de motivering van het rechterlijk causaliteitsoordeel naar huidig recht niet altijd even eenvoudig is te doorgronden. Uiteraard bepalen de beroepsgronden welke causaliteitsvragen een rechter kan beantwoorden. Gelet op de doelstelling van vergroting van de rechtszekerheid is echter aanbevolen dat de rechter bij beantwoording van die vragen altijd expliciteert welke causaliteitsvraag hij wanneer beantwoordt én welke omstandigheden hij daarbij in welke mate relevant acht. ${ }^{48}$ In het verlengde hiervan is de aanbeveling gedaan dat de rechter zoveel mogelijk één uniforme formule hanteert om invulling te geven aan de toerekeningsvraag. Daarbij zou kunnen worden gedacht aan:

"Schade die in zodanig verband met [de beweerde schadeoorzaak] staat dat zij [het bestuursorgaan] mede gezien de aard van de aansprakelijkheid en van de schade, als een rechtstreeks gevolg van [de beweerde schadeoorzaak] kan worden toegerekend."

Opvolging van deze aanbevelingen zou bijdragen aan de vergroting van de rechtszekerheid doordat het causaliteitsoordeel inzichtelijker en daarmee voorspelbaarder wordt. Tevens zou dit de rechtszekerheid en rechtsgelijkheid vergroten, doordat overlap wordt voorkomen tussen het causaliteitscriterium en andere eisen die titel $4.5 \mathrm{Awb}$ aan de toekenning van nadeelcompensatie stelt.

\section{Invulling dubbele redelijkheidstoets bij schadebeperkende maatregelen}

In paragraaf 5.4.3 $3^{49}$ bleek dat de Afdeling de dubbele redelijkheidstoets bij de beoordeling van de vergoedbaarheid van kosten van schadebeperkende maatregelen strenger invult dan de civiele rechter. Het lijkt er niet op dat de Afdeling op dit punt bewust de keuze heeft gemaakt om van het civiele recht af te wijken. Ook overigens zie ik geen goede redenen om dit verschil met het civiele recht in stand te houden. Bezien vanuit het uitgangspunt van aansluiting bij het BW, is daarom aanbevolen dat de bestuursrechter een einde maakt aan dit soort onwenselijke verschillen met de civielrechtelijke invulling van de dubbele redelijkheidstoets.

$48 \quad$ Zie ook Huijts \& Tjepkema 2017, p. 302.

49 Zie het kopje 'De invulling van de dubbele redelijkheidstoets'. 


\section{Voorafgaand aan het conceptadvies gemaakte deskundigenkosten}

In paragraaf 5.5.1.6 bleek dat de Afdeling gedurende enige tijd tegenstrijdige jurisprudentielijnen bezigde ten aanzien van de vergoeding van deskundigenkosten gemaakt voorafgaand aan het conceptadvies van de door het bestuur geraadpleegde deskundige, zonder dat daarvoor een duidelijke verklaring kan worden aangedragen. Gelet op de doelstellingen van vereenvoudiging, uniformering en harmonisering van het nadeelcompensatierecht, vergroting van de rechtszekerheid, en vergroting van de doelmatigheid van het nadeelcompensatierecht en vermindering van bestuurslasten, is in paragraaf 5.5.3 aanbevolen dat onder het toekomstige recht een duidelijk en eenduidig standpunt wordt ingenomen ten aanzien van de vergoedbaarheid van deze kosten. Naar aanleiding daarvan, is om verschillende redenen aanbevolen dat de rechter de jurisprudentielijn verlaat dat voorafgaand aan het conceptadvies gemaakte deskundigenkosten nooit voor vergoeding in aanmerking komen. Hij zou de redelijkheid van deze kosten steeds moeten bepalen aan de hand van de omstandigheden van het individuele schadegeval. Voor een niet-limitatieve opsomming van factoren die daarbij een rol kunnen spelen, verwijs ik naar paragraaf 5.5.3. ${ }^{50}$

\section{Aansluiting bij normering omtrent het normaal maatschappelijk risico}

In paragraaf 11.4.2 is ingegaan op de redenen waarom de rechter zoveel mogelijk zou moeten aansluiten bij art. 15.7 lid $1 \mathrm{Ow}$ (originele bepaling)/art. 15.9 lid $1 \mathrm{Ow}$ (als aanbevolen) voor de beoordeling van het normaal maatschappelijk risico in gevallen van permanente waardevermindering van onroerende zaken die niet onder het bereik van afd. 15.1 Ow vallen. Gelet op de doelstelling van uniformering en harmonisering van het nadeelcompensatierecht, ligt het eveneens voor de hand dat de rechter voor permanente inkomensschade, en tijdelijke inkomensschade die niet wordt veroorzaakt door infrastructurele werkzaamheden zoveel mogelijk aansluiting zoekt bij de voorgestelde amvb omtrent ondernemersrisico bij schade door dat type werkzaamheden. ${ }^{51}$

\section{Overzichtsuitspraak over normaal maatschappelijk risico bij tijdelijke derving van woongenot}

Gelet op de doelstelling van vergroting van de rechtszekerheid, is in paragraaf 6.4.3 ${ }^{52}$ aanbevolen dat de Afdeling een overzicht geeft van haar jurisprudentielijnen inzake het normaal maatschappelijk risico bij tijdelijke derving van woongenot, ongeacht of het kabinet besluit tot de in paragraaf 11.4.2 aanbevolen instelling van een werkgroep die onderzoekt in hoeverre sturing kan worden geboden

\footnotetext{
50 Zie het kopje 'Voorafgaand aan het conceptadvies gemaakte deskundigenkosten en invulling van de dubbele redelijkheidstoets'.

51 Zie daarover paragraaf 11.4.2 onder het kopje 'Codificatie Handleiding nadeelcompensatie en instelling werkgroep ondernemersrisico'. Zie het kopje 'Een overzichtsuitspraak'.
} 
omtrent de afbakening van het normaal maatschappelijk risico bij dit type schade. Ondanks dat een dergelijke overzichtsuitspraak beperkt in omvang zal zijn, ${ }^{53}$ vormt zij een middel om - in afwachting van de uitkomsten van het onderzoek door de werkgroep - op korte termijn relatief veel zekerheid te verschaffen.

\section{Stoppen met verwarrende overweging omtrent passieve risicoaanvaarding}

Bij bestudering van planschadejurisprudentie viel op dat de rechterlijke macht soms overweegt dat de benadeelde geen gebruik heeft gemaakt van de mogelijkheid om schade te beperken doordat hij voorafgaand aan de schadeveroorzakende planologische maatregel geen concrete poging heeft ondernomen om de daardoor vervallen planologische bouw- of gebruiksmogelijkheid te benutten, waardoor hem passieve risicoaanvaarding kan worden tegengeworpen. Dergelijke overwegingen brengen het risico met zich dat het onderscheid tussen risicoaanvaarding en het niet voldoen aan de algemene schadebeperkingsplicht - twee afzonderlijke vormen van eigen schuld - onnodig wordt vertroebeld. Dat past niet goed bij de doelstelling van vergroting van de rechtszekerheid. In paragraaf 8.3.3.2 is daarom aanbevolen dat de rechterlijke macht deze overweging achterwege laat bij toepassing van titel 4.5 Awb.

\subsubsection{Aanbevelingen aan overige bestuursorganen}

Hierna worden de aanbevelingen weergegeven die zijn gericht aan andere bestuursorganen dan de regering. Opvolging van deze aanbevelingen zou voor een deel leiden tot vaststelling van nieuwe regelgeving, praktisch gezien veelal in de vorm van een gemeentelijke verordening. Bij het lezen van die aanbevelingen dient in gedachten te worden gehouden dat de staatsrechtelijke grenzen als besproken in paragraaf 2.5, tot gevolg zullen hebben dat alle thans bestaande nadeelcompensatieverordeningen van rechtswege zullen komen te vervallen. ${ }^{54}$ De voorgestelde bepalingen vormen het minimum aan decentrale regelgeving dat ik nodig acht om titel 4.5 Awb en afd. 15.1 Ow te laten functioneren op de wijze die het best past bij de doelstellingen en uitgangspunten die aan de Wns ten grondslag liggen.

\section{Meervoudige causaliteit}

Bezien vanuit de doelstellingen van vergroting van de rechtszekerheid en rechtsgelijkheid, vereenvoudiging, uniformering en harmonisering van het nadeelcompensatierecht, en vergroting van de doelmatigheid van het nadeelcompensatierecht en vermindering van bestuurslasten, zijn in paragraaf 4.4.2 enkele aanbevelingen

53 Er is namelijk niet veel jurisprudentie gewezen omtrent dit onderwerp, zie paragraaf 6.4.1.2 e.v.

54 Daarvoor is relevant dat de in paragraaf 11.2.1 aanbevolen redactie van titel 4.5 Awb aanzienlijk meer normering bevat omtrent de procedure waarlangs een aanvraag om nadeelcompensatie dient te worden behandeld dan de originele redactie van deze titel. 
gedaan aan het bestuur omtrent meervoudige causaliteit. Ten aanzien van schade die ontstaat naar aanleiding van meerdere handelingen van hetzelfde bestuursorgaan, is aanbevolen dat dit bestuursorgaan zich meedenkend opstelt bij de beantwoording van de vraag welk deel van de beweerdelijk schadeveroorzakende overheidshandelingen onder het bereik van titel 4.5 Awb en/of afd. 15.1 Ow kan worden gebracht. Ook zijn enkele aanbevelingen gedaan aan bestuursorganen die gezamenlijk een project aangaan dat potentieel tot aanvragen om nadeelcompensatie zou kunnen leiden. Zij zouden mijns inziens zo vroeg mogelijk in contact moeten treden met elkaar én met potentiële benadeelden. Verder zouden zij een eventuele aanvraag om nadeelcompensatie gezamenlijk moeten behandelen, en gezamenlijk één rechterlijke procedure moeten voeren als de aanvrager zich niet kan vinden in de uitkomst van de primaire besluitvorming en de besluitvorming in de bezwaarfase.

\section{Kosten van schadebeperkende maatregelen}

Bezien vanuit de doelstellingen van codificatie van het nadeelcompensatierecht en vergroting van de rechtszekerheid, is in paragraaf $5.4 .3^{55}$ een aanbeveling aan het bestuur gedaan met betrekking tot de vergoeding van kosten van schadebeperkende maatregelen. Indien een maatregel of project tot schade voor een grote groep burgers zal leiden en dit type schade doorgaans kan worden voorkomen door een bepaald type schadebeperkende maatregel, zou het bestuur er goed aan doen om in een wetsinterpreterende beleidsregel vast te leggen dat het nemen van een dergelijke maatregel in elk geval redelijk zal worden geacht tot een bepaald bedrag aan kosten.

\section{Forfaitaire begrotingsmaatstaven}

In paragraaf 5.7.3.3 is aanbevolen dat - waar mogelijk - een op empirisch onderzoek gebaseerde, forfaitaire begrotingsmaatstaf wordt neergelegd in titel $4.5 \mathrm{Awb}$ interpreterende verordeningen of beleidsregels die betrekking hebben op schadeveroorzakend overheidshandelen dat een duidelijk af te bakenen groep burgers op min of meer gelijke wijze beïnvloedt. Dergelijke forfaitaire regelingen dienen wel steeds voldoende ruimte te laten tot afwijking in het individuele schadegeval. In algemene zin sluiten dit soort regelingen goed aan op de doelstellingen van vergroting van de rechtszekerheid, codificatie van het nadeelcompensatierecht, en vergroting van de doelmatigheid van het nadeelcompensatierecht en vermindering van bestuurslasten. Een bijkomend voordeel zou zijn dat een veelvoud van dit soort 'micro-onderzoekjes' op termijn eraan zou kunnen bijdragen dat genoeg data beschikbaar komt om een algemener toepasbaar forfaitair stelsel vast te stellen op nationaal niveau. 


\section{Aansluiting bij normering omtrent het normaal maatschappelijk risico}

In paragraaf 11.4.2 is ingegaan op de redenen waarom het bestuur zoveel mogelijk zou moeten aansluiten bij art. 15.7 lid $1 \mathrm{Ow}$ (originele bepaling)/art. 15.9 lid $1 \mathrm{Ow}$ (als aanbevolen) voor de afbakening van het normaal maatschappelijk risico in gevallen van permanente waardevermindering van onroerende zaken die niet onder het bereik van afd. 15.1 Ow vallen. Gelet op de doelstelling van uniformering en harmonisering van het nadeelcompensatierecht, ligt het eveneens voor de hand dat het bestuur voor permanente inkomensschade, en tijdelijke inkomensschade die niet wordt veroorzaakt door infrastructurele werkzaamheden zoveel mogelijk aansluiting zoekt bij de voorgestelde amvb omtrent ondernemersrisico bij schade door dat type werkzaamheden. ${ }^{56}$

\section{Beleidsregel over normaal maatschappelijk risico bij tijdelijke derving van woongenot}

Gelet op de doelstellingen van codificatie van het nadeelcompensatierecht en vergroting van de rechtszekerheid, is in paragraaf 6.4.3 aanbevolen dat bestuursorganen het in een titel 4.5 Awb-interpreterende beleidsregel kenbaar maken wanneer zij voornemens zijn het normaal maatschappelijk risico bij tijdelijke derving van woongenot op één specifieke manier te vormgeven. Bij het opstellen van de voorgestelde beleidsregels, zou de eerder in paragraaf 11.4.3 aanbevolen overzichtsuitspraak als inspiratiebron kunnen dienen. De beleidsregels zouden kunnen komen te vervallen als de regering op een later moment zou besluiten een dwingendrechtelijke amvb over dit onderwerp vast te stellen. ${ }^{57}$

\section{Speciale last}

In paragraaf 11.2.1 is voorgesteld om in art. 4:130 Awb een normatieve maatstaf op te nemen ter invulling van het criterium van de speciale last. Voor de toepassing van die maatstaf is doorslaggevend of de schadeoorzaak tot stand is gekomen met de intentie een (door een bepaalde groep personen of ondernemers in het leven geroepen) nadeel voor de samenleving weg te nemen. Gelet op de doelstellingen van vergroting van de rechtszekerheid, en vergroting van de doelmatigheid van het nadeelcompensatierecht en vermindering van bestuurslasten, is daarom in paragraaf 7.5 aanbevolen dat informatie omtrent de reden van totstandkoming wordt opgenomen in de toelichting op een potentieel schadeveroorzakend besluit. Indien dergelijke informatie zich in algemene zin laat verwoorden ten aanzien van de schadeoorzaken die onder de reikwijdte vallen van een titel 4.5 Awb-interpreterende verordening of beleidsregel, zou dergelijke informatie ook kunnen worden verstrekt in de toelichting op die verordening respectievelijk beleidsregel.

56 Zie daarover paragraaf 11.4.2 onder het kopje 'Codificatie Handleiding nadeelcompensatie en instelling werkgroep ondernemersrisico'.

57 Zie daarover paragraaf 11.4.2 onder het kopje 'Instelling werkgroep normaal maatschappelijk risico bij tijdelijke derving woongenot en eventuele vaststelling amvb'. 


\section{Beleidsregels omtrent risicoaanvaarding}

In paragraaf 8.2.3.1 is aanbevolen dat bestuursorganen steeds nagaan in hoeverre zij in wetsinterpreterende verordeningen of beleidsregels op voorhand zekerheid kunnen verschaffen omtrent de peildatum voor risicoaanvaarding. Soms zal daarbij kunnen worden gewerkt met een tabel vergelijkbaar met die uit de VNNZ, maar vaak zal ook kunnen worden volstaan met een bepaling waaruit blijkt welke datum als peildatum wordt gehanteerd voor veronderstelde voorzienbaarheid bij behandeling van een bepaalde categorie aanvragen. Beide opties passen goed bij de doelstellingen van vergroting van de rechtszekerheid en rechtsgelijkheid, en vergroting van de doelmatigheid van het nadeelcompensatierecht en vermindering van bestuurslasten. Gelet op de doelstelling van vergroting van de rechtszekerheid verdient wel aanbeveling dat in dit soort beleidsregels of verordeningen geen bepalingen worden opgenomen met opsommingen omtrent het onderwerp van de voorzienbaarheid. Dergelijke opsommingen kunnen namelijk verwarrend werken doordat de daarin genoemde onderwerpen veelal onderlinge overlap zullen vertonen, én overlap met de in de jurisprudentie gestelde voorwaarden voor tegenwerping van risicoaanvaarding.

\section{Introductie van een aanvraagformulier en normering inzake aan te leveren documenten}

In paragraaf 10.3.3 is aanbevolen dat regelgevers en uitvoerende bestuursorganen steeds nagaan in hoeverre het mogelijk is om in titel 4.5 Awb-interpreterende regelgeving respectievelijk beleidsregels te concretiseren welke specifieke documenten de aanvrager dient aan te leveren bij zijn aanvraag om nadeelcompensatie. Het ligt voor de hand dat de mogelijkheid daartoe met name zal bestaan als de desbetreffende regeling uitsluitend ziet op schadeveroorzakend overheidshandelen dat een duidelijk af te bakenen groep burgers op min of meer gelijke wijze beïnvloedt. Ook is aanbevolen dat onder titel 4.5 Awb en afd. 15.1 Ow wordt gewerkt met een aanvraagformulier als bedoeld in art. 4:4 Awb. Mijns inziens zou dat op centraal overheidsniveau het best kunnen geschieden door de minister van I\&W te laten nagaan of, en zo ja in hoeverre, zijn onder de BnIW 2019 gebruikte aanvraagformulier daartoe aanpassing zou behoeven. Op basis van de bevindingen van de minister zou een organisatie als de VNG een modelformulier kunnen opstellen voor de decentrale overheden. Beide aanbevelingen zijn ingegeven door de doelstellingen van uniformering en harmonisering van het nadeelcompensatierecht, ${ }^{58}$ vergroting van de rechtszekerheid, en vergroting van de doelmatigheid van het nadeelcompensatierecht en vermindering van bestuurslasten.

58 Mogelijk leidt het werken met een (model)aanvraagformulier ook tot vereenvoudiging van het nadeelcompensatierecht, omdat hierdoor de noodzaak tot raadpleging van lagere regelgeving afneemt. 


\section{Voorlichting}

Ten slotte is in paragraaf 10.4.3 aanbevolen dat het bestuur reeds in een vroeg stadium in contact treedt met (potentiële) benadeelden teneinde voorlichting te geven over de relatief strenge voorwaarden voor toekenning van nadeelcompensatie. In de Handleiding nadeelcompensatie wordt beschreven hoe dat het best kan worden aangepakt. ${ }^{59}$ Deze aanbeveling is ingegeven door de doelstellingen van vergroting van de rechtszekerheid, en vergroting van de doelmatigheid van het nadeelcompensatierecht en vermindering van bestuurslasten. Zij schept namelijk duidelijkheid omtrent de criteria voor toekenning van nadeelcompensatie en voorkomt daardoor dat aanvragen om nadeelcompensatie (te) lichtzinnig worden ingediend.

\subsection{SLOTOPMERKING}

In het tweede hoofdstuk van dit proefschrift is beschreven hoe het hedendaagse nadeelcompensatielandschap geleidelijk is ontstaan door een meer dan anderhalve eeuw durend samenspel van de formele wetgever, lagere regelgevers, uitvoerende bestuursorganen en de rechter. Inmiddels staan we op de rand van een nieuw tijdperk. Behoudens nieuw uitstel (of afstel) zal het nadeelcompensatielandschap zoals we dat vandaag de dag kennen namelijk ingrijpend wijzigen door de inwerkingtreding van titel 4.5 Awb en afd. 15.1 Ow op 1 januari 2021. Ik hoop van harte dat de onderzoeksbevindingen en aanbevelingen uit dit proefschrift eraan zullen bijdragen dat de transitie naar dit nieuwe nadeelcompensatierecht voorspoedig zal verlopen, niet alleen voor de hiervoor genoemde actoren, maar zeker ook voor u de lezer van dit proefschrift! 


\section{Hoofdstuk 12}

\section{Valorisatie-addendum}

\subsection{DOELGROEP VAN HET PROEFSCHRIFT}

Aan de hand van een analyse van het huidige en toekomstige nadeelcompensatierecht zijn in dit boek aanbevelingen gedaan aan de belangrijkste actoren in het nadeelcompensatierecht. Het boek is daarmee niet alleen relevant voor wetenschappers geïnteresseerd in het nadeelcompensatierecht en/of het snijvlak tussen publiek- en privaatrecht, maar ook voor de formele wetgever, lagere regelgevers, rechters en (uitvoerende) bestuursorganen. Tevens kan het boek nuttig zijn voor praktijkjuristen - zoals juridisch adviseurs en advocaten - bij de bestudering van het huidige en toekomstige nadeelcompensatierecht en de behartiging van de belangen van hun cliënten. Ten slotte kan het boek ook behulpzaam zijn voor de individuele burger die zich wil verdiepen in het nadeelcompensatierecht, al dan niet met de intentie om een aanvraag om nadeelcompensatie in te dienen of op te komen tegen een door het bestuur genomen nadeelcompensatiebesluit.

\subsection{DE ALGEMENE MAATSCHAPPELIJKE WAARDE VAN HET PROEFSCHRIFT}

In de eerste twee paragrafen van het eerste hoofdstuk van dit proefschrift is de aanleiding voor dit proefschrift beschreven: titel 4.5 Awb is ruim zes en een half jaar na zijn publicatie in het Staatsblad nog steeds niet in werking getreden. Deze regeling wordt - al vanaf de ontwerpfase, en na haar publicatie in het Staatsblad nog steeds - omgeven door discussie. Het belang van een algemene nadeelcompensatieregeling wordt breed onderschreven, maar het heeft er veel van weg dat de met de regeling gemoeide vragen dermate lastig zijn te beantwoorden en de betrokken (financiële) belangen dermate groot zijn dat de inwerkingtreding van deze wet steeds verder wordt uitgesteld. Een belangrijk deel van de vragen waarmee de wetgever wordt geconfronteerd, ziet op de reikwijdte van titel 4.5 Awb en - in relatie daarmee - de mate waarin deze regeling ruimte laat of zou moeten laten voor, dan wel in de plaats kan treden van, (onderdelen van) het thans bestaande veelvoud van bijzondere wettelijke en buitenwettelijke nadeelcompensatieregelingen. De keuzes omtrent het al dan niet (in ongewijzigde vorm) in stand houden van thans bestaande nadeelcompensatieregelgeving kunnen alleen op zinvolle wijze worden gemaakt als voldoende inzicht bestaat in de verhouding van titel 4.5 Awb tot afd. 15.1 Ow en tot overige bijzondere nadeelcompensatieregelingen. Gebrek aan dit inzicht lijkt in belangrijke mate bij te dragen aan het steeds opnieuw uitstellen van de inwerkingtreding van titel 4.5 Awb. 
De beantwoording van de in paragraaf 1.2 opgeworpen onderzoeksvragen heeft geleid tot inzicht in de verhouding tussen enkele van de naar huidig recht belangrijkste nadeelcompensatieregelingen. Per materieel criterium en procedureel voorschrift voor toekenning van nadeelcompensatie is onderzocht welke verschillen tussen deze regelingen bestaan en of, en zo ja in hoeverre, zij kunnen worden verklaard. Ook is inzicht verschaft in de wijze waarop het toekomstige nadeelcompensatierecht door de wetgever is vormgegeven en hoe dit recht in de praktijk zal moeten worden toegepast. Ten slotte is gebleken hoe dit nieuwe recht aansluit op de doelstellingen die de wetgever daarmee beoogde te realiseren, en hoe de belangrijkste actoren in het nadeelcompensatierecht ervoor kunnen zorgen dat deze aansluiting wordt verbeterd. De hierdoor opgedane inzichten zouden de inwerkingtreding van titel 4.5 Awb kunnen vergemakkelijken. Ook is het mijn verwachting dat opvolging van de gedane aanbevelingen zou bijdragen aan een beter functionerend nadeelcompensatierecht. De maatschappelijke baten daarvan zijn legio. Beschouwd vanuit economisch perspectief kan eveneens winst worden geboekt, aangezien een deel van de aanbevelingen (mede) is gedaan met het oog op de doelstelling van vergroting van de doelmatigheid van het nadeelcompensatierecht en vermindering van bestuurslasten.

\subsection{TOEGEVOEGDE WAARDE VAN HET PROEFSCHRIFT VOOR ACTOREN IN DE NADEELCOMPENSATIEPRAKTIJK}

In dit boek zijn veel aanbevelingen gedaan aan de formele wetgever. Opvolging van deze aanbevelingen zou onder andere ertoe leiden dat het toekomstige nadeelcompensatierecht beter aansluit op de oorspronkelijke doelstellingen van de wetgever, onnodige verschillen tussen het toekomstige nadeelcompensatierecht en het civiele recht worden weggenomen, en het nadeelcompensatierecht efficiënter functioneert. Zo wordt het bestuur bijvoorbeeld een hanteerbare maatstaf voor het criterium van de speciale last aangereikt en is voorgesteld alleen deskundigenadvies in te winnen als dat noodzakelijk is om tot een inhoudelijk juist besluit te komen. Als de formele wetgever de aan hem gedane aanbevelingen in eerste instantie niet zou overnemen, dan kunnen zij alsnog nuttig zijn. De andere actoren in het nadeelcompensatierecht kunnen dan immers nagaan in hoeverre zij deze aanbevelingen op een lager niveau kunnen implementeren. De formele wetgever zou de desbetreffende aanbevelingen echter ook als vertrekpunt kunnen nemen voor toekomstige evaluaties van het functioneren van titel $4.5 \mathrm{Awb}$ en afd. 15.1 Ow.

Ook de overige actoren uit de nadeelcompensatiepraktijk kunnen hun voordeel doen met de bevindingen uit dit proefschrift. Aan de rechter zijn enkele aanbevelingen gedaan om zijn uitspraken begrijpelijker te maken. Daarbij kan worden gedacht aan aanbevelingen voor een inzichtelijker causaliteitsoordeel, aanbevelingen om niet onnodig af te wijken van civielrechtelijke rechtspraak, en overige aanbevelingen om met relatief kleine inspanning te komen tot nog beter te begrijpen uitspraken. Dat kan niet alleen bijdragen in het vertrouwen in de rechtspraak, maar ook voorkomen dat onnodig in rechte wordt opgekomen tegen uitspraken gedaan 
in eerste aanleg. Tevens zijn aanbevelingen gedaan aan de regering en overige bestuursorganen. Daarbij kan worden gedacht aan voorstellen voor vaststelling van regelgeving of beleid, modelbrieven- en besluiten, en aanvraagformulieren. Voorts is bijvoorbeeld aanbevolen tot het geven van voorlichting en het in een vroeg stadium in contact treden met potentiële benadeelden. Ook opvolging van dit soort aanbevelingen zal naar mijn verwachting bijdragen aan een efficiënter en gebruiksvriendelijker nadeelcompensatierecht. Dat kan niet alleen financiële voordelen hebben voor de samenleving, bijvoorbeeld omdat minder wordt geprocedeerd tegen primaire nadeelcompensatiebesluitvorming, maar ook bijdragen aan (herstel van) het vertrouwen in de overheid.

Ten slotte hoop ik dat dit proefschrift ook in meer algemene zin nuttig zal zijn voor de maatschappij. Het planschade- en nadeelcompensatierecht is niet eenvoudig te doorgronden. Burgers hebben vaak hulp nodig van een gespecialiseerde advocaat om zich zowel materieel als procedureel een weg door het nadeelcompensatielandschap te waren. Ook het bestuur blijkt in de praktijk relatief veel deskundigenadvisering in te winnen om tot een gedegen nadeelcompensatiebesluit te komen. Ik hoop dat dit proefschrift voor al deze actoren zal bijdragen aan hun inzicht in de materiële criteria en procedurele voorschriften voor de toekenning van nadeelcompensatie, zodat zij efficiënter en zelfstandiger kunnen navigeren binnen het nadeelcompensatielandschap.

\subsection{VERHOUDING TOT ANDERE WETENSCHAPPELIJKE PUBLICATIES}

Schadevergoeding wegens rechtmatig overheidshandelen is reeds geruime tijd ${ }^{1}$ onderwerp van wetenschappelijke bestudering en discussie in het algemeen, en van proefschriften in het bijzonder. Enkele belangrijke studies zijn bijvoorbeeld het proefschrift van Van den Broek ${ }^{2}$ uit 2002 over de planschadevergoedingsregeling uit art. 49 WRO, het proefschrift van Tjepkema ${ }^{3}$ uit 2010 over het égalitébeginsel, het proefschrift van Dijkshoorn ${ }^{4}$ uit 2011 over de verhouding tussen het planschaderecht en het privaatrechtelijke schadevergoedingsrecht, en het proefschrift van De Jongh $^{5}$ uit 2012 waarin vanuit rechtshistorisch perspectief wordt gezocht naar rechtvaardigingen in het recht voor de toekenning van nadeelcompensatie.

Het proefschrift van Van den Broek is een waardevolle bron van informatie gebleken als het aankomt op de toepassing van art. 49 WRO door de Kroon, de Afdeling voor de geschillen van het bestuur van de Raad van State, de Afdeling rechtspraak van de Raad van State, en de Afdeling bestuursrechtspraak van de Raad van State

$1 \quad$ Zie bijvoorbeeld Verburg 1958.

2 Van den Broek 2002.

3 Tjepkema 2010.

4 Dijkshoorn 2011a.

$5 \quad$ De Jongh 2012. 
tot 2002. Het planschaderecht heeft echter niet stilgestaan en aanzienlijke ontwikkelingen doorgemaakt. Dat lag ook voor de hand. Waar de grondslag van art. 49 WRO moest worden gevonden in de materiële rechtszekerheid, moet de grondslag van de planschaderegeling van afd. 6.1 Wro immers worden gevonden in het égalitébeginsel. Het verbaast dan ook niet dat sinds 2002 een grote hoeveelheid jurisprudentie inzake planschade is verschenen die kan leiden tot nieuwe inzichten in het nadeelcompensatierecht in algemene zin, en het égalitébeginsel in het bijzonder. Dat geldt te meer voor de stortvloed aan door de Afdeling bestuursrechtspraak van de Raad van State gewezen jurisprudentie inzake afd. 6.1 Wro, die begin 2012 op gang is gekomen. Waar Dijkshoorn slechts kon uitgaan van de Kamerstukken behorende bij afdeling 6.1 Wro en art. 49 WRO, en de in het kader van art. 49 WRO gewezen jurisprudentie, kon in het onderhavige proefschrift uitgebreid worden stilgestaan bij de lessen die uit de nieuwe jurisprudentie inzake afd. 6.1 Wro kunnen worden getrokken. Verder hoop ik dat de onderzoeksresultaten kunnen bijdragen aan de - ook regelmatig door Dijkshoorn bepleite - aansluiting van het nadeelcompensatierecht op het civiele schadevergoedingsrecht. Anders dan in het proefschrift van Dijkshoorn, was een vergelijking met dit civiele schadevergoedingsrecht niet het hoofddoel van het onderhavige proefschrift. Dat laat echter onverlet dat de vergelijking met het privaatrecht wel een belangrijke rol speelde, omdat een van de aan de Wns ten grondslag liggende uitgangspunten bleek dat (waar mogelijk) wordt aangesloten op het BW.

Het startpunt van Tjepkema's onderzoek naar het nadeelcompensatierecht is het ongeschreven égalitébeginsel. Zijn proefschrift leverde een schat aan informatie op over onder andere de oorsprong van dit beginsel, de implementatie daarvan in het Nederlandse recht, en de interpretatie van het beginsel in de (Nederlandse) jurisprudentie. Uiteraard heeft Tjepkema ook onderzoek gedaan naar de implementatie en ontwikkeling van het égalitébeginsel in geschreven formele wetten en regelingen van lagere rangorde. In de beschrijving van zijn onderzoek wordt echter geëxpliciteerd dat de lezer "geen gedetailleerde beschrijvingen [zal] aantreffen van het recht op nadeelcompensatie op verschillende deelterreinen waar geschreven regelingen worden toegepast, zoals de ruimtelijke ordening (art. 6.1 Wro, voorheen art. 49 WRO), milieumaatregelen (art. 15.20 Wet milieubeheer), de bestrijding van dierziektes (de Gezondheids- en welzijnswet voor dieren), strafvorderlijk optreden (art. 89 Wetboek van Strafvordering) en infrastructurele projecten (bijv. de Verordening Nadeelcompensatie Noord-Zuidlijn)." Ook beoogde Tjepkema niet in te gaan op de afstemmingsproblemen die de "wirwar" aan dit soort regelingen meebrengt. ${ }^{6}$ Aangezien de aanleiding voor het onderhavige proefschrift juist is gelegen in de afstemming van huidige nadeelcompensatieregelingen op titel 4.5 Awb en afd. 15.1 Ow - en het geschreven nadeelcompensatierecht dus het vertrekpunt van dit onderzoek vormt - hoop ik dat dit proefschrift het proefschrift van Tjepkema op fraaie wijze kan complementeren. 
Het proefschrift van De Jongh leverde - evenals het proefschrift van Tjepkema waardevolle rechtshistorische informatie op omtrent het égalitébeginsel. Het onderhavige proefschrift complementeert dat onderzoek doordat het een meer positiefrechtelijke insteek kent. De focus ligt op het huidige nadeelcompensatierecht in verhouding tot het toekomstige nadeelcompensatierecht. Dat laat onverlet dat het rechtshistorische perspectief zeker niet uit het oog is verloren. Zo bleken veel verschillen tussen de geselecteerde, thans geldende nadeelcompensatieregelingen historisch te kunnen worden verklaard. Ook is in het tweede hoofdstuk van dit proefschrift in vogelvlucht weergegeven hoe het hedendaagse nadeelcompensatielandschap vorm heeft gekregen.

Ten slotte zijn de afgelopen decennia natuurlijk ook veel annotaties, kronieken, boekbijdragen en andere wetenschappelijke commentaren op het nadeelcompensatierecht verschenen. Dat zijn er zelfs zoveel, dat het onmogelijk was al deze bronnen in het onderhavige proefschrift te betrekken. Ik hoop desondanks dat dit proefschrift een waardevolle bijdrage zal leveren aan de discussies die in deze bronnen zijn gevoerd, en ook na publicatie van dit proefschrift aan die discussies te mogen bijdragen. 



\section{Hoofdstuk 13}

\section{Summary}

\subsection{REASON FOR THE STUDY}

This is a book about compensation due to no-fault state liability, known in Dutch as 'nadeelcompensatie'. Late in the 1990s, attempts were already made to include a general regulation on nadeelcompensatie in the General Administrative Law Act (hereinafter referred to as 'Awb'). Reasons for this included the "increasing social importance" of nadeelcompensatie and a large number of developments in case law. In 2004, the situation gained momentum when the government noted in its memorandum 'Towards decisive administrative law' that the Groningen/Raatgever judgment gave "cause to think about amending the legislation on compensation for governmental actions." Subsequently, on the initiative of the Committee for Legislation on General Administrative Law, an expert meeting on this subject was organized at the Ministry of Justice on 29 March 2004. Experts from the judiciary, the legal profession, ministerial departments, and academia were present. With regard to the subject of nadeelcompensatie, dissatisfaction existed in particular due to the complex division of powers between the civil and administrative courts, something which still exists today. The experts present therefore advocated a general statutory system of nadeelcompensatie based on the principle of 'égalité devant les charges publiques', or 'equality before the public burdens' (hereinafter referred to as the 'égalité principle'), which would be in line with the decisionmaking model that works well in current legal practice on nadeelcompensatie.

After this expert meeting, the Minister of Justice, also on behalf of the Minister of the Interior and Kingdom Relations, set up a broad-based study group. The task of this study group was to find solutions to bottlenecks in the area of compensation for unlawful government acts. If necessary, it was also allowed to include compensation for damage caused by lawful government acts. The study group got underway at the beginning of 2005 and published a preliminary draft report in May 2007. This preliminary draft report has developed to become the 'Nadeelcompensatie and compensation for damage caused by unlawful public decisionmaking Act' ${ }^{1}$ published in the Bulletin of Acts, Orders and Decrees on 15 February 2013. The part of this Act that deals with compensation for unlawful government acts has already entered into force. The part of this Act that concerns nadeelcompensatie (hereinafter referred to as 'the Wns') has yet to enter into force. For this

1 In Dutch: de Wet nadeelcompensatie en schadevergoeding bij onrechtmatige besluiten. 
dissertation, it is particularly important that this Act will include a general basis to grant nadeelcompensatie, based on the égalité principle, in Title 4.5 of the Awb.

The Wns has been the subject of discussion since early in its development stage. The importance of general legislation about nadeelcompensatie is widely recognized, but it appears that the questions involved are so difficult to answer and the (financial) interests are so great that the entry into force of Title 4.5 of the Awb is increasingly being postponed. An important part of the issues confronting the legislature concern the scope of Title 4.5 of the Awb and - in relation to this - the extent to which this Title leaves room for, or should leave room for, or can replace (parts of) the multitude of special statutory and extra-statutory nadeelcompensatie schemes that currently exist.

The legislature has repeatedly stated its intention to substitute many of the current nadeelcompensatie schemes with Title 4.5 of the Awb. Depending on the response to the aforementioned questions, the Title could contribute greatly to the extent to which the legislature achieves its objective of simplifying, standardizing and harmonizing Dutch nadeelcompensatie law. This harmonizing effect is not limited to the substantive criteria and procedural requirements for the granting of nadeelcompensatie. Title 4.5 of the Awb will also have a harmonizing effect in the field of legal protection. It will always - with a few exceptions, such as damage caused by formal legislation or criminal investigations - serve as a basis under public law for deciding on applications for nadeelcompensatie. As a result, such decisions qualify as decisions that can be contested before an administrative court. Nevertheless, arguments have also been put forward in support of the assertion that there will continue to be a need for special regulations even after Title 4.5 of the Awb enters into force. It is this tension between the objective of simplification, standardization and harmonization on the one hand, and the need for nadeelcompensatie regimes tailored to special situations on the other, which formed the direct reason to write this dissertation. In this book, I focus in particular on two 'legislative relationships': (1) the relationship of Title 4.5 of the Awb to special, formal nadeelcompensatie legislation; and (2) the relationship of Title 4.5 of the Awb to special, 'lower' nadeelcompensatie schemes. I will explain both briefly below.

With regard to the relationship between Title 4.5 of the Awb and special, formal nadeelcompensatie legislation, the debate in recent years has mainly focused on the question whether a special compensation regime should apply to environmental law, or whether, on the contrary, the current status separate from environmental law should be abolished. In this context, choices have to be made regarding, among other things, the legal standardization of the requirement of an abnormal burden ${ }^{2}$ and whether or not to maintain exclusive and exhaustive enumerations of potential causes of damage that may give rise to damage eligible for nadeelcom-

2 One of the requirements for granting nadeelcompensatie which, together with the requirement for a special burden, characterizes the égalité principle. 
pensatie. This discussion is currently being conducted in particular in the context of the Environmental Law $\mathrm{Act}^{3}$ (hereinafter referred to as 'Ow'). Upon adoption and ratification of the bill currently pending before the First Chamber of the Senate for the Environmental Law Implementation Act (hereinafter referred to as ' $\mathrm{OOw}$ '), ${ }^{4}$ a special nadeelcompensatie scheme - in the form of Section 15.1 of the Ow - will be added to the Ow for damage resulting from lawful governmental actions based on the Ow. It follows from the explanatory documents accompanying the IOw that Title 4.5 of the Awb will come into force at the latest at the same time as Section 15.1 of the Ow. This is expected to take place on 1 January 2021.

Section 15.1 of the Ow will operate as a supplement to Title 4.5 of the Awb and will also replace a multiplicity of nadeelcompensatie schemes that are important under current law. The best-known example of this is the regulation on compensation for planning damage laid down in Section 6.1 of the Spatial Planning Act. ${ }^{5}$ Other examples are Article 22 of the Transport Infrastructure (Planning Procedures) Act, ${ }^{6}$ Article 7.14 of the Water Act $^{7}$ and Article 4.2 of the General Environmental Law Act. ${ }^{8}$ As a result, the majority of applications for nadeelcompensatie under future law will be dealt with under Title 4.5 of the Awb, which may or may not be supplemented by Section 15.1 of the Ow and/or other (lower) nadeelcompensatie schemes. When it comes to the relationship between Title 4.5 of the Awb and formal nadeelcompensatie legislation, this dissertation therefore mainly focuses on the relationship between this title and Section 15.1 of the Ow.

The relationship between the formal general nadeelcompensatie legislation of Title 4.5 of the Awb and 'lower' special nadeelcompensatie schemes must also be clarified before Title 4.5 of the Awb can enter into force. Such schemes are referred to here as special nadeelcompensatie schemes, because the substantive and procedural provisions laid down in Title 4.5 of the Awb are regarded in this dissertation as the main source of general nadeelcompensatie law, compared to which all other nadeelcompensatie schemes are of a special nature. This does not alter the fact that these special schemes may be of a more or less general nature. An example of a nadeelcompensatie scheme of a more general nature is the 'Policy Rule on nadeelcompensatie Infrastructure and Water Management 2019'. 9 This policy rule plays a particularly important role in the practice of wet and dry water management by the Ministry of Infrastructure and Water Management. Moreover, this policy rule has served as an example in the adoption of many other policy rules and regulations, and even in the adoption of Title 4.5 of the Awb. Another example of a special nadeelcompensatie scheme of a general nature is the 'Gene-

3 In Dutch: de Omgevingswet.

4 In Dutch: de Invoeringswet Omgevingswet.

5 In Dutch: de Wet ruimtelijke ordening.

6 In Dutch: de Tracéwet.

7 In Dutch: de Waterwet.

8 In Dutch: de Wet milieubeheer.

9 In Dutch: de Beleidsregel nadeelcompensatie Infrastructuur \& Milieu 2019. 
ral Nadeelcompensatie Ordinance of the Municipality of Amsterdam'. ${ }^{10}$ In principle, it applies to all lawful acts of the Amsterdam municipal authority. However, it does not apply to damage caused by the construction of the "North/South Line'11 - a metro line connecting the north and south of Amsterdam. For the compensation of this damage, the Amsterdam municipal council has in fact adopted a separate regulation in the form of the 'North/South Line Nadeelcompensatie Ordinance'. ${ }^{12}$ Another example of a special nadeelcompensatie scheme that - like the North/ South Line Nadeelcompensatie Ordinance - has a less general character is the 'Joint nadeelcompensatie regulation for the expansion of Schiphol Airport'. ${ }^{13}$

\subsection{OBJECTIVE OF THE STUDY AND THE RESEARCH QUESTIONS TO BE ANSWERED}

The standards laid down in Title 4.5 of the Awb will, in principle, apply to the majority of all applications for nadeelcompensatie once it enters into force. However, it is conceivable that competent legislatures or administrative bodies will make use of the explicit or implicit possibilities offered by Title 4.5 of the Awb for interpretation, derogation and/or supplementation. Choices as to whether or not to maintain (in an unchanged form) the existing nadeelcompensatie schemes can only be made in a meaningful manner if there is sufficient insight into the relationship between Title 4.5 of the Awb and Section 15.1 of the Ow and other special nadeelcompensatie schemes. Lack of this insight seems to be a major contributory factor in the repeated postponement of the entry into force of Title 4.5 of the Awb. The purpose of this study is to contribute to this insight. To this end, the following main research question will be answered:

Do the objectives and underlying principles of the Wns, partly in the light of explanations for the differences between the current nadeelcompensatie schemes, give reason to: (a) amend Title 4.5 of the General Administrative Law Act (Awb); (b) amend Section 15.1 of the Ow; and/or (c) provide any other means for a special interpretation of Title 4.5 of the Awb, supplementation of Title 4.5 of the Awb, or deviation from Title 4.5 of the Awb?

Subsections (a) and (b) are intended to clarify which points of Title 4.5 of the Awb and Section 15.1 of the Ow respectively need to be amended in order to bring them more in line with the objectives and underlying principles of the Wns. Subsection (c) deals with other measures to which these objectives and underlying principles could give rise. These could include the adoption or amendment of a formal Act other than Title 4.5 of the Awb or Section 15.1 of the Ow. Consideration may also

10 In Dutch: de Algemene Verordening Nadeelcompensatie van de gemeente Amsterdam.

11 In Dutch: de Noord/Zuidlijn.

12 In Dutch: de Verordening Nadeelcompensatie Noord/Zuidlijn

13 In Dutch: de Gemeenschappelijke regeling Schadeschap Luchthaven Schiphol. 
be given to the adoption of lower regulations and/or policies, for example at the municipal level. Finally, other types of measures are also conceivable. For instance, the court or the administration may sometimes be able to contribute to the promotion of the objectives and underlying principles by motivating a court ruling or decision in a certain way. A recommendation to adopt a model letter or a model decision could also be considered.

The main research question is first addressed in Chapters 3 to 10 for each material criterion and procedural rule determining the granting of nadeelcompensatie (such as the criteria of abnormal and special burden, and procedural requirements for the submission and processing of the application for nadeelcompensatie). The insights gained then form the basis for a comprehensive answer to the main research question in Chapter 11 - the final chapter of this dissertation. The main question is divided into three sub-questions. The first sub-question is of a general nature:

\section{What are the objectives and underlying principles of the Wns?}

This sub-question is answered in section 2.4.2 and aims to determine the assessment framework for this dissertation. This assessment framework consists of the objectives and underlying principles of the Wns. This was chosen because these objectives and underlying principles are the most recent reflection of the values that the formal legislature considers important for a general nadeelcompensatie scheme.

In addition, in order to address the main question in Chapters 3 to 10, it was necessary to answer a second and third sub-question relating to the substantive criterion or procedural requirement to be examined. They read as follows:

2. Are there differences in the way in which the selected schemes currently in force shape the right to nadeelcompensatie and, if so, how can these differences be explained?

3. How will Title 4.5 of the General Administrative Law Act and Section 15.1 of the Ow shape the future right to nadeelcompensatie?

\subsection{STRUCTURE}

This dissertation consists of three parts. The first part consists of the first two chapters of the book. The first chapter is, of course, included to set out the reason, purpose and structure of the dissertation. The second chapter answers the first sub-question but also has a different function. It describes the emergence of the current 'nadeelcompensatie landscape' and maps out the most important contours of that landscape. These contours are the result of the interplay between various actors, who are jointly responsible for the content of (general and special) nadeelcompensatie law. Some insight into these contours, and how they have developed, 
is required because they were a reason for the formal legislature to adopt Title 4.5 of the Awb and Section 15.1 of the Ow. Moreover, some insight into the role played nowadays by the various actors with regard to the application and interpretation of the égalité principle (and nadeelcompensatie schemes based thereon) is required in order to be able to adequately answer the second and third sub-question and the main question. Of great importance, for example, is the formation of law by the formal legislature, which, among other things, incorporates exclusive and exhaustive enumerations of potential causes of damage that may give rise to damage eligible for compensation (for example Article 6.1, paragraph 2, of the Spatial Planning Act) or further prescribes the demarcation of the normal social risk (for example Article 6.2 of the Spatial Planning Act). It also regularly occurs that a decentralized regulator provides for nadeelcompensatie regulation for special projects (for example the North/South Line Nadeelcompensatie Ordinance) or, in a general sense, includes specific substantive criteria and/or procedural requirements in a regulation (for example the Policy Rule on nadeelcompensatie Infrastructure and Water Management 2019 and the General Nadeelcompensatie Ordinance of the Municipality of Amsterdam). Executive administrative bodies apply such formal laws and other regulations, after which the administrative court, in turn, can rule on concrete executive decisions regarding nadeelcompensatie.

The second part of the book provides for the examination of the substantive criteria and procedural requirements for the granting of nadeelcompensatie. In Chapters 3 to 9 the second and third sub-questions and the main question are answered with regard to all the material criteria. Respectively, consideration is given to the potential causes of damage that may give rise to damage eligible for compensation (Chapter 3), the requirements regarding the causal relationship between the alleged damage and the alleged cause of damage (Chapter 4), what damage is eligible for compensation and how it should be assessed (Chapter 5), the criteria of abnormal burden (Chapter 6) and special burden (Chapter 7), active and passive risk acceptance and other types of situations in which the applicant contributed to the occurrence of the damage (Chapter 8), and other reasons for leaving damage at the applicant's expense (Chapter 9). Chapter 10 answered these research questions with regard to the procedural requirements for the granting of nadeelcompensatie.

Thus, in the second part of this dissertation the main question is answered per material criterion and procedural requirement for the granting of nadeelcompensatie. These fragmented answers to the main question form the basis of a comprehensive answer to the main question in Chapter 11 - the final part of this dissertation.

\subsection{ANSWERING THE RESEARCH QUESTIONS}

In the remainder of this summary, I will discuss the answers to the research questions. However, it would make little sense here to attempt to summarize the answers to these sub-questions exhaustively. After all, to do so, I would have to list all the differences between the selected nadeelcompensatie schemes currently in force 
and the explanations found for them, or provide a conclusive overview of Title 4.5 of the Awb and Section 15.1 of the Ow, as well as the way in which the provisions contained therein are to be applied. With regard to these sub-questions, therefore, I shall confine myself to a few general remarks. For more detailed information, I refer to the relevant sections of the previous chapters of this book.

\subsection{THE FIRST SUB-QUESTION}

Section 2.4.2 of this book shows that the Wns has four objectives, namely: (1) simplification, standardization and harmonization of nadeelcompensatie law; (2) increasing legal certainty and legal equality; (3) codification of nadeelcompensatie law; and (4) increasing the effectiveness of nadeelcompensatie law and reducing administrative burdens. It also has three underlying principles: Title 4.5 of the Awb should: (1) only codify the égalité principle; (2) be consistent with the decree model; and (3) where possible, be consistent with the Awb and the Civil Code.

\subsection{THE SECOND SUB-QUESTION}

An answer to the second sub-question was needed in the first place because the objectives and underlying principles of the Wns are not absolute in nature. For example, the codification of a special risk acceptance regime in Section 15.1 of the Ow could be in line with the objective of increasing legal certainty, but at the same time undermine the objective of standardizing and harmonizing (as far as possible) the right to nadeelcompensatie. By analysing the differences between the nadeelcompensatie schemes currently in force and the explanations that can be given for them, this study will contribute to the understanding that the legislature needs in order to be able to make the choices necessary for the entry into force of Title 4.5 of the Awb. After all, on the basis of this, statements can be made about the desirability and/or necessity of a certain type of provision in Title 4.5 of the Awb, Section 15.1 of the Ow, or lower legislation or policy. However, this is not the only reason why the law currently in force was examined. After all, a study of that law is also relevant because one of the objectives of Title 4.5 of the Awb is to codify current nadeelcompensatie law. The extent to which Title 4.5 of the Awb and Section 15.1 of the Ow are suitable for achieving this objective cannot be determined without examining the extent to which the substantive criteria and procedural requirements for the granting of nadeelcompensatie are consistent with the interpretation of those criteria and rules under current law.

Since, under current law, there are dozens of formal statutory nadeelcompensatie schemes and hundreds of lower-ranking nadeelcompensatie schemes, the second sub-question can only be answered with regard to a selection of currently applicable nadeelcompensatie schemes. The choice fell on Section 6.1 of the Spatial Planning Act, the Joint nadeelcompensatie regulation for the expansion of Schiphol Airport, the Policy Rule on nadeelcompensatie Infrastructure and Water Management 2019, the North/South Line Nadeelcompensatie Ordinance and the General 
Nadeelcompensatie Ordinance of the Municipality of Amsterdam. This selection of schemes is sufficiently representative of contemporary nadeelcompensatie law to be able to make general recommendations regarding the development of this field of law. To this end, it is important that the selected schemes are of great practical importance and have a valuable background in their origin and application. A balance was also sought between formal statutory schemes and schemes of lower rank, a balance between central and decentralized schemes, and a balance between schemes of a general and special nature.

In answering the second sub-question, it was noted that a relatively large number of differences between the selected current nadeelcompensatie schemes can only be explained by the fact that these schemes have been drawn up by different regulators over a period of several decades, while those regulators do not seem to have paid attention to alignment with other nadeelcompensatie schemes and/or consultation with each other, let alone intended to create a substantive difference. This does not detract from the fact that other kinds of explanations have also regularly been found. I will suffice here with two examples. First of all, in sections 6.1 and 7.2.1 it emerged that the criteria of abnormal burden and special burden did not play a significant role under Article 49 of the former Spatial Planning Act. ${ }^{14}$ This can be explained by the fact that this provision was not based on the unwritten égalité principle, but on the principle of material legal certainty. The second example of a different kind of explanation can be found in section 4.2.3.2. It follows that the Administrative Jurisdiction Division of the Council of State introduced an alternative causality test for nadeelcompensatie disputes settled under Article 21 'Aanwijzingsbesluit 1996 ' ${ }^{15}$ in order to prevent the Minister from taking advantage, to the detriment of the affected citizens, of the fact that he had neglected his statutory duty to establish sound noise standards for about 18 years.

\subsection{THE THIRD SUB-QUESTION}

The third sub-question concerns the design of the future right to nadeelcompensatie through Title 4.5 of the Awb and Section 15.1 of the Ow. The necessity of its answering speaks for itself. After all, knowledge of the content of both regulations, and insight into the way in which these regulations should be applied according to the accompanying explanatory documents, is necessary in order to be able to determine how these regulations relate to the objectives and underlying principles of the Wns. By answering the third sub-question, it became clear that Title 4.5 of the Awb provides relatively little substantive and procedural guidance for the processing of an application for nadeelcompensatie. Section 15.1 of the Ow, on the other hand, does provide such guidance on the substantive aspects of the right to

14 In Dutch: de Wet op de Ruimtelijke Ordening.

15 A decision designating the airport area of Schiphol. Among other things, this decision established noise zones and made it possible to intensify the use of the existing four runways and the construction and use of the fifth runway. 
nadeelcompensatie for damage caused by lawful governmental actions based on the Ow. The choices made by the government in its proposal for this section can to a large extent be explained by the way in which future environmental law will be shaped by the Ow. Furthermore, some provisions of Section 15.1 of the Ow raise the question of why the standards contained therein have not been included in Title 4.5 of the Awb so that they would apply uniformly to the greater part of nadeelcompensatie law.

\subsection{THE MAIN RESEARCH QUESTION}

The main research question is answered in a fragmented manner throughout Chapters 3 to 10 with regard to all the substantive criteria and procedural requirements for the granting of nadeelcompensatie. The insights gained and recommendations given are considered in relation to each other in Chapter 11. Sections 11.2 and 11.3 describe respectively how Title 4.5 of the Awb and Section 15.1 of the Ow would look if the legislature were to adopt all these recommendations. The recommended provisions generally fit in well with the objectives of simplifying, standardizing and harmonizing nadeelcompensatie law, increasing legal certainty, and codifying nadeelcompensatie law. Depending on the relevant criterion or procedural requirement, other objectives or principles underlying the Wns also played a role. Sometimes they were important in deciding whether or not to recommend the inclusion of standards in Title 4.5 of the Awb or Section 15.1 of the Ow - for instance, the principle of adherence to the Civil Code advocated against the inclusion of special standards relating to the assessment of damage. However, these objectives and underlying principles often also influenced the way in which the recommended provisions were formulated - for example, the principle of adherence to the Awb led to the recommendation of including a provision on advance payments in Title 4.5 of the Awb formulated as a supplement to the general provision concerning advance payments of 4:95 Awb.

\section{Title 4.5 of the Awb}

Examination of Title 4.5 of the Awb shows that from a substantive point of view, this title consists only of a summary of the criteria for awarding nadeelcompensatie. However, the title does not provide any rules on how these criteria should be applied. This is noteworthy because of the objectives of the Wns to codify nadeelcompensatie law and to increase legal certainty. To a certain extent, the lack of substantive guidance seems to be explained by the broad scope of Title 4.5 of the Awb. For example, it is difficult to prescribe a demarcation of the normal social risk or method of damage assessment that can be applied in a general sense to all forms of loss of income, without creating the risk of undesirable and/ or unreasonable outcomes. Although I have not found any concrete indications for this, I do not rule out the possibility that political reasons also played a role at the time in the government's choice to submit a bill that offered relatively little substantive guidance. After all, a legislative proposal that merely lists the criteria 
for the granting of nadeelcompensatie that have been undisputed in the judiciary for several decades, is less likely to meet with opposition in parliament than a legislative proposal that, for example, offers further guidance on the demarcation of the normal social risk. This was already known at the time by the experiment of the statutory fixed amount of Article 6.2, paragraph 2, of the Spatial Planning Act, and was recently reconfirmed during the parliamentary discussion of the proposal for the statutory fixed amount of Article 15.7, paragraph 1, of the Ow. The wording of Title 4.5 of the Awb that I have proposed offers considerably more substantive guidance. For example, it contains a provision entirely devoted to the criterion of a causal link between the damage and the allegedly damaging government actions. Another example concerns the inclusion of a normative criterion to apply the criterion of the special burden.

Title 4.5 of the Awb also provides relatively little procedural guidance. This may be partly due to the fact that the Awb was originally a regulation that in a general sense provided procedural standards for the formation of decisions, and the way in which citizens are dealt with who have reservations about a decision which is proposed or was already adopted. However, Chapter 10 shows that all of the selected nadeelcompensatie schemes currently in force show a need for more far-reaching standards than those offered by the interplay between Chapter 3 and Title 4.1 Awb and the procedural requirements from the current wording of Title 4.5 of the Awb. Therefore the objectives of simplifying, standardizing and harmonizing nadeelcompensatie law, increasing legal certainty and codifying nadeelcompensatie law regularly led me to recommend the inclusion of more procedural standards in Title 4.5 of the Awb. These provisions address, among other things, expert consultation, time limits to be observed by the administration, and interruption of limitation periods.

\section{Section 15.1 of the $\mathrm{Ow}$}

Two characteristics of the environmental law laid down by the Ow were decisive for the government's proposal for Section 15.1 of the Ow. First of all, this environmental law - like current environmental law - is characterized by tiered decisionmaking. The government is of the opinion that this kind of tiered decision-making combines poorly with the broad scope of Title 4.5 of the Awb. For this reason, an exhaustive and exclusive enumeration of potential causes of damage that may give rise to damage eligible for compensation has been included in Article 15.1, paragraph 1, of the Ow. Section 3.4.2.1 of this study shows that the exclusive nature of this enumeration is ambivalent in relation to the objectives and principles underlying the Wns. As a result, they do not constitute sufficient reason to abandon this exclusive character. On the contrary, it seems desirable and possibly even necessary now that environmental law is characterized by a system of tiered decisionmaking. In my opinion, however, the objectives and principles underlying the Wns do require that a solution be found for the problems experienced with regard to 
damage caused by actions based upon the Ow not included in the enumeration (hereinafter referred to as 'indicative governmental actions'). ${ }^{16}$

Secondly, it is established in section 2.4.3 that the zoning plan based on the Ow norms will have a much more global character than the zoning plan based on the Spatial Planning Act norms. It follows from section 3.4.2.3 that in both the Advisory Division of the Council of State and legal literature, critical comments have been made on the desirability of a zoning plan with such a global character. I, too, have my reservations about the desirability of this more global character of the zoning plan, partly seen from the objectives and principles underlying the Wns. However, the purpose of this study is not to assess the desirability of the way in which the Ow will shape environmental law. In answering the question of whether the objectives and underlying principles of the Wns give cause to amend Section 15.1 of the Ow, I therefore proceed on the basis of the way in which this Section functions within the context of environmental law regulated by the Ow, and how this relates to the nadeelcompensatie law of Title 4.5 of the Awb.

Because of the more global nature of the zoning plan standardized by the Ow, the government envisages a "generic shift" of "the moment an application for compensation can be made." Without this shift, I do not rule out the possibility that Section 15.1 of the Ow would become so unworkable that it would conflict with all the objectives and principles underlying the Wns. Nonetheless, this shift also entails complications, some of which relate to the causality test and the estimation of damages. In short, I recommend that the government clarifies these complications. Another complication is that the shift actually leads to an increase in the problems regarding damage caused by indicative governmental actions. The government wanted to offer a solution to this problem with its proposal for Article 15.5 Ow. However, there is consensus in the legal literature that this solution is too ineffective. I have taken this into account in my search for the previously recommended, generic solution to this problem.

This solution partly consists of a provision that lifts the exclusive nature of the exhaustive enumeration of potential causes of damage that may give rise to damage eligible for compensation in case of loss of income. One of the reasons for this provision is that - barring errors in the ascertainment of such damage - there is no risk of overcompensation if the applicant is able to demonstrate that he or she has suffered the loss of income as a result of indicative governmental actions. Moreover, in order to ensure that global planning is not obstructed too much - as the government fears in a general sense - the second paragraph of the recommended provision stipulates that the damage must have a certain severity and duration in order

16 In Dutch these problems are referred to as 'schaduwschadeproblematiek'. The enumeration only contains final and binding governmental actions based on the Ow. Therefore indicative governmental actions based on the $\mathrm{Ow}$ - which for example do affect the value of real estate - like the publishing of a spatial development strategy, cannot lead to the granting of nadeelcompensatie. 
to qualify for compensation. For damage in the form of temporary depreciation of real estate, a provision has been suggested that limits the refusal of nadeelcompensatie because of active risk acceptance by the applicant. Because of this provision, potential purchasers should attach less value to indicative governmental actions. Of course, it cannot be ruled out that a buyer of real estate will take account of the fact that $4 \%$ of the damage that will be caused if the measure announced by the indicative governmental actions is realized, because of Article 15.7, paragraph 1, of the Ow, will continue to be borne by him. However, the selling party will have to take this for granted, because the $4 \%$ would have remained for its account even if it had not sold. Moreover, it is free to agree with the buyer that, for example, each party will bear $2 \%$. Sometimes real estate will also become temporarily unsaleable. For those situations, it is recommended that in Chapter $11 \mathrm{Ow}$, a right of buy-out is granted to the owner who has not been able to sell his house for a certain period of time as a result of the indicative governmental actions.

Unlike Title 4.5 of the Awb, Section 15.1 of the Ow, as adopted by the Lower House of Parliament, does provide some guidance on the application of the criteria for the granting of nadeelcompensatie. In view of the objective of simplifying, standardizing and harmonizing nadeelcompensatie law (and sometimes also the objective of increasing legal equality), this regularly raised the question of why this guidance was not included in Title 4.5 of the Awb. This led on several occasions to the recommendation that the content of provisions from Section 15.1 of the Ow in a general sense be moved to Title 4.5 of the Awb. In some cases, proposals were made for additional special provisions in Section 15.1 of the Ow. For instance, it was proposed that the basic conditions for passive risk acceptance should be included in Title 4.5 of the Awb and that these conditions should be tailored more closely to environmental law in Section 15.1 of the Ow. Sometimes, proposals were also made to bring the provisions of this section more into line with current case law and/or developments that are expected to take place therein. Finally, it was recommended that the $4 \%$ threshold proposed by the government as a demarcation of the normal social risk should apply not only to indirect but also to direct damage. ${ }^{17}$

\section{Remaining recommendations}

In answering the main question, in addition to some other proposals for formal legislation, recommendations are also made to provide for special interpretations and supplementations of Title 4.5 of the Awb. These recommendations are addressed to the main actors in the legal field of nadeelcompensatie: namely the government, other administrative bodies, and the courts. I provide an example for every actor. Section 6.4 .3 concludes that at first sight, it is poorly geared toward

17 Indirect damage will be suffered as a result of developments on surrounding plots of land, while direct damage will be suffered as a result of changes to the rules for the use of one's own plot of land. 
the objectives of simplifying, standardizing and harmonizing nadeelcompensatie law, increasing legal certainty, and codifying nadeelcompensatie law that Title 4.5 of the Awb and Section 15.1 of the Ow do not contain any special rules on the demarcation of the normal social risk in the event of damage in the form of temporary loss of enjoyment of residence. However, it also became apparent that too little guidance can be found in the current law and jurisprudence to set such standards. It is therefore recommended that the government sets up a working group to investigate how more legal certainty can be offered to citizens, the government and/or courts. On the basis of the findings of this working group, the government could decide to adopt regulations.

It is argued in section 4.4.1 that it is not always easy to fathom out the reasons for the judicial causality judgment under current law. Of course, the grounds of appeal determine which causality questions a court can answer. However, in view of the objective of increasing legal certainty, it is recommended that when answering these questions, the courts should always explicitly state which causality question it answers when, and which circumstances it considers relevant to what extent. In line with this, it is recommended that the courts should, as far as possible, use one uniform formula when answering the attribution question that is part of the causality test, namely:

"Damage that is in such a connection with [the alleged cause of damage] that, also in view of the nature of the liability and of the damage, it can be attributed to [the administrative body] as a direct consequence of [the alleged cause of damage]".

Implementation of these recommendations would contribute to increased legal certainty by making the causality assessment more understandable and therefore more predictable. It would also increase legal certainty and equality by avoiding an overlap between the causality criterion and other requirements of Title 4.5 of the Awb for the granting of nadeelcompensatie.

In view of the objectives of increasing legal certainty and equality, simplifying, standardizing and harmonizing nadeelcompensatie law, and increasing the effectiveness of nadeelcompensatie law and reducing administrative burdens, section 4.4.2 makes a number of recommendations to administrative bodies regarding complex causality questions. With regard to damage arising as a result of multiple acts by the same administrative body, it is recommended that this administrative body should take a constructive approach when answering the question as to which part of these acts can be brought within the scope of Title 4.5 of the Awb and/or Section 15.1 of the Ow. A number of recommendations are also made to administrative bodies that jointly enter into a project that could potentially lead to applications for nadeelcompensatie. In my view, they should contact each other and citizens who could potentially be affected as early as possible. Furthermore, they should deal with any applications for nadeelcompensatie jointly, and should jointly conduct a single judicial procedure if the applicant does not agree with the 
outcome of the primary decision-making and the decision-making at the objection stage.

\subsection{FINAL REMARK}

I would like to thank everyone who contributed to the realization of this book. I hope the book will be useful for the actors involved in nadeelcompensatie law and in its future development. 


\section{Lijst van aangehaalde literatuur}

A

Advies HR consultatie Wns

Advies HR consultatie Wns, bijlage bij Kamerstukken II 2010/11, 32 621, nr. 3 (MvT, Wns), identifier 'blg-99935'.

Alterman 2010
R. Alterman, Takings International. A Comparative Perspective on Land Use Re-
gulations and Compensation Rights, American Bar Association 2010.

\section{Van Amerongen \& Schuurmans 2019}

N.H. van Amerongen \& Y.E. Schuurmans, 'Advies van een deskundige of algoritme? De toetsing van 'black box'-besluiten door de bestuursrechter', in: P.J. Huisman, A.R. Neerhof \& F.J. van Ommeren (red.), Verwant met verband: Ruimte, Recht en Wetenschap (Vriendenbundel voor prof. mr. J. Struiksma), 's-Gravenhage: IBR 2019, p. 175-196.

\section{Asser/Sieburgh 6-II 2017}

C.H. Sieburgh, Mr. C. Assers Handleiding tot de beoefening van het Nederlands Burgerlijk Recht. 6. Verbintenissenrecht. Deel II. De verbintenis in het algemeen, tweede gedeelte, Deventer: Wolters Kluwer 2017.

\section{B}

\section{Backes 1993}

C.W. Backes, Juridische bescherming van ecologisch waardevolle gebieden (dissertatie UU), Zwolle: Tjeenk Willink 1993.

\section{Baks 2011}

S. Baks, 'Wetsvoorstel kostendekkende griffierechten' (redactioneel), TvPP 2011, afl. 5, p. 145-146.

\section{Barendrecht e.a. 1995}

J.M. Barendrecht e.a., Berekening van schadevergoeding, Zwolle: Tjeenk Willink 1995.

\section{Barkhuysen \& Van Emmerik 2002}

T. Barkhuysen \& M.L. van Emmerik, 'De betekenis van art. 1 van het Eerste Protocol bij het EVRM voor het Nederlandse recht inzake overheidsaansprakelijkheid', $O \& A$ 2002, afl. 4, p. 102-116. 


\section{Barkhuysen \& Tjepkema 2006}

T. Barkhuysen \& M.K.G. Tjepkema, 'Aansprakelijkheid uit 'rechtmatige' overheidsdaad: het samenspel tussen de nationale égalité en het Europese eigendomsrecht', RMThemis 2006, afl. 5, p. 179-201.

\section{Barkhuysen e.a. 2018}

T. Barkhuysen e.a., Bestuursrecht in het Awb-tijdperk, Deventer: Wolters Kluwer 2018.

\section{Van den Berg 2012}

F. van den Berg, 'Gedupeerden krijgen snel geld', Haarlems Dagblad 6 maart 2012.

\section{Van den Berk 1991}

J.A.M. van den Berk, Schadevergoeding voor rechtmatig toegebrachte schade door de overheid (dissertatie UU), Zwolle: Tjeenk Willink 1991.

\section{Berns 2015}

S. Berns, 'De realiteit in het planschaderecht', Praktijk Omgevingsrecht 2015/96, p. $77-82$.

\section{Besselink \& Procee 2015}

H.J.M. Besselink \& J.S. Procee, 'Een algemene nadeelcompensatieregeling, ook in het omgevingsrecht', TO 2015, afl. 2, p. 76-83.

\section{Bierens de Haan 2014}

W.D. Bierens de Haan, 'De vaststellingsovereenkomst met de fiscus: binding en rechtsbescherming bij een fiscaal compromis, $O A A$ 2014, DOI: 10.5553/ OAA/.000001.

\section{Boonekamp, GS Schadevergoeding}

R.J.B. Boonekamp, 'Commentaar op art. 6:98 BW', in: A.T. Bolt (red.), Groene Serie Schadevergoeding, Deventer: Wolters Kluwer (losbladig en online).

\section{Bots 2004}

A.M.M.M. Bots, 'Het zorgvuldigheidsbeginsel en advisering', in: R.J.N. Schlössels e.a. (red.), In beginsel. Over aard, inhoud en samenhang van rechtsbeginselen in het bestuursrecht, Deventer: Kluwer 2004, p. 141-165.

\section{Botter \& Franssen 2013}

H.X. Botter \& T.W. Franssen, 'Verslag VAR-studiemiddag: Wet nadeelcompensatie [...]', NTB 2013/9, p. 59-64. 


\section{Bregman 2012}

A.G. Bregman, 'Het terugdringen van planologische overcapaciteit en het risico van (plan)schade', te raadplegen op www.rvo.nl/sites/default/files/2014/01/Notitie $\% 20$ Terugdringen $\% 20$ planologische $\% 20$ overcapaciteit.pdf.

\section{Bregman \& Karens 2017}

A. Bregman \& J. Karens, 'Infrastructurele NIMBY-projecten. De balans tussen algemeen belang en rechtsbescherming en nadeelcompensatie voor de burger', $A A$ 2017, p. 446-454.

\section{Van den Brink \& Den Ouden 2019}

J.E. van den Brink \& W. den Ouden, 'Van regel naar uitzondering. Over hoe de Algemene wet bestuursrecht veel 'subsidierelaties' niet of nauwelijks normeert', in: T. Barkhuysen e.a. (red.), 25 jaar Awb. In eenheid en verscheidenheid, Deventer: Wolters Kluwer 2019, p. 213-223.

\section{Van den Broek 2002}

G.M. van den Broek, Planschadevergoeding. Het recht op planschadevergoeding bij wijziging van het planologische regime, Deventer: Kluwer 2002.

\section{Van den Broek 2004}

G.M. van den Broek, 'Het wetsontwerp voor een nieuwe planschaderegeling', $B R$ 2004, p. 643-654.

\section{Van den Broek 2007}

G.M. van den Broek, 'Het voorontwerp voor een algemene nadeelcompensatieregeling in de Awb', $O \& A 2007 / 73$, p. 119-128.

\section{Van den Broek 2011}

G.M. van den Broek, 'Wetsvoorstel nadeelcompensatie in de Awb. Geen all-inone oplossing voor nadeelcompensatie bij bouw- infrastructuurprojecten', TBR 2011/177, p. 984-994.

\section{Van den Broek 2012}

G.M. van den Broek, 'Forfaitaire vergoeding van waardevermindering door aantasting van woongenot', in: T. Barkhuysen, W. den Ouden \& M.K.G. Tjepkema (red.), Coulant compenseren? Over overheidsaansprakelijkheid en rechtspolitiek, Deventer: Kluwer 2012, p. 437-453.

\section{Van den Broek 2013a}

G.M. van den Broek, 'Tracébesluiten: planschade of nadeelcompensatie?, in: P.J.J. van Buuren (red.), Toonbeelden. Gedachten over provinciaal omgevingsrecht ter herinnering aan Toon de Gier, Deventer: Kluwer 2013, p. 177-185. 


\section{Van den Broek 2013b}

G.M. van den Broek, 'Flexibiliteitsbepalingen en het recht op planschadevergoeding: het spanningsveld tussen flexibiliteit en rechtszekerheid', in: M. van der Heiden e.a. (red.), Co \& Co. Liber Amicorum, aangeboden aan dr. J.W. van Zundert, Deventer: Kluwer 2013, p. 81-94.

\section{Van den Broek 2014}

G.M. van den Broek, 'Lessen uit 15 jaar Schadeschap Luchthaven Schiphol', in: T.W. Franssen e.a. (red.), Op het grensvlak. Opstellen aangeboden aan prof. mr. drs. B.P.M. van Ravels, Den Haag: Stichting Instituut voor Bouwrecht 2014, p. 21-32.

\section{Van den Broek \& Groothuijse 2008}

G.M. van den Broek \& F.A.G. Groothuijse, 'De schadevergoedingsregeling in de Waterwet', $O \& A 2008 / 50$, p. 146-158.

\section{Van den Broek \& Tjepkema 2015}

G.M. van den Broek \& M.K.G. Tjepkema, De reikwijdte en rechtsgrondslag van nadeelcompensatie in het omgevingsrecht (VBR preadvies, nr. 43), IBR 2015.

\section{Van den Broek \& Tjepkema 2016}

G.M. van den Broek \& M.K.G. Tjepkema, 'De regeling van planschadevergoeding in de Omgevingswet: ondoordachte voorstellen met rigoureuze gevolgen', NJB 2016/1942, p. 2818-2826.

\section{Van den Broek \& Tjepkema 2017}

G.M. van den Broek \& M.K.G. Tjepkema, 'De nadeelcompensatieregeling in de Omgevingswet: geen aantrekkelijk alternatief voor het huidige planschadestelsel', TO 2017, afl. 1, p. 21-33.

\section{Van den Broek, in: T\&C Wabo}

J.H.G. van den Broek, 'commentaar op art. 3.3 en 3.4 Wabo', in: A.G.A. Nijmeijer \& R. Uylenburg (red.), Tekst \& Commentaar Wabo, Deventer: Wolters Kluwer (online).

\section{Bröring e.a. 2019}

H.E. Bröring e.a., Bestuursrecht 1, Den Haag: BJu 2019.

\section{De Bruijn 2011}

C. de Bruijn, 'Het wetsvoorstel kostendekkende griffierechten en de toegang tot de rechter in het bestuursrecht', NJB 2011/1937, p. 2568-2574.

\section{Brunner 1981}

C.J.H. Brunner, 'Causaliteit en toerekening van schade', Verkeersrecht 1981, p. 210-217 en p. 233-236. 


\section{Van Buuren e.a. 2014}

P.J.J. van Buuren e.a., Hoofdlijnen ruimtelijk bestuursrecht, Deventer: Kluwer 2014.

\section{Van Buuren e.a. 2017}

P.J.J. van Buuren e.a., Hoofdlijnen ruimtelijk bestuursrecht, Deventer: Wolters Kluwer 2017.

\section{C}

\section{Çapkurt \& De Poorter 2017}

F. Çapkurt \& J.C.A. de Poorter, 'Rechterlijke toetsing van algemeen verbindende voorschriften. Over de indringendheid van de rechterlijke toetsing in een toekomstig direct beroep tegen algemeen verbindende voorschriften', NTB 2017/10, p. 84-95.

\section{D}

\section{Damen 2006}

L.J.A. Damen, 'De bestuursrechter: van materiële waarheidsvinder tot marginaal toetsende achteroverleuner?', in: N.J.M. Kwakman (red.), Partijautonomie of materiële waarheid?, Den Haag: BJu 2006, p. 21-31.

\section{Damen 2014}

L.J.A. Damen, 'En de bestuursrechter maar marginaal toetsen', in: A.G. Bregman, H.E. Bröring \& K.J. de Graaf (red.), Onbegrensde rechtsbeoefening. Opstellen aangeboden aan prof. mr. D.A. Lubach, Den Haag: IBR 2014, p. 67-76.

\section{Dijkshoorn 2009}

W. Dijkshoorn, 'Een ander licht op schaduwschade. Wat de leer van de redelijke toerekening kan betekenen voor de schaduwschadeproblematiek in het planschaderecht', $O \& A$ 2009/53, p. 100-109.

\section{Dijkshoorn 2011a}

W. Dijkshoorn, Planschaderecht en privaatrechtelijk schadevergoedingsrecht. Een intern rechtsvergelijkende studie (diss. Erasmus Universiteit Rotterdam), Den Haag: BJu 2011.

\section{Dijkshoorn 2011b}

W. Dijkshoorn, 'Over de problemen die in 'ieder geval' en 'twee procent' in artikel 6.2 Wro met zich brengen en hoe deze problemen kunnen worden opgelost', Gst. 2011/93, p. 498-502. 


\section{Dijkshoorn 2011c}

W. Dijkshoorn, 'De leer van de redelijke toerekening: back to the eighties', $A V \& S$ 2011/30, p. 257-268.

Dölle, Elzinga \& Engels 2004

A.H.M. Dölle, D.J. Elzinga \& J.W.M. Engels, Handboek van het Nederlandse gemeenterecht, Deventer: Kluwer 2004.

\section{Drupsteen 1988}

Th.G. Drupsteen, 'Vergelijkend schadevergoedingsrecht. Vragen van aansprakelijkheid', in: Vergelijkend schadevergoedingsrecht(Preadvies VBR, nr. 16), Deventer: Kluwer 1988, p. 3-46.

\section{$\mathbf{E}$}

\section{Van Ettekoven 2011}

B.J. van Ettekoven, Wat is normaal? Van planschade naar nadeelcompensatie, Amsterdam: Vossiuspers UvA 2011.

\section{Van Ettekoven 2012}

B.J. van Ettekoven, 'Meer rechtseenheid in het nadeelcompensatierecht?', in: T. Barkhuysen, W. den Ouden \& M.K.G. Tjepkema (red.), Coulant compenseren? Over overheidsaansprakelijkheid en rechtspolitiek, Deventer: Kluwer 2012, p. 329-357.

\section{Van Ettekoven 2016}

B.J. van Ettekoven, 'De deskundige deskundige. Over registers en de 'disclosure statement", $O \& A 2016 / 53$, p. 82-92.

\section{Van Ettekoven, Van Ravels \& Tjepkema 2011}

B.J. van Ettekoven, B.P.M. van Ravels \& M.K.G. Tjepkema, 'Waarom makkelijk als het moeilijk kan? Het vereiste van de processuele connexiteit in het voorstel voor een Wet nadeelcompensatie', $O \& A$ 2011/36, p. 58-68.

\section{Van Ettekoven e.a. 2018}

B.J. van Ettekoven e.a., 'Overheidsaansprakelijkheid anno 2018: de stand van de rechtsontwikkeling’, $O \& A 2018 / 23$, p. 43-98.

\section{$\mathbf{F}$}

\section{Franssen 2010}

P.E.M. Franssen, 'Nadeelcompensatie, waar komt het vandaan en waar is het gebleven? Een stand van zaken in de praktijk', Tijdschrift voor praktisch bestuursrecht 2010-4, p. 4-8. 


\section{Franssen 2014}

T.W. Franssen, 'Grenzen van risicoaanvaarding', in: T.W. Franssen e.a. (red.), $O p$ het grensvlak. Opstellen aangeboden aan prof. mr. drs. B.P.M. van Ravels, Den Haag: IBR 2014, p. 33-48.

\section{Franssen e.a. 2014}

T.W. Franssen e.a., 'Overheidsaansprakelijkheid', NTB 2014/26, p. 218-231.

\section{Franssen, Roozendaal \& Van de Sande 2015}

T.W. Franssen, B.J.P.G. Roozendaal \& S.A.L. van de Sande, 'Overheidsaansprakelijkheid', NTB 2015/35, p. 265-283.

\section{Franssen, Roozendaal \& Van de Sande 2016}

T.W. Franssen, B.J.P.G. Roozendaal \& S.A.L. van de Sande, 'Overheidsaansprakelijkheid' (Kroniek), NTB 2016/10, p. 80-96.

\section{Franssen \& Van de Sande 2017}

T.W. Franssen \& S.A.L. van de Sande, 'Overheidsaansprakelijkheid' (Kroniek), NTB 2017/8, p. 61-79.

\section{Franssen \& Van de Sande 2018a}

T.W. Franssen \& S.A.L. van de Sande, 'Overheidsaansprakelijkheid' (Kroniek), NTB 2018/17, p. 77-96.

\section{Franssen \& Van de Sande 2018b}

T.W. Franssen \& S.A.L. van de Sande, 'Overheidsaansprakelijkheid' (Kroniek), NTB 2018/55, p. 319-334.

\section{Franssen \& Van de Sande 2019}

T.W. Franssen \& S.A.L. van de Sande, 'Overheidsaansprakelijkheid' (Kroniek), NTB 2019/9, p. 75-93.

\section{G}

\section{Geertjes \& Huijzer 2012}

G.J. Geertjes \& E. Huijzer, 'Laat de rechter met rust!' (Redactioneel), AA 2012, afl. 1, p. 5.

\section{Van Geest e.a. 2000}

H.J.A.M. van Geest e.a., Vergelijking planschaderegelingen (Rijksplanologische Dienst, Studierapport no. 3), Den Haag: Ministerie van VROM 2000. 


\section{Gevangenen van een Tracé 2013}

Gevangenen van een Tracé. Rapport betreffende klachten over de minister van Infrastructuur en Milieu te Den Haag (rapportnummer 2013/144), Den Haag: Nationale ombudsman 2013.

\section{Gierveld 2018}

H.A.J. Gierveld, 'Afdeling bestuursrechtspraak als bestuursrechter in eerste en enige aanleg in zaken over vergoeding van schade als gevolg van een tracébesluit?', TBR 2018/188, p. 1239-1248.

\section{Van der Gouwe (losbl.)}

J.A.C. van der Gouwe (red.), Onteigening en schadevergoeding bij rechtmatige overheidsdaad. Een verkenning op het terrein van schadevergoeding bij rechtmatige overheidsdaad waar onteigenen centraal staat (losbl.), Den Haag: VUGA, z.j.

\section{De Graaf \& Tolsma 2014}

K.J. de Graaf \& H.D. Tolsma, 'Rechtmatige overheidsdaad: een rol voor het specialiteitsbeginsel?, $O \& A 2014 / 50$, p. 81-89.

\section{Groothuijse \& Kegge 2017}

F.A.G. Groothuijse \& R. Kegge, Het omgevingsplan, integraal en marginaal? (Preadvies voor de Vereniging voor Bouwrecht, nr. 45), Instituut voor Bouwrecht 2017.

\section{H}

\section{De Haan 1975}

P. de Haan, 'De wetsontwerpen inzake de grondpolitiek', Anti-revolutionaire Staatkunde 1975, p. 323-335 (raadpleegbaar op http://irs.ub.rug.nl/dbi/51ac73d460aac).

\section{Hartlief 2014}

T. Hartlief, 'Een vak apart', NJB 2014/2108, p. 2917.

Hartlief, Verbintenissen uit de wet en Schadevergoeding (SBR 5)

T. Hartlief e.a., Verbintenissen uit de wet en Schadevergoeding (Studiereeks Burgerlijk Recht, deel 5), Deventer: Wolters Kluwer 2018.

\section{Ten Have \& Thoonen 2017}

T. ten Have \& J.J. Thoonen, 'De rol van de externe deskundige bij nadeelcompensatie in de Omgevingswet', $O \& A$ 2017/66, p. 162-166.

\section{Van Heesbeen 2014}

A.C.M.M. van Heesbeen, 'Verdiscontering van schade', in: T.W. Franssen e.a. (red.), Op het grensvlak. Opstellen aangeboden aan prof. mr. drs. B.P.M. van Ravels, Den Haag: Stichting Instituut voor Bouwrecht 2014, p. 59-71. 


\section{Van der Heijden 2006}

K. van der Heijden, Subsidieverstrekking een praktische handreiking, Den Haag: Elsevier Overheid 2006.

\section{Van Heijst 2017}

I.P.A. van Heijst, 'Schadeoorzaken en schaduwschade in de nieuwe Omgevingswet’, $O \& A 2017 / 64$, p. 149-155.

\section{Hemmer e.a. 2013}

K. Hemmer e.a., Verwaltungsrecht I: Das Prüfungswissen, Berlijn: Springer-Verlag $\mathrm{GmbH} 2013$.

\section{Heringa e.a. 2018}

A.W. Heringa e.a., Staatsrecht, Deventer: Wolters Kluwer 2018.

\section{Hirsch Ballin 2015}

E.M.H. Hirsch Ballin, 'Dynamiek in de bestuursrechtspraak' in: Rechtsontwikkeling door de bestuursrechter (VAR-reeks 154), Den Haag: BJu 2015 p. 7-58.

\section{Hoitink \& Koetser 2007}

J.E. Hoitink \& M.B. Koetser, 'Nadeelcompensatie: waarom, wanneer en hoeveel? Voorontwerp Studiegroep Schadevergoeding biedt rechtspraktijk onvoldoende houvast', NTB 2007/44, p. 334-343.

\section{Hoitink \& de Looij 2007}

J.E. Hoitink \& I.M.A.M. de Looij, Nadeelcompensatie in beeld. Onderzoek in opdracht van het ministerie van VenW naar de mogelijkheid van harmonisatie van nadeelcompensatieregelingen, uitgave van het Ministerie van Verkeer \& Waterstaat 2007.

\section{Holthuijsen-van der Kop 2015}

C.C.H.A. Holthuijsen-van der Kop, 'De redelijke toerekening en de deelregels anno 2015: een update', WPNR 2015/7065, p. 520-527.

\section{Horlings 2007}

E.H. Horlings, 'Een (on)billijke drempel bij het toekennen van nadeelcompensatie', $O \& A 2007 / 108$, p. 209-217.

\section{Huijts \& Backes 2015}

J.H.M. Huijts \& C.W. Backes, 'Reden tot discussie over het Nederlandse planschadestelsel?’, TO 2015, afl. 3, p. 133-142.

\section{Huijts \& Tjepkema 2017}

J.H.M. Huijts \& M.K.G. Tjepkema, 'Meervoudige causaliteit bij nadeelcompensatie en tegemoetkoming in planschade', JBplus 2017, afl. 4, p. 288-304. 


\section{Huijts \& Tjepkema 2019}

J.H.M. Huijts \& M.K.G. Tjepkema, 'Nadeelcompensatie in het schemergebied tussen rechtmatige en onrechtmatige overheidsdaad', in: T. Barkhuysen e.a. (red.), 25 jaar Awb. In eenheid en verscheidenheid, Deventer: Wolters Kluwer 2019, p. 193-202.

\section{$\mathbf{J}$}

\section{Jaarverslag Raad voor de Rechtspraak 2011}

Jaarverslag Raad voor de Rechtspraak 2011, te raadplegen op www.rechtspraak. $\mathrm{nl} /$ SiteCollectionDocuments/Jaarverslag-2011.pdf.

\section{Jaarverslag Raad van State 2017}

Jaarverslag Raad van State 2017, te raadplegen op https://jaarverslag.raadvanstate.nl/2017/wp-content/uploads/2018/03/Webversie-jaarverslag-2017-Raad-vanState.pdf.

\section{Joling 2005}

J. Joling, De accountant en de berekening van schade (diss. Nyenrode), Nyenrode Business Universiteit 2005.

\section{De Jongh 2012}

E.L. de Jongh, De rechtsgronden voor nadeelcompensatie in rechtshistorisch perspectief (diss. Radboud Universiteit Nijmegen), Deventer: Kluwer 2012.

\section{K}

\section{Kegge 2018}

R. Kegge, 'Indringende(re) toetsing door de bestuursrechter. Over veranderende toetsingsintensiteiten en de nieuwe terminologie van de Afdeling', JBplus 2018, afl. 4, p. 3-19.

\section{Keirse 2003}

A.L.M. Keirse, Schadebeperkingsplicht. Over eigen schuld aan de omvang van de schade (diss. Rijksuniversiteit Groningen), Deventer: Kluwer 2003.

\section{Keirse 2010}

A.L.M. Keirse, 'De schadebeperkingsplicht ingeleid', in: F.T. Oldenhuis, Schadebeperkingsplicht. Wie verwacht wat van wie?, Den Haag: BJu 2010, p. 13-34.

\section{Keirse \& Jongeneel 2013}

A.L.M. Keirse \& R.H.C. Jongeneel, Monografieёn Privaatrecht. Eigen schuld en mede-aansprakelijkheid (deel 16), Deventer: Kluwer 2013. 


\section{Klaassen 2017}

C.J.M. Klaassen, Monografieёn BW. Schadevergoeding algemeen, deel 2 (B35), Deventer: Wolters Kluwer 2017.

\section{Kortmann 2006}

C.N.J. Kortmann, Onrechtmatige overheidsbesluiten (diss. UU), Deventer: Kluwer 2006.

\section{Kortmann 2016}

C.N.J. Kortmann, 'Het omgevingsrecht als inspiratiebron voor de algemene nadeelcompensatieregeling van art. 4:126 Awb - Enige beschouwingen naar aanleiding van het preadvies voor de Vereniging voor Bouwrecht', $O \& A$ 2016/78, p. 161-169.

\section{Kortmann 2017}

C.N.J. Kortmann, 'Schaduwschade, een conceptuele verkenning. Naar een oplossing voor de problematiek van schaduwschade door middel van een zaaksgebonden voorschot', $O \& A 2017 / 90$, p. 188-196.

\section{Kortmann \& Boersen 2013}

C.N.J. Kortmann \& S.L. Boersen, "Voldoende anderszins verzekerd': Het voorkomen, beperken en afwentelen van planschadekosten', Gst. 2013/46, p. 260-267.

\section{Kummeling 1988}

H.R.B.M. Kummeling, Advisering in het publiekrecht. Een rechtsvergelijkende studie (diss. KUN), Den Haag: Sdu 1988.

$\mathbf{L}$

\section{Lagerweij-Duits 2017}

Ch. Lagerweij-Duits, 'Reactie consultatieversie Omgevingswet hoofdstuk 15', te raadplegen via www.internetconsultatie.nl/invoering_omgevingswet/reacties.

\section{Lam \& Gerritsen 2015}

T.E.P.A. Lam \& L.J. Gerritsen, 'Planschade en uitwerkingsplichten: (on)duidelijk', Gst. 2015/2, p. 2-5.

\section{Van der Lee \& Wiersema 2017}

C.M.L. van der Lee \& H.P. Wiersema, 'Nadeelcompensatie in de Omgevingswet. Een verkenning op basis van de internetconsultatie Invoeringswet', TBR 2017/95, p. $600-608$.

Lindenbergh, in: GS Schadevergoeding

S.D. Lindenbergh, 'Commentaar op art. 6:96 BW', in: A.T. Bolt (red.), Groene Serie Schadevergoeding, Deventer: Wolters Kluwer (online). 


\section{Lindenbergh, in: T\&C BW}

S.D. Lindenbergh, 'commentaar op art. 6:96 BW', in: H.B. Krans, C.J.J.M. Stolker \& W.L. Valk (red.), Tekst \& Commentaar BW, Deventer: Wolters Kluwer (online).

\section{M}

\section{Van Maanen 2002}

G.E. van Maanen, 'De onrechtmatige rechtmatige overheidsdaad bij de burgerlijke rechter: zoektocht naar de kwadratuur van de cirkel', in: Schadevergoeding bij rechtmatige overheidsdaad (VAR-Reeks 128), Den Haag: BJu 2002, p. 7-84.

\section{Van Manen 2003}

D. van Manen, 'Aanleg Noord/Zuidlijn Amsterdam en schademanagement', TBR 2003/865, p. 865-871.

\section{Van der Meulen 1991}

B.M.J. van der Meulen, 'De normering van het feitelijk handelen der overheid', NTB 1991, p. 267-278.

\section{Van Mierlo 2014}

H.J.M. van Mierlo, 'Van Kazernestraat naar Kneuterdijk, en retour', in: T.W. Franssen e.a. (red.), Op het grensvlak. Opstellen aangeboden aan prof. mr. drs. B.P.M. van Ravels, Den Haag: Stichting Instituut voor Bouwrecht 2014, p. 95-103.

\section{Van Mierlo \& Van Ravels 2011}

H.J.M. van Mierlo \& B.P.M. van Ravels, 'Kapitalisatie en nadeelcompensatie', $O \& A 2011 / 83$, p. 140-149.

\section{Ministerie van Binnenlandse Zaken 2012}

Ministerie van Binnenlandse Zaken, directie Woningbouw, Rapportage praktijkverkenningen Omgevingswet, 2012.

\section{Van Montfoort 2010}

L.A. van Montfoort, 'Planschade; adviesbureaus en taxatiemethoden', NTB 2010/17, p. 93-95.

\section{Van Monfoort met naschrift Wiersema 2014}

L.A. van Monfoort, 'Reactie op TBR 2013/188 (ABRvS 18 september 2013, No. 201211480/1/A2 (Planschade Westervoort))', inclusief naschrift van H.P. Wiersema, TBR 2014/41, p. 227-228.

\section{Müller 2013}

B. Müller, Verwaltungsrecht. Schnell erfaßt, Berlijn: Springer-Verlag GmbH 2013. 


\section{Nentjes 2008}

A. Nentjes, 'Over de juiste raming van bestemmingsplanschade', NJB 2008/1857, p. $2362-2365$.

\section{Nentjes 2010}

A. Nentjes, 'Planschade: het adviesbureau, de taxatiedeskundige en de rechter', NTB 2010/6, p. 23-30.

\section{Nijmeijer 2017}

A.G.A. Nijmeijer, 'invoeringswet Omgevingswet: gefragmenteerde nadeelcompensatie omgevingsplan', TBR 2017/18, p. 78-80.

\section{Nuyten \& Gawronski 2013}

S.M.C. Nuyten \& S.A. Gawronski, 'Nadeelcompensatie, schadevergoeding en bestuursrechtelijke geldschulden: welke rechter, welke regels?', Maandblad voor Vermogensrecht 2013, afl. 7, p. 207-213.

\section{$\mathbf{O}$}

\section{Van Oosten \& Span 2016}

J.C. van Oosten \& A. Span, 'Overzichtsuitspraak van de Afdeling over planschade in perspectief: de uitspraak bezien vanuit de voorgestelde wijzigingen onder de Omgevingswet', $B b$ 2016/91, p. 315-319.

\section{$\mathbf{P}$}

\section{Peters 2017}

J.A.F. Peters, 'De ledigheid van de publieke taak', $A A$ 2017, p. 104-112.

\section{Planbureau voor de Leefomgeving 2009}

E. Buitelaar \& N. Sorel, Ex-durante evaluatie Wro. Evaluatieontwerp en nulmeting, Planbureau voor de Leefomgeving 2009.

\section{Planbureau voor de Leefomgeving 2010}

E. Buitelaar e.a., Ex-durante evaluatie Wet ruimtelijke ordening: eerste resultaten, Planbureau voor de Leefomgeving 2010.

\section{Planbureau voor de Leefomgeving 2012}

E. Buitelaar e.a., Ex-durante evaluatie Wet ruimtelijke ordening: tweede rapportage (PBL-publicatienummer: 500160001), Den Haag: Uitgeverij Planbureau voor de Leefomgeving 2012. 


\section{Planbureau voor de Leefomgeving \& Urhahn Urban Design 2012}

E. Buitelaar e.a., Vormgeven aan de spontane stad belemmeringen en kansen voor organische stedelijke herontwikkeling (PBL-publicatienummer: 500232002), Den Haag: Uitgeverij Planbureau voor de Leefomgeving 2012.

\section{Planken \& Hazen 2017}

M.A.E. Planken \& R.J.R Hazen, 'De planschadevergoedingsregeling in de Omgevingswet. Oplossing of probleem?', $O \& A$ 2017/5, p. 36-39.

\section{Planken \& Tjepkema 2015}

M.A.E. Planken \& M.K.G. Tjepkema, 'Drempels en kortingen bij nadeelcompensatie na de Wouwse Tol', O\&A 2015/2, p. 2-14.

\section{Polak 1992}

J.E.M. Polak, 'Waterstaatszorg en bestuurscompensatie', in: S.B. Boelens e.a. (red.), Waterstaatswetgeving. Verleden, heden en toekomst, Zwolle: Tjeenk Willink 1992, p. 289-302.

\section{Polak 2002}

J.E.M. Polak, 'Schadevergoeding bij rechtmatige daad in het algemeen en de Regeling nadeelcompensatie Verkeer en Waterstaat 1999 in het bijzonder', BR 2002, p. 114-127.

\section{Polak e.a. 2008}

J.E.M. Polak e.a., 'Overheidsaansprakelijkheid anno 2008: de stand van de rechtsontwikkeling', $O \& A$ 2008/48, p. 101-126.

\section{Polak 2010}

J.E.M. Polak, 'Ontwikkelingen op het terrein van de overheidsaansprakelijkheid; over grenzen van privaatrecht en bestuursrecht heen', NTB 2010/46, p. 315-323.

\section{De Poorter, in: T\&C Awb}

J.C.A. de Poorter, 'commentaar op art. 4:13 Awb', in: T.C. Borman \& J.C.A. de Poorter (red.), Tekst \& Commentaar Awb, Deventer: Wolters Kluwer (online).

\section{De Poorter \& Soest-Ahlers 2008}

J.C.A. de Poorter \& Y.M. van Soest-Ahlers, Advisering in het bestuursrecht. Over advisering aan bestuursorganen in het kader van de uitoefening van een publiekrechtelijke bevoegdheid, Alphen aan den Rijn: Kluwer 2008.

\section{$\mathbf{R}$}

\section{Rapport Commissie Samkalden 1983}

Commissie Samkalden, Rapport van de commissie artikel 49 WRO, Augustus 1983. 


\section{Van Ravels 1999}

B.P.M. van Ravels, 'Planologische schaduwschade', in: A. van Hall, Th. G. Drupsteen \& H.J.M. Havekes (red.), De staat van water. Opstellen over juridische, technische, financiële en politiek-bestuurlijke aspecten van waterbeheer, p. 195216.

\section{Van Ravels 2002}

B.P.M. van Ravels, 'Nadeelcompensatie en andere vergoedingen in de waterstaatszorg. Materiële aspecten van schadevergoeding bij rechtmatige overheidsdaad', in: Schadevergoeding bij rechtmatige overheidsdaad (VAR-Reeks 128), Den Haag: BJu 2002, p. 261-423.

\section{Van Ravels 2006a}

B.P.M. van Ravels, 'Schadevergoeding (w.o. onrechtmatige overheidsdaad)', NTB 2006/5, p. 25-36.

\section{Van Ravels 2006b}

B.P.M. van Ravels, 'Vergoeding van planschade omstreeks 2005', Gst. 2006/70, p. 255-270.

\section{Van Ravels 2008}

B.P.M. van Ravels, 'De nieuwe redelijkheid bij tegemoetkomen in planschade', $O \& A 2008 / 49$, p. 128-145.

\section{Van Ravels 2009a}

B.P.M. van Ravels, 'Het nadeelcompensatiedoolhof', JBplus 2009, p. 130-161.

\section{Van Ravels 2009b}

B.P.M. van Ravels, 'Planschade: van vergoeden naar tegemoetkomen', in: 40 jaar Instituut voor Bouwrecht, Den Haag: Stichting Instituut voor Bouwrecht 2009, p. 91-156.

\section{Van Ravels 2009c}

B.P.M. van Ravels, 'Schadevergoeding (w.o. onrechtmatige overheidsdaad)', NTB 2009/4, p. 16-28.

\section{Van Ravels 2010a}

B.P.M. van Ravels, 'Twijfel zaaien en nadeelcompensatie oogsten. Over bewijswaardering en nadeelcompensatie', AA 2010, p. 543-551.

\section{Van Ravels 2010b}

B.P.M. van Ravels, 'Schadevergoeding (w.o. onrechtmatige overheidsdaad)', NTB 2010/38, p. 242-255. 


\section{Van Ravels 2011a}

B.P.M. van Ravels, 'Schadevergoeding (w.o. onrechtmatige overheidsdaad)', NTB 2011/14, p. 97-111.

\section{Van Ravels 2011b}

B.P.M. van Ravels, 'Schadevergoeding (w.o. onrechtmatige overheidsdaad)', NTB 2011/36, p. 250-261.

\section{Van Ravels 2011c}

B.P.M. van Ravels, 'Het is eigenlijk heel eenvoudig... Abstraheren, maximaliseren, objectiveren, relativeren, toerekenen en taxeren bij het beoordelen van planschade', in: A.A.J. de Gier \& G.T.M. Jurgens, Goed verdedigbaar. Vernieuwing van bestuursrecht, Deventer: Kluwer 2011, p. 131-148.

\section{Van Ravels 2012a}

B.P.M. van Ravels, 'Schadevergoeding (w.o. onrechtmatige overheidsdaad)', NTB 2012/17, p. 111-121.

\section{Van Ravels 2012b}

B.P.M. van Ravels, "Harde en snelle' regels bij de afbakening van het normale maatschappelijke risico', in: T. Barkhuysen, W. den Ouden \& M.K.G. Tjepkema (red.), Coulant compenseren? Over overheidsaansprakelijkheid en rechtspolitiek, Deventer: Kluwer 2012, p. 359-380.

\section{Van Ravels 2012c}

B.P.M. van Ravels, 'In de schaduw van de onteigening', in: E.W.J. de Groot (red.) \& R.D. Harteman (red.), Bijzonder geschikt voor het werk. H.J.M. van Mierlo bundel, Den Haag: Stichting Instituut voor Bouwrecht 2012, p. 93-102.

\section{Van Ravels 2013a}

B.P.M. van Ravels, 'Schadevergoeding (w.o. onrechtmatige overheidsdaad)', NTB 2013/14, p. 95-110.

\section{Van Ravels 2013b}

B.P.M. van Ravels, 'De Wet nadeelcompensatie en de bijzondere wettelijke regeling van tegemoetkoming in planschade', $O \& A 2013 / 2$, p. 2-17.

\section{Van Ravels 2014a}

B.P.M. van Ravels, 'Hoe groot is het normaal maatschappelijk risico?', NTB 2014/2, p. 4-17.

\section{Van Ravels 2014b}

B.P.M. van Ravels, 'Schadevergoeding (w.o. onrechtmatige overheidsdaad)', NTB 2014/4, p. 31-46. 


\section{Van Ravels 2015}

B.P.M. van Ravels, 'Deskundigenadvisering bij nadeelcompensatie en tegemoetkoming in planschade', $O \& A 2015 / 88$, p. 160-174.

\section{Van Ravels 2017}

B.P.M. van Ravels, 'Jaap en de (overzichts-)uitspraak', in: M. Bosma e.a. (red.), De conclusie voorbij. Liber amicorum aangeboden aan Jaap Polak, Nijmegen: AAL 2017, p. 241-251.

\section{Van Ravels 2019}

B.P.M. van Ravels, 'Over de onafhankelijke deskundige in procedures over overheidsaansprakelijkheid', in: T. Barkhuysen e.a. (red.), 25 jaar Awb. In eenheid en verscheidenheid, Deventer: Wolters Kluwer 2019, p. 181-192.

\section{Rijksvastgoed- en ontwikkelingsbedrijf 2012}

Rijksvastgoed- en ontwikkelingsbedrijf, Praktijkverkenning Omgevingswet, 2012.

\section{Van Rooy 2011}

P. van Rooy, 'Uitnodigingsplanologie als sociaal-cultureel perspectief', in: Building Business, 20 december 2011.

\section{S}

\section{Sanderink 2013}

D.G.J. Sanderink, 'Een recht op onteigening of schadevergoeding bij schaduwschade? Een voorstel mede in het licht van art. 1 EP', TBR 2013/124, p. 839-847.

\section{Sanderink 2015}

D.G.J. Sanderink, Het EVRM en het materiële omgevingsrecht (diss. Radboud Universiteit Nijmegen), Deventer: Wolters Kluwer 2015.

\section{SAOZ 2017}

C.M.L. van der Lee, 'Reactie consultatieversie Omgevingswet hoofdstuk 15', te raadplegen via www.internetconsultatie.nl/invoering_omgevingswet/reacties.

\section{SAOZ en Kraan \& De Jong 2018}

SAOZ en Kraan \& De Jong, Advies inzake de waardeontwikkeling van woningen in relatie tot de conceptregeling voor nadeelcompensatie in de Omgevingswet, te raadplegen via www.omgevingswetportaal.nl/documenten/publicaties/2019/01/25/advies-inzake-de-waardeontwikkeling-van-woningen-in-relatietot-de-conceptregeling-voor-nadeelcompensatie-in-de-omgevingswet. 


\section{Van der Schans 1988}

E. van der Schans, 'Schadevergoeding, redelijkheid en billijkheid', in: Vergelijkend schadevergoedingsrecht (preadvies voor de Vereniging voor Bouwrecht nr. 16), Deventer: Kluwer 1988, p. 49-106.

\section{Van der Schans 2004 \\ E. van der Schans, 'Planschade, uitvoeringsschade en tijdelijke schade', BR 2004, p. $12-17$.}

\section{Scheltema 2011}

M.W. Scheltema, 'Het wetsvoorstel nadeelcompensatie en schadevergoeding bij onrechtmatige besluiten en de geldschuldenregeling in de Awb', $O \& A$ 2011/64, p. $120-127$.

\section{Schilder \& Brouwer 2015}

A.E. Schilder \& J.H. Brouwer, Gemeentelijke verordeningen, Nijmegen: AA 2015.

\section{Schlössels 1998}

R.J.N. Schlössels, Het specialiteitsbeginsel. Over de structuur van bestuursbevoegdheden, wetmatigheid van bestuur en beleidsvrijheid (diss. UM), Den Haag: Sdu 1998.

\section{Schlössels 2017}

R.J.N. Schlössels, 'Beginselen van behoorlijk bestuur (Kroniek)', NTB 2017/36, p. 326-336.

\section{Schueler 2002}

B.J. Schueler, 'Goede besluiten met slechte gevolgen. De verplichting tot nadeelcompensatie in het bestuursrecht', in: Schadevergoeding bij rechtmatige overheidsdaad (VAR-reeks 128), Den Haag: BJu 2002, p. 91-199.

\section{Schueler 2005}

B.J. Schueler, Schadevergoeding en de Awb. Aansprakelijkheid voor appellabele besluiten, Deventer: Kluwer 2005.

\section{Schueler 2012}

B.J. Schueler, 'Toegang tot de rechter in het omgevingsrecht', in: Ch.W. Backes e.a., Naar een nieuw omgevingsrecht (Preadvies voor de Vereniging voor Bouwrecht, nr. 40), p. 143-161.

\section{Schutgens 2017}

R.J.B. Schutgens, 'Rechtsbescherming tegen algemene regels: tijd om de Awb te voltooien', in: Algemene regels in het bestuursrecht (VAR-reeks 158), Den Haag: BJu 2017, p. 95-143. 


\section{Sietses 2016 (Verslag jaarvergadering VBR d.d. 10 december 2015)}

D. Sietses, 'De reikwijdte en rechtsgrondslag van nadeelcompensatie in het omgevingsrecht. Verslag van de jaarvergadering van Vereniging voor Bouwrecht gehouden op 10 december 2015 te Amersfoort', TBR 2016/34, p. 207-217.

\section{Sluysmans 2012}

J.A.M.A. Sluysmans, 'Wat kan het nadeelcompensatierecht leren van het onteigeningsrecht?', in: T. Barkhuysen, W. den Ouden \& M.K.G. Tjepkema (red.), Coulant compenseren? Over overheidsaansprakelijkheid en rechtspolitiek, Deventer: Kluwer 2012, p. 455-470.

\section{$\mathbf{T}$}

\section{Ten Kate 2013}

B.S. Ten Kate, 'De schaduwzijde van het aanvaard risico', in: M. van der Heiden e.a. (red.), Co \& Co. Liber Amicorum, aangeboden aan dr. J.W. van Zundert, Deventer: Kluwer 2013, p. 103-112.

\section{Teunissen 1997}

J.M.H.F. Teunissen, 'Wederom: Planschadevergoeding, tweesporigheid en causaliteit. Een beschouwing n.a.v. de uitspraak ABRvS 13-3-1997 (planschadevergoeding Welschap)', Gst. 1997, no. 7059, p. 470-474.

\section{Tieman \& Krans 2010}

J.R.C. Tieman \& H.H.C. Krans, 'Nogmaals nadeelcompensatie. Het Voorontwerp nadeelcompensatie bezien vanuit overheidsperspectief', NTB 2010/15, p. 77-84.

\section{Tjepkema 2004}

M.K.G. Tjepkema, 'Het referentiekader van het égalité-beginsel. Over de vergelijking met andere burgers in égalité-situaties', $O \& A$ 2004, p. 12-22.

\section{Tjepkema 2010}

M.K.G. Tjepkema, Nadeelcompensatie op basis van het égalitébeginsel: een onderzoek naar nationaal, Frans en Europees recht (diss. Universiteit Leiden), Deventer: Kluwer 2010.

\section{Tjepkema 2011}

M.K.G. Tjepkema, 'De codificatie van het égalitébeginsel: een paard van Troje in de Awb', NJB 2011/1086, p. 1374-1382.

\section{Tjepkema 2012}

M.K.G. Tjepkema, 'Tussen rechtszekerheid en flexibiliteit: contouren van het nieuwe planschaderecht', in: T. Barkhuysen, W. den Ouden \& M.K.G. Tjepkema (red.), Coulant compenseren? Over overheidsaansprakelijkheid en rechtspolitiek, Deventer: Kluwer 2012, p. 381-418. 


\section{Tjepkema 2014a}

M.K.G. Tjepkema, 'Het normaal maatschappelijk risico: de allesreiniger van het nadeelcompensatierecht?', in: T.W. Franssen e.a. (red.), Op het grensvlak. Opstellen aangeboden aan prof. mr. drs. B.P.M. van Ravels, Den Haag: Stichting Instituut voor Bouwrecht 2014, p. 21-32.

\section{Tjepkema 2014b}

M.K.G. Tjepkema, 'Nadeelcompensatie', in: R.J.N. Schlössels e.a. (red.), Jurisprudentie Bestuursrecht Select, Den Haag: Sdu 2014, p. 403-429.

\section{Tjepkema 2016}

M.K.G. Tjepkema, 'De Wouwse Tol. Nadeelcompensatie op grond van het beginsel 'égalité devant les charges publiques', in: T. Barkhuysen e.a. (red.), AB Klassiek. Standaarduitspraken bestuursrecht, opnieuw en thematisch geannoteerd, Deventer: Wolters Kluwer 2016, p. 609-627.

\section{Tjepkema 2017}

M.K.G. Tjepkema, 'Égalité à la Hollandaise: de evolutie van het recht op schadevergoeding bij rechtmatig overheidsoptreden in Nederland', in: R. Palmans e.a. (red.), Overheidsbeperkingen op vastgoedgebruik. De invloed van overheidsmaatregelen op de waarde van onroerend goed, Antwerpen: Intersentia 2017, p. 61-94.

\section{Tjepkema 2019}

M.K.G. Tjepkema, 'Nadeelcompensatie', in: R.J.N. Schlössels e.a. (red.), Jurisprudentie Bestuursrecht Select, Den Haag: Sdu 2019, p. 461-479.

\section{Tjepkema \& Mijnheer 2019}

M.K.G. Tjepkema \& K. Mijnheer, 'Nut, noodzaak en toekomst van de Handleiding nadeelcompensatie bij infrastructurele maatregelen’, $O \& A$ 2019/3, p. 3-13.

\section{Tjong Tjin Tai 2010}

T.F.E. Tjong Tjin Tai, 'Meervoudige causaliteit, bewijs en draagplicht', $B b$ 2010/28, p. 98-101.

\section{$\mathbf{V}$}

\section{Veenhof \& Keus 2013}

R. Veenhof \& G. Keus, 'Normaal maatschappelijk risico en de omstandigheden van het geval. Een analyse van de jurisprudentie', StAB 2013, afl. 2, p. 7-14.

\section{Verburg 1958}

G. Verburg, Enige aspecten van het vraagstuk "Schadevergoeding bij rechtmatige overheidsdaad" (Preadvies voor de Calvinistische Juristenvereniging), Utrecht: Calvinistische Juristenvereniging 1958. 


\section{Vereniging eigen huis 2017}

Vereniging eigen huis, 'Reactie consultatieversie Omgevingswet hoofdstuk 15', te raadplegen via www.internetconsultatie.nl/invoering_omgevingswet/reacties.

\section{Verheij 2002}

N. Verheij, 'Overheidsaansprakelijkheid in de Awb. Vragen voor de wetgever', $O \& A$ 2002, afl. 4, p. 117-126.

\section{Van Viegen 2012}

S.J. van Viegen, 'Nadeelcompensatie en het draagkrachtbeginsel: de sterkste schouders dragen de zwaarste lasten?' in: T. Barkhuysen, W. den Ouden \& M.K.G. Tjepkema (red.), Coulant compenseren? Over overheidsaansprakelijkheid en rechtspolitiek, Deventer: Kluwer 2012, p. 493-513.

\section{Voermans 2017}

W.J.M. Voermans, 'Algemene regels in het bestuursrecht', in: Algemene regels in het bestuursrecht (VAR-reeks 158), Den Haag: BJu 2017, p. 7-94.

\section{De Vries 2015}

H.J. de Vries, 'De vernieuwende aanpak van de kantorenleegstand door de provincie Utrecht. Een aanpak die onder de Omgevingswet niet meer op vergelijkbare wijze mogelijk is, tenzij alsnog de reikwijdte van het projectbesluit wordt verbreed!', TO 2015, afl. 3, p. 113-132.

\section{W}

\section{Van Wijmen \& Van Ravels 1988}

P.C.E. van Wijmen \& B.P.M. van Ravels, 'Nadeelcompensatie: op zoek naar de publiekrechtelijke grondslag', $B R$ 1988, p. 267-274.

\section{Willems 2008}

P. Willems, 'Artikel 49 WRO wordt artikel 6.1 Wro: de nieuwe planschaderegeling', StAB 2008, afl. 2, p. 8-14.

\section{Winter 1985}

R.R. Winter, 'Nadeelcompensatie bij bestuursoptreden; publiek- of privaatrecht?', NJB 1985, p. 548-553.

\section{$\mathbf{Z}$}

\section{Van Zeben 1999}

C.J. van Zeben, 'Van plan naar schade', BR 1999, p. 561-570. 


\section{Zijlstra e.a. 2012}

S.E. Zijlstra (red.) e.a., Wetgeven. Handboek voor de centrale en decentrale overheid, Deventer: Kluwer 2012.

\section{Zijlstra 2017}

S.E. Zijlstra, 'De Awb en de bijzondere wet. Harmonisatie door de Awb in de wetgevingspraktijk', NTB 2017/24, p. 202-209.

\section{Van Zundert 2014}

J.W. van Zundert, 'Ontwikkelingen in het planschaderecht', BR 2014/99, p. 520526.

\section{Van Zundert, in: Ruimtelijk Bestuursrecht}

J.W. van Zundert, 'commentaar op art. 29 Monw 1988, aant. 2.2', in: J. van Dam e.a./A.Ch. Fortgens e.a., Ruimtelijk Bestuursrecht, Deventer: Wolters Kluwer.

\section{Van Zundert, in: T\&C BW}

J.W. van Zundert, 'commentaar op art. 6.5 Wro', in: J.W. van Zundert e.a. (red.), Tekst \& Commentaar Ruimtelijk bestuursrecht, Deventer: Wolters Kluwer (online). 


\section{Jurisprudentieregister}

\section{Hoge Raad der Nederlanden}

- HR 31 december 1915, ECLI:NL:HR:1915:AG1773 (Guldemond/Noordwijkerhout)| 2.2 .

- HR 17 februari 1939, ECLI:NL:HR:1939:81 (Voorste Stroom IV)| 2.2.

- HR 20 december 1940, ECLI:NL:HR:1940:106 (Voorste Stroom V)| 2.2.

- HR 19 maart 1943, ECLI:NL:HR:1943:66 (Voorste Stroom VI)| 2.2.

- HR 18 februari 1944, ECLI:NL:HR:1944:33 (Haagse Duinwaterleiding)| 2.2 .

- HR 4 maart 1952, ECLI:NL:HR:1952:AG1979 (Emmense baliekluivers)| 2.5.5.

- HR 19 december 1952, ECLI:NL:HR:1952:AG1997 (Voorste Stroom VII) | 2.2.

- HR 24 januari 1969, ECLI:NL:HR:1969:AC4903 (Pocketbooks II)| 2.5.4.

- HR 20 maart 1970, ECLI:NL:HR:1970:AC5007 (Schade waterwinning)| 4.2.2.

- HR 22 juni 1973, ECLI:NL:HR:1973:AD2208 (Fluoridering)| 2.5.4.

- HR 1 juli 1983, ECLI:NL:HR:1983:AD5666 (Staat/LSV, ook wel bekend als Prijzenbescherming medisch specialisten $\mid$ 2.5.4.

- HR 16 mei 1986, ECLI:NL:HR:1986:AC9354 (Landbouwvliegers)| 2.5.4.

- HR 27 juni 1986, ECLI:NL:HR:1986:AM9331 (Methadonbrief)| 2.5.4.

- HR 3 april 1987, ECLI:NL:HR:1987:AG5568| 5.5.1.3.

- HR 14 april 1989, ECLI:NL:HR:1989:AD5725 (Harmonisatiewet)| 2.5.2.

- HR 17 november 1989, ECLI:NL:HR:1989:ZB1084| 5.5.1.3.

- HR 18 januari 1991, ECLI:NL:HR:1991:AC4031 (Leffers/Staat)| 2.2, 4.2.3.2, 5.3.3, 6.2.1.5, 7.1, 7.3.

- HR 28 juni 1991, ECLI:NL:HR:1991:ZC0300 (Dekker/Van der Heide)| 8.4.2.

- HR 28 februari 1992, ECLI:NL:HR:1992:ZC0527 (Changoe/Staat)| 2.2.

- HR 11 juni 1993, ECLI:NL:HR:1993:ZC0995 (Ruijsch/Apeldoorn)| 1.4, 7.2.1.

- HR 29 april 1994, ECLI:NL:HR:1994:ZC1358 (Bouwvergunning Schuttersduin $\mid$ 4.3.2, 8.2.1.4.

- HR 3 april 1998, ECLI:NL:HR:1998:ZC2622 (Varkensmester Meiland)| 7.1.

- HR 19 november 1999, ECLI:NL:HR:1999:AA1058 (De Dommel)| 9.2.1.

- HR 17 december 1999, ECLI:NL:HR:1999:ZC3059 (Groningen/Raatgever)| 1.1 .

- HR 24 december 1999, ECLI:NL:HR:1999:AA4004 (Nugteren/Meskes) | 4.4.2, 4.4.4.

- HR 30 maart 2001, ECLI:NL:HR:2001:AB0801 (Staat/Lavrijsen)| 2.2, 3.3.1, 7.4 . 
- HR 6 december 2002, ECLI:NL:HR:2002:AE8182 (Pannenkoekenhuis De Kabouter).

- HR 2 mei 2003, ECLI:NL:HR:2003:AF2848 (Nunspeet/Mulder) | 10.4.1, 10.10 .1 .

- $\quad$ HR 20 juni 2003, ECLI:NL:HR:2003:AF7902 (Harrida) | 6.2.3.1, 7.1, 7.4.

- HR 9 april 2004, ECLI:NL:HR:2004:AO3170 (Fibromyalgie)| 4.2.2.

- HR 13 augustus 2004, ECLI:NL:HR:2004:AI0408| 10.4.1.

- HR 17 september 2004, ECLI:NL:HR:2004:AO7887 (Uzi) | 5.3.2, 6.1, 6.2.2.1.

- HR 18 november 2005, ECLI:NL:HR:2005:AT7755 (Politieregio AmsterdamAmstelland) | 3.3.1.

- HR 9 november 2007, ECLI:NL:HR:2007:BB3776 (Planschade Egmond) | 3.2.2, 3.2.3.

- HR 28 maart 2008, ECLI:NL:HR:2008:BC0256 (Asha)| 1.4, 2.2, 3.2.2.

- HR 11 april 2008, ECLI:NL:HR:2008:BC1649 (Zandwinning Maasbommel)| 3.2.2, 3.2.3.

- $\quad$ HR 5 december 2008, ECLI:NL:HR:2008:BE9998 (Rijnstate/R.)| 5.7.3.1.

- HR 6 maart 2009, ECLI:NL:HR:2009:BG5051| 3.2.2, 3.2.3.

- HR 26 maart 2010, ECLI:NL:HR:2010:BL0539| 5.7.3.1.

- HR 11 juni 2010, ECLI:NL:HR:2010:BM1733 (Fortes e.a./ Van der Bie) | 8.3.1.

- $\quad$ HR 3 juni 2016, ECLI:NL:HR:2016:1049 (Universiteiten/SCAU) | 2.2.

- HR 16 december 2016, ECLI:NL:HR:2016:2888 (Nertsenhouders) | 6.2.1.5, 6.2.3.

- $\quad$ HR 10 februari 2017, ECLI:NL:HR:2017:214 (Avi/Verweerder)| 5.3.2.

\section{Gerechtshoven}

- Hof 's-Gravenhage 19 juni 2008, ECLI:NL:GHSGR:2008:BD6919| 8.1.

- Hof Den Haag 20 december 2013, ECLI:NL:GHDHA:2013:5079| 10.4.1.

- Hof 's-Hertogenbosch 26 augustus 2014, ECLI:NL:GHSHE:2014:2970 10.5.3.

\section{Rechtbanken}

- $\quad$ Rb. Amsterdam 5 september 2007, ECLI:NL:RBAMS:2007:BB7627 | 6.1 .

- Rb. Amsterdam 22 oktober 2007, ECLI:NL:RBAMS:2007:BB7619| 8.2.1.4.

- Rb. Amsterdam 27 november 2007, ECLI:NL:RBAMS:2007:BF5171 (Vingerhoedje, eerste aanleg) $\mid$ 8.2.1.3, 8.2.1.4.

- Rb. Amsterdam 27 november 2009, ECLI:NL:RBAMS:2009:BK6517| 8.3.1.

- Rb. Amsterdam 5 november 2010, ECLI:NL:RBAMS:2010:BP2179 (JSA/ Amsterdam) | 5.7.1.2.

- Rb. Amsterdam 27 september 2011, ECLI:RBAMS:2011:BU3590 | 8.3.1.

- Rb. Amsterdam 12 oktober 2012, ECLI:NL:RBAMS:2012:BY6896 (Pembroek) | 8.2.1.1.

- $\quad$ Rb. Amsterdam 1 maart 2013, ECLI:NL:RBAMS:2013:BZ5716 | 4.2.4.

- Rb. Amsterdam 15 mei 2013, ECLI:NL:RBAMS:2013:3113 | 10.7.1. 
- $\quad$ Rb. Amsterdam 27 juni 2014, ECLI:NL:RBAMS:2014:3930| 5.7.1.3, 6.4.1.3.

- Rb. Amsterdam 18 december 2014, ECLI:NL:RBAMS:2014:9829| 5.7.1.3, 6.4.1.3.

- Rb. Amsterdam 21 april 2015, ECLI:NL:RBAMS:2015:2740| 5.7.1.3.

- Rb. Amsterdam 21 april 2015, ECLI:NL:RBAMS:2015:2741| 5.7.1.3.

- $\quad$ Rb. Amsterdam 1 maart 2017, ECLI:NL:RBAMS:2017:3575 | 8.2.1.4.

- Rb. Amsterdam 2 augustus 2018, ECLI:NL:RBAMS:2018:5704 | 8.2.1.2, 8.2.1.3.

- $\quad$ Rb. Amsterdam 19 maart 2019, ECLI:NL:RBAMS:2019:1962 | 8.2.1.2.

- $\quad$ Rb. Arnhem 19 juni 2003, ECLI:NL:RBARN:2003:AG9390| 6.4.1.2, 6.4.1.3.

- Rb. Arnhem 19 juni 2003, ECLI:NL:RBARN:2003:AH2446| 6.4.1.2, 6.4.1.3.

- Rb. Arnhem 19 juni 2003, ECLI:NL:RBARN:2003:AH9171| 6.4.1.2, 6.4.1.3.

- Rb. Arnhem 19 juni 2003, ECLI:NL:RBARN:2003:AH9172| 6.4.1.2, 6.4.1.3.

- Rb. Arnhem 24 januari 2008, ECLI:NL:RBARN:2008:BC2698| 9.2.1.

- Rb. Arnhem 30 december 2012, ECLI:NL:RBARN:2012:2316 (Voorzienbaarheid door koopovereenkomst, eerste aanleg) | 8.2.1.3.

- Rb. Assen 13 februari 2001, ECLI:NL:RBASS:2001:AA9980 (Schietpartij bij C1000) | 5.3.2.

- Rb. Gelderland 13 december 2016, ECLI:NL:RBGEL:2016:6639| 3.2.3.

- $\quad$ Rb. Gelderland 8 juni 2018, ECLI:NL:RBGEL:2018:2538| 6.2.1.3.

- Rb. 's-Gravenhage 9 juli 1999, ECLI:NL:RBSGR:1999:AA3745 | 6.3.1.

- Rb. 's-Gravenhage 20 juli 2000, ECLI:NL:RBSGR:2000:AA6588 | 3.4.2.2.

- Rb. 's-Gravenhage 3 februari 2010, ECLI:NL:RBSGR:2010:BL6467| 7.2.2.

- $\quad$ Rb. Den Haag 12 juli 2017, ECLI:NL:RBDHA:2017:7424 | 5.7.1.3.

- Rb. Haarlem 16 februari 2010, ECLI:NL:RBHAA:2010:BL5526 | 8.2.1.4.

- Rb. Haarlem 19 april 2012, ECLI:NL:RBHAA:2012:BW5717 (Bodyfashion Zwanenburg, eerste aanleg) $\mid$ 4.2.4, 5.5.1.2, 5.5.3, 5.7.1.2.

- $\quad$ Rb. Haarlem 29 juni 2012, ECLI:NL:RBHAA:2012:BX0779| 8.2.1.4.

- $\quad$ Rb. Haarlem 9 juli 2012, ECLI:NL:RBHAA:2012:BX2062 | 8.2.1.2.

- Rb. Haarlem 14 november 2012, ECLI:NL:RBHAA:2012:BZ3738 | 5.7.1.3, 8.2.1.4.

- Rb. Haarlem 26 november 2012, ECLI:NL:RBHAA:2012:BY5380 | 8.2.1.1, 8.2.1.2.

- Rb. Limburg 8 september 2015, ECLI:NL:RBLIM:2015:7633 (Knooppunt Kunderberg, eerste aanleg) | 4.4.2.

- $\quad$ Rb. Limburg 2 februari 2017, ECLI:NL:RBLIM:2017:898 | 6.2.1.3.

- Rb. Limburg 5 december 2018, ECLI:NL:RBLIM:2018:11437| 6.2.1.3.

- Rb. Midden-Nederland 2 september 2016, ECLI:NL:RBMNE:2016:4828 5.7.1.2.

- $\quad$ Rb. Noord-Holland 25 juni 2013, ECLI:NL:RBNHO:2013:6092 | 8.2.1.2.

- Rb. Noord-Holland 8 december 2015, ECLI:NL:RBNHO:2015:10485 10.13.3.

- $\quad$ Rb. Noord-Holland 5 juli 2018, ECLI:NL:RBNHO:2018:6314| 5.7.1.1.

- Rb. Oost-Brabant 24 mei 2017, ECLI:NL:RBOBR:2017:2820 | 6.4.1.3.

- $\quad$ Rb. Oost-Brabant 8 november 2017, ECLI:NL:RBOBR:2017:5843 | 6.2.1.3.

- $\quad$ Rb. Roermond 7 juli 2008, ECLI:NL:RBROE:2008:BD7739 | 6.3.1. 
- $\quad$ Rb. Utrecht 10 oktober 2012, ECLI:NL:RBUTR:2012:BY4681 | 6.3.1.

- Rb. Zutphen 16 februari 1998, ECLI:NL:RBZUT:1998:AA6732 | 7.3.

- Rb. Zutphen 13 december 2004, ECLI:NL:RBZUT:2004:AS1993 | 8.4.1, 8.4.3.

- Rb. Zwolle-Lelystad 9 maart 2012, ECLI:NL:RBZLY:2012:BV8409 | 2.6, 6.3.1.

\section{Afdeling voor de geschillen van het bestuur van de Raad van State}

- AGRvS 14 april 1988, ECLI:NL:RVS:1988:AS7637 (Waardevermindering Heino $)$ 8.2.1.1.

- AGRvS 10 oktober 1988, ECLI:NL:RVS:1988:AN0391 (Binnenmaas)| 8.3.1.

- AGRvS 10 oktober 1988, ECLI:NL:RVS:1988:AQ9164 (Sint-Michielsgestel)| 8.2.1.1.

- AGRvS 12 oktober 1988, ECLI:NL:RVS:1988:AN1470 (Barendrecht)| 8.3.1.

- AGRvS 25 september 1989, ECLI:NL:RVS:1989:AS7120 (Landarbeiderswoning Den Dungen) | 8.2.1.3.

- AGRvS 21 juni 1990, ECLI:NL:RVS:1990:AQ4434 (Wegaanleg Groenlo)| 9.3.1.

- AGRvS 28 januari 1991, ECLI:NL:RVS:1991:AN1978 | 7.2.1.

- AGRvS 31 oktober 1991, ECLI:NL:RVS:1991:AN2436 (Mossel/Borne) 4.2.4.

- AGRvS 21 november 1992, ECLI:NL:RVS:1992:AN3910| 10.6.1.

- AGRvS 20 oktober 1993, ECLI:NL:RVS:1993:AN3433| 5.2.2.

\section{Afdeling rechtspraak van de Raad van State}

- ARRvS 12 januari 1982, ECLI:NL:RVS:1982:AM7845 (Paul Krugerbrug I)| 2.2, 3.2.4.

- ARRvS 12 juli 1982, ECLI:NL:RVS:1982:AM6627| 10.9.1.

- ARRvS 19 augustus 1983, ECLI:NL:RVS:1983:AM7349| 2.2.

- ARRvS 22 november 1983, ECLI:NL:RVS:1983:AM7385 (Paul Krugerbrug II) | 2.2.

- ARRvS 12 juli 1985, ECLI:NL:RVS:1985:AM8613 | 10.9.1.

- ARRvS 14 mei 1986, ECLI:NL:RVS:1986:AM9085 (Metroschade)| 2.2.

- ARRvS 18 november 1987, ECLI:NL:RVS:1987:AM9615 (Kromhout/Rijkswaterstaat) $\mid 2.2$.

- ARRvS 5 januari 1988, ECLI:NL:RVS:1988:AM9847 (Toonen/Rijkswaterstaat)| 2.2.

\section{Afdeling bestuursrechtspraak van de Raad van State}

- ABRvS 22 juli 1994, ECLI:NL:RVS:1994:AS6114 (Restaurant Nijmegen) | 5.4.1.1, 5.4.1.2, 5.4.2.

- ABRvS 25 juli 1994, ECLI:NL:RVS:1994:AS6109 (Waardevermindering Doorn) | 9.3.1.

- ABRvS 29 september 1994, ECLI:NL:RVS:1994:AN4171| 5.6.1.

- ABRvS 17 oktober 1994, ECLI:NL:RVS:1994:AS6059| 7.2.1. 
- ABRvS 17 maart 1995, ECLI:NL:RVS:1995:AS5927 (Benzinestation Meppel) | 4.2.3.1.

- ABRvS 21 maart 1995, ECLI:NL:RVS:1995:AS5925 (Waardevermindering Dronten) | 5.4.1.1, 5.4.1.2.

- ABRvS 9 augustus 1995, ECLI:NL:RVS:1995:AN5100 (Wegverlegging Hellevoetsluis) | 8.2.1.1.

- ABRvS 1 december 1995, ECLI:NL:RVS:1995:AN5048 | 2.5.6.

- ABRvS 28 december 1995, ECLI:NL:RVS:1995:AN5020| 9.1.1.

- ABRvS 5 maart 1996, ECLI:NL:RVS:1996:AN5056 (Snackbar Lemsterland)| 4.2.3.1.

- ABRvS 15 augustus 1996, ECLI:NL:RVS:1996:AN5184| 8.3.1.

- ABRvS 29 augustus 1996, ECLI:NL:RVS:1996:AN5470| 8.2.1.1.

- ABRvS 9 december 1996, ECLI:NL:RVS:1996:AN5533 | 8.4.2.

- ABRvS 18 februari 1997, ECLI:NL:RVS:1997:ZF2587 (Beurskens)| 2.2, 3.2.1, 3.2.4, 5.3.1.

- ABRvS 13 maart 1997, ECLI:NL:RVS:1997:AN5427 (Vliegveld Welschap) 4.2.3.2, 8.3.1, 9.3.1.

- ABRvS 6 mei 1997, ECLI:NL:RVS:1997:AA6762 (Van Vlodrop)| 2.2, 3.2.1, 3.2.4, 5.3.1.

- ABRvS 1 augustus 1997, ECLI:NL:RVS:1997:AE0422| 5.5.1.3, 5.5.1.4.

- ABRvS 1 augustus 1997, ECLI:NL:RVS:1997:AN5515 | 5.5.1.1 t/m 5.5.1.4.

- ABRvS 7 augustus 1997, ECLI:NL:RVS:1997:AE0422| 8.2.1.4.

- ABRvS 18 november 1997, ECLI:NL:RVS:1997:ZF3093 | 10.13.3.

- ABRvS 15 januari 1998, NJB 1998, afl. 9, p. 405, nr. $18 \mid$ 5.2.1.

- ABRvS 20 januari 1998, ECLI:NL:RVS:1998:ZF3150| 5.5.1.1, 5.5.1.4.

- ABRvS 12 augustus 1999, ECLI:NL:RVS:1999:AN6216| 9.1.1.

- ABRvS 17 augustus 1999, ECLI:NL:RVS:1999:AP5877 (Wooneenheden Oldenzaal) | 9.2.1.

- ABRvS 13 januari 2000, ECLI:NL:RVS:2000:AN6240| 10.6.1.

- ABRvS 4 februari 2000, ECLI:NL:RVS:2000:AN6495 | 9.2.1.

- ABRvS 25 februari 2000, ECLI:NL:RVS:2000:AN6317| 2.2.

- ABRvS 11 mei 2000, ECLI:NL:RVS:2000:AA6821 8.2.1.2.

- ABRvS 30 mei 2000, ECLI:NL:RVS:2000:AL3239| 5.2.1.

- ABRvS 10 augustus 2000, ECLI:NL:RVS:2000:AP5434 (Bankfiliaal Liemeer) | 8.1.

- ABRvS 2 oktober 2000, ECLI:NL:RVS:2000:AA9029| 8.4.2.

- ABRvS 14 december 2000, ECLI:NL:RVS:2000:AA9544 (Schaduwschade aanwijzing luchtvaartterrein Maastricht) | 3.2.3.

- ABRvS 20 februari 2001, ECLI:NL:RVS:2001:AL3065 | 2.5.4.

- ABRvS 5 september 2001, ECLI:NL:RVS:2001:AD3527 (Verordening nadeelcompensatie Den Haag) | 2.6, 6.3.1.

- ABRvS 12 december 2001, 200101227/1, StAB 2002/143 | 5.6.1, 5.6.3.

- ABRvS 6 maart 2002, ECLI:NL:RVS:2002:AE0350| 2.5.1.

- ABRvS 15 mei 2002, ECLI:NL:RVS:2002:AE2594| 6.3.1.

- ABRvS 26 juni 2002, ECLI:NL:RVS:2002:AE4653| 8.4.2.

- ABRvS 17 juli 2002, ECLI:NL:RVS:2002:AE5401| 3.2.2, 3.2.3, 3.2.4. 
- ABRvS 17 juli 2002, ECLI:NL:RVS:2002:AE5405 | 3.2.3.

- ABRvS 13 november 2002, ECLI:NL:RVS:2002:AF0262 | 8.4.1 t/m 8.4.3.

- ABRvS 5 februari 2003, ECLI:NL:RVS:2003:AF3937 (Onzuiver Schadebesluit Haarlemmermeer) | 8.2.1.2.

- ABRvS 16 april 2003, ECLI:NL:RVS:2003:AF7337| 5.5.2.

- ABRvS 18 juni 2003, ECLI:NL:RVS:2003:AG1747 | 8.2.1.4.

- ABRvS 23 juli 2003, ECLI:NL:RVS:2003:AI0248 | 3.3.1.

- ABRvS 20 augustus 2003, ECLI:NL:RVS:2003:AI1217| 3.2.1, 3.2.3.

- ABRvS 20 augustus 2003, ECLI:NL:RVS:2003:AI1268| 2.2.

- ABRvS 23 oktober 2003, ECLI:NL:RVS:2003:AM2916| 10.6.1.

- ABRvS 12 november 2003, ECLI:NL:RVS:2003:AN7851 (Prostitutiezone Heerlen/Ontkoppelingsuitspraak) | 2.2, 3.2.2, 5.3.1.

- ABRvS 12 november 2003, ECLI:NL:RVS:2003:AN7882 | 5.1, 5.3.1, 5.3.2.

- ABRvS 24 december 2003, ECLI:NL:RVS:2003:AO0820 | 6.2.2.3, 9.1.1, 9.1.2.

- ABRvS 21 januari 2004, ECLI:NL:RVS:2004:AO2002 | 5.2.1.

- ABRvS 25 februari 2004, ECLI:NL:RVS:2004:AO4344 (Planschade Hummelo \& Keppel) | 8.2.1.1.

- ABRvS 24 maart 2004, ECLI:NL:RVS:2004:AO6051 (Infiltratieschade Leiduin) | 3.2.4.

- ABRvS 31 maart 2004, ECLI:NL:RVS:2004:AO6524| 3.2.3.

- ABRvS 31 maart 2004, ECLI:NL:RVS:2004:AO6543 (Rijssen-Holten) | 8.2.1.1, 8.2.1.2.

- $\quad$ ABRvS 14 april 2004, ECLI:NL:RVS:2004:AO7460 | 5.4.1.1, 8.3.1, 9.3.1.

- ABRvS 14 april 2004, ECLI:NL:RVS:2004:AO7483| 6.3.1.

- ABRvS 6 mei 2004, ECLI:NL:RVS:2004:AO8857| 2.2,6.1.

- ABRvS 6 mei 2004, ECLI:NL:RVS:2004:AO8865 | 8.1.

- ABRvS 2 juni 2004, ECLI:NL:RVS:2004:AP0376| 2.2.

- ABRvS 9 juni 2004, ECLI:NL:RVS:2004:AP1102 (Eneco) | 3.4.2.4, 4.2.4, 4.4.1, 4.4.2.

- ABRvS 18 augustus 2004, ECLI:NL:RVS:2004:AQ7003 (Schadevergoeding jachtvergunning) | 2.2.

- ABRvS 1 september 2004, ECLI:NL:RVS:2004:AQ8752 (Planschade Schaesberg) | 10.5.1.

- ABRvS 8 september 2004, ECLI:NL:RVS:2004:AQ9948| 6.1, 6.3.1.

- ABRvS 6 oktober 2004, ECLI:NL:RVS:2004:AR3330| 8.2.1.1.

- ABRvS 6 oktober 2004, ECLI:NL:RVS:2004:AR3365 (Voorzienbaarheid Assen $) \mid$ 8.2.1.4.

- $\quad$ ABRvS 13 oktober 2004, ECLI:NL:RVS:2004:AR3748| 8.2.1.4.

- ABRvS 13 oktober 2004, ECLI:NL:RVS:2004:AR3796| 6.3.1.

- ABRvS 27 oktober 2004, ECLI:NL:RVS:2004:AR4607| 4.2.4.

- ABRvS 15 december 2004, ECLI:NL:RVS:2004:AR7552 | 5.1, 5.3.1, 5.3.3.

- ABRvS 15 december 2004, ECLI:NL:RVS:2004:AR7586 (Grim/Meerssen)| 4.2.1.

- ABRvS 12 januari 2005, ECLI:NL:RVS:2005:AS2148| 5.7.1.3.

- ABRvS 16 maart 2005, ECLI:NL:RVS:2005:AT0552| 5.1, 5.3.1, 5.3.2. 
- ABRvS 16 maart 2005, ECLI:NL:RVS:2005:AT0553 | 5.3.2.

- ABRvS 16 maart 2005, ECLI:NL:RVS:2005:AT0554 | 3.2.3.

- ABRvS 16 maart 2005, ECLI:NL:RVS:2005:AT0572| 6.2.1.1, 6.4.1.3.

- ABRvS 23 maart 2005, ECLI:NL:RVS:2005:AT1990| 6.4.1.3.

- ABRvS 30 maart 2005, ECLI:NL:RVS:2005:AT2807| 8.2.1.2.

- ABRvS 27 april 2005, ECLI:NL:RVS:2005:AT4747| 9.2.1, 9.3.1, 9.3.3.

- ABRvS 27 juli 2005, ECLI:NL:RVS:2005:AU0126 (Drechterland)| 8.2.1.1.

- ABRvS 3 augustus 2005, ECLI:NL:RVS:2005:AU0430 (Heemstede)| 9.2.2.

- ABRvS 17 augustus 2005, ECLI:NL:RVS:2005:AU1131 (Leeuwarden)| 8.1.

- ABRvS 21 september 2005, ECLI:NL:RVS:2005:AU2988| 8.4.2.

- ABRvS 26 oktober 2005, ECLI:NL:RVS:2005:AU4988 | 2.5.2.

- ABRvS 11 januari 2006, ECLI:NL:RVS:2006:AU9408 | 5.3.3.

- ABRvS 18 januari 2006, ECLI:NL:RVS:2006:AU9810| 5.3.3.

- ABRvS 18 januari 2006, ECLI:NL:RVS:2006:AU9838| 2.5.2.

- ABRvS 25 januari 2006, ECLI:NL:RVS:2006:AV0284 (Planschade Hengelo $)$ | 6.2.1.3, 8.2.1.3, 8.2.2.1.

- ABRvS 8 februari 2006, ECLI:NL:RVS:2006:AV1254| 5.6.1.

- ABRvS 15 februari 2006, ECLI:NL:RVS:2006:AV1760| 10.2.1, 10.4.3.

- ABRvS 22 februari 2006, ECLI:NL:RVS:2006:AV2272 (Emmen)| 4.2.3.1.

- ABRvS 15 maart 2006, ECLI:NL:RVS:2006:AV5061| 9.2.1.

- ABRvS 19 april 2006, ECLI:NL:RVS:2006:AW2291| 2.2, 6.1.

- ABRvS 19 april 2006, ECLI:NL:RVS:2006:AW2297| 4.2.2, 4.2.3.

- ABRvS 26 april 2006, ECLI:NL:RVS:2006:AW4004 (Verkoopwagen Via Delta) $\mid$ 5.6.1, 5.6.2, 8.1, 8.3.1.

- ABRvS 21 juni 2006, ECLI:NL:RVS:2006:AX9047| 2.6, 6.3.1, 6.3.3, 6.4.3.

- ABRvS 28 juni 2006, ECLI:NL:RVS:2006:AX9484| 5.3.2, 8.3.1.

- ABRvS 19 juli 2006, ECLI:NL:RVS:2006:AY4221| 9.2.1.

- ABRvS 16 augustus 2006, ECLI:NL:RVS:2006:AY6334| 8.2.1.3.

- ABRvS 20 september 2006, ECLI:NL:RVS:2006:AY8507| 5.7.1.3, 6.4.1.3, 6.4.3.

- ABRvS 8 november 2006, ECLI:NL:RVS:2006:AZ1762 | 5.3.1, 5.3.2.

- ABRvS 29 november 2006, ECLI:NL:RVS:2006:AZ3259| 2.2, 5.5.1.1, 5.5.1.3, 5.5.1.4, 6.2.1.5.

- ABRvS 27 december 2006, ECLI:NL:RVS:2006:AZ5163| 8.2.1.1, 8.2.1.2 $\mathrm{t} / \mathrm{m}$ 8.2.1.4.

- ABRvS 30 mei 2007, ECLI:NL:RVS:2007:BA6022| 4.2.3.1.

- ABRvS 6 juni 2007, ECLI:NL:RVS:2007:BA6794| 5.2.1, 5.7.1.3, 6.4.1.3.

- ABRvS 13 juni 2007, ECLI:NL:RVS:2007:BA7098| 10.3.2.

- ABRvS 27 juni 2007, ECLI:NL:RVS:2007:BA8139| 5.7.1.2.

- ABRvS 11 juli 2007, ECLI:NL:RVS:2007:BA9289| 10.10.1.

- ABRvS 8 augustus 2007, ECLI:NL:RVS:2007:BB1304| 4.2.3.1, 4.2.4.

- ABRvS 5 september 2007, ECLI:NL:RBAMS:2007:BB7627| 9.2.1.

- ABRvS 5 december 2007, ECLI:NL:RVS:2007:BB9458| 5.7.1.1.

- ABRvS 19 december 2007, ECLI:NL:RVS:2007:BC0536| 2.6, 6.3.1.

- ABRvS 23 januari 2008, ECLI:NL:RVS:2008:BC2532| 5.5.2.

- ABRvS 13 februari 2008, ECLI:NL:RVS:2008:BC4221| 4.2.4. 
- ABRvS 2 april 2008, ECLI:NL:RVS:2008:BC8472| 2.6, 6.3.1.

- ABRvS 9 april 2008, ECLI:NL:RVS:2008:BC9040| 4.2.3.2, 6.1, 7.2.1, 7.2.2, 8.2.1.4, 9.1.1.

- $\quad$ ABRvS 21 mei 2008, ECLI:NL:RVS:2008:BD2119| 9.2.1.

- ABRvS 13 augustus 2008, ECLI:NL:RVS:2008:BD9961| 3.2.3.

- ABRvS 29 oktober 2008, ECLI:NL:RVS:2008:BG1839| 2.5.3, 10.11.1.

- ABRvS 5 november 2008, ECLI:NL:RVS:2008:BG3375 (Vingerhoedje, hoger beroep) | 8.1, 8.2.1.1, 8.2.1.4.

- ABRvS 18 december 2008, ECLI:NL:RVS:2008:BG8265 | 4.2.3.1.

- ABRvS 14 januari 2009, ECLI:NL:RVS:2009:BG9741| 10.3.2.

- ABRvS 28 januari 2009, ECLI:NL:RVS:2009:BH1100| 4.2.1, 4.2.4.

- ABRvS 25 februari 2009, ECLI:NL:RVS:2009:BH3961| 9.2.1.

- ABRvS 11 maart 2009, ECLI:NL:RVS:2009:BH5487 (Planschade Ohé en Laak) | 4.2.3.1.

- ABRvS 22 april 2009, ECLI:NL:RVS:2009:BI1836| 10.5.1.

- ABRvS 17 juni 2009, ECLI:NL:RVS:2009:BI8464| 5.6.1.

- ABRvS 11 november 2009, ECLI:NL:RVS:2009:BK2907 (Insula Heerlen)| 8.2.1.2.

- ABRvS 2 december 2009, ECLI:NL:RVS:2009:BK5083| 8.2.1.1.

- ABRvS 3 februari 2010, ECLI:NL:RVS:2010:BL1791| 4.2.1, 4.2.4, 4.2.3, 4.4.1.

- ABRvS 24 februari 2010, ECLI:NL:RVS:2010:BL5333| 7.2.2.

- ABRvS 24 februari 2010, ECLI:NL:RVS:2010:BL5383 | 3.2.3.

- ABRvS 31 maart 2010, ECLI:NL:RVS:2010:BL9576| 6.2.1.1, 8.2.1.1.

- ABRvS 14 april 2010, ECLI:NL:RVS:2010:BM1021 (Risicoaanvaarding planschade Bloemendaal) | 2.5.1, 8.2.1.1.

- ABRvS 14 juli 2010, ECLI:NL:RVS:2010:BN1157| 5.3.2.

- ABRvS 25 augustus 2010, ECLI:NL:RVS:2010:BN4940 (Bergen op Zoom)| 8.2.1.1.

- ABRvS 13 oktober 2010, ECLI:NL:RVS:2010:BO0241 | 4.2.3.1.

- ABRvS 20 oktober 2010, ECLI:NL:RVS:2010:BO1122| 8.2.1.3.

- ABRvS 3 november 2010, ECLI:NL:RVS:2010:BO2722 | 5.7.1.1.

- ABRvS 10 november 2010, ECLI:NL:RVS:2010:BO3436 | 4.2.3.2, 5.6.1, 5.7.1.1, 6.2.1.5, 7.2.2, 8.2.1.2, 8.2.1.4.

- $\quad$ ABRvS 5 januari 2011, ECLI:NL:RVS:2011:BO9791| 6.2.1.5.

- $\quad$ ABRvS 16 maart 2011, ECLI:NL:RVS:2011:BP7753| 8.2.1.1, 8.2.1.4.

- ABRvS 23 maart 2011, ECLI:NL:RVS:2011:BP8755| 8.2.1.1.

- ABRvS 30 maart 2011, ECLI:NL:RVS:2011:BP9544| 4.2.3.1.

- ABRvS 20 april 2011, ECLI:NL:RVS:2011:BQ1889| 5.5.1.6.

- ABRvS 11 mei 2011, ECLI:NL:RVS:2011:BQ4066| 5.7.1.1.

- ABRvS 18 mei 2011, ECLI:NL:RVS:2011:BQ4893| 3.4.2.4, 6.3.1.

- ABRvS 18 mei 2011, ECLI:NL:RVS:2011:BQ4941| 2.6, 6.3.1.

- ABRvS 6 juli 2011, ECLI:NL:RVS:2011:BR0497| 7.2.2.

- ABRvS 13 juli 2011, ECLI:NL:RVS:2011:BR1397| 4.1.

- ABRvS 20 juli 2011, ECLI:NL:RVS:2011:BR2290| 8.2.1.1.

- ABRvS 12 oktober 2011, ECLI:NL:RVS:2011:BT7434| 5.7.1.2. 
- ABRvS 12 oktober 2011, ECLI:NL:RVS:2011:BT7442| 8.2.1.1.

- ABRvS 2 november 2011, ECLI:NL:RVS:2011:BU3111 | 3.3.2.1.

- ABRvS 9 november 2011, ECLI:NL:RVS:2011:BU3719| 10.5.1.

- ABRvS 21 december 2011, ECLI:NL:RVS:2011:BU8882 | 8.2.1.1.

- ABRvS 15 februari 2012, ECLI:NL:RVS:2012:BV5105| 6.2.3.1.

- ABRvS 22 februari 2012, ECLI:NL:RVS:2012:BV6510| 6.2.1.3.

- ABRvS 22 februari 2012, ECLI:NL:RVS:2012:BV6535| 2.5.2.

- ABRvS 29 februari 2012, ECLI:NL:RVS:2012:BV7254 (Tilburg/Vugts)| 2.6, 6.2.1.3, 8.2.1.2.

- $\quad$ ABRvS 14 maart 2012, ECLI:NL:RVS:2012:BV8765 | 9.1.1.

- ABRvS 14 maart 2012, ECLI:NL:RVS:2012:BV8766| 9.1.1.

- ABRvS 14 maart 2012, ECLI:NL:RVS:2012:BV8790| 10.4.1.

- ABRvS 18 april 2012, ECLI:NL:RVS:2012:BW3066 (Steenfabriek of scheepswerf?) | 8.2.1.1, 8.2.1.4.

- ABRvS 25 april 2012, ECLI:NL:RVS:2012:BW3907| 3.2.1.

- ABRvS 16 mei 2012, ECLI:NL:RVS:2012:BW5932 (Benzinestation gemeente Hulst, tussenuitspraak) | 5.5.1.3, 5.5.1.6, 5.7.1.1, 5.7.3.1.

- ABRvS 30 mei 2012, ECLI:NL:RVS:2012:BW6926 (Tankstation gemeente Hardenberg, tussenuitspraak) | 5.7.3.1, 6.3.1.

- $\quad$ ABRvS 6 juni 2012, ECLI:NL:RVS:2012:BW7613 | 6.2.1.1, 8.2.1.1.

- ABRvS 27 juni 2012, ECLI:NL:RVS:2012:BW9537| 5.6.1, 5.6.3.

- ABRvS 27 juni 2012, ECLI:NL:RVS:2012:BW9562 | 5.6.1.

- ABRvS 11 juli 2012, ECLI:NL:RVS:2012:BX1032| 5.5.1.6, 5.7.3.1.

- ABRvS 18 juli 2012, ECLI:NL:RVS:2012:BX1863| 9.3.3.

- ABRvS 1 augustus 2012, ECLI:NL:RVS:2012:BX3259| 2.6, 8.3.1.

- ABRvS 1 augustus 2012, ECLI:NL:RVS:2012:BX3290| 5.4.1.1.

- ABRvS 22 augustus 2012, ECLI:NL:RVS:2012:BX5293| 8.3.1.

- ABRvS 5 september 2012, ECLI:NL:RVS:2012:BX6492 (Heiloo) | 2.6, 6.2.1.2, 6.2.1.3.

- ABRvS 10 oktober 2012, ECLI:NL:RVS:2012:BX9702| 8.2.1.4.

- ABRvS 17 oktober 2012, ECLI:NL:RVS:2012:BY0372 (Bergeijk) | 8.2.1.1.

- ABRvS 31 oktober 2012, ECLI:NL:RVS:2012:BY1724| 5.5.1.5.

- ABRvS 7 november 2012, ECLI:NL:RVS:2012:BY2475| 4.2.3.1.

- ABRvS 28 november 2012, ECLI:NL:RVS:2012:BY4355 (Benzinestation gemeente Hulst, einduitspraak) | 5.7.3.1.

- ABRvS 28 november 2012, ECLI:NL:RVS:2012:BY4393 | 5.7.1.3, 8.2.1.1 (Randweg Eindhoven).

- ABRvS 28 november 2012, ECLI:NL:RVS:2012:BY4394| 3.2.1, 6.2.1.1, 8.2.1.1.

- ABRvS 5 december 2012, ECLI:NL:RVS:2012:BY5105 (Wouwse Tol, tussenuitspraak) | 2.6, 5.5.3, 6.2.3.1, 6.3.1.

- $\quad$ ABRvS 19 december 2012, ECLI:NL:RVS:2012:BY6653 | 8.2.1.1.

- ABRvS 23 januari 2013, ECLI:NL:RVS:2013:BY9196| 5.5.1.6.

- ABRvS 6 februari 2013, ECLI:NL:RVS:2013:BZ0707 (Tankstation gemeente Hardenberg, einduitspraak) | 5.7.3.1.

- $\quad$ ABRvS 13 februari 2013, ECLI:NL:RVS:2013:BZ1221 | 4.2.4. 
- ABRvS 13 februari 2013, ECLI:NL:RVS:2013:BZ1258 | 8.2.1.4.

- ABRvS 20 februari 2013, ECLI:NL:RVS:2013:BZ1658| 8.2.1.1.

- ABRvS 27 februari 2013, ECLI:NL:RVS:2013:BZ2513| 6.2.3.1.

- ABRvS 6 maart 2013, ECLI:NL:RVS:2013:BZ3338| 2.5.4.

- ABRvS 6 maart 2013, ECLI:NL:RVS:2013:BZ3398 | 8.2.1.3.

- ABRvS 20 maart 2013, ECLI:NL:RVS:2013:BZ4948 (Horecagelegenheid Amsterdam) | 8.2.1.1.

- ABRvS 27 maart 2013, ECLI:NL:RVS:2013:BZ7497 (Hanzelijn) | 8.2.1.1.

- ABRvS 10 april 2013, ECLI:NL:RVS:2013:BZ7681| 8.1, 8.2.1.1, 8.2.1.3, 8.2.1.4, 8.2.2.3.

- ABRvS 17 april 2013, ECLI:NL:RVS:2013:BZ7707| 4.2.3.1.

- ABRvS 1 mei 2013, ECLI:NL:RVS:2013:BZ9072 | 9.3.1.

- ABRvS 8 mei 2013, ECLI:NL:RVS:2013:BZ9769| 6.3.1.

- ABRvS 22 mei 2013, ECLI:NL:RVS:2013:CA0631| 2.6, 6.3.1, 6.3.3, 6.4.3.

- ABRvS 5 juni 2013, ECLI:NL:RVS:2013:CA2051| 2.6.

- ABRvS 5 juni 2013, ECLI:NL:RVS:2013:CA2052 (Hollandse Brug, tussenuitspraak) $\mid 2.6,6.2 .1 .3,6.3 .1$.

- ABRvS 5 juni 2013, ECLI:NL:RVS:2013:CA2092| 8.2.1.1.

- ABRvS 12 juni 2013, ECLI:NL:RVS:2013:CA2858| 2.5.1.

- ABRvS 3 juli 2013, ECLI:NL:RVS:2013:160| 3.2.1, 6.2.1.1.

- ABRvS 10 juli 2013, ECLI:NL:RVS:2013:192| 2.6, 5.7.1.2.

- ABRvS 10 juli 2013, ECLI:NL:RVS:2013:216| 6.2.1.3.

- ABRvS 31 juli 2013, ECLI:NL:RVS:2013:558| 2.2, 6.2.1.1, 6.2.3.1.

- ABRvS 31 juli 2013, ECLI:NL:RVS:2013:566| 4.2.3.1.

- ABRvS 14 augustus 2013, ECLI:NL:RVS:2013:737| 5.6.1.

- ABRvS 21 augustus 2013, ECLI:NL:RVS:2013:811 (Kollumerland en Nieuwkruisland) | 8.2.1.1.

- ABRvS 28 augustus 2013, ECLI:NL:RVS:2013:923 | 8.2.1.1.

- ABRvS 18 september 2013, ECLI:NL:RVS:2013:1159 (Voorzienbaarheid door koopovereenkomst, hoger beroep) | 8.2.1.3.

- ABRvS 25 september 2013, ECLI:NL:RVS:2013:1222 (Bodyfashion Zwanenburg, hoger beroep) $\mid$ 2.6 | 4.2.4, 5.7.1.2, 6.1.

- ABRvS 2 oktober 2013, ECLI:NL:RVS:2013:1323| 8.2.1.1, 8.2.1.4, 8.2.2.3.

- ABRvS 23 oktober 2013, ECLI:NL:RVS:2013:1621 (Urilift, eerste tussenuitspraak) | 3.4.2.4, 5.2.1.

- ABRvS 30 oktober 2013, ECLI:NL:RVS:2013:1727| 4.2.3.1, 4.2.4.

- ABRvS 6 november 2013, ECLI:NL:RVS:2013:1821| 5.6.1, 8.2.1.4.

- ABRvS 6 november 2013, ECLI:NL:RVS:2013:1824| 5.6.1.

- ABRvS 13 november 2013, ECLI:NL:RVS:2013:1895| 8.2.1.2.

- ABRvS 4 december 2013, ECLI:NL:RVS:2013:2203 | 8.3.1.

- ABRvS 4 december 2013, ECLI:NL:RVS:2013:2232| 4.2.3.1.

- ABRvS 11 december 2013, ECLI:NL:RVS:2013:2317 (Hollandse brug, einduitspraak) $\mid$ 6.3.1, 9.1.1.

- ABRvS 16 december 2013, ECLI:NL:RVS:2013:916 (Raalte)| 5.7.1.1.

- ABRvS 18 december 2013, ECLI:NL:RVS:2013:2499| 4.2.4.

- ABRvS 24 december 2013, ECLI:NL:RVS:2013:2578| 4.2.3.1, 4.2.4, 9.2.1. 
- ABRvS 24 december 2013, ECLI:NL:RVS:2013:2580| 4.2.3.1, 4.2.4.

- ABRvS 15 januari 2014, ECLI:NL:RVS:2014:28 | 5.3.2, 8.2.1.3.

- ABRvS 22 januari 2014, ECLI:NL:RVS:2014:114 (Nadeelcompensatie Tirion) $\mid$ 8.3.1, 10.13.1.

- ABRvS 29 januari 2014, ECLI:NL:RVS:2014:182 | 9.2.1.

- ABRvS 29 januari 2014, ECLI:NL:RVS:2014:226| 6.3.1.

- $\quad$ ABRvS 5 februari 2014, ECLI:NL:RVS:2014:305 | 9.2.1, 9.3.1.

- ABRvS 12 februari 2014, ECLI:NL:RVS:2014:402 | 8.2.1.3.

- ABRvS 19 februari 2014, ECLI:NL:RVS:2014:518| 6.2.1.2.

- ABRvS 19 februari 2014, ECLI:NL:RVS:2014:572 (Risicolocatie Schiphol)| 2.6, 4.2.3.2, 6.1, 6.2.1.3, 6.2.1.5, 6.4.1.3, 7.2.1, 7.2.2, 9.1.1.

- ABRvS 12 maart 2014, ECLI:NL:RVS:2014:831| 4.2.4.

- ABRvS 26 maart 2014, ECLI:NL:RVS:2014:1051| 8.2.1.1.

- ABRvS 9 april 2014, ECLI:NL:RVS:2014:1198 (Kustversterking Noordwijk)| 2.6, 4.2.3.2, 6.2.1.3, 6.2.1.5, 6.4.1.3.

- $\quad$ ABRvS 9 april 2014, ECLI:NL:RVS:2014:1228| 8.2.1.1, 8.2.1.2.

- ABRvS 16 april 2014, ECLI:NL:RVS:2014:1292 | 5.2.1.

- ABRvS 16 april 2014, ECLI:NL:RVS:2014:1294 (Schadebeperkende groenstrook?) | 8.3.1.

- ABRvS 16 april 2014, ECLI:NL:RVS:2014:1300| 3.4.2.4.

- ABRvS 23 april 2014, ECLI:NL:RVS:2014:1433 | 9.1.1.

- ABRvS 28 mei 2014, ECLI:NL:RVS:2014:1868 (Wouwse Tol, einduitspraak)| 6.3.1.

- ABRvS 4 juni 2014, ECLI:NL:RVS:2014:2006| 7.2.2.

- ABRvS 4 juni 2014, ECLI:NL:RVS:2014:2033| 6.2.1.3.

- $\quad$ ABRvS 25 juni 2014, ECLI:NL:RVS:2014:2287| 8.2.1.1, 8.2.1.4.

- ABRvS 2 juli 2014, ECLI:NL:RVS:2014:2396 (Dijkverhoging)| 2.2, 3.2.2, 4.2.3.2, 6.2.1.3, 6.2.1.5.

- ABRvS 9 juli 2014, ECLI:NL:RVS:2014:2510 (Bloemendaal)| 4.2.1.

- ABRvS 9 juli 2014, ECLI:NL:RVS:2014:2512| 8.2.2.2.

- ABRvS 9 juli 2014, ECLI:NL:RVS:2014:2554| 8.1, 8.2.1.1.

- ABRvS 14 juli 2004, ECLI:NL:RVS:2004:AQ1051 | 7.3.

- ABRvS 30 juli 2014, ECLI:NL:RVS:2014:2865 (Audio Design t. Utrecht) | 6.3.1.

- ABRvS 6 augustus 2014, ECLI:NL:RVS:2014:2950| 8.2.1.1.

- ABRvS 13 augustus 2014, ECLI:NL:RVS:2014:3005 | 6.2.1.3, 8.2.1.4.

- ABRvS 13 augustus 2014, ECLI:NL:RVS:2014:3022 | 9.1.1.

- ABRvS 17 september 2014, ECLI:NL:RVS:2014:3378| 6.3.1, 6.3.3, 6.4.3.

- ABRvS 17 september 2014, ECLI:NL:RVS:2014:3382| 6.4.1.3.

- ABRvS 24 september 2014, ECLI:NL:RVS:2014:3480| 5.2.1.

- ABRvS 24 september 2014, ECLI:NL:RVS:2014:3485 (Uitwerkingsplicht Veenendaal) | 4.2.3.1.

- ABRvS 8 oktober 2014, ECLI:NL:RVS:2014:3636| 6.2.3.1.

- ABRvS 15 oktober 2014, ECLI:NL:RVS:2014:3715 | 8.2.1.3.

- ABRvS 22 oktober 2014, ECLI:NL:RVS:2014:3796| 8.2.1.1.

- ABRvS 22 oktober 2014, ECLI:NL:RVS:2014:3800| 8.2.1.1. 
- ABRvS 29 oktober 2014, ECLI:NL:RVS:2014:3851 | 6.2.1.2.

- ABRvS 12 november 2014, ECLI:NL:RVS:2014:4033 | 6.2.1.3.

- ABRvS 19 november 2014, ECLI:NL:RVS:2014:4193 | 5.7.1.1.

- ABRvS 19 november 2014, ECLI:NL:RVS:2014:4198 | 4.2.4.

- ABRvS 19 november 2014, ECLI:NL:RVS:2014:4203 | 2.2.

- ABRvS 26 november 2014, ECLI:NL:RVS:2014:4239| 8.2.1.1.

- ABRvS 3 december 2014, ECLI:NL:RVS:2014:4410| 6.4.1.3.

- ABRvS 10 december 2014, ECLI:NL:RVS:2014:4033 (Urilift, tweede tussenuitspraak) | 3.4.2.4.

- ABRvS 10 december 2014, ECLI:NL:RVS:2014:4489| 9.1.1, 9.1.3.

- ABRvS 24 december 2014, ECLI:NL:RVS:2014:4668 (Planschade Lisse)| 2.6, 6.2.1.3, 6.2.3.1.

- ABRvS 11 februari 2015, ECLI:NL:RVS:2015:336 (Fietstunnel Rijksweg 7 bij Sneek) | 5.7.1.2, 6.2.1.1, 6.2.3.1, 6.3.1.

- ABRvS 11 februari 2015, ECLI:NL:RVS:2015:349 (De Wolden)| 2.6, 6.2.1.2, 6.2.1.3.

- ABRvS 4 maart 2015, ECLI:NL:RVS:2015:617| 6.2.1.3.

- ABRvS 11 maart 2015, ECLI:NL:RVS:2015:763| 8.2.1.1, 8.2.1.3.

- ABRvS 11 maart 2015, ECLI:NL:RVS:2015:765| 8.2.1.1, 8.2.1.3.

- ABRvS 11 maart 2015, ECLI:NL:RVS:2015:767| 8.2.1.1, 8.2.1.3.

- ABRvS 11 maart 2015, ECLI:NL:RVS:2015:768| 8.2.1.1, 8.2.1.3.

- ABRvS 11 maart 2015, ECLI:NL:RVS:2015:776| 8.2.1.1, 8.2.1.3.

- ABRvS 18 maart 2015, ECLI:NL:RVS:2015:832| 8.4.3.

- ABRvS 18 maart 2015, ECLI:NL:RVS:2015:845 | 9.1.1.

- ABRvS 29 april 2015, ECLI:NL:RVS:2015:1359| 8.2.1.1.

- ABRvS 27 mei 2015, ECLI:NL:RVS:2015:1626| 8.2.1.1.

- ABRvS 3 juni 2015, ECLI:NL:RVS:2015:1720 (Twenterand)| 6.2.1.3.

- ABRvS 10 juni 2015, ECLI:NL:RVS:2015:1837| 2.5.1.

- ABRvS 24 juni 2015, ECLI:NL:RVS:2015:1971| 6.2.1.2.

- ABRvS 1 juli 2015, ECLI:NL:RVS:2015:2071 (Mook \& Middelaar)| 2.2, 2.3.1, 2.6, 6.2.1.3, 6.2.1.5, 6.2.2.2.

- ABRvS 1 juli 2015, ECLI:NL:RVS:2015:2074| 6.2.1.3.

- ABRvS 1 juli 2015, ECLI:NL:RVS:2015:2075 | 6.2.1.3.

- ABRvS 8 juli 2015, ECLI:NL:RVS:2015:2153 | 3.4.1.

- ABRvS 5 augustus 2015, ECLI:NL:RVS:2015:2462| 4.2.4.

- ABRvS 5 augustus 2015, ECLI:NL:RVS:2015:2463| 8.2.1.3.

- ABRvS 12 augustus 2015, ECLI:NL:RVS:2015:2567 (Lansingerland) | 8.2.1.1.

- ABRvS 26 augustus 2015, ECLI:NL:RVS:2015:2680| 6.2.1.3.

- ABRvS 26 augustus 2015, ECLI:NL:RVS:2015:2688| 5.7.3.1.

- ABRvS 9 september 2015, ECLI:NL:RVS:2015:2828 (Best)| 2.6, 6.2.1.3, 6.3.1.

- ABRvS 4 november 2015, ECLI:NL:RVS:2015:3350| 3.2.1, 5.2.1, 6.2.1.1.

- ABRvS 18 november 2015, ECLI:NL:RVS:2015:3493| 5.7.1.1.

- ABRvS 25 november 2015, ECLI:NL:RVS:2015:3608 (Oirschot) | 2.6, 6.2.1.3. 
- ABRvS 25 november 2015, ECLI:NL:RVS:2015:3611 | 6.2.1.3.

- ABRvS 25 november 2015, ECLI:NL:RVS:2015:3612| 6.2.1.1.

- ABRvS 25 november 2015, ECLI:NL:RVS:2015:3626| 4.4.3.

- ABRvS 28 november 2015, ECLI:NL:RVS:2015:3182| 10.5.1.

- ABRvS 9 december 2015, ECLI:NL:RVS:2015:3721 (Wijdemeren) | 2.6, 6.2.1.2, 6.2.1.3.

- ABRvS 9 december 2015, ECLI:NL:RVS:2015:3726 (Planschade Harkema, eerste tussenuitspraak) $\mid$ 4.2.3.1.

- $\quad$ ABRvS 9 december 2015, ECLI:NL:RVS:2015:3735 | 4.4.2.

- ABRvS 9 december 2015, ECLI:NL:RVS:2015:3743 | 4.2.4.

- ABRvS 9 december 2015, ECLI:NL:RVS:2015:3767| 3.4.2.4, 5.2.3, 8.2.1.4, 8.3.3.1, 8.4.3, 9.3.3.

- ABRvS 16 december 2015, ECLI:NL:RVS:2015:3819 (Urilift, einduitspraak)| 3.4.2.4, 5.7.1.1, 5.7.1.2, 6.3.1.

- ABRvS 23 december 2015, ECLI:NL:RVS:2015:3934| 10.6.1.

- ABRvS 23 december 2015, ECLI:NL:RVS:2015:3986 (Kermis Leiderdorp)| 6.4.1.2.

- ABRvS 30 december 2015, ECLI:NL:RVS:2015:4047| 8.2.1.1.

- ABRvS 13 januari 2016, ECLI:NL:RVS:2016:50 (Achtkarspelen)| 6.2.1.4, 9.3.1.

- ABRvS 27 januari 2016, ECLI:NL:RVS:2016:143 (Twenterand)| 6.2.1.3.

- ABRvS 2 maart 2016, ECLI:NL:RVS:2016:526 (Planschade Deurne I) | 6.2.1.4.

- ABRvS 2 maart 2016, ECLI:NL:RVS:2016:529 (Planschade Deurne II) | 6.2.1.4.

- ABRvS 2 maart 2016, ECLI:NL:RVS:2016:530 (Rijsbergen)| 2.3.1, 6.2.1.3, 6.2.2.2, 6.4.1.3.

- ABRvS 9 maart 2016, ECLI:NL:RVS:2016:593| 4.2.3.1.

- ABRvS 16 maart 2016, ECLI:NL:RVS:2016:729 (Air Operator Certificate)| 4.2.4, 4.4.1, 7.2.2.

- ABRvS 30 maart 2016, ECLI:NL:RVS:2016:858 (Nunspeet)| 6.2.1.3.

- ABRvS 13 april 2016, ECLI:NL:RVS:2016:963 (Vereniging Stop Awacs Overlast/Minister van $I \& M) \mid 3.2 .2$.

- ABRvS 13 april 2016, ECLI:NL:RVS:2016:986 (Wierden)| 6.2.1.3.

- ABRvS 20 april 2016, ECLI:NL:RVS:2016:1049| 8.2.1.1, 8.2.1.4.

- ABRvS 4 mei 2016, ECLI:NL:RVS:2016:1200 (Bergen)| 2.3.1, 6.2.1.4, 6.2.2.2.

- $\quad$ ABRvS 4 mei 2016, ECLI:NL:RVS:2016:1205 (Orac)| 6.2.1.1, 6.2.1.5.

- ABRvS 11 mei 2016, ECLI:NL:RVS:2016:1250| 6.4.1.2.

- ABRvS 18 mei 2016, ECLI:NL:RVS:2016:1349 (Sugar City)| 8.2.1.2.

- ABRvS 25 mei 2016, ECLI:NL:RVS:2016:1395 | 8.3.3.2.

- ABRvS 25 mei 2016, ECLI:NL:RVS:2016:1396| 8.2.1.1.

- ABRvS 1 juni 2016, ECLI:NL:RVS:2016:1467| 6.2.1.5, 6.4.1.3.

- ABRvS 8 juni 2016, ECLI:NL:RVS:2016:1602 (Boskoop I)| 6.2.1.3.

- ABRvS 8 juni 2016, ECLI:NL:RVS:2016:1603 (Boskoop II) | 6.2.1.3. 
- ABRvS 15 juni 2016, ECLI:NL:RVS:2016:1650 (Nadeelcompensatie Eindhoven/AH Cassandraplein) | 5.7.1.2, 6.2.3.1, 6.3.1.

- ABRvS 15 juni 2016, ECLI:NL:RVS:2016:1651 (Bandencentrum Eindhoven) | 5.4.1.2, 5.4.1.3, 6.3.1.

- ABRvS 15 juni 2016, ECLI:NL:RVS:2016:1652 (Supermarkt Haarlem)| 2.6, 3.2.2, 6.3.1.

- ABRvS 6 juli 2016, ECLI:NL:RVS:2016:1876 (Planschade Doesburg) | 8.2.1.1.

- ABRvS 6 juli 2016, ECLI:NL:RVS:2016:1882| 8.2.1.1.

- ABRvS 13 juli 2016, ECLI:NL:RVS:2016:1970 (Raalte) | 10.1, 10.7.1, 10.7.3.

- ABRvS 20 juli 2016, ECLI:NL:RVS:2016:2018| 10.2.1.

- ABRvS 17 augustus 2016, ECLI:NL:RVS:2016:2255 (Kabeldansen)| 4.2.3.1.

- ABRvS 24 augustus 2016, ECLI:NL:RVS:2016:2315 (Knooppunt Kunderberg, hoger beroep) | 4.4.2, 5.4.1.1, 8.1.

- ABRvS 7 september 2016, ECLI:NL:RVS:2016:2399| 2.5.1.

- ABRvS 14 september 2016, ECLI:NL:RVS:2016:2487 (Lankes)| 2.6, 6.2.1.3.

- ABRvS 21 september 2016, ECLI:NL:RVS:2016:2502 (Schoonrewoerd) | 2.6, 6.2.1.3, 6.2.2.2.

- ABRvS 28 september 2016, ECLI:NL:RVS:2016:2543 | 2.6, 6.2.1.3, 6.2.3.1.

- ABRvS 28 september 2016, ECLI:NL:RVS:2016:2582 (Overzichtsuitspraak).

- ABRvS 28 september 2016, ECLI:NL:RVS:2016:2583 | 6.2.1.3.

- ABRvS 16 november 2016, ECLI:NL:RVS:2016:3047 (Uptown)| 3.3.1, 4.2.4, 4.4.1, 4.4.2, 6.3.1, 8.2.2.2.

- ABRvS 23 november 2016, ECLI:NL:RVS:2016:3134 (Wormerland) | 8.2.1.4.

- ABRvS 30 november 2016, ECLI:NL:RVS:2016:3168 (Wegafsluiting Hoevelaken $)$ 5.2.1, 5.7.1.1, 6.2.1.1.

- ABRvS 30 november 2016, ECLI:NL:RVS:2016:3196| 8.2.1.4.

- ABRvS 11 januari 2017, ECLI:NL:RVS:2017:18 (Pijnacker-Nootdorp) | 6.2.1.4.

- ABRvS 8 februari 2017, ECLI:NL:RVS:2017:321 | 3.4.1.

- ABRvS 8 februari 2017, ECLI:NL:RVS:2017:326| 6.2.1.4.

- ABRvS 15 maart 2017, ECLI:NL:RVS:2017:691| 4.2.3.1.

- ABRvS 12 april 2017, ECLI:NL:RVS:2017:1022 (Planschade Kerkrade)| 4.2.3.1.

- ABRvS 19 april 2017, ECLI:NL:RVS:2017:1052 | 4.4.1.

- ABRvS 17 mei 2017, ECLI:NL:RVS:2017:1293 (De Lunet)| 2.3.1, 6.2.1.4, 6.2.2.2, 8.2.1.1, 8.2.1.2, 9.3.3, 10.1, 10.7.3.

- ABRvS 24 mei 2017, ECLI:NL:RVS:2017:1402 | 6.2.1.3.

- ABRvS 7 juni 2017, ECLI:NL:RVS:2017:1511 (Planschade Woudenberg)| 8.2.1.1.

- ABRvS 21 juni 2017, ECLI:NL:RVS:2017:1653 (Beuningen)| 6.2.1.3.

- ABRvS 28 juni 2017, ECLI:NL:RVS:2017:1700| 8.2.1.1, 8.2.1.3.

- ABRvS 5 juli 2017, ECLI:NL:RVS:2017:1787| 6.4.1.2.

- ABRvS 5 juli 2017, ECLI:NL:RVS:2017:1793 ('t Vennewater)| 8.2.1.4. 
- ABRvS 19 juli 2017, ECLI:NL:RVS:2017:1968| 9.1.1.

- ABRvS 26 juli 2017, ECLI:NL:RVS:2017:1988 (OK Oliecentrale)| 8.2.1.1, 8.2.1.4.

- ABRvS 26 juli 2017, ECLI:NL:RVS:2017:2024| 8.2.1.1, 8.2.1.4.

- ABRvS 26 juli 2017, ECLI:NL:RVS:2017:2025 | 5.2.1.

- ABRvS 26 juli 2017, ECLI:NL:RVS:2017:2026| 8.2.1.1.

- ABRvS 23 augustus 2017, ECLI:NL:RVS:2017:2241 | 3.4.1.

- ABRvS 23 augustus 2017, ECLI:NL:RVS:2017:2248| 2.6, 6.2.1.3.

- ABRvS 30 augustus 2017, ECLI:NL:RVS:2017:2300| 4.2.1, 4.2.4, 4.4.1.

- ABRvS 30 augustus 2017, ECLI:NL:RVS:2017:2340 (Expert Soest)| 4.2.4, 4.4.1.

- ABRvS 6 september 2017, ECLI:NL:RVS:2017:2416| 6.1.

- ABRvS 20 september 2017, ECLI:NL:RVS:2017:2553 (De Ruige Hoek)| 8.2.2.2.

- ABRvS 27 september 2017, ECLI:NL:RVS:2017:2598 (Bedrijfswoning Zaanstad) $\mid$ 6.2.1.4.

- ABRvS 27 september 2017, ECLI:NL:RVS:2017:2600| 5.5.1.1, 5.5.1.3, 5.5.1.5, 5.5.1.6, 5.6.1, 5.7.1.2.

- ABRvS 18 oktober 2017, ECLI:NL:RVS:2017:2802| 4.2.3.1.

- ABRvS 18 oktober 2017, ECLI:NL:RVS:2017:2805 | 4.2.3.1, 6.2.1.1.

- ABRvS 25 oktober 2017, ECLI:NL:RVS:2017:2889| 6.2.1.3.

- ABRvS 25 oktober 2017, ECLI:NL:RVS:2017:2902| 5.7.1.2.

- ABRvS 25 oktober 2017, ECLI:NL:RVS:2017:2903 (Hoogezand-Sappemeer $) \mid$ 2.6, 6.2.1.3.

- ABRvS 1 november 2017, ECLI:NL:RVS:2017:2927| 8.3.3.2.

- ABRvS 29 november 2017, ECLI:NL:RVS:2017:3271| 2.5.4.

- ABRvS 6 december 2017, ECLI:NL:RVS:2017:3304 (BARIN)| 2.3.4, 10.1, 10.7.1.

- ABRvS 6 december 2017, ECLI:NL:RVS:2017:3305 (Planschade DSM) | 9.3.3.

- ABRvS 22 december 2017, ECLI:NL:RVS:2017:3557| 2.5.4.

- ABRvS 31 januari 2018, ECLI:NL:RVS:2018:294| 9.1.1.

- ABRvS 7 februari 2018, ECLI:NL:RVS:2018:380| 6.2.1.4.

- ABRvS 7 februari 2018, ECLI:NL:RVS:2018:427| 4.2.3.1.

- ABRvS 14 februari 2018, ECLI:NL:RVS:2018:480| 3.4.1.

- ABRvS 14 februari 2018, ECLI:NL:RVS:2018:504 | 6.2.3.1.

- ABRvS 7 maart 2018, ECLI:NL:RVS:2018:778| 2.6.

- ABRvS 14 maart 2018, ECLI:NL:RVS:2018:849 (Ooststellingwerf)| 2.6.

- ABRvS 16 maart 2018, ECLI:NL:RVS:2018:888| 4.2.3.1.

- ABRvS 21 maart 2018, ECLI:NL:RVS:2018:930| 8.2.1.1.

- ABRvS 21 maart 2018, ECLI:NL:RVS:2018:973 (Lochem)| 2.6.

- ABRvS 23 mei 2018, ECLI:NL:RVS:2018:1698| 3.2.3.

- ABRvS 13 juni 2018, ECLI:NL:RVS:2018:1935| 6.2.1.3.

- ABRvS 20 juni 2018, ECLI:NL:RVS:2018:2040| 6.4.1.1.

- ABRvS 18 juli 2018, ECLI:NL:RVS:2018:2420 (Koekelberg)| 6.2.1.4.

- ABRvS 25 juli 2018, ECLI:NL:RVS:2018:2517| 2.6. 
- ABRvS 8 augustus 2018, ECLI:NL:RVS:2018:2620 (Stolwijk)| 6.2.1.3.

- ABRvS 22 augustus 2018, ECLI:NL:RVS:2018:2764| 4.2.3.3, 10.5.1, 10.12.3.

- ABRvS 19 september 2018, ECLI:NL:RVS:2018:3023 (Startnotitie A2 Maastricht $) \mid$ 8.2.1.1.

- ABRvS 19 september 2018, ECLI:NL:RVS:2018:3026| 6.2.1.4.

- ABRvS 26 september 2018, ECLI:NL:RVS:2018:3120 (Leusden) | 6.2.1.5.

- ABRvS 10 oktober 2018, ECLI:NL:RVS:2018:3272 (Gemzelaar) | 2.6, 6.4.1.3.

- ABRvS 24 oktober 2018, ECLI:NL:RVS:2018:3431| 2.2, 3.2.1.

- ABRvS 7 november 2018, ECLI:NL:RVS:2018:3601 (Voorst)| 2.6.

- ABRvS 28 november 2018, ECLI:NL:RVS:2018:3871| 6.2.1.4.

- ABRvS 5 december 2018, ECLI:NL:RVS:2018:3938| 6.2.1.5.

- ABRvS 18 december 2008, ECLI:NL:RVS:2008:BG8265 | 3.2.2.

- ABRvS 19 december 2018, ECLI:NL:RVS:2018:4170| 5.2.1, 5.6.1.

- ABRvS 19 december 2018, ECLI:NL:RVS:2018:4193 (Grondgeluid)| 7.2.2, 8.2.1.3.

- ABRvS 30 januari 2019, ECLI:NL:RVS:2019:258 | 8.4.1.

- ABRvS 6 februari 2019, ECLI:NL:RVS:2019:343 | 6.4.1.3.

- ABRvS 20 februari 2019, ECLI:NL:RVS:2019:495 (Meierijstad)| 6.2.1.3.

- ABRvS 6 maart 2019, ECLI:NL:RVS:2019:729 (Olasfa)| 2.3, 6.4.3.

- ABRvS 13 maart 2019, ECLI:NL:RVS:2019:776| 2.6.

- ABRvS 1 mei 2019, ECLI:NL:RVS:2019:1436| 2.6.

- ABRvS 1 mei 2019, ECLI:NL:RVS:2019:1438| 6.2.1.3.

- ABRvS 12 juni 2019, ECLI:NL:RVS:2019:1884| 6.2.1.3, 7.2.2.

- ABRvS 26 juni 2019, ECLI:NL:RVS:2019:2025 | 4.2.4, 4.4.2.

- ABRvS 28 augustus 2019, ECLI:NL:RVS:2019:2953 (Grubbenvorst)| 2.6.

- ABRvS 6 november 2019, ECLI:NL:RVS:2019:3762| 8.4.2.

\section{Centrale Raad van Beroep}

- CRvB 16 september 2003, ECLI:NL:CRVB:2003:AM2447| 2.2.

- CRvB 1 juli 2019, ECLI:NL:CRVB:2019:2016| 2.5.4.

- CRvB 1 juli 2019, ECLI:NL:CRVB:2019:2017| 2.5.4.

- CRvB 1 juli 2019, ECLI:NL:CRVB:2019:2018| 2.5.4.

- CRvB 1 juli 2019, ECLI:NL:CRVB:2019:2019| 2.5.4.

\section{College van Beroep voor het bedrijfsleven}

- $\quad$ CBb 6 juni 2007, ECLI:NL:CBB:2007:BA8636| 8.4.2.

- CBb 5 december 2007, ECLI:NL:CBB:2007:BB9363 (Radio 538) | 7.3, 7.4.

- CBb 10 december 2008, ECLI:NL:CBB:2008:BH0855 | 8.2.1.1.

- CBb 16 april 2009, ECLI:NL:CBB:2009:BI1934| 7.2.2.

- CBb 22 mei 2017, ECLI:NL:CBB:2017:188| 5.5.1.4.

\section{Koninklijke Besluiten}

- $\quad$ KB 7 september 1971, BR 1971, p. 645-647 (Leersum)| 4.2.4. 
- $\quad$ KB 20 mei 1975, ECLI:NL:XX:1975:AR9927| 4.2.4, 7.2.1.

- KB 9 november 1976, ECLI:NL:XX:1976:AM3523 (Dalfsen)| 7.2.1.

- KB 29 december 1976, ECLI:NL:XX:1976:AM3540 (Velsen)| 8.3.1.

- KB 27 januari 1983, ECLI:NL:XX:1983:AS9888 (Zwijndrecht)| 8.3.1.

- KB 26 oktober 1990, ECLI:NL:XX:1990:AN1968| 7.3.

\section{Europese Hof voor de Rechten van de Mens}

- EHRM 23 oktober 1985, ECLI:NL:XX:1985:AC9055 (Benthem)| 1.4.

- EHRM 30 augustus 2007, ECLI:CE:ECHR:2007:0830JUD004430202 (Pye Land Ltd t. Verenigd Koninkrijk) | 2.5.1.

- EHRM 25 oktober 2012, ECLI:CE:ECHR:2012:1025JUD007124301 (Vistiņš en Perepjolkins t. Letland) | 2.5.1.

\section{Europese Commissie voor de Rechten van de Mens}

- ECieRM 9 maart 1989, ECLI:CE:ECHR:1989:0309DEC001176385 (Banér t. Zweden) | 2.5.1. 



\section{Trefwoordenregister}

- $\quad$ aanvraag, eisen gesteld aan de | 462-467, 560-561

- aanvrager, eisen gesteld aan de | 460-462

- abnormale last | zie 'normaal maatschappelijk risico'

- anderszins verzekerde schadevergoeding | 439-446, 448, 453-455, 575

- belangenafweging, eis van een | 176-189

- beleidsregels als grondslag voor nadeelcompensatie | 23-24, 26-29, 34, 50, $74-75,82-83$

- bestuurscompensatie | 23-24

- bevoegdheidsverdeling | 1, 13, 19-34, 49-51, 112, 542-546, 561, 587-588

- bruidsschat | 63

- causaal verband | 131-167,575

- alternatieve causaliteit | 161

- condicio sine qua non | 134-142, 146-152, 163-167, 246, 250, 252, 589

- exclusieve schadeoorzaken | 109-111, 149, 151

- meervoudige causaliteit | 157-163, 575, 578, 594-595

- motivering door de rechter | 142-146, 154-157, 166-167, 592

- toerekening naar redelijkheid | 133-135, 138-139, 142-148, 153-157, 163, $167,183-185,592$

- compensatie in natura | 269-270,447-455, 575

- competentieverdeling | zie 'bevoegdheidsverdeling'

- connexiteitseisen | 29-34, 51, 88-89, 104, 112-113, 542-543

- deskundigenadvisering | 486-524, 556-559, 577-578

- informatievergaring door de adviescommissie | 510-516

- $\quad$ inhoud van het advies | 503-509

- inspraakmogelijkheden | 517-524

- (verplichte) raadpleging van de adviescommissie | 486-492

- $\quad$ samenstelling van de adviescommissie | 493-503

- draagkracht | 261-262, 286

- draagplichtige derden | 467, 542-544, 546-547, 587

- dubbele redelijkheidstoets | 192-201, 203-205, 210, 212-214, 252, 592

- duidelijkheid, eis van | 442-444, 450, 454-455, zie ook 'anderszins verzekerde schadevergoeding'

- Eerste Protocol EVRM, art. 1

- als grondslag voor nadeelcompensatie | 94, 101, 122

- fair balance-toets | 64-66

- toetsing van nadeelcompensatieregelingen aan... | 64-66, 69-75, 82-83, 261,289

- égalitébeginsel | 2, 8-10, 27-34, 53, 64-67, 69-75, 81-83, 88, 104-105

- $\quad$ eigen schuld | 359-427

- $\quad$ afzonderlijke bepaling inzake resterende vormen van eigen schuld | 415425,576 
- $\quad$ verschillende vormen van eigen schuld | 359-361

- de vier stappen van art. 6:101 BW | 361-363, 382-391, 405-406, 412-415, 421-426

- $\quad$ gebundelde aanvraag | 281-282, 290-292, 485, 544-545

- globale planologie | zie 'uitnodigingsplanologie'

- grondslagendebat | 18-19, 186-187

- Handleiding nadeelcompensatie bij infrastructurele maatregelen | 40, 239240, 301-309, 318-319, 322-325, 588, 590-591

- heffing van een recht | 467-476, 528-529, 539, 555, 577

- hoofdelijke aansprakelijkheid | 161-163, 165-166

- interbestuurlijke samenwerking

- incidentele | 158-160

- structurele | 160-161

- $\quad$ kosten van deskundigenbijstand | 201-216, 251-252, 576-577, 593

- kosten van schadebeperkende maatregelen | 190-201, 251-252, 576-577, 592, 595

- nadeelcompensatielandschap of - doolhof | 14-15, 17, 19-34, 49-51, 81-82, 112-113, 546, 598

- nadeelcompensatieregelingen

- hedendaagse regelingen | 34-48

- toekomstige regelingen | 48-64, 112

- nauw verweven overheidshandelingen | 281-282, 290-292, 433-435, 437-438, 454-456, 586-587

- negatieve ontwikkelingsschade | 95-96, 127-129

- normaal maatschappelijk risico | 60-61, 255-326, 575-576, 586, 589-591, 593-594, 596

- Heiloo-factoren | 264-276, 283-284, 289

- normaal ondernemersrisico | 293-309, 322-325, 590-591, 593, 596

- Omgevingswet en het nieuwe omgevingsrecht | 58-64, 107-111, 119-121, 544, 584-585

- $\quad$ ontkoppelingsjurisprudentie | 30, 179, 184

- ontwikkelingsplanologie | zie 'uitnodigingsplanologie'

- $\quad$ onzuiver schadebesluit | 25-26, 28-29, 31-32, 34, 53, 112, 188

- $\quad$ overnamebevoegdheid | 158-160, 162-163, 165-167, 578, 586, 589

- planvergelijking | 135-139

- $\quad$ procedurele inrichting en beslistermijnen | 524-541, 558-559, 578

- rechtsmachtverdeling | zie 'bevoegdheidsverdeling'

- $\quad$ rechtsmiddelen | 542-547, 561, 587-588

- redelijkerwijsformule | 21-24, 38-39, 81

- referentiegroep

- $\quad$ bij beschikkingen | 336-337, 340, 349-350

- bij besluiten van algemene strekking, niet zijnde wettelijke voorschriften 338-339, 348-349

- $\quad$ bij grote (infrastructurele) projecten | 340-343, 348

- bij wettelijke voorschriften | 336-337, 346-348

- $\quad$ een normatieve maatstaf | 350-357, 576, 596 
- $\quad$ streng, gematigd of rekkelijk | 329-331

- regres | 161

- reikwijdte van nadeelcompensatieregelingen | 49-51, 60, 85-129

- exclusiviteit | 92-94, 96-101, 104-108, 112, 114-116, 128-129, 403-404, $566,584-585$

- limitatieve opsommingen | 86-90, 104-108

- $\quad$ publiekrechtelijke bevoegdheid of taak | 49-51, 86-89, 101-104, 112-114

- $\quad$ uitputtendheid | 90-91

- relativiteitsvereiste | $138-139,147-148$

- $\quad$ risicoaanvaarding | 359-407, 423-427, 576, 584-586, 594, 597

- actieve risicoaanvaarding (algemeen) | 364-366

- bronnen van voorzienbaarheid | 376-382, 390-392, 400, 402, 423, 425426

- $\quad$ concreet en openbaar beleidsvoornemen | 365-366, 376-378

- doorbroken voorzienbaarheid | 384

- gedeeltelijke voorzienbaarheid | 366-368, 373-376, 386-391

- geen actieve risicoaanvaarding wegens art. $15.5 \mathrm{Ow} \mid 60-61,121,125$, 392-395, 400, 403-404, 423, 426, 585

- $\quad$ in verhouding tot schaduwschade | 94-95, 121, 124, 248, 585

- $\quad$ onderwerp van voorzienbaarheid | 374-376, 390, 402, 597

- passieve risicoaanvaarding (algemeen) | 369-371

- passieve risicoaanvaarding op grond van art. 15.6 Ow | 60-61, 395-401, 404-407, 423-427, 586

- peilmoment voor voorzienbaarheid | 364-365

- uitdrukkelijke risicoaanvaarding | 378-381

- verhouding tot overige vormen van eigen schuld | 360-361

- veronderstelde risicoaanvaarding | 377-381

- $\quad$ schadebegrip | 170-176, 251-252

- $\quad$ schadebegroting | 223-250, 252-253, 575, 589

- forfaitaire begroting van waardedaling | 230-231, 245, 250, 253, 595

- huurwaardevergelijking | 236-238, 244

- kapitalisatie(factoren) | 235-236

- $\quad$ schadefactorenmethode | 229-231

- vergelijkingsmethode | 227-229

- VROM-puntenstelsel | 43, 237

- $\quad$ schadebeperkingsplicht | 360-361, 407-415, 423-426, 576, 594

- extra schade | 412-413

- $\quad$ verhouding tot overige vormen van eigen schuld | 360-361

- schademoment, verschuiving van het | 60-61, 108-111, 119-121, 148, 163$165,245-249,281-282,290-292,392-395,400,483-485,585,589$

- schadeverhaalsovereenkomst | zie 'draagplichtige derden'

- schaduwschade

- definitie | 92

- indicatief overheidshandelen | 92

- motieven van de rechter | 97-98

- $\quad$ motieven van de wetgever | 98-101, 104-111, 114-119 
- rol van actieve risicoaanvaarding |94-95, 121, 124, 248

- toerekeningsproblemen | 92-93

- verschillende vormen van schaduwschade | 94-96

- voorstel voor een oplossing | 121-129, 403-404, 423, 426, 584-585, 587

- smeermiddelfunctie | $12,31,35,70-71,284$

- speciale last | 327-357, 576, 596, zie ook 'referentiegroep'

- specialiteitsbeginsel | 181-182

- staatrechtelijke grenzen in het nadeelcompensatierecht |64-75, 82-83

- stuiting | zie 'verjaring'

- toetsingsintensiteit | $15,75-83$

- uitnodigingsplanologie | 38, 58-59, 108-109, 119, 125, 277, 584-585

- verjaring | 476-485, 556,578

- vertrouwensbeginsel $\mid 8,188$

- voordeelverrekening | 281-282, 291, 429-438, 453-456, 575

- voorrangsregeling art. $8.31 \mathrm{Wlv} \mid 88$

- voorschot op nadeelcompensatie | 548-555, 559-560, 577

- wettelijke rente, vergoeding van | 216-223, 251-252, 505, 550, 552-554, 560, 576-577

- zekerheid, eis van | 442-445, 450-455, zie ook 'anderszins verzekerde schadevergoeding'

- zuiver schadebesluit | 26-34, 90-91,112 


\section{Curriculum vitae}

Jonathan Huijts is op vrijdag 31 juli 1992 geboren te Maastricht. In de periode van september $2009 \mathrm{t} / \mathrm{m}$ augustus 2013 voltooide hij de bacheloropleiding Nederlands recht en de masteropleiding Nederlands privaatrecht aan de Universiteit Maastricht. Hij behoorde tot de top 3\% studenten van het academisch jaar 2010/2011. ${ }^{1}$ In de periode van juli $2011 \mathrm{t} / \mathrm{m}$ juni 2013 was Jonathan werkzaam als student(-assistent) bij het Infopunt Schade A2 Maastricht, een samenwerkingsverband tussen de Universiteit Maastricht, het Projectbureau A2 Maastricht, de gemeente Maastricht, Avenue 2 en het A2-Buurtenplatform. Hier kwam hij voor het eerst in aanraking met het nadeelcompensatie- en planschaderecht, dat ook het onderwerp was van zijn masterscriptie. Van 15 augustus 2013 t/m 31 juli 2016 was Jonathan werkzaam als docent aan de afdeling staats- en bestuursrecht van de Universiteit Maastricht. Vanaf 1 augustus 2016 tot op heden is hij werkzaam aan de afdeling staats- en bestuursrecht van de Universiteit Leiden; aanvankelijk als docent, vanaf 1 september 2018 als onderzoeker en vanaf 1 januari 2020 als universitair docent. Sinds 1 januari 2018 was Jonathan tevens als onafhankelijk wetenschappelijk adviseur verbonden aan vanState Advocaten. Per 1 september 2018 is dat kantoor samengegaan met Corten De Geer Advocaten. Vanaf 18 september 2019 is Jonathan in officiële hoedanigheid als onafhankelijk wetenschappelijk adviseur verbonden aan Corten De Geer Advocaten.

1 Tevens het laatste jaar dat de top 3\% werd bekendgemaakt. 


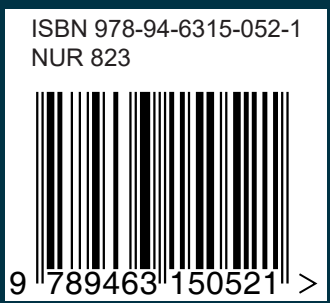

